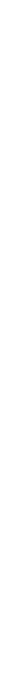

\title{
SUSTAINABLE ARCHITECTURAL DESIGN - Principles - In the Albanian Language
}

\begin{tabular}{|c|c|}
\hline Authors: & Bujar Q. Bajçinovci \\
\hline Submitted: & 26. July 2017 \\
\hline Published: & 27. July 2017 \\
\hline Volume: & 4 \\
\hline Issue: & 3 \\
\hline Affiliation: & $\begin{array}{l}\text { University of Prishtina, Faculty of Civil Engineering and } \\
\text { Architecture, Kosovo }\end{array}$ \\
\hline Keywords: & $\begin{array}{l}\text { Architecture, Sustainable Design, Textbook, Monograph, } \\
\text { Language: Albanian }\end{array}$ \\
\hline DOI: & 10.17160/josha.4.3.306 \\
\hline
\end{tabular}




\section{SUSTAINABLE ARCHITECTURAL DESIGN}

\section{Principles}

This book is originally and especially dedicated to the students of Architecture Department of the University of Prishtina for Educational, and Not-for-profit purposes. The monograph itself incorporates contemporary knowledge of the design domain, followed by discussion, extracts, quotes and citations by various authors, as well as official government publications as academic comparative references. Seeing the lack of literature in the field of Architecture, especially in Albanian language, I was inspired by the research and writing this monograph, which elaborates the field of Sustainable Architectural Design. The book is a free and not-for-profit purposes, it is intented as basic academic literature of Master courses which I taught at University of Prishtina. In the monograph I have reflected my personal professional experience and literature review I have consulted so far. The monograph introduces the principles of design, the concept of understanding the design process, guided by philosophical and architectural creativity. There are sixteen chapters, each chapter extensive explain and discuss issues related to the specific topic of Architectural Design.

Prof.As.Dr. BUJAR BAJÇINOVCI Dipl.Ing.Arch. Faculty of Civil Engineering and Architecture University of Prishtina, Kosovo

\section{Prishtinë, 2017}


Recensues shkencorë:

Prof. Asoc. Dr. FLAMUR DOLI Arch.

Akademik Prof. Dr. Dr. h. c. FEJZULLAH KRASNIQI

Falënderim i posaqëm për recensuesit shkencorë, që kishin konsideratë për ta lexuar monografinë, për propozimet, sugjerimet dhe vërejtjet teknike të cilat më kanë ndihmuar gjatë shkruarjes dhe finalizimit të kësaj monografie. Konsiderojë se pa kontributin e tyre, kjo monografi nuk do të ishte ashtu siq është.

Bujar Bajçinovci @. Attribution-NonCommercial 4.0 International (CC BY-NC 4.0). This book is licensed under a (Creative Commons Attribution-NonCommercial 4.0 International License. ) license. See the license for more details: You can share this book as long as you credit the author, and don't use for the commercial purposes, and do make it available to everyone else under the same terms.

Copyright, Autori/Author. Prof.Ass.Dr. Bujar Bajçinovci Inxh.Dipl.Ark. 2017.

Mësimdhënës, Katedra e Projektimit

Fakulteti i Ndërtimtarisë dhe Arkitekturës

Universiteti i Prishtinës

Prill 2017.

Kopertina: Bujar Bajçinovci

Photo: SarahTz. 2014. Flickr. Com. (CC BY-2.0)

Licensed: Creative Commons Attribution 2.0 Generic

Gjirokastër. Baba Meto Hostel. Albania.

All photos are from file sharing, Flickr.com under Creative Commons, and Public Domain

2 


\section{PROJEKTIMI I QËNDRUESHËM ARKITEKTONIK}

\section{Parimet}

MONOGRAFI SHKENCORE NGA LËMIA E

PROJEKTIMIT TË QËNDRUESHËM

Prof.Ass.Dr. BUJAR BAJÇINOVCI Arch.

\section{Prishtinë, 2017}




\section{PARATHËNIE}

Kjo monografi fillimisht iu dedikohet studentëve të Arkitekturës. Për më tepër, shpresoj që këtë libër ta gjejnë si udhëzues edhe profesionistët e lëmisë së Arkitekturës dhe Inxhinierisë së Ndërtimit. Monografia në vete ngërthen njohuritë bashkëkohore të lëmisë së projektimit duke u përcjellë me diskutim, ekstrakte, pjesë dhe citime nga autorë të ndryshëm, si dhe publikime zyrtare qeveritare në cilësi të referencave krahasuese.

Duke parë mungesën e literaturës në lëminë e Arkitekturës, sidomos në gjuhën shqipe, u frymëzova që t'i përvilem punës e të shkruarit të kësaj monografie, e cila shtjellon tematikën e Projektimit të Qëndrueshëm. Në libër kam pasqyruar përvojën personale profesionale si dhe të kuptuarit e lëmisë së projektimit me literaturën botërore të cilën e kam konsultuar deri më tani. Monografia prezanton parimet e projektimit, konceptin e të kuptuarit së procesit të projektimit, e udhëhequr nga standardet, rregulloret, udhëzimet administrative si dhe mendësisë filozofike e të krijuarit arkitektonik.

Në kontekst kuptimor monografia prezanton autonominë e të krijuarit arkitektonik, si proces kreativ evolutiv, i cili ngërthen në vete brendësinë e gjendjes mentale të çdo krijuesi. Autonomi e cila i jep të drejtë çdo individi të krijojë në të mirë të mbarë shoqërisë si dhe mundësisë të implemetojë në praktikë premisat e dëshiruara në arritje të kualitetit më të mirë të jetesës.

Prof.Ass.Dr. Bujar Bajçinovci. I.D.A Mësimdhënës, Katedra e Projektimit Fakulteti i Ndërtimtarisë dhe Arkitekturës Universiteti i Prishtinës

Prill 2017 
PËRMBAJTJA :

PROJEKTIMI I QËNDRUESHËM ARKITEKTONIK

PARATHËNIE

PËRMBAJTJA

SHKURTESAT-PËRKUFIZIMET

INDEKSI E FIGURAVE DHE TABELAVE

FALËMINDERIM

I: HYRJE

II : SPECIFIKAT DHE VEÇORIT

2.1 MJEDISI NATYROR

2.2 KARAKTERISTIKA TË PËRGJITHSHME PËR KOSOVËN

2.2.1 Pozita gjeografike

2.2.2 Relievi

2.2.3 Klima

2.2.4 Hidrografia

2.2.5 Sistemi i energjisë elektrike në Kosovë

2.2.6 Projekti - Kosova e Re

2.2.7 Traktati për Komunitetin e Energjisë

2.2.8 Bashkëpunimi rajonal

2.2.9 Struktura e popullsisë
2.2.9.1 Burimet e të dhënave
2.2.9.2 Popullsia bazë
2.2.9.3 Shtimi natyror
2.2.9.4 Migrimi
2.2.9.5 Rritja e përgjithshme

2.2.10 Ngrohja qendrore

III : PËRKUFIZIMET THEMELORE

3.1 PROJEKTIMI TRANSDISCIPLINAR

3.2 HOLIZMI

3.3 ARKITEKTURA BIOKLIMATIKE

3.4 BIM

3.5 EFIÇIENCA ENERGJETIKE

3.6 SINDROMI, SBS

3.7 E-SMOG

\section{IV : PROBLEMATIKA ARKITEKTONIKE}

4.1 SFIDAT ME TË CILAT PËRBALLET ARKITEKTURA
4.1.1 Veçoritë sociale
4.1.2 Mjedisi dhe shoqëria

4.2 ARKITEKTURA DHE SHËNDETI PUBLIK
4.2.1
QALY

4.3 OBJEKTIVAT 
4.3.1 Komisioni Evropian, Evropa Creative

4.4 KOMISIONI EVROPIAN /EUROPA CREATIVE/

4.5 PROJEKTIMI AKTUAL LINEAR

4.5.1 Shembull studimi

4.6 EXITUS

V : ARKITEKTURA ORGANIKE - BIOKLIMATIKE .............

$5.1 \quad$ NATYRA

5.1.1 Tumë termitesh

5.1.2 Cappadocia

5.1.2.1 Vendbanimet nëntokësore të Cappadocias

5.1.3 Santorini

5.1.4 Ulqini

5.1.5 Berati, qyteti me njëmijë dritare

5.1.6 Ohri

5.1.7 Arkitektura vernakulare e Kosovës

\section{VI : KOMFORI}

\subsection{KOMFORI I BRENDSHËM TERMIK}

6.2 MODELI I KOMFORIT

6.3 ELEMENTET E MODELIT TË KOMFORIT

6.4 KOMFORI HIGJIENIK

6.4.1 Shtëpia e jonë (me baktere)

6.5 KOMFORI AKUSTIK-ZË IZOLUES

6.5.1 Heshtja, nuk është zgjidhje

6.5.2 Indeksi i privatësisë

6.6 KOMFORI NGA ASPEKTI I NDRIÇIMIT

6.6.1 Shembull studimi/Franca

VII : PROJEKTIMI I INTEGRUAR

7.1 NDËRTESAT PUBLIKE DHE BANIMORE

7.2 PYETJET GLOBALE

7.3 NDRYSHIMET KLIMATIKE

7.4 FILOZOFIA EKOLOGJIKE

7.5 EPISTEMOLOGJIA

7.6 LEGJISLACIONI

7.7 PLANIFIKIMI

7.8 ZHVILLIMI

7.9 EKO SHËNDETI

7.10 PROCESI I PROJEKTIMIT TË INTEGRUAR

7.10.1 Dizajni

7.10.2 Përcaktimi i problemit- Formulimi i çrregullt

7.11 PROBLEMI I INJORANCËS EKOLOGJIKE - MOHIMI 
8.1 PRINCIPET E PROJEKTIMIT TË QËNDRUESHËM

8.2 QËLLIMET E PROJEKTIMIT TË QËNDRUESHËM

8.3 ANALIZA E SITUACIONIT DHE VEÇORITË BIOKLIMATIKE

8.4 RRUGËTIMI I DIELLIT DHE POZITA DIELLORE

8.4.1 Variacionet sezonale dhe datat e rëndësishme

8.5 MBËSHTJELLËSI I OBJEKTIT

8.5.1 Muri i rrafshët

8.5.2 Sasia e nxehtësisë e nevojshme për ngrohje

8.5.3 Llogaritja e humbjeve termike

8.5 PRINCIPET PASIVE TË PROJEKTIMI TË QËNDRUESHËM
8.5.1 Energjia e drejtpërdrejtë Diellore
8.5.2 Muri i Trombit
8.5.3 Atria dhe Patio
8.5.4 Ftohja pasive - Ventilimi
8.5.5 Strategjitë për ventilim
8.5.6 Ventilimi i tërthortë
8.5.7 Ventilimi në parim të oxhakut
8.5.8 Ftohja - Lagështimi i ajrit
8.5.9 Ftohja - Energjia gjeotermale
8.5.10 Shtëpitë në tokë
8.5.11 Fensterimi
8.5.12 Fasadat e mençura

8.6 PRINCIPET AKTIVE TË PROJEKTIMI TË QËNDRUESHËM
8.6.1 Të pamurit
8.6.2 Ndriçimi artificial
8.6.2.1 Këndi hapësinor
8.6.2.2 Intensiteti i dritës
8.6.2.3 Llojet e trupave ndriçues
8.6.2.4 Ndriçimi estetik vizual

8.6.3 HVAC

8.6.3.1 Ngrohja qendrore

8.6.3.2 Llojet e ngrohjes qendrore

8.6.3.3 Ngrohja etazhe

8.6.3.4 Ngrohja me avull

8.6.3.5 Ngrohja me panele

8.6.3.6 Ngrohja së largu

8.6.3.7 Trupat ngrohës

8.6.3.8 Llogaritja e radiatorëve

8.6.3.9 Trupat ngrohës me gypa

8.6.3.10 Konvektorët

8.6.3.11 Kaldajat

8.6.3.12 Kaldatorja

8.6.3.13 Oxhaku

8.6.4 Energjia solare

8.6.4.1 Potenciali i energjisë diellore

8.6.4.2 Orientimi i kolektorëve dhe këndi i azimitit 
8.6.5 Hidro Energjia

8.6.5.1 Potenciali Hidro-energjetik

8.6.6 Energjia e erës

8.6.6.1 Njësitë Ekzistuese

8.6.6.2 Potenciali i Energjisë nga era

8.6.6.3 Kërkesat për një mulli të erës

8.6.7 Himawari - Sistemi i ndriçimit

8.6.8 Ajrimi

8.6.8.1 Materiet me erë

8.6.8.2 Temperatura dhe lagështia

8.6.8.3 Llojet e shtypjeve gjatë ajrimit artificial

8.6.8.4 Ventilimi qendror

8.6.8.5 Instalimet e ventilimit

8.6.8.6 Furnizimi me ajër

8.6.8.7 Dhoma e pajisjeve - centralizuar/decentralizuar

8.6.8.8 Filtrimi i ajrit

8.6.8.9 Ngrohja e ajrit

8.6.8.10 Kanalet e ventilimit

8.6.8.11 Hyrja e ajrit në lokal

8.6.9 Klimatizimi

8.6.9.1 Instalimet e klimatizimit

8.6.9.2 Kthina e klimatizimit

8.6.9.3 Regjimi dimëror

8.6.9.4 Regjimi veror

8.6.9.5 Sistemet e klimatizimit

8.6.9.6 Sistemet e klimatizimit me (Fan Coil)

8.6.9.7 Kthinat qendrore

8.6.9.8 Pajisjet shumë zonale të klimatizimit

8.6.9.9 Freskuesit-qilarët

8.6.10 Gjeotermale - sistemi aktiv

IX : SHEMBUJ STUDENTESH - NIVELI MASTER

9.1 SHEMBULL STUDIMOR 1

9.2 SHEMBULL STUDIMOR 2

9.3 SHEMBULL STUDIMOR 3

\section{$X: \quad$ ARKITEKTURA - UJI}

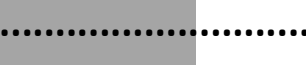

\subsection{UJ NATYROR}

10.1.1 Uji atmosferik

10.1.2 Uji sipërfaqësor

10.1.3 Uji nëntokësor

\subsection{VEÇORITË E UJIT}

10.2.1 Veçoritë fizike të ujit

10.2.2 Veçoritë kimike të ujit

10.2.3 Veçoritë biologjike të ujit

10.3 PËRMIRËSIMI I CILËSISË SË UJIT

10.4 FURNIZIMI ME UJË

10.5 KAPTAZHI I UJIT SIPËRFAQËSOR 
10.6 KAPTAZHI I UJIT NËNTOKËSOR

10.7 PUSET GYPORE

10.8 OBJEKTET PËR KAPTAZHIN E UJIT BURIMOR

10.9 PAJISJET PËR SHTYTJEN E UJT

10.10 PAISJET E UJËSJELLËSIT

10.10.1 Sjellja e ujit deri te konsumuesit

10.11 LLOJET E RRJETIT TË UJËSJELLËSIT

10.12 TUBAT UJËSJELLËSE

10.13 KYÇJA SHTËPIAKE

\section{XI : QASJA NË LËVIZJE}

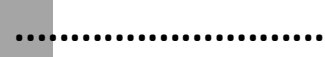

11.1 ASHENSORI

11.2 INOVIMET E NEVOJSHME 11.2.1 Multi

XII : ARKITEKTURA - MJEDISI

12.1 DEPONITË E BRAKTISURA

12.1.1 Deponia në Kelmend

12.1.2 Parku industria në Mitrovicë

12.2 DEPONITË E HIRIT NGA TERMOELEKTRANAT

12.2.1 Deponia e TC-A

12.2.2 Deponia e TC-B

12.3 GURORET E BRAKTISURA

12.4 VLERËSIMI I NDIKIMIT NË MJEDIS

12.4.1 Përshkrimi i lokacionit dhe mjedisi

12.4.2 Popullata dhe vendbanimi

12.4.3 Erërat

12.4.4 Pedologjia

12.4.5 Bimësia dhe vegjetacioni

12.4.6 Fauna

12.4.7 Peizazhi

12.4.8 Ajri

12.4.9 Uji

12.4.10 Vlerësimet e ndikimeve në mjedis

12.4.11 Rikultivimi teknik

12.4.12 Rikultivimi bioteknik

12.4.13 Veçoritë e sigurisë

12.5 GURORJA E BRAKTISUR NË VASILEVË

12.5.1 Vlerësimet e ndikimeve në mjedis, Vasilevë

12.5.2 Ujërat nëntokësorë

12.5.3 Stabiliteti i terrenit

12.5.4 Flora

12.5.5 Fauna

12.5.6 Peizazhi 

12.5.7 Dukshmëria
12.5.8 Masat për parandalimin e ndikimeve në mjedis
12.5.9 Ndikimet në tokë
12.5.10 Trashëgimia kulturore
12.5.11 Kualiteti i ujit dhe drenazhimi
12.5.12 Kushtet ekologjike
12.5.13 Kualiteti i ajrit
12.5.14 Zhurma
12.4.15 Rikultivimi teknik
12.5.16 Punimet përgat. për rehabilitimin e gurores
12.5.17 Rikultivimi Bioteknik
12.4.18 Gjendja e eks. dhe karakteristikat pedologjike
12.5.19 Rikultivimi biologjik
12.5.20 Rikultivimi bioteknik
12.5.21 Veçoritë e sigurisë
12.5.22 Rekomandimet

XIII : MBETURINAT - MJEDISI

13.1 MBETURINAT

13.2 KLASIFIKIMI DHE LLOJET E MBETURINAVE

13.3 MBETURINAT KOMUNALE

13.4 MBETURINAT E NDËRTIMIT

XIV : ARKITEKTURA NË KONTEKST

14.1 SFIDAT E QYTETIT ME ZHVILLIM TË SHPEJTË

14.2 ZHVILLIMI I PRISHTINËS

14.3 MASTER PLANI - 1987

14.4 STRUKTURA EKZISTUESE URBANE E PRISHTINËS

14.5 DALLIMET KONCEPTUALE

14.6 BANIMI - ATRIBUTET EKZISTUESE

14.7 GENESIS - ULPIANA

14.7.1 Banimi - Rrokaqiejt

14.7.2 Rrokaqiejt ndryshe

14.7.3 Planet rregullative

14.8 ZHVILLIMI I PRISHTINËS SË RE

14.9 KONCEPTI I STRUKTURËS SË RE URBANE

XV : PROCESI I INTEGRUAR I PROJEKTIMIT

15.1 ANATOMIA - MODELI I PROJEKTIMIT TË INTEGRUAR

15.2 DALLIMI I SË TASHMES

15.3 FAKTORËT LOKAL

15.4 OBJEKTIVAT E PROJEKTIMIT TË INTEGRUAR

15.5 ZHVILLIMI I HAPËSIRËS KONCEPTUALE 


\subsection{EU}

15.6.1 Strategjia 20/20/20

15.7 ADOPTIMI I STANDARDEVE

15.8 IDENTITETI KULTUROR DHE REGJIONAL

15.9 PERSPEKTIVAT

XVI : STANDARDET PROJEKTUESE

16.1 STANDARDET PROJEKTUESE

16.6.1 Personat me nevoja të veçanta 
SHKURTESAT - PËRKUFIZIMET

ACE:

Architect's Council of Europe. Këshilli i arkitektëve të Evropës, ACE, i themeluar në Treviso (Itali), më 11 maj 1990. Duke bashkuar ish-Komitetin e arkitektëve të Evropës së bashkuar (CLAEU) dhe ish-Këshillin e arkitektëve Evropian (AZO). Struktura e punës së ACE është e konceptuar në atë mënyrë që ruan dhe siguron një nivel të lartë të efikasitetit në arkitekturë, në Bashkësinë Evropiane si dhe promovon politikat profesionale.

ASHRAE:

American Society of Heating, Refrigerating and Air-Conditioning Engineers. Është një organizatë teknike ndërkombëtare për të gjithë individët dhe organizatat e interesuara në Ngrohje, Ventilim, Ajër të kondicionuar dhe Ftohje. ASHRAE ofron shumë mundësi për pjesëmarrje në zhvillimin e njohurive të reja nëpërmjet kërkimit shkencor dhe të një numri të komiteteve teknike. Shoqata ka rreth 50.000 anëtarë dhe ka selinë në Atlanta, Gjeorgji në Shtetet e Bashkuara.

BIM:

Building information modeling. Është procesi i projektimit, krijimit dhe menaxhimit e të dhënave të ndërtimit, gjatë ciklit të jetës së saj. BIM përfshin paraqitjen e projekteve ndërtimore, gjenerimin e tyre në forma të caktuara që varen nga gjeometria e tyre, marrëdhëniet ndërmjet veti dhe atributet e elementeve përbërëse. Mjetet e BIM-it gjatë projektimit, mundësojnë gjenerimin e pakufishëm e pjesëve përbërëse të një projekti të ndërtimit, vizatimi i modelit, finalizimi i modeleve për prodhimin praktik me CAM.

CAA:

Commonwealth Association of Architects. Commonwealth Asociacioni i Arkitektëve është një organizatë e Instituteve të Arkitektëve në vendet e komunitetit të "Commonwealth-it". Ajo u themelua në vitin 1965 për të promovuar bashkëpunimin dhe avancimin e arkitekturës në komunitet dhe në veçanti për të rritur njohuritë arkitektonike, aktualisht numëron 37 anëtarë. Shoqata është e njohur mirë për procedurat e saj për njohjen e kurrikulave dhe kurseve në arkitekturë, e cila organizon komisione të ekspertëve për të vlerësuar kurset në shkolla. Këto rezultate organizohen në një listë të kualifikimeve, pastaj rekomandohen për njohje nga anëtarët e tjerë.

CSU:

California State University. Një lider i edukimit të studentëve me cilësi të lartë. Me 23 kampuse, rreth 412.000 studentë, me 43.000 staf të fakultetit, më i madhi dhe më i gjithanshmi, gjithashtu edhe sistemi më i mirëfilltë universitar në vend (SHBA). 
DHA:

Definimi $i$ hapësirës arkitektonike. Hapësira është një nga termët më të hapura, sa që filozofia, të gjitha shkencat natyrore, shoqërore dhe artet, rishtazi e kanë vështirë për ta interpretuar.

Hapësira është termi më i përgjithshëm që është i karakterizuar nga: gjithanshmëria, përjetësia, dimensionaliteti. Andaj, hapësira është e gjitha që është, çfarë ishte dhe çfarë do të jetë.

\section{LEED:}

Leadership in Energy and Environmental Design. Është një standard-certifikim i njohur ndërkombëtarisht i "ndërtesave të gjelbërta", vlerëson dhe njeh certifikimin e palës së tretë që një ndërtesë ose një komunitet është projektuar dhe ndërtuar duke përdorur strategjitë me qëllim për të përmirësuar performancën: si kursimi i energjisë, efikasitetin e përdorimit të ujit, zvogëlimi i emetimeve të $\mathrm{CO} 2$, përmirësimi i komforit të brendshëm, menaxhimi i resurseve dhe në vëmendje të veçantë ndaj ndikimeve të tyre. Standard i themeluar nga U.S. Green Building Council.

\section{OECD:}

Organisation for Economic Co-operation and Development. Organizata për Bashkëpunim Ekonomik dhe Zhvillim. Krijimi i ka rrënjët në rrënojat e Evropës pas Luftës së Dytë Botërore. Udhëheqësit evropianë kanë kuptuar se mënyra më e mirë për të siguruar paqe të qëndrueshme, është duke theksuar bashkëpunimin dhe rinovimin. Sot, organizata ka 34 vende anëtare në mbarë botën, ku të gjithë anëtarët janë të hapura në identifikimin e problemeve, diskutimeve, analizave dhe promovimi i politikave në shtetet anëtare.

\section{DB, Design-Build:}

Projekt-ndërtimi, metodë në ofrimin e projektit i cili është duke u përdorur në industrinë e ndërtimit. Kjo është një metodë e dorëzimit të projektit në të cilin, projektimi - ndërtimi shërbime të kontraktuara në një njësi të vetme të njohur si kontratë projekt-ndërtim.

\section{PM:}

Particulate matter. Lëndë me grimca shumë të vogla. Ndahen kryesisht në dy grupe $\mathrm{PM}_{10}$, me grimca më të vogla se $10 \mu \mathrm{m}$ dhe $\mathrm{PM}_{2.5}$, me grimca më të vogla se $2.5 \mu \mathrm{m}$. Grimcat e ndotjes janë një grup i komponentëve: grimca pluhuri, metalet në tokë, gazrat nga trafiku i makinave, emetimet e pluhurit nga termocentralet, duke përfshirë silikate apo hidrokarbure.

\section{QALY:}

Quality Adjusted Life Years. Një njësi matëse që kombinon vdekshmërinë dhe përmirësimet në cilësinë e jetës. Llogaritet (koeficienti 1-100) duke matur vitet totale të humbura për shkak të një sëmundjeje ose të fituar nga trajtimi mjekësor.

\section{RIBA:}

The Royal Institute of British Architects. Instituti Mbretëror i Arkitektëve Britanikë, një pionier në projektimin e ndërtesave më të mira, komunitete dhe mjedisit nëpërmjet arkitekturës. Ofrojnë standarde, trajnime, mbështetja dhe njohja në Mbretërinë e Bashkuar dhe jashtë vendit. Me qeverinë (UK), bashkëpunojnë duke përmirësuar cilësinë e projektimit e ndërtesat publike, shtëpive të reja të banimit dhe komuniteteve të reja. 
SBS:

Sick Building Syndrome. Sindromi i ndërtesës së sëmur, përdoret për të përshkruar situatat në të cilat ndërtimet "vuajnë" nga një mungesë akute e shëndetit dhe komforit. Simptomat korrespondojnë me kohën e kaluar në ndërtesë, në të cilën nuk mund të identifikohen sëmundje të veçanta apo shkaqet e këtyre sëmundjeve. 'Sëmundje' të tilla mund të lokalizohen në një dhomë të veçantë ose në një zonë, ose mund të jetë i përhapur në të gjithë ndërtesën. Një raport nga Organizata Botërore e Shëndetësisë ka theksuar se $30 \%$ të ndërtesave të reja dhe të rinovuara në të gjithë botën mund të jetë subjekt $\mathrm{i}$ ankesave shëndetësore që lidhen me cilësinë e ajrit të brendshëm.

\section{USGBC:}

U.S. Green Building Council. Këshilli Green Building SHBA është një organizatë që promovon qëndrueshmërinë në projektimin, ndërtimin dhe funksionimin e ndërtesave. Organizata ka më shumë se 18.500 anëtarë nga të gjitha sektorët e ndërtimit.

\section{WHO:}

World Health Organisation. Organizata Botërore e Shëndetësisë. Është një agjenci e specializuar e Kombeve të Bashkuara me përgjegjësi parësore për çështje të shëndetit ndërkombëtar dhe shëndetit publik. Kjo organizate e cila numëron 191 vende të botës shkëmben dijet dhe përvojën e saj me synimin për të bërë të mundur shëndetin nga të gjithë qytetarët. Qendra është në Gjenevë. 


$\begin{array}{ll}\text { AER } & \text { Agjencioni Evropian për Rindërtim } \\ \text { AMMK } & \text { Agjencia për Mbrojtjen e Mjedisit të Kosovës } \\ \text { AKM } & \text { Agjencioni Kosovar i Mirëbesimit } \\ \text { ASK } & \text { Agjencia e Statistikave të Kosovës } \\ \text { BE } & \text { Bashkimi Evropian } \\ \text { ESK } & \text { Enti i Statistikave të Kosovës } \\ \text { GTZ } & \text { Bashkëpunimi Teknik Gjerman } \\ \text { IHMK } & \text { Instituti Hidrometeorologjik i Kosovës } \\ \text { IKSHPK } & \text { Instituti Kombëtar i Shëndetësisë Publike të Kosovës } \\ \text { KFOR } & \text { Forcat Paqeruajtëse të NATO-s në Kosovë } \\ \text { KEK } & \text { Korporata Energjetike e Kosovës } \\ \text { KUR } & \text { Kompania e Ujësjellësve Rajonal } \\ \text { KK } & \text { Kuvendi Komunal } \\ \text { MEF } & \text { Ministria e Financave } \\ \text { MMPH } & \text { Ministria e Mjedisit dhe Planifikimit Hapësinor } \\ \text { OSBE } & \text { Organizata për Siguri dhe Bashkëpunim në Evropë } \\ \text { PKVM } & \text { Plani i Kosovës për Veprim në Mjedis } \\ \text { PPU } & \text { Plani i Përgjithshëm Urbanistik } \\ \text { QKMF } & \text { Qendra Komunale e Mjekësisë Familjare } \\ \text { SHUKOS } & \text { Shoqata e Ujësjellësve dhe Kanalizimeve të Kosovës } \\ \text { TC } & \text { Termocentral } \\ \text { TCA } & \text { Termocentrali A } \\ \text { TCB } & \text { Termocentrali B } \\ \text { UA } & \text { Udhëzim Administrativ } \\ \text { UNMIK } & \text { Misioni i Kombeve të Bashkuara në Kosovë } \\ \text { VMV } & \text { Vlerat Mesatare Vjetore } \\ \text { VNM } & \text { Vlerësimi i Ndikimit në Mjedis } \\ \text { ZRRUM } & \text { Zyra Rregullatori për Ujë dhe Mbeturina } \\ \text { PM10 } & \text { Partikula 10 } \mu \text { g } \\ \text { PM } 2.5 & \text { Partikula } 2.5 \mu \text { g }\end{array}$




\section{INDEKSI I FIGURAVE - TABELAVE}

\section{FIGURAT :}

Figura 1. Manhattan.

(Burimi): CCO. Public Domain

Figura 2. Ulqini, kalaja e vjetër

(Burimi): Bujar Bajçinovci, 2014.

Figura 3. Vitruvius, modelet kryesore gjatë projektimit (Burimi): Bujar Bajçinovci

Figura 4. QALY. Koeficienti

(Burimi): Bujar Bajçinovci

Figura 5. Filharmonia në Szczecin. PL. Fituesit; Alberto Veiga \& Fabrizio Barozzi (Burimi): Kapitel, 2014. Creative Commons Attribution ShareAlike 1.0

Figura 6. Filharmonia në Szczecin. PL. Fituesit; Alberto Veiga \& Fabrizio Barozzi (Burimi): Kapitel, 2014. Creative Commons Attribution ShareAlike 1.0

Figura 7. Filharmonia në Szczecin. PL. Fituesit; Alberto Veiga \& Fabrizio Barozzi (Burimi): DrKssn. Creative Commons Attribution ShareAlike 1.0

Figura 8. Filharmonia në Szczecin. PL. Fituesit; Alberto Veiga \& Fabrizio Barozzi (Burimi): UMSzczecin. Creative Commons Attribution ShareAlike 4.0

Figura 9. Hartë e trafikut urban

(Burimi): Fisnik Ismaili, 2013. Creative Commons Attribution ShareAlike 3.0 Unported

Figura 10. Qyteti i Prishtinës, vendi i zgjedhur për garazhin publik të qytetit, 2004. (Burimi): Bujar Bajçinovci, GoogleEarth. 2011.

Figura 11. Qyteti Prishtinë, pozicioni i garazhës me QKUK, PR.

(Burimi): Bujar Bajçinovci, GoogleEarth. 2011.

Figura 12. Fija e flokut të njeriut.

(Burimi): http://baaqmd.gov/Divisions/Planning-and-Research/Particulate-Matter.aspx_.Maj/2011.

Figura 13. Emisionet e matura të pluhurit për TC B1 në vitin $2007 / 2008$, në mg/Nm3. (Burimi): Përpunuar Bujar Bajçinovci, MMPH. Raport për gjendjen e ajrit. 2012. 
Figura 14. Emisionet e matura të pluhurit për TC B2 në vitin 2007/2008 në mg/Nm3. (Burimi): Përpunuar Bujar Bajçinovci, MMPH. Raport për gjendjen e ajrit. 2012.

Figura 15. Emisionet e kalkuluara të pluhurit në mg/Nm3 për TC A, 2007-2011. (Burimi): Përpunuar Bujar Bajçinovci, MMPH. Raport për gjendjen e ajrit. 2012.

Figura 16. Emisionet e kalkuluara të pluhurit në mg/Nm3 për TC B 2007-2011. (Burimi): Përpunuar Bujar Bajçinovci, MMPH. Raport për gjendjen e ajrit. 2012.

Figura 17. Emisionet e kalkuluara të SO2 në mg/Nm3 për TC A 2007-2011. (Burimi): Përpunuar Bujar Bajçinovci, MMPH. Raport për gjendjen e ajrit. 2012.

Figura 18. Emisionet e kalkuluara të SO2 në mg/Nm3 për TC B 2007-2011. (Burimi): Përpunuar Bujar Bajçinovci, MMPH. Raport për gjendjen e ajrit. 2012.

Figura 19. Emisionet e kalkuluara për $\mathrm{CO}_{2}$ në TC A dhe TC B, ton/vit 2007-2011. (Burimi): Përpunuar Bujar Bajçinovci, MMPH. Raport për gjendjen e ajrit. 2012.

Figura 20. Qyteti Prishtinë, Stacionet matëse të cilësisë së ajrit. PM10 dhe PM2.5 (Burimi): Përpunuar Bujar Bajçinovci, IMK. Raport për gjendjen e ajrit. 2012.

Figura 21. Vlerat në stacionet matëse të cilësisë së ajrit. $\mathrm{PM}_{10}$ dhe $\mathrm{PM}_{2.5}$ (Burimi): Bujar Bajçinovci, IHMK. 2010

Figura 22. Mesatarja e cilësisë së ajrit në Londër. Lënda Grimcore $\mathrm{PM}_{10}$ (Burimi):_http://www.londonair.org.uk.

Figura 23. Mesatarja e cilësisë së ajrit në Londër. Lënda Grimcore $\mathrm{PM}_{2.5}$ (Burimi): http://www.londonair.org.uk.

Figura 24. Përqendrimi i $\mathrm{PM}_{10}$ dhe $\mathrm{PM}_{2.5}$ në Prishtinë, Dhjetor/2015 (Burimi): Latifi, L. \& Shala, Sh. IHMK. 2015.

Figura 25. Përqendrimi i ndotësve të gaztë në Prishtinë, Dhjetor/2015 (Burimi): Latifi, L. \& Shala, Sh. IHMK. 2015.

Figura 26. Përqendrimi i ndotësve të gaztë në Prishtinë, Ulpianë. Janar/2016 (Burimi): Komuna e Prishtinës. Pilot projekt. http://air.fara.rocks/. 2016

Figura 27. Përqendrimi i ndotësve të gaztë në Prishtinë, Ulpianë. Janar/2016 (Burimi): Komuna e Prishtinës. Pilot projekt. http://air.fara.rocks/. 2016

Figura 28. Fallingwater nga Frank Lloyd Wright (Burimi): Chris, Spike55151, 2005. Creative Commons Attribution ShareAlike 2.0.

Figura 29. Guggenheim Museum, New York nga Frank Lloyd Wright (Burimi): heipei, Creative Commons Attribution ShareAlike 2.0

Figura 30. Tumë termitesh, Namibia.

(Burimi): David Siu, 2010. Attribution 2.0 Generic. 
Figura 31. Tumë termitesh. Struktura e mbrendshme organizative. (Burimi): Bujar Bajcinovci. 2015.

Figura 32. Dy të moshuar afër një Tumë termitesh. Northern Territory, Australia. (Burimi): thinboyfatter, 2010. Creative Commons Attribution ShareAlike 3.0.

Figura 33. Tumë termitesh. Struktura funksionale.

(Burimi): J. Brew.2009. Creative Commons Attribution ShareAlike 3.0

Figura 34. Oxhaqet, formacion shkëmbor, Goreme, Cappadocia, Turqi qendrore. (Burimi): Benh LIEU SONG.2010. Creative Commons Attribution ShareAlike 3.0 Unported

Figura 35. Cappadocia. Foto nga Murat Ertuğrul Gülyaz.

(Burimi): Republika e Turqisë. Cappadocia, Publikim i Ministrisë së kulturës dhe turizmit. 2012.

Figura 36. Toaleti. Cappadocia. Fotot nga Murat Ertuğrul Gülyaz.

(Burimi): Republika e Turqisë. Cappadocia, Publikim i Ministrisë së kulturës dhe turizmit. 2012.

Figura 37. Cappadocia, foto nga Murat Ertuğrul Gülyaz.

(Burimi): Republika e Turqisë. Cappadocia, Publikim i Ministrisë së kulturës dhe turizmit. 2012.

Figura 38. Cappadocia

(Burimi): Reric and Mary Ellen, 2007. (Flickr). E licensuar nga Creative Commons Attribution ShareAlike 2.0 Generic.

Figura 39. Cappadocia. Fotot nga Murat Ertuğrul Gülyaz.

(Burimi): Klim Levene, 2017. (Flickr). E licensuar nga Creative Commons Attribution 2.0 Generic

Figura 40. Cappadocia

(Burimi): Klim Levene, 2017. (Flickr). E licensuar nga Creative Commons Attribution 2.0 Generic

Figura 41. Cappadocia

(Burimi): Klim Levene, 2017. (Flickr). E licensuar nga Creative Commons Attribution 2.0 Generic

Figura 42. Santorini. Greece. Struktura urbane.

(Burimi): Mstyslav Chernov, 2008. Commons Attribution ShareAlike 3.0 Unported

Figura 43. Santorini. Greece. Struktura urbane.

(Burimi): Mstyslav Chernov, 2008. Commons Attribution ShareAlike 3.0 Unported

Figura 44. Santorini. Greece. Struktura urbane.

(Burimi): Harvey Barrison, 2009. Creative Commons Attribution ShareAlike 3.0 Unported

Figura 45. Santorini. Greece. Struktura urbane.

(Burimi): Mstyslav Chernov, 2011. Commons Attribution ShareAlike 3.0 Unported

Figura 46. Santorini. Greece. Struktura urbane.

(Burimi): Mstyslav Chernov, 2009. Commons Attribution ShareAlike 3.0 Unported 
Figura 47. Ulqini peisazh, struktura urbane (Burimi): Bujar Bajçinovci, 2014

Figura 48. Ulqini, kalaja.

(Burimi): Bujar Bajcinovci, 2014.

Figura 49. Ulqini.

(Burimi): Bujar Bajcinovci

Figura 50. Ulqini. Hyrja në kala, 2015.

(Burimi): Bujar Bajcinovci

Figura 51. Ulqini. Hyrja në kala nga lindja, 2015.

(Burimi): Bujar Bajçinovci

Figura 52. Ulqini.

(Burimi): GoogleEarth, Bujar Bajçinovci

Figura 53. Ulqini. Struktura e komunikimit, 2015.

(Burimi): Bujar Bajçinovci

Figura 54. Berati. Struktura urbane. 2014.

(Burimi): SarahTz, 2014. Creative Commons Attribution ShareAlike 3.0 Unported.

Figura 55. Berati. Struktura urbane. 2014.

(Burimi): Franco Pecchio, 2014. Creative Commons Attribution ShareAlike 3.0 Unported

Figura 56. Berati. Muzeu Etnologjik.

(Burimi): Jason Rogers, 2007. Creative Commons Attribution ShareAlike.

Figura 57. Berati. Strukturë urbane. 2012

(Burimi): Ark. Ramadan Aliu.

Figura 58. Berati. Struktura e kështjellës. 2012

(Burimi): Ark. Ramadan Aliu.

Figura 59. Berati. Struktura urbane.

(Burimi): SarahTz, 2014. Attribution 2.0 Generic

Figura 60. Gjirokastra. Struktura e urbane.

(Burimi): SarahTz, 2014. Attribution 2.0 Generic

Figura 61. Gjirokastra. BabaMeto Hostel.

(Burimi): SarahTz, 2014. Attribution 2.0 Generic

Figura 62. Durrës, Strukturë urbane

(Burimi): SarahTz, 2014. Attribution 2.0 Generic 
Figura 63. Berati. Muzeu Etnologjik.

(Burimi): Peter Boer, 2012. Creative Commons Attribution ShareAlike.

Figura 64. Ohri. Strukturë urbane. 2019

(Burimi): UNESCO Venice Office.(2009). Macedonian cultural heritage. Ohrid world heritage site.

Figura 65. Ohri. Strukturë urbane. 2012

(Burimi): UNESCO Venice Office.(2009). Macedonian cultural heritage. Ohrid world heritage site.

Figura 66. Prizreni. Strukturë urbane. 2012

(Burimi): Berat Hoxha. 2012. (Flickr). Creative Commons Attribution-Share Alike 3.0

Figura 67. Kulla e Destan Shurdhajt. Struktura arkitektonike. F. Banjë, Malishevë. (Burimi): Flamur Doli. Arkitektura vernakulare e Kosovës. SHRTA, 2009.

Figura 68. Climate consultant 6.0 Beta. Diagrami i zonës së komforit. (Burimi): Bujar Bajçinovci, 2017. Quaestiones Geographicae, 2017.

Figura 69. Trëndafili i erërave

(Burimi): Bujar Bajçinovci, 2015

Figura 70. Trëndafili i erërave për Prishtinë.

(Burimi): Bujar Bajçinovci, 2015

Figura 71. Diagrami i temperaturave mesatare (Max. dhe Min.) mujore për Prishtinë. (Burimi): Bujar Bajçinovci, 2017

Figura 72. Diagrami i temperaturave mesatare (Max. dhe Min.) mujore për Ulqin. (Burimi): Bujar Bajçinovci, 2017. Quaestiones Geographicae, 2017.

Figura 73. Diagrami i reshjeve mesatare mujore për Prishtinë.

(Burimi): Bujar Bajçinovci, 2017

Figura 74. Diagrami i ditëve me diell, (orë në ditë), mujore për Prishtinë.

(Burimi): Bujar Bajçinovci, 2017

Figura 75. Ditë me diell, Ulqin 2017

(Burimi): Bujar Bajçinovci, 2017

Figura 76. Strukturë urbane, e vjetra dhe e reja. Ulqin 2017.

(Burimi): Bujar Bajçinovci, 2017

Figura 77. Analiza: Perspirimi, evaporimi dhe ndikimi solar tek njeriu (Burimi): Bujar Bajçinovci, 2015

Figura 77-A. Ekuilibri energjetik tek njeriu. Aktiviteti dhe ushqimi (Burimi): Bujar Bajçinovci, 2015.

Figura 78. Diagrami i zonës së komforit, zonat toleruese dhe individuale (Burimi): Bujar Bajçinovci, 2017 
Figura 79. Komfori, ndjenjë e një natyre të përcaktuar nga subjektiviteti personal. (Burimi): Bujar Bajçinovci, 2017

Figura 80. Kursimet energjetike, kriteriume konforti: Tradicionale dhe të avancuara (Burimi): Bujar Bajçinovci, 2017

Figura 81. Të përjetuarit e komforit. (Burimi): Bujar Bajcinovci, 2015

Figura 82. Mostër: Anketa, vlerësimi i rezultateve. Përmbledhje (Burimi): Barbera'n, A. et al. 2015 The ecology of microscopic life in household dust. 2015.

Figura 83. Sistemet e klimatizimit - Split. Gjendja aktuale e zakonshme, filterët. (Burimi): Bujar Bajcinovci. 2015.

Figura 84. Higjiena dhe pajisja, bakteret dhe këpurdhat/funghi. (Burimi): Bujar Bajcinovci. 2015.

Figura 85. Realiteti i 15\% të punësuarve.

(Burimi): Bujar Bajçinovci, 2017

Figura 86. Rritja e nivelit të zhurmës.

(Burimi): Bujar Bajçinovci, 2015

Figura 87. Modalitetet. Niveli i koncentrimit në punë. (Burimi): Bujar Bajçinovci, 2017

Figura 88. Ndriçimi natyror në legjislacion. Sipërfaqja dritare në \% të sip. dyshemesë. (Burimi): Bujar Bajçinovci, 2017

Figura 89. Befreiungshalle1. Kelheim, Bavaria. Gjermani

(Burimi): Patrick Huebgen, 2007. Own work (own picture). Public Domain Commons

Figura 90. Masdar City, Abu Dhabi.

(Burimi): stuart.childs 2013. (Flickr). Commons Attribution ShareAlike 2.0

Figura 91. Masdar City, Abu Dhabi.

(Burimi): Forgemind ArchiMedia 2010. Commons Attribution ShareAlike 2.0

Figura 92. Emanimet e $\mathrm{CO}_{2}$ në përgjithësi

(Burimi): Bujar Bajçinovci, 2017

Figura 93. Antarctic Blue

(Burimi): Christopher Michel, 2011. (Flickr). Commons Attribution ShareAlike 2.0

Figura 94. Relacioni i kërkesave të resurseve natyrore dhe rezervat Botërore. (Burimi): Bujar Bajçinovci, 2017 
Figura 95. Relacioni urban. Emanimi i Industrisë në cilësinë e ajrit të venbanimeve (Burimi): Bujar Bajçinovci. Urban Resettlements and Environmental Engineering as a Context for Human Development. A Case Study: Hade. Journal of Applied Engineering Sciences. Vol. 6(19), Is. 2/2016, Art. No. 203, pp. 7-14. 2016, DOI: 10.1515/jaes-2016-0011

Figura 96. Konsumi i energjisë elektrike, Kosova

(Burimi): http://data.worldbank.org/indicator/EG.USE.ELEC.KH.PC. 2015.

Figura 97. Konsumi Energjetik, Kosova

(Burimi): http://data.worldbank.org/indicator/EG.USE.PCAP.KG.OE. 2015.

Figura 98. Konsumi i energjisë, karburantet, Kosova

(Burimi): http://data.worldbank.org/indicator/EG.USE.COMM.FO.ZS. 2015.

Figura 99. Mbeturinat e ripërtëritshme të djegshme, Kosova

(Burimi): http://data.worldbank.org/indicator/EG.USE.CRNW.ZS. 2015.

Figura 100. Ameba, DAP.

(Burimi): Ahmet Hadrović. DAP. (2004). Definiranje Arhitektonskog Prostora. Sarajevo, BiH.

Figura 101. Strategjitë e menaxhimit energjetik

(Burimi): Bujar Bajçinovci

Figura 102. Relacionet e ndërvarura, Projektimi i qendrueshëm arkitektonik (Burimi): Bujar Bajçinovci, 2017

Figura 103. Efiçienca e modelit, Projektimi i qendrueshëm arkitektonik (Burimi): Bujar Bajçinovci, 2017

Figura 104. Efiçienca e modelit, Variacionet e hulumtuara në kërkim të zgjidhjeve të mundëshme.

(Burimi): Bujar Bajçinovci, 2017

Figura 105. Diagrami i procesit të hulumtimit, analizës dhe i përfundimit, Dr.sc. (Burimi): Bujar Bajçinovci, 2012.

Figura 106. Projektimi qendrueshëm, veçoritë naturore dhe parimet e ligjeve të fizikës (Burimi): Bujar Bajçinovci, 2017. Quaestiones Geographicae, 2017.

Figura 107. Uji. Të dhënat statistikore. 27/06/2017.

(Burimi): World Statistics, V1.1. Tobias Oliver Khan. Trendet aktuale.

Figura 108. UBC. CIRS. Qendra për Kërkime Interaktive mbi Qëndrueshmërinë. (Burimi): Xicotencatl, (Flickr). E licensuar nga Commons Attribution ShareAlike 2.0.

Figura 109. Atmosfera, Oqeanet Modeli - parashikimet e ngrohjes sipërfaqësore (Burimi): Climate Change 2007: Synthesis Report, Intergovernmental Panel on Climate Change, IPCC 
Figura 110. Atmosfera, Oqeanet Modeli - parashikimet e ngrohjes sipërfaqësore (Burimi): Climate Change 2007: Synthesis Report, Intergovernmental Panel on Climate Change, IPCC

Figura 111. Ujëvara e Mirushës.

(Burimi): Ben Njeri, 2013. (Flickr). E licensuar nga Creative Commons Attribution ShareAlike 3.0 Unported

Figura 112. Diagrami Stereografik 3D modeli. Varshmëria pozita e diellit - objekti (Burimi): Bujar Bajçinovci, 2017

Figura 113. Diagrami Stereografik 3D modeli. Varshmëria, pozita e diellit - objekti (Burimi): Bujar Bajçinovci, 2017

Figura 114. Relacioni gjërësi dhe gjatësi gjeografike (Burimi): Përpunuar, Mike1024, (Flickr). E licensuar ngaCreative Commons Attribution ShareAlike 3.0

Figura 115. Trëndafili i erërave për Prishtinë.

(Burimi): Bujar Bajçinovci, 2017

Figura 116. Ndërvarësia e zgjedhjes së lokacionit (Burimi): Bujar Bajçinovci

Figura 117. Relacionet e sistemeve urbane (Burimi): Bujar Bajçinovci, 2017

Figura 118. Distanca minimale anësore në mes të objekteve (Burimi): Komuna e Prishtinës, Plani rregullues Prishtina e Re, 2013.

Figura 119. Distanca minimale e kombinuar në mes të objekteve (Burimi): Komuna e Prishtinës, Plani rregullues Prishtina e Re, 2013.

Figura 120. Distanca minimale në mes ndërtesave (Burimi): Komuna e Prishtinës, Plani rregullues Prishtina e Re, 2013.

Figura 120-A. Analizë e lokacionit, model nga veçoritë bioklimatike (Burimi): Bujar Bajçinovci, 2017

Figura 121. Fushë terrace orizi, reale. Honghe Hani, Kinë (Burimi): Jialiang Gao, (Flickr). E licensuar nga Creative Commons Attribution-Share Alike 3.0 Unported.

Figura 122. Ndotja, pastërtia, Prishtinë (Burimi): Numbeo, 2015. http://www.numbeo.com/common/

Figura 123. Procesi NVM në Kosovë në pajtim me ligjin nr. 03/L-214 për NVM (Burimi): Kosovë, Analiza mjedisore e shtetit. Raport i Bankës Botërore me MMPH.

Figura 124. Pika e vlimit të ujit dhe shkrirjes së akullit të ujit (Burimi): Bujar Bajçinovci,2015 
Figura 123-A. Transmetimi i nxehtësisë për murin e rrafshët (Burimi): Bujar Bajçinovci, 2015

Figura 124. Transmetimi i nxehtësisë për murin e rrafshët shumështresor (Burimi): Bujar Bajçinovci, 2015

Figura 125. Transmetimi i nxehtësisë për murin e rrafshët shumështresor (Burimi): Bujar Bajçinovci, 2015

Figura 126. Transmetimi i nxehtësisë për murin e rrafshët, dilatimet temperaturale (Burimi): Bujar Bajçinovci, 2015

Figura 127. Procesi NVM në Kosovë në pajtim me ligjin nr. 03/L-214 për NVM (Burimi): INDEP, Efiçienca e Energjisë Bizneset, 2015.

Figura 128. Humbjet termike në objekte, vlera të përafërta (Burimi): Bujar Bajçinovci, 2015

Figura 129. Procesi NVM në Kosovë në pajtim me ligjin nr. 03/L-214 për NVM (Burimi): Termoizolim dhe modernizim me OKnauf, broshurë, 09/2014.

Figura 130. Procesi NVM në Kosovë në pajtim me ligjin nr. 03/L-214 për NVM (Burimi): Termoizolim dhe modernizim me CKnauf, broshurë, 09/2014.

Figura 131. Muri me shtresë termike

(Burimi): Termoizolim dhe modernizim me OKnauf, 09/2014.

Figura 132. Mbështjellja me shtresë termike

(Burimi): Termoizolim dhe modernizim me Knauf, 09/2014.

Figura 133. Hollësirë nga praktika profesionale (Burimi): Termoizolim dhe modernizim me Knauf, 09/2014.

Figura 134. Procesi i vendimmarrjes, lloji i termoizolimit (Burimi): Bujar Bajçinovci, 2015

Figura 135. Djellosja nga dritaret, akumulimi i nxehtësisë (Burimi): Bujar Bajçinovci, 2015

Figura 136. Muri i "Trombit", principet (Burimi): Bujar Bajçinovci, 2015

Figura 137. Qarkullimi i nxehtësisë, muri Trombe (Burimi): Bujar Bajçinovci, 2017

Figura 138. Qarkullimi i nxehtësisë, mur masë termike (Burimi): Bujar Bajçinovci, 2015 
Figura 139. Shtëpia 'SunSpace', përdorimi i murit Trombe (Burimi): naturalflow, 2007. (Flickr). E licensuar nga Commons Attribution ShareAlike 2.0.

Figura 140. Djellosja, verës, gjatë dimrit, benefite të shumta. (Burimi): Bujar Bajçinovci, 2015

Figura 141. Atria si fenomen dhe funksion arkitektonik (Burimi): Bujar Bajçinovci, 2017

Figura 142. Elementet konstruktive, djellosja dhe pajisjet (Burimi): Bujar Bajçinovci, 2017

Figura 143. Lëvizjet e masave, të ajrit, oqeanet, klima (Burimi): William Putman/NASA Goddard Space Flight Center. 2015 https://www.nasa.gov/content/a-portrait-of-global-winds

Figura 144. Siluetë qyteti, ajrimi natyror (Burimi): Bujar Bajçinovci, 2015

Figura 145. Bllok urbanistik, ndikimi i veqorive natyrore - aerosja - era (Burimi): Bujar Bajçinovci, 2015

Figura 145-A. Bllok urbanistik, ndikimi i veqorive natyrore - aerosja - era (Burimi): Bujar Bajçinovci, 2015

Figura 146. Mundësitë e ventilimit natyror (Burimi): Bujar Bajçinovci, 2015

Figura 147. Mundësitë e ventilimit natyror (Burimi): Bujar Bajçinovci, 2015

Figura 148. Efekti në lëvizjen e ajrit brenda dhe jashtë ndërtesave (Burimi): Bujar Bajçinovci, 2017

Figura 149. Hapësirë e "re" në oxhakun e termocentralit. Lodz Poland. 2015. (Burimi): IrDA, 2015. (Flickr). E licensuar nga Commons Attribution ShareAlike 2.0.

Figura 150. Parimi i Bernouli-it në objekte bashkëkohore Arkitektonike (Burimi): Bujar Bajçinovci

Figura 150-A. Vlerat aproksimative e shtypjes së erës. Detyrat themelore. (Burimi): Bujar Bajçinovci, 2015

Figura 150-B. Parimet e projektimit, ventilimi. (Burimi): Bujar Bajçinovci, 2017

Figura 150-C. Detyrat primare të ventilimit (Burimi): Bujar Bajçinovci, 2015 
Figura 151. Alhambra, Spanjë. Oborri i mbrendhëm - duke krijuar mikroklimë (Burimi): Loizeitung, 2006. WP. (Flickr). E licensuar nga Commons Attribution ShareAlike. 2.0

Figura 151-A. Pika uji, lagështimi i ajrit.

(Burimi): andreysuzdaltsev, 2015. E licensuar nga Commons Attribution ShareAlike. 2.0

Figura 152. Alhambra, Spanjë. Oborri i mbrendhëm - duke krijuar mikroklimë (Burimi): Colin Moss, 2008. (Flickr). E licensuar nga Commons Attribution ShareAlike 2.0

Figura 153. Alhambra, Spanjë. Morfologjia - Klima

(Burimi): Bujar Bajçinovci, GoogleEarth. 2011.

Figura 154. Alhambra, Spanjë. Oborri i brendshëm - duke krijuar mikroklimë (Burimi): Sebastian Appelt, 2014. (Flickr). E licensuar nga Commons Attribution ShareAlike, 4.0

Figura 155. Energjia gjeotermale, detaje nga lokacioni

(Burimi): SHERK, Shoqata për Energji të Ripërtëritshme e Kosovës, 2015.

Figura 156. Harta e temperaturës, gjeotermale, thellësi 3000m'

(Burimi): Alfred Frashëri, Nevton Kodhelaj, 2010. Burimet e energjisë gjeotermale në Shqipëri dhe platformë për përdorimin e tyre.

Figura 157. Sistemi funksional i ngrohjes pasive gjeotermale, sistem i mbyllur vertikal (Burimi): Bujar Bajçinovci, 2015

Figura 158. Projektim shumë/sistemësh. Gjeotermia (Burimi): (C) REHAU. Prospekt, 2011.

Figura 159. Shtëpitë në tokë. Island në Keldur (Burimi): Chris 73, 2006. (Flickr). E licensuar nga Commons Attribution ShareAlike 2.0

Figura 160. Earthship, Brighton Earthship pamjet (Burimi): Dominic Alves, 2008. (Flickr). E licensuar nga Commons Attribution ShareAlike 2.0

Figura 161. Inkorporimi i shtëpivë në tokë (Burimi): Bujar Bajçinovci

Figura 162. Objekt në tokë. Ohio, USA. (Burimi): Oydman, 2008. at en.wikipedia

Figura 163. Dritare Bashkëkohore (Burimi): Rollplast, broshura 2014/15

Figura 164. Ndriçim lateral arrin vetëm kaq larg në dhomë (Burimi): Bujar Bajçinovci,2015

Figura 165. Pozita e dritares dhe madhësia në faktor të ndriçimit (Burimi): (Burimi): Bujar Bajçinovci,2017 
Figura 166. Amstrdam, Borneo akcent fasade

(Burimi): Rankeelaw, 2008. (Flickr). E licensuar nga Commons Attribution ShareAlike 2.0

Figura 167. Amstrdam, Borneo

(Burimi): Fredrik Linge, 2009. (Flickr). Creative Commons Attribution ShareAlike 2.0

Figura 168. Philamlife, tower. Filipine

(Burimi): Acullador, 2009. (Flickr). Creative Commons Attribution ShareAlike 2.0

Figura 169. Federation Square. Melburne, Australia

(Burimi): eosdude, 2014. (Flickr). Creative Commons Attribution Share Alike 2.0

Figura 170. Syri

(Burimi): Foto nga 8thstar, 2006. en.wikipedia. Qasja/2015.

Figura 171. Syri

(Burimi): Javalenok, 2013. (Flickr). Creative Commons Attribution ShareAlike 3.0 Unported

Figura 172. Kuptimet themelore, fluksi dhe intensiteti i dritës, ndriçimi i ref. dhe në sip. (Burimi): Bujar Bajçinovci, 2015

Figura 173. Këndi vizual

(Burimi): (c) ERCO. Guide, 2013.

Figura 174. Njeriu, këndi i shikimit (Burimi): (C) ERCO. Guide, 2013.

Figura 175. Ndriçimi Brandenburg Gate. Ndriçimi dhe efektet në prapavijë (Burimi): Stacey MacNaught, 2012. (Flickr). E licensuar nga Creative Commons Attribution 2.0 Generic

Figura 176. Ndriçimi Brandenburg Gate. Ndriçimi dhe efektet në prapavijë (Burimi): Ed Webster, 2013. (Flickr). E licensuar nga Creative Commons Attribution 2.0 Generic

Figura 177. Aurora, Milo. Maine US.

(Burimi): Mike Lewinski, 2015. (Flickr). E licensuar nga Creative Commons Attribution 2.0 Generic

Figura 178. Kisha, Hallgrímskirkja, Reykjavik, dhe Libraria publike Shtutgart RFGJ. (Burimi): O Palson, 2011. (Flickr). E licensuar nga Creative Commons Attribution 2.0 Generic

Figura 179. Librari - Qendër mësimi. Zaha Hadid, Vienë dhe Atriumi i muzeut Mercedes Benz, Shtutgart RFGJ.

(Burimi): O Palson, 2014. (Flickr). E licensuar nga Creative Commons Attribution 2.0 Generic

Figura 180. Objekt shkollor, llogaritjet e përafërta të ndriçimit (Burimi): Bujar Bajçinovci, 2015

Figura 181. Parimi i ngrohjes gravituese

(Burimi): Bujar Bajçinovci, 2015 
Figura 182. Sistemi dy gypor me shpërndarje të poshtme (Burimi): Bujar Bajçinovci, 2017

Figura 183. Ngrohja me etazhe (Burimi): Bujar Bajçinovci, 2017

Figura 184. Radiatoret me ujë (Burimi): Cschirp, 2014. Creative Commons Attribution Share Alike 3.0 Unported

Figura 185. Aparatet ngrohëse me gypa

(Burimi): Krasniqi, F., Selimaj, R., Malsiu, I.(2004).

Figura 186. Aparatet ngrohëse me gypa (Burimi): Krasniqi, F., Selimaj, R., Malsiu, I.(2004).

Figura 187. Kaloriferi

(Burimi): Krasniqi, F., Selimaj, R., Malsiu, I.(2004).

Figura 188. Kaldaja,Hoval DuoLut LN

(Burimi): Installation \& Service manual

Figura 189. Kaldaja e lidhur me oxhakun nëpërmjet gypëzimit lidhës (Burimi): E përpunuar, Krasniqi, F., Selimaj, R., Malsiu, I.(2004).

Figura 190. Gardens by the Bay, 'photovoltaic' trees

(Burimi): TinoM, 2016. (Flickr). E licensuar nga Creative Commons Attribution 2.0 Generic

Figura 191. Farma Solare

(Burimi): Michael Mess, 2011. (Flickr). Creative Commons Attribution 2.0 Generic

Figura 192. Prodhimi i energjisë mujore nga sistemi PV

(Burimi): Vjollca Komoni, Isuf Krasniqi, Arben Leka, Ilir Gashi. Analiza e performancës së sistemit fotovoltaik me fuqi $3.9 \mathrm{kwp}$ të palidhur në rrjetin elektrik. FIEK. UP.

Figura 193. Energjia e diellit (rrezatimi) në dy ditë të ndryshme

(Burimi): Vjollca Komoni, Isuf Krasniqi, Arben Leka, Ilir Gashi. Analiza e performancës së sistemit fotovoltaik me fuqi $3.9 \mathrm{kwp}$ të palidhur në rrjetin elektrik. FIEK. UP.

Figura 193-A. Qarku ekuivalent i celulës diellore

(Burimi): Vjollca Komoni, Isuf Krasniqi, Arben Leka, Ilir Gashi. Analiza e performancës së sistemit fotovoltaik me fuqi $3.9 \mathrm{kwp}$ të palidhur në rrjetin elektrik. FIEK. UP.

Figura 194. Analiza e pjerrtësise, solstici, gjeometria e kolektoreve dhe paneleve solar (Burimi): Bujar Bajçinovci, 2015

Figura 195. Solucar PS10, Spanjë

(Burimi): afloresm, 2007. (Flickr). Creative Commons Attribution 2.0 Generic

Figura 196. Solucar PS10, PS20, Spanjë

(Burimi): Koza 1983, 2007. (Flickr). Creative Commons Attribution 3.0 Unported 
Figura 197. HC Ujmani - Energjia neto në Dispozicion

(Burimi): Jeannelle. Blanchard. KEK-energy. Një vlerësim praktik i potencialeve të BRE dhe MAK për energji në Kosovë.

Figura 198. HC e Vogla Ekzistuese - Kapaciteti Total Mujor në Dispozicion

(Burimi): Jeannelle.Blanchard. KEK-energy. Një vlerësim praktik i potencialeve të BRE dhe MAK për energji пё Kosovë.

Figura 199. HC-të e Vogla Ekzistuese - Energjia Totale Mujore në Dispozicion

(Burimi): Jeannelle.Blanchard. KEK-energy. Një vlerësim praktik i potencialeve të BRE dhe MAK për energji nё Kosovë.

Figura 200. Hidro-kapaciteti Neto Mujor në Dispozicion

(Burimi): Jeannelle.Blanchard. KEK-energy. Një vlerësim praktik i potencialeve të BRE dhe MAK për energji nё Kosovë.

Figura 201. Hidrocentrali i Dikances - Dragash

(Burimi): Nj.tytyri. 2011. (Flickr). Creative Commons Attribution-Share Alike 3.0 Unported

Figura 202. Hidro-energjia Neto Mujore në Dispozicion

(Burimi): Jeannelle.Blanchard. KEK-energy. Një vlerësim praktik i potencialeve të BRE dhe MAK për energji пё Kosovë.

Figura 203. Ndricimi solar në objekte publike, Administratë (Burimi): (c) Himawari, La Forêt Engineering Co.,Ltd. Japan

Figura 204. Cooper Veraria në Louisa, SHBA. LEED çmimi platinum (Burimi): U.S. Department of Agriculture, 2011. (Flickr). E licensuar nga Creative Commons Attribution 2.0 Generic

Figura 205. Cooper Veraria në Louisa, SHBA. LEED çmimi platinum (Burimi): U.S. Department of Agriculture, 2011. (Flickr). E licensuar nga Creative Commons Attribution 2.0 Generic

Figura 206. EarthShip, ventilimi natyror

(Burimi): Anasofiapaixao. Creative Commons Attribution ShareAlike 3.0 Unported

Figura 207. Pompidue, Paris

(Burimi): jandiano, 2008. (Flickr). Creative Commons Attribution ShareAlike 3.0 Unported

Figura 208. The Queen's Building, De Montfort University, Leicester

(Burimi): Steve Cadman, 2008. (Flickr). Creative Commons Attribution Share Alike 3.0 Unported

Figura 209. Etazhat teknike në objektet e larta

(Burimi): Bujar Bajçinovci, 2015

Figura 210. Antwerpen Stacioni, Ventilimi

(Burimi): Mark Ahsman, 2010. (Flickr). Creative Commons Attribution Share Alike 3.0 Unported

Figura 211. Antwerpen Stacioni, Ventilimi

(Burimi): ConstiAB, 2014. (Flickr). Creative Commons-NoDerivs 2.0 Generic 
Figura 212. Futja e ajrit të ngrohtë: $a$ - nga poshtë dhe b- nga lart (Burimi): Bujar Bajçinovci,2015

Figura 213. Ventilimi i tërthortë dhe ai qarkor i lokalit (Burimi): Bujar Bajçinovci, 2015

Figura 214. Mundësitë e ndryshme të vendosjes së vrimave të ventilimit. (Burimi): Bujar Bajçinovci, 2015

Figura 215. Struktura punuese e klimatizimit (Burimi): Tim Padfield, 2000. How air conditioning works.

Figura 216. University of Chicago South Campus Chiller Plant (Burimi): angwe23, 2009. (Flickr). Creative Commons-NoDerivs 2.0 Generic

Figura 217. Klimatizimi në banim, Ha Yakon (Burimi): Yoni Lerner. 2009. (Flickr). Creative Commons-NoDerivs 2.0 Generic

Figura 218. Klimatizimi, sistemi njësi

(Burimi): PEO ACWA, 2012. (Flickr). E licensuar nga Creative Commons 2.0 Generic

Figura 219. Njësia e ajrit të kondicionuar, Passage qendër tregtare në Linz, Austri (Burimi): Dein Freund der Baum, 2009. (Flickr). Creative Commons Attribution Share Alike 3.0

Figura 220. Ventilo Konvertorët (Burimi): Bujar Bajçinovci, 2015

Figura 221. WS Econ Chillers (Burimi): jblevine2004, 2011. (Flickr). Creative Commons Attribution Share Alike 3.0

Figura 222. Projekt me banim luksoz. Qillarët dhe HVAC (Burimi): Soundfighters Systems, 2007. (Flickr). Creative Commons Attribution 2.0 Generic

Figura 223. HVAC Systemi, funksioni dhe komponentët (Burimi): Tim Padfield, 2000. How air conditioning works.

Figura 224. HVAC Systemi, funksioni dhe komponentët (Burimi): @ REHAU

Figura 225. Bibliotekë, Situacioni, Therandë (Burimi): Fakulteti i Ndërtimtarisë dhe Arkitekturës, Universiteti i Prishtinës

Figura 226. Bibliotekë, Situacioni, Therandë (Burimi): Fakulteti i Ndërtimtarisë dhe Arkitekturës, Universiteti i Prishtinës

Figura 227. Bibliotekë, Situacioni, Therandë (Burimi): Fakulteti i Ndërtimtarisë dhe Arkitekturës, Universiteti i Prishtinës 
Figura 228. Bibliotekë, Situacioni, Therandë

(Burimi): Fakulteti i Ndërtimtarisë dhe Arkitekturës, Universiteti i Prishtinës

Figura 229. Pyetësori, Prishtinë

(Burimi): Fakulteti i Ndërtimtarisë dhe Arkitekturës, Universiteti i Prishtinës

Figura 230. Mindmapping

(Burimi): Fakulteti i Ndërtimtarisë dhe Arkitekturës, Universiteti i Prishtinës

Figura 231. Shkolla e mesme teknike "28 Nëntori"

(Burimi): Fakulteti i Ndërtimtarisë dhe Arkitekturës, Universiteti i Prishtinës

Figura 232. Bazat. Shkolla e mesme teknike "28 Nëntori"

(Burimi): Fakulteti i Ndërtimtarisë dhe Arkitekturës, Universiteti i Prishtinës

Figura 233. Vlerësimet energjetike. Shkolla e mesme teknike "28 Nëntori"

(Burimi): Fakulteti i Ndërtimtarisë dhe Arkitekturës, Universiteti i Prishtinës

Figura 234. MindMapping

(Burimi): Fakulteti i Ndërtimtarisë dhe Arkitekturës, Universiteti i Prishtinës

Figura 235. Rezultatet dhe statistikat e pyetësorit

(Burimi): Fakulteti i Ndërtimtarisë dhe Arkitekturës, Universiteti i Prishtinës

Figura 236. Rezultatet dhe statistikat e pyetësorit

(Burimi): Fakulteti i Ndërtimtarisë dhe Arkitekturës, Universiteti i Prishtinës

Figura 237. Albion Falls, Hamilton Ontario

(Burimi): Joe deSousa. 2012. E licensuar nga, Public Domain. CCO 1.0

Figura 238. Lumi nëntokësor, Shpella Sof Omer, Etiopi

(Burimi): Rod Waddington. 2013. (Flickr). E licensuar nga Creative Commons Attribution ShareAlike 2.0 Generic

Figura 239. $\mathrm{H}_{2} \mathrm{O}$

(Burimi): Bujar Bajçinovci, 2015

Figura 239-A. Pompa e dorës

(Burimi): Manco Capac, 2008. (Flickr). E licensuar nga Creative Commons Attribution ShareAlike 3.0 Unported

Figura 239-B. Burimi i Drinit, Radavci

(Burimi): Naserthaci, 2005. (Flickr). E licensuar nga Creative Commons Attribution ShareAlike 4.0 International

Figura 240. Ashensorët e së ardhmes

(Burimi): Bujar Bajçinovci, 2017 
Figura 241. Ashensorët e së ardhmes. Lëvizje edhe në horizontale.

(Burimi): Bujar Bajçinovci, 2017

Figura 242. Ashensorët e së ardhmes. Struktura arkitektonike të pamvarura nga transporti klasik vertikal

(Burimi): Bujar Bajçinovci, 2017

Figura 243. Mega Struktura urbane të pamvarura nga transporti klasik vertikal (Burimi): Bujar Bajçinovci, 2017

Figura 244. Pamje deponisë së Kelmendit (Burimi): AGROVET, 2013. MZHE

Figura 245. Skema e transportit të mbetjeve nga flotacioni në Tunel të Parë (Burimi): AGROVET, 2013. MZHE

Figura 246. Deponia e mbeturinave industriale nga Industria Kimike (Burimi): AGROVET, 2013. MZHE

Figura 247. Deponia Kosova A (Burimi): AGROVET, 2013. MZHE

Figura 248. Deponia Kosova B (Burimi): AGROVET, 2013. MZHE

Figura 249. Miniera në Dubovc (Burimi): Bujar Bajçinovci, AGROVET, 2013. MZHE

Figura 250. Tereni dhe morfologjia e minierës (Burimi): Bujar Bajçinovci, AGROVET, 2013. MZHE

Figura 251. Realizimi i mbylljes së puseve dhe pjeti poshtë në miniere (Burimi): Bujar Bajçinovci, AGROVET, 2013. MZHE

Figura 252. Miniera e gurit gëlqeror Vasilevë (Burimi): Bujar Bajçinovci, AGROVET, 2013. MZHE

Figura 253. Querco fraineto, Quercus cerris (Burimi): AGROVET, 2013. MZHE

Figura 254. Tereni dhe gjendja aktuale e gurores në Vasilevë (Burimi): Bujar Bajçinovci, AGROVET, 2013. MZHE

Figura 255. Tereni dhe gjendja aktuale e gurores në Vasilevë, në aksionometri (Burimi): Bujar Bajçinovci, AGROVET, 2013. MZHE

Figura 256. 3D Prezantimi, tereni dhe gjendja aktuale e gurores në Vasilevë (Burimi): Bujar Bajçinovci, AGROVET, 2013. MZHE 
Figura 257. 3D Modeli, tereni dhe gjendja e ri projektuar e gurores në Vasilevë (Burimi): Bujar Bajçinovci, AGROVET, 2013. MZHE

Figura 258. 3D Prezantimi, terreni dhe gjendja e ri kultivuar e gurorës në Vasilevë (Burimi): Bujar Bajçinovci, AGROVET, 2013. MZHE

Figura 259. 3D Prezantimi, terreni dhe gjendja e ri kultivuar e gurorës në Vasilevë (Burimi): Bujar Bajçinovci, AGROVET, 2013. MZHE

Figura 260. Kyoto, Say NO to the environmental pollution..

(Burimi): Pavel Ahmed, 2010. E licensuar nga Creative Commons Attribution ShareAlike 2.0 Generic

Figura 261. Pjesëmarrja e mbeturinave

(Burimi): MMPH. Agjencia e Kosovës për mbrojtjen e mjedisit, 2008.

Figura 262. Deponitë e egra, Prishtinë.

(Burimi): Zyra e auditorit të përgjithshem. Menaxhimi i sistemit të mbeturinave komunale në Kosovë. 2012

Figura 263. Kontejnerët dhe mbeturinat në liqenin e Batllavës.

(Burimi): Zyra e auditorit të përgjithshëm. Menaxhimi i sistemit të mbeturinave komunale në Kosovë. 2012

Figura 263-A. Niveli i mbulimit të teritorit me shërbime pastrimi (Burimi): Raporti i Performancës së Komunave 2012. MAPL.

Figura 264. Popullsia që ka qasje në shërbimet e pastrimit (Burimi): Agjencia e Kosovës për mbrojtjen e mjedisit. 2012. MMPH.

Figura 264-A. Popullsia që ka qasje në shërbimet e pastrimit sipas zonave (Burimi): Agjencia e Kosovës për mbrojtjen e mjedisit. 2012. MMPH.

Figura 265. Përmbledhje e përformancave (Burimi): The World Economic Forum,2015. http://reports.weforum.org/global-competitiveness-report2014-2015/economies/

Figura 266. Ndërvarësia e projektimit të qëndrueshëm (Burimi): Bujar Bajçinovci

Figura 266. Hyjnesha në fron

(Burimi): Instituti Arkeologjik i Kosovës

Figura 267. Prishtina në kohë (Burimi): PPU, 1987. Komuna e Prishtinës

Figura 267. Prishtina në kohë (Burimi): PPU, 1987. Komuna e Prishtinës

Figura 268. Prishtina me 1916

(Burimi): PPU, 1987. Komuna e Prishtinës 
Figura 269. Hulumtimet urbano-arkitektonike

(Burimi): PPU, 1987. Komuna e Prishtinës

Figura 270. Prishtina në relacion me qendrat e tjera

(Burimi): MMPH, 2011. Plani hapësinor i Kosovës

Figura 271. Prishtina, struktura urbane aktuale

(Burimi): Komuna e Prishtinës. Zhvillimi strategjik 2004-2020

Figura 272. Transformimi i sistemeve

(Burimi): Bujar Bajçinovci, 2012.

Figura 273. Sistemet disiplinare. Transformimi i sistemeve të hulumtimit. (Burimi): Bujar Bajçinovci, 2012.

Figura 274. Rokaqiejt në Ulpianë (Burimi): Lowlso, 2011.

Figura 275. Struktura urbane, Ulpianë (Burimi): Vizatim, Bujar Bajçinovci, 2012.

Figura 276. Timeline, zhvillimi urban dhe refleksionet aktuale (Burimi): Bujar Bajçinovci, 2012.

Figura 277. Prishtina, qytet metropolitan

(Burimi): Dr. Isa Mustafa. Programi dhe vizioni

Figura 278. Tërësia urbane, me pesë zona rregullative

(Burimi): Dr. Isa Mustafa. Programi dhe vizioni

Figura 279. Procesi dhe Koha

(Burimi): Bujar Bajçinovci, 2012.

Figura 280. Natyra e procesit iterativ

(Burimi): Vizatim, Bujar Bajçinovci, 2011.

Figura 281. Natyra e procesit iterativ në kontekst të sistemit të integruar (Burimi): E përpunuar Bujar Bajçinovci, 2012. Gharajedaghi J. (2006).

Figura 282. Procesi iterativ, Projektimi arkitektonik (Burimi): Bujar Bajçinovci, 2011.

Figura 283. Procesi aktual i zgjidhjeve të problemeve arkitektonike (Burimi): Bujar Bajçinovci, 2015.

Figura 284. Procesi i preferuar në zgjidhjen e problemeve arkitektonike (Burimi): Bujar Bajçinovci, 2012 
Figura 285. Zgjidhja e veçantë, problemi, sistemet dhe nënsistemet (Burimi): Bujar Bajçinovci, 2012

Figura 286. Vëzhgimi i sistemit nga hapësira "e jashtme"? (Burimi): Bujar Bajçinovci, 2012

Figura 287. Procesi aktual i projektimit (Burimi): Bujar Bajçinovci, 2012

Figura 288. Metoda algoritmike iterative në procesin e projektimit. (Burimi): Bujar Bajçinovci, 2012

Figura 289. $M A B$, modeli. Skenari, Strategjia dhe Vendimmarrja (Burimi): Përpunuar, Bujar Bajçinovci. Hadorn, H. G. et al.(2008). ( P. Messerli, 1986.)

Figura 290. Tërësia e sistemit. Arkitektura, Teknologjia dhe Mjedisi (Burimi): Përpunuar Bujar Bajçinovci. Klaus Daniels, (2003). Advanced Building Systems.

Figura 291. Indikatorët dhe konceptet, lidhjet e klimës dhe të energjisë. (Burimi): Eurostat. 2015.

Figura 292. BE, strategjia $20 / 20 / 20$

(Burimi): http://www.bsria.co.uk/news/. 2011.

Figura 293. Nivelet e vendimmarrjes, qëndror dhe lokal (Burimi): Bujar Bajçinovci, 2011.

Figura 294. Ndërvarësit dhe harmonia fubksionale e sistemit dhe sub sistemeve (Burimi): Bujar Bajçinovci, 2011.

Figura 295. Realiteti i Ajsbergut, në procesin e projektimit.

(Burimi): Bujar Bajçinovci, 2015. 


\section{TABELAT:}

Tabela 1. Kapacitetet e instaluara prodhuese të energjisë elektrike. (Burimi): MZHE. Strategjia e energjisë e republikës së Kosovës 2013 - 2022. 2015.

Tabela 2. Popullsia e Kosovës dhe shtimi natyror për vitin 2014, nivel i komunave. (Burimi): Agjencia e Statistikave të Kosovës. Popullsia e Kosovës 2014. 2015.

Tabela 3. Lëvizja e numrit të përgjithshëm të popullsisë në Kosovë. 1948-1981.² (Burimi): Ministria e mjedisit dhe planifikimit hapësinor. Raport, Gjendja e ujërave në Kosovë. 2010.

Tabela 4. Kapaciteti i ngrohtoreve qendrore në Kosovë.

(Burimi): MZHE. Strategjia e energjisë e republikës së Kosovës 2013 - 2022. 2015.

Tabela 5. Linja e autobusëve urbanë

(Burimi): https://sq.wikipedia.org/wiki/Transporti_në_Prishtinë

Tabela 6. Trajtimi i pacientëve në kampusin e QKUK.

(Burimi): Instituti Kombëtar i Shëndetit Publik. 2011.

Tabela 7. Matjet e $\mathrm{PM}_{10}$ në pikat referente.

(Burimi): Përpunuar Bujar Bajçinovci, IHMK. 2010

Tabela 8. Matjet e $\mathrm{PM}_{2.5}$ në pikat referente.

(Burimi): Përpunuar Bujar Bajçinovci, IHMK. 2010

Tabela 9. Matjet e $\mathrm{PM}_{10}$ dhe $\mathrm{PM}_{2.5}$ në pikat referente.

(Burimi): Përpunuar Bujar Bajçinovci, IHMK. 2010

Tabela 10. Vlerat kufitare të BE-së, $\mathrm{PM}_{10}$ dhe $\mathrm{PM}_{2.5}$ dhe $\mathrm{NO}_{2}$ në cilësinë e ajrit. 2008. (Burimi): E përkthyer, Bujar Bajçinovci.The Mayor's Air Quality Strategy. Clearing the air. London. 2010.

Tabela 11. Koeficientët, absorbimi për materialet e zakonshme të përdorura në ndërtim (Burimi): Broshurë, Screen Solutions Ltd. Acousticcomfort. 2012.

Tabela 11. Rregulloret, kërkesë për leje ndërtimi

(Burimi): Përkthyer. Meijer, F., Visscher, H., Sheridan L.(2002).

Building regulations in Europe and Nederlands: Delft Uni.

Tabela 12. Procedurat për kategori të ndryshme, të lejeve.

(Burimi): Përkthyer. Meijer, F., Visscher, H., Sheridan L.(2002).

Building regulations in Europe and Nederlands: Delft Uni.

Tabela 13. Rregulloret, fillimi i ndërtimit, inspektimit, përfundimi.

(Burimi): Përkthyer. Meijer, F., Visscher, H., Sheridan L.(2002).

Building regulations in Europe and Nederlands: Delft Uni. 
Tabela 14. (c) Knauff, raporti A/Ve

(Burimi): Termoizolim dhe modernizim me @Knauf, broshurë, 09/2014.

Tabela 15. Vlerat e projektuara të përcjellshmërisë termike, $\lambda\left[\mathrm{W} /\left(\mathrm{m}^{2} \mathrm{~K}\right)\right]$, dhe vlerat e përafërta të faktorit të rezistencës së difuzioni i avullit te ujit, $\mu$ (Burimi): Kodi Unik i Ndërtimit i Republikës së Kosovë, Kapitulli II - Kursimi i Energjisë Termike dhe Mbrojtja Termike, i pa edituar. MMPH

Tabela 16. Vlerat e projektuara të përcjellshmërisë termike, $\lambda\left[\mathrm{W} /\left(\mathrm{m}^{2} \mathrm{~K}\right)\right]$, dhe vlerat e përafërta të faktorit të rezistencës së difuzioni i avullit te ujit, $\mu$ (Burimi): Kodi Unik i Ndërtimit i Republikës së Kosovë, Kapitulli Il - Kursimi i Energjisë Termike dhe Mbrojtja Termike, i pa edituar. MMPH

Tabela 17. Vlerat e projektuara të përcjellshmërisë termike, $\lambda\left[\mathrm{W} /\left(\mathrm{m}^{2} \mathrm{~K}\right)\right]$, dhe vlerat e përafërta të faktorit të rezistencës së difuzioni i avullit te ujit, $\mu$ (Burimi): Kodi Unik i Ndërtimit i Republikës së Kosovë, Kapitulli Il - Kursimi i Energjisë Termike dhe Mbrojtja Termike, i pa edituar. MMPH

Tabela 18. Vlerat më të larta të lejuara të koeficienteve të kalimit të nxehtësisë, $U$ $\left[W /\left(m^{2} K\right)\right]$, e pjesëve të ndërtesave të vëllimit te vogël $\left(V \leq 100 \mathrm{~m}^{3}\right)$, të shtëpive familjare dhe pas ndërhyrjeve ne ndërtesat ekzistuese.

(Burimi): Kodi Unik i Ndërtimit i Republikës së Kosovë, Kapitulli Il - Kursimi i Energjisë Termike dhe Mbrojtja Termike, i pa edituar. MMPH

Tabela 19. Rregullat për vlerësimin optimal të orientimit kardinal-jug për diellosjen e drejtpërdrejtë dhe për murin Trombe.

(Burimi): Bujar Bajçinovci.

Tabela 20. Rregullat për vlerësimin e Masës Termike së kërkuar nga diellosja direkte (Burimi): Bujar Baj̧̧inovci.

Tabela 21. Rregullat për vlerësimin e trashësisë së murit të Trombit (Burimi): Bujar Bajçinovci, 2015.

Tabela 22. Rregullat për vlerësimin e trashësisë së murit të Trombit (Burimi): Krasniqi, F. UP.

Tabela 23. Karakteristikat prodhuese për dritaret (Burimi): Rollplast, broshura 2014/15

Tabela 24. Karakteristikat prodhuese për dritaret (Burimi): Rollplast, broshura 2014/15

Tabela 25. Ndriçimi i propozuar, lejuar për hapësira të ndryshme (Burimi): http://www.energy.ca.gov/. 2015

Tabela 26. Të dhënat për radiatorët e tipit " TERMIK" (për një anëtar të radiatorit) (Burimi): Krasniqi, F., Selimaj, R., Malsiu, I.(2004). Instalimet Makinerike. Universiteti i Prishtinës. 
Tabela 27. Koeficienti i transmetimit të nxehtësisë për radiatorët $\left(k_{R}\right)$.

(Burimi): Krasniqi, F., Selimaj, R., Malsiu, I.(2004). Instalimet Makinerike. Universiteti i Prishtinës.

Tabela 28. Nxehtësia që jep I[ $\left.\mathrm{m}^{\prime}\right]$ e gypit të lëmuar

(Burimi): Krasniqi, F., Selimaj, R., Malsiu, I.(2004). Instalimet Makinerike. Universiteti i Prishtinës.

Tabela 29. Ndarja e komunave sipas zonave të intensitetit të rrezatimit diellor (Burimi): Studimi për përgatitjen e të dhënave projektuese për sistemet e shfrytëzimit të energjisë diellore në Kosovë i kryer nga B2B \& Energy, Ministria e Zhvillimit Ekonomik (MZHE) 2010

Tabela 30. Të dhënat për Prishtinën për energjinë diellore sipas databazës të Komisionit Evropian.

(Burimi): Bujar Bajcinovci, PVGIS (c) European Communities, 2001-2012

Tabela 31. Potenciali energjetik i rrezatimit diellor në rrafsh optimal (Burimi): Studimi për përgatitjen e të dhënave projektuese për sistemet e shfrytëzimit të energjisë diellore në Kosovë i kryer nga B2B \& Energy, Ministria e Zhvillimit Ekonomik (MZHE) 2010

Tabela 32. Potenciali energjetik i për panelet PV

(Burimi): Studimi për përgatitjen e të dhënave projektuese për sistemet e shfrytëzimit të energjisë diellore në Kosovë i kryer nga B2B \& Energy, Ministria e Zhvillimit Ekonomik (MZHE) 2010

Tabela 33. Potenciali energjetik solar për ngrohjen e ujit sanitar (Burimi): Studimi për përgatitjen e të dhënave projektuese për sistemet e shfrytëzimit të energjisë diellore në Kosovë i kryer nga B2B \& Energy, Ministria e Zhvillimit Ekonomik (MZHE) 2010

Tabela 34. Potenciali energjetik solar për ngrohjen e ujit sanitar (Burimi): Studimi për përgatitjen e të dhënave projektuese për sistemet e shfrytëzimit të energjisë diellore në Kosovë i kryer nga B2B \& Energy, Ministria e Zhvillimit Ekonomik (MZHE) 2010

Tabela 35. Potenciali energjetik solar për Prishtinën, PVW

(Burimi): Studimi për përgatitjen e të dhënave projektuese për sistemet e shfrytëzimit të energjisë diellore në Kosovë i kryer nga B2B \& Energy, Ministria e Zhvillimit Ekonomik (MZHE) 2010

Tabela 36-37. HC e vogla ekzistuese - Përmbledhje

(Burimi): Jeannelle. Blanchard. KEK-energy. Një vlerësim praktik i potencialeve të BRE dhe MAK për energji në Kosovë

Tabela 38. HC e vogla. Kapaciteti Neto në Dispozicion dhe Energjia (Burimi): Jeannelle. Blanchard. KEK-energy. Një vlerësim praktik i potencialeve të BRE dhe MAK për energji në Kosovë

Tabela 39. Specifikat teknike të përbashkëta të turbinave të erës (Burimi):Bujar Bajçinovci, Universiteti Prishtinës. OSANDER+PARTNER. Balkan.wind-index.com

Tabela 40. Të dhënat e matura për erën

(Burimi): Dragusha, B., Rexha, B., Limani, I. The use of wind generators in Kosovo. Universiteti Prishtinës.

Tabela 41. RETScreen në regjionin e prishtinës

(Burimi): Dragusha, B., Rexha, B., Limani, I. The use of wind generators in Kosovo. Universiteti Prishtinës. 
Tabela 42. Të dhënat e matura për erën. Prishtinë 2010-2014.

(Burimi):Bujar Bajçinovci, Universiteti Prishtinës. OSANDER+PARTNER. Balkan.wind-index.com

Tabela 43. Specifikimet e Himawari, veçoritë

(Burimi): (C) Himawari, La Forêt Engineering Co.,Ltd. Japan

Tabela 44. Sasitë e $\mathrm{CO}_{2}$, avullit të ujit dhe të nxehtësisë që i liron njeriu brenda orës (Burimi): Krasniqi, F., Selimaj, R., Malsiu, I.(2004). Instalimet Makinerike. Universiteti i Prishtinës.

Tabela 45. Ndërrimi i sasisë së ajrit në ore, varësisht prej funksionit (Burimi): Përkthyer, Bujar Bajcinovci. Sistemet - Instalimet

Tabela 46. Pompat termike, funksioni dhe komponentët (Burimi): () REHAU

Tabela 46. Pompat termike, funksioni dhe komponentët (Burimi): (C) REHAU

Tabela 47. Dimensionet. Shkolla e mesme teknike "28 Nëntori" (Burimi): Fakulteti i Ndërtimtarisë dhe Arkitekturës, Universiteti i Prishtinës

Tabela 48. Potenciali i kursimit i prezantuar përmes indikatorëve financiar (Burimi): Fakulteti i Ndërtimtarisë dhe Arkitekturës, Universiteti i Prishtinës

Tabela 49. Potenciali i kursimit i prezantuar përmes indikatorëve financiar (Burimi): Fakulteti i Ndërtimtarisë dhe Arkitekturës, Universiteti i Prishtinës

Tabela 50. Masat e propozuara

(Burimi): Fakulteti i Ndërtimtarisë dhe Arkitekturës, Universiteti i Prishtinës

Tabela 51. Masat e propozuara

(Burimi): Fakulteti i Ndërtimtarisë dhe Arkitekturës, Universiteti i Prishtinës

Tabela 52. Pompat termike, funksioni dhe komponentët (Burimi): (C) REHAU

Tabela 53. Evidentimi dhe verifikimi i lokacioneve me deponi në Kosovë (Burimi): AGROVET, 2013. MZHE

Tabela 54. Sasia e mbetjeve (Burimi): Trepça, UNDP. 2011. Raporti i konferencës ndërkombëtare

Tabela 55. Karakteristikat kimike të hirit të TC-A (Burimi): AGROVET, 2013. MZHE

Tabela 56. Llojet e mbeturinave

(Burimi): MMPH. Agjencia e Kosovës për mbrojtjen e mjedisit, 2008. 
Tabela 57. Materialet dhe koha e shpërbërjes

(Burimi): AmEn. 2014. http://amen-ks.org/

Tabela 58. Banimi individual

(Burimi): Përpunuar, Bujar Bajçinovci. PPU, 1987. Komuna e Prishtinës

Tabela 59. Banimi individual i përzier

(Burimi): Përpunuar, Bujar Bajçinovci. PPU, 1987. Komuna e Prishtinës

Tabela 60. Banimi kolektiv

(Burimi): Përpunuar, Bujar Bajçinovci. PPU, 1987. Komuna e Prishtinës

Tabela 61. Banimi si program urban

(Burimi): Përpunuar, Bujar Bajçinovci. PPU, 1987. Komuna e Prishtinës

Tabela 62. Banimi në tërësi, sipas PPU

(Burimi): Përpunuar, Bujar Bajçinovci. PPU, 1987. Komuna e Prishtinës 


\section{PROJEKTIMI I QËNDRUESHËM ARKITEKTONIK C (CC BY NC-4.0).}

Kjo monografi është një udhëzues i procesit të integruar të projektimit arkitektonik, i cili - ngërthehet nga teoria e projektimit, efiçiença e energjisë, sistemet bashkëkohore, industrisë së ndërtimit, shëndetit publik dhe parimeve ekologjike në arkitekturë. Secili : kapitull, pasqyron detajet teknike të projektimit, ilustruar me fotografi, vizatime dhe raste studimore. Monografia përshkruan konceptet e integruara teknologjike nga hapësirat e vogla e deri tek zyrat e mëdha, spitalet, shkollat dhe qytetet. Libri përmban ekstrakte, : pjesë dhe standarde nga publikimet qeveritare si pasqyrë e kodeve dhe akteve normative, : si dhe përshkrimet nga vlerësimet sikurse: LEED ${ }^{\circledR}$.

Kjo Monografi ju dedikohet prindërve: Babait Qazim dhe Nënës Mahie.

\section{FALËMINDERIM}

Autori u është mirënjohës familjes, bashkëshortes Mire, djemve Bard dhe Uliks për mirëkuptim dhe përkrahje të madhe gjatë punës, hulumtimit dhe shkruarjes e monografisë. I falënderojë për krijimin dhe mbajtjen e ambientit pozitiv dhe harmonik. 
KAPITULLI I

\section{HYRJE}

$\mathrm{N}$

ë kontinuumin e evolucionit dhe përshtatjes së organizmave të gjallë, duke filluar nga mikroorganizmat e deri te qeniet njerëzore, ekzistojnë cikle të caktuara kohore që bartin me veti ndryshime kardinale, me të cilat njeriu duhet të përballet dhe të gjejë harmoninë më të mirë të mundshme të përshtatshmërisë. Sfidat e ditëpërditshme duhet të nxisin kërkime të reja shkencore dhe realisht duhet të drejtohen në shfrytëzimin e të gjitha resurseve, mbi të gjitha, ato mendore në mënyrë që të sigurohet një cilësi më e mirë e jetesës. Arkitektura, në aspektin e aktiviteteve transdisiplinare si dhe pjesëmarrjes së saj në zgjidhjen e problemeve projektuese, mund ti zgjidhë sfidat e ardhshme më strategji të përshtatshme dhe bashkëkohore. Mileniumi i ri sjell me vete një stil të ri jetese si rezultat i një sërë faktorësh përcaktues, të kryesuar nga zhvillimi i teknologjisë dhe fenomeni i globalizimit.

Andaj, kemi ardhur në një situatë kur duhet të shtrohen një sërë pyetjesh në lidhje me domosdoshmërinë e ripërcaktimit të shumë shprehive jetësore të ditëpërditshme. Pavarësisht vërtetimit praktik dhe përparësitë e procesit të integruar të projektimit në arkitekturë, ekzistojnë vështirësi të caktuara dhe kufizime në mos zbatimin e strategjive të natyrshme dhe evolutive të projektimit, të kushtëzuara nga stili i ri i jetesës, zhvillimi teknologjik, globalizimit dhe fenomenit të ridefinimit të vlerave të deritashme. Projektimi arkitektonik përballet me sfida të mëdha, si rezultat i ndryshimeve evidente klimatike si dhe shprehive krejtësisht të reja të jetesës, globalizimi përshkruhet si një proces në të cilin ekonomitë rajonale, shoqëritë dhe kulturat, integrohen përmes një rrjeti global të ideve politike, komunikimit, transportit dhe vlerës integrale të tregut global. Fenomeni i globalizimit është një proces i pandalshëm historik i cili reflekton me rinovimet përkatëse teknologjike, shkencës, strategjive të reja ekonomike dhe ekologjike. Gjersa, kulturat e lashta, duke mos përdorur fjalën "ekologji" kanë ndërtuar me ekologjinë në mendësi, në të kundërtën injorimi do të sillte shkatërrim, epidemi, uri dhe shpërbërje shoqërore e klasore.

Qasja arkitektonike në fenomenet holistike theksohet te nevoja për të krijuar harmoni në mes nevojës së funksionit dhe ideve racionale të shfaqura për situata dhe mjedise të caktuara. Praktika aktuale e projektimit linear është e natyrës njëkahore apo sekvenciale, pra, është modeli i cili aktualisht më së shumti përdoret apo shumica e të gjitha ndërtesave të sotme janë të projektuara konform këtij procesi.

Jemi dëshmitarë për nevojën imediate e të adresuarit për problemet sociale dhe ekonomike, ndërsa në të njëjtën kohë jemi duke përjetuar degradimin e mjedisitlokalitetit. Duhen të zhvillohen studime shkencore në lidhje me dukuritë relativisht të lëna pas dore në sektorin e ndërtimit banesor, në aspektin e programimit, planifikimit dhe projektimit arkitektonik. Kjo ndodhë pjesërisht për shkak të njohurive të kufizuara dhe të informatave të kufizuara, politikave joadekuate urbane dhe pjesërisht për shkak të kostos së lartë fillestare për projektimin e integruar, në veçanti në efikasitetin e sektorit të ndërtimit. 
Procesi i projektimit të integruar, paraqet në thelb praktikën e projektimit të qëndrueshëm, modeli i projektimit të integruar arkitektonik në natyrë është proces evolutiv. Andaj, mekanizmi stimulues i të menduarit kreativ lateral (Edward de Bono, 1967). në procesin e projektimit, realizohet në momentin kur barrierat konvencionale projektuese të janë kaluar për të krijuar diçka të re, unike, të qëndrueshme në të cilën fokusi thellohet në gamën e problemit të caktuar, të cilin duhet zgjidhur.

Të kuptuarit e drejtë të ruajtjes së resurseve për gjeneratat e ardhshme, konsiston në faktin që ne jemi në ndërvarshmëri në mes kërkesave për resurse natyrore si dhe fuqizimin e alternativave të mundshme në ruajtjen e ekosistemit për të ardhmen. Kemi shembuj të mirëfilltë nga historiografia për civilizime të kaluara dhe zhdukja e tyre si fenomen i boshatisjes së resurseve esenciale të nevojshme për jetesë. Andaj, qasja dhe të menduarit se ky fenomen do i ndodhë një gjenerate tjetër e jo gjeneratës aktuale, krijon një realitet të gabuar, pasi i gjithë ekosistemi është në interaksion dhe varshmëri direkte, në tashmen por edhe në të ardhmen. Është e njohur në përgjithësi, se objektet janë përdorues për të paktën gjysmën e energjisë totale të prodhuar në botë, si për: ngrohje, ndriçim, ajër të kondicionuar, ftohje, ndërtim dhe industri. Përqindja më e madhe e këtij shpenzimi është e lidhur direkt me projektimin arkitektonik, maksima esenciale e qëndrueshmërisë do zbatim harmonik të strategjive të projektimit për të bashkëvepruar me natyrën.

Arkitektura ka qenë gjithmonë e përfshirë në shfrytëzimin e burimeve natyrore për nevojat njerëzore. Historikisht ajo ka një traditë të gjatë në krijimin e objekteve që komunikojnë me mjedisin. Projektimi arkitektonik është duke u përballur me sfida të mëdha si rezultat i globalizimit. Trendi i globalizimit është një proces i pandalshëm historik i cili do të reflektojë në teknologji të reja, shkencë dhe strategji evolutive urbane. Në dhjetëvjeçarin e fundit, globalizimi është bërë promotor i zhvillimit, duke impenjuar në arkitekturë me një dozë të "humbjes së identitetit" dhe të specifikave të një mjedisi të caktuar lokal?

Ekziston një konsensus i përgjithshëm se identiteti rajonal dhe lokal do të luajë një rol të rëndësishëm në vazhdimësinë e diversitetit të kulturës dhe atributeve etnologjike, në të cilën mirëmbahet identiteti lokal dhe komuniteti. Ndjenja që ne i përkasim diçka je, si një pjesë e tërësisë, si do kujdesemi ne, atëherë, edhe tërësia do kujdeset për ne. Këto janë elementet dhe veçorit e ri jetësimit të qëndrueshmërisë globale, po ashtu edhe në Republikën e Kosovës. Mileniumi i ri sjell me vete situata të veçanta fondamentale, ku vihet në pyetje domosdoshmëria e ripërcaktimit të stilit të jetesës.

Cili do jetë reagimi i arkitektëve të rinj apo industrisë së ndërtimit në lidhje me ndryshimet klimatike, me efektin serrë, me emanimin e jashtëzakonshëm të $\mathrm{CO}_{2}$ ? A do të vazhdon industria e fuqishme e ndërtimit të kontribuojë me rreth $45 \%$ të gazit serrë?

Në mungesën evidente për libër në gjuhën shqipe në tematikën e projektimit arkitektonik, shpresoj që ky libër të shërbej si literaturë bazë në të kuptuarit e sfidave të projektimit arkitektonik nga ana e studenteve, me të cilët jam se bashku shumë vite. Shpresoj se ky libër do jetë një kurs optimal në studimin e mëtutjeshëm të procesit të projektimit, në lëmine e lëndës: Projektim Arkitektonik. 


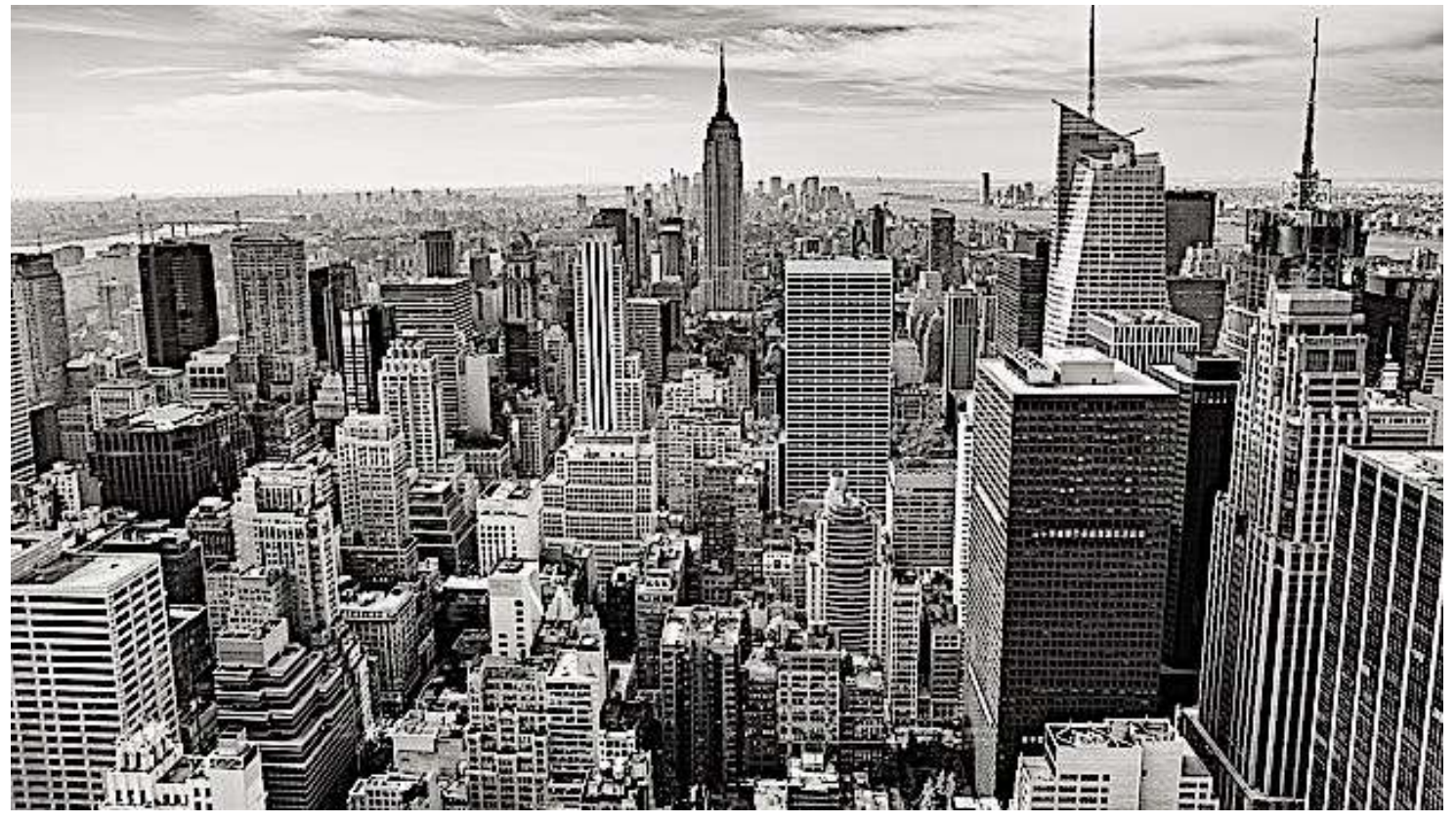

Figura 1. Manhattan.

(Burimi): E licensuar nga Public Domain CC0.

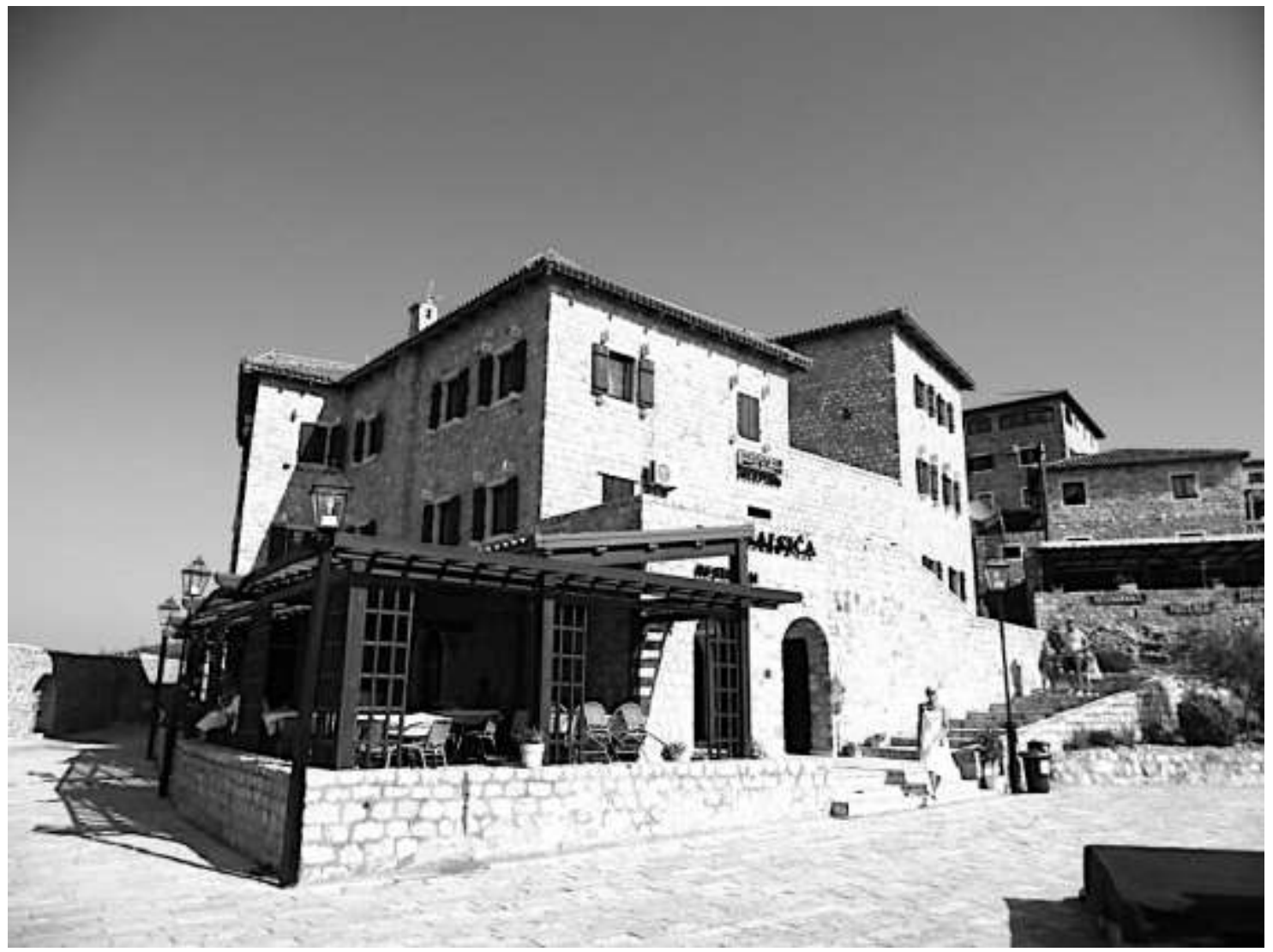

Figura 2. Ulqini, kalaja e vjetër

(Burimi): Bujar Bajçinovci, 2014. 
Secili kapitull në vete pasqyron detajet udhëzuese teknike të projektimit të qëndrueshëm duke u ilustruar me fotografi, vizatime dhe raste studimore. Libri ndahet në 16 kapituj të cilët realisht për shkak të specifikës së studimit dhe problematikës janë të ndarë si të tillë dhe përbëjnë një tërësi kohezive të monografisë.

Kapitulli i dytë: Paraqet dhe shtjellon specifikat e problemit projektues i cili paraqet praktikën aktuale të procesit të projektimit linear. Për më tepër, ky kapitull paraqet të dhënat themelore, karakteristikat dhe veçoritë e Republikës së Kosovës, si pikënisje e shtjellimit të sfidave aktuale arkitektonike.

Kapitulli i tretë: Paraqet dhe shtjellon përkufizimet themelore në kontekst të diversitetit të variacioneve kuptimore, përcaktimin e koncepteve dhe dallimet brenda kategorive të përdorura në këtë monografi. Definimet themelore kanë për detyrë të shkoqisin kuptuarjen dhe sqarimet për nocionet e përdorura, të cilat janë të përfshira në shtjellimin e tematikës.

Kapitulli i katërt: Prezanton qasjet e reja me të cilat arkitektët janë duke ju përgjigjur sfidave të krijimit të arkitekturës së qëndrueshme. Sfida projektuese, të paraqitura si koncepte kreative në praktikën e projektimit arkitektonik, duke u ndërlidhur me pyetje hulumtuese profesionale: Si mund të jetë një ndërtesë 'ekologjike'? Si mund arkitektët në praktikë ta kryejnë hulumtimin? Çfarë është 'green' në zgjidhjen e një problemi projektues.

Kapitulli i pestë: Përkufizon qasjet e arkitekturës organike, të frymëzuar nga natyra. Koncepti i qasjes origjinale të përshtatjes së strukturave arkitektonike me natyrën. Veçori dhe parim i cili u thellua edhe më shumë me besimin se objektet duhet të mishërohen me lokacionin dhe të përfitojnë nga parimet projektuese bioklimatike.

Kapitulli i gjashtë: Në vazhdimësi të shtjellimit të tematikës së projektimit të qëndrueshëm, kapitulli i gjashtë analizon dhe përshkruan veçorinë themelore të një projektimi të mirëfilltë siç është komfori, respektivisht, komfori i brendshëm. Po ashtu në këtë kapitull si vazhdimësi studimore, veçohen edhe komfori vizual dhe ai higjienik.

Kapitulli i shtatë: Shtjellon një prej kahjeve kryesore të kësaj monografie, në të cilin përshkruhet fuzionimi profesional në procesin e projektimit konceptual. Një qasje e integruar e projektimit arkitektonik është vendimtare për arritjen e projektimit të qëndrueshëm, si dhe arritjes së performancës optimale në funksion të kualitetit të jetesës.

Kapitulli i tetë: Paraqet boshtin kryesor të kësaj monografie, në të cilin përshkruhen strategjitë, udhëzimet dhe parimet projektuese konceptuale në drejtim të një projektimi të mirëfilltë arkitektonik. Natyrisht, në këtë kapitull përshkruhen parimet udhëzuese se si të inkorporohen qysh në fazën fillestare të programimit, në strategjitë e arkitekturës së qëndrueshme.

Kapitulli i nëntë: Paraqet punën e studentëve në ciklin master në lëndën Sisteme Bashkëkohore, kontributi i tyre studioz me punime semestrale të cilët kanë veçuar sfidat e projektimit të qëndrueshëm. Lëndë e cila dëgjohet dhe është në kurikulën e studimeve të fakultetit të Ndërtimtarisë dhe Arkitekturës, Universiteti i Prishtinës "Hasan Prishtina". 
Kapitulli i dhjetë: Paraqet dhe shtjellon specifikat e ujit në arkitekturë. Përshkruhen ndarjet dhe veçimi i resurseve natyrore ujore në kontekst të përkufizimeve themelore. Definimet themelore dhe analiza e tyre kanë për detyrë të shkoqisin kuptuarjen dhe sqarimet të cilat janë të përfshira në shtjellimin e tematikës të arkitekturës së qëndrueshme, si dhe ruajtjes së resurseve ujore, si sfond jetik për mbijetesë.

Kapitulli i njëmbëdhjete: Shtjellon qasjet bashkëkohore të lëvizjes si veçori kardinale në projektimin arkitektonik. Përshkruhen avancimet teknologjike dhe të arriturat e lëvizjes në vertikale në një strukturë arkitektonike. Barrierë dhe sfidë e kamotshme në teorinë e projektimit arkitektonik, e analizuar dhe e komentuar shekuj me radhë.

Kapitulli i dymbëdhjetë: Paraqet analizën mjedisore dhe biodiversitetin në kontekst të projektimit arkitektonik dhe kualitetit të jetesës në komunitet. Duke veçuar sfidat aktuale në problematikën mjedisore të Republikës së Kosovës, me shembuj studiues: Deponitë e braktisura, deponitë e hirit, guroret e braktisura, minierat e braktisura si dhe rikultivimi si fenomen i rivitalizimit të mjedisit natyror.

Kapitulli i trembëdhjetë: Paraqet analizën dhe sfidat mjedisore në kontekst të mbeturinave dhe kualitetit të jetesës në komunitet. Në kapitull shtjellohet analizat dhe të dhënat për pjesëmarrjen e komunitetit në sasitë e mbeturinave urbane, si dhe paraqiten në formë ligjore obligimet dhe detyrimet e çdo pjesëmarrësi në kontekst të kontaminimit të mjedisit natyror dhe atë social.

Kapitulli i katërmbëdhjetë: Përkufizon po ashtu një prej kaheve studimore kryesore të kësaj monografie, në të cilin përshkruhet misioni i arkitekturës si proces kreativ shoqëror, në procesin e projektimit konceptual zhvillimor. Përshkruhet zhvillimi i qytetit të Prishtinës në kohë dhe hapësirë, dallimet konceptuale, formulimi i problemeve urbane dhe sociale, veçoritë banimore, si dhe qasjet e preferueshme arkitektonike në zgjidhjen e mundshme të këtyre fenomeneve shoqërore.

Kapitulli i pesëmbëdhjetë: Paraqet procesin e integruar të projektimit, respektivisht modelin e shqyrtuar projektues në kontekst të anamnezës së sfidave arkitektonike aktuale, më të cilat jemi duke u ballafaquar në këtë fazë të shtet formimit. Dallimi i së tashmes përshkruhet si fenomen i ndërlidhur me globalizimin, dukuri e cila ka tendencë ta dallojë të tashmen.

Kapitulli i gjashtëmbëdhjetë: Paraqet qasjen për ti njoftuar studentët me jetën përreth nesh, me persona të cilët kanë nevoja të veçanta, një komunitet në rritje e pjesës së popullatës sonë, me diversitet si nga kërkesat ashtu edhe nga nevojat e veçanta. Është parë e udhës që t'i përmbledh standardet projektuese si ndihmesë kryesisht për studentët e arkitekturës, që përpos ligjëratave ky kapitull t'iu shërbej si kujtesë për respektin dinjitar që duhet ta kenë në çfarëdo rrethana projektuese, e posaçërisht kur të kenë rastin të projektojnë me këto standarde si udhëzues modest fakultativ. 
KJO FAQE ËSHTË LËNË QËLLIMISHT E ZBRAZËT! 
KAPITULLI II

\section{SPECIFIKAT DHE VEÇORIT}

pecifika e problemit projektues është vetë natyra origjinale e veprimtarisë kreative arkitektonike e cila paraqet praktikën aktuale të procesit të projektimit linear, i cili kontribuoi veçanërisht në studimin e sfidave arkitektonike në Kosovë. Kjo monografi ka për qëllim të lehtësojë të kuptuarit e qëndrueshmërisë dhe efikasitetin në procesin e projektimit, të inicioj të kuptuarit e strategjisë së projektimit të integruar si dhe zbatimin e mundshëm në udhëzimet institucionale, në nivel lokal apo qendror në Republikën e Kosovës. Efikasiteti i procesit të projektimit evolutiv, rezulton me cilësi më të lartë në modelin e shqyrtuar, futja e konceptit transdisciplinar në dizajnim zvogëlon në masë të madhe gabimet e mundshme gjatë procesit të projektimit të cilët reflektohen direkt në sektorin e ndërtimit dhe në mjedis.

\subsection{Mjedisi natyror}

"Mjedisi është një kompleks i faktorëve të jashtëm që ndikojnë në sistem duke përcaktuar kursin e tij dhe formën e ekzistencës. Një mjedis mund të shihet si një tubim i madh grupor në të cilin nënsistemi i veçuar është një nëngrup. Mjedisi mund të ketë një ose më shumë parametra, të trajtës fizike apo të tjetër. Mjedisi i një sistemi të caktuar apo nënsistemi i tij duhet domosdoshmërisht të ndërveprojë me sistemin origjinal bazik"1

\subsection{Karakteristika të përgjithshme për Republikën e Kosovës}

\subsubsection{Pozita gjeografike}

Kosova ka pozitë qendrore gjeografike dhe strategjike në gadishullin Ballkanik. Gjendet

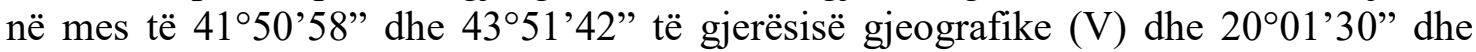
$21^{\circ} 48^{\prime} 02^{\prime \prime}$ të gjatësisë gjeografike (L). Pozita gjeografike dhe veçoritë e R. Kosovës konsiderohen me rëndësi të veçantë nga aspekti ekonomik, kulturor dhe politik me rajonin dhe botën. Kosova ka sipërfaqe $10.887 \mathrm{~km}^{2}$, me rreth 1804944 banorë (vlerësim i vitit 2014, ASK) dhe me dendësi mesatare prej 166,2 banorë në $\mathrm{km}^{2}$ (vlerësim i vitit 2013, ASK). Kufizohet me Shqipërinë (në jugperëndim), me Maqedoninë (në juglindje), me Serbinë (në lindje, veri dhe verilindje) dhe me Malin e Zi (në perëndim). Gjatësia e përgjithshme e kufirit të Kosovës me vendet fqinje është rreth $700 \mathrm{~km} .{ }^{2}$

\subsubsection{Relievi}

Kosova është vend malor, me ultësira e përbërë nga Fusha e Kosovës (me lartësi mbidetare 510-570 m) dhe Rrafshi i Dukagjinit (lartësia mbidetare 350-450 m). Nga aspekti morfologjik, paraqet një mozaik të vërtetë të fushëgropave me dimensione të ndryshme të përkufizuar me male të mesme e të larta.

1 Dhankhar, S. S. (2010). Environmental Studies. Hisar: Agricultural University.

2 Ministria e mjedisit dhe planifikimit hapësinor. Raport, Gjendja e ujërave në Kosovë. 2010. 
Në morfologjinë e relievit veçohen zonat malore, në ndërtimin e të cilës marrin pjesë shkëmbinjtë e moshave të ndryshme gjeologjike. Më prezent janë paleozoiku dhe mezozoikut ndërsa në zonën e ulët të fushës mbizotërojnë sedimentet e reja të pliocenit të përbëra kryesisht nga shkëmbinjtë terigjen. Lartësia mesatare mbidetare e Kosovës është 810 m, kurse pika me e ulët është 270 m, e ajo më e larta 2,656 m (Gjeravica). Formësim kryesor në relievin e Kosovës janë: Malet me (63\%) dhe Fushëgropat (37\%). ${ }^{2}$

\subsubsection{Klima}

Klima është e mesme kontinentale, me ndikim mbizotërues të klimës Adriatiko Mesdhetare në Rrafshin e Dukagjinit, përmes luginës së Drinit të Bardhë, si dhe me ndikim më të vogël të klimës së ndryshuar Adriatiko-Egjeniane në fushën e Kosovës. Të reshurat mesatare vjetore $596 \mathrm{~mm}$. Temperaturat mesatare vjetore $10^{\circ} \mathrm{C}$, (temperatura minimale $-27^{\circ} \mathrm{C}$ dhe maksimale $39^{\circ} \mathrm{C}$ ). Makrofaktorët kryesorë klimatik, të cilët ndikojnë në klimën e Kosovës janë: pozita e saj ndaj masave tokësore (Evroazia dhe Afrika), masat ujore (Oqeani Atlantik dhe Deti Mesdhe), masat e ajrit (tropike dhe arktike-maritine apo kontinentale), pozita e sistemeve barike (maksimumi i Azoreve dhe minimumi i Islandës). Faktorët lokal kryesorë që ndikojnë në klimën e Kosovës janë: relievi, ujërat, trualli dhe bimësia. (Ekstrakt) ${ }^{2}$

\subsubsection{Hidrografia}

Kosova ka rezerva të pamjaftueshme ujore, që në të ardhmen do të jenë një faktorë kufizues për zhvillimin ekonomik dhe shoqëror të vendit. Vlerësohet se Kosova ka vetëm $1600 \mathrm{~m} 3 /$ ujë/vit për kokë banori. Në aspektin hidrografik Kosova ndahet në 4 pellgje lumore: Drini i Bardhë, Ibri, Morava e Binçës, dhe Lepeneci. Nga territori i Kosovës në vitin me lagështi mesatare rrjedhin përafërsisht 3.8 x 109 ujë përkatësisht $121.2 \mathrm{~m} 3 / \mathrm{sec}$. Karakteristikë kryesore hidrologjike në Kosovë është shpërndarja jo e barabartë dhe jo adekuate e resurseve ujore në krahasim me nevojat. Potenciali për energji ujore në Kosovë është shumë i vogël dhe deri më tani shfrytëzimi i saj është mjaft modest. Rezervat e ujërave nëntokësore janë të kufizuara dhe gjenden kryesisht në pjesën perëndimore të Kosovës, ku edhe rezervat e ujërave sipërfaqësore janë më të mëdha, në krahasim me pjesën lindore me rezerva të pakta dhe pjesën jug-lindore ku nevojat për ujë janë shumë të mëdha. Kosova ka numër të vogël të liqeneve natyrore. Liqene artificiale janë: Batllava, Gazivoda, Radoniqi, Përlepnica dhe Badovci, si dhe një numër të vogël të liqeneve për ujitje. Kosova ka burime të rëndësishme të ujërave termale të cilat shfrytëzohen për qëllime shërimi dhe rekreacioni. Mbrojtja, ruajtja dhe zhvillimi i resurseve ujore është shumë i rëndësishëm dhe një ndër sfidat më të mëdha mjedisore të Kosovës. (Ekstrakt) $)^{2}$

\subsubsection{Sistemi i energjisë elektrike në Kosovë}

Sistemi i energjisë elektrike në Kosovë tejet i vjetruar është jo adekuat dhe i pasigurt, paraqet sfida të mëdha për rritjen ekonomike dhe zhvillim. Ndërprerjet e shpeshta të energjisë elektrike pengojnë investimet dhe dëmtojnë prodhimin, arsimin si dhe shërbimet shëndetësore. Qeveria e Kosovës e ka bërë prioritet modernizimin dhe përmirësimin e sektorit të energjisë në vend dhe ata kanë kërkuar nga partnerët e tyre zhvillimor që t'ju ndihmojnë. Kushtet e furnizimit me energji janë të ndryshme nëpër botë dhe secili vend përcakton rrugën e vet për arritjen e aspiratave për energji. 
Opsionet e furnizimit me energji në Kosovë kufizohen nga disponueshmëria e kufizuar e burimeve të ripërtëritshme, vjetrimi dhe pasiguria e termocentraleve, reduktimet në furnizim në Ballkan që kufizojnë mundësinë e Kosovës për të importuar energji elektrike, dhe një mungesë e ndonjë burimi të gazit natyror apo sistem të gypave për importim të gazit. Viteve të fundit kërkesa për energji elektrike ka tejkaluar furnizimin dhe ky problem pritet të përkeqësohet në veçanti me rritjen e ekonomisë së Kosovës.(Ekstrakt) ${ }^{3}$

Sot kapaciteti operues elektrik i Kosovës është rreth 900 MW, gati thuajse e tëra vije nga dy termocentrale të vjetra që prodhojnë me djegie të thëngjillit. Me rritjen e popullatës, kufizimet e vazhdueshme sa i përket energjisë vazhdojnë të rriten - me kërkesat për energji që pritet të jenë 4.6\% më të larta në vitin 2020 sesa në vitin 2010. Me qëllim të plotësimit të kërkesës gjithnjë e në rritje për energji, për të reduktuar ndërprerjet e energjisë, dhe për të ulur emisionet e gasit serë (GHG). Realisht R. Kosovës është duke punuar për të përmirësuar gjendjen e energjisë në një mënyrë gjithëpërfshirëse. Këto përmirësime përfshijnë një plan për rehabilitimin e termocentralit Kosova B - i cili është më i vjetër se 25 vjet - për ta vendosur atë që të jetë në përputhje me Direktivat përkatëse të Bashkimit Evropian, dhe ndërtimi i një termocentrali me djegie ligniti që është më efikas për të zëvendësuar termocentralin Kosova A i cili është 45 vjeç i vjetër dhe i cili bënë një ndotje të madhe. (Ekstrakt) ${ }^{4}$

Prodhimi i energjisë elektrike në vend bëhet kryesisht nga Korporata Energjetike e Kosovës (KEK sh.a), e cila përbëhet nga dy termocentrale (Kosova A dhe Kosova B) si dhe Minierat e Qymyrit (sektori Mihja e re Sibovci Jug-Perëndim dhe Sitnica), dhe në një masë të vogël nga hidrocentralet (Ujmani, Lumbardhi, Radaci, Dikanci dhe Burimi). Kapacitetet e instaluara të termocentraleve janë 1478 MW, mirëpo për shkak tëvjetërsisë së tyre, aktualisht kapaciteti operativ i tyre sillet rreth915 MW.Prodhimi bruto i energjisë elektrike nga termocentralet ekzistuese për vitin 2012 ka qenë 5,383.981GWh. Kapacitetet e instaluara hidrike janë 45.84 MW, prodhimi i të cilave gjatë vitit $2012 \mathrm{ka}$ qenë $95.582 \mathrm{GWh}$

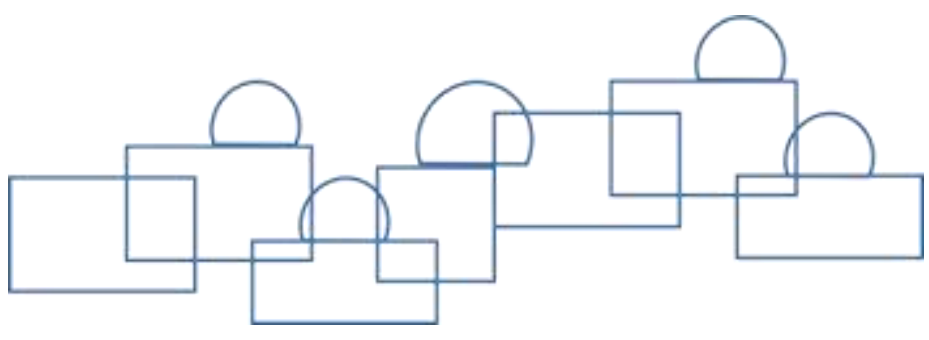

3 http://www.worldbank.org/en/country/kosovo/brief/al-energy-in-Losovo. Korrik/2015.

4 http://www.worldbank.org/en/country/Kosovo/brief/al-energy-infra-Kosovo. Shtator/2013. 2015. 
Tabela 1. Kapacitetet e instaluara prodhuese të energjisë elektrike. ${ }^{5}$

(Burimi): MZHE. Strategjia e energjisë e Republikës së Kosovës 2013 - 2022. 2015.

\begin{tabular}{|c|c|c|c|c|}
\hline \multirow{2}{*}{ Njësitë prodhuese } & \multicolumn{3}{|c|}{ Kapaciteti i njësive (MW) } & \multirow{2}{*}{$\begin{array}{c}\text { Futja në } \\
\text { operim }\end{array}$} \\
\hline & Instaluar & Neto & Min/max & \\
\hline \multicolumn{5}{|l|}{ Termocentralet } \\
\hline A1 & 65 & Nuk operon & & 1962 \\
\hline $\mathrm{A} 2$ & 125 & Nuk operon & & 1964 \\
\hline A3 & 200 & 182 & $100-130$ & 1970 \\
\hline A4 & 200 & 182 & $100-130$ & 1971 \\
\hline A5 & 210 & 187 & 135 & 1975 \\
\hline TC Kosova A & 800 & 551 & & \\
\hline B1 & 339 & 310 & $180-260$ & 1983 \\
\hline $\mathrm{B} 2$ & 339 & 310 & $180-260$ & 1984 \\
\hline TC Kosova B & 678 & 620 & & \\
\hline Total TC & 1478 & 1171 & & \\
\hline \multicolumn{5}{|c|}{ Hidrocentralet } \\
\hline HC Ujmani & 35 & 32 & & 1983 \\
\hline HC Lumbardhi & 8.80 & 8.00 & & $1957(2006)$ \\
\hline HC Dikanci 1 & 1.00 & 0.94 & & $1957(2010)$ \\
\hline HC Radavci & 0.90 & 0.84 & & $1934(2010)$ \\
\hline HC Burimi & 0.86 & 0.80 & & $1948(2011)$ \\
\hline Total HC & 46.56 & 42.58 & & \\
\hline Energjia nga era & 1.35 & & & 2010 \\
\hline Total & $1,525.91$ & $1,213.58$ & & \\
\hline
\end{tabular}

\subsubsection{Projekti - Kosova e Re}

Termocentrali Kosova e Re është një nga projektet kryesore që mbështet të gjitha shtyllat e Strategjisë së Energjisë së Republikës së Kosovës. Ky termocentral parashihet të ketë 2 njësi me rreth $300 \mathrm{MW}$ për njësi dhe do të ndërtohet me teknologjinë më të mirë të disponueshme (BestAvailableTechnology, BAT) në treg.

Synimi i projektit është që të arrihet siguria e furnizimit në formën më të qëndrueshme mjedisore, si dhe duke optimizuar shfrytëzimin e resurseve natyrore në dispozicion. Termocentrali Kosova e Re do ndërtohet duke implementuar "Industrial Emmissions Directive", e cila paraqet standardin më të lartë Evropiane për mjedis. Implementimi i këtij standardi do të nënkuptoj se ky termocentral do të prodhoj energjinë elektrike me emisione që janë të njëjta me nivelin e pranueshëm për termocentrale të reja në Evropë. Njëkohësisht, përmes zhvillimit të këtij termocentrali do të mundësohet edhe mbyllja e Termocentralit Kosova A, që është një nga ndotësit kryesor në Republikën e Kosovës. $(\text { Ekstrakt })^{5}$

5 Ministria e zhvillimit ekonomik. Strategjia e energjisë e Republikës së Kosovës 2013 - 2022. 2015. 
Projekti i zhvillimit të TC Kosova e Re do të menaxhohet duke respektuar ligjet e Kosovës dhe standardet më të larta të transparencës dhe nxitjes së konkurrencës. Përgjatë historisë së tij, në këtë projekt kanë ndodhur disa ndryshime në strukturë si rezultat i kërkesave të investitorëve. Këto ndryshime në strukturë kanë qenë rezultat i qëllimit që të sigurohet pjesëmarrje sa më e lartë e investitorëve të interesuar, në mënyrë që përmes konkurrencës të sigurohet se çmimet e energjisë elektrike nga ky projekt do të jenë sa më të përballueshme për qytetarët e Kosovës. Qeveria e Kosovës do të angazhohet edhe tutje që procedura e përzgjedhjes së investitorëve dhe ndërtuesve si dhe struktura e projektit do të kenë për qëllim nxitjen e konkurrencës dhe sigurimin e çmimeve sa më të përballueshme nga ky termocentral.

\subsubsection{Traktati për Komunitetin e Energjisë}

Kosova është nënshkruese e Traktatit për Themelimin e Komunitetit të Energjisë (TKE) të Evropës Juglindore, i cili ka hyrë në fuqi me 1 korrik 2006. Në këtë kontekst, Qeveria e Kosovës është e angazhuar substancialisht për ta zhvilluar sektorin e energjisë në përputhje me kërkesat e TKE-së. Ky Traktat obligon implementimin e 'AcquisCommunautaire' të BE nga ana e secilës palë kontraktuese, sipas një kalendari për zbatim të reformave të kërkuara. Duhet të theksohet se sistemi i transmisionit në Kosovë është nyje aktive e rëndësishme për bartjen e energjisë elektrike të sistemeve tjera elektro-energjetike të rajonit, po ashtu dhe për tregtarët e energjisë elektrike. Në këtë kontekst Qeveria do të angazhohet që të marr disa funksione nga TKE apo KE ne funksion te zhvillimit të tregut te energjisë elektrike. (Ekstrakt) ${ }^{5}$

\subsubsection{Bashkëpunimi rajonal}

Qeveria konsideron se bashkëpunimi rajonal është mjaft i rëndësishëm për Kosovën. Natyrisht, për sektorin e energjisë ky bashkëpunim merr rëndësi të veçantë, sepse synon jo vetëm integrimin e tregjeve energjetike, por edhe rritjen e mirëkuptimit të ndërsjellë dhe shtimin e shkëmbimeve energjetike që janë mjaft të rëndësishme për rritjen e sigurisë së furnizimit me energji. Në kushtet kur infrastrukturat energjetike në vendet e rajonit nuk janë të zhvilluara në masën e duhur që të mundësojnë shkëmbime të mjaftueshme energjetike pa probleme. Bashkëpunimi rajonal do të synojë edhe në shkëmbimin e eksperiencave, unifikimin e qasjeve dhe praktikave për çështje relevante si dhe për trajtimin e çështjes për shfrytëzimin e ujërave për qëllime energjetike. Për këtë sa ma shpejt që të jetë e mundur do të bisedohet me Shqipërinë për arritjen e një marrëveshje të re sa i përket shfrytëzimit të ujërave. Andaj, është jetike që Qeveria e Republikës së Kosovës të angazhohet në avancimin e marrëdhënieve të bashkëpunimit në sektorin e energjisë edhe me shtetet tjera në rajon. (Ekstrakt) ${ }^{5}$

\subsubsection{Struktura e popullsisë}

Në përgatitjen e këtij vlerësimi, ASK ka aplikuar metodat e praktikuara mbi vlerësimin e popullsisë, që bëhen nga institucionet statistikore, duke shfrytëzuar burimet e ndryshme. Baza e të dhënave për ta vlerësuar numrin e popullsisë për vitin 2014 është marrë numri i vlerësuar i popullsisë rezidente në Kosovë në fund të vitit $2013 .^{6}$

6 Agjencia e Statistikave të Kosovës. Popullsia e Kosovës 2014. 2015. 


\subsubsection{Burimet e të dhënave}

Janë shfrytëzuar burime të ndryshme statistikore si: Vlerësimi i vitit 2013, baza e të dhënave nga Regjistrimi i Popullsisë 2011, bazat e shënimeve nga Statistikat e Lindjeve dhe Vdekjeve (ASK), të dhënat nga anketat që zhvillohen në ASK, të dhënat administrative (baza e ASK), të dhënat nga komunat e Kosovës, të dhënat nga Ministria e Punëve të Brendshme, baza e shënimeve nga Eurostati, dhe të dhënat nga zyrat statistikore dhe ato të migrimit të 33 shteteve, ku është i shprehur më shumë emigrimi kosovar. Po ashtu, janë shfrytëzuar të dhënat e tjera administrative nga institucionet vendore, anketat, raportet dhe hulumtimet e tjera. Këto të dhëna janë analizuar sipas metodave statistikore, duke shërbyer si instrumente dhe shënime të rëndësishme statistikore, për ta bërë vlerësimin e numrit të popullsisë në nivel vendi dhe në nivel të komunave. $\left(\right.$ Ekstrakt) ${ }^{6}$

\subsubsection{Popullsia bazë}

Sipas "Vlerësimit të vitit 2013" numri i popullsisë rezidente në Kosovë ishte vlerësuar në 1820631 banorë.

\subsubsection{Shtimi natyror}

Lindjet: sipas të dhënave, nga baza e shënimeve të ASK-së, numri i lindjeve (të regjistruara) për vitin 2014 ishte gjithsej 32369 lindje të gjalla. Prej tyre, 32087 lindje ishin me vendbanim të përhershëm të nënës në Kosovë (rezident).

Vdekjet: sipas të dhënave nga baza e shënimeve të ASK-së, numri i vdekjeve (të regjistruara) për vitin 2014 ishte gjithsej 8165 vdekje (me vendbanimin rezident në Kosovë). Shtimi natyror: popullsia e Kosovës gjatë vitit 2014 është rritur për 23922 banorë.

\subsubsection{Migrimi}

Imigrimi ndërkombëtar: sipas të dhënave nga Ministria e Punëve të Brendshme (MPB), UNHCR-ja, IOM-i dhe të dhënat nga disa komuna, numri i të kthyerve (imigrantëve) në Kosovë, gjatë vitit 2014, ishte gjithsej 5720 banorë. Emigrimi ndërkombëtar: numri i emigrantëve kosovarë gjatë vitit 2014 ishte gjithsej 45333 banorë. Në këtë numër janë përfshirë të gjithë emigrantët, legalë dhe ilegalë. Migrimi kombëtar: gjatë vitit 2014 vlerësohet se një numër i konsiderueshëm i popullsisë rezidente në Kosovë ka ndërruar vendbanimin (komunën) për arsye të ndryshme. Sipas vlerësimit, numri i personave që e kanë ndërruar komunën e mëparshme (nga një komunë në komunën tjetër) është gjithsej 9466 banorë.

\subsubsection{Rritje e përgjithshme}

Bazuar në këto të dhëna, përkundër shtimit natyror të popullsisë (32 087 lindje), popullsia rezidente e Kosovës për periudhën 01 janar - 31 dhjetor 2014 është zvogëluar për 15687 banorë, për shkak të emigrimit ndërkombëtar. Popullsia rezidente në Kosovë për vitin 2014 vlerësohet të jetë 1804944 banorë. 
Tabela 2. Popullsia e Kosovës dhe shtimi natyror për vitin 2014, nivel i komunave. ${ }^{6}$ (Burimi): Agjencia e Statistikave të Kosovës. Popullsia e Kosovës 2014. 2015.

\begin{tabular}{|c|c|c|c|c|c|c|}
\hline \multirow{2}{*}{$\mathrm{Nr}$. } & \multirow{2}{*}{ Komuna } & \multirow{2}{*}{$\begin{array}{c}\text { Gjithsej } \\
\text { popullsia e } \\
\text { vlerësuar } \\
(31 \\
\text { dhjetor } \\
\text { 2013) }\end{array}$} & \multicolumn{2}{|c|}{$\begin{array}{l}\text { Sipas vendbanimit të } \\
\text { përhershëm në komunë }\end{array}$} & \multirow{2}{*}{$\begin{array}{c}\text { Shtimi } \\
\text { natyror } \\
(01.01- \\
31.12 / 2014)\end{array}$} & \multirow{2}{*}{$\begin{array}{c}\text { Gjithsej } \\
\text { popullsia } \\
\text { dhe shtimi } \\
\text { natyror } \\
(01.01- \\
31.12 \text { 2014) }\end{array}$} \\
\hline & & & $\begin{array}{l}\text { Nataliteti } \\
(2014)\end{array}$ & $\begin{array}{l}\text { Mortaliteti } \\
\text { (2014) }\end{array}$ & & \\
\hline 1 & Deçan & 40,549 & 639 & 153 & 486 & 41,035 \\
\hline 2 & Gjakovë & 96,162 & 1,598 & 518 & 1,080 & 97,242 \\
\hline 3 & Gllogoc & 59,990 & 1,093 & 245 & 848 & 60,838 \\
\hline 4 & Gjilan & 91,489 & 1,557 & 476 & 1,081 & 92,570 \\
\hline 5 & Dragash & 34,364 & 562 & 267 & 295 & 34,659 \\
\hline 6 & Istog & 40,126 & 664 & 192 & 472 & 40,598 \\
\hline 7 & Kaçanik & 33,875 & 575 & 163 & 412 & 34,287 \\
\hline 8 & Klinë & 39,555 & 930 & 178 & 752 & 40,307 \\
\hline 9 & Fushë Kosovë & 37,843 & 701 & 164 & 537 & 38,380 \\
\hline 10 & Kamenicë & 35,261 & 423 & 213 & 210 & 35,471 \\
\hline 11 & Mitrovicë & 73,363 & 1,565 & 434 & 1131 & 74,494 \\
\hline 12 & Mitrovica e V. & 12,139 & 20 & 8 & 12 & 12,151 \\
\hline 13 & Leposaviq & 13,485 & 11 & 6 & 5 & 13,490 \\
\hline 14 & Lipjan & 59,196 & 1,140 & 237 & 903 & 60,099 \\
\hline 15 & Novobërdë & 6,923 & 46 & 27 & 19 & 6,942 \\
\hline 16 & Obiliq & 22,105 & 393 & 80 & 313 & 22,418 \\
\hline 17 & Rahovec & 57,645 & 1,038 & 204 & 834 & 58,479 \\
\hline 18 & Pejë & 97,706 & 1,625 & 493 & 1,132 & 98,838 \\
\hline 19 & Podujevë & 89,051 & 1,443 & 340 & 1,103 & 90,154 \\
\hline 20 & Prishtinë & 207,477 & 3,709 & 810 & 2,899 & 210,376 \\
\hline 21 & Prizren & 182,449 & 3,359 & 840 & 2,519 & 184,968 \\
\hline 22 & Skenderaj & 51,361 & 1,081 & 221 & 860 & 52,221 \\
\hline 23 & Shtime & 28,096 & 522 & 127 & 395 & 28,491 \\
\hline 24 & Shtërpcë & 6,873 & 94 & 19 & 75 & 6,948 \\
\hline 25 & Suharekë & 61,352 & 1,360 & 291 & 1,069 & 62,421 \\
\hline 26 & Ferizaj & 111,842 & 1,982 & 537 & 1,445 & 113,287 \\
\hline 27 & Viti & 47,774 & 831 & 213 & 618 & 48,392 \\
\hline 28 & Vushtrri & 71,212 & 1,303 & 354 & 949 & 72,161 \\
\hline 29 & Zubin Potok & 6,508 & 22 & 2 & 20 & 6,528 \\
\hline 30 & Zveçan & 7,319 & 13 & 4 & 9 & 7,328 \\
\hline 31 & Malishevë & 56,482 & 1,267 & 208 & 1,059 & 57,541 \\
\hline 32 & Junik & 6,226 & 76 & 18 & 58 & 6,284 \\
\hline 33 & Mamushë & 5,688 & 105 & 15 & 90 & 5,778 \\
\hline 34 & Hani i Elezit & 9,613 & 194 & 57 & 137 & 9,750 \\
\hline 35 & Graçanicë & 11,359 & 60 & 5 & 55 & 11,414 \\
\hline 36 & Ranillug & 3,791 & 52 & 21 & 31 & 3,822 \\
\hline 37 & Partesh & 1,731 & 19 & 18 & 1 & 1,732 \\
\hline 38 & Kllokot & 2,651 & 15 & 7 & 8 & 2,659 \\
\hline & Gjithsej & $1,820,631$ & 32,087 & 8,165 & 23,922 & $1,844,553$ \\
\hline
\end{tabular}


Tabela 3. Lëvizja e numrit të përgjithshëm të popullsisë në Kosovë. 1948-1981. ${ }^{2}$

(Burimi): Ministria e mjedisit dhe planifikimit hapësinor. Raport, Gjendja e ujërave në Kosovë. 2010.

\begin{tabular}{|c|c|c|}
\hline Viti & Numri i banorëve & Komentet \\
\hline $\mathbf{1 9 4 8}$ & 727820 & Regjistrimi \\
\hline $\mathbf{1 9 6 1}$ & 963988 & Regjistrimi \\
\hline $\mathbf{1 9 7 1}$ & 1243693 & Regjistrimi \\
\hline $\mathbf{1 9 8 1}$ & 1584440 & Regjistrimi \\
\hline
\end{tabular}

\subsubsection{Ngrohja qendrore}

Sistemet e ngrohjes qendrore ekzistojnë vetëm në Prishtinë, Gjakovë, Mitrovicë dhe Zveçan. Këto sisteme janë të shtrira për aq sa përmbushin vetëm 3\% të kërkesës së përgjithshme për ngrohje të hapësirave, këto të dhëna reflektojnë situatën aktuale deri në momentin kur "Termokosi" në Prishtinë funksionalizohet me shërbimin e ko gjenerimit, ku situata e ngrohjes në Prishtinë është duke u përmirësuar esencialisht.

Tabela 4. Kapaciteti i ngrohtoreve qendrore në Kosovë. ${ }^{5}$

(Burimi): MZHE. Strategjia e energjisë e republikës së Kosovës 2013 - 2022. 2015.

\begin{tabular}{|l|c|c|c|c|}
\hline $\begin{array}{c}\text { Ndërmarrja } \\
\text { (Qyteti) }\end{array}$ & $\begin{array}{c}\text { Kapaciteti } \\
\text { i instaluar } \\
\text { MWt }\end{array}$ & $\begin{array}{c}\text { Kapaciteti } \\
\text { operacionalMWt }\end{array}$ & $\begin{array}{c}\text { Gjatësia e } \\
\text { rrjetit të } \\
\text { shpërndarjes } \\
\text { km }\end{array}$ & $\begin{array}{c}\text { Nr. } \\
\text { nënstacioneve }\end{array}$ \\
\hline NQ Termokos & 135.62 & 135.62 & 70 & 312 \\
\hline NQ Gjakova & 38.6 & 20 & 23.5 & 275 \\
\hline NQ Mitrovicë & 16.9 & & 4.5 & 20 \\
\hline NQ Zveçan & 1.6 & & 0.8 & \\
\hline
\end{tabular}

Ngrohtorja e Mitrovicës dhe e Zveçanit, për shkak të rrethanave të njohura, nuk i përgjigjen kërkesave për licencim/rregullim dhe monitorim nga ZRRE-ja, kështu që pamundësohet sigurimi i të dhënave përkatëse të azhurnuara. Përgjatë viteve 2009-2012 janë realizuar disa investime, si në rehabilitimin e pajisjeve të prodhimit; ndërrimin e rrjetit të vjetër të termo-përçuesit; zgjerimin e rrjetit të ngrohjes; zgjerimin e sipërfaqes ngrohëse. Me gjithë zhvillimet pozitive, këto kompani ende nuk funksionojnë si biznese të vetë-qëndrueshme dhe profitabile, për shkak të mos grumbullimit të borxheve nga konsumatorët dhe humbjeve të larta. Andaj, këto kompani ende mbesin të varura nga subvencionet e Buxhetit të Kosovës, apo komunave respektive. Më qëllim të furnizimit të sigurt të Prishtinës me ngrohje, është në realizim projekti i koogjenerimit TC 'Kosova B' - Termokos, i cili financohet nga Bashkimi Evropian, Qeveria e Gjermanisë nëpërmjet KfW, Qeveria e Luxemburgut, Qeveria Suedisë dhe Komuna e Prishtinës. Përmes këtij projekti do të rritet siguria e furnizimit, efiçienca si dhe do të bëhet zëvendësimi i përdorimit të mazutit si lëndë djegëse për ngrohje. 
Më qellim të identifikimit të opsioneve të mundshme të termofikimit dhe për të mundësuar riverifikimin e burimeve të energjisë për ngrohje në vitin 2012 është realizu studimi për ngrohjen qendrore në Pejë, Prizren, Gjilan dhe Ferizaj. (Ekstrakt) ${ }^{5}$

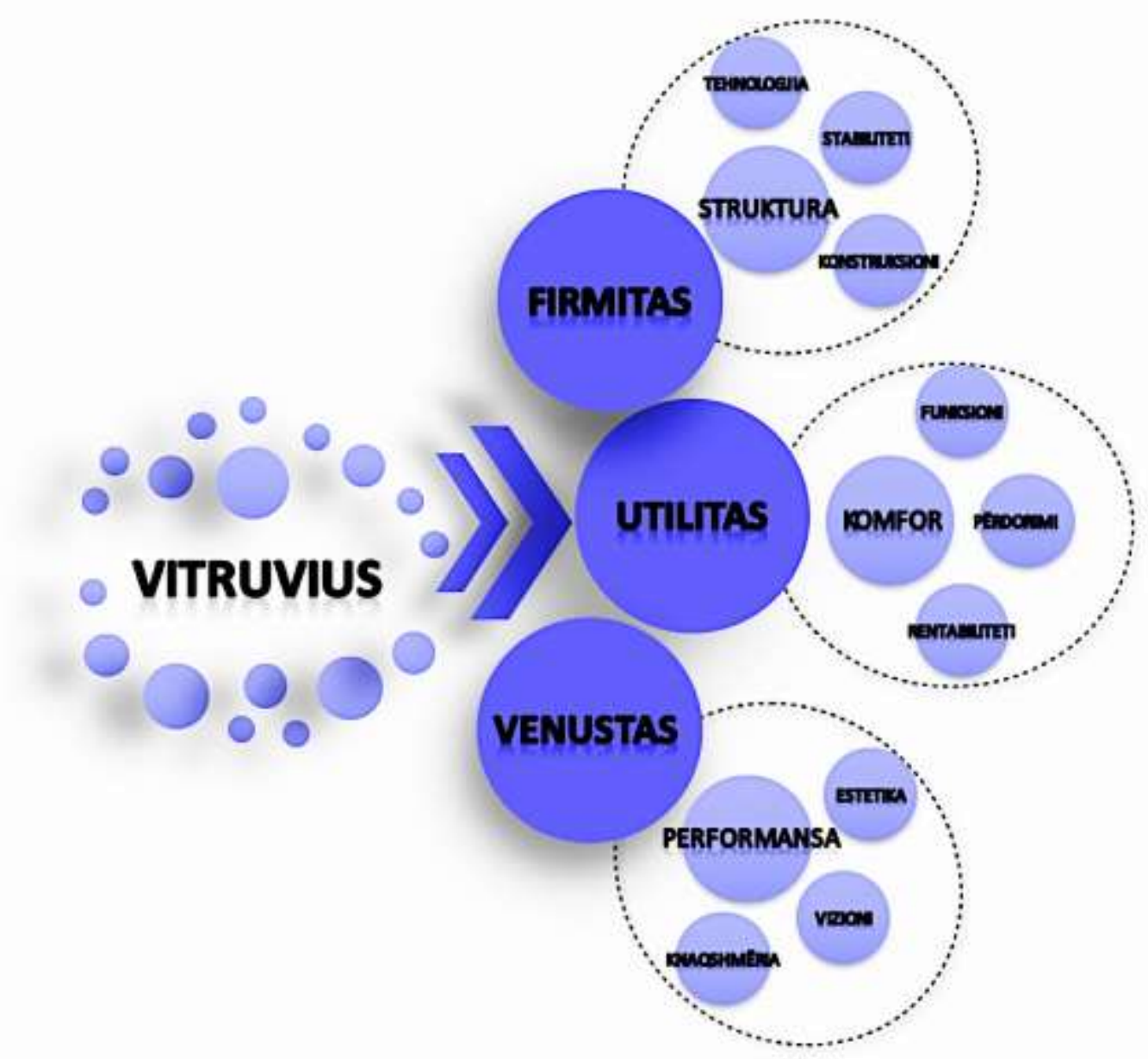

Figura 3. Vitruvius, modelet kryesore gjatë projektimit

(Burimi): Bujar Bajçinovci, 2015.

Vitruvius (Marcus Vitruvius) besonte se një arkitekt duhet të fokusohet në tri veçori qendrore në procesin e projektimit: FIRMITAS (stabiliteti), UTILITAS (funksionaliteti), dhe VENUSTAS (bukuria). Por teoria e VENUSTAS (ose e bukurisë) është një koncept shumë i ndërlikuar. Vitruvius besonte se një nocion i përjetshëm i bukurisë do të mund të mësohet nga "e vërteta e natyrës", natyra e bazuar në ligjet universale të proporcionit dhe simetrisë. Ai besonte se proporcionet e trupit të njeriut mund të përdoren si një model i përsosmërisë natyrore proporcionale. Hulumtoi për mënyrën se si dijetarët e lashtë kanë ekzaminuar shumë shembuj të "burrave me formë të mirë". Për më tepër, diskutonte duke argumentuar me ilustrime se ekzistonte lidhja në mes formave të përsosura gjeometrike dhe trupit të njeriut. Në këtë mënyrë, trupi apo trajta e njeriut është parë si një rregull e gjallë, që përmban proporcionet dhe ligjet universale nga natyra. ${ }^{7}$

7 http://www.bl.uk/learning/cult/bodies/vitruvius/proportion.html, Shtator/2015. 
KJO FAQE ËSHTË LËNË QËLLIMISHT E ZBRAZËT! 


\section{PËRKUFIZIMET THEMELORE}

$\mathrm{D}$ iversiteti i variacionit, përcaktimi i koncepteve dhe dallimet brenda kategorive të përdorura në këtë monografi veçohen me definimet themelore e të të kuptuarit. Definimet themelore kanë për detyrë të shkoqisin kuptuarjen dhe sqarimet për nocionet e përdorura, të cilat janë të përfshira në shtjellimin e tematikës.

\subsection{Projektimi transdisciplinar}

Thelbi i projektimit transdisiplinar nuk është ende i qartë sa duhet. Len të kuptohet, se është një tërësi e profesioneve të ndryshme të lidhura ngushtë me detyrën e hartimit apo zgjidhjes së mundshme të problemit, apo ndoshta është një tërësi e një procesi i cili tejkalon kufijtë e zakonshëm dhe konvencional të disiplinave të involvuara. Aktualisht, jemi dëshmitarë të studimeve suplementare akademike, duke përfshirë edhe krijimin e profesioneve të reja, të cilat pasqyrojnë mënyrën aktuale të jetesës. Arkitektura, një profesion i cili nga gjeneza e saj, ka natyrë ndërdisiplinore, me kalimin dhe zhvillimin e teknologjisë futen relacione të reja me natyrë transdisiplinare në mënyrë të përgjigjes së kërkesave bashkëkohore arkitektonike. Kjo monografi sqaron parimet themelore se mu arkitektura është profesioni më evolutiv që mund të praktikojë pa barriera mentale konceptin transdisiplinar. Jemi në një epokë të re konceptesh dhe stileve të reja të jetesës, Simbiozë. ${ }^{8}$

Sipas Mittelstraß-it (1995), koncepti i hulumtimit transdisiplinar shtjellon dhe gjeneron probleme reale, synon të identifikojë dhe të zgjidhë problemet e dhëna, duke mos u mbështetur në veçanti në disiplinën kryesore e cila udhëheq procesin kreativ.

Andaj, koncepti transdisiplinar, paraqet hulumtim të integruar i cili përmirëson të kuptuarit e sistemit, arrin zgjidhje më të përshtatshme dhe potencialisht më inovative në procesin e projektimit arkitektonik. Procesi nënkupton strategji inovative të projektimit arkitektonik. Modeli i projektimit linear, është modeli aktual i lidhur direkt me praktikën dhe industrinë ndërtimore rajonale por edhe më gjerë. Objektet ndërtimore janë krijime komplekse me të cilat jemi të lidhur me të kaluarën, më të tashmen por edhe me të ardhmen. Ndërtimi i një hapësire funksionale arkitektonike jo vetëm që ofron strehim, një vend për të punuar, për të luajtur, të jesh intim i lirë dhe rekreativ, me një fjalë hapësira arkitektonike ka ndikim shumë të fuqishëm në jetën tonë.

Dizajni arkitektonik, proces përmes algoritmeve matematikore që janë bërë nga super kompjuterët ka veçuar kuptuarjen e gjuhës së përbashkët dhe përshtatjen në mes arkitektit dhe makinës llogaritëse duke avancuar marrëdhëniet interaktive në emër të shkencës dhe progresit teknologjik.

8 Kurokawa. K., (1991). Intercultural Architecture: The Philosophy of Symbiosis. American Institute of Architects Press. Washington DC. 
Raporti i arkitektëve dhe i teknologjisë së re është zgjeruar edhe më shumë me futjen në përdorim të CAM, ky bashkëpunim ka ringjallur simbiozë interaktive nga projektimi virtual në realizimin fizik ndërtimor. CAM ka reduktuar kohën, si dhe paragjykimin se bashkëpunimi në mes arkitektit dhe kompjuterit do të rezultojë dhe qëndrojnë vetëm në nivelin e botës virtuale.

Në disa punëtori profesionale mund të ofrohen pikëpamje shkencore dhe artistike se arkitektura me interaksion të CAD, krijon qasje vetëm në nivel të formave arkitektonike, formave komplekse, transformimeve, metamorfozë të formave dhe në fund të gjitha me një pasqyrim apo 'rendering' të shkëlqyer. Arkitektura është më shumë se çdo formë, e transformuar ose jo, me pasqyrim të bukur 3D apo jo. Duke përdorur algoritme (software) për dizajn arkitektonik në jemi vetëm te fillimi pionier, me përparimet në teknologji interaktive ne sapo kemi filluar një bashkëpunim shumë kreativ. Megjithatë, me një qasje krejtësisht të re të projektimit është ndryshuar edhe qasja e të menduarit kreativ duke marrë funksione të reja, sisteme që janë duke u bërë më komplekse, të shoqëruara me kërkesa polifunksionale bashkëkohore. Strategjia aktuale e projektimit arkitektonik duhet të ripërcaktohet, e shoqëruar me zhvillimin e pashmangshëm të teknologjisë, mënyrën e jetesës, funksionet dhe kërkesat e reja, si dhe esencialisht nga mungesa e burimeve primare të energjisë dhe ndryshimeve klimatike të konfirmuara. Është më se e nevojshme, që arkitektura të filloj nga e para me transformimin dhe ridefinimin e lëmisë, aktivitet i padiskutueshëm nga rrethanat kohore dhe mileniumit të ri, kohë që sjell fenomene kardinale të pakthyeshme.

\subsection{Holizmi}

Deklarata e Aristotelit, " e tëra është më shumë se sa shuma e pjesëve të saj ", mund të konsiderohet si përkufizimi i parë konceptual i holizmit. Gjithashtu, holizmi është definuar edhe nga (Jan Smuts, 1926) i cili përkufizon se: Tendenca e natyrës është për të formuar tërësi, që janë më të mëdha se shuma e pjesëve të saj, një tërësi përmes evolucionit krijues. Në fizikë, disa fenomene kuantike, duket të ndodhin vetëm në sistem dhe nuk mund të shpjegohen nga ndërveprimi i komponentëve individuale të sistemit. Fenomenet metafizike të tilla si jeta, mendja dhe ndërgjegjja, ndodhin vetëm në sistem të tërësisë, kjo do të thotë se gjërat nuk mund të shpjegohen nga studimet individuale si: qelizat nervore apo atomet"9.

"Teoria e universit, dhe sidomos ajo mbi natyrën: shikohen në aspektin e ndërveprimit të tërësisë (si organizmat e gjalla), të cilat janë më shumë se shuma e pjesëve elementare. "

\subsection{Arkitektura Bioklimatike}

Arkitektura bioklimatike është aplikimi i parimeve universale të rrjedhjes së energjisë dhe karakteristikat rajonale klimatike të rajonit në projektin aktual arkitektonik. Pra, ndërtimi dhe funksionimi i objektit në mënyrë që të arrihet komfori termik duke përfshirë parimet bazë të natyrës si: orientimi, dielli, përdorimi efikas i energjisë, materialet lokale natyrore si dhe burimet e ripërtëritshme të energjisë. Sipas ligjit të termodinamikës dhe rrjedhave të energjisë, definohen ndërtesa "aktive dhe pasive". Një sfidë për arkitektët dhe parimet konceptuale të projektimit arkitektonik.

9 Smuts, J.(1927). Holism and Evolution. London: McMillan and Co Limited. 
3.4 Building Information Modeling, /Menaxhimi i të dhënave të ndërtesave, Modelimi/

Building Information Modeling (BIM) është procesi i krijimit dhe menaxhimi i të dhënave, projektimi i ndërtesave ose strukturave dhe eksploatimi gjatë ciklit të jetesës së ndërtesës me ndihmën e kompjuterëve. BIM përfshin prezantimin e projektit si një tërësi e figurave themelore, i cili gjeneron dhe simulon produkte të caktuara, objekte të ngurta ose volumenë të cilët përcaktojnë gjeometrin, marrëdhëniet dhe atributet e tyre. Mjetet e BIM projektimit lejojnë gjenerimin e pamjeve të ndryshme, seksione të modelit së ndërtesës si vizatime ose plane për prodhimin e produkteve. Këto pamje të ndryshme rregullohen automatikisht, në kuptimin që të gjitha objektet i takojnë një sistemi, secili objekt është i përcaktuar në fillim, si në realitet për të shmangur shumë gabime. ${ }^{10}$

\subsection{Efiçienca e energjisë}

Efiçienca e energjisë është përcaktuar si përdorimi i mençur i energjisë, për të arritur të njëjtën detyrë me më pak energji, përdorimin i qëndrueshëm i energjisë si strategji e objektivave përcaktuese mjedisore dhe ekonomike, por realisht premisa kryesore do ishte për të ruajtur energjinë dhe për të zvogëluar ndikimin e saj negativ në mjedis. Në bazë të koncepteve të mësipërme, standardet referuese janë miratuar nga ASHRAE. ${ }^{11}$

Segment i rëndësishëm i politikës së Republikës së Kosovës, e pasqyruar në programin e saj, është promovimi i Efiçiencës së Energjisë (EE), zbatimi i masave të EE në sektorët përkatës sipas PVKEE 2010-2018 dhe Bashkë Prodhimit (BP). Kjo politikë nxitëse e promovuese ndikon në rritjen e zhvillimit ekonomik, kursimin e energjisë, rritjen e sigurisë së furnizimit me energji dhe në mbrojtjen e mjedisit. ${ }^{5}$

Në periudhën 2009-2012 janë ndërmarrë hapa të rëndësishëm programorë, ligjorë dhe institucionalë për promovimin e EE, hartimin e Planit të Veprimit të Kosovës për Efiçiencë të Energjisë (PVKEE) për periudhën 2010-2018, hartimi i planit të parë afatmesëm të Veprimit të Kosovës për Efiçiencë të Energjisë (PVKEE) 20102012,hartimi i Planit të Dytë Afatmesëm Kombëtar të Veprimit për Efiçiencë të Energjisë (PKVEE) 2013-2015. Me ndihmën e AKEE, niveli komunal do të hartojë planet komunale për Efiçiencë të Energjisë.

Janë zhvilluar një sërë projektesh në fushën e Efiçiencës së Energjisë e që kryesisht kanë të bëjnë me masat konkrete siç janë; auditimi i energjisë në ndërtesat publike si dhe implementimi i masave të auditimit, ndriçimi publik në qytete të ndryshme, instalimi i paneleve solare në Qendrën Klinike Universitare, Konvikte të Studentëve dhe në objekte qeveritare në nivel qendror. Raporti i progresit të PVKEE 2010-2012 i parë afatmesëm tregon së caku indikativ i kursimit të energjisë prej $3 \%$ është arritur.

10 Eastman, C. (2009). Building Information Technology: Digital Building Lab@Georgia Tech. http://bim.arch.gatech.edu/?id=402.

11 OPR-2007,ASHRAE "Energy Efficiency and Environmental Sustainability Goals, The facility Will be designed to comply with the energy efficiency requirements prescribed in ASHRAE Standard 90.1-2004." 
Në PVKEE 2010-2018, respektivisht në PKVEE 2013-2015 të dytë afatmesëm, janë të paraqitura të gjitha aktivitetet e nevojshme që duhet të zhvillohen, afati kohor i realizimit të tyre, kostoja, burimi i financimit dhe institucioni përgjegjës. Për të arritur caqet e parapara sipas këtij plani (9\%, ose 92ktoe të kursimit të energjisë), në vazhdimësi janë duke u zhvilluar projekte konkrete në ndërmarrjen e masave të EE si në objekte të nivelit qendror ashtu edhe atë të menaxhuara nga niveli lokal.

Renovimi i ndërtesave dhe modernizimi i sistemeve të ngrohjes dhe ftohjes përbejnë potencialin më të madhe të kursimit (Efiçiencës së Energjisë), të energjisë. Gjithashtu shfrytëzimi me racional i energjisë nëpër komuna do të kontribuonte në masë të madhe në arritjen e caqeve të parapara. (Ekstrakt) ${ }^{5}$

\subsection{Sick Building Syndrome (SBS), /Sindromi i ndërtesës së sëmuar/}

Sindrom, i njohur gjerësisht se ndërtesa duhet të ofrojë një mjedis të shëndetshëm, të sigurt dhe të këndshëm për banuesit. Megjithatë, është diagnostifikuar një fenomen relativisht i ri, i ashtuquajturi Sick Building Syndrome i cili aktualisht është i njohur nga Organizata Botërore e Shëndetësisë (OBSH), sipas Jack Rostron (1997).

SBS është një kombinim i sëmundjeve ose simptomeve (sindroma) që janë të lidhura ose të lidhura me një vend të veçantë. Ndërtesat e dëmtuara nga uji (WDB), specifike në simptomet e numëruara nga (SBS), kanë efekte negative në shëndetin e njeriut, sipas përshkrimit të studimit të kryer nga pjesëmarrësit e Komisionit për hulumtimin e sëmundjeve kronike të organeve respiratore (ASN), Ritchie C. Shoemaker, MD, laura Mark MD, Scott McMahon, MD 2010. ${ }^{12}$

Pra, në dukje të padukshme objektet e tilla shfaqin një numër të praktikave të dëmshme mbi shëndetin e njeriut dhe të kafshëve, një sindromë që është njohur zyrtarisht nga Organizata Botërore e Shëndetësisë. E rëndësishme të theksohet se në vendin tonë nuk ka asnjë hulumtim në terren në nivelin lokal apo qendror, i cili shkencërisht do të diagnostifikonte ndërtesat e prekura nga ky fenomen.

Në mjedisin urban të qytetit (Prishtinës) ishte një seri e apeleve nga shoqëria civile për mjedise të caktuara që kanë të bëjnë me dyshimet të bazuara se fenomene të caktuara po ndikojnë drejtpërdrejt në shëndetin e njeriut. Këto fenomene kryesisht janë të lidhura me mbeturinat e deponisë në qytet, afërsia e thertoreve industriale në blloqet e banimit, sistemet e vjetra të ujërave të zeza dhe nga antenat për telefoninë celulare GSM.

12 Shoemaker, R., Mark, L., McMahon, S.(2010). “ Studimet kërkimore aktuale të bërë në njerëz kanë treguar një model të qëndrueshëm të simptomeve, sëmundje të identifikuara pas ekspozimit ndaj mjedisit të brendshëm të WDB. Mbi 40 studimeve, duke përfshirë më shumë se 50.000 pacientë nga 14 vende, të botuara që nga raporti i IOM-it, tregojnë se sindromi është i njohur globalisht”. 


\subsection{E - Smog, / Ndotja elektromagnetike /}

Trendi i ri i jetesës dhe një formë e re e ndotjes quhet 'Electrosmog'. Më herët kishte një dakordim që nuk ka rrezik nga këto fenomene elektromagnetike, por studimet e reja shkencore tregojnë një rrezik, madje edhe me sëmundje të kancerit " raste të bazuara në dëshmi, " sipas Revistës Amerikane të Mjekësisë Industriale (2008). ${ }^{13}$

Gjatë gjumit, sistemi ynë imun dhe metabolizmi reduktojnë aktivitetin si pjesë e procesit të rigjenerimit fiziologjik. Electrosmog, dukuri ose aktivitete të ngjashme mund të kanë një ndikim të veçantë në këtë fazë të rigjenerimit. Në SHBA, ka rregulla të veçanta që përcaktojnë qartë se rrezja e sigurisë dhe parimet e vendosjes së antenës për transmetues celular, si dhe rregulloret dhe standardet që kushtojnë vëmendje të veçantë për radiusin e sigurisë pranë çerdheve të fëmijëve, shkollave, spitaleve dhe komplekseve për sport dhe rekreacion. Gjykata e Lartë e Francës, në shkurt të vitit 2009. " Telekomit të Bouygues urdhëroi për të çmontuar një antenë për telefoninë celulare për shkak të pasigurisë në lidhje me ndikimin e saj mbi shëndetin. Qytetarët në rrethin Charbonnières Rhône hedhin në gjyq kompaninë duke pretenduar se shëndeti me efektet e rrezatimit të emetuara nga antena e lartë 19 metra është duke u dëmtuar. ${ }^{14}$

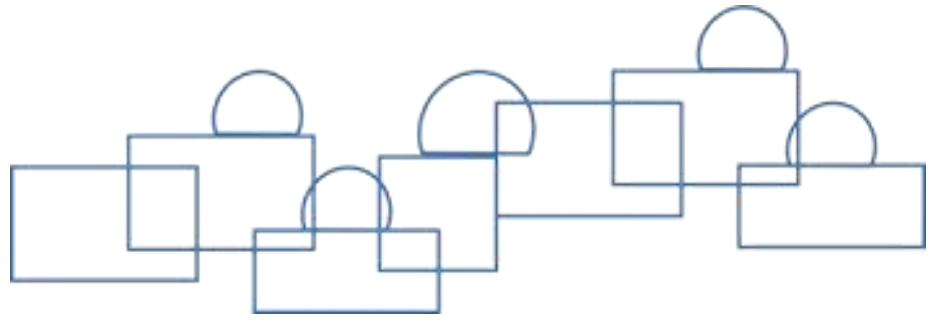

13 Milham, \& Morgan, L. (2008). Analiza e fundit, raportohet nga Milham dhe kolegu i tij, L. Lloyd Morgan, në vitin 2008 e tutje, në Revistën Amerikane të Mjekësisë Industriale: ekspozimi kumulativ ndaj rreziqeve të transmetimit në shkollën pët rritur, gjasat që mësuesi të zhvillojnë kancerin ishin 64\% . Për një vit pune u ngritë rreziku në $21 \%$. Shanset e mësuesve që në ta të zhvillohet melanoma, kanceri i gj. tiroide, kanceri i mitrës, ishin veçanërisht të larta. "Edhe pse nuk ishin të përfshirë në të gjitha tabelat, rreziqet për studentët e rinj ishin ndoshta edhe më të mëdha. "

14 Barstad, Stine. (Shkurt/2009). Kunne ikke bevise at strålingen var ufarlig. 
KJO FAQE ËSHTË LËNË QËLLIMISHT E ZBRAZËT! 


\section{PROBLEMATIKA ARKITEKTONIKE}

$\mathrm{M}$ ënyrat e reja me të cilat arkitektët janë duke ju përgjigjur sfidave të krijimit të arkitekturës së qëndrueshme, paraqesin koncepte kreative në praktikën e projektimit arkitektonik. Si mund të jetë një ndërtesë 'ekologjike'? Si mund arkitektët në praktikë ta kryejnë hulumtimin? Çfarë është 'green' në zgjidhjen e problemit të një programi projektues. Një sfidë e re në organizimin e ri të ndërtimit dhe praktikës arkitektonike, duke u angazhuar edhe klientët dhe përdoruesit për të marr pjesë në 'strategjitë e gjelbra'? Projektimi i qëndrueshëm shqyrton si pionier qysh në fazën fillestare, procesin e projektimit duke e përparuar praktikën arkitektonike. Andaj, praktikat bashkëkohore arkitektonike janë të kuptuarit esencial në promovimin e "qëndrueshmërisë", se çfarë lloj i teknologjisë, mjeteve, qasjeve dhe teknikave të reja janë duke u zhvilluar në lëminë e industrisë së ndërtimit.

Pothuajse të gjithë arkitektët, duke përjashtuar arkitektët e peizazhit, kanë studiuar pa ndonjë prapavijë serioze në ekologji apo biologji mjedisore. Në artikullin "Çfarë është projektimi ekologjik? Ken YEANG sugjeron se ajo që ne po bëjmë tani në profesion nuk është arkitekturë ekologjike, projektimi ekologjik në një të ardhme të afërt kërkon riorientim fondamental e të menduarit dhe të projektimit në lidhje me mjedisin dhe krijimin arkitektonik. Ekzistojnë mënyra të ndryshme për të kuptuar dhe për të përcaktuar arkitekturën ekologjike, dhe në këtë kontekst është e nevojshme të merret në konsideratë arkitektura përtej ndërtesave. Përkufizimi i Aaron Betsky se arkitektura përfshin të gjitha gjërat përreth ndërtesës: "Arkitektura është gjithçka që ka të bëjë me ndërtimin. Kjo është se si ne mendojnë për ndërtimin, si ne i projektojmë ndërtesat, si ne i organizojmë ndërtesat, si shfaqen ndërtesat..., mirëpo, ndërtesat janë ndërtesa; Arkitektura është diçka tjetër".

Në librin "The technology of ecological building", inxhinieri gjerman Klaus Daniels përcakton parimet ekologjike për objekte të cilat përfshijnë nevojën për një shumëllojshmëri të detajuar në studime të mirëfillta: forma, ndërtimi, analiza e orientimit, klima lokale... Qasja e tij është e thelluar në optimizimin, integrimin e sistemeve të ndërtimit, duke u kombinuar me zgjidhje teknologjike të sisteme pasive për ta përmirësuar performancën. Daniels argumenton se ndërtesat e së ardhmes duhet të shfrytëzojë 'state of the art' materiale dhe teknologji në mënyrë për të minimizuar kërkesën për energji dhe kështu në mënyrë aktive ta mbrojnë mjedisin. Arkitekt dhe teoricieni Michael Lauring argumenton se "Arkitektura ekologjike", apo ky nocion është i ngarkuar me kuptimin kulturor, ky term ndryshon me kalimin e kohës dhe nuk ka një përcaktim të qartë. Po ashtu beson se termi ka qenë dhe është i lirë për përkufizim. Në një artikull të kohëve të fundit në Journal Nordik, të kërkimeve arkitektonike, shpjegohet se: "Ngadalë gjatë shtatëdhjetave" termi ekologjik ka evoluar në të qenit shkencor, term përshkrues për të qenë normativ, pa normë për kritere, por me shumë fotografi dhe shoqata kryesisht nga zona rurale apo vernakulare. (Ekstrakt) ${ }^{15}$

15 AD.(2011). Architectural Design. Experimental green strategies. 2011. 


\section{1 Sfidat me të cilat përballet arkitektura}

Rishikimi i rolit dhe rëndësisë së profesionit të arkitekturës është më së i rëndësishëm për tu shqyrtuar se si të punojmë së bashku për të siguruar bashkëpunim të mirëfilltë të integruar, për të ardhmen e cila është mjaft sfiduese në shumë aspekte.

Si arkitektë kemi kapacitet të krijojmë, duke u përshtatur me të gjitha veçoritë bashkëkohore, ku së pari kërkohet një kohezion mu në fazën e programimit arkitektonik me klientët dhe komunitetin. Mund të duket paksa ironike, por, është më së e nevojshme që të merret në konsideratë ridefinimi i rolit të arkitektin në të ardhmen e afërt. Sfidat për të cilat mendoj se veç janë të pranishme për profesionin arkitektonik, janë si vijojnë:

\section{Profesioni i arkitektit është në ri definim}

Arkitektura po vuan nga një krizë besimi. Gjithnjë e më shumë personalitete të veçanta në fushën e arkitekturës janë duke pranuar se profesioni ynë "ka humbur rrugën". Për tu përmendur: Frank Gehry, arkitekt nga më të famshmet në botë, deklaron "98\% e çdo gjë që është ndërtuar dhe projektuar sot është një hiç i pastër. Nuk ka kuptim të projektit, nuk ka respekt për njerëzimin apo për ndonjë gjë tjetër."!

\section{Konkurrenca dhe modalitetet}

Së paku kur bëhet fjalë për Kosovën, mund të ndodhë që jo shumë rrallë të kemi konkurrencë jo parimore, e bazuar në mos definime të qarta ligjore dhe procese të mos definuara mirë në konkurset publike.

\section{Subspecializimet në arkitekturë}

Arkitekti e ka rolin udhëheqës të projektit, duke përmbushur kërkesat e klientit dhe ruajtjen e cilësisë së projektit. Arkitektët tani zotojnë aftësi në modelimin e projektimit virtual, duke çuar përpara procesin e koordinimit në ndërtesa shumë komplekse. Si profesion, jemi duke u aftësuar me mjete bashkëkohore për mobilitet, bashkëpunim, komunikim on-line, automatizim në të ashtuquajturin term të ri "cloud" me efektshmeri të mëtejshme, shpejtësi, saktësi të integrimit dhe ulje të kostos. Andaj, përfshirja e hershme e klientit është një tendencë në rritje, duke çuar në një rol të zgjeruar për profesionin për të krijuar integrim të mirëfilltë me lëmi të subspecializuara. Për më tepër, vijmë deri të nevoja e arkitekteve të rinj me specializime dhe fusha të ngushta studimi.

\subsubsection{Veçoritë sociale}

Kosova ballafaqohet me probleme shumë të vështira sociale. Sipas vlerësimeve të Bankës Botërore dhe studimeve të realizuara, $34.5 \%$ e popullsisë jeton nën vijën e varfërisë me $€ 1.55$ në ditë. Megjithëse varfëria është e shpërndarë në mënyrë të barabartë mes zonave urbane dhe rurale, ka diferenca të mëdha rajonale dhe etnike. Të rinjtë përbëjnë rreth $60 \%$ të njerëzve nën vijën e varfërisë. Gjithashtu ka një lidhje të konsiderueshme mes varfërisë dhe edukimit, ku ata që nuk e kanë përfunduar shkollimin e mesëm kanë më shumë mundësi të gjenden në këtë grup se ata që e kanë përfunduar. Sikurse në shumicën e vendeve të tjera, ekziston një lidhje e konsiderueshme mes varfërisë dhe papunësisë të cilat rezultojnë me gjendje të vështirë sociale. 
Shkalla e papunësisë në Kosovë është rreth $44 \%$ e fuqisë punëtore, megjithatë shifrat e sakta janë të pamundshme për shkak të përmasave të ekonomisë jo formale. Shkalla e pjesëmarrjes në tregun e punës është e ulët në krahasim me vendet e rajonit, posaçërisht për femrat, për të cilat shkalla në vitin 2009 ishte $29 \%$, krahasuar me $67 \%$ për meshkuj. Papunësia ndër të rinjtë është posaçërisht e lartë - $82 \%$ për femra dhe $69 \%$ për meshkuj. Sektorët e edukimit dhe shëndetësisë janë duke u ballafaquar me sfida fondamentale. Cilësia e infrastrukturës shkollore është nën standardin e rajonit dhe ka probleme me regjistrimin e femrave dhe personave që jetojnë në familje të varfra. Sektori i shëndetësisë është duke u ballafaquar me rritje të kërkesës për shërbime dhe rënie të fondeve publike (si përqindje e BPV-së) dhe sistemi i shëndetësisë në përgjithësi ka nevojë për një reformë të përgjithshme për përmirësimin e standardeve dhe llogaridhënies. Autoritetet kanë përgatitur një plan të veprimit për adresimin e sfidave në sektorin e shëndetësisë për periudhën 2010-14. ${ }^{16}$

Në vitet e fundit, numri i projekteve për energji të qëndrueshme në Kosovë ka qenë i vogël. Zhvillimi i projekteve të qëndrueshme të EQ për ndërmarrjet vendore të vogla dhe të mesme dhe për përdoruesit e tjerë të fundit të energjisë (p.sh për sektorin vendor dhe jo-vendor të ndërtimit) ka qenë i vështirë për shkak disa arsye, duke përfshirë: mungesën e fondeve për realizimin e programeve investive të ndërmarrjeve; qasjen $\mathrm{e}$ pamjaftueshme në financim afatgjatë; kapacitetet e ulëta për zhvillim të projekteve dhe ekspertizës së nevojshme për efikasitetin e energjisë dhe masave të energjisë së ripërtëritshme në sektorin e ndërtimit. (Ekstrakt) ${ }^{16}$

\subsubsection{Mjedisi dhe shoqëria}

Kosova në vitet e pasluftës ka sjellë një varg politikash, strategjish dhe ligjesh me të cilat rregullohet çështja e respektimit, ruajtjes dhe përparimit të mjedisit jetësor dhe zhvillimit të qëndrueshëm. Fatkeqësisht, në periudhën e deritashme i janë shkaktuar dëme të mëdha hapësirës së Kosovës edhe në zonat me vlerat më të larta, në shkallën më të lartë ligjore të mbrojtjes kombëtare dhe ndërkombëtare, siç është rasti i rezervatit të arnenit në Prevallë nga ndërtimet, atij të rrëqebullit në Rusenicë nga gurthyesit .

Sistemi jo adekuat i mbrojtjes dhe menaxhimit është shprehur dhe në vlerat e diversitetit biologjik të ekosistemeve, resurset pyjore, burimeve dhe rrjedhave të ujit, tokat pjellore. Situata me mbeturinat është pothuajse alarmante, andaj në çdo vend janë prezentë mbeturinat që paraqesin rrezik për mjedisin dhe shëndetin e njerëzve. Problemet e mëdha mjedisore janë të shprehura si rezultat i politikave joadekuate, si dhe organizimi jo i duhur i institucioneve përkatëse dhe shoqërisë, gjë që vështirëson realizimin e suksesshëm dhe kualitativ të detyrave.

Problemi qëndron në mos angazhimin e institucioneve dhe kuadrove profesionale, si në nivel qendror ashtu dhe në atë lokal. Problem i shprehur është moszbatimi i ligjeve dhe rregulloreve, si dhe strategjive dhe planeve që janë miratuar. Problemi është dhe në nivelin e vetëdijes së qytetarëve, që duhet të jetë çështje gjithëpërfshirëse dhe sistematike e kultivimit në programet arsimore.

16 Banka evropiane për rindërtim dhe zhvillim. Strategji për Kosovën. 2013. 
Duhet organizim më i mire në nivel shtetëror, shkallë më e lartë e ngritjes në të gjitha nivelet si dhe koordinimi dhe përkrahja, veçmas organeve lokale të pushtetit. Krahas Qeverisë edhe Kuvendi duhet të ketë aktivitet më të shprehur në kuptim të përkrahjes së zbatimit të ligjeve që i ka sponsoruar, përkatësisht miratuar. (Ekstrakt) ${ }^{17}$

Rritja e vetëdijes dhe veprimit të qytetarëve në mbrojtjen e vlerave më të larta të natyrës dhe mjedisit do të ishte faktor i fuqishëm i zhvillimit të qëndrueshëm të Republikës së Kosovës në harmoni me vlerat ekologjike të saj. Shkalla e lartë e vetëdijesimit për mbrojtjen e natyrës dhe një zhvillimi të qëndrueshëm të Kosovës, mund të jetë jo vetëm element i rëndësishëm i njohjes në botë, por dhe themel i bashkëpunimit me shumë shtete dhe institucione ndërkombëtare.

Nismat dhe veprimet e deritashme nuk janë të mjaftueshme dhe të mira, për çka është e nevojshme raport i ri i individëve dhe të gjithë pjesëtarëve të shoqërisë ndaj natyrës dhe mjedisit. MMPH duhet të përpilojë masat për rivitalizimin e mjediseve të degraduara të niveleve të ndryshme, pastaj masat juridike, ligjore, organizative, profesionale, programore, shkencore, kulturore dhe në të gjitha aspektet tjera të mbrojtjes së natyrës dhe mjedisit jetësor në përgjithësi.

Vlerat e larta natyrore, mjedisore dhe të resurseve të Kosovës, begatia e lartë e biodiversitetit që për rëndësinë që kanë janë të njohura dhe jashtë kufijve të vendit duhet të valorizohen në mënyrën më të mirë të qëndrueshme. Këto vlera duhet të mbrohen prej faktorëve të shumtë të presionit, jo planifikimit, menaxhimit jo profesional si dhe aktiviteteve jo legale. Duhet të kërkohet nga qeveria që urgjent të pasqyrojë shkaqet për shkak të cilave nuk realizohen ose shumë ngadalë planet, politikat dhe strategjitë që i ka sjellë vet për sektorët e caktuar të natyrës dhe mjedisit e veçmas mbi menaxhimin e mbeturinave dhe ujërave të zeza.

Gjendja e tanishme në këtë fushë seriozisht rrezikon mjedisin jetësor dhe shëndetin e njerëzve, prandaj është domosdoshmëri dhe urgjencë të ndërmerren masa për veprime efikase, ku gjendja në këto fusha shpejt dhe në themel të ndërrojë në të mire, të zbatohen ligjet përkatëse, ndërsa mbetjet të fitojnë tretmanin e lëndës e cila në pjesën më të madhe mund të shfrytëzohet për riciklim dhe përfitim të energjisë. Duke bërë favorizime për ata të ndërgjegjshmit dhe njëkohësisht duke përdorur politika ndëshkimi, duhet sjellë masa efikase në grumbullimin e selektuar dhe riciklimin e mbeturinave, pastrimin e ujërave të zeza, zgjidhjen e problemit të mbetjeve industriale dhe të rrezikshme duke përgatitur dhe koordinuar punën e organeve drejtuese lokale, duke ngritur kadastrën integrale të gjithë ndotësve në Kosovë si regjistër publik me të gjitha të dhënat e nevojshme. Kur është fjala për planifikimin dhe menaxhimin e hapësirës ku janë shkaktuar shumë lëshime, kërkohet që të ndërpritet degradimi dhe jo planifikimi i mëtejmë i saj, shfrytëzimi jo racional, veçmas i tokës bujqësore, si dhe ndërtimet e paplanifikuara dhe jo legale. Në të gjitha planet hapësinore në të gjitha nivelet, si dhe në realizimin e tyre duhet bërë baraspeshën e strukturës hapësinore, sistemin urbanistik policentrik dhe raport të ri të mjedisit urbano rural.

17 Mustafa, B. (2013). Gjendja e mjedisit në Kosovë 14 vjet pas çlirimit. Kryetar i Shoq. së Ekologëve. Mënjanimi i duhur i ujërave të zeza është çështje vitale dhe ligjore për shëndetin publik. Është çështje brengosëse në Kosovë, mos trajtimi adekuat për mënjanimin e tyre ndotë lumenjtë dhe resurset ujore. Fabrikat për trajtimin e ujërave të zeza duhet të janë me prioritet, pavarësisht që mund të kushtojnë në aspektin financiar, alternative tjetër aktualisht nuk ka. 
Duhet të ndalet urgjent tjetërsimi, veçmas tokës punuese bujqësore dhe mjedisore me vlera të larta natyrore, zvogëlimin deri në ndërprerjen e zhvendosjeve nga fshatrat, me programe kualitative të zhvillimit të përgjithshëm rural dhe prodhimit të ushqimit ekologjik e të shëndetshëm. Duhet menaxhim i qëndrueshëm i pyjeve dhe resurseve pyjore që të mundësojnë plotësimin e nevojave ekonomike, ekologjike, kulturore dhe të tjera për gjeneratat e tashme dhe të ardhshme. (Ekstrakt) ${ }^{16}$

Energjia është kusht i zhvillimit në përgjithësi, ndërsa resurset energjetike në Kosovë, veçanërisht kur është fjala për burimet ripërtëritëse të energjisë së pastër, paraqesin potencialin e saj të madh të pa shfrytëzuar, si një element shumë i rëndësishëm i zhvillimit të saj të qëndrueshëm. Në periudhën e ardhshme duhet të zhvillohen politika dhe vendime që janë në funksionalizim të resurseve, veçmas energjisë solare dhe biomasës, por dhe erës e hidro energjisë. Republika e Kosovës ka mundësi të bëjë shumë më tepër në avancimin e masave dhe qëllimeve për energji efikase për t'iu afruar standardeve evropiane për aq sa mundet, si dhe t'i kushtojë kujdes më të madh ndërtimit të objekteve të qëndrueshme.

\subsection{Arkitektura dhe Shëndeti Publik}

ACE në studimin (Këshilli i Arkitektëve të Evropës), me titull "Arkitektura dhe cilësia e jetës" potencon në qëllimin kryesor, se politikanët janë vendim marrësit dhe vetë ekspertët, të vetëdijshëm për nevojën për të sjellë së bashku objektivat politike kryesore të cilat përfshijnë zhvillimin ekonomik, konkurrencën dhe qëndrueshmërinë si një veçori e domosdoshme. Andaj, kemi të bëjmë me premisën se e tëra është tek kualiteti i jetesës, në kuptimin që nuk duhet të ketë asnjë dyshim se në vitet e ardhshme do të jenë këto veçori vendimtare të cilat do e determinojnë projektimin e qëndrueshëm.

"Është më se nevojshme të sigurohet që programet e ardhshme për hulumtime duhet formuluar siç duhet, për të adresuar çështje me rëndësi të tilla si cilësia e jetës, mjedisit urban, trashëgimisë dhe qasjeve inovative për ndërtimin e BE-së, në lidhje me arkitekturën. Përveç kësaj, ACE i bën thirrje Komisionit Evropian për të siguruar që vendimet që i merr në mënyrë adekuate të ketë në konsideratë rezultatet e një studimi të tillë në përgjithësi dhe zbatimin politik i të njëjtit, i cili do të ketë ndikim të drejtpërdrejtë në mjedis."18 Në këtë moment, zgjedhje të madhe për të ardhmen e Evropës, që lidhet me Kushtetutën dhe zgjerimin, është koha për të rivlerësuar idetë tona të trashëguara dhe të miratohen qasje të cilat janë pragmatike dhe realiste me mekanizmat financiarë që kanë të bëjnë me cilësinë e jetës. E gjithë kjo duhet të arrihet në kuadër të vizionit për jetën e përditshme të 450 milionëve të qytetarëve tanë.

Politika e Shëndetësisë është përdorur për të identifikuar problemet prioritare. Megjithatë, problemet e shëndetit mund të zhvillohen shumë shpejt, prioritetet duhet të jenë periodikisht dhe rregullisht të azhurnuara, kurse, ndryshimet pasojnë sipas vendeve individuale, prioritetet kombëtare duhet të përshtaten me kushtet lokale. Së fundi, përcaktimi i prioriteteve e definon se çfarë është urgjente ose më pak urgjente dhe e rëndësishme.

18 EU. (2004). Architect's Council of Europe. Architecture and Quality of Life. Bruxelles, Belgium: EU 
Kështu, është e qartë se vetëm një mjedis i shëndetshëm, në kuptimin më të gjerë ose më të ngushtë të konceptit të cilësisë së jetës dhe arkitekturës në aspektin e bashkëveprimit dhe pjesëmarrjes në zgjidhje të problemeve mund të rezultojë me zgjidhje adekuate. Mijëvjeçari i ri sjell me vete një mënyrë jetese të re si rezultat i një sërë faktorësh përcaktues, por para se gjithash nga zhvillimi i teknologjisë, kemi ardhur në situatë ku duhet pyetur veten në lidhje me domosdoshmërinë e ri përcaktimit të shumë e zakoneve. Andaj, problemet kritike globale shëndetësore; një problem i rëndësishëm shëndetësor konsiderohet të jetë globale, nëse:

1. Emanon dhe ndikon tek njerëzit në shumë rajone.

2. Shpërndahet dhe prek komunitetet në një ose më shumë rajone, por ka potencial dhe gjasa të përhapet dhe të ndikojë në njerëz në shumë rajone.

3. Dukurinë nuk mund të zgjidhë vetëm një rajon.

4. I kufizuar në një rajon të veçantë, edhe pse rezultatet e studimit mund të tregohen të dobishme edhe për rajone të tjera, si model.

5. Thirrje për hulumtim dhe monitorim ndërkombëtar, një studim interdisiplinar.

\subsubsection{QALY}

Një njësi matëse që kombinon vdekshmërinë dhe përmirësimet në cilësinë e jetës (si rezultat i trajtimit mjekësor i matur si numri i viteve të jetës së fituar, i modifikuar sipas cilësisë). Llogariten duke matur vitet totale të humbura për shkak të një sëmundjeje ose të fituar nga trajtimi mjekësor, duke ponderuar çdo vit me një tregues (koeficient) të cilësisë së jetës (nga 0 që përfaqëson shëndetin më të keq deri në 1 ose 100 që përfaqëson shëndetin më të mirë) për të pasqyruar cilësinë e jetës në atë vit. ${ }^{19}$

Shumë qasje nga aspekte të ndryshme përdoren për të gjeneruar vlerësimet e cilësisë së jetës. Rezultatet në lidhje me atributet e shëndetit, vlerësimet janë të lidhura me çdo atribut të gjendjes shëndetësore të vlerave në mes të 0 dhe 1 , ku 0 është e barabartë me vdekjen dhe 1 përfaqëson shëndetin më të mirë të mundshëm.

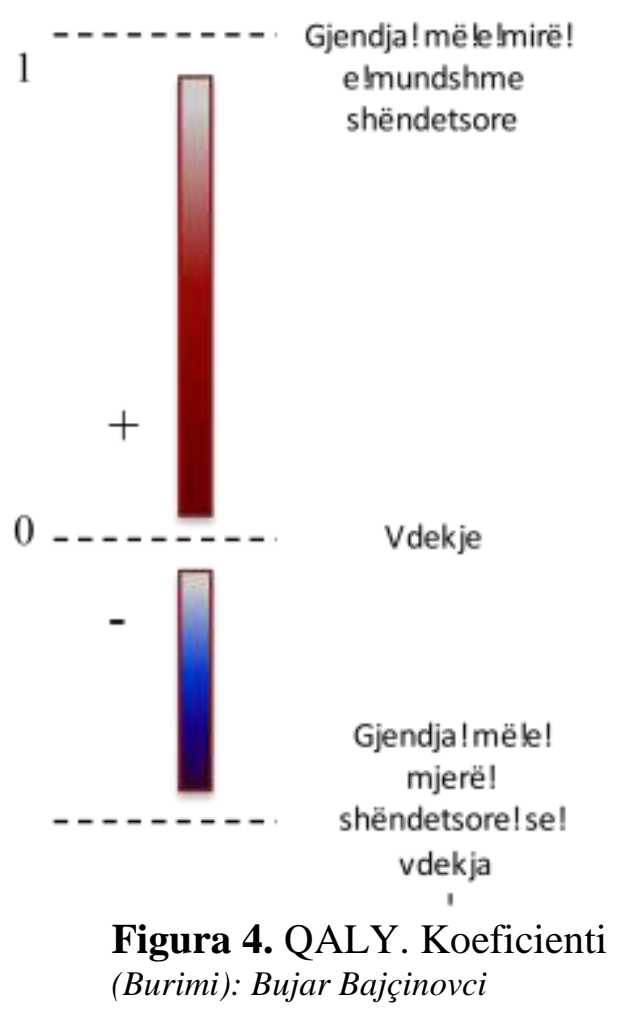

Edhe pse mund të ketë disa gjendje shëndetësore ku konsiderohen më keq se vdekja dhe kanë vlerë negative.

19 http://fjalorishendetesise.com/home/id.QALY. Korrik/2015. 


\subsection{Objektivat}

UIA është një organizatë ndërkombëtare, organizatë jo qeveritare, e themeluar në Lozanë në vitin 1948 për të bashkuar arkitektë nga të gjitha kombet në të gjithë botën, pavarësisht nga kombësia, raca, feja apo shkolla arkitektonike, në kuadër të federatave dhe shoqatave të tyre kombëtare.

UIA përfaqëson më shumë se një milion Arkitektë në të gjithë botën përmes shoqatave të tyre kombëtare arkitektonike që formojnë seksionet anëtare të UIA. UIA është e përbërë nga pothuajse 100 seksionet anëtare të cilat janë organizata profesionale më përfaqësues të arkitektëve në botë. Seksionet anëtare kontribuojë në drejtim të zhvillimin ekonomik dhe financiar të unionit përmes pagesës së kuotave të anëtarësisë që përbëjnë resurset thelbësore të UIA.

Kongresi Botëror, rajoni IV i UIA në Programin e Punës për Arkitekturën e njeh rolin e rëndësishëm të profesionit të arkitekturës në krijimin e një mjedisi të sigurt, fleksibil dhe të përgjegjshëm, duke ndërtuar me një ekuilibër midis zhvillimit dhe ekosistemit.

Kjo deklaratë vendosë:

Që arkitektët kanë një përgjegjësi morale, të natyrshme për të qenë pjesë e komunitetit të tyre, duke siguruar që në rrjedhën e praktikës së tyre ata të minimizojnë ndikimin në mjedis, qasje profesionale e ndërtuar mbi parametrat natyror.

Se arkitektët duhet të jetë gjithmonë të gatshëm për t'iu përgjigjur emergjencave të sjella nga fatkeqësitë natyrore dhe të bëra nga faktori njeri, apo të tilla si lufta dhe konflikti, të asistojnë me komunitetet e zhvendosura, në gjetjen e zgjidhjeve të qëndrueshme për strehim të komunitetit dhe ruajtjes së trashëgimisë.

Pra, arkitektët duhet të jetë katalizator dhe të marrin përgjegjësi mbi vete, për të krijuar zgjidhje të mirëfillta arkitektonike të cilat janë të qëndrueshme, duke marrë në konsideratë mirëqenien e të gjithë personave, veçanërisht ato që kërkojnë ndihmë.

Arkitektët duhet të praktikojnë si parim kryesor të projektimit, planifikimit të qëndrueshëm miratimin dhe përdorimin e burimeve të rinovueshme dhe parimeve efikase të efiçiencës së energjisë për të reduktuar emisionet e karbonit, promovimin e ndërtesave të shëndetshme, mbrojtjen e ekosistemit dhe biodiversitetin e saj.

Arkitektët të cilët punojnë në një vend tjetër duhet të bashkëpunojnë me arkitektë vendas, në mënyrë për të arritur një nivel projektimi të ndjeshëm nga ana e trashëgimisë kulturore po ashtu për të nxitur respektin e ndërsjellë, veçanërisht në ndarjen e njohurive, punës dhe aftësive.

Arkitektët duhet të arrijnë nivele konsulentë për qeveritë e tyre qendrore dhe lokale për t'i informuar me rolin jetik në arritjen e qëllimeve dhe objektivave të projektimit të qëndrueshëm. Që arkitektët kanë detyrim për të vepruar, për të përfituar shoqëria në përgjithësi si një detyrë primare nga praktika e arkitekturës. Deklarata është miratuar me 5 gusht 2014, gjatë Unionit të 25 Ndërkombëtar, Kongresi Botërore i Arkitektëve në Qendrën Ndërkombëtare të Konventës, Durban, Afrika e Jugut. 


\subsection{Komisioni Evropian /Evropa Creative/}

Çmimi i Bashkimit Evropian për arkitekturën bashkëkohore. Është një çmim i cili ka për qëllim të njoh dhe të shpërblej shembujt e shkëlqyer të veprave arkitektonike, po ashtu çmimi është i plotësuar më titull, Arkitekturë e veçantë.

Çmimet, $60,000 €$ dhe $20,000 €$, marrin veprat të cilat demonstrojnë përsosmëri në aspektin konceptual, teknik dhe konstruktiv.

Çmimi ndihmon për të rritur ndërgjegjësimin e përsosmërisë në fushën e arkitekturës, duke tërhequr vëmendjen për kontributet e profesionistëve evropiane në zhvillimin e koncepteve të reja arkitektonike, teknikave dhe teknologjive të implementuara.

Nga viti 2015 themelohet programi "Talentët e Rinjë/Internship" i cili realizon idenë që arkitektët e rinjë të sapo diplomuar, të punojnë në zyrën e fituesi të çmimit.

Drejtohet nga Komisioni Evropian në bashkëpunim me Mies van der Rohe Foundation, me seli në Barcelonë, i mbështetur nga një rrjet prej 15 institucioneve të arkitekturës, si dhe një komision ekspertësh nga 31 shtete. ${ }^{20}$

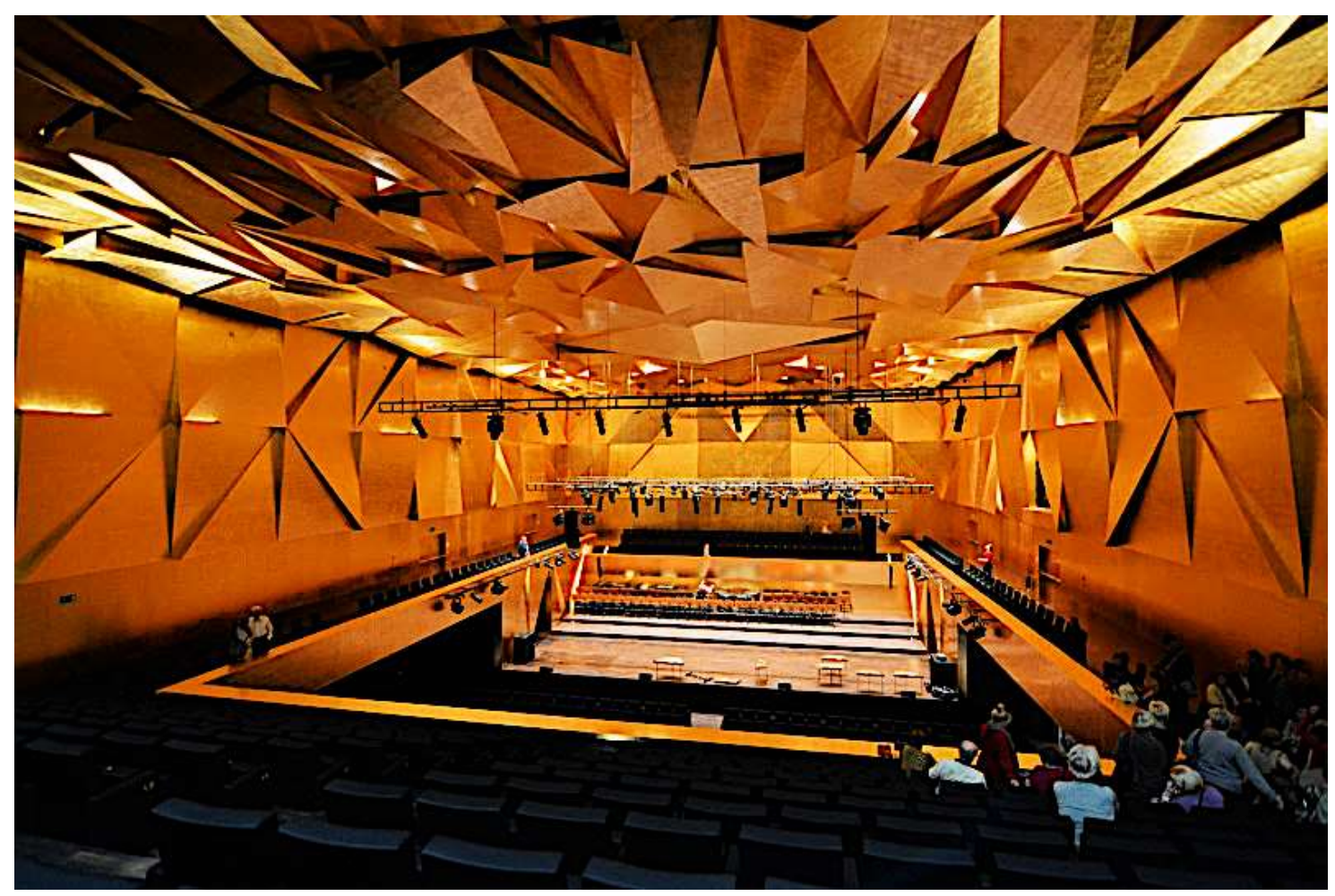

Figura 5. Filarmonia në Szczecin. PL. Fituesit; Alberto Veiga \& Fabrizio Barozzi (Burimi): Kapitel, 2014. E licensuar nga Creative Commons Attribution ShareAlike 1.0

20 Creative Europe. European Union prize for contemporary architecture, 2015. 


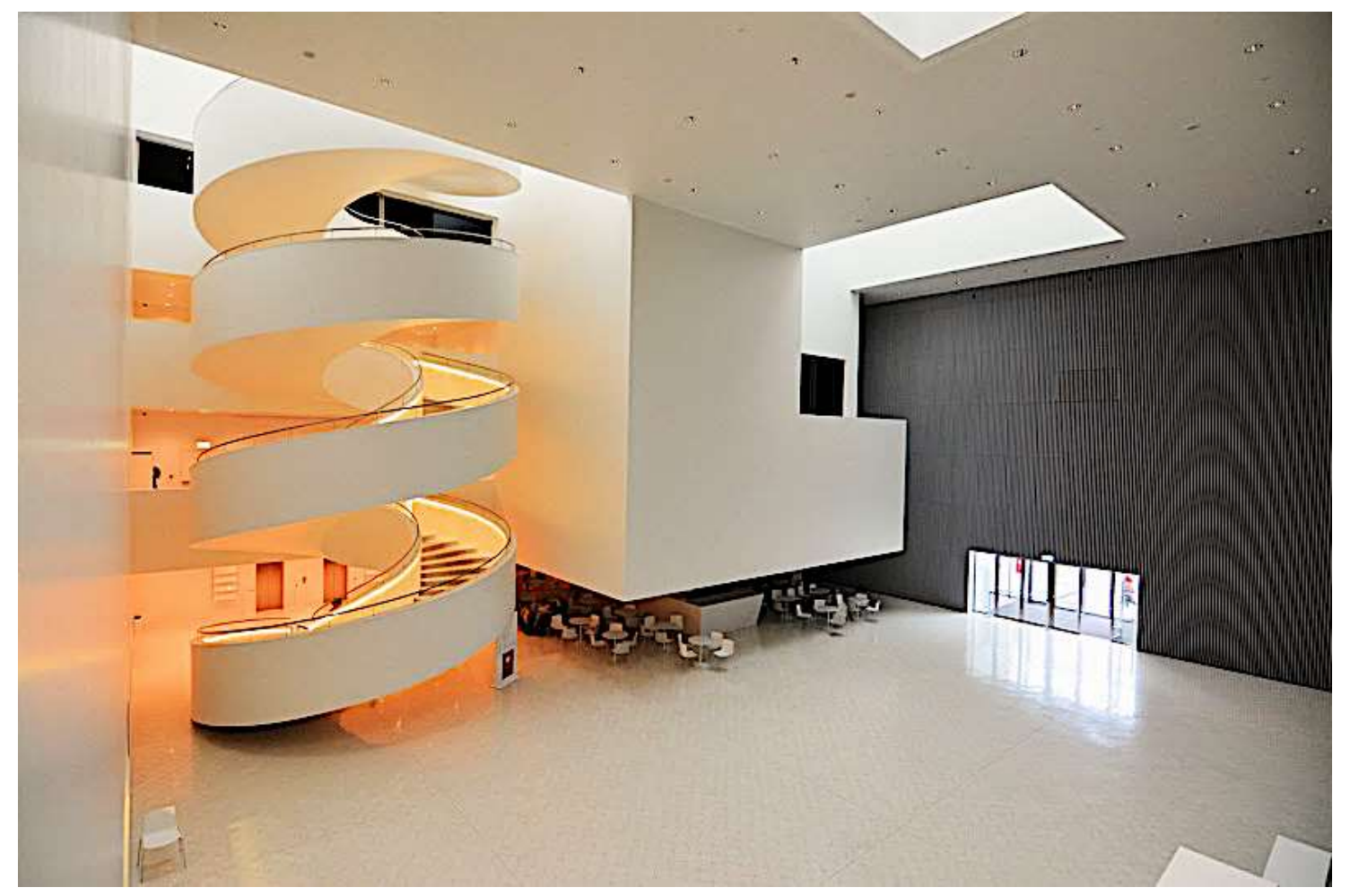

Figura 6. Filarmonia në Szczecin. PL. Fituesit; Alberto Veiga \& Fabrizio Barozzi (Burimi): Kapitel, 2014. E licensuar nga Creative Commons Attribution ShareAlike 1.0

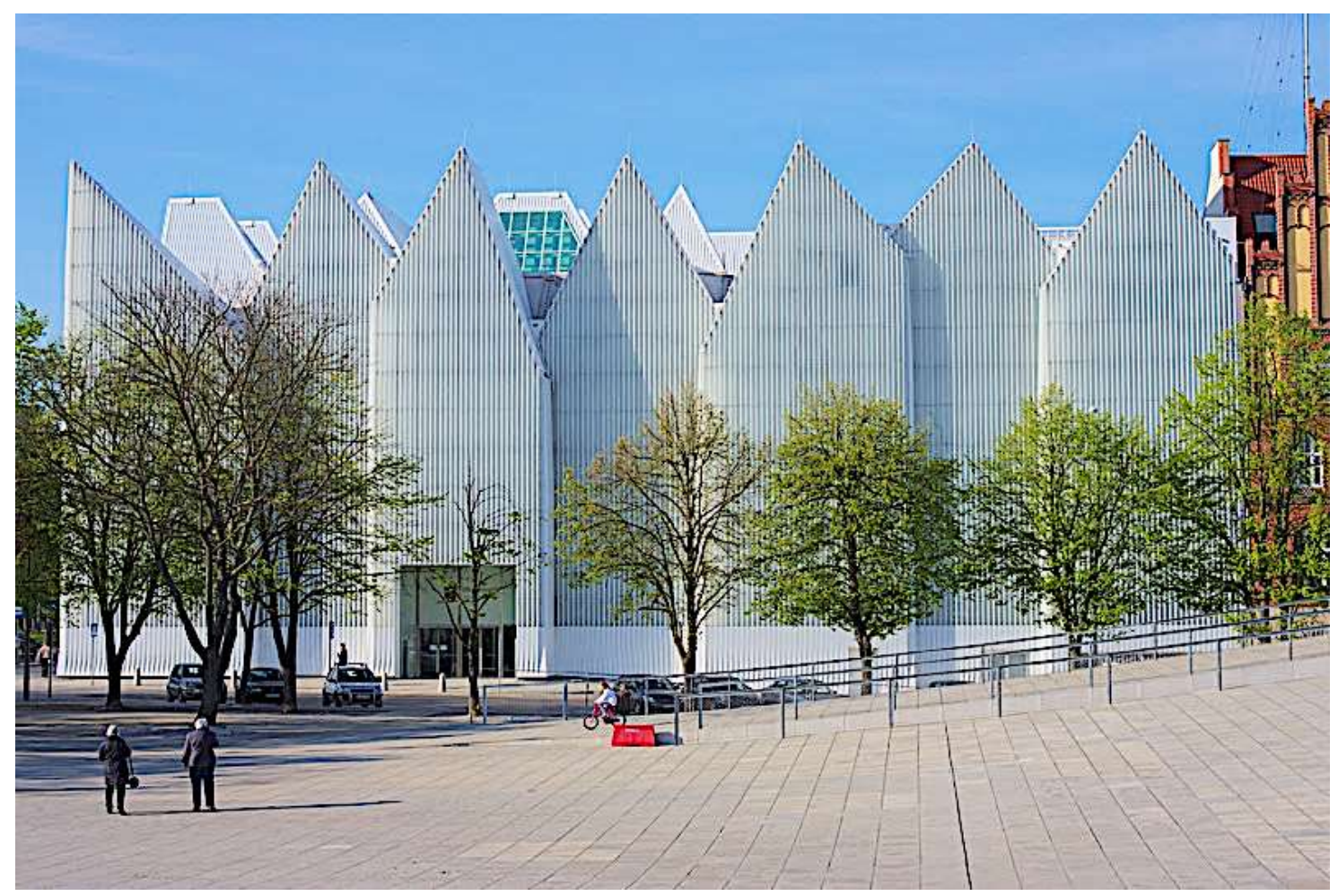

Figura 7. Filarmonia në Szczecin. PL. Fituesit; Alberto Veiga \& Fabrizio Barozzi (Burimi): DrKssn. E licensuar nga Creative Commons Attribution ShareAlike 1.0 
Arkitektura është një proces gradual që përshtatet me ndryshimet shoqërore, politike dhe ekonomike. Nominimet për çmim marrin në konsideratë dhe ndjekin objektivat e mëposhtme:

1. Njohin dhe përgëzojnë përsosmëri në arkitekturën Evropiane, me ide konceptuale, sociale, kulturore, nga kushtet teknike dhe konstruktive.

2. Nxjerrin në pah qytetin evropian si një model për qytetin e qëndrueshëm, duke kontribuar në ekonominë e qëndrueshme evropiane.

3. Promovimin e komisioneve arkitektonike transnacionalë, në të gjithë Evropën dhe jashtë saj.

4. Mbështet arkitektët e rinj dhe talentet e reja, të cilët posa fillojnë karrierën.

5. Rrisin bashkëpunimin në mes të profesionistëve të arkitekturës në shtetet anëtare të BE.

6. Po ashtu edhe ato vende që lidhin një marrëveshje me BE.

7. Kujdesi ndaj klientëve si dhe të promovuesve.

8. Hulumtimi i të bërit biznes në një treg më të gjerë global

9. Nxjerrë në pah përfshirjen e Bashkimit Evropian në mbështetje të arkitekturës si një lëmi e rëndësishme, që pasqyron diversitetin e shprehjes arkitektonike Evropiane, promovon rolin e saj si një element unifikues për të përcaktuar një kulturë të përbashkët Evropiane. ${ }^{20}$

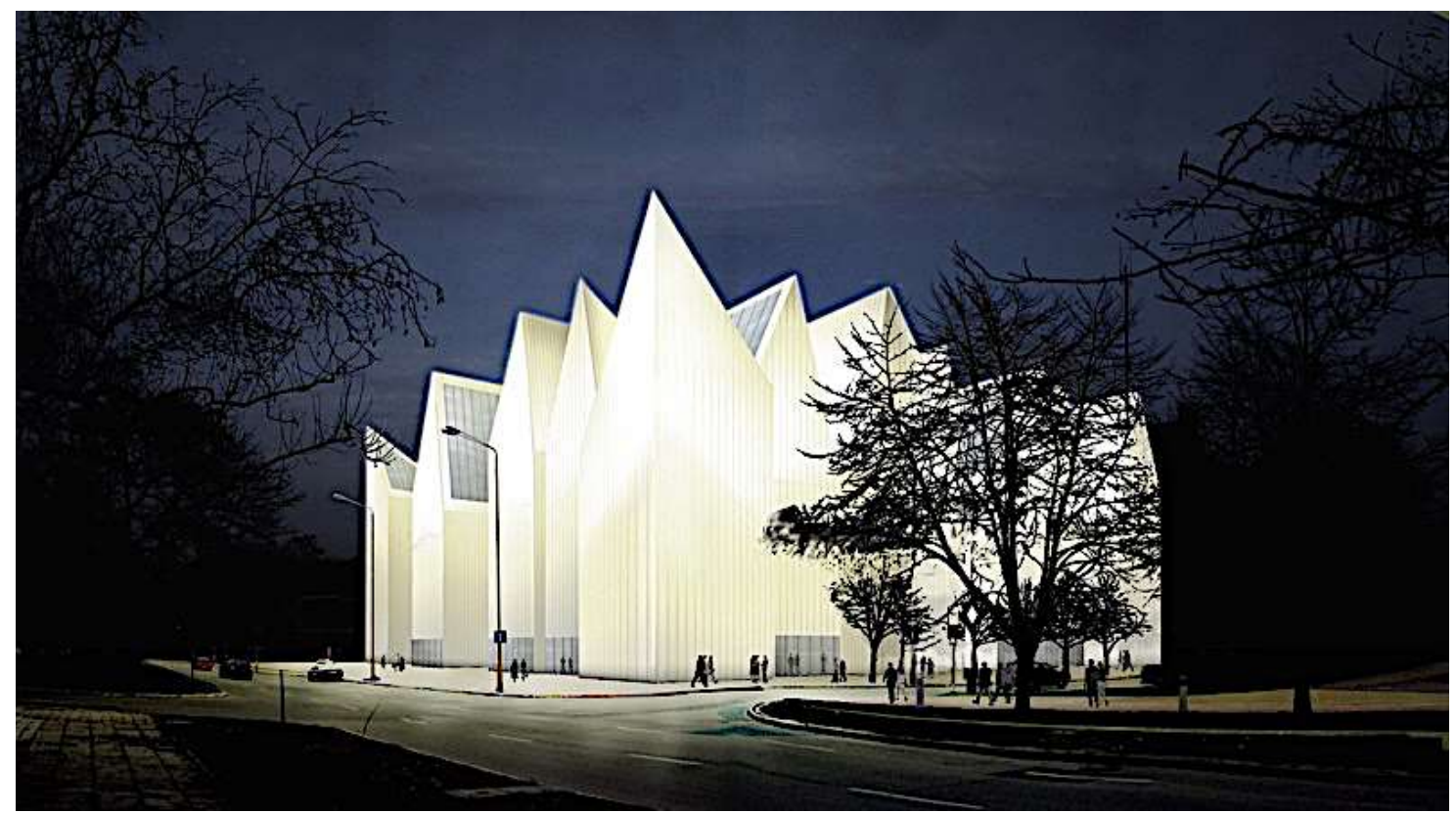

Figura 8. Filarmonia në Szczecin. PL. Fituesit; Alberto Veiga \& Fabrizio Barozzi (Burimi): UMSzczecin. E licensuar nga Creative Commons Attribution ShareAlike 4.0 


\subsection{Projektimi aktual linear}

Ka shembuj të shumtë të improvizimeve në praktikën ekzistuese në procesin e projektimit, të koncepteve të paqëndrueshme të strategjisë së zhvillimit. Mund të konkludohet se, strukturat institucionale nuk janë të gatshme për ndryshime konceptuale dhe strategji të reja projektuese. Qasja ekzistuese e projektimit linear në planifikim nuk ka lëvizje bashkëkohore në dekadat e fundit.

Jemi dëshmitarë të një bumi teknologjik aktualisht, gjithashtu kemi qasje të re epistemologjike në fenomenin e uljes së burimeve natyrore dhe ndryshimeve klimatike tani më të konfirmuara. Departamentet e ndryshme qeveritare e kanë përfshirë mbrojtjen e mjedisit si një prioritet, Ministria e Mjedisit dhe Planifikimit Hapësinor ka përgjegjësinë ligjore të planifikimit dhe mbrojtjes së mjedisit të Kosovës, tani këto obligime janë të akceptueshme dhe të pranuara sipas ligjit dhe udhëzimeve administrative:

- Akti i Mbrojtjes Ajrore 2004/30. Qëllimi i këtij ligji është që të rregullojë të drejtat e qytetarëve për të jetuar në një ajër të pastër, duke mbrojtur shëndetin e njeriut, faunën, florën dhe vlerat natyrore e kulturore të mjedisit të Kosovës. ${ }^{21}$

- Akti i Mbrojtjes së Mjedisit 2009/03-L-025 Ky ligj do të harmonizojë zhvillimin ekonomik dhe siguri sociale me parimet themelore të mbrojtjes së mjedisit, konceptin e zhvillimit të qëndrueshëm. Qëllimi i këtij ligji është të promovojë krijimin e një mjedisi të shëndetshëm dhe koordinim me standardet e BE-së. ${ }^{23}$

- $\quad$ Akti për Mbrojtjen e Natyrës Nr-2004 / XX;

- Strategjia e mbrojtjes së mjedisit dhe zhvillimit të qëndrueshëm 2005;

- $\quad$ Ligji për Vlerësimin e Ndikimit në Mjedis në 2009/03-L-024;

- Ligji për vlerësimin strategjik mjedisor 03 / L-015;

- U. A. No.22 / 05-MMPH, emisionet e ndotësve të mjedisit;

- U. A. Emetimet ajrore standarde nga burimet e lëvizshme të ndotjes;

- U. A. Mbi rregullat dhe standardet e shkarkimeve në ajër të STAC. Burim;

- U. A. Nr.04 / 2009 mbi tarifat dhe gjobat për ndotësit;

Në komunat (lokale) dhe në nivelin qendror, "Rregullat për mbrojtjen e ajrit" është rregullorja që nga viti 2004 si dhe rregullorja e UNMIK-ut 2004/48. ${ }^{22}$ Kjo urdhëresë siguron bazën ligjore për krijimin e një mjedisi të shëndetshëm, dhe jep ndëshkime për ndotësit e mundshëm. Sipas rregulloreve, një komunë duhet vazhdimisht të shqyrtojë cilësinë e ajrit, ndikimin mjedisor dhe shëndetin e popullatës.

Ligjërisht, misioni i rregullave është garantues i të drejtave të qytetarëve për të jetuar në një ajër të shëndetshëm dhe të pastër, mbrojtjen e shëndetit të njeriut, florën dhe faunën dhe mjedisin natyror dhe kulturor nga ndotësit potencial. Deri në fund të vitit 2008, me përgjegjësi të plotë për zgjidhjen e ndotjes së mjedisit kishte ekskluzivisht Ministria e Mjedisit dhe Planifikimit Hapësinor.

21 Kuvendi i Kosovës, Qeveria, http://www.mmph-rks.org/sq/Ligjet-e-Mjedisit1. 2015.

22 UNMIK. http://www.unmikonline.org/regulations/2004/re2004_48.pdf. 2015. 
Realiteti është zakonisht i ndryshëm, dhe rregullat e tanishme për mbrojtjen e ajrit nuk janë të zbatueshme në mënyrë adekuate. Arsyet janë të lidhura me institucionet dhe probleme të ndryshme të trashëguara. Departamenti për Mbrojtjen e Mjedisit në Ministrinë është përgjegjës për propozimin dhe hartimin e ligjeve, udhëzimeve administrative dhe politikave që kanë të bëjnë me mjedisin, si dhe bashkërendimi i punës në nivel lokal. Agjencia për Mbrojtjen e Mjedisit është themeluar nga ministria në fjalë, në bazë të Aktit të Mbrojtjes së Mjedisit 2009/03-L-025 Kjo agjenci është përgjegjëse për aktivitetet ligjore, teknike dhe shkencore në fushën e mbrojtjes së mjedisit, zonat e ruajtjes dhe diversitetit.

Në punën e përditshme nuk ka kapacitete të mjaftueshme në veprimtari mbi çështjet e mjedisit, po ashtu nuk ka studime të veçanta që lidhen me mjedisin, duke theksuar se nuk ka ekspertë vendas të mjaftueshëm me tituj shkencor dhe akademik. Në nivel lokal, në lidhje me ligjin për vetëqeverisje lokale, komunat kanë kompetenca të plota dhe ekskluzive në shumë fusha, duke përfshirë mjedisin lokal. Në kryeqytet, Departamenti për Mbrojtjen e Mjedisit është themeluar në kuadër të Departamentit të Planifikimit Urban, Kadastër dhe Mbrojtje të Mjedisit. Si një sektor i ri është themeluar në vitin 2009, burimet financiare duhet të sigurohen nga buxheti komunal, donacionet dhe forma të tjera të sponsorizuara, në përputhje me dispozitat e Ligjit për Menaxhimin e Financave Publike dhe Përgjegjësitë 2008/03-L048. ${ }^{23}$

\subsubsection{Shembull Studimi}

Për këtë studim do të përdoret metoda e hulumtimit në terren (in situ), dhe metoda e intervistës. Në përgjithësi, do të mbështetet nga analizat e dokumenteve të arkivës së komunës së Prishtinës, rregulloreve PPU të vitit 1985, Institutit të Shëndetit Publik të Kosovës, Institutit Hidro Meteorologjik të Kosovës si dhe raportet përkatëse të periudhës së caktuar kohore. Qasja në analizën dhe shtjellimin e mundshëm të problemit, do të përdorë pyetjet e mëposhtme hulumtuese:

1. Përse është zgjedhur lokacioni në fjalë për një garazh publike?

2. Çfarë bëjmë ne me kampusin e QKUK?

3. Çfarë është hetuar mbi cilësinë e ajrit?

4. Sa është real koncesioni i dhënë, çfarë përfitimi ka Komuna e Prishtinës?

Prishtina asnjëherë në historinë e saj nuk ka pasur një tramvaj ose transport të ngjashëm publik më të lirë, përveç autobusëve urban. Qyteti në rritjen e tije lineare arriti kulmin prej rreth 220,000 banorë. Kështu, qyteti ka jetuar me një infrastrukturë të ngushtë të rrugëve, dhe nuk do kishte problem të dukshëm për komunitetin, derisa mos u rrit numri i automjeteve apo automjeteve frekuentuese të ditëpërditshme në vëllim të madh, dukuri e zhvilluar dhe e shtuar në fillim të mijëvjeçarit të ri. Kishte ide dhe koncepte të ndryshme në komunë sa i përket zgjidhjes apo zbutjes së problemit, që rrugët të behën njëkahore, megjithatë, nuk pat ndonjë zgjidhje e qëndrueshme optimale, gjersa idetë u bënë pjesë e "rrethit vicioz" të kërkimit.

23 Komuna e Prishtinës. Qeveria e lokale. http://kk.rks-gov.net/prishtina/. 2015. 


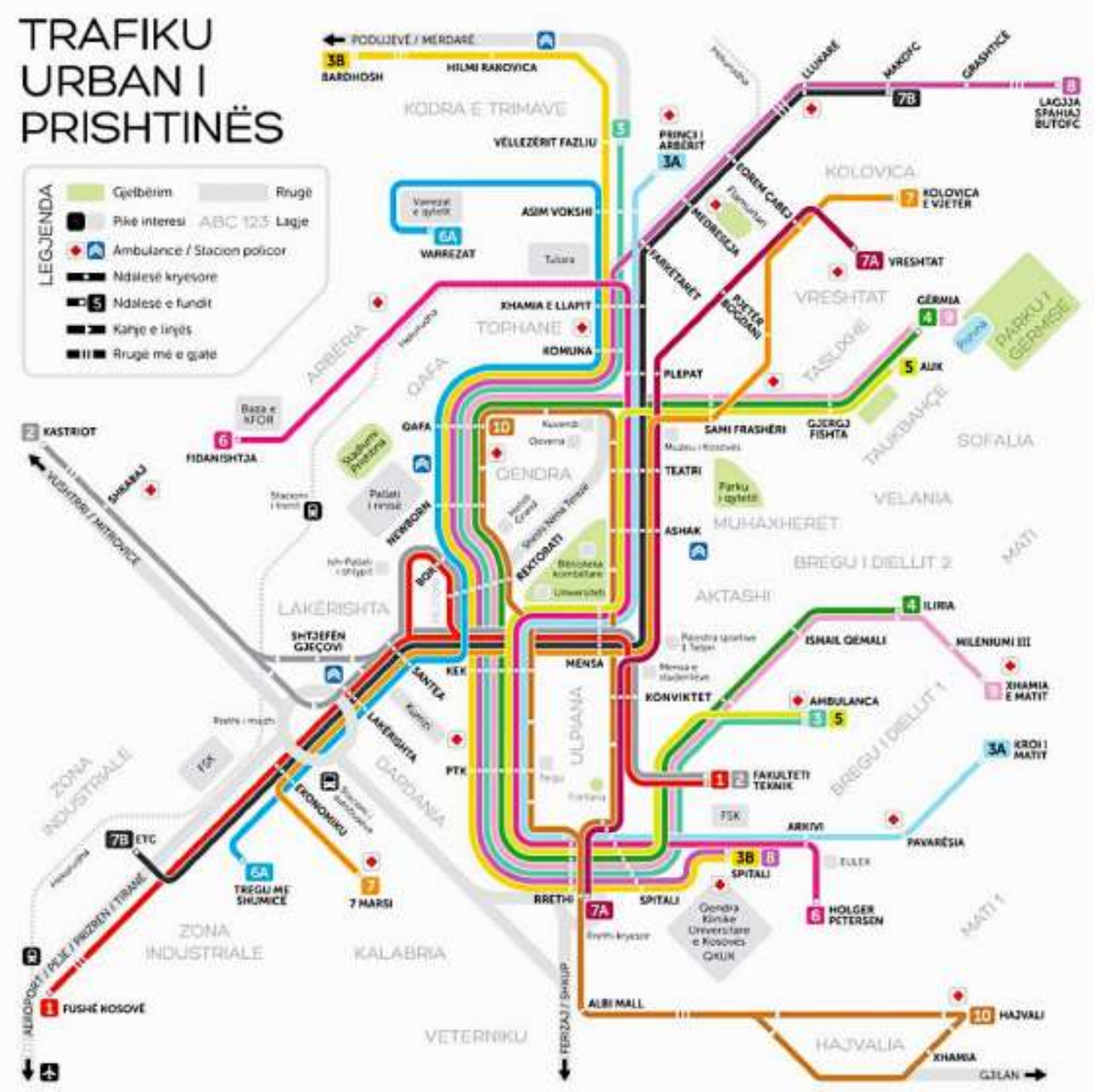

Figura 9. Hartë e trafikut urban të Prishtinës

(Burimi): Fisnik Ismaili, 2013. E licensuar nga Creative Commons Attribution ShareAlike 3.0 Unported

Ka qenë gjithmonë një nevojë reale për ndërtimin e garazheve publike, ose disa prej tyre, por sfidat konceptuale ishin: Sa? Kapaciteti? Nëntokësore apo mbitokësore? Në qendër ose në unazën e mesme për lehtësimin e qendrës së qytetit? Fizibiliteti i ndërtimit, në pronësi të komunës ose partneritet publiko privat.

Natyrisht, të gjithë këto analiza duhet të jenë në program të cilësisë, me kujdes të madh, për të ruajtur mjedisin dhe mbi të gjitha cilësinë e ajrit në vendin e synuar. Nuk do ishte asnjë problem i vërtetë me fenomenin e parkimit, apo edhe me parkingjet e vendosura në lokacione të ndjeshme për këto lloj strukturash, mirëpo së pari duhet analizuar shembujt e praktikës së mirëfilltë arkitektonike të vendeve të zhvilluara, të harmonizuara me veçoritë lokale urbane, të ushqyera nga kultura socio urbane e vetë urbanitëve si dhe nga mundësitë reale ekonomiko hapësinore. 
Tabela 5. Linja e autobusëve urbanë të Prishtinës (Burimi): https://sq.wikipedia.org/wiki/Transporti_nё_Prishtinë

\begin{tabular}{|c|c|c|}
\hline Linja e autobusit & Fillimi & Mbarimi \\
\hline $\mathbf{1}$ & Fakulteti Teknik & Fushë Kosovë \\
\hline $\mathbf{2}$ & Fakulteti Teknik & Kastriot \\
\hline $\mathbf{3}$ & Bregu i Diellit & Bardhosh \\
\hline 3/A & Matiçani & Kodra e Trimave \\
\hline 3/b & Spitali i qarkut & Bardhosh \\
\hline $\mathbf{4}$ & Bregu i Diellit & Gërmi \\
\hline $\mathbf{5}$ & Bregu i Diellit & Sofali \\
\hline $\mathbf{6}$ & Arbëria & Rruga Malush Kosova \\
\hline $\mathbf{6 / A}$ & Arbëria & VIVA Market përpara ETC-s \\
\hline $\mathbf{7}$ & Kolovica & March 7 (Emshir) \\
\hline $\mathbf{7 / A}$ & Rruga Xhavit Ahmeti & Rrethi i Madh \\
\hline $\mathbf{8}$ & Butofc & Qendra e spitalit \\
\hline $\mathbf{9}$ & Matiçani & Gërmi \\
\hline $\mathbf{1 0}$ & Hajvalia & Rreth Prishtinës \\
\hline
\end{tabular}

Duke pas njohuri për ndjeshmërinë e trendëve globale dhe emanimet e ndryshme të $\mathrm{CO}_{2}$ me burime të forta lokale në regjionin e Prishtinës, po ashtu me kujdes të shtuar në përhapjen e ndotjes në tipologjinë morfologjike dhe hapësinore të Prishtinës, hapësirë e cila është e organizuar në trajtë të luginës. Drejtoria për Planifikim, Urbanizëm dhe Ndërtim e Komunës së Prishtinës në vitin 2005, miratoi një vendim për ndërtimin e një parkingu stacionar me garazhë publike të tipit të hapur, e stacionuar në perimetrin e kampusit të Qendrës Klinike Spitalore në Prishtinë. Objekti do të organizohej nga një strukturë e vetme me një qendër të vogël tregtare, me etazhitet garazh $\mathrm{B}+\mathrm{P}+3$, me një sipërfaqe totale të programuar prej rreth $46,000 \mathrm{~m} 2$ dhe cca. 1000 vend parkingje!

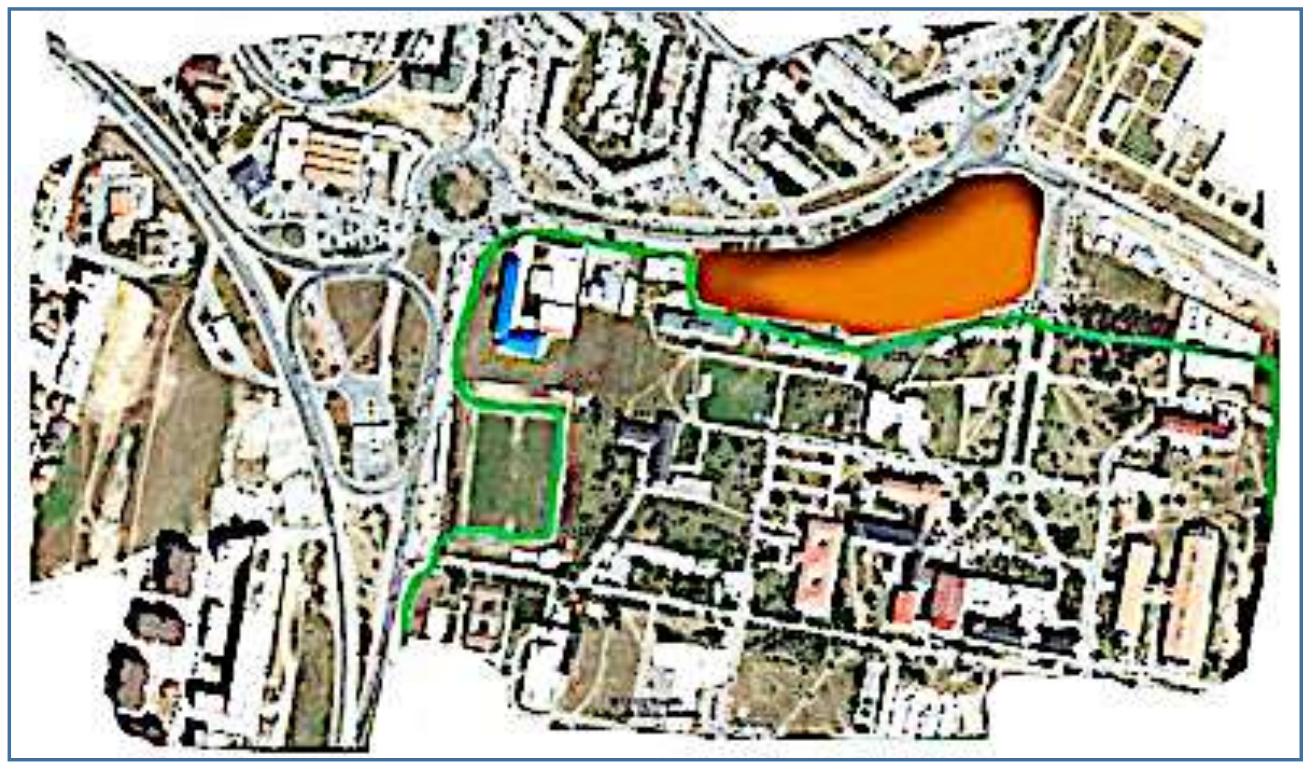

Figura 10. Qyteti i Prishtinës, vendi i zgjedhur për garazhin publik të qytetit, 2004. (Burimi): Bujar Bajçinovci, Chrome, GoogleEarth. 2011. 
Në trendin aktual të ofruesve të shërbimeve shëndetësore, është më se normale që të kemi edhe hapësirat e rezervuara për parkingje automobilistike. Hapësira parkimi për pacientët dhe vizitorët në spitale, mirëpo hapësirat janë me dimensione modeste në afërsinë e drejtpërdrejtë me objektet në kampus. Ku në përgjithësi, koha është e kufizuar dhe shërbimet janë të shtrenjta. Në kontekstin e ndërtimit të strukturave të kësaj natyre, si i garazhës publike të qytetit pranë QKUK, janë krijuar situata paradoksale mjedisore, shëndetësore dhe arkitektonike.

Në anën tjetër, kemi diskutime publike dhe procese të rënda të debateve publike me premisa të akteve ligjore, kur shfaqet interesi i ndërtimit të klinikave kardiovaskulare private në kampusin e QKUK nga specialistë të shquar dhe mjekë të njohur të Evropës. Për më tepër, është publikisht e njohur humbja apo eksporti i mjeteve të mëdha financiare të cilat derdhen jashtë R. Kosovës në mungesë të shërbimeve të avancuara shëndetësore për pacientët e Kosovës?

Tabela 6. Trajtimi i pacientëve në kampusin e QKUK.

(Burimi): Instituti Kombëtar i Shëndetit Publik. 2011.

\begin{tabular}{|c|c|c|c|c|c|c|c|c|c|c|c|}
\hline \multirow[t]{4}{*}{ QKUK-TOTALI } & \multirow{4}{*}{$\begin{array}{l}\frac{\text { Ditë }}{\text { mjekimi }} \\
\text { te } \\
\text { pacientëv } \\
\text { e te } \\
\text { lëshuar }\end{array}$} & & Totali & $\begin{array}{l}\text { Jan- } \\
\text { dhjetor }\end{array}$ & 2010 & & & 1096.3 & $=\mathrm{Nr}$, mes & tretërve (c & \\
\hline & & \multicolumn{7}{|c|}{ Numri i pacientëve } & \multicolumn{2}{|c|}{ Operacione } & \multirow{3}{*}{$\begin{array}{c}\text { Shkalla e } \\
\text { shfrytëzim. } \\
\text { te } \\
\text { kapacitetit } \\
\%\end{array}$} \\
\hline & & \multirow[b]{2}{*}{$\begin{array}{c}\text { Të bartur } \\
\text { nga dita } \\
\text { parapr. }\end{array}$} & \multicolumn{2}{|c|}{ Të shtrimë brenda } & \multicolumn{3}{|c|}{ Të lëshuar brenda ditës (0-24) } & \multirow[b]{2}{*}{$\begin{array}{c}\text { Gjendja } \\
\text { në fund } \\
\text { te dites } \\
\text { (mesnatë) }\end{array}$} & \multirow[b]{2}{*}{ Gjithsej } & \multirow[b]{2}{*}{$\begin{array}{c}\text { Prej tyre } \\
\text { me } \\
\text { anestez. } \\
\text { total }\end{array}$} & \\
\hline & & & Gjithsej & $\begin{array}{c}\text { Prej } \\
\text { tyre } \\
\text { nga } \\
\text { repart. } \\
\text { tjera }\end{array}$ & Gjiths. & $\begin{array}{c}\text { Prej } \\
\text { tyre; } \\
\text { Të } \\
\text { vdek. }\end{array}$ & $\begin{array}{c}\text { Prej } \\
\text { tyre; } \\
\text { Transf. }\end{array}$ & & & & \\
\hline $\begin{array}{l}\text { Klinika e } \\
\text { Pulmologjisë }\end{array}$ & 21095 & 47 & 1228 & 95 & 1231 & 51 & 94 & 44 & 0 & 0 & 84.8 \\
\hline $\begin{array}{l}\text { Klinia e } \\
\text { Psikiatrike }\end{array}$ & 20388 & 61 & 1008 & 169 & 1032 & 2 & 169 & 37 & 0 & 0 & 63.5 \\
\hline $\begin{array}{l}\text { Klinika e } \\
\text { Ortpedise } \\
\end{array}$ & 31116 & 68 & 2014 & 64 & 2014 & 9 & 57 & 68 & 1214 & 1183 & 78.3 \\
\hline $\begin{array}{l}\text { Klinika e } \\
\text { ORL-se }\end{array}$ & 20286 & 31 & 2198 & 0 & 2214 & 6 & 2 & 15 & 1674 & 721 & 75.8 \\
\hline $\begin{array}{l}\text { Klinika e } \\
\text { Oftalmologjisë }\end{array}$ & 11870 & 15 & 1522 & 1 & 1500 & 0 & 0 & 37 & 949 & 127 & 66.7 \\
\hline $\begin{array}{l}\text { Klinika e } \\
\text { Neurologjisë }\end{array}$ & 19574 & 33 & 2858 & 328 & 2853 & 318 & 323 & 38 & 0 & 0 & 80.6 \\
\hline $\begin{array}{l}\text { Klinike e } \\
\text { Neurokirurgjise } \\
\end{array}$ & 7936 & 13 & 1000 & 0 & 997 & 3 & 0 & 16 & 449 & 447 & 67.9 \\
\hline $\begin{array}{l}\text { Kirurgjia } \\
\text { Maxilofaciale }\end{array}$ & 4262 & 2 & 465 & 0 & 465 & 1 & 1 & 2 & 820 & 322 & 64.9 \\
\hline $\begin{array}{l}\text { Klinika e } \\
\text { Kirurgjisë } \\
\end{array}$ & 42776 & 72 & 5031 & 169 & 5039 & 98 & 168 & 64 & 2732 & 2728 & 73.2 \\
\hline $\begin{array}{l}\text { Klinika } \\
\text { Interne } \\
\end{array}$ & 62862 & 139 & 5947 & 486 & 5942 & 336 & 489 & 144 & 0 & 0 & 80.3 \\
\hline $\begin{array}{l}\text { Klinika } \\
\text { Infektive } \\
\end{array}$ & 34173 & 75 & 2830 & 25 & 2782 & 29 & 10 & 123 & 0 & 0 & 71.9 \\
\hline $\begin{array}{l}\text { Klinika e } \\
\text { Dermatovener. }\end{array}$ & 7901 & 2 & 556 & 0 & 536 & 0 & 0 & 22 & 0 & 0 & 60.1 \\
\hline $\begin{array}{l}\text { Klika e } \\
\text { Anesteziologjise }\end{array}$ & 12793 & 26 & 4278 & 311 & 4286 & 143 & 304 & 18 & 13040 & 13040 & 92.6 \\
\hline $\begin{array}{l}\text { Klinika e } \\
\text { Pediatrisë } \\
\end{array}$ & 80426 & 127 & 657 & 646 & 6487 & 135 & 645 & 212 & & & 100.9 \\
\hline $\begin{array}{l}\text { Klinika e } \\
\text { Gjinekologjise } \\
\end{array}$ & 116708 & 189 & 42587 & 16613 & 42576 & 204 & 16628 & 200 & 0 & 3524 & 67.7 \\
\hline TOTALI & 494166 & 900 & 74179 & 18907 & 79954 & 1335 & 18890 & 1040 & 20878 & 22092 & \\
\hline
\end{tabular}

Nga tabela mund të konkludohet qartë se QKUK në Prishtinë kishte gati një gjysmë milion ditë trajtimi të pacientëve në vitin 2010, mesatarja ditore ishte kapaciteti prej 1.096 shtretërve të plotësuar. 
Pra, lehtë mund të konkludohet se realisht kemi të bëjmë me kapacitet të ngarkuara, duke mos llogaritur stafin mjekësor, administratën dhe vizitorët. Ndotësit mobil të ajrit janë mjetet motorike të cilët gravitojnë direkt në QKUK me kapacitetin e planifikuar prej 1000 makinave stacionare, në afërsi të drejtpërdrejtë me emanimin e ndotjeve të: NOx, $\mathrm{SOx}, \mathrm{CO} 2, \mathrm{CO}, \mathrm{PM}_{10}, \mathrm{PM}_{2.5}$.

Sipas autorëve Salthammer T. dhe E. Uhde 2009, të cilët elaborojnë se gjatë ligjëratave të tyre në temën " Indoor Air Quality " me studentë e arkitekturës, kanë zakon që shpesh i pyesin studentët se sa sipas mendimit të tyre, sa peshon ajri ...

Përgjigja më e zakonshme që kemi marrë është se $1 \mathrm{~m}^{3} \mathrm{i}$ ajrit duhet të peshojë vetëm $\mathbf{1 g}$ ose më pak. Ata besojnë se ajri është shumë i lehtë. Megjithatë, pesha e $1 \mathrm{~m}^{3}$ të ajrit është cca $1.2 \mathrm{~kg}$. Shkalla jonë e përditshme e frymëmarrjes është $15-20 \mathrm{~m}^{3}$ ajër, pra rreth 0.3 $\mathrm{m}^{3}$ për $1 \mathrm{~kg}$ të peshës trupore. Andaj për të marrë frymë ne, na nevojitën rreth $20 \mathrm{~kg}$ të substancës çdo ditë. Masa e thithur e ajrit është shumë më e lartë se doza ditore e përdorur për ujë të pijshëm dhe ushqim ". ${ }^{24}$

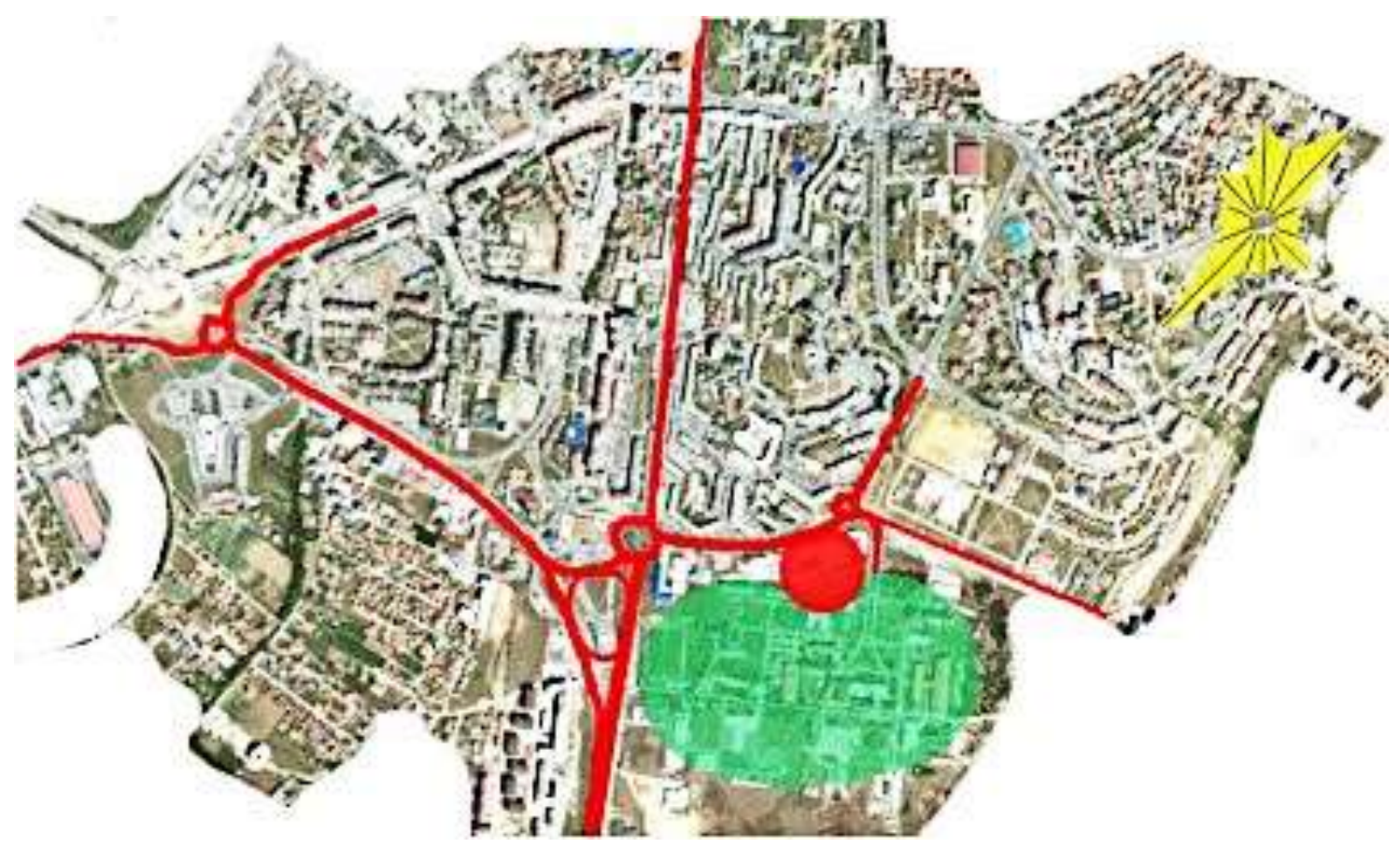

Figura 11. Qyteti Prishtinë, pozicioni i garazhës me QKUK, PR. (Burimi): Bujar Bajçinovci, Chrome, GoogleEarth. 2011.

Pra, për të marrë frymë nevojiten rreth $20 \mathrm{~kg}$ të substancës çdo ditë, por duhet ditur se në vëllimin e ajrit, hyjnë agjentë të ndryshëm që janë jashtëzakonisht të dëmshëm për shëndetin e njeriut: NOx, SOx, CO2, CO. Për qëllimet e këtij studimi do të analizohen materialet apo grimcat lëndore të pluhurit (PM).

24 Salthammer, T., Uhde E., (Eds).(2009). Organic Indoor Air Pollutants. Braunschweig, Germany 
Grimcat e imta (grimcat) janë të përbëra nga thërrmija shumë të vogla, apo të grimcave të ngurta në ajër, dhe përfshijnë grimcat më pak se 10 mikron në diametër $\left(\mathrm{PM}_{10}\right)$, dhe grimcat më të vogla se 2.5 mikron në diametër $\left(\mathrm{PM}_{2.5}\right)$. Grimca me një diametër të ndërmjetshëm 2.5 dhe 10 mikron nganjëherë janë referuar si "grimca të përafërta".

Ndotja bëhet nga grimca të cilat janë emetuar drejtpërdrejt si bloza dhe pluhuri në lëvizje, si dhe të grimcave të mesme të cilat janë të formuara në atmosferë nga reaksionet që përfshijnë ndotësit të tillë si oksidi i azotit, oksideve të squfurit, komponimeve organike të paqëndrueshme (NOx, SOx) të amoniakut . Grimcat lëndore të mesme (PM) dhe bloza priren të jenë grimcat e imta apo grimca të përafërta. ${ }^{25}$

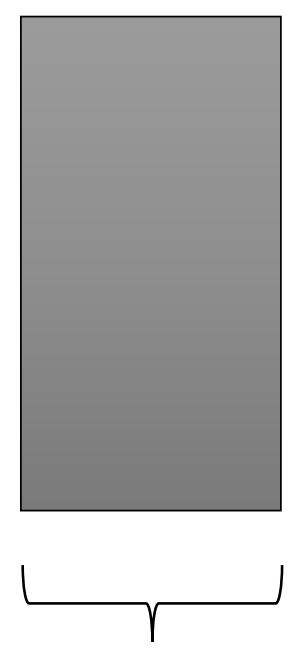

( $70 \mu \mathrm{m}$ nё diametër)

\section{(70 $\mu \mathrm{m}$ - Diameter)}

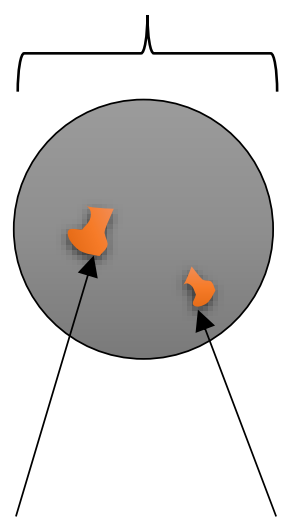

$P M(10 \mu m)^{26}$

Figura 12. Fija e flokut të njeriut dhe partikulat (Burimi): Bujar Bajcinovci, 2015.

KEK vazhdon të jetë një ndër burimet e fuqishme të ndotjes së ajrit për shkak të emisioneve të larta nga tymtarët e Termocentraleve Kosova A dhe Kosova B. Akoma nuk është instaluar sistem kontinual i monitorimit të emisioneve nga TC Kosova A, B. Për periudhën e ardhme, KEK planifikon rekonstruimin e sistemit të elektrofilterëve në TEC Kosova A (A3, A4 dhe A5) duke ngritur efikasitetin e elektrofilterëve ekzistues. Derisa tek TC Kosova B edhe pse vërehet me sy dhe raportohet për nivel më të ultë të emisioneve, gjithashtu janë evidente tejkalimet e emisioneve të lejuara. ${ }^{27}$

Vlerësimi i emisioneve nga termocentralet TC A dhe TC B bazohet nga rezultatet e matjeve dhe kalkulimeve të realizuara, për këta parametra ndotës: Pluhuri, SO2, NOx dhe $\mathrm{CO} 2$.

\footnotetext{
25 http://baaqmd.gov/Divisions/Planning-and-Research/Particulate-Matter.aspx. 2011.

${ }^{26}$ Grimcat e imta (grimca lëndore të madhësisë më pak se 10 mikron - $\mathrm{PM}_{10}$ dhe më pak se $2.5 \mu \mathrm{m}-\mathrm{PM}_{2,5}$ ). nga vlerësimi i studimeve të shumta epidemiologjike, konkludohet se edhe nivele shumë të ulëta të partikulave në ajër (të tilla si $10-25 \mathrm{mg} / \mathrm{m}^{3} \mathrm{PM}_{10}$, është e lidhur me një rritje të rrezikut për shëndetin e popullatës. Për këtë arsye, përcaktimi i "shëndetit të bazuar në vlera udhëzuese", OBSH rekomandon që vlerat të cilat u ekspozohemi këtyre grimcave lëndore, të janë realisht sa ma të ulëta të jetë e mundur.

27 MMPH. Raport për gjendjen e ajrit. 2012.
} 


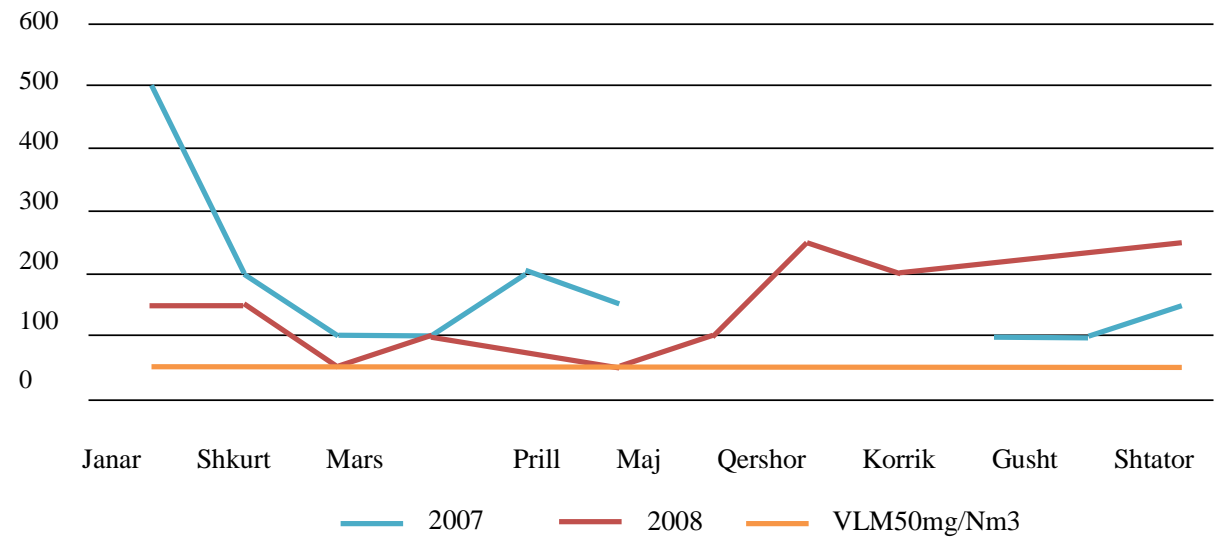

Figura 13. Emisionet e matura të pluhurit për TC B1 në vitin 2007/2008, në mg/m³n. (Burimi): Përpunuar Bujar Bajçinovci, MMPH. Raport për gjendjen e ajrit. 2012.

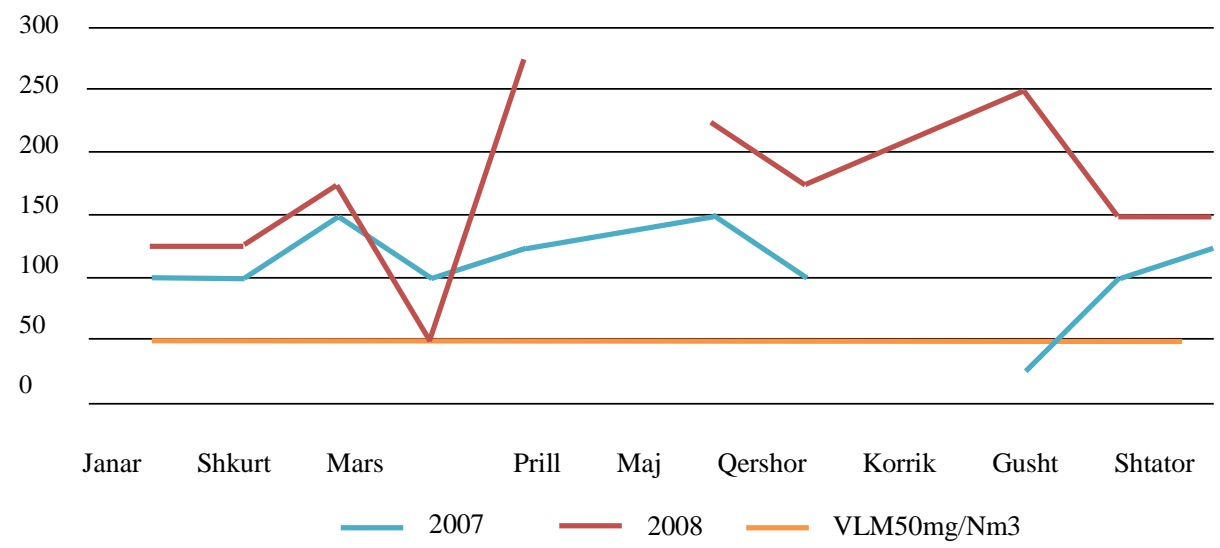

Figura 14. Emisionet e matura të pluhurit për TC B2 në vitin 2007/2008 në mg/mn (Burimi): Përpunuar Bujar Bajçinovci, MMPH. Raport për gjendjen e ajrit. 2012.

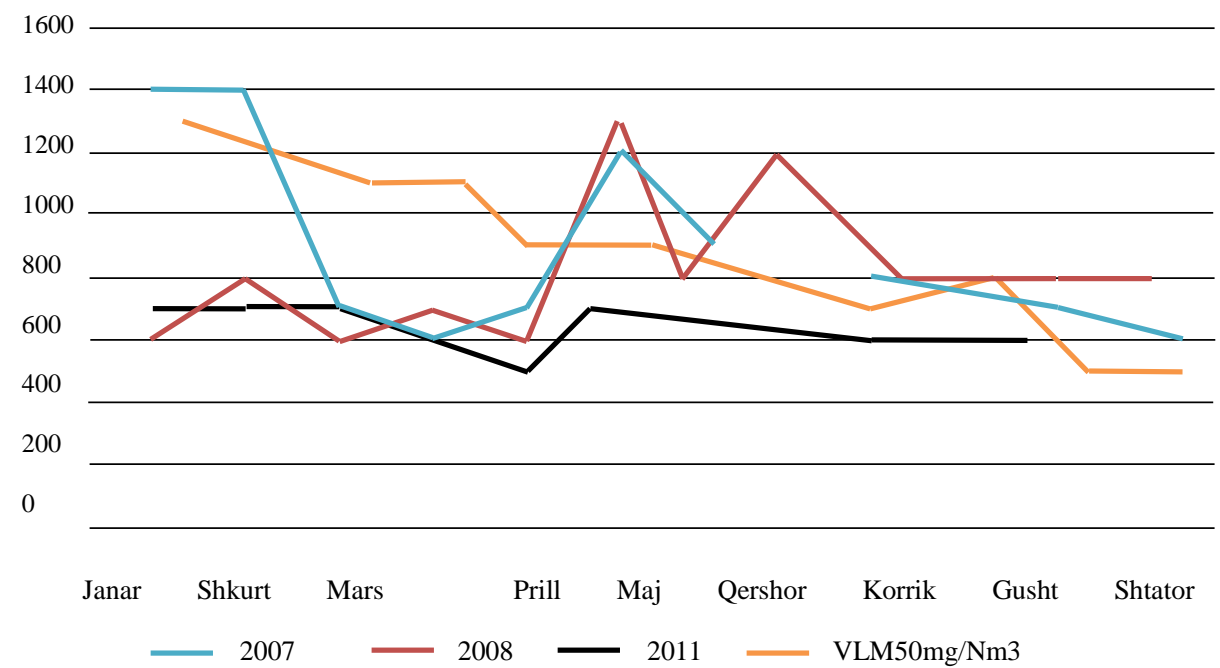

Figura 15. Emisionet e kalkuluara të pluhurit në $\mathrm{mg} / \mathrm{m}^{3} \mathrm{n}$ për TC A, 2007-2011. (Burimi): Përpunuar Bujar Bajçinovci, MMPH. Raport për gjendjen e ajrit. 2012. 
Nga figurat e prezantuara më lartë vërehet qartë se gjatë viteve 2007-2011 ka tejkalime të vlerës maksimale të lejuar $\left(50 \mathrm{mg} / \mathrm{m}^{3} \mathrm{n}\right)^{28}$, sidomos te TC A, ku janë regjistruar tejkalime enorme të pluhurit.

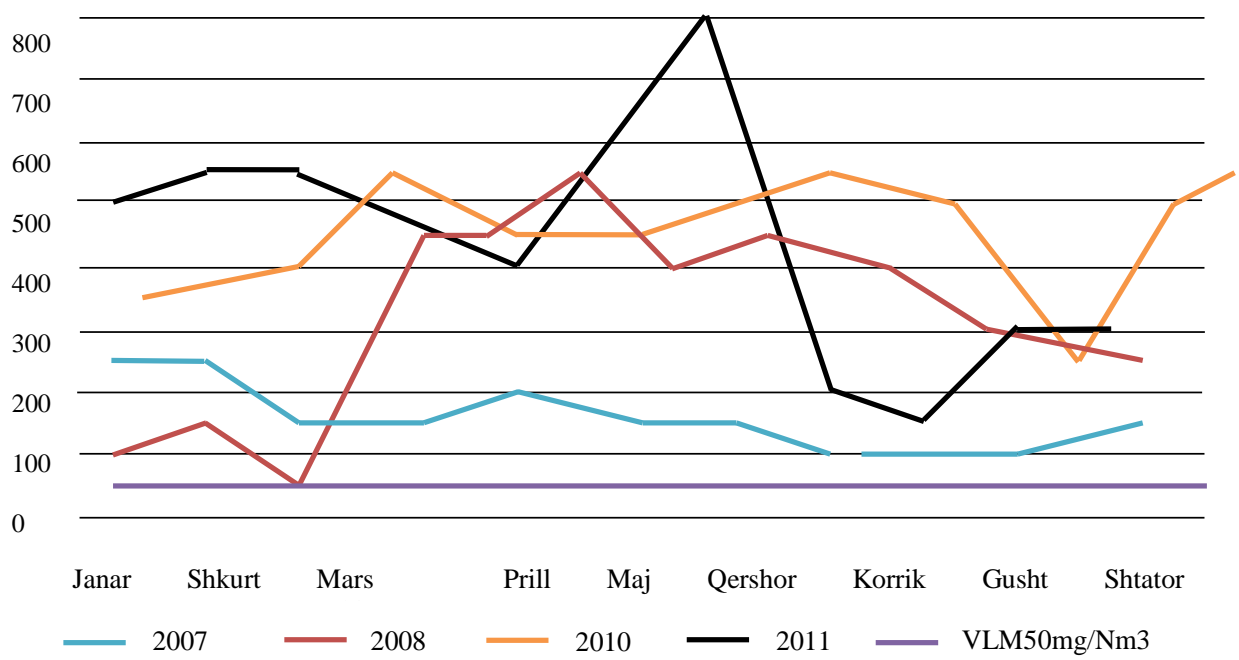

Figura 16. Emisionet e kalkuluara të pluhurit në $\mathrm{mg} / \mathrm{m}^{3} \mathrm{n}$ për TC B 2007-2011. (Burimi): Përpunuar Bujar Bajçinovci, MMPH. Raport për gjendjen e ajrit. 2012.

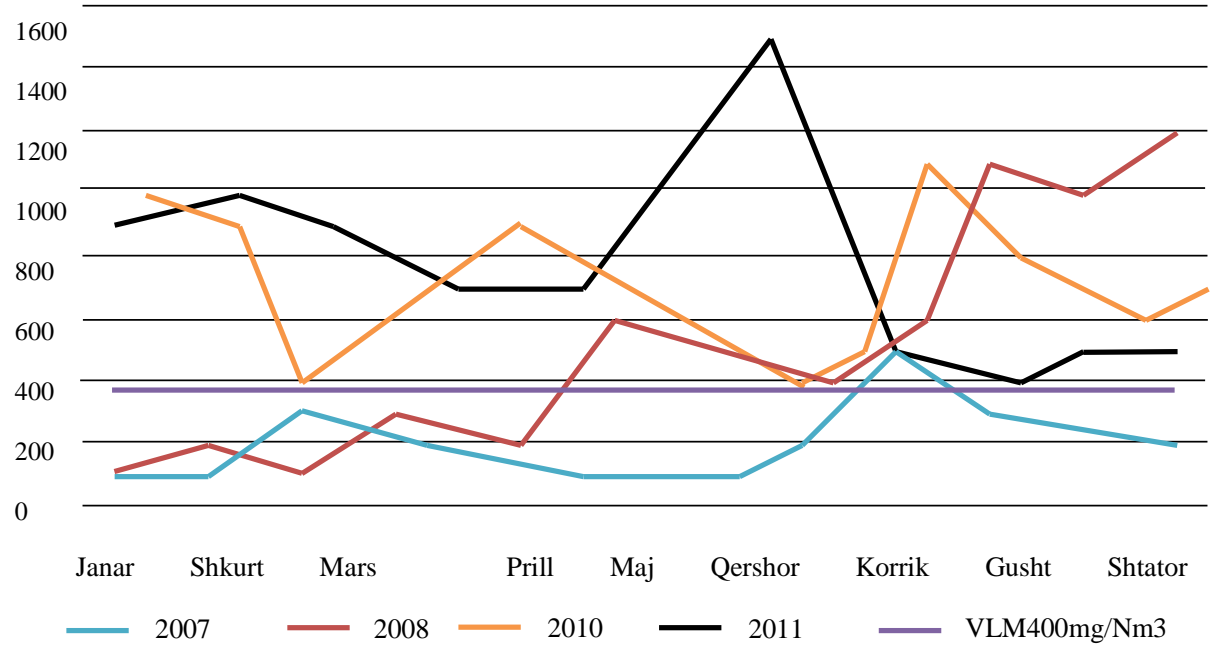

Figura 17. Emisionet e kalkuluara të SO2 në mg/m³n për TC A 2007-2011 $1^{29}$. (Burimi): Përpunuar Bujar Bajçinovci, MMPH. Raport për gjendjen e ajrit. 2012.

28 UA-2007. Mbi rregullat dhe normat e shkarkimeve në ajër nga burimet e palëvizshme të ndotjes.

29 Raportet vjetore dhe mujore të DMM-KEK. 
Nga fig. 17 vërehet se gjatë vitit 2010 dhe 2011 ka pas tejkalime të vlerave maksimale të lejuara $(400 \mathrm{mg} / \mathrm{Nm} 3)^{32}$, ndërsa gjatë vitit 2007; gjatë tërë vitit koncentrimi i SO2 të emituar ka qenë nën vlerën maksimale të lejuar me përjashtim të muajit shtator.

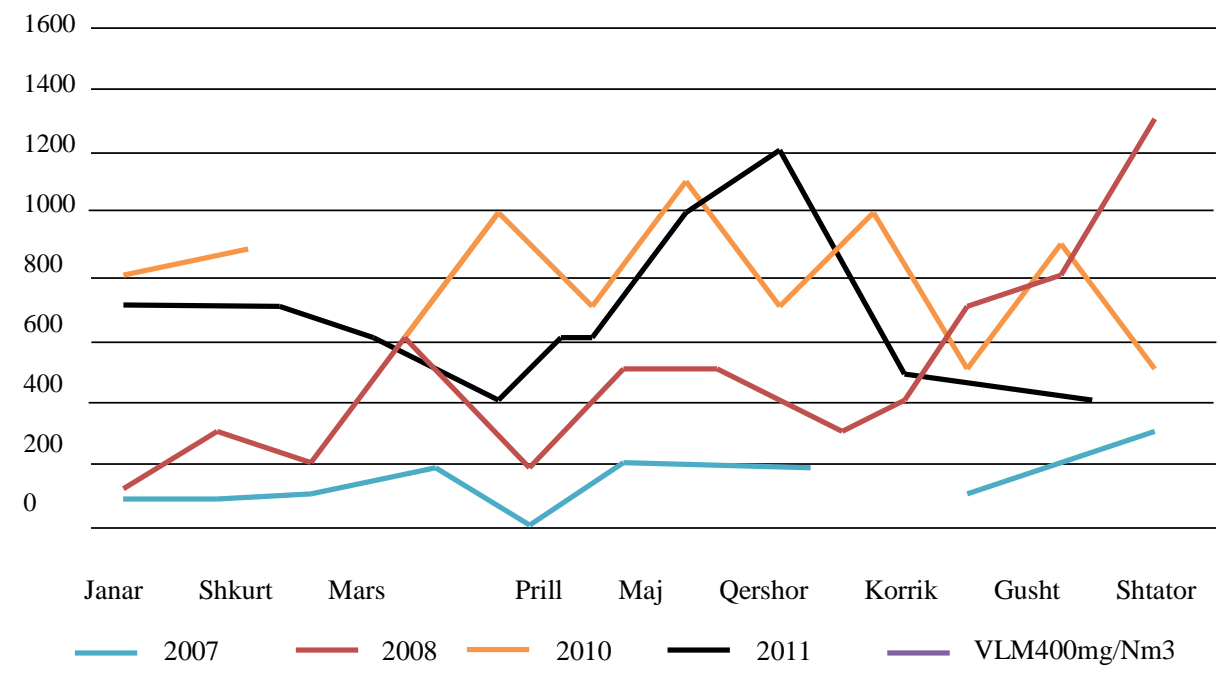

Figura 18. Emisionet e kalkuluara të $\mathrm{SO} 2 \mathrm{në} \mathrm{mg} / \mathrm{m}^{3} \mathrm{n}$ për TC B 2007-2011. (Burimi): Përpunuar Bujar Bajçinovci, MMPH. Raport për gjendjen e ajrit. 2012.

Për TC B prezantohen të dhënat e kalkuluara në fig.18, nga ku vërehet se gjatë tërë vitit 2010 dhe 2011 ka pas tejkalim të vlerës së lejuar maksimale. Gjendje më e mirë ka qenë në vitin 2007, ndërsa në vitin 2008 ka pas tejkalime gjatë muajve prill, qershor, korrik, tetor, nëntor dhe dhjetor.

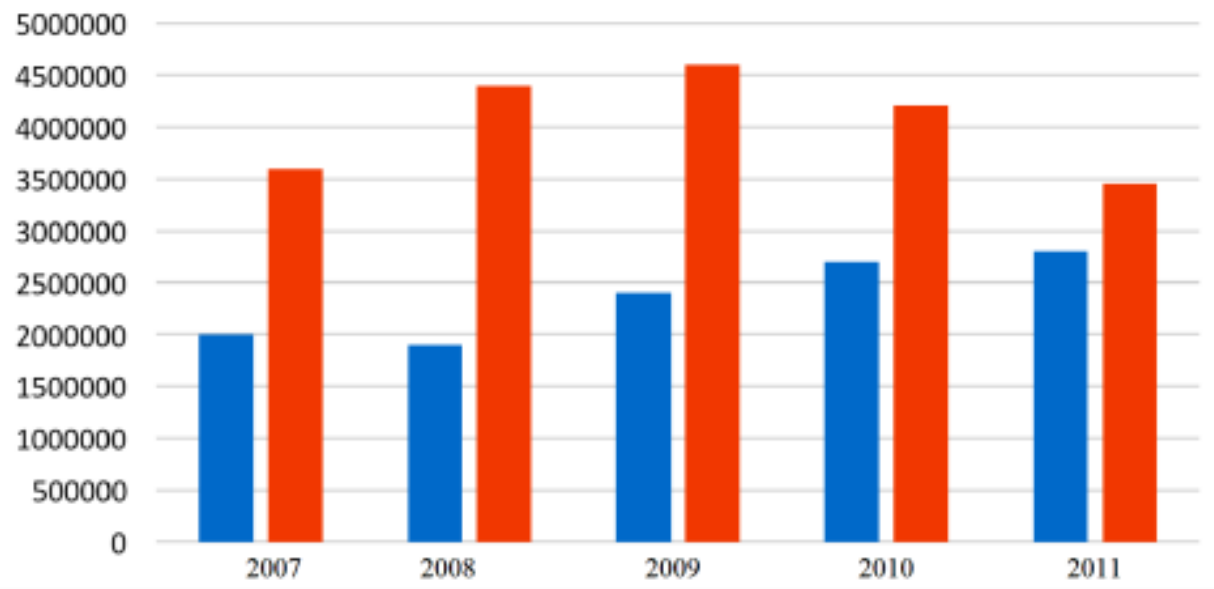

Figura 19. Emisionet e kalkuluara për $\mathrm{CO}_{2}$ në TC A dhe TC B, ton/vit 2007-2011. (Burimi): Përpunuar Bujar Bajçinovci, MMPH. Raport për gjendjen e ajrit. 2012. 
Shumë studime shkencore kanë lidhur ekspozimin afatshkurtër ndaj grimcave të imta (Partikula, PM) me një numër të problemeve shëndetësore, duke përfshirë. ${ }^{38}$

1. Vështirësi në traktin respirator, astmë

2. Rritje e simptomave të frymëmarrjes, kollitje dhe gulçime të dhimbshme

3. Bronkitin kronik

4. Reduktim të funksionimit të mushkërive

5. Miokardi

6. Kanceri dhe vdekja

Për këtë rast studimor, do të shërbehemi me të dhënat dhe matjet e Institutit HidroMetereologjik të Kosovës ${ }^{30}$, i cili i vetëm aktualisht bën matjen e grimcave PM, dhe rezultatet janë valide dhe shkencërisht të vlefshme. Instituti ka pajisje për matjen PM (Sharp 5030) në 3 vende të caktuara, 2 prej të cilave janë urbane dhe një suburbane.

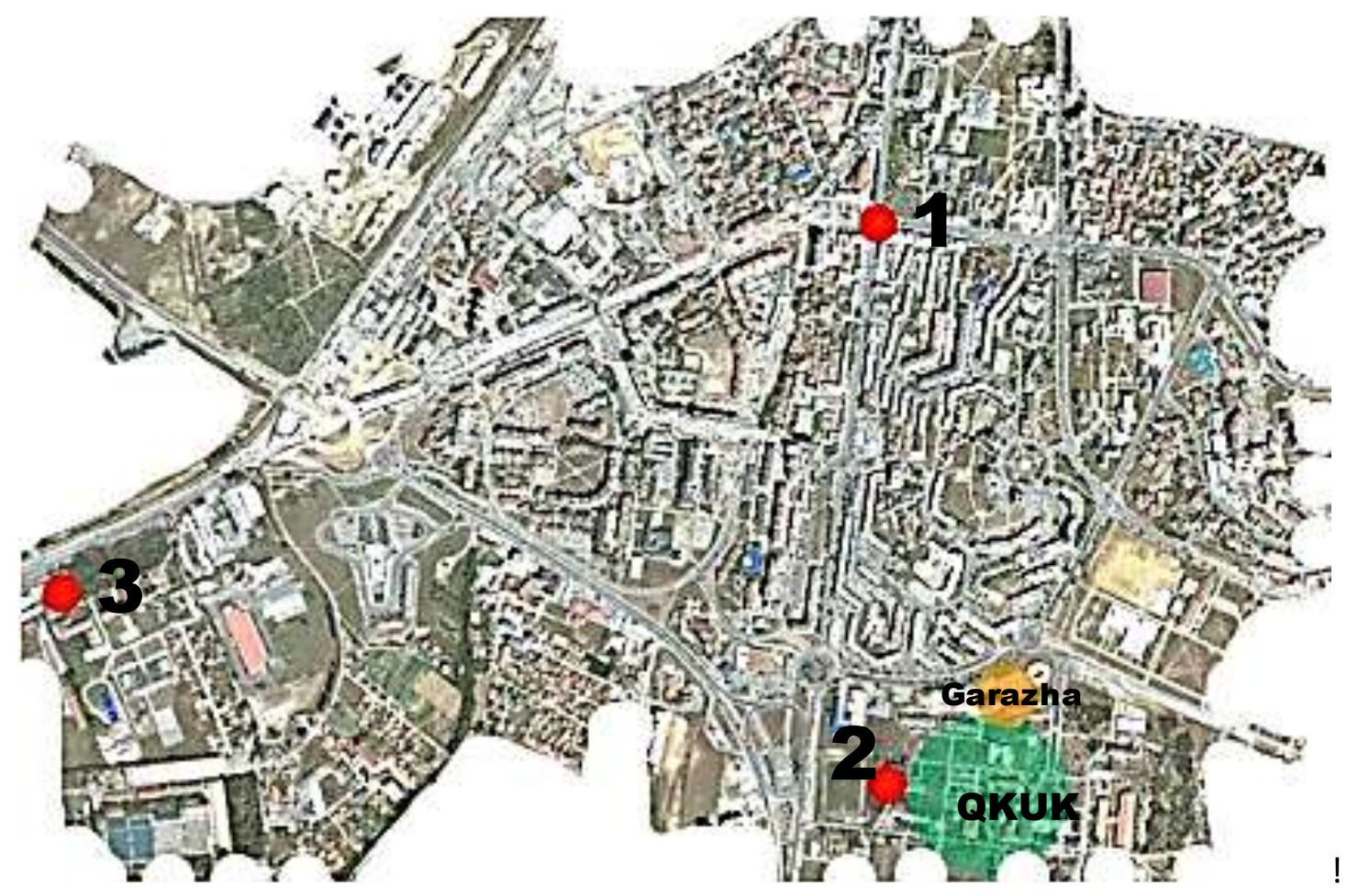

Figura 20. Qyteti Prishtinë, Stacionet matëse të cilësisë së ajrit. $\mathrm{PM}_{10}$ dhe $\mathrm{PM}_{2.5}$ (Burimi): Përpunuar Bujar Bajçinovci, Chrome-GoogleEarth. IMK. Raport për gjendjen e ajrit. 2012.

Stacioni Nr.1. është shënuar me ISHP1 cila është e vendosur në zonën urbane të Prishtinës. Ky stacion është një përfaqësues i denjë i ndotjes së ajrit nga trafiku. Stacioni Nr.2. është e shënuar me ISHP2 cila është e vendosur në afërsi të IKSHP i afërt me kampusin e QKUK, hapësirë që mund të cilësohet si zonë shumë e ndjeshme, sepse ka një ndotje të madhe të ajrit. Stacioni Nr.3. është IHMK, një vend matje e cilësisë së ajrit në zonën periferike të Prishtinës.

30 Tahirsylaj S. \& Latifi L. (2010). Quality of Air in Urban and suburban Area's of the Prishtina. Ohër 
Po ashtu duhet të merret në konsideratë se në çfarë mase ka ndikimi i ndotjes së ajrit nga TC Kosova A dhe B të cilët emanojnë ndotje. Kështu, cilësia e ajrit është e ndikuar dhe për shkak të termocentraleve në afërsi nga vija ajrore e shkurtë, duke e bërë ndotjen e ajrit më të përhershme, sidomos pasi termocentralet vështirë i rinovojnë filtrat.

Stacionet e monitorimit për matje të ndotjes kanë regjistruar vlera të larta të $\mathrm{PM}_{10}$ dhe $\mathrm{PM}_{2.5}$. Pra, max. vlera mujore e $\mathrm{PM}_{10}(278,63 \mu \mathrm{g} / \mathrm{m} 3)$ është regjistruar në nëntor, ndërsa max. PM 2.5 mujore është regjistruar me $(148.87 \mu \mathrm{g} \mathrm{m} 3)$ në nëntor të 2010.

Tabela 7. Matjet e $\mathrm{PM}_{10}$ në pikat referente. ${ }^{30}$

(Burimi): Tahirsylaj S. \& Latifi L. IHMK. 2010. Përpunuar Bujar Bajçinovci.

\begin{tabular}{|l|c|c|c|c|c|c|}
\hline PM10 & mesatarja & max & min & nr.data & good.data & \% good data \\
\hline & & & & & & \\
\hline Shtator & 51.7 & 83.1 & 24.1 & 30 & 27 & 90 \\
\hline Tetor & 50.6 & 128.2 & 10.6 & 31 & 28 & 90.3 \\
\hline Nëntor & 153.84 & $\mathbf{2 7 8 . 6 3}$ & 37.97 & 30 & 19 & 63.33 \\
\hline Dhjetor & 53.23 & 141.79 & 16.96 & 31 & 28 & 90.32 \\
\hline Janar & 54.45 & 155.9 & 14.07 & 31 & 30 & 96.77 \\
\hline Shkurt & 51.84 & 125.98 & 16.05 & 28 & 25 & 89.3 \\
\hline Mars & 49.74 & 73.05 & 24.19 & 31 & 5 & 16.2 \\
\hline
\end{tabular}

Tabela 8. Matjet e $\mathrm{PM}_{2.5}$ në pikat referente. ${ }^{30}$ (Burimi): ): Tahirsylaj S. \& Latifi L. IHMK. 2010. Përpunuar Bujar Bajçinovci.

\begin{tabular}{|l|c|l|c|c|c|c|}
\hline PM2.5 & mesatarja & max & min & nr.data & good.data & \% good data \\
\hline & & & & & & \\
\hline Nëntor & 93.88 & $\mathbf{1 4 8 . 8 7}$ & 26.02 & 30 & 19 & 63.33 \\
\hline Dhjetor & 39.31 & 110.2 & 13.73 & 31 & 29 & 93.54 \\
\hline Janar & 44.38 & 144.74 & 11.38 & 31 & 30 & 96.77 \\
\hline Shkurt & 41.97 & 110.3 & 10.23 & 28 & 26 & 92.85 \\
\hline Mars & 32.36 & 46.61 & 18.93 & 31 & 5 & 16.2 \\
\hline
\end{tabular}

Tabela 9. Matjet e $\mathrm{PM}_{10}$ dhe $\mathrm{PM}_{2.5}$ në pikat referente. ${ }^{30}$ (Burimi): ): Tahirsylaj S. \& Latifi L. IHMK. 2010. Pёrpunuar Bujar Bajçinovci.

\begin{tabular}{|l|c|c|c|}
\hline & ISHP1 & ISHP2 & (PM10+PM2.5)+IHMK \\
\hline Janar & $\mathbf{1 2 7 . 0 9}$ & $\mathbf{1 4 6 . 7}$ & $\mathbf{9 8 . 8}$ \\
\hline Shkurt & 91.65 & 86.21 & 93.8 \\
\hline Mars & 95.12 & 91.32 & 82.1 \\
\hline Mesatarja & 104.62 & 108.07 & 91.58 \\
\hline
\end{tabular}




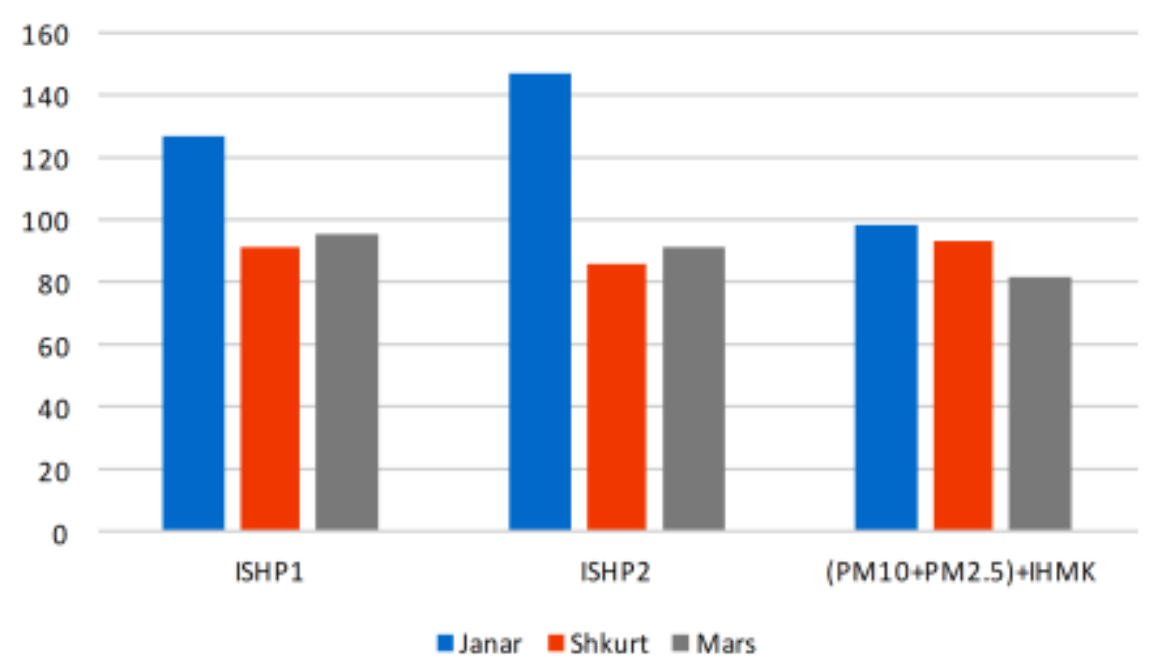

Figura 21. Vlerat në stacionet matëse të cilësisë së ajrit. $\mathrm{PM}_{10}$ dhe $\mathrm{PM}_{2.5}$ (Burimi): Tahirsylaj S. \& Latifi L. IHMK. 2010. Përpunuar Bujar Bajçinovci.

Tabela 10. Vlerat kufitare të BE-së, $\mathrm{PM}_{10}$ dhe $\mathrm{PM}_{2.5}$ dhe $\mathrm{NO}_{2}$ në cilësinë e ajrit. 2008. (Burimi): E përkthyer, Bujar Bajçinovci.The Mayor's Air Quality Strategy. Clearing the air. London. 2010.

\begin{tabular}{|c|c|c|c|c|}
\hline Ndotësi & Obligative & Periudha kohore & Data e aprovimit & $\begin{array}{c}\text { Tejkalimi I lejuar çdo } \\
\text { vit }\end{array}$ \\
\hline \multirow{2}{*}{$\begin{array}{l}\text { Lënda grimcore } \\
\text { (PM10) }\end{array}$} & $\begin{array}{l}\text { Vlerë e limituar } 50 \\
\qquad \mu \mathrm{g} / \mathrm{m}^{3}\end{array}$ & 24 orë & 1/Janar/2005 & Jo më shumë se 35 \\
\hline & $\begin{array}{l}\text { Vlerë e limituar } 40 \\
\qquad \mu \mathrm{g} / \mathrm{m}^{3}\end{array}$ & 1 vit & 1/Janar/2005 & \\
\hline \multirow{2}{*}{ Dyoksid Azoti(NO2) } & $\begin{array}{l}\text { Vlerë e limituar } 200 \\
\qquad \mu \mathrm{g} / \mathrm{m}^{3}\end{array}$ & 1 orë & 1/Janar/2010 & Jo më shumë se 18 \\
\hline & $\begin{array}{l}\text { Vlerë e limituar } 40 \\
\mu \mathrm{g} / \mathrm{m}^{3}\end{array}$ & 1 vit & 1/Janar/2010 & \\
\hline \multirow{4}{*}{$\begin{array}{l}\text { Lënda grimcore } \\
\text { (PM2.5) }\end{array}$} & $\begin{array}{l}\text { Vlerë e limituar } 25 \\
\qquad \mathrm{gg} / \mathrm{m}^{3}\end{array}$ & Mesatare vjetore & 1/Janar/2015 & \\
\hline & $\begin{array}{c}\text { Niveli } 2 \text { Vlerë e limituar } \\
20 \mu \mathrm{g} / \mathrm{m}^{3}\end{array}$ & Mesatare vjetore & 1 Janar 2020* & \\
\hline & $\begin{array}{l}\text { Koncetrimi I ekspozimit } \\
20 \mu \mathrm{g} / \mathrm{m}^{3}\end{array}$ & $\begin{array}{c}\text { Treguesi i } \\
\text { mesatares së } \\
\text { ekspozimit } 3 \\
\text { vjeçare (AEI) }\end{array}$ & 1/Janar/2010 & \\
\hline & $\begin{array}{l}\text { Reduktimi I ekspozimit në } \\
\text { krahasim me } 2010 \mathrm{AEI} \\
\text { (0\% to } 20 \% \\
\text { reduktim) }\end{array}$ & $\begin{array}{l}\text { Treguesi i } \\
\text { mesatares së } \\
\text { ekspozimit } 3 \\
\text { vjeçare (AEI) }\end{array}$ & 2020 & \\
\hline
\end{tabular}

Këto grafi krahasojnë të dhënat mesatare të cilësisë së ajrit gjatë ditës për muajt e cekur, duke e krahasuar me të njëjtin muaj të para 2 viteve. 


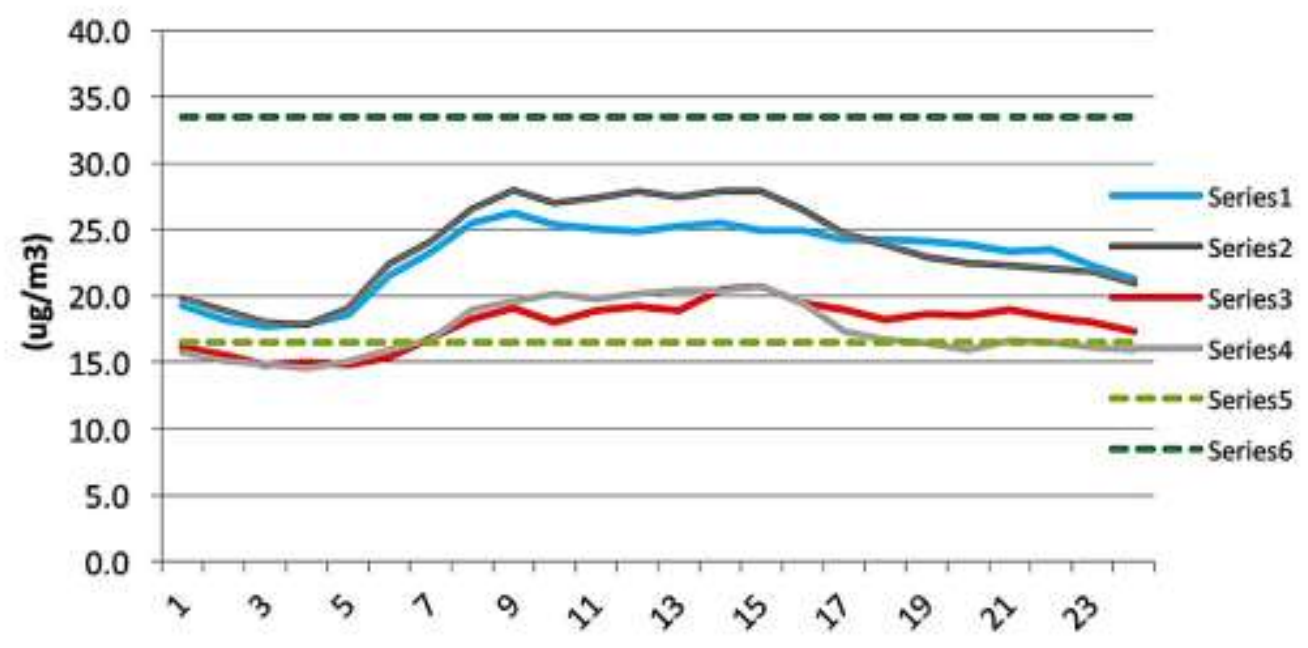

Figura 22. Mesatarja e cilësisë së ajrit në Londër. Lënda Grimcore PM 10 (Burimi): http://www.londonair.org.uk.

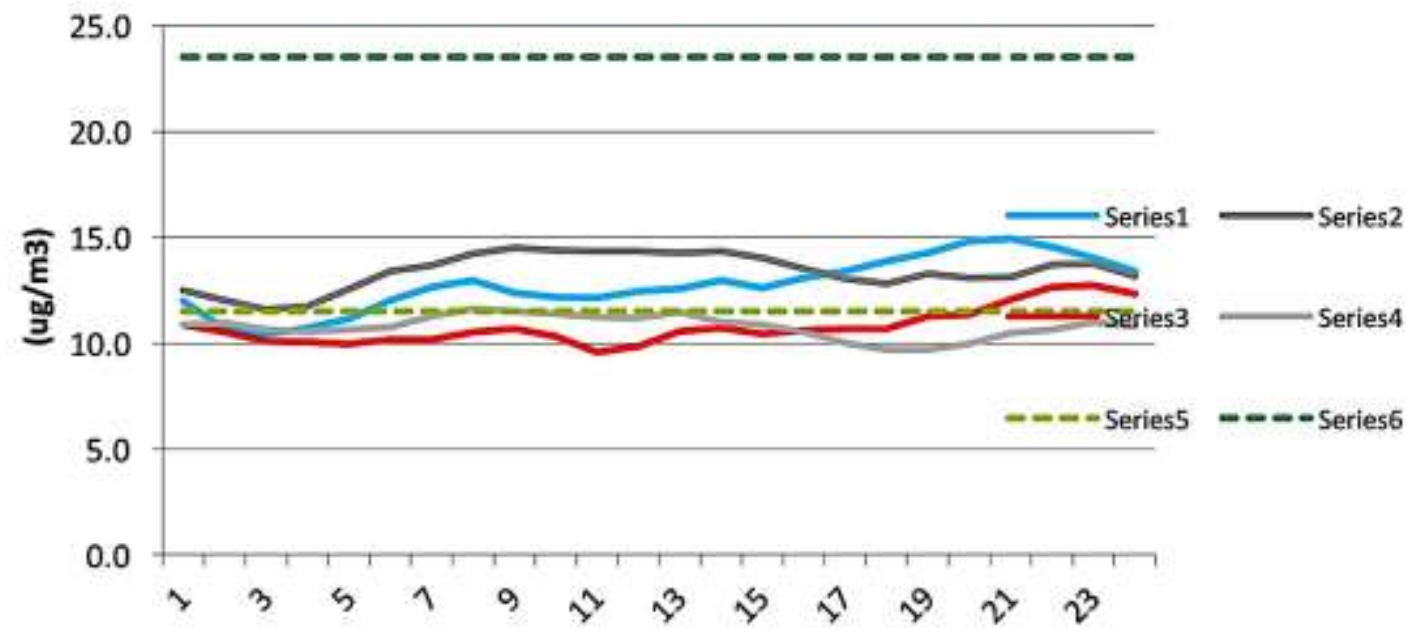

Figura 23. Mesatarja e cilësisë së ajrit në Londër. Lënda Grimcore $\mathrm{PM}_{2.5}$ (Burimi): http://www.londonair.org.uk.

Konceptualisht, mund të konstatohet nga të dhënat e mësipërme se Prishtina është pothuajse 4 herë më e "fortë" se sa Londra në lidhje me grimcat $\mathrm{PM}_{10}$ dhe $\mathrm{PM}_{2.5}$. Prishtina në përgjithësi është e ndotur për shkak të pozicionit të saj gjeomorfologjik në lidhje me ndotësit kryesorë, TC Kosova A dhe B. Përveç kësaj, ndotja është ndihmuar edhe me erërat dominante, për shembull në shtator 2009 e deri në mars 2010. Megjithatë, sipas rezultateve, vendi i parë i takon ndotjes në stacionin matës 2 në kampusin QKUK, ISHP2 me matjet e $146,7 \mu \mathrm{g} / \mathrm{m} 3$. 
Andaj, cilësia e ajrit në kampusin e QKUK në Prishtinë është shumë e degraduar dhe tejkalon kufijtë e dhënë me standardet e BE, si dhe më e degraduar ndaj rezultateve të stacioneve tjera matëse në Prishtinë. Është për tu magjepsur se si u përzgjedhë lokacioni për ndërtimin e garazheve publike të qytetit, (për të zgjedhur problemin e parkimit në Prishtinë si model fillestar) mu pranë kampusit të QKUK, pavarësisht nga të dhënat për ndotjen, drejtimet e erërave dominante, për më së gjysmë milion pacientëve të trajtuar, ku prodhuesit kryesor mobil të $\mathrm{PM}_{10}, \mathrm{PM}_{2.5}$ dhe $\mathrm{CO}$, janë automjetet. Sipas policisë së Kosovës dhe të dhënat e tyre zyrtare, në Prishtinë "orbitojnë” përditshëm rreth 120.000 automjete $^{31}$, duke pas në konsideratë se $80 \%$ e makinave janë të prodhimit të vjetër. Është më se e qartë se janë burim i drejtpërdrejt në transmetimin e materialit jo djegës dhe emanimin e lëndës grimcore PMxx, së bashku me ndotësit kryesorë të ajrit, TC A dhe B. "Ekspozimi PMxx rrit rrezikun e vdekshmërisë, si në afat të gjatë, si dhe në periudha afat shkurta. Ekspozimi afatgjatë është i lidhur me një reduktim të jetëgjatësisë, sëmundjeve kardiopulmonare dhe kancerit të mushkërive." 32

Efektet shëndetësore kronike janë studiuar në një grup njerëzish, hulumtimet që kanë pasur target grupin e përcaktuar me analizat si: eksponimi me kalimin e kohës dhe krahasimi me nivelin e ekspozimit ndaj PMxx. Shumica e studimeve janë kryer në Shtetet e Bashkuara ... EPA (EPA, 2005) si dhe të vlerësuara nga Harvardi. Studimet janë kryer në gjashtë qytete, së bashku me American Cancer Society (ACS), vërehet një ndikim i konsiderueshëm në mes vdekshmërisë dhe ekspozimi afatgjatë për $\mathrm{PM}_{2.5}$.

Bazuar në këto studime, EPA vlerëson se rritja e rrezikut të vdekshmërisë rritet veçanërisht nga sëmundjet kardiopulmonare, kur ka përqendrim brenda kufirit 6-13\% ... të $\mathrm{PM}_{2.5}$. Respektivisht, vdekshmëria nga kanceri në mushkëri, në bazë të një raporti që ka vlerësuar efektet e eksponimit, ACS (Pope et al., 2002), ishte se vdekshmëria ka rritje $13 \%$, në rast të rritjes vjetore të përqendrimeve $10 \mu \mathrm{g} / \mathrm{m} 3 \mathrm{PM}_{2.5 .}{ }^{32}$ "Për vlerësimin e ndërveprimit, janë shqyrtuar 5,422 fëmijë të moshës 10-12 vjeçare. Është raportuar një rritje e të kollës kronike, bronkitit dhe të dhimbjeve të gjoksit, të cilat ishin të lidhura me nivelin e ndotjes së grimcave ( TSP, $\mathrm{PM}_{10}, \mathrm{PM}_{2.5}$ ). ${ }^{33}$ "Ka pasur disa studime mbi eksponimin ndaj $\mathrm{PM}_{10}$ në natyrë, dhe rrezikun e infeksioneve të traktit respirator të sipërm dhe të poshtëm të frymëmarrjes në mesin e fëmijëve. Dy analiza janë kryer në kohë të ndryshme në Utah Valley në Shtetet e Bashkuara, duke matur ndotësit në natyrë dhe të ekspozimit ndaj tyre në bazë ditore. Disa rezultate kanë raportuar me rritje prej 3,7\% - 5,1\% me më shumë simptome në traktin e sipërm dhe të poshtëm të frymëmarrjes, me rritjen e përqendrimit të $10 \mu \mathrm{g} / \mathrm{m} 3$ të $\mathrm{PM}_{10}$ "37

\section{Cilësia e ajrit në Prishtinë gjatë periudhës 01-09 dhjetor 2015}

"Cilësia e ajrit në Prishtinë monitorohet përmes sistemit të matjeve automatike që do të thotë se bëhen matje kontinuale pa ndërprerje. Parametrat qe monitorohen janë: Dyoksidi i sulfurit (SO2), Monoksidi i karbonit (CO), Dyoksidi i azotit (NO2), Ozoni (O2), grimcat e suspenduara ne ajër $\mathrm{PM}_{10}$ dhe $\mathrm{PM}_{2.5}$.

\footnotetext{
31 Policia e Kosovës. (2011).http://kosovopolice.com/?page=1,14

32 WHO, Europe., Marttuzi M. et al,(2006). Health impact of PM10 and ozone in 13 Italian cities. Copenhagen, Denmark: WHO Regional Office for Europe.

33 WHO, Europe.(2005). Effects of air pollution on children's health and development : A Review Of the Evidence. Copenhagen, Denmark: WHO Regional Office for Europe.
} 
Nga analiza e rezultateve të fituara i cilësisë se ajrit është konstatuar se gjatë periudhës monitoruese 01-09.12.2015 janë paraqitë tejkalime të vlerave kufitare ditore me $\mathrm{PM}_{10}$. Vlera kufitare ditore e lejuar për mbrojtjen e shëndetit të njeriut është $50 \mathrm{ug} / \mathrm{m} 3$. Gjatë tërë këtyre ditëve janë regjistruar 7 ditë (raste) me tejkalime të vlerave kufitare ditore, vetëm dy ditë kanë qenë përqendrimet e $\mathrm{PM}_{10}$ brenda kufijve të lejuar. Ndërsa gjatë një viti lejohen 35 ditë me tejkalime të vlerave kufitare ditore."

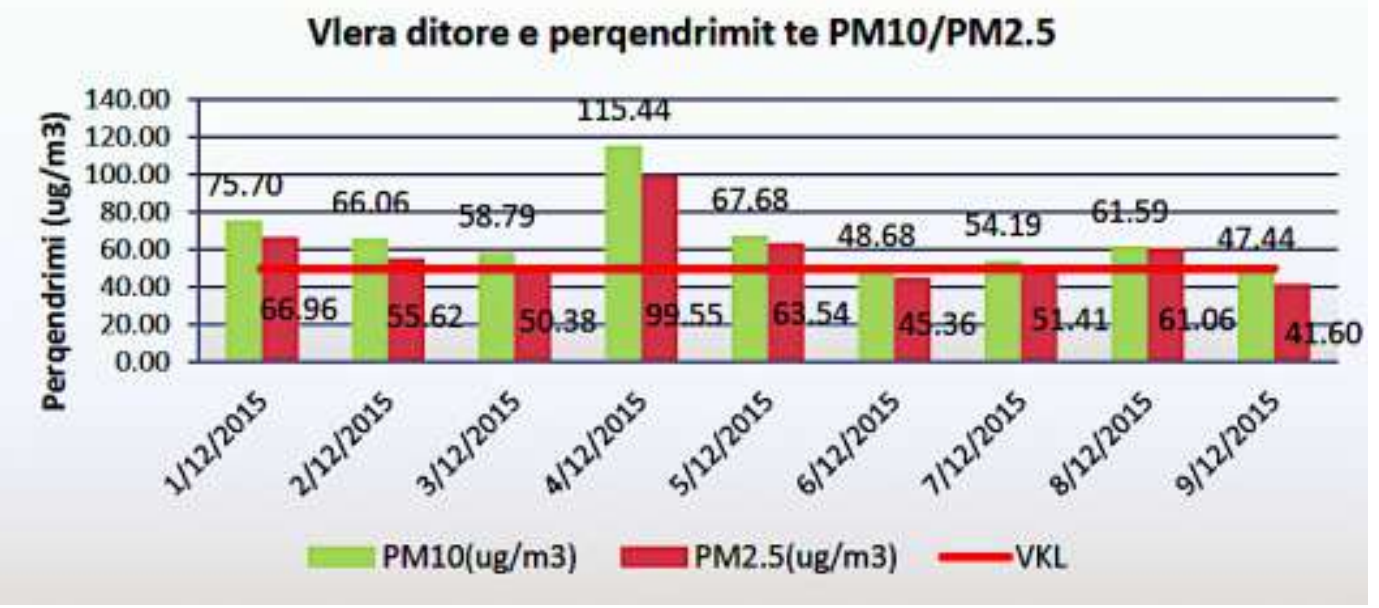

Figura 24. Përqendrimi i $\mathrm{PM}_{10}$ dhe $\mathrm{PM}_{2.5}$ në Prishtinë, Dhjetor/2015 (Burimi): Latifi, L. \& Shala, Sh. IHMK. 2015.

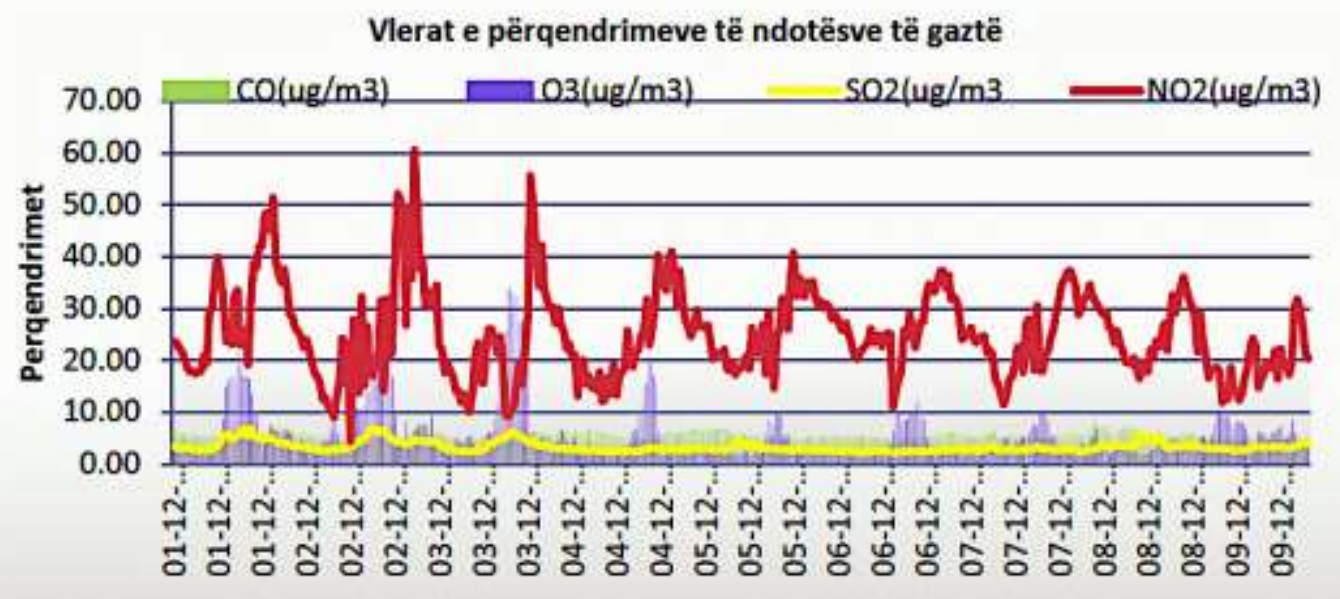

Figura 25. Përqendrimi i ndotësve të gaztë në Prishtinë, Dhjetor/2015 (Burimi): Latifi, L. \& Shala, Sh. IHMK. 2015.

Vlera maksimale e përqendrimit të $\mathrm{PM}_{10} \mathrm{ka}$ arritur në 115.44 me datë 04.12.2015 dhe është 2.3 herë më e lartë se vlera e kufitare e lejuar. Po ashtu edhe përqendrimi i PM 2.5 është i ngritur në krahasim me muajt e kaluar. 
Kësaj gjendje i kontribuojnë jo vetëm shkarkimet nga transporti, industria por edhe konsumimi i lëndëve djegëse që përdorën për ngrohje si dhe kushtet jo të favorshme për disperzionin e ndotësve që shkarkohen në ajër nga burimet e lartë përmendura e të cilët në këtë raste akumulohen në afërsi të tokës dhe nuk shpërndahen lartë në atmosferë. (Ekstrakt, Latifi, L. \& Shala, Sh. IHMK. 2015.)

Konkluzione dhe Rekomandime

1. “Nga analiza e rezultateve të lartë përshkruara është konstatuar se përqendrimet e larta të $\mathrm{PM}_{10}$ e bëjnë që cilësia e ajrit në Prishtinë të jetë jo e kënaqshme.

2. Kësaj gjendje i kontribuojnë shkarkimet e ndotësve nga burimet e lartpërmendura sikur janë industria, transporti dhe konsumimi i lendeve të ngurta djegëse qe përdoren për ngrohje si dhe kushtet e pafavorshme meteorologjik për disperzionin e ndotjes qe emetohet në ajër.

3. Gjate këtyre ditëve për të cilat jemi duke shqyrtuar gjendjen e cilësisë se ajrit në Prishtinë ka mbretëruar një mot me mjegull të dendur(dukshmëri $<30 \mathrm{~m}$ ) dhe lagështi të larte të ajrit mbi $85 \%$ si dhe mungesë e erës dhe kur këtyre kushteve u shtohen edhe shkarkimet e ndotësve në ajër atëherë vije deri te krijimi i gjendjes së smogut ( $i$ thirrur smogu $i$ Londrës) qe është karakteristik për paraqitjen e tij gjate sezonit dimëror dhjetor- janar dhe i cili shkakton eksitim të bronkeve dhe kollitje.

4. Ne këto raste rekomandohet qe kategoria e ndjeshme (personat me probleme nga sëmundjet e organeve respiratore të mos qëndrojnë gjate në ambiente të tilla.

5. Te reduktohen lëvizjet e panevojshme me automjete sidomos në zonat e frekuentuara nga këmbësorët."

Autorë:Letafete Latifi, Shkumbin Shala. IHMK. 2015. http://mmph-rks.org/sq/Lajmet/Ajri-i-ndotur-ne-Prishtine-Faktor-mjegulla-dhe-lendet-djegese-1320

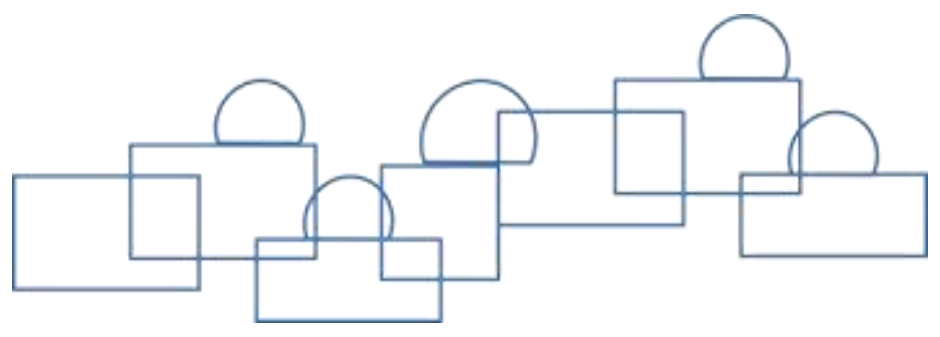




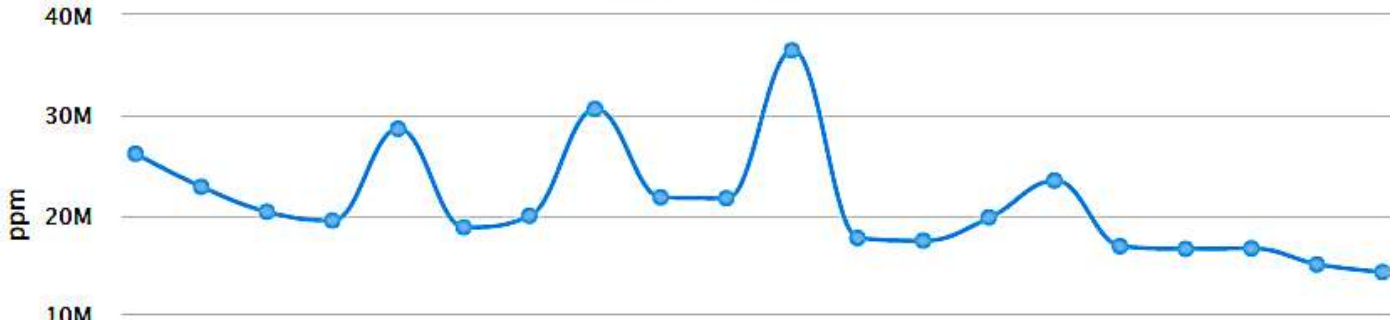

$0 \mathrm{M}$

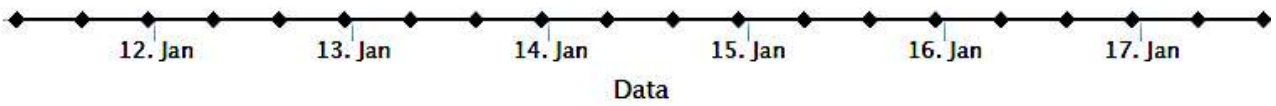

$\approx \mathrm{CO} 2 \leadsto$ Limiti i lejuar

CO

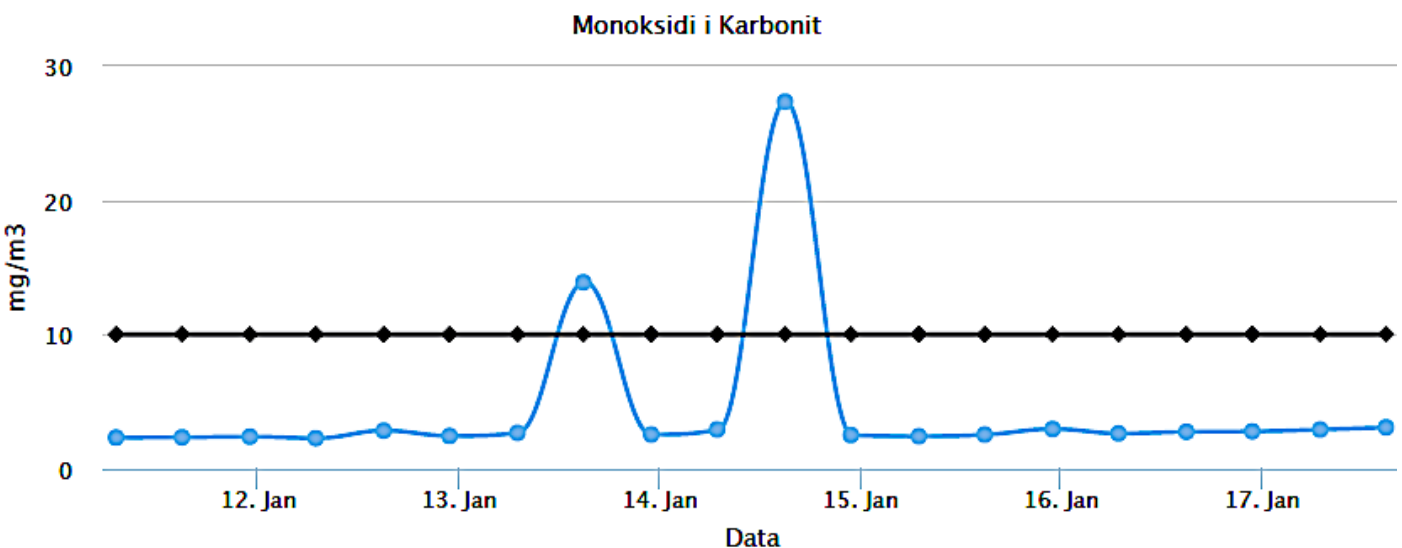

$\leadsto$ CO $\leadsto$ Limiti i lejuar

$4 \mathrm{H} 2 \mathrm{~S}$

Hidrogjen Sulfuri

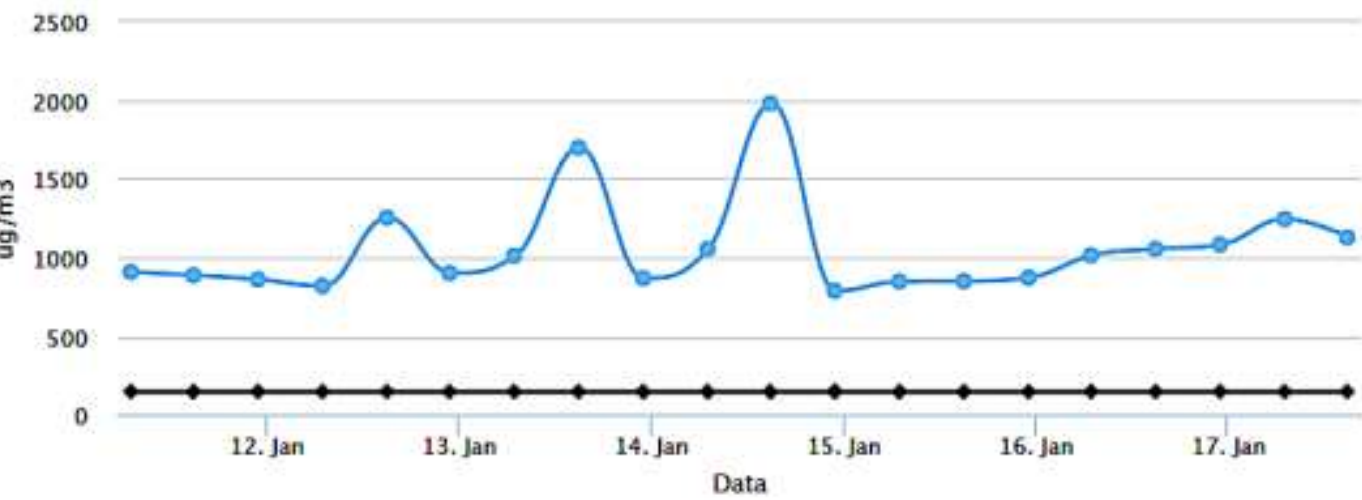

$\approx 4 \mathrm{H} 2 \mathrm{~S} \rightleftharpoons$ Limiti i lejuar

Figura 26. Përqendrimi i ndotësve të gaztë në Prishtinë, Ulpianë.

(Burimi): Komuna e Prishtinës. Pilot projekt. http://air.fara.rocks/. Shkurt/2016. 

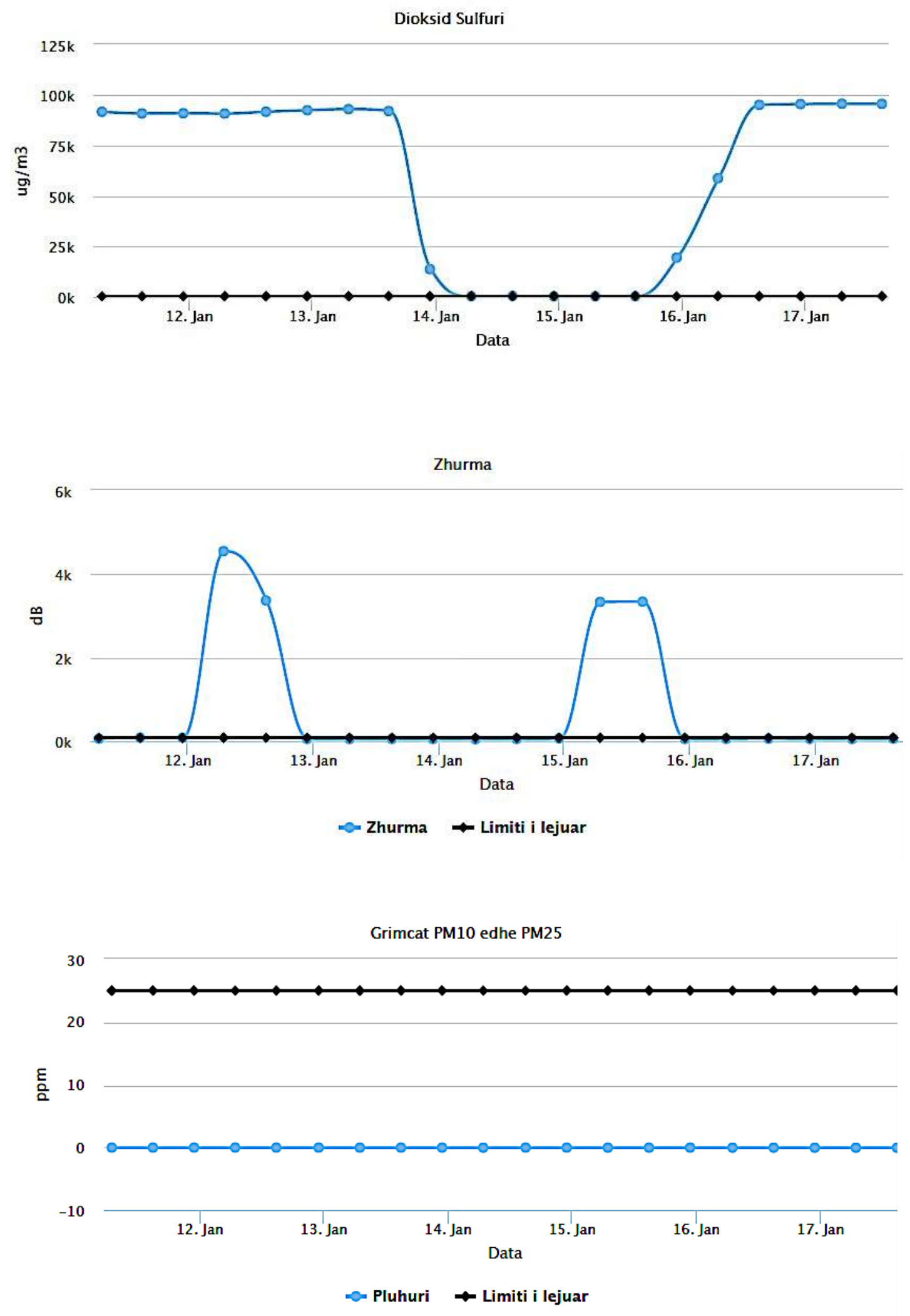

Figura 27. Përqendrimi i ndotësve të gaztë në Prishtinë, Ulpianë. Burimi): Komuna e Prishtinës. Pilot projekt. http://air.fara.rocks/. Shkurt/2016. 


\subsection{Exitus}

Gjendja aktuale e degradimit mjedisor kërkon përgjigje specifike dhe aktivitete të bazuara në mënyrë shkencore, veçanërisht nëse ato janë të lidhura me cilësinë e shëndetit. Si çdo aktivitet i cili duhet të jetë në një proces evolutiv, arkitektura gjithashtu apo arkitekti duhet të plotësohet me edukim shtesë dhe të specializuar, në të kundërtën të gjitha aktivitetet e mundshme të projektimit do të jenë të destinuara në improvizim, stagnim dhe eventualisht në depresion profesional. "Qytetet dhe kodet e vjetra të ndërtimit, Amerikane, ndonjëherë përmbajnë rregulla dhe rregullore arkaike që janë të pazbatueshme në realitetin bashkëkohor, në ofrimin e banimit të mirëfilltë. ${ }^{34}$

34 U.S. (1991). Department of Housing and Urban Development. 


\section{ARKITEKTURA ORGANIKE - BIOKLIMATIKE}

$\mathrm{N}$ atyra, e bukur dhe shumë frymëzuese. Natyra ka frymëzuar artistë të shumtë me famë botërore, ndër ta: "I lindur më 8 qershor 1867 Frank Lloyd Wright është jo vetëm një nga arkitektët më të mëdhenj në botë, por ai ishte edhe më produktivi dhe më frymëzuesi. Ishte shkrimtar, koleksionist arti, filozof, vizionar dhe të gjitha këto të frymëzuara nga qasja e tij për arkitekturën. I njohur ndërkombëtarisht për stilin e tij të objekteve të veçanta frymëzuese. Konceptoi qasje origjinale të përshtatjes së strukturave arkitekonike me natyrën. Kjo përvojë u thellua edhe më shumë me besimin e tij se objektet duhet të mishërohen me lokacionin dhe të përfitojnë nga mikrolokaliteti. Këto qëndrime, avangarde për kohën e tij, edhe sot janë ende të praktikuara dhe të nderuara." $(\text { Ekstrakt })^{35}$ Sipas koncepteve të arkitekturës organike, disa parime si më poshtë:

1. "Arkitekti duhet të jetë një profet ... një profet në kuptimin e vërtetë të termit ... në qoftë se ai nuk mund të shoh të paktën dhjetë vjet përpara nuk duhet quajtur atë një arkitekt."

Frank Lloyd Wright ishte qartazi një njeri përpara kohës së tij. Dizajni i shumë prej shtëpive të tij dukej shumë vite përpara kohës së tyre, po ashtu njerëzit kishin shpesh probleme me të kuptuarit vizionit të tij, por pothuajse të gjithë e ndanin mendimin se idealet e tij ishin të rëndësishme.

2. "Çdo arkitekt i madh është domosdoshmërisht - një poet i madh. Ai duhet të jetë një interpretues i madh origjinal i kohës së tij, koha e tij, mosha e tij..."

Frank Lloyd Wright i pari u bë i njohur për stilin e tij të arkitekturës organike (prairie style) e cila inkorporonte kulmet e ulëta, strehët e mëdha, një oxhak qendror si dhe planet e katit të hapura që ai besonte se ishin një antipod për arkitekturën e mbyllur. Wright është i njohur mirë për Arkitekturën organike, e cila buronte nga burimet natyrore të kombinuara me ndikimin e arkitekturës japoneze. Stili organik pastaj u bë i njohur si koncept kreativ.

3. "Duhet të ketë sa më shumë stile të shtëpive, siç ka lloje të njerëzve dhe sa më shumë diferencime, apo siç ka individë të ndryshëm. Një njeri që ka individualitetin, ka të drejtën e shprehjes së tij dhe të drejtën për mjedisin e tij."

4. "Një ndërtesë duhet të rritet lehtë nga lokacioni i saj dhe të jetë një formë e harmonizuar me rrethinën e saj, ashtu siç është e manifestuar natyra në lokacion."

5. "Asnjë shtëpi nuk duhet të jetë në një kodër apo mbi ndonjë gjë. Ajo duhet të jetë poshtë kodrës. Ti përkas asaj. Kodra dhe shtëpia duhet të jetojnë së bashku të lumtur. "

35 http://freshome.com/2012/09/03/10-great-architectural-lessons-from-frank-lloyd-wright/.2015. 
Askund tjetër nuk është kjo më e dukshme se sa në arkitekturën e tij organike. Veçanërisht këto frymëzime paraqiten në shtëpinë "Fallingwater", ku shtëpia dhe natyra me të vërtetë janë bashkuar për tu bërë Një.

6. " Nëna e artit është arkitektura. Pa një arkitekture të mëvetshme, të tonën, nuk e kemi shpirtin dhe civilizimin tonë. "

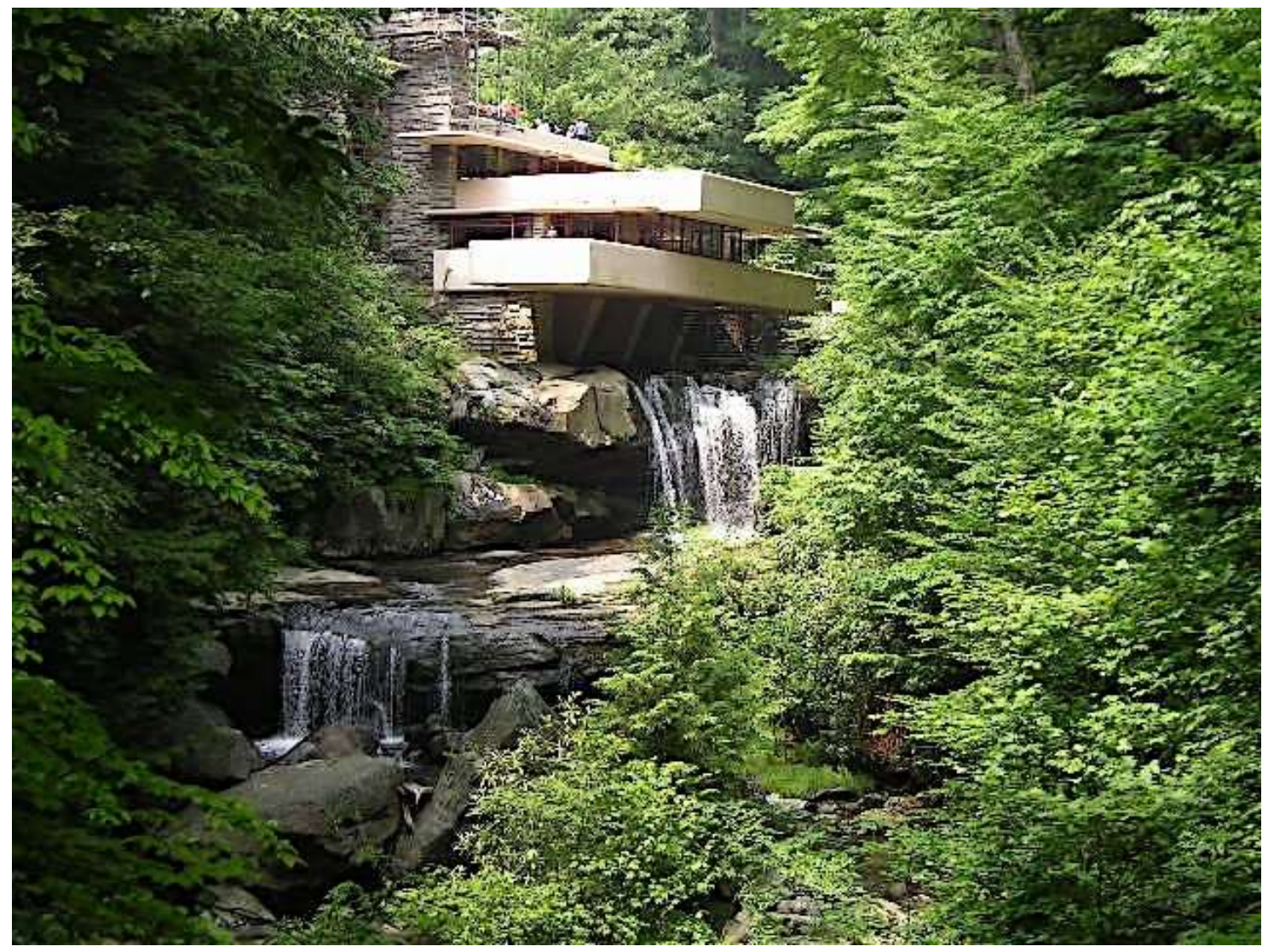

Figura 28. Fallingwater, Frank Lloyd Wright

(Burimi): Chris, Spike55151, 2005. E licensuar nga Creative Commons Attribution ShareAlike 2.0.

Frank Lloyd Wright ka projektuar, ndërtuar sipas vizionit të tij, çfarë do të jetë e ardhmja?

Realisht ai e pa nevojën që shtëpitë të jenë më fluide, më të hapura dhe më të jetueshme.

Parashikoi nevojën për të ndërtuar për lokacionin dhe mjedisin.

8. "Ndërtesa e mirë, kur nuk e atakon peizazhin, por që, e bën peizazhin më të bukur, se sa që ishte para vendosjes së ndërtesës."

9. "Arkitektura është jeta, ose të paktën ajo është vetë jeta duke e marrë formën. " 
Arkitektura është ndoshta dokumentimi më i besueshëm se si një qytetërim ka jetuar dhe evoluar. Arti tregon historinë e një momenti në kohë. Arkitektura tregon historinë e një të kaluare, të tashmen dhe të ardhmen. Kontributi më i rëndësishëm i Frank Lloyd Wright në arkitekturë, në art dhe i shoqërisë, është muzeu Guggenheim në New York City. Në këtë ndërtesë, historia e njerëzimit, e kohës, e artit dhe të arkitekturës, janë të gjitha të bashkuara. Në këtë ndërtesë moderne arti, shkenca, natyra, arkitektura dhe antropologjia bashkekzistojnë në paqe. Një vizionar i vërtetë, Wright ishte një arkitekt i kohës së tij por ishte edhe para kohës së tij. (Ekstrakt) ${ }^{35}$

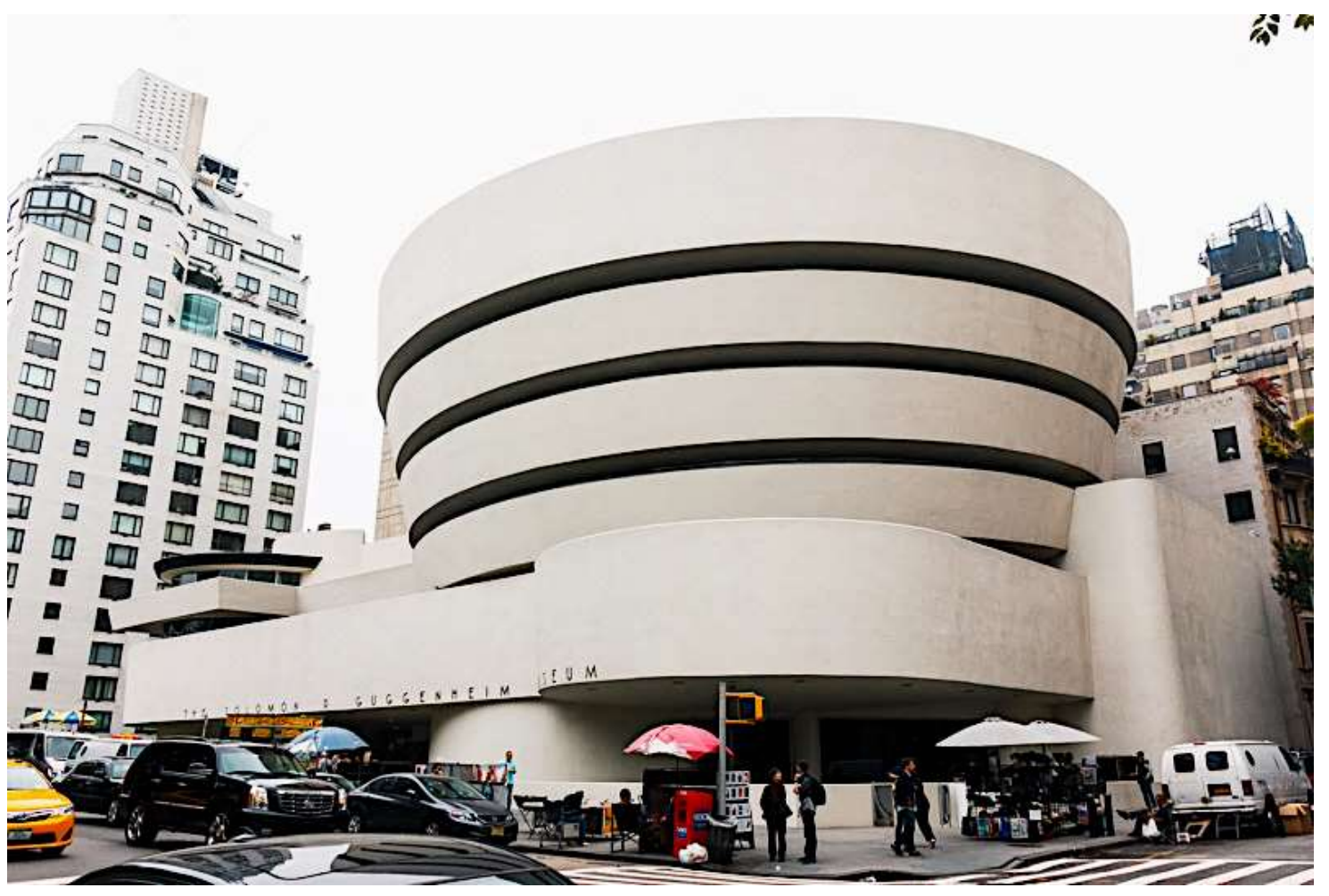

Figura 29. Guggenheim Museum, New York nga Frank Lloyd Wright (Burimi): heipei. E licensuar nga Creative Commons Attribution ShareAlike 2.0

Çfarë do të thotë, në mënyrë të veçantë arkitektura e qëndrueshme, se çfarë mund të bëhet? Projektimi i qëndrueshëm (i gjelbër) mishëron strategji projektuese për të reduktuar impaktin kolektiv negativ në mjedis gjatë gjithë jetës së ndërtesës, nga industria ekstraktive me lëndët e para, projektimi, ndërtimi, mirëmbajtja e gjer te faza e demolimit.

Procesi i ndërtimit të qëndrueshëm vazhdimisht kërkon sensin për të arritur harmoninë ekologjike dhe estetike në mes të objektit dhe mjedisit natyror dhe shoqëror. Estetika në asnjë rrethanë nuk duhet të cenohet nga projektimi i qëndrueshëm. Por, realisht duhet të ketë një simbiozë gjithëpërfshirëse në kontekst të arritjes së kualitetit të jetesës përmes një procesi të mirëfilltë projektues. 


\subsection{Natyra}

\subsubsection{Tumë termitesh}

Që nga gjeneza kemi raste të lashta dhe mrekulli të krijuara nga nevoja, një arkitekturë krijuese, bashkëkohore, në të gjithë shekujt e evoluimit? Kolonitë nëntokësore të milingonave që të gjitha së bashku shtrihen sa muri i madh i Kines, struktura termitesh të cilat në proporcion më madhësinë e tyre janë gati dy herë më të larta se sa Burj Al Arab, Dubai (rrokaqiell i njohur dhe i lartë). Strukturë ndërtuese, tumë me funksione të veçanta organizative, duke involvuar principet bioklimatike projektuese, e projektuar nga arkitektët e "vegjël".

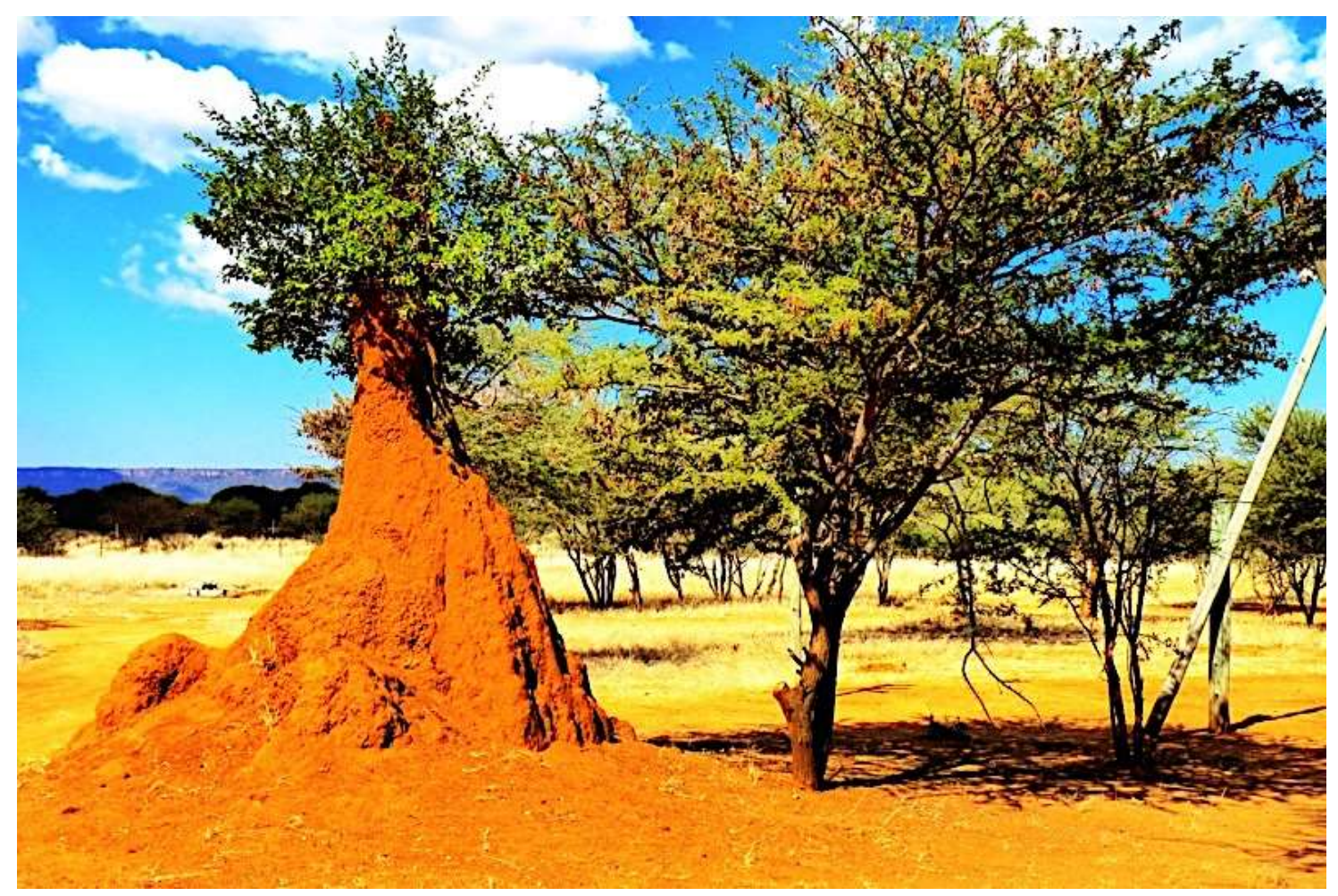

Figura 30. Tumë termitesh, Namibia.

(Burimi): David Siu, 2010. E licensuar nga Creative Commons Attribution ShareAlike 2.0 Generic.

Gjersa disa lloje të termiteve jetojnë në shtëpitë tona, të tjerët ndërtojnë struktura të veçanta dhe shtëpitë e tyre, disa nga strukturat më mbresëlënëse në botën shtazore. Kodrinat (Tumat) janë qytete termitesh të cilat janë përgjithmonë në zhvillim, të bëra nga materialet e thjeshta organike.

Funksionojnë duke punuar në mënyrë të pavarur, pa ndonjë mjet reference, ata mbajnë temperaturën e kontrolluar në mjedis, që përfshinë ventilimin dhe sistemin e ftohjes me dhoma të specializuara për ruajtjen e ushqimit, përmbajnë kopshte fungale, mbajnë vezë 
dhe e kanë pallatin për mbretëreshën. Si koloni, ata janë në gjendje për të krijuar mjedis apo arkitekturë që tejkalon kapacitetet e tyre individuale.

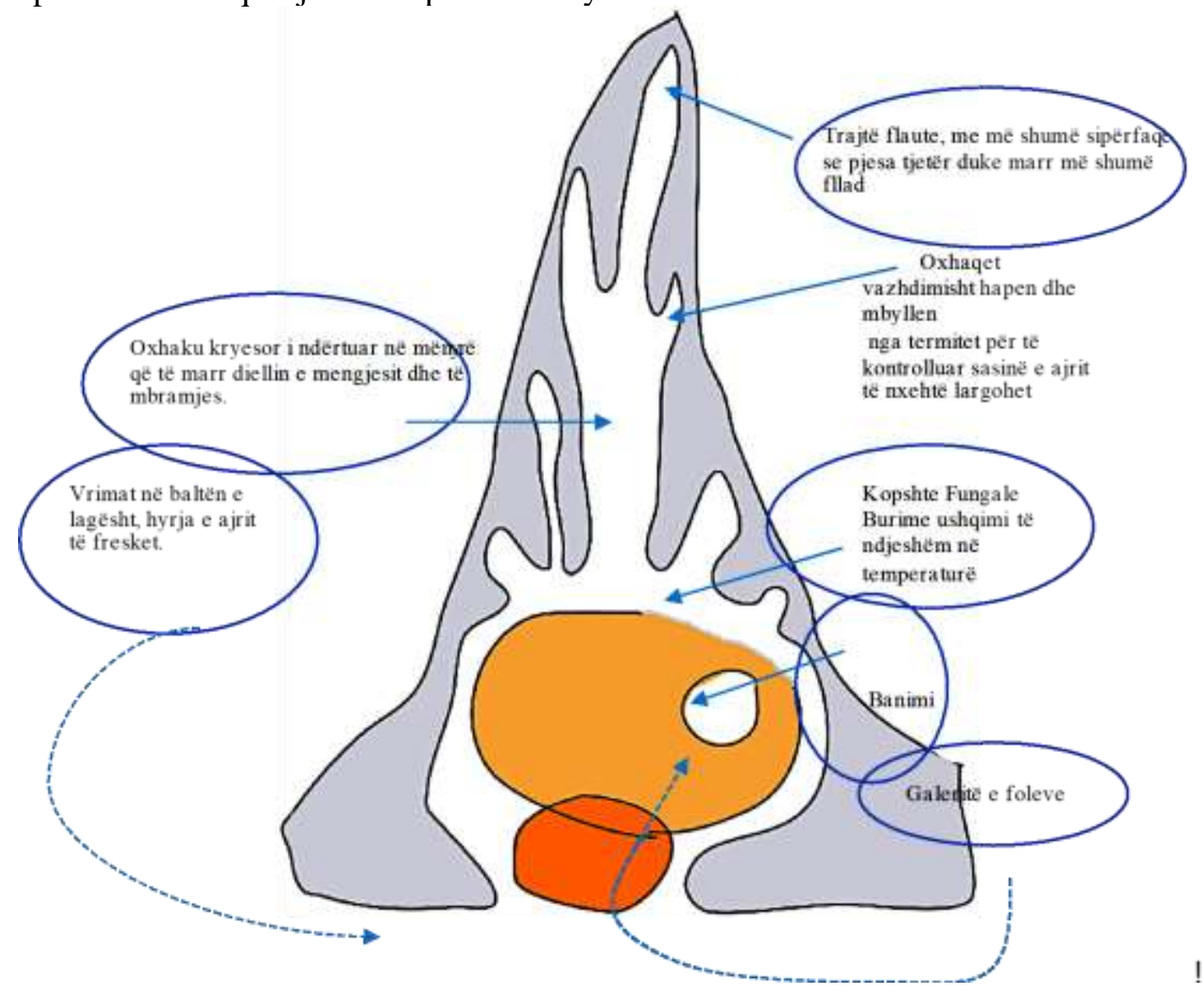

Figura 31. Tumë termitesh. Struktura e brendshme organizative.

(Burimi): Rivizatuar nga Bujar Bajçinovci. 2015. Sipas

http://www.skyscraperdictionary.com/?project=naturescraper

Si koloni në mënyrë organizative, krijojnë struktura magjepse organike, duke veçuar:

1. Tuma është e ndërtuar nga një përzierje e tokës, sekreteve të termiteve dhe fekaleve. Megjithëse tuma duket solide, struktura është tepër poroze. Muret e saj janë të mbushura me vrima të vogla që lejojnë lëvizjen e ajrit jashtë, ky qarkullim apo ventilim e përshkon të gjithë strukturën.

2. Kreu i tumës përbëhet nga një oxhak qendror i rrethuar nga një rrjet i ndërlikuar të tuneleve dhe pasazheve. Ajri qarkullon nëpër muret poroze në seri të tuneleve të vogla deri sa ta arrijë oxhakun qendror në maje. Kur ajri i freskët futet brenda në strukturë i nënshtrohet parimit të lëvizjes fizike, dallimi në temperaturë dhe shtypje e bën të mundshme qarkullin e ajrit. Ky sistem ventilimi vazhdimisht e qarkullon ajrin dhe e siguron oksigjenin që të arrijë në zonat më të sigurta të tumës, aty ku mbahen folët, duke u siguruar që të mos mbinxehen.

3. Termitet nuk jetojnë të gjithë në tumë, por e kalojnë shumicën e kohës së tyre në një fole të vendosur në tokë, ose nën nivelin e tokës. Struktura është e përbërë nga galeritë e shumta të ndara me mure të holla. Milingonat (punëtore) janë 
vazhdimisht të angazhuar në riparimin e pjesëve që kërkojnë mirëmbajtje, po ashtu duke shtuar tunele të reja dhe korridore në fole.

Një qytet termitesh kërkon një sasi të madhe ushqimi, grumbull materialesh organike në dhomat e magazinimit, burim primar i insekteve për ushqim. Termitet gjithashtu kultivojnë kopshte fungale, të vendosura brenda zonës kryesore të foleve. Termitet konsumojnë materiet ushqyese nga kërpudhat të cilat i nxjerrin nga druri që ata $\mathrm{i}$ konsumojnë. Mbajtja e kopshteve fungale, të cilët termitet e mbajnë në kontrollin e saktë të temperaturës, arkitektura organike e strukturës së tumës e mban temperaturën pothuajse konstante.

"Mbretëresha dhe Mbreti" banojnë në suitën (dhomën) mbretërore! Qëllimi i vetëm është që mbretëresha të prodhojë koloni termitesh të reja, të cilët ndihmojnë ndërtimin dhe mbrojtjen e foleve. Për më tepër, mbretëresha mund të prodhojë mijëra vezë në ditë dhe të jetojnë deri në 45 vjet, gjatë së cilës kohë ajo do të rritet deri në pikën ku ajo është në gjendje të lëvizë. Punëtorët mbajnë vezët e saj në një çerdhe të veçantë ku ata ushqehen me një përzierje substrati deri sa të bëhën të rritur. (Ekstrakt) ${ }^{36}$

4. Në tumë ekzistojnë disa hapje që termitet përdorin për të hyrë dhe për të dalë nga foleja. Termitet bëjë lëvizje jashtë tumës për të mbledhur ushqimin gjatë natës, kur temperaturat janë më freskuese.

5. Në distancë të theksuar nën nivelin e tokës është bodrumi, kjo është edhe pjesa më e ftohët e strukturës. Pjesa e sipërme apo plafoni i saj përbëhet nga një seri shtresash që akumulojnë lagështinë për kolonitë e mësipërme, një mekanizëm efikas dhe origjinal i ftohjes. Pasi të avullojë lagështira, temperatura bie, andaj edhe kemi ftohje të ajrit rreth folesë. ${ }^{36}$

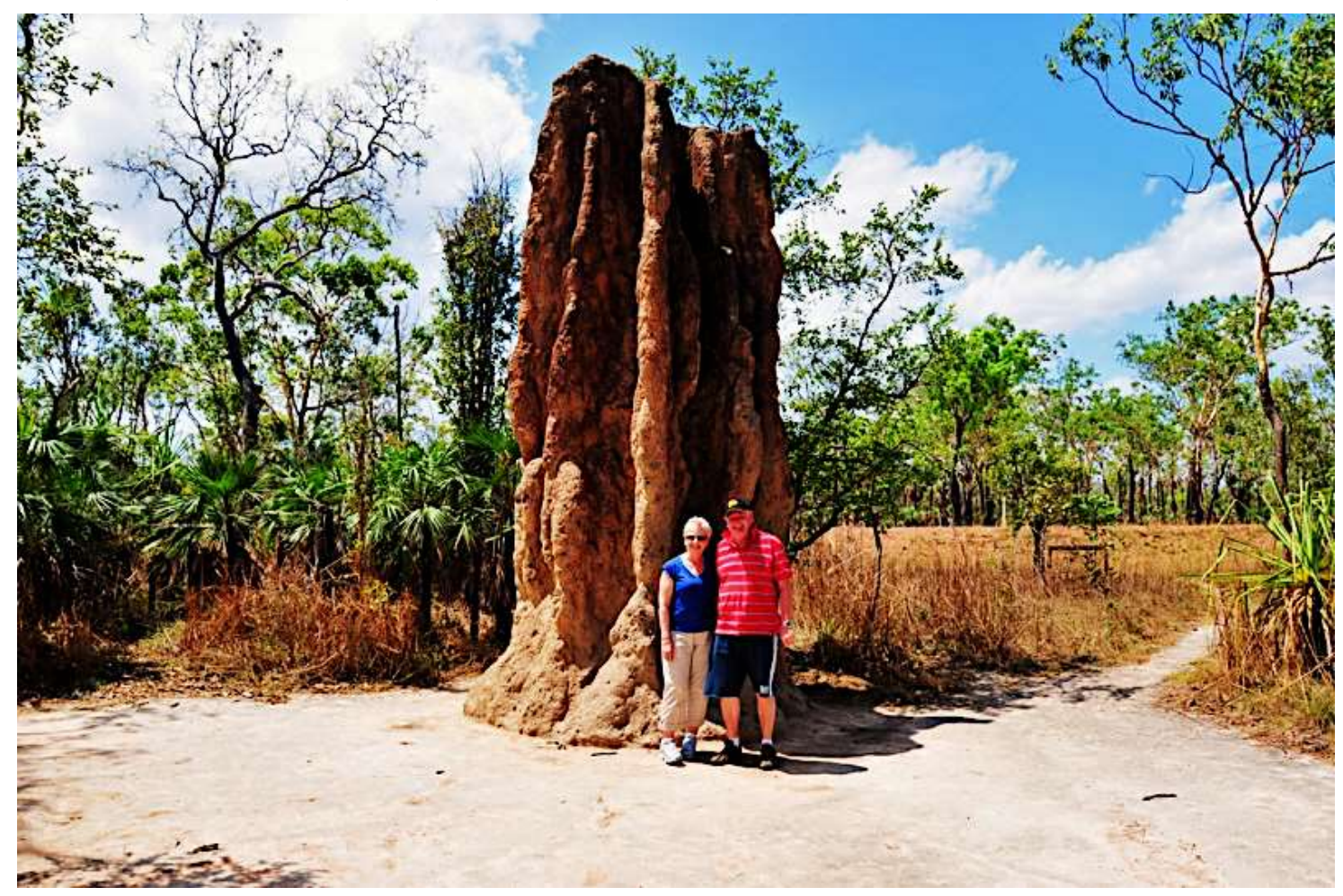

36 http://www.pbs.org/wnet/nature/the-animal-house-the-incredible-termite-mound/7222/. /2015. 
Figura 32. Dy të moshuar afër një Tumë termitesh. Northern Territory, Australia. (Burimi): thinboyfatter, 2010. E licensuar nga Creative Commons Attribution ShareAlike 3.0.

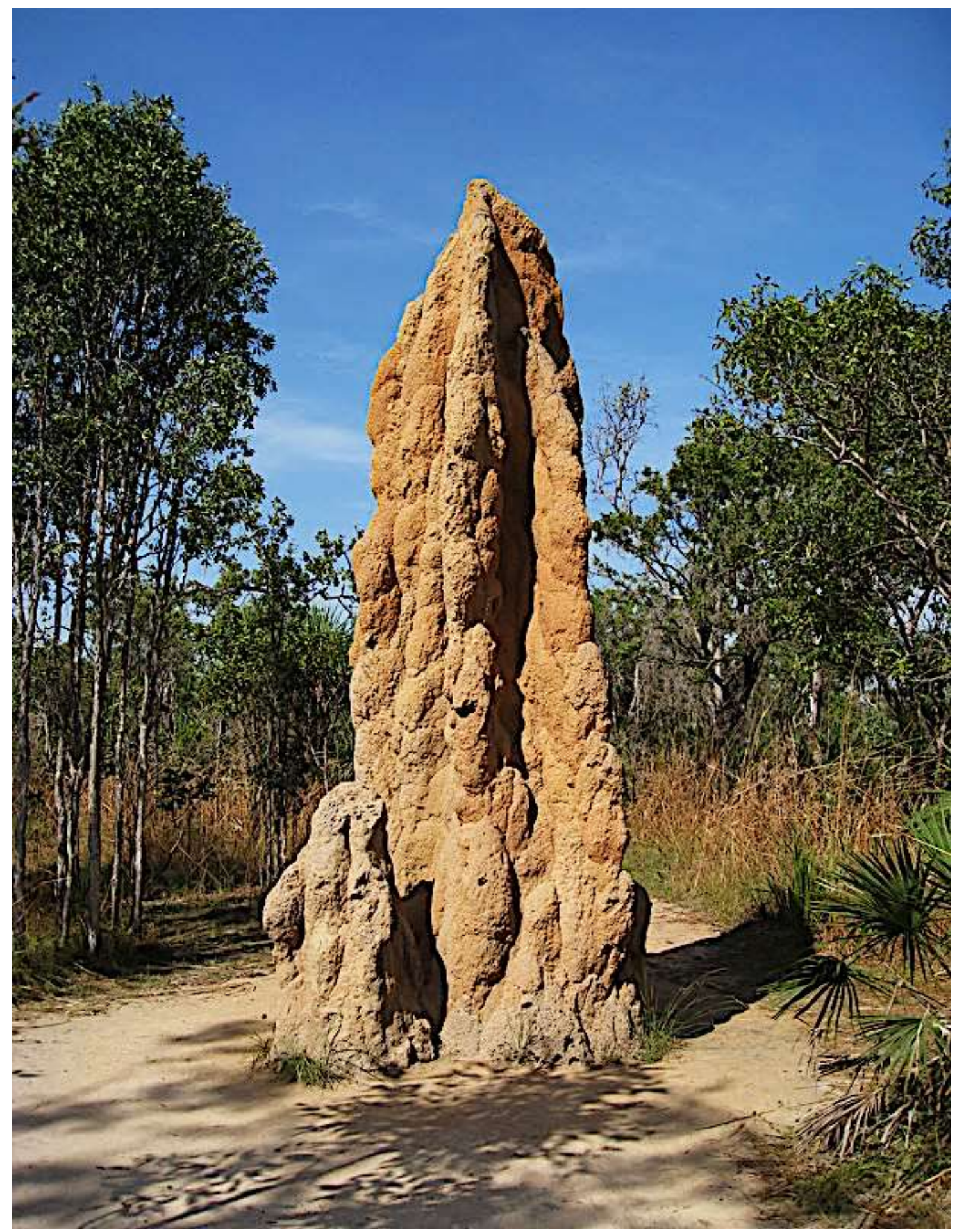

Figura 33. Tumë termitesh. Struktura funksionale.

(Burimi): J. Brew.2009. E licensuar nga Creative Commons Attribution ShareAlike 3.0 


\subsubsection{Cappadocia}

Cappadocia, e përfshirë në Trashëgiminë Kulturore të UNESCO në vitin 1985, si "Goreme Parku Kombëtar dhe i Kapadokisë", është një nga shembujt më origjinale të harmonisë në mes natyrës dhe vendbanimeve njerëzore. Me strukturat e saj interesante gjeologjike, si dhe vendbanimet e saj të gdhendura - të thelluara në shkëmbinj, kishat e saj, kanalet nëntokësore, Cappadocia është një nga ato vende të rralla në tokë që janë me dy fenomene siq janë veçoritë: ajo natyrore dhe qendra kulturore.

Komunitetet që kanë jetuar dhe ende jetojnë në Cappadocia, paraqesin një nga qytetërimet e shumta gjatë gjithë historisë, me ngjarje të rëndësishme në historiografinë e Anatolisë. Mjedis i cili është bërë plotësisht i integruar me natyrën dhe historinë, duke e ruajtur jetesën e tyre me të gjitha vështirësitë që rrjedhin nga mos diellosja, era, moti dhe mjedisi i hapur natyror. Banorët e parë të Cappadocia ishin gjahtarë. Në veçoritë e motit të ashpër, kushtet dhe rreziqet e shumta të natyrës, ata kërkuan strehim në hapësirën e afërta të mbyllura, duke i dhënë fund jetës nomade, duke u vendosur në shpella si strehimore, të cilat ishin të bollshme në këtë regjion. Struktura gurore që mbulon rajonin e Cappadocia është gdhendur shumë lehtë dhe kjo ishte arsyeja e parë pse njerëzit zgjodhën për tu vendosur këtu. Vendbanimet janë ndërtuar kryesisht në shpatet e pjerrëta të luginave ose brenda strukturave natyrore të cilat ishin gdhendur në shkëmbinj, shembull strehimi dhe në përputhje me mënyrën e jetesës së njerëzve së asaj kohe. ${ }^{37}$

Teknika e gdhendjes së shkëmbinjve ka mbetur e pandryshuar gjatë shekujve, kjo për shkak të klimës së thatë, gjurmët e gdhendjes mbi muret dhe plafonet janë ruajtur sot e kësaj dite. Këto hapësira të gdhendura në shkëmbinjë ishin shumë të përshtatshëm për banim të njeriut, pasi ato nga aspekti i komforit termik, ishin dhe janë të ngrohta gjatë dimrit dhe të ftohtë gjatë verës, arsyeja kryesore pse njerëzit vazhduan të jetojnë në to për shumë shekuj. Strukturat banimore në shkëmbinj ishin poshto të përshtatshme gjithashtu për praktikimin e riteve fetare, ishte një vend ideal adhurimi për murgjit që zgjodhën të tërhiqen këtu si dhe për kolonitë të cilët çuan jetë askete. Si rrjedhojë, u paraqitën vepra të ndryshme arkitektonike, u ndërtuan kisha dhe manastire në mjedis shkëmbor.

Vendbanimet nëntokësore, të cilat përbëjnë një nga tiparet më interesante kulturore të rajonit Cappadocia, janë ndërtuar kryesisht si strehim të përkohshëm, nga gërmimi vertikal në material të butë, në këto lugina dhe shpate. Banorë e zonës përdoren këto hapësira të gdhendura në shkëmbinj për të ruajtur ushqimet, edhe në ditët e sotme agrumet dhe frutat ruhen dhe deponohen në këto trajta natyrore. (Ekstrakt) ${ }^{37}$

\subsubsection{Vendbanimet nëntokësore të Cappadocia}

Shumë vendbanime nëntokësore të madhësive të ndryshme gjenden në Cappadocia, të cilat përbëjnë disa nga vendbanimet më interesante natyrore dhe kulturore të rajonit. Ky

37 Republic of Turkey, Ministry of Culture and Tourism. 2012. Göreme National Park and the Rock Sites of Cappadocia. 
numër nga 150-200, mund në fakt të jetë edhe më i lartë, pasi ka vendbanime të madhësive të ndryshme në të gjitha qytetet dhe fshatrat e Cappadocia.

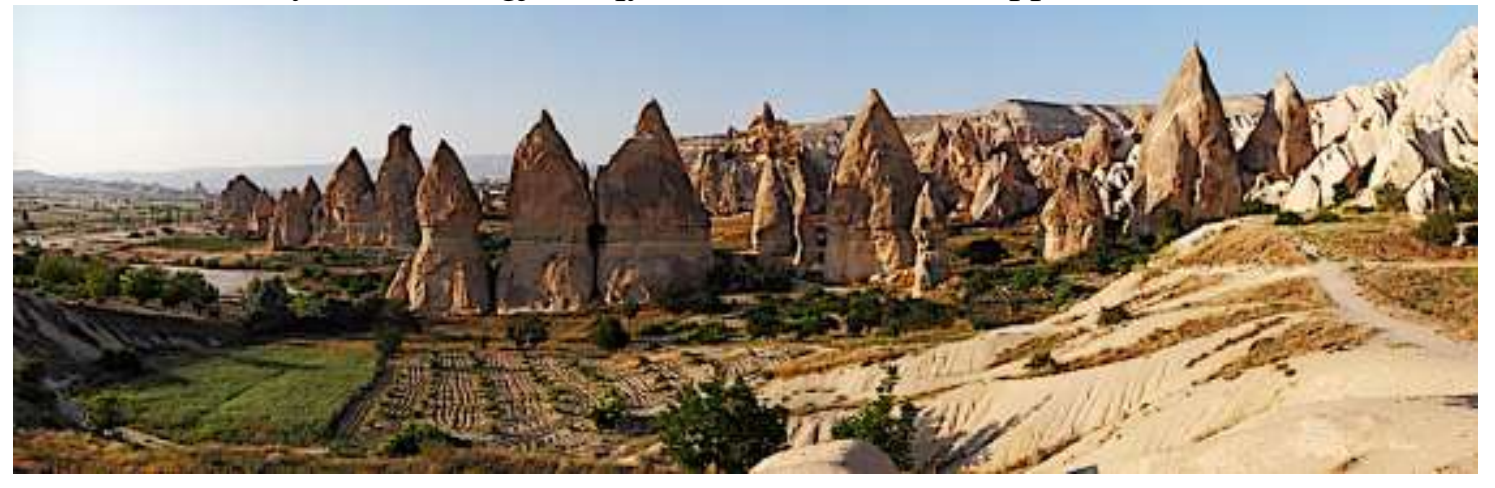

Figura 34. Oxhaqet, formacion shkëmbor, Goreme, Cappadocia, Turqi qendrore. (Burimi): Benh LIEU SON,.2010. E licensuar nga Creative Commons Attribution ShareAlike 3.0 Unported

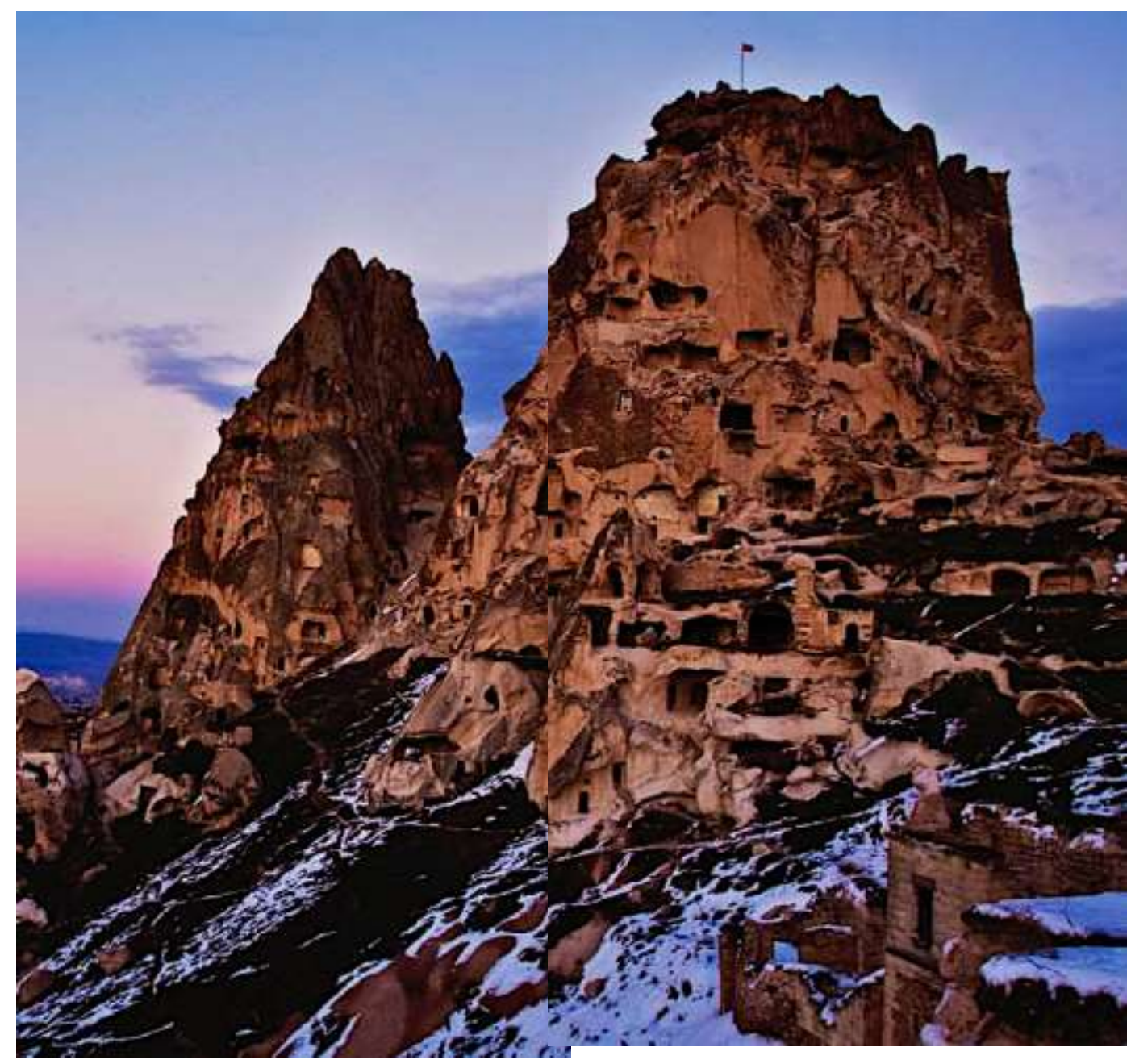

Figura 35. Cappadocia. Foto nga Murat Ertuğrul Gülyaz.

(Burimi): Republika e Turqisë. Cappadocia, Publikim i Ministrisë së kulturës dhe turizmit. 2012.

Nuk dihet shumë në lidhje me ndërtimin dhe teknikat e përdorura, përveç asaj që mund të shifet nga shenjat e lëna nga mjetet për gdhendje. Katet e sipërme të këtyre 
vendbanimeve nëntokësore ishin gdhendur më pak në trajta të rregullta, ndërsa katet e ulëta ishin më të organizuara.

"Ky fakt tregon se këto vendbanime nëntokësore ishin të banuara nga fise të ndryshme. Megjithatë, nuk ka informacione të mjaftueshme mbi numrin e njerëzve që jetonin në këto vendbanime nëntokësore. "Qyteti nëntokësor" është përdorur shumë shpesh edhe prej këtyre vendbanimeve, mund të ketë strehuar deri në tridhjetë mijë njerëz. Rajoni i Cappadocia ishte shpesh objekt i sulmeve, objektivi kryesor prapa ndërtimit të këtyre qyteteve ishte strehimi i përkohshëm për popullatën në kohë e rrezikut.

Këto qytete nëntokësore ishin gjithashtu të lidhura me zona të fshehura të kalimit. Në kërkim të sigurisë nga sulmuesit, banorët e rajonit kishin ngritur kurthe dhe dhoma fshehtë të përgatitura, të vështira për tu gjetur, me gurrë të prerë me diametër $\mathrm{d}=1$ deri 2 m të cilët peshonin rreth $200-500 \mathrm{~kg}$. Ka pasur edhe dyer druri në qytetet nëntokësore që shërbenin për qëllime estetike. Katet më të "vjetra" të qyteteve nëntokësore në përgjithësi ishin hapësirat e hyrjes dhe janë përdorur përgjithësisht si stalla, pasi ka qenë e vështirë për tu marrë kafshët në katet e mëposhtme. Qytetet nëntokësore ishin të ngrohta në dimër. Duke marrë parasysh numrin e kufizuar të kuzhinave që gjenden në qytetet nëntokësore, është e qartë se çdo familje nuk e kishte luksin e kuzhinës së veçantë, por më tepër kuzhinë të përbashkët. Kuzhina përmbante furrat 'tandoori', stil që është ende sot në përdorim në qytetet dhe fshatrat e Cappadocia. Kishte po ashtu disa gjurmë, hapësira të vogla që janë hapur në të gjitha kuzhinat, në mënyrë që të vendosen kavanozat. Këto kavanoza janë përdorur për elb, grurë dhe misër, i cili ende në nivel lokal prodhohet në sasi të mëdha. Po ashtu, kishte edhe vrima vertikale për komunikim, në sajë të këtyre vrimave banorët e qyteteve nëntokësore ishin në gjendje të komunikojnë pa pasur nevojë të ecin nëpër tunele të lodhshme, si dhe për të vepruar shpejt dhe me lehtësi në situata emergjente. Çështja e tualeteve ende nuk është plotësisht e sqaruar. " (Ekstrakt) ${ }^{37}$

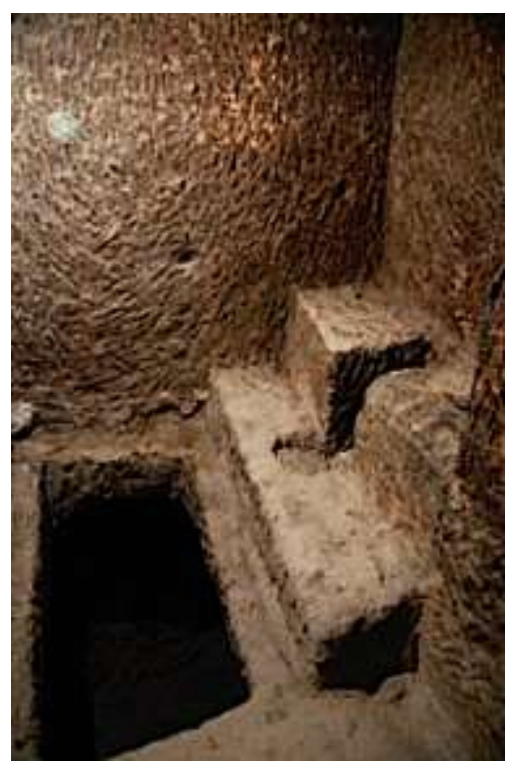

Figura 36. Tualeti. Cappadocia. Fotot nga Murat Ertuğrul Gülyaz. 
(Burimi): Republika e Turqisë. Cappadocia, Publikim i Ministrisë së kulturës dhe turizmit. 2012.

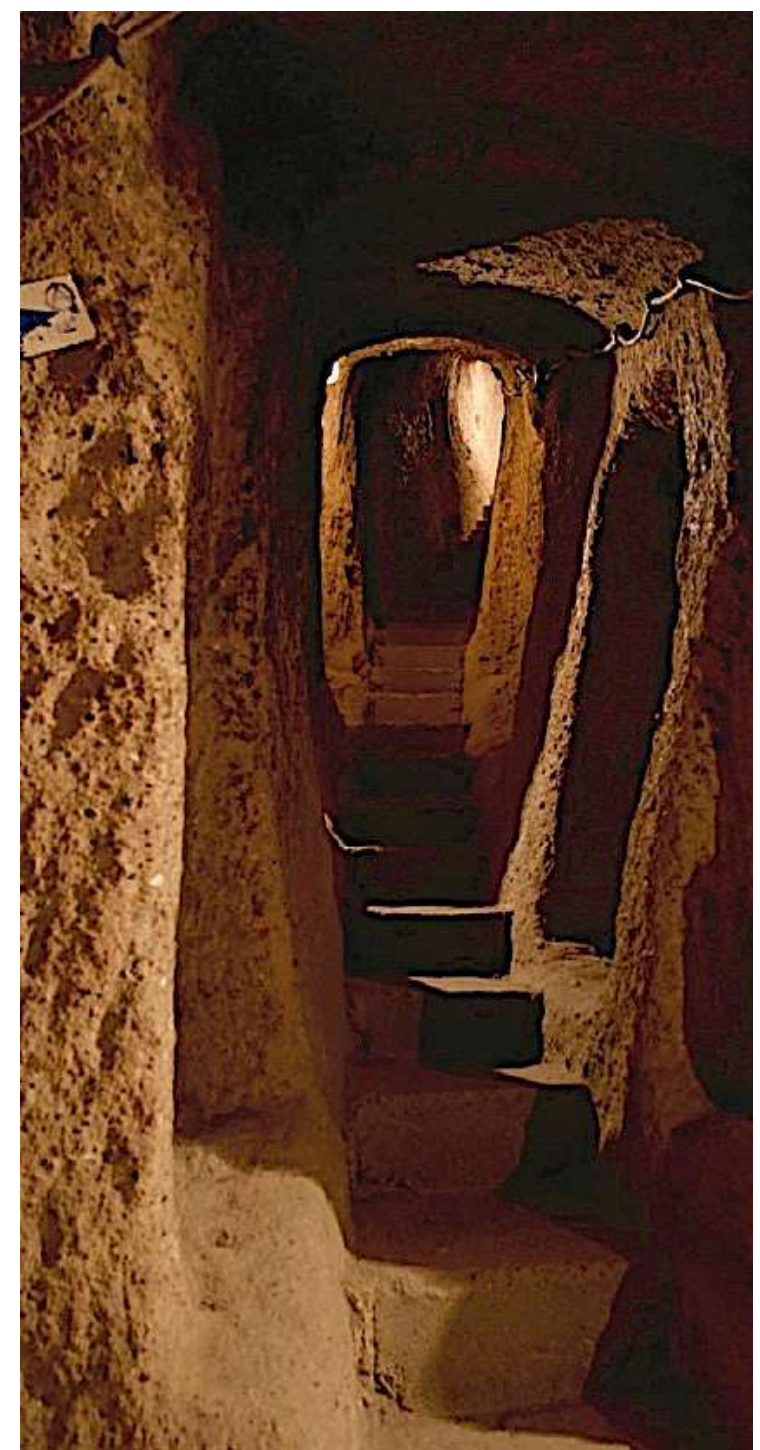

WC janë gjetur vetëm në disa qytetet nëntokësore. Këto tualete kanë trajta jo të zakonshme. Këto vendbanime, të cilat janë përdorur për një kohë të gjatë, përmbanin jo vetëm hapësirat për të jetuar dhe punuar por edhe hapësira varrimi.

Figura 37. Cappadocia, foto nga Murat Ertuğrul Gülyaz. (Burimi): Republika e Turqisë. Cappadocia, Publikim i Ministrisë së kulturës dhe turizmit. 2012.

"Tunelet e ngushta janë përdorur edhe si puse për pije, disa puse nuk lidhen fare me sipërfaqen e tokës, me qëllim për të parandaluar helmimit e ujit nga armiku. Edhe pse disa studiues pohojnë se vendbanimet nëntokësore ishin të lidhura vazhdimisht me njëri tjetrin nëpërmjet tuneleve, gjetjet apo faktet për ta verifikuar këto pohime ende nuk janë zbuluar. Në ditët e sotme popullsia lokale kalon nëpër këto tunele, të cilat i përdorin për të arritur në pjesët e qytetit nëntokësor, me funksion si depo apo stalla. Tunelet janë të ngushta, të ulëta, por dhomat kanë tavanet e larta dhe janë të vendosura kryesisht rreth boshteve të ventilimit. Qyteti nëntokësor ende nuk është pastruar plotësisht dhe vetëm katër etazhe janë zbuluar. Bazuar në numrin e depove që gjenden brenda një zone të vogël, ekziston një probabilitet i lartë që një numër i madh i njerëzve kanë jetuar në këtë qytet nëntokësor. (Ekstrakt) ${ }^{37}$

Derinkuy qyteti nëntokësor, i njohur si "Melagobia" në të kaluarën, është rreth $85 \mathrm{~m}$ në thellësi. Derinkuy ka shumë prej hapësirave që asocojnë në përgjithësi në një qytet nëntokësor të qëndrueshëm, me veçori si: qilar, mensë, kishë dhe një hapësirë për prodhimin e verës së rrushit, shkollë misionare në katin e dytë e cila mbulon një zonë të gjerë, ka një tavan shumë të pazakontë për qytetet nëntokësore, dhe është i mbuluar me një qemer.

Vetëm dhjetë për qind e qyteti nëntokësor i cili u hap në vitin 1965, mund të vizitohet. Edhe pse ka vendbanime që datojnë nga epoka parahistorike në Cappadocia, ende nuk dihet nëse ata kishin ndonjë lidhje me qytetet nëntokësore. Megjithatë, duke pasur parasysh strukturën gjeologjike të rajonit, mund të supozojmë që banorët e epokës parahistorike mund të kenë kërkuar strehim në shkëmbinjtë, të përbërë nga një dhomë e vetme, të gdhendur me mjete primitive të bëra nga xhami vullkanik." (Ekstrakt) ${ }^{37}$ 


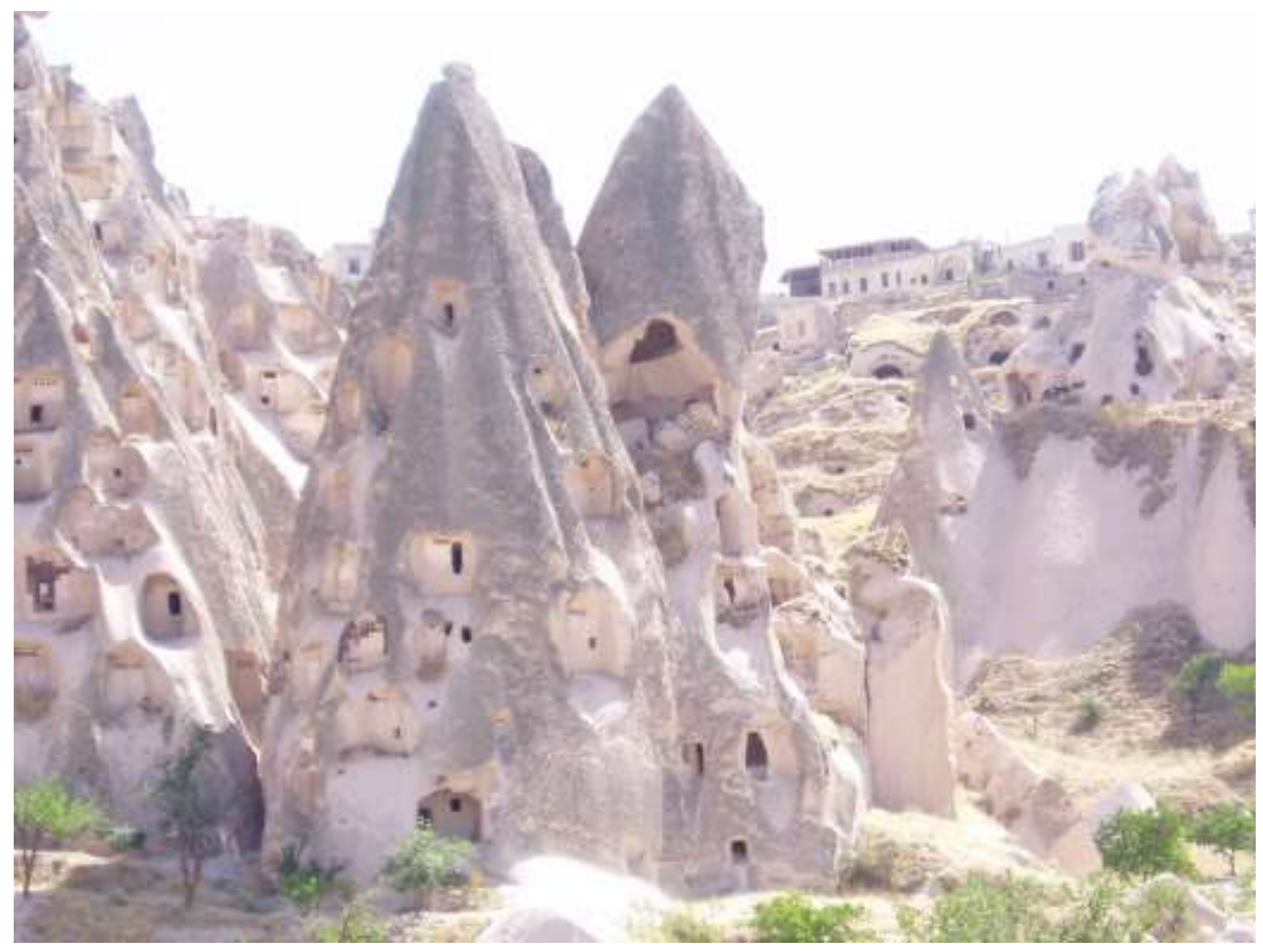

Figura 38. Cappadocia

(Burimi): Reric and Mary Ellen, 2007. (Flickr). E licensuar nga Creative Commons Attribution ShareAlike 2.0 Generic

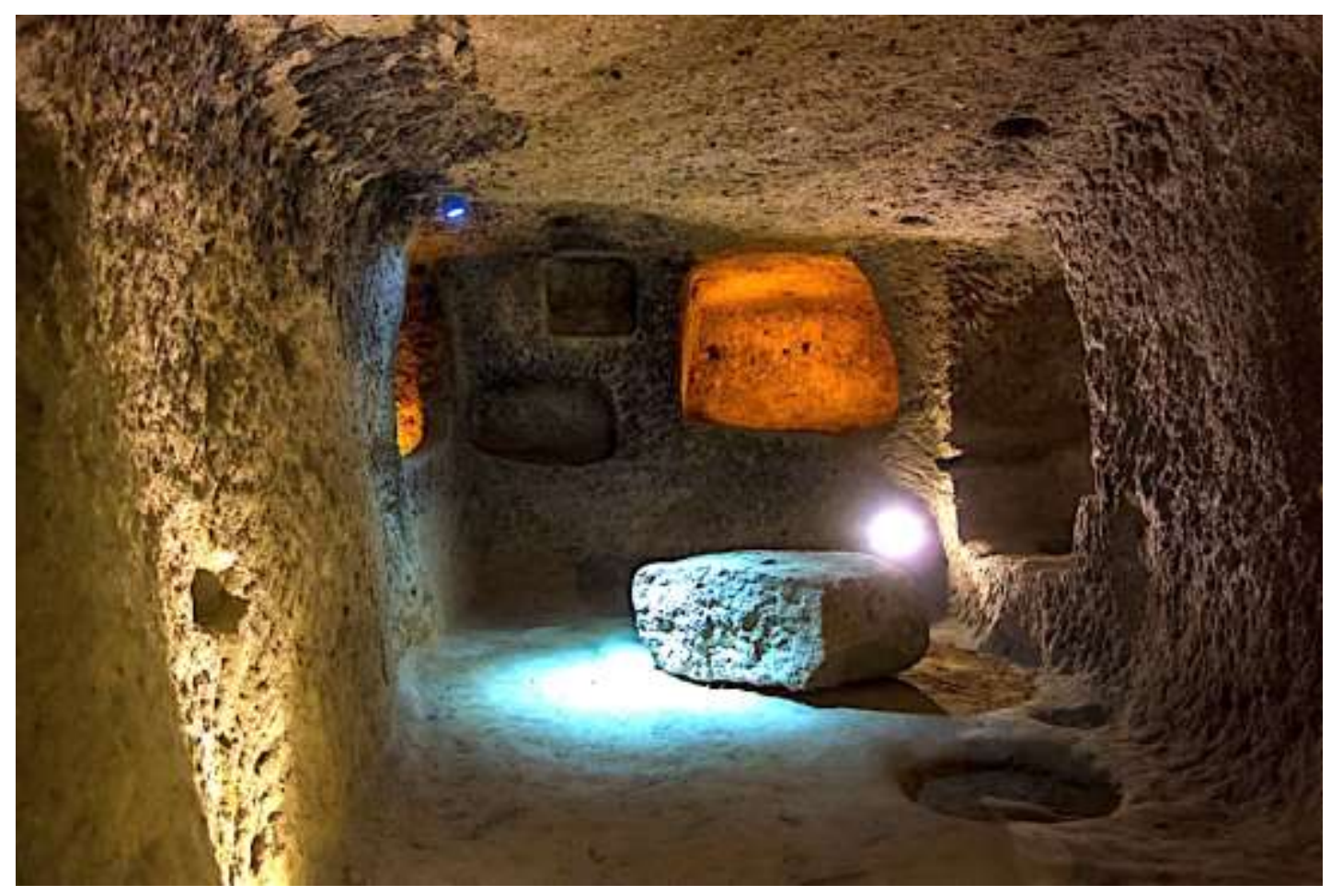

Figura 39. Cappadocia 


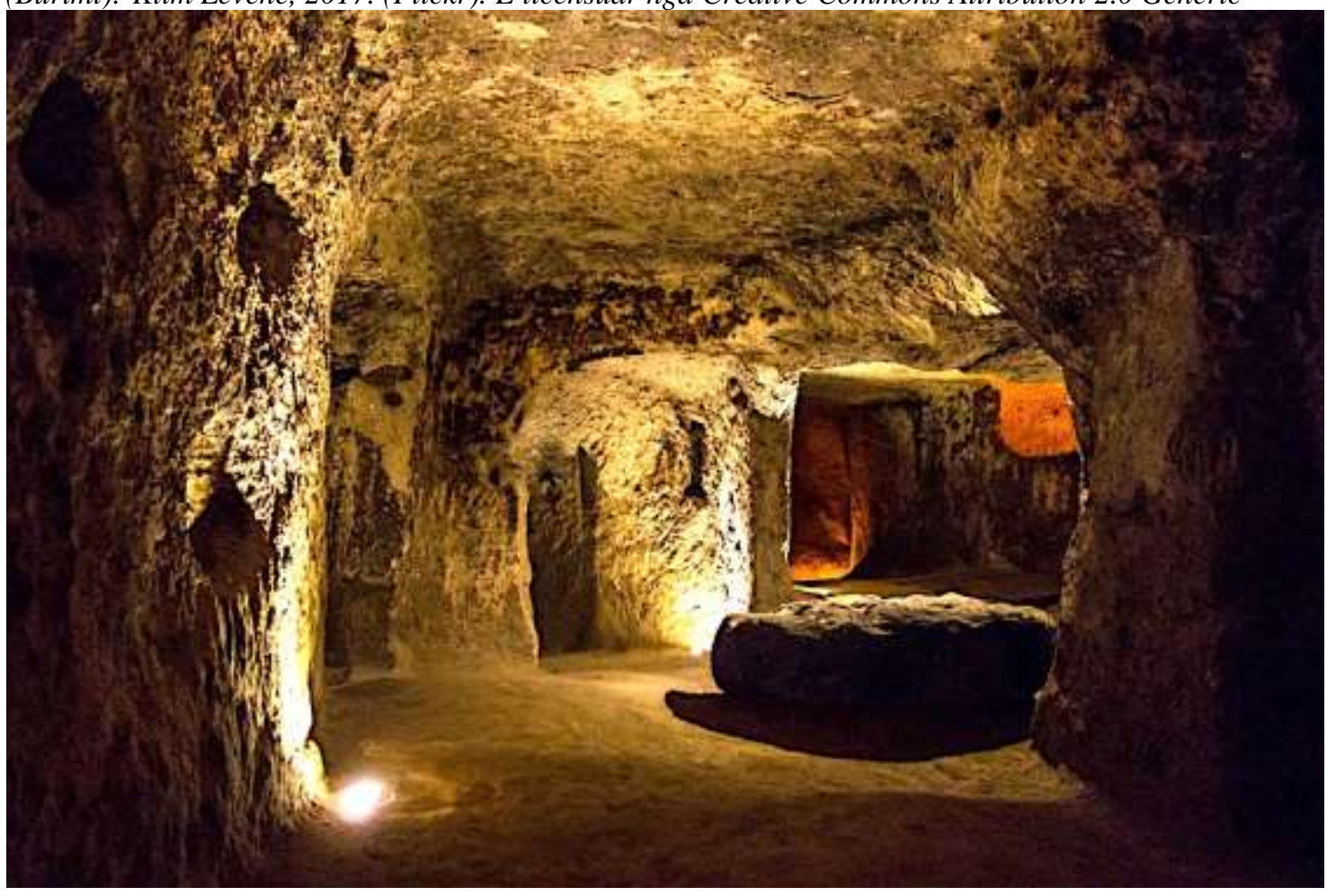

Figura 40. Cappadocia

(Burimi): Klim Levene, 2017. (Flickr). E licensuar nga Creative Commons Attribution 2.0 Generic

"Të gjitha gjetjet që kanë të bëjnë me qytetet nëntokësore datojnë nga shekulli 5-10, të periudhës bizantine. Në këtë kohë ka pasur një rritje të numrit të qyteteve nëntokësore që kanë shërbyer për nevoja religjioze dhe strehimi. Në kohën kur filluan sulmet arabe në shekullin e VII, bashkësitë krishtera që ishin në Cappadocia u tërhiqen për në strehimoret tyre. Të vetëdijshëm për shumë rreziqe që i priste brenda. Sulmuesi atëherë u përpoq për të nxjerrë popullsinë jashtë duke helmuar puset.

Në shekullin e XIX, shtëpitë në Cappadocia ishin ose të gdhendura në shkëmbinj ose të ndërtuara prej guri. I vetmi material arkitektonik në dispozicion në këtë mjedis ishte guri i cili mund të përpunohej, për shkak të origjinës së tij vullkanike ishte i butë kur kishte dalë nga toka, por gjithashtu ishte ngurtësuar shumë shpejt pas ardhjes në kontakt me ajrin. Për shkak të bollëkut me gurë të tillë dhe fakti se mund të punohej lehtë, ky lloj guri ishte unik për këtë rajon, duke u zhvilluar në një traditë bioklimatike arkitektonike. Në oborre dhe në shtëpi dyert ishin përgjithësisht të bëra nga druri. (Ekstrakt) ${ }^{37}$

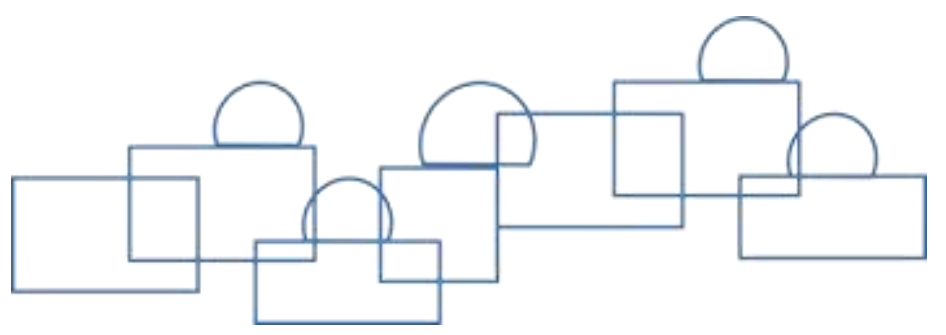




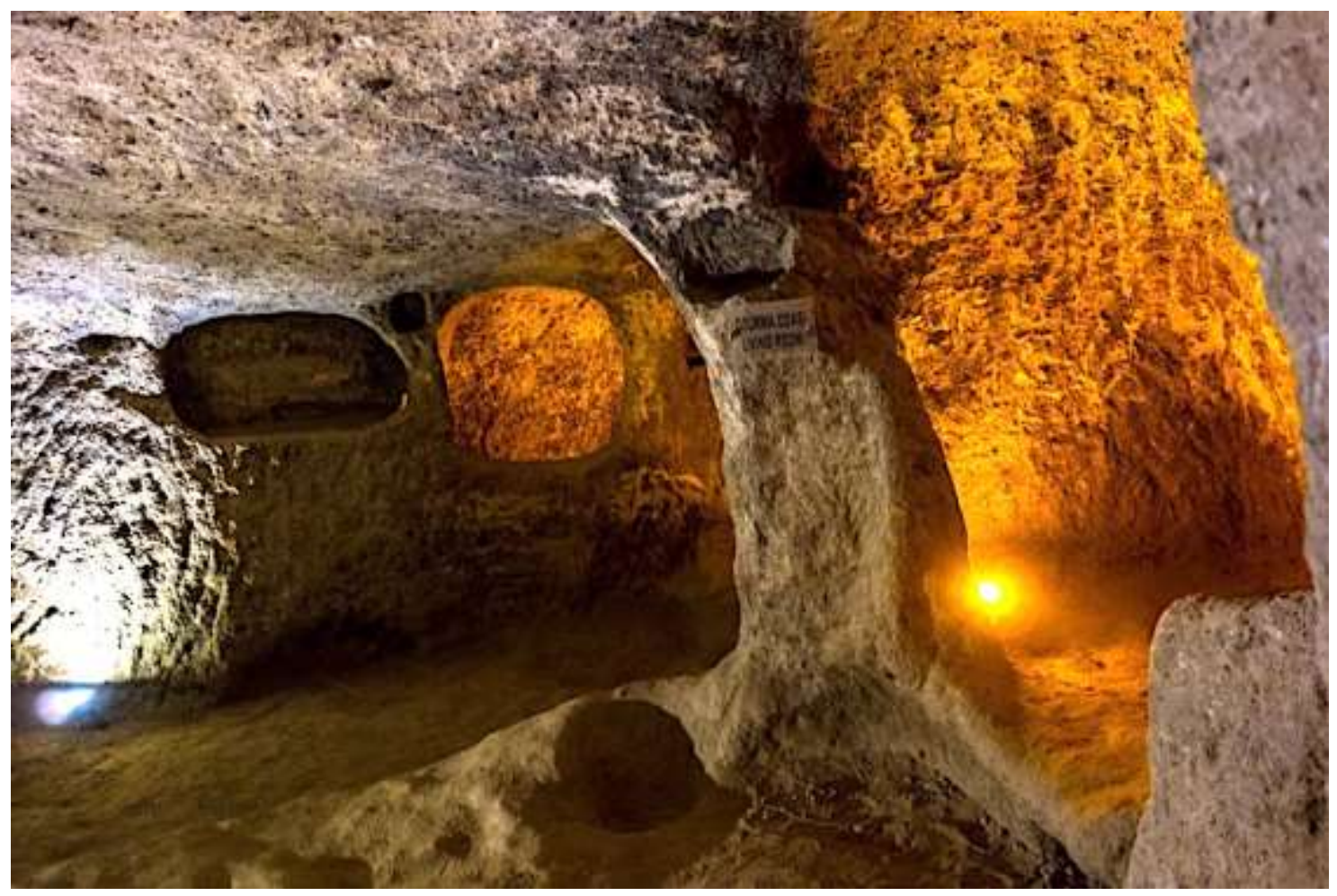

Figura 41. Cappadocia

(Burimi): Klim Levene, 2017. (Flickr). E licensuar nga Creative Commons Attribution 2.0 Generic

Andaj, të krijuarit e tumave është kushtëzuar drejtpërsëdrejti nga ligjshmëritë bionike të natyrës, të cilat ligjshmëri janë shprehur në krijimin e strukturave të tumave pa vetëdije, por me instinkt të milingonave. Të cilin instinkt, s'do mend se, e kanë zhvilluar pas një evoluimi për një periudhë shumë të gjatë kohore.

Gjithësesi, në kontekst të krijimit të strukturave të tumave të termiteve dhe strukturave kodrinore prej shkëmbi të Cappadocias, në të cilat u thelluan hapësirat për strehim me karakter shumë funksional praqet një analogji të pavetëdijshme. ( Doli, Flamur. 2016).

Pamvarsisht nga distanca kohore, hapësinore dhe konteksti i specieve, gjejmë një analogji në të krijuarit e arkitekturës organike në të dy rastet studimore, si pasojë e mbijetesës dhe e sigurisë.

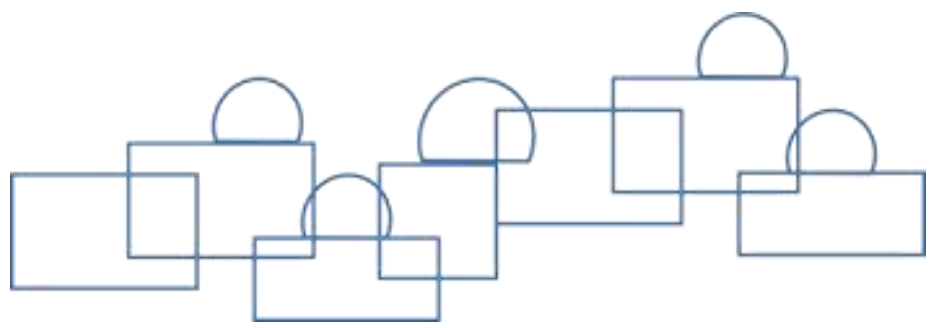




\subsubsection{Santorini}

Vendbanim i vjetër, Santorini daton nga Mileniumi i II p.e.s., ky qytet dhe port në atë kohë ishte në prosperitet në bregun lindor të ishullit Akrotiri. Sot, rrënojat janë në një gjendje shumë të mirë që dëshmojnë ekzistencën e shtëpive në kat apo në etazhe, të mbuluara me çati të thjeshtë që është përdorur si tarracë. Shtëpitë janë ndërtuar me gurë vullkanik dhe gurë të lehtë, ndërsa janë përforcuar me dru, një nivel i lartë ndërtimi në atë kohë. Shtëpitë janë të zbukuruara me afreska mbresëlënëse. Gjatë periudhës bizantine, deri në shekullin e XIII, Santorini ishte i banuar vetëm në kodrinë, në veri të malit Inner. Fillimi i përdorimit të qemerëve në mënyrë për të zgjeruar madhësinë e shtëpisë, u bë më se e pranueshme nga komuniteti, rrënojat të cilat dëshmojnë për më se 19 shtëpi, të cilat janë gërmuar, tregojnë se qemeri i mbështetur në korniza druri mbi të cilat $\mathrm{u}$ formuan kulmet e thjeshta ishte i pranishëm dhe $\mathrm{u}$ bë standard.

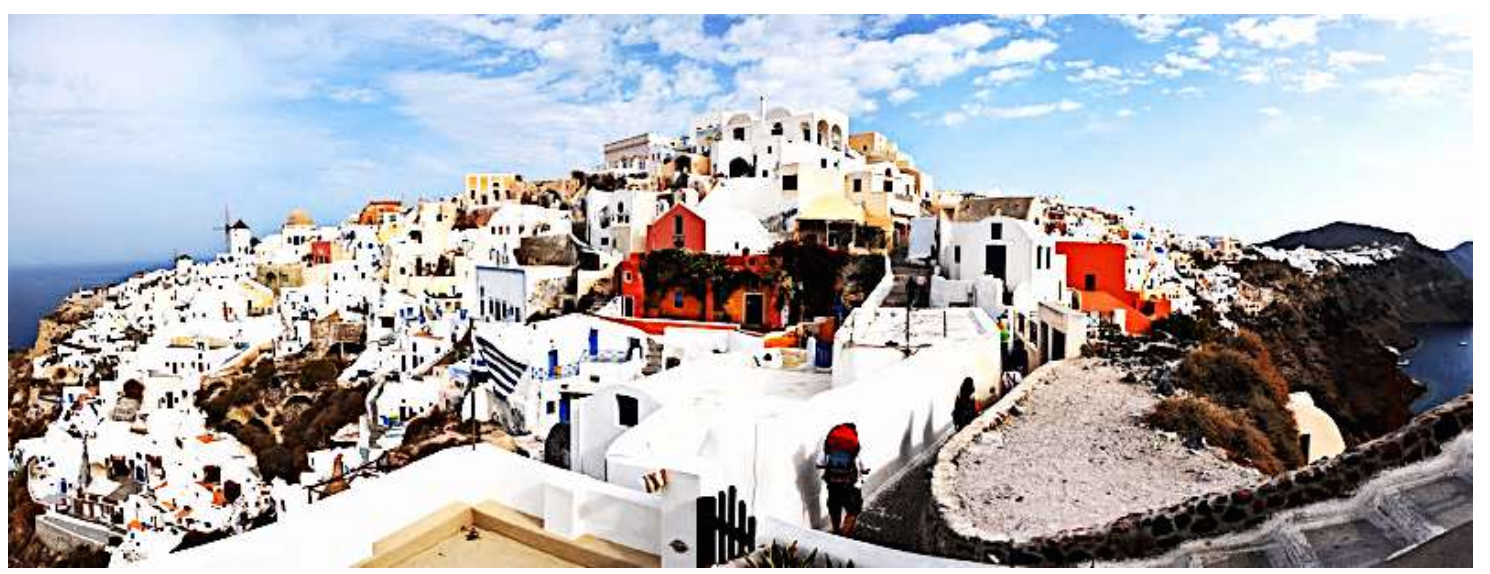

Figura 42. Santorini. Greqi. Struktura urbane.

(Burimi): Mstyslav Chernov, 2008. (Flickr). E licensuar nga Commons Attribution ShareAlike 3.0 Unported

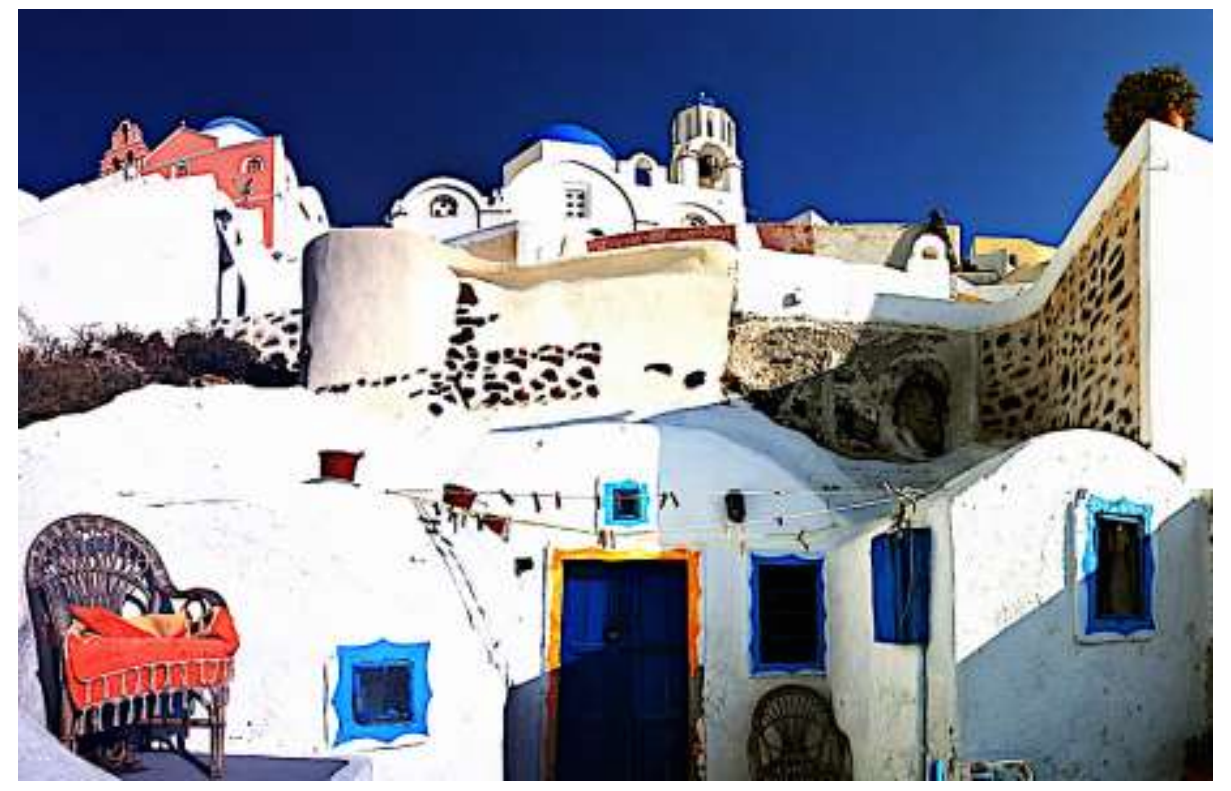

Figura 43. Santorini. Greqi. Struktura urbane.

(Burimi): Mstyslav Chernov, 2008. E licensuar nga Commons Attribution ShareAlike 3.0 Unported 


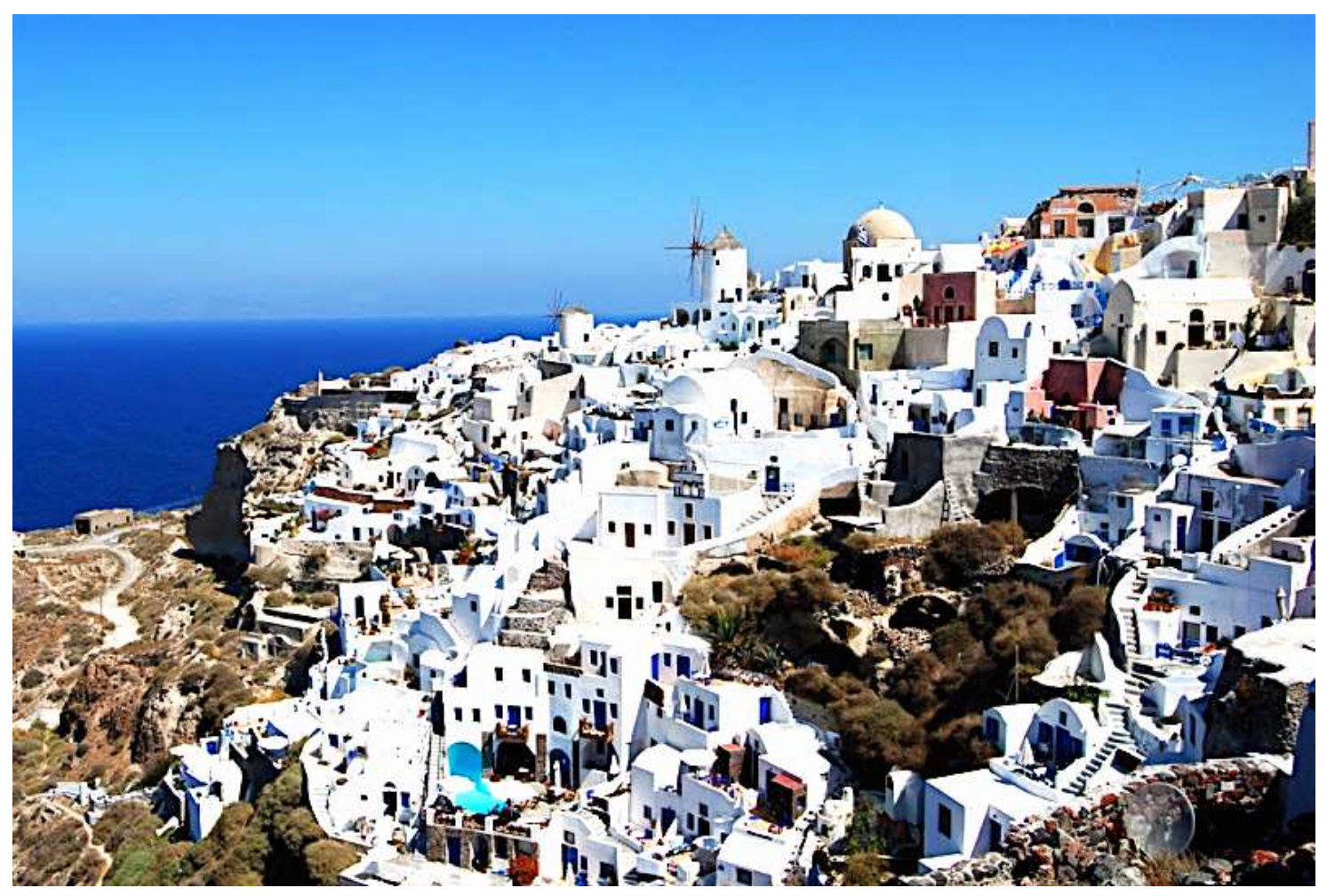

Figura 44. Santorini. Greqi. Struktura urbane.

(Burimi): Harvey Barrison, 2009. (Flickr). E licensuar nga Creative Commons Attribution ShareAlike 3.0 Unported

Santorini, ujdhese me klimë mesdhetare me shumë diell, me të reshura të pakta. Po ashtu rajoni i cekur mesdhetar karakterizohet me erëra të konsiderueshme të cilat vazhdimisht fryjnë nga veriu. Realisht Santorini ka dimër të butë, potencohen masivet e ujdhesës nga vie lagështia, duke krijuar ambient të mrekullueshëm bregdetar.

Në kontekst të konceptit urban, evolutiv, Santorini karakterizohet me strukturë urbane tipike mesdhetare, por me premisa dhe veçori autoktone. Rrugët e ngushta, shtëpi të vogla me densitet të lartë, si pasojë e mungesës së tokës për ndërtim me veçori normale për jetesë. Ky koncept urban konsiston në faktin e mbrojtjes së ndërsjellë, nga dielli dhe erërat dominante, nga siguria kolektive dhe ekonomizimi i ndërtimit, më i lirë.

Si karakteristika të veçanta arkitektonike mundë të veçohet se objektet kryesisht janë me mure të trasha, vëllime masive, hapje të vogla. Të gjitha këto njësi banimi të përsëritura apo duke u përcjellë nga një ritëm i caktuar urbano arkitektonik. Trajtat organike të shprehura në strukturën urbane të cilat formojnë reliefë të bukura vizuale. Të gjitha ndërtimet veçohen me përdorimin e materialeve lokale të ndërtimit duke respektuar në mënyrë rigoroze mjedisin, me premisa të projektimit bioklimatik.

Natyrisht, kemi të bëjmë me një qasje të veçantë të adaptimit apo më mirë të thuhet një simbiozë e shkëlqyer e nevojave njerëzore me veçoritë mjedisore dhe klimës, një harmoni e lidhur me respekt të duhur, në mes natyrës dhe njeriut. 


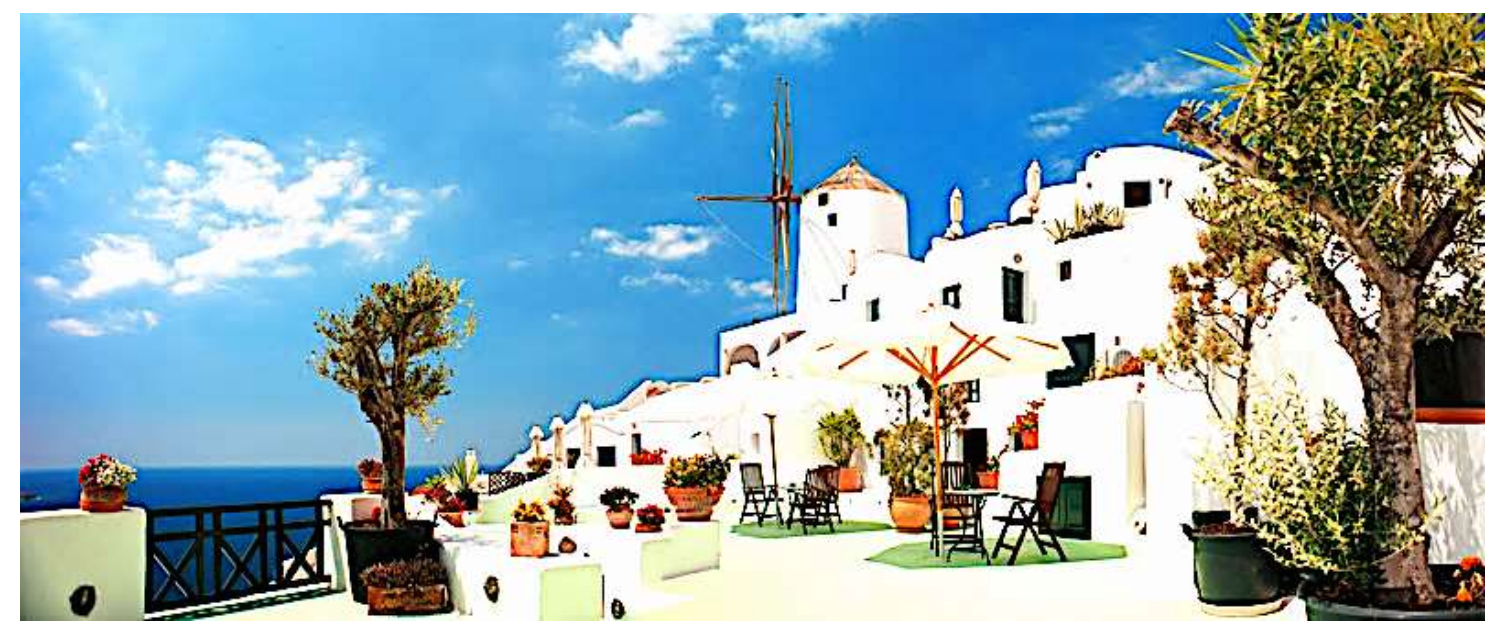

Figura 45. Santorini. Greqi. Struktura urbane.

(Burimi): Mstyslav Chernov, 2011. (Flickr). E licensuar nga Commons Attribution ShareAlike 3.0 Unported

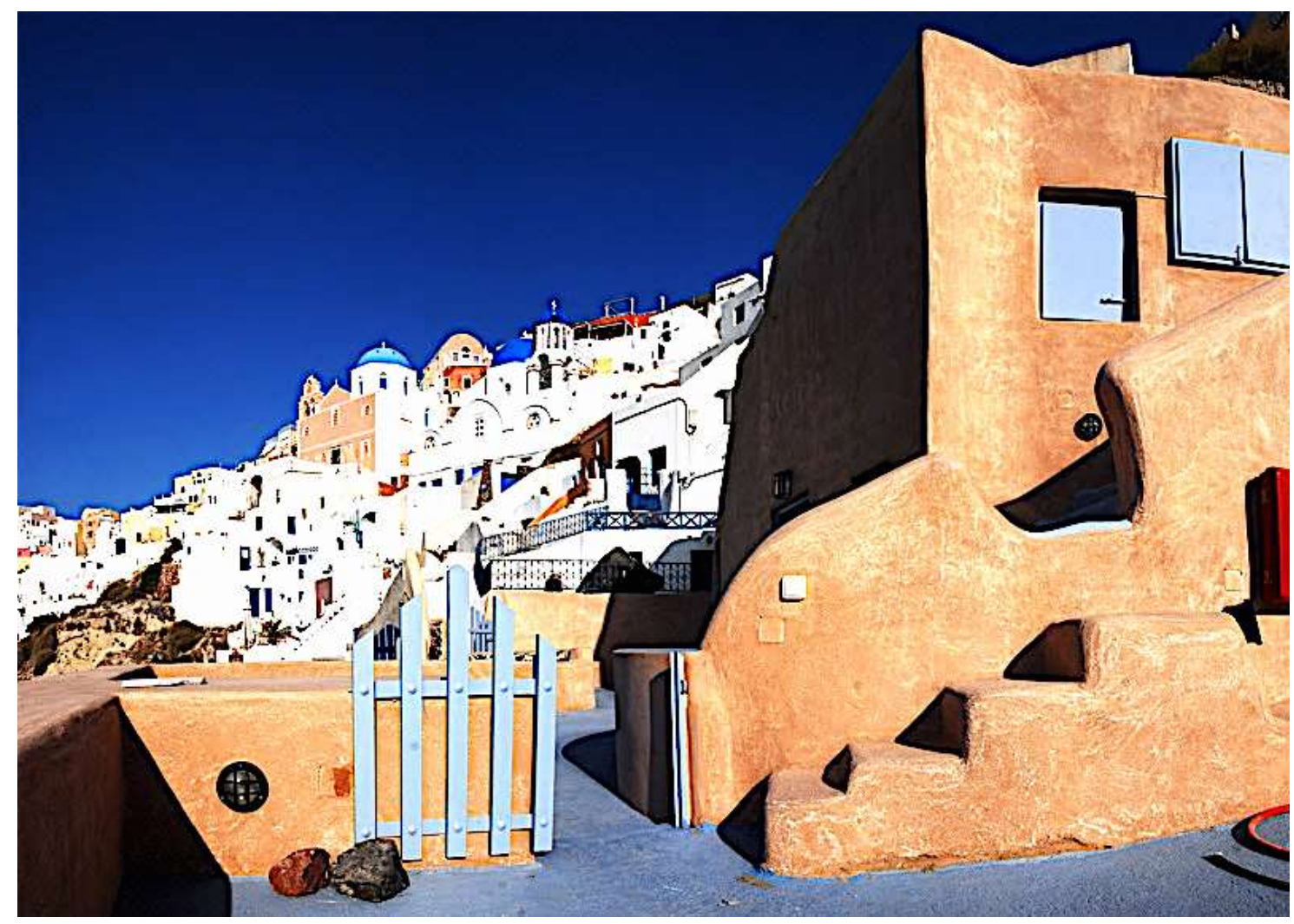

Figura 46. Santorini. Greqi. Struktura urbane.

(Burimi): Mstyslav Chernov, 2009. (Flickr). E licensuar nga Commons Attribution ShareAlike 3.0 Unported 


\subsubsection{Ulqini}

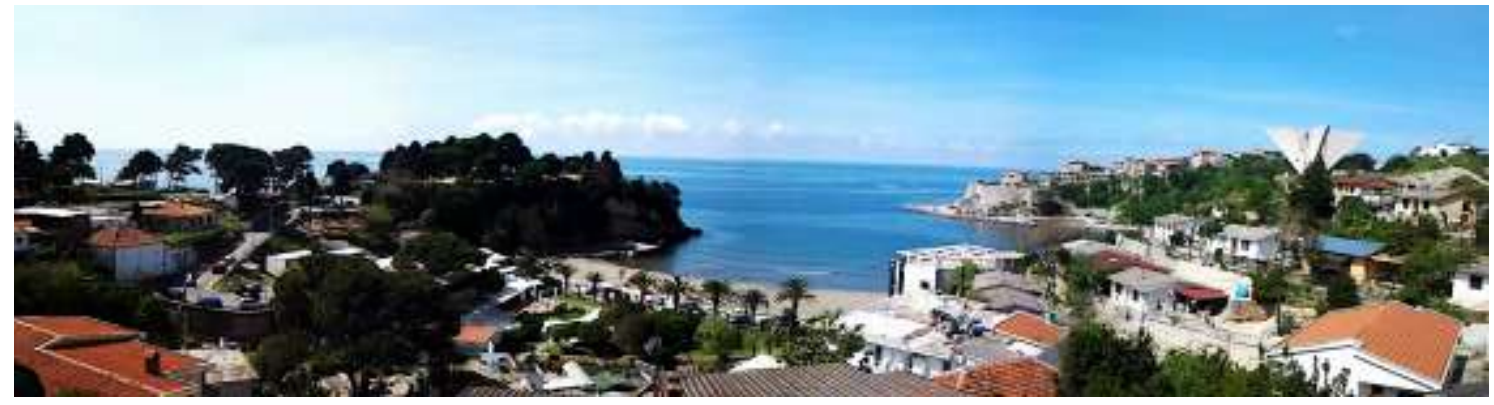

Figura 47. Ulqini peisazh, struktura urbane (Burimi): Bujar Bajçinovci, 2014

Mendohet se Ulqini është një nga qytetet më të vjetra në bregdetin e Adriatikut. Ulqini është themeluar rreth shekullit V p.e.s. nga Ilirët, ndërsa në vitin 163 p.e.s. u pushtua nga Romakët dhe pas ndarjes së perandorisë i takon Bizantit. Për shkak të pozicionit të tij gjeografik ka qenë cak i një numri të pushtuesve. Qytet kala me rëndësi gjeopolitike ku janë karakterizuar tregtia dhe transporti detar dhe rrugor. Në periudhën feudale të rendit shoqëror Ulqini disa herë ishte kryeqytet. Vazhdimisht përgjatë lumit të Bunës dhe rrugëve që lidhnin basenin e liqenit të Shkodrës dhe bregdetit u zhvillonte transporti dhe tregtia e konsiderueshme. Për këto rrugë ka gjurmë të shumta parahistorike të civilizimeve të lashta, sidomos Ilire. Në veçanti ishte me rëndësi drejtimi i rrugës që shkonte për në Kosovë dhe Maqedoni, po ashtu përmes Shkodrës dhe periferitë e sajë. Në fushën e Ulqinit me zgjidhje urbane, karakterizohet kalaja me një strukturë të mrekullueshme arkitektonike, si nga aspekti i sigurisë dhe i mbrojtjes po ashtu edhe nga pamja vizuale dominante në qytet. Shtëpitë u vendosën në një strukturë për rreth rrjedhës së lumit në ultësira, përreth lumit të Bunës dhe në pellgun e liqenit të Shkodrës. Ulqini, për shkak të vendndodhjes së tij dhe të qasjes në det dokumentohet se ka qenë një komunitetin i madh, nga fiset ilire në shekullin e V p.es., me organizim shoqëror të asaj kohe ku ka mundësuar ngritje sociale shoqërore dhe aktivitete të planifikimit urban. ${ }^{38}$

Në veçanti ndërtesat e mesjetës në rajonin e Ulqinit sidomos në kala veçohet bedeni Ilir, i zbuluar në truallin e pjesës së sipërme të kështjellës, ekzistojnë gjurmë të mureve ciklopike të ndërtuara me blloqe të mëdha guri. Respektivisht, kemi të bëjmë me një strukturë ndërtimi me blloqe guri si material lokal i ngjashëm me traditën ndërtimore të Santorinit. Kjo teknikë ndërtimi është e shprehur edhe përgjatë bregdetit ose më në jug të Adriatikut përgjatë vijës bregdetare, ku kanë qenë ndërtuar qytetet e vjetra ilire. Ulqini karakterizohet me klimën mesdhetare dhe me vegjetacionin subtropikal. Ka klimë të përshtatshme dhe nga ky aspekt mundë të krahasohet me qendrat më të njohura turistike të Mesdheut. Temperatura e ajrit në Ulqin është e përshtatshme për rrezitje dhe larje ne det, dhe zgjatë gjashtë muaj, prej majit deri ne tetor, po ashtu në ketë periudhë, temperaturës i përgjigjet temperatura e ujit. Ulqini bën pjesë ne vendet më me diell të bregdetit Adriatik. Mesatarja e ditëve me diell ne Ulqin është 218 ditë, qe do te thotë mesatarisht 2,706 orë ne vit, ose 7.4 orë në ditë. Gjatë verës Ulqini ka ma shumë ore me diell rreth 11,5 orë në ditë. ${ }^{39}$

38 http://znamenitostiulcinja.blogspot.com/. /2015.

39 https://sq.wikipedia.org/wiki/Ulqini . /2015. 


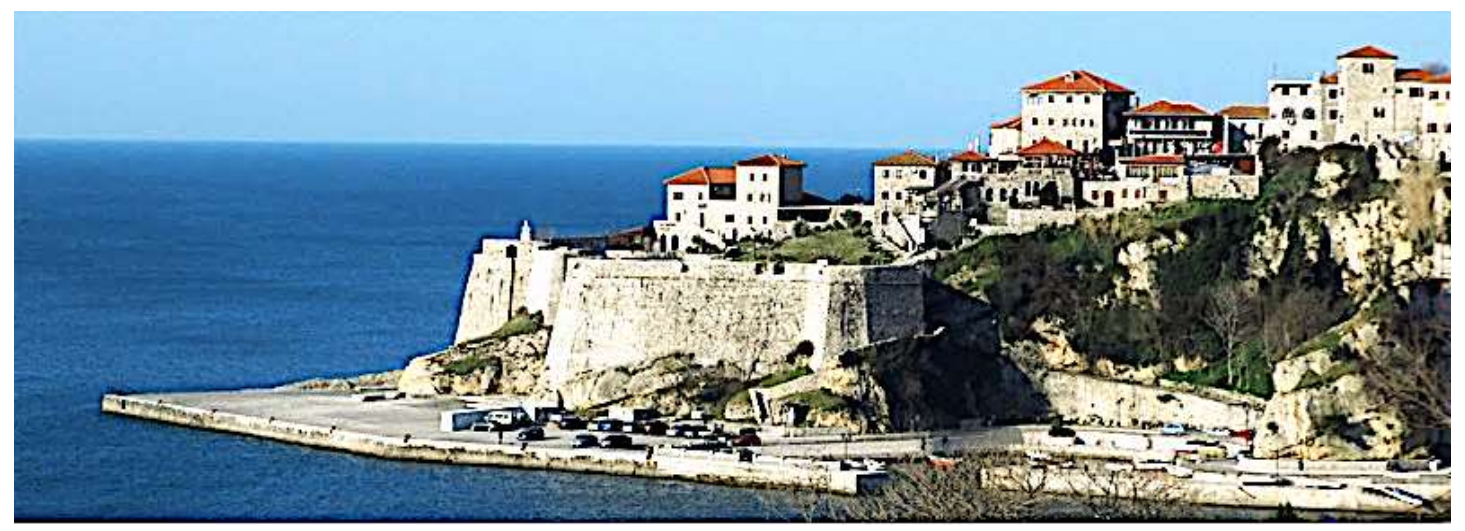

Figura 48. Ulqini, kalaja.

(Burimi): Bujar Bajçinovci, 2014.

Qyteti i vjetër, është bërthama e trashëgimisë kulturore historike të Ulqinit. Në platonë e epërme të kalasë gjendet kompleksi muzeal i qytetit. Në këtë hapësirë janë edhe monumentet më interesante të historisë së Ulqinit, ku janë ekspozuar të gjitha gjetjet nga qyteti i vjetër. Vlerë të posaçme kanë postamenti antik me mbishkrimin grek kushtuar perëndeshës Artemidë, një figurë antike që paraqet perëndeshën Athinë me helmetë, dy sëpata të tipit Shkodrano Dalmat të epokës së bronzit.

Në lapidarium janë të ekspozuara kapitele jonike, pjesë të ciboriumit të kishës së vogël të shekullit IX dhe objekte nga periudha turke. Menjëherë prapa muzeut gjendet kulla e Balshajve, hapësira e te cilës përdoret sot për galeri. Përpara paraqitet një shesh i vogël që dikur ishte sheshi i skllevërve i rrethuar nga kazamatet e Revelinit. Në hyrje është luara e Revelinit kurse përballë saj muri i lartë Bolani nga koha e Venedikut. ${ }^{40}$

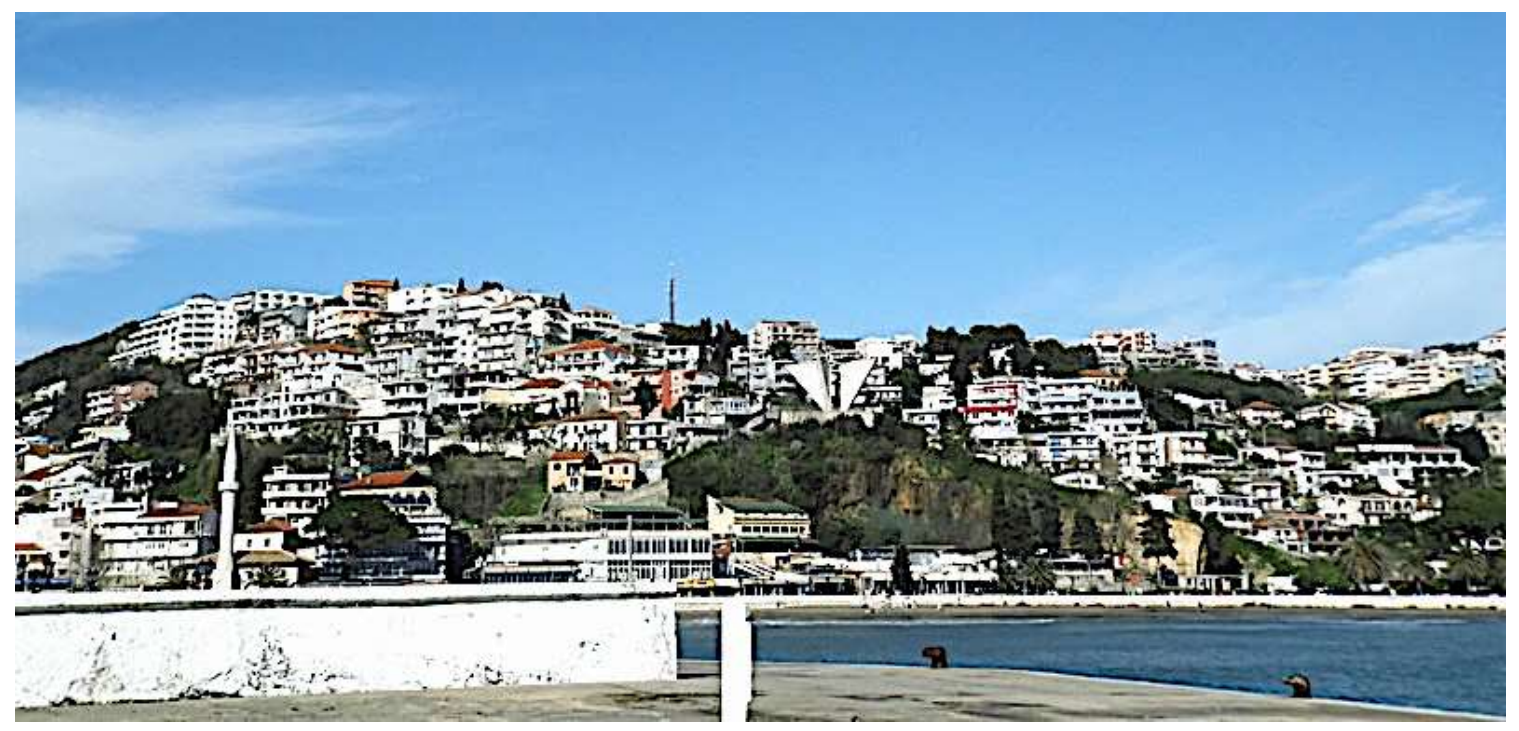

Figura 49. Ulqini.

(Burimi): Bujar Bajçinovci, 2012. 
"Nëpër shumë rrugica arrihet deri te platoja e kështjellës. Aty, para hyrjes jugore të qytetit, gjenden themelet e Kishës ortodokse të Zonjës së Bekuar nga shekulli XII që më vonë është shndërruar në kishë katolike të Shën Markut. Afër kësaj kishë është cisterna e madhe e qytetit e ndërtuar në kohën e sundimit të Venedikut. Supozohet se mbështetet në themelet e katedrales se Kishës së Shën Marisë nga shekulli XIII.

Pak më larg është "barutana" turke nga shekulli XVIII e mbuluar me kalotë. Në vendin ku gjendet sot pallati Venecia, ekzistonin mbeturinat e ndërtesës për të cilën supozohet se ishte selia e kryetarit të qytetit në kohën e sundimit të Venedikut. Për shkak të bukurisë dhe funksionalitetit të saj edhe sundimtarët më të vjetër e shfrytëzonin këtë pallat si oborr të tyre. Afër Venecias gjenden pallatet e Balashajve të cilat i përbën në të vërtetë ndërtesa e Venedikut. Kjo ndërtesë atraktive është ndërtuar në mënyrë suksesive, pjesa më e vjetër e saj është pjesa qendrore. " (Ekstrakt) ${ }^{40}$

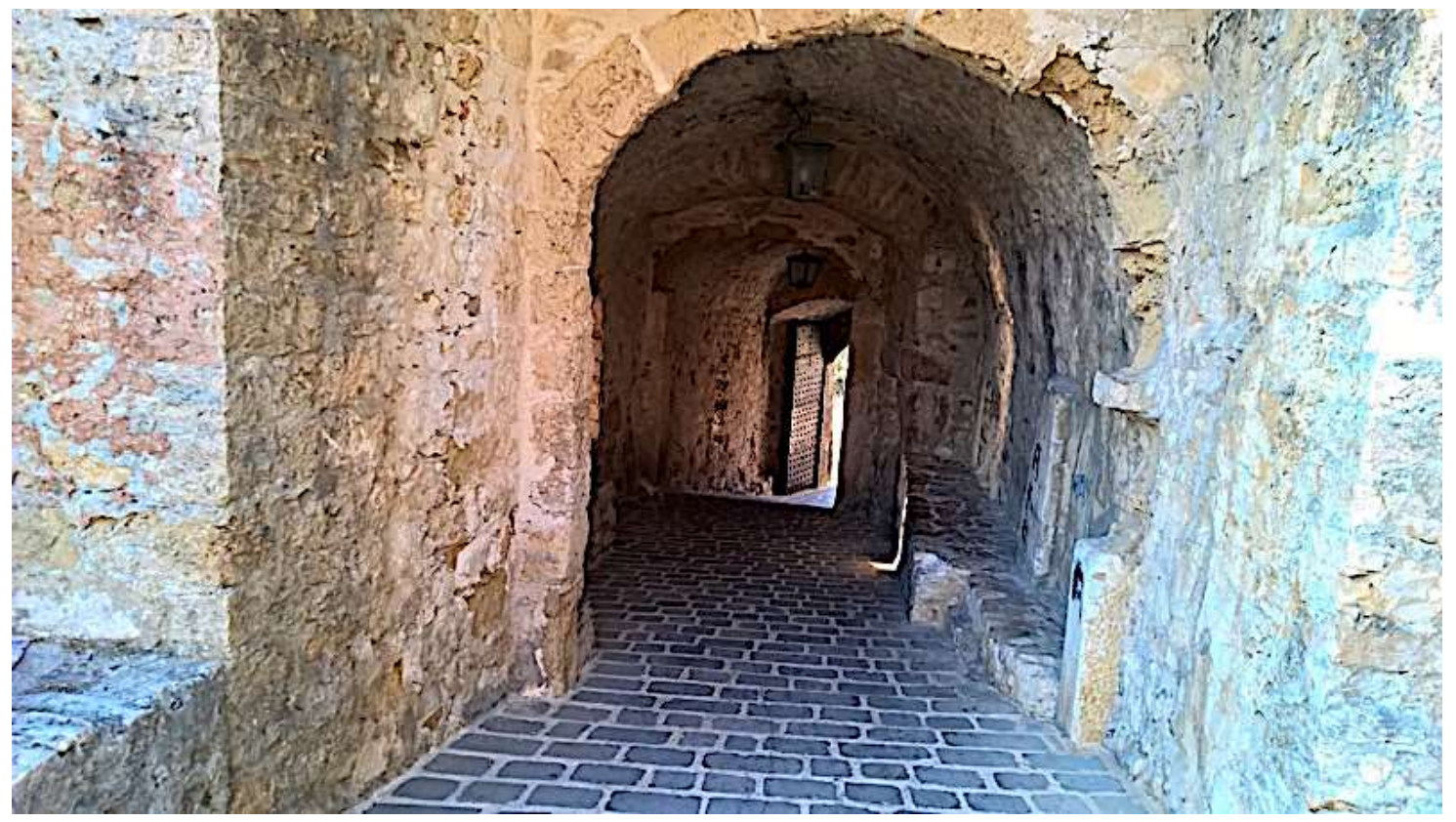

Figura 50. Ulqini. Hyrja në kala, 2015.

(Burimi): Bujar Bajçinovci, 2015.

Ulqini është shumë i pasur nga pikëpamjet etno kulturore. Nëpër Ulqin por edhe në rrethinë dallohen disa kostume popullore: kostumi i shqiptarëve të Ulqinit (i ashtuquajturi Kostumi i Qytetit), kostumi i Shqiptarëve të Anës së Malit, kostumi i bregacorëve, kostumi i Shestanit, kostumi i malësorëve, kostumi i goranëve dhe kostumi i Malazezëve. Të gjithë këto kostume rëndësi më të madhe i kushtojnë veshjeve të femrës. Muzeu i Ulqinit i themeluar në vitin 1975, ndodhet brenda kalasë dhe kryen evidentimin, hulumtimet sistematike, mbledhjen e eksponateve të ndryshme, mbrojtjen e specializuar dhe përpunimin e materialit të gjetur, ekspozimin e veprave me vlera kulturore, shkencore dhe artistike. Pranë Muzeut punon reparti arkeologjik (në ndërtesën e Kishë Xhamisë), reparti etnologjik si dhe Galeria e Arteve (në Kullën e Ballshajve).

40 http://francesko06.tripod.com/ulqini_i_vjeter.htm , /2015. 


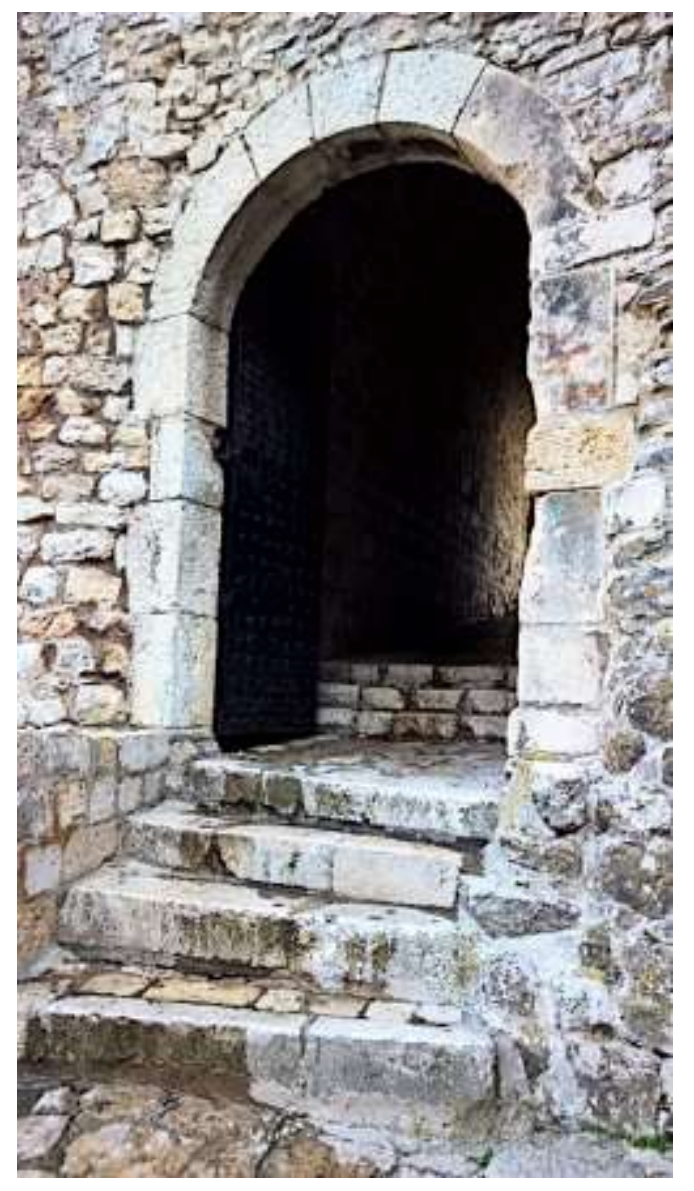

Ulqini posedon një pasuri të madhe arkitektonike që kanë vlera të mëdha kulturore. Ndër ta bëjnë pjesë kishat, xhamitë, krojet dhe mbetjet arkeologjike. ${ }^{41}$

Qyteti i vjetër është një trevë e vërtetë, thesar i vendbanimeve kulturore dhe formon thelbin e trashëgimisë kulturore dhe historike të Ulqinit. Në këtë zonë ka monumente nga më të rëndësishme të historisë Ulqinit, sidomos nga kohët e lashta, parahistoria si dhe veçanërisht qyteti antik kalaja e ndërtuar mbi shkëmbin e lartë buzë detit. E tërë kalaja është e rrethuar me mure që janë me histori të trazuar. I rindërtuar dhe i ndryshuar në kohë të ndryshme.

Figura 51. Ulqini. Hyrja në kala nga Lindja, 2015. (Burimi): Bujar Bajçinovci, 2015.

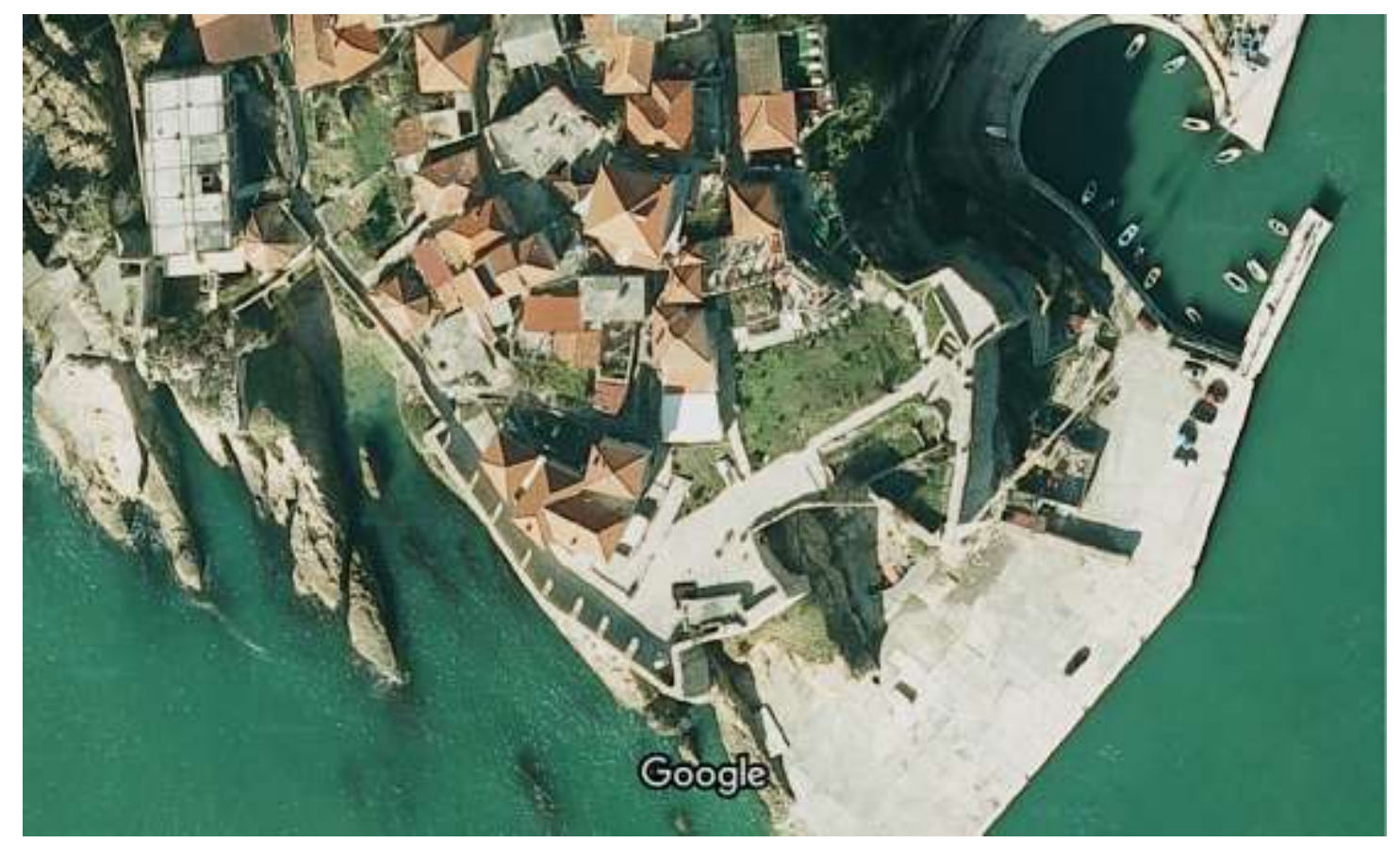

Figura 52. Ulqini.

(Burimi): Google Map. 2016. Chrome, 2016.

41 http://www.wikiwand.com/sq/Ulqini\#/Arti_dhe_kultura ,/2015. 


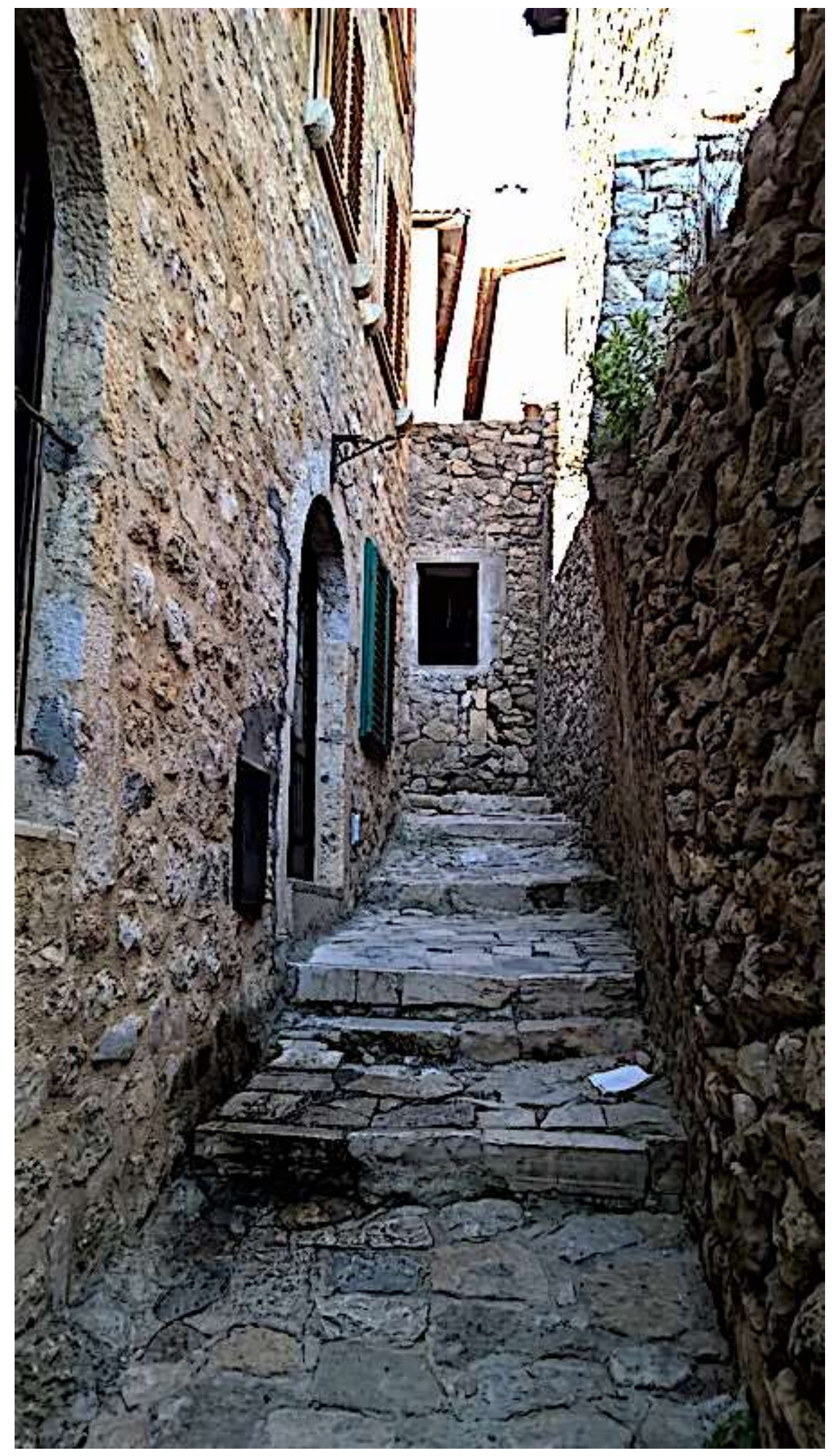

Figura 53. Ulqini. Strukturë e komunikimit, 2015. (Burimi): Bujar Bajçinovci, 2015. 


\subsubsection{Berati, qytet me dritare një mbi një.}

Qyteti i Beratit, i deklaruar Qytet Muze në vitin 1961 nga Qeveria Shqiptare, iu shtua Listës së Trashëgimisë Kulturore të Unesco-s në 2008, si një shembull i rrallë i një qyteti të periudhës Otomane. Berati është një qendër historike e fortifikuar, i cili dëshmon pasurinë dhe diversitetin e trashëgimisë arkitekturore të rajonit. Berati është vendosur në Lumin Osum, ndërmjet Malit të Tomorrit dhe luginës së Myzeqesë. Siti përbëhet nga tre pjesë: Kalaja e Beratit e ndërtuar mbi një kodër në anën veriore të lumit, lagjja Mangalem vendosur në këmbët e kodrës së kalasë, kalaja e Goricës dhe lagjja e saj vendosur në bregun jugor të lumit. Qendra urbane e qytetit ka dëshmi të jashtëzakonshme të llojeve të ndryshme të monumenteve dhe ndërtesa urbane që i takojnë periudhës Klasike Otomane. Qyteti i Beratit ndodhet në Shqipërinë Jug-Qendrore, 120 km në jug të Tiranës. Ai ka një popullsi prej rreth 64.000 banorë. Qendra Historike e qytetit është përfshirë në Listën e Trashëgimisë Botërore të UNESCO-s në 8 Korrik 2008 si "një shembull i rrallë i një karakteri arkitektural tipik i periudhës Otomane". Berati është shpallur Qytet Muze në vitin 1961 nga Qeveria Shqiptare.

"Qyteti është ndër më të vjetrit në Shqipëri, fillimet e të cilit i gjejmë në një vendbanim ne formë fortese -Kalaja, e cila ka ekzistuar që prej shekullit IV para Krishtit me një jetë të pandërprerë deri në ditët e sotme. Ai ka qenë vendbanim i fisit Ilir të Desaretëve ,të cilët ishin të parët që ndërtuan fortifikimet në qytet. I njohur si Antipatrea qyteti u pushtua prej romakëve në shekullin e II para Krishtit. Romakët e quajtën qytetin Albanorum Oppidum (Kështjella Shqiptare). Gjatë periudhës Bizantine në shekullin e V qyteti njihet si Pulcheriopolis, nga Pulheria emri i motrës së Perandorit Bizantin Teodos i cili pushtoi qytetin. Emri Pulcheriopolis do të thoshte "qytet i bukur, i pasur, i fuqishëm" dhe jo rastësisht iu vu qytetit; ai po bëhej një qendër kyçe me rritje të madhe kulturore. Në shekullin e VII filluan invazionet Bullgare,të cilat zgjatën deri në vitin 1018 duke e quajtur Beratin si Beograd - Qyteti Bardhë.

Me rënien e Perandorisë Bizantine, Berati u kthye në një nga qendrat më të rëndësishme për autoritetet fetare të Epirit. Ai ishte rezidenca e Mikele Angelo Komneno despoti I qendrës klerike të Epirit. Në shekullin e XIV, qyteti u transformua në kryeqendrën e një principate të madhe nën sundimin e familjes fisnike të Muzakajve. Në vitin 1417 Berati u vu nën pushtimin Turk. Gjatë pushtimeve otomane, ai mbeti një prej qyteteve më të mëdhenj të Shqipërisë. Deri në fillimin e shekullit XX qyteti kishte një infrastrukturë solide, dhe ishte nyje lidhëse drejt Lindjes dhe Kostandinopojës por gjithashtu edhe në drejtim të Jugut për në Janinë - Greqi.

Qyteti është i njohur për trashëgiminë e tij kulturore, arkitekturën historike dhe bukurinë natyrore dhe njihet si Qyteti i një mbi një dritareve " për shkak të numrit të madh të dritareve të shtëpive të vjetra që shikojnë mbi qytet. Është një qytet i mrekullueshëm skenik me ndërtesa të bukura shumë interesante nga pikëpamja arkitektonike dhe historike. Berati mbart dëshminë e bashkëjetesës së feve të ndryshme dhe komuniteteve të shumta kulturore përgjatë shekujve. Pjesa e vjetër historike përbëhet nga tre lagje të ndara nga lumi Osum: Kalaja, Gorica dhe Mangalemi. Qyteti ka gjithashtu Qendrën Mesjetare e cila përbëhet nga monumente. "(Ekstrakt) ${ }^{42}$

42 http://www.ata.gov.al/berati-oaz-i-historise-dhe-i-mrekullise-se-artit-139410.html, /2014. 


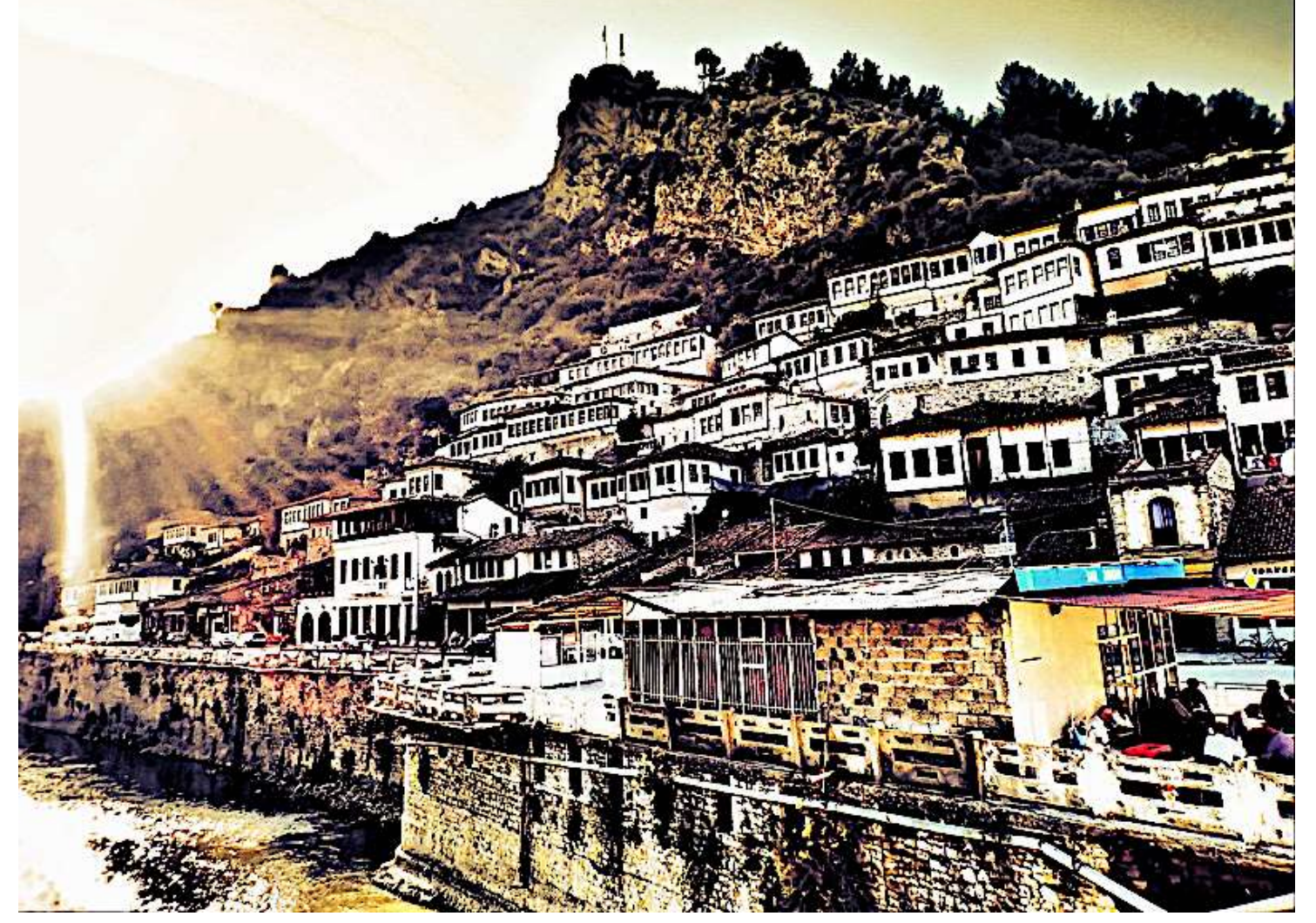

Figura 54. Berati. Struktura urbane. 2014.

(Burimi): SarahTz, 2014. (Flickr). E licensuar nga Creative Commons Attribution ShareAlike 3.0 Unported.

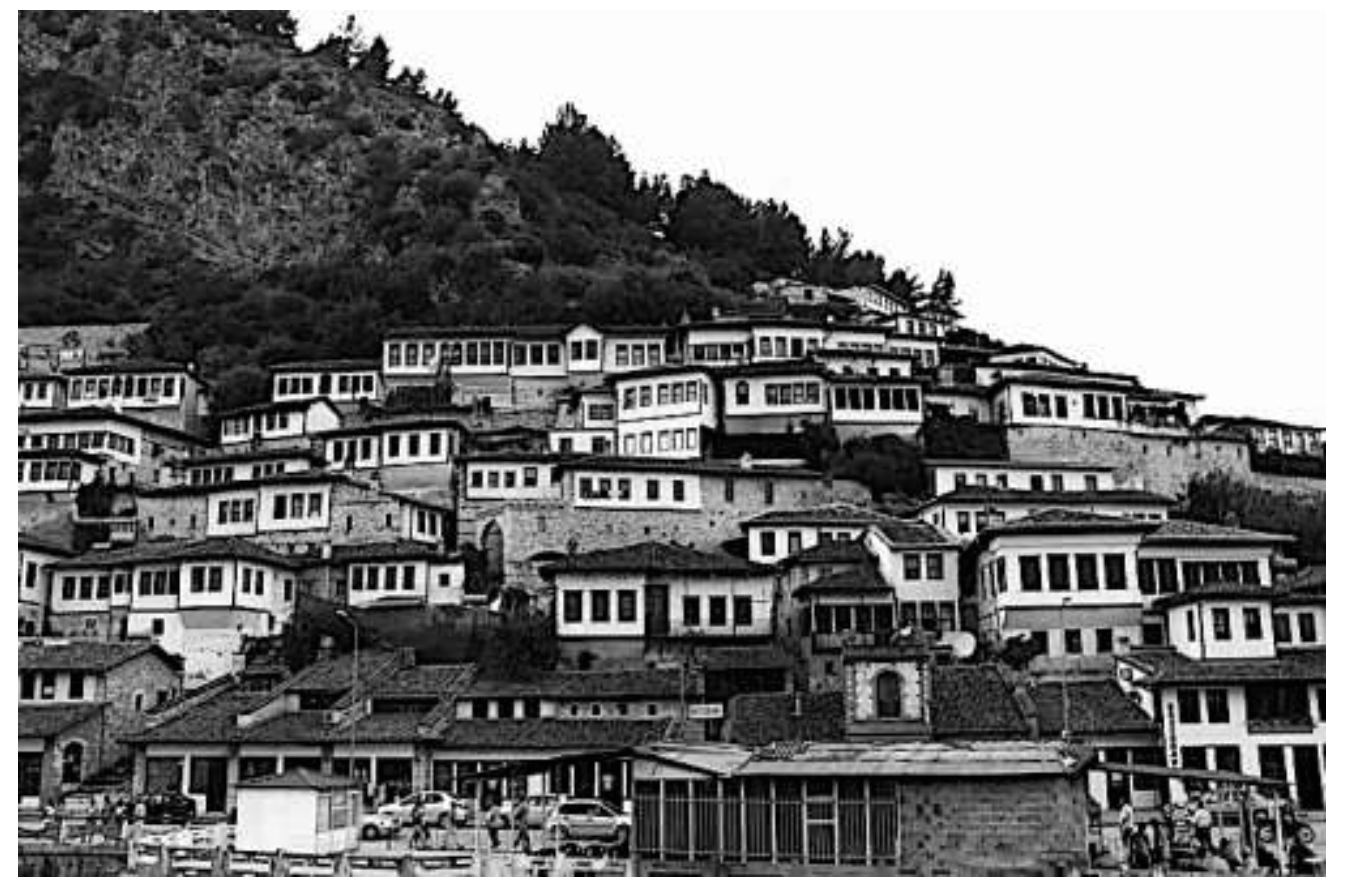

Figura 55. Berati. Struktura urbane. 2014.

(Burimi): Franco Pecchio, 2014. (Flickr). E licensuar nga Creative Commons Attribution ShareAlike 3.0 Unported 
Qendra urbane dhe vlera e tij urbane, tregojnë qartë se Berati u zhvillua në përputhje me parimet, standardet dhe natyrën e qytetarëve të saj, i ndërtuar me mjeshtëri dhe është një lloj i ndërtimit që përcakton stilin e qytetit. Respektivisht, ka elementin kryesor kompozicional dhe strukturën mirë të qëlluar arkitektonike.

Ndërtesat në Berat zëjnë një pozicion të veçantë në mënyrën e tipologjisë së shtëpive shqiptare, në shtëpitë e banimi urban, me karakteristika të veçanta projektuese me planimetri dhe elemente të veçanta arkitektonike dhe strukturore duke mbajtur karakteristikat e saj autoktone arkitektonike. Banesa në Berat evoluojnë me kalimin e kohës, nga format e saj më të hershme deri në fillim të shekullit të XX.

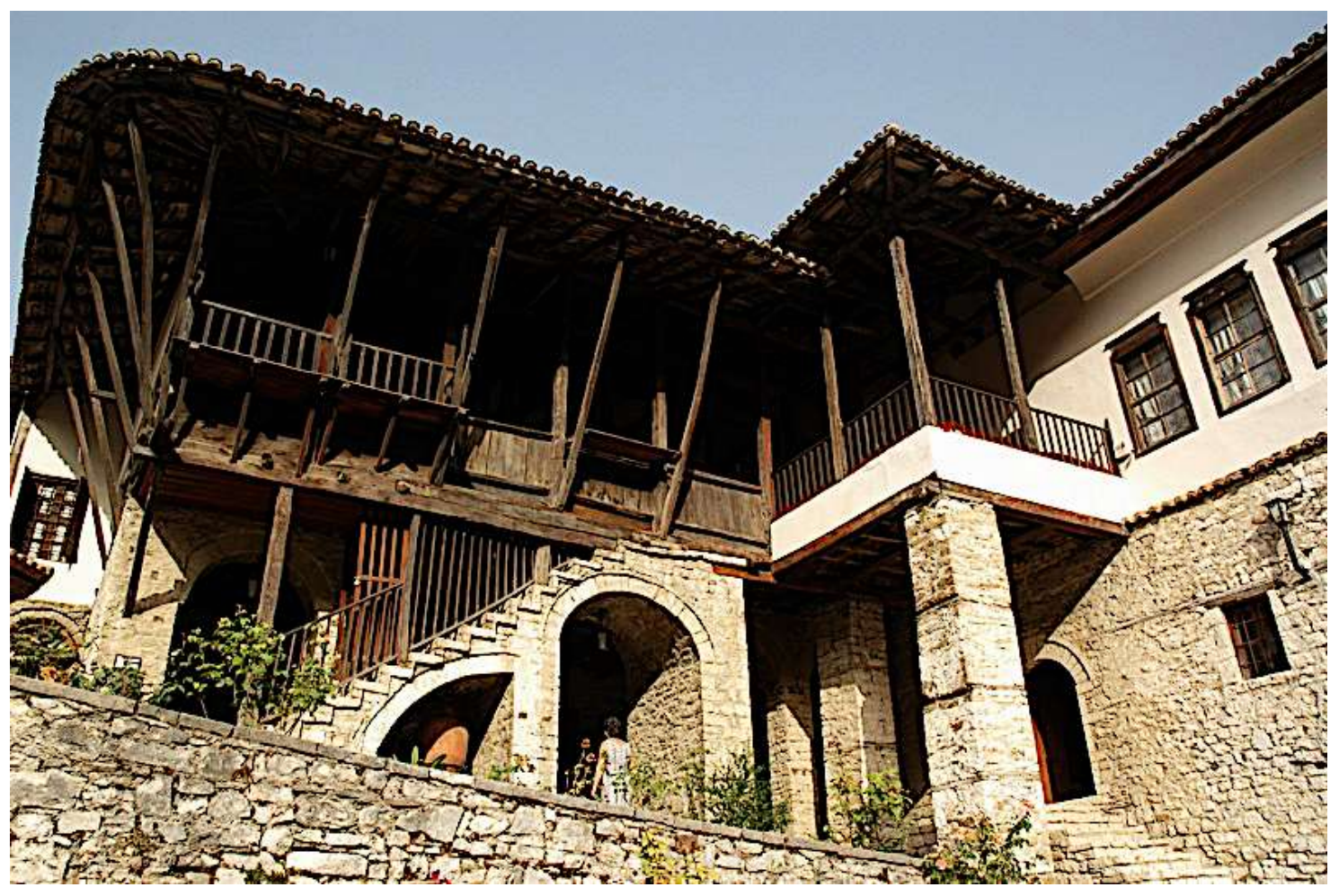

Figura 56. Berati. Muzeu Etnologjik.

(Burimi): Jason Rogers, 2007. (Flickr). E licensuar nga Creative Commons Attribution ShareAlike 2.0

Parimet e arkitekturës bioklimatike janë arritur në nivelin më të lartë të dizajnit në varësi të kohës në të cilën është ndërtuar, edhe pse projektuesi kishte vështirësi për të ndërtuar në një vend të kufizuar, me truall shkëmbor për të realizuar ndërtesa banimi në një strukturë urbane me një skemë horizontale dhe vertikale.

Kështu, në etapa dhe kohë të ndryshme ndërtuesit kanë ndjekur parimet e arkitekturës bioklimatike. Duke insistuar në vende me diellosje dhe me ekspozim nga ana jugore. 


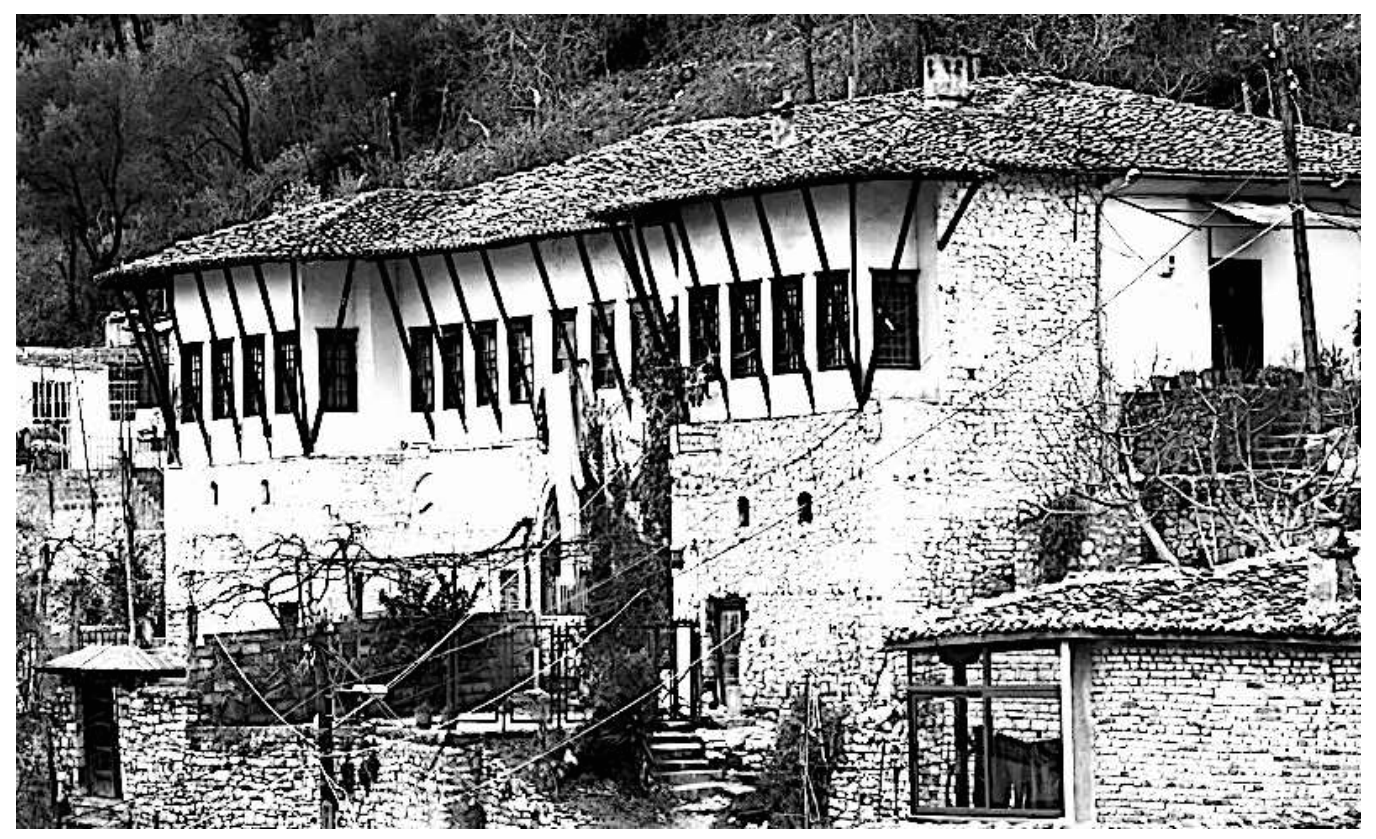

Figura 57. Berati. Strukturë urbane. 2012

(Burimi): Ark. Ramadan Aliu. 2012.

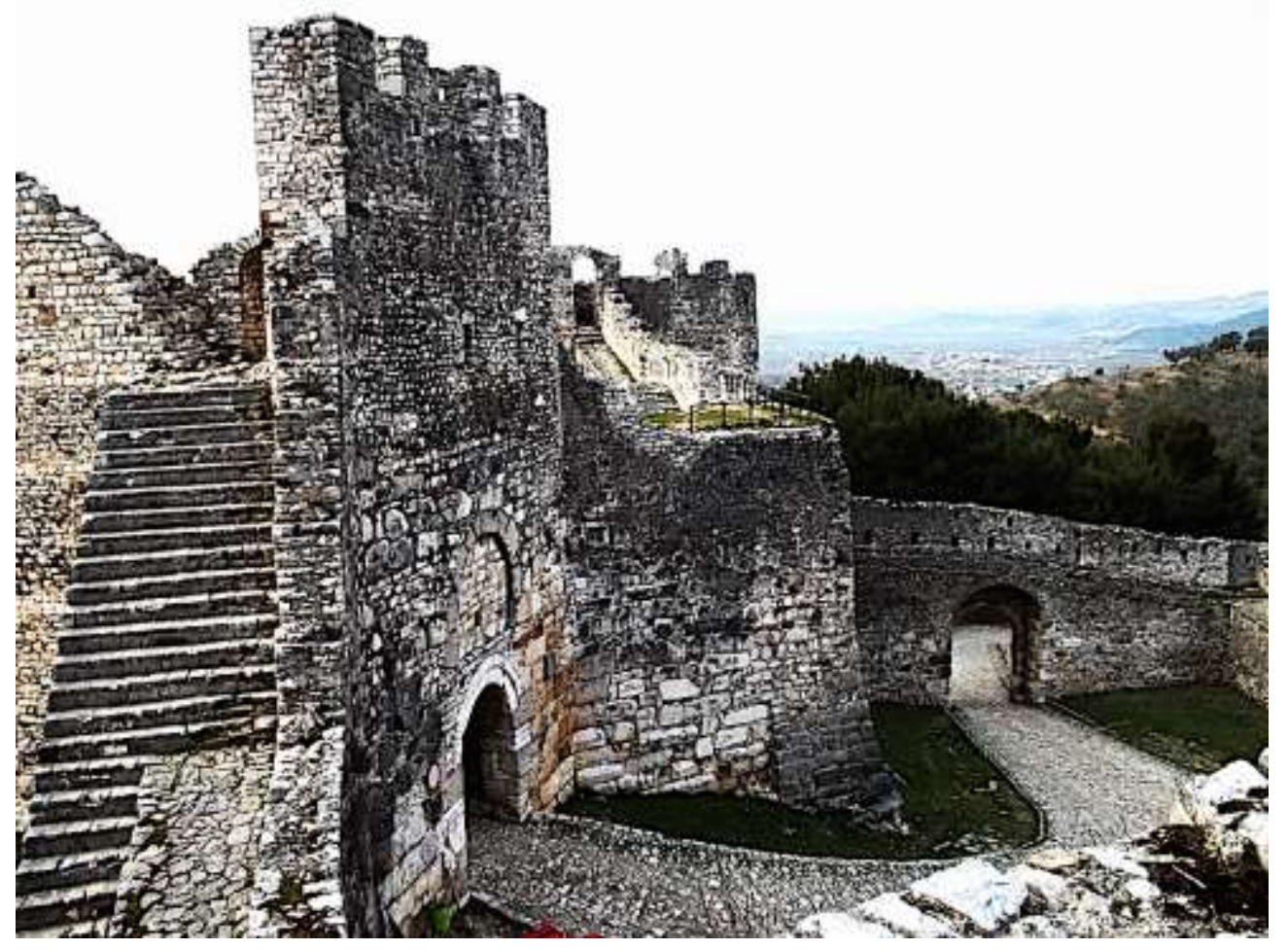

Figura 58. Berati. Struktura e kështjellës. 2012

(Burimi): Ark. Ramadan Aliu. 2012. 


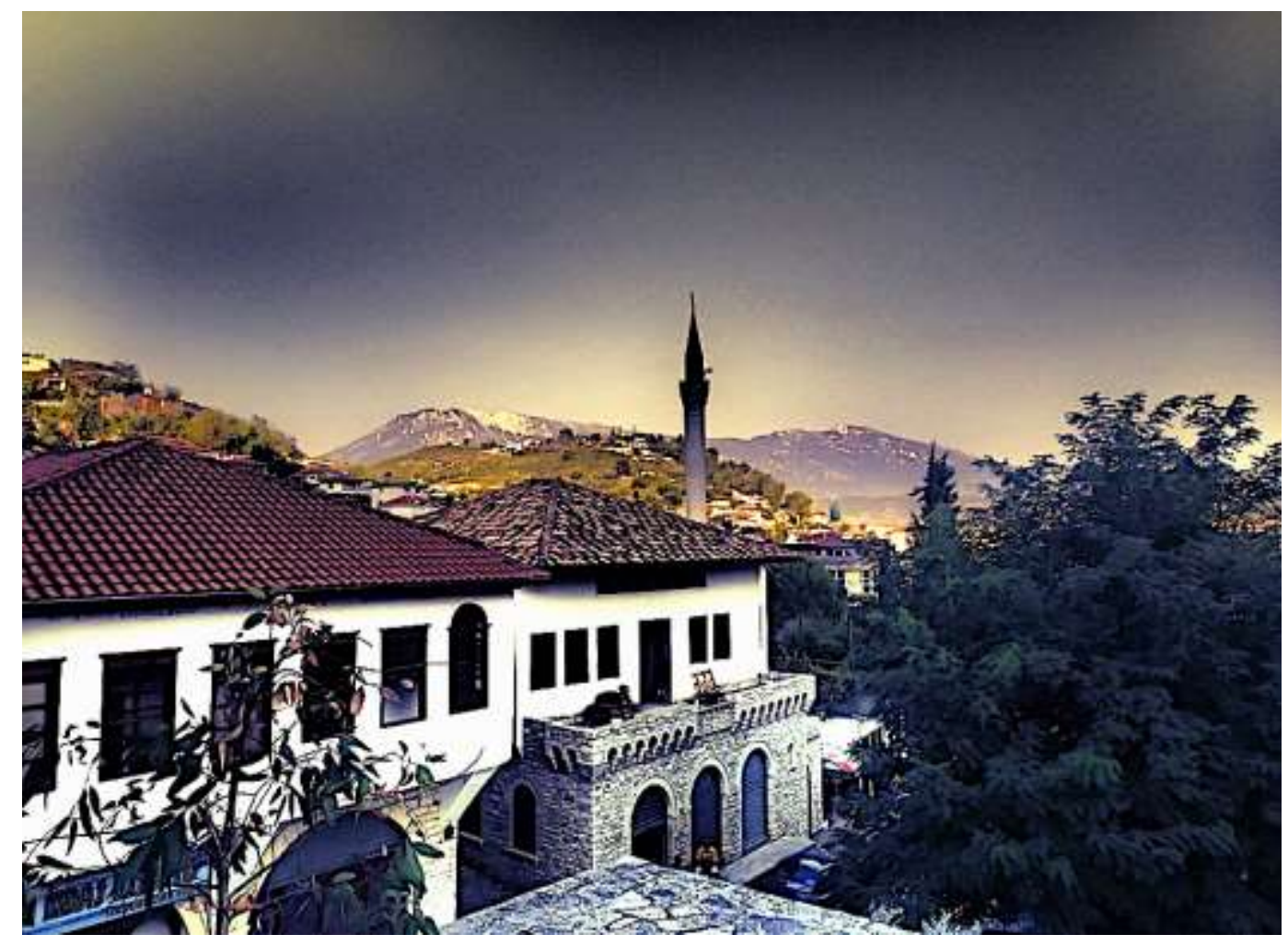

Figura 59. Berati. Struktura urbane.

(Burimi): SarahTz, 2014. (Flickr). E licensuar nga Creative Commons Attribution 2.0 Generic

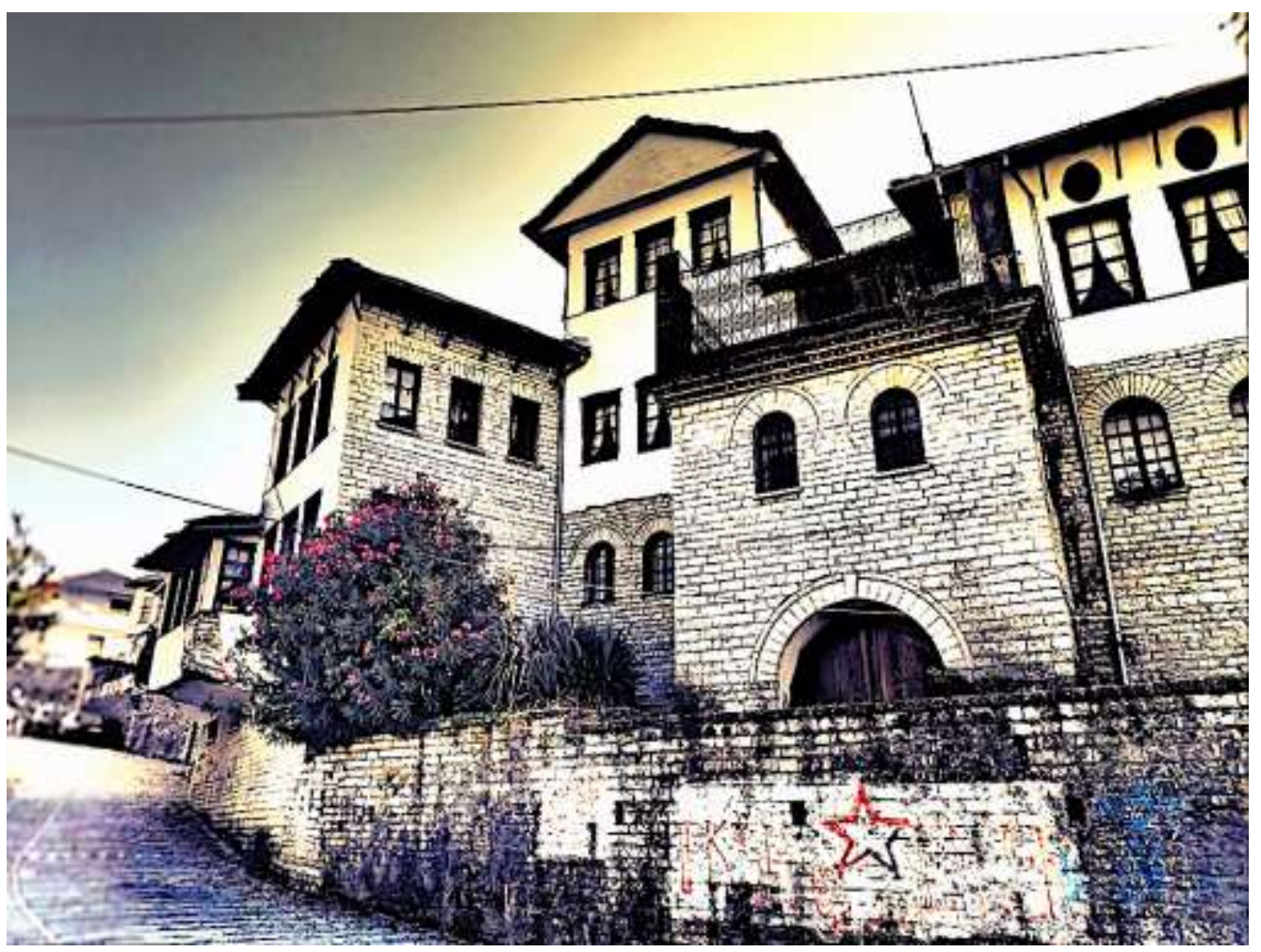

Figura 60. Gjirokastra. Struktura e urbane.

(Burimi): SarahTz, 2014. (Flickr). E licensuar nga Creative Commons Attribution 2.0 Generic 


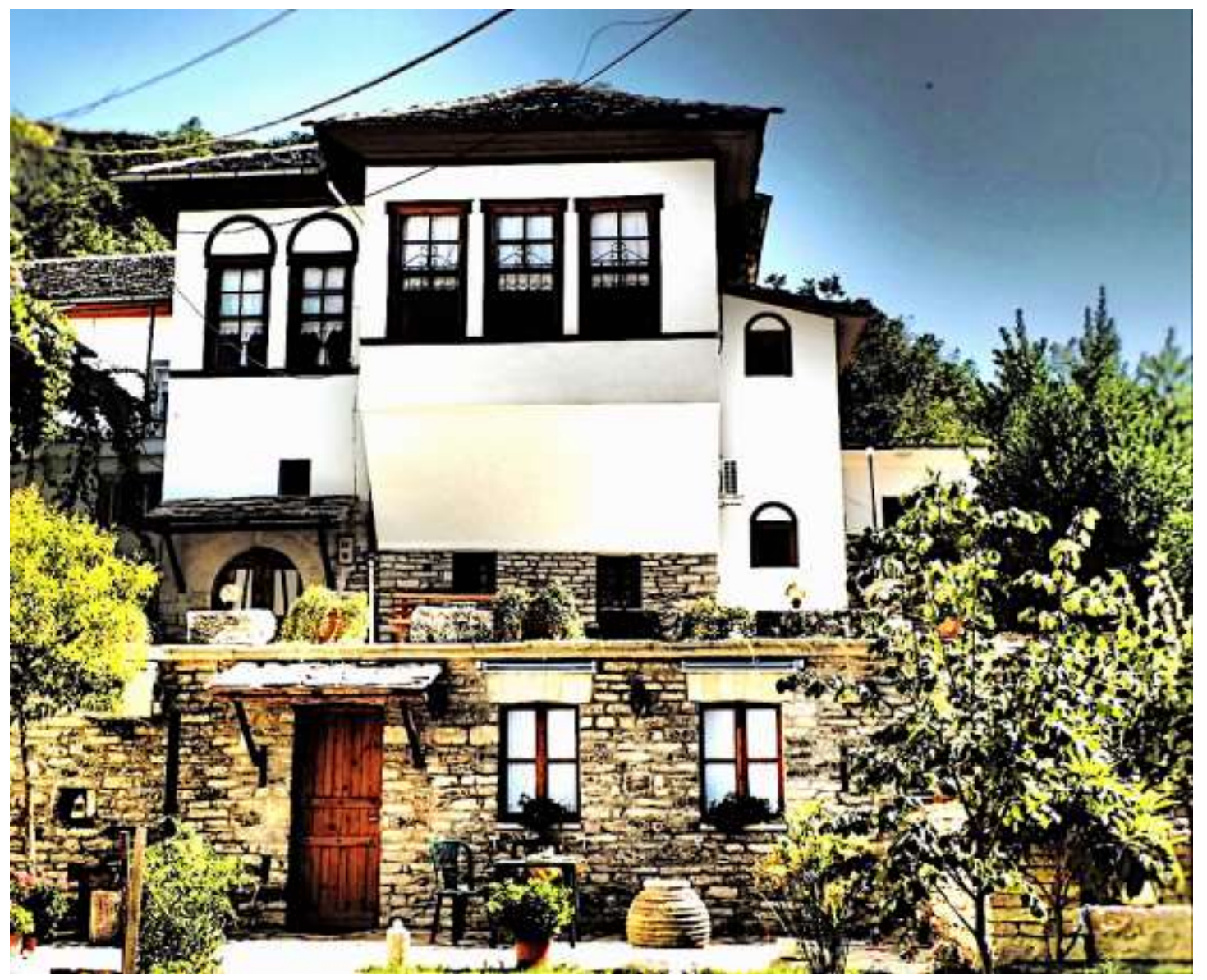

Figura 61. Gjirokastra. BabaMeto Hostel.

(Burimi): SarahTz, 2014. (Flickr). E licensuar nga Creative Commons Attribution 2.0 Generic

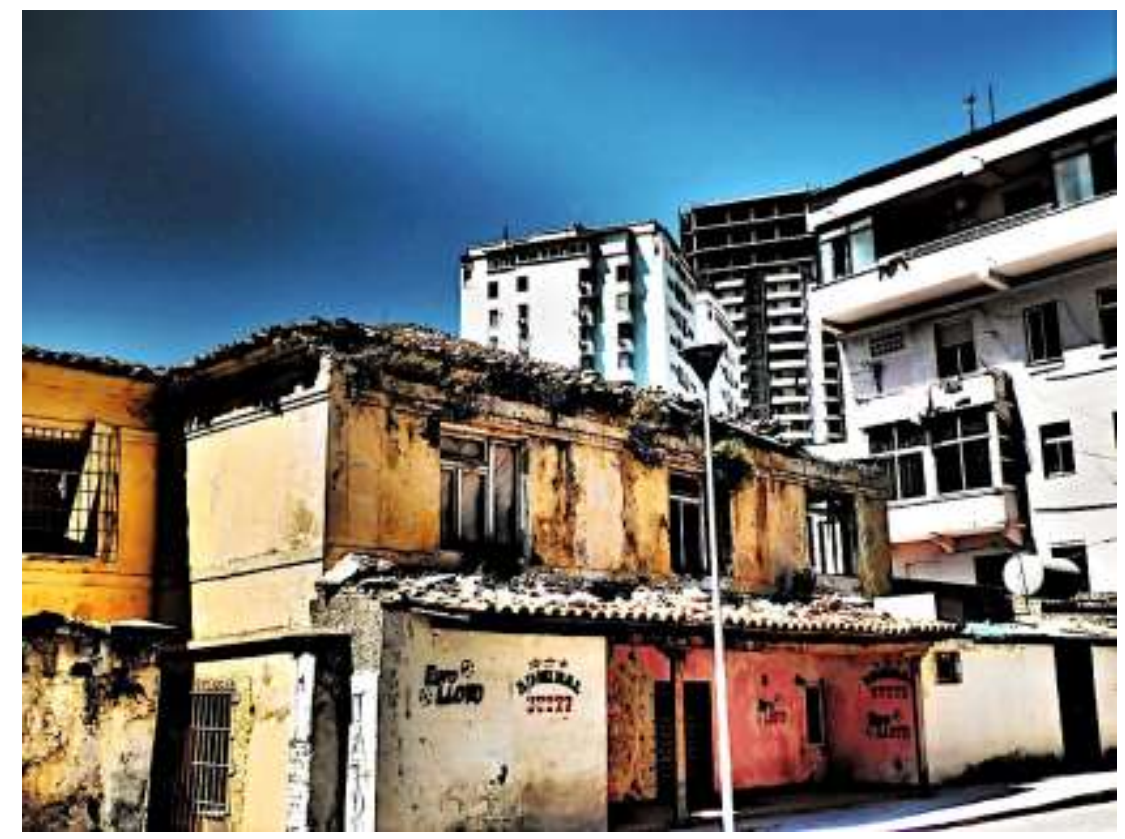

Figura 62. Durrës, Strukturë urbane

(Burimi): SarahTz, 2014. (Flickr). E licensuar nga Creative Commons Attribution 2.0 Generic 


\subsubsection{Ohri}

"Në thesarin e historisë Evropiane, Ohri është një "qytet i gjallë", është një qytet urban buzë liqenit të Ohrit, i cili së bashku me liqenin Baikal dhe Liqenin Tanganyika konsiderohet se është ndër liqenet më të vjetër në botë. Ky sistem aquatik nuk është vetëm me specie endemike dhe faunë, por edhe në fund të liqeni ruhen vlera të jashtëzakonshme arkeologjike nga periudha parahistorike.
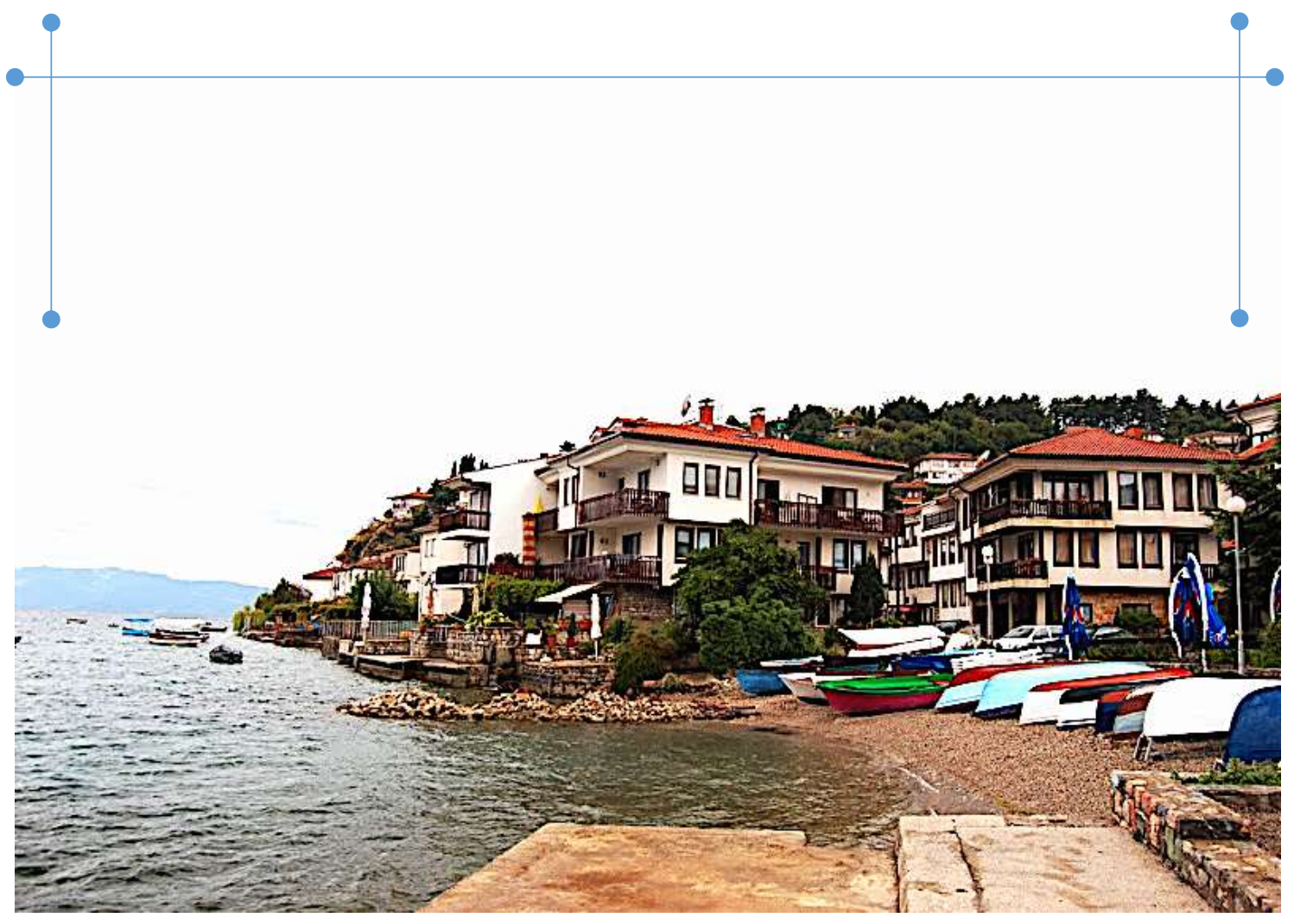

Figura 63. Ohri, lagjja e peshkatarëve

(Burimi): Peter Boer, 2012. (Flickr). E licensuar nga Creative Commons Attribution ShareAlike 2.0

Struktura arkitektonike e Ohrit zhvillohet në mbetjet e Lychnidos të lashtë, mbi pozitat e qytetit Antik që është rreth $1.50 \mathrm{~m}$ nën nivelin e sotëm të Ohrit. Rrethinat arkitektonike u themeluan në kodër të Ohrit mbi bregun e liqenit. Në zonën e sipërme të shpatit gjendet kalaja e Samuelit, kështjella e fortifikuar e Ohrit, që është në perëndim dhe një pjesë në jug. Respektivisht qyteti është i rrethuar nga muret e kalasë. (Ekstrakt) ${ }^{45}$

Kjo hapësirë urbane është e lidhur në aspektin arkitektonik, duke u mbledhur rreth objekteve të shenjta siç janë kishat e St.Clementit dhe Shën Pantelejmonit, Virgjëreshës së Shenjtë, Sophia e Shenjtë, Shën. Konstandinit dhe Helenës, Shën Klementit, spitalit të Shën. Nikollës dhe Virgjërshës së Shenjtë." (Ekstrakt) ${ }^{43}$

43 UNESCO Venice Office.(2009). Macedonian cultural heritage. Ohrid world heritage site. 


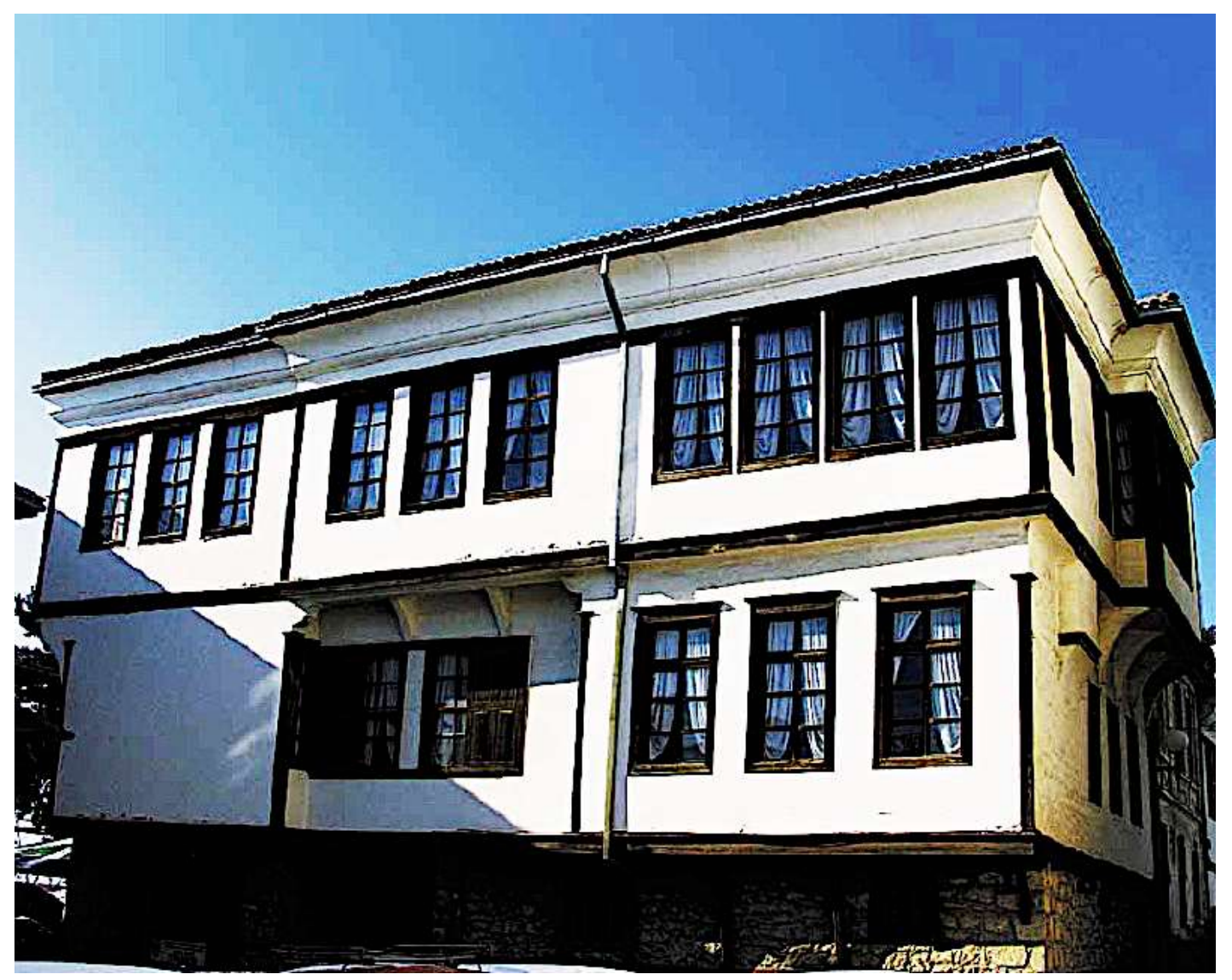

Figura 64. Ohri. Strukturë urbane.

(Burimi): UNESCO Venice Office.(2009). Macedonian cultural heritage. Ohrid world heritage site.

"Lidhja arkitektonike lidhë rajonin lindor dhe kodrën më të vogël e cila përfundon në vendin popullor, tregut i Ohrit (Çarshia). Jashtë mureve të qytetit është rrethi i njohur gjerësisht si mesokastro që u krijua gjatë sundimit osman dhe ka karakteristika arkitektonike me zonën e Varoshit.

Në krahasim me rritjen industriale të Evropës Perëndimore, komuniteti kishte mbetur në korniza mesjetare të ndërtimit, për objekte ishin përdorur materialet mjedisore natyrore si: guri, druri dhe gëlqerja. Guri është përdorur kryesisht në ndërtimin e bodrumeve apo mureve në tokë, shpesh ka ndodhur që këto mure nga guri janë ngritur lartë dhe kanë tejkaluar etazhën e parë.

Ndërsa nivelet e sipërme ishin realizuar nga një sistem skeletor prej druri i quajtur bondruk. Ndërtimet fleksibile horizontale dhe vertikale ishin të lidhura në një tërësi të qëndrueshme (Çipan), po ashtu me ndihmën e trajtave të trekëndëshit të cilat janë përfshirë në mure është siguruar stabiliteti i strukturave, muret janë lyer nga të dyja anët dhe janë suvatuar me llaç gëlqere." (Ekstrakt) ${ }^{43}$ 


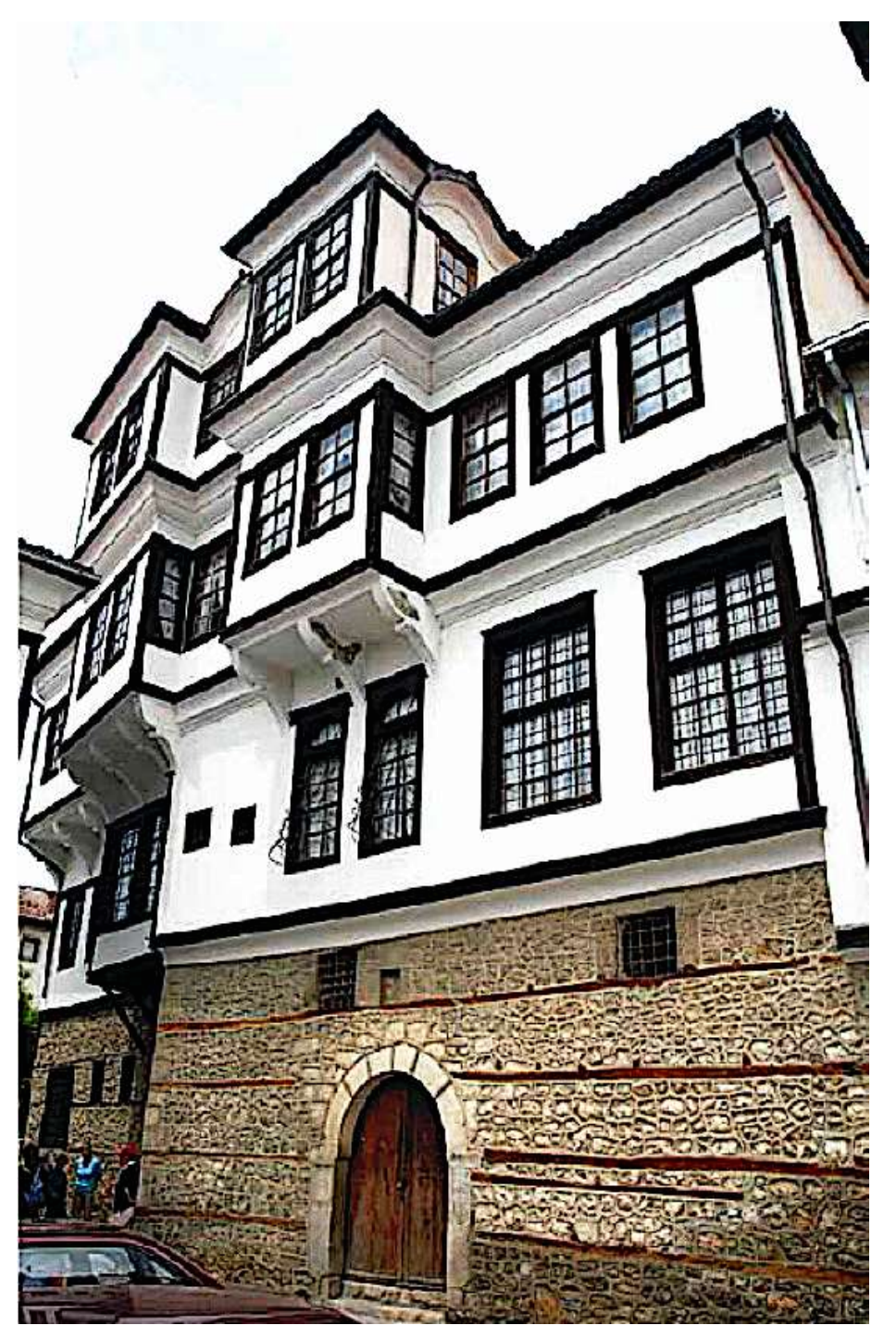

Figura 65. Ohri. Strukturë urbane.

(Burimi): UNESCO Venice Office.(2009). Macedonian cultural heritage. Ohrid world heritage site.

\subsubsection{Arkitektura vernakulare e Kosovës}

Prof. Flamur Doli, thekson: "Në historinë e gjithmbarshme të popullit tonë, me një lashtësi mijëvjeçare, bën pjesë edhe historia e arkitekturës shqiptare, e cila karakterizohet me një vazhdimësi të pandërprerë që nga parahistoria e këtej. Trashëgimia arkitektonike shqiptare përfshin gjini të ndryshme ndërtimesh, ku vend të posaçëm zë arkitektura e ndërtuar nga mjeshtrit shqiptarë, anonimë e të pashkolluar. Këta mjeshtër krijuan vlera kulmore arkitektonike, si dokumente të pakundërshtueshme me vërtetësi të një shkalle më të lartë... Pa dyshim se sfondin më të madh të arkitekturës popullore e përbën shtëpia e vjetër fshatare dhe qytetare. Për këtë gjini të të ndërtuarit popullor në trevën e Kosovës, $\mathrm{u}$ tha se i përket arkitekturës, e cila në mënyrë sovrane, ka mbretëruar mbi të ndërtuarit profan, në pjesën më të madhe të Gadishullit Ballkanik, si edhe në pjesën perëndimore të Azisë së Vogël. Dhe njëmend, në këtë gjini ndërtimesh, fuqia e madhe krijuese e gjeniut popullor arriti shprehjen e saj të plotë... 
Kjo provohet me faktin se mjeshtri popullor shqiptar, në lëmin e arkitekturës popullore, krijoi vlera kulmore arkitektonike, me tipare të mëvetësishme apo autoktone, origjinale, unike dhe struktura konstruktive nga më të guximshmet në tërë arkitekturën popullore ballkanike. Me këtë, mjeshtri popullor shqiptar, jo vetëm se i ndoqi rrjedhat aktuale, por njëherësh i arriti kulmet e krijimtarisë arkitektonike në kontekst të kulturës së gjithmbarshme ballkanike. Veprimtaria e mjeshtrit popullor shqiptar në kuadër të veprimtarisë së përgjithshme, veç të tjerash, bëri që "kultura jonë popullore, doket, zakonet, folklori, veshja, arkitektura popullore etj, të jenë mbrojtje e fuqishme gjatë historisë nga shkombëtarizimi dhe zhdukja e plotë e kombit shqiptar nga faqja e dheut".

"Nocioni i arkitekturës popullore, nuk i vë në plan të parë veprat individuale të mjeshtërve, por ai e nënkupton krijimin e vlerave artistike popullore si një veprimtari të përbashkët popullore, në dimensionin e saj më kompleks. Rrjedhimisht, arkitektura popullore, apo vlerat e kulturës etnografike, janë prodhim spontan dhe i qëndrueshëm i veprimtarisë së një populli të tërë me një trashëgimi të përbashkët, përkatësisht me vepra të krijuara sipas përvojës së përbashkët...

Në këtë kontekst, në kulturën materiale të një populli, ngulimi i banimit paraqet njërin prej objekteve më të rëndësishëm të ndërtimit popullor. Kjo, sepse tek mënyra e ndërtimit të ngulimit të banesës në formë të kondensuar është pasqyruar kultura tradicionale e një populli në dimensionin e saj më kuptimplotë. E gjithë kjo, siç do të shohim nga përmbajtja shumë komplekse e monografisë që e shtjellon kulturën e ngulimeve autoktone të banimit të popullit shqiptar, na mundëson që në këtë rrafsh ta shpleksim historinë e këtij populli që nga etnogjeneza e deri te ndërtimet popullore më të fundit, përkatësisht deri në kohën tonë...

Sipas profesorit Luigi Luca Cavalli - Sforca, trashëgimia njerëzore përbëhet nga dy pjesë: nga trashëgimia biologjike (gjenet) dhe trashëgimia kulturore (sjellja). Për më tepër, gjenet e popujve bashkëkohorë përmbajnë regjistrin historik të qenies njerëzore. Më tej, Prof. Luigji dhe shkencëtarë të tjerë, lidhjet që ekzistojnë ndërmjet gjeneve, popujve dhe gjuhëve, i provuan mirëfilli vetëm atëherë kur ato u ndërlidhën me të dhënat botërore të grumbulluara në gjenetikë, arkeologji dhe gjuhës. Për më tepër, duke zbatuar metodën multidisiplinare të studimeve të zhvilluara në kontekst të mësipërm,... shkencëtarët arritën në përfundim se, në kuadër të pemës së 63 gjuhëve Indo-Evropiane, gjuha shqipe radhitet si më e vjetra dhe i përket kohës së fillimit të përhapjes së bujqësisë 9.500 10.000 vjet më parë. Në këtë kontekst, si përfundim themelor, këta studiues nxjerrin prova se: pema gjenetike e botës përputhet me pemën kulturore (ku përfshihet gjuha dhe sjelljet - trashëgimia kulturore)...

Ideja për zhvillimin e kulturës materiale shqiptare në formën e paraqitur sipas kësaj skeme, natyrisht se rezultoi pas një pune të ngulmët hulumtuese shkencore shumëvjeçare në rrafshin e studimeve albanologjike. Në thelb të kësaj skeme paraqitet gjuha shqipe, krahas saj, që nga parahistoria, si në rrafshin diakronik, po ashtu edhe në ë sinkronik, u zhvilluan, apo më drejt bashkëjetuan në kuptimin e një dukurie veçantë, edhe lëmenjtë e tjerë të kulturës materiale shqiptare." (Ekstrakt) ${ }^{44}$

44 Doli, Flamur. (2009). Arkitektura vernakulare e Kosovës. Prishtinë, 2009. 


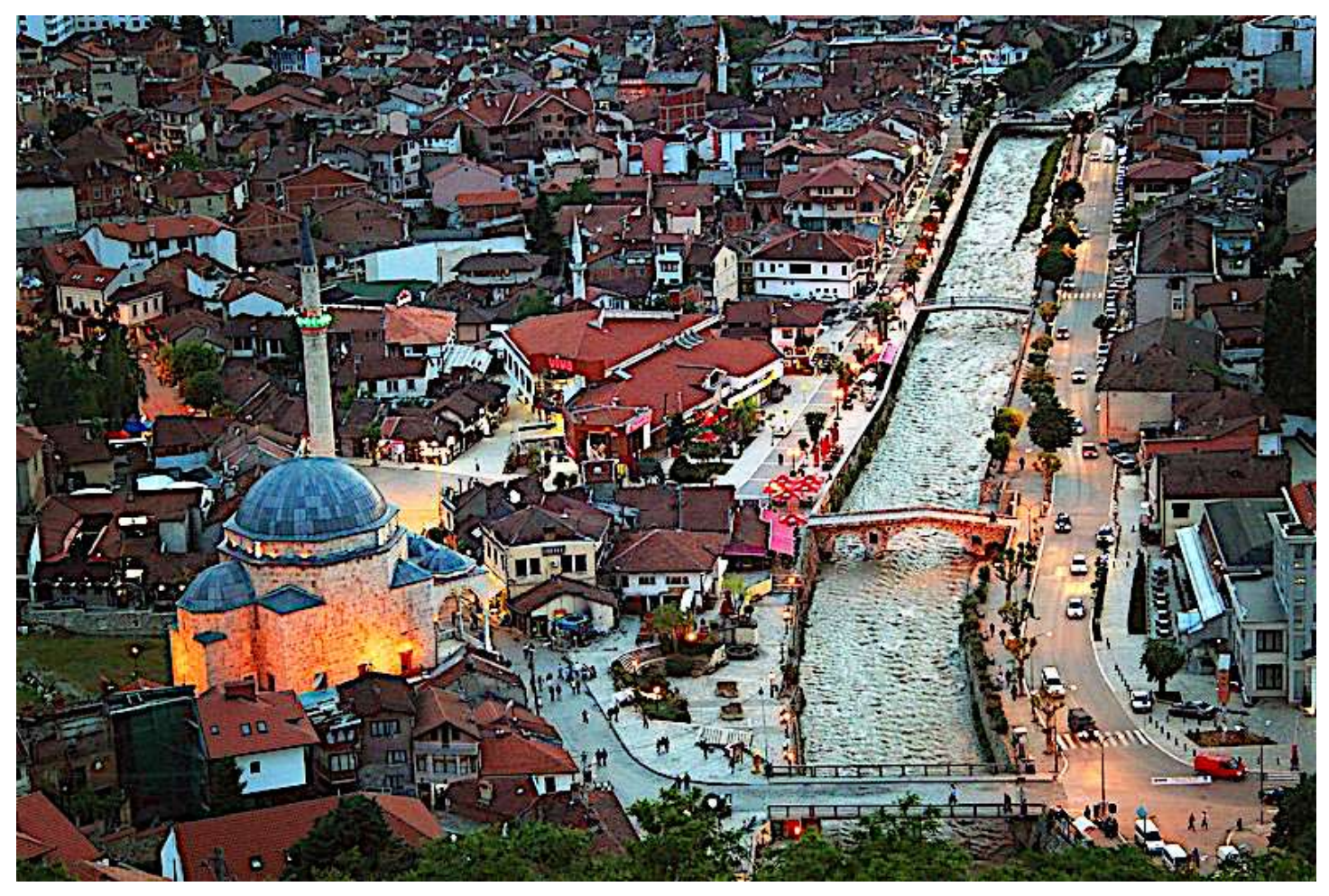

Figura 66. Prizreni. Strukturë urbane. 2012

(Burimi): Berat Hoxha. 2012. (Flickr). E licensuar nga Creative Commons Attribution ShareAlike 3.0

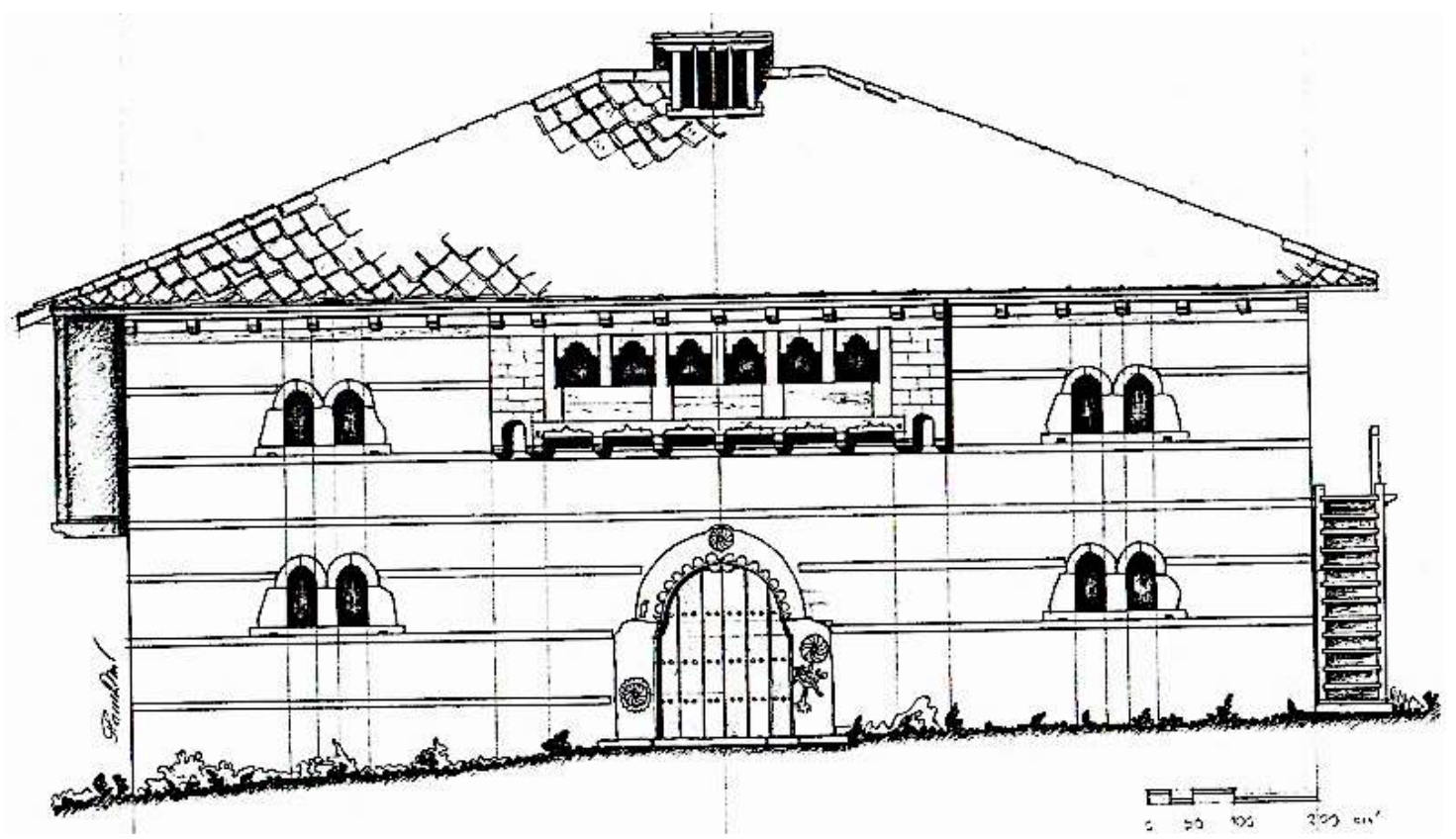

Figura 67. Kulla e Destan Shurdhajt. Strukturë arkitektonike. F. Banjë, Malishevë. (Burimi): Flamur Doli. Arkitektura vernakulare e Kosovës. Prishtinë, 2009. 
KJO FAQE ËSHTË LËNË QËLLIMISHT E ZBRAZËT! 


\section{KOMFORI}

$\mathrm{K}$ omfori i brendshëm termik i njeriut arrihet në atë rast: kur mjedisi i siguron kushtet e duhura për të shmangur ndjenjën shumë të ftohtë apo të nxehtë. Shumë faktorë ndikojnë dhe janë determinues në ambientin e knaqshëm për njeriun: temperatura e ajrit, lagështia relative e ajrit, veshmbathja, shpejtësia e rrymimit të ajrit, temperatura e sipërfaqeve kufizuese (mureve), diellosja, lagështia dhe ftohja sipas kërkesës funksionale arkitektonike.

\subsection{Komfori i brendshëm termik}

Objektivi kryesor i çdo përpjekje për të zhvilluar ndërtesa efikase të energjisë, është plotësimi i kushteve të komfortit termik, me konsum minimal të energjisë, duke përdorur projektimin e qëndrueshëm me koncept të ndërtimit bioklimatik. Një nga pikat kyçe është që të sigurohet rehatia termike tek banorët, natyrisht duke mos humbur qasjen për të reduktuar kërkesat për energji. Prandaj çdo hulumtim në temën për të vlerësuar efikasitetin e një ndërtese të caktuar, duhet marr në konsideratë kriterin e komforit termik si kusht për vlerësimin e ndërtimit, dhe të performancës... ${ }^{45}$

"Modeli më i thjeshtë i ekuilibrit termik që e konsideron tërë trupin e njeriut si një sistem të hapur ( pra, duke përfshirë frymëmarrjen dhe flukset në masë të djersës), merr parasysh nxehtësinë e cila mund të akumulohet në trupin e njeriut dhe ka formën (Ole Fanger):

$$
\Delta \mathrm{A}=\mathrm{M}-\mathrm{W}-\left(\mathrm{Q}_{\text {lëkures }}+\mathrm{Q}_{\text {respir }}\right)=\mathrm{P}-\mathrm{H}
$$

Për kushtët e ekuilibrit termik $\Delta \mathrm{A}=0$ arrihet ekuilibri termik sipas të cilit sasia e nxehtësisë që prodhohet $(\mathrm{P})$ është e barabartë me humbjet e përgjithshme të nxehtësisë $(\mathrm{H}),($ dmth. $\mathrm{P}=\mathrm{H})$. Ku janë: $\mathrm{M}$ - energjia e prodhuar nga metabolizmi, W/m²; W energjia që shpenzohet për punë mekanike, $\mathrm{W} / \mathrm{m}^{2}$; Qlëkurës - humbjet termike prej lëkurës, $\mathrm{W} / \mathrm{m}^{2}$; $\mathrm{Q}_{\text {respir }}$ - humbjet termike nëpërmjet respiracionit, $\mathrm{W} / \mathrm{m}^{2}$."46

Njeriu ka luftuar gjithmonë për të krijuar një ambient të rehatshëm. Kjo më së miri reflektohet në ndërtimin e strukturave ndërtimore gjithandej, nga historia e lashtë e deri më sot. Por çfarë është saktësisht Komfori termik? Termi është përcaktuar në standardin ISO 7730 ku deklarohet: "Është gjendja mendore e cila shpreh kënaqësinë me mjedisin nga aspekti termik." Një përkufizim që shumica e njerëzve mund të bien dakord me të, por edhe një përkufizim i cili nuk është lehtë të konvertohet në parametra fizik dhe vlera të ditëpërditshme. Komfori termik, konsiderohet të jetë së bashku me faktorët tjerë si cilësia e ajrit, e dritës dhe niveli i zhurmës kur vlerësojmë mjedisin tonë të punës.

45 Kordjamshidi, M.(2011). Green Energy and Technology. House Rating Schemes. Springer-Verlag.

46 Fejzullah Krasniqi, Rexhep Selimaj.(2014). Analiza e komfortit termik të njeriut në kushte të Kosovës 
Nëse ne nuk do të ndjehemi të rehatshëm në ambientin e punës, performanca jonë në vend pune do të pësojë në mënyrë të pashmangshme. Andaj, rehatia termike ka gjithashtu një ndikim të madh në efikasitetin tonë gjatë orarit të punës. Metabolizmi njerëzor kërkon një temperaturë të trupit midis 35 dhe $40{ }^{\circ} \mathrm{C}$, për të cilat konsiderohet se $37^{\circ} \mathrm{C}$ është normalja. Temperatura e lëkurës është zakonisht në mes të 31 dhe $34{ }^{\circ} \mathrm{C}$. Në kushte optimale, temperatura e mjedisit rrethues duhet të jetë më pak se temperatura e lëkurës. Variabla më e rëndësishme për të përcaktuar komoditetin e njeriut është temperatura e ajrit. Megjithatë ky nuk është treguesi i vetëm. Një numër faktorësh tjerë po ashtu ndikojnë në proceset e ndryshme të shkëmbimit të ngrohjes në sipërfaqen e trupit të cilat ndikojnë në ndjesinë e rehatisë (Szokolay, 1980).

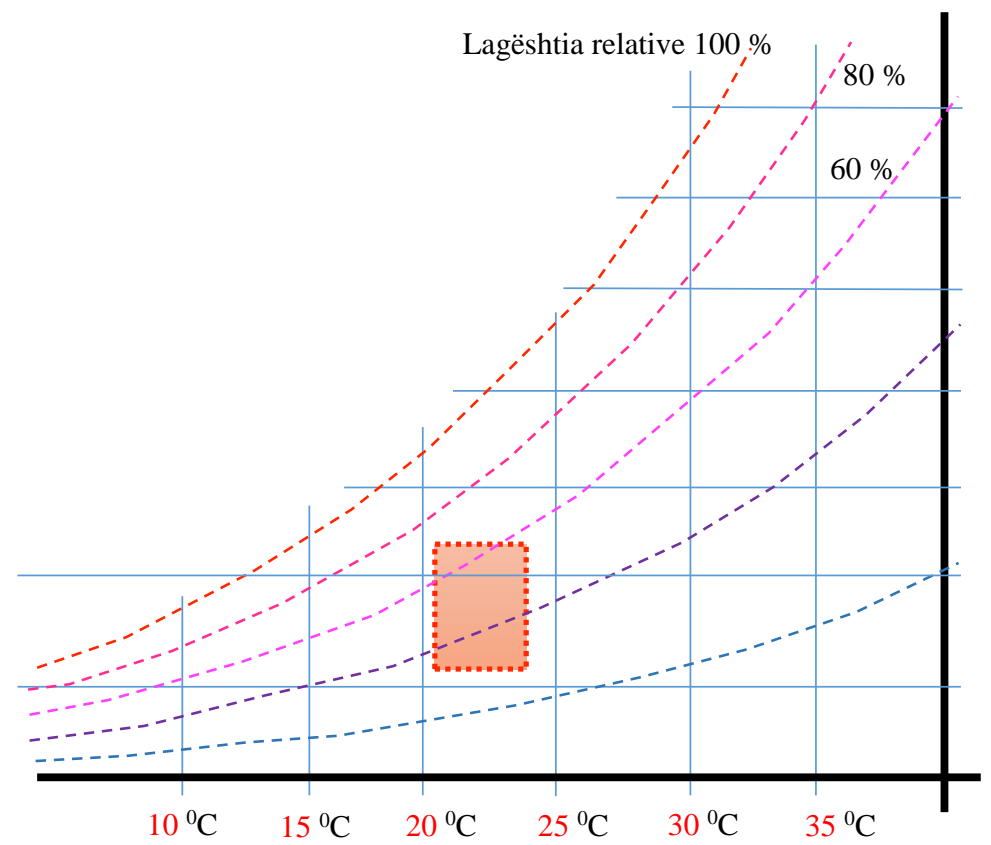

Figura 68. Diagrami i zonës së komforit.

(Burimi): Bujar Bajçinovci, 2017. Quaestiones Geographicae, 2017.

Faktorët determinues janë të ndarë në dy grupe: Mendore "jo-klimatik" dhe faktorëve mjedisor "klimatik". Parametrat kryesore mjedisore janë identifikuar si:

1. Temperatura

2. Lagështia

3. Shpejtësia e ajrit

4. Rrezatimi (Parsons, 2003)

Përveç kësaj, ka edhe faktorë të tjerë të përfshirë, të tillë si shkuji, një ndryshim në lartësi apo në vertikale, në mes të temperaturës së kokës dhe këmbëve apo një ndryshim temperatural asimetrik rrezatues. Rritja e temperaturës gjithmonë shkakton një ndryshim korrespondues me ndjesinë termike. Ndikimi i lagështisë relative në komforin termik njerëzor është veçori komplekse. Ka efekt të rëndësishëm në rehatinë termike nëse temperaturat janë shumë të larta apo të ulëta. Realisht, në bazë të hulumtimeve është treguar se deri cca $27{ }^{\circ} \mathrm{C}$ një person i ulur nuk mund të përjetojë ndonjë ndryshim potencial në mes lagështisë relative prej 30\% deri 80\% (Givoni, 1998). 


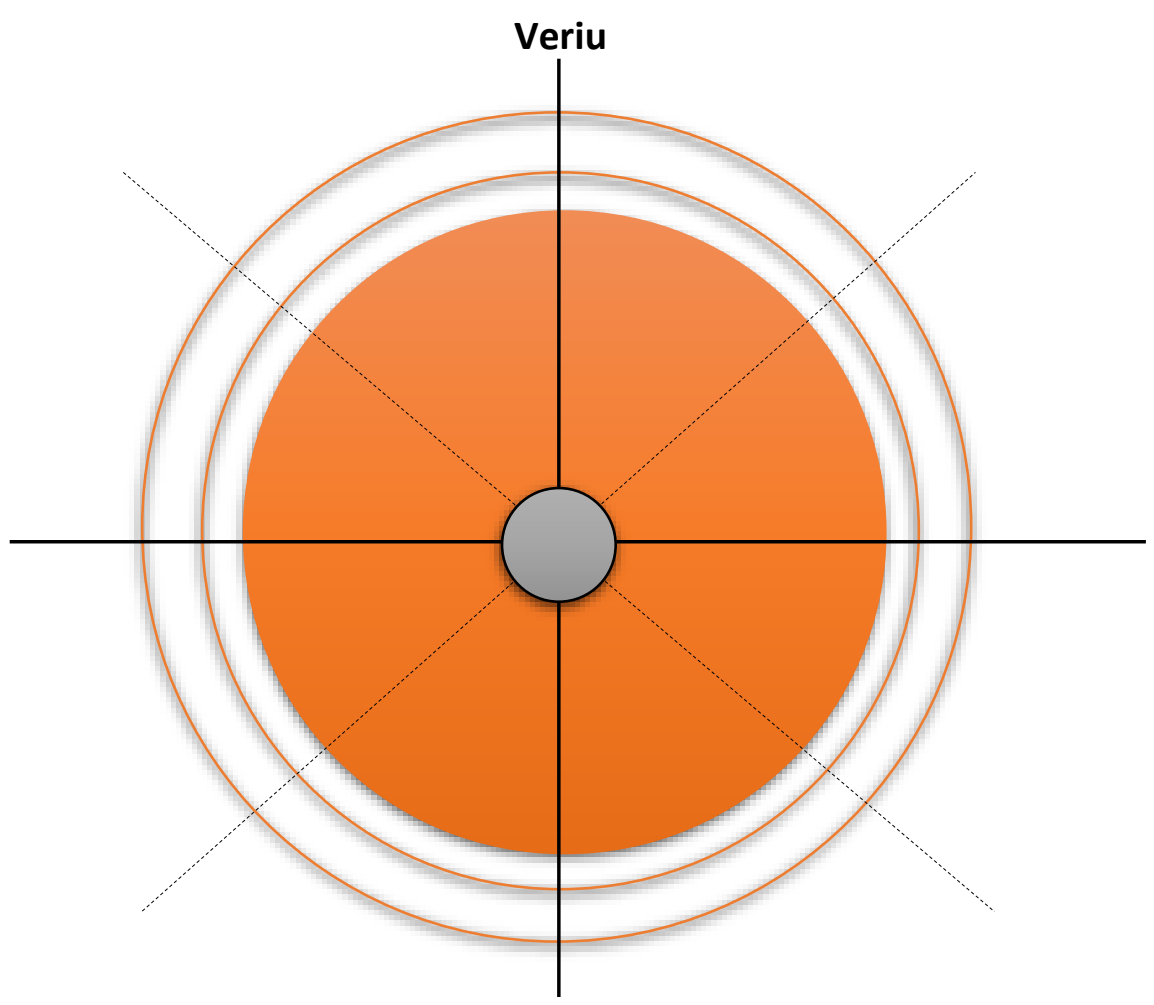

Figura 69. Trëndafili i erërave

(Burimi): Bujar Bajçinovci, 2015.

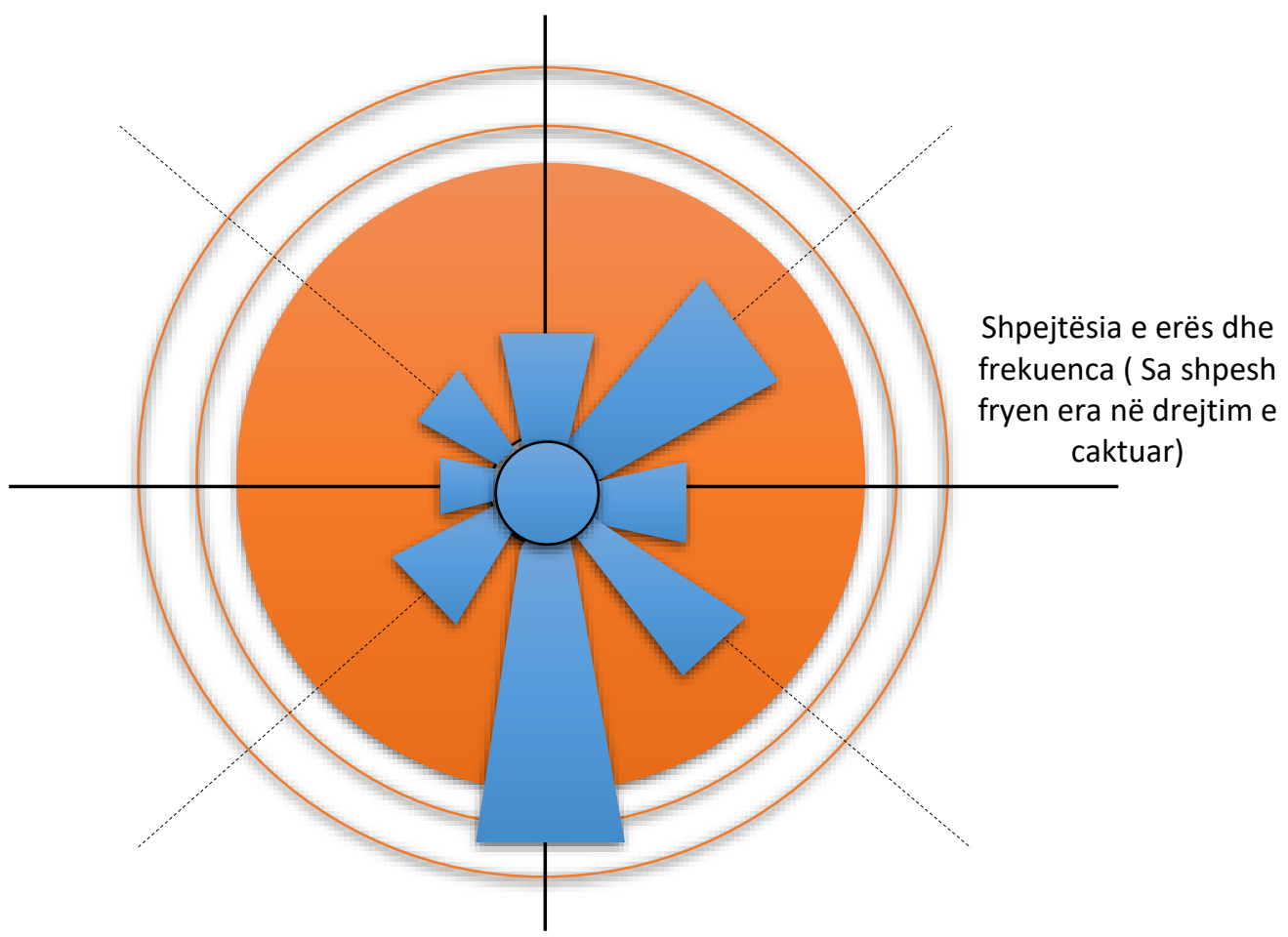

Figura 70. Trëndafili i erërave për Prishtinë (Burimi): Bujar Bajçinovci, 2015. 


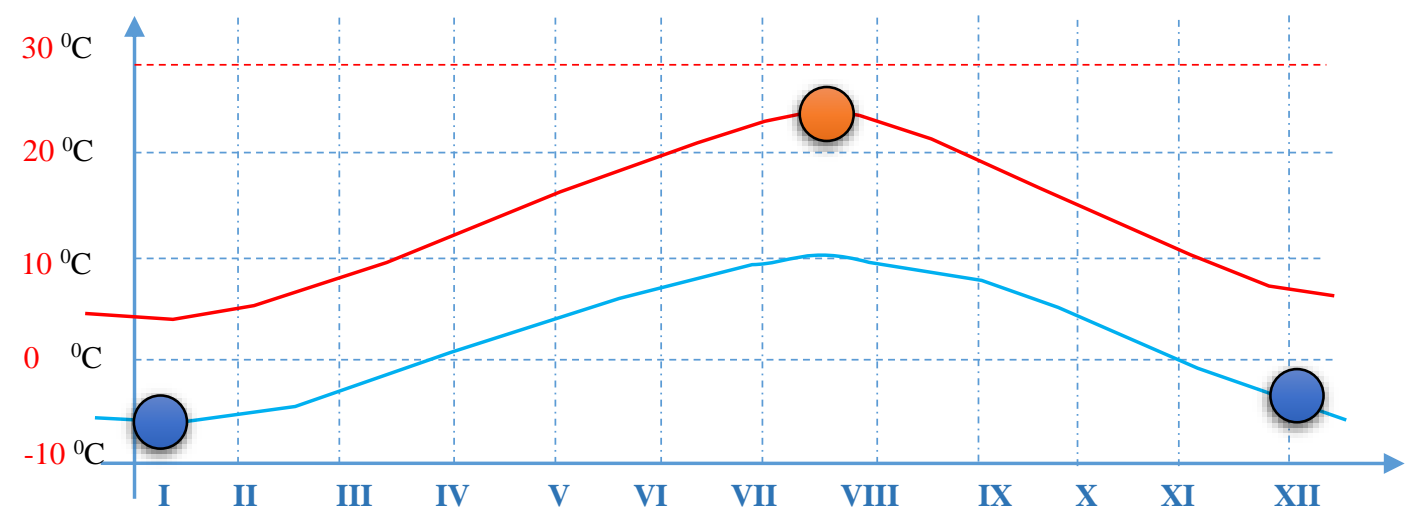

Figura 71. Diagrami i temperaturave mesatare (Max. dhe Min.) mujore për Prishtinë. (Burimi): Bujar Bajçinovci, 2017.

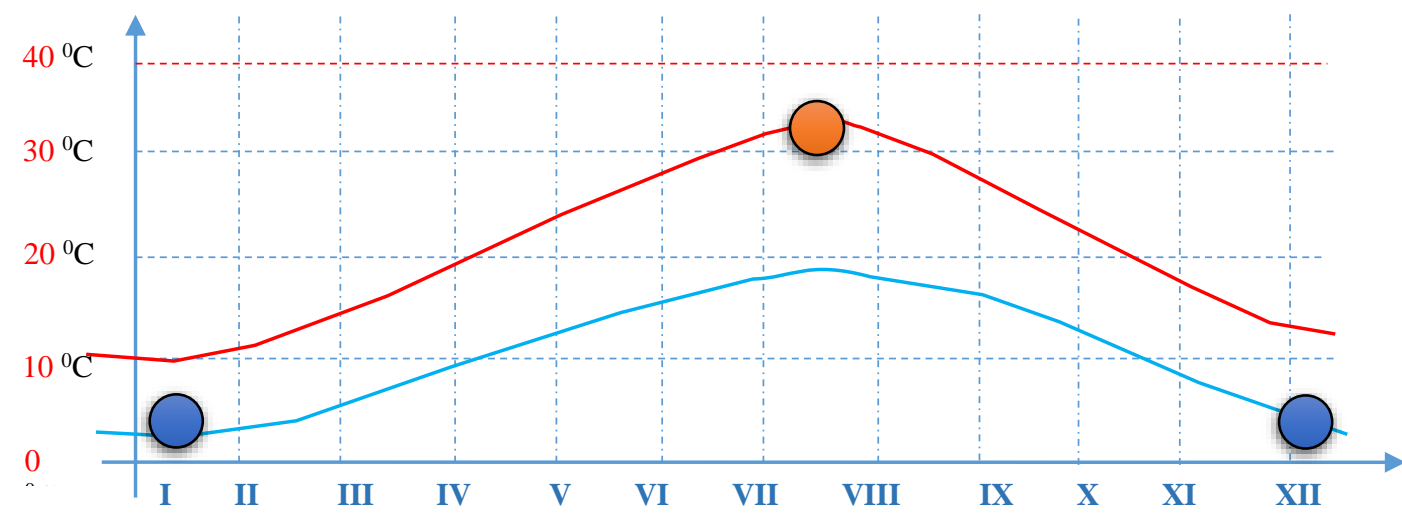

Figura 72. Diagrami i temperaturave mesatare (Max. dhe Min.) mujore për Ulqin. (Burimi): Bujar Bajçinovci, 2017. Quaestiones Geographicae, 2017.

Në një temperaturë të rehatshme, perspirimi nuk është i veçuar posaçërisht, por mekanizmi i shpërndarjes së ngrohjes është i rëndësishëm në temperatura të larta. Shkalla e avullimit të djersës varet nga lagështia absolute e rrethinës. Përqindje të larta të lagështisë (mbi $12 \mathrm{~g} / \mathrm{kg}$ ) mund të shkaktojnë ndjesi të pakëndshme për shkak të kufizimit të avullimit dhe si rrjedhojë paraqitet efekti i ftohjes. Lagështia e ulët (zakonisht më pak se $4 \mathrm{~g} / \mathrm{kg}$ ) mund të shkaktojë tharje të mukozës.

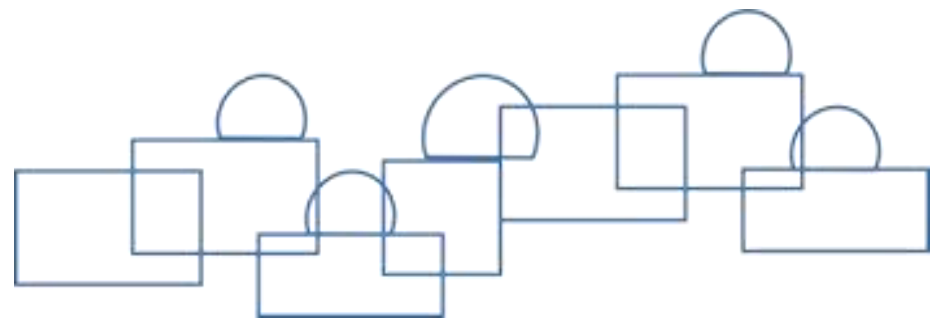




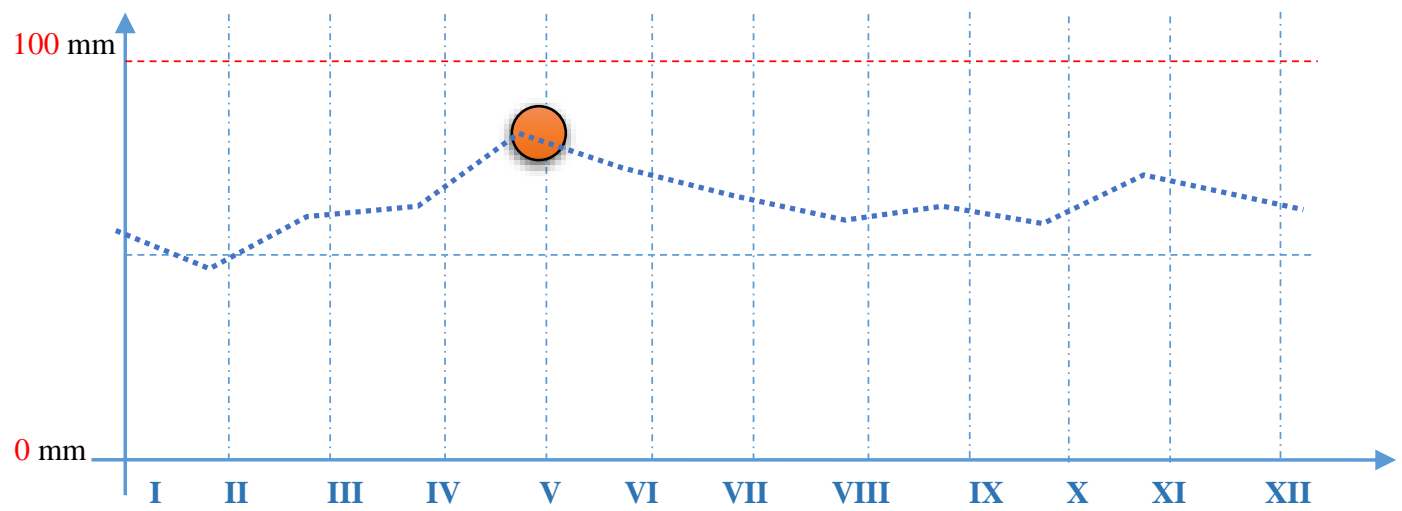

Figura 73. Diagrami i reshjeve mesatare mujore për Prishtinë.

(Burimi): Bujar Bajçinovci, 2017.

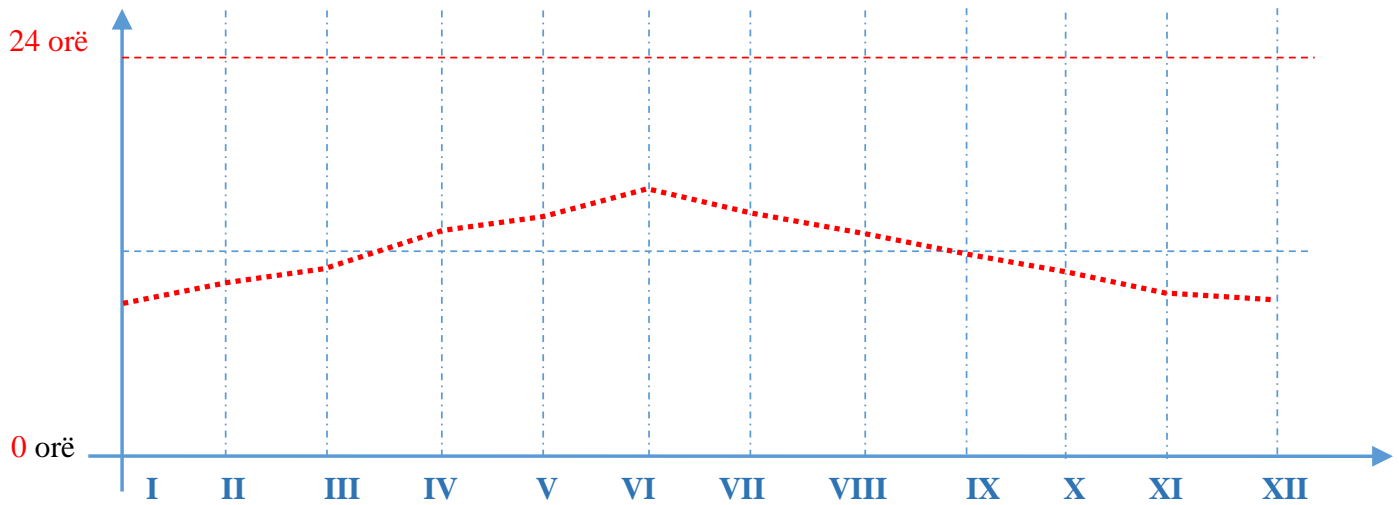

Figura 74. Diagrami i ditëve me diell, (orë në ditë), mujore për Prishtinë. (Burimi): Bujar Bajçinovci, 2017.

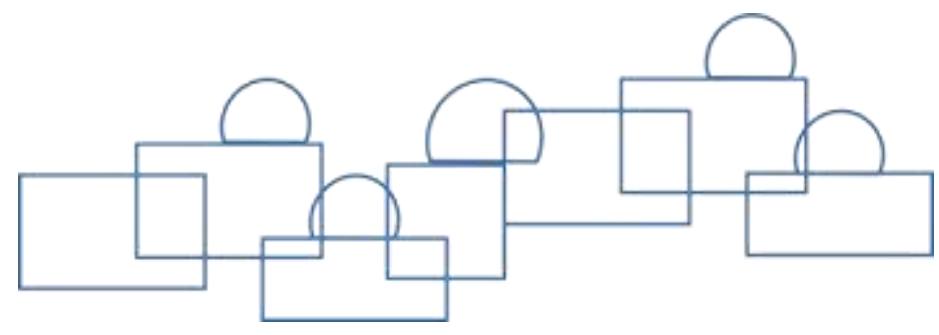




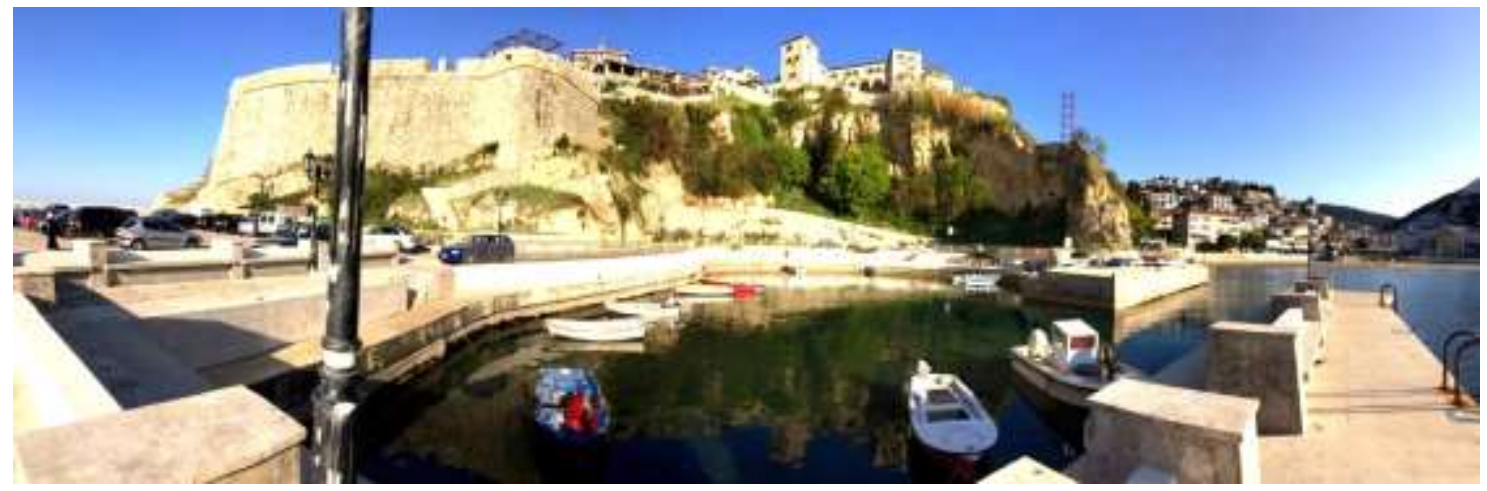

Figura 75. Ditë me diell, Ulqin 2017

(Burimi): Bujar Bajçinovci, 2017.

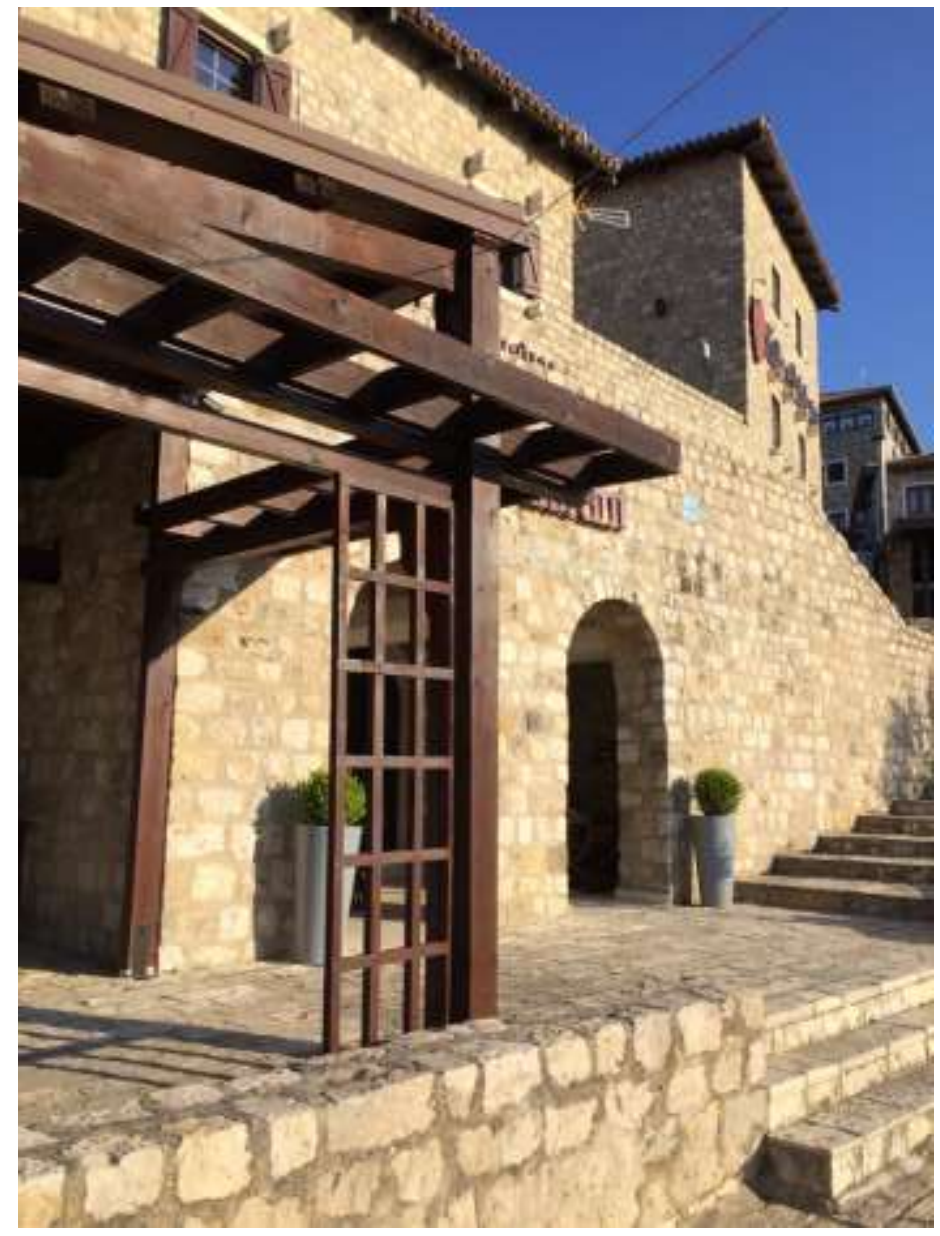

Figura 76. Strukturë urbane, e vjetra dhe e reja. Ulqin 2017.

(Burimi): Bujar Bajçinovci, 2017.

Andaj, efekti i lagështisë relative në komforin termik nuk mund të injorohet në një atmosferë, ku lagështia relative (LR) është më e lartë shumë kohë, sesa vlerat normale apo optimale. Lëvizja e ajrit përreth trupit transferohet me konveksion duke ngrohë apo duke shkaktuar ftohje. 
Ajri që rrethon trupin tonë prodhon një shtresë të hollë izolimi rreth trupit. Lëvizja e ajrit zvogëlon efektin e këtij izolimi, duke reflektuar me ndjesi të efektit ftohës. Andaj, është një mekanizëm i rëndësishëm për zvogëlimin e nxehtësisë së gjeneruar nga trupi, veçanërisht kur niveli i lagështisë është i lartë. Rritja shpejtësisë së ajrit, e ulë sasinë e lagështisë së mbajtur në ajër rreth trupit dhe rritë sasinë e avullimit (ASHRAE, 1981).

Realisht gjatë projektimit, efekti i dobishëm i shpejtësisë së ajrit nuk duhet të injorohet në një model të qëndrueshëm, veçanërisht kur kemi të bëjmë me një klimë me lagështi. Për më tepër, është një pikë kyçe në programimin apo hartimin e detyrës projektuese për ndërtesa. Qasja dhe shfrytëzimi i parimeve pasive, apo i një strategjie të veçantë për të siguruar qarkullimin natyror të ajrit në hapësirat e brendshme duhet të jetë një nga prioritetet e projektimit, për ndërtesa të cilat kanë për lokalitet një klimë të moderuar me lagështi relative të lartë.

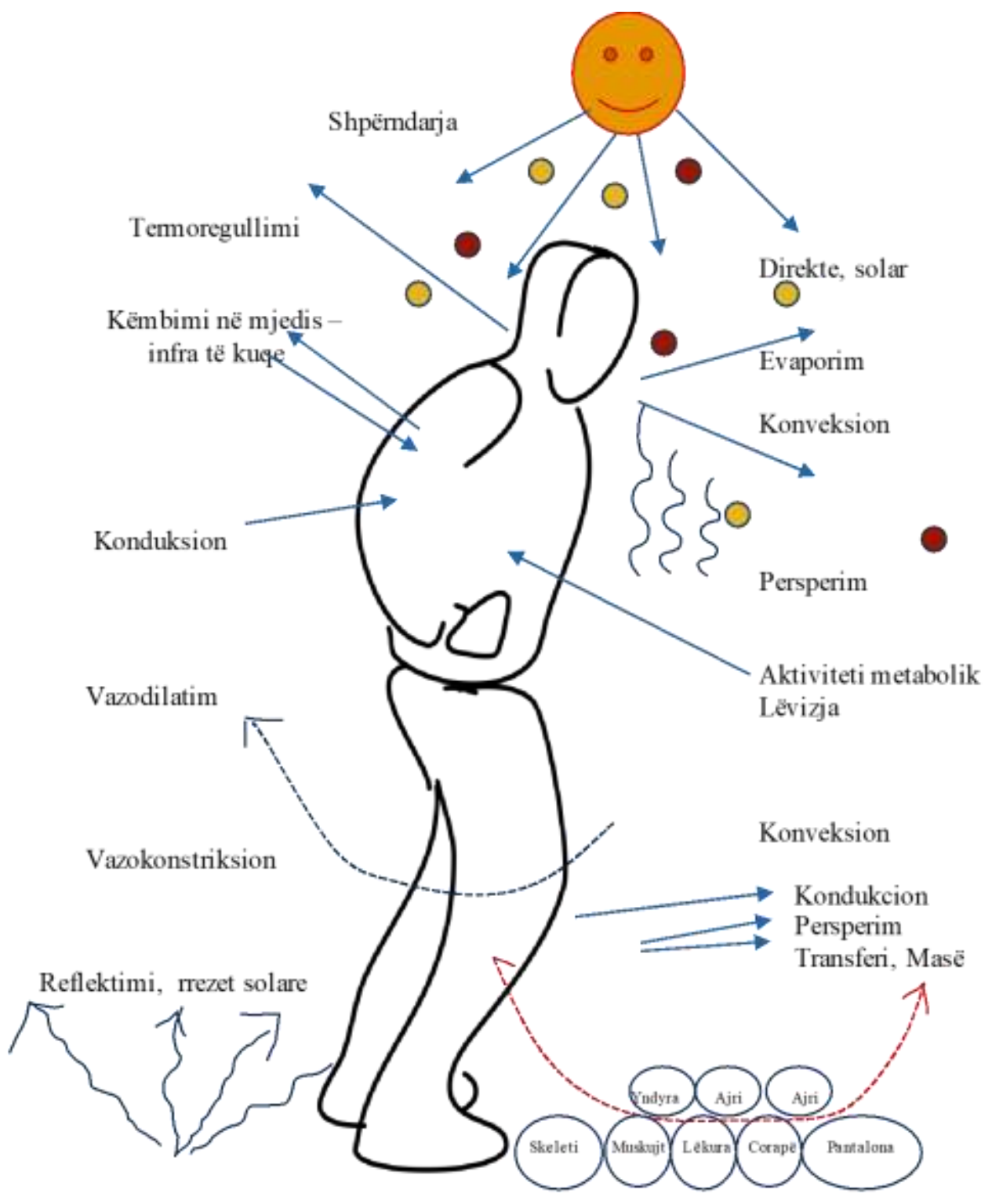

Figura 77. Analiza: perspirimi, evaporimi dhe ndikimi solar tek njeriu (Burimi): Bujar Bajçinovci, 2015. 
Metabolizmi bazal i referohet sasisë minimale të energjisë së nevojshme për mbajtjen e funksioneve vitale të organizmit, kur organizmi është në gjendje të pushimit të plotë. E tërë kjo energji shpenzohet për funksionet vitale të organizmit, disa prej këtyre proceseve janë frymëmarrja, qarkullimi i gjakut, termorregullimi, funksioni i trurit dhe i sistemit nervor.

Metabolizmit bazal është përgjegjës për rreth 60 deri $70 \%$ të kalorive që harxhojmë për çdo ditë, ndërsa ndikohet nga disa faktorë, si:

1. Faktorët gjenetikë

2. Ndërtimi i trupit

3. Mosha

4. Pesha

5. Gjinia

6. Përqindja e indit dhjamor

7. Stërvitja dhe aktiviteti

8. Gjëndrat

9. Sëmundjet e ndryshme

Është me rëndësi të veçuar të theksohet raporti i shpenzimit të energjisë hyrëse dhe energjisë dalëse në aritjen e ekulibrit energjetik. Siç shifet në fig. 77-A, vazhdimisht duhet të jetë në proporcion energjia hyrëse dhe ajo dalëse në mënyrë që ta arrijmë ekuilibrin energjetik.

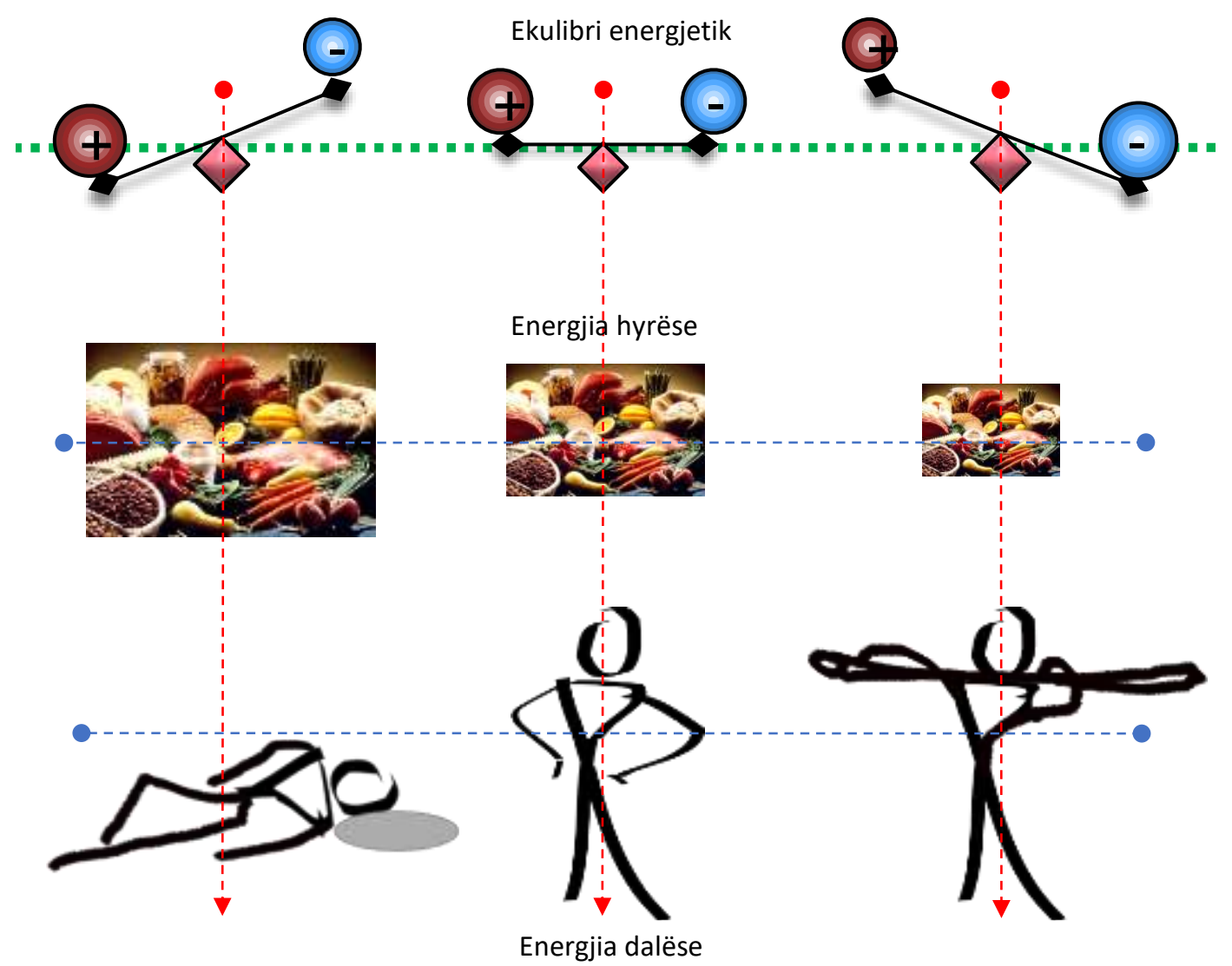

Figura 77-A. Ekuilibri energjetik tek njeriu. Aktiviteti dhe ushqimi (Burimi): Bujar Bajçinovci, 2015. 
Ndjesia termike, e përjetuar nga një trup në një mjedis, përjetohet ndjeshëm nga këmbimi i nxehtësisë në mes të trupit të njeriut dhe sipërfaqes e cila e rrethon. Kjo kontribuon në më shumë se $30 \%$ e të gjithë shkëmbimeve termike (La Gennusa et al., 2005). Temperatura nga rrezatimi, përdoret për të përcaktuar temperaturën mesatare e të gjitha sipërfaqeve në një hapësirë të caktuar në të cilën trupi është i ekspozuar. Temperatura nga rrezatimi është dy herë më e rëndësishme se sa temperatura "llambë e thatë" (Dry Bulb) për njerëzit e veshur lehtë. Olgyay (1963) në kartelën e tij bioklimatike tregon ndërveprimin e katër faktorëve kryesorë të mjedisit për komforin termik, kjo tabelë megjithatë ka qenë e rishikuar dhe është bërë më e komplikuar në studimet e mëvonshme më të sofistikuara. Mirëpo, duhet njohur standardin e aprovuar të ASHRAE. Ndërveprimi në mes të katër ndryshoreve klimatike është ajo që e bën një mjedis të brendshëm të rehatshëm ose të pakëndshëm nga aspekti i komforit. Givoni (1998) vë në dukje se gjendja e diskomforit nga aspekti i ngrohjes brenda ndërtesave është i lidhur zakonisht me "temperaturën e mjedisit" dhe shpejtësisë së ajrit mbi trup. Temperatura e mjedisit është efekti i kombinuar i temperaturës së ajrit.

Andaj, temperatura e mjedisit duket të jetë një tregues më i përshtatshëm se vetëm temperatura e ajrit, si një nga faktorët për vlerësimin e shkallës së komoditetit dhe kushtet e klimës së brendshme të një ndërtese. Një nomenklaturë e zonave të veçanta ku duhet të kemi kujdes për konfliktet midis masave pasive, uljes të energjisë dhe komforit janë të veçuara si më poshtë:

- Duhet shmangur mos ngrohjen e hapësirës (edhe fqinje), duke siguruar trupa të mjaftueshëm ngrohës me kapacitet optimal.

- Duhet shmangur mbingrohjen e hapësirës në raport me nivelin e aktivitetit të banuesit dhe të veshmbathjes (CLO).

- Duhet shmangur humbjen e ngrohjes lokale nga shkuji poshtë/lartë, për shkak të afërsisë me zona të ndryshme funksionale.

- Duhet pasur kujdes në pozicionimin e trupave ngrohës në dhomë, përdorimi i shumëfishtë apo i ulët i emetuesve të nxehtësisë shmang faktorin e optimizimit.

- Në ndërtesat me ajër të kondicionuar, duhet pozicionuar drejtë daljen e grilave për shpërndarje të mirë të ajrit.

- Duhet shmangur ngrohjen e hapësirës nga diellosja, duke përdorur mbrojtje nga drita. Duhet siguruar ventilim të mjaftueshëm natyror.

- Nuk duhet pasur konflikt projektues në mes ngrohjes së ambientit, dhe maksimizimit të përfitimeve nga ndriçimi natyror dhe rrezatimi diellor.

- Duhet pasur shfrytëzim efikas i resurseve energjetike, duke impenjuar në maksimum principet bioklimatike gjatë projektimit të modelit në fillim, dhe gjatë finalizimit. 


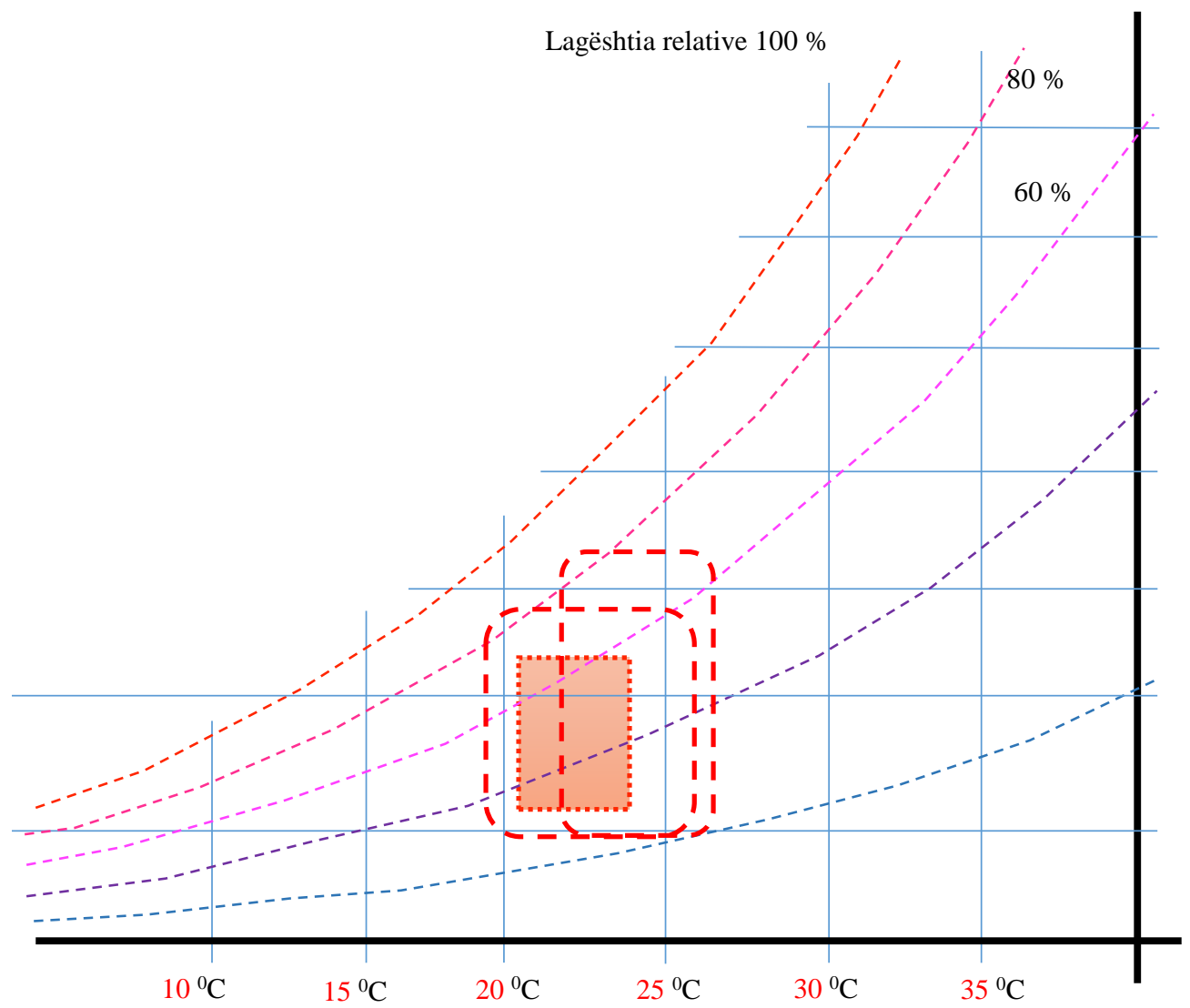

Figura 78. Diagrami i zonës së komforit, zonat toleruese dhe individuale (Burimi): Bujar Bajçinovci, 2017.

\subsubsection{Komfori, si fenomen subjektiv}

- Komfori është një ndjenjë, i një natyre të përcaktuar nga subjektiviteti personal.

- Komfori ndikohet nga faktorë të ndryshëm (fizik, fiziologjik, psikologjik).

- Komfori është një reagim ndaj mjedisit.

Pra, këto tri pika nuk janë për tu debatuar, ashtu siç e definon thënia "De gustibus non est disputandum" një maksimë e vjetër Latine e sprovuar ndër shekuj! Andaj, rehatia termike është një përvojë subjektive, është e një rëndësie të veçantë sepse kjo ndjenjë ka të bëjë me qëllimin kryesor të dizajnit arkitektonik. Një produkt në vetvete nuk mund të jetë i rehatshëm, por, duke funksionuar bëhet komfor, ose jo. Shfrytëzuesi vendos nëse është komfor apo jo duke e përdorur hapësirën/produktin. Kjo paksa e komplikon projektimin në realizimin e rehatisë, sepse nuk na është e njohur se si çdo individ do të reagojë, në produktin e shqyrtuar. Për shembull, nga përditshmëria jonë: një automobil më katër pasagjer në një rrugëtim të gjatë, nga prapa pasagjeri 3 dhe 4 e dëshirojnë komforin e ulëses së parë me më shumë hapësirë. Këto dëshira e bëjnë paksa të komplikuar realizimin projektues për të gjithë, dhe është një nga arsyet pse projektimi i produkteve ergonomikë është i vështirë. ${ }^{47}$

47 Vink, P. (2005). Comfort and Design. CRC Press. 


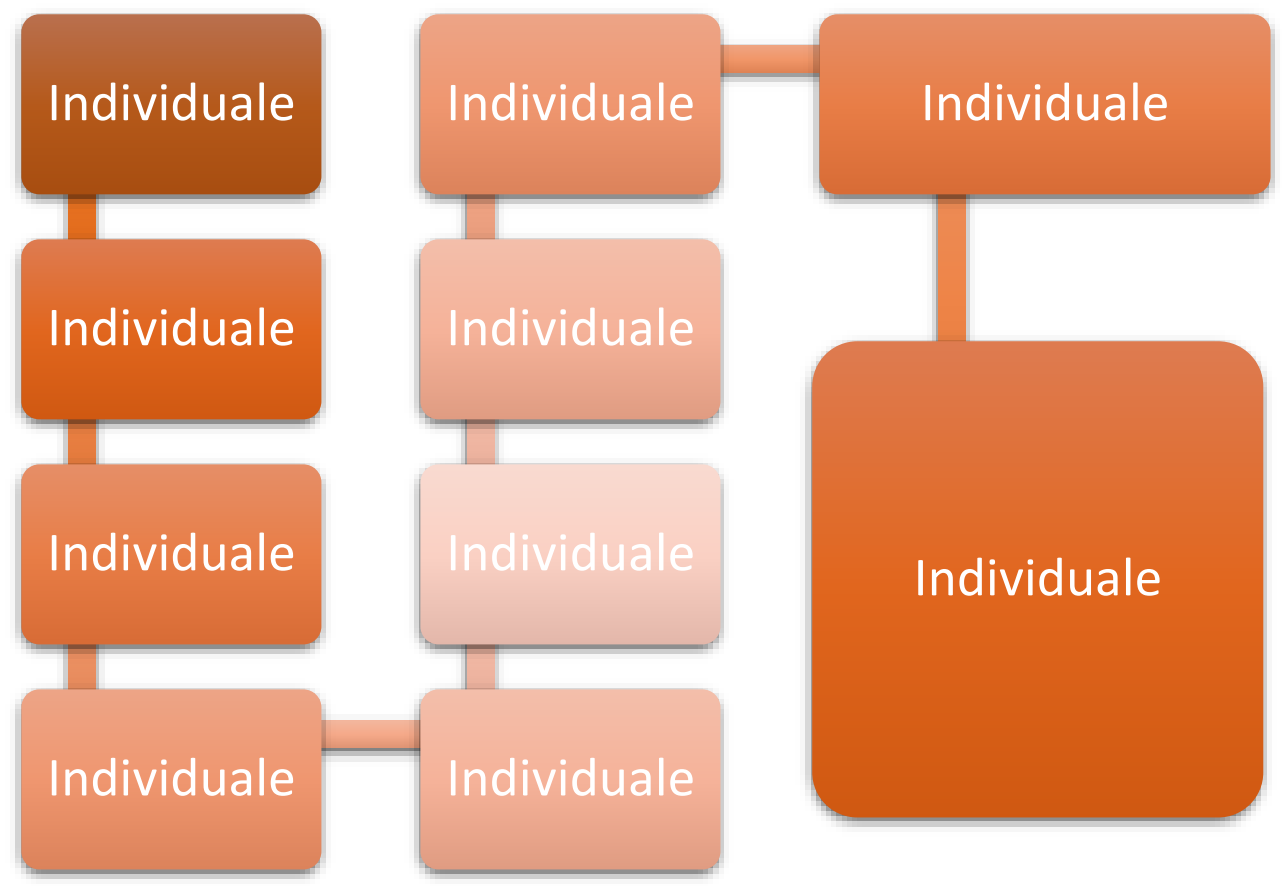

Figura 79. Komfori, ndjenjë e një natyre të përcaktuar nga subjektiviteti personal. (Burimi): Bujar Bajçinovci, 2017.

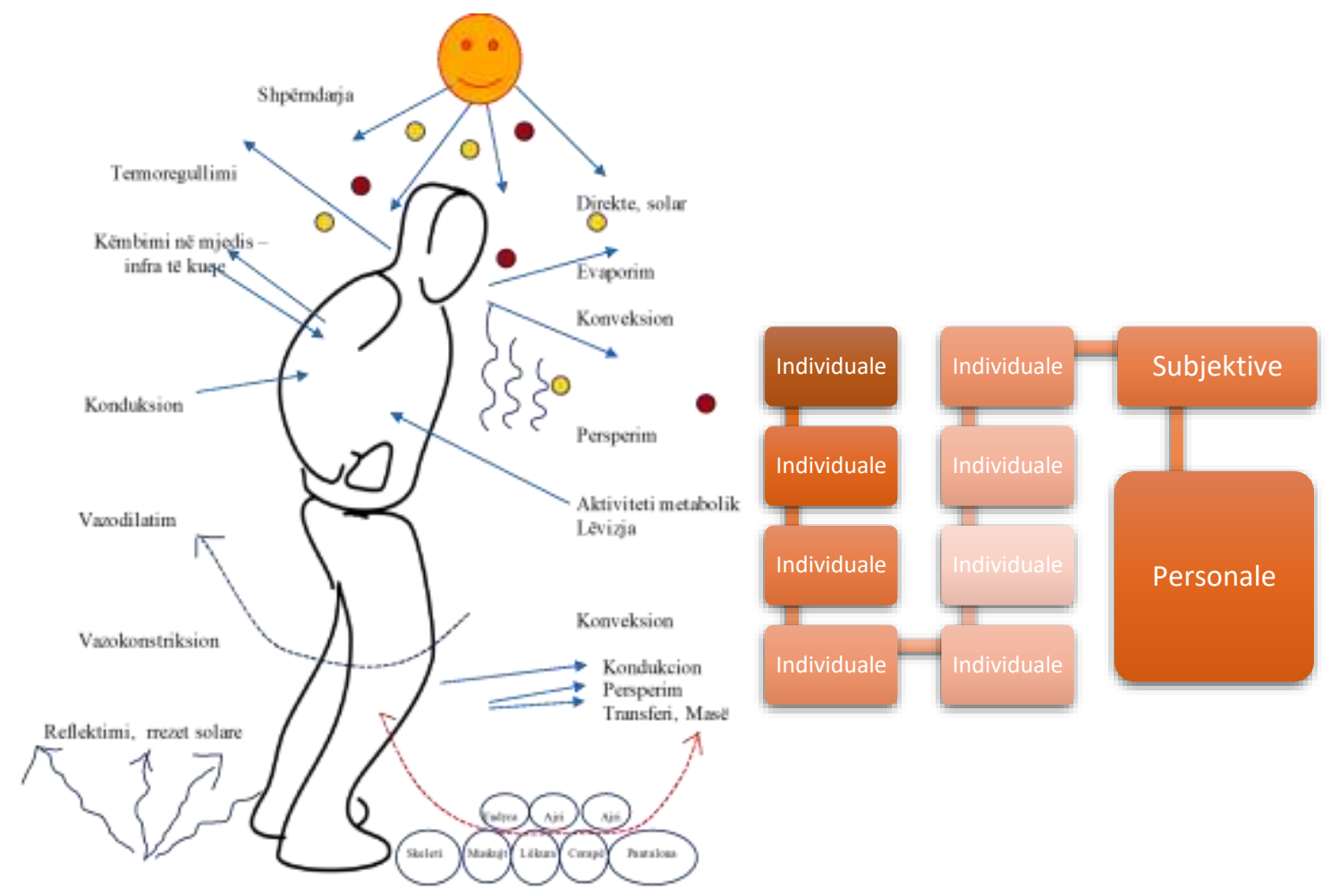

Figura 80. Kursimet energjetike, kriteriume komforti: Tradicionale dhe të avancuara (Burimi): Bujar Bajçinovci, 2017. 


\subsection{Modeli i komforit}

Komfori si koncept mund ti ketë tri gjendje:

1. Diskomfort. Personi ka përvojë jo të kënaqshme.

2. Pa deklarim. Personi apo pjesëmarrësi nuk është në dijeni të shqetësimit.

3. I kënaqshëm, komfort. Personi ka gjendje të rehatshme.

Modeli i prezantuar në Fig. 81 është një thjeshtësim i një modeli më të detajuar të zhvilluar nga (Looze et al. 2003). Gjendja mendore e individit është e paraqitur në anën e djathtë të modelit: komfort, pa deklarim dhe diskomfort. Përvoja jonë dhe gjendja e mendore, i rehatshëm apo jo reflektohet pjesërisht për shkak të ndjeshmërisë subjektive: (A) kujtesa e rehatisë, përvoja përcakton pritjet tona për një produkt bazuar në atë se çfarë kemi përdorur, (B) organizmi i ynë mund të jetë i ngacmuar apo i relaksuar, gjendje e cila ndikon në disponimin tonë, dhe $(\mathbf{C})$ natyrisht e gjithë kjo ndodhë në një mjedis të caktuar.

Përvoja e komfortit apo diskomforit ndikohet edhe nga stimuj të jashtëm. Veçoritë janë të paraqitura në anën e majtë të figurës. Për shembull, shqisat tona marrin vlera dhe përjetime, pas kësaj të dhënat apo proceset përpunohen dhe peshohen me gjendje finale mendore. ${ }^{47}$

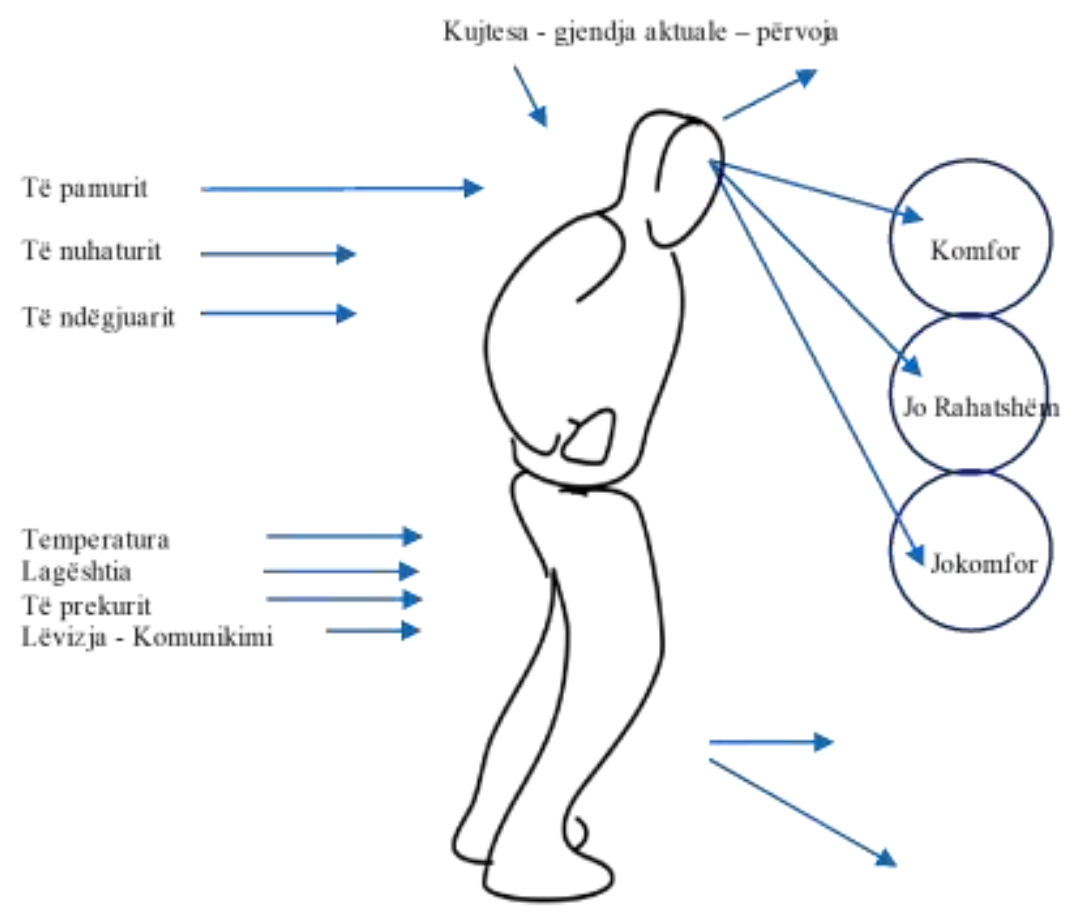

Figura 81. Të përjetuarit e komforit të brendshëm.

(Burimi): Bujar Bajçinovci, 2015. 
Bazuar në këto procese, një produkt apo një mjedis shfaq kënaqshmëri, jo kënaqshmëri, ose gjendje neutrale, që ne jemi të vetëdijshëm. Ndjesia apo gjendja mendore është e ndikuar nga mjedisi dhe ky është një faktor i rëndësishëm. Një reflektim nga analizat praktike është se një produkt duhet gjithmonë të testohet në një mjedis që është sa më afër realitetit të jetë e mundur apo kushteve të punës.

\subsection{Elementet e modelit të komforit}

Do ti studiojmë elementet e modelit të komforit veçmas, por në realitet këto elemente nuk janë të ndara gjatë procesit të projektimit. Nuk dihet se si elementet janë të lidhura me njëra tjetrën dhe çfarë kontributi secili element ndikon gjatë përvojës së përgjithshme. Kjo është arsyeja pse është e rëndësishme që të analizohet situata dhe të kryhen eksperimente në fazën e projektimit, në një mjedis sa më të afërt me gjendjen mendore apo situatën.

1. Historiku ndikon në përvojë, kjo është e rëndësishme për një produkt. Produktet duhet të jenë të paktën në nivelin e komforit për tu përdorur. Ne gjithmonë e vlerësojnë pamjen dhe stilin e një produkti me të kaluarën tonë si një referencë. Kjo do të thotë se një projektues duhet ta ketë parasysh historinë dhe sjelljen shoqërore e grupit të shqyrtuar, apo target grupit. Andaj, një objekt i projektuar drejtë duhet të përformojë ambient të rehatshëm dhe komotë, sidomos kur kemi të bëjmë me komforin fondamental dhe parametrat si: temperatura, lagështia dhe rrymimi i ajrit.

2. Trupi ynë ndikohet nëse përjetojmë siklet apo rehati. Pas disa orë të ushtrimeve të rënda fizike, një vend i qetë është më së i rehatshëm. Picard (1997) tregoi në hulumtime se emocionet, ndjenjat dhe humori luajnë një rol të konsiderueshëm në mënyrën se si dikush e vlerëson një produkt. Mjedisi dhe situata, ndikojnë në gjendjen mendore të njerëzve.

3. Të pamurit ndikon edhe në përvojat tona. Informacioni vizual luan një rol të madh, është përshtypja e parë e rehatisë. Në botën e dizajnit, informacioni vizual është më së i rëndësishëm, idetë e para komunikohen shpesh vizualisht (Lugt 2001), edhe më vonë në procesin e projektimit. Është e rëndësishme të kuptohet se komfori nuk ndikohet vetëm nga stili apo pamja. (Bronkhorst et al., 2001) tregon se në testin e 49 punëtorëve me përvojë në zyrë, për ti vlerësuar 1 nga 4 karriget të bazuara nga informacionin vizual (një karrige kafe tradicionale). Në kundërshtim me atë që pritej, kjo karrige është vlerësuar pozitivisht, pasi në fakt ka qenë duke u përdorur, që një kohë! Andaj, përvoja dhe kujtesa nga njëherë luajnë rol vendimtar.

4. Shqisa e të nuhaturit gjithashtu ka një ndikim. Autorë të ndryshëm (Theimer, 1982) konkludon se era ndikon në përvojat tona, dhe kryesisht nuk jemi të vetëdijshëm për këtë efekt. Kjo ndikon edhe në aktivitetin tonë, qëndrimin dhe sjelljen. Në disa raste ne të gjithë e dimë se, kur i afërmi është i ndyrë, ne padashur e lëvizim trupin tonë në anën e kundërt për ta shmangur erën. Ashtu si me veçori të tjera, çdo person do të reagojë ndryshe në erë. 
5. Zhurma, zëri është një lloj ndikimi që mund të ndikojë pozitivisht ose negativisht në komfort. Zhurma e ndonjë makine duke punuar mund të çojë në shqetësim (Vink et al. 2001), ndërsa zhurma e një Harley Davidson, mund të jetë një lloj muzike për disa të tjerë.

6. Temperatura dhe lagështia janë të lidhura me komforin. Duke kërkuar për rehati për ndonjë vend turistik, duke kërkuar në internet, ne kryesisht e vlërësojmë temperaturën dhe klimën. Një klimë e këndshme shpesh nuk vihet re, por një temperaturë e lartë apo e ulët tërheq vëmendjen dhe perceptohet si shqetësim. Sipas Carrier, (www.carrier.com, 2001) një nga prodhuesit më të mëdhenj të sistemeve të cilësisë së ajrit në objekte: cilësia e ajrit të brendshëm është arsyeja më e rëndësishme pse kontratat me qira nuk janë zgjatur për zyra. Kjo sidoqoftë nuk është një informatë ekskluzive vendimtare, mirëpo tregon për rëndësinë e veçorisë.

7. Goossens et al. (2002), kanë bërë hulumtime mbresëlënëse. Ata treguan se pjesëmarrësit apo participantët janë në gjendje të perceptojnë dallimet e vogla të presionit, dhe mund të përkthehen në diskomfort. Një qilim i trashë përjetohet si diçka ndryshe nga një dysheme betoni, nën këmbët tona.

8. Aktiviteti dhe lëvizjet e përcaktojnë nëse mjedisi gjithashtu mund të çojë në diskomfort apo edhe veglat e ndryshme të punës. Në afat të gjatë kjo mund të rezultojë në çrregullime muskulore apo skeletore (Proper et al 1999). Dhimbje qafe dhe dhimbjet në supe janë gjetur pothuajse në një të katërtën e punëtorëve Evropianë. Jo vetëm që rezulton me faktorin njeri, por edhe rritë shpenzimet. Në përgjithësi lëndimet muskulore/skeletore kushtojnë mjaft Euro në vit (Bongers et al. 2000). Problemi është mjaft i madh, kjo është një mundësi për projektuesit: që produktet, hapësirat apo veglat e punës të mos shkaktojnë lëndime muskulore apo skeletore. Me fjalë të tjera, duhet përdorur modele gjatë procesit të projektimit për të shmangur lëndimet apo diskomforin. (Ekstrakt) ${ }^{47}$

Në projektimin e një hapësire apo të një produkti, të gjitha modalitetet shqisore duhet të merren parasysh. Kjo mund të jetë një punë shumë e madhe. Kohëve të fundit, në Delft University (Teknologjisë), janë bërë disa studime për të vlerësuar kontributin e mundshëm të çdo modaliteti ndaj përvojave të përgjithshme të produktit (Schifferstein dhe Cleiren 2004). Informacioni vizual, dhe ai i prekjes, duket të jenë më të rëndësishmet dhe sipas hulumtimeve rezultojnë me kujtime të qarta ndaj ngjarjeve të kaluara.

\subsection{Komfori higjienik}

Në arkitekturë, higjiena është një përcaktues i shëndetit dhe një nga detyrat parësore në përmirësimin e performancës së ndërtesave. Higjiena e mirë është: ndihma e shëndetit, bukurisë, rehatisë dhe e marrëdhënieve shoqërore. Higjiena e mirë drejtpërdrejtë ndihmon në parandalimin e sëmundjeve apo izolimin e sëmundjeve. Respektivisht, në qoftë se ju jeni të shëndetshëm, masat e mira higjienike do të ju ndihmojnë për të shmangur sëmundjet, në qoftë se jeni i sëmurë, higjiena e mirë mund të ndihmojë në shërim apo do të zvogëlojë bartjen e sëmundjeve në të tjerët. 
Realisht, ne shpenzojmë rreth 90\% të kohës sonë në ndërtesa, natyrisht që ndërtesat mund të kenë efekt mbi shëndetin tonë dhe produktivitetin, (Wargocki et al. 1999; Fisk, WJ et al. 2000) sëmundjet dhe alergjitë janë rritur ndjeshëm gjatë dekadave të fundit në vendet me mënyrën e jeteses moderne. Një numër i rritjeve të rasteve të reja dhe i përhapjes së alergjive dhe sëmundjeve të tjera kanë qenë të lidhura me ndryshimet në mjedisin e brendshëm. Personat alergjik ose tepër të ndjeshëm, kanë më shumë predisponim për të perceptuar ndryshim në mjedis se sa personat jo alergjik ose më pak të ndjeshëm. Nuk është teknikisht apo ekonomikisht e mundur që ndërtesat t'iu përshtatën të gjitha llojeve të alergjive. Prandaj ndërtesat duhet të përshtaten në mënyrë individuale ose të projektohen/përshtatën me sa më pak emanime të dëmshme. Mbindjeshmëria e shkaktuar nga fushat elektrike dhe magnetike janë relativisht pak të hulumtuara tek ne, andaj, nuk janë temë elaborimi e kësaj monografie. Procesi arkitektonik i projektimit në masë të madhe varet nga vizioni, andaj nuk është dukuri e re, tërheqja e vëmendjes në aspektin vizual të ndërtesës. Mirëpo, se si objekti shifet, nuk pasqyron gjendjen si ndihemi. Kompozicioni mund të jetë i mrekullueshëm, me ngjyra të përshtatshme dhe ikonografi mbresëlënëse, megjithatë objekti mund të jetë i ekspozuar ndaj veprimeve të zhurmshme, me erë të keqe ose të jetë i bezdisshëm!"Partneri i zgjedhur për shkak të bukurisë fizike mund të jetë në trend, megjithatë, kur ajo bukuri fizike fillon të zbehet, nuk do të mbetet më, çka të vlerësohet. Komfori nuk ka një shprehje ekuivalente matematikore, nuk mund të shihet apo të prekët, mirëpo mund të jetë më e rëndësishme se çdo gjë tjetër. " 48

\subsubsection{Shtëpia e jonë (me baktere)}

Shoqëria njerëzore apo specia e jonë, ndikon direkt në ekosistemet e Tokës. Këto veprime janë duke u bërë gjithnjë e më të zakonshme dhe normale pavarësisht ndikimit në mjedis. Mirëpo specie të tjera kemi edhe rreth familjeve tona të cilat janë shumë interesante. Ato janë specie që ndërveprojnë mes shpesh, janë specie të cilat evolucioni i ka bërë të shumohen më shpejtë, si për shkak të biomit të tyre, si për shkak se ato janë shumë të vogla dhe riprodhohen shpejt. Këto specie që jetojnë me ne dhe pranë nesh janë gjithashtu interesante për një arsye tjetër shumë të rëndësishme: prania dhe mungesa e tyre mund të ndikojë drejtpërdrejt në shëndetin tonë dhe mirëqenien. Megjithatë, shkencëtarët i kanë kushtuar relativisht pak vëmendje për të kuptuar ekologjinë dhe evolucionin e specieve që jetojnë së bashku me ne: bakteret, kërpudhat apo edhe insektet deri më tani. Mikrobet janë të bollshëm dhe kudo mund të gjinden në trupin tonë, në mjedis, në shtëpitë tona, në rrobat tona. Por ne dimë shumë pak në lidhje me diversitetin e tyre në relacion me vendet më të përditshme. ${ }^{49}$ Një grup shkencëtarësh, merren me këtë lloj hulumtimi që katër vite, duke hulumtuar me modelin më origjinal që kam hasur në ketë vit. Respektivisht, ky hulumtim ka marr për shqyrtim prezencën e specieve me të cilat bashkëjetojmë si dhe ndikim e tyre në jetën e përditshme në situata të caktuara të shqyrtimit. Andaj, ideja ka qenë që të sensibilizohet komuniteti apo komunitetet në Shtetet e Bashkuara të Amerikës veç e veç me informata të bollshme, si dhe ftesën për të participuar çdonjëri, në atë mënyrë që të mbledhin kampionët shqyrtues në vendet të cilat kanë menduar se mund të gjejnë specie të ndryshme apo mikroorganizma në ndërtesat e tyre. Më pas këto kampione janë dërguar për shqyrtim tek projekti i mësipërm në adresë të caktuar.

48 Davis, P. R. (1998). Architect. http://www.rpd611.com/RPDcomfort/comfort.html . 2015.

49 Your (Bacterial) Home: The Next Ecological Frontier. http://homes.yourwildlife.org/. /2015. 
Natyrisht, me një kompensim modest për harxhimet e postës për kampionet nga participantët si dhe komunikimin e rezultateve "real time" në adresë të caktuar të www, për të gjithë participantët e projektit, voluntar. Si premisë kanë qenë hipotezat fillestare me formulime të qarta, të cilat do i determinojnë kornizat e hulumtimit. Për këtë monografi, jam përqendruar në hipotezat të cilat i kanë marr, dhe kanë të bëjnë me lëminë e arkitekturës dhe ambientit të brendshëm, si:

\section{HIPOTEZA 1: KARAKTERISTIKAT FIZIKE TË SHTËPISË SË JUAJ, NDIKOJNË NË KOMUNITETET MIKROBIALE TË GJETURA BRENDA SAJ.}

Sipas rezultateve preliminare: "Ne mendojmë se disa nga atributet fizike, si dhe ndërtimi i shtëpisë së juaj mund të përcaktojë llojet mikrobiale që jetojnë aty." Andaj, pyetjet hulumtuese kanë qenë si në vazhdim: Si pasojë, ne do të ju pyesim në lidhje me arkitekturën, materialet e ndërtimit, shtrojën/qilimat, ventilimin si dhe sistemin e ngrohjes dhe të ftohjes së shtëpisë tuaj, të cilët karakterizojnë kushtet ekologjike brenda shtëpisë tuaj.

HIPOTEZA 3: KARAKTERISTIKAT E POZITËS, GJEOGRAFISË, KLIMËS DHE PEISAZHIT NDIKOJNË NË PËRBËRJEN MIKROBIALE BRENDA DHE JASHTË SHTËPIVE TONA.

Konkludim:

"Rezultatet na tregojnë se llojet e baktereve dhe kërpudhave që gjenden në pluhurin e mbledhur brenda shtëpive, janë në një farë mase të parashikueshme. Shumica e kërpudhave të gjetura nga shtëpitë e ndryshme janë të parashikueshme nga klima dhe rajonet gjeografike. Nga ana tjetër, përbërja e komuniteteve bakteriale të gjetura në pluhurin shtëpiak nuk ishte e parashikueshme nga vendndodhja por ishte i ndikuar më fuqishëm nga numri dhe struktura e banorëve që jetojnë në ndërtesë. Në veçanti, qentë apo macet në ndërtesë kishin një ndikim të rëndësishëm mbi llojet e baktereve që jetojnë brenda shtëpive tona, andaj, në qoftë se dëshirojmë të ndryshojmë llojet e kërpudhave që u jemi të ekspozuar në ndërtesat tona, atëherë është mirë për të nderuar shtëpinë (mundësisht më larg). Respektivisht, nëse dëshirojmë të ndryshojmë nga ekspozimet aktuale bakteriale, atëherë ne duhet të ndryshojmë stilin dhe mënyrën e jetesës." 50

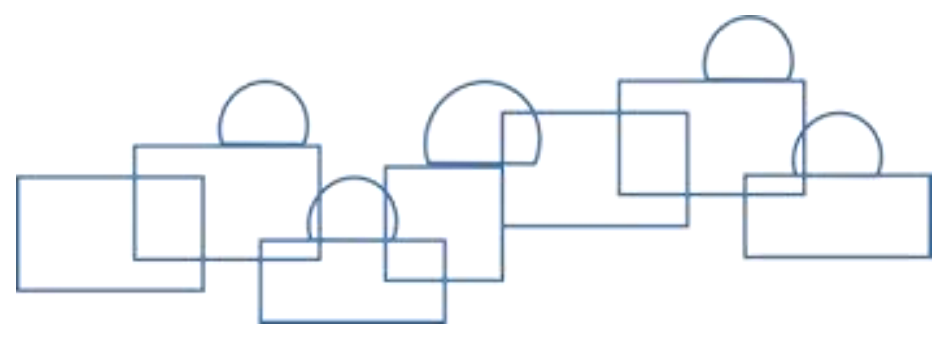

50 Barbera'n A et al. 2015 The ecology of microscopic life in household dust. Proc. R. Soc. B 282: 20151139. http://dx.doi.org/10.1098/rspb.2015.1139 

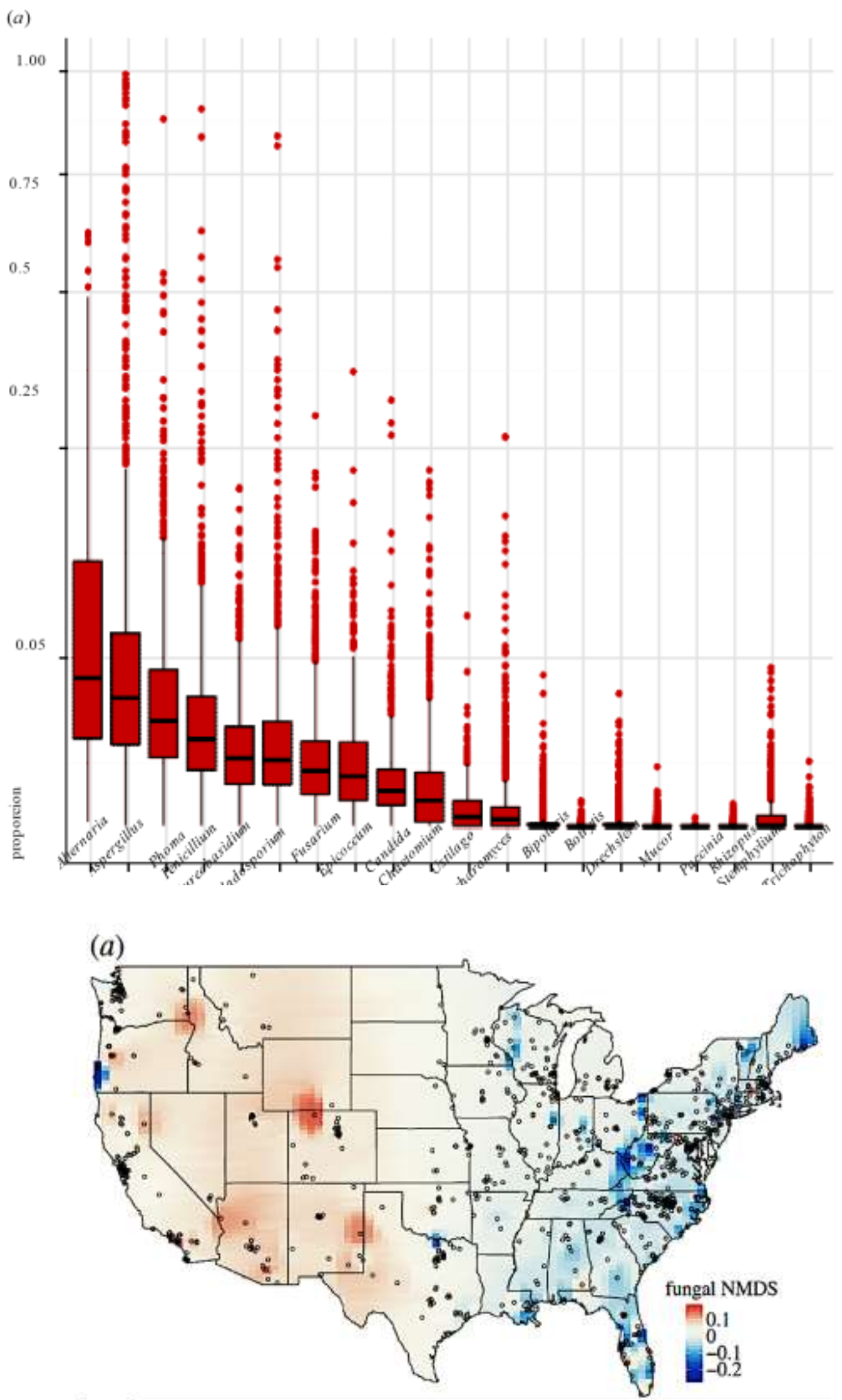

Figura 82. Mostër: Anketa, vlerësimi i rezultateve, përmbledhje.

(Burimi): Barbera'n, A. et al. 2015 The ecology of microscopic life in household dust. 2015. 


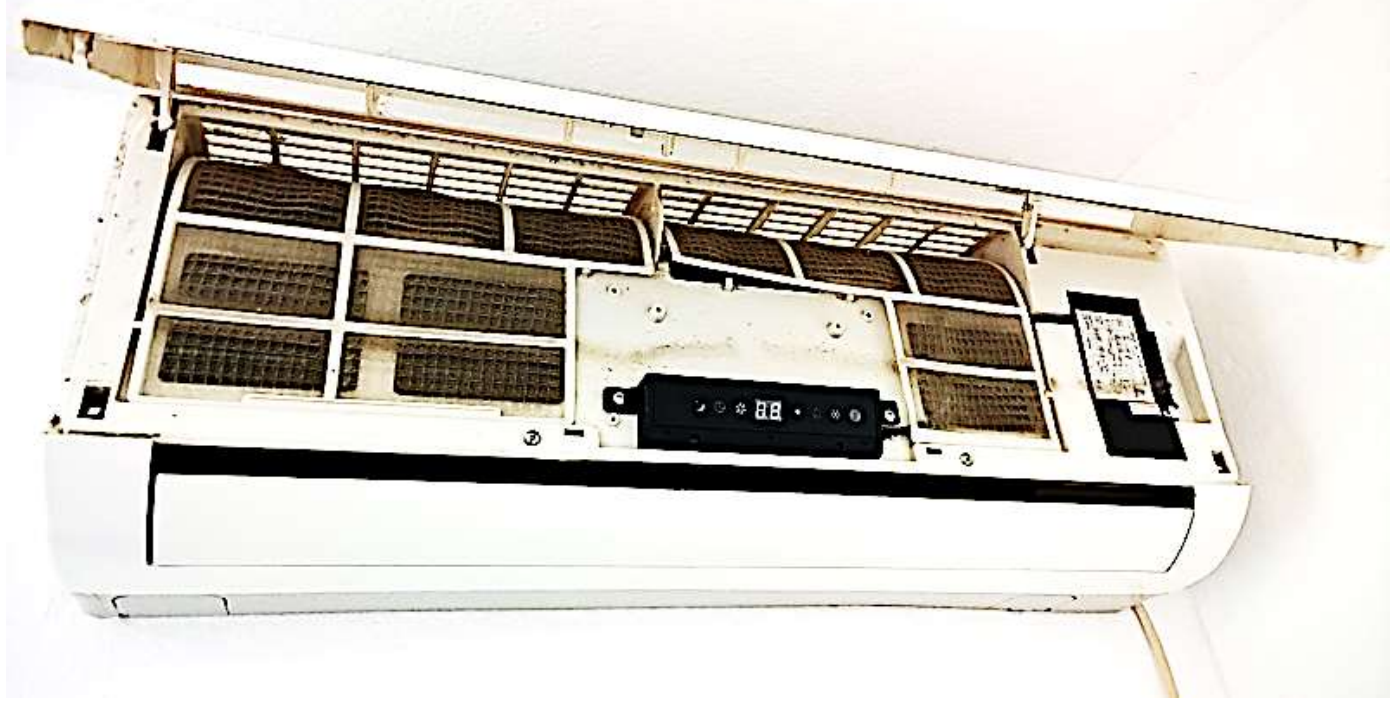

Figura 83. Sistemet e klimatizimit - Split. Gjendja aktuale e zakonshme, filterët. (Burimi): Bujar Bajçinovci. 2015.

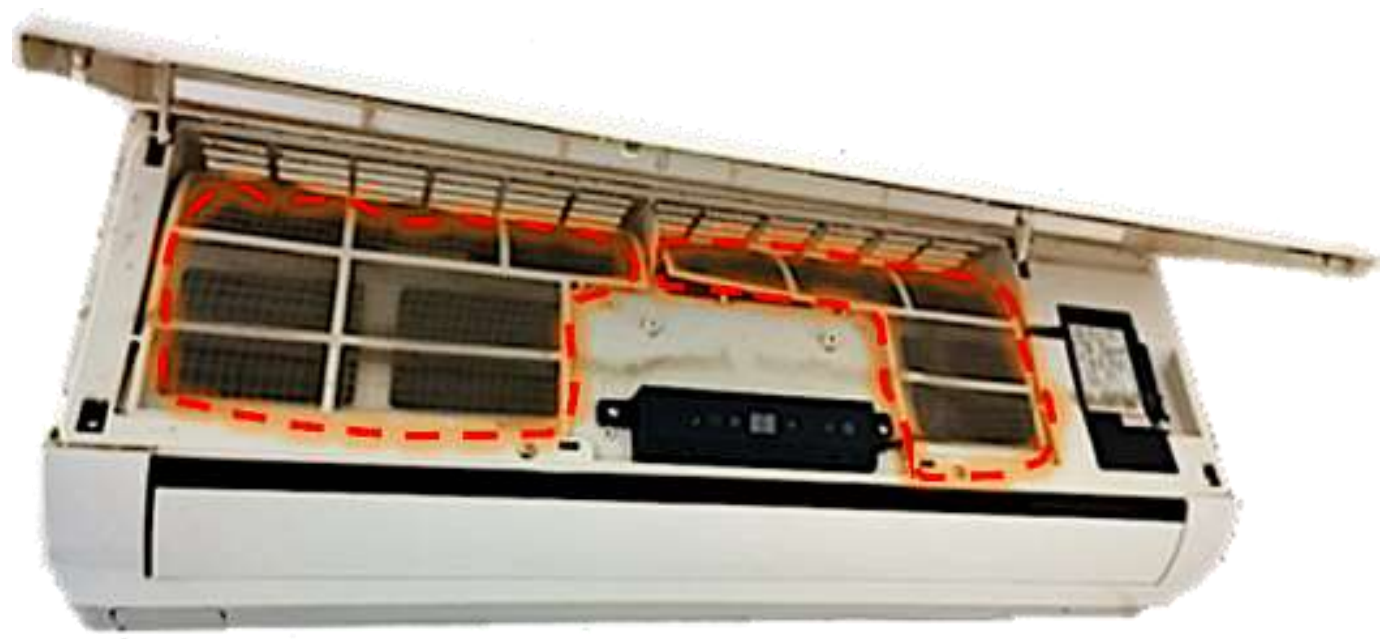

Figura 84. Higjiena dhe pajisja. Filterët, bakteret dhe këpurdhat/funghi. (Burimi): Bujar Bajçinovci. 2015. 


\subsection{Komfori akustik - zë izolues}

Në kontekstin e komforit të përgjithshëm vend të rëndësishëm paraqet komfori nga zëri, akustika apo zë izolimi. Është më së e preferuar që gjatë procesit të projektimit të pritet arritja e nivelit të mirëfilltë dhe të komforit nga zëri. Është themelore arritja e rehatisë akustike, e cila është e së njëjtës rëndësi ergonomike si drita, temperatura dhe higjiena. Funksionaliteti dhe estetika e zonës së punës janë zakonisht veçori primare dhe fokus kryesor i arkitektëve gjatë procesit të projektimit apo edhe gjatë fazës së programimit. Sigurimi i një mjedisi të këndshëm për të punësuarit në mënyrë të konsiderueshme kontribuon në punën e tyre optimale dhe në reduktimin e mungesave në punë. Derisa zhurma, hulumtohet dhe studiohet nga burimet që arrijnë nga trafiku i jashtëm, pajisjet mekanike në dhomë dhe zyre, tingujt e fotokopjuesve, telefonat dhe pajisjet brenda zonës së punës.

1. 72\% e të punësuarve janë të pakënaqur me nivelin e intimitetit nga aspekti akustik, zë izolues. (Universiteti i Kalifornisë në Berkeley, studim) ${ }^{51}$

2. 64\% e punëtorëve të zyrës u "penguan" në punë, dhe atë, deri në 20 herë në ditë (Brother Research)

3. 59\% e punonjësve shpenzojnë orë të konsiderueshme, duke u përpjekur për të bërë një ambient të përshtatshëm pune, nga aspekti i zhurmës në hapësirat e punës. (hulumtim, BOST)

4. 70\% e të punësuarve kanë deklaruar se, mund të jenë më produktivë në mjedisin me më pak zhurmë. (studim, ASID)

Bizneset investojnë mjete financiare të konsiderueshme dhe kohë duke krijuar ambiente të përshtatshme për stafin e tyre. Ndriçimi, kontrolli i temperaturës, ergonomia e pajisjeve në punë, të gjitha janë të nevojshme, natyrisht që komfori nga zhurma dhe "qetësia" janë shumë relevante.

Në çdo zyrë ekziston niveli i pranueshëm i rehatisë akustike, zë izolimi i mirë është një element thelbësor ergonomik. Sigurimi i niveleve të privatësisë, kuptueshmërisë e të folurit të qartë janë cilësi të shëndosha në përmirësimin kushteve të punës dhe mirëqenien e fuqisë punëtore. Studimet të shumta tregojnë se zhurma dhe mungesa e privatësisë janë duke udhëhequr problemet në ndërtesat e sotme, ndërhyrja nga kolegët gjatë bisedave, nga punëtorët pranë zyrës, apo të krijuara nga pajisjet e teknike. Zhurma është një forcë e fuqishme e cila e tërheq vëmendjen larg nga detyrat gjatë punës, mund të merr edhe deri në katër herë kohë, aq sa është ndërprerja nga zhurma para se të kthehemi në kushtet e mëparshme të koncentrimit. Kjo mesatarisht është e barabartë me 15 minuta para se personi ta rimerr përqendrimin. Zhurma është tingull i vazhdueshëm që karakterizohet në një hapësirë dhe në një kohë. Nëse etazha e punës është shumë e lartë, mjedisi i punës do të jetë iritues dhe i mundimshëm, nëse etazha është shumë e ulët, bisedat dhe mund të jenë lehtë të përgjuara dhe zhurma mund të bëhet deprimuese.

51 Screen Solutions Ltd. (2012). www.acousticcomfort.co.uk. Acousticcomfort. 2012. 
Në zyrat e hapura me organizim të lirë peisazhor zhurmat e lehta dhe bisedat janë të kuptueshme deri 15,2 metra larg. Vetëm një tingull i mëvetshëm mund të arrijë nivelin e duhur të zhurmës, i cili është në përgjithësi midis $42 \mathrm{~dB}-48 \mathrm{db}$. Andaj për shkak të zhurmës, duhet rritur privatësinë nga të folurit, duke bërë zyra më të rehatshme.

Problemet me të cilën përballen Arkitektët:

Marrja e një zyre për ta analizuar është një veçanti e cila kërkon një përkushtim për menaxherët dhe ekipet planifikuese. Akustika e varfër është shpesh rezultat i kombinimit të faktorëve, duke përfshirë si më poshtë:

1. Zgjedhja e materialeve në trend: qelqi, betoni, dru ose materiale të ngjashëm me plafone metalike, të gjitha kanë akustikë të dobët dhe reflektojnë pothuajse të gjithë zhurmën përsëri në dhomë.

2. Prirja për të ndërtuar mure ndarëse në etazhë me lartësi, deri në gjysmë $(1 / 2)$ etazhe, respektivisht jo në deri në plafon, çon në varfërinë e privatësisë së bisedave të punëtorëve.

3. Zhurma nga ventilimi, ngrohja dhe klimatizimi janë efekte të jashtme, të cilat pengojnë qëllimin projektues dhe funksional në ndërtesa siç janë bibliotekat, leximoret, hapësira leximi apo hapësirat shkollore. ${ }^{51}$

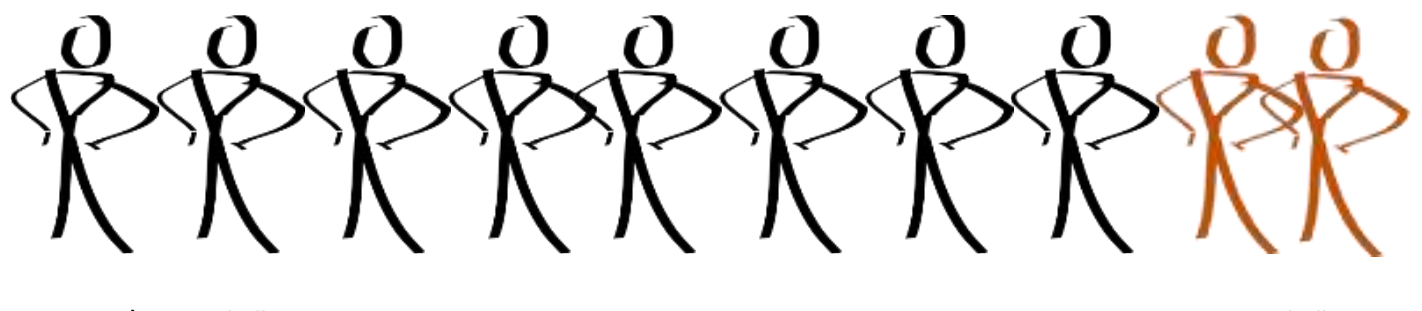

Nuk Punojnë

Punojnë

Figura 85. Realiteti i $15 \%$ të punësuarve.

(Burimi): Bujar Bajçinovci, 2017..

Studimi dhe hulumtimi i porositur nga "Brothers" dëshmon se i punësuari merr një mesatare prej 15 minutash për të rimarrë përqendrim prapë, nga hutimi dhe zhurma e padëshiruar. Nëse çdo person ndërprehet pesë herë në ditë, dhe merret deri në 15 minuta për tu rifituar përqendrimi i plotë, kjo barazohet me një $15 \%$ të reduktimit të produktivitetit mbi një mesatare për 8 orë pune në ditë.

Shembulli i mësipërm Fig. 85, ilustron vizualisht reduktimin e 15\% në produktivitet. Respektivisht, vizualizohet se si në mënyrë efektive jemi duke u paguar pa bërë asgjë! Përfitimi potencial i reduktimit të ndërprerjeve nga zhurma, me një mesatare vjetore të pagës prej $£ 20.000$ /person, rezulton me një rritje të produktivitetit për $15 \%$, $£$ në vit. ${ }^{51}$ 
Studimet tregojnë se edhe niveli i butë i zhurmës brenda hapësirave të punës mund të shkaktojë stres, të çojë në de motivim në mesin e të punësuarve dhe shpesh redukton produktivitetin e tyre. Shembull i mësipërm tregon se kthimi nga investimet e bëra ndodhë gjatë një periudhe prej disa javësh, jo vitesh.

Tabela 11. Koeficientet, absorbimi për materialet e zakonshme të përdorura në ndërtim (Burimi): Broshurë, Screen Solutions Ltd. Acousticcomfort. 2012.

\begin{tabular}{|l|c|c|c|c|c|c|}
\hline & $\mathbf{1 2 5} \mathbf{~ H z}$ & $\mathbf{2 5 0 ~} \mathbf{~ z}$ & $\mathbf{5 0 0 ~} \mathbf{~ z}$ & $\mathbf{1 ~} \mathbf{~ H z}$ & $\mathbf{2 ~} \mathbf{~ H z}$ & $\mathbf{4} \mathbf{~ k H z}$ \\
\hline Qilim & 0.01 & 0.02 & 0.06 & 0.15 & 0.25 & 0.45 \\
\hline Dysheme betoni (të palyera, të final. vrazhdë) & 0.01 & 0.02 & 0.04 & 0.06 & 0.08 & 0.1 \\
\hline Dysheme mermeri & 0.01 & 0.01 & 0.01 & 0.01 & 0.02 & 0.02 \\
\hline Parket druri & 0.15 & 0.11 & 0.1 & 0.07 & 0.06 & 0.07 \\
\hline Mur me tulla & 0.03 & 0.03 & 0.03 & 0.04 & 0.05 & 0.07 \\
\hline Dyer (panele druri solide) & 0.1 & 0.07 & 0.05 & 0.04 & 0.04 & 0.04 \\
\hline Qelqi (shtresë 6mm, panel i madh) & 0.18 & 0.06 & 0.04 & 0.03 & 0.02 & 0.02 \\
\hline Mur rigipsi (12mm panel) & 0.29 & 0.1 & 0.06 & 0.05 & 0.04 & 0.04 \\
\hline Plafon rigipsi (12mm - plafon i lëshuar) & 0.15 & 0.11 & 0.04 & 0.04 & 0.07 & 0.08 \\
\hline
\end{tabular}

\subsubsection{Heshtja, nuk është zgjidhje!}

Mjedis pune shumë i qetë apo me zë të lartë? Zhurma përçan koncetrimin dhe shkakton shpërqendrim dhe bën vështirë të fokusohemi në punë, për çdo punonjës të angazhuar në aktivitete të përditshme punonjëse. Ashtu siç është e padëshirueshme një mjedis me zhurmë, po ashtu një qetësi absolute de motivon dhe shkakton ndjenja të vetmisë. Një mjedis i balancuar nga zhurma shpesh është përgjigja më e mirë. Duke vepruar kështu, strategjitë e kontrollit të zhurmës janë ndjekur në "The Quest for Absolute Silence", nocioni akustikë e mirë, arrihet kur nivelet e zhurmës, jehonës dhe reverbërimit janë të "shëndosha" në mjedis dhe hapësirë. Megjithatë, ashtu si faktorët ergonomik: si drita, temperatura dhe lagështia për komfor të shëndoshë, vlerat nuk janë zero. ${ }^{51}$

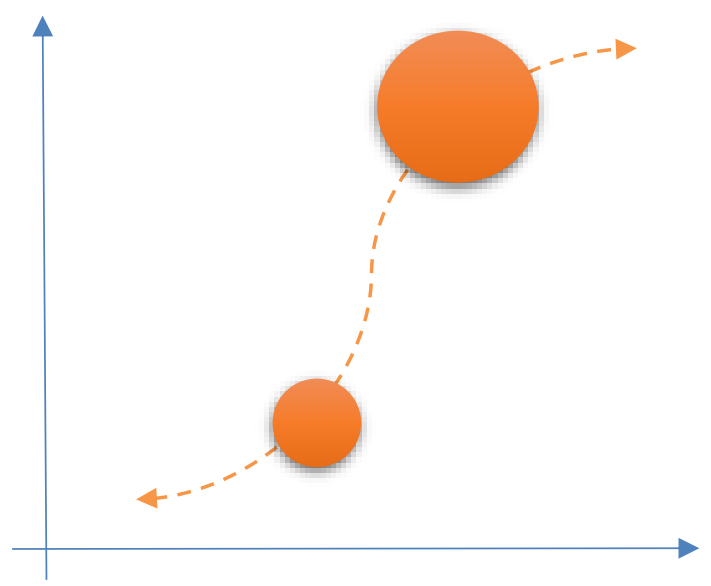

Figura 86. Rritja e nivelit të zhurmës.

(Burimi): Bujar Bajçinovci, 2015. 

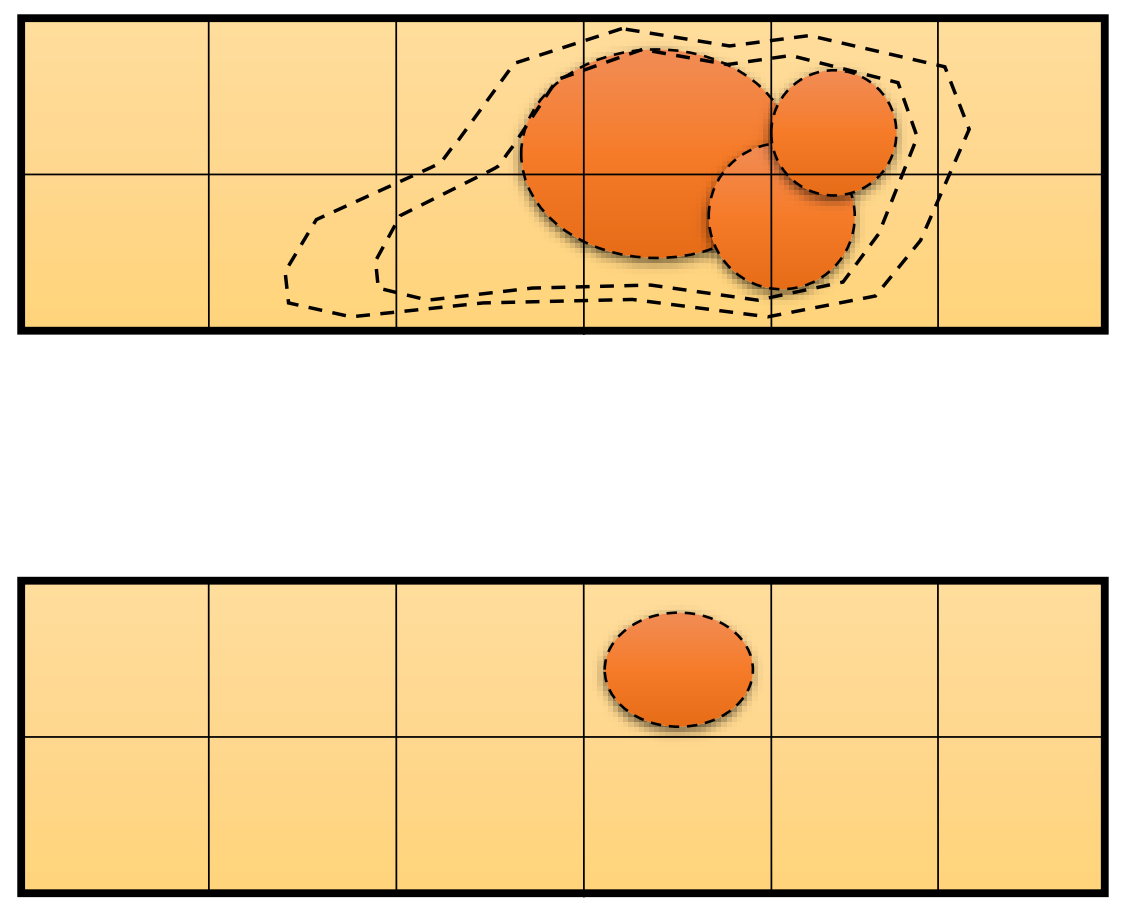

Figura 87. Modalitetet. Niveli i koncentrimit në punë dhe zhurma. (Burimi): Bujar Bajçinovci, 2017.

\subsubsection{Indeksi Privatësisë}

Privacy Index (PI), është një matje standarde në industri, e shprehur në përqindje, e përdorur për të treguar shkallën e privatësisë për vende të hapura ose të mbyllura të punës. Duke konsideruar performancën e kombinuar akustike/zëizoluese e çdo hapësire, duke përfshirë plafonet, muret, mbulesat dhe orenditë. Përqindjet më të larta janë më të mira.

Niveli 1, Jo Privatësi, PI 0-69\%: Biseda dhe fjalimi i një punëtori kuptohet qartë, është i kuptueshëm për punëtorët fqinjë dhe është plotësisht i kuptueshëm për dëgjuesit e rastit. Ky nivel është i zakonshëm në zyrat e hapura, apo nga plani organizativ peisazhor.

Niveli 2, Tranzitor apo privatësia e vogël, PI 70-79\%: Fjalimi i një punëtori shpesh tërheqë vëmendjen e tjetrit. Kjo shkallë e intimitetit ekziston në objekte ku ka një nivel i lartë i ndërveprimit ndërmjet punonjësve.

Niveli 3, Privatësia normale, PI 80-94\%: Në këtë nivel, të punësuarit në afërsi kanë mjaft privatësi kështu që edhe pse ata mund të dëgjojnë fjalët e të tjerëve, kuptueshmëria është e shkëputur nga artikulimi. Ky është një nivel i kënaqshëm për shumicën.

Niveli 4, Privatësia konfidenciale, PI 95-100\%: Fjalimi i një punonjësi nuk është i kuptueshëm për tjetrin, fjalimi mund të dëgjohet por nuk do të kuptohet. Kështu privatësia e ka nivelin e plotë. ${ }^{51}$ 


\subsection{Komfori nga aspekti i ndriçimit}

Kriteri i komforit nga aspekti i ndriçimit është një nga elementet më të rëndësishme dhe fondamentale, por njehërit është edhe një kërkesë themelore për perceptimin hapësirës. Drita, ose rrezet e diellit janë fenomen jetik për shëndetin dhe jetën e qenieve të gjalla. Ka hulumtime të panumërta shkencore që përmbledhin komforin e padiskutueshëm të kënaqshmërisë dhe komoditetit nga aspekti i ndriçimit, përndryshe paraqitën simptome të ndryshme të depresionit, sëmundjeve të ndryshme serioze, apati dhe në afat të gjatë çon në verbëri. Për të folur për arkitekturën, është për të folur për dritën, dhe mbi të gjitha për dritën natyrore. Kjo nuk është vetëm në lidhje me kapacitetin fizik që na lejon të shohim formën e brendshme dhe të jashtme të ndërtesës, por në ofrimin e arkitekturës me një komponentë kryesore të energjisë së nevojshme për ekzistencën e një dualiteti të integruar, të materies dhe energjisë, e cila nga dobia e thjeshtë gjeneron një sens estetik për përdoruesit. ${ }^{52}$

1. Historia e arkitekturës është histori e luftës për dritën, duke luftuar për një dritare. (LeCorbusier, 1989). ${ }^{53}$

2. Sipas mendimit tim, komfori i arkitekturës realizohet nga dy fjalë. E para prej tyre është "hapësira" e dyta është "drita". (Santiago Calatrava, CNN. 2006).

Pse është e rëndësishme drita?

63\% e të anketuarve e vlerësojnë dritën natyrore si një veçori më të rëndësishme për një ndërtesë (sondazh: HOMEWISE, "Pa hapësirë + dritë", 2015).

1. Drita përmirëson rehatinë vizuale dhe psikologjike, ka një efekt pozitiv mbi performancën e njerëzve, të vëmendjes, kënaqësisë dhe kapacitetit për të mësuar.

2. Drita lehtëson çrregullim sezonal emocional (një formë depresioni).

3. Ekspozimi në dritë të ndritshme është treguar të jetë një mënyrë efektive për trajtimin e çrregullimit të gjumit.

4. Ndriçimi përmes dritareve është burimi kryesor për të siguruar nivelet e larta të dritës së nevojshme, për të mbështetur funksionimin e sistem circadian. ${ }^{54}$

52 Ed. C, Gallo., M, Sala., A.M.M, Sayigh.(Eds).(1988). Architecture: Comfort and Energy. Elsevier.

53 Corbusier, L. (1989). Towards a new architecture. Oxford: Butterworth Architecture

54 "Sistemi "circadian" na mban në sinkronizim me ditën 24-orëshe. Ora e brendshme e trupit tonë dërgon sinjale në shumë pjesë të ndryshme të trupit, si tretja, lirimi i hormoneve të caktuara, temperatura e trupit, dhe shumë më tepër! Një nga funksionet kryesore të orës së brendshme është të rregullojë fiziologjinë kur ndjehemi vigjilent dhe kur jemi gati për të fjetur. Shkencëtarët kanë parë për shembull, se kur njerëzit janë mbajtur të mbyllur pa rreze diellit ose pa orë për tu treguar atyre se çfarë është koha, ata zgjoheshin dhe bënin gjumë në një model afërsisht 24 orësh. Bimët e bëjnë këtë shumë interesant: vazhdojnë të lulëzojnë në mëngjes, edhe kur ato janë mbajtur në errësirë.“

Njeriu mbanë orën e brendshme në hap me ditën 24 orësh nëpërmjet rrezeve të diellit, ushqimit dhe aktiviteteve të tjera gjatë ditës, mirëpo, po ashtu edhe me errësirën gjatë natës. Ky proces i përshtatjes me orën e brendshme apo metabolizmit me sinjalet nga mjedisi vazhdon permanent. Me fjalë të tjera, ora e brendshme është disi fleksibile, kjo është arsyeja pse trupi ynë mund të mbajë me pauza gjatë ditës apo luhatjeve të lehta sezonale. Kjo është edhe arsyeja pse ne kur udhëtojmë nëpër zonat kohore trupi ynë përfundimisht do të hyjë në sinkronizim me kohën lokale." (Ekstrakt): http://sleepfoundation.org/ sleepnews/sleep-and-the-circadian-system. 


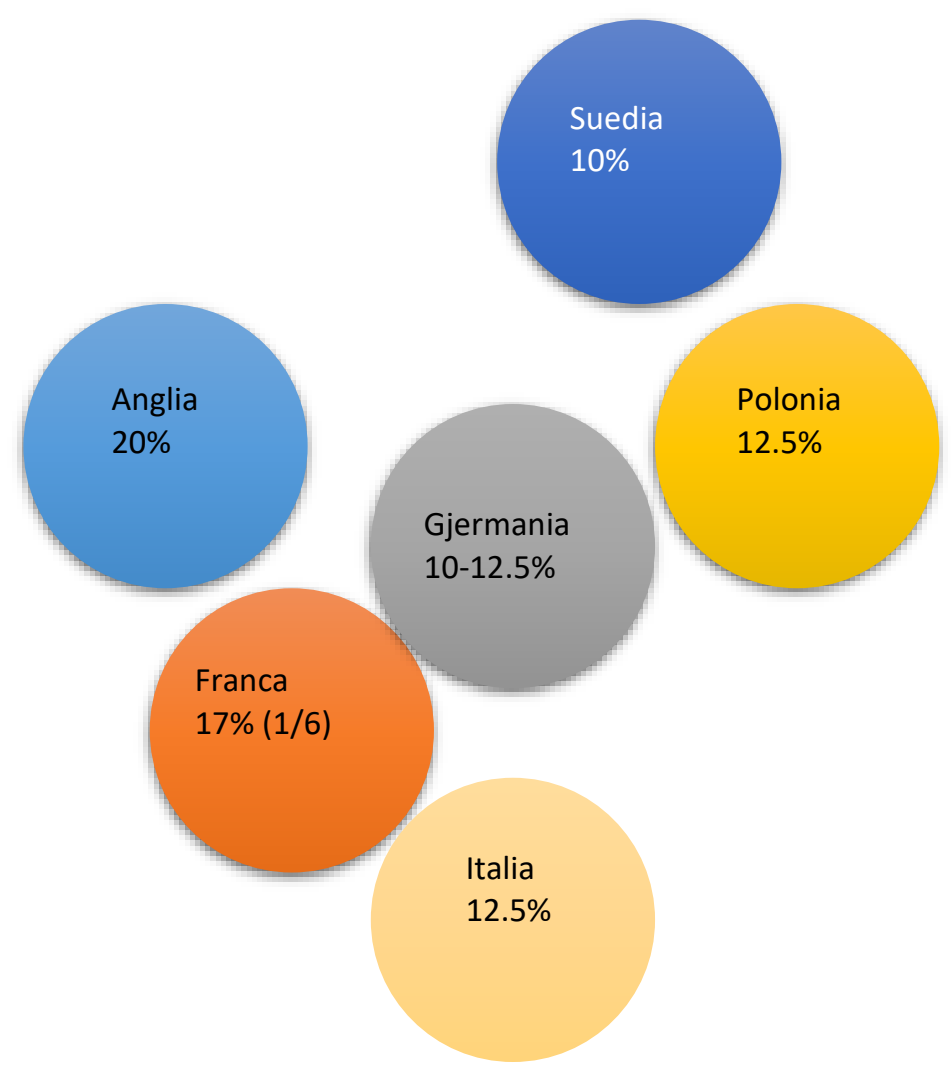

Figura 88. Ndriçimi natyror në legjislacion. Raporti Dritare/Dysheme, në \%, EU. (Burimi): Bujar Bajçinovci, 2017.

\subsubsection{Shembull studimi / Francë}

Në Francë, dhoma kryesore duhet të ketë një sipërfaqe të hapur dhe sipërfaqe transparente të jashtme. Këto sipërfaqe mund të ndahen, e jashtme, nga një tjetër sipërfaqe e dritares (të lejuar për ngrohje nga dielli apo për tu rritur zë izolimi) në qoftë se raporti i krijuar nga dritaret e jashtme dhe sipërfaqeve të qelqit udhëhiqen nga disa parime:

1. Vetëm një sipërfaqe e hapjes së jashtme

2. Është projektuar për tu lejuar ventilimi

3. Nuk e ka sistemin për ngrohje

4. Nuk është një oborr i mbuluar

5. Ka një sipërfaqe të dritares së jashtme të paktën $60 \%$ për banim kolektiv, dhe $80 \%$ për banim individual. 
Për më tepër, sipërfaqja e dritares nuk duhet të jetë më pak se $1 / 6$ e sipërfaqes së dyshemesë/banesës. Përveç ndriçimit natyral, treguesi $\mathrm{B}_{\text {bio, }}$, kërkohet nga $\mathrm{RT}_{2012}$, përfshin nevojat për ndriçim elektrik. Ky tregues $B_{\text {bio }}$ duhet të mbetet nën një vlerë maksimale të quajtur $B_{\text {biomax }}$, dhe llogaritet sipas formulës së më poshtme:

$$
\text { Bbio }=2 \text { E ngrohjes }+2 \text { E ftohjes }+5 \text { Endriçimit }
$$

Nevojat e energjisë për ndriçim janë me një koeficient më të lartë se sa koeficientet për ngrohje dhe ftohje. Në të njëjtën kohë, konsumi elektrikë për ndriçim merr gjithashtu parasysh treguesin e dytë të energjisë KEP (Konsumi në energji primare), e cila duhet të jetë nën vlerën maksimale $\mathrm{K}_{\text {epmax. }}\left(\right.$ Ekstrakt) ${ }^{55}$

Andaj:

1. Përdorimi i dritës natyrore për të kompensuar ndriçim artificial paraqet një sasi të madhe kursimi të energjisë potenciale.

2. Të gjitha vendet përfshijnë të paktën një referencë themelore, në kontekst të dritës në kodet e tyre të ndërtimit.

3. Kërkesat e diellosjes apo rekomandimet në legjislacion, kryesisht specifikojnë një pjesë minimale të dritares/sipërfaqe ndriçimi, ose thjesht përcaktojnë nevojën për qasje të rrezeve të diellit në ndërtesa.

4. Danimarka është vendi i vetëm që kërkon vlera minimale të diellosjes në dimër, për rastet e ndërtesave të reja dhe renovimet më të mëdha.

5. Ligji Suedez është unik, ky Ligj rekomandon përdorimin e sistemeve të menaxhimit të dritës për ndriçuesit e instaluar të përhershëm.

6. Vetëm në disa kode të ndërtimit, (Bruksel, Danimarkë, Gjermani) nxjerrin në pah rëndësinë e vizurave, një pamje e jashtme si një pjesë e rëndësishme e komforit vizual.

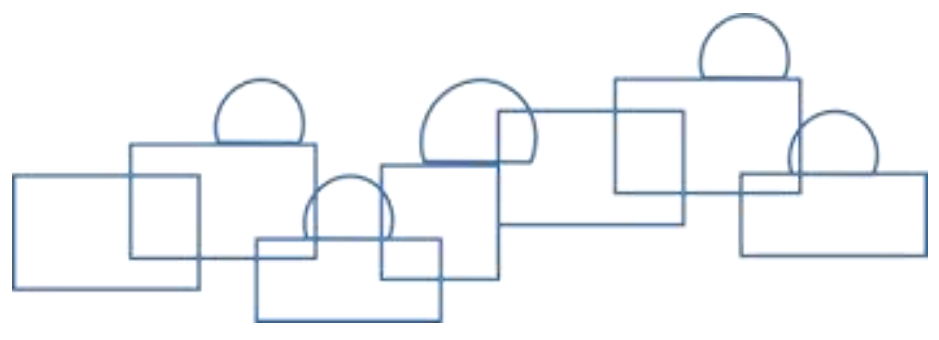

55 Sara Kunkel, Eleni Kontonasiou, Aleksandra Arcipowska, Francesco Mariottini, Bogdan Atanasiu. (2015). Indoor air quality, thermal comfort and daylight. Buildings Performance Institute Europe (BPIE). 


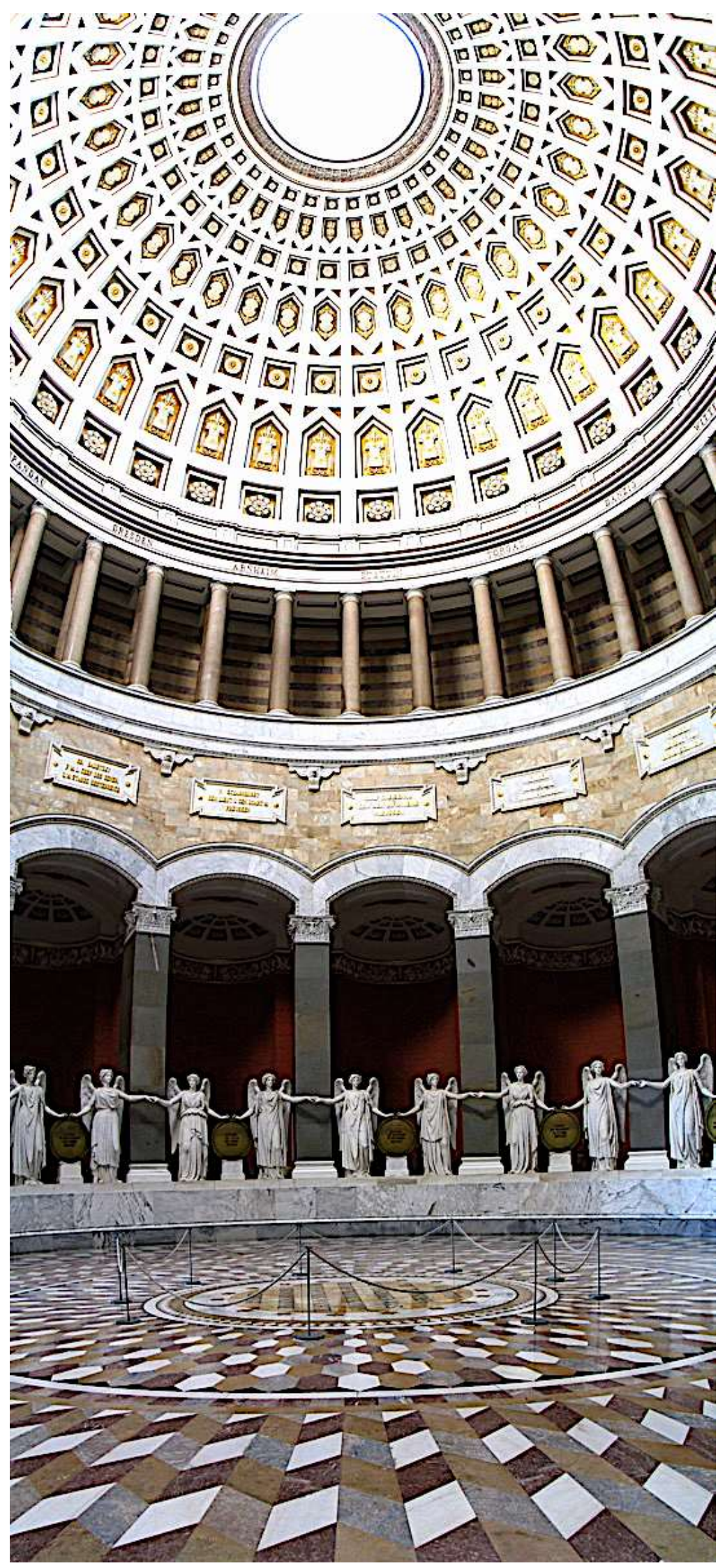

Figura 89. Befreiungshalle1. Kelheim, Bavaria. Gjermani

(Burimi): Patrick Huebgen, 2007. E licensuar nga, Own work. Public Domain Commons 


\section{PROJEKTIMI I INTEGRUAR}

$\mathrm{K}$ onsumi i energjisë vazhdimisht në rritje, dëshmitarë të ndryshimeve klimatike globale, ndotja e mjedisit dhe implikimet për fenomenet e lartpërmendura janë përgjigje bashkëkohore e shekullit të XXII, shumë aspekte janë të lidhura me procesin e integruar të projektimit, duke veçuar: qasjet transdisiplinare, holistike, kursimet dhe efiçienca e energjisë, performanca e përgjithshme e ndërtesave. Një masë e bollshme e literaturës botërore procedon hulumtimet e kësaj lëmie, do i veçojmë disa prej tyre: sipas hulumtimit të $\mathrm{CSU}^{56}$ dhe $\mathrm{PER}^{57}$, shpjegohet se një dizajn i integruar optimizon punën $\mathrm{e}$ ndërtimit dhe rritë efikasitetin e burimeve ndërtuese, marrëdhëniet e ndërsjella në mes të sistemeve të ndërtesës, eksploatimin dhe "ciklin e jetës" së ndërtesës. Procesi i integruar i projektimit kërkon qëllim të përbashkët funksional, hartimin e rrjedhshëm dhe të vazhdueshëm të informacionit ndërmjet të gjithë palëve të involvuara në projekt. Rezultati do të jetë një "ndërtesë e tërësishme", projekt, në të cilin të gjithë sistemet e ndërtimit janë të harmonizuara me qëllim sa më të lartë të ndërveprimit, si sistem i gjërë dhe total.

Një qasje e integruar e projektimit arkitektonik është vendimtare për arritjen e projektimit të qëndrueshëm, si dhe arritjes së performancës optimale të ndërtesës. Prandaj, kërkesa për themelimin e ekipit transdisiplinar në fazat e hershme të programimit, me argumente dhe objektiva të caktuara dhe me prioritete, klasifikon dhe sinkronizon koordinim të vazhdueshëm e të gjithë anëtarëve të ekipit të projektimit.

Për më tepër, programi PER shfaq rezultate, që integrimi i ekipeve të projektimit mund të zbulojë më mirë elementët e një " konflikt të mundshëm ", për të përfituar një sinergji midis participantëve dhe ekipeve të projektimit, të cilët pastaj mund të ristrukturojnë vendimmarrjen si dhe aktivitete në drejtim të fuzionimit të ndryshimeve pasuese në fazën e projektimit. Sigurimi që në fazat e hershme të analizave së detyrës projektuese, mundëson që ekipet do të jenë në gjendje për ta konsoliduar bazën e vendimeve gjatë projektimit, duke llogaritur punën dhe ciklin e jetës së materialeve në përmirësimin e efikasitetit të energjisë, i cili redukton koston e investimeve.

Në nivelin e strategjisë së CSU, propozohet se është e nevojshme që të përfshihen të paktën disiplinat e mëposhtme dhe pjesëmarrësit në komisione për planifikimin e strategjisë, sikurse: stafi planifikues menaxherial, arkitektë, arkitektë peizazhi, inxhinierë, inxhinierë instalimesh, specialistë në qëndrueshmëri, teknolog, specialistë të shëndetit publik, personel operacional dhe subspecializantët e lëmive të tjera të nevojshme.

56 California State University. http://www.calstate.edu/.

57 Program for Environmental Responsibility. http://137.145.170.165/cpdc/sustainability/envr-res.shtml 
Në procesin kreativ programues arkitektonik, së pari duhet të përcaktohen prioritetet dhe objektivat e projektit apo hulumtimit, vendimet kryesore të projektimit duke përfshirë metodën e ndërtimit, orientimin, sistemet e ndërtimit, sistemet e ujërave dhe të reshurave, ngrohjes dhe ventilimit (HVAC). Premisat nga sistemi do të analizohen veç e veç, duke shkoqitur veçori të cilat do të merren parasysh gjatë gjithë procesit të dizajnit, me aksent në optimalizim dhe efikasitet.

Sipas PER, është e rëndësishme për tu themeluar struktura e ekipeve të punës, të cilat do kërkojnë vijat kryesore apo kornizën, për të gjetur opsionet më optimale:

1. Krijimi i prioriteteve dhe objektivave për qëndrueshmërinë dhe efikasitetin e ndërtesës.

2. Analiza e resurseve, mundësitë dhe kufizimet lokale.

3. Listimi i të gjitha kufizimeve të tjera të projektit, përfshirë buxhetin total, buxhetin e ndërtimit, koha e ndërtimit dhe mirëmbajtjes, teknikat dhe mjeshtëritë të cilat janë në dispozicion, analiza e ciklit të jetës, parametrat vitale dhe kostoja.

4. Një listë e sistemeve të mundshme përdoruese, e teknologjive dhe strategjive për tu përmbushur objektivat e projektit.

5. Identifikimi i përparësive dhe sinergjitë e mundshme në mes të sistemeve, teknologjive dhe burimeve njerëzore.

6. Identifikimi i kufizimeve të mundshme të sistemit të propozuar, teknologjisë dhe strategjisë.

7. Prioritetet e sistemit të propozuar, teknologjive dhe strategjisë.

8. Identifikimi i sistemeve alternative, teknologjive dhe strategjisë.

9. Vlerësimi i elementeve të propozuara me kriteret LEED.

Në nivelin e legjislacionit, udhëzimeve dhe masave të shtetit të Kalifornisë, të zbatuara aktualisht si model relevant për shtjellimin e temës, do janë:

1. Vendimi dhe akti për ngrohjen globale. Akti 2006 apo California Bill 32 (Nunez, Pavley), drejton udhëzimin e Air California, për rregullimin e emetimeve të gazrave me efekt serrë, duke filluar nga viti 2012.

2. Adaptimi, procesi i ndryshimit të funksioneve në ndërtesat historike, duke i ruajtur elementet e rëndësishme historike.

3. Albedo, pasqyron raportin e sipërfaqës dhe rrezatimit elektromagnetik, i njohur si reflektim diellor.

4. Biophilia, qasje në arkitekturë, nga ngjashmëria e dukurive biologjike natyrore, si vegjetacioni, pemët, lulet si dhe nga ndryshimet mjedisore klimatike. 
5. Dizajni i integruar, proces i projektimit në të cilin një numër i disiplinave dhe aspekteve të ndërlidhura gjatë hartimit të projektit janë të fuzionuara, në një mënyrë që siguron një përfitim sinergjik efikas.

Sipas (Wilson. A, 2001) ${ }^{58}$ në rolin e editorit/botuesit i cili përmbledh hulumtimet që i përkasin dizajnit të integruar, procesit të projektimit të ndërtesës në të cilën involvohën shumë disiplina dhe veçori në dukje të parë të palidhura në mes veti. "Qëllimi është për të arritur performancë të lartë dhe përfitime më të mëdha nga një çmim më i ulët investiv se sa kombinimi i përgjithshëm i të gjithë komponentëve të cilat mund të shihen në fillim."

Ky proces shpesh përfshin strategjinë e integrimit të "dizajnit të gjelbër" nga kriteret konvencionale të dizajnit, formave të ndërtimit, funksioneve dhe kostot e ndërtimit. Ndërmarrje kyçe në projektimin e integruar të ndërtesave është pjesëmarrja e njerëzve nga lëmi të specialiteteve të ndryshme të projektimit: arkitekturës së përgjithshme, HVAC, fazave nga instalimet elektrike dhe ndriçimit, dizajnit të brendshëm, dizajn peisazhor dhe mjedisit. Duke punuar së bashku në pikat kyçe në procesin e projektimit, pjesëmarrësit mund të identifikojnë shpesh zgjidhje projektuese më atraktive ngaqë do të mund ti hasnim në proceset klasike dhe lineare të projektimit.

Opsionet dhe përfshirja e projektimit të integruar, dizajni i integruar i ndërtesave mund të jetë pjesë e çdo projekti të objekteve arkitektonike, megjithatë, është më i përshtatshëm për projektimin e ndërtesave të reja ose i rëndësishëm për projekte për renovim të tërësishëm. Dizajni i integruar është më efektiv kur çështjet kryesore trajtohen në fazën e hershme të planifikimit dhe procesit të projektimit. Mundësitë identifikohen më lehtë përmes një procesi të hapur të kërkimit, më lehtë për tu kombinuar dhe zbatuar strategjitë në arritjen e rezultateve. Gjithashtu, nëse ndërtesa është projektuar "në proces klasikë", dhe më pastaj janë aplikuar teknologjitë dhe strategjitë për një çështje të mëvonshme në proces të integruar, rezultatet për t'u integruar janë të dobëta në projektimin e përgjithshëm të ndërtesës, qëllimet dhe rezultatet e fundme me siguri do të jenë të dobëta dhe me të kushtueshme. Në ndërtesat ekzistuese, aftësia për të përmirësuar performancën e ndërtesave me strategjinë e projektimit të integruar si një nga idetë kryesore të rindërtimit të ndërtesës, dhe komponentëve të sistemit mundë të arrihen. Pra, kur ne mendojmë për strategjinë e projektimit të integruar të ndërtesës, që përfshin të gjitha aspektet e "projektimit të gjelbër": përmirësimi i efikasitetit energjetik, planifikimi i qëndrueshëm i mjedisit, ruajtjen e ujit, po ashtu duke krijuar një mjedis të shëndetshëm me theks në përdorimin e materialeve të padëmshme për mjedisin.

Autori, (Wilson, A. 2001) ${ }^{58}$ thekson se procesi i projektimit dhe analizat për zhvillimin e një dizajni të integruar të ndërtesave, duhet të përfshijnë:

1. Krijimi i një skenari bazë. Për shembull, profili i performancës tregon përdorimin e energjisë dhe kostot specifike për objektin që është në përputhje me standardet Federale të energjisë dhe masave të tjera për llojin e projektit, vendndodhjen, madhësinë .

58 Eds.Wilson, A. (2001).Greening Federal Facilities. Brattleboro, Vermont : U.S. Department of Energy. 
2. Vargu i identifikimit të zgjidhjeve, të cilat kanë potencial për një çështje të veçantë apo projekt.

3. Vlerësimi i efikasitetit të strategjive individuale: një nga një, me anë të analizës apo procesit të eliminimit për parametrat e caktuara.

4. Strategjitë, grupimi i atyre që janë të efikasitetit të lartë, në kombinime apo kombinatorikë të ndryshme, për të vlerësuar performancën.

5. Përzgjedhja e strategjive, përmirësimi i dizajnit me iterimin e solucioneve dhe aplikimi i analizave gjatë gjithë procesit.

Për të gjetur "recetën" e nevojshme për ndërtim, gjatë projektimit nëpërmjet një procesi të integruar mund të jetë e vështirë, dhe në të njëjtën kohë sfiduese dhe tërheqëse. Ekipet e projektimit shpesh gjatë procesit të projektimit bëjnë edhe ndryshime të mëdha që janë efektive dhe kontribuojnë në "performancë të lartë", madje shpesh edhe me çmime shumë rentabile. Megjithatë, gjatë projektimit, ka raste dhe mundësi të mëtejshme kërkimore që nganjëherë mund të kontribuojnë në arritjen e rezultateve të papritura, në të cilën ekipi i projektimit i thyen pengesat klasike.

" Unë duhet t'ju them se Toka u takon të gjithëve ... çdo brezi gjatë kohës të ekzistencës së tij, plotësisht me të drejtat e tyre... Asnjë brez nuk mund të ketë një barrë më të madhe mbi përgjegjshmërinë ndaj mjedisit përveç gjatë kohës së ekzistencës së tij. "

Thomas Jefferson, 1789.

Hulumtime në këtë lëmi prezanton (Cadima, P. 2007) ${ }^{59}$, duke theksuar se dizajni arkitektonik po bëhet çdo ditë një proces e më kompleks, duke përfshirë aspekte të ndryshme të qëndrueshmërisë. Mënyra se si ndërtesa është programuar, forma, ndërtimi, peizazhi i saj urban dhe i mjedisit, është bërë çështje e procesit të projektimit të qëndrueshëm. Procesi i dizajnit arkitektonik duhet të jetë dinamik dhe holistik e të gjithë sistemeve të ndërtimit dhe të teknologjisë, duke përfshirë veçanërisht dimensionin urban. Projektimi me konceptin e qëndrueshmërisë është një dizajn me një qasje të integruar holistike.

Kompleksiteti i ndërtesave në zonat urbane është vazhdimisht në rritje, në aspektin e teknologjisë dhe të ndërtimit, shërbimeve dhe sistemeve të infrastrukturës, në këtë mënyrë përbëjnë një arkitekturë multidisiplinare, dhe me qasje në planifikimin urban më shumë se kurrë. Bashkëpunimi dhe komunikimi janë esencial, më së të domosdoshëm për një dizajn të qëndrueshëm.

59 Cadima, P. (2007). An integrated building design approach. European Commission. EACI. Brussels, Belgium: Executive Agency for Competitiveness and Innovation. 
Qasja në dizajn të integruar kërkon vullnetin dhe aftësinë e secilit anëtar të ekipit, duke përfshirë arkitektë, inxhinierë, planifikuesit urban dhe sipërmarrësit. Bashkëpunimi i përbashkët i të cilëve kontribuon në gjetjen e zgjidhjeve më të mira. Procesi i projektimit duhet të jetë me pjesëmarrje, dhe përfshinë një shumëllojshmëri të projektimi, duhet të jetë një proces dinamik në mënyrë holistike me të gjitha dimensionet e sistemeve të ndërtimit, duke përfshirë dimensionin e mbrojtjes së mjedisit ".

Në ditët e sotme, termi Arkitekt është përdorur edhe në shumë disiplina të tjera inxhinierie, për projektimin, ndërtimin, mirëmbajtjen dhe renovimin e ndërtesave, me një theks të veçantë në ndikimin e tyre në mjedis.

Në disa gjuhë, termi "arkitekti" është përkthyer fjalë për fjalë si "inxhinier arkitektonik". Ndarja në mes të inxhinierisë, arkitekturës dhe të artit duhet të zhduken, për të lehtësuar zhvillimin dhe evoluimin e njohurive të reja dhe të shprehjes së re arkitektonike. Përdorimi i termit "evoluim" i njohurive të reja arkitektonike është më se aktual dhe bashkëkohor.

Në mënyrë që të harmonizohet integrimi i të gjitha aspekteve të procesit të projektimit, arkitekti apo inxhinieri arkitektonik, duhet të jenë në gjendje të komunikojë dhe të përdorë të njëjtin fjalor me aktorë të ndryshëm të përfshirë në ekipin e projektimit. Megjithatë, pengesa për integrimin e të gjitha aspekteve të procesit të projektimit ende ekziston dhe duhet të tejkalohet.

Andaj konsiderojë se, në lidhje me barrierat ekzistuese për të zbatuar dizajnin apo projektimin e integruar, paraqitet problemi i integrimit të koncepteve të qëndrueshme dhe varet kryesisht nga praktika arkitektonike dhe qasja, infrastruktura ligjore, por gjithashtu kjo është edhe një problem i kulturës së përgjithshme, veçanërisht në aspektin e mungesës së vizionit. Vizioni i arkitektit i referohet arsimimit të tij dhe nivelit të njohurive universale. Ekziston një hendek midis dijes dhe praktikës akademike. Në përgjithësi, çështjet mjedisore që lidhen me çështjet teknike, disa arkitektë besojnë se dominojnë aspektet teknike?

Për fat të keq, ka ende shumë çështje teknike të cilat arkitektët i shohin si kufizime të krijimtarisë dhe lirisë, mirëpo kjo është një sfidë në procesin e projektimit dhe të evoluimit. Arsyeja kryesore për këtë qëndrim është rezultat i nivelit të arsimit akademik dhe atë të përgjithshëm. Hulumtimet tregojnë mënyrat e mundshme për të kapërcyer pengesat ekzistuese, përdorimi i teknologjive të reja duhet të shihet si mundësi për të eksploruar potencialin funksional dhe estetik për kontrollin dhe mbrojtjen e mjedisit. Investitori është gjithmonë në kërkim për përdorim cilësor të hapësirës, natyrisht me koncept të njëjtë është gjithashtu edhe arkitekti. Ndonjëherë është e nevojshme për të rritur ndërgjegjësimin e klientit, të rregullohet raporti ndërmjet kostos dhe përfitimit, duke mos aluduar vazhdimisht vetëm në profit. Aftësia për të zbatuar zgjidhje të favorshme të projektimit të integruar, mund të stimulojë dhe të kontribuojë edhe në konceptin e të kuptuarjes së nivelit kulturor.

Njerëzit nuk i pëlqejnë ndryshimet... Por vazhdimisht janë duke bërë ndryshime, të shpejta dhe të mjaftueshme, aq sa që shkojnë nga një lloj "normale" tek te tjetra ...

Terry Pratchet, 2008. 
Libri (7group \& Reed, B. 2009), fillon me premisën, nga mjeshtri kryesor $i$ shekullit XXI: ku jemi dhe si arritëm deri këtu. Libri përmbledhë procesin e projektimit të integruar, i ndryshëm në shumë aspekte nga projektimi konvencional, për të cilat kemi studiuar me metodën me të cilën jemi akomoduar. Pra, në ekipin e projektimit duhet pasur zgjedhjen e objektivave të identifikuara me vizione, metodologji dhe analiza. Përndryshe, ekipi i projektimit do të funksionojë pa ide të mëdha dhe relativisht do të ketë shtesë dhe rritje në koston totale. Duke përpunuar idetë konceptuale me proceset "klasike" të projektimit, arkitektët lehtë mund të bien në praktikën e modeleve konvencionale, prandaj duhet të përpiqen të jenë pjesëmarrës në ekipin e projektimit si një organizëm i vetëm.

Sipas autorëve të librit duhet të jetë " e gjallë " qasja e të kuptuarit të ndërlidhjes ndërmjet kërkesave dhe sistemeve komplekse, strukturave dhe komponentëve të veçanta. Në një perspektivë unike të ndërtesës, si një organizëm funksional i qëndrueshëm.

Qëndrueshmëria nuk është e transferueshme, qëndrueshmëria nuk është një gjë. Qëndrueshmëria është jo vetëm efikase në teknologji dhe në teknikë, qëndrueshmëria është kuptimi i fjalë për fjalshëm i qëndrueshmërisë së jetës. Veprimet me të cilat qeniet e gjalla, kontribuojnë në interaksion me mjedisin për të siguruar vitalitetin dhe qëndrueshmërinë e secilit pjesëmarrës në procesin e gjatë të ekzistencës.

J. Porritt, kryetar i komitetit për zhvillimin e qëndrueshmërisë së Britanisë së Madhe, vazhdon me një formulim që është i njohur gjerësisht dhe i cituar " Nëse diçka është e qëndrueshme, kjo do të thotë që atë mund ta bëjmë pothuajse gjatë tërë kohës, nëse jo, atëherë nuk mundemi, dhe nuk është e qëndrueshme", paksa përkufizim i rreptë dhe $\mathrm{i}$ vështirë për t'u zbatuar në vendin tonë, arsye ka shumë! Dizajni i integruar i takon jetës reale, me theks të veçantë në atë që është me të vërtetë e rëndësishme në hartimin apo projektimin e qëndrueshëm arkitektonik.

Instituti Amerikan i Arkitektëve, e pranon zyrtarisht projektimin e integruar, Instituti Amerikan i Arkitektëve (AIA) po ashtu miraton edhe kurse dhe punëtori në ketë lëmi. Këshilli Green Building, SHBA (USGBC) ka aprovuar dhe miratuar për cilësi teknike dhe akademike të kursit, për $1 \mathrm{GBCI} / \mathrm{CE}$ orë, për certifikatë LEED, dhe qëndrueshmërinë e programit.

Pas përfundimit të këtij kursi, pjesëmarrësit do të jenë në gjendje të:

1. Definojnë një proces të integruar të projektimit dhe të përshkruajnë se çfarë e dallon nga projektimi konvencional.

2. Përshkruan procesin bashkëpunues, dhe një listë të arsyeve pse seancat duhet të jenë më bashkëpunuese.

3. Listimin e disa parametrave, për të caktuar objektivat dhe për të matur suksesin e projektit.

4. Përshkruan se si BIM mund të ndihmojë dhe përparojë një proces të integruar të projektimit. 
Çfarë ndodh kur ekipi i projektit refuzon procesin konvencional linear të projektimit në favor të dizajnit të integruar? Sipas mbrojtësve të konceptit të dizajnit të integruar, ata prodhojnë një ndërtesë me performancë më të lartë mjedisore me një kosto më të ulët. Dizajni i integruar, merr më shumë anëtarë të ekipit të projektimit rreth tryezës, duke bërë bashkëpunim me të gjitha disiplinat dhe inkurajon risi. Edhe pse ky proces mund të duket së kërkon më shumë kohë dhe çmim më të lartë në fillim, mbështetësit deklarojnë se kjo vetëm ndodhë në fazën fillestare apo gjatë fazës së parë të procesit të projektimit, duke rezultuar në kursime në kohë dhe në ndërtim. Shembujt janë të shumtë të sistemeve të integruara të projektimit të ndërtesave që reduktojnë vlerat ekonomike dhe të buxhetit. Aktualisht, ekziston një nevojë reale për një lloj të re të arkitekturës dhe një mënyrë e re e të kuptuarit për arkitekturën.

\subsection{Ndërtesat publike dhe banimore}

Një pjesë e madhe, pothuajse të gjitha ndërtesa publike dhe individuale të ndërtuara që nga viti 1999 në Kosovë, kanë nevojë për rinovim nga aspekti i efiçiencës së energjisë. Konsumi i energjisë apo humbja termike në këto ndërtesa është veçanërisht i lartë. Prandaj, sa më shumë konsum të energjisë për ngrohje, reflektohet direkt ne emanimet e $\mathrm{CO}_{2}$. Hulumtimet për qytetet e Komunitetit Evropian, tregojnë sipas studimeve se, objektet individuale dhe përdoruesit e tjerë janë përgjegjës për rreth $35 \%$ të emetimeve të $\mathrm{CO}_{2}$ nga energjia e konsumuar. Prandaj, një qasje më e qëndrueshme në funksion të kost-benefitit, konsumi i energjisë në këtë sektor mund të reduktohet në mënyrë optimale. Në figurën e mëposhtme, paraqitet një strukturë polifunksionale dhe një tërësi urbarkitektonike si shembull studimi në këtë lëmi, kjo strukturë urbane është një projekt kompleks. Kompleksiteti i tillë në vete përfshin elemente të ndryshme të qëndrueshme. Sidomos në qasje, mendim holistik, dhe si një sistem i tërë funksional i mëvetshëm. Masdar ka një sistem unik të pesë njësive të integruara në një tërësi, të cilat janë të strukturuara për të inkurajuar shkëmbimin e njohurive, biznesit dhe ekspertizave të specializuara. Sistemi Masdar përfshin: Masdar energjinë, karbon, qytetin dhe Institutin Masdar të Shkencës dhe të Teknologjisë.

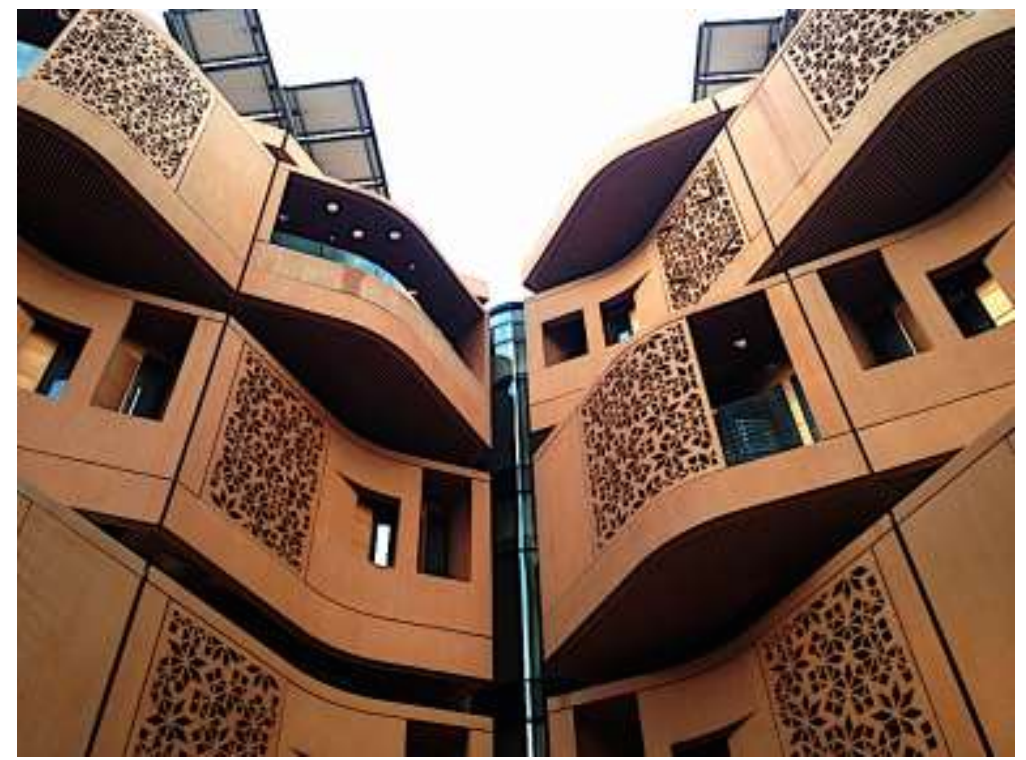

Figura 90. Masdar City, Abu Dhabi.

(Burimi): stuart.childs 2013. E licensuar nga Commons Attribution ShareAlike 2.0 


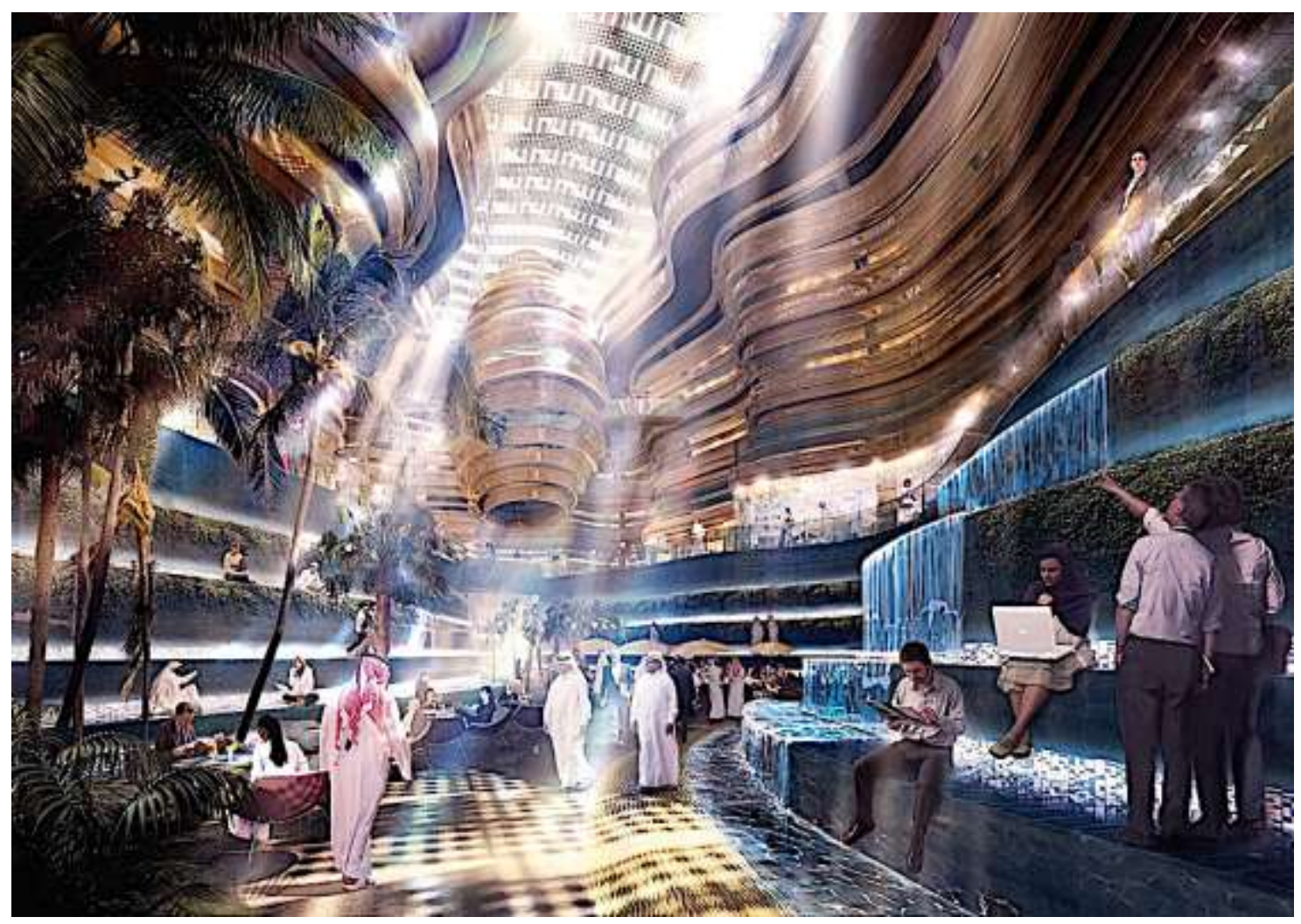

Figura 91. Masdar City, Abu Dhabi.

(Burimi): Forgemind ArchiMedia 2010. E licensuar nga Commons Attribution ShareAlike 2.0

"Si i kemi shfrytëzuar burimet primare të energjisë që furnizojnë qytetet tona, pa kontribut ndaj ndryshimeve klimatike? Si të krijohen teknologji që janë fleksibile dhe që përdorin më pak energji ...? Si të furnizojmë me ujë të pijshëm vendet ku ka reduktime të burimeve të ujit të pijshëm? Si të bëhet rritja ekonomike pa mbështetje kryesore në lëndët djegëse fosile ...? Tani, këto sfida ushtrojnë presion në mbarë botën, por janë veçanërisht të dukshme këtu në Gjirin Arabik. Ne e dimë se furnizimi i naftës është në rënie, burimet ujore janë në rënie. Strategjia e vjetër për zhvillim, prosperitet dhe rritje ekonomike nuk do të funksionojë më."60

\subsection{Pyetjet globale}

Gjendja aktuale e sektorit të banimit apo ndërtesave për banim është e tillë që ai është një konsumator i madh i energjisë, konsumues i madh i burimeve natyrore. Si nga industria ndërtimore për ndërtesat e banimit, apo vetë banimi si koncept arkitektonik është gjenerator substancial i fitimeve financiare. Megjithatë, gjersa po ndërtojmë në të njëjtën kohë jemi duke krijuar një ndikim të caktuar në mjedis, në resurset e energjisë, industrisë ekstraktive, ujit dhe burimeve të tjera natyrore.

60 Clinton, R. H.(2011).US. Secretary of State, addresses the Masdar Institute. 
Sipas hulumtimit aktual, konsumi i përgjithshëm i energjisë në sektorin e ndërtimit është rreth 50-60\%. Natyrisht, për të pasur një mjedis të qëndrueshëm, ka shumë për tu bërë dhe për tu reduktuar ndikimet negative mjedisore.

Nevoja për të përmirësuar performancën e objekteve është detyrë imediate e projektuesve dhe dizajnerëve në raport me vetën, komunitetin dhe klientin. Pra, paraqitët nevoja për të zhvilluar një sistem të matjes së efikasitetit, në mënyrë që efiçienca mund të vlerësohet dhe të ketë përmirësime të vazhdueshme duke promovuar kosto rentabile, kohëzgjatjen, e ndërtimit, mirëmbajtjen efikase, fleksibilitetin, rivitalizimin dhe arritjen e performancës së mirëfilltë. Qëndrueshmëria arkitektonike kërkon një kuptim të sofistikuar të aspekteve natyrore, funksionale, sociale, kulturore dhe arkitektonike. Diçka që është më së e nevojshme në zhvillimin e koncepteve "konvencionale". Është përgjegjësi e secilit arkitekt, të deklarohet hapur në lidhje me ndërgjegjësimin ekologjik dhe të promovojë ruajtjen e mjedisit.

Autorët e studimit (Quatman. W. \& Dhar. R. 2003), të angazhuar për hulumtim nga AIA për problemin e ripërcaktimin të profesionit të arkitektit, arritën në përfundimin se gjatë viteve të '90, arkitektët u përballën me sfidat e tregut që përfaqësonin praktikat aktuale të atëhershme, reagimi ishte i fuqishëm. Instituti Amerikan i Arkitektëve (AIA), ka nisur një seri përpjekjeve për të "ripërcaktuar profesionin". Adresimi i kërkesave të tregut nga aspekti i dizajnit dhe i ofrimit të shërbimeve, AIA pranojnë se koncepti i ri "DesignBuild" është një koncept tjetër, një mundësi e re për praktikën arkitektonike.

Koncepti i shërbimeve projektuese është duke ndryshuar vazhdimisht. PN (projektndërtim), si një ofertë e shërbimit, i njohur si një nga format e shumta alternative të shërbimeve të projektimit, aktualisht mund të jetë metoda më e preferuar e cila përdorët në praktikë. Disa hulumtime tregojnë se në vitin 2002 në SHBA pothuajse $40 \%$ e të gjitha ndërtesave janë të ndërtuara me shërbime (PN). Ka shumë mundësi për rolin udhëheqës të arkitektit me metodën e konceptit (PN), por realisht arkitektët ende nuk e kanë marrë një rol të fortë të udhëheqjes në ofrimin e shërbimeve të tilla. Studimet tregojnë se gara për udhëheqjen në këtë fushë ende është vitale, shumica e arkitektëve janë në fazën e një fillimi të ngadaltë. Për cilësinë e profesionit të arkitekturës, arkitekti duhet të jetë i vetëdijshëm për trendët aktuale, metodat dhe teknologjitë bashkëkohore. Duhet të mbështetemi në të kaluarën mirëpo e ardhmja është më së sfiduese.

Pra, duhet rritur ritmin, në gjetjen e strategjive bashkëkohore për të rimarrë drejtim të ri. Investitorët janë duke lëvizur ngadalë drejt (PN), për një mori arsyesh, duke përfshirë veçori si:

1. Burim unik për projektim dhe ndërtim

2. Ofrim i të dy shërbimeve, me të njëjtën organizatë

3. Kostoja e garantuar e projektit, marrëveshja që në fillim

4. Zvogëlimi i gabimeve në koordinim dhe sinkronizim

5. Kontakt dhe konsultë vetëm me një person, për të dy shërbimet profesionale 
Në një shoqëri të tregut të lirë, me masa të forta ekonomike dhe të profitit, tregu evoluon nga një pozicion në tjetrin, i adaptueshëm dhe fleksibil. Arkitekti duhet të vendosë për rolin e tij. Arkitekti i cili do të udhëheqë procesin (PN), do ta këtë në ofertë të ofrojë më shumë. Duke u akceptuar së për të bërë një projekt të mirë dhe një ndërtim të mirëfilltë, roli i arkitektit është shumë i rëndësishëm, procesi (PN) lejon kontroll më të mirë të buxhetit të projektit, kohën e ndërtimit dhe cilësinë e përgjithshme të projektit. Megjithatë, në procesin (PN) ka diçka për tu humbur nga krenaria.

Pavarësisht pritjes së përgjithshme dhe trendi i shterimit të burimeve primare energjetike, ndotjes në rritje, ka një numër të çështjeve ekonomike, sociale dhe mjedisore të cilat kanë potencial për të krijuar një gjendje kritike globale.

"Çështjet sociale, politike, ekonomike dhe mjedisore ndikojnë tek të gjithë, pa dallim"61

Kështu, duke veçuar një numër të sfidave globale, aktualisht nuk është e mundur për tu kuptuar dhe të trajtohen si duhet vetëm në një kontekst, sfidat dhe problemet janë të natyrës së sofistikuar dhe duhet marrë parasysh të gjithë zanafillën e formimit të tyre. Të kuptuarit dhe përgjegjësia për të vendosur në të cilat drejtimet e mundshme të zgjidhjes së problemeve bashkëkohore, këto janë sfida komplekse të cilat duhet shtrirë në rrafshin e të kuptuarit holistik.

Hulumtime dhe studime të ndryshme konfirmojnë se bota është në një fluks konstant, historikisht duke filluar nga periudha e ngrohjes ekstreme dhe të ftohtit ekstrem apo periudhës së akullit. Këto cikle kanë pasur efekte katastrofike në forma të ndryshme të jetës, speciet kanë vdekur, të tjerët gjenetikisht kanë ndryshuar në forma të reja të jetës dhe të mbijetuarit. Prandaj, ngrohja globale është pjesë e vërtetë e stories aktuale të ciklit të Tokës.

Megjithatë, çështja është tek aktiviteti njerëzor, për shkak të veprimtarive njerëzore, emisionet e dyoksidit të karbonit kanë përshpejtuar nivelin e ngrohjes globale. Temperatura kontrollohet nga ekuilibrit midis energjisë hyrëse nga dielli dhe asaj të humbur përsëri në hapësirë. Gazrat të caktuara atmosferike janë kritike për këtë balans temperaturash, të cilët njihen si gazra serë.

"Një nga argumentet kryesore në provë të teorisë së $\mathrm{CO}_{2}$ vjen nga mostrat e akujve që përfshihen para 160,000 viteve, të marra nga hapësira polare. Këto mostra tregojnë se përqendrimet e $\mathrm{CO}_{2}$ sot, janë vlera maksimale se në çdo kohë tjetër (AAC)."62

Një nga temat në debatin mbi ngrohjen globale, tashmë e konfirmuar dhe e pranuar nga të gjithë është se nuk ka prova të qarta se niveli i dyoksidit të karbonit atmosferik ishte në rritje që nga fillimi i revolucionit industrial. Për të parën herë, matja e përqendrimit të $\mathrm{CO}_{2}$ në atmosferë filloi në vitin 1958, në 4.000 metra mbi nivelin e detit, në majën e malit Mauna Loa në Hawaii.

${ }^{61}$ Global Issues., http://www.globalissues.org/. 2012.

62 CAA. (2006). An Architect's Guide to Designing for Sustainability. Commonwealth Association of Architects: Edgware. UK. 
Matjet u kryen në këtë vend në mënyrë që të shmanget kontaminimi potencial dhe sa më larg nga burimet lokale të ndotjes. Ajo që është treguar qartë në analizën e bërë është se përqendrimi atmosferik i $\mathrm{CO}_{2}$ është rritur çdo vit që nga viti 1958 (Maslin, M., 2004). Ndërsa burimet për emanacionin e $\mathrm{CO}_{2}$ janë lëndët djegëse fosile: vajguri, vaji, thëngjilli dhe gazit natyror. Është llogaritur si emanim në vlerë prej 75\%, nga totali. Për prodhimin e çimentos, shpyllëzimet brutale, prerja dhe djegia e pyjeve, e përbëjnë $20 \%$ tjetër. Në kontekst të frymës së njëjtë, vëmendje të posaçme ju është përkushtuar zhvillimit të teknologjive alternative, prodhim që nuk mbështetet në lëndët djegëse fosile për prodhimin e energjisë (AAC. 2006). Dyoksidi i karbonit mbetet në atmosferë për rreth 100 vite, masat korrigjuese duhet të përforcohen më shumë.

\subsection{Ndryshimet klimatike}

"Ekzistojnë përkufizime të ndryshme për klimën, sipas Konrad, V. (1936) klima definohet si gjendje mesatare e atmosferës mbi një vend të caktuar për një periudhë të caktuar kohore, duke përfshirë lëkundjet mesatare dhe ekstreme apo të skajshme." ${ }^{63}$

Ndryshimi klimatike janë një nga çështjet më të rëndësishme që e karakterizojnë këtë shekull, ndër atributet më të vështira të ndryshimeve klimatike pritet të rritet intensiteti dhe ngjarjet ekstreme të motit, duke përfshirë përmbytjet dhe thatësirat, më shumë stuhi të dhunshme, valë më intensive të ngrohjes dhe përshkallëzim i mundshëm në konflikte për ushqim dhe resurse ujore. Masat për ndryshimet klimatike duhet të zhvillohen në fronte të gjera, është e nevojshme që të përfshihet adaptim dhe zbutje në të njëjtën kohë. Gjysma e popullsisë së botës jeton në zonat urbane, dhe kjo pjesë është duke u rritur vazhdimisht, duke u parashikuar që rritja të arrin në 60\% deri në vitin 2030.

Qytetet konsumojnë shumicën e të gjithë resurseve, 60-75\% të prodhimit të energjisë në botë, duke u llogaritur se kjo është përafërsisht vlera kryesore e emetimeve të $\mathrm{CO}_{2}$ në nivel global.Hulumtimet e kryera nga (OECD, 2010) tregojnë se stabiliteti dhe prosperiteti i qyteteve mbështeten në infrastruktura të mëdha të rrjetit që ofrojnë shërbime fondamentale, hedhja e mbeturinave të ngurta, trajtimi i ujërave të zeza, transporti, uji i pijshëm, energjia dhe sistemet e sanitacionit, të gjitha këto shërbime jetike, kanë ndikim të madh në mjedisin lokal dhe global. Jo vetëm që këto dukuri shpesh tregojnë efekte jo lineare dhe kumulative, efektet negative në mjedis rezultojnë në humbjen e pakthyeshme të vlerës ekologjike (OECD, 2008). Përkeqësimi i sistemeve të infrastrukturës së krijuar, jo efikasiteti dhe ngadalësimi i përparimit të përgjithshëm, imponon kosto shtesë në ekonominë lokale dhe kombëtare. Infrastruktura urbane është projektuar zakonisht për ti trajtuar ngjarjet "normale", veçanërisht në vendet në zhvillim (Hallegatte et al., 2010). ${ }^{64}$ Edhe pse infrastruktura e qytetit është një nga atributet dhe elementet jetike për funksionimin e qyteteve, qytetet në shumë pjesë të botës janë duke luftuar për ti plotësuar nevojat bazike të popullsisë së tyre, kanë burime të kufizuara dhe vështirë përshtaten me ndryshimet klimatike (Ruth et al,. 2006).

Anketa (OECD, 2010) arrin në përfundimin se politika urbane, ekonomikisht racionale mund të kontribuojë në axhenden e ndryshimeve klimatike, duke potencuar masat e mëposhtme për tu ndërmarr:

63 Pllana, R. (2015) Klima e Kosovës. ASHAK, Prishtinë.

64 OECD (2010), Cities and Climate Change. Paris, France : OECD Publishing. 


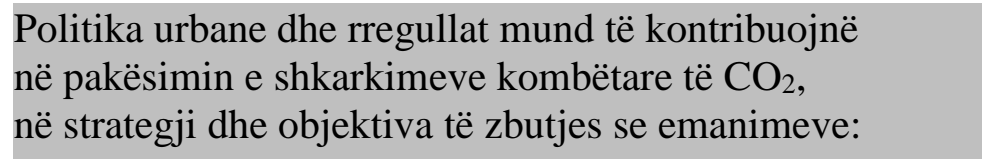

Gjetjet nga modelet e simuluara në kompjuter (IMACLIM-R), me modulin urban, tregojnë se politika urbane mund të çojë në një reduktim në nivel global të $\mathrm{CO}_{2}$, me kosto relativisht të ulët. Duke ndryshuar politikat, në të cilën zbatimi i objektivave të reduktimit të emisioneve janë ide parësore, shpenzimet mund të reduktohet në qoftë se në të gjitha degët e ekonomisë, politikës dhe mjedisit plotësohen me politika adekuate urbane. Kjo është për shkak të ndërvarshmërisë me objektivat dhe politikat tjera, siç janë nivelet më të ulëta të pushtetit lokal, politikat shëndetësore dhe të sigurisë. ${ }^{64}$

\section{Prioritetet e klimës duhet të integrohen \\ në çdo fazë të politikës urbane, në procesin e \\ vendimmarrjes, dizajnit dhe strategjive, zbatimi dhe vlerësimi i politikave:}

Qytetet kanë filluar të përfshijnë si prioritetet ndryshimet e klimës, për të zbutur efektet negative në menaxhimin e fitimeve shoqërore, nga përfitimet e mundshme mjedisore dhe ekonomike. Mirëpo, niveli i strategjive të përshtatjes urbane janë të rralla dhe kanë nevojë për më shumë akceptim. Shpesh mund të ndodhë që politikat urbane janë zhvilluar dhe janë integruar jashtë kornizave të planifikimit urban. Pengesat kryesore për politikat e integruara klimatike janë mungesa e institucioneve përkatëse për të menaxhuar apo mungesa e departamenteve të veçanta qeveritare, mungesa e ekspertizës dhe mungesa e fondeve. Aktualisht, pak ka vlerësim në zbatimin e politikave urbane në temën e klimës, dhe matjen e progresit në parandalimin e ndotjes në shumë qytete. ${ }^{64}$

\section{Stili i jetës, planifikimi hapësinor, komuniteti, transporti gjithashtu janë dominues dhe të rëndësishëm në prodhimin e emetimeve të $\mathrm{CO}_{2}$ :}

Mënyra se si njerëzit qarkullojnë nëpër qytet, zhvillimi i pakontrolluar urban, sasia e energjisë që njerëzit e përdorin në shtëpi për ngrohje, rezulton se qytetet janë konsumatorët më të mëdhenj të energjisë dhe njëherit ndotësit më të mëdhenj. Zonat urbane janë duke u bërë më të dendura dhe më shumë mbështeten në transportin publik, emisionet e dyoksidit të karbonit janë duke u rritur. Gjithashtu, jo të gjitha qytetet, njëjtë në të gjitha shtetet ose vendet në të njëjtin kontinent kontribuojnë në emisionet e dyoksidit të karbonit. Niveli i emisioneve ndryshon gjerësisht brenda vendit, pjesërisht për shkak të dallimeve nga dendësia urbane dhe zhvillimore. ${ }^{64}$

\section{NASA, dhjetor/ 2010, është bërë një model kompjuterik me parashikime në kontekstin e ndryshimeve klimatike.}

Simulimi (NASA) kompjuterik ka gjetur se me rritjen shtesë të bimësisë dhe të pemëve, në modelin e shqyrtuar është zvogëluar përqindja e dyoksidit të karbonit atmosferik, duke u krijuar një situatë të re. Efekt i ftohjes, një sistem i parashikuar që do të mund të punojë në reduktimin ngrohjes globale, në të ardhmen. "Në këtë moment, këto rezultate e kanë ngadalësuar emanimin, por nuk e kanë zgjidhur efektin." NASA. (Bounoua, L. 2010) 


\subsection{Filozofia ekologjike}

Dekurajimi dhe sfida më e madhe e njerëzimi sot po përballet me ndryshimin e klimës globale. Efekte janë duke u rritur në masa akute dhe urgjente çdo ditë, nevoja për një qasje transdisciplinare në strategji duket se është më se e nevojshme dhe shumë urgjente. Përgjigje për këto ndodhi të rëndësishme nuk mund të jenë thjesht të natyrës shkencore dhe teknologjike. Duhet mbështetur me të kuptuarit filozofike që do të marrë në konsideratë universalitetin e natyrës, natyrën njerëzore dhe marrëdhëniet reciproke ndërmjet njeriut dhe mjedisit. Filozofia dhe etika e një mjedisi të shëndetshëm janë frymëzim për jetesë krijuese jo vetëm në teori, por jetesa bashkëkohore inkorporon në kohët e fundit vetëdijesimin në sferat e metafizikës, epistemologjisë, filozofisë shoqërore dhe politike.

Nuk duhet të debatojnë tepër për ndryshimet klimatike.. Duhet ndaluar, efektin serë?

Duhet kuptuar se sa më shumë industri dhe prodhimtari të produkteve, ne bëjmë ndikim të rëndësishëm në mjedis. Gjurmët e prodhimit të karbonit janë diçka që të gjithe janë të vetëdijshëm, andaj duhet vepruar shpejt dhe në mënyrë ekologjike. ${ }^{65}$

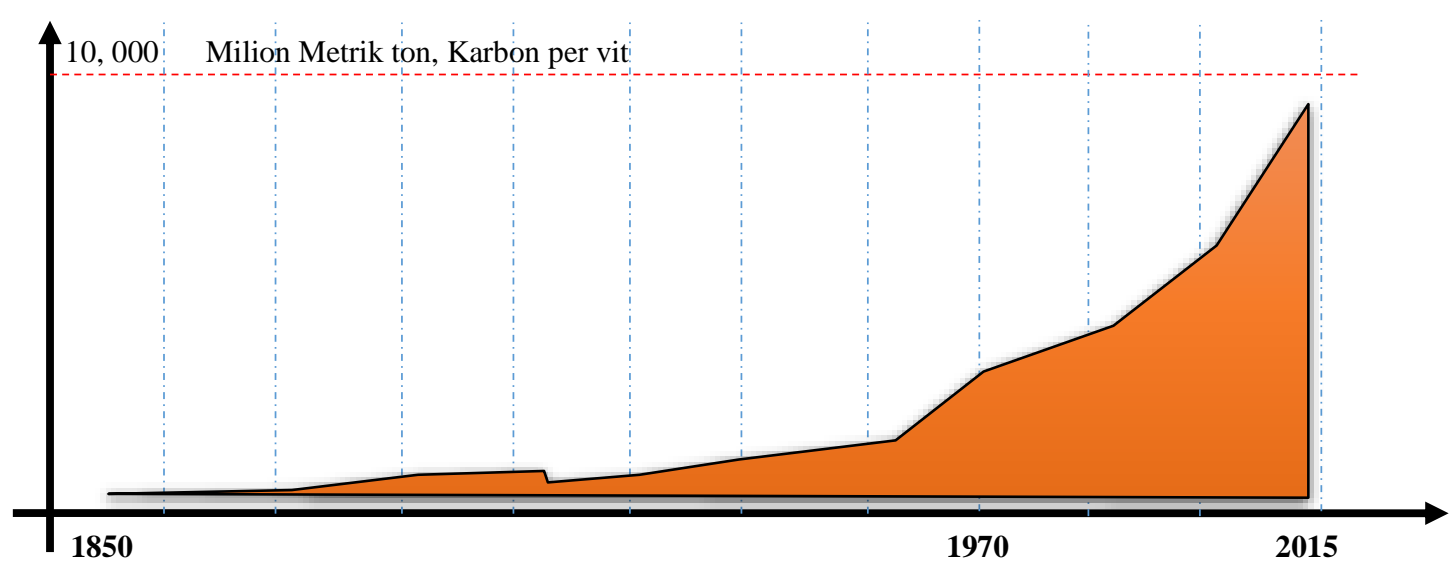

Figura 92. Emanimet e $\mathrm{CO}_{2}$ të përgjithëshme, në botë (Burimi):Bujar Bajçinovci, 2017.

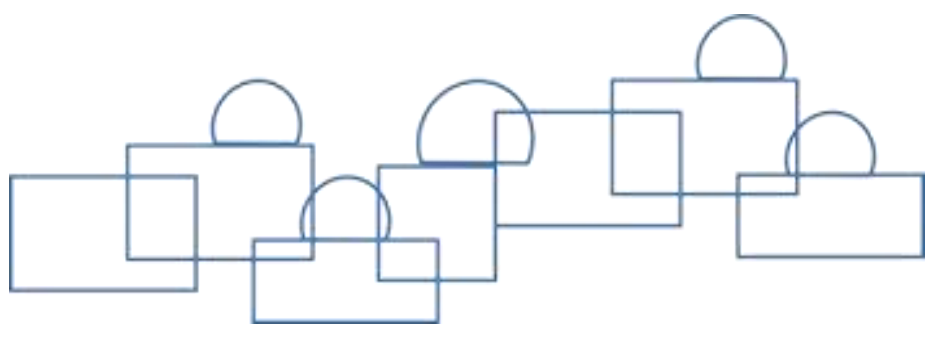

65 Behxhet Mustafa, 2015. 


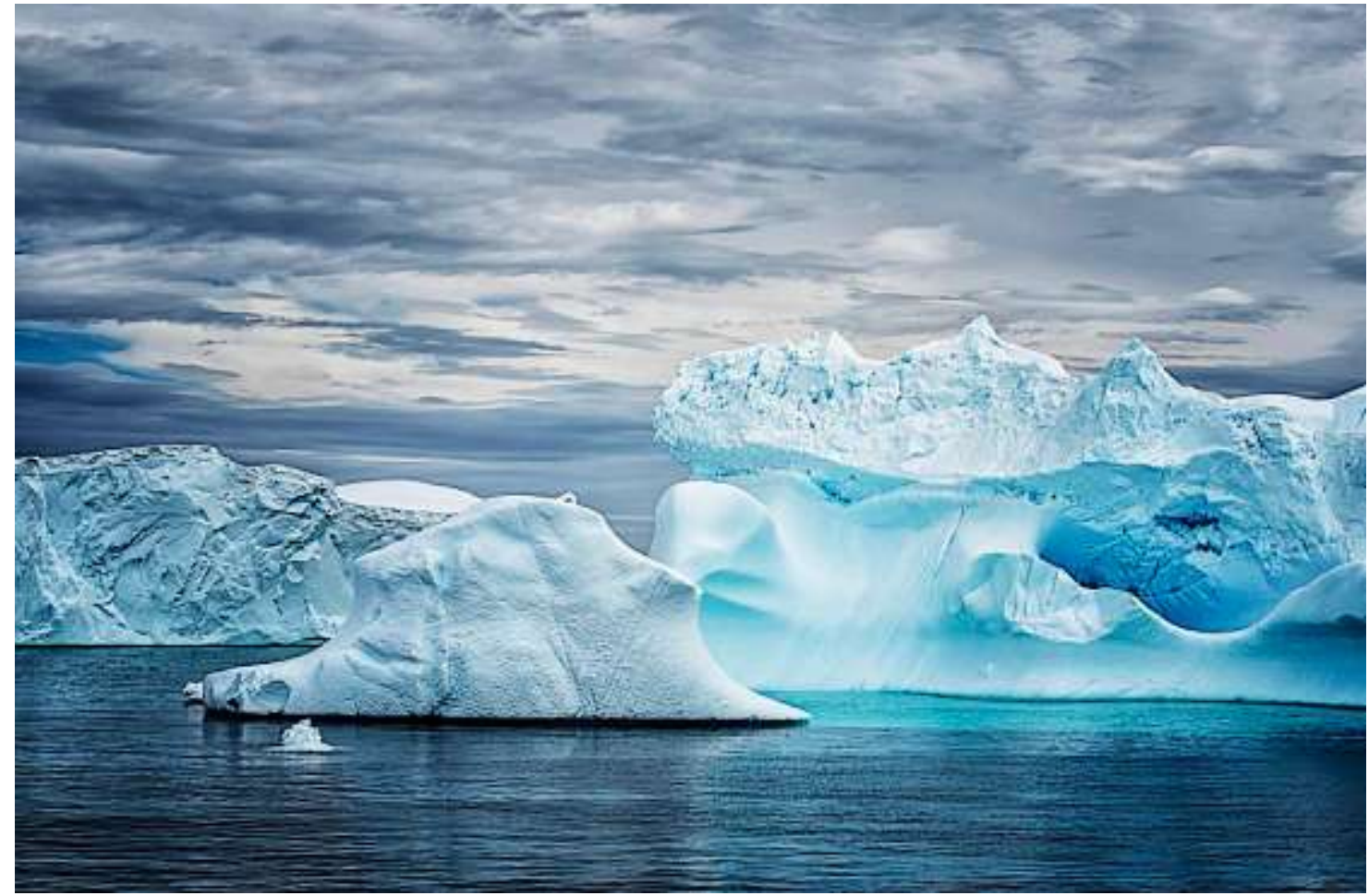

Figura 93. Antarctic Blue

(Burimi): Christopher Michel, 2011. (Flickr). E licensuar nga Creative Commons Attribution ShareAlike 2.0

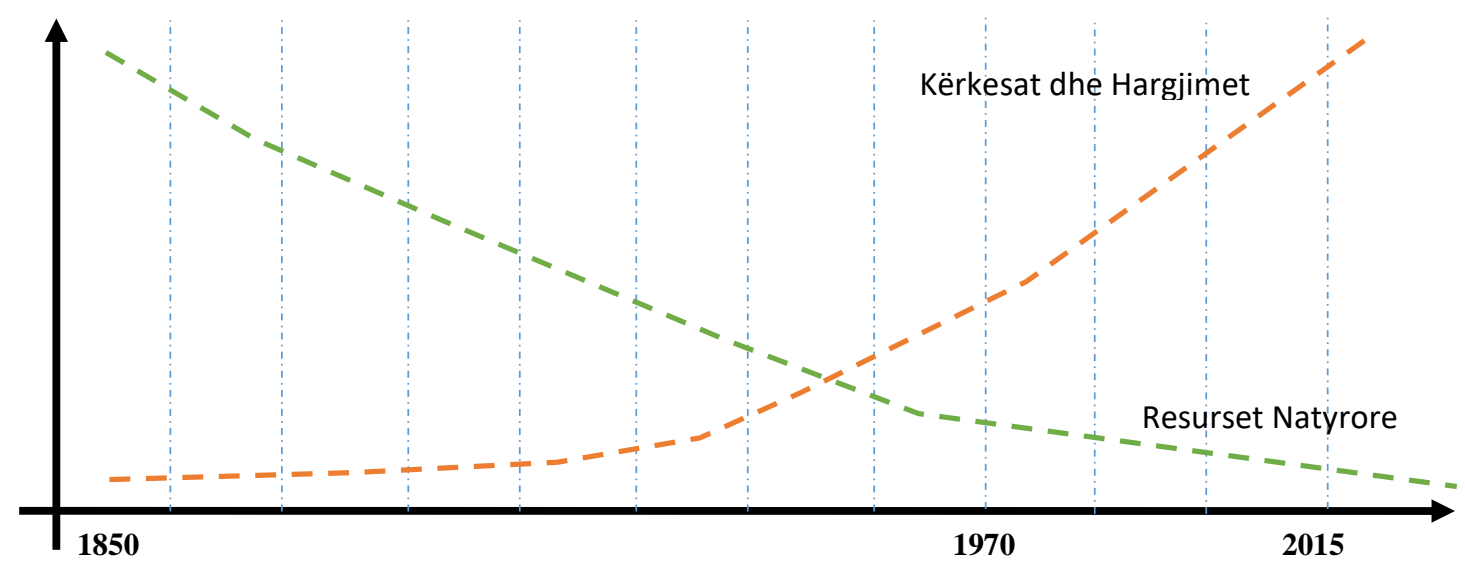

Figura 94. Relacioni i kërkesave të resurseve natyrore dhe rezervat Botërore. (Burimi): Bujar Bajçinovci, 2017.

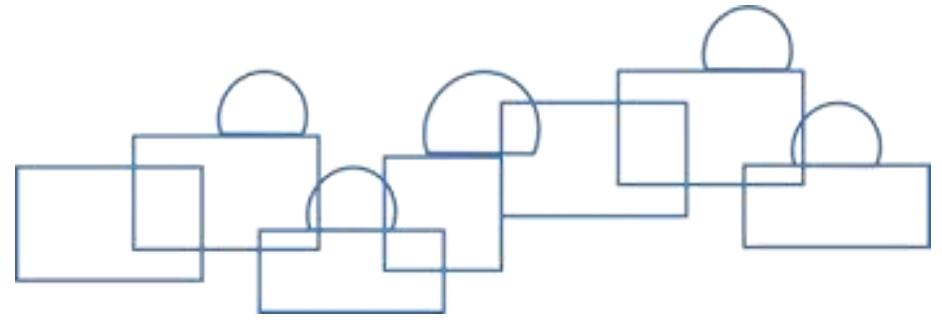




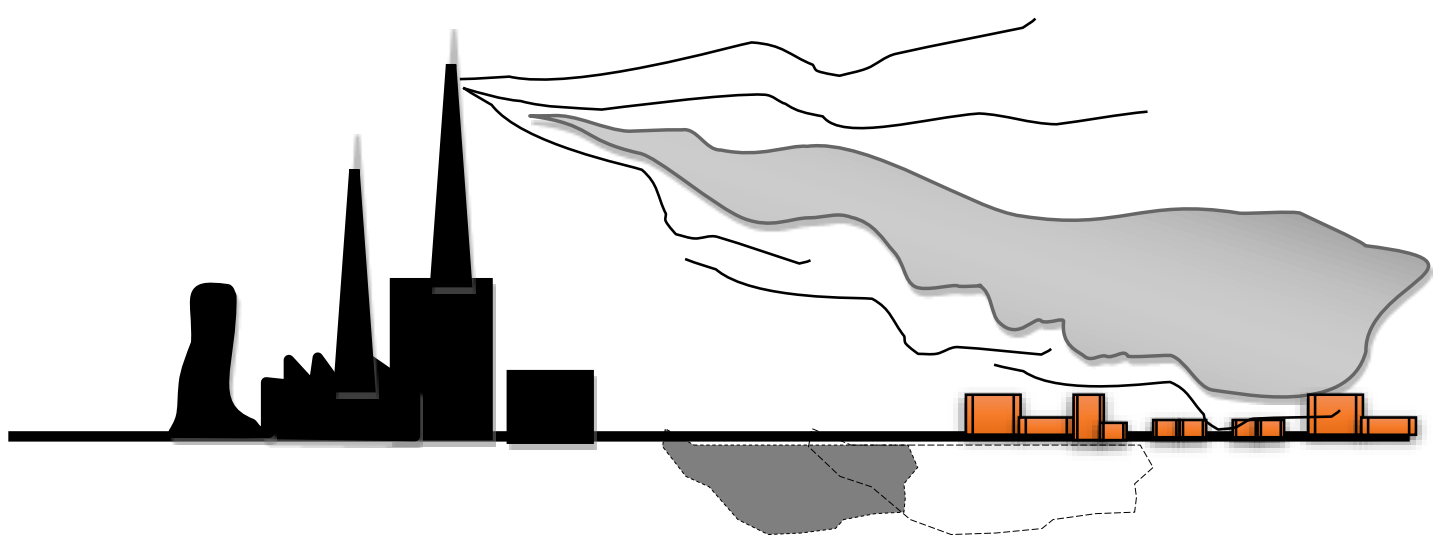

Figura 95. Relacioni urban. Emanimi i Industrisë në cilësinë e ajrit të venbanimeve. (Burimi): Bujar Bajçinovci. Urban Resettlements and Environmental Engineering as a Context for Human Development. A Case Study: Hade. DOI: 10.1515/jaes-2016-0011

\section{Kosova, Konsumi i energjisë elektrike (kWh per capita)}

EG.USE.ELEC.KH.PC

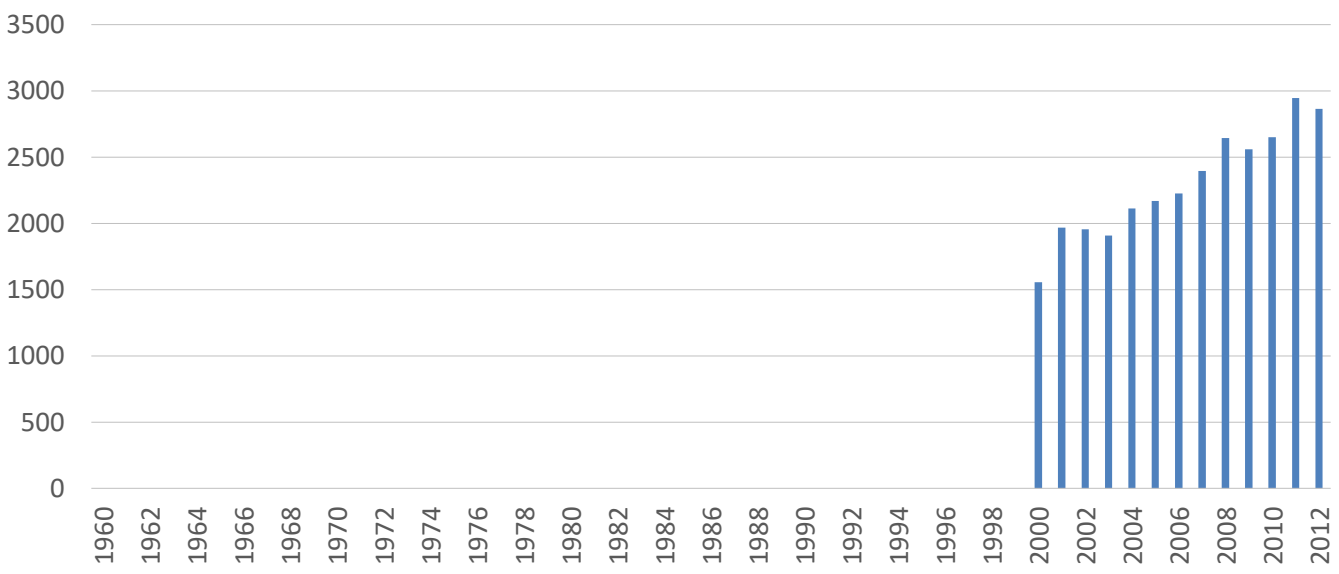

Figura 96. Konsumi i energjisë elektrike, Kosova

(Burimi): http://data.worldbank.org/indicator/EG.USE.ELEC.KH.PC. 2015.

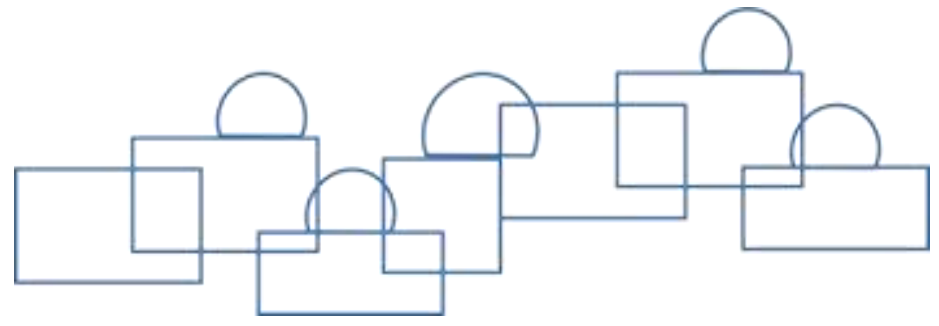


Kosova, Konsumi Energjetik ( $\mathrm{kg}$ of oil equivalent per capita) EG.USE.PCAP.KG.OE

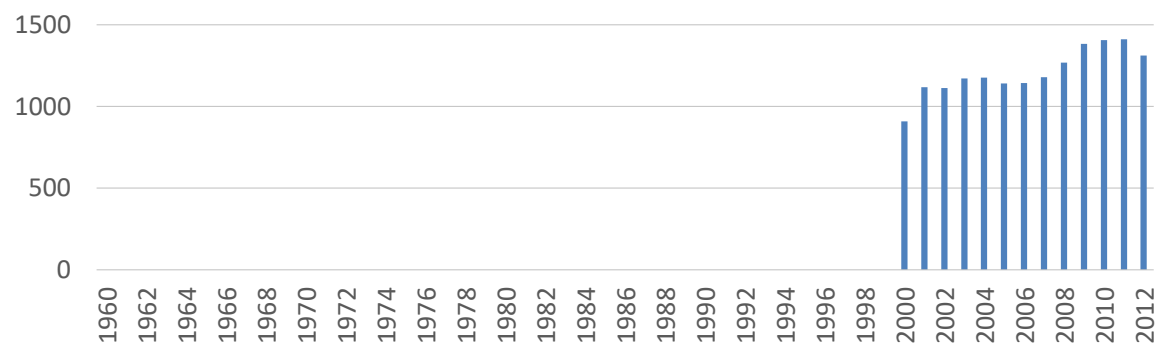

Figura 97. Konsumi Energjetik, Kosova

(Burimi): http://data.worldbank.org/indicator/EG.USE.PCAP.KG.OE. 2015.

Kosova, Konsumi i energjisë, karburantet (\% of total) EG.USE.COMM.FO.ZS

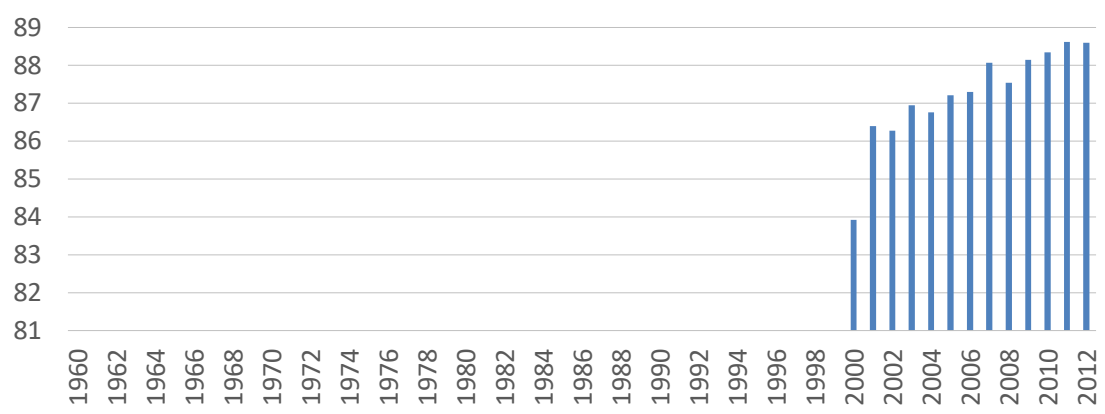

Figura 98. Konsumi i energjisë, karburantet, Kosova (Burimi): http://data.worldbank.org/indicator/EG.USE.COMM.FO.ZS. 2015.

Kosova, Mbeturinat e ripërtëritshme të djegshme (\% of total energy) EG.USE.CRNW.ZS

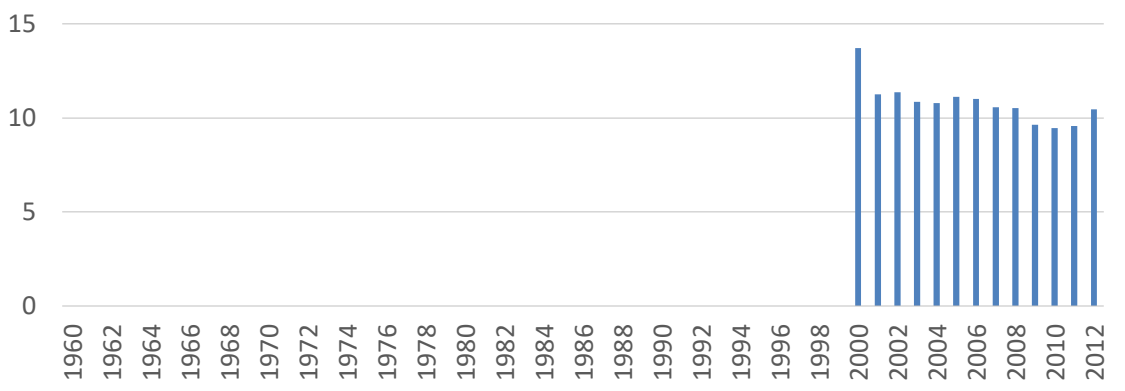

Figura 99. Mbeturinat e ripërtëritshme të djegshme, Kosova (Burimi): http://data.worldbank.org/indicator/EG.USE.CRNW.ZS. 2015. 


\subsection{Epistemologjia}

Epistemologji është shkenca që merret me origjinën dhe mënyrën e dijes, veçanërisht ka të bëjë me mënyrën se si ne mendojmë, një koncept dhe vizion për të zgjedhur dhe për të paraqitur njohuritë shkencore. (Downton. P. 2009.) ${ }^{66}$

Konceptualisht, metoda heuristike është një metodë me të cilën, saktësinë e tregton me shpejtësi në mënyrë që problemi të zgjidhet shpejt, dhe realisht është gati përgjigjja më e mirë e mundshme në bazë të vlerësimeve të arsyeshme dhe njohurive aktuale në dispozicion. Si bazë për epistemologjinë, heuristika ka një avantazh në ofrimin e mundësive të akomodimit të arsyetimit intuitiv. Duke lejuar përdorimin intuitiv, mund të jetë e dobishme me fenomene që nuk mund të kuptohen me reduksionizmin, shembuj të tillë siç janë qytetet. Metodat deduktive, konkretisht: modeli konceptual i qytetit mund të përdoret për hulumtimin e marrëdhënieve të ndërsjella të elementeve, të tilla si infrastruktura sociale apo fizike.

Në praktikë, shpjegimet, sqarimet dhe metaforat mund të ndihmojnë për ta provuar modelin, identifikimin e problemeve dhe zhvillimin e zgjidhjeve të mundshme. Njohurit në disiplinat e arkitekturës dhe planifikimit duhet të përfshijnë ose të dalin përtej kufijve të arkitekturës dhe projektimit. Respektivisht njohuri në gjeografi, ekologji, biologji, sociologji, ekonomi dhe filozofi politike, në një përpjekje për të mbledhur një shumëllojshmëri të metodologjive. Sot kur integrimi intelektual ka arritur nga praktikat e ndryshme, plotësuese dhe gjithëpërfshirëse, ka për qëllim të arrijë tri gjëra:

1. Arkitektura, planifikimi dhe projektimi urban në kontekstin e përgjithshëm mund të identifikohen qartë si elementet e ekologjisë urbane.

2. Përshkrim rigoroz i aktiviteteve vendimmarrëse të qytetit, arkitektët dhe profesionistët tjerë urban, kanë përgjegjësi profesionale.

3. Sistemi i njohurive dhe i praktikës në dizajn, zhvillimi i vendbanimeve, profesionistët duhet të merren me një gamë të gjerë të hulumtimeve.

Hulumtime të zgjeruara, avokimi i domosdoshëm që qasja transdisiplinare është me shumë shtigje, me kalime ose transformime të profesionit me ide, shtresa, shtigje të ndërthurura kërkimi. Programet kërkimore që ndikojnë në mjedis janë shpesh të natyrës ndërdisiplinore.

Qytetet ku banorët duhet të jetojnë shëndetshëm, ndërsa profesionistët duhet ofruar "ofertë për futjen e mjeteve fleksibile analitike, të nevojshme për të zgjidhur problemin për sistemet organike, amorfe" (Doyle, 1997). Qytetet zhvillohen në përputhje me përkufizimit e "sistemeve organike amorfe ", problemet e tyre janë të gjithanshme dhe jetike për disa edhe unike të mëvetshme.

66 Downton, P. (2009). Architecture and Cities for a Changing Climate. Colligwood, Australia: Springer.CSIRO Publishing. 
Përkufizimi i "sistemeve amorfe organike" i gjejmë në favor të konceptit tek autori (Hadrović, A. 2004), në përcaktimin apo definimin e hapësirës arkitektonike, i cili arrin në përfundimin se kushtet e përgjithshme për ekzistencën e arkitekturës janë:

1. Mjedisi

2. Njeriu

3. Kufijtë

4. Perspektivat

Mjedisi, me mjedis nënkuptohet çdo mundësi e realizimit të ekzistencës njerëzore. Në këtë mënyrë, arkitektura nuk është vetëm ajo që deri tani ka qenë ...65

Figura 100. Ameba, DAP. (Burimi): Ahmet Hadrović. DAP. (2004). Definiranje Arhitektonskog Prostora. Sarajevo, BiH.

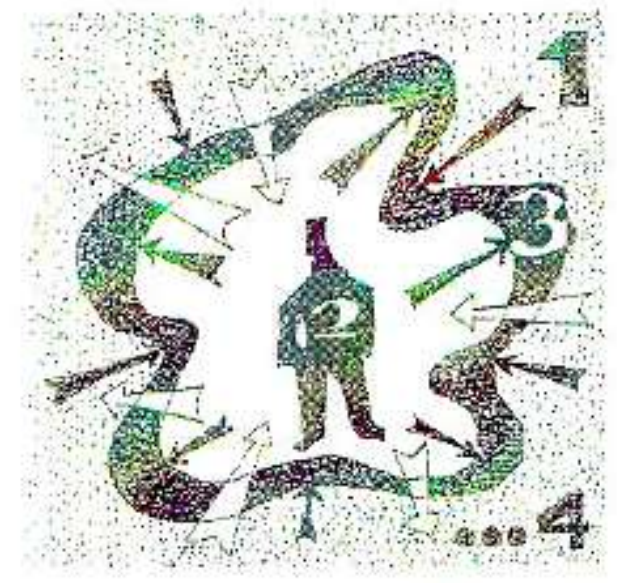

"Njeriu, një qenie natyrore, sociale dhe njëherit krijues i së bukurës. Kjo do të thotë që qeniet e gjalla, përkundër vullnetit të tyre, janë të përfshira në rrjedhën e materies dhe energjisë në natyrë; për të jetuar në një komunitet me njerëz të tjerë në kuadër të marrëdhënieve të caktuara, e cila në raste edhe kundër dëshirës së tyre, por që mund të ndryshohen ... Kufiri njëkohësisht e distancon njeriun dhe e përfshin atë në mjedis. Një strehim përfshin një mbrojtje të ndikimit në lidhje me mjedisin në aspektin e të këmbimit të materies dhe energjisë nga mjedisi. Nëse tensionit ndërmjet nevojave njerëzore dhe kushteve të mjedisit, pra, janë më të lartë dhe komplekse, atëherë kufiri përveç që mund të jetë i saktë apo irracional, mund të jetë edhe një reflektim i vizioneve të caktuara të njeriut apo "një pamje e re e botës". ${ }^{67}$

"Vendi i vërtetë në botën shpirtërore quhet vendi i realitetit, sepse kushdo që vjen aty, në atë vend, e shef të njëjtën formë si gjithë të tjerët. Megjithatë, gjëja imagjinare nuk quhet vend i vërtetë, pasi imagjinaren çdo kush e imagjinon ndryshëm."68

\subsection{Legjislacioni}

"Arkitektura apo Revolucioni" (Le Corbusier 1922). Shumë arkitektë moderne ishin të bindur në rolin social të arkitekturës, apo roli i stabilitetit social i shoqërisë. Bashkimi Evropian ka prezantuar një sërë masash për të siguruar lëvizjen e lirë të mallrave në të gjithë Bashkimin Evropian dhe të tregtisë duty-free. Për më tepër, cilësi e direktivave të përafrimit dhe udhëzimeve për qëllim kontrolli të produkteve, mbi të gjitha, harmonizim teknik të gjitha produkteve në Evropë.

Andaj, standardet dhe rregulloret janë në përgjithësi së bashku të harmonizuara, megjithatë, duhet ditur se këto janë dy gjëra krejtësisht të ndryshme. Gjersa rregullat janë të detyrueshme, do të thotë në bazë të legjislacionit, standardet nuk janë.

67 Hadrović, A. (2004). Definiranje Arhitektonskog Prostora.Sarajevo, BiH : Acta. Et Urbanistica.

68 Rabbi Ashlag, Y. (2009). Shamati. New York. Laitman Pub. 
Koncepti i përgjithshëm i standardeve është që synojnë shfrytëzimin/cilësinë e mallrave, shërbimeve, produkteve për ta lehtësuar tregtinë e lirë. Megjithatë, ekziston një mundësi që rregulloret dhe udhëzimet ju referohen standardeve të caktuara, atëherë konsiderohet se një standard ka fuqi ligjore-juridike dhe duhet të respektohet.

Koncepti i harmonizimit të standardeve gjithashtu është një nga veprimet ligjore, BE deklaron: "Standard i harmonizuar" është një specifikim teknik i miratuar nga autoritetet Evropiane për normat e autorizuara nga Komisioni i BE. Në përputhje me procedurat e parashtruara në Direktivën 98/34/ EC, pajtueshmëria me një "standardi të harmonizuar", nuk është e detyrueshme." 69

Ligji për ndërtimin e Kosovës 2004/15, përcakton situatën aktuale dhe përcakton më tej në përgjithësi, roli i këtij ligji specifikohet me nenin 1.1. Ky ligj përcakton kërkesat kryesore për projektim, ndërtim, përdorim të produkteve ndërtimore, mbikëqyrje profesionale dhe procedurën për marrjen e lejeve të ndërtimit, lejet e punës dhe inspektimin e ndërtimit. Ky ligj përcakton kërkesat kryesore për projektim, ndërtim, përdorim të produkteve ndërtimore, mbikëqyrje profesionale si dhe për procedurat $e$ lejeve të ndërtimit, lejeve të përdorimit dhe inspektimin e ndërtimit.

Termat e përdorura në këtë Ligj kanë përkufizimet e mëposhtme:

Projekt: Kompleksi i planifikuar i ndërtimit me vetitë e tij teknike, të ndërtimit dhe vendosjes, duke përfshirë mënyrën e ekzekutimit të punëve të ndërtimore. Projekti hartohet për qëllime të vërtetimit të konceptit të objektit si para projekt dhe projekt ideor; për qëllime të përcaktimit të kushteve dhe mënyrës së ndërtimit - si projekt kryesor dhe projekt zbatues; për qëllime të plotësimit të dokumentacionit pasi të jetë ndërtuar objekti dhe për qëllime të mirëmbajtjes së tij - si projekt i objektit të ndërtuar;

Ndërtim: ngritja, instalimi, rikonstruktimi, rinovimi, zgjerimi, ndryshimi (ndërrim destinimi), rrënimi i objektit ndërtimor, duke përjashtuar punët për mirëmbajtjen e ndërtimeve ekzistuese dhe punimeve të vogla të specifikuara nga organi kompetent komunal me udhëzime komunale, të cilat kanë leje të përkohshme apo nuk kanë;

Objekt ndërtimi: struktura fizike, e cila lidhet me tokën dhe përbëhet nga produkte ndërtimi, përfshirë pjesë të ndërtimeve, mjete ose pajisje të veçanta instalimi, të cilat bashkërisht paraqesin një kompleks ndërtimor teknik. Termi gjithashtu përfshin hapësira parkimi për automjete, hapësira magazinimi dhe zona për kampe;

Ndërtesë: strukturë fizike e mbuluar, e përdorshme në mënyrë të pavarur, e përshtatshme dhe e parashikuar për strehimin e njerëzve, kafshëve ose objekteve;

Mirëmbajtja e ndërtesës: Përcjellja e gjendjes së ndërtesës dhe ndërmarrja e punëve ndërtimore dhe të tjera, si dhe ndërmarrja e masave të duhura në funksion të mirëmbajtjes së ndërtesës, të cilat nuk i ndryshojnë kushtet e lokacionit sipas të cilave është ndërtuar ndërtesa; $(\text { Ekstrakt })^{70}$

${ }^{69}$ EU. Legislation. Directive 2004/108/EC, of the European Parliament and of the Council. 
Rindërtimi: Ndërmarrja e punëve ndërtimore, punëve dhe masave tjera në ndërtesën ekzistuese përmes të cilave bëhet sanimi, adaptimi, aneksimi, mbindërtimi, largimi i një pjese të ndërtesës; bëhet ndryshimi i elementeve konstruktive për qëllime të stabilitetit të ndërtesës; ndërrimi ose vendosja e instalimeve dhe pajisjeve të reja; ndryshimi i destinimit të ndërtesës, ndryshimi i procesit teknologjik, ndryshimi i pamjes së jashtme; ndikohet në sigurinë e ndërtesave dhe lokacioneve fqinje dhe të mjedisit jetësor; ndryshohen kushtet e mbrojtjes së vlerave natyrore dhe të vlerave të paluajtshme kulturore të cilat janë nën mbrojtje (me përjashtim të punëve të konservimit dhe restaurimit), me ç'rast ndryshojnë kushtet e lokacionit sipas të cilave është ndërtuar ndërtesa;

Vend ndërtimi: hapësira ku kryhen punët ndërtimore, vendi ku bëhet vendosja e objektit dhe hapësira përreth e cila shfrytëzohet përkohësisht;

Ndërtimet e përkohshme: objektet ndërtimore të vendosura përkohësisht, për nevojat e ndërtimit me destinim të përkohshëm për përdorim të teknologjisë përkatëse të ndërtimit, si dhe për organizimin e panaireve, manifestimeve publike e të ngjashme;

Shtëpi familjare: objekt i dedikuar ekskluzivisht për qëllime banimi në parcelën e posaçme të ndërtimit, në sipërfaqe të gjithmbarshme ndërtimore deri në $450 \mathrm{~m} 2$, me më së shumti bodrumin, kati përdhes dhe dy kate mbi të, duke përfshirë sipërfaqen e ndërtimeve ndihmëse (garazha, depo, kaldajë .), nëse ndërtohen në të njëjtën parcelë ndërtimi;

Pronar: titullar i një objekti ndërtimor ose prone të paluajtshme, ku lejohet ndërtimi dhe i cili mund të provojë pronësinë;

Fqiu: pronar ose shfrytëzues të tjerë të pronave ngjitur;

Pjesëmarrës në ndërtim: investuesi, projektuesi, realizuesi, inxhinieri mbikëqyrës dhe të gjithë personat e përfshirë në procesin e ndërtimit; (Ekstrakt $)^{70}$

\section{PROJEKTET}

\section{Parimi Themelor}

Neni 24

Varësisht nga qëllimi dhe niveli i përpunimit, projekti duhet të përpunohet ashtu që objekti të ndërtohet konform kërkesave të këtij Ligji. Projektet, sipas qëllimit dhe nivelit të përpunimit, ndahen në:

- paraprojekti

- projekti ideor

- projekti kryesor

- projekti zbatues

- projekti i objektit të zbatuar.

70 Ligji nr.2004/15 për ndërtimin, Republika e Kosovës. 


\section{Paraprojekti}

Neni 25

Paraprojekti përmban analizat mbi lokacionin e gjerë; variantet e mundshme të zgjidhjes në aspektin e përshtatjes në hapësirë; të dhënat për kushtet natyrore, vlerësimin për ndikimet në mjedis, konform dispozitave ligjore të Ligjit për Mbrojtjen e Mjedisit; të dhënat për aspektin funksional dhe racional të zgjidhjes së përvetësuar; konceptin tekniko teknologjik dhe mënyrën e sigurimit të infrastrukturës teknike, të dhënat për objektet ose zonat historike-kulturore; arsyeshmërinë e investimit për objektet kapitale.

Projekti ideor, Neni 26

Projekti ideor është dokumentacion teknik i cili përmban të dhëna bazë dhe të tjera, të nevojshme për përpilimin e projektit kryesor, lidhur me lokacionin e ngushtë dhe mënyrën e vendosjes së objektit; vlerësimin mbi ndikimet në mjedis si dhe masat për parandalimin ose uljen e ndikimeve negative në mjedisin jetësor, konform dispozitave ligjore të Ligjit për Mbrojtjen e Mjedisit; zgjidhjen themelore të formës dhe të funksionit, si dhe zgjidhjen teknike të objektit; vlerësimin preliminar të stabilitetit dhe sigurisë së objektit; zgjidhjen ideore të infrastrukturës teknike, të dhënat për objektet ose zonat historike-kulturore; skemat teknologjike, koston e përafërt të ndërtimit, transportin, mirëmbajtjen, propozimin për sigurimin e energjisë.

Projekti kryesor, Neni 27

27.1. Projekti kryesor është tërësi e projekteve të harmonizuara në mënyrë të ndërsjellët, me të cilat jepet zgjidhja teknike e objektit. Projekti kryesor përpilohet konform kushteve të dala nga leja urbanistike dhe në bazë të tij lëshohet leja e ndërtimit. 27.2. Varësisht nga struktura teknike e ndërtesës, projekti kryesor përmban:

1. Projektin arkitektonik,

2. Projektin ndërtimor,

3. Projektet e instalimeve në objekte - hidroteknike dhe elektroteknike, gjegjësisht, ujësjellës dhe kanalizim, instalime elektrike dhe të ngrohjes;

4. Paramasën dhe parallogaritë për të gjitha punët,

5. Projektin e gjendjes ekzistuese, për objektet që rindërtohen;

6. Të dhënat gjeoteknike dhe sipas nevojës edhe të dhënat për punët tjera të hulumtimit të lokacionit të objektit,

7. Raportin për mbrojtjen e mjedisit, për ato objekte destinimi i të cilave është definuar si veprimtari që mund të cenojë mjedisin jetësor, konform Ligjit për Mbrojtjen e Mjedisit;

8. Raportin për mbrojtjen nga zjarri dhe eksplodimet. (Ekstrakt $)^{70}$ 
27.4. Projekti kryesor i një objekti mund të shfrytëzohet për ndërtimin e objekteve të tjera, të njëjta si kjo, nëse paraprakisht është arritur marrëveshja në mes të investuesit dhe projektuesit dhe me kusht që të bëhet përshtatja e projektit kryesor me kushtet e ndërtimit në parcelat që do të ndërtohen.

\section{Projekti zbatues}

Neni 28

Projekti zbatues shfrytëzohet për ndërtimin e objektit. Me projekt zbatues përpunohet zgjidhja teknike e dhënë në projektin kryesor me të cilën definohen në tërësi detajet e punëve zbatuese të objektit që do të ndërtohet, përfshirë detajet karakteristike dhe skemat e punëve të zdrukthëtarisë - metalike, të drurit dhe të tjera. Në bazë të projektit zbatues bëhet pranimi teknik i objektit dhe lëshohet leja e përdorimit.

\section{LEJA E NDËRTIMIT}

Kërkesat e lejes

Neni 33

Përveç kur parashikohet ndryshe, leja e ndërtimit lëshohet për objektet e planifikuara ose për aneksim, mbindërtim ose formë tjetër të rindërtimit në objektet ekzistuese, nëse plotësohen kërkesat e të gjitha rregullave dhe kërkesat sipas këtij Ligji dhe sipas ligjeve të tjera të zbatueshme, veçanërisht kërkesat dhe miratimet e lokacionit, sipas nenit 23 të Ligjit të Planifikimit Hapësinor, si dhe nëse është lëshuar leja e kërkuar, sipas ligjeve të tjera.

Përgjegjësitë e institucioneve

\section{Neni 34}

34.1. Komunat janë kompetente për dhënjen e lejes për të gjitha ndërtimet, përveç rasteve të regjistruara në nenin 35 të këtij Ligji. Në rast se ndërtimi prek territorin e dy ose me shumë komunave, komuna ku investuesi ka bërë kërkesën për leje ndërtimi lëshon lejen. Komuna e cila lëshon lejen duhet të koordinoj veprimet me komunën tjetër.

34.2. Ministria përkatëse është kompetente për dhënien e lejes së ndërtimit për ndërtimet e regjistruara në nenin 35 të këtij Ligji dhe në pajtim me ligjet tjera në fuqi. (Ekstrakt) ${ }^{70}$

Aktet ligjore dhe udhëzimet e R. Kosovës mund të krahasohen me hulumtimet përkatëse, në mënyrë që të evidentohet dhe krahasohet koordinim më i mirë në konkluzionet $\mathrm{e}$ mundshme, si një studim apo pikë referimi do të analizohen dokumentet dhe hulumtimet: Rregulloret e ndërtimit në Evropë (Sheridan, L. et al. 2002), i cili do të ketë nivelin e vijës shkencore dhe të referencës: 
"Ky raport është rezultat i një projekti ndërkombëtar kërkimor në sistemin e rregulloreve të ndërtimit, zbatimit dhe monitorimit. Sistemet teknike në tetë vende Evropiane, si: Holandë, Angli, Francë, Gjermani, Suedi, Norvegji, Belgjikë dhe Danimarkë"71

Një studim në kontekstin e krahasimeve të vendeve pjesëmarrëse: Në shumicën e vendeve të analizuara rregullat në lidhje me lejet e ndërtimit dhe procedurat, kërkesat teknike dhe aspektet e planifikimit janë të përcaktuara në nivel kombëtar. Belgjika dhe Gjermania janë përjashtime nga ky rregull.

Në Belgjikë, tre rajone janë të pavarura (Brukseli, Wallonia dhe Flander) janë përgjegjëse vetë për rregullimin në këtë fushë. Në anën tjetër, ligjet kombëtare (të cilat ndikojnë drejtpërdrejt në përgjegjësinë e ndërtimit) rezultojnë me më shumë harmonizim.

Në Gjermani, vende të ndryshme kanë një rol jetik në krijimin e natyrës së tyre të ndërtimit, megjithatë, ato janë të bazuara në të njëjtat modele kombëtare të ndërtimit të pranuara dhe të akceptuara. Pra, tendenca është që, në praktikë të rezultohet me një nivel të lartë harmonizimi. Belgjika, metodat e ndërtimit të mjedisit i planifikimit me dekret. Dekreti gjithashtu përfshin aspektet e planifikimit. Për të aplikuar për një leje ndërtimi, komunat duhet pasur planet hapësinore dhe strukturore komunale, të cilat e kanë fuqinë e vendimmarrjes. Kërkesat teknike mund të gjenden në ligjet kombëtare ose në dokumentet rregullatore. Ligji është i rëndësishëm sepse përcakton përgjegjësitë dhe detyrimet në industrinë e ndërtimit. Sistemi i dalur nga kjo formë është garantuesi kryesor për ndërtimin dhe ruajtjen e cilësisë.

Tabela 12. Rregulloret, kërkesë për leje ndërtimi

(Burimi): Përkthyer, Bujar Bajçinovci. Meijer, F., Visscher, H., Sheridan L.(2002).

Building regulations in Europe and Nederlands: Delft Uni.

\begin{tabular}{|c|c|c|}
\hline & $\begin{array}{l}\text { Lejet e ndërtimit - procesi } \\
\text { kërkesat teknike }\end{array}$ & Aspektet e planifikimit \\
\hline $\begin{array}{l}\text { Belgjika } \\
\text { (Flandres) }\end{array}$ & $\begin{array}{c}\text { Rregullorja Planifikimi Mjedisor } 2000 \\
\text { Rregullorja për organizimin e planifikimit } \\
\text { rajonal } \\
\text { Kodi Civil (Kodi Civil) }\end{array}$ & $\begin{array}{c}\text { Rregullorja Planifikimi Mjedisor } 2000 \\
\text { Rregullorja për organizimin e } \\
\text { planifikimit rajonal } \\
\text { Kodi Civil (Kodi Civil) }\end{array}$ \\
\hline Danimarka & $\begin{array}{c}\text { Ligji i ndërtimit 1995 } \\
\text { Kodet e ndërtimit 1995, } 1998\end{array}$ & $\begin{array}{c}\text { Ligji i ndërtimit (1999, dhe aktet tjera) } \\
\text { Ligji i Planifikimit }\end{array}$ \\
\hline Anglia & $\begin{array}{c}\text { Ndërtimi Akti } 1983 \text { dhe } \text { Kodet e } \\
\text { Ndërtimit } \\
2001\end{array}$ & $\begin{array}{c}\text { Planifikimit Qytetit dhe Shtetëror } \\
\text { Akti } 1990 \\
\text { (të cilat formojnë bazën për } \\
\text { vendime dhe rregullore) }\end{array}$ \\
\hline Franca & Kodi i Ndërtimit dhe i banimit & Kodi Urbanistik \\
\hline Gjermane & (model) Rregulloret Ndërtimore & Akti Federal i Ndërtimit 1987 \\
\hline Holanda & $\begin{array}{l}\text { Ligji i marrëdhënieve të banimit dhe } \\
\text { vendimi për ndërtesa }\end{array}$ & Ligji i Planifikimit Hapësinor 1962 \\
\hline Norvegjia & $\begin{array}{l}\text { Planifikimi dhe Kodi I Ndërtimit } \\
\text { Rregulloret e ndërtimit } 1997\end{array}$ & $\begin{array}{l}\text { Planifikimi dhe Kodi I Ndërtimit } \\
\text { Aktet nënligjore mbi planet lokale }\end{array}$ \\
\hline Suedia & $\begin{array}{c}\text { Planifikimi dhe Ligji i Ndërtimit } 1996 \\
\text { Rregulloret e ndërtimit } 1996\end{array}$ & $\begin{array}{l}\text { Planifikimi dhe Ligji i Ndërtimit } 1997 \\
\text { Rregulloret e ndërtimit }\end{array}$ \\
\hline
\end{tabular}

\footnotetext{
${ }^{71}$ Meijer, F.,Visscher, H., Sheridan L.(2002).Building regulations in Europe. I. Nederlands : Delft Uni. 176
} 
Ligjet Daneze, mbi ndërtimin japin udhëzime kryesore dhe kërkesat e përgjithshme të zbatueshme për ndërtesa dhe cilësinë e ndërtimit. Të dy rregulloret kryesore që burojnë nga ky ligj (një ndërtesë e madhe apo e vogël), përshkruajnë procedurat dhe kërkesat teknike. Aspektet e projektit, përcaktohen në një rregullore dhe Ligj të veçantë, të cilat janë në lidhje me shumë akte të tjera juridike që kanë impakt hapësinor (Akti i mbrojtjes së natyrës, mbrojtja e pyjeve).

Rregulloret në Angli dhe Uells, kanë referencë Aktin e Ndërtimit (1984) i cili ofron një kornizë ligjore për Kodin Kombëtar të Ndërtimit 2001 (duke përfshirë edhe rregulloret e veçanta). Kodet e ndërtimit në përgjithësi përshkruajnë procedurat e duhura. Çështjet e planifikimit janë të definuara me akte urbane dhe rurale të planifikimit (1990), duke përfshirë edhe pjesë të zonave të ndërtimit dhe ruajtjes së materieve të rrezikshme. Bazuar në këto ligje, rregullore dhe dekrete, janë lëshuar lejet e ndërtimit. Përveç lejeve të ndërtimit, lejet e planifikimit janë të nevojshme në Angli dhe Uells në rastet e ndërtimit specifik. $^{71}$

Në Francë, Ligji për ndërtimin i njohur si Ligji Spinetta, ka një rol të rëndësishëm në përcaktimin e përgjegjësive dhe detyrimet të palëve në industrinë e ndërtimit. Ai ndikon në çdo aspekt tjetër procedural si dhe në rolin e palëve në procedurë për një leje ndërtimi, cilësinë dhe mënyrën e ndërtimit. Ndryshe nga Belgjika, në Francë, aspektet procedurale dhe teknike janë të përfshira në ligjin kombëtar, kodet e ndërtimit janë të ndara në pjesën legjislative dhe rregullative (vendimet e Asamblesë Kombëtare).

Kërkesat e tjera teknike mund të gjenden në një gamë të ligjeve, dekreteve dhe rregulloreve ministrore dhe udhëzimeve. Kodet për planifikimin urban ofrojnë udhëzime për qeveritë lokale dhe planifikimin urban lokal, të cilat duhet të merren parasysh kur merren vendime mbi ndërtimin e objekteve ekzistuese si dhe atyre të rejave. ${ }^{71}$

Modeli i rregullave të ndërtimit, në Gjermani janë juridikisht në nivelin federal, ofrojnë udhëzime për rregulloret e nxjerra në shtetet federale. Përmbajtja e rregulloreve të vendeve të ndryshme, janë më shumë se $90 \%$ të ngjashme. Kodet e ndërtimit parashikojë rregulla procedurale dhe rekomandime për kërkesat teknike (të cilat janë të përshkruara në detaje në standardet gjermane). Akti Federal i ndërtimit (1997) merret me planifikimin urban, masat dhe zhvillimin urban të qytetit.

Në Holandë, Akti i Banimit ofron kornizën procedurale për lejet e ndërtimit, procedurat dhe rregullat teknike. Dispozitat e detajuara janë të formuluara në rregullat e përgjithshme administrative, e cila përmban kërkesa teknike. Planifikimit Hapësinor merret me zhvillimin hapësinor të vendit, komunat lokale janë pjesë e kuadrit ligjor përgjegjës për formulimin dhe ekzekutimin e planeve urbanistike vendore.

Planifikimi dhe ndërtimi, pjesë e rëndësishme e kornizës ligjore Norvegjeze për procedurat për marrjen e lejeve të ndërtimit, planifikimit dhe rregullat teknike. Rregulloret e ndërtimit përmbajnë një grup të veçantë të kërkesave teknike. Disa akte nënligjore që rregullojnë aspektet e planifikimit urban dhe të qytetit, kryesisht të detajuara, për procedurën e aplikimit dhe marrjes së lejes së ndërtimit. (Ekstrakt) ${ }^{71}$ 
Tabela 13. Procedurat për kategori të ndryshme, të lejeve.

(Burimi): (Burimi): Përkthyer, Bujar Bajçinovci. Meijer, F., Visscher, H., Sheridan L.(2002).

Building regulations in Europe and Nederlands: Delft Uni.

\begin{tabular}{|c|c|c|c|}
\hline & Përjashtimet & Procedura të lehtësuara & Procedura Komplete \\
\hline Belgjika & Po & $\begin{array}{c}\text { proces urbanistik } \\
\text { Projekti i thjeshtë }\end{array}$ & Leje urbane, Komplet projekti \\
\hline Danimarka & Po & Informacion Ndërtimi & $\begin{array}{c}\text { Dy llojet të lejeve } \\
\text { ndërtesa të vogla dhe të tjera }\end{array}$ \\
\hline Anglia & Po & $\begin{array}{c}\text { Informacioni } \\
\text { ndërtim(ndërtim i ri dhe } \\
\text { ndryshimet) }\end{array}$ & Projekti i plotë \\
\hline Franca & Po & Informacion Ndërtimi & Leje ndërtimi \\
\hline RF.Gjermane & Po & Leja fillestare & Leje ndërtimi \\
\hline Holanda & Po & Leja fillestare & Leje e rregullt \\
\hline Norvegjia & Po & $\begin{array}{c}\text { Informacion Ndërtimi } \\
\text { Sore dhe finale }\end{array}$ \\
\hline Suedia & Po & $\begin{array}{c}\text { Informacion Ndërtimi } \\
\text { Leje ndërtimi }\end{array}$ \\
\hline
\end{tabular}

Tabela 14. Rregulloret, fillimi i ndërtimit, inspektimit, përfundimi.

(Burimi): (Burimi): Përkthyer, Bujar Bajçinovci. Meijer, F., Visscher, H., Sheridan L.(2002).

Building regulations in Europe and Nederlands: Delft Uni.

\begin{tabular}{|c|c|c|c|}
\hline & Fillimi i ndërtimit & $\begin{array}{c}\text { Inspektimi gjatë } \\
\text { ndërtimit }\end{array}$ & Përfundimi i procedurave \\
\hline Belgjika & Pas lëshimit të lejes & Jo & Jo \\
\hline Danimarka & $\begin{array}{c}\text { Pas lëshimit të lejes } \\
\text { dhe deklaratës së fillimit të } \\
\text { punimeve }\end{array}$ & Po & $\begin{array}{c}\text { Pas shpalljes së aplikantit } \\
\text { se rregullorja është } \\
\text { respektuar }\end{array}$ \\
\hline Anglia & $\begin{array}{l}2 \text { ditë pas marrjes së } \\
\text { aplikimit }\end{array}$ & $\begin{array}{l}\text { Inspektimi i rregullt } \\
\text { vizita të detyrueshme }\end{array}$ & $\begin{array}{l}\text { Certifikatë pranimi } \\
\text { Ndërtesa }\end{array}$ \\
\hline Franca & Pas lëshimit të lejes & Jo & $\begin{array}{c}\text { Certifikatë pranimi } \\
\text { Ndërtesa , edhe pas } 2 \\
\text { viteve të finalizimit }\end{array}$ \\
\hline Gjermania & $\begin{array}{l}\text { Pas lëshimit të lejes } \\
\text { ( në afat } 3 \text { vjeçar) }\end{array}$ & $\begin{array}{l}\text { Kontrolli i plotë i } \\
\text { punëve ndërtimore, } \\
\text { përpara fillimit të } \\
\text { punës. (Aplikanti } \\
\text { mund të kërkojë një } \\
\text { certifikatë inspektimi) }\end{array}$ & $\begin{array}{c}\text { Ndërtesa mund të përdoret } \\
\text { pas pranimit teknik dhe } \\
\text { deklaratës pozitive }\end{array}$ \\
\hline Holanda & $\begin{array}{l}\text { Pas lëshimit të lejes dhe } \\
\text { deklaratës së fillimit të punimeve }\end{array}$ & $\begin{array}{l}\text { Inspektimi i rregullt } \\
\text { vizita të detyrueshme }\end{array}$ & Jo \\
\hline Norvegjia & $\begin{array}{l}\text { Maksimum prej } 4 \text { javësh pas } \\
\text { aplikimit me projekt të detajuar }\end{array}$ & $\begin{array}{l}\text { Plani I mbikëqyrjes } \\
\text { dhe inspektimi }\end{array}$ & $\begin{array}{l}\text { Certifikatë pranimi } \\
\text { Ndërtesa }\end{array}$ \\
\hline Suedia & 3 javë pas aplikimit të ndërtimit & $\begin{array}{l}\text { Plani I mbikëqyrjes } \\
\text { dhe inspektimi }\end{array}$ & $\begin{array}{l}\text { Autoriteti lokale kryejnë } \\
\text { procedurat e inspektimit }\end{array}$ \\
\hline
\end{tabular}


Në Suedi, kodi i ndërtimi vepron sipas (PBA, 1987), është dokumenti kryesor që përmban rregullore për planifikim dhe ndërtim. Dispozitat e detyrueshme dhe rekomandimet e përgjithshme në lidhje me strukturën, mund të gjenden në rregulloret $\mathrm{e}$ hartuara (BKR, 2000). Rregulloret mbi ndërtimin, në përputhje me rregulloren dhe Aktin e Ndërtimit (1994), si dhe Dekretit (1994) mbi kërkesat teknike për punimet e ndërtimit.

Çështjet e planifikimit, të tilla si master plani komunal, planet e hollësishme të zhvillimit janë të caktuara edhe me këtë Ligj. Andaj, mund të konkludojmë se (përveç në Belgjikë dhe në një masë më të vogël në Gjermani) në të gjitha vendet e përfshira në procedurat e anketës, lejet e ndërtimit dhe planifikimit janë të rregulluara në nivel kombëtar. Ndërsa, rregulloret dhe kërkesat teknike ndryshojnë midis vendeve të ndryshme. ${ }^{71}$

\subsection{Planifikimi}

Në disa vende, kontrollet dhe inspektimet që janë të lidhura me vendndodhjen e punëve ndërtimore bien jashtë fushëveprimit apo procedurës së lejeve të ndërtimit. Anglia (dhe Uellsi) bëjnë dallimin në mes lejeve të ndërtimit. Pra, një organ tjetër ligjor lokal ose departament në lidhje me kontrollin e lejeve të ndërtimit apo planifikimit. Realisht duhet të ketë një licencë planifikimi për të aplikuar për një leje ndërtimi. Avantazhi i këtij modeli është se procedura e duhur për leje ndërtimi mund të minimizohet, për një kohë të shkurtër, përveç në rastin e Holandës ku ndonjëherë ndodh e kundërta. Në Francë dhe Belgjikë, kontrolli i aspektit të planifikimit është pjesë e procesit të marrjes së lejeve të ndërtimit (kjo është edhe pjesa më e rëndësishme e procesit).

Para se fillojë dizajni i ndërtesës, apo strukturës që duhet të zhvillohet, aplikanti duhet të ketë certifikim nga shteti, të veçantë në përputhje me të gjitha dispozitat dhe aktet ligjore. Kjo i jep aplikantit një pjesë të kohës, dhe në fund të procesit, nuk mund të ketë ndonjë befasi në lidhje me kërkesat e punëve ndërtimore, formës, dimensioneve. Në Holandë, procedura e marrjes së lejes ndërtimore është futur në faza. ${ }^{71}$

\subsection{Zhvillimi}

Evropa Perëndimore ka shkallë të lartë urbanizimi dhe të popullimit, shumica e popullatës, në kuadër të komunitetit Evropian jetojnë në qytetet të mëdha urbane, gjithashtu, qytetet janë të përqendruara në të ashtuquajturat rajone metropolitane. Rajone nga më të urbanizuarat janë: Jugu i Anglisë, rajonet në Francë (Nord-Pas-de-Calais, pellgu i Parisit - d'Ile-de-France), po ashtu në Belgjikë (rajoni Walloon, Flanders dhe Brukseli), në Holandë (Jugu, Perëndimi dhe Lindja), në Gjermani (North Rhine Westphalia) dhe Luksemburgu. Hapësirë që lidhë rajonin zë vetëm $13 \%$ të komunitetit Evropian (1990), por ajo pritet të zë më shumë se $25 \%$ e popullatës, duke përfshirë edhe 12 milion njerëz në Londër, 11 milionë d'Ile-de-France, mes 4 dhe 5 milion në Randstad dhe 10 milionë në Rhine-Ruhr.

Vlen të përmendet fakti se në qendrat e lartpërmendura të mëdha metropolitane janë të vendosura shërbimet më të mëdha globale, serviset e gjithë botës. Shpërndarja e popullsisë është shumë e ndryshme në komunitetin e Bashkimit Evropian. Franca është e njëjtë si Mbretëria e Bashkuar, me një përqendrim shumë të lartë të popullatës në kryeqytet. 
Vende të tjera, si Gjermania, Italia dhe Holanda kanë një shpërndarje më të përhapur të popullsisë urbane me një pjesë të qyteteve provinciale, duke mos e ndarë rregullimin hapësinor dominues të qyteteve. Kjo është e rëndësishme, pasi që qytetet e mëdha kanë tendencë të kenë një varësi më të madhe nga transporti publik, veçanërisht ai hekurudhor në raport me qytetet e "mesme". Parisi, Londra dhe Berlini kanë një sistem shumë të përpunuar hekurudhor. ${ }^{72}$

Qytetet evropiane historikisht kanë dendësi të madhe urbane dhe janë kompakte, vazhdimisht kanë qenë të varura nga transporti publik. Veçori e përbashkët është se qytetet Britanike janë më pak të dendura se në zonat kontinentale Evropiane. Nëse krahasojmë dendësinë, zonë me zonë, qytetet tipike Britanike dhe ato tipike Gjermane, nuk ka shumë ndryshim, përtej kufijve të qyteteve në të dyja shtetet ka një rënie të densitetit në pjesët rurale.

Pas Luftës së Dytë Botërore, në kohë të ndryshme dhe në rrethana të ndryshme, të gjitha qytetet e Evropës Perëndimore janë decentralizuar. Ky proces filloi në Britani të Madhe dhe në vendet e Beneluksit në vitin 1950, 1960 dhe u përhapë pastaj në vendet Skandinave dhe në Gjermani, në vitet 1970 - 1980 në Francë, Spanjë, Portugali dhe Itali. $^{64}$

Kështu, dallimet në detaje varen nga vendi në vend, decentralizimi urban gjendet në llojet e planifikimit dhe funksionimit të sistemit planifikues. Planifikimi dhe zhvillimi i qyteteve të reja satelitore ka pasur një efekt të madh në urbanizimin dhe prosperitetin e regjioneve. Mendohet se zonat periferike urbane të Parisit, Stokholmit, Amsterdamit, ishin planifikuar dhe projektuar si pjesë e zonës suburbane që nga fillimi.

Planifikuesit kanë pasur pak ndikim në këtë proces, sepse në këtë kuptim, përdorimi i makinave personale dhe transporti i mallrave është bërë përmes transportit rrugor i cili vazhdimisht ka shënuar ngritje, gjithashtu ka dominuar në aspektin faktik, ndërsa transporti me metro dhe ai hekurudhor ishte i rëndësishëm për "Commuting" në qendrat e mëdha metropolitane dhe për distanca shume të gjata.

\subsection{Eko shëndeti}

Në fushën e eko shëndetit, aktualisht po implementohet më shumë marketing shëndetësor i cili vazhdimisht është duke promovuar kualitetin e jetesës. Studimet ndryshojnë nga ato tradicionale, disiplina në mëvetësi ngërthen hulumtim i cili përdor një qasje të ndryshme, duke sjellë disiplina të natyrës së subspecializuar si anëtare në hulumtim. Nëpërmjet procesit të programimit para takimeve fillestare, ekipi projektues miraton një strategji të përbashkët dhe çasje në veprim, për të definuar problemin e caktuar. Këto takime shpesh çojnë në formulime kreative të problemit dhe mund të çojnë në zgjidhje më efikase të detyrës projektuese. Hulumtime e bëra janë rezultat i të gjithë participantëve dhe ekipeve të përfshira, duke përfshirë edhe "udhëzimet politike". (Jean Lebel, 2003) ${ }^{73}$ identifikoi tri shtyllat kryesore të ekoshëndetit të cilat janë: transdisiplina, pjesëmarrja e përgjithshme dhe balansi natyror.

\footnotetext{
72 Eds.Banister D.(2005). Transport and Urban Development. London.UK: Taylor \& Francis. E \& FN Spon, an imprint of Chapman \& Hall.

73 Lebel J.(2003). Health, An Ecosystem Aproach. Canada.IDRC.
} 
"Shkencëtarët duke përdorur një qasje transdisiplinare dërgojnë një sinjal të fortë në drejtim të duhur në aspektin e zgjidhjes së problemit, ku nga afër përfshihet komuniteti dhe rrethi social me pushtetin lokal, në kontekstin e vendimmarrjes dhe kualitetit të jetesës së tyre."

\subsection{Procesi i Projektimit të integruar}

Procesi i projektimit të integruar ofron mundësinë e të kuptuarit më të mirë në specifikat e detyrës projektuese, në favor për të arritur një zgjidhje adekuate. Në vitet e fundit kemi një progres të madh në të kuptuarit teknik të sistemeve energjetike në ndërtesa apo të efiçiencës, përdorim më të mirë të energjisë diellore, diellosjes, ventilimit natyror dhe përdorimin e materialeve ekologjike të riciklueshme.

Shumë objekte aktualisht tregojnë përmirësime të konsiderueshme të performancës krahasuar me standardet konvencionale të konsumit të energjisë, rehatisë dhe ndikimit në mjedis. Procesi i projektimit në këto objekte të ndërtuara, tregon se jo vetëm që është ridefinuar përdorimi i teknologjisë, por edhe trajta dhe forma, materialet, sistemet dhe koncepti projektues.

Procesi i integruar i projektimit, mbështetet në aftësitë dhe njohuritë e disiplinave të ndryshme dhe ndërveprimit të sistemeve të ndryshme, kompleksitetit e të gjithë pjesëmarrësve, në mënyrë që të prodhojnë një projekt më origjinal, më efikas dhe më të përgjegjshëm për mjedisin në raport me çmim racional. Projektimi i integruar i konsideron marrëdhëniet dhe relacionin ndërmjet atributeve dhe njësive pjesëmarrëse që shpesh konsiderohen si elemente të pavarura në proces.

"Në kundërshtim me besimin e përhapur, nocioni i popullarizuar i një qasje multidisiplinare nuk është një qasje sistematike në proces. Në fakt, aftësia për të sintetizuar diçka të veçantë është një tërësi koherente dhe shumë më e rëndësishme sesa aftësia për të prodhuar informacione nga perspektiva të ndryshme. Procesi i përdorur i një qasje multidisiplinare mund të jetë një përvojë zhgënjyese, sikur: duke u përpjekur të identifikohet një elefant në terr të plotë. Çdo participant duke qenë i pozicionuar në pjesë të ndryshme të elefantit në terr të plotë, çdo kush mund të raportojë gjetjet nga vendndodhja e tij, si: "ky është një gjarpër (duke aluduar në hundën e elefantit), "kjo është një shtyllë (për këmbën e elefantit)", "kjo është një shtizë (për dhëmbin e elefantit)." ${ }^{.74}$

Procesit i hulumtimit sqaron se çdo projekt është unik, është një përgjigje specifike për një problem specifik. Çdo projekt ndërton një hipotezë në vetvete, në lidhje me një përgjigje të pranueshme për problemet specifike kontekstuale. Në relacion me arkitekturën, çdo problem specifik ka një kuptim të plotë në njohuritë shkencore në lidhje me elementet, pajisjet, materialet dhe sistemet që mund të kontribuojnë në zgjidhjen e sfidave. ${ }^{75}$ Dizajni është një proces bashkëpunues, asnjë person, asnjë profesion tjetër nuk ka të gjitha njohuritë dhe aftësitë e nevojshme për të kuptuar të gjitha detajet.

74 Gharajedaghi J.(2006).Systems Thinking. Managing Chaos and Complexity. London, UK:Elsevier.

75 Kwok G.A. et al.(2007). Environmental strategies for schematic design. Oxford.UK:Elsevier. 
E vetmja mënyrë racionale e zgjidhjes së detyrave në projekt, pasqyrohet një njohuri të thellë e të zhvilluar nga kontributet e shumë disiplinave.

Procesit i projektimit të integruar, ekstrakton dhe përdor parimet e zbatueshme, si dhe inkorporon ekspertë nga profesione të ndryshme. Dizajni i integruar mund të përcaktohet ose të krahasohet vetëm me procese sinergjike dhe evolutive.

Hulumtimet nga autorët (Kwok G.A. et al., 2007), përmbledhin njohuri të mileniumit të ri dhe teknologjive të reja, të cilat kanë çuar në rritjen e specializimit dhe fragmentimin e profesioneve të ngushta. Njohuri shumë të specializuara, procese duke u përpjekur për të kuptuar funksionimin e gjithë sistemit, në vend se të gjejë vetëm një përgjigje teknike. Dizajni i integruar nuk është proces i natyrës lineare, dizajni "konvencional" është një proces që është përshkruar shpesh si një tranzicion linear, kalimi nga një fazë në një tjetër pa algoritëm reversibil.

Cilësia cenohet ndjeshëm kur njëra palë vendosë, pa pjesëmarrësit e tjerë, dizajni konvencional mund të konceptohet si një njohuri që aplikohet në seri, në anën tjetër, dizajni i integruar mund të njihet si proces që aplikohet në shumë drejtime ose sistemike. Kështu, dizajnin duhet kuptuar si kreativitet, duhet participuar plotësisht në proces në të gjitha fazat e ciklit kreativ, me fuzionim të shpejtë të ideve dhe të kërkohet më shumë nga rrugët alternative. Ajo që është shumë e rëndësishme, është se udhëheqja e projektit ende është e nevojshme, por menaxherët e projektit duhet të jenë mbi detyrën e fuzionimit në kërkimin e integrimit të anëtarëve të tjerë të procesit të projektimit.

Andaj, nuk është proces i vjetër zbatimi përmes një shumëllojshmërie të standardeve të aplikuara në kuadër të hulumtimit strategjik. Strategjia e dizajnit të integruar, aplikon metodat dhe parimet e vjetra që janë përdorur më parë, mirëpo, çështja është se investitorët duan produktivitet më të lartë, komfor më të madh, reduktim të përdorimit të sistemeve të HVAC, dhe natyrisht profit më të madh. Të gjitha këto atribute të kërkuara, nuk janë të lehta, kështu që Ligjet, rregulloret, standardet kanë evoluar në përgjigje të një sistemi që është rezultat i pikëpamjeve bashkëkohore.

Funksionet e deri tanishme të procesit projektues, mënyra se si është projektuar për të zgjidhur gjërat një nga një, si të mëvetshme, ka kaluar. Ndërtimi i ndërtesave, komuniteti dhe qyteti duhet të mbështesin shëndetin e njeriut si veçori jetike, në këtë drejtim dhe në këtë mënyrë duhet përmirësuar mjedisin, i cili aktualisht është mjaft i degraduar. Dizajni i integruar kërkon aktivitete komplekse, duke kërkuar që të gjithë pjesët e sistemit në bashkëveprim të funksionojnë në mënyrën më të mirë të mundshme, duhet përdorur njohuri nga hulumtimet elitare për zgjidhjen dhe përmirësimin e kualitetit të jetesës së pari, me ato kardinale jetike, e më pastaj duke u pasuar me të tjera sipas prioritetit.

\subsubsection{Dizajni}

Diversiteti i madh dhe kompleksiteti i profesionit të arkitektit, projektuesit, në mënyrë të veçantë ka evoluar me kalimin e kohës. Gjersa premisa kryesore e definimit përpiqet ta përkufizojë dizajnin si një proces shumë kompleks dhe i natyrës komplekse të krijimtarisë sistematike. Kështu që një përshkrim apo definim i lehtë i procesit të projektimit është vështirë për tu gjetur. 
Bryan Lawson (2005.), ${ }^{76}$ në një studim të veçantë përshkruan dhe kategorizon përpjekjet e mëposhtme për të përcaktuar procesin e projektimit nga autorë të ndryshëm:

1. Zgjidhje optimale e shumë nevojave aktuale, nën një grup të caktuar të rrethanave (Matchett, 1968).

2. Procesi i Dizajnit është i njëjtë, pavarësisht nëse kemi të bëjmë me hartimin e rafinerisë së re, ndërtimin e katedrales ose shkrimin e Komedisë Hyjnore të Dantes (Gregory Sydney, 1966).

3. Inicion një ndryshim, në krijimin e veprave njerëzore (Chris Jones, 1970).

Sipas Lawson, shumë autorë janë përpjekur për të përshkruar diagramin skematik të procesit të projektimit nga fillimi e gjer në fund, megjithatë, ideja e përbashkët e të gjitha skemave të tilla është se procesi i projektimit përbëhet nga një seri aktivitetesh të ndryshme dhe të identifikuar që ndodhin në një renditje logjike, të parashikueshme dhe të identifikueshme.

Kështu, në pamje të parë apo në shikim të parë, një formulim mjaft i arsyeshëm, në qasjen e analizës së procesit të projektimit.

The Royal Institute of British Architects (RIBA) ${ }^{77}$. Në manualin, praktikat arkitektonike dhe të menaxhimit, 1965, thekson se procesi i projektimit mund të ndahet në katër faza:

\section{Faza 1 - Akumulimi, sortimi, vlefshmëria}

Akumulimi dhe rregullimi i informatave të përgjithshme dhe informatave specifike në lidhje me problemin e tanishëm.

\section{Faza 2 - Hulumtimi i përgjithshëm}

Studimi mbi natyrën e problemit, i shqyrtuar nga zgjidhjet e mundshme apo burimin e gjenezës së zgjidhjeve të mundshme.

\section{Faza 3 - Zhvillimi}

Zhvillimi dhe përmirësimi i një ose më shumë zgjidhjeve të kushtëzuara, që janë të izoluara dhe të preferuara gjatë $\boldsymbol{F a z \ddot { e } s} \mathbf{2}$.

\section{Faza 4 - Komunikimi}

Komunikimi i një ose më shumë zgjidhjeve apo solucioneve, brenda dhe jashtë ekipit të projektimit. Manuali i "RIBA" thekson se të katër fazat nuk janë domosdoshmërisht vijuese në rend, dhe lehtë mund të duket logjike se zhvillimi i përgjithshëm i dizajnit ndjek fazën 1 të fazës 4 . Për këtë arsye, është mjaft e vështirë për projektuesin që të ketë njohuri se çfarë informacioni është mbledhur në fazën 1, dhe nëse ka, cilat ndikime mund të ketë në hulumtimet e fazës 2 . Me futjen e metodave sistematike të projektimit, procesi akademik i mësimnxënjes është bërë një qasje dhe tendencë që studentët duhet të përgatisin raporte të dëshiruara sipas preferencës së tyre.

\footnotetext{
${ }^{76}$ Lawson, B. (2005). How Designers Think. Oxford. UK, Elsevier.

77 UK. (1965).The Royal Institute of British Architects. Architectural Practice and Manual. UK.
} 


\subsubsection{Përcaktimi i problemi, formulimi i çrregullit}

Autori Gharajedaighi Jamshid ${ }^{74}$, e përshkruan dizajnin me natyrë interaktive dhe e identifikon me mendimet e Russell Ackoff. Për Ackoff, "zgjedhja apo për të zgjedhur" është në zemër të zhvillimit njerëzor, zhvillimi i aftësisë për të zgjedhur është mjeti i dizajnit në përmirësimin e modeleve dhe koncepteve e të menduarit holistik. Dizajni interaktiv mund të jetë edhe një vëllim (paketë) i përsosur, në qoftë se në të përfshihen tri elemente: kërkimorë iteraktive, të menduarit sistematik dhe qasja neg-entropike ${ }^{78}$, në formulimin e një hulumtimi gjithëpërfshirës e të projektuarit të sistemit.

1. "E ardhmja nuk është në të kaluarën, shumë mbetet për t'u shkruar." (Ackoff, 1982).

2. Mënyra më e mirë për të mësuar dhe për të kuptuar sistemin është të ri projektohët apo të demontohet.

3. Njerëzit janë më të prirur për të pranuar një ide, nëse vetë marrin pjesë në atë proces.

4. Performanca e sistemit, është në thelb e të krijuarit kreativ, projektimi dhe përmirësimi i përfomansës cakton përmasat e ridefinimit.

5. Pjesët e pa realizuara dhe jo të lidhura në shikim të parë, mund të krijojnë një entitet të qëndrueshëm. (Ackoff, 1982).

Studimi thekson se, ndarja e përcaktimit të probleme dhe e zgjidhjeve të projektimit janë veçori unike e dizajnit interaktiv. Sipas Ackoff, ne shpesh dështojmë, jo sepse nuk arrijmë të zgjidhim problemet me të cilat përballemi, por për shkak se nuk kemi të njohur problemin e vërtetë. "Ne vazhdimisht kemi mësuar se si ti zgjidhim problemet, por asnjëherë si ti definojmë!"Tradicionalisht, janë tri mënyra për ti përcaktuar problemet. Qasja më e zakonshme për të përcaktuar problemin është se është një devijim nga norma. Disavantazhi i kësaj qasjeje është përveç vështirësisë në përcaktimin e "normës", po ashtu se çka është sistemi social kulturor me praktikën ekzistuese...

Kjo është bërë zakonisht, pavarësisht dyshimeve se praktika e tanishme mund të jetë burimi i problemit! Mungesa e burimeve është mënyra tjetër popullore për të përcaktuar një problem. Realisht duket që në njëfarë mënyre nuk mund të marrim informata të mjaftueshme, fonde, dhe sigurisht nuk kemi kohë të mjaftueshme për t'u marrë me shumicën e situatave. Kjo nuk duhet të jetë një justifikim, sepse koha, informatat dhe fondet janë kufizime universale. Ne kurrë nuk do të kemi para të mjaftueshme, ne kurrë nuk do të kemi kohë të mjaftueshme dhe ne kurrë nuk do të kemi informata të mjaftueshme. "ipse se nihil scire id unum sciat" 79

78 Gharajedaghi J.(2006). Systems Thinking. Managing Chaos and Complexity. London, UK:Elsevier. "Entropia është një masë e rastësisë dhe e çrregullimit në univers. Sipas ligjit të dytë të termodinamikës sistemet e mbyllura "priren drejt rritjes së çrregullimit apo entropisë e një niveli më të lartë". Megjithatë, sistemet e hapura njerëzore paraqesin tendenca të kundërta, ato janë duke lëvizur në drejtim të rendit dhe harmonisë, dukuri e cila prodhon negacionin e entropisë (neg-entropic)."

79 Cicero, Academica, Libri I, kapitulli 1. v45 p.e.s. 
Në vendin e tretë, sipas autorëve të hulumtimit, dhe ndoshta më sfiduesi, është se si ne për ta definuar problemin kemi tendencë ta zgjidhim me metodat që tashmë i kemi të njohura. Zgjidhjet ekzistuese, thjesht na mbrojnë ta shohim realitetin, kështu që ne lehtë e pranojmë problemin duke e "zgjidhur" me qasje ekzistuese. Ky është koncepti i hapjes dhe i deprimimit, realisht kjo do të thotë se nuk ka problem. Andaj, as zgjidhja nuk mund të realizohet jashtë kontekstit të asaj që ne mund ta pranojmë duke mos dashur të dalim nga zona e komforit mental, dhe jashtë kontekstit të njohur. Gjithashtu, një zgjidhje që mund të arrijë rezultate të efektshme në kontekstin aktual, nuk mund të funksionojë në një situatë tjetër. Megjithatë, tendenca për të definuar problemet në drejtim të zgjidhjeve adekuate, është një tendencë drejt të njohurës, dhe që shpesh rezulton në një rreth vicioz, të mbyllur për të gjetur zgjidhjet e mundshme.

"Procesi vazhdon rigjenerimin e së kaluarës, duke na lënë të pyesim veten se si historia e përsërit veten, duket sikur, kurrë nuk i kemi mësuar leksionet " (Gharajedaghi, J. 2006).

\subsection{Problemi i injorancës ekologjike, mohimi!}

Autori (David, Orr, 2002.) ${ }^{80}$ argumenton se në bazë të evoluimit, është ardhë deri tek iluminizmi ekologjik, periudhë prej 3.8 miliardë vitesh. Historia e evoluimit përshkruan procesin e natyrës me të gjithë diversitetin dhe shumëllojshmërinë e saj në një sistem të madh të krijimtarisë fizike dhe spirituale. Koncepti i madh i botës së industrializuar, është se ne jemi të pavarur nga natyra që rregullon pjesën e jetesës, natyra në këtë kuptim është diçka që nuk na tangon! Projektimi arkitektonik me natyrën, nga ana tjetër disiplinon qëllimin e njeriut, në njohuritë se si natyra funksionon si një sistem unik holistik. Qëllimi nuk është tek sundimi i plotë që shkakton shkatërrimin e mjedisit, por te harmonia për qenë së bashku në një ndërvarshmëri. Dhe jo vetëm në krijimin e veprave arkitektonike të reja, por në riformulimin e pranisë njerëzore në botë, kështu që për të respektuar dhe për tu respektuar. Eko dizajni, është një koncept që kombinon shkencën dhe shkathtësitë praktike në fushën e artit, politikës, etikës, moralit dhe ekonomisë. ${ }^{80}$

Problemi shumëvjeçar i ekologjisë humane buron nga kulturat e ndryshme me resurset për ushqim, strehim, energjisë dhe jetesës në mjedis të shëndoshë, (SMIL, 1994) ${ }^{80}$. Andaj projektimi i mirëfilltë duhet të harmonizojë teknologji dhe strategji me të cilat cikli i jetesës njerëzore bëhët mbi bazat e nevojave të shëndosha dhe të ripërtritshme duke mos dëmtuar ambientin apo ekosistemin. Mjedisi natyror është dëmtuar dhe aktualisht po dëmtohet vazhdimisht nga veprimi njerëzor. Jeta, stili, kultura, shëndeti, resurset duhet të jenë pjesë e një ekuacioni i cili mund të zgjidhet duke mos dëmtuar pariparueshëm ekosistemin.

"Asnjë aq i verbër, se sa ata të cilët nuk dëshirojnë të shohin."

Mathew Henry

80 Orr W. D. (2002). The Nature of Design. Oxford. UK : Oxford Uni. Press., str. 5. 


\section{PROJEKTIMI I QËNDRUESHËM}

A rkitektët e njohur bashkëkohorë: Mick Pearce, Sir Norman Foster, Thomas Herzog, Glen Mercutt dhe Sir Richard Rogers, kanë përqafuar arkitekturën e qëndrueshme si pjesë e praktikës së tyre arkitektonike. Objektet e tyre janë estetike dhe stimuluese, të qëndrueshme dhe shpesh promovojnë qasje në "biomimicry". Në thelb, realiteti dhe praktika arkitektonike insistojnë që shkollat e arkitekturës të angazhojnë në kurikulën e tyre mësimdhënie në projektim të qëndrueshëm, si pjesë e programit të ndërlidhjes në mes praktikës dhe teorisë bashkëkohore.

Në revistën, Harvard Design Magazine, 2003, Susannah Hagan vë në dukje se ka arsye intelektuale, praktike, teknike, ekonomike dhe pedagogjike pse shkollat dhe praktika arkitektonike duhet të miratojnë parimet e qëndrueshme të projektimit. Disa nga mendimet e saj janë të përfshirë si më poshtë:

Natyra, në çfarëdo mase ne e kuptojmë, është komplekse dhe jo lineare. Dizajnerët mund të përfaqësojnë natyrën dinamike të arkitekturës, në vend të aspektit statikë. Arkitektët e vlerësojnë intelektualisht natyrën dhe vazhdimisht aplikojnë proceset e saj në projektim. Për shembull, lulëzimi i një pemë mund të duket njësoj, por çdo lule e saj është e ndryshme. Mund të mësojmë nga origjinaliteti i natyrës duke mos u përsëritur asgjë plotësisht identike. Paramendoni se si ky koncept mund të aplikohet në shtëpitë tona në ritëm dhe në shumë elemente të përsëritura të një ndërtese, duke sfiduar kufijtë konvencionale të arkitekturës.

Në çështjet e projektimit të qëndrueshëm, aktualisht në arkitekturë janë dy kahje. Një drejtim ndjek teknologjinë mbresëlënëse bashkëkohore, dhe drejtimi tjetër thekson estetikën abstrakte arkitektonike, artin dhe aspektin futuristik të arkitekturës. Shpesh këto dy qasje zhvillojnë rrugëtim paralel, duke mos u bashkuar në mënyrën kuptimplotë. Megjithatë, ka edhe përjashtime, selia e re holandeze, TNT EXPRESS, e projektuar nga arkitekti Paul de Ruiter, është me të vërtetë një ndërtesë e qëndrueshme. Qëndrueshmëria e ndërtesës u njoh nga LEED® Platinum dhe sistemit holandez GreenCalc me një rezultat prej 1.005 pikë.

Qendra është transparente, me orientimin e duhur, duke u përgjigjur kushteve urbanistike, sensin social, logjistikës dhe qëndrueshmërisë në të gjitha dimensionet e zgjedhjes së materialeve, emisioneve $\mathrm{CO}_{2}$, cilësisë së ajrit të brendshëm. Me një atrium të shkëlqyer, shkallë terracore, qoshe formale dhe joformale për fuksione hoteljere, dhe dhoma takimi elegante. Arkitektura rezultuese është një kombinim i frymës lokale, përdorimi i duhur i materialeve dhe hapësirave, dhe teknologjisë në projektim të qëndrueshëm. ${ }^{81}$

81 Kuppaswamy, I. (2015). Sustainable Architectural Design. Routledge.Taylor \& Francis. NY. 
Projektimi i qëndrueshëm arkitektonik është vetëdijesim i të menduarit kreativ për problemet lokale mjedisore si dhe ato globale ekologjike. Të kuptuarit e kontekstit mjedisor thellon çasje të reja e të mbijetuarit në rrethana me sfida të shumëfishta nga aspekti i përgjithshëm, e posaçërisht nga projektimi arkitektonik. Shqyrtimi i çështjeve mjedisore dhe ekologjike të ndërlidhura ngushtë me lëminë e arkitekturës duhet të reflektojnë në një sens të ri të përgjegjësisë për profesionistet e arkitekturës.

Përkufizimet e pranuara dhe të njohura globalisht, duke tentuar të definohet qëndrueshmëria? janë si vijon: Projektimi i qëndrueshëm synon të reduktoje ndikimet negative në mjedis, shëndetin dhe komoditetin e banuesve, në relacion duke përmirësuar performancën e ndërtimit. Objektivat themelore të qëndrueshmërisë janë të reduktohet konsumi i burimeve të jo ripërtërishme, minimizmi i mbeturinave si dhe krijimi i ambienteve të shëndetshme. ${ }^{82}$

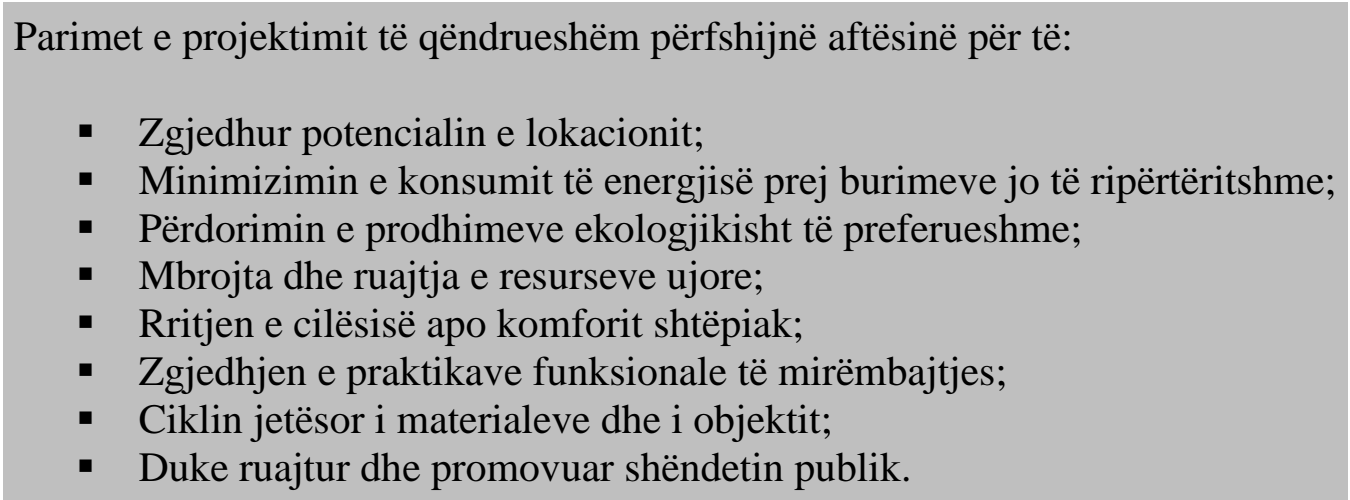

Njohja dhe çasja në filozofinë e projektimit të qëndrueshëm inkurajon vendime relevante në çdo fazë të procesit të projektimit, që do të qonte në zvogëlimin e ndikimeve negative në mjedis dhe në shëndetin e banorëve, duke mos kompromentuar qëllimin apo idenë fillestare të projektimit. Në esencë, është një qasje e integruar, holistike që inkurajon në kompromis dhe në zgjidhjen me të mirë të mundshme të njohur. Një qasje e tillë e integruar ndikon pozitivisht në të gjitha fazat e ciklit të ndërtesës, duke përfshirë projektimin, ndërtimin, funksionimin dhe demolimin. ${ }^{82}$

Përkufizime me tutje:

Arkitektura e qëndrueshme, ka për qëllim për ti përmbushur nevojat e brezit aktual pa kompromentuar aftësinë e brezave të ardhshëm për të plotësuar nevojat e tyre. Qeveritë tani duhet plotësuar boshllëqet e mëdha në ligjin ekzistues kombëtar dhe ndërkombëtar në lidhje me mjedisin, për të gjetur mënyra për të njohur dhe mbrojtur të drejtat e brezave të sotëm dhe të ardhshëm në një mjedis të përshtatshëm për shëndetin dhe mirëqenien tyre. $^{83}$

Shumë nga kahjet e zhvillimit të shteteve të industrializuara janë një model i paqëndrueshmërisë. Njëkohësisht, vendimet për zhvillimin e këtyre vendeve në kontekst të fuqisë së tyre të madhe politike dhe ekonomike, kanë një efekt të thellë mbi aftësinë e të gjithë popujve për të mbështetur përparimin e njeriut, për brezat që vijnë. ${ }^{83}$

82 http://www.gsa.gov/portal/content/104462, Korrik/2015.

83 Report - World Commission on Environment and Development: Our Common Future, 1987. 


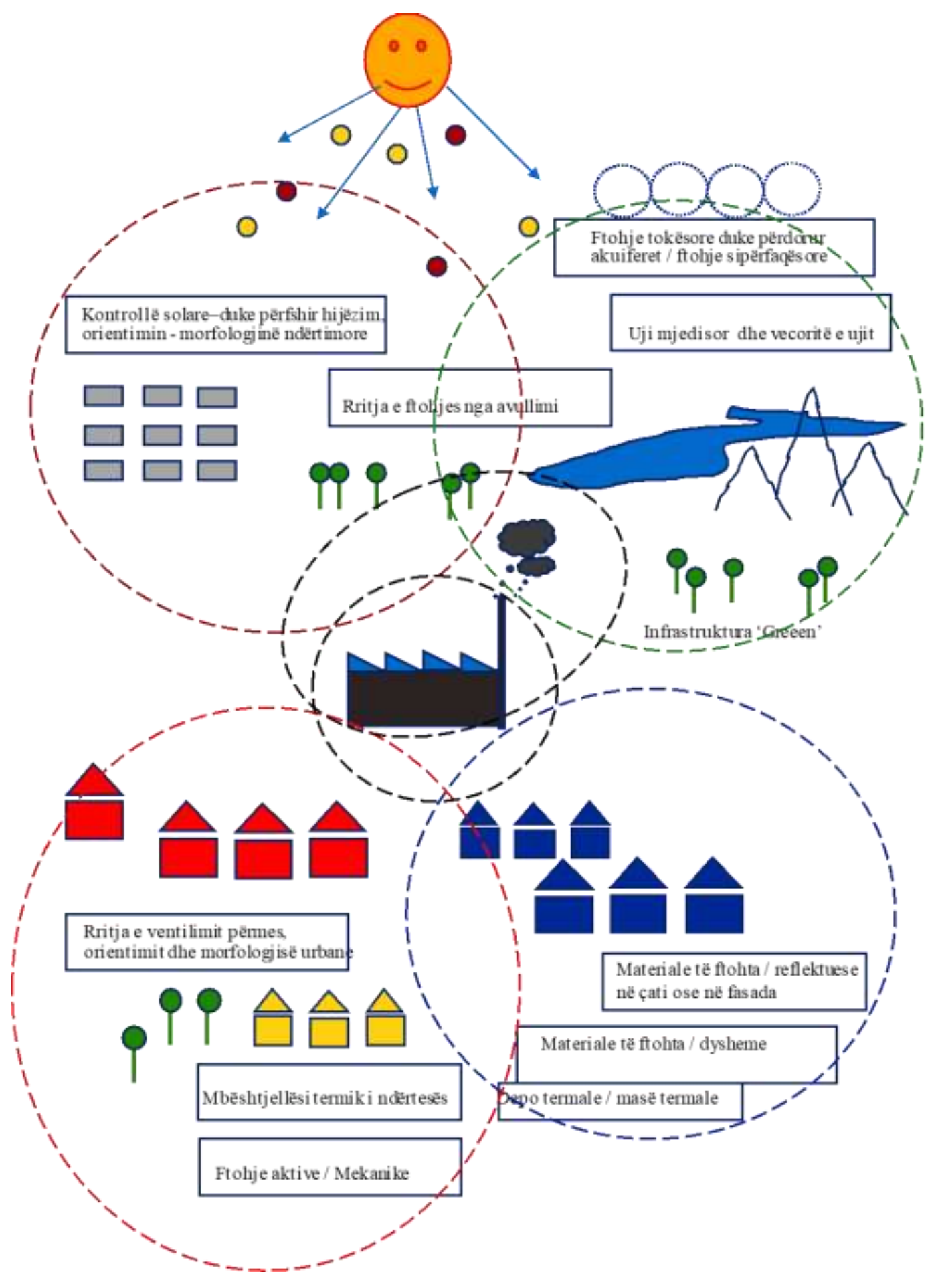

Figura 101. Strategjitë e menaxhimit energjetik (Burimi): Bujar Bajçinovci, 2015. 
"Strategjitë bioklimatike apo projektimi bioklimatik është i koncipuar me qëllim për të minimizuar ndikimin mjedisor të ndërtesës, si me aplikimin e sistemeve jo konvencionalë për ajër të kondicionuar, si me përdorimin e teknologjive për shfrytëzimin e burimeve të ripërtëritshme të energjisë për të mbuluar kërkesat e energjisë. Analiza e klimës vendore do të udhëheq procesin e projektimit, për të minimizuar kërkesën për energji për ngrohje dimrit, ftohjes në verë dhe për të inkurajuar ventilim natyror gjatë stinëve të ndërmjetme. Për këtë arsye, përveç izolimit të lartë, janë ndërtuar struktura masive, e karakterizuar nga një kapacitet të lartë termal dhe një fasadë të dyfishtë nga jugu.

Ngrohja gjatë periudhës së dimrit, sistemi i ngrohjes aktivizohet për të ngrohë ajrin në lokalet apo hapësirat, ky sistem i integruar kur është e nevojshme largon jashtë ajrin nga objekti i cila kalon në fasadën e dyfishtë, kjo arrihet natyrshëm nga kontributi diellor, duke arritur një temperaturë të përshtatshme. Përsa i përket hapësirës bazë, ngrohja kalon nëpër një seri të gypave nga gjeotermalja. Sistemi i ngrohjes së ajrit po ashtu është i integruar në plafon, me anë të aktivizimit termik të masës nga pllaka meskatshe e betonit. Pompa për shtytjen e ngrohjes gjeotermale, e mundësuar nga "photovoltaics", siguron energji termike për trupat ngrohës të vendosura në kate." 84

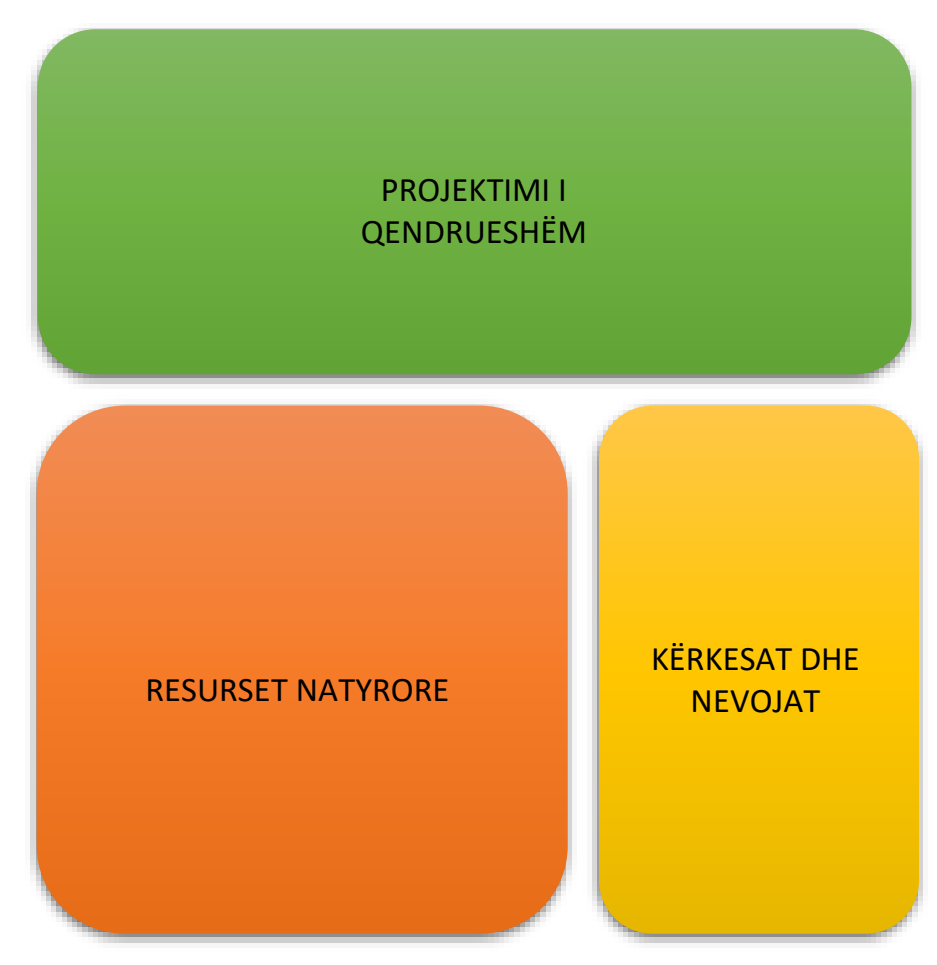

Figura 102. Relacionet e ndërvarura, Projektimi i qendrueshëm arkitektonik (Burimi): Bujar ajçinovxi, 2017.

84 Mario Cucinella Architects S.R.L. Objekt ekologjik dhe eficient. 


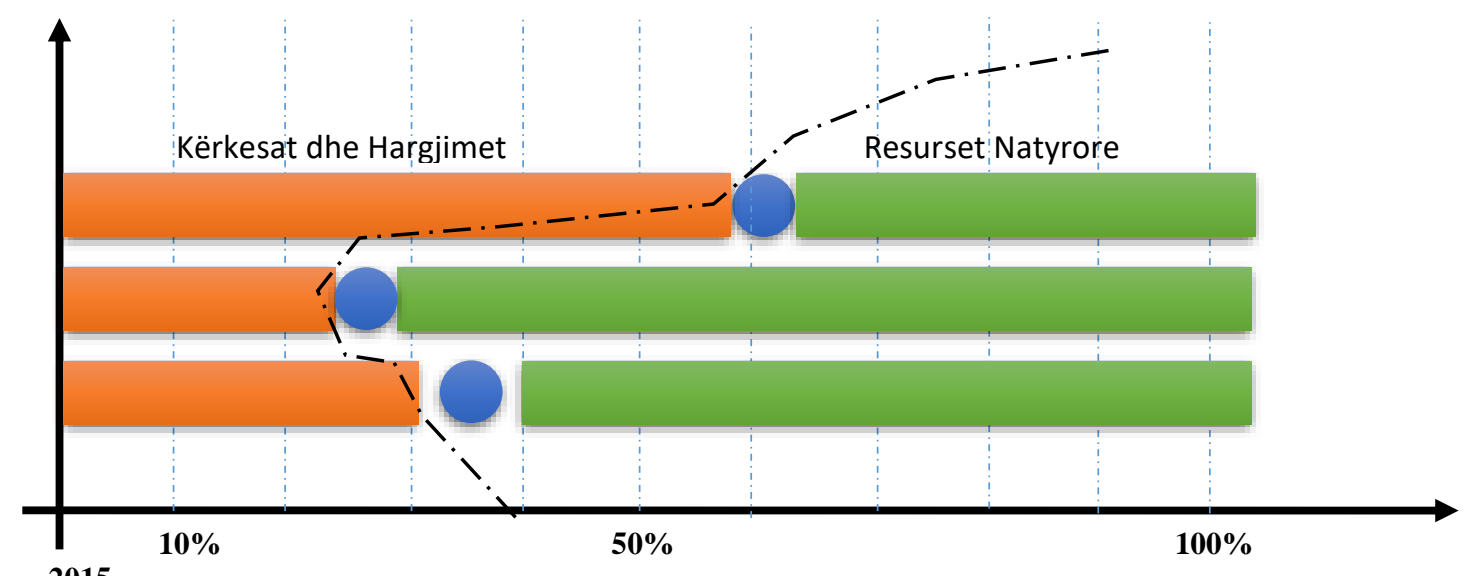

Figura 103. Efiçienca e modelit, Projektimi i qendrueshëm arkitektonik (Burimi): Bujar Bajçinovci, 2017.
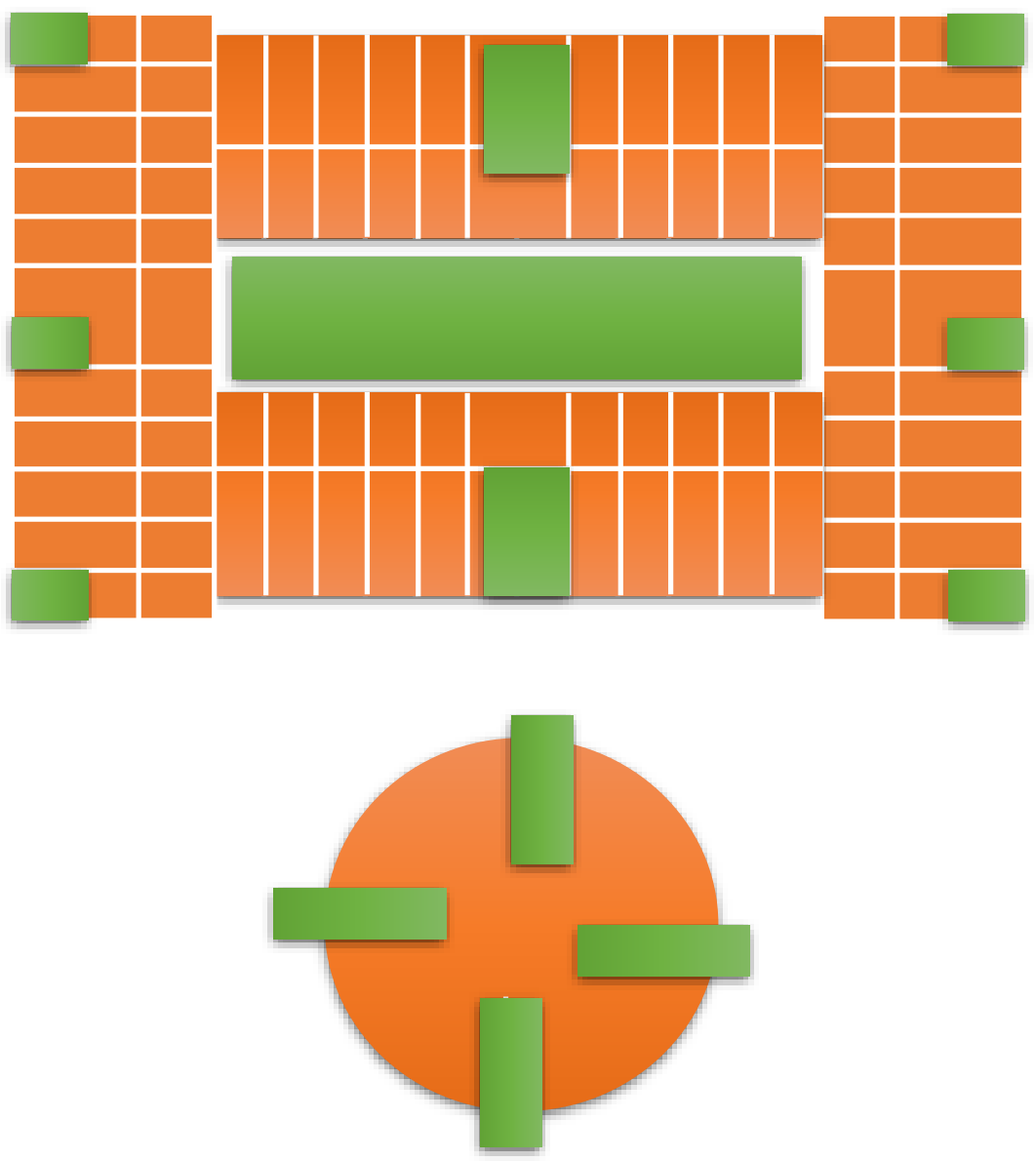

Figura 104. Efiçienca e modelit, Variacionet e hulumtuara në kërkim të zgjidhjeve të mundëshme.

(Burimi): Bujar Bajçinovci, 2017. 


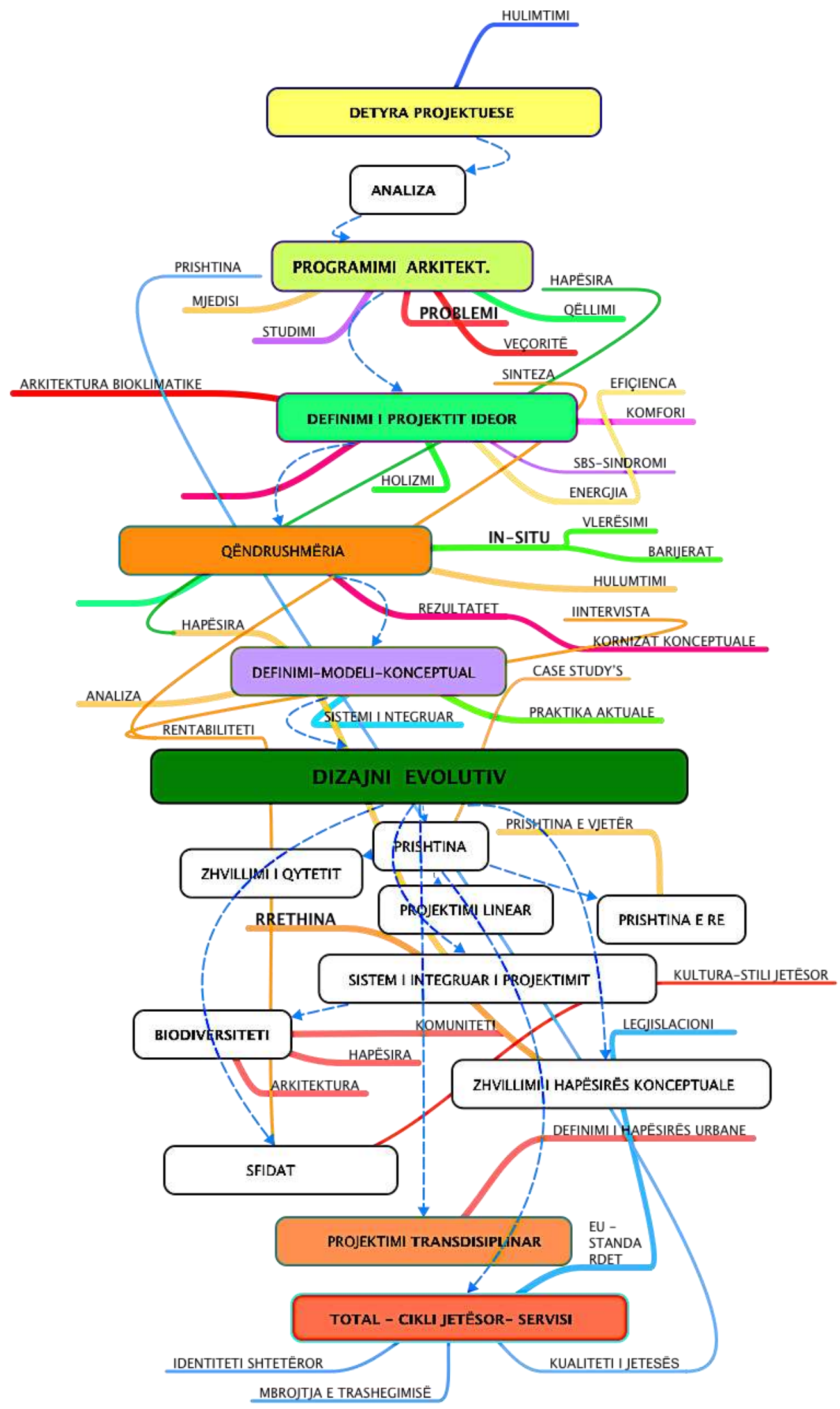

Figura 105. Diagrami i procesit të hulumtimit, analizës dhe i përfundimit, Dr.sc. (Burimi): Bujar Bajçinovci 


\subsection{Parimet e projektimit të qëndrueshëm}

Faktorët kryesor që duhet përdorur për të krijuar hapësira të qëndrueshme nga aspekti i projektimit, janë për një sistem të projektuar mirë që ka të bëjë me zvogëlimin e humbjes së nxehtësisë, fitimin e energjisë për ngrohje, ndriçimit, diellosjes, ventilimit natyror, cilësisë së ajrit, lagështisë dhe komforit, të cilët ndikojnë në mënyrë direkte në veçoritë e qëndrueshmërisë.

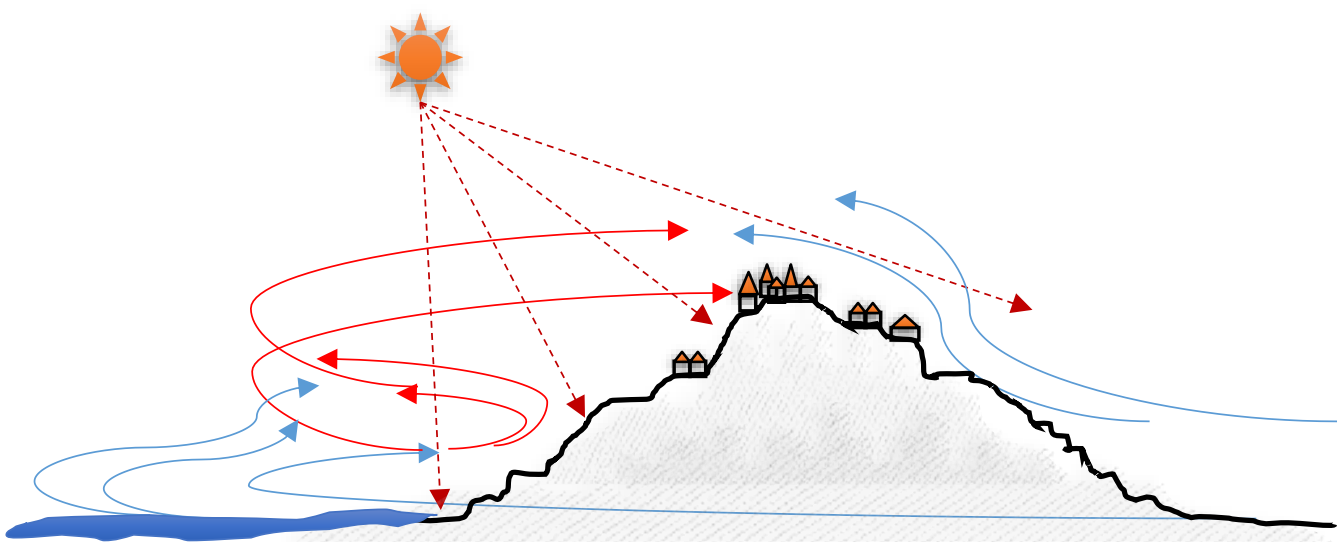

Figura 106. Projektimi qendrueshëm, veçoritë naturore dhe parimet e ligjeve të fizikës (Burimi): Bujar Bajçinovci, 2017. Quaestiones Geographicae, 2017.

Sipas autorit Kuppaswamy, I. (2015). Rekomandon këto parime të qëndrueshmërisë: ${ }^{81}$

1. Zgjedhja e duhur e lokacionit ose përdorim i mirë i një lokacioni. Është jashtëzakonisht e rëndësishme që të investohet kohë e mjaftueshme dhe analiza të thukëta në zgjedhjen e një vendi për ndërtesën, objekti duhet përfituar nga pasuritë natyrore si dielli, era, reliefi i tokës, disponueshmëria e resurseve të ujit, vizurave dhe nga komuniteti. Vizurat dhe orientimi, akset kardinale të botës janë veçori të rëndësishme për mundësitë e peizazhit, duke përdorur pemë, impiante "brisoley" për mbrojtje nga drita, ftohje, mbrojtje nga era e padëshiruar dhe parandalimi i zhurmës. ${ }^{81}$

2. Klima dhe pozita gjeografike. Klima është e përcaktuar si mot mesatar i një vendi të caktuar gjatë një periudhe prej disa vitesh. Ndërsa moti është gjendja e çastit e mjedisit atmosferik (temperatura, shpejtësia e erës dhe e reshjeve) e një vendi të caktuar. Klima mund të përkufizohet si shumësi total i të gjithë motit që ndodh në një vend. Klima është relativisht konstante dhe pavarësisht ndryshimeve të rastësishme dhe të shpejta, modelet e motit përsëriten në intervale të caktuara kohore. Ndërsa një projektues, duhet interesuar kryesisht në vlerat kufitare të klimës që prekin komforin njerëzor dhe rastet ekstreme eventuale. 
3. Informacion i rëndësishëm, ndryshimet e temperaturës, ndryshimi i temperaturës në mes ditës dhe natës, temperaturat ekstreme, efektet e erës që kontrollojnë infiltrimin, dëbora dhe shpërndarja e saj, kushtet e mjedisit, breshëri, uraganet dhe stuhitë. Tek ne të dhënat klimatike janë në dispozicion në Institutin Hidrometeorologjik të Kosovës. Në SHBA, klima është e ndarë gjerësisht në katër rajone sipas kushteve mbizotëruese të motit: rajonet e ftohta, rajonet e ngrohta, rajonet e nxehta dhe të lagështa, dhe rajone të nxehta dhe të thata. ${ }^{81}$

4. Përdorimi i materialeve të përshtatshme të ndërtimit. Transferimi i nxehtësisë në ndërtimtari duhet të studiohet në kuptim e qartë dhe të izolimit të mureve, dyshemeve, kulmeve, si dhe çdo materiali të tjetër i cili përdorët. Materiale të qëndrueshme të tilla si fibër çimento apo materiale kompozite me veçori të shkëlqyera arkitektonike. Sigurisht, projektanti duhet të studioi modele të ndryshme para se të përcaktohet për mbështjellësin e objektit dhe atributet elementare fizike. ${ }^{81}$

5. Projektimi i sistemeve efikase të mjedisit: teknologjitë e nevojshme aktive. ndriçim artificial, ngrohja, ftohja, ajri i kondicionuar me përdorim konstant të energjisë elektrike ose formave të tjera të energjisë, përbëjnë sistemet aktive. Në projektimin e qëndrueshëm, zvogëlimi i këtyre sistemeve redukton përdorimin e lëndëve djegëse fosile dhe si pasojë nivelin e ndotjes të emanuar në atmosferë. Projektuesi mund të kontribuojë në mënyrë të konsiderueshme, në përpjekjet për të reduktuar ndotjen nga dyoksid karboni. ${ }^{81}$

6. Mbajtja e cilësisë së duhur të ajrit të brendshëm. Ventilimi dhe qarkullimi i ajrit apo siç $\mathrm{i}$ themi ne në arkitekturë ajrimi, ventilimi ndikohet nga dallimet në mes të temperaturave të brendshme dhe të jashtme, dhe era. Qarkullimi i ajrit të nxehtë apo të ftohtë bëhet veçanërisht nëpër të çara rreth dyerve dhe dritareve, ose depërtimit nëpërmjet të çarave të tjera në ndërtesë dhe përmes së materialeve të ndërtimit të përdorura qëllimisht për këtë detyrë apo si rastësi për të cilën nuk kemi informata. Dizajni i kujdesshëm i këtyre atributeve minimizon humbjen e energjisë dhe koston e shtrenjtë. Ideja kryesore është se projektuesi duhet që në projektet e tyre, ta njohë klimën dhe konform të gjeturave profesionale ti fuqizojnë teknikat pasive duke inkurajuar për të gjetur mënyra në reduktimin e përdorimit të energjisë nga burimet fosile, duke hapur rrugë për kursime shtesë në teknologjitë aktive dhe në pajisje. ${ }^{81}$

7. Uji dhe menaxhimi i mbeturinave. Një sfidë e madhe e komunitetit të Prishtinës dhe R. Kosovës në përgjithësi. Uji është me të vërtetë një temë e jetës dhe varësia e jonë për ujë të pastër është një kërkesë jetike që ne të gjithë e ndajmë. Që nga viti 1980, përdorimi i ujit global botëror është trefishuar. Përdorimi më i lartë i ujit, shton koston e jetës dhe ulë rezervat e ujit të pijshëm po ashtu ndotja e ujit gjithashtu vazhdon të jetë një problem i madh në mbarë botën. E gjithë kjo do të thotë se ne duhet pasur kujdes në përdorimin e ujit. Vetëdijesimi, kërkon që ne të përdorim pajisje për ruajtjen e ujit, përdorimi i sistemeve efikase të pompimit, inkurajimi për bujqësi efikase. Ulja, ripërdorimi, riciklimi dhe shumë produkte të tjera për t'u bërë harxhimi efikas. ${ }^{81}$ 

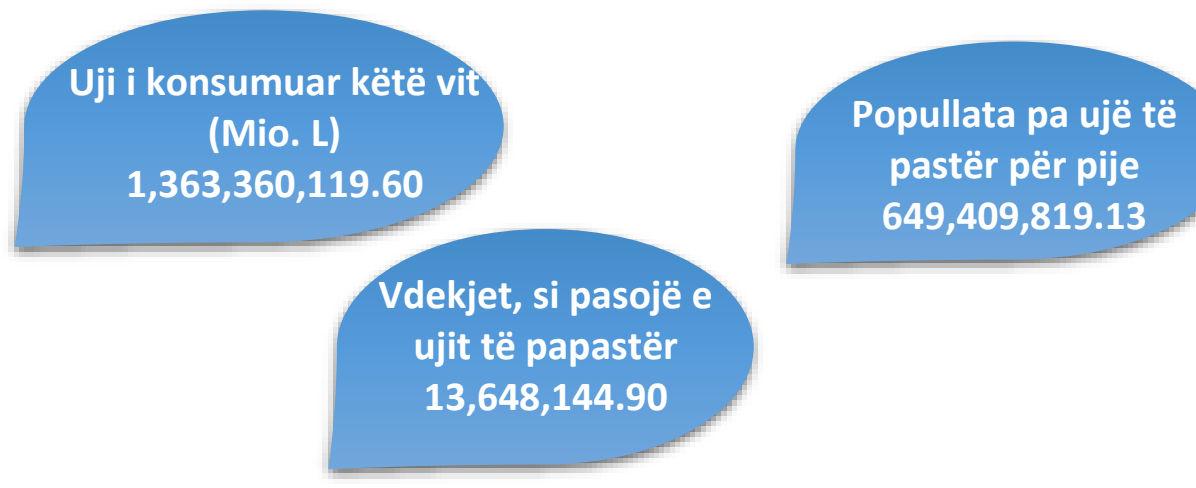

Figura 107. Uji. Të dhënat statistikore për vitin, deri më 27/06/2017.

(Burimi): World Statistics, V1.1. Tobias Oliver Khan. Vlerat janë sipas trendeve aktuale.

"Qendra për Kërkime Interaktive mbi Qëndrueshmërinë (Center for Interactive Research on Sustainability, CIRS) është zhvilluar në përgjigje të sfidës së krijimit të një mjedisi më të qëndrueshëm. Qëllimi i saj është që të jetë një institucion i njohur ndërkombëtarisht në hulumtime që përshpejtojnë adaptimin e teknologjive të qëndrueshme të ndërtimit, si dhe praktikave të zhvillimit të qëndrueshëm urban. Hulumtimi në kuadër të qendrës angazhon në çështje të lidhura me formën e ndërtesave të qëndrueshme dhe modelet e zhvillimit urban. Hulumtimet e tilla kërkojnë ndërvarësi komplekse dhe veçori interdisiplinore dhe zhvillim i koncepteve që janë integruese, sintetike dhe që në mënyrë aktive krijojnë sinergji pozitive midis sistemeve të reja bashkëkohore." ${ }^{85}$

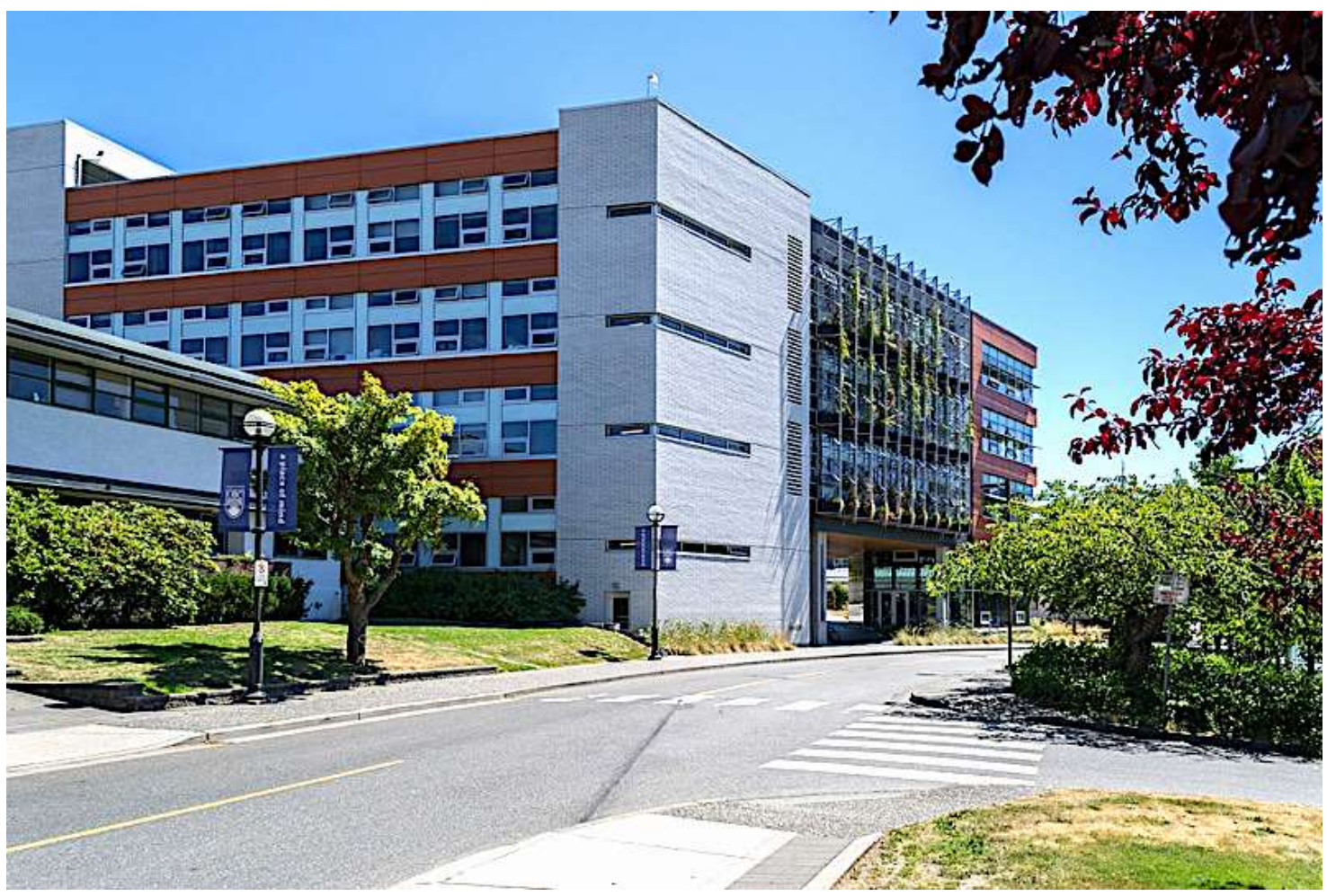

Figura 108. UBC. CIRS. Qendra për Kërkime Interaktive mbi Qëndrueshmërinë. (Burimi): Xicotencatl, (Flickr). E licensuar nga Creative Commons Attribution ShareAlike 2.0.

${ }^{85}$ UBC. CIRS. Qendra për Kërkime Interaktive mbi Qëndrueshmërinë. http://cirs.ubc.ca/. 2015. 
Sipas autorit Kuppaswamy, I. (2015). CIRS është ndërtuar që të tejkalojë LEED® Platinum dhe Living Building Challenge standardet. Kjo qëndër me lokalitet në një zonë të pyllëzuar në British Columbia, CIRS është një nga ndërtesat e pakta të ndërtuara kryesisht prej drurit të certifikuar. Struktura e drurit kursen më shumë se 500 tonelata karbon, kompensimin i madh nga emetimet e gazrave serrë që rezultojnë nga përdorimi i materialeve të tjera të ndërtimit të cilat janë jo të rinovueshme, të tilla si çimentoja, çeliku dhe alumini.

Tiparet kryesore të këtij objekti nga aspekti i projektimit të qëndrueshëm ( 5,574 metra katrore, objektit katërkatësh) përfshijnë, si më poshtë:

1. Vendi: lokacioni i menduar mirë për ndërtimin dhe orientimi (jugperëndim).

2. Koncepti Klimatik: projektuesi ka pasur ekspertizë për lokacionin apo vendndodhjen gjeografike, klima e butë (e ndikueshme nga malet dhe Oqeani Paqësor).

3. Materialet: Strukturë druri, e lameluar.

4. Sistemet: CIRS përdor ngrohjen nga mbeturinat, nga toka, dielli për ngrohje të mëvetshme dhe pastaj i kthehen 600 megavat orë energji të tepërta përsëri në kampus.

5. Mjedisi i brendshëm: Një trajtë në formën e shenjes $U$, maksimizon vlerën e ditës natyrore dhe ajrit të pastër, të cilët kontrollojnë mjedisin e tyre (nivelet e dritës, temperaturës) nëpërmjet kompjuterëve. Dizajni fleksibël lejon që hapësirat e punës të riformohen plotësisht brenda natës.

6. Riciklimi i Shiut: Mbledhja e shiut dhe trajtimi i tij do të sigurojë nevojat ujit për 200 banorë, së bashku me vizitorët në auditorium dhe në caffe. Teprica e ujit do të përdoret për ti vaditur sipërfaqet.

7. Përgjigjet e përdoruesve: CIRS inkurajon njerëzit që të aplikojnë qëndrueshmërinë në jetën e tyre. BC Hydro Theatre, dizajni dhe specifikimet e pajisjeve për Hidro Teatrin u zhvilluan rreth tri parimeve kryesore: fleksibiliteti, infrastruktura dhe përdorimi aktual dhe i të së ardhmes. Kjo është një hapësirë e madhe që konfigurohet lehtë, në një shumëllojshmëri të përshtatshme për angazhimin e komunitetit, punëtorive interaktive dhe për takime të vogla dhe të mëdha. Posedon audio/vizualizim të avancuar dhe ndërveprim të teknologjive. ${ }^{77}$

\subsection{Qëllimet e projektimit të qëndrueshëm}

Për të projektuar objekt të performancës së lartë, duhet së pari caktuar objektivat konkrete dhe të aplikohet një proces i integruar i projektimit. Një simbiozë ndërmjet komforit, kërkesave njerëzore dhe funksionit. Zakonisht përdorimi i energjisë është ndikimi më i madh mjedisor, atëherë, metoda dhe strategjia Net Zero Energji është një objektiv i cili është gjithnjë e më aktual i projektimit. 
Ekziston, gati konsensus unanim shkencor për ndryshimet klimatike, i cila po ndodhë si rezultat i aktivitetit njerëzor. Modelet matematikore, të ndryshimit të klimës globale kanë referuar se aktiviteti i njeriut ka ndikim në rritjen e temperaturave globale (sidomos në 250 vitet e fundit, që nga revolucioni industrial). Burimi kryesor i kësaj rritjeje i është atribuuar emisioneve të gjeneruara nga përdorimi i energjisë fosile. Ndryshimi i klimës ka qenë i lidhur me ndikimet e vazhdueshme në fenomene si zvogëlimi i gleqerëve, humbja e akullnajave në rajonet polare të Tokës, ndryshime në kohën e pranverës dhe një rritje në frekuencën dhe intensitetin e ngjarjeve ekstreme të motit. Respektivisht, cunamet, valët e të nxehtit, stuhitë e mëdha, uraganet dhe tornadot, përmbytjet, thatësirat.

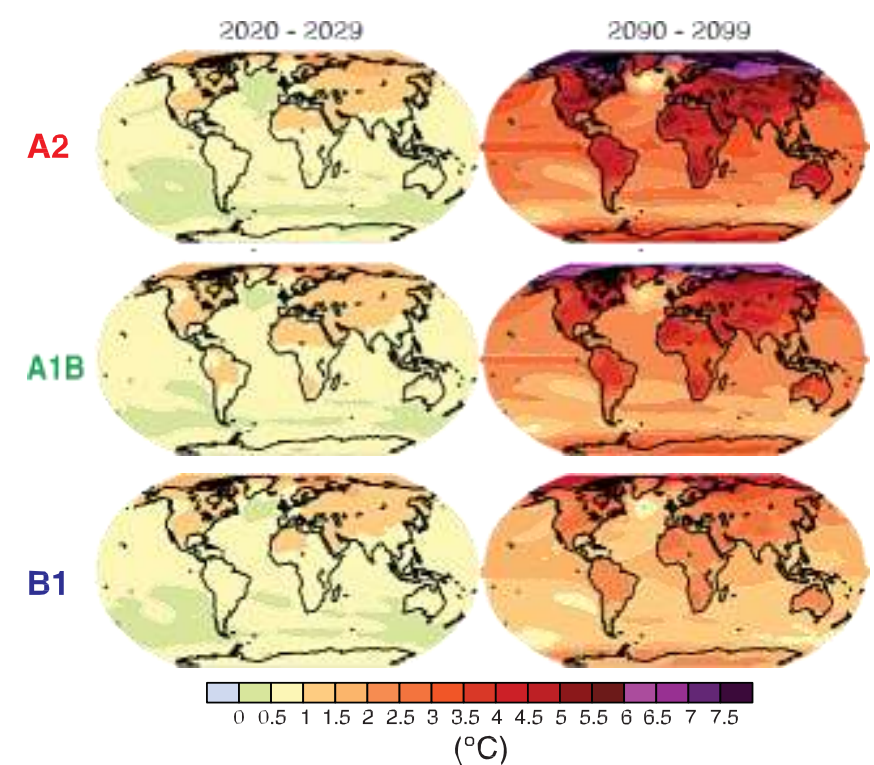

Figura 109. Atmosfera, Oqeanet Modeli - parashikimet e ngrohjes sipërfaqësore (Burimi): Climate Change 2007: Synthesis Report, Intergovernmental Panel on Climate Change, IPCC

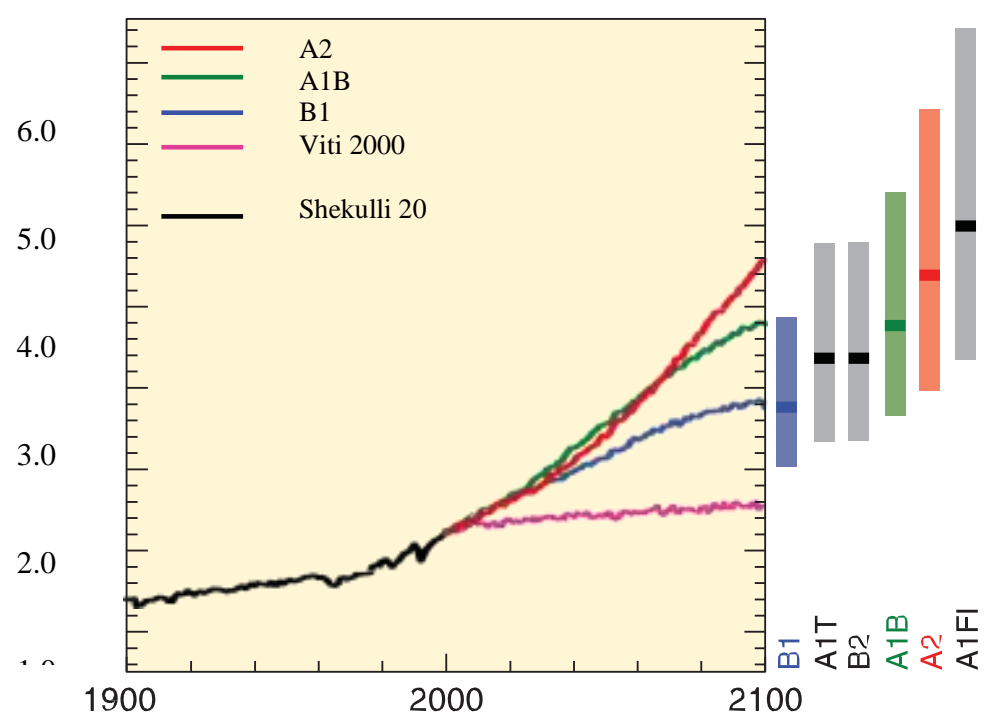

Figura 110. Atmosfera, Oqeanet Modeli - parashikimet e ngrohjes sipërfaqësore (Burimi): Climate Change 2007: Synthesis Report, Intergovernmental Panel on Climate Change, IPCC 
Ndryshimet klimatike pritet të përkeqësojnë situatën aktuale në burimet e ujit, konsumi nga rritja e popullsisë dhe përdorimin i tokës bujqësore si dhe shkalla e urbanizimit, janë fenomene që do të godasen në dekadat në vijim. Në shkallë rajonale, malet me borë, akullnajat dhe sipërfaqet e vogla të akullit, luajnë një rol vendimtar në disponueshmërinë e ujërave të ëmbla. Rast konkret, do ishte shembulli i Prishtinës dhe lagjet e furnizuara me ujë të pijshëm nga liqenet artificiale të Badocit dhe Batllavës. Viteve të fundit në mos prezencën e të reshurave të dëborës në Kosovë, kishte situata alarmante dhe drastike për ta siguruar sfondin e nevojshëm për ujë të pijes por edhe të ujit në përgjithësi.

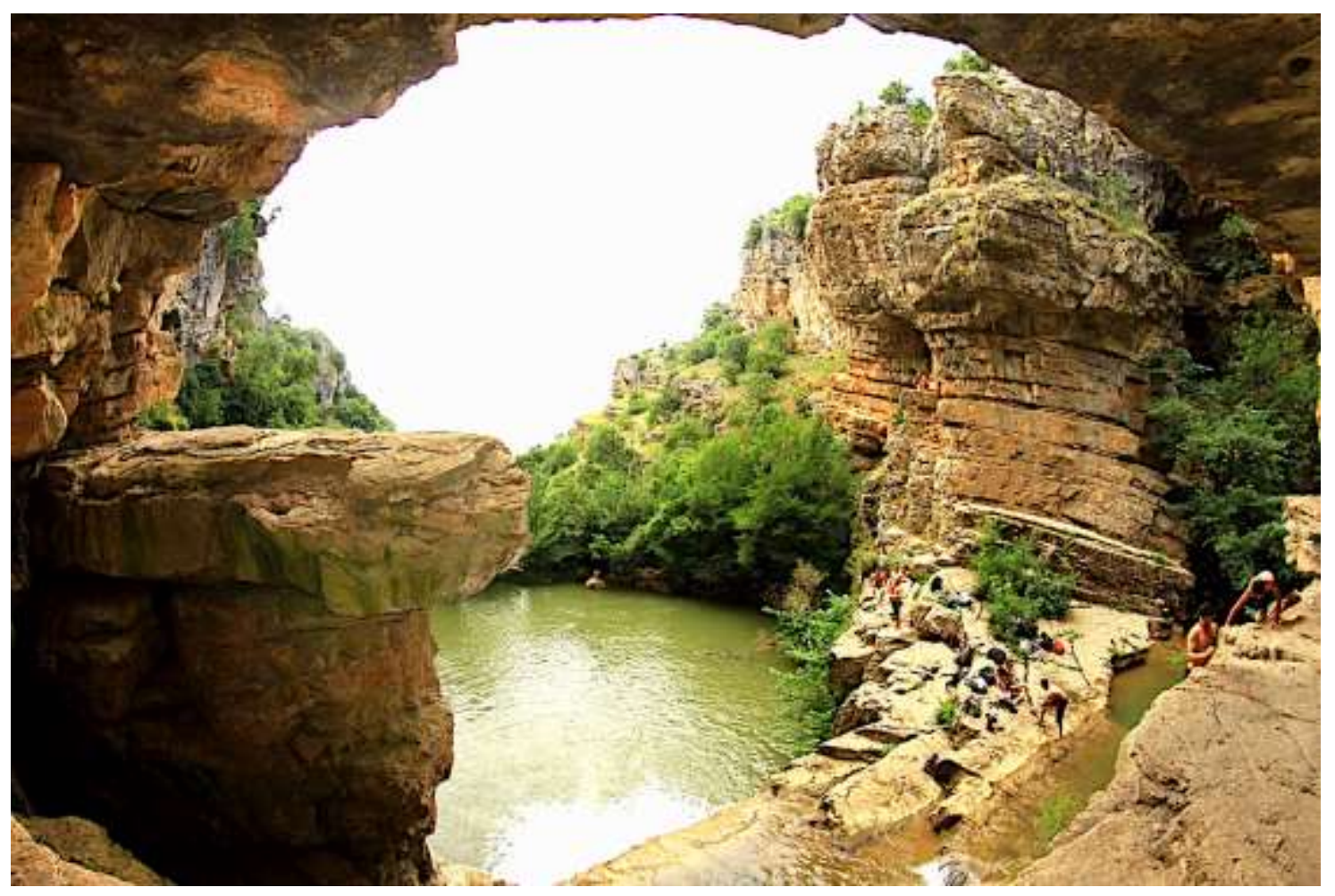

Figura 111. Ujëvara e Mirushës.

(Burimi): Ben Njeri, 2013. E licensuar nga Creative Commons Attribution ShareAlike 3.0 Unported

Një vitet e fundit, ndodhi që edhe resurset e ujit në ujëvarat e Mirushës të zvogëlohen, po ashtu u evidentuan nivelet më të ulëta të ujit në liqenet e Badocit dhe të Batllavës. $U$ kërkuan mundësitë alternative e furnizimit me ujë të pijshëm për qytetarët e Prishtinës.

Humbjet në masë të gjerë nga akullnajat dhe zvogëlimi i hapësirave të mbuluara nga dëbora gjatë dekadave të fundit janë përshpejtuar gjatë gjithë shekullit të XXI, duke reduktuar sasinë dhe disponueshmërinë e ujit, potencialin hidroenergjetik dhe ndryshimin e sezonalitetit të flukseve në rajone të furnizuara nga shkrirja e borës. Vargjet malore të mëdha (Hindu Kush, Himalaja, Andet), ku aktualisht më shumë se një e gjashta e popullsisë botërore jeton. Hulumtimet kanë parashikuar me besueshmëri të lartë, rritje të thatësirave nga 10 - 40\% nga mesi i shekullit në lartësi më të larta dhe në disa zona me klimë tropikale, duke përfshirë edhe zonat e populluara në Azinë juglindore, dhe 10 deri në $30 \%$ rritje të thatësirave në disa rajone me lartësi të mesme mbidetare dhe në ato me klimë tropikale, për shkak të zvogëlimit të reshjeve dhe niveli të lartë të avullimit. 
Po ashtu me hulumtime të besueshmërisë së lartë, rezulton se pellgu i Mesdheut, Shtetet e Bashkuara pjesa perëndimore, Afrika jugore dhe Brazili verilindor do të vuajnë një rënie në burimet ujore për shkak të ndryshimeve klimatike. Zonat e prekura nga thatësira janë parashikuar të rriten, me potencial për ndikime negative mbi sektorë të shumtë si: bujqësia, furnizimi me ujë, prodhimi i energjisë dhe shëndeti publik.

\subsection{Analiza e situacionit dhe veçorit bioklimatike}

Në konsideratë të lokacionit përfshihen ndikimet klimatike (dielli dhe retë, era, temperatura, lagështia dhe reshjet). Në rrethinën e afërt të ndërtesës duhet të konsiderohen ndërtesat e tjera, pemët, vegjetacioni, parkingjet, ndotja nga zhurma, dhe vendndodhja në kontekst të gjerë të qytetit apo zonave të tjera. Duhet konsideruar qasja në lagje, transporti urban, siguria, pozita ndaj qendrës së qytetit, morfologjia e terrenit, ndotja. Në kontekst të regjionit duhet konsideruar, topografinë, cilësinë e tokës, ujit, biodiversiteti, mikroklimës dhe diellosjes.

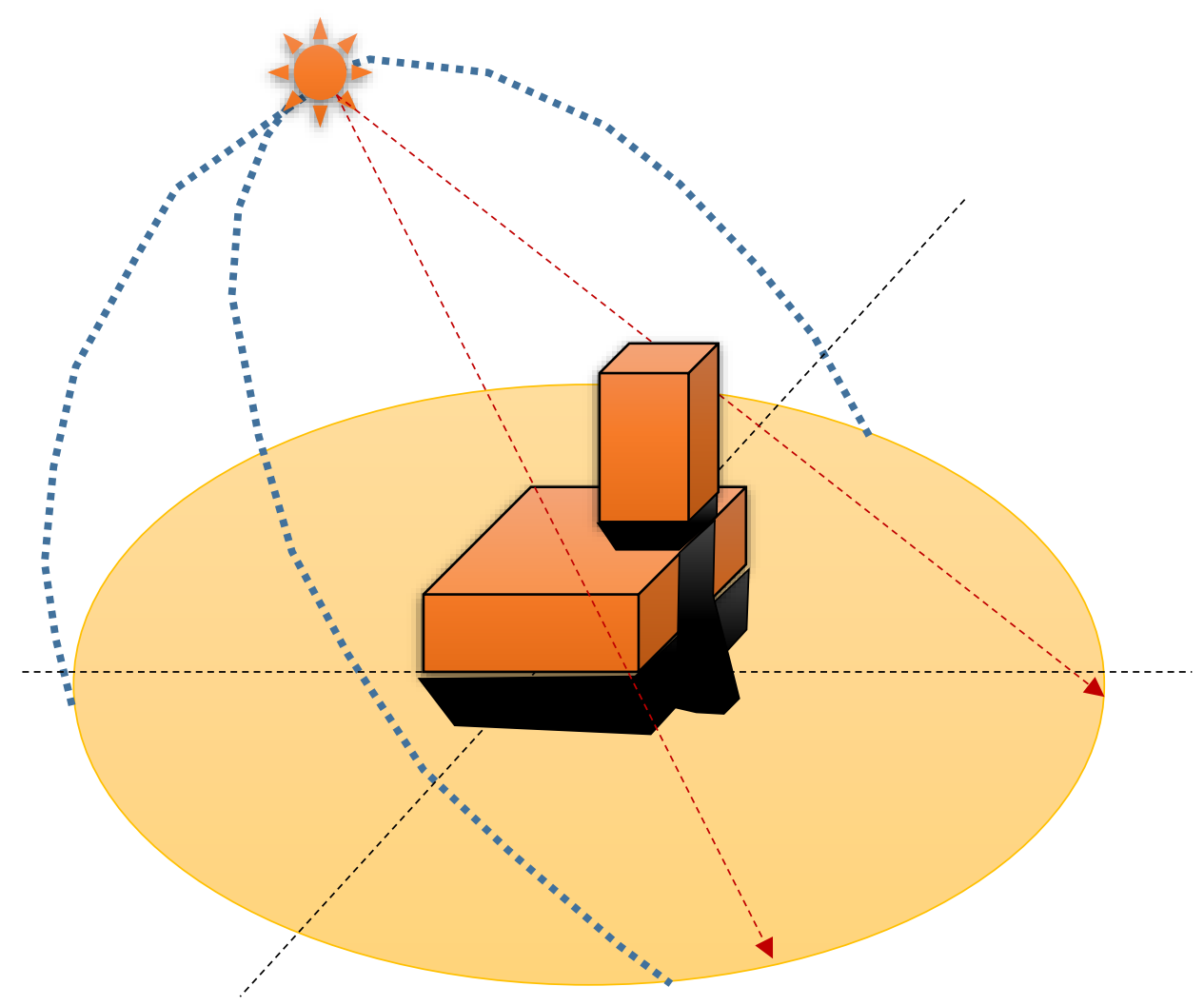

Figura 112. Diagrami Stereografik 3D modeli. Varshmëria pozita e diellit - objekti (Burimi): Bujar Bajçinovci, 2017.

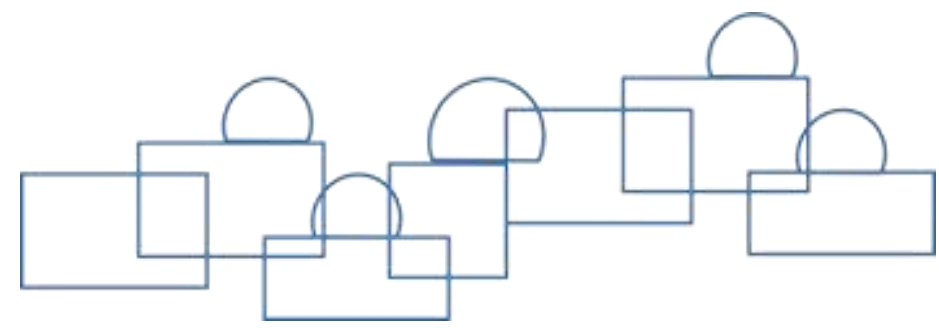




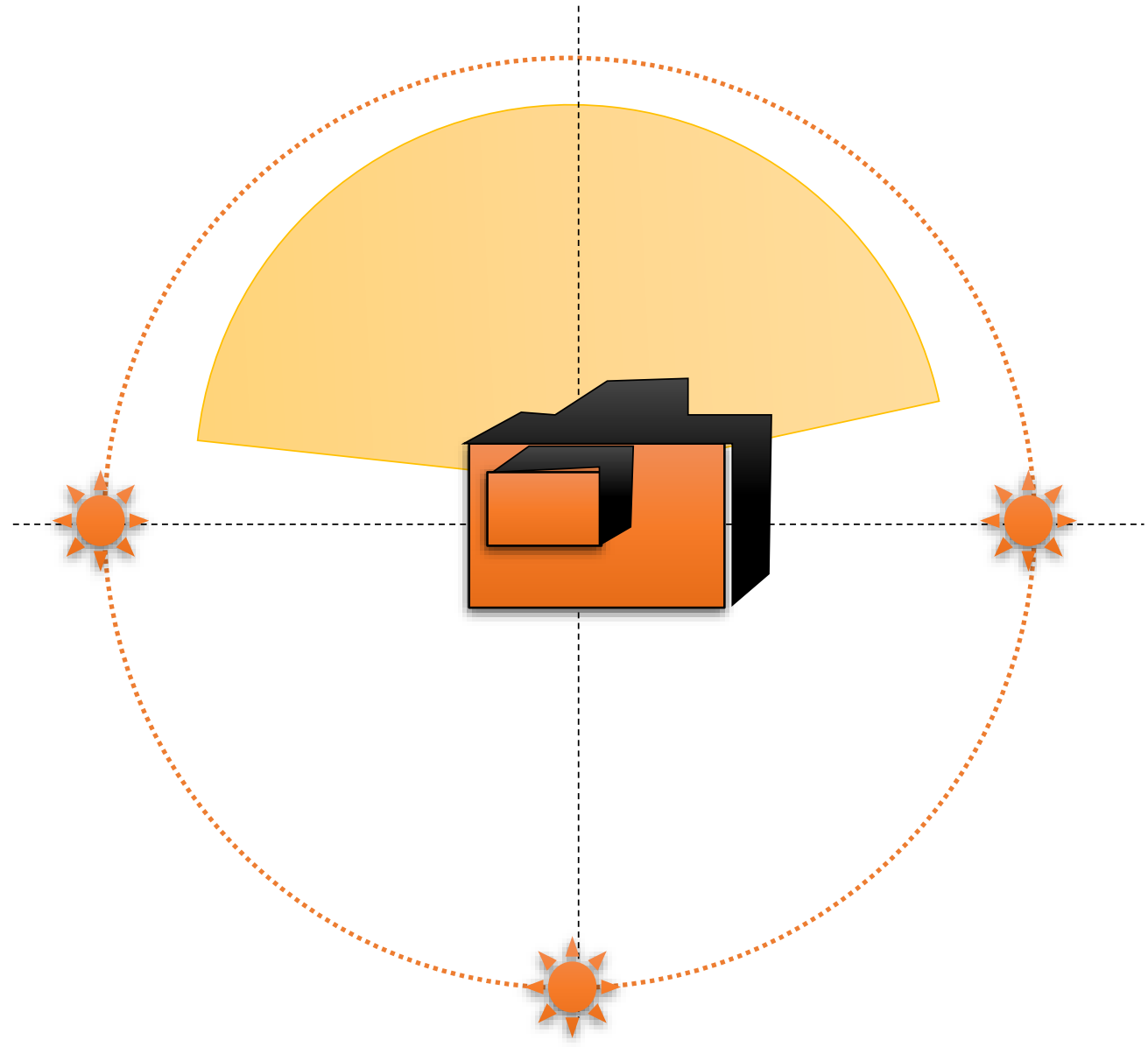

Figura 113. Diagrami Stereografik 3D modeli. Varshmëria, pozita e diellit - objekti (Burimi): Bujar Bajçinovci, 2017.

Nuk ekziston asnjë vend i përsosur. Në kushtet e qëndrueshmërisë, një vend i mirë duhet të ketë ajër të pastër, qasje në ujë, kushte të mira pedologjike, morfologjisë, diellosje, sipërfaqe adekuate për qëllime të ndërtimit. Andaj, theksi është në zgjedhjen e vendit për projektet e reja, pasi ndonjëherë është e vështirë ose e pamundur për të rivitalizuar ndërtesat e vjetra. Në projektimin e qëndrueshëm, karakteristikat e një vendi të veçantë janë zgjedhjet e bëra në lidhje me ndërtimin, orientim, vendndodhjen, shëndetin dhe peizazhin.

\subsection{Rrugëtimi i diellit dhe pozita diellore}

Gjëja e parë për tu kuptuar nga një projektues është trajektorja e diellit në vendndodhjen e shqyrtuar. Në çdo pikë të caktuar në trajektoren e diellit, lartësia e tij në qiell quhet lartësia e tij dhe kënd i tij në rrafshin horizontal në raport me veriun, e që quhet azimiti.

Variacionet sezonale dhe datat e rëndësishme, trajektorja e diellit ndryshon gjatë gjithë vitit. Në verë dielli është i lartë në qiell, lind në lindje dhe perëndon në perëndim (-). Po ashtu lind më herët dhe perëndon shumë më vonë në verë se në dimër. Për të studiuar pozitat e skajshme, të diellit gjatë verës, duhet studiuar trajektoren e diellit në solsticin veror, më 21 korrik, e cila është dita më e gjatë e vitit ku dita zgjat 15 orë e 10 minuta dhe dielli gjendet 72 gradë lart horizontit. 
Në dimër dielli është i ulët në qiell. Për të studiuar pozitat e skajshme, të diellit gjatë dimrit, duhet studiuar trajektoren $\mathrm{e}$ diellit në solsticin dimëror, dita e parë të dimrit, me 21 dhjetor fillon dita më e shkurtër e vitit me gjatësi rreth 9 orë e 11 minuta, ndërsa dielli ngrihet vetëm 25 gradë lart horizontit. Për të studiuar më shumë pozita duhet studiuar, trajektoren e diellit në mes ekuinokseve të pranverës dhe të vjeshtës.

Figura 114. Relacioni

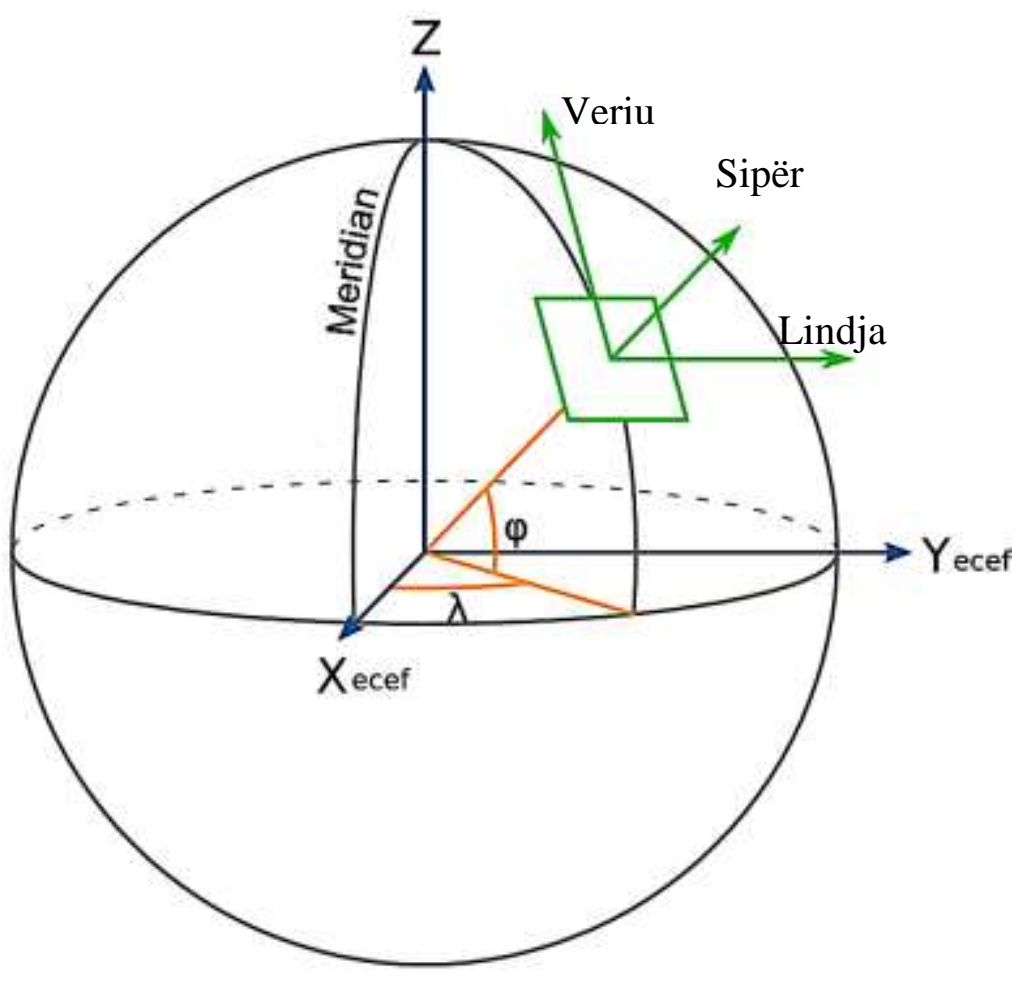
gjerësi dhe gjatësi gjeografike (Burimi): Përpunuar, Mike1024, E licensuar nga Creative Commons Attribution ShareAlike 3.0

Lartësia e diellit në mesditë në ekuinoks përcaktohet nga kosinus gjerësia. Kjo është arsyeja pse për këndin optimal të paneleve solare është më rëndësi gjerësia. Në këtë kënd, rrezet e diellit janë më pingul në panelin për shumicën e ditëve gjatë vitit.

Figura 115. Trëndafili i erërave për Prishtinë. 2015

(Burimi): Bujar Bajçinovci, 2017.

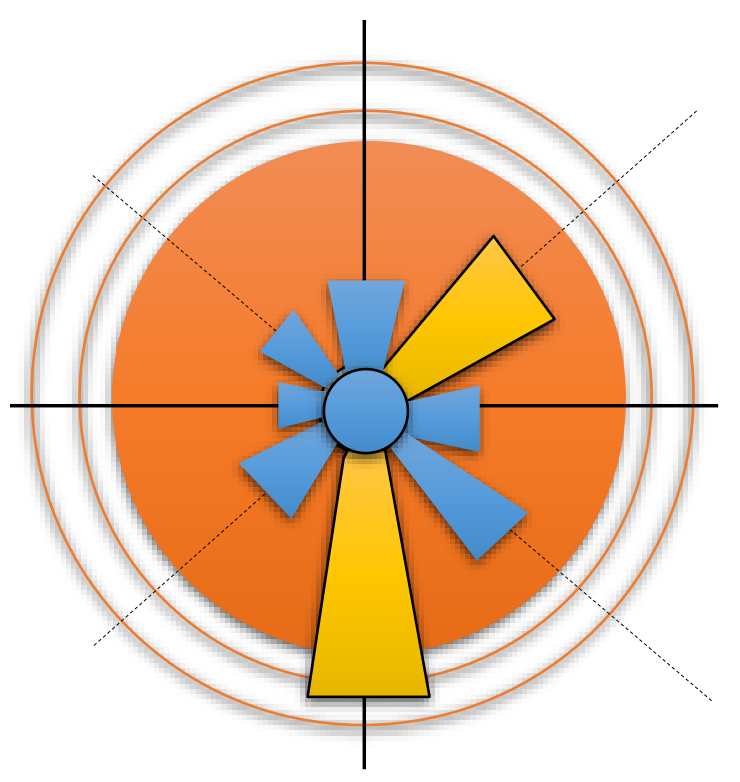

Rrymimi ajrit, varet nga presioni i lartë dhe presionit i ulët. Kjo është e rëndësishme për tu mbajtur mend, sepse ky është parimi themelor për ventilimin apo ajrimin si dhe për ventilimin e oxhaqeve, principi i Bernoullit. Kur era has në një pengesë, ajo do të rrjedhë rreth objektit dhe do të vazhdojnë të lëviz në të njëjtin drejtim. Kjo është e ngjashme me rrjedhjen e ujit (bazat e rrjedhjes fluide). Është e rëndësishme të theksohet se në qoftë se era është e "bllokuar" nga një konturë e tokës apo nga ndërtesa përreth, era nuk do të ndalet, por vetëm se drejtimi ka me devijuar paksa. 
Shpejtësia e erës ndryshon me lartësi, dhe me terren. Me rritjen e lartësisë, ndryshon shpejtësia e erës. Ndërsa, siç bëhet terreni më i vrazhdë, era me shpejtësi fillon të ngadalësohet. Kjo do të thotë se shpejtësia e erës në një vend të hapur, rural apo mjedis të hapur do të rritet shumë më shpejt se sa shpejtësia e erës në një qendër të dendur urbane. Kjo normë e rritjes është e njohur si një gradient apo shkallë e erës. Si rezultat, shpejtësia e erës mund të ndryshojnë në mes terreneve të ndryshme në të njëjtën lartësi.

Kuptimi i shpejtësisë së erës është po aq i rëndësishëm sa të kuptuarit nga po vjen era, respektivisht drejtimi i erës. Era mund të fëshfëritë gjethe në një pemë, ose ajo mund të shkaktojë dëme të rënda strukturore në ndërtesa. E gjitha varet nga sa shpejt është duke lëvizur. Shpejtësia e erës matet zakonisht në nyje, milje në orë, metra për sekondë, kilometra në orë.

Kujdes të madh në përzgjedhje të lokacionit, duhet konsideruar edhe reduktimin në ndikimin mjedisor gjatë ndërtimit. Në vijim janë disa nga pikat thelbësore që duhet të merren parasysh për një lokacion të "qëndrueshëm":

1. Duhet parandaluar çdo lloj të dëmtimit të mjedisit

2. Duhet bëre çdo përpjekje për të sjellë përsëri një vend të degraduar në nivel optimal nga aspekti i mjedisit dhe të diversitetit biologjik.

3. Duhet ruajtur monumentet historike, një shtëpi të vjetër për shembull, urat, mullinjtë, trashëgiminë kulturore.

4. Duhet kuptuar kushtet klimatike, për përfitim maksimal solar.

5. Duhet kuptuar se si era mund të shfrytëzohet për përdorim të sistemeve pasive energjetike dhe ventilim natyror.

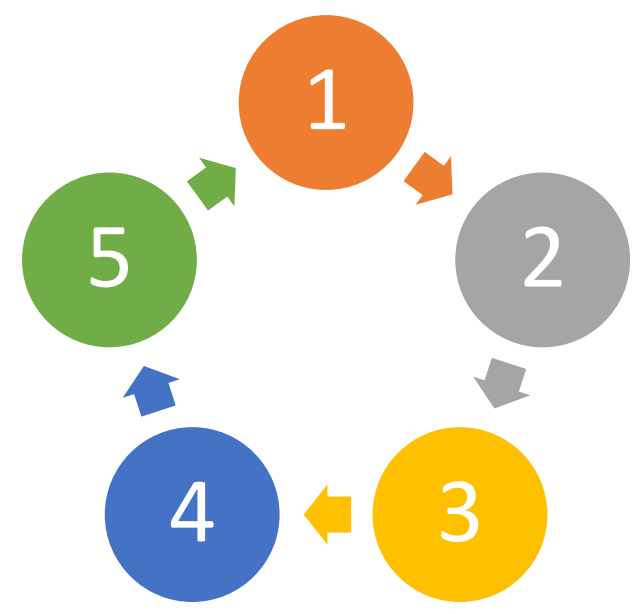

Figura 116. Ndërvarësia e zgjedhjes së lokacionit (Burimi): Bujar Bajçinovci 


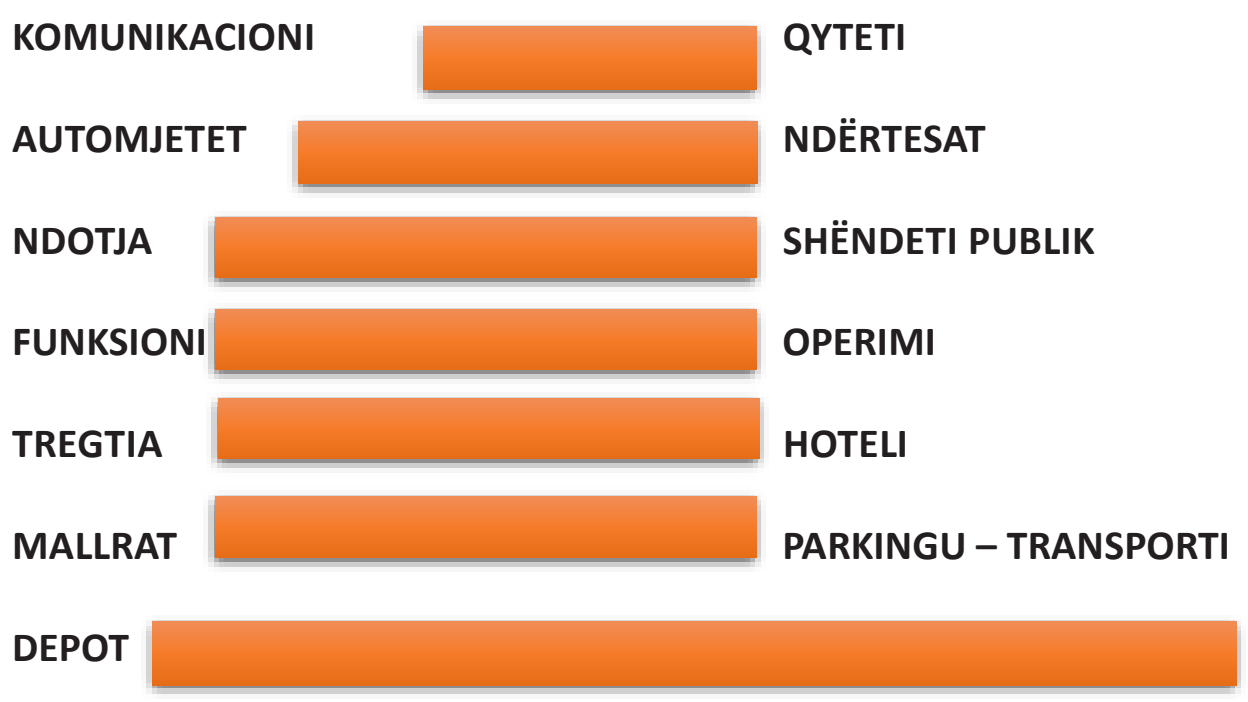

Figura 117. Relacionet dhe ndërvarësitë e sistemeve funksionale urbane (Burimi): Bujar Bajçinovci, 2017

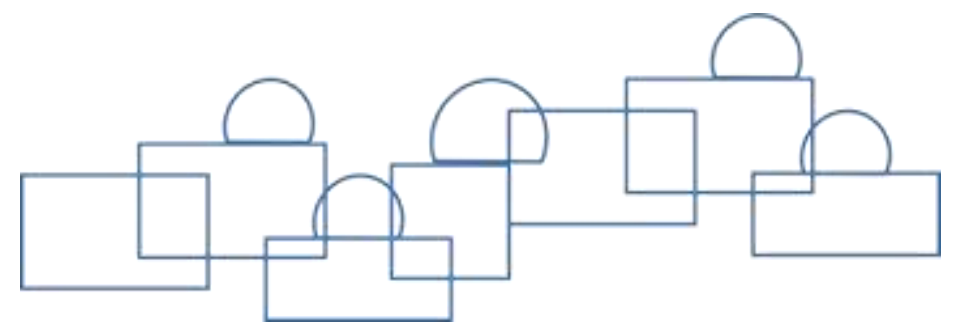


Disa nga rregullat e komunës së Prishtinës. Distanca me e vogël nga parcela fqinjë te banimi individual është $3.0 \mathrm{~m}$. Teraset, shkallet e jashtme, ballkonet, konzollat, nuk mund të ndërtohen në distance me të vogël se $3.0 \mathrm{~m}$ nga parcela fqinjë. Ndërtesat qe ndërtohen në varg apo të ngjitura në njëren anë vendosen në kufi të parcelës, por duhet të kenë murin e zbatuar me standarde për mbrojtje nga zjarri. Distanca në mes të objekteve ( banimi kolektiv dhe ndërtesat afariste ) duhet të jetë $1 \mathrm{H}$, mes objektit dhe ngastrës fqinje $0.5 \mathrm{H}$, dhe min. $7 \mathrm{~m}$ pa ndriçim primar.

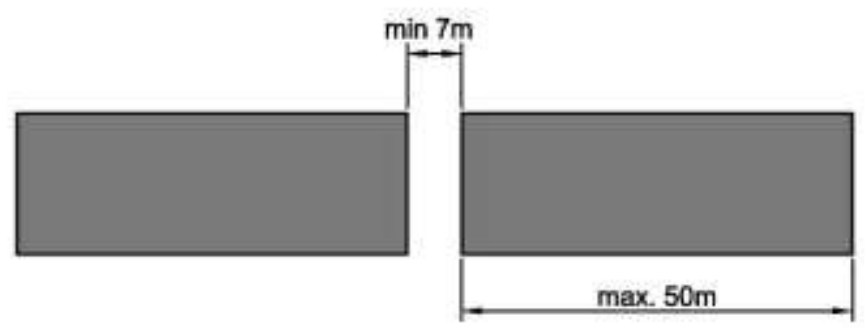

Figura 118. Distanca minimale anësore në mes të objekteve (Burimi): Komuna e Prishtinës, Plani rregullues Prishtina e Re, 2013.

Figura 119. Distanca minimale e kombinuar në mes të objekteve (Burimi): Komuna e Prishtinës, Plani rregullues Prishtina e Re, 2013.

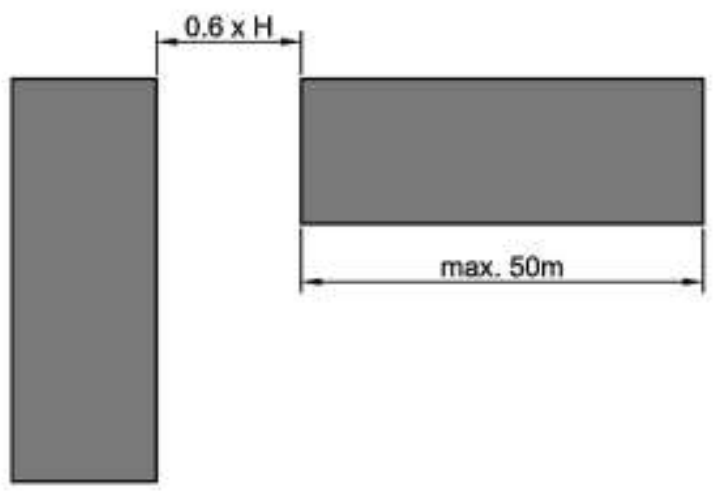

Figura 120. Distanca minimale në mes (Burimi): Komuna e Prishtinës, Plani rregullues Prishtina e Re, 2013.

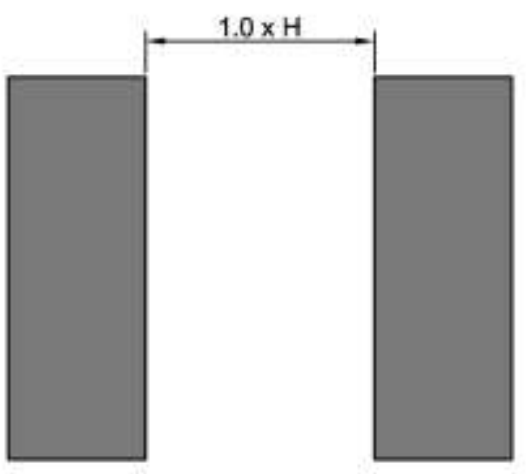




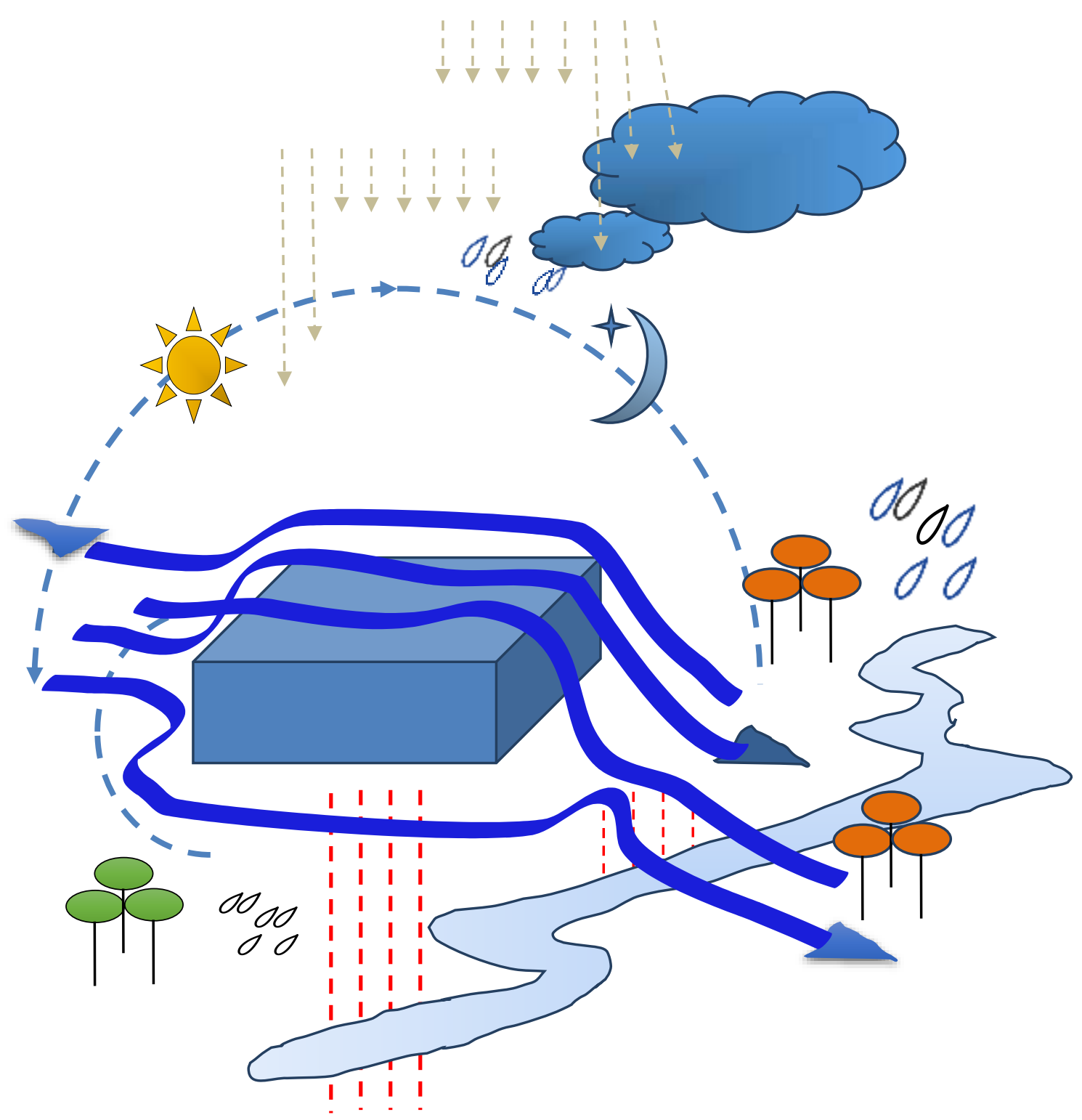

Figura 120-A. Analizë e lokacionit, model nga veçoritë bioklimatike (Burimi): Bujar Bajçinovci, 2015.

Vlerësimet e Ndikimit Mjedisor (VNM), Ligjet e aplikueshme, janë Ligji për mbrojtjen e mjedisit, Ligji për vlerësimin e ndikimit mjedisor, që ngarkon MMPH-në me përgjegjësinë për të aplikuar procedurat e VNM, dhe Ligji për vlerësimin strategjik mjedisor, që synon sigurimin e nivelit të lartë të mbrojtjes së mjedisit dhe shëndetit të njeriut përmes vlerësimit strategjik mjedisor të planeve dhe programeve të caktuara, si dhe udhëzimet e aplikueshme administrative për vlerësimin e ndikimit në mjedis. 


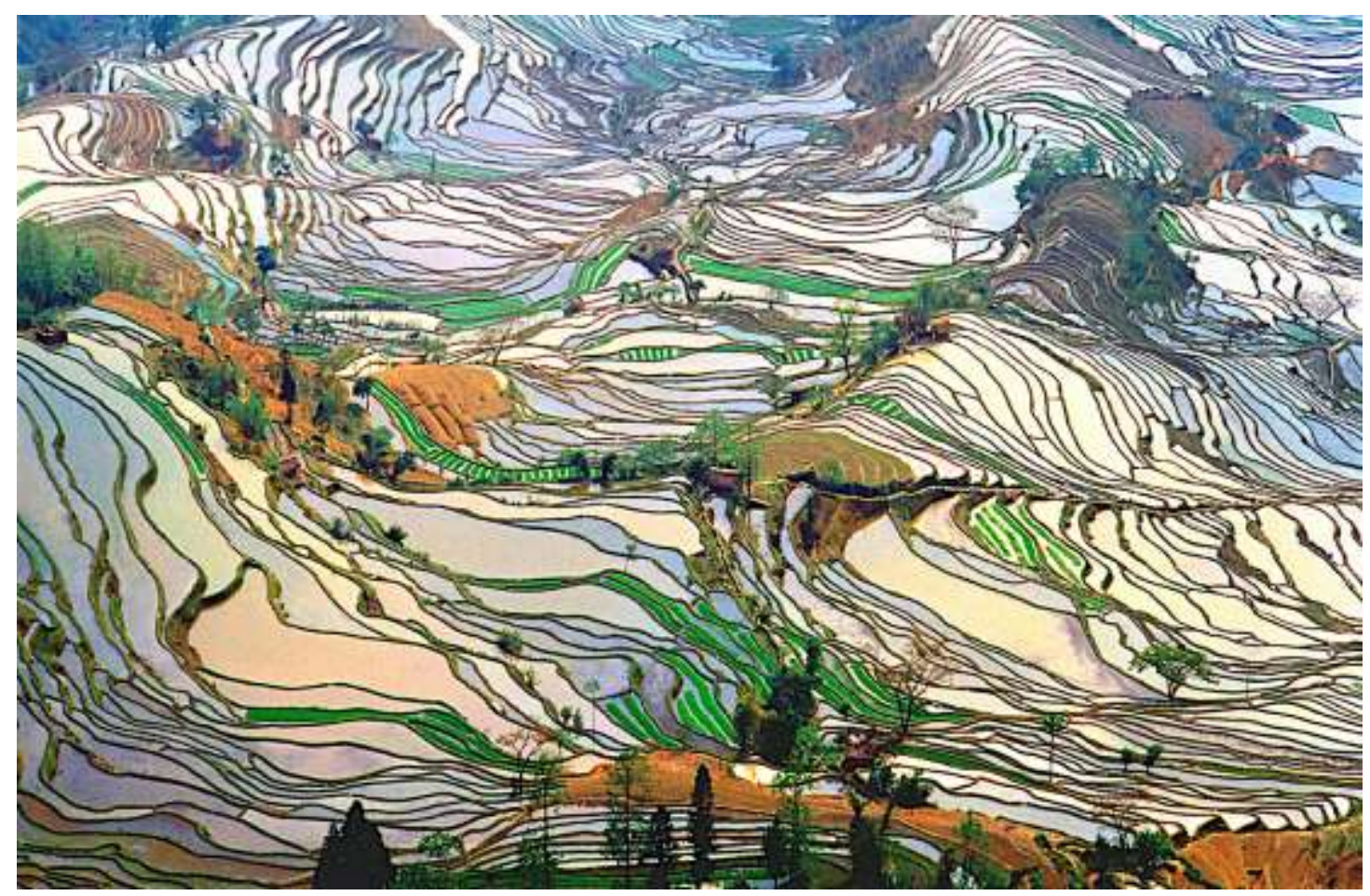

Figura 121. Fushë tarracë orizi, reale. Honghe Hani, Kinë

(Burimi): Jialiang Gao, E licensuar nga Creative Commons Attribution-Share Alike 3.0 Unported.

Ndotja në Prishtinë, Kosovë

Ndotja e ajrit

Ndotja e ujit për pirje dhe qasja

Pakënaqësia me hudhjen e mbeturinave

Pastërtia dhe jo rregulli

Zhurma dhe ndotjet e lehta

Ndotja e ujit

Pakënaqësia të kalohet koha në qytet

Pakënaqësia gjelbërimit dhe parqet

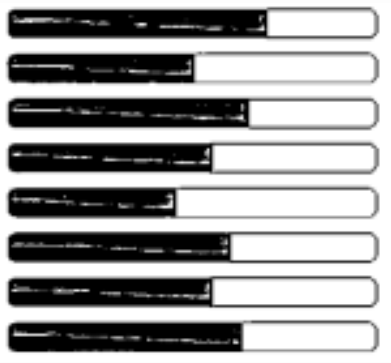

70.00 lartë 50.00 moderuar 65.00 lartë 55.00 moderuar 45.00 moderuar 60.00 lartë 55.00 moderuar 62.50 lartë

Pastërtia dhe Papastërtia në Prishtinë, Kosovë

\author{
Cilësia e ajrit \\ Cilësia e ujit për pirje dhe qasja \\ Hudhja e mbeturinave, Kënaqshmëria \\ Pastërtia dhe rregulli \\ I qetë, nuk ka problem me drita, natën \\ Cilësia e ujit \\ E rehatshme të kalohet koha në qytet \\ Cilësia e gjelbërimit dhe parqet
}

30.00 ulët

50.00 moderuar 35.00 ulët

45.00 moderuar 55.00 moderuar 40.00 moderuar 45.00 moderuar 37.50 ulët

Figura 122. Ndotja, pastërtia në Prishtinë sipas intervistës (Burimi): Numbeo, 2015. http://www.numbeo.com/common/ 


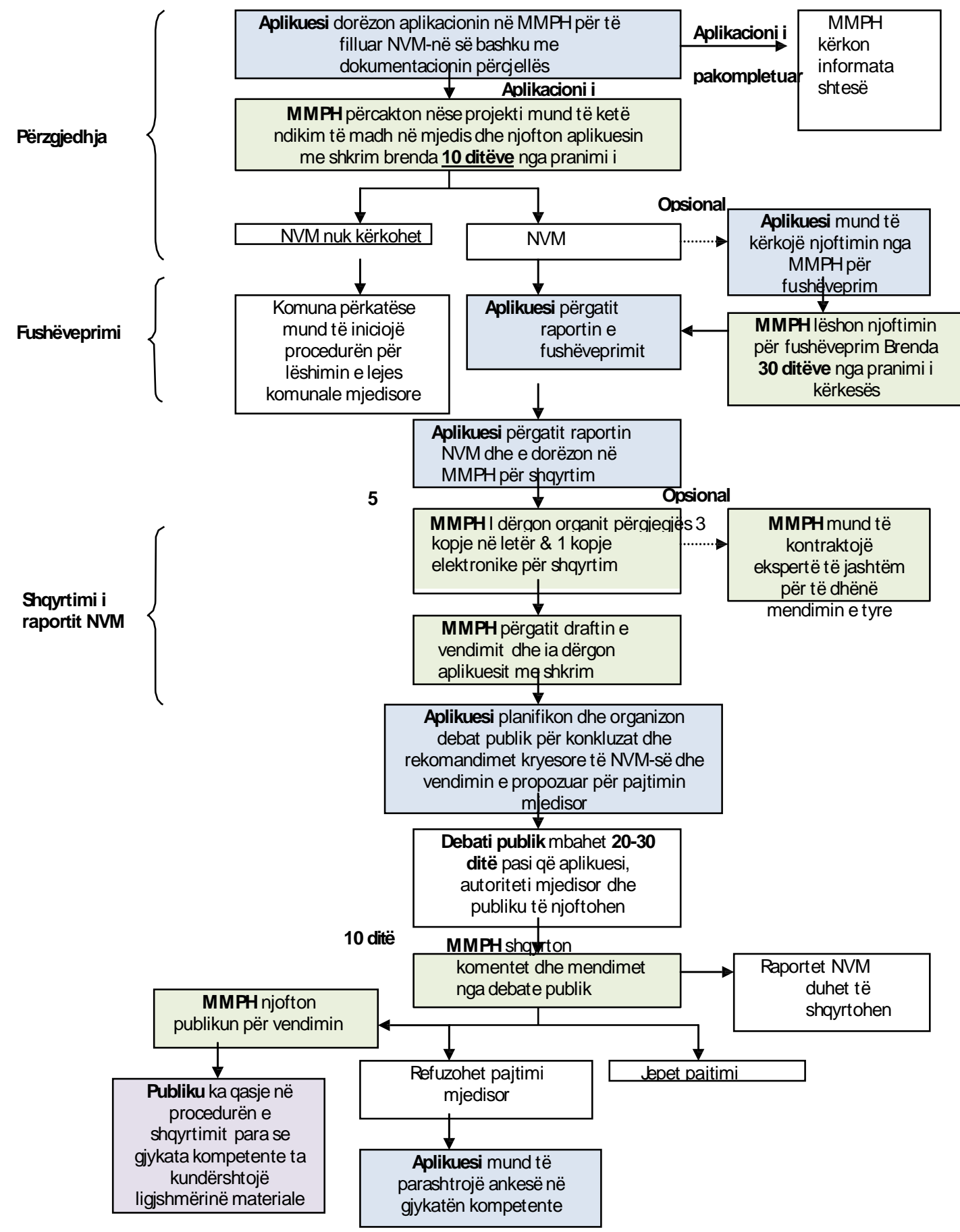

Figura 123. Procesi NVM në Kosovë në pajtim me ligjin nr. 03/L-214 për NVM (Burimi): Kosovë, Analiza mjedisore e shtetit. Raport i Bankës Botërore me MMPH. 
Analiza situacionit është një hap jetik në procesin e projektimit. Ajo përfshin vlerësimin aktual, ekzistues ose të mundshëm në lidhje me programin e zhvillimit, ndikimit në mjedis, ndikimet në komunitet dhe të pronave afër, buxhetit të projektit si dhe faktorin kohë. Analiza e vendndodhjes identifikon veçori mjedisore, programimin arkitektonik, si dhe kufizimet e zhvillimit dhe mundësitë. Një analizë e ekzekutuar mirë formon bazën thelbësore për një kosto efektive racionale për mjedisin dhe për zhvillimin e projektit.

\subsection{Mbështjellësi i objektit}

Mbështjellësi i ndërtesës është ndarës fizik në mes të ambientit të kushtëzuar dhe të pakushtëzuar të një ndërtese, duke përfshirë rezistencën ndaj ajrit, ujit, ngrohjes, ndikimeve mjedisore të lehta, si dhe zhurmës. Tri elemente themelore janë të veçuara për t'u marrë në konsideratë: klima, ajri-era, dhe rezistenca termike. Mbështjellësi i ndërtesës si term është përdorur shpesh edhe si sinonim merr murin e objektit, por ky term në vete gjithashtu përfshin aspekte më të gjera si: struktura, siguria nga zjarri, estetikën, sigurinë fizike.

Funksionimi i të dy teknologjive pasive dhe aktive realizohet mbi parimet e termodinamikës, dhe realisht potenciali për krijimin e qëndrueshmërisë efektive mbështetet direkt në procesin e projektimit të mirëfilltë.

Nga të gjitha elementet e ndërtimit me potencial të qëndrueshëm të projektimit, ndikim më të madh do ta tërheqë zgjedhja e mbështjellësit të ndërtesës apo ndërvarëshmërisë së konturës së objektit me idenë konceptuale të projektimit. Për të ndërtuar "fasada" ekologjikisht efikase, duhet kuptuar funksionimin e mekanizmit të transferimit të ngrohjes apo transferit të energjisë në trupë.

Bartja e nxehtësisë realizohet kur energjia termike kalon në mes të trupave me temperatura të ndryshme. Ky është një princip dhe gjendje e përgjithshme e natyrës për të krijuar ekuilibër, në këtë rast ekuilibër termik. Kur ekzistojnë dallime në temperaturë, procesi i transferit nuk mund të ndalet.

Bartja e nxehtësisë zhvillohet në tri mënyra, me:

1. Rrezatim, radiacion

2. Përçueshmëri, kondukcion

3. Rrymimit, konvekcion

Ligji i dytë i termodinamikës i cili pranohet si një nga ligjet themelore të fizikës, deklaron se në kushte normale to gjitha sistemet e lëna në vetveten e tyre do të tentojnë të çrregullohen, disperzohen dhe shkatërrohen në proporcion të drejtpërdrejtë me gjatësinë e kohës që kalon. Gjithçka, qoftë kjo e gjallë apo jo, zhvishet, prishet, degjenerohet, dezintegrohet dhe shkatërrohet.

Ky është fundi absolut dhe me këtë do të ballafaqohen të gjitha qeniet, në një mënyrë apo në një tjetër, dhe sipas ligjit nuk ka shmangie nga ky proces. 
Andaj, nxehtësia bartet nga njeri trup në tjetrin në tri mënyra:

a. Me anë të përcjellshmërisë, /konduksionit/ kur grimca e nxehur i jap nxehtësinë me kontakt grimcës fqinje. Grimcat e ngrohta oshilojnë shpejt, bartin këtë lëvizje në grimcat fqinje dhe kjo ndodh derisa të gjitha molekulat nuk fillojnë të oshilojnë shpejt, do të thotë nxehtësia bartet me përcjellshmëri.

b. Me anë të rrymimit, /konveksionit/ ku nxehtësia bartet vetëm në materie të lëngëta dhe në gazra. Ngrohja e grimcave bëhet lehtë, specifikisht më lehtë. Pasi kohezioni në to ashtë i panjohur, ato lehte ndërrojnë pozitën e tyre dhe gjatë rrugës ua japin nxehtësinë grimcave fqinje të materies së vet ose trupave të ngurtë të ftohtë që i kontaktojnë .

c. Me ane të rrezatimit, /radiacionit/ ku nxehtësia bartet nga trupi i ngrohtë në atë të ftohtë pa ngrohje të mjedisit nëpër të cilin depërtojnë rrezet. Rrezet e nxehta paraqiten edhe si ndriçim, drite, përhapen në mënyre drejtvizore, përthehen dhe dëbohen.

Sasia e nxehtësisë paraqet ndryshimin që lënda punuese e ekspozon gjate kalimit të saj prej një gjendje në tjetrën. Ajo nuk mund të matet drejtpërdrejti, por mund të llogaritet. Shprehet në njësi kJ. Nxehtësia specifike është ajo sasi e nxehtësisë së nevojshme që trupin me mase prej $1 \mathrm{~kg}$ ta ngrohe për $1^{\circ} \mathrm{C}$. Nxehtësia specifike e ajrit është $\mathrm{c}_{\mathrm{a}}=1,004$ $\mathrm{kJ} / \mathrm{kgK}$, kurse ajo e ujit $\mathrm{c}_{\mathrm{u}}=4,186 \mathrm{~kJ} / \mathrm{kgK}$, në temperature $20^{\circ} \mathrm{C}$ dhe shtypje prej 1,0133 bar. Temperatura është shkalla e ngrohjes së ndonjë trupi. Ajo matet me termometër. Në Evropë është në përdorim shkalla e Celsiusit $/ t,{ }^{\circ} \mathrm{C} /$. Duhet të theksohet se në termoteknikë përdoret me së shumti temperatura absolute, që shënohet me $\mathrm{T}$ dhe matet me shkallë Kelvin. Në përdorim janë edhe shkalla e Fahrenheit-it $/ t,{ }^{\circ} F$ në USA dhe UK, dhe ajo e Réaumur $/ t,{ }^{\circ}$ Ré/. Lidhja ndërmjet këtyre shkalleve qëndron në trajtën :

$$
\left.\mathrm{t}\left[{ }^{\circ} \mathrm{C}\right]=\mathrm{T}[\mathrm{K}]-273=\left(\left[{ }^{\circ} \mathrm{F}\right]-32\right) 5 / 9=\mathrm{t}\left[{ }^{\circ} \mathrm{Ré}\right]\right) 5 / 4
$$

Pika e shkrirjes së akullit të ujit për shkallet e cekura arrihet në $0^{\circ} \mathrm{C}, 273 \mathrm{~K}, 32^{\circ} \mathrm{F}, 0^{\circ} \mathrm{Ré}$ kurse pika e vlimit të ujit në $100{ }^{\circ} \mathrm{C}, 373 \mathrm{~K}, 212^{\circ} \mathrm{F}, 80^{\circ}$ Ré gjate shtypjes atmosferike $760 \mathrm{mmHg}$, përkatësisht 1,0133 bar.

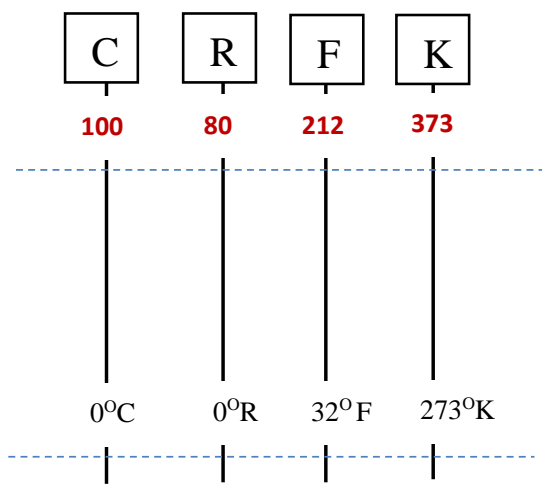

Figura 124. Pika e vlimit të ujit dhe shkrirjes së akullit të ujit (Burimi): Bujar Bajçinovci, 2015. 


\subsubsection{Muri i rrafshët}

Sipas autorëve: Akademik Krasniqi, F., Selimaj, R., Malsiu, I. (2004). Të cilët mënyrë të thukët e shpjegojnë transmetimin e nxehtësisë për murin e rrafshët, do i marrim sqarimet e mëposhtme nga literatura e tyre: Nëse në të dy anët e një muri të rrafshët ka ndryshim temperaturash atëherë nxehtësia transmetohet nga ana e murit me temperaturë më të lartë në anën me temperaturë më të ulët. Nxehtësia së pari kalon nga ajri në mur të lokalit, pastaj kalon nëpër mur dhe nga muri në ajrin e jashtëm. Andaj:

$\mathrm{Q}_{\mathrm{e}}=\alpha_{\mathrm{b}} \mathrm{F}\left(\mathrm{t}_{\mathrm{bp}}-\mathrm{t}_{1}\right)$

$\mathrm{Q}_{e}=(\lambda / \delta) \mathrm{F}\left(\mathrm{t}_{1}-\mathrm{t}_{2}\right)$

$\mathrm{Q}_{\mathrm{e}}=\alpha \mathrm{j} F\left(\mathrm{t}_{2}-\mathrm{t}_{\mathrm{jp}}\right)$

Pas rregullimit të barazimeve arrihet

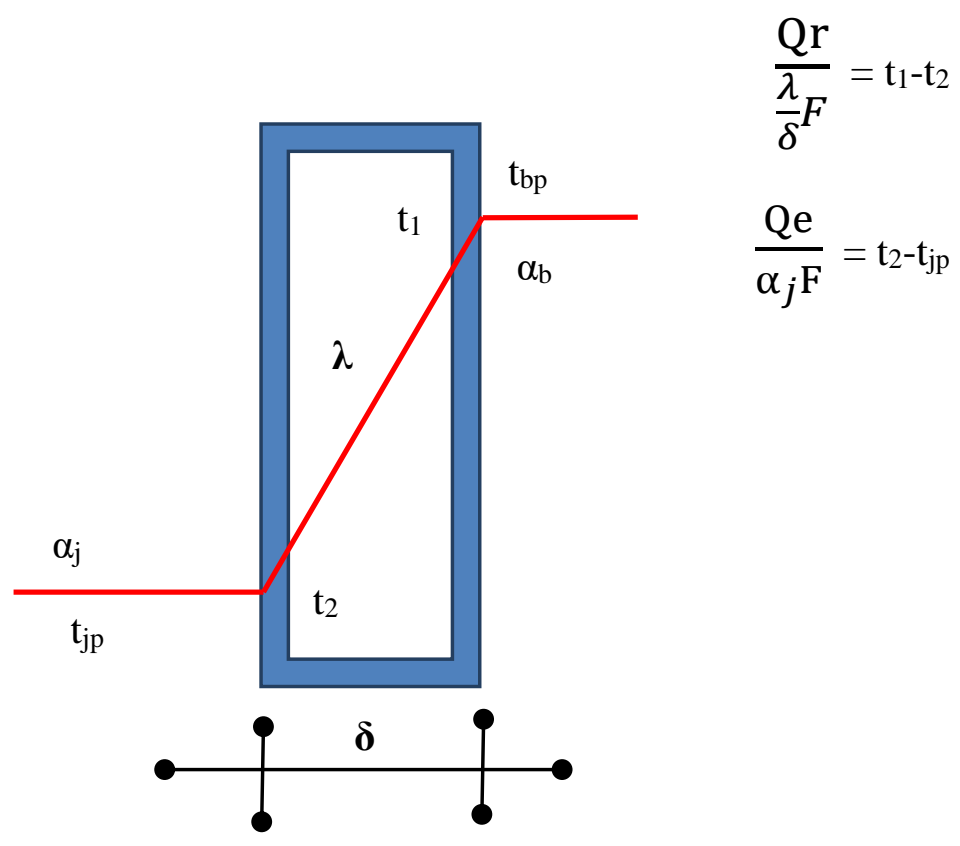

$$
\frac{\mathrm{Qe}}{\alpha_{b} \mathrm{~F}}=\mathrm{tbp}^{\mathrm{t}} \mathrm{t}_{1}
$$

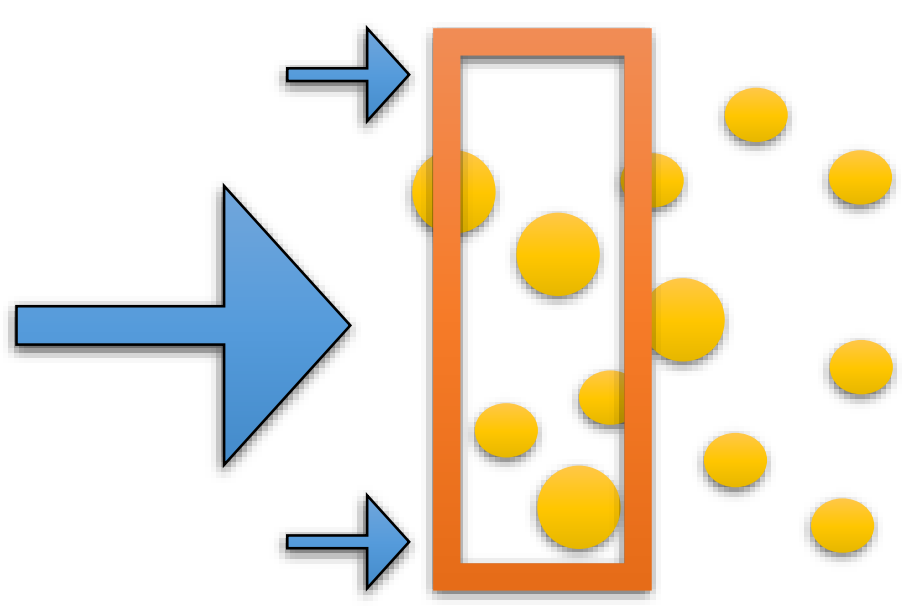

Figura 123. Transmetimi i nxehtësisë për murin e rrafshët (Burimi): Bujar Bajçinovci, 2017. 


$$
\frac{\mathrm{Qe}}{\mathrm{F}}\left\{\frac{1}{\alpha_{b}}+\frac{\delta}{\lambda}+\frac{1}{\alpha_{j}}\right\}=\mathrm{t}_{b p}-\mathrm{t}_{b j} \quad \mathrm{Qe}=\frac{F\left(\mathrm{t}_{b p}-\mathrm{t}_{b j}\right)}{\frac{1}{\alpha_{b}}+\frac{\delta}{\lambda}+\frac{1}{\alpha_{j}}}
$$

ku janë:

$$
Q e=k F\left(t_{b p}-t_{j p}\right) \ldots[\mathrm{W}]
$$

Qe[W]-sasia e nxehtësisë që kalon nëpër ndonjë element-sipërfaqe të murit; $k=1 /\left(1 / \alpha_{b}+\delta / \lambda+1 / \alpha_{j}\right)\left[\mathrm{W} /\left(m^{2} \mathrm{~K}\right)\right]$-koeficienti i transmetimit të nxehtësisë; $\mathrm{F}\left[\mathrm{m}^{2}\right]$-sipërfaqja nëpër të cilën kalon nxehtësia (mur, dritare, dyer); $\mathrm{t}_{\mathrm{bp}}\left[{ }^{\circ} \mathrm{C}\right]$-temperatura e ajrit të brendshëm;

$\mathrm{tj}_{\mathrm{p}}\left[{ }^{\circ} \mathrm{C}\right]$ a) temperatura e jashtme e projektuar, nëse konsiderojmë se sipërfaqja e murit të lokalit kufizohet me ajrin e jashtëm, ose

b) temperatura e hapësirës fqinje, nëse sipërfaqja $F$ kufizohet me hapësirën fqinje;

$\mathrm{t}_{1}, \mathrm{t}_{2}\left[{ }^{\circ} \mathrm{C}\right]$-temperatura në sipërfaqen e brendshme dhe në të jashtmen të murit; $\alpha_{b}\left[\mathrm{~W} /\left(\mathrm{m}^{2} \mathrm{~K}\right)\right]$-koeficienti i konveksionit të nxehtësisë nga ajri në murin e brendshëm; $\alpha \mathrm{j}\left[\mathrm{W} /\left(\mathrm{m}^{2} \mathrm{~K}\right)\right]$-koeficienti i konveksionit të nxehtësisë nga muri në ajrin e jashtëm;

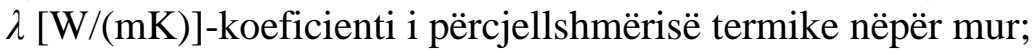
$\delta[\mathrm{m}]$-trashësia e murit.

Koeficienti i transmetimit të nxehtësisë për murin me shumë shtresa, është:

$$
k=1 /\left[1 / \alpha_{\mathbf{b}}+\Sigma(\delta i / \lambda i)+1 / \alpha_{\mathbf{j}}\right.
$$

Nëse kemi shtresë ajri të izolimit, atëherë kemi:

$$
k=1 /\left[1 / \alpha_{\mathrm{b}}+\Sigma(\delta i, / \lambda i)+1 / \lambda i+1 / \alpha \mathrm{j}\right.
$$

$k u: 1 / \lambda i\left[\mathrm{~W} /\left(\mathrm{m}^{2} \mathrm{~K}\right)\right]$ është rezistenca termike nëpër shtresë të ajrit.

Rezistenca termike e murit shprehet nëpërmjet barazimit: $R_{m}=1 / k\left[m^{2} K / W\right]$.

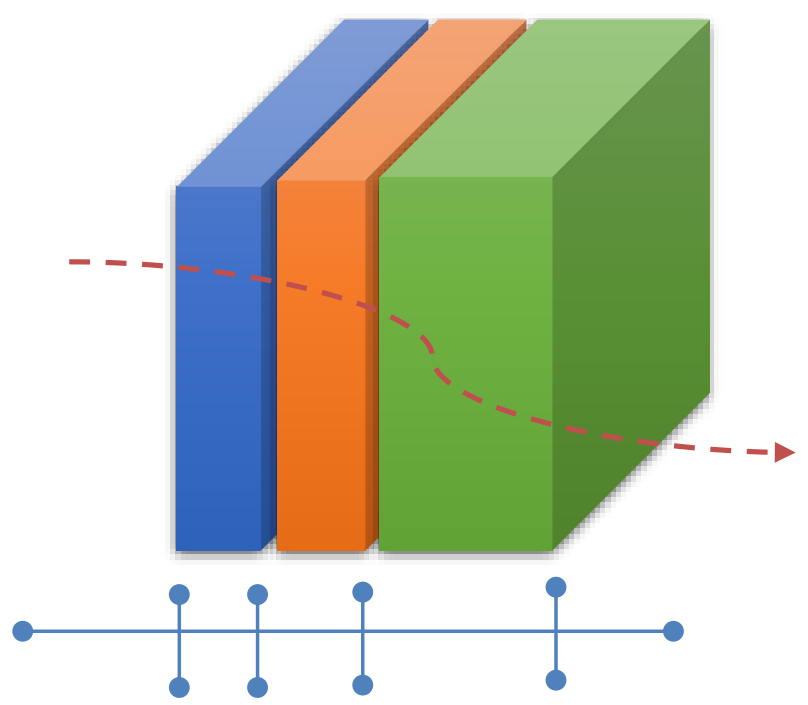

Figura 124. Transmetimi i nxehtësisë për murin e rrafshët shumështresor (Burimi): Bujar Bajçinovci, 2015. 


\section{SHEMBULL:}

I gjithë shembulli, sipas autorëve Krasniqi, F., Selimaj, R., Malsiu, I. (UP, 2004).

Llogariteni koeficientin e transmetimit të nxehtësisë për murin e jashtëm me përbërje: llaç gëlqeror në shtresën e jashtme me trashësi $2 \mathrm{~cm}$, tulla $12 \mathrm{~cm}$, shtresa e ajrit $5 \mathrm{~cm}$, betoni $8 \mathrm{~cm}$, llaç allçie në shtresën e brendshme $1 \mathrm{~cm}$.

Zgjidhje:

Gjejmë vlerat për koeficientin e konveksionit $\boldsymbol{\alpha}_{\mathbf{j}}=25 \mathrm{~W} /(\mathrm{m} 2 \mathrm{~K})$ dhe $\boldsymbol{\alpha}_{\mathbf{b}}=8 \mathrm{~W} /(\mathrm{m} 2 \mathrm{~K})$,

Nxjerrim vlerat (nga Tabelat, shtojcë) për koeficientin e përcjellshmërisë së nxehtësisë, në varshmëri të përbërjes së shtresës së murit, përkatësisht: $\lambda 1=0,87 \mathrm{~W} /(\mathrm{mK}) ; \lambda 2=0,68$ $\mathrm{W} /(\mathrm{mK}) ; \lambda 3=1,28 \mathrm{~W} /(\mathrm{mK})$ dhe $\lambda 4=0,70 \mathrm{~W} /(\mathrm{mK})$

Gjejmë rezistencën termike të shtresës së ajrit 1/A $a=0,16 \mathrm{~m} 2 \mathrm{~K} / \mathrm{W}$.

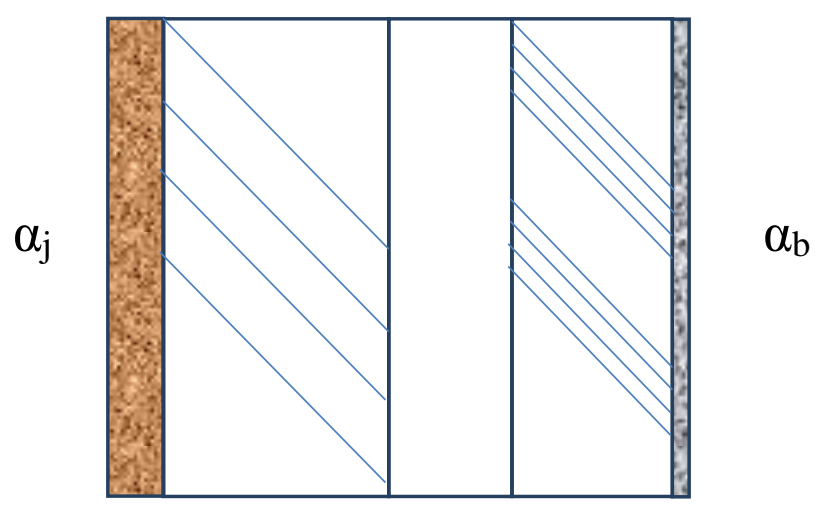

Figura 125. Transmetimi i nxehtësisë për murin e rrafshët shumështresor (Burimi): Bujar Bajçinovci, 2015.

$$
\begin{gathered}
\mathrm{K}=\frac{1}{\frac{1}{\alpha_{b}}+\frac{\delta 1}{\lambda 1}+\frac{\delta 2}{\lambda 2}+\frac{\delta 3}{\lambda 3}+\frac{\delta 4}{\lambda 4}+\frac{\delta 5}{\lambda 5}+\frac{1}{\alpha_{j}}}\left[\mathrm{~W} / \mathrm{m}^{2} \mathrm{~K}\right] \\
\mathrm{k}=\frac{1}{\frac{1}{25}+\frac{0.02}{0.87}+\frac{0.12}{0.68}+0.16+\frac{0.08}{1.28}+\frac{0.01}{0.70}+\frac{1}{8}}=1.66\left[\mathrm{~W} / \mathrm{m}^{2} \mathrm{~K}\right]
\end{gathered}
$$


Sasia e nxehtësisë e nevojshme për ngrohje:

Sasia e nxehtësisë e nevojshme (Q) për ngrohjen e një hapësire përfshin sasinë e nxehtësisë që humbet me transmetim $\left(\mathrm{Q}_{\mathfrak{t}}\right)$ dhe me ventilim $\left(\mathrm{Q}_{\mathbf{v}}\right)$ :

$$
\mathrm{Q}=\mathrm{Q}_{\mathbf{t}}+\mathrm{Q}_{\mathbf{v}}
$$

Nxehtësia me transmetim llogaritet në bazë të humbjeve termike Qo, që paraqitet në hapësirën e caktuar me transmetimin e nxehtësisë nëpër sipërfaqen që e kufizon dhe e ndan hapësirën nga hapësira, e që ka vlerë tjetër të temperaturës.

Llogaritja e humbjeve termike

Humbjet termike llogariten për periudhën (kohën) prej një ore dhe përcaktohen me anë të shprehjeve për transmetimin e nxehtësisë dhe atë për çdo element, apo sipërfaqe të veçantë të murit:

$$
\mathrm{Qe}=\operatorname{kiFi}\left(\mathrm{t}_{\mathbf{b p}}-\mathrm{t}_{\mathbf{j p}}\right)[\mathrm{W}]
$$

Sasia e nxehtësisë që humbet me transmetim nëpër të gjitha muret e një hapësire është:

$$
\mathrm{Qo}=\Sigma \mathrm{Qe}=\Sigma \mathrm{kiFi}\left(\mathrm{t}_{\mathbf{b p}}-\mathrm{t}_{\mathbf{j p}}\right)[\mathrm{W}]
$$

ku janë :

Qe[W] - sasia e nxehtësisë që kalon nëpër ndonjë element-sipërfaqe të murit; Qo[W] - sasia e nxehtësisë që hapësira (lokali) e humb me transmetim nëpër të gjitha sipërfaqet e saj rrethuese (mure, dritare, dysheme, tavan);

$\mathrm{ki}\left[\mathrm{W} / \mathrm{m}^{2} \mathrm{~K}\right]$ - koeficienti i transmetimit të nxehtësisë për ndonjë sipërfaqe "i"; Fi $\left[\mathrm{m}^{2}\right]$ - sipërfaqja (e murit, dritares, derës, dyshemesë, tavanit) nëpër të cilën këmbehet nxehtësia;

$t_{\text {bp }}\left[{ }^{\circ} \mathrm{C}\right]$ - temperatura e brendshme e projektuar;

$\left.\mathrm{t}_{\mathbf{j p}}\left[{ }^{\circ} \mathrm{C}\right]-\mathrm{a}\right)$ temperatura e jashtme e projektuar, nëse sipërfaqja e shqyrtuar e murit e ndan hapësirën nga ambienti i jashtëm ose

-b) temperatura e hapësirës fqinje, nëse sipërfaqja $F$ ndan hapësirën e shqyrtuar me lokalin (hapësirën) fqinjë.

Të kuptuarit teknik e humbjes termike është një kërkesë thelbësore për të projektuar një mbështjellës të mirëfilltë të objektit. Nxehtësia natyrshëm rrjedh nga objektet e ngrohta në objekte të ftohta, nëpërmjet proceset të rrezatimit, rrymimit dhe përçueshmërisë. Rrezatimi i nxehtësisë e merr formën e valëve elektromagnetike që udhëtojnë nëpër hapësirë. E kemi të njohur energjinë rrezatuese nga dielli, dhe ndikimi i saj në jetën tonë, duke bashkëjetuar që nga fëmijëria me diellin, në të njëjtin princip valët elektromagnetike na ngrohin. Një kulm me materiale të errëta në një ditë të nxehtë me diell do të absorbon 70-90 \% të energjisë së diellit dhe do ta ri rrezatojë ndërtesën. 
Pa ventilim adekuat në kulm apo ndërkulm dhe pa izolim termik kostos së ngrohjes mund të shtohet $40 \%$ të ngarkesës për ftohje nga kondicionimi. Në mot të ftohtë, në një hapësirë të izoluar dobët ose pranë një dritareje humbjet termike janë të konsiderueshme.

Konsumi i energjisë në shtëpitë e pa izoluara, apo të izoluara dobët do të jetë shumë më i lartë, sesa në ato të izoluara, kurse komoditeti do të jetë më e ulët, ku shumica e dhomave do të jenë të pa ngrohura. Për më tepër, mungesa e suvatimit përfundimtar, lë pjesët e shtëpisë pa ndonjë mbrojtje nga kushtet atmosferike që rezulton me dëmtimin dhe uljen e vlerës së shtëpisë.

Kursimi i energjisë, pa dyshim, varet nga mënyra e ngrohjes së shtëpisë nga shfrytëzuesi i saj, kur ajo nuk është e izoluar, si dhe nga kostoja e energjisë së shfrytëzuar për ngrohje. Nëse të gjitha dhomat do të ngroheshin normalisht me energji elektrike, kursimet do të arrinin 1000 euro në vit për një shtëpi të zakonshme. Kursimet aktualisht do të jenë dukshëm më të vogla, rreth 200 deri në 400 Euro, sepse shtëpitë nuk ngrohen aq sa duhet.

Disa fabrika në Kosovë prodhojnë materiale termoizoluese, gjë që e bën më të ulët koston e izolimit termik të ndërtesave. Burimet të ndryshme paraqesin shifra të ndryshme sa i përket kostos së izolimit termik të fasadave, varësisht nga origjina dhe cilësia e materialeve, si dhe nga kryesi i punëve. Kjo çështje duhet qartësuar përmes një studimi profesional. Paraprakisht konsiderohet se për një shtëpi tipike dykatëshe (10 m x $10 \mathrm{~m})$, kostoja është 3500-5000 € për izolim fasade. Duke pasur parasysh që pronarët dëshirojnë të përfundojnë shtëpitë e tyre sa më shpejt që është e mundshme, si dhe faktin se secili vit i kaluar pa izolim të ndërtesës paraqet humbje energjie dhe dëmtim të shtëpisë, atëherë është e pritshme që grantet subvencionuese do të ishin më së të mirëseardhura. Fillimisht, për shumicën e pronarëve, një kredi e butë duke përfshirë një grant prej $25 \%$ do të dukej mjaft atraktive.

Duhet shfrytëzuar mundësinë për të krijuar lidhje me një skemë ekzistuese të kredive, si do të ishte skema e Programit të Kredive të Banimit. Ky program bazohet në një fond të mbështetur nga AER-i, i cili jep kredi për riparimin dhe rinovimin e shtëpive: ato jepen përmes bankës përkatëse.

Përfitimet nga lidhja me një program të tillë do të ishin të konsiderueshme, me një strukturë menaxhimi ekzistuese dhe me procedura të përshtatshme për:

1. Vërtetimin e të drejtave pronësore mbi shtëpinë për aplikuesin,

2. Menaxhimin e rrezikut me afate të shkurtra, apo shfrytëzimin e hipotekës,

3. Monitorimin që fondi të përdoret në përputhje me synimet,

4. Kontaktet me kërkuesit e kredive për shpërndarjen e informatave mbi grantin.

Programi i Kosovës për Efiçiencë të Energjisë dhe Burime të Ripërtëritshme të Energjisë për periudhën 2007-2009, Ministria e Energjisë dhe Minierave. Synimet për përmirësimin dhe izolimin e njësive ekzistuese për të përmirësuar efiçiencën e ngrohjes së hapësirës në ndërtesat ekzistuese banesore. ${ }^{86}$

86 Programi i Kosovës për Efiçiencë të Energjisë dhe Burime të Ripërtëritshme të Energjisë për periudhën 2007-2009. 


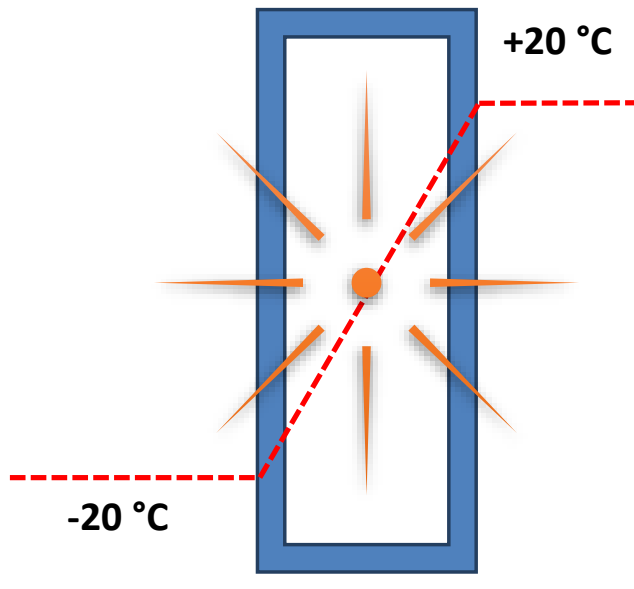

Figura 126. Transmetimi i nxehtësisë për murin e rrafshët, dilatimet temperaturale (Burimi): Bujar Bajçinovci, 2015.

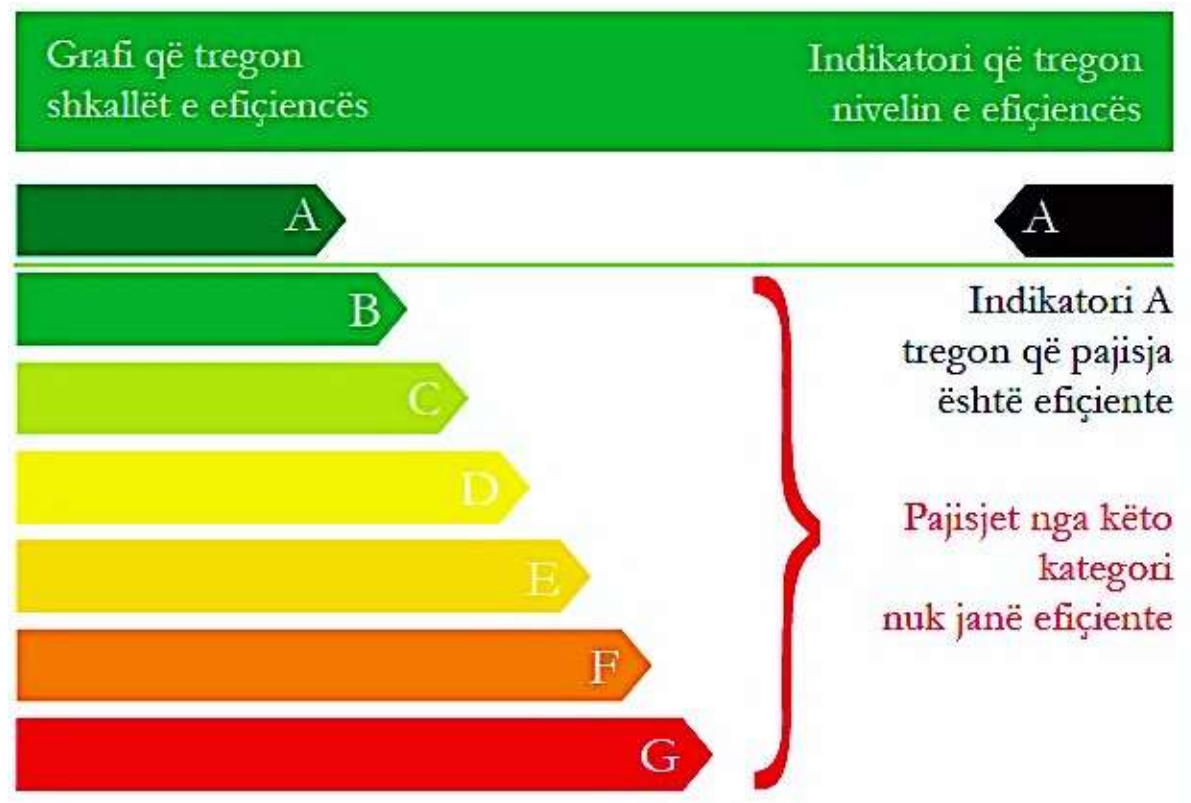

Ekzistojnë pajisje të cilat janë edhe më efiçiente se kategoria A. Ato janë: $\mathrm{A}+, \mathrm{A}++, \mathrm{A}+++$. Sa më shumë plusa (+) aq më efiçiente është pajisja.

Figura 127. Procesi NVM në Kosovë në pajtim me ligjin nr. 03/L-214 për NVM (Burimi): INDEP, Efiçienca e Energjisë Bizneset, 2015. 


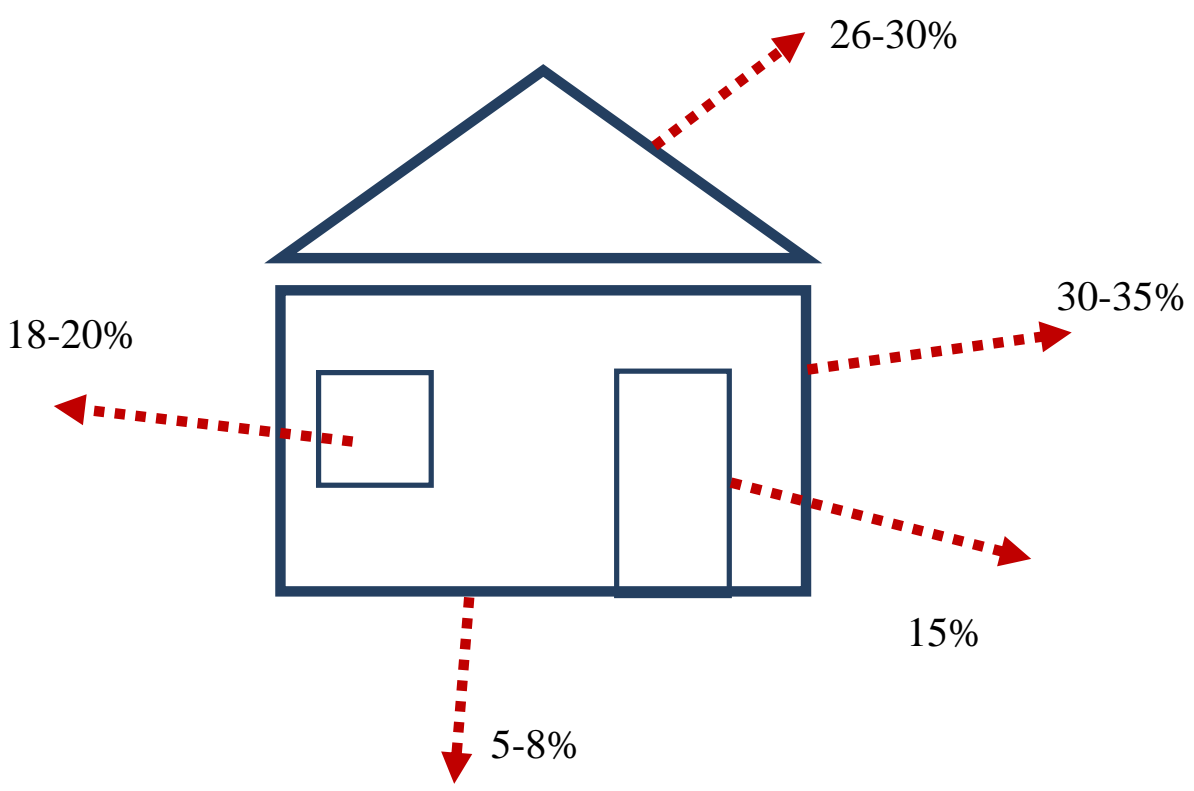

Figura 128. Humbjet termike në objekte, vlera të përafërta (Burimi): Bujar Bajçinovci, 2015.

"Në Kosovë, 70\% të objekteve janë të pa izoluara. Mungesa e termoizolimit, dritareve, dyerve, mureve apo çatisë bënë që 50\% të energjisë të humbet, posaçërisht gjatë ngrohjes dhe ftohjes, që rezulton edhe në ngritjen e çmimeve të faturave të energjisë elektrike. Duke e marrë parasysh që $40 \%$ e shfrytëzimit total të energjisë shkon vetëm për ngrohje apo ftohje, tregon se sa e nevojshme është investimi për izolim. Investimi në izolim është mënyra më direkte dhe efektive për të kursyer të financat që shkojnë për pagesë të energjisë elektrike.

Përmes përdorimit të materialeve izoluese në mure, çati/tarracë apo në dysheme të shtëpisë sigurohet një kontroll më i mirë i nxehtësisë në dimër dhe freskisë në verë. Rjedhimisht humbjet janë 26\% nga çatia, $15 \%$ nga dyert dhe ventilimi, $18 \%$ nga dritaret me një xhamë, $33 \%$ nga muret." 87

Izolimi termik i ndërtesave është një nga mënyrat më efikase për të siguruar efiçencën e energjisë. Instalimit të dritareve efiçiente me dy apo me tre xhama të cilët bëjnë të mundur të reduktohet shfrytëzimi i energjisë dhe të kursejmë nga 12-25\%. Vendosja e dyerve hermetike dhe efiçiente rezultojnë në kursim nga 4-12\% të shfrytëzimit total të energjisë. Vendosja e izolimit termik në fasadë dhe muret e jashtme bënë që të kursejmë për ngrohje dhe ftohje nga $25-35 \%$ të shfrytëzimit total të energjisë.

Vendosja e izolimit termik $6 \mathrm{~cm}$ në dysheme, bënë që të kursehet energji deri në $5 \%$. Vendosja e $6 \mathrm{~cm}$ të izolimit termik në çati/tarracë me materiale të ndryshme si polisterol i thjeshtë, polistrol me densititet të lartë, lesh xhami, lesh guri, si rezultat i kësaj reduktohet humbja e nxehtësisë dhe freskisë, e cila bënë që të kursehet prej 17-22\%.

87 INDEP, Efiçienca e Energjisë Bizneset, 2015. 


\section{Nevoja për energji \\ Emisionot $-\mathrm{CO}_{2}{ }^{1)} 51,9 \quad\left[\mathrm{~kg} /\left(\mathrm{m}^{2} \cdot \mathrm{a}\right)\right]$ \\ Nevoja për energjinè $\mathrm{e}$ fundit \\ $228,4 \mathrm{kWh} /\left(\mathrm{m}^{2}-\mathrm{a}\right)$

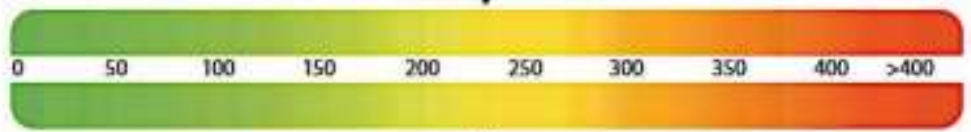 \\ $227,5 \mathrm{kWh} /\left(\mathrm{m}^{3} \cdot\right.$ a) \\ Nevoja për energii primare "eficienca e energjisè totale"}

\section{Prova e përputhjes me $\S 3$ ose $\S 9$ paragrafi 1 EnEV ${ }^{2)}$}

Nevoia per energi primare

Vlera aktuale e nderteses

$227.5 \mathrm{kWh} /\left(\mathrm{m}^{2} \cdot \mathrm{al}\right)$

Cillesia energitike e mbeshtfielligs se nderrtoses

Vlera e kerkuar EnEV

$113.4 \mathrm{kWh} /\left(\mathrm{m}^{2} \cdot \mathrm{al}\right)$

Vera aktuale e ndêrtesies $\mathrm{H}_{T}$

1,30

Vlera s kerkuar EnEV H:

0,65

$W / m^{2}-K$

$\mathrm{W} / \mathrm{m}^{2}-\mathrm{Kg}$

\section{Nevoja për energjinë e fundit}

\begin{tabular}{|c|c|c|c|c|}
\hline \multirow[b]{2}{*}{ Burimi energiliste } & \multicolumn{3}{|c|}{ Nevojat vjetore pề energij $\mathrm{kWh} /\left(\mathrm{m}^{\mathrm{l}}\right.$-a) për } & \multirow[b]{2}{*}{ Total nê kWh/(m²-a) } \\
\hline & Ngrohtesi & Ulingrohtes & Aparatura ndihmesse" & \\
\hline Gaz natyror $\mathrm{H}$ & 151,2 & 16,6 & & 142,9 \\
\hline Energij elektrike & 0,0 & 0,0 & 12,3 & 12,3 \\
\hline Ristela druri & 40,1 & 8,2 & & 68,3 \\
\hline
\end{tabular}

Figura 129. Procesi NVM në Kosovë në pajtim me ligjin nr. 03/L-214 për NVM (Burimi): Termoizolim dhe modernizim me @ Knauf, broshurë, 09/2014.

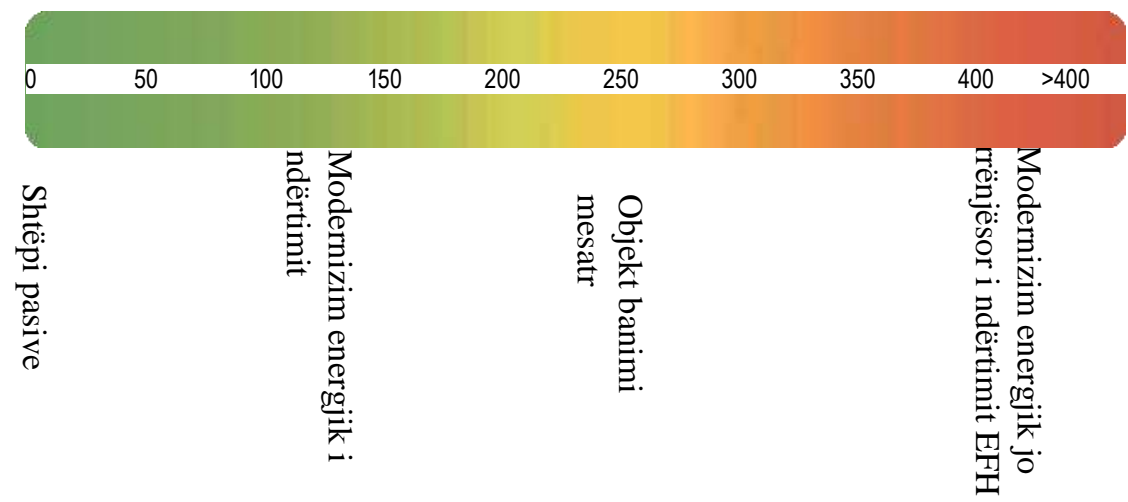

Figura 130. Procesi NVM në Kosovë në pajtim me ligjin nr. 03/L-214 për NVM (Burimi): Termoizolim dhe modernizim me @Knauf, broshurë, 09/2014. 
Vlerat më të larta të nevojës vjetore të energjisë primare, duke u referuar sipërfaqes së shfrytëzueshme dhe e humbjeve specifike të transmetimit të nxehtësisë në relacion mes sipërfaqes rrethuese ku transmetohet nxehtësia, në varësi të raportit $\mathrm{A} / \mathrm{Ve}$

Tabela 15. (c) Knauff, raporti A/Ve

(Burimi): Termoizolim dhe modernizim me () Knauf, broshurë, 09/2014.

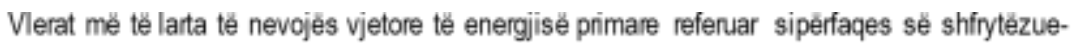
shme dhe e humbjeve specifike e transmetimit tê nxehtësisê referuar sipērfaqes methuese ku transmetohet nxehtésia nẻ varësi të raportit $\mathrm{A} / \mathrm{V}$ 。

\begin{tabular}{|c|c|c|}
\hline $\begin{array}{l}\text { Raporti } \\
\mathrm{A} / \mathrm{V}_{\mathrm{e}}\end{array}$ & 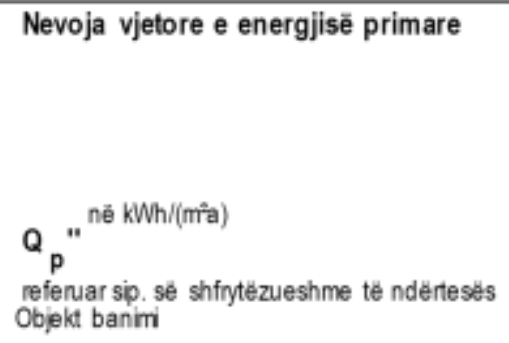 & 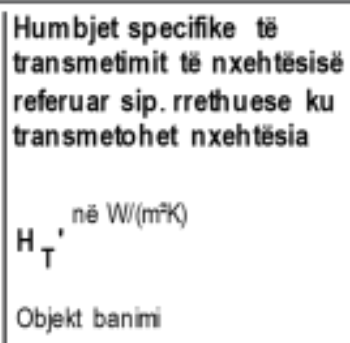 \\
\hline$\leq 0,2$ & $66,00+2,600 /\left(100+A_{N}\right)$ & 1,05 \\
\hline 0,3 & $73,53+2.600 /\left(100+A_{N}\right)$ & 0,80 \\
\hline 0,4 & $81,06+2.600 /\left(100+A_{N}\right)$ & 0,68 \\
\hline 0,5 & $88,58+2.600 /\left(100+A_{N}\right)$ & 0,60 \\
\hline 0,6 & $96,11+2.600 /\left(100+A_{N}\right)$ & 0,55 \\
\hline 0,7 & $103,64+2.600 /\left(100+A_{N}\right)$ & 0,51 \\
\hline 0,8 & $111,17+2.600 /\left(100+A_{N}\right)$ & 0,49 \\
\hline 0,9 & $118,70+2.600 /\left(100+A_{N}\right)$ & 0,47 \\
\hline 1,0 & $126,23+2.600 /\left(100+A_{N}\right)$ & 0,45 \\
\hline 1,05 & $130,00+2.600 /\left(100+A_{N}\right)$ & 0,44 \\
\hline
\end{tabular}

Shembull llogaritje: kufizimi i nevojës për energji primare sipas EnEV ${ }^{88}$ Të dhënat ekzistuese:

Sipërfaqe mbështjellëse e ambienteve që ngrohen: $A=800 \mathrm{~m}^{2}$ Vëllimi bruto i ambienteve që ngrohen: $V_{\mathrm{e}}=2000 \mathrm{~m}^{3}$

Formulë e dhënë sipas EnEV:

$\mathrm{A}_{\mathrm{N}}=0,32 \times \mathrm{V}_{\mathrm{e}}=0,32 \times 2000=\mathbf{6 4 0} \mathrm{m}^{2}$

Sipërfaqe e shfrytëzueshme

Të dhëna të marra nga përllogaritja inxhinierike e mëparshme e nevojës për energji Humbjet ekzistuese të transmetimit të nxehtësisë

$\mathbf{H}_{\text {T,ekzis }}=\mathbf{0 , 6 0} \mathrm{W} /\left(\mathrm{m}^{2} \mathrm{~K}\right)$

Nevoja për energji primare në vit:

88 Termoizolim dhe modernizim me Knauf, 09/2014. 
QP,ekzis $=80 \mathrm{kWh} /\left(\mathrm{m}^{2} \mathrm{a}\right)$

Kërkesa sipas EnEV

Llogaritja e QP max dhe $\mathrm{H}_{\mathrm{T} \max }$

Vlerat më të larta sipas EnEV, tabela 14.

Raporti A/Ve në m1 : $800 / 2000=\mathbf{0 , 4}$

Humbja specifike e lejuar, duke referuar sipërfaqen gjatë transmetimit të nxehtësisë në $\mathrm{W} /\left(\mathrm{m}^{2} \mathrm{~K}\right): \mathrm{H}_{\mathrm{T} \max }=0,68$

Kërkesa e lejuar e energjisë primare në vit $\mathrm{kWh} /\left(\mathrm{m}^{2} \mathrm{a}\right):$

$\mathrm{Q}_{\mathrm{P} \max }=81,06+2600 / 100+640=\mathbf{8 4 . 5 7}$

\section{Rezultatet:}

$\mathrm{H}_{\text {Tekzis }}=\mathbf{0 , 6 0} \mathbf{W} /\left(\mathbf{m}^{2} \mathbf{K}\right) \leq \mathbf{0 , 6 8}=\mathrm{H}_{\mathrm{T} \max }$ në $\mathrm{W} /\left(\mathrm{m}^{2} \mathrm{~K}\right)$

$\mathrm{Q}_{\text {Pekzis }}=\mathbf{8 0} \leq \mathbf{8 4 , 5 7}=\mathrm{Q}_{\text {Pmax }} \mathrm{në} \mathrm{W} /\left(\mathrm{m}^{2} \mathrm{~K}\right)$

Kërkesat sipas EnEV janë plotësuar

Kjo ndërtesë ka nevojë për 8 litra naftë për $\mathrm{m}^{2}$ „Shtëpi 8 Litërshe“"

Paraqitja e përcjellshmërisë dhe transmetimit termik nëpërmjet procesit të transmetimit të temperaturës në një element konstruktiv. Përcjellshmëria termike e shtresave të elementit konstruktiv

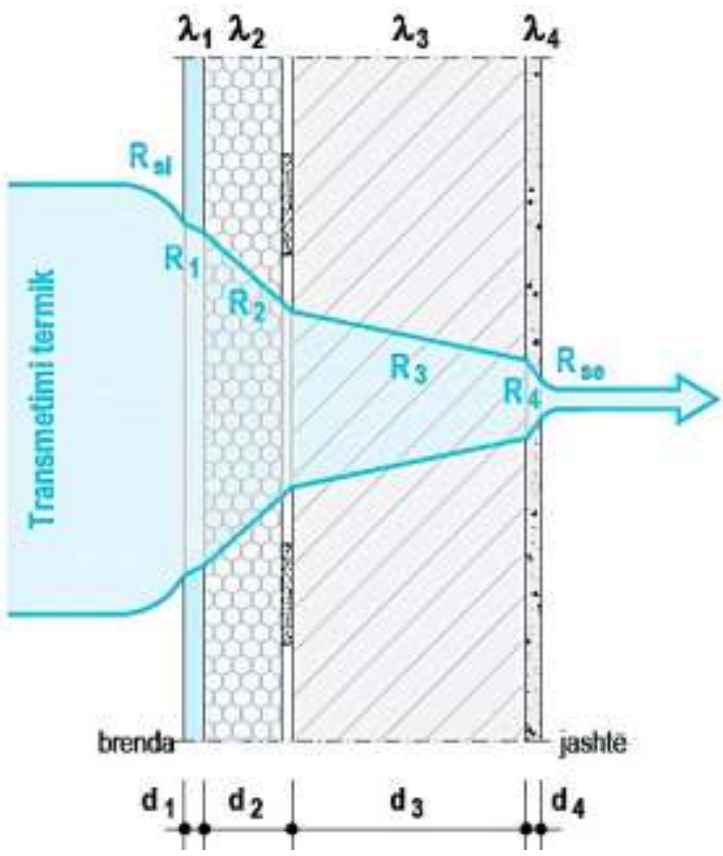

R1, R2, R3, R4 = Rezistenca termike e shtresave të elementit konstruktiv (d / $\lambda$ )

$\mathrm{R}$ si $=$ Rezistenca termike e brendshme

$\mathrm{R}$ se $=$ Rezistenca termike jashtme

Figura 131. Muri me shtresë termike

(Burimi): Termoizolim dhe modernizim. (C) Knauf, Kosovë. 09/2014. 

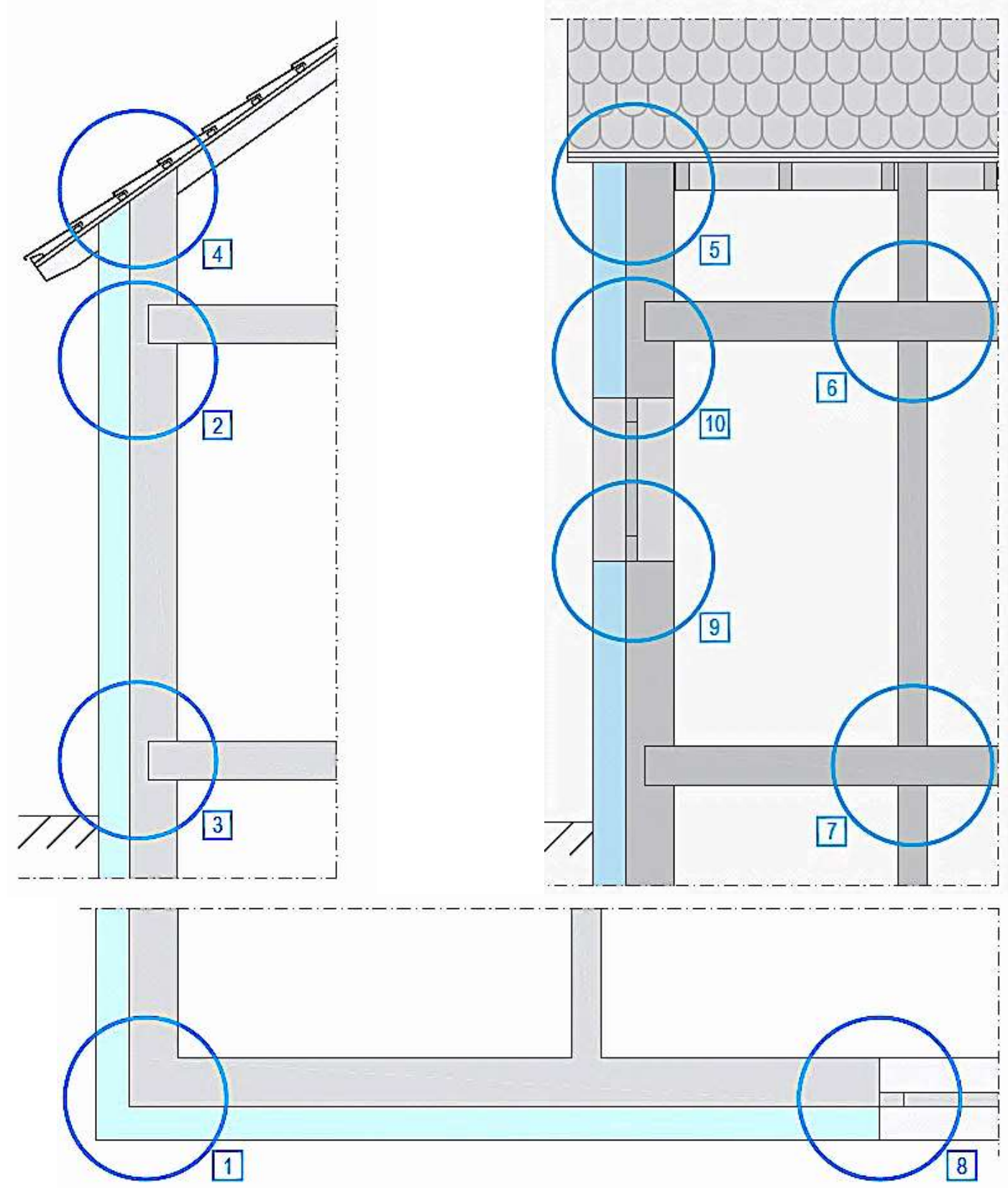

1. Soletë

2. Bashkim i soletës së katit

3. Bashkim me soletën e bodrumit, cokla

4. Bashkimi i çatisë

5. Bashkimi i çatisë

6. Bashkim i murit ndarës- soleta e katit të sipërm

7. Bashkim me murin ndarës- tavani i bodrumit

8. Bashkimi me dritaren- Shpatullimet

9. Bashkimi me dritaren- Parvazi

10. Bashkimi me dritaren

Figura 132. Mbështjellja me shtresë termike

(Burimi): Termoizolim dhe modernizim. (OKnauf, 09/2014. 


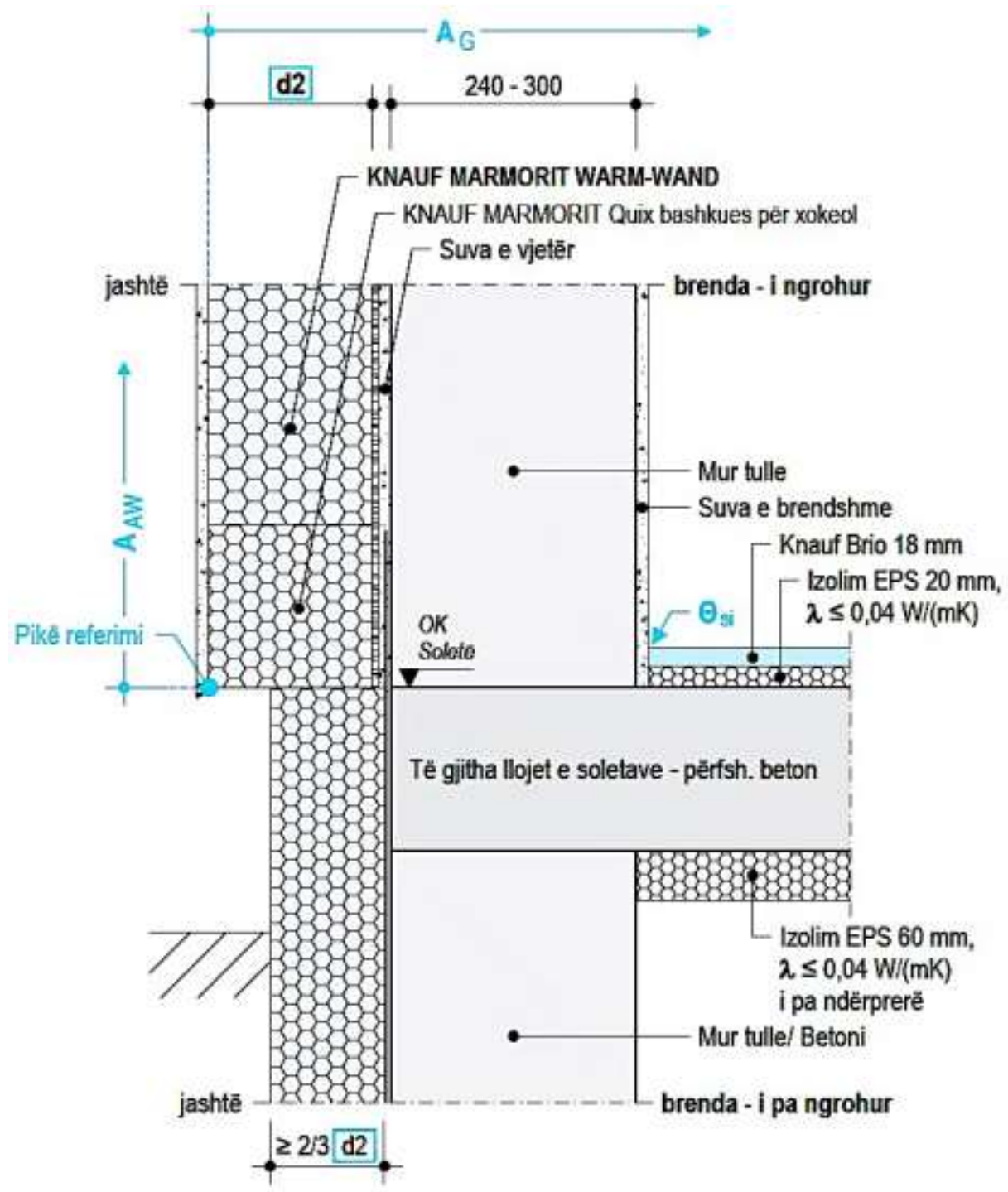

Figura 133. Hollësirë nga praktika profesionale

(Burimi): Termoizolim dhe modernizim. @Knauf, 09/2014.

Një projektues ka disa faza për t'i kaluar në marrjen e vendimeve të duhura për materialet izoluese. Natyrisht, duke zgjedhur një plafon me mure të larta dhe sipërfaqe të mëdha do të kërkojë sasi të mëdha të materialeve izoluese, të cila paraqesin kosto më të lartë. Pasi projektuesi ka identifikuar vendndodhjen e zonave në një ndërtesë që kërkojnë izolim të mirëfilltë, duhet përcaktuar se çfarë vlere të nevojshme $\boldsymbol{k}$ do të jetë, pastaj është faza për të vendosur se çfarë lloji të izolimit duhet përdorur.

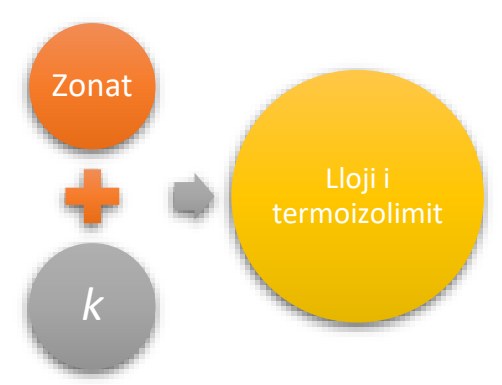

Figura 134. Procesi i vendimmarrjes, lloji i termoizolimit (Burimi): Bujar Bajçinovci, 2015. 
Tabela 15. Vlerat e projektuara të përcjellshmërisë termike, $\lambda\left[\mathrm{W} /\left(\mathrm{m}^{2} \mathrm{~K}\right)\right]$, dhe vlerat e përafërta të faktorit të rezistencës së difuzioni i avullit te ujit, $\mu$ (Burimi): Kodi Unik i Ndërtimit i Republikës së Kosovë, Kapitulli II - Kursimi i Energjisë Termike dhe Mbrojtja Termike, i pa edituar. MMPH. 2015.

\begin{tabular}{|c|c|c|c|c|c|}
\hline $\begin{array}{l}\mathrm{Nr} . \\
\text { rend }\end{array}$ & Materialet ndërtimore & $\begin{array}{c}\text { Dend- } \\
\text { ësia } \\
\rho \\
\mathrm{kg} / \mathrm{m} 3\end{array}$ & $\begin{array}{c}\text { Koeficienti i } \\
\text { përcjellshmë } \\
\text { risë termike } \\
\lambda \\
\mathrm{W} /(\mathrm{m} \cdot \mathrm{K})\end{array}$ & $\begin{array}{l}\text { Kapaciteti } \\
\text { specifik } \\
\text { termik } \\
\mathrm{c}_{\mathrm{p}} \\
\mathrm{J} /(\mathrm{kg} \cdot \mathrm{K})\end{array}$ & $\begin{array}{c}\text { Faktori i } \\
\text { rezistencës } \\
\text { së difuzionit } \\
\text { te avullit te } \\
\text { ujit } \mu\end{array}$ \\
\hline 1 & \multicolumn{5}{|c|}{ MURET, duke përfshirë llaçrat korniza } \\
\hline 2 & Tullat e plota nga argjila & 1800 & 0,81 & 900 & $5 / 10$ \\
\hline 3 & Tullat e plota nga argjila & 1600 & 0,68 & 900 & $5 / 10$ \\
\hline 4 & Tullat e klinkerit & 1900 & 0,85 & 800 & $50 / 100$ \\
\hline 5 & Tullat e klinkerit & 1700 & 0,80 & 800 & $50 / 100$ \\
\hline 6 & $\begin{array}{l}\text { Tullat e plota nga argjila për } \\
\text { fasadë }\end{array}$ & 1800 & 0,83 & 900 & $5 / 10$ \\
\hline 7 & $\begin{array}{l}\text { Tullat e plota nga argjila për } \\
\text { fasadë }\end{array}$ & 1600 & 0,70 & 900 & $5 / 10$ \\
\hline 8 & $\begin{array}{l}\text { Tullat e vrimëzuara nga } \\
\text { argjila për fasadë }\end{array}$ & 1200 & 0,55 & 900 & $5 / 10$ \\
\hline 9 & Blloqet poroze nga argjila & 1100 & 0,48 & 900 & $5 / 10$ \\
\hline 10 & Blloqet poroze nga argjila & 900 & 0,42 & 900 & $5 / 10$ \\
\hline 11 & Tulla e plotë silik. gëlqerore & 1800 & 0,99 & 900 & $15 / 25$ \\
\hline 12 & Tulla e plotë silik. gëlqerore & 1600 & 0,79 & 900 & $15 / 25$ \\
\hline 13 & \begin{tabular}{|l}
$\begin{array}{l}\text { Blloqet poroze silikate } \\
\text { gëlqerore }\end{array}$ \\
\end{tabular} & 1200 & 0,56 & 900 & $15 / 25$ \\
\hline 14 & Guri natyror & 2000 & 1,40 & 1000 & 50 \\
\hline 15 & Blloqet poroze nga betoni & 1000 & 0,70 & 1000 & $5 / 15$ \\
\hline 16 & Blloqet poroze nga betoni & 1600 & 1,10 & 1000 & $20 / 30$ \\
\hline 17 & Blloqet poroze të betonit & 2000 & 1,40 & 1000 & $20 / 30$ \\
\hline 18 & $\begin{array}{l}\text { Blloqet poroze nga betoni i } \\
\text { lehtë }\end{array}$ & 500 & 0,30 & 1000 & $5 / 10$ \\
\hline 19 & $\begin{array}{l}\text { Blloqet poroze nga betoni i } \\
\text { lehtë }\end{array}$ & 700 & 0,37 & 1000 & $5 / 10$ \\
\hline 20 & $\begin{array}{l}\text { Blloqet poroze nga betoni i } \\
\text { lehtë }\end{array}$ & 900 & 0,46 & 1000 & $5 / 10$ \\
\hline
\end{tabular}


Tabela 16. Vlerat e projektuara të përcjellshmërisë termike, $\lambda\left[\mathrm{W} /\left(\mathrm{m}^{2} \mathrm{~K}\right)\right]$, dhe vlerat e përafërta të faktorit të rezistencës së difuzioni i avullit te ujit, $\mu$ (Burimi): Kodi Unik i Ndërtimit i Republikës së Kosovë, Kapitulli II - Kursimi i Energjisë Termike dhe Mbrojtja Termike, i pa edituar. MMPH. 2015.

\begin{tabular}{|c|l|l|l|l|l|}
\hline & \multicolumn{6}{|l|}{ DYSHEMETË, MURET DHE TAVANET E MVESHURA } \\
\hline 1 & Pllakat nga gjips kartoni & 900 & 0,25 & 900 & 8 \\
\hline 2 & $\begin{array}{l}\text { Pllakat nga gjipsi me shtesë të } \\
\text { fijeve celuloze }\end{array}$ & 1300 & 0,38 & 1000 & $10 / 15$ \\
\hline 3 & Pllakat qeramike & 2300 & 1,30 & 840 & 200 \\
\hline 4 & Pllakat e gurit & 2500 & 2,80 & 1000 & $40 / 200$ \\
\hline 5 & Druri & 550 & 0,15 & 2000 & $50 / 70$ \\
\hline
\end{tabular}

Tabela 17. Vlerat e projektuara të përcjellshmërisë termike, $\lambda\left[\mathrm{W} /\left(\mathrm{m}^{2} \mathrm{~K}\right)\right]$, dhe vlerat e përafërta të faktorit të rezistencës së difuzioni i avullit te ujit, $\mu$ (Burimi): Kodi Unik i Ndërtimit i Republikës së Kosovë, Kapitulli II - Kursimi i Energjisë Termike dhe Mbrojtja Termike, i pa edituar. MMPH. 2015.

\begin{tabular}{|c|c|c|c|c|c|}
\hline & MATERIALET TERMOIZOI & LUESE & & & \\
\hline 1 & $\begin{array}{l}\text { Leshi mineral (LM) sipas } \\
\text { SK EN } 13162\end{array}$ & $\begin{array}{ll}10 & \text { deri } \\
200 & \\
\end{array}$ & $\begin{array}{ll}0,035 & \text { deri } \\
0,050 & \end{array}$ & 1030 & 1 \\
\hline 2 & $\begin{array}{l}\text { Polistiren i ekspanduar sipas } \\
\text { (PES) SK EN } 13163\end{array}$ & 15 deri 30 & $\begin{array}{ll}0,035 & \text { deri } \\
0,040 & \end{array}$ & 1450 & 60 \\
\hline 3 & $\begin{array}{|lrr|}\text { Shkuma e e rstruduar } & \text { e } \\
\text { polistirenit } & \text { (XPS) sipas } & \text { SK } \\
\text { EN 13164 } & & \end{array}$ & $\geq 25$ & \begin{tabular}{ll|}
0,030 & deri \\
0,040 &
\end{tabular} & 1450 & 150 \\
\hline 4 & $\begin{array}{l}\text { Shkumë e fortë poliuretani } \\
\text { (SHFP) sipas SK EN } 13165\end{array}$ & $\geq 30$ & $\begin{array}{ll}0,020 & \text { deri } \\
0,040 & \end{array}$ & 1400 & 60 \\
\hline 5 & $\begin{array}{l}\text { Shkumë fenoli (SHF) sipas SK } \\
\text { EN } 13166\end{array}$ & $\geq 30$ & $\begin{array}{ll}0,030 & \text { deri } \\
0,045 & \end{array}$ & 1400 & 50 \\
\hline 6 & $\begin{array}{l}\text { Xhami celular (shkumor) } \\
(\mathrm{ZHC}) \text { sipas SK EN } 13167\end{array}$ & $\begin{array}{ll}100 & \text { deri } \\
150 & \end{array}$ & $\begin{array}{ll}0,045 & \text { deri } \\
0,060 & \end{array}$ & 1000 & $\infty$ \\
\hline 7 & $\begin{array}{l}\text { leshi i drurit (LD) sipas SK EN } \\
13168\end{array}$ & $\begin{array}{ll}360 & \text { deri } \\
460 & \\
\end{array}$ & \begin{tabular}{ll|}
0,065 & deri \\
0,09 & \\
\end{tabular} & 1470 & $3 / 5$ \\
\hline & $\begin{array}{l}\text { Leshi i drurit (LD) sipas SK } \\
\text { EN } 13168 \text { trashësia e pllakës } \\
15 \mathrm{~mm} \leq \mathrm{d} \leq 25 \mathrm{~mm}\end{array}$ & 550 & 0,150 & 1470 & $4 / 8$ \\
\hline 8 & $\begin{array}{l}\text { Perliti i ekspanduar (PRE) } \\
\text { sipas SK EN } 13169\end{array}$ & $\begin{array}{ll}140 & \text { deri } \\
240 & \\
\end{array}$ & $\begin{array}{|ll|}0,040 & \text { deri } \\
0,065 & \\
\end{array}$ & 900 & 5 \\
\hline 9 & $\begin{array}{l}\text { Tapë e ekspanduar (TE) sipas } \\
\text { SK EN } 13170\end{array}$ & \begin{tabular}{|lr}
80 & deri \\
500 & \\
\end{tabular} & $\begin{array}{|ll|}0,045 & \text { deri } \\
0,055 & \\
\end{array}$ & 1560 & $5 / 10$ \\
\hline 10 & $\begin{array}{l}\text { Fibrat e drurit sipas (FD) SK } \\
\text { EN } 13171\end{array}$ & $\begin{array}{ll}110 & \text { deri } \\
450 & \end{array}$ & $\begin{array}{l}0,035 \\
0,070\end{array}$ & 1400 & $5 / 10$ \\
\hline
\end{tabular}


Tabela 18. Vlerat më të larta të lejuara të koeficienteve të transmetimit të nxehtësisë, $U\left[\mathrm{~W} /\left(\mathrm{m}^{2} \mathrm{~K}\right)\right]$, e pjesëve të ndërtesave të vëllimit të vogël $\left(\mathrm{V} \leq 100 \mathrm{~m}^{3}\right)$, të shtëpive familjare, si dhe pas ndërhyrjeve në ndërtesat ekzistuese.

(Burimi): Kodi Unik i Ndërtimit i Republikës së Kosovë, Kapitulli II - Kursimi i Energjisë Termike dhe Mbrojtja Termike, i pa edituar. MMPH. 2015.

\begin{tabular}{|c|c|c|c|c|c|}
\hline \multirow{3}{*}{$\begin{array}{l}\text { Nr. } \\
\text { Rend }\end{array}$} & \multirow{3}{*}{ Pjesët e ndërtesës } & \multicolumn{4}{|l|}{$U\left[\mathrm{~W} /\left(\mathrm{m}^{2} \mathrm{~K}\right)\right]$} \\
\hline & & $\Theta_{\mathrm{i}} \geq 18^{\circ} \mathrm{C}$ & \multicolumn{3}{|c|}{$12^{\circ} \mathrm{C}<\Theta_{\mathrm{i}}<18^{\circ} \mathrm{C}$} \\
\hline & & $\begin{array}{l}\Theta_{\mathrm{e}, \mathrm{mj}, \min }>3 \\
{ }^{\circ} \mathrm{C}\end{array}$ & $\begin{array}{l}\Theta_{\mathrm{e}, \mathrm{mj}, \mathrm{min}} \leq 3 \\
{ }^{\circ} \mathrm{C}\end{array}$ & $\begin{array}{l}\Theta_{\mathrm{e}, \mathrm{mj}, \min }>3 \\
{ }^{\circ} \mathrm{C}\end{array}$ & $\begin{array}{l}\Theta_{\mathrm{e}, \mathrm{mj}, \min } \leq 3 \\
{ }^{\circ} \mathrm{C}\end{array}$ \\
\hline 1 & $\begin{array}{l}\text { Muret e jashtme, muret kah } \\
\text { garazhi, tavani }\end{array}$ & 0,60 & 0,45 & 0,75 & 0,75 \\
\hline 2 & $\begin{array}{l}\text { Dritaret, dyert e ballkonit, } \\
\text { dritaret e kulmeve, } \\
\text { elemente transparente në } \\
\text { anën e ballinës }\end{array}$ & 1,80 & 1,80 & 3,00 & 3,00 \\
\hline 3 & $\begin{array}{l}\text { Kulmet e rrafshëta dhe te } \\
\text { pjerrëta mbi hapësirën e } \\
\text { ngrohur, plafoni kah tavani }\end{array}$ & 0,40 & 0,30 & 0,50 & 0,40 \\
\hline 4 & $\begin{array}{l}\text { Plafoni mbi ajrin e } \\
\text { jashtëm, plafoni mbi } \\
\text { garazhi }\end{array}$ & 0,40 & 0,30 & 0,50 & 0,40 \\
\hline 5 & $\begin{array}{l}\text { Muret dhe plafonët kah } \\
\text { kthinat e pa ngrohura dhe te } \\
\text { shkalleve të pa ngrohura } \\
\text { me temperaturë me te lartë } \\
\text { se } 0^{\circ} \mathrm{C}\end{array}$ & 0,65 & 0,50 & 2,00 & 2,00 \\
\hline 6 & $\begin{array}{l}\text { Muret kah toka, dyshemetë } \\
\text { mbi tokë }\end{array}$ & 0,50 & 0,50 & $0,80^{1)}$ & $0,65^{1)}$ \\
\hline 7 & $\begin{array}{l}\text { Dyert e jashtme me krahun } \\
\text { jotransparent }\end{array}$ & 2,90 & 2,90 & 2,90 & 2,90 \\
\hline 8 & Muret e kutisë për roleta & 0,80 & 0,80 & 0,80 & 0,80 \\
\hline
\end{tabular}

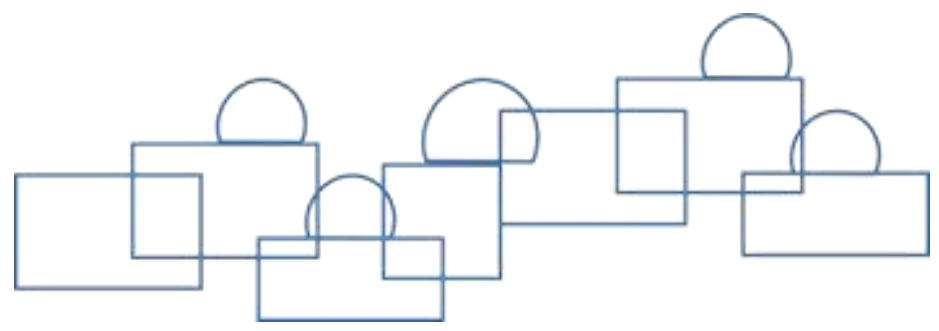




\subsection{Principet pasive të projektimi të qëndrueshëm}

Sistemet e përdorura në procesin e projektimit ndahen në dy kategori kryesore: pasive dhe aktive. Teknologjitë pasive janë të qëndrueshme dhe përfitojnë nga rrjedhat natyrore të energjisë, nuk shpenzojnë shumë nëse ka ndonjë kërkesë për energji nga lëndët djegëse fosile. Teknologjitë pasive duhet të mbizotërojnë mbi ato aktive, të cilat kërkojnë përdorimin e lëndëve djegëse për funksionim. Për sistemet efektive pasive dhe aktive, projektuesi ka nevojë për një kuptim të plotë të termoteknikës, transferimin e nxehtësisë dhe klimës.

Te veçojmë së pari si funksion trupi i njeriut!

Çfarë është saktësisht metabolizmi?! Ta themi thjesht, Metabolizmi është proces me të cilin kaloritë e fituara nga ushqimi, në trupin tonë konvertohen në energji apo "lëndë djegëse". Metabolizmin përbëhet nga anabolizmi dhe katabolizmi. Anabolizmi është një proces në të cilin energjia përdoret për ndërtimin e qelizave të reja dhe indet, dhe katabolizmi paraqet ruajtjen e energjisë (në formën e yndyrës) në trup për të siguruar funksionimin e duhur e të gjithë organizmit.

Metabolizmi, te njeriu ndryshon shumë prej individit në individ, ndërsa në të njëjtin individ ndryshon varësisht prej kushteve dhe rrethanave të mjedisit. Shpejtësia e metabolizmit rritet gjatë stresit, kur temperatura e trupit rritet, po ashtu temperatura rritet edhe gjatë kohës së ushtrimeve. Prandaj koha më e përshtatshme e matjes së shpejtësisë të metabolizmit është kur individi pushon dhe kur ka temperaturë trupore normale. Kjo quhet shpejtësia bazale e metabolizmit dhe shprehet në kalori ose kiloxhula $(\mathrm{kJ})$ për metër katror të sipërfaqes trupore/ në orë...

Njerëzit që kanë shpejtësi të madhe bazale të metabolizmit mund të hanë sasi të madhe të ushqimit dhe të mos e shtojnë peshën, sepse katabolizmi i materieve ushqyese (në qeliza) të tyre ndodh aq shpejt sa sasia e tepërt e yndyrës nuk grumbullohet si rezervë. Njerëzit që kanë shpejtësi të ulët bazale të metabolizmit lehtë e shtojnë peshën. Në shpejtësinë e metabolizmit ndikojnë disa lloje hormonesh, veçmas trioksina, adrenalina dhe noradrenalina. ${ }^{89}$

Metabolizmi varet nga shumë faktorë, në disa prej këtyre faktorëve mund të ndikojmë, por në disa thjesht nuk mundemi, si mosha sepse sa më të vjetër jemi ne kemi humbur më shumë masën e muskujve, po ashtu kemi rritur sasinë e yndyrës. Andaj, humbja e muskujve ngadalëson metabolizmin. Meshkujt në përgjithësi kanë një metabolizëm më të shpejtë se femrat, për shkak se ata kanë peshë më të madhe, po ashtu nuk duhet harruar se kemi të bëjmë edhe me faktorin gjenetik.

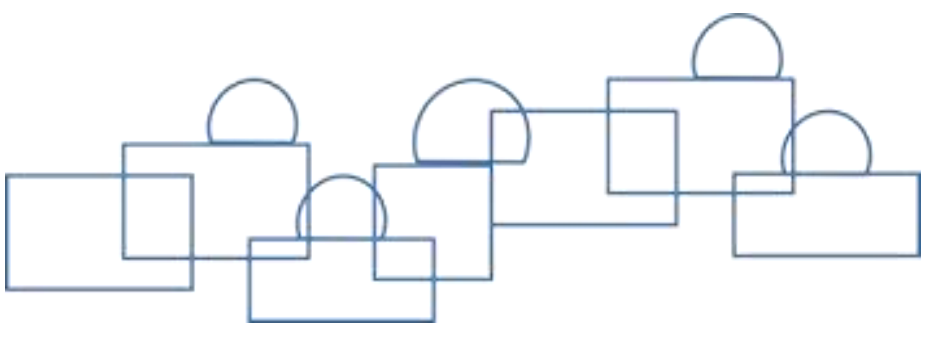

89 https://sq.wikipedia.org/wiki/Procesi_i_metabolizmit 


\subsubsection{Energjia e drejtpërdrejtë Diellore}

Përdorimi i energjisë diellore është mënyra me e zgjuar që vjen në mbrojtje të mjedisit. Me energji diellore nënkuptohet energjia e prodhuar nga shfrytëzimi i drejtpërdrejtë i energjisë së rrezatuar nga Dielli drejt Tokës. Sasia e energjisë diellore që arrin në sipërfaqen e tokës është shumë e lartë.

Fitimi i drejtpërdrejtë diellor është i rëndësishëm për çdo vend që ka nevojë për ngrohje, sepse kjo është mënyra më e thjeshtë dhe më pak e kushtueshme, respektivisht ngrohje pasive. Fitimi i mirë i drejtpërdrejtë i energjisë solare, matet apo parashikohet duke llogaritur dhe përcaktuar se sa energji për ngrohje dielli i emanon hapësirës gjatë gjithë ditës dhe vitit, për lokacioni e caktuar. Në shumë vende, kërkohet më shumë fitim të energjisë solare gjatë dimrit kryesisht për ngrohje, kur dielli është me kënd të ulët, ndërsa më pak është e dëshiruar në verë. Gjithashtu, përfitim të energjisë kërkohet më shumë në mëngjes, se sa gjatë kohës së tjetër të ditës.
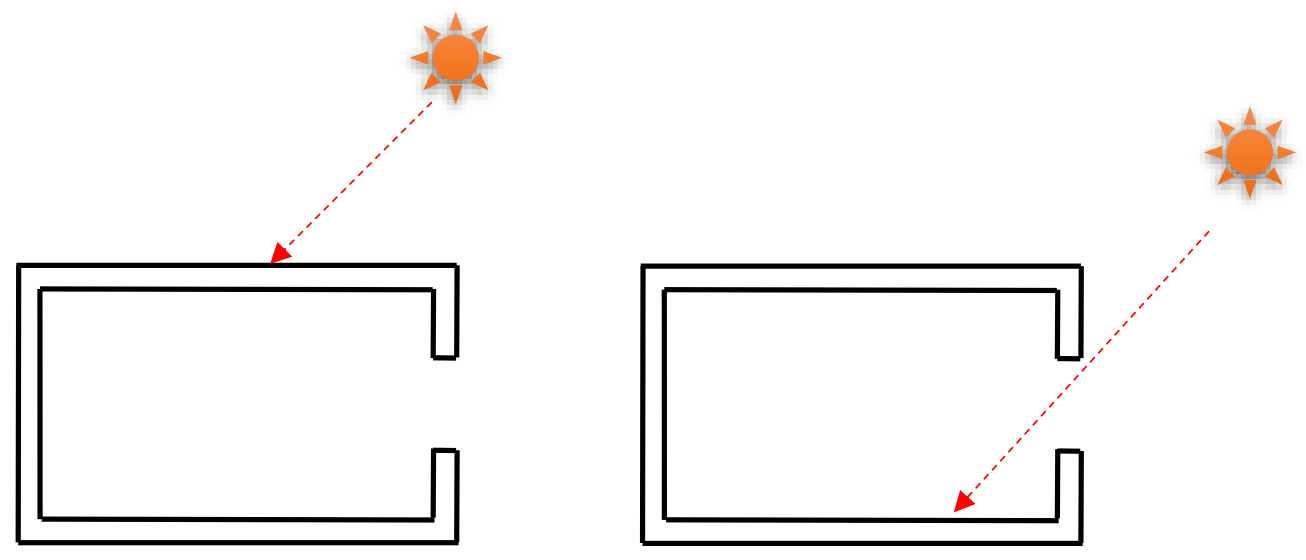

Figura 135. Diellosja nga dritaret, akumulimi i nxehtësisë (Burimi): Bujar Bajçinovci. 2015.

Masa termike është vendimtare për të akumuluar energji solare për nevoja të ngrohjes. Ajo akumulon dhe mban efektin e ngrohjes, do të thotë se masa termike vjen në shprehje për të rrezatuar nxehtësi pasi që dielli të këtë perënduar. Pa masë termike, nxehtësia e cila ka hyrë në një hapësirë thjesht do të rikthehet prapa shpejt, duke e bërë hapësirën tepër të nxehtë me rrezet e diellit dhe tepër të ftohtë pa të.

Natyrisht, një sistem i ngjashëm aktiv për ta krahasuar nga përditshmëria jonë do ishte stufa elektrike e njohur më mirë si "Elind". Principi u punës do ishte i njëjtë me dallimin kryesor se këtu përdoret energjia elektrike, atëherë, stufa në veti përmban tulla shamoti si masë termike, dhe zakonisht për kursim lehet të "mbushet" gjatë natës për të kursyer, mandej gjatë kohës së ditës përmes ventilatorëve mekanik "frynë" nxehtë dhe ngrohë hapësirën. Andaj, paramendoni një sistem të ngjashëm natyror pasiv me efekt të njëjtë vetëm se në këtë rast kemi kursime të mëdha financiare. Për ta kuptuar më mirë kursimin duhet këtë rast ta shumëzojmë N-herë ( $n$.. x ), në kuadër të lagjes apo qytetit, fitimet janë nga njëherë marramendëse, si financiare ashtu edhe nga kursimi i dëmit në mjedis. 


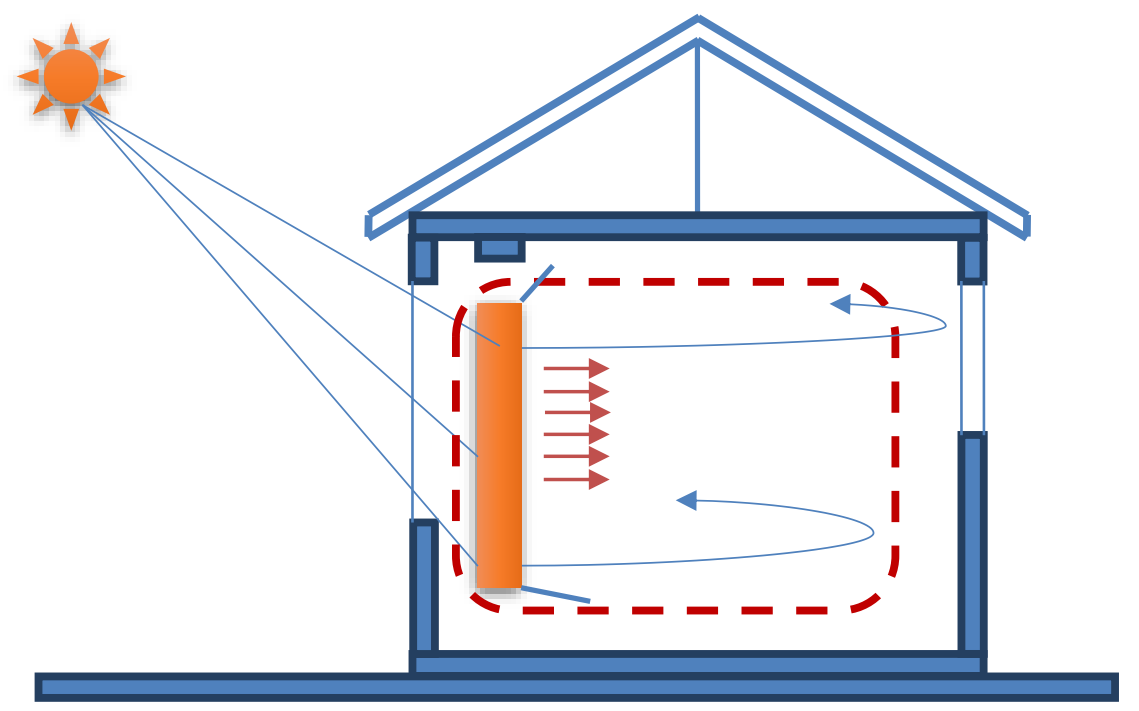

Figura 136. Muri i "Trombit", principet (Burimi): Bujar Bajçinovci. 2015.

\subsubsection{Muri i Trombit, (Felix Trombe)}

Ruajtja, konservimi i energjisë diellore është edhe një mundësi për reduktimin e kërkesës së energjisë elektrike. Energjia e pranuar dhe e akumuluar në shtëpi, zakonisht përmes anës së jugut, paraqet bazën themelore për paraqitjen e murit të Trombit. Ç'është muri i Trombit? Muri i Trombit paraqet një mur kushtimisht me masë vëllimore sa më të madhe, për shkak të akumulimit sa më të madh të nxehtësisë, zakonisht realizohet nga tullat dhe guri, mirëpo mund të preferohet të ndërtohet edhe nga betoni. Zakonisht ka trashësi të madhe në krahasim me muret e zakonshme, në praktikë e hasim me trashësi prej $50 \mathrm{~cm}$ ' apo edhe $80 \mathrm{~cm}$ '. Për të funksionuar ashtu siç duhet muri i Trombit duhet të jetë pranë një sipërfaqe qelqi apo dritareje, mundësisht i orientuar nga ana jugore. E tërë kjo për tu përfituar energji sa më shumë. Për kërkesat banesore dhe publike, muret Trombë të përdorur për mbledhjen dhe ruajtjen e ngrohjes, mund të ndihmojnë dukshëm në kompensimin e faturave të energjisë elektrike.

Muri termikë, i njohur si muri Trombë, i quajtur sipas profesorit Felix Trombe, 1960, është një mur i trashë, i veshur apo ngjyrosur me një material të errët, masa termike e murit është e orientuar nga dielli, i cili ngrohë hapësirën e dedikuar duke rritur temperaturën për shkak të konveksionit. Hapjet të cilat shifen në fund dhe në krye të murit trombë kanë për qëllim që ajri të qarkullojë në dhomë, ndërsa qarkullimi i ajrit mund të kontrollohet nga pengesat, të projektuara enkas.

Projektuesi duhet të vlerësojë pro dhe kontra, për një përdorim të murit Trombë. Duhet veçuar se ky sistem i ngrohjes dhe i ruajtjes së energjisë, megjithatë, nuk është në dispozicion për përdorim të menjëhershëm. Respektivisht, nxehtësia transmetohet me kalimin e kohës në zonën e përcaktuar. Shumica e dizajnerëve preferojnë mure trombë të pa ventilim për banesa, të cilat kërkojnë ngrohje kryesisht gjatë natës. Në vendet me klimë të ftohtë, ku gjatë ditës kërkesat për ngrohje janë të larta, është e dëshirueshme që të përdorin një mur Trombë të ventiluar. 
Gjersa në vendet me klimë të moderuar ku ngrohja gjatë ditës nuk është edhe aq e rëndësishme sa ngrohja gjatë natës, një sistem i mbyllur mund të jetë e preferueshëm.

Parimet projektuese me qasje të ruajtjes së energjisë, nënkuptojnë:

1. Izolim dhe formë adekuate, duke mbajtur ngrohtë dhe ftohtë objektin, participon në kursimin e përgjithshëm në masë të konsiderueshme.

2. Duhet mbrojtur ndërtesën nga erërat e ftohta, qasje projektuese në minimizimin e fenomeneve të padëshirueshme.

3. Duhet promovuar, përdorimin e energjisë solare përmes sistemeve të drejtpërdrejta apo me akumulim në masat termike.

4. Duhet jap prioritet dhe përparësi burimeve pasive të ngrohjes si: masat termike, gjeotermalja...

5. Duhet minimizuar humbjet nga infiltrimi. Projektimi i mirëfilltë i dritareve, dyerve, çative dhe sipërfaqeve të tjera ku duhet zvogëluar depërtimin e ajrit.

Fitimi i drejtpërdrejtë i ngrohjes diellore përfshin ngrohjen rrezatuese e cila rezulton nga rrezet e diellit të pranuara direkt në hapësirat banuese/punuese, sidomos kur janë në anën jugore me dritare të bollshme, të cilat ngrohin sipërfaqet e brendshme të tilla si muret, orenditë, dyshemetë dhe materiale të tjera. Për përfitim optimal të drejtpërdrejtë, zona jug perëndimore paraqet një opsion të duhur në varësi me klimën. Materialet si tulla, guri, betoni, dhe materiale të tjera kompozite janë efektive si masë termike, për sistemet e drejtpërdrejta, sepse ata absorbojnë ngrohtësinë dhe rrezatojnë apo lirojnë nxehtësinë ngadalë. Një shtëpi mirë e projektuar me sistem pasiv solar mund të mbajë një temperaturë konstante të brendshme të $20-23^{\circ} \mathrm{C}$ me ngrohje minimale shtesë të sistemeve aktive të ngrohjes.

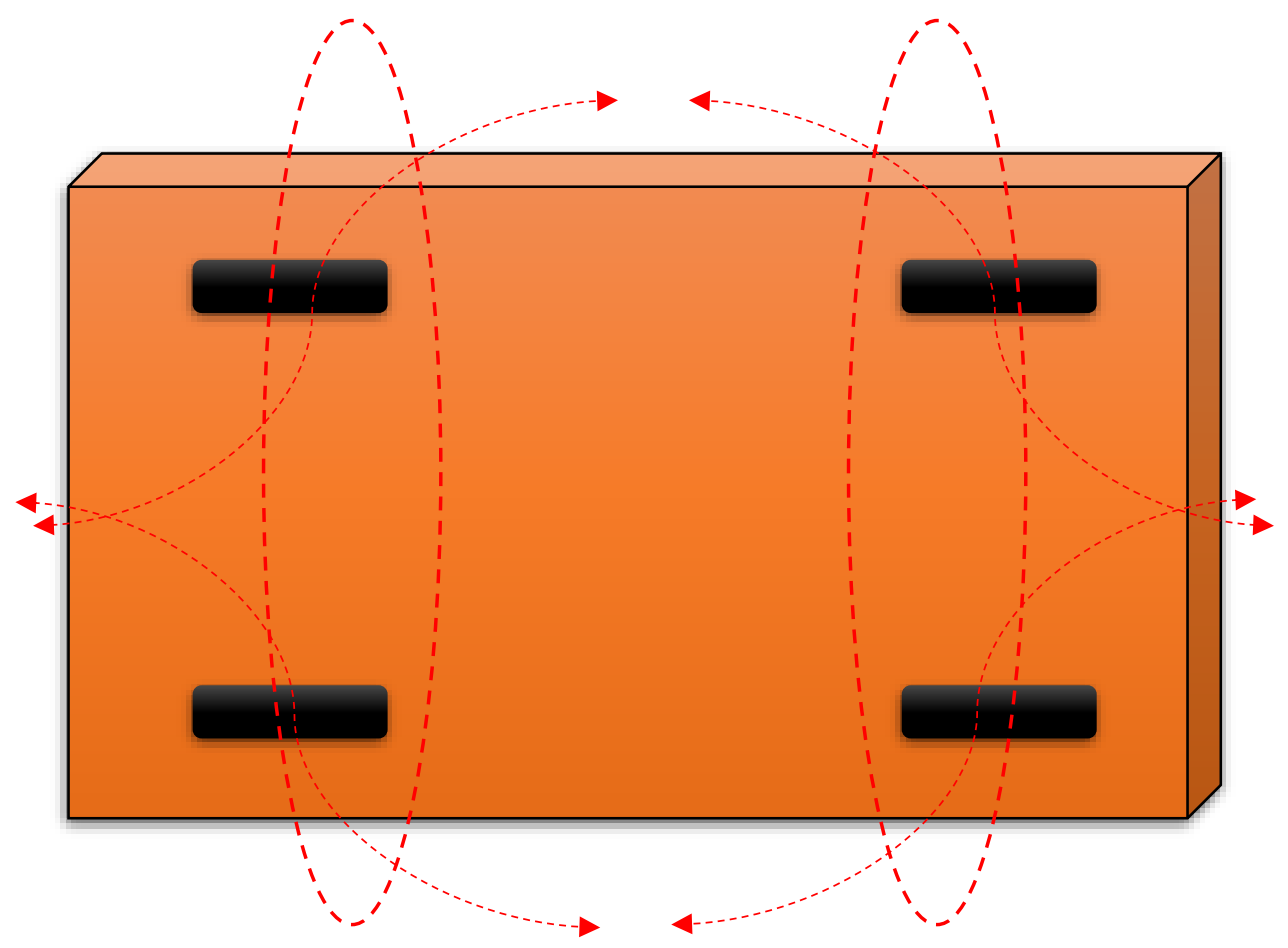

Figura 137. Qarkullimi i nxehtësisë, muri Trombë (Burimi): Bujar Bajçinovci, 2017. 


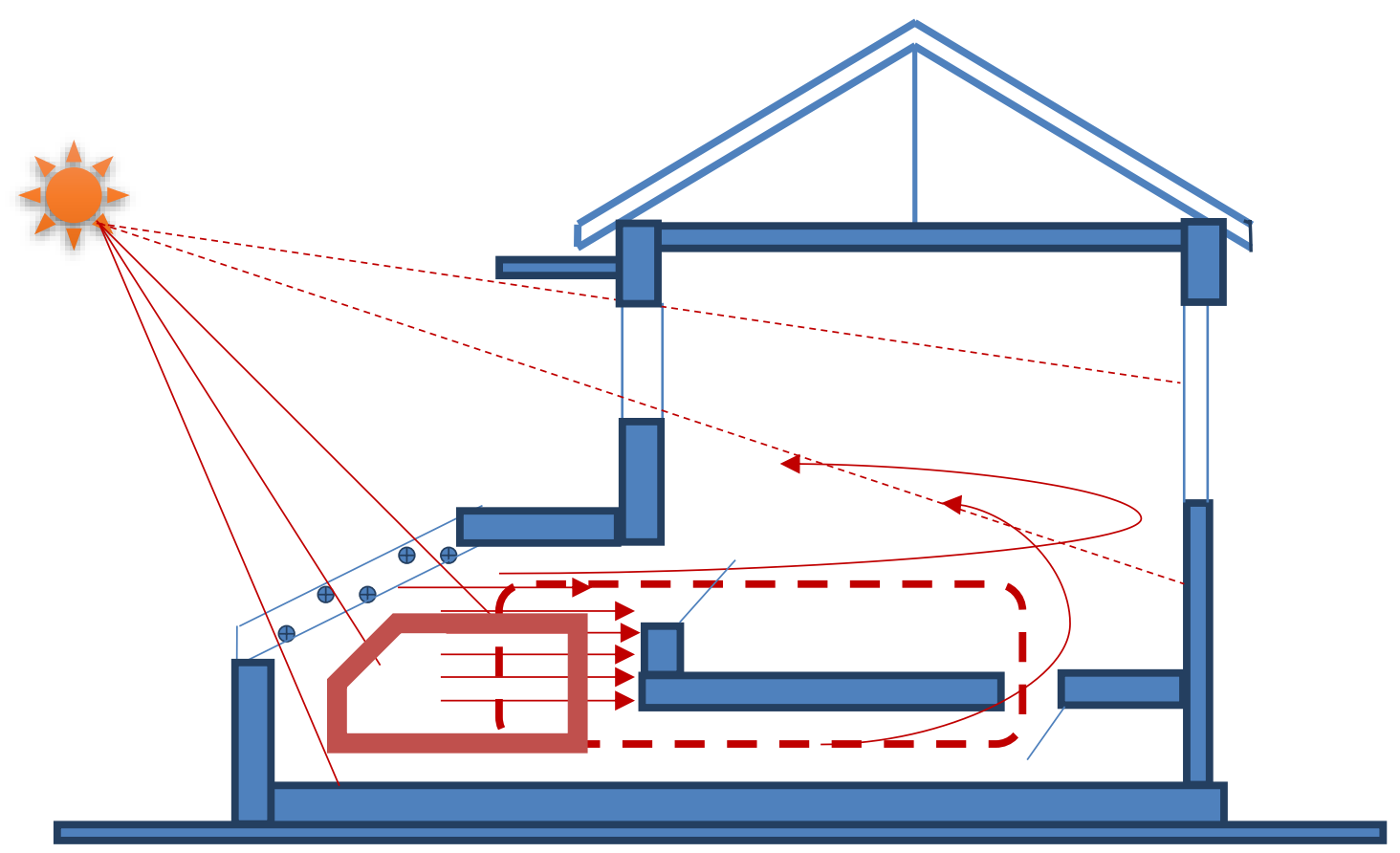

Figura 138. Qarkullimi i nxehtësisë, nga masa termike (Burimi): Bujar Bajçinovci, 2015.

Parimet konceptuale për dizajnimin e masës termike:

1. Duhet zgjedhur drejtë vëllimin e masës termike. Kjo është përcaktuar se sa energji për ngrohje hapësira kërkon (bazuar në klimën, materialin dhe llojin), respektivisht sa energji diellore kërkohet (bazuar në klimën, orientimin dhe mjedisin). Në përgjithësi, komfori dhe rritja e performancës arrihet me rritjen e masës termike, dhe nuk ka asnjë limit për lirinë e të krijuarit dhe të projektimit kreativ.

2. Raporti i sipërfaqeve të masës termike, me ekspozim të mjaftueshëm diellor. Një parim i pranuar është raporti: masë termike/xham, 6/1.

3. Në ruajtje të energjisë së drejtpërdrejtë të fituar, një masë e hollë është më efektive se sa masa e trashë. Trashësia më efektive në materialet e muratimit është $100 \mathrm{~mm}$. Trashësi përtej 150mm janë zakonisht të padobishme.

4. Duhet izoluar konservimin apo magazinimin termik nga kushtet klimatike të jashtme, në mënyrë që ato të mos kanë efekte të kundërta me qëllimin projektues. Megjithatë, në disa zona klimatike, mund të ketë përjashtime nga këto rregulla.

5. Është më së e rëndësishme për të gjetur një masë sa më shumë “termike" të jetë e mundur. Po ashtu, një masë që është e vendosur direkt në rrezet e diellit, është gjithashtu e rëndësishme për performancën e përgjithshme. 
6. Materiali i akumulimit në masën termike është katër herë më efektiv kur masa ngrohet direkt nga dielli në krahasim nëse masa ngrohet vetëm nga konveksioni.

7. Vendosja e masës termike si mur ndarës në enterier është më efektive se sa rasti i mureve të jashtme. Duke supozuar se të dy rastet kanë qasje të barabartë diellosje, nxehtësia nga muri i brendshëm do të emanojë nxehtësinë në të dyja sipërfaqet ndërsa muret e jashtme shpesh humbasin gjysmën e ngrohtësisë për nga jashtë.

8. Masat termike të brendshme të realizuar si mur i brendshëm janë më efektive kur janë të vendosura në mes të dy hapësirave.

9. Masë termike mund të kombinohet me diellosje edhe me muret Trombë. $(\text { Ekstrakt })^{90}$

Masë termike është më e dobishme në vende që kanë oscilime të mëdha të temperaturës gjatë ditës dhe natës, sikurse shkretëtirat. Në vendet me klimë që është vazhdimisht e nxehtë apo vazhdimisht e ftohtë, efekti i masës termike në fakt mund të jetë e dëmshme. Kjo është për shkak se të gjitha sipërfaqet e masës do të priren drejt temperaturës mesatare ditore, nëse temperatura është mbi ose nën nivelin e komforit, kjo do të rezultojë me më shumë jo rahati të banuesve për shkak të efekteve të padëshiruara rrezatuese ose për shkak të humbjeve. Kështu, në klimat e ngrohta tropikale dhe ekuatoriale, ndërtesat priren të jenë shumë të hapura. Në rajonet shumë të ftohta dhe nën polare, ndërtesat janë zakonisht të izoluara shumë me shumë, pa masë të ekspozuar termike, madje edhe në qoftë se ajo është përdorur për arsye strukturore.

\section{Detyrë:}

Të gjendet sipërfaqja e nevojshme e murit Trombë, për Shtëpinë 90m²

Duhet marr rekomandimin e përgjithshëm, nga diellosja në jug, sipas tabelave:

Tabela 19. $22 \%$ në $\sim 90 \mathrm{~m}^{2}=19.8 \mathrm{~m}^{2}$

Gjysma e vlerës për diellosje do të jetë

për përfitim të drejtpërdrejtë, muri Trombë

do të kërkojë $50 \%$

$0.5 \mathrm{~A} \sim 19.8 \mathrm{~m}^{2}=9.9 \mathrm{~m}^{2}$

Në qoftë se do të përdorim një mur Trombë me tulla, ai do të ketë një sipërfaqe prej 10 $\mathrm{m}^{2}$ dhe një trashësi të paktën $25 \mathrm{~cm}$ ( Tabela 21). Dritare për përfitim të drejtpërdrejtë do të jetë sipërfaqja prej $9.9 \mathrm{~m}^{2}$ x $2=19.8 \mathrm{~m}^{2}$ ) (Tabela 20)

Duhet konsideruar përdorimin e një muri Trombë të lartë 1.1 m' dhe i gjatë 9 m' $=(1.1$ x $9 \mathrm{~m}=9.9 \mathrm{~m}^{2}$ ). Duhet patur kujdes që të mos bllokohet murit Trombë me orendi të ndryshme, pasi ai duhet vepruar si një radiator gjatë natës.

90 http://sustainabilityworkshop.autodesk.com/buildings/thermal-mass. /2015. 
Tabela 19. Rregullat për vlerësimin optimal të orientimit në jug për diellosjen e drejtpërdrejtë dhe për murin Trombë.

(Burimi): Bujar Bajçinovci. 2015.

\begin{tabular}{|l|l|c|l|c|}
\hline \multicolumn{4}{|l|}{$\begin{array}{l}\text { Rregullat për vlerësimin optimal të orientimit në jug për diellosjen e } \\
\text { drejtpërdrejtë dhe për murin Trombë }\end{array}$} \\
\hline $\begin{array}{l}\text { Nënzonat } \\
\text { klimatike }\end{array}$ & Qyteti & $\begin{array}{c}\text { Jugu-Raporti } \\
\text { sipërfaqe } \\
\text { dritare/dysheme }\end{array}$ & $\begin{array}{l}\text { Kontributi nga diellosja } \\
(\%)\end{array}$ \\
\cline { 3 - 5 } & & $\begin{array}{l}\text { Me Roleta të } \\
\text { jashtme }\end{array}$ & $\begin{array}{l}\text { Pa Roleta } \\
\text { të jashtme }\end{array}$ \\
\hline Zona 2 & Prishtine & 22 & 33 & 60 \\
\hline Zona 4 & Gjilan & 28 & 27 & 50 \\
\hline Zona 1 & Gjakovë & 18 & 39 & 67 \\
\hline Zona 2 & Prizren & 20 & 33 & 60 \\
\hline
\end{tabular}

Tabela 20. Rregullat për vlerësimin e Masës Termike së kërkuar nga diellosja direkte (Burimi): Bujar Bajçinovci. 2015.

\begin{tabular}{|l|l|l|}
\hline Rregullat për vlerësimin e Masës Termike së kërkuar & \multicolumn{3}{l|}{ nga diellosja direkte } \\
\hline Masa Termike & $\begin{array}{l}\text { Trashësia } \\
(\mathrm{cm})\end{array}$ & $\begin{array}{l}\text { Raporti i } \\
\text { Sipërfaqes } \\
\text { dysheme/dritare }\end{array}$ \\
\hline Mur i muratosur, apo nga betoni me diellosje direkte & $10-15$ & $2-3$ \\
\hline Mur i muratosur, apo nga betoni me diellosje indirekte & $5-10$ & $5-6$ \\
\hline Vëllim uji me diellosje indirekte & $15-30$ & Rreth $1 / 2$ \\
\hline Material I ndryshëm me diellosje direkte & $2.4-10$ & 1 \\
\hline
\end{tabular}

Tabela 21. Rregullat për vlerësimin e trashësisë së murit të Trombit (Burimi): Bujar Bajçinovci. 2015.

\begin{tabular}{|l|l|l|}
\hline \multicolumn{3}{|l|}{ Rregullat për vlerësimin e trashësisë se murit të Trombit } \\
\hline Masa termike & Trashësia $(\mathrm{cm})$ & $\begin{array}{l}\text { Raporti i } \\
\text { sipërfaqes } \\
\text { dysheme/dritare }\end{array}$ \\
\hline Tulla Argjil -Qerpiq & $15-25$ & 1 \\
\hline Beton apo tullë & $25-40$ & 1 \\
\hline Ujë & 20 & 1 \\
\hline
\end{tabular}




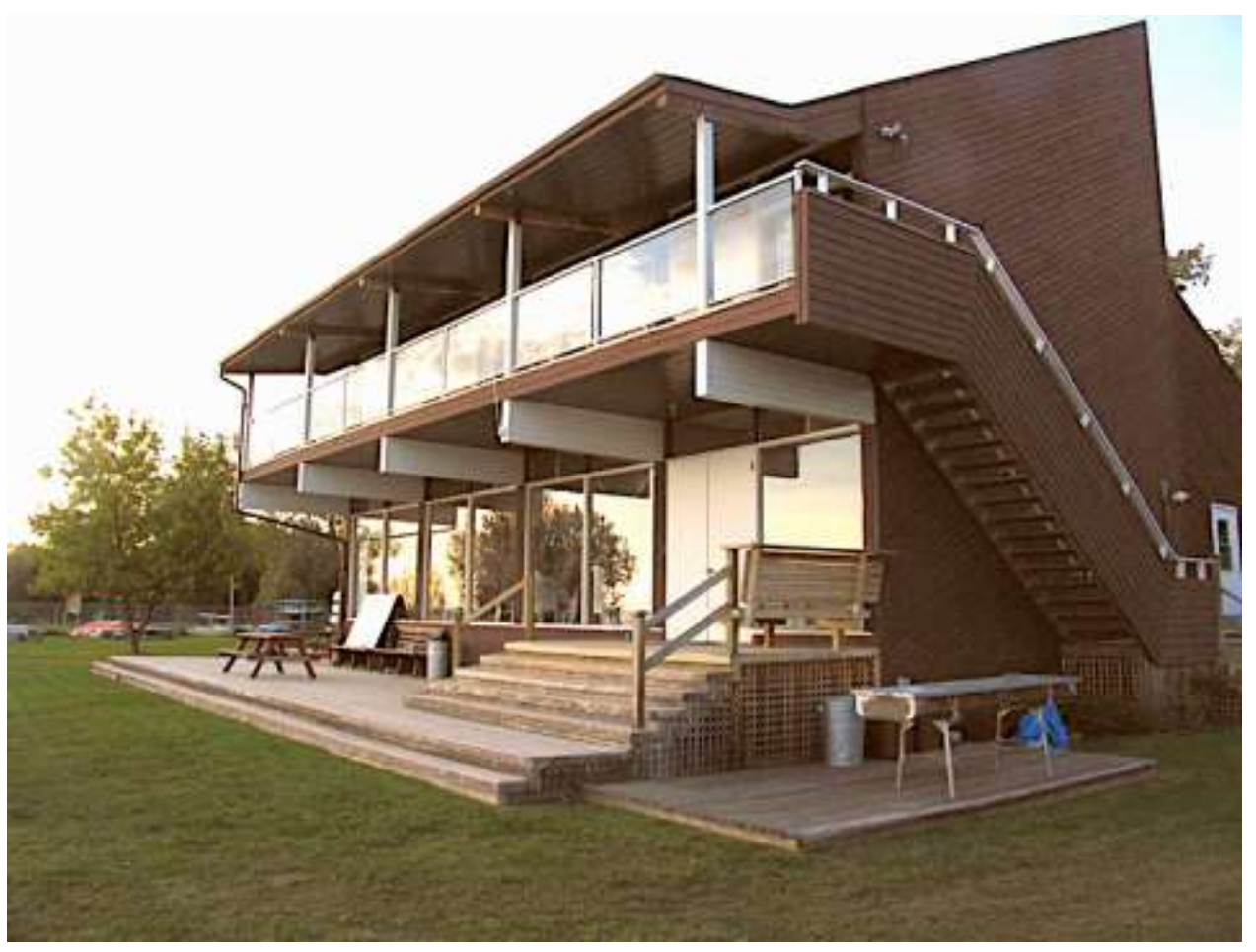

Figura 139. Shtëpia 'SunSpace', përdorimi i murit Trombë (Burimi): naturalflow, 2007. E licensuar nga Commons Attribution ShareAlike 2.0.

Shembull i mirë i komforit termik me diellosje, me strehë të mjaftueshme për hije gjatë verës, shifet në Fig. 139. Duhet lejuar dhe preferohet më shumë dritë brenda, gjate dimrit sidomos në ditët kur kemi nevojë emocionalisht ta ndjejmë ngrohtësinë e rrezeve diellore të cilat na mbushin plotë optimizëm.
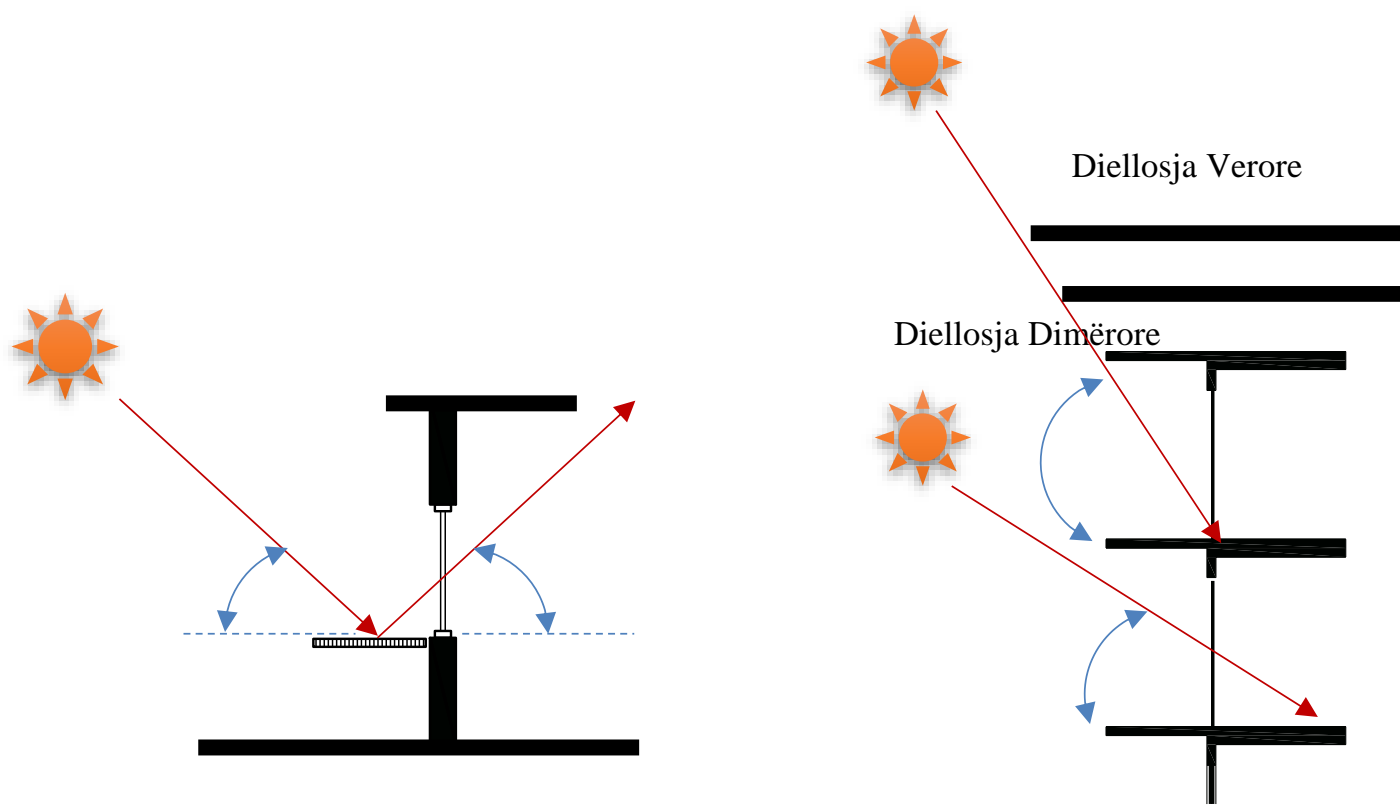

Figura 140. Diellosja, verës, gjatë dimrit, benefite të shumta. (Burimi): Bujar Bajçinovci. 2015. 


\subsubsection{Atria}

Atriumi ka potencialin për të transformuar një hapësirë të brendshme në një hapësirë me atribute të mjedisit të jashtëm, natyrisht, kuptohet se kemi të bëjmë me dimensione modeste. Kërkesë e kamotshme që në objektet e errëta me pak diellosje të bëhet një zgjidhje e volitshme arkitektonike. Për këtë arsye, mbulimi i hapësirave në mes të ndërtesave me mbulim me xhama apo edhe pa i mbuluar fare është bërë një tipar i përbashkët i shfrytëzimi të potencialit për diellosje, ndriçim si dhe vizura të këndshme.

Një atrium i projektuar në mënyrë korrekte do të përmirësojë komoditetin e brendshëm, do të prezantojë natyrën mu në mes të objektit, me sipërfaqe të këndshme të vegjetacionit të kultivuar, me fontana uji, e në disa raste edhe me piaceta dhe shtigje këmbësorësh. Shumica e ndërtesave, natyrisht, kanë nevojë për ngrohje dhe ftohje sezonale, kështu që duhet të miret në konsideratë shkalla e rregullimit dhe e ndërveprimit për të përmbushur kushtet e komforit optimal.

Përveç kësaj, në shumë vende kushtet mikroklimatike me veçoritë lokale mjedisore krijojnë sfida projektuese, duke marr në konsideratë: erërat me intensitet të mëdha, ekspozimi i fasadës jugore, të reshurat atmosferike në sasi të mëdha. Andaj, duhet pasur kujdes gjatë evaluimit të detyrës projektuese në veçoritë e kushteve mikroklimatike si dhe rregulloret lokale ndërtimore të cilat mund të vendosin kufizime të mëtejshme mbi projektuesin. Aftësia për të arritur përgjigje optimale në projektim nuk nënkupton vetëm klimën, së fundi, konsideratat e energjisë të mëvetshme nuk mund të përcaktojnë formën e ndërtesës. Projektimi si proces kreativ krijues kërkon fleksibilitet dhe lirinë për ti inkurajuar standardet e të së ardhmes. Mirëpo, vazhdimisht duke mos harruar se trashëgimia arkitektonike përben bazën e shëndoshë projektuese se kush jemi dhe të cilët synojmë të jemi në të ardhmen.

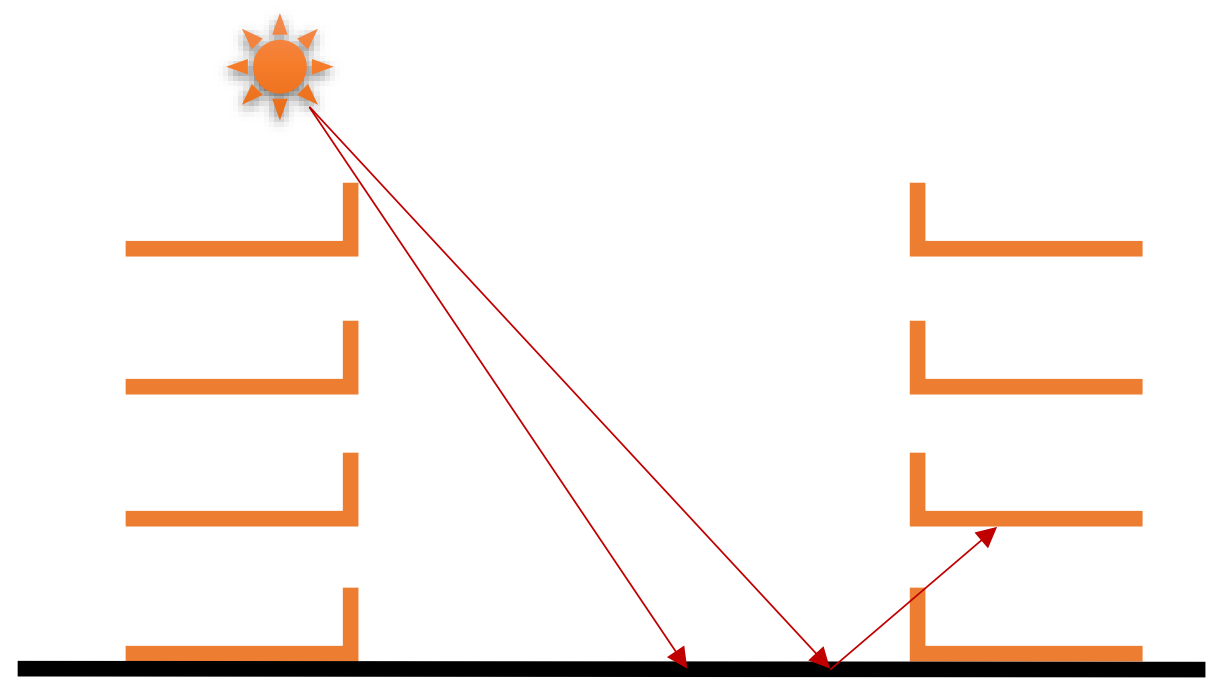

Figura 141. Atria si fenomen dhe funksion arkitektonik (Burimi): Bujar Bajçinovci, 2017.

Funksioni i atrias si hapësirë funksionale, apo tampon zonë, sfidën kryesore e përballon nga humbjet termike të cilat varen dhe shkaktohen nga humbjet specifike të sipërfaqeve nga xhami. 
Andaj, fitimi optimal nga rrezatimi diellor duhet të vlerësohet me kujdes, sepse një sasi e madhe e rrezatimit termik mund të ritransmetohen në objekt, veçanërisht në rastet kur sipërfaqet rrethuese të atrias janë absorbuese dhe të errëta. Një atrium mund të transmetojë në mes 30-85\% të rrezatimit lokal, në varësi të madhësisë, vendndodhjes, kapacitetit të ndërlidhur me ndërtesën, ngjyrës, gjeometrisë si dhe materialet e përdorura për realizimin e objektit dhe atrias.

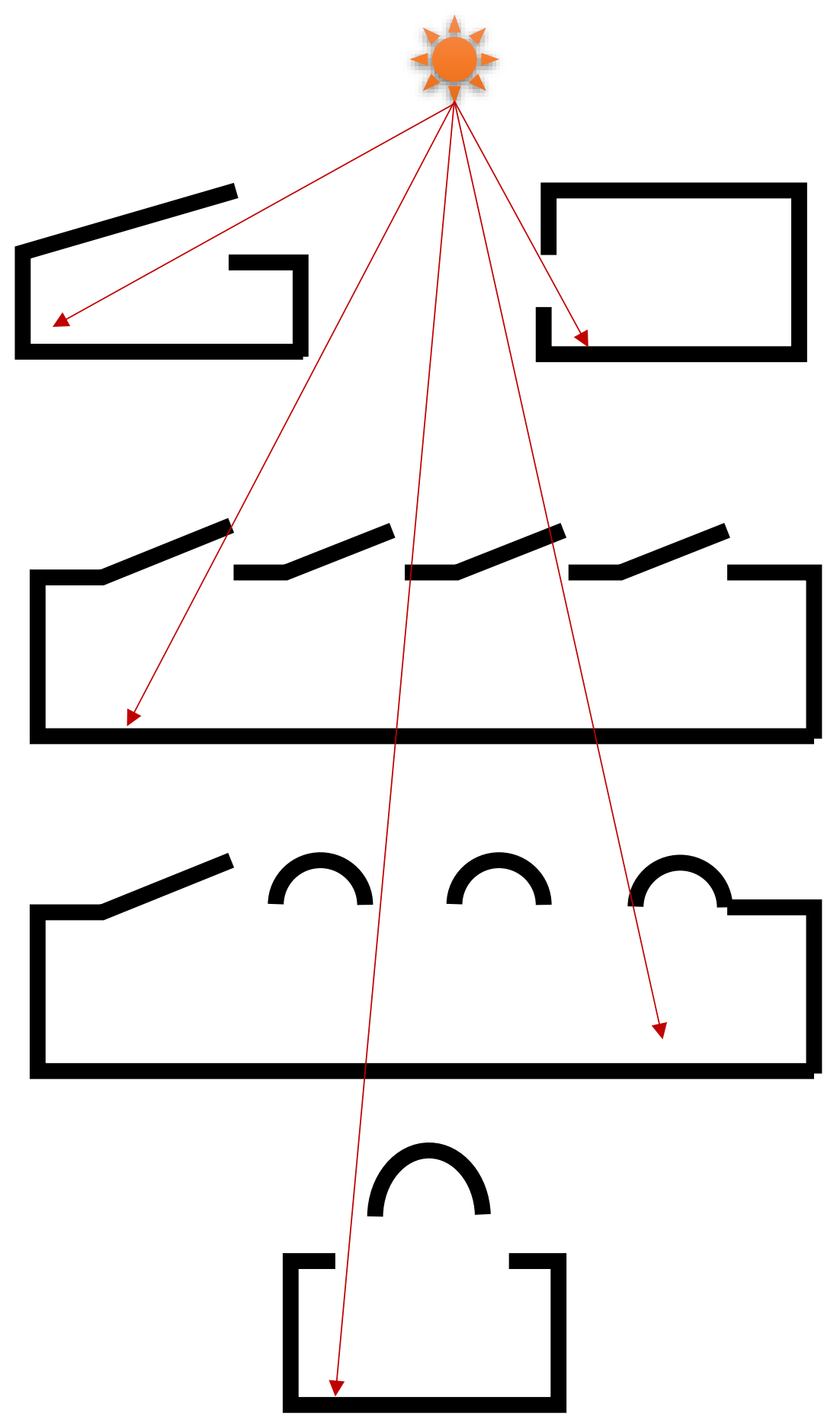

Figura 142. Elementet konstruktive, diellosja dhe pajisjet (Burimi): Bujar Bajçinovci, 2017. 
Diellosja mund të përdoret në mënyrë efektive si një burim pasiv i energjisë për ngrohje duke siguruar gjatë ditës një sfond optimal plotësues. Përdorimi i lëndëve djegëse fosile duhet minimizuar, andaj, ndërtesat që përdorin energjinë e diellit mund të reduktojnë ndjeshëm madhësinë e faturave për energji elektrike dhe gaz natyror. Natyrisht, qëllimi parësor do jetë përdorimi i teknologjive pasive të ngrohjes diellore. Çështjet e fitimit të energjisë sikur: muret trombë, mbrojtësit nga diellosja, brisolei, patio, atria, ndriçimit natyror, ajrimit dhe ventilimit janë parime të domosdoshme në projektimin qëndrueshëm arkitektonik.

\subsubsection{Ftohja pasive - Ventilimi}

Ky lloj ajrimi bazohet në ndërrimin e ajrit nëpërmes të shpërndarjes natyrore të shtypjes e cila ekziston për shkak të ndryshimit të temperaturave. Kur ajri është në një lokal më i ngrohtë se sa ajri i jashtëm atmosferik, ndodhë që ndryshimi i temperaturave të ajrit specifik të lehtë dhe të ngrohtë, në krahasim me të jashtëm të ftohtë dhe të rëndë, krijohen ndryshimet e shtypjeve dhe rrymimet të cilat rriten me shpejtësinë e erës. Krijimi dhe mirëmbajtja e higjienës së domosdoshme, lagështisë dhe shpejtësia e ajrit bëhet me ajrim natyror dhe artificial. Ajrimi natyror bëhet në lokale (hapësira) ku është ndotja e ajrit më e dobët dhe ku numri i njerëzve është i vogël. Ashtu si ngrohja pasive, edhe ftohja dhe ventilimi është e rëndësishme për reduktimin e përdorimit të energjisë në ndërtesa. Në mënyrë të veçantë, duke përdorur si strategji projektuese: ftohjen pasive dhe ventilim natyror, kondicionimi dhe hijezimi mund të zvogëlojmë kërkesat për pajisje mekanike, njëkohësisht duke ruajtur komforin termik. Ventilim natyror, i quajtur gjithashtu ventilim pasiv, përdor lëvizjet e ajrit në dallimet natyrore të presionit, natyrisht, për më tepër duhet referuar për studim principi i Bernoulit. Ventilim natyror është më së i rëndësishëm pasi reflekton lëvizjet natyrore të masave të mëdha të ajrit, të shfaqura nga diferencat e shtypjeve dhe temperaturave. Ventilim i suksesshëm natyror përcaktohet duke pasur rehati të lartë termale dhe ajër të mjaftueshëm të freskët për hapësirat ajrosura, ndërsa ka përdorim pak ose aspak të energjisë për ftohje aktive me kondicioner dhe ventilim.

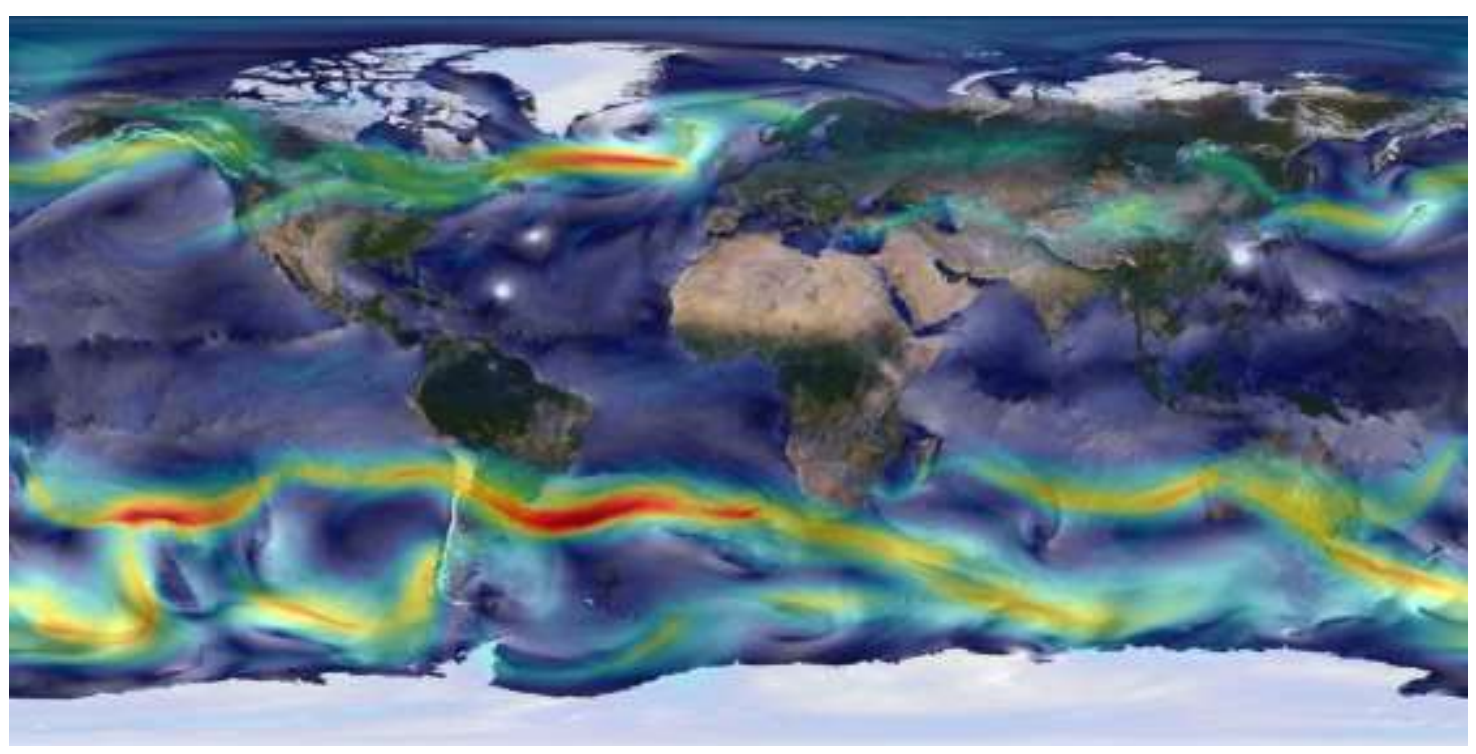

Figura 143. Lëvizjet e masave të ajrit, oqeanet, klima

(Burimi): William Putman/NASA Goddard Space Flight Center. 2015 https://www.nasa.gov/content/a-portrait-of-global-winds 


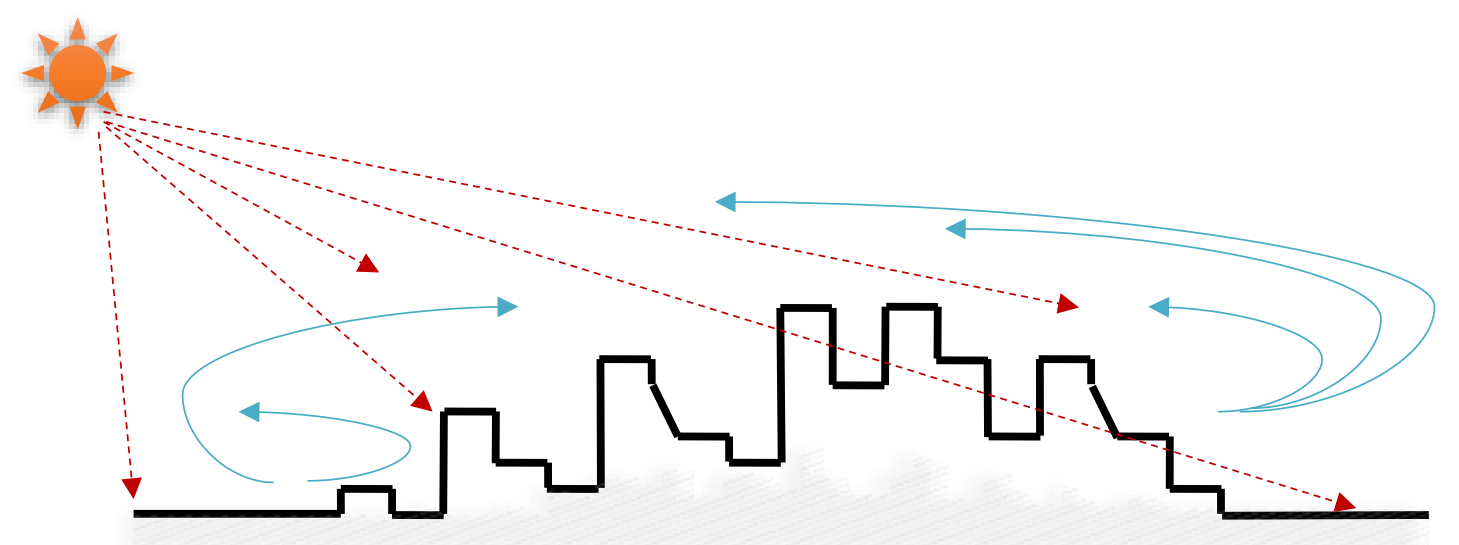

Figura 144. Siluetë qyteti, ajrimi natyror (Burimi): Bujar Bajçinovci. 2015.

Për çdo ndërtesë, ventilimi duhet të sigurohet për të zëvendësuar ajrin e ndenjur të brendshëm me ajër të freskët të jashtëm në mënyrë që të mbahen $\mathrm{CO}_{2}$ dhe ndotësit tjerë në një nivel të pranueshëm koncentrimi dhe për të siguruar nivel të përshtatshëm të lagështisë. Dy mënyrat kryesore për shkëmbimin e ajrit ndërmjet ndërtesës dhe ambientit të jashtëm janë ventilimi i qëllimshëm dhe infiltrimi i rastësishëm i ajrit. Pasi që ventilimi shkëmben ajrin e temperaturave të ndryshme, edhe në nivele të ndryshme të energjisë, krijon qarkullim.

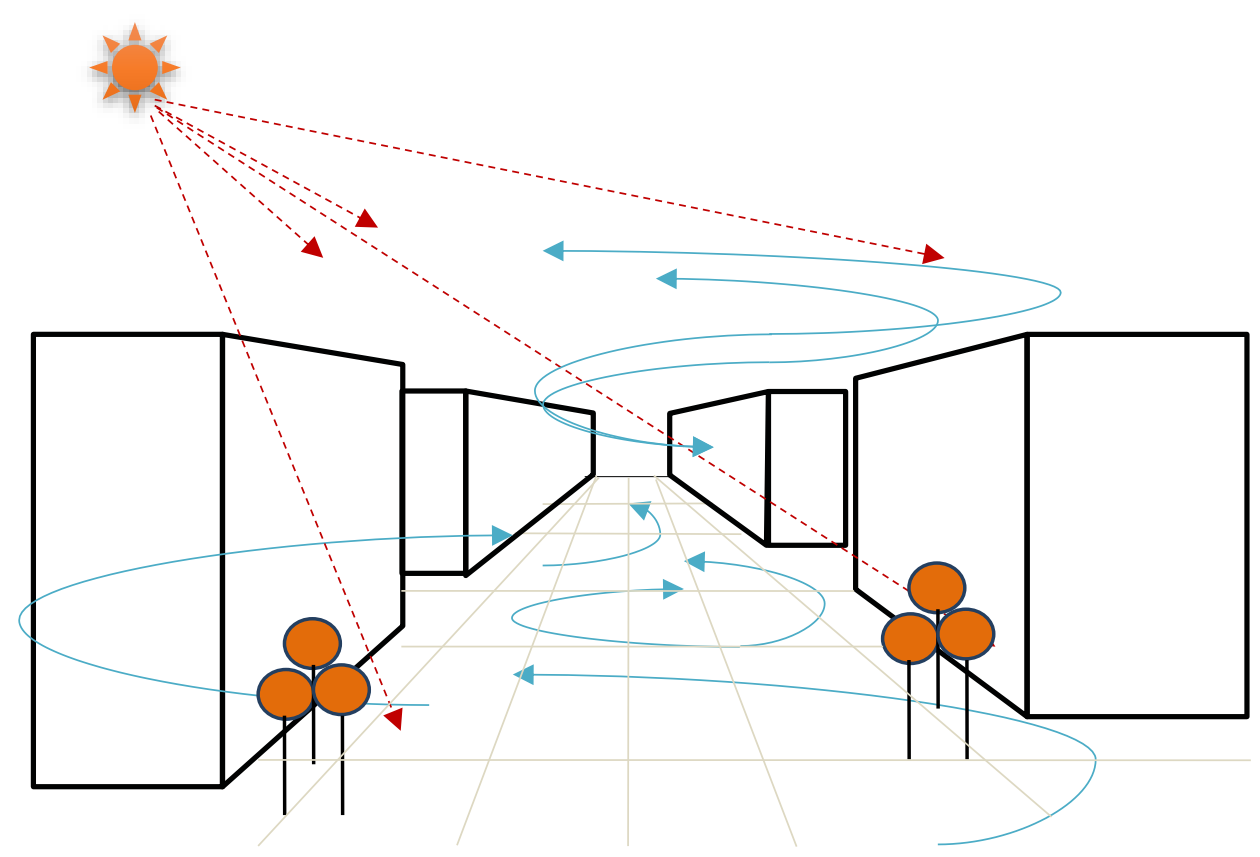

Figura 145. Bllok urbanistik, ndikimi i veçorive natyrore, ajrosja - era (Burimi): Bujar Bajcinovci. 2015. 
Ventilimi mund të shkaktojë probleme edhe në verë, dhe në dimër: kur temperaturat jashtë janë të ulëta, energjia ngrohëse humbet me ajrin e dalë jashtë; në verë ajri i ngrohtë nga jashtë mund të fusë energji të tepërt në shtëpi që mund të rrisë ngarkesën për ftohje. Përdoruesit mund të reduktojnë humbjet nga ventilimi me sjellje adekuate, p.sh., hapjen e dritareve plotësisht vetëm për një kohë të shkurtër më parë se sa të hapen dritaret pakëz për orë të tëra. Sjellja e përdoruesit, sidoqoftë, është shumë e vështirë të parashikohet, prandaj përbën një variabël të pasigurt në llogaritje.

Rrjedha e nxehtësisë nga ventilimi ndikohet nga fenestrimi dhe hapjet tjera, orientimi i tyre përkitazi me drejtimin erës, mekanizmat e tyre të mbylljes, ngushtësia e përgjithshme e ajrit ose depërtueshmëria e ajrit në mbështjellës; dhe nga sistemet mekanike të ventilimit nëse ka. Forma e ndërtesës ka gjithashtu një ndikim të fortë në krijimin zonave pozitive dhe negative të presionit në sipërfaqen e mbështjellësit të ndërtesës, që ndikon në infiltrimin e ajrit. Disa sisteme të fasadave përdorin këto fenomene për të përmirësuar ventilimin natyror edhe në kushte të pafavorshme.

Humbjet e ngrohjes nga ventilimi përfshijnë humbjet e shkaktuara nga infiltrimi përmes zbrazëtirave, ventilimit të përhershëm nga përdoruesi duke hapur dritaret dhe humbjet përmes ventilimit mekanik. Humbjet nga ventilimi mund të mbahen në nivele më të ulëta duke ndërtuar mure dhe dritare hermetike dhe duke përdorur ventilim natyral dhe mekanik me rikuperim të ngrohjes. Megjithatë, instalimi i sistemeve të ventilimit rit në mënyrë të ndjeshme punën që kërkohet në enterierin të ndërtesës. Zonat vertikale dhe horizontale që kërkohen për instalime të tilla kanë një efekt në paraqitjen e brendshme dhe pajimin dhe punët përfundimtare të dhomave individuale. (Ekstrakt) ${ }^{91}$

Llogaritja e humbjeve termike nga ventilimi QV, (metoda e thjeshtuar e llogaritjes) ${ }^{91}$

Me testin e rrjedhjes së ajrit

$\mathrm{HV}=0,19 \mathrm{x} \mathrm{Ve}[\mathrm{W} / \mathrm{K}]$

Pa test të rrjedhjes së ajrit

$\mathrm{HV}=0,163 \times \mathrm{Ve}[\mathrm{W} / \mathrm{K}]$

$0,19=0,7 \mathrm{~h}-1 \times 0,34 \mathrm{Wh} /\left(\mathrm{m}^{3} \mathrm{~K}\right] \times 0,8\left[\mathrm{~W} / \mathrm{Km}^{3}\right]$

$0,163=0,6 \mathrm{~h}-1 \times 0,34 \mathrm{Wh} /\left(\mathrm{m}^{3} \mathrm{~K}\right) \times 0,8\left[\mathrm{~W} / \mathrm{Km}^{3}\right]$

- 0,34 = cp,a x $\rho \mathrm{a}=1200 \mathrm{Ws} / \mathrm{m}^{3} \mathrm{~K}:$ kapaciteti i ngrohjes volumetrike të ajrit të lagësht $=$ cp,a $\times$ pa $=0,34 \mathrm{Wh} /\left(\mathrm{m}^{3} \mathrm{~K}\right)$

- nw = 0,6 h-1 me test të rrjedhjes së ajrit

- tash $=0,7$ h-1 pa test të rrjedhjes së ajrit

- $\mathrm{Ve}=0,8 \times \mathrm{Ve}\left[\mathrm{m}^{3}\right]$

$\mathrm{Qh}=66 \times(\mathrm{HT}+\mathrm{HV})-0,95 \times(\mathrm{Qi}+\mathrm{Qs})+\mathrm{QTW}[\mathrm{kWh}]$

- $66=(2900 \mathrm{Kd} \times 0,95$ (temperatura e programuar gjatë natës $) \times 24 \mathrm{~h} / \mathrm{d}) / 1000)$

91 Kodi Unik i Ndërtimit i Republikës së Kosovës, Kapitulli I - Ventilimi dhe Klimatizimi. Draft. 2015 
- Kd - shkalla e ngrohjes-ditë: përkufizuar si deficiti kumulative i temperaturës poshtë një baze të caktuar të temperaturës $\mathrm{Tb}, \mathrm{p} . \mathrm{sh} ., 18^{\circ} \mathrm{C}$ të përmbledhur gjatë vitit. Kurdo që temperatura mesatare e ditës ( $\mathrm{T}$ ) është më e ulët se kjo Tb, ne shkruajmë ndryshimin dhe i shtojmë këto (ndryshimet negative injorohen). Këto shuma mund të prodhohen ndaras për çdo muaj, vit ((prej 1 deri në 365) Kh $=\mathrm{Kd}$ x 24.

- 0,95 - faktori i efiçencës (përdorueshmëria) i fitimit të ngrohjes 95\%

- Qh kërkesa vjetore për ngrohje

- HT - koeficienti i transmetimit të nxehtësisë ndërmjet enterierit të ngrohur dhe eksterierit $[\mathrm{W} / \mathrm{K}]$

- H - humbja specifike e nxehtësisë $(\mathrm{Hv}+\mathrm{HT})$

Disa nga teknikat pasive të ftohjes për ndërtesat në zona të nxehta dhe të thata janë:

1. Ndërtimi me materiale masive, mbron nga temperaturat gjatë ditës dhe natës.

2. Duhet përdorur ngjyra të lehta për çatitë dhe muret.

3. Duhet pranuar diellosjen në dimër për të minimizuar kërkesat e ngrohjes.

4. Duhet përdorur dritare me qelq të dyfishtë dhe me izolim të mjaftueshëm.

5. Përfitim të plotë nga ventilimi natyror dhe lëvizja e ajrit, ajrimi.

Parimet për ftohje pasive në zonat e nxehta dhe me lagështi janë:

1. Të përfitohet nga lëvizja e ajrit për të maksimizuar qarkullimin e ajrit.

2. Gjatë kohës me diell, duhet siguruar hije nga dielli dhe vegjetacion të duhur.

3. Të përfitohet nga diellosja dimrit për ngrohje, mirëpo, duhet shmangur ajrin e ftohtë në dimër me formën e duhur të projektimit.

4. Duhet parandaluar shumë lagështi, duke mos vendosur pishina në afërsi apo impiante të ngjashme, duhet përdorur ventilim natyror për të shmangur lagështinë shtesë.

5. Ndërtimi me materiale masive, mbron nga temperaturat gjatë ditës dhe natës

Ftohja pasive kërkon vëmendje të karakteristikave mbizotëruese të erës dhe të mikroklimës (zona të vogla me klimë që mund të ndryshojnë nga ajo e rajonit të përgjithshëm), dhe gjithashtu lokalitetit apo mjedisit urban. Tre karakteristikat kryesore të erës janë: temperatura e ajrit, shpejtësia dhe drejtimi. Veçori të cilat kanë implikime në orientimin e ndërtesës, përdorimin e ventilimit natyror si dhe kontrollin e lëvizjes së ajrit në fasada. 
Njohja themelore se si lëviz ajri është më se e domosdoshme për projektimin e qëndrueshëm. Projektuesi duhet kushtuar më shumë vëmendje për mikroklimën e një vendi të veçantë ndërtimi sesa në klimën e përgjithshme të rajonit. Duke studiuar një vit të plotë të dhënave klimatike vendin e caktuar, duke përfshirë edhe erërat, projektuesi mund të përcaktojë përgjigjet e duhura për peizazhin, kontekstin urban dhe formën e ndërtimit. Drejtimi i erës dhe shpejtësia mesatare mujore mund të merret nga stacionet lokale meteorologjike apo më hollësisht nga Instituti Hidrometeorologjik i Kosovës apo edhe nga një aeroport. Zakonisht shpejtësitë e erës në nivel shkalle tregohen në milje në orë (mph), tek ne shpejtësinë e erës zakonisht e prezantojmë me kilometra në orë apo edhe në metra në sekondë. Parimet e Përgjithshme në lidhje me lëvizjet ajrit në ndërtesa

1. Për shkak të kontaktit të parë, shpejtësia e ajrit është më e ngadalshme në afërsi të sipërfaqes së tokës se sa më lartë në atmosferë. Andaj, ekspertët e motit dhe pilotët e dinë, se shpejtësitë e erës janë më të larta në 10.000 m'se sa ata në terren. Po ashtu arkitektët dhe inxhinierët e dinë se pjesët më të larta të një ndërtese përjetojnë efekte më të mëdha të shpejtësisë së erës se sa katet më të ulëta.

2. Sipas ligjin të Njutonit, për shkak të inercionit (një trup në lëvizje ka tendencë për të qëndruar në lëvizje), ajri tenton të vazhdojë të lëvizë në drejtim të njëjtë derisa të përballet me një pengesë. Kjo rezulton në ajër atëherë kur paraqitën pengës apo duke shkuar nëpër objekte të tilla si muret, pemët dhe shkëmbinjtë...

3. Ajri rrjedh nga zonat e presionit të lartë në zonat e presionit të ulët. Kur ajri i dendur në lartësi të ulëta ngrohet për shkak të rrezatimit diellor, rritet presioni i ajrit. $^{78}$

\subsubsection{Strategjitë për Ventilim}

Koncepti më i preferuar gjatë projektimit të ventilimit natyror janë orientimi i ndërtesës dhe vëllimi, si dhe fensterimi respektivisht vendosja e hapjeve të përshtatshme për komforin klimatik. Në mënyrë për të maksimizuar ventilim natyror, duhet kërkuar dallimin e presionit në mes ajrit në hyrje dhe ajrit brenda (dalje) të jetë maksimaloptimal. Në pothuajse të gjitha rastet, presione të larta ndodhin në anën që fryn era në një ndërtesë dhe presionet e ulëta në anën e kundërt.

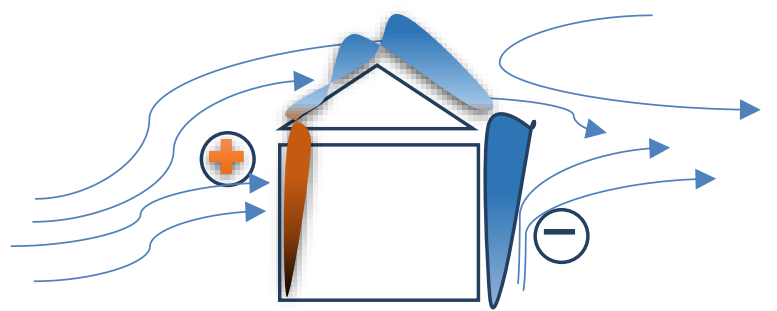

Figura 145. Bllok urbanistik, ndikimi i veçorive natyrore - ajrosja - era (Burimi): Bujar Bajçinovci. 2015.

Klima lokale mund të ketë erëra të forta mbizotëruese në një drejtim të caktuar, apo puhiza të lehta ndryshueshme, ose mund të ketë kushte shumë të ndryshme të erës në kohë të ndryshme. Klima lokale mund të jetë herë shumë e nxehtë gjatë ditës ose vitit, ndërsa herë të tjera mund të jetë mjaft e ftohtë (sidomos në shkretëtirë). 
Në verë, ajrimin duhet përdorur sa më shumë të jetë e mundur për furnizimin me ajër të pastër, ndërsa në dimër, ventilimin natyror duhet reduktuar zakonisht në nivele të mjaftueshme vetëm për të larguar lagështinë e tepërt dhe ajrin e moshuar.

Në punëtori dhe në uzina prishja e ajrit shpeshherë shkaktohet nga vetë procesi i punës. Në restorante, prishja e ajrit shkaktohet nga erërat e gjellërave dhe nga tymi i duhanit. Në lokale që ndriçohen në mënyrë artificiale, nxehtësia që jepet përmes ndriçimit, shtrojnë nevojën që këto lokale të ventilohen. Rëndësi të veçantë ka prishja e ajrit që vjen nga vetë njeriu, njeriu vazhdimisht i jep ajrit të rrethinës nxehtësi, dyoksid karboni, avull uji dhe materie me erë.

Tabela 22. Lirimi i $\mathrm{CO}_{2}$, avullit, nxehtësisë

(Burimi): Akademik Fejzullah Krasniqi et al. Universiteti i Prishtinës

\begin{tabular}{l|lrrrr} 
& & $\mathrm{C02}$ l/h & Materiet me erë & Avulli i ujit gr/h & Nxehtësia W \\
\hline Njeriu & në qetësi & 20 & Të pamatura & 70 & 120 \\
\hline & në punë & 70 & Të pamatura & 130 & 300
\end{tabular}

Dyoksidi i karbonit lirohet në procesin e frymëmarrjes dhe me kohë përqendrimi i tij në lokal rritet. Megjithatë përmbajtja e dyoksid karbonit mezi arrin në të mijtat pjesë, edhe kur është fjala për lokale të vogla, e të puthitura mirë. Sipas të dhënave të higjienike përmbajtja e dyoksid karbonit 1-2 \% pa efekte negative mund të durohet gjatë gjithë javës. Materiet me erë janë përbërje organike të kombinuara, ku një pjesë lirohet nëpërmjet lëkurës, kurse pjesa tjetër me anë të frymëmarrjes. Sasia e tyre është aq e vogël sa shumë vështirë identifikohet nga aspekti kimik ose me matje, bile edhe kur era është tërësisht e ndjeshme. Kështu që prania e tyre ndërlidhet me praninë e dyoksidit të karbonit dhe konsiderohet që grumbullimi i tyre shkon paralelisht.

Hapësirat ku qëndrojnë njerëzit, njëkohësisht rriten si temperatura ashtu edhe lagështia. Nëse temperatura dhe lagështia në ndonjë lokal rriten aq shumë saqë trupi nuk mund të japë më as nxehtësi as lagështi, atëherë ndodh goditja termike. Sot me siguri mund të flasim se në sallat e mbushura, ajri i prishur nuk bëhet për shkak të mungesës së oksigjenit dhe nga teprica e dyoksidit të karbonit, por për shkak të temperaturës së lartë, të kombinuar me lagështi të madhe. Nëse në sallë futet pak ajër dhe nëse në të ka shumë frekuentues, atëherë prishja e ajrit do të rritet shpejt dhe shpejt do të arrihet kufiri i lejueshëm higjienik. Posa të arrihet kjo gjendje duhet që të bëhet ndërrimi i fuqishëm i ajrit, me çka salla tërësisht ajroset (ventilohet), ashtu që sa më parë të arrihet gjendja optimale e ajrit. Kur bëhet fjalë vetëm për përtëritjen e përmbajtjes së ajrit atëherë për këtë nevojitet vetëm pak kohë.

Megjithatë duhet llogaritur në atë që materiet të cilat e prishin ajrin; frymëmarrja, tymi i duhanit, avullimi i gjellërave, ngritën për mure dhe në gjësende tjera në lokal, nga të cilat më vonë paraqiten përsëri. Ventilimi i tërësishëm ka për detyrë që, përveç ndërrimit të ajrit, t'i pastrojë me ajër të freskët të gjitha gjësendet në lokal. 


\subsubsection{Ventilim i tërthortë}

Kur vendosim hapje të ventilimit, duhet zgjedhur opsionin më praktik që ndjek parimet e ventilimit natyror. Fensterimi apo dritaret e vendosura në anët e kundërta të ndërtesës, japin puhizë natyrore në ajrimin e të gjithë strukturës arkitektonike. Kjo quhet ventilimi i tërthortë. Ventilimi i tërthortë në përgjithësi është forma më efektive e ajrosjes. ${ }^{85}$
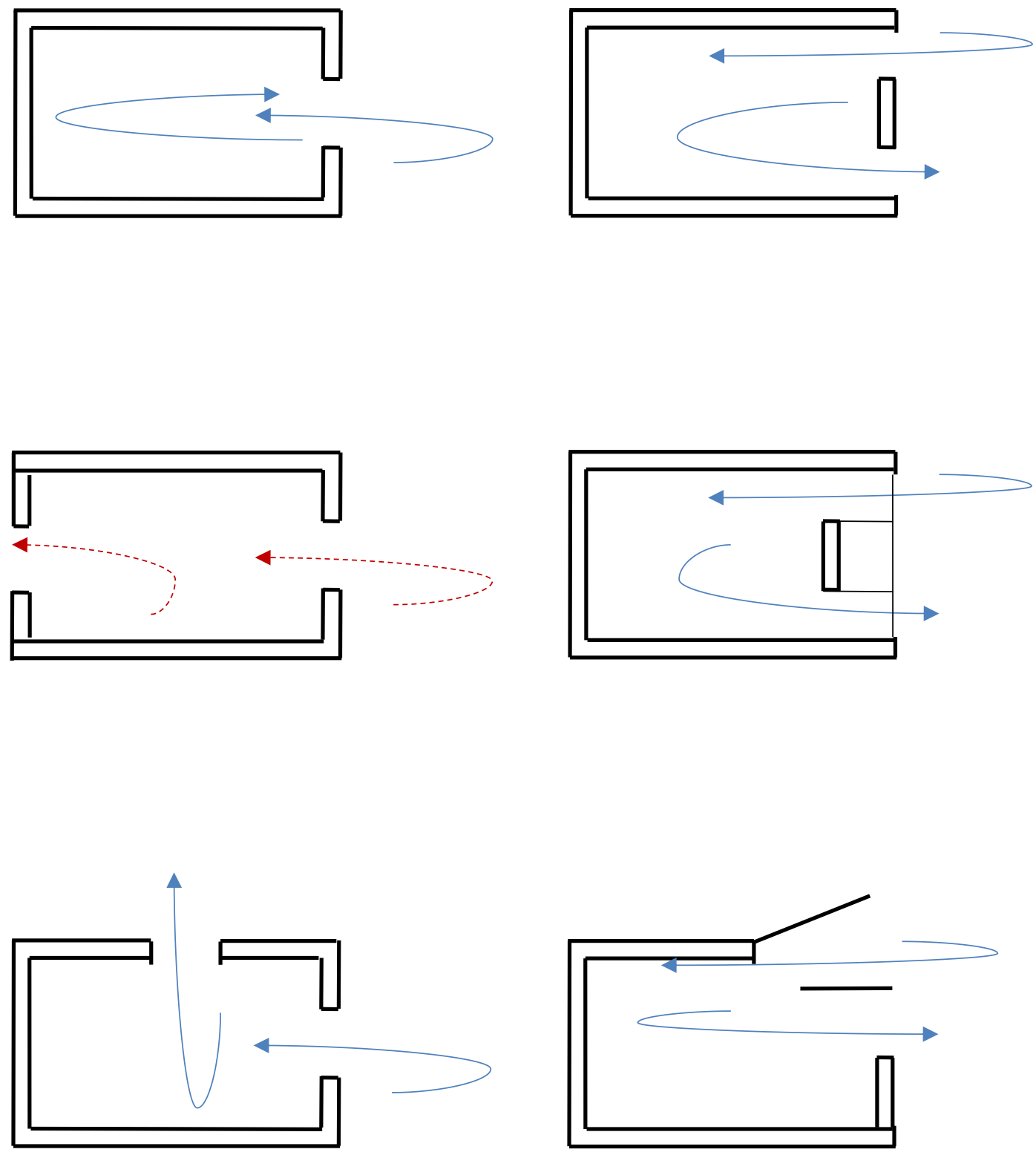

Figura 146. Mundësitë e ventilimit natyror (Burimi): Bujar Bajçinovci. 2015. 


\subsubsection{Ventilimi në parim të oxhakut}

Ventilimi i oxhakut dhe parimi Bernoulli, lloje të ventilimit pasiv që përdorin dallimet e presionit të ajrit për shkak të lartësisë. Presionet e ulëta dhe të larta në ndërtesë ndihmojnë në tërheqjen ajrit lartë.

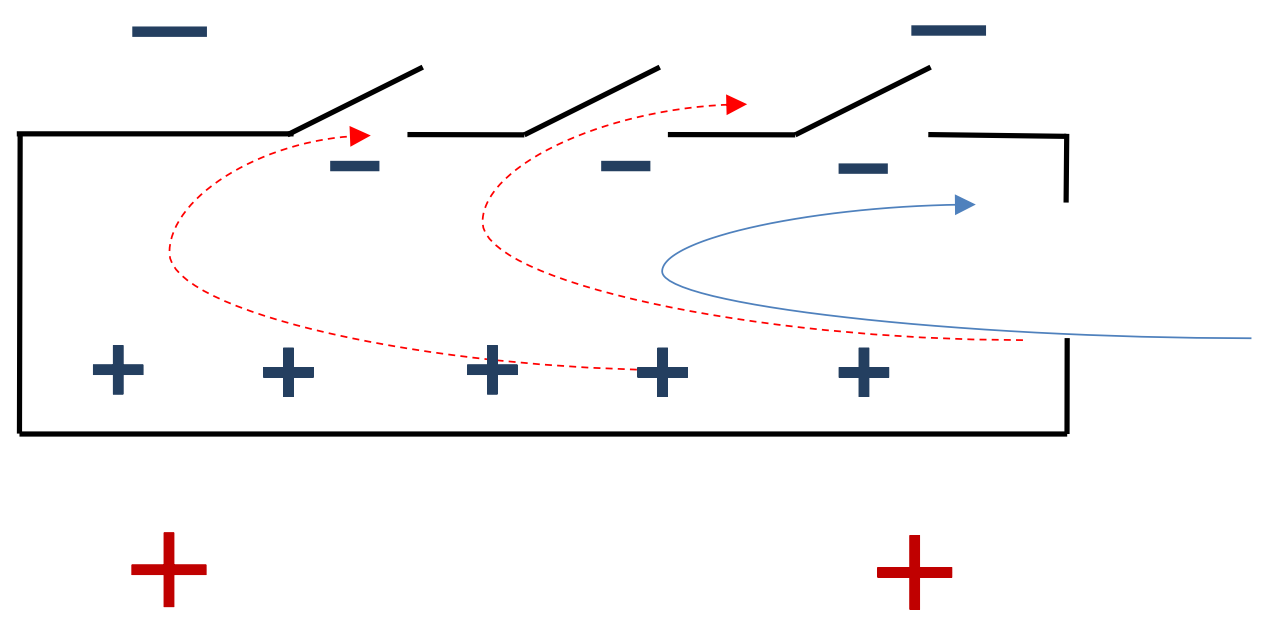

Figura 147. Mundësitë e ventilimit natyror (Burimi): Bujar Bajcinovci. 2015.

Parimi Bernoulli, përdor dallimet e shpejtësisë së erës për të lëvizur ajrin. Ky është një parim i përgjithshëm në dinamikën e fluideve. Nga aspekti arkitektonik, këto parime mund të shfrytëzohen në situata të përgjithshme kur adresojmë parime të projektimit të qëndrueshëm. Andaj diferencat në presion ndihmojnë në lëvizjen e ajrit të pastër në hapësirat e ndërtesës. Një ndërtesë mund të shfrytëzojë në masë të madhe këtë strategji, duke kursyer më shumë energji.

Avantazhi i parimit Bernoulli është se kjo metodë në procesin e projektimit shumëfishon efektivitetin e ventilimit natyror. Në të shumtën e rasteve, projektimi për një mënyrë efektive nënkupton implementimin e të dy strategjive.

Figura 148. Efekti në lëvizjen e ajrit brenda dhe jashtë ndërtesave (Burimi): Bujar bajçinovci, 2017. 
Në të dy strategjitë, ajri i ftohtë hyn në hapje të ulëta dhe lëvizja e ajrit shkon nëpërmjet hapjeve të lart. Shkalla e ventilimit është proporcionale me fushën e hapjeve. Vendosja e hapjeve në fund dhe në krye të një hapësirë do të inkurajojë ventilim natyror. Hapjet në krye dhe në fund duhet të jetë afërsisht të së njëjtës madhësi për të optimizuar rrjedhjen e ajrit përmes hapësirës vertikale.

Për të projektuar për këto efekte, konsiderata më e rëndësishme është që të ketë një ndryshim të madh në lartësi, në mes fillimit dhe fundit të kanalit. Sa më i madh të jetë ndryshimi, aq më mirë.

Kullat dhe oxhaqet mund të jenë të dobishme për të larguar ajrin jashtë, ose si elemente për ndriçim zenital në ndërtesa më dimensione modeste. Por këto strategji duhet llogaritur qysh në fillim të procesit projektues, duke potencuar në lëvizjen e ajrit në mes niveleve të ndërtesës. Ndërtesat shumëkatëshe duhet të kenë atria vertikale apo hapësira/boshte që mundësojnë qarkullimin e ajrit me këto parime në kate të ndryshme.

Ndriçimi diellor mund të përdoret për të rritur efektin e ventilimit në hapësirat e larta të hapura. Duke i lejuar rrezatimit diellor përmes sipërfaqeve të dedikuara enkas të fensteruara në kulm që të nxejnë sipërfaqet e brendshme, ashtu duke rritur temperaturën në hapësira e cila do të përshpejtojë efektin e ventilimit natyror, me hapje në lartësi dhe në fund.

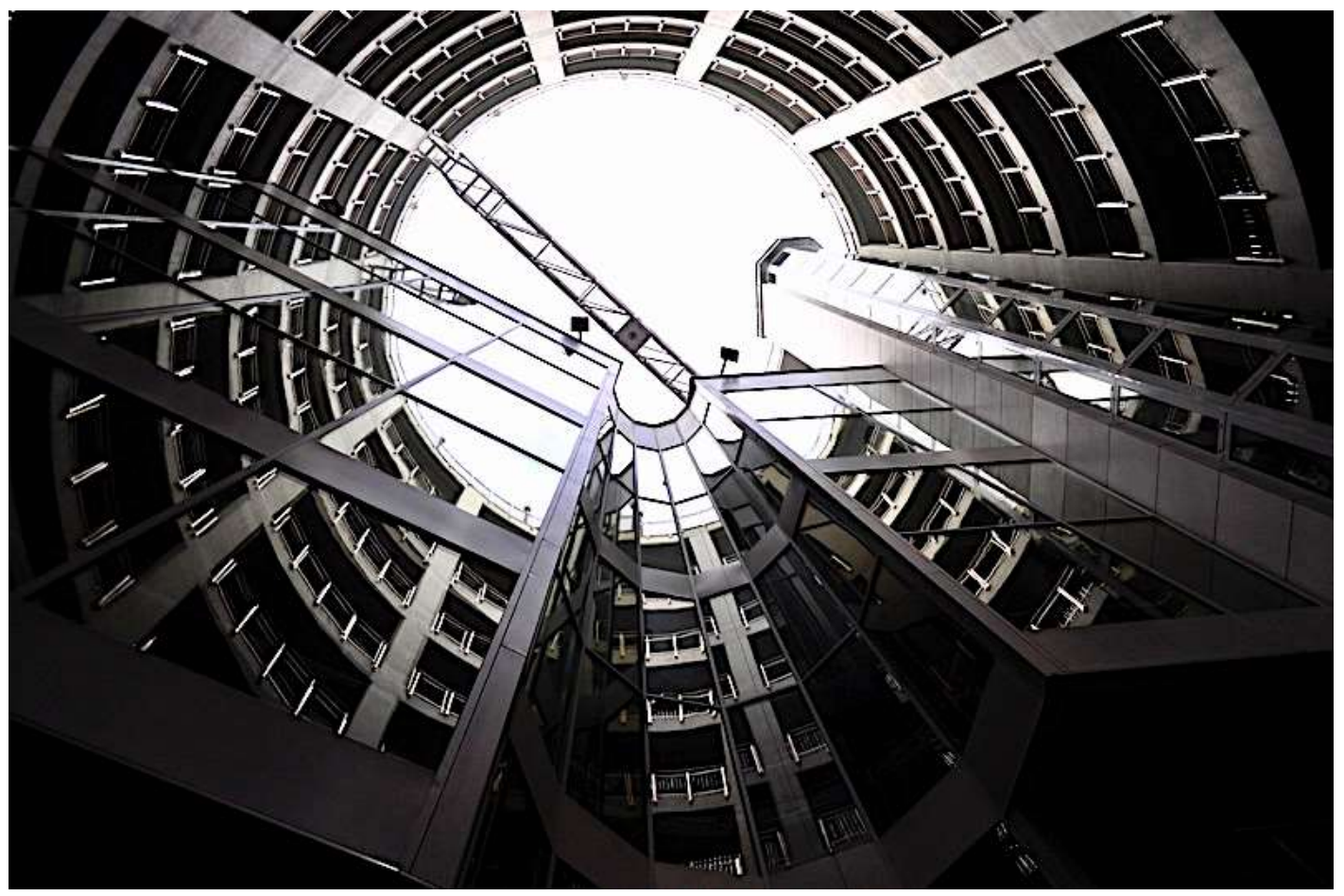

Figura 149. Hapësirë e "re" në oxhakun e termocentralit. Lodz Poland. 2015. (Burimi): IrDA, 2015. E licensuar nga Commons Attribution ShareAlike 2.0. 


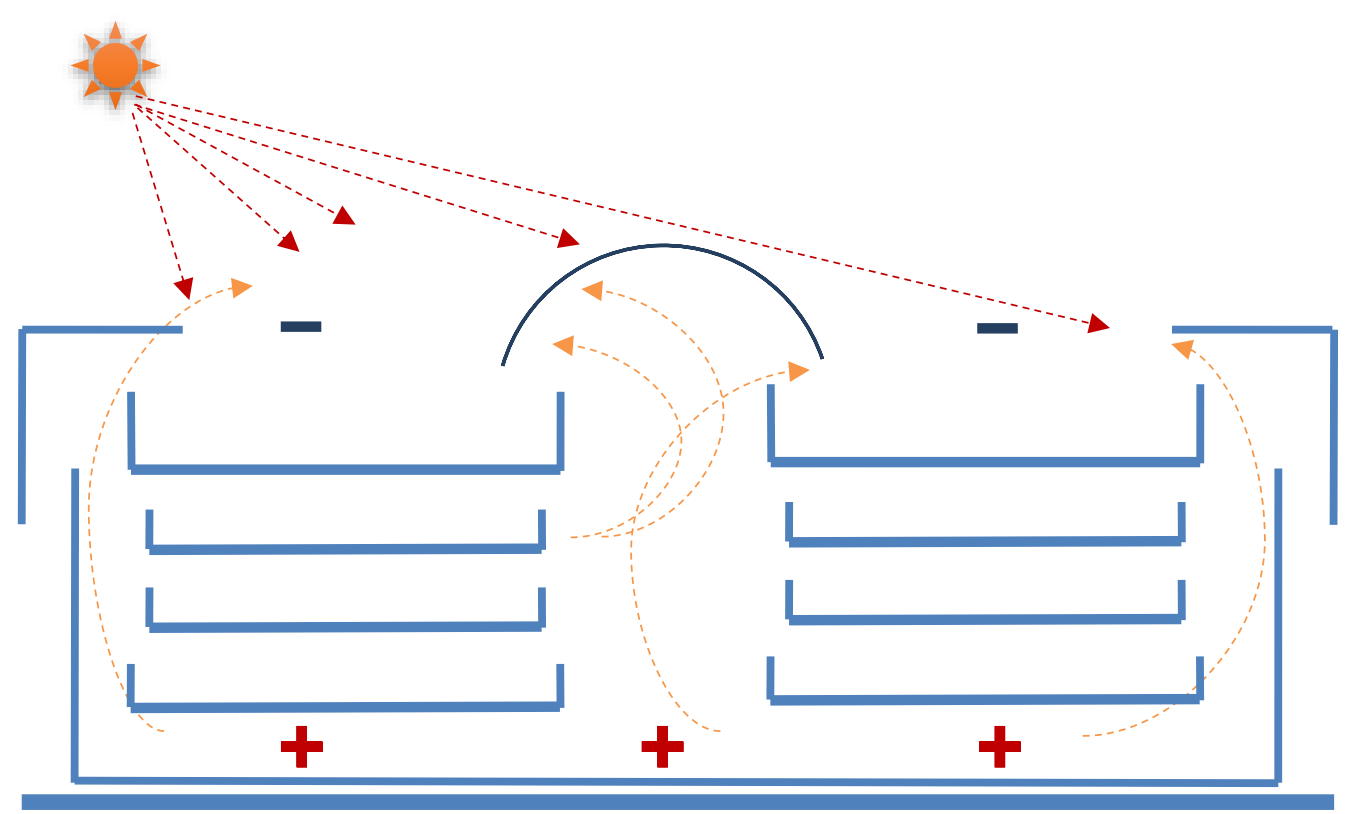

Figura 150. Parimi i Bernouli-it, në objekte bashkëkohore Arkitektonike (Burimi): Bujar Bajçinovci. 2015.

\begin{tabular}{c|cc} 
Shpejtësia e Erës $[\mathrm{m} / \mathrm{s}]$ & Presioni $[\mathrm{Pa}]$ & Depresioni $[\mathrm{Pa}]$ \\
\hline 2 & 3 & 1 \\
\hline 5 & 16 & 5 \\
\hline 10 & 66 & 23
\end{tabular}

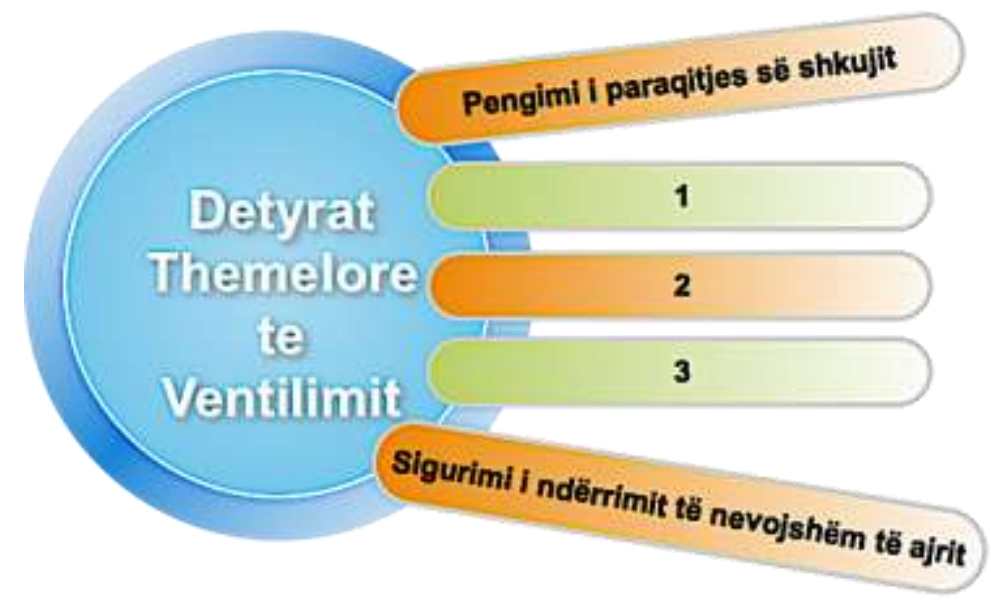

Figura 150-a. Vlerat aproksimative e shtypjes së erës. Detyrat themelore. (Burimi): Bujar Bajçinovci.2015. 


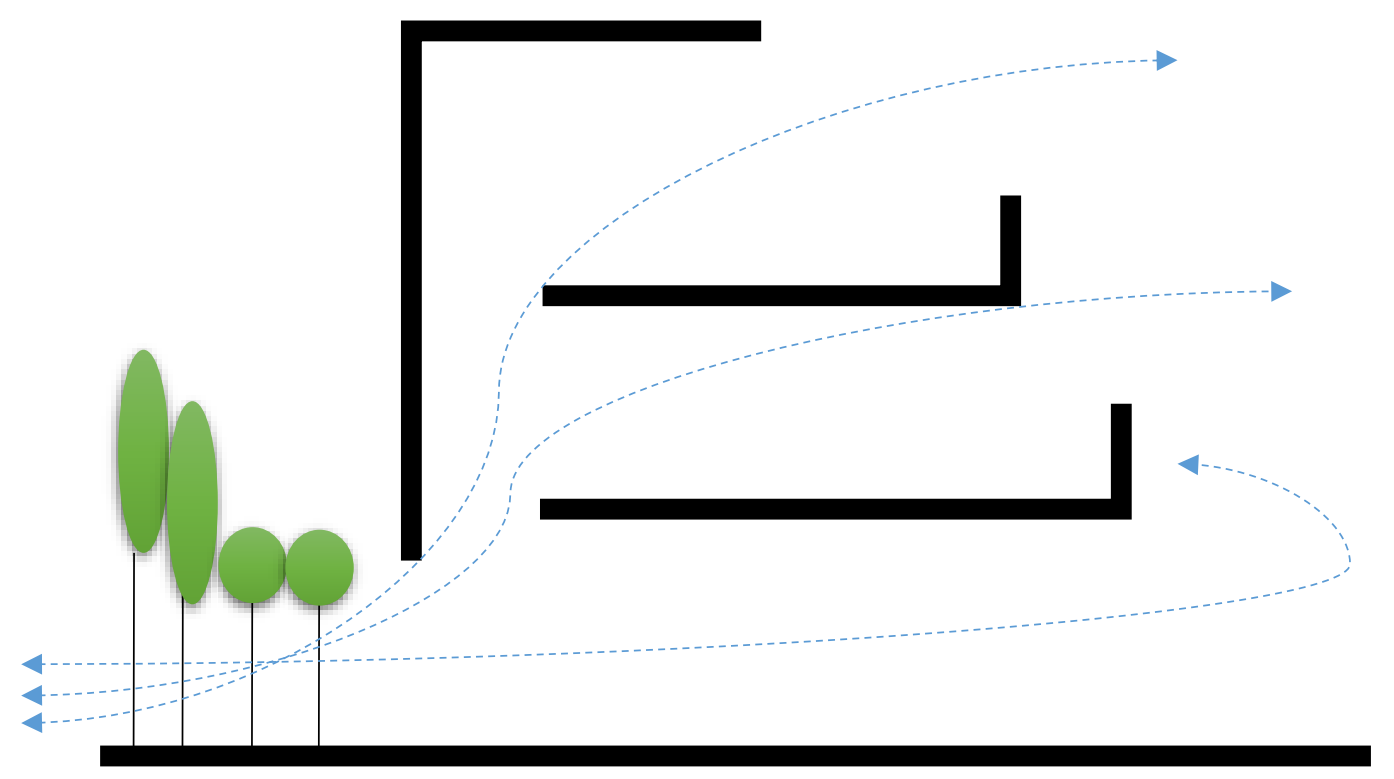

Figura 150-b. Parimet e projektimit, ventilimi. (Burimi): Bujar Bajçinovci, 2017.

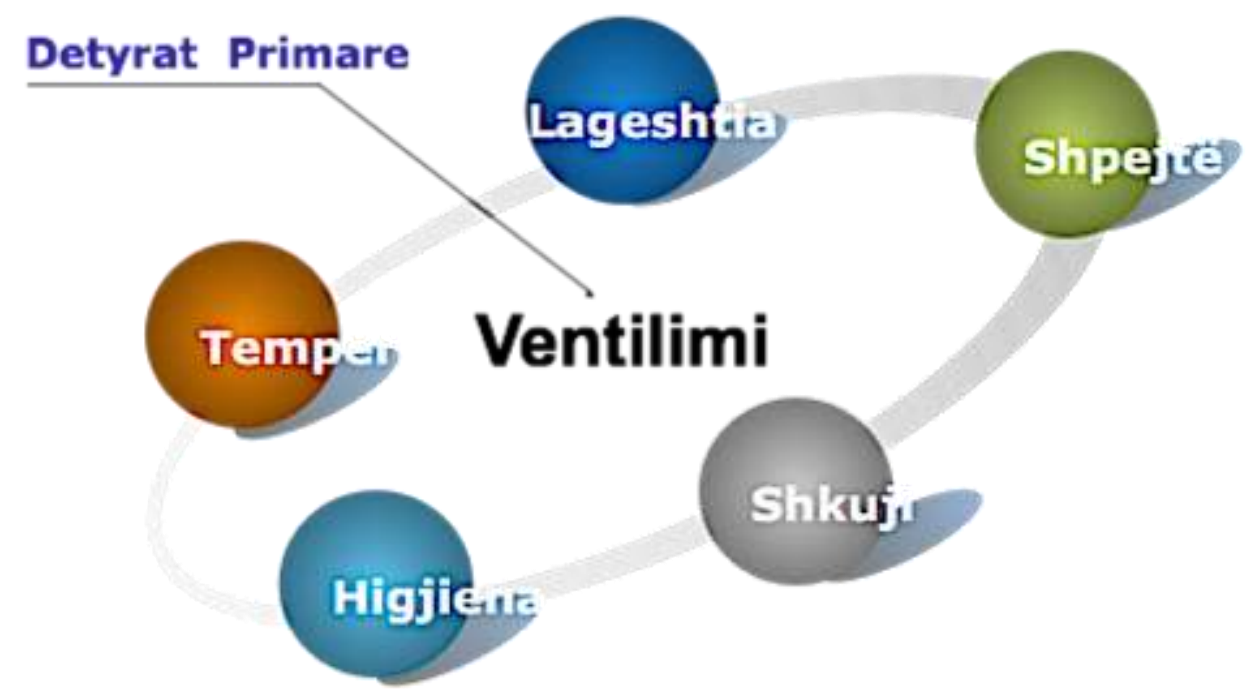

Figura 150-c. Detyrat primare të ventilimit (Burimi): Bujar Bajçinovci, 2015.

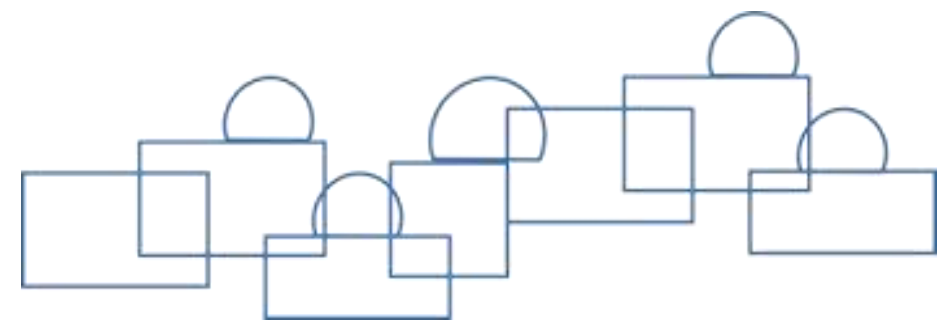




\subsubsection{Ftohja - lagështimi i ajrit}

Në vendet me klimë shumë të nxehtë, shpesh është e nevojshme për të parandaluar ngrohjen e ajrit në ndërtesë, megjithatë, ventilimi natyror mund të jetë një opsion në klimat e nxehta, veçanërisht në klimat e nxehta dhe të thata. Në këto raste dy parime mund të përdoren: duke rritur lëvizjen e ajrit, si dhe parimi i ftohjes pasive, kontrollimi për aq sa është e mundur për ftohje të ajrit gjatë hyrjes në strukturën arkitektonike. Lëvizja më e shpejtë e ajrit në lëkurën e njerëzve ndihmon për shkak se ajo inkurajon avullimin e djersës, duke na bërë që të ndihemi me komfor në temperatura më të larta se sa ato normale. Duhet veçuar se kondicionimi apo ventilimi pasiv mund të arrihet atëherë kur në "hyrje" para se ajri të është tërhequr në ndërtesë, të ftohet me avullues apo lagështues.

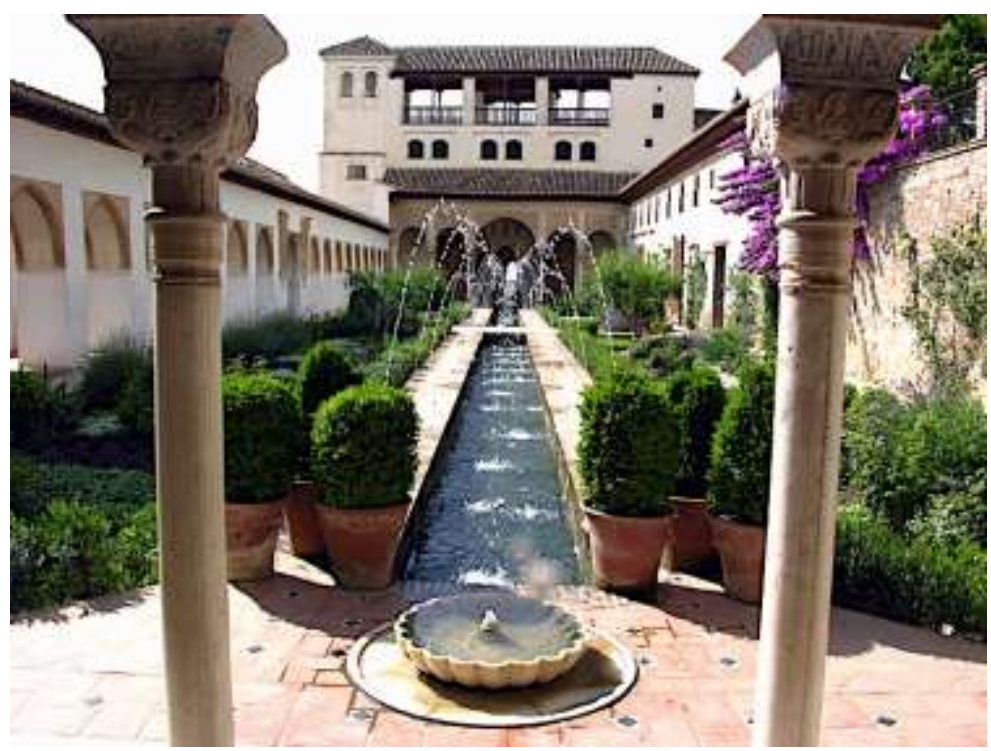

Figura 151. Alhambra, Spanjë. Oborri i brendshëm - krijimi i mikroklimës (Burimi): Loizeitung, 2006. WP. (Flickr). E licensuar nga Commons Attribution ShareAlike. 2.0

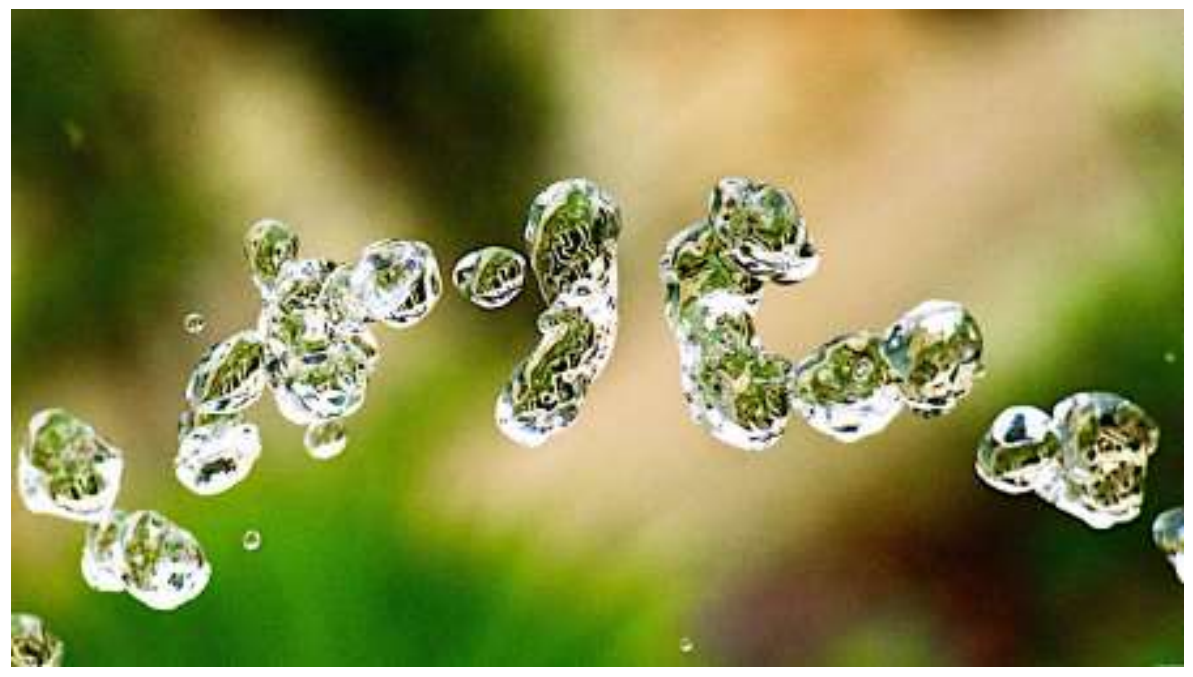

Figura 151-a. Pika uji, lagështimi i ajrit.

(Burimi): andreysuzdaltsev, 2015. (Flickr). E licensuar nga Commons Attribution ShareAlike. 2.0 


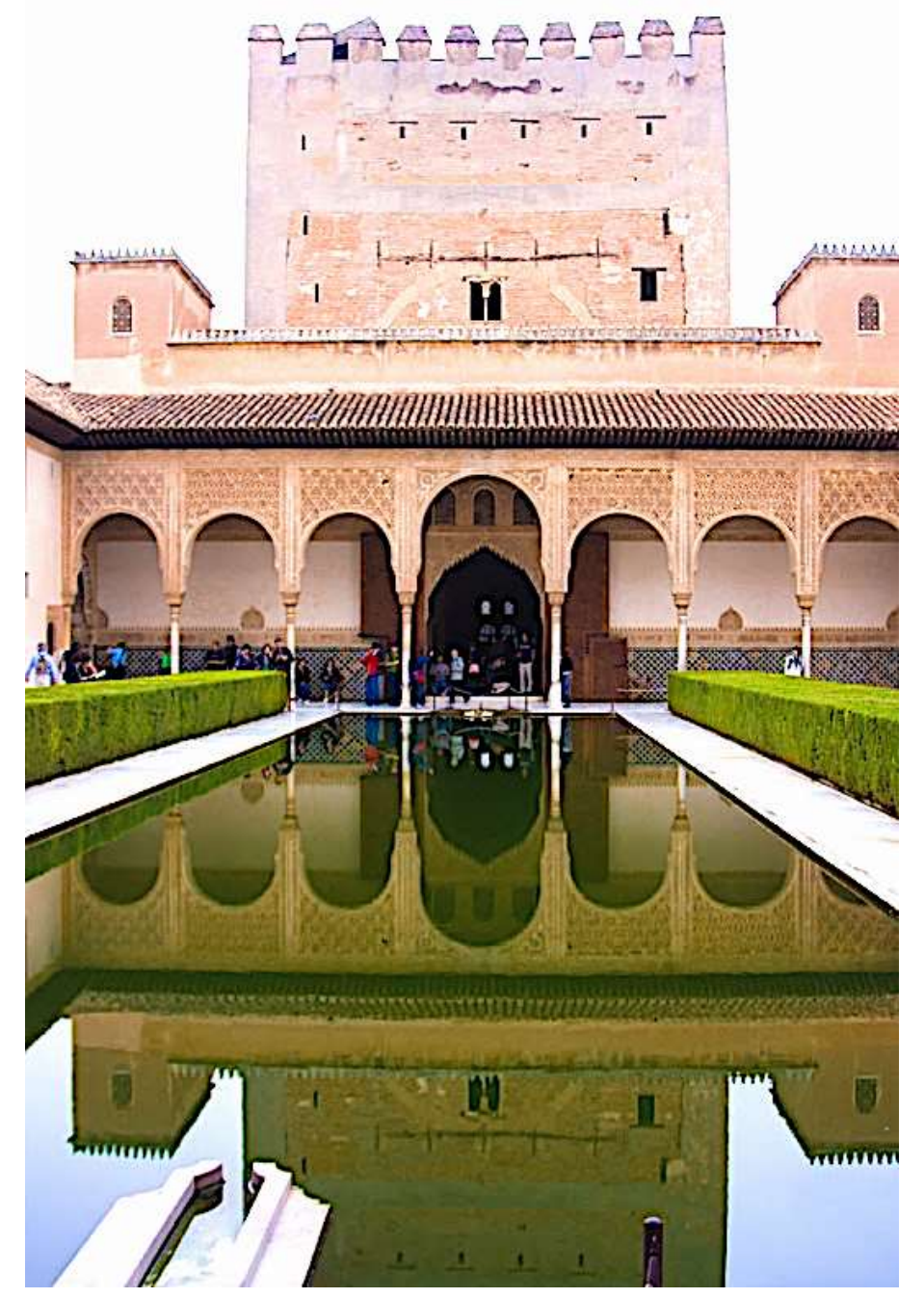

Figura 152. Alhambra, Spanjë. Oborri i brendshëm - krijimi i mikroklimës (Burimi): Colin Moss, 2008. (Flickr). E licensuar nga Commons Attribution ShareAlike 2.0

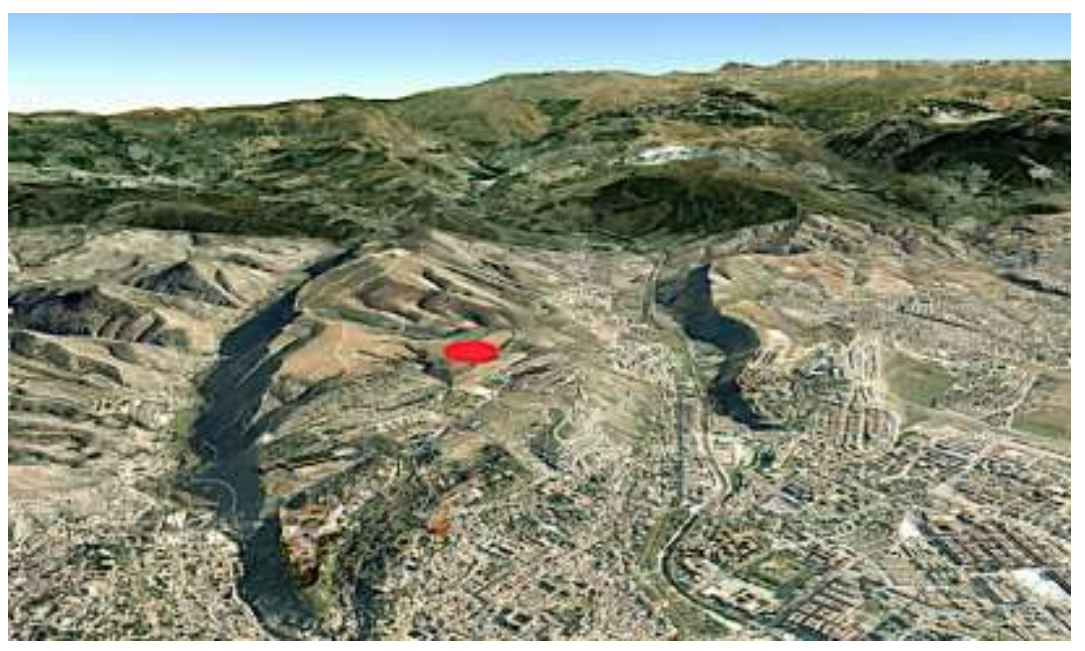

Figura53.Alhambra, Spanjë. Morfologjia - Klima (Burimi): Bujar Bajçinovc, GoogleEarth. 2011. 


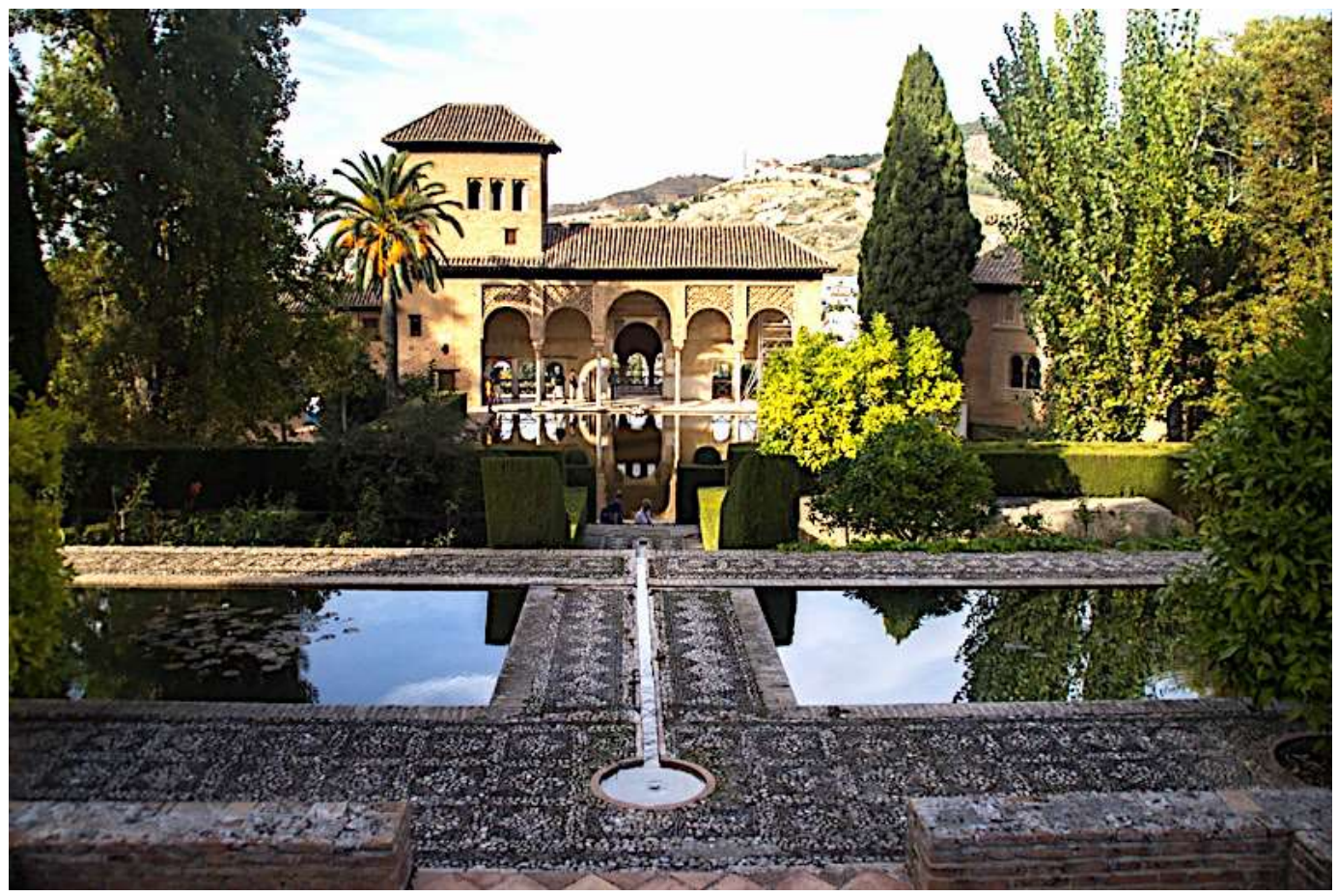

Figura 154. Alhambra, Spanjë. Oborri i brendshëm - krijimi i mikroklimës (Burimi): Sebastian Appelt, 2014. (Flickr). E licensuar nga Commons Attribution ShareAlike, 4.0

Oborri i brendshëm "Patio" merr pozicionin e qarkullimit të erërave dhe ventilimit lokal. Muret e trasha të ndërtesës janë të projektuara për të ruajtur energjinë (grumbulluar) për ngrohje të strukturës gjatë periudhave të ftohta, dhe e kundërta, pjesa e brendshme është e mbrojtur nga dielli në sezonin veror. Patio i brendshëm vepron si një orë diellore, në çdo kohë të ditës mund ta gjeni një vend të rehatshëm ku dielli luan rrezet e tij nëpër çati të hapur. Gjithashtu kopshti vepron si një tubë i hapur për ajër të ftohtë gjatë natës si dhe ftohja e cila shpërndahet në orët e para të mëngjesit në dhomat përreth. Gjatë ditës, kur dielli fillon të ndërhyjë në oborrin e brendshëm, struktura e oborrit vepron si një hapësirë për qarkullimin e ajrit të ndenjur të nxehtë, nga ana e dhomave periferike.

Vetëm materialet lokale autoktone janë të përdorura, guri dhe druri, për të ndërtuar oborrin e brendshëm, si dhe njësitë e tjera funksionale të pallatit. Oborri i brendshëm shpesh herë është trajtuar si një hapësirë vetë freskuese dhe atmosferë për relaksim.

Trashësia e mureve, ngjyrat e bardha, reflektojnë rrezet e nxehta të verës dhe izolojnë hapësirat e brendshme, duke rezultuar me ajër të freskët nga jashtë. Hapjet e vogla në mure të cilat përballen me erërat mbizotëruese, të cilat mundësojnë dhe realizojnë hyrjen e drejtpërdrejt të ajrit të freskët. Këto hapje të vogla shtrihen direkt mbi kopshtet dhe fontanat të cilat rrisin përqindjen e lagështisë në ajër dhe në të njëjtën kohë filtrojnë grimcat në ajër. Për pozicionin urban, Alhambra gjendet mbi 150 metra nga qyteti i Granadës, po ashtu shumica e kopshteve të brendshme, oborret dhe pavijonet fshikullohen nga kreshtat e maleve, ku rënia e ajrit të freskuar vjen nga një lartësi dhe përshpejtohet në shpatet e niveleve të mëposhtme. 
Ide mahnitëse dhe origjinale, ku arkitektët janë frymëzuar me mundësinë e rrjedhjes së erës në principet e ftohjes pasive, "ajër i kondicionuar" ajër natyror pa emetim të gazrave serë! Përdorimi i bollshëm i ujit në kopshtet e Alhambras gjithashtu ka kontribuar në mikroklimën lokale. Uji që ishte i derdhur nëpër kanale të kopshteve kishte krijuar ambiente freskuese relaksuese. Përdorimi i pllakave qeramike kishte thelluar perceptimin e thellësisë së pishinës, efekti psikologjik për freski dhe ftohje ishte edhe më i madh. Teknika në përdorimin e ujit ishte metodë specialiteti Maur i mbledhjes së ujit në klima relativisht të thata. Burimet ujore ishin të numëruara në përgjithësi si dhe përdorimi $\mathrm{i}$ burimeve nëntokësore të ujit për shkak se ato ishin në dispozicion gjatë gjithë vitit, gjersa lumenjtë ishin tharë shpesh në verë.

Maurët po ashtu sollën ujë nga burimet malore duke përdorur ujësjellës të hollë me rrugë të gjarpëruara duke përdorur gravitetin, të kalibruara në mënyrë të përkryer. Andaj, shpejtësia e ujit ishte optimale, jo shumë e shpejt për t'u derdhur as shumë e ngadaltë për tu tharë. Gjithashtu në shekullin e X, në një kohë kur asnjë qytet tjetër nuk i kalonte mbi 10.000 banorë, Cordoba ishte e banuar me gjysme milioni njerëz të cilët kishin sistemin më të avancuar të ujësjellësit në botë.

Rrjeti i dendur i pemëve dhe i luleve, prodhimi i frutave, hijezimi i hapësirave për banorët e Alhambras, fontanat dhe pishinat të cilat mbajtshin një rrjedhë të qëndrueshme të ajrit të lagësht për ftohje, i cili u pasuronte me oksigjen gjatë qarkullimi nëpër pemë, po ashtu gjethet e mëdha të gjelbra kontribuonin në lojën e përgjithshëm të dritës dhe të hijes. Këto ishin parimet pasive të projektimit të qëndrueshëm të realizuara në praktikë në mënyrë perfekte, duke mos harruar për periudhën e ardhjes së Maurëve në Spanjë dhe teknologjitë e ndërtimit të njohura në atë kohë.

Në këtë nivel të dimensioneve natyrore dhe të kufijve, të qëndrueshmërisë në kulturat tradicionale shpesh hasim në marrëdhënie shumë të mira në mes objekteve, materialeve dhe mjedisit, vlerave kulturore, besimeve si dhe stilit të jetës. Traditat dhe trashëgimia kulturore mund të jenë një shembull $i$ mirë se si duhet jetuar në një mënyrë më të qëndrueshme. Ne mund të mësojmë nga dizajni i përdorur, të cilët mund të na japin njohuri të duhura në larminë dhe pasurinë e diversitetit lokal. (Hadrovic, A. 2004)

\subsubsection{Ngrohja/Ftohja - Energjia gjeotermale}

Energjia gjeotermike, si energji që del nga toka dhe që nuk emeton gazra të cilët e ndotin ambientin, hyn në kategorinë e burimeve të ripërtërishme të energjisë. Në Kosovë, energjia gjeotermike ka filluar të përdoret vetëm viteve të fundit dhe niveli i investimeve në këtë lloj energjie është shumë i ulët dhe i kufizuar kryesisht në investime private.

Përkundër kostos së lartë fillestare që kërkon instalimi i sistemit gjeotermik, dobitë në një periudhë afatgjate i tejkalojnë këto kosto. Kthimi i investimeve në instalimin e sistemit gjeotermik llogaritet të jetë 4 deri në 5 vite, varësisht prej kapacitetit të instalimit.

Sipas një studimi të bërë nga Riinvesti, zëvendësimi i energjisë elektrike me atë gjeotermike do të rezultonte me një zvogëlim të shpenzimeve të ngrohjes për katër herë. Nëse një zëvendësim i tillë do të bëhej në nivel vendi, atëherë një pjesë e konsiderueshme e energjisë elektrike e cila do të përdorej për ngrohje do të mund të kursehej. 
Bërthama e tokës është shumë e nxehtë, e nxehtë e mjaftueshme për të shkrirë shkëmbinjët. Energjia gjeotermale rrjedh nga një përçueshmëri e vazhdueshme e ngrohjes nga bërthama në sipërfaqe. Shkencëtarët pohojnë teorikisht, se burimet gjeotermale e Tokës janë më se të mjaftueshme për të furnizuar nevojat për energji të njerëzimit.

Gjithashtu, hulumtimet vlerësojnë se për çdo 30m', që do të shkojmë poshtë nga niveli i tokës, temperatura do të ngritët për $1^{\circ} \mathrm{C}$. Nxehtësia e tokës është një burim i rinovueshëm i energjisë që mund te përdoret për të gjeneruar energji elektrike dhe për të kontrolluar temperaturat në ndërtesa. Duke instaluar tuba të mbushura me ujë, temperatura nëntokësore mund të transferohen në sipërfaqe dhe në hapësira arkitektonike për shumë qëllime. Andaj, është më së e volitshme për tu përdorur në përgjithësi në dimër për temperatura të ulëta, dhe në verë duke mundësuarr transferimin e nxehtësisë për ftohje.

Këto lloje të shkëmbimit të energjisë, për tu ngrohur apo ftohur, mund të jenë të dobishme në ruajtjen e temperaturës së brendshme të ndërtesave. Të njëjtat parime gjeotermale mund të përdoren në të gjitha rastet e ngjashme të paraqitura për të ngrohë apo për të ftohë. Energjia gjeotermale direkte është përdorur për mijëra vite në disa vende dhe shtete, e përdorur kryesisht për gatim dhe ngrohje. Në vende të vullkaneve aktive si Zelanda e Re dhe Islanda energjia gjeotermale është një burim i rinovueshëm për prodhimin e energjisë elektrike dhe i përdorimit të ujit të nxehtë. Energjia e prodhuar mund të përdoret për shumë qëllime, duke përfshirë për ajër të kondicionuar, duke zvogëluar varësinë nga lëndët djegëse fosile.

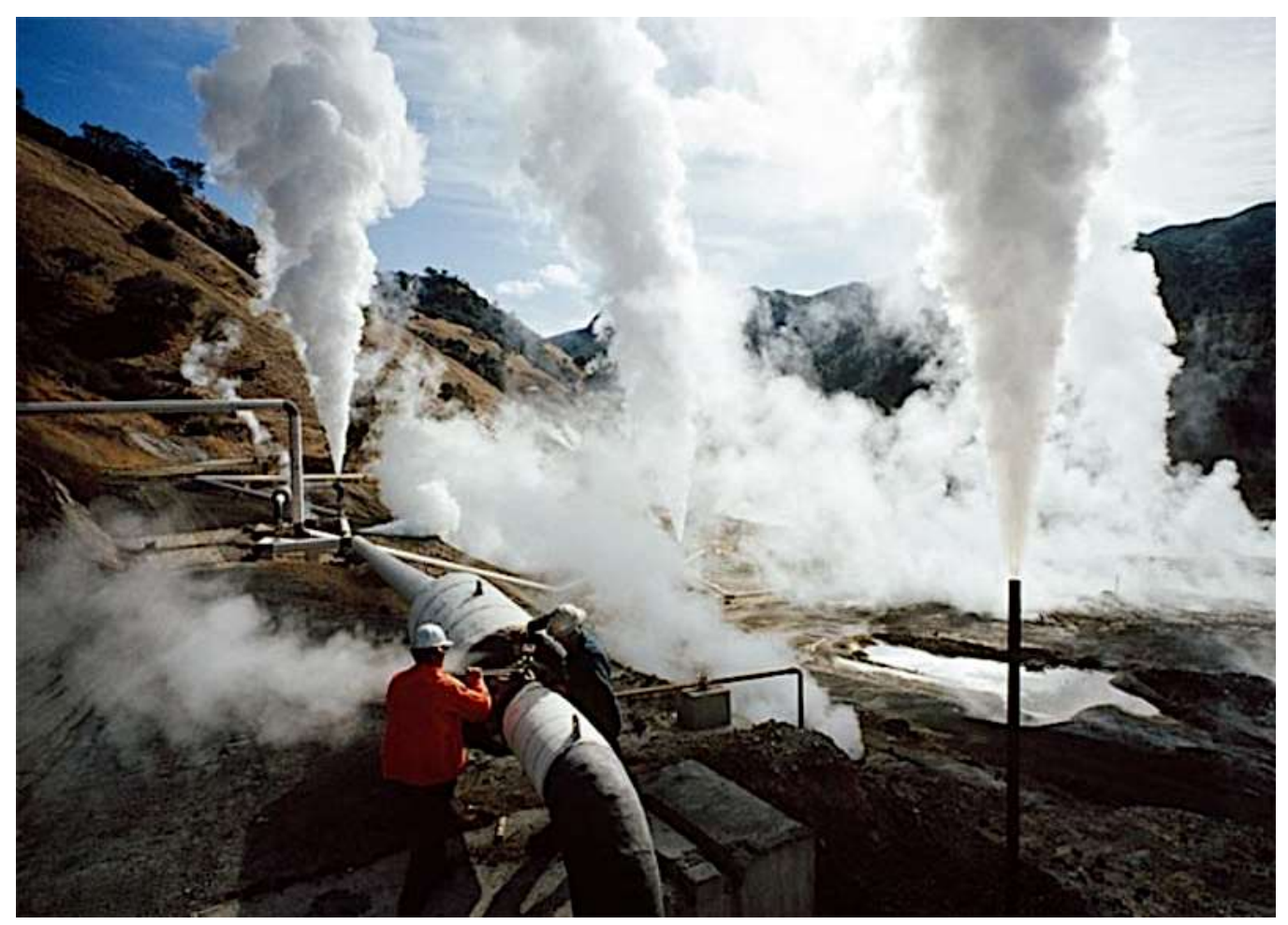

Figura 155. Energjia gjeotermale, detaje nga lokacioni

(Burimi): SHERK, Shoqata për Energji të Ripërtëritshme e Kosovës, 2015. 


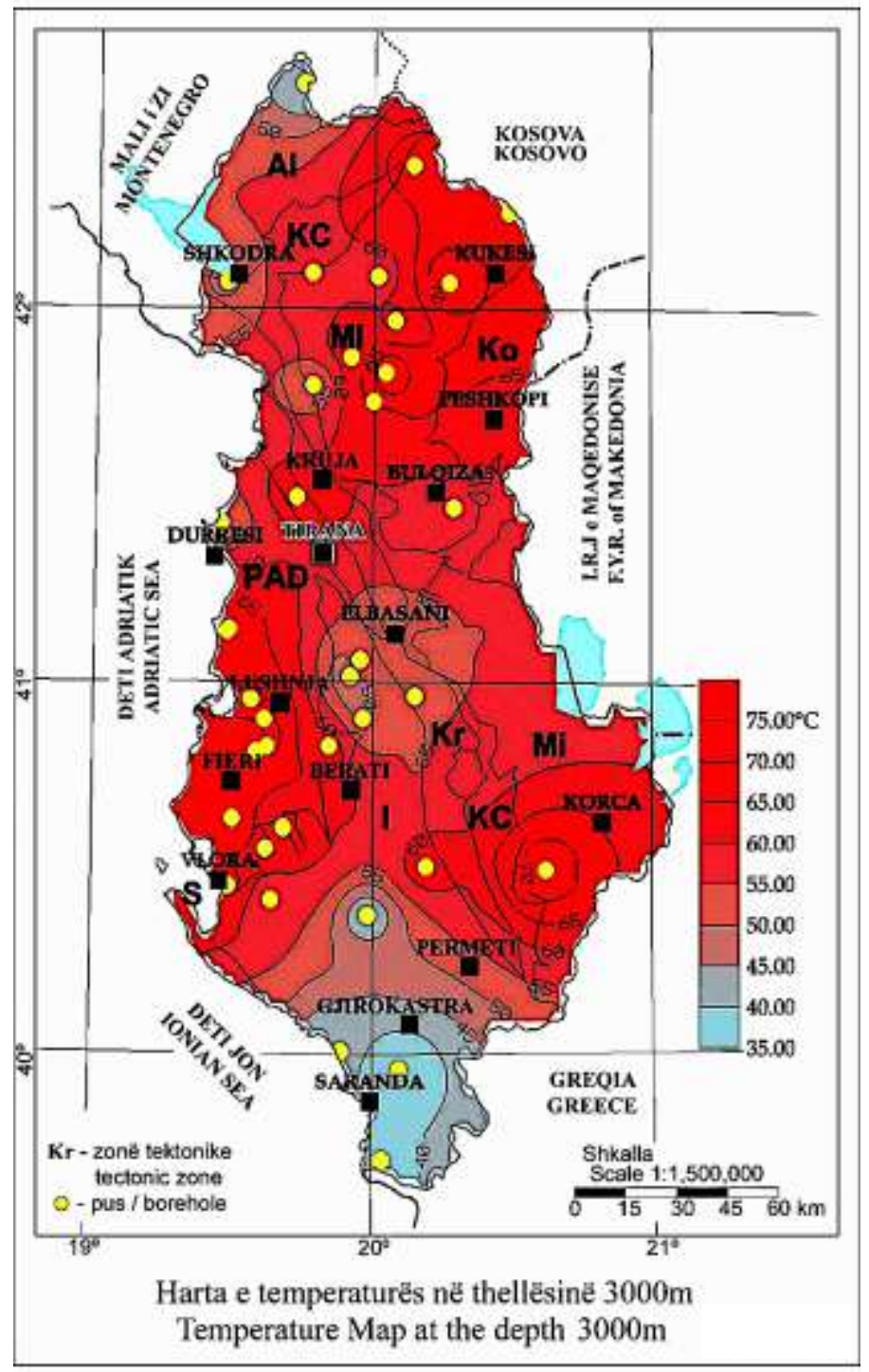

Figura 156. Harta e temperaturës, gjeotermale, thellësi $3000 \mathrm{~m}$

(Burimi): Alfred Frashëri, Nevton Kodhelaj, 2010. Burimet e energjisë gjeotermale në Shqipëri dhe platformë për përdorimin e tyre.

Parametrat e energjisë gjeotermale. Sipas autorëve në tërësi: Alfred Frashëri, Nevton Kodhelaj, 2010, shembull i prezantuar për llogaritje për studentët. (Ekstrakt) ${ }^{92}$

"Kapaciteti i instalueshëm (K):

$\mathrm{K}=\mathrm{R}_{\max }\left(\mathrm{t}_{\mathrm{h}}-\mathrm{t}_{\mathrm{d}}\right) \times 0.004184 \mathrm{në}$

$[\mathrm{kW}]$

ku: K - kapaciteti termik i instalueshëm, në $\mathrm{kW}$

Rmax - madhësia e rrjedhjes maksimale të ujit termal, në kg/s

th $\quad$ - temperature në hyrje, në ${ }^{\circ} \mathrm{C}$

td $\quad$ - temperature në dalje, në ${ }^{\circ} \mathrm{C}$

92 Alfred Frashëri, Nevton Kodhelaj, 2010. Burimet e energjisë gjeotermale në Shqipëri dhe platformë për përdorimin e tyre. 
Nëse fluidi është avull (pra njëfazor) ose edhe dy fazor përllogaritjet bëhen sipas madhësisë së entalpisë:

$\mathrm{K}=\mathrm{R}_{\max }\left(\mathrm{e}_{\mathrm{h}}-\mathrm{e}_{\mathrm{d}}\right) \times 0.004184$ në

$[\mathrm{kW}]$

ku: K- - kapaciteti termik, në $[\mathrm{kW}]$

Rmax - pruarja maksimale të ujit termal, në kg/s

ih $\quad$ - entalpia në hyrje, në $\mathrm{kJ} / \mathrm{kg}$

id - entalpia në dalje, në $\mathrm{kJ} / \mathrm{kg}$

Energjia vjetore e shfrytëzuar (Ev):

$\mathrm{E}_{\mathrm{v}}=\mathrm{R}_{\mathrm{mes}}\left(\mathrm{t}_{\mathrm{h}}-\mathrm{t}_{\mathrm{d}}\right) \times 0.01319$ në

$\mathrm{ku}:$

Ev - energjia vjetore e shfrytëzuar, në TJ/vit

Rmes - madhësia e rrjedhjes mesatare e ujit termal, në $\mathrm{kg} / \mathrm{s}$

th $\quad$ - temperature në hyrje, në ${ }^{\circ} \mathrm{C}$

td $\quad$ - temperature në dalje, në ${ }^{\circ} \mathrm{C}$

Nëse fluidi është avull (pra njëfazor) ose edhe dy fazor përllogaritjet bëhen sipas madhësisë së entalpisë:

$E_{v}=R_{\text {mes }}\left(t_{h}-t_{d}\right) \times 0.03154$ në në [TJ/vit $]$

ku:Ev - energjia vjetore e shfrytëzuar, në TJ/vit

Rmax - madhësia e rrjedhjes maksimale të ujit termal, në kg/s

eh - entalpia në hyrje, në KJ/kg

ed - entalpia në dalje, në $\mathrm{KJ} / \mathrm{kg}$

Faktori kapacitiv $(\mathrm{Fc})$ është:

$$
\mathrm{Fc}=\frac{\mathrm{E}}{\mathrm{K}} \times 0.03171
$$

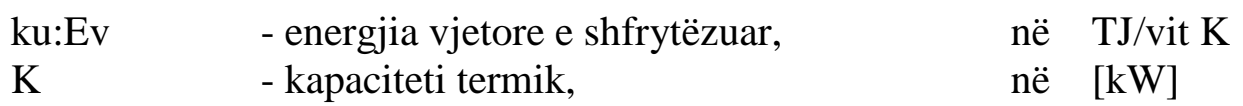

Faktori kapacitiv ka madhësi teorike më të vogël ose të barabartë me 1.00; por praktikisht është përherë më i vogël se 1.00 , përderisa projektet nuk funksionojnë me $100 \%$ të kapacitetit vjetor.

Koeficientit i performancës (COP) shprehet me raportin:

$$
\mathrm{COP}=\frac{\mathrm{Ed}}{\mathrm{Eh}}
$$

ku: Ed - Energjisë gjeotermale në dalje

Eh - Energjia gjeotermale në hyrje të kompresorit.

Për klimën konkrete të vendit, ky raport është i barabartë me ngarkesën e plotë për orët e punës, ose me Faktorin e kapacitetit $(\mathrm{Fc}) \times 8760 . "\left(\right.$ Ekstrakt) ${ }^{92}$ 
Sistemi i mbyllur i pompave të përdorur për shfrytëzimin e energjisë gjeotermike shfrytëzojë temperaturat tokësore për të ngrohur ose për të ftohur një ndërtesë. Edhe pse emri i këtij sistemi lë të kuptohet se është përdorur për ngrohje, ky sistem është edhe i kthyeshëm dhe mund të përdoret për ftohje. Ky lloj sistemi funksionon me pompa për ngrohje, përbëhet nga një cikël i mbyllur i avulli të komprimuar të lidhur me një këmbyes. Shumica e këtyre sistemeve janë të njohura si sisteme indirekte, që qarkullojnë nëpër gypa të mbyllur nëntokësor. Tubacionet për këtë lloj të sistemit përbëhen nga gypa vertikale dhe horizontal, gjenden nën tokë në varësi të temperaturës së terrenit dhe disponueshmërisë së tokës ndërtimore. Kur sipërfaqja e tokës ndërtimorë është e vogël ka kuptim për të përdorur tuba vertikale.

Temperaturat tokësore në terren janë shpesh më uniforme se temperatura e ajrit mbi tokë gjatë gjithë vitit, GCHP mund të veprojë me efikasitet më të lartë në krahasim me sistemet konvencionale elektrike. Ata mund të kursejnë 50-70 për qind të energjisë së ngrohjes, në varësi të kushteve klimatike, në krahasim me ngrohje elektrike. Kur ftohësi është i nevojshëm, sistemi do të prodhojë efikasitet të ngjashëm. Instalimi i kujdesshëm i spirales në terren është i nevojshëm për të siguruar që transferimi i vazhdueshëm dhe $i$ besueshëm i ngrohjes mbahet konstant.

Mirëmbajtja e nevojshme për këtë sistem është më pak se sa për një sistem tipik elektrikë, pasi që shumica e pjesëve nuk janë të ekspozuar ndaj përkeqësimit të motit. Me mirëmbajtje të mirë periodike këto sisteme mund të zgjasin 20-25 vite. Ky sistem zvogëlon përdorimin e lëndëve djegëse fosile, si dhe gjithashtu kontribuon në reduktimin e emisioneve të gazrave serë.

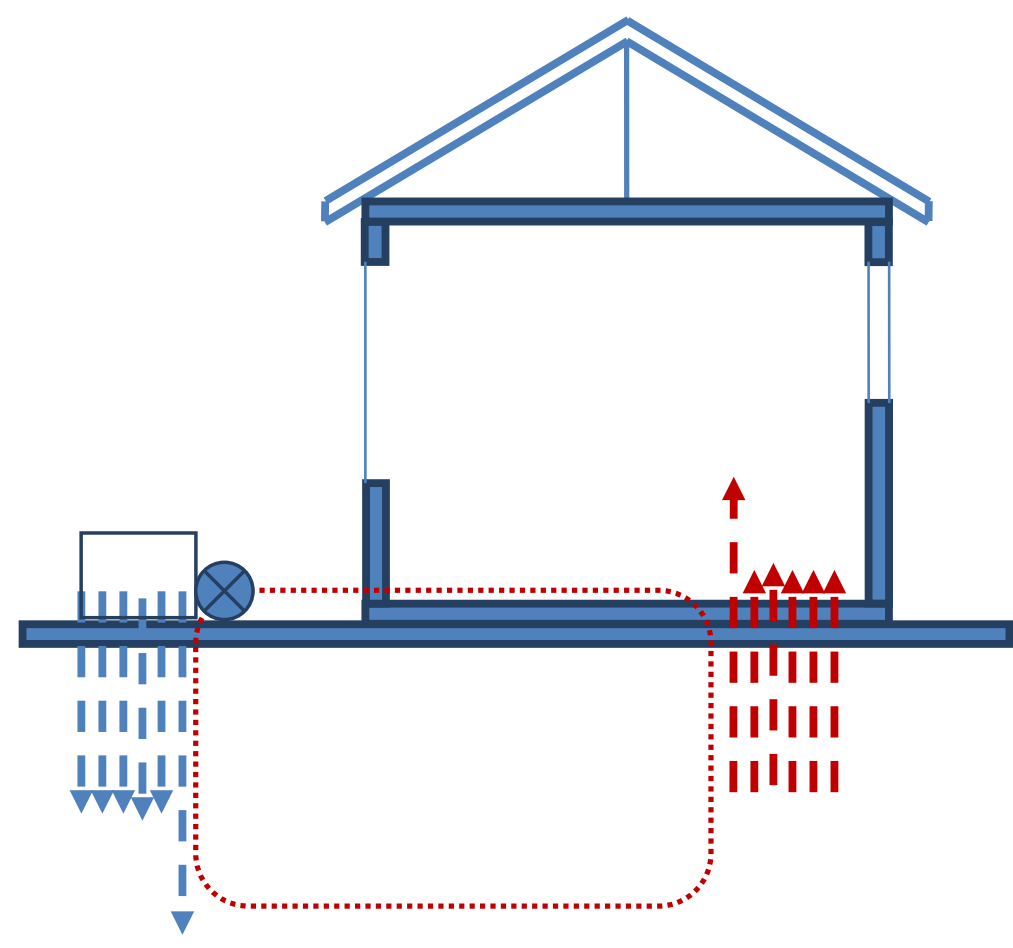

Figura 157. Sistemi funksional i ngrohjes pasive gjeotermale, sistem i mbyllur vertikal (Burimi): Bujar Bajçinovci. 2015. 
Resurset e energjisë në truall mund të shfrytëzohen pavarësisht nga moti i lig ose në cilëndo pjesë të ditës dhe është në disponim tanimë prej $1,2 \mathrm{~m}$ ' thellësi. Sistemi ofron zgjidhje të kompletuara sistemike për shfrytëzimin e gjeotermisë në shtresat e sipërme të sistemit të kolektorit, nëpërmjet ndarësve dhe pusetave, dhe deri te kyçja e pompës termike.

Avantazhet e shfrytëzimit të ngrohtësisë tokësore janë:

*Kursimi i energjisë gjatë ngrohjes dhe ftohjes deri në $75 \%$ me ngrohje tokësore falas *Burime të rinovueshme energjetike të pa varur nga moti i lig, çdo stinë vjetore ose cilëndo pjesë e ditës

*Zvogëlim i konsiderueshëm i lirimit të $\mathrm{CO}_{2}$

*Kombinimi optimal me ngrohje dhe kursimi në kushte të temperaturave të ulëta

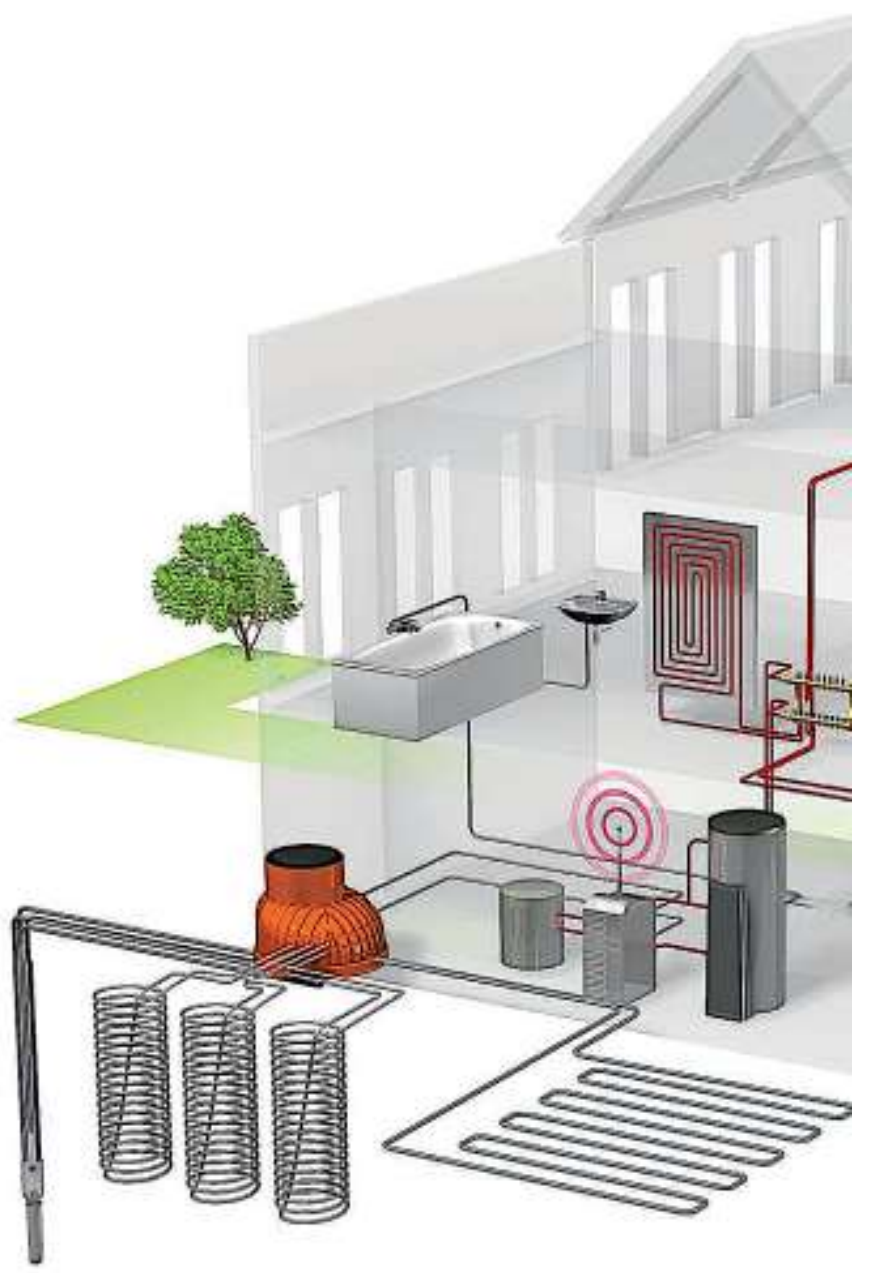

Figura 158. Projektim shumë/sistemesh. Gjeotermia (Burimi): () REHAU. Prospekt, 2011.

\subsubsection{Shtëpitë në tokë}

Shtëpitë në tokë, është praktika arkitektonike e përdorimit të tokës në cilësi të strehimit, pa mure të ndërtimit, për masë të jashtme termike. Duke reduktuar humbjen e nxehtësisë apo ftohtësisë, duke ruajtur një temperaturë të qëndrueshme në shtëpi. Strehimi në tokë është bërë relativisht më aktual dhe popullor në kohët moderne, veçanërisht në mesin e ambientalistëve dhe simpatizantëve të arkitekturës së qëndrueshme. Megjithatë, kjo mënyrë e ndërtimit dhe banimit ka qenë praktikë për gati sa kohë që njerëzit kanë kërkuar strehim. 


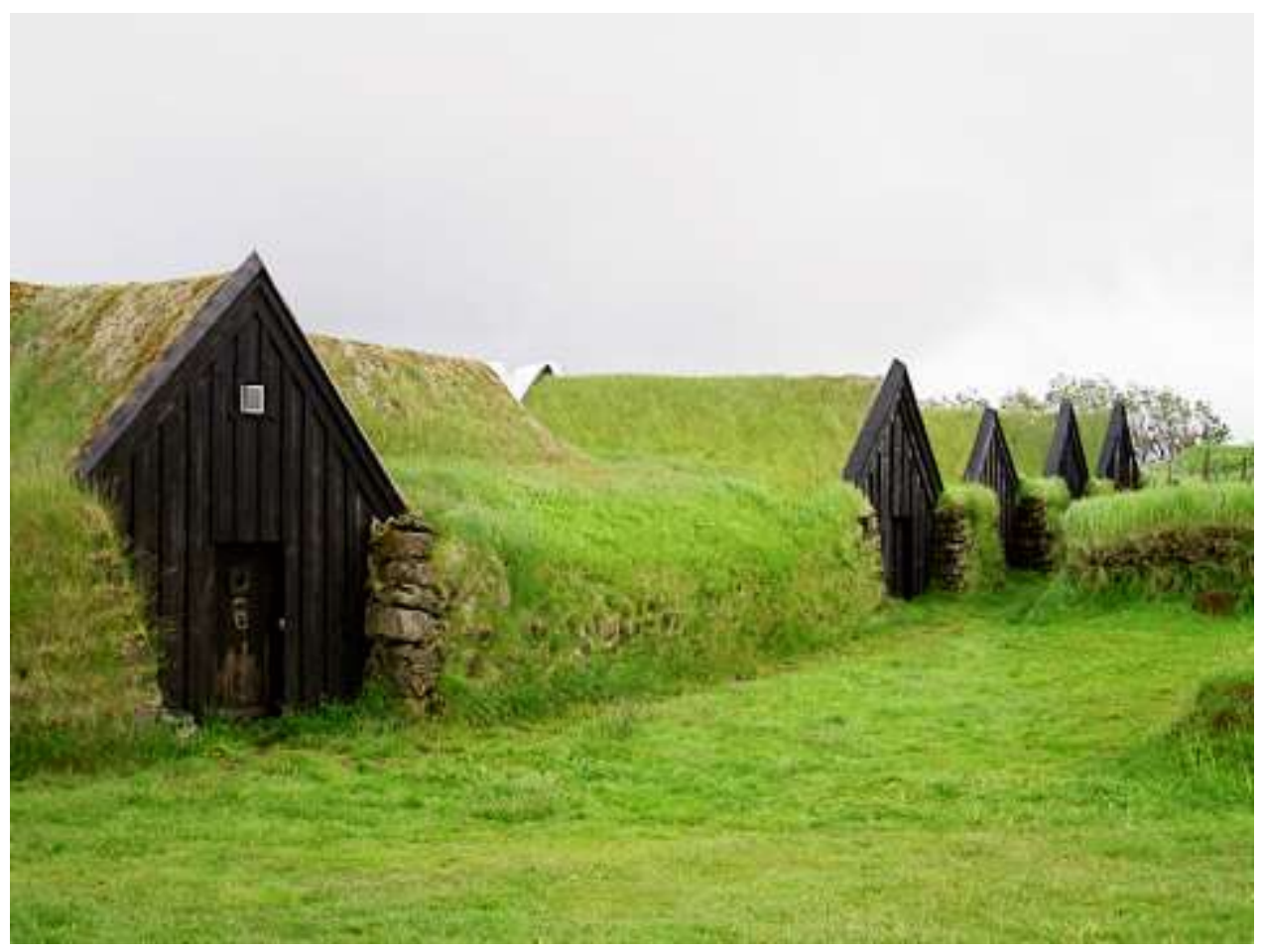

Figura 159. Shtëpitë në tokë. Island në Keldur (Burimi): Chris 73, 2006. (Flickr). E licensuar nga Creative Commons Attribution ShareAlike 2.0 Generic

Jetesa brenda në tokë ka qenë traditë e një pjesë të madhe e historisë njerëzore. Lidhja për strehim në tokë filloi me përdorimin e shpellave, dhe me kalimin e kohës evoluon me teknologjitë e ndërtimin, si pasojë, paraqitja e banesave të përshtatura për jetesë në tokë. Sot, veçanërisht në SHBA gjatë krizës energjetike dhe të naftës në vitin 1973, së bashku me lëvizjen "prapa në tokë”, ka pasur një rritje të interesit për shtëpitë në tokë apo nëntokësore, një përpjekje drejt vetë mjaftueshmerisë së jetesës. Megjithatë, progresi ka qenë i ngadaltë dhe ndërtimi i shtëpive në tokë është parë shpesh nga arkitektët dhe inxhinierët si një metodë e pazakontë e ndërtimit dhe e jetesës. (Wikipedia, 2015)

Megjithatë, përfitimet nga shtëpitë në tokë janë të shumta, ato përfshijnë: përfitimi nga toka si një masë termike, duke ofruar mbrojtje shtesë nga ndikimet natyrore, kursimin e energjisë, duke siguruar jetën private të konsiderueshme, përdorimin efikas të tokës në mjediset urbane. Këto shtëpi kanë kërkesa të ulëta të mirëmbajtjes, strehimi në tokë zakonisht merr avantazhin dhe përdorimin pasiv të energjisë diellore.

Shtëpitë në tokë akumulojnë dhe mbajnë nivelin e ngrohjes. Për shkak të densitetit të lartë të tokës, ndryshimi në temperaturën e tokës ndodhë ngadalë. Kjo është e njohur si parim termik tokësor. Për shkak të këtij parimi, toka siguron një temperaturë mjaft konstante për strehimoret nëntokësore, madje edhe kur temperaturat e jashtme pësojnë luhatje të mëdha. Në shumicën e Shteteve të Bashkuara të Amerikës, temperatura mesatare e tokës është mbi vijën e acarit dhe është midis 55 dhe 57 gradë Fahrenheit (13 deri në 14 gradë Celsius), tek ne, në ndërtimtari supozohet si rregull që toka në thellësi prej $80 \mathrm{~cm}$ ' është $5^{\circ}$ Celsius. 
Thellësitë e ngrirjes ndryshojnë nga rajoni në rajon. Gjatë verës, niveli i temperaturave ndihmon për të ftohur shtëpinë. Reduktimi i infiltrimit të ajrit brenda në strehë të tokës mund të jetë shumë fitimprurës. Sepse të tre muret e strukturës janë të rrethuar kryesisht nga toka, shumë pak sipërfaqe është e ekspozuar ndaj ajrit të jashtëm. Kjo veçori e redukton problemin e ajrit të ngrohtë të infiltrohet nga shtëpia nëpër boshllëqet rreth dritareve dhe dyerve dhe elementeve të tjera të mos puthitura. Për më tepër, muret nga toka mbrojnë kundër erërave të dimrit dhe të ftohta të cila përndryshe mund të depërtojnë në këto boshllëqe. Sidoqoftë, kjo dukuri mund të paraqet problem me ajrin e moshuar, ajri i pastër është kusht i pa diskutueshëm, shëndeti është kyç.

Si rezultat i rritjes së masës termike të këtyre strukturave, masa termike e tokës, mbrojtja kundër infiltrimit të padëshiruar të ajrit dhe përdorimi i kombinuar i teknikave pasive diellore, nevoja për ngrohje dhe ftohje si shtesë është minimale. Prandaj, ka një ulje drastike në konsumin e energjisë së nevojshme për këto shtëpi në krahasim me shtëpitë e ndërtimit tipik. Shtëpitë në tokë gjithashtu sigurojnë intimitetin nga fqinjët, si dhe zë izolimin. Terreni dhe toka ofrojnë mbrojtje zë izoluese kundër zhurmave të jashtme. Këto cilësi mund të jenë një përfitim i madh në zonat urbane apo pranë autobanëve. Në zonat urbane, një tjetër përfitim i strehimit nëntokësor është përdorimi efikas i tokës, shumë shtëpi mund të realizohen nën shkallën dëmtimit të mjedisit. (Wikipedia, 2015)

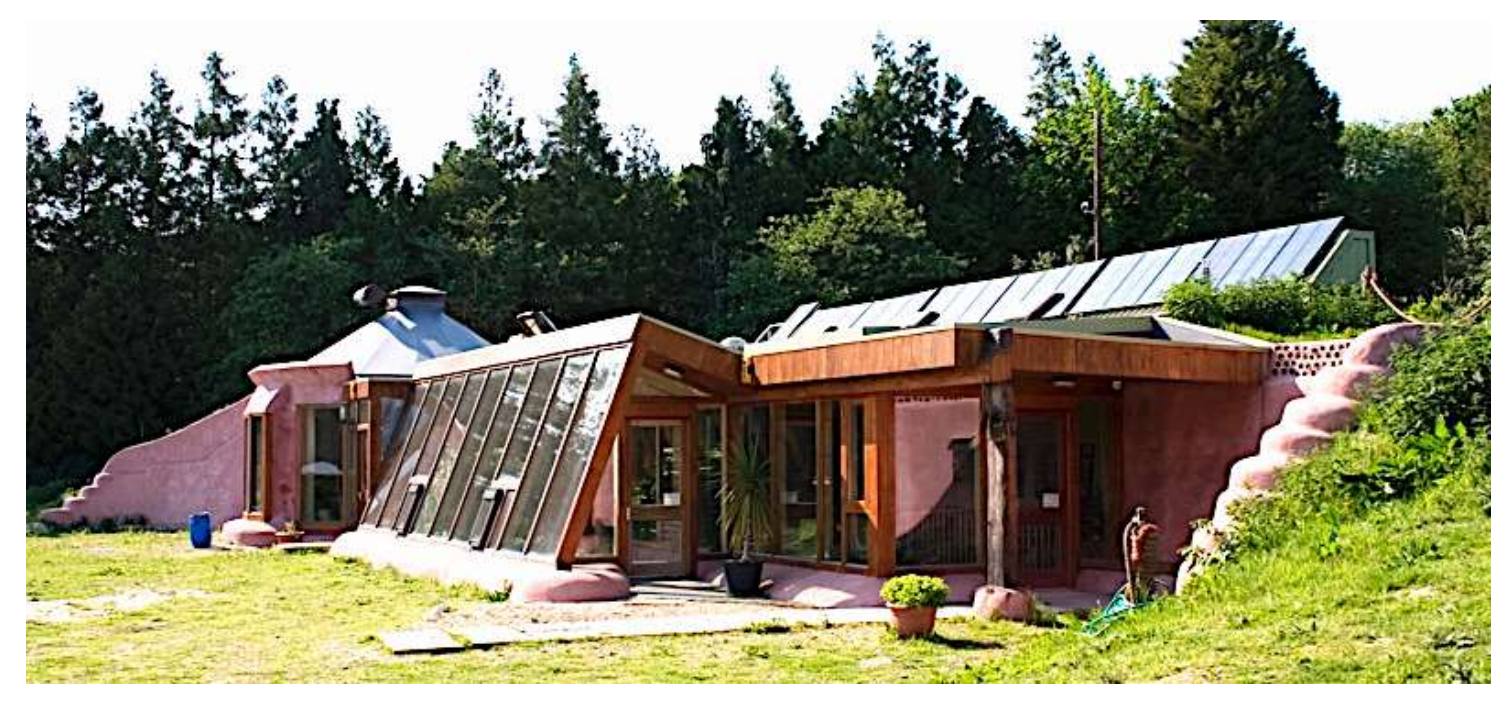

Figura 160. Earthship, Brighton Earthship, pamjet

(Burimi): Dominic Alves, 2008. (Flickr). E licensuar nga Creative Commons Attribution ShareAlike 2.0 Generic

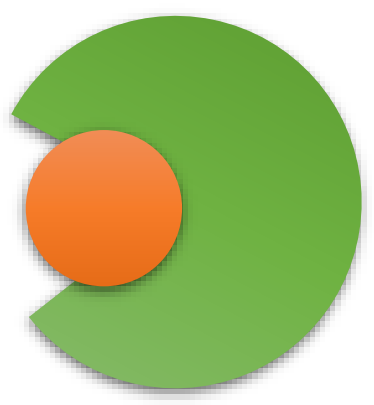

Figura 161. Inkorporimi i shtëpive në tokë (Burimi): Bujar Bajçinovci. 2015. 


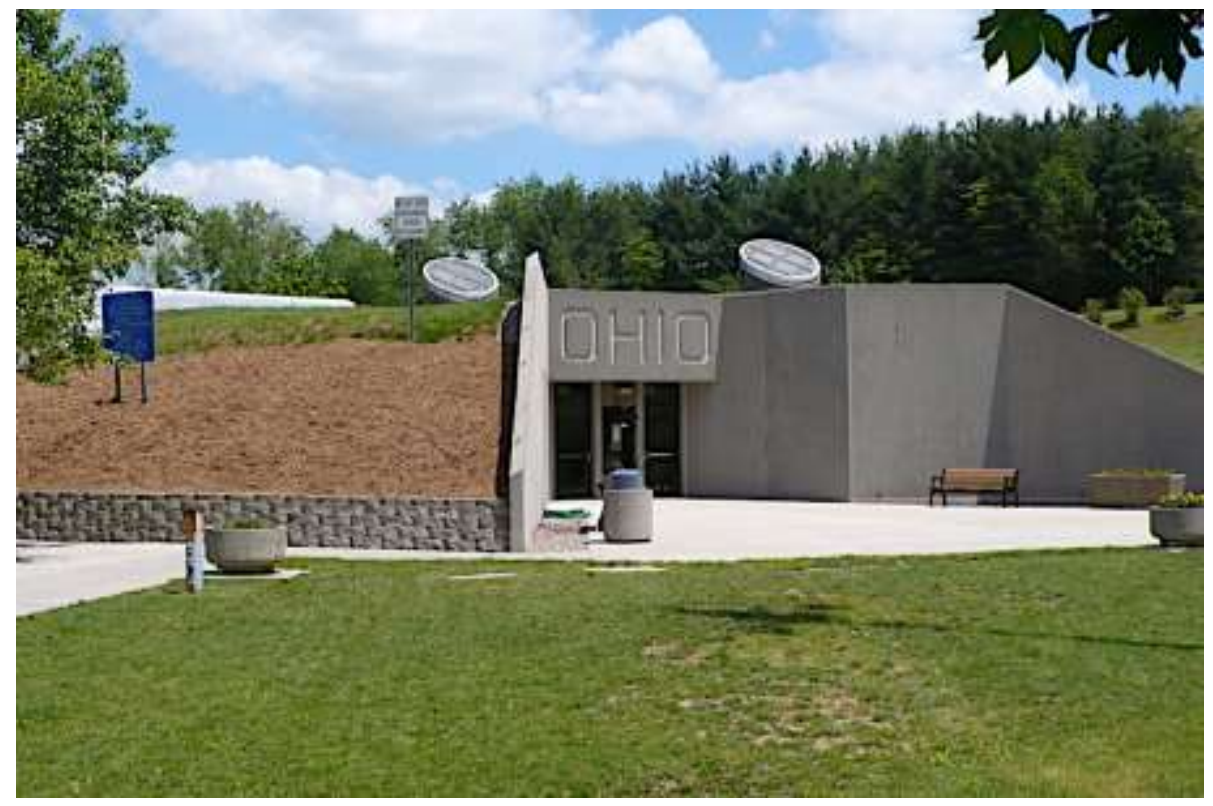

Figura 162. Objekt në tokë. Ohio, USA.

(Burimi): Oydman, 2008. at en.wikipedia, public domain.

\subsubsection{Fensterimi}

Dritaret formojnë fasadën e çdo objekti si asnjë element tjetër ndërtimor. Në fakt ato e krijojnë stilin e ndërtesës. Elementët e rëndësishme janë: madhësia dhe përmasat, forma, materiali dhe ngjyra. Pavarësisht nga forma standarde drejtkëndëshe, dritaret mund të krijohen në shumëllojshmërinë e pakufishme të trajtave.

Për efikasitetin energjetik dhe izolimin termik në ndërtesa, rëndësi të madhe kanë dritaret, pasi pikërisht ato janë përgjegjëse për humbjen e $40 \%$ të nxehtësisë. Prej 2014, normat evropiane kërkojnë që koeficienti i humbjes së nxehtësisë të jetë më i vogël se $1,4 \mathrm{w} / \mathrm{m} 2 \mathrm{k}$. Duke marrë parasysh këtë, prodhues të ndryshëm ofrojnë produkte të cilat arrijnë $0,8 \mathrm{w} / \mathrm{m} 2 \mathrm{k}$ - deri $1,4 \mathrm{w} / \mathrm{m} 2 \mathrm{k}$.

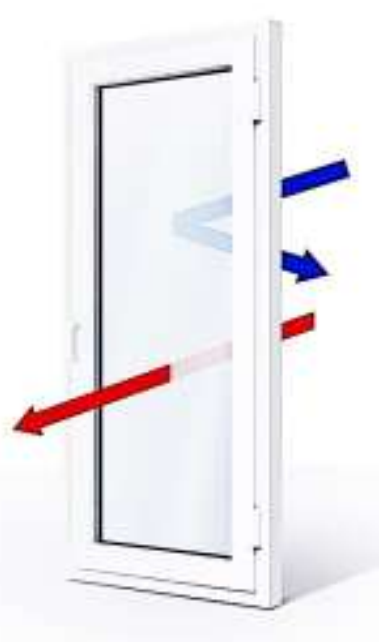

Figura 163. Dritare bashkëkohore

(Burimi): Rollplast, broshura 2014/15. Kosovë 
Elementi tjetër me shumë rëndësi është xhami, i cili është sa $80 \%$ e sipërfaqes së dritares për izolim termik më të mirë, rekomandohet xham të trefishtë me ndarës termik të cilësisë së lartë. Jeta stresuese dhe rritja e numrit të veturave në qytete të mëdha, tërheq vëmendjen te një faktor serioz, zhurma apo ndotja nga zhurma, nga e cila varet qetësia dhe shëndeti ynë. Njëri ndër faktorët kryesor për një ambient të brendshëm "pa zhurmë", është xhami i dritares. Prodhuesit ofrojnë një gamë të gjerë të kombinimeve të ndryshme të xhamit, prej të cilave standardi i xhamit $24 \mathrm{~mm}$ arrin deri në $31 \mathrm{~dB}$. Zgjidhje e mirë për zhurmën e padëshirueshme janë dritaret Rollplast Guard, me xham i cili arrin 34 deri $41 \mathrm{~dB}$. Për izolim më të mirë të zërit shumë me rëndësi janë edhe disa element të tjerë: gomat në kornizë, kombinimi i xhamit dhe montimi i mirë i tyre.

Tabela 23. Karakteristikat prodhuese për dritaret (Burimi): Rollplast, broshura 2014/15. Kosovë.

\begin{tabular}{|l|l|l|l|l|c|c|}
\hline \multicolumn{1}{|c|}{ Profili } & $\begin{array}{l}\text { Mekanizmi } \\
\text { Winkhaus }\end{array}$ & Xhami & $\begin{array}{l}\text { Përçuesi i } \\
\text { nxehtësisë Uw }\end{array}$ & $\begin{array}{l}\text { Koeficienti } \\
\text { Uw }\end{array}$ & $\begin{array}{l}\text { Izolimi i } \\
\text { zhurmës }\end{array}$ & $\begin{array}{c}\text { Rritja e kostos } \\
\%\end{array}$ \\
\hline Rollplast Standard 70 & ProPilot & $24 \mathrm{~mm}$ & $1.4 \mathrm{~W} / \mathrm{m} 2 \mathrm{~K}$ & - & $31 \mathrm{~dB}$ & - \\
\hline Trocal Classic 76 & ActivePilot & $40 \mathrm{~mm}$ & $0.9 \mathrm{~W} / \mathrm{m} 2 \mathrm{~K}$ & $36 \%$ & $35 \mathrm{~dB}$ & $24 \%$ \\
\hline Trocal Prestige 88+ & ActivePilot & $50 \mathrm{~mm}$ & $0.8 \mathrm{~W} / \mathrm{m} 2 \mathrm{~K}$ & $43 \%$ & $36 \mathrm{~dB}$ & $50 \%$ \\
\hline
\end{tabular}

Hulumtimet tregojnë për një harxhim të energjisë nga ndriçimi artificial për rreth $50 \%$ të energjisë së përdorur në zyra, si komponentë e rëndësishme në kursimin energjisë, e përdorur në ndërtesa publike apo banimore. Në vitet e fundit, përdorimi i diellosjes e kombinuar me ndriçimin artificial me performancë të lartë do të thotë kursim në mes 30$50 \%$ të energjisë, ndërsa në disa raste ekstreme edhe 60-70\% e kursimeve janë të mundshme. Kështu, duke aplikuar këto parime të projektimit të qëndrueshëm do të çojë në kursime të konsiderueshme të energjisë. Hapësirat me diellosje të mjaftueshme janë shpesh më tërheqëse dhe më ekonomike për të punuar dhe jetuar. Përveç kësaj, një mangësi e diellit në jetesën tonë dhe në ambientin e punës mund të çojë në probleme të shëndetit, të tilla si çrregullimi emocional sezonal dhe në mungesë të Vitaminës D.

Kërkesat për ndriçim natyror apo diellosje do të varet nga funksioni i ndërtesës, orët e përdorimit, lloji i përdoruesit, kërkesat për vizura dhe pamje, nevojën për privatësinë si dhe kërkesa për ventilim, parime në kursimin e energjisë dhe mbrojtjen e mjedisit. Perceptimi i përshtatshëm dhe vizurat e rehatshme janë të ndikuar nga njëtrajtshmëria e dritës dhe nga mungesa e shkëlqimit dhe reflektimit verbues.

Si rregull e pranuar në praktikën arkitektonike do të ishte, diellosja në një ndërtesë në raportin: dysheme/sipërfaqe fensterimi $1 / 6-1 / 5$. Niveli i diellosjes në një pikë në një hapësirë varet në masë të madhe në ndriçimin e përgjithshëm në lx, sasinë e ndriçimit nëpër dritare në këtë pikë. Për shembull, hapjet e larta dhe të ngushta do të sigurojnë një shpërndarje më të mirë të dritës në një dhomë, se sa ato të ulëta dhe të gjera. Për hapësira me raport të dyfishtë me dysheme dhe lartësi, ose ato në ndërkulme apo ato në katin më të lartë, hapjet më shumë në fasadë apo hapjet në kulm do të përmirësojnë dukshëm shpërndarjen e dritës. Forma dhe madhësia e dritares do të varen nga faktorë të tillë si thellësia e hapësirës dhe orientimi i hapjes. 
Dritaret e mëdha sigurojnë depërtim më të mirë të dritës në pjesën e fundme të hapësirës. Shpesh, fensterimi mund të ndahet për tu përballuar me kërkesat e ndryshme, një pjesë e ndarë më e ulët mund të sigurohet për të parë, dhe një pjesë tjetër më e lartë për kërkesat e sasisë së dritës. Secila sipërfaqe mund të hijezohet veçmas.

Tabela 24. Karakteristikat prodhuese për dritaret, nga katalogu i prodhuesit. (Burimi): Rollplast, broshura 2014/15. Kosovë.

\begin{tabular}{|c|c|c|c|c|c|c|c|c|c|}
\hline Produkti & $\begin{array}{l}\text { Njësia e } \\
\text { Xhamit }\end{array}$ & $\begin{array}{l}\text { Dimensionet, } \\
\mathrm{mm}\end{array}$ & $\begin{array}{l}\text { Ug } \\
\text { koeficienti } \\
\text { (w/m2k) } \\
\text { me ajër }\end{array}$ & $\begin{array}{l}\text { Ug } \\
\text { koeficienti } \\
(w / m 2 k) \\
\text { me gaz } \\
\text { argoni }\end{array}$ & $\begin{array}{l}\text { Rw } \\
\text { izolimi i } \\
\text { zhurmës } \\
\text { (dB) }\end{array}$ & $\begin{array}{c}\text { Koeficienti } \\
\text { i } \\
\text { depërtimit } \\
\text { të rrezeve } \\
\text { ultra UV } \\
(\%)\end{array}$ & $\begin{array}{l}\text { Faktori } \\
\text { diellor } \\
(\%)\end{array}$ & $\begin{array}{c}\text { Koeficienti } \\
\text { i } \\
\text { depërtimit } \\
\text { të dritës } \\
(\%)\end{array}$ & $\begin{array}{l}\text { Refleksioni } \\
(\%)\end{array}$ \\
\hline & $\begin{array}{c}\text { ХHAM I } \\
\text { THJESHTË }\end{array}$ & 4 & 5.8 & - & 23 & 69 & 86 & 90 & 8 \\
\hline & $\begin{array}{l}\text { I THJESHTË/ } \\
\text { I THJESHTË }\end{array}$ & 24 & 2.7 & 2.6 & 30 & 54 & 77 & 81 & 15 \\
\hline & $\begin{array}{l}\text { I THJESHTË/ } \\
\text { EMISION I } \\
\text { ULËT }\end{array}$ & 24 & 1.4 & 1.1 & 30 & 34 & 62 & 79 & 12 \\
\hline & $\begin{array}{l}\text { ENERGJI TË } \\
\text { LARTË/ I } \\
\text { LAMINUAR }\end{array}$ & 24 & 1.4 & 1.1 & 35 & 3 & 42 & 66 & 26 \\
\hline & $\begin{array}{c}\text { ENERGJI TË } \\
\text { LARTË/ I } \\
\text { THJESHTË }\end{array}$ & 24 & 1.3 & 1.0 & 30 & 25 & 42 & 66 & 26 \\
\hline & \multirow{5}{*}{$\begin{array}{c}\text { ENERGJI TË } \\
\text { LARTË } \\
\text { /I THJESHTË/ } \\
\text { EMISIVITET I } \\
\text { ULËT }\end{array}$} & 32 & 1.0 & 0.8 & 32 & 15 & 38 & 60 & 29 \\
\hline & & 36 & 0.9 & 0.7 & 32 & 15 & 38 & 59 & 29 \\
\hline & & 40 & 0.8 & 0.6 & 35 & 15 & 38 & 60 & 29 \\
\hline & & 44 & 0.7 & 0.5 & 35 & 15 & 38 & 60 & 29 \\
\hline & & 51 & 0.7 & 0.5 & 35 & 15 & 38 & 60 & 29 \\
\hline & \multirow{5}{*}{$\begin{array}{c}\text { EMISIVITET } \\
\text { TË ULËT } \\
\text { /I THEJSHTË/ } \\
\text { EMISIVITET I } \\
\text { ULËT }\end{array}$} & 32 & 1.1 & 0.8 & 32 & 20 & 49 & 71 & 15 \\
\hline & & 36 & 0.9 & 0.7 & 32 & 20 & 49 & 71 & 15 \\
\hline & & 40 & 0.8 & 0.6 & 35 & 20 & 49 & 71 & 15 \\
\hline & & 44 & 0.8 & 0.6 & 35 & 20 & 49 & 71 & 15 \\
\hline & & 51 & 0.7 & 0.5 & 35 & 19 & 49 & 71 & 15 \\
\hline
\end{tabular}

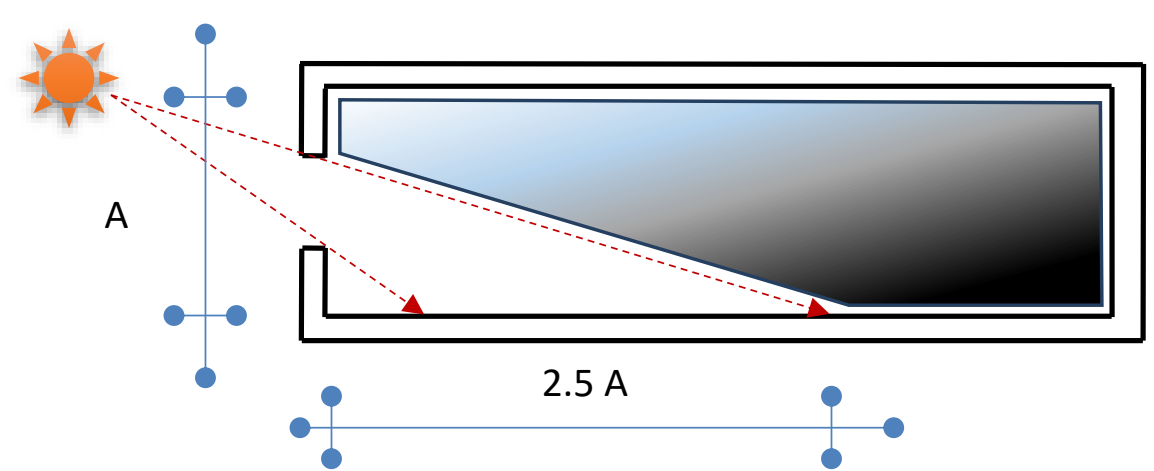

Figura 164. Ndriçim lateral arrin vetëm aq larg në dhomë (Burimi): Bujar Bajçinovci. 2015. 
Drita që vjen nga një anë apo e quajtur laterale, mund të depërtojnë vetëm 2.5 herë sa lartësia e etazhës. Kjo është arsyeja pse duhet studiuar mirë parimet fizike të ndriçimit natyror si dhe rekomandimet ligjore për lloje të ndryshme të ndërtesave. Një rregull i thjeshtë është se drita e diellit depërton në një dhomë afërsisht 2.5-3 herë sa lartësia e dritares.
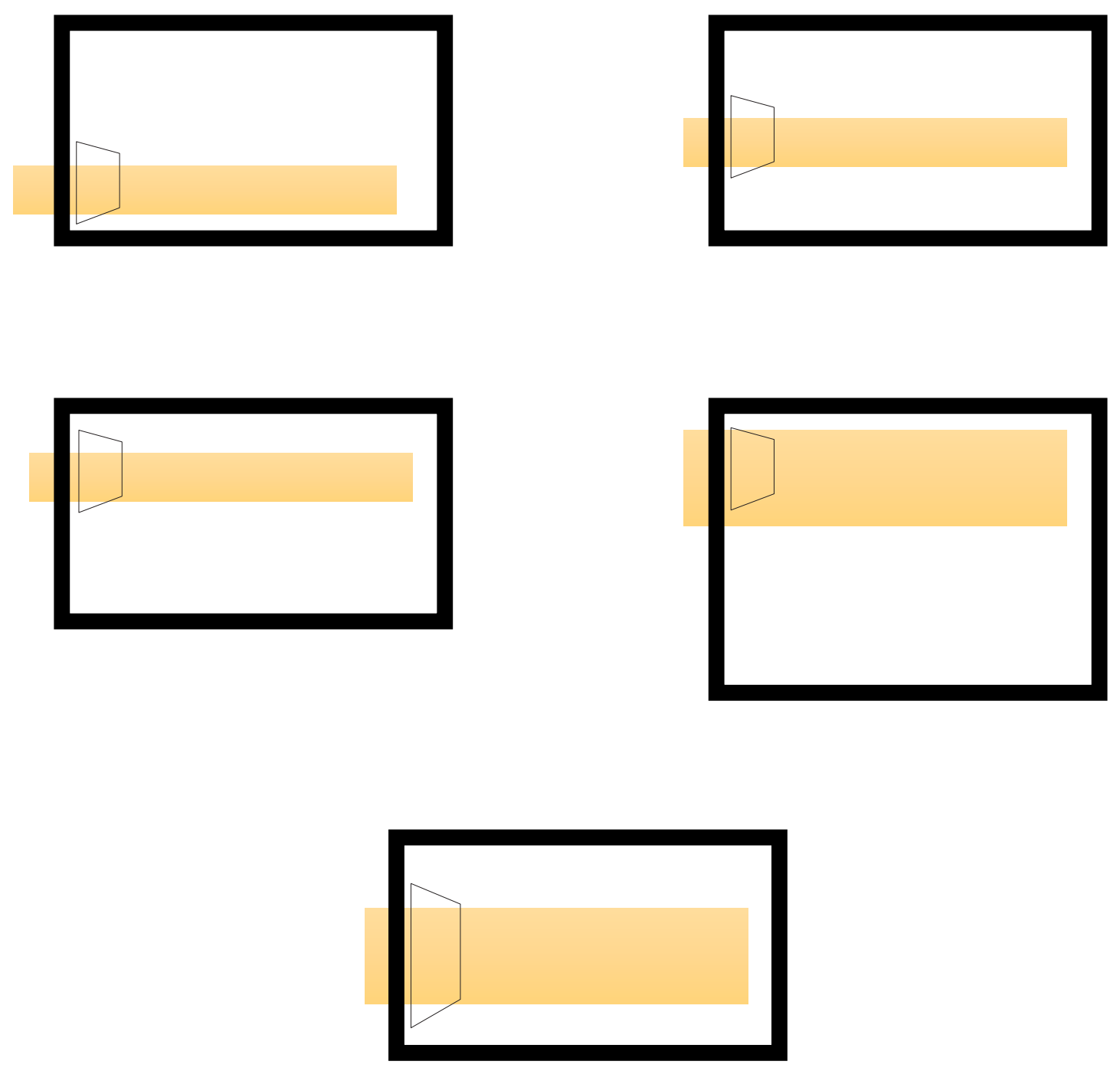

Figura 165. Pozita e dritares dhe madhësia në faktor të ndriçimit (Burimi): Bujar Bajçinovci, 2017.

Dritaret e orientuara nga lindja dhe perëndimi mund të japin dritë shumë të ndritshme në mëngjes ose në mbrëmje, por dritë të pamjaftueshme në kohë të tjera të ditës dhe janë shumë të prirë për shkëlqim verbues. Dritaret e orientuara nga ana jugore kanë ndriçim të vazhdueshëm gjatë ditës, mirëpo me oscilime të intensitetit të ndriçimit, po ashtu të prirë për shkëlqim verbues. 


\subsubsection{Fasadat e "mençura"}

Një fasadë inteligjente vepron si një dritare. Këto fasada kanë aftësinë për ta njohur formën e tyre optimale, parashikojnë ndikimin mjedisor në ndërtesa dhe për t'iu përgjigjur në mënyrë të përshtatshme kërkesave për të mbajtur banorët në komfor. Gjithashtu mund të zgjedhin përdorimin e energjisë në shumicën e rasteve. Ndërtesa inteligjente përfshin idenë se fasada nuk është statike, por një mbështjellës dhe situatë dinamike. Fasada mund të ndryshojë sjelljen e saj për t'iu përgjigjur kushteve mjedisore duke ndryshuar ngjyrën e saj, duke shtuar hije siç kërkohet, apo orientimin e mëvetshëm për të minimizuar ndikimin dhe harxhimin e energjisë. Aktualisht, fasadat inteligjente gjinden në ndërtesat bashkëkohore komerciale. Natyrisht, konceptet që dalin nga kjo ide mund të përfshihen në çdo ndërtesë, me kusht që, ka justifikim ekonomik.

Teknikisht, fasadat e mençura që i përshtaten mjedisit apo kushteve daton nga dritarja e parë, por ideja bashkëkohore e fasadës se mençur është në trend në dekadat e fundit, e ndihmuar së bashku me përparimet e fundit në shkencën kimike dhe në teknologjinë e nanomaterialeve.

Një fasadë përfaqëson këto parime:

1. Rritjen e dritës, reflektorët

2. Mundësin e maksimizimit të dritës, ndriçimi nga atria

3. Mbrojtjen nga dielli

4. Izolimin, roletat, "shutters" gjatë natës

5. Ventilimin, automatikë

6. Mbledhjen e nxehtësisë, mbledhësit diellore

7. Mbrojtjen nga nxehtësia

8. Mbrojtjen nga zhurma

9. Gjenerimin e energjisë elektrike, /photovoltaics/

10. Shfrytëzimin e diferencave të presionit, parimi i oxhaqeve të ventilimit ${ }^{93}$

Ndërtesat janë ndërtuar me shekuj më parë pa u fut ne konceptin e inteligjencës, atëherë, më të drejtë shtrohet pyetja se përse janë relevante. Rasti për ndërtimin e fasadave inteligjente qëndron në kërkesat gjithnjë e më të sofistikuara për komforin të cilat shoqërohen me zhvillimin e formave komplekse të ndërtimit dhe të përmbajtjeve funksionale, me kërkesa ligjore për kursimin e energjisë. Një ndërtesë konvencionale apo klasike, pa atribute ndaj lëvizjeve mjedisore është ndërtesë statike, mos të themi objekt i pajetë. Ajo lëvizë vetëm pak në përgjigje të streseve strukturore dhe termike. Natyra e saj inerte nuk krijon kushte të brendshme mjedisore të cilat ndryshojnë me ndryshimet e mjedisit të jashtëm. Kushtet klimatike të cilat i ofron mjedisit i caktuar, konteksti klimatik në çdo vend gjeografik ndryshon në mes paradites dhe pasdites, në mes të ditës dhe natës dhe në mes të stinëve. Një nga funksionet kryesore e ndërtesave është për ti mbrojtur banuesit nga ekstremet e klimës, dhe si të tillë këto ndërtesa duhet të veprojnë si modiatorë në mes të kushteve të brendshme dhe të jashtme.Ndërtesat duhet të ndërveprojnë nga ekstremet e klimës për të prodhuar apo ofruar kushtet e brendshme të cilat ndryshojnë vetëm brenda kufijve të cilët konsiderohen si të rehatshëm apo komfor nga banorët. ${ }^{93}$

93 Michael Wigginton \& Jude Harris, 2002. Inteligent Skins. Elsevier. Oxford. 


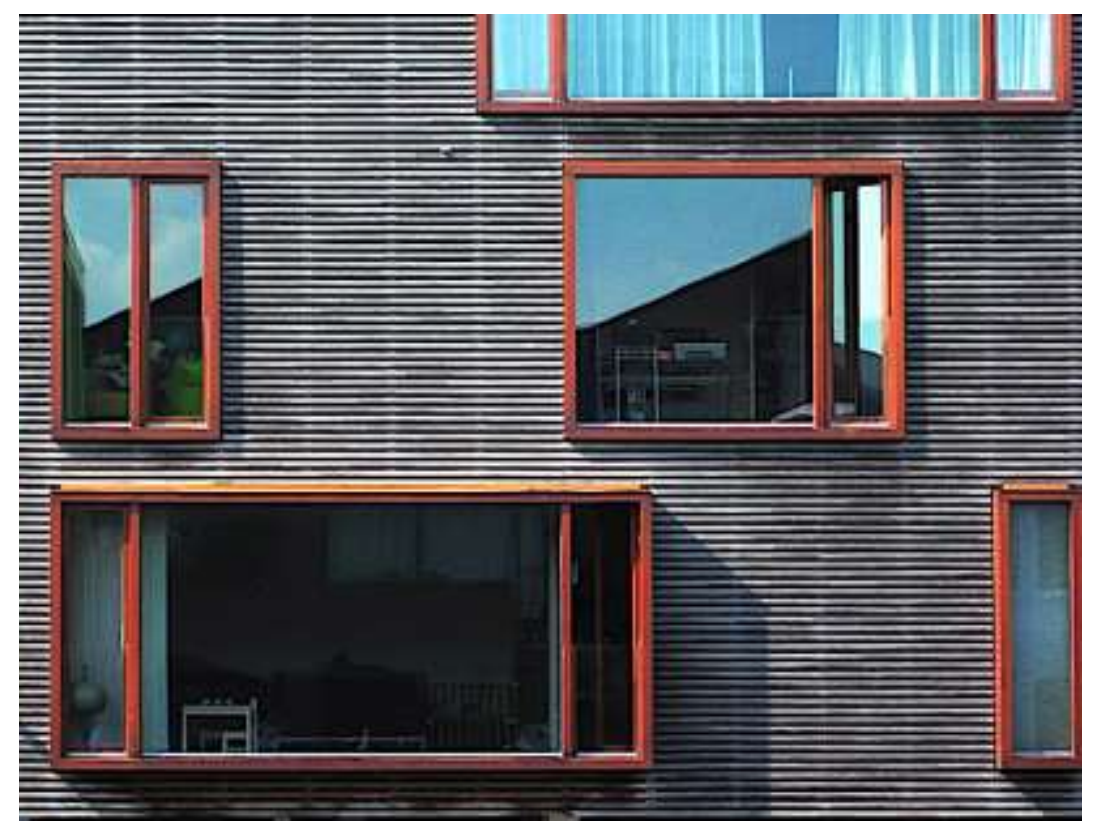

Figura 166. Amsterdam, Borneo akcent fasade

(Burimi): Rankeelaw, 2008. (Flickr). E licensuar nga Commons Attribution ShareAlike 2.0

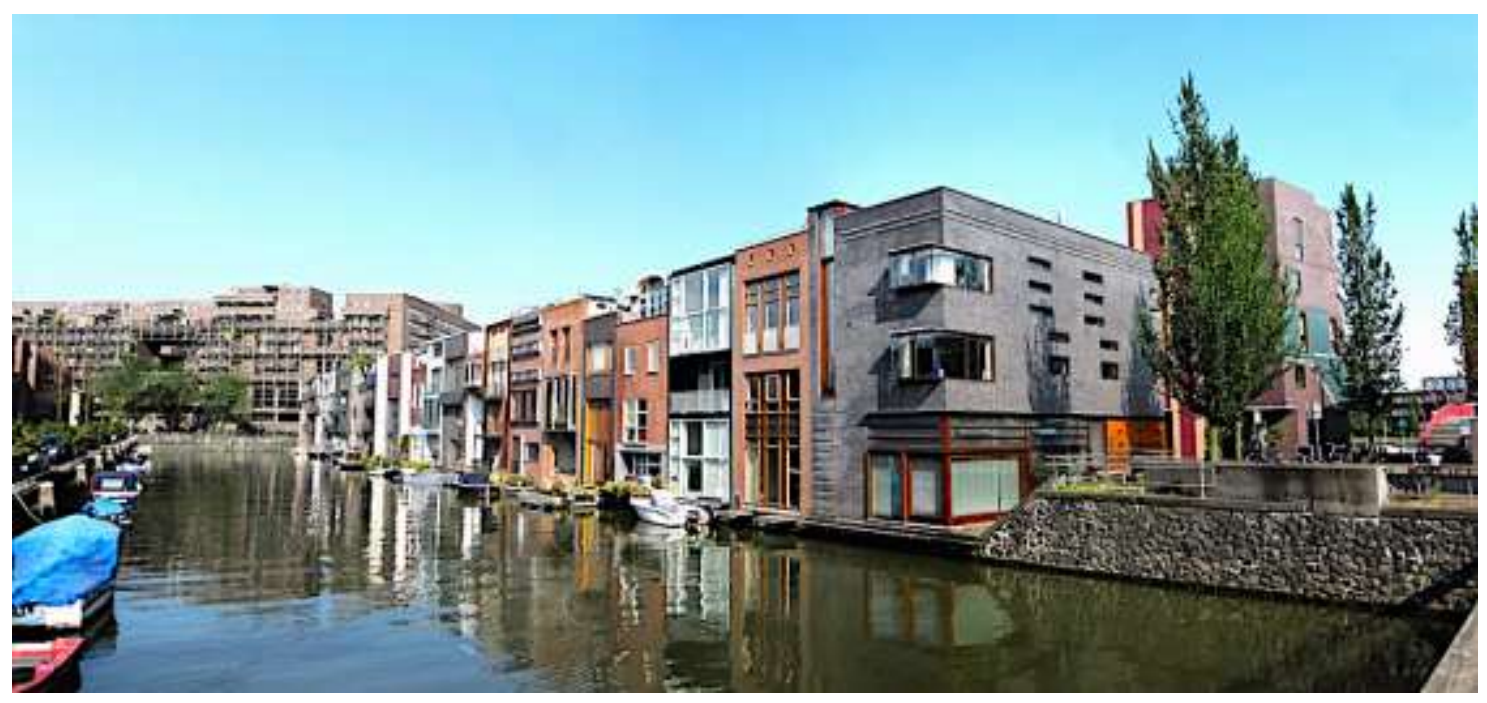

Figura 167. Amsterdam, Borneo

(Burimi): Fredrik Linge, 2009. (Flickr). Creative Commons Attribution ShareAlike 2.0

Philamlife, kulla është një rrokaqiell me zyra i vendosur në Makati City, Filipine. Ajo është në pronësi dhe është zhvilluar nga Philam Corporation, dega e pasurive të patundshme, e lartë 200 metra aktualisht është ndërtesa e katërt më e lartë në Makati City dhe njëherit është ndërtesa e gjashtë më e lartë në Metro Manila dhe në Filipine ( korrik 2009). Ndërtesa ka 48 kate mbi tokë, dhe 5 nivele në bodrum për parkim. Ndër karakteristikat e saj të shumta, përfshihen: $100 \%$ dyshemesë është e ngritur, një tipar që ofron hapësirë nën dysheme për vendosjen e kabllove dhe instalime elektrike të avancuara, sistemet e kabllove të strukturuara, sisteme automatike sensoresh, fasada të dyfishta, menaxhimit të integruar, sistemit automatik në qasje të kontrollit, mundësi 24 orësh për ajër të kondicionuar, 16 ashensorë me shpejtësi të lartë dhe një heliopad. Kulla po ashtu ka hapësira të tjera polifunksionale. 


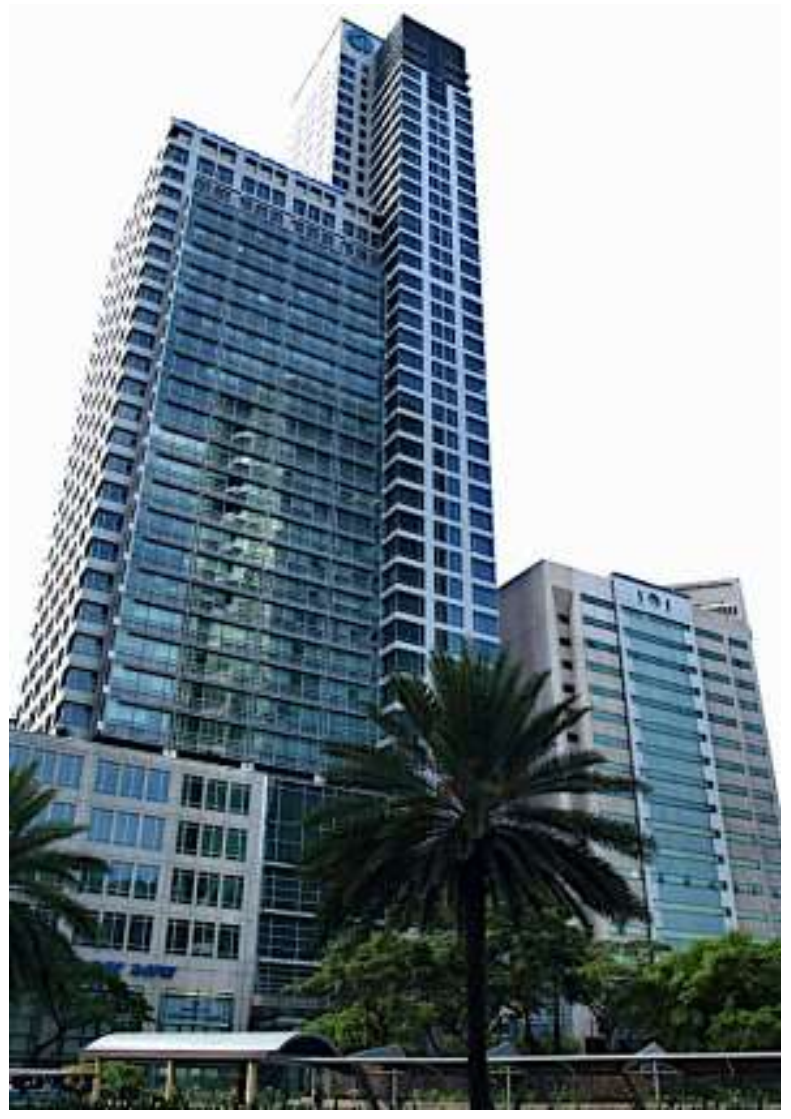

Figura 168. Philamlife, tower. Filipine

(Burimi): Acullador, 2009. (Flickr). Creative Commons Attribution ShareAlike 2.0

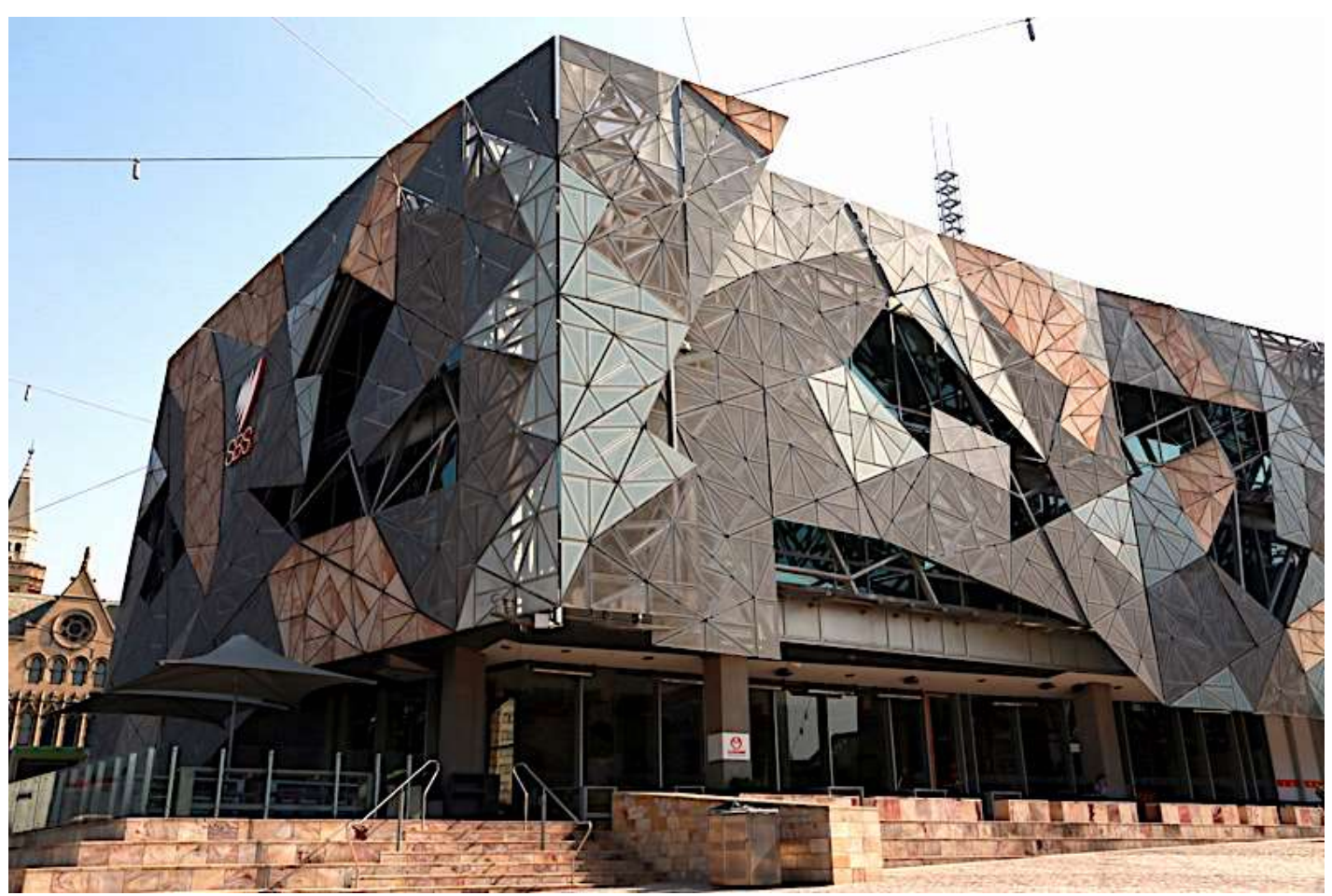

Figura 169. Federation Square. Melburne, Australia

(Burimi): eosdude, 2014. (Flickr). Creative Commons Attribution Share Alike 2.0 


\subsection{Sistemet aktive të projektimi të qëndrueshëm}

\subsubsection{Të pamurit}

Syri funksionon pak a shumë si një aparat fotografik. Kornea (xhami i syrit) vepron si një lente qelqi dhe është ekuivalent i lentës së jashtme të aparatit fotografik. Pupila korrespondon me diafragmën dhe lentja e syrit korrespondon lentet e brendshme të aparatit fotografik. Retina është e krahasueshme me filmin që ndodhet në brendësi të aparatit fotografik. Kornea, pupila dhe kristalini (lentja natyrale e syrit) krijojnë një imazh të mjedisit në retinë. Në mënyrë të ngjashme, lentet e aparatit fotografik krijojnë një imazh të pastër të mjedisit në filmin fotografik.

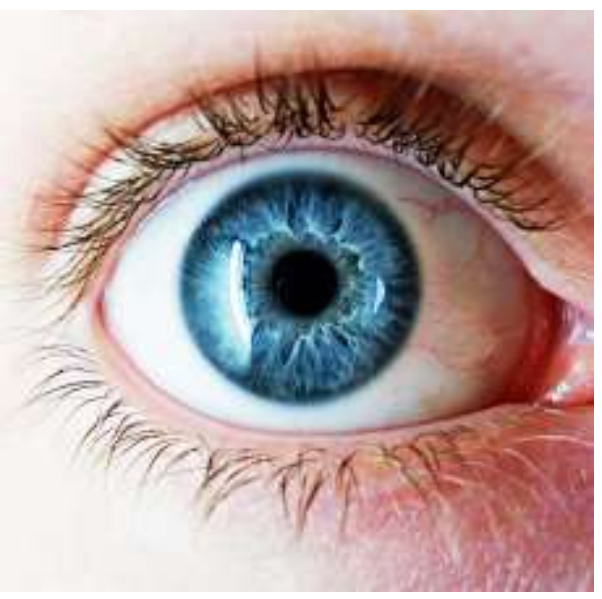

Figura 170. Syri

(Burimi): 8thstar, 2006. en.wikipedia. 2015. Public Domain.

Përpara marrjes së fotos, lentja e kamerës duhet të fokusohet - manualisht apo automatikisht, duke bërë kështu të mundur krijimin e një imazhi të pastër. Në syrin e njeriut fokusimi kryhet nëpërmjet ndryshimit të formës së kristalit.

Një sy normal ka gjithmonë një pamje të fokusuar mirë në retinë kur sheh larg. Për të parë afër, sikurse kur lexojmë, kristalini e ndryshon formën automatikisht duke bërë të mundur procesin e ashtuquajtur akomodim. Aftësia e kristalinit për të ndryshuar formën e tij (për të akomoduar) bie me kalimin e moshës, gjë që bëhet më e dukshme pas moshës 40 vjeçare.

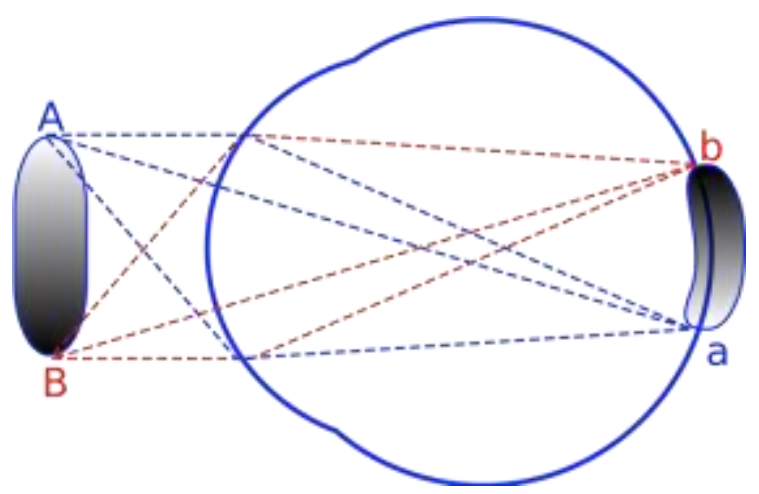

Figura 171. Syri

(Burimi): Javalenok, 2013. (Flickr). E licensuar nga Creative Commons Attribution ShareAlike 3.0 Unported 
Shumica e informacionit që marrim për rrethinën tonë është e dhënë nga sytë tanë. Ne jetojmë në një botë vizuale. Syri është organi më i rëndësishëm në kuptimin e shqisave të njeriut, trajton rreth $80 \%$ të gjitha informatave hyrëse. Pa dritë, do të ishte e pamundur të shohim, drita është mediumi që e bën të mundur perceptimin vizual. Drita e pamjaftueshme shkakton errësirë dhe ndjenjën e pasigurisë. Ne mungesë të informacionit, ne humbasim ndjenjat jetike. Ndërsa ndriçimi artificial gjatë orëve të errësirës na bën të ndjehemi të sigurt.

Drita jo vetëm që na mundëson të shohim, por edhe ndikon në disponimin tonë dhe sensin e mirëqenies. Niveli i ndriçimit dhe përjetimi i ngjyrave, paraqesin kërkesat jetike për të funksionuar dhe përcaktojnë ritmin e jetës sonë. Në rrezet e diellit, për shembull, ndriçimi është rreth 100.000 lux, në hijen e një pemë është rreth 10.000 lux ndërsa në një natë me dritë hëne është 0,2 lux.

Njerëzit sot kalojnë shumicën e ditës në shtëpi me ndriçim prej 50 deri 500 lux. Drita përcakton ritmin e orës biologjike, dhe mund të ketë efekt në sistemin circadian (?1.000 lux). Andaj, për shumicën e kohës sa jetojmë në errësirë pasojat mund të janë, gjumë i trazuar, mungesë energjie, irritim dhe mund të ketë depresion të rëndë. Siç thuhet në shumë raste drita është jeta, ndriçimi i mirë është i rëndësishëm për të parë botën rreth nesh, çfarë duam të shohim duhet ndriçuar. Ndriçimi i mirë gjithashtu ndikon në mënyrën se si ndjehemi, po ashtu ndihmon në stilin dhe cilësinë e jetës.

Rreth 300.000 vite më parë, njeriu filloi të ndez zjarr, i përdorur si një burim i ngrohtësisë dhe për ndriçim. Me zjarr të ndezur njerëzimit ju mundësua që të jetojnë në shpella ku rrezet e diellit nuk mund të depërtojnë. Vizatimet e mrekullueshme në Altamira, datojnë rreth 15.000 vjet më parë, natyrisht, se ato u realizuan falë ndriçimit nga drita e zjarrit, e jo nga drita e diellit. Por zjarri si formë ndriçimi nuk është përdorur vetëm në hapësira të mbyllura, (rreth vitit 260 p.e.s. në Pharos të Aleksandrisë) po ashtu ka dëshmi se nga viti 378 p.e.s. kanë ekzistuar "dritat në rrugë" nga zjarri, në qytetin e lashtë të Antiokisë.

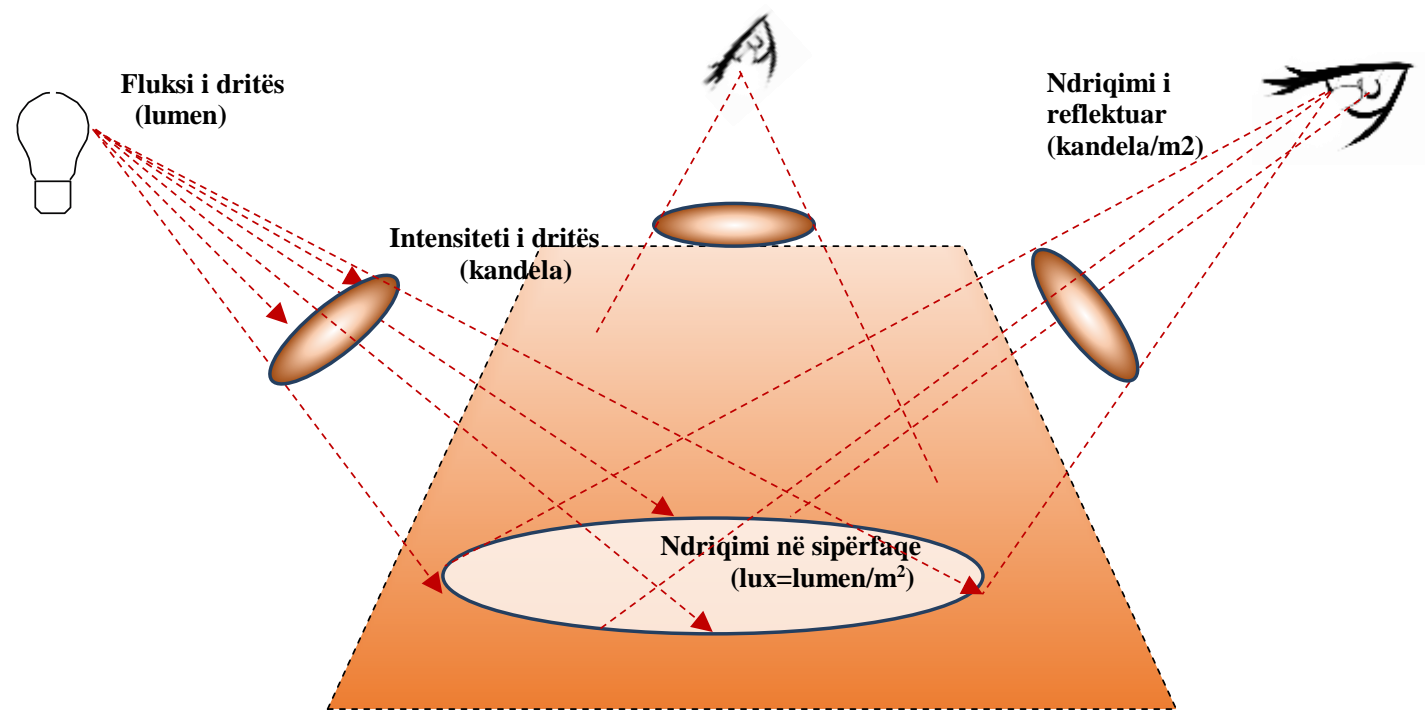

Figura 172. Kuptimet themelore, fluksi dhe intensiteti i dritës, ndriçimi i reflektuar. (Burimi): Bujar Bajçinovci. 2015. 


\subsubsection{Ndriçimi artificial}

Për ndriçimin artificial shfrytëzohen trupa ndriçues me fuqi të ndryshme. Prodhohen me një asortiment të madh për nevoja të llojllojshme. Energjia elektrike shndërrohet në dritë në dy mënyra: me nxehjen termike të metalit që skuqet dhe në temperaturën e lartë rrezaton dritë, si dhe me ndihmën e jonizimit goditës me gaze dhe avuj në metale. Burimet e para janë përfaqësues tipik të rrezatimit termik. Brenda tyre më tepër energji shfrytëzohet për nxehje e më pak për prodhimin e dritës. Të dytët janë shumë më ekonomikë, sepse për shkak të jonizimit kanë fuqi disa herë më të madhe. Trupat ndriçues kanë disa karakteristika, sikurse:

Fluksi i dritës $(F)$ është masë për forcën e rrezatimit, të cilën burimi i dritës e emeton në hapësirën përreth. Njësia për fluksin e dritës është lumeni (lm).

Intensiteti i dritës (I), përcakton se në ç'mënyrë fluksi (rrjedha) i dritës i burimit të dritës është i shpërndarë në hapësirën përreth dhe shfrytëzohet për përllogaritjen e ndriçimit. Në bazë të matjes së intensitetit të dritës nën këndin dhe rrafshet e caktuara, bashkë me vizatimin e dritës, prodhuesit japin edhe diagramet polare, kurse njësia e matjes është kandela (cd).

Intensiteti i ndriçimit (E) është herësi ndërmjet rrjedhës së dritës që ka rënë mbi ndonjë sipërfaqe dhe vetë sipërfaqes $\mathrm{F} / \mathrm{m}^{2}$. Në projekte, bashkë me shenjën e trupit ndriçues, shenohet edhe intensiteti (fuqia) e nevojshme e ndriçimit. Njësia e matjes së intensitetit të ndriçimit është luksi (lx).

Ndriçimi mesatar i ndonjë lokali matet mbi rrafshin horizontal në një lartësi prej 1,00 m' nga dyshemeja. Ndriçimi më i madh dhe ai më i vogël përcaktojnë njëtrajtshmërinë e ndriçimit.

Temperatura e ngjyrës është shumë e rëndësishme, sepse burimet artificiale të dritës nuk rrezatojnë të gjitha ngjyrat e dritës natyrore, porse drita e tyre ka një ton të caktuar. Po qe se burimi i dritës emeton valë gjatësie ngjyrash jo të dëshiruar, objekti i vështruar humbë ngjyrën. Njësia e matjes është kelvini (K).

Indeksi i rikthimit apo i riproduksionit të ngjyrës është raporti ndërmjet burimit të dritës dhe temperaturës së ngjyrës. Nuk varet përjashtimisht prej tipareve të burimit të dritës, por prej ndriçueses dhe hapësirës që e ndriçon, për shembull: muri, plafoni e të ngjashme.

Shkalla e shfrytëzimit të burimit të dritës është e rëndësishme për shkak të shpenzimit të energjisë elektrike. Trupat ndriçues te shpenzimi i njëjtë i energjisë elektrike nxehtësinë e emetojnë në mënyrë të llojllojshme. Sa më të madh ta ketë numrin e lumenëve, trupi ndriçues për njësinë e fuqisë elektrike/vatit, jep dritë më efikase. Me rastin e zgjedhjes së trupit ndriçues duhet pasur kujdes edhe për këtë veti e cila shënohet me (n). 


\subsubsection{Këndi hapësinor}

Këndi hapësinor $(\Omega)$ paraqet hapësirën e kufizuar më mbështjellësin e konit me kulm në mesin e sferës me rreze $r$, baza e të cilit është një pjesë e sipërfaqes së topit, e cila shihet nga mesi nën këndin hapësinor. Këndi hapësinor definohet me raportin në mes të sipërfaqes $S$, pra pjesës së sipërfaqes së topit të kufizuar dhe katrorit të rrezes së tij.

$$
\Omega=\frac{S}{r^{2}}
$$

Njësia e këndit hapësinor është steradiana (sr). Një steradian është i përkufizuar nga këndi hapësinor, nga i cili prej mesit të sferës me rreze $r$, shihet sipërfaqja në mbështjellës, e cila është e barabartë me katrorin e rrezes së saj $S=r^{2}$. Këndi hapësinor i plotë përfshinë tërë hapësirën përreth burimit të dritës, e më të edhe tërë sipërfaqen e mbështjellësit të sferës përreth burimit të dritës.

Këndi hapësinor i plotë është:

$$
\Omega=\frac{S}{r^{2}}=\frac{4 \pi \cdot r^{2}}{r^{2}}=4 \pi=12.56(s r)
$$

\subsubsection{Intensiteti i dritës}

Intensiteti i dritës paraqet masën për vlerësimin e dritës, e cila emitohet rrezatohet ë drejtim të caktuar. Intensiteti i dritës ( 1 burimit të dritës në drejtim të caktuar), sipas CIE është përkufizuar me raportin në mes të fluksit të dritës, të cilin burimi e rrezaton nëpër këndin hapësinor elementar në drejtimin e dhënë, dhe këndit hapësinor elementar:

$$
\mathrm{I}=\mathrm{Iv}=\frac{d \phi v}{\mathrm{~d} \Omega}
$$

Nëse fluksi i dritës është i njëjtë në të gjitha drejtimet, ose nëse shqyrtohet (vëzhgohet) fluksi i fundëm i dritës $\varnothing$, të cilin burimi i dritës e rrezaton në këndin hapësinor $\Omega$, atëherë barazimi mund të tregohet në formën më të thjeshtë

$$
\mathrm{I}=\frac{\phi}{\Omega}
$$

Njësia e intensitetit të dritës është kandela (cd). Kandela (cd) është njësi matëse themelore e sistemit ndërkombëtar të njësive matëse - SI. Kandela është intensiteti i dritës në drejtimin e dhënë, i burimit i cili emiton rrezatim monokromatik me frekuencë 540 $1012 \mathrm{~Hz}$, dhe intensiteti rrezatues i të cilit në atë drejtim është 1/683 vatë për steradijan. 


\section{Shembull detyre:}

Të caktohet intensiteti mesatar i burimit të dritës fluksi i tërë i të cilit është $\emptyset=1500 \mathrm{~lm}$

\section{Zgjidhje:}

Fluksi i tërë i dritës së burimit me intensitet të dritës $\boldsymbol{I}$, është:

$$
\text { Imes }=\frac{\phi}{\Omega}=\frac{\phi}{4 \pi}=\frac{1500}{4 \cdot 3.14}=119(c d)
$$

Të caktohet fluksi i tërë i dritës, i burimit të dritës me intensitet $\quad I=75 \mathrm{~cd}$.

\section{Zgjidhje:}

Fluksi i tërë i dritës së burimit me intensitet të dritës $\boldsymbol{I}$, është:

$$
\phi=I \cdot \Omega=I \cdot 4 \pi=75 \cdot 4 \cdot 3.14=942(\mathrm{~lm})
$$
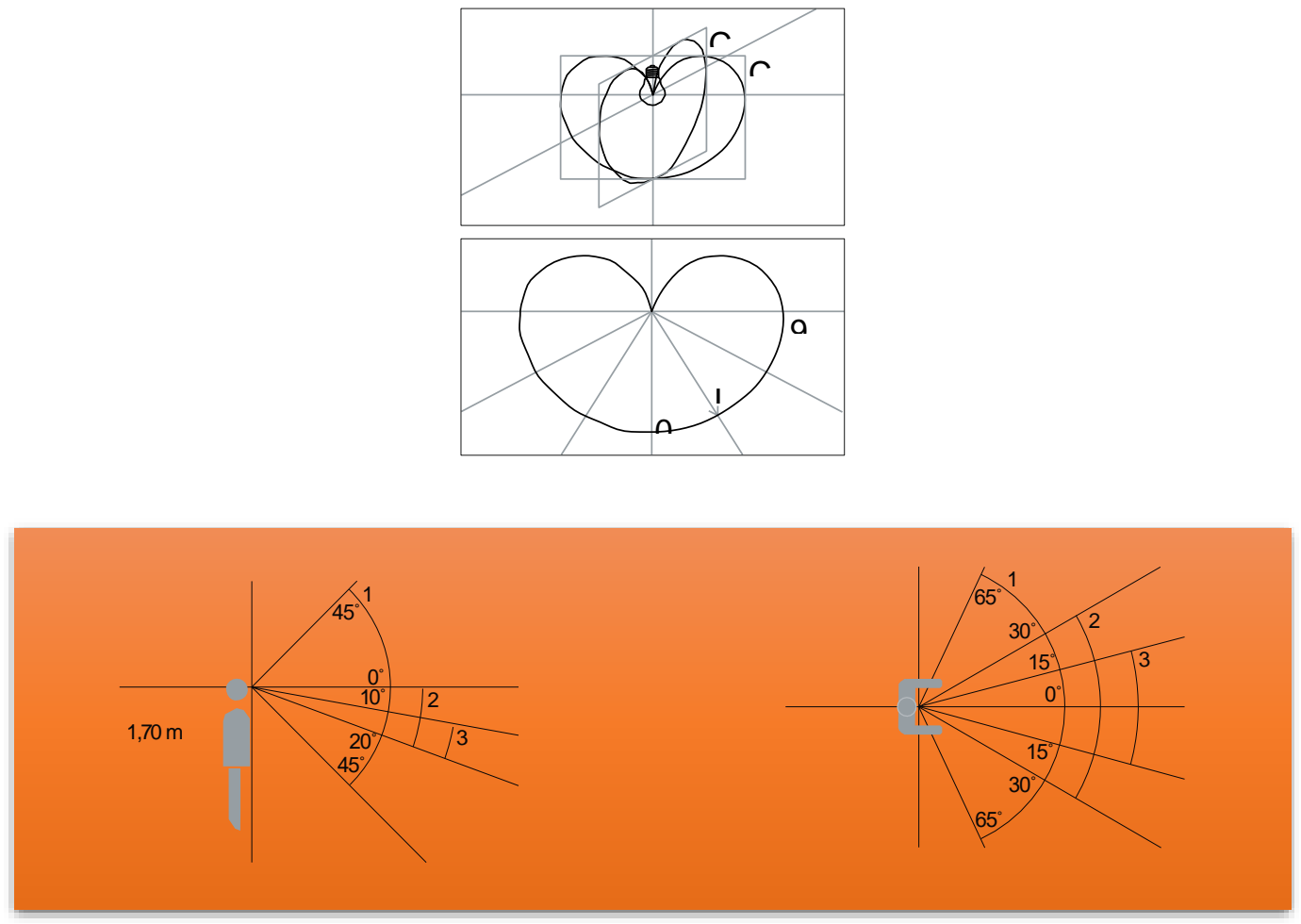

Figura 173. Këndi vizual

(Burimi): (C) ERCO. Guide, 2013. 


\subsubsection{Llojet e trupave ndriçues}

Llambat e thjeshta me fije të skuqur prej volframi në balonin pa ajër, japin rreze më të madhe të dritës, të rrjedhës duke shpenzuar më shumë energji elektrike. Kanë një spektër të pandërprerë, mirëpo ngjyra e kuqe është më shumë e përfaqësuar. Baloni i llambave të thjeshta punohet në trajtë dardhe. Llambat speciale dallohen sipas formës dhe punimit. Mund të jenë nga fundi me një sferë të zgjeruar në formë të qiririt ose të gypit të errësuar ose më ngjyrë.

Llambat reflektorë janë pjesërisht të lyera me një shtresë të metalit për ta drejtuar dritën në kahun e caktuar.

Llambat halogjenë vendosen horizontalisht. Gypthi i tyre është i mbushur me jod ose brom dhe kanë një rënie shumë të vogël të rrjedhës së dritës. Llambat speciale prodhohen për kopjim, për aparate projektuese, për fotografime me ngjyra e të ngjashme.

Llambat e zhivës për vendosjen vertikale ose horizontale prodhohen në mënyrë standarde me reflektorë te montuar. Shfrytëzohen aty ku ka nevojë që ngjyrat të shihen mirë.

Gypat dhe llambat e natriumit janë më të qëndrueshme nga të gjitha llojet e trupave ndriçues, mirëpo, ngjyrat nuk dallohen mirë (indeksi i dobët i rikthimit). Mund të shfrytëzohen vetëm për ndriçimin e stabilimenteve industriale dhe për dritat e jashtme.

Dritat e neonit janë gypa të qelqit të mbushur me gaze fisnike me një shtesë avulli të zhivës. Ato varësisht nga lloji i gazit emetojnë ngjyra të llojllojshme të dritës: të kuqe, portokalli, të verdhë-zbehtë, të kaltër azure dhe te kaltër.

Dritat fluoreshente janë gypa të qelqit të lyer nga ana e brendshme me lyerje fotoluminishente, sepse fluoreshenca ose shndërrimi i rrezatimit ultraviolet në dritë bëhet me ndihmën e bashkë dyzimeve të fosfatit. Emetojnë dritë të ftohtë. Shfrytëzimi ndriçues i tyre është rreth pesë herë më i madh sesa te llambat e thjeshta. Janë më të shtrenjta, mirëpo edhe shpenzimet e përdorimit të tyre janë më të vogla. Shfrytëzohen në ambiente ku nuk ndizen e fiken shpesh, sepse me ketë u zvogëlohet qëndrueshmëria.

Kandilat apo fenerët shërbejnë për vendosjen e llambave dhe për përcjelljen e rrjedhës së dritës në një drejtim të caktuar. Llambat pa fenerë me shkëlqimin e tyre të marrin sytë, drita përndahet keq ose jo në rregull, nuk duken bukur dhe u ekspozohen më tepër thyerjeve.

Sipas llojit të ndriçimit fenerët mund të jenë për: ndriçim të drejtpërdrejtë, kryesisht të drejtpërdrejtë, të njëtrajtësisë gjysmindirekt, indirekt dhe sipërfaqësor. Shkalla e shfrytëzimit dhe ekonomizmi i ndriçimit varen prej fuqisë së reflektimit të dritës nga sipërfaqja, si dhe nga ngjyra e saj.

Ndriçimi i drejtpërdrejtë e lëshon dritën e llambës në rrafshin e caktuar teposhtë dhe pjerrtas për së gjeri. Pjesa e epërme e fenerit është e patejdukshme. 
Ndriçimi kryesisht indirekt pjesën më të madhe të dritës e lëshon teposhtë dhe pjesën më të vogël drejt plafonit.

Ndriçimi i njëtrajtësishëm ose i përzier dritën e drejton në të gjitha anët. Drita prapësohet nga muret e plafonit dhe kështu zbutet shfaqja e hijes. (Nuk rekomandohen muret me ngjyrë të errët).

Ndriçimi kryesisht indirekt pjesën më të madhe të dritës e çon në plafon e më të voglën teposhtë. Zbatohet më së forti në lokalet e punës.

Ndriçimi indirekt tërë dritën e çon në plafon prej 'të cilit ajo prapësohet e reflektohet. Vendoset në hollët e teatrove, në holle të tjera e të ngjashme.

Ndriçimi sipërfaqësor prapësohet duke përhapur dritën nëpër ndonjë rrafsh të tejdukshëm. Emeton dritë difuze (shpërhapëse). Zbatimin më të madh e gjen në sallat kirurgjike, pastaj në salla me pullaz qelqi, në kopshte dimërore .

\subsubsection{Ndriçimi estetik vizual}

Pjesë të ndryshme të fasadave ose tërë fasadat ndriçohen me reflektorë të vendosur në mënyrë të përshtatshme që kanë llamba speciale, për shembull, me avull zhive ose natriumi. Sipas numrit të objekteve, të detajeve arkitektonike, shtatoreve e të ngjashme, caktohet edhe numri dhe renditja e reflektorëve, kurse sipas sipërfaqes së fasadës përllogaritet intensiteti i ndriçimit dhe caktohet ngjyra e dritës. Panotë ndriçues të reklamave ose shkronjat, punohen asisoj që në to vihen llamba që gjenden në një largësi të ndërvetshme aksiale prej $15 \mathrm{~cm}$ e të larguara nga mbështjella për $10-15 \mathrm{~cm}$ dhe mbulohen me një mbështjellë prej qelqi ose plastmase. Shkronjat reklamuese mund të punohen edhe prej një a më shumë gypash të qelqit të përkulur me ngjyrë drite varësisht nga lloji i gazit me të cilin janë mbushur. Ndriçimi LED, (light-emitting diode) është bërë kohët e fundit ndriçim shumë aktual. Kanë përparësi të shumta mbi llampat e zakonshme, duke përfshirë konsumin më të ulët të energjisë, jetën më të gjatë, kan të përmirësuar rezistencën fizike, masë më të vogël. Mund të përdoren në të gjitha hapësirat arkitektonike dhe kanë një numër të madh avantazhesh në krahasim me llampat tradicionale-klasike. LED është një mundësi jashtëzakonisht bashkëkohore për ndriçim artificial. Këto drita janë tepër efikase për konvertimin e energjisë, rreth $75 \%$ në dritë, sidomos kursejnë energji. Përparsi tjetër kualitative e ndriçimit LED është se dritat janë vazhdimisht të ftohta, nuk emetojnë nxehtësi. Dritat LED kanë një kosto të ulët të mirëmbajtjes, si dhe njëherit janë të papërshkueshëm nga uji.

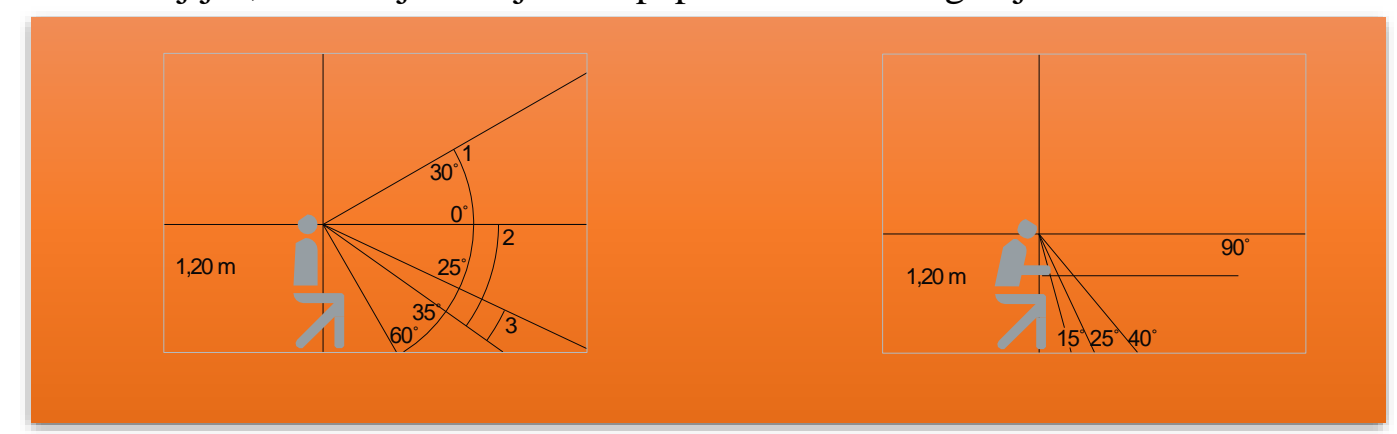

Figura 174. Njeriu, këndi i shqimit

(Burimi): (C) ERCO. Guide, 2013. 


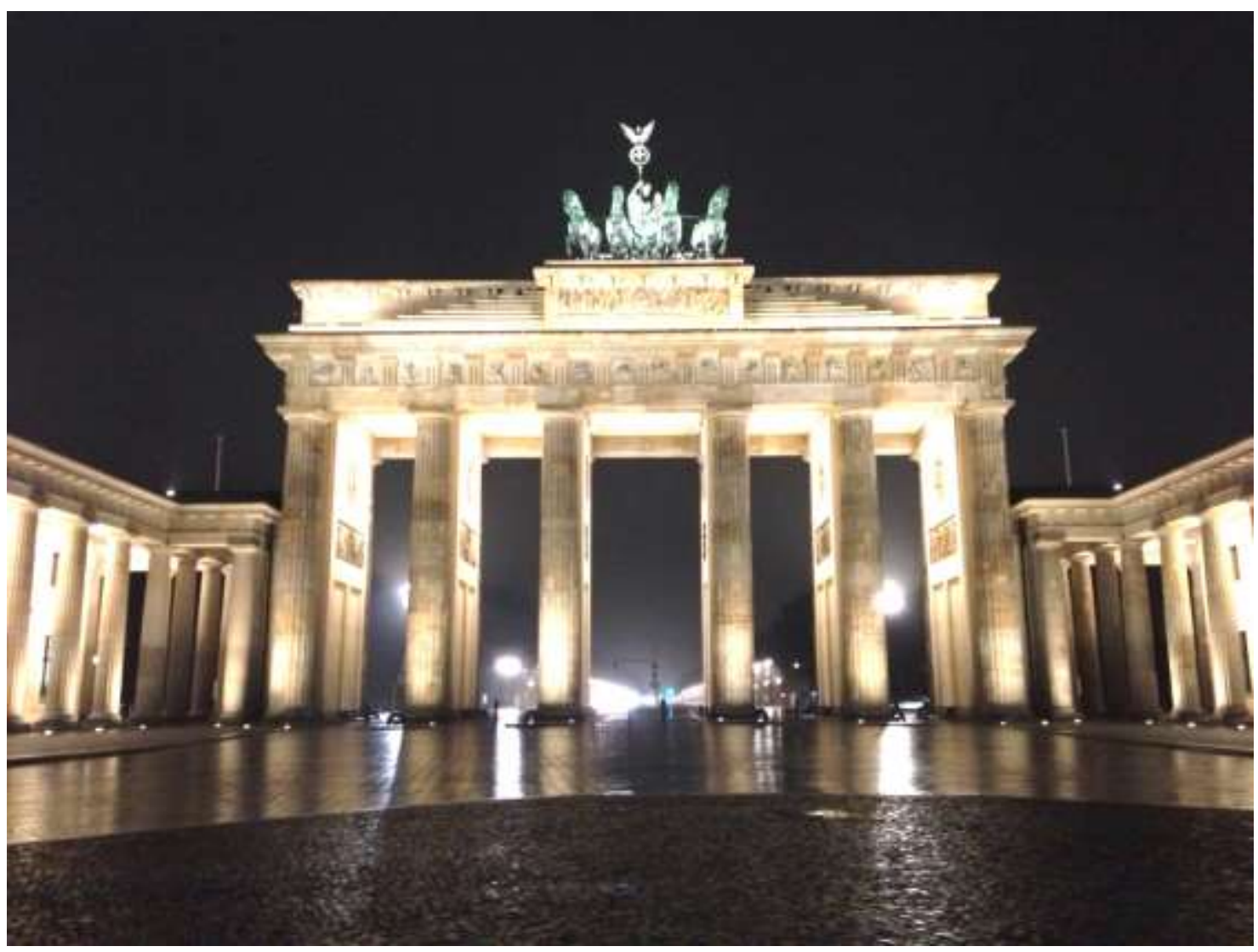

Figura 175. Ndriçimi Brandenburg Gate. Ndriçimi dhe efektet në prapavijë (Burimi): Stacey MacNaught, 2012. (Flickr). E licensuar nga Creative Commons Attribution 2.0 Generic

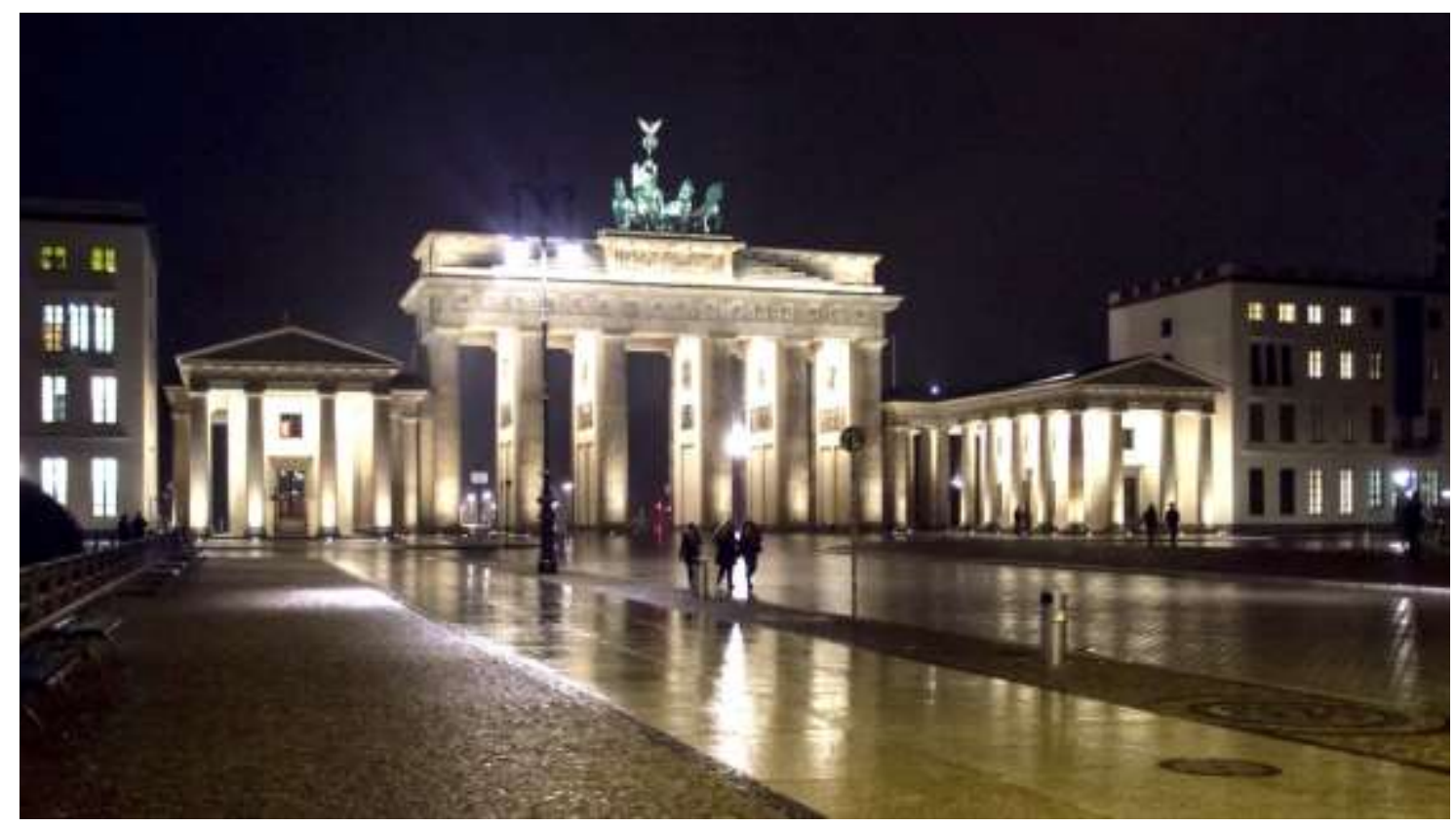

Figura 176. Ndriçimi Brandenburg Gate. Ndriçimi dhe efektet në prapavijë (Burimi): Ed Webster, 2013. (Flickr). E licensuar nga Creative Commons Attribution 2.0 Generic 

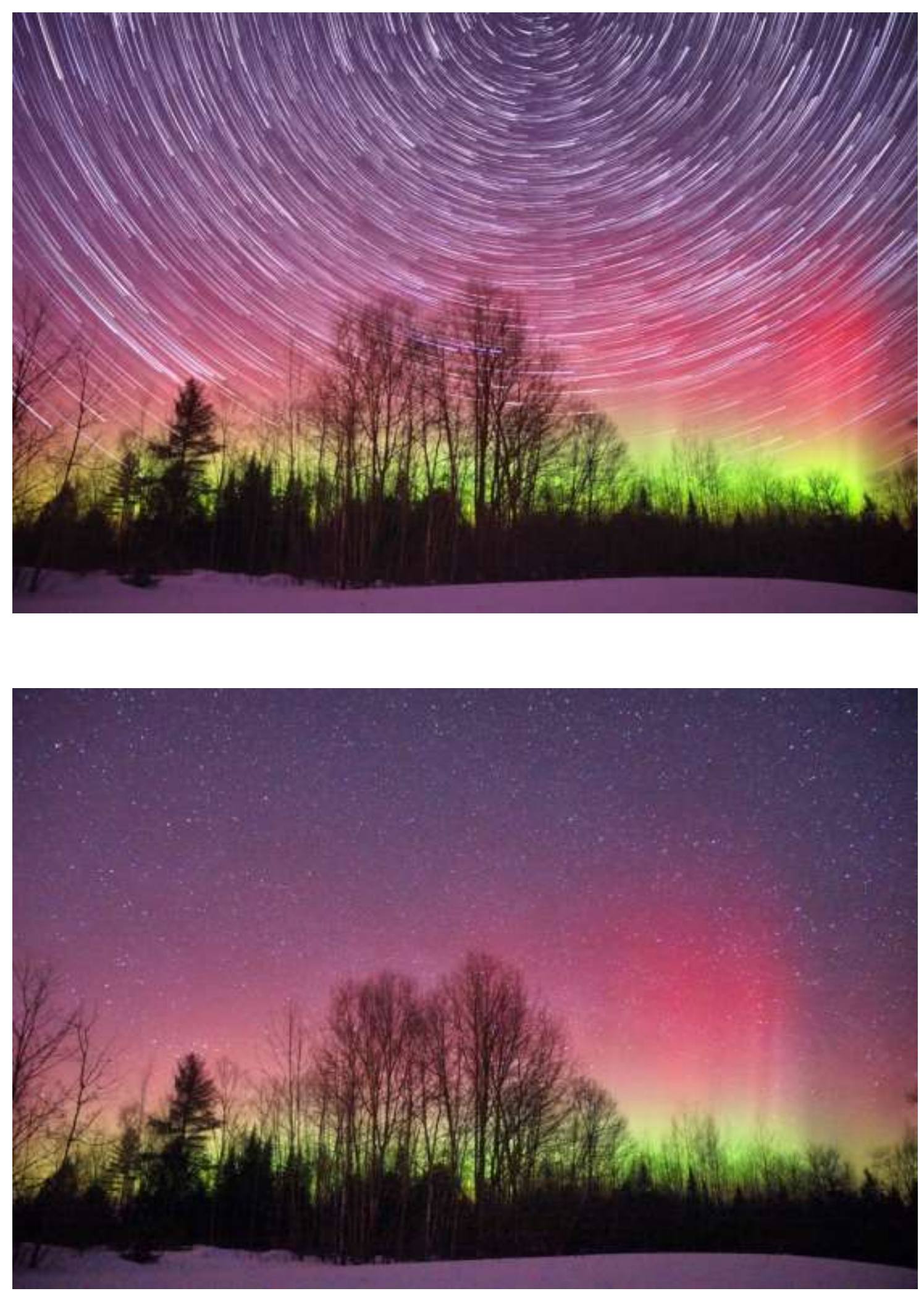

Figura 177. Aurora, Milo. Maine US.

(Burimi): Mike Lewinski, 2015. (Flickr). E licensuar nga Creative Commons Attribution 2.0 Generic 

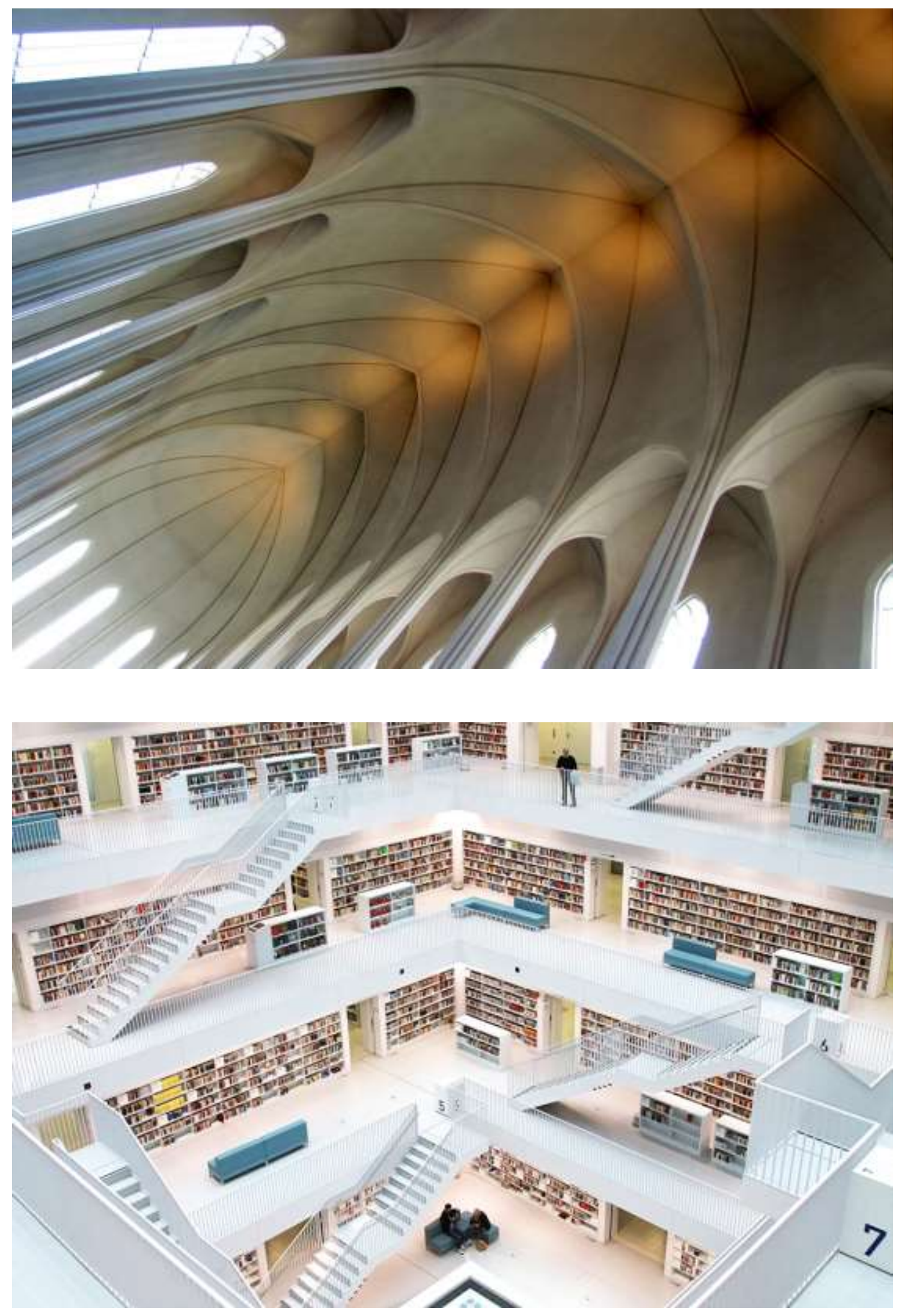

Figura 178. Kisha, Hallgrímskirkja, Reykjavik, dhe Libraria publike Shtutgart RFGJ. (Burimi): O Palson, 2011. (Flickr). E licensuar nga Creative Commons Attribution 2.0 Generic 

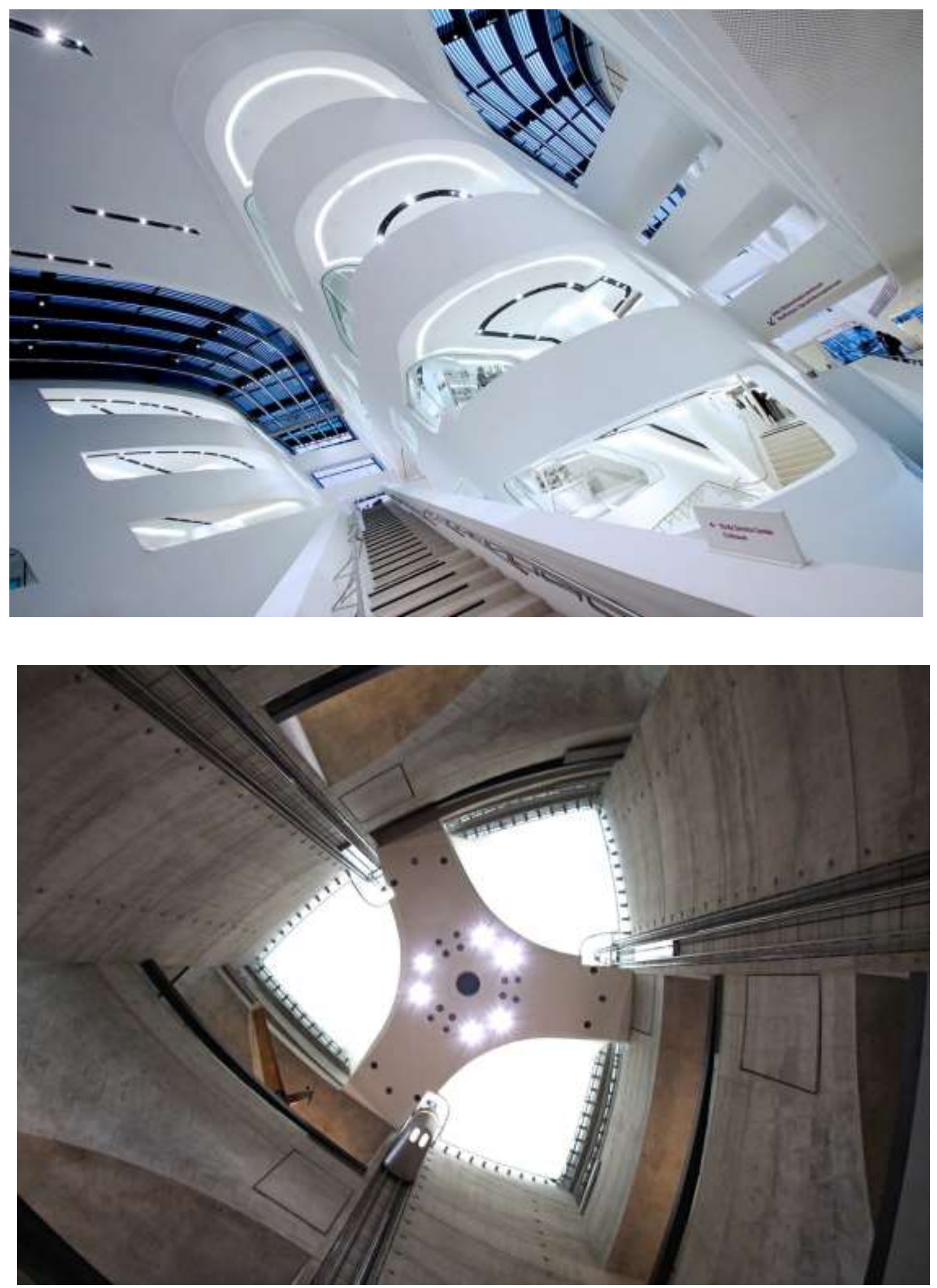

Figura 179. Librari - Qendër mësimi. Zaha Hadid, Vienë dhe Atriumi i muzeut Mercedes Benz, Shtutgart RFGJ. (Burimi): O Palson, 2014. (Flickr). E licensuar nga Creative Commons Attribution 2.0 Generic 
Tabela 25. Ndriçimi i propozuar, lejuar për hapësira të ndryshme (Burimi): http://www.energy.ca.gov/. 2015

\begin{tabular}{|lc|}
\hline Lloji i objektit & Ndriçimi i lejuar W/. ${ }^{2}$ \\
\hline Auditoriumet & 16.14 \\
\hline Objekte shkollore & 11.83 \\
\hline Ndërtesat industriale dhe depot & 6.45 \\
\hline Objekte publike - manifestime & 12.91 \\
\hline Institucionet financiare - bankat & 11.83 \\
\hline $\begin{array}{l}\text { Ndërtesa tregtare dhe industriale } \\
\text { Të larta }\end{array}$ & 10.76 \\
\hline Të ulëta & 10.76 \\
\hline Dyqane ushqimore & 16.14 \\
\hline Bibliotekat & 13.98 \\
\hline Spitale dhe klinikat mjekësore & 11.83 \\
\hline Objektet administrative & 9.14 \\
\hline Garazha - parkingje & 3.22 \\
\hline Objektet fetare & 17.21 \\
\hline Restorantet & 12.91 \\
\hline Shkollat & 10.76 \\
\hline Teatrot & 13.98 \\
\hline Gjithë të tjerat & 6.45 \\
\hline
\end{tabular}

Arkitektët dhe profesionistë mund të përdorin llogaritjet e përafërta të ngarkesës për projektimin e ndriçimit, Tabela sipër, duke planifikuar efektivitetin maksimal të ndriçimit dhe qëndrueshmërisë.

\section{Shembull:}

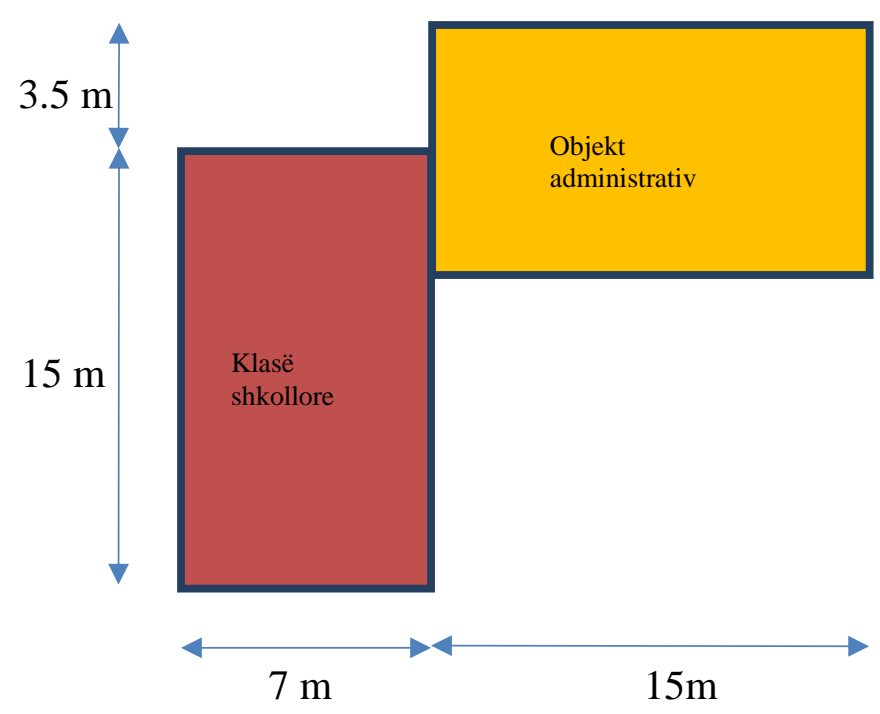

Figura 180. Objekt shkollor, llogaritjet e përafërta të ndriçimit (Burimi): Bujar Bajçinovci. 2015 
Nga kjo, rrjedhë:

Sipërfaqja për klasën $=7 \times 15=105 \mathrm{~m}^{2}$

Sipërfaqja për administratën $=7 \times 15=105 \mathrm{~m}^{2}$

Për, klasën sipas tabelës sipër. Koeficienti 10.76 x 105=1129.8 W

Për, administratën sipas tabelës sipër. Koeficienti 9.14 x 105=959.7 W

$$
\Sigma \text { tot }=S 1+S 2=1129.8+959.7=2089[\mathrm{~W}]
$$

Fuqia e kërkuar për ndriçim=2.089 [kW]

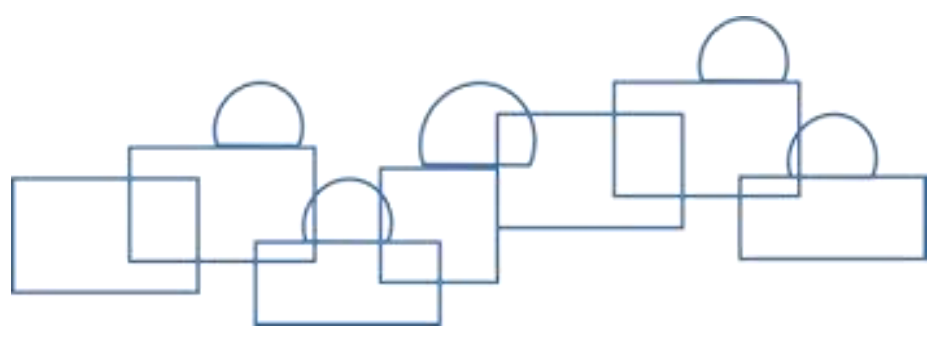




\subsubsection{HVAC - (heating, ventilating, and air conditioning)}

\subsubsection{Ngrohja qendrore}

Me sisteme për ngrohjen qendrore sigurohet ngrohja e një ose me tepër objekteve prej trupave ngrohës, nxehtësia përcillet nëpër gypa e kanale deri te trupat ngrohës në ambiente të dëshiruara.

Varësisht nga vëllimi i objekteve, ngrohja mund të jetë:

1. Qendrore

2. Etazhe

3. Ngrohje së largu

Epërsitë e ngrohjes qendrore janë: funksionimi ekonomik dhe i sigurt, aftësia ngrohëse e lëndës djegëse shfrytëzohet drejt, ndezja dhe mbikëqyrja janë të centralizuara, përcaktohen në mënyrë profesionale e destinuese lartësitë e temperaturave të ngrohjes dhe nxehtësia renditet drejt. Ambientet brenda ndërtesave nuk ndyhen, as që u prishet ajri. Një numri të madh shfrytëzuesish u bëhet e mundshme një qëndrim i këndshëm e higjienik.

Trupat ngrohës vendosen në vende ku më së paku pengojnë, dhe parashihet kujdes që nxehtësinë ta emetojnë njëtrajtësisht. Së këndejmi vendosen kryesisht nën dritare për ta ngrohur ajrin e ftohtë posa ky të depërtojë në ambient, prandaj nuk ka rrymime të ftohta ajrore sipër dyshemeve.

Të metat e ngrohjes qendrore janë: shpenzimet e larta të investimeve dhe manipulimi i domosdoshëm profesional gjatë eksploatimit. Problemi i ngrohjes së ndërtesave në kohën kalimtare, kur temperaturat janë vetëm kohë pas kohe të larta, d.m.th. kur lëshimi në punë i tërë instalimeve është joekonomik, zgjidhet me ngrohje kohëzgjatjeje të shkurtër.

Detyra e ngrohjes qendrore është që në lokal ta mbajë temperaturën në një vlerë të caktuar, pavarësisht nga temperatura e jashtme. Sipas vëllimit ngrohja qendrore mund të jetë për ngrohje vetëm të një banese, të një ndërtese ose të blloqeve të veçanta të ndërtesave, apo të qytetit në tërësi.

Përparësitë e ngrohjes qendrore, krahas asaj lokale, janë:

1. Ngrohja e njëtrajtshme e të gjitha dhomave, madje edhe e atyre të korridoreve, shkallëve

2. Përhapja e njëtrajtshme e temperaturës në dhoma, për shkak se ka mundësi që radiatorët të vihen nën dritare

3. Pastërtia e ajrit në dhoma është më e madhe për shkak se nga furra nuk lirohen gazra. Përveç kësaj nuk ka ndytës gjatë dërgimit dhe kthimit të lëndës djegëse dhe as gjatë ndezjes se saj 
4. Emanimi dhe hedhja më e vogël e tymit dhe e blozës në rrethinë, për shkak të ndezjes së zjarrit vetëm në një furrë, në vend të ndezjes në disa sosh

5. Rregullimi i lehtë i temperaturës në trupat ngrohëse ose në kaldajë, manualisht ose automatik

6. Manipulimi i lehtë dhe i thjeshtë, madje është vetëm një vend për ndezje. Në afërsi të kaldajave, zakonisht janë bodrumi me lëndë djegëse dhe dhoma për zgjyrë dhe hi, me çka mjaft është lehtësuar puna e mënjanimit

7. Siguria më e madhe nga zjarri, sepse kemi të bëjmë me një furrë në kaldatore në dysheme prej betoni, për dallim nga furrat e rëndomta, që në këtë aspekt janë më pak të mbrojtura

8. Ekonomizimi në prodhim, sepse kaldajat e ngrohjes qendrore, sipas rregullit teknikisht janë më të përsosura dhe ato i mbikëqyrë një personel i kualifikuar. Meqë ndizet vetëm një zjarr dhe ngrohet vetëm një tymtar, gjithashtu arrihet kursim në nxehtësi

9. Trupat ngrohëse zënë hapësirë shumë të vogël në lokale dhe atë zakonisht nën dritare.

10. Në rast të ngrohjes nga ko gjenerimi, siç e kemi tash rastin në Prishtinë, atëherë ngrohja qendrore e gjen veten në rastin e përkryer të funksionimit

Mangësitë e ngrohjes qendrore:

1. Investimi i madh fillestar;

2. Vështirësitë që i shkakton moti i ligë në ndonjë stinë (vjeshtë dhe pranverë), kur e fillon punën sistemi për punë në kohë të shkurtër ashtu që ky funksionim i instalimit nuk është ekonomik;

3. Është rrezik të ngrihet uji në instalim

4. Nga djegia e pluhurit organik në radiatorë të ngrohtë krijohet ndjenja e thatësisë së ajrit.

Megjithatë përparësitë e ngrohjes qendrore, ndaj asaj individuale, janë shumë të mëdha dhe m'u për këtë arsye numri më i madh i objekteve që ndërtohen sot, janë me ngrohje qendrore. Ngrohja qendrore, sipas bartësit të nxehtësisë, mund të jetë me ujë, me avull uji dhe me ajër. Me zgjedhjen e drejtë të sistemit të ngrohjes dhe me mirëmbajtjen higjienike të pastërtisë së sipërfaqes së trupave ngrohës, përjashtohet mundësia e ndjenjës së rreme se ajri është i thatë. 


\subsubsection{Llojet e ngrohjes qendrore}

Sipas mjetit fluidit me të cilin transmetohet nxehtësia prej stabilimenteve ngrohëse deri te trupat ngrohës, ngrohja mund të bëhet:

1. Me ujë të nxehtë,

2. Me avull uji, ngrohja avullore

3. Ngrohje ajrore, me ajër të nxehtë

4. Ngrohje e kombinuar ose e përzier.

Sistemi i ngrohjes me ujë të ngrohtë përbëhet prej: kazanit ku uji nxehet, rrjetit gypor i mbushur me ujë nëpër të cilin rrymon uji i ngrohtë deri te trupat ngrohës dhe me ndihmën e tyre nxehtësia u emetohet ambienteve. Tepricën e ujit që sajohet nga bymimi me rastin e ngrohjes e pranojnë enët ekspanduese. Ato njëkohësisht edhe shkarkojnë rrjetin nga shtypja e madhe. Për rregullimin e ngrohjes shërbejnë mbyllësit dhe valvulet.

Sipas lartësisë së temperaturës së ujit të ngrohur, sistemi i ngrohjes mund të jete: me ujë të nxehtë e të valë. Me ujë të nxehtë ngrohen ndërtesat pa ndërprerje në ngrohje, për shembull, ndërtesat e banimit spitalet e të ngjashme. Uji i nxehtë shfrytëzohet për ngrohje së largu. Sipas mënyrës së funksionimit sistemi i ngrohjes me ujë të ngrohtë mund të jetë:

1. Me gravitacion, përkatësisht me qarkullim natyror të ujit

2. I detyruar, me qarkullim me ndihmën e pompave.

Ngrohjet e gravitetit me ujë të ngrohtë

Qarkullimi, rrjedhja ose qarkullimi natyror i ujit me rënie të lirë mbështet në ndryshimin e densiteteve të ujit të ngrohur në dalje të kaldajës, e të pa ngrohur në hyrje të kaldajës dhe ekziston përderisa uji të nxehet e të ftohet. Parimi i qarkullimit të ujit është paraqitur në figurën 181 .

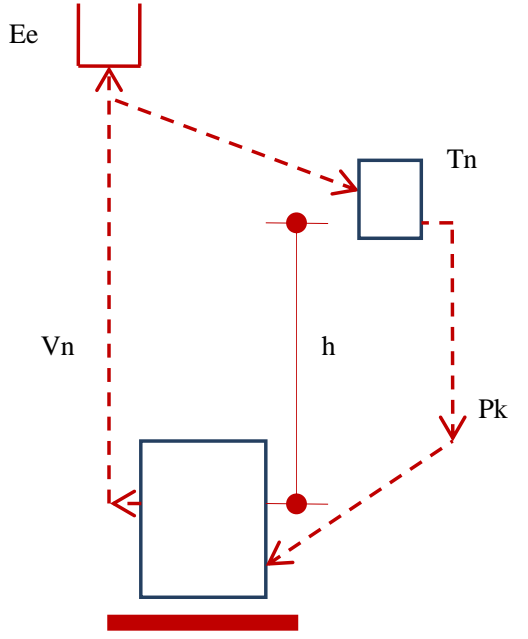

Figura 181. Parimi i ngrohjes gravituese (Burimi): Bujar Bajçinovci. 2015.
Parimi i nxehjes gravitu-es me ujë të ngrohtë: kaldaja (K), trupi nxehes (Tn), ena ekspanduese (Ee), vertikalja ngritëse (Vn), tubi kthyes (pk), (h) ndryshimi i lartësisë. 
Uji i ngrohur në kaldajë, me peshë më të vogël specifike (më i lehtë), ngritët në vertikalen ngjitëse deri te trupi ngrohës, aty emeton nxehtësinë dhe ftohet. Uji i ftohur me peshë më të madhe specifike (më i rëndë), kthehet nëpërmjet gypit kthyes në kaldajë për ngrohje të serishme.

Mundi gravitacional mund të njehsohet me formulën:

$$
\begin{gathered}
M=g \cdot h\left(\rho_{o}-\rho_{k}\right) \\
\frac{m}{s^{2}} \cdot m \cdot \frac{k g}{m^{3}} \equiv \frac{N}{m^{2}} \equiv P a
\end{gathered}
$$

ku janë:

$\mathrm{h}=$ ndryshimi i lartësisë ndërmjet stabilimentit ngrohës dhe trupit ngrohës

$\rho_{o^{-}}$densiteti i ujit të nxehtë në shpërndarje, $\mathrm{kg} / \mathrm{m}^{3}$

$\rho_{k}$ - densiteti i ujit të ftohtë në përcjellësin kthyes, $\mathrm{kg} / \mathrm{m}^{3}$

Nga formula vërehet se, sa më e madhe të jetë largësia ndërmjet stacionit ngrohës dhe trupit ngrohës dhe sa më i madh të jetë ndryshimi i temperaturave të ujit shtypja është aq më e lartë. Rrjedhja varet edhe nga gjatësia e rrjetit për shkak të rezistencës dhe fërkimit. Qarkullimi dobësohet bashkë me gjatësinë e rrjetit dhe është më i vogël në trupat më të largët ngrohës.

Ajri në rrjet dhe tubacion krijon pengesa në qarkullim. Për t'u përcjellur më lehtë jashtë sistemit nëpër gypin shfryrës të enës ekspanduese, të gjithë përcjellësit horizontalë vendosen në një ngritje të butë tërmale prej 1\%. Epërsitë e ngrohjes me ujë janë: trupat ngrohës nuk kanë temperatura tepër të larta (temperaturat janë nën $70^{\circ} \mathrm{C}$ ), nxehtësinë $\mathrm{e}$ emetojnë lehtë dhe gjatë menjëherë pas ndërprerjes së ndezjes së kaldajë; stabilimentet punojnë pa shushuritje dhe temperatura e ujit rregullohet lehtë.

E metë është, ngrohja e ngadalshme e ujit si dhe mundësia e çarjes së gypave dhe të trupave ngrohës në acar. Së këndejmi, në ujë shtohet ndonjë mjet kundër ngrirjes. Sipas mënyrës së shpërndarjes sistemi i ngrohjes me ujë të nxehtë mund të jetë dy gypor, ku përcillet ndaras uji i nxehtë nga ai i ftohti dhe një gypor me rrjet të përbashkët për ujë të ngrohtë e të ftohtë.

Sistemi dy gypor i ngrohjes me ujë të ngrohtë ka dy rrjete të veçanta, njërin për ujin e ngrohtë e tjetrin për atë të ftohtë. Sistemi përbëhet prej vertikaleve dhe rrjetit horizontal dhe degëzimeve për lidhje me trupat ngrohës nëpër të cilët uji rrymon në kahun e caktuar. Rrjeti horizontal i gypave shtrohet në dy mënyra: sipër etazhit më të lartë dhe etazhit më të ulët, përkatësisht me shpërndarje të epërme ose të poshtme. Sistemi dy gypor me shpërndarje të sipërme, nga kaldaja uji i ngrohtë rrymon përpjetë nëpër vertikalen kryesore ngjitëse deri te rrjeti i epërm shpërndarës në plafon. Vertikalet zbritëse në degëzime ujin e çojnë në trupat ngrohës. Prej trupave ngrohës uji i ftohur hyn në degëzime të tjera në përcjellësit vertikalë dhe në përcjellësit mbledhës rikthehet në kaldajë. Rrjeti i epërm shpërndarës ka rënie 1\% drejt vertikaleve që ajri të mund të shkojë më lehtë në enën ekspanduese dhe në gypin shfryrës jashtë. Me përcjellësin ekspandues ena është e lidhur me vertikalen ngritëse. 
Nëse ena ekspanduese nuk mund të vendoset, për shembull, në kthinën mbi kulmin e rrafshët, atëherë vendoset në etazhin më të lartë të ndërtesës. Sistemi dy gypor i shpërndarjes, për shkak të rrjetit të gjatë të gypave, është dukshëm më i shtrenjtë se sistemet e tjera. Epërsi ka, qarkullimi i mirë i ujit.

Sistemi dy gypor me shpërndarje të poshtme ka të dy rrjetet shpërndarëse nën plafon në bodrum. Prej rrjetit të poshtëm shpërndarës ndahen përcjellësit ngritës dhe përmes degëzimeve ujin e ngrohtë e çojnë në trupat ngrohës. Uji i ftohur me anë të përcjellësve zbritës rikthyes dhe nëpër rrjetin e poshtëm rikthyes kthehet në kalda. Përcjellësi ajror vendoset nën plafon, deri te ena e ekspanduese

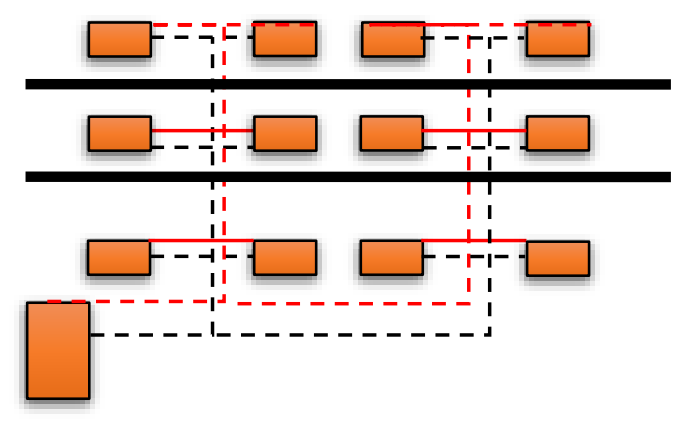

Figura 182. Sistemi dy gypor me shpërndarje të poshtme (Burimi): Bujar Bajçinovci, 2017.

Epërsitë e shpërndarjes së poshtme në krahasim me të epërmen janë: gjatësia më e vogël e gypave dhe humbjet më të vogla të nxehtësisë. Nuk zbatohet në ndërtesat me bodrume për ruajtjen e artikujve ushqimorë. Vendoset kryesisht në ato ndërtesa me madhësi të vogël e mesatare.

Sistemi një gypor_i përcjellësve ka vetëm një rrjet me shpërndarje të epërme. Nga trupat ngrohës në etazhet e larta uji i ftohur shkarkohet nëpër gypin prurës të ujit të ngrohtë, përzihet me ujin e ngrohtë dhe hyn në trupat ngrohës në etazhet e poshtme. Në lartësinë e duhur të rrjetit montohet ena e hapur ekspanduese. Epërsia e sistemit një gypor të shpërndarjes së ujit të nxehtë, ka pamje më të mirë. Ka zbatim të madh në ndërtesat njëkatëshe, dhe qëndron fakti se rrjeti është dukshëm më i shkurtër dhe më i thjeshtë në lokale në katin përdhese, në të cilët sipas dispozitave ngrohen me temperatura diç më të ulëta se ambientet e banimit.

\subsubsection{Ngrohja me etazhe}

Te ngrohja me etazhe, në të njëjtin etazhë janë stabilimentet që nxehen, rrjeti dhe trupat ngrohës. Qarkullimi është më i dobët dhe caku i ngrohjes më i shkurtër. Për këtë arsye edhe shfrytëzohet zakonisht për ngrohjen vetëm të një banese. Në qarkullimin e ujit ndikon ftohja si në gypa, ashtu edhe në trupat ngrohës. Rrjeti i epërm shpërndarës vendoset nën plafon, kurse i poshtmi nën dysheme. 
Anët pozitive të ngrohjes me etazhe qëndrojnë në faktin se çdo banues mund ta nxehë banesën kur të dojë, madje deri në temperaturën e dëshiruar. Komfori është më i vogël sepse shfrytëzuesit vetë e blejnë lëndën djegëse, ndezin zjarrin dhe pastrojnë hirin nga kaldaja . Ena ekspansive shihet në ambient. Gypat janë me diametra më të mëdhenj, qarkullimi është më i ngathët dhe nevojitet edhe tymtari për çdo kaldajë. Në relacion me ngrohjen lokale gjithsesi është më lehtë të furnizohet e të manipulohet vetëm me një furrë.

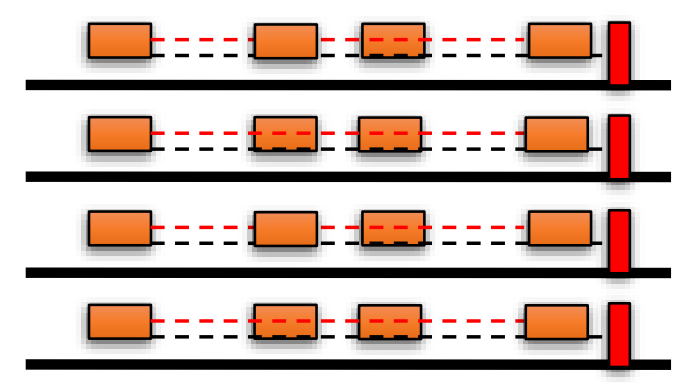

Figura 183. Ngrohja me etazhe (Burimi): Bujar Bajçinovci, 2017.

Ngrohja me ujë të ngrohtë me qarkullim të dhunshëm

Në ndërtesat e gjata e të degëzuara qarkullimi natyror nuk është i mjaftueshëm ta hedhë ujin deri te radiatorët e largët. Shfaqen rezistenca të mëdha dhe është joekonomike të vendosen gypa me diametra më të mëdhenj, sepse kjo kërkon sasi më të madhe uji e me këtë edhe shpenzim më të madh të lëndës djegëse duke shkaktuar kosto më të lartë të ngrohjes.

Qarkullimi i dhunshëm arrihet me pompa centrifugale të vendosura në përcjellës kryesorë, ose rikthyes. Ato sigurojnë qarkullimin e nevojshëm me të njëjtën shpejtësi pa marrë parasysh ndryshimin e temperaturës të ujit dhe ndryshimin e lartësisë ndërmjet trupit më të lartë ngrohës të epërm dhe kaldajës. Me shpejtimin e rrymimit vështirësohet veçimi i ajrit, kurse për qetësimin e ujit në vendin me të lartë në ndërtesë bashkë me enën ekspanduese vendoset edhe ena e ventilimit, pompa punon me ndihmën e elektromotorit dhe për siguri më të madhe, vendosen nga dy.

Është domosdoshme të ndërmerren masa në pikëpamje të izolimit që zhurma të mos bartet më tutje nëpër gypa. Shtjellimi dhe përbërja e sistemit me qarkullim të dhunshëm parimisht është i njëjte si te sistemi i gravitimit të ngrohjes, kështu që edhe këtu zbatohen të gjitha mënyrat e përmendura të shpërndarjes. 
Ngrohja me pompë më tepër zbatohet se ajo me gravitet. Më shpejt vihet në funksionim dhe më e shpejt bëhet ngrohja e lokaleve edhe më të largëta. Është më i lehtë edhe rregullimi i temperaturës. Gypat kanë diametra më të vegjël, sepse rezistencat nuk kanë rol aq të madh si te sistemi me gravitim.

Përcjellësit shtrihen më lehtë dhe shpenzimet për izolim janë më të vogla. Anët negative janë në procesin investiv në pompa dhe në varësinë e përhershme nga energjia elektrike, gjë kjo që shton shpenzimet. Gjatë ndërprerjes së rrymës ngrohje s'ka. Është i përshtatshëm veçanërisht sepse me valvula mund të shkyçen etazhe të ndryshme. Për çdo vertikale mund të vendoset veças edhe ujëmatësi, që konsumi të përllogaritet e paguhet veçmas.

\subsubsection{Ngrohja me avull}

Sistemi i ngrohjes qendrore me avull dallohet prej ngrohjes me ujë, ngase uji në kaldajë nxehet përderisa të mos shndërrohet në avull dhe më pas nëpër gypat e zbrazët të rrjetit shpërndarës përcillet deri te trupat ngrohës. Brenda tyre avulli jep nxehtësinë, ftohet dhe i kondensuar kthehet nëpër rrjetin kthyes në kaldaja.

Epërsitë e ngrohjes avullore në krahasim me atë ujore konsistojnë në faktin se me anë të avullit transmetohen edhe në largësi të mëdha sasi shumë më të mëdha të nxehtësisë me një masë më të vogël. Diametrat e gypave janë dukshëm më të vegjël si dhe sipërfaqet e epërme të trupave ngrohës. Sistemi është i zbrazët kur nuk punon dhe nuk plasaritet në temperatura të ulëta.

Të metat e këtij sistemi janë: temperaturat shumë të larta të trupave ngrohës (mbi $100^{\circ} \mathrm{C}$ ), mbi ta digjet pluhuri, nuk akumulojnë nxehtësi dhe ftohen shpejt dhe ekziston rreziku nga korrozioni.

Sipas lartësisë së shtypjes së avullit dallohen ngrohjet avullore:

1. Të shtypjes së ulët $(0,2$ bar)

2. Me vakum (shtypja më e ulët se 1 bar)

3. Të shtypjes së lartë $(0,05-2,00$ bar $)$

Ngrohja avullore e shtypjes së ulët. Parimi funksionon në bazë të shfrytëzimit të nxehtësisë së lidhur që lirohet duke u kondensuar. Mbi nivelin e ujit në kaldajën e avullit gjendet avulli deri në nivelin në trupin ngrohës. Avulli ka peshe më të vogël specifike se ajri, prandaj e shtyn ajrin teposhtë në përcjellësin e kondensimit deri në nivelin e përcaktuar. Në trupin ngrohës krijohen: zona e epërme me avull dhe e poshtmja me ajër. Për të mos shkuar avulli teposhtë dhe në përcjellësin e kondensimit dhe me këtë të shkaktojë shushuritje e zhurmë, në trupat ngrohës vendosen valvula speciale. Me ta rregullohet ardhja vetëm e atyre sasive të avullit që mund të kondensohen.

Për shkak të tensionit të avullit, niveli i ujit në përcjellësin e kondensimit është më i lartë se niveli i ujit në kaldajë në lartësinë e shtypjes në kaldajë. Ky ndryshim quhet zona e shtypjes. Madhësia e saj merret nga tabelat sipas largësisë më të madhe horizontale në metra prej trupit të epërm deri te kaldaja. 
Mënyrat e shpërndarjes së avullit, janë të njëjta si te sistemi i ngrohjes me ujë të nxehtë, përkatësisht me shpërndarje të epërme e të poshtme. Avulli i ujit, nëpër përcjellësit e ngjitjes sillet në trupat ngrohës nga rrjeti shpërndarës. Përcjellësit e kondensatit mbledhin dhe përcjellin kondensatin në gypin kryesor mbledhës dhe më tutje në kaldajë. Nëse përcjellësi i kondensatit gjendet mbi vijën ujore, ky lloj instalimi quhet me rrjet të thatë të kondensatit. Kur përcjellësi i kondensatit është nën vijën e ujit, atëherë quhet rrjet i ulët ose i zhytur i kondensatit.

Ngrohja avullore me vakum. Sistemi funksionon mbi parimin e uljes së shtypjes nën shtypjen atmosferike ( 1 bar), meqë atëherë uji avullohet në temperaturën më të ulët se $100^{\circ} \mathrm{C}$. Me ngrohje vakumi me ndihmën e stabilimentit për rregullimin e shtypjes rregullohet lehtë shtypja e avullit e me këtë edhe temperatura e trupave ngrohës. Në këtë mënyrë arrihen temperaturat e dëshiruara sikurse edhe te ngrohja me ujë, dhe së këndejmi kjo ngrohje është shumë higjienike. Në saje të avullit të ujit, ngrohja është shumë më e shpejtë dhe nuk ka rrezik nga ngrirja. Kondensati kthehet më shpejt në kaldajë.

Të metat e këtij sistemi janë: shpenzimet e larta investive dhe të funksionimit, rrjeti patjetër duhet të jetë i realizuar me precizitet dhe është e domosdoshme aftësia e lartë teknike e personave që manipulojnë me sistemin.

Ngrohja me avull të shtypjes së lartë. Te ky sistem mbretëron shtypje më e lartë se 0,5 barë. Temperatura e sipërfaqeve ngrohëse është më e lartë se 110C dhe nuk u përgjigjet kërkesave higjienike të ambienteve të banimit e të lokaleve të punës. Zbatohet kryesisht në industri, e të ngjashme. Rregullimi emetimit të nxehtësisë bëhet me dorë ose në mënyrë automatike duke i ndarë pjesët e ndryshme në trupat ngrohës me ndihmën e valvuleve. I tërë sistemi sendërtohet sipas dispozitave të posaçme, sikurse edhe kaldatoret, për shkak të sigurisë nga shpërthimet eventuale.

\subsubsection{Ngrohja me panele}

Te ngrohja me panele nxehtësia emetohet përmes sipërfaqeve të ngrohura të dyshemeve, plafonëve ose të mureve. Në relacion me fluidin termik kjo ngrohje mund të jetë: me ujë, me avull, me gaz, elektrike dhe ajrore. Uji i ngrohur, avulli dhe gazi përcillen nëpër sistemin e gypave të metalit e të plastikës. Ngrohësit elektrikë janë rezistuesit e montuar në konstruksione. Ajri i ngrohur kalon nëpër kanale dhe përmes grilave kalon në ambiente.

Ngrohja panel me ujë te nxehtë ose avull të ujit. Për këtë lloj ngrohje sistemi i shpërndarjes në parim është i njëjtë si për llojet e tjera të ngrohjes qendrore. Dallimi qëndron në llojet dhe vendet e vendosjes së trupave ngrohës. Trupat ngrohës për ngrohjen panel punohen në trajtë të gypave të drejtë ose të përdredhur në formë gjarpërore të vendosur në plafonë, dysheme ose mure të ndërtesave.

Në këtë mënyrë temperaturat renditen në mënyrë shumë më të volitshme dhe sigurohet një komoditet më i madh në ambiente. Trupat ngrohës të vendosur nën dritare ose pranë mureve të brendshme nxehin ambientet me qarkullimin natyror të ajrit, kurse në një pjesë më të vogël me rrezatimin sepse dihet se pranë dyshemesë temperaturat janë gjithmonë më të ulëta, kurse pranë plafonëve më të larta se optimalja. 
Ngrohja panel sipas vendit të vendosjes së trupave ngrohës, mund të jetë:

1. E plafonëve

2. E dyshemeve

3. E mureve

Ngrohja e plafonëve. Këtu trupat ngrohës gjenden në nivelin më të lartë të ambientit. Pranë tyre një shtresë e ajrit nxehet me përcjellje porse qëndron i qetë, sepse është më i lehtë se ajri tjetër më i ulët e më i ftohtë, kështu që nuk mund të bëhet konveksioni. Nxehtësia transmetohet teposhtë dhe me rrezatim, nxeh te gjitha objektet, dyshemetë dhe njerëzit në ambient. Ajri nxehet me përcjellje dhe vetëm me rrymimin e dobët ndërmjet sendeve të ngrohura ndodh një konveksion i butë. Trupat ngrohës të ngrohjes me plafon nxehen me fluidin e temperaturës dukshëm më të ulët, prej rreth $30^{\circ} \mathrm{C}$, kurse çdo gjë i është ekspozuar rrezatimit prej rreth $20^{\circ} \mathrm{C}$. Temperatura e ajrit në dhomë është më e ulët se optimalja përreth $2^{\circ} \mathrm{C}$. Kjo nuk u pengon njerëzve të ndihen këndshëm, sepse nxehtësinë trupore nuk e emetojnë me rrezatim në objekte të ftohta. Çdo gjë është e ngrohur dhe këmbët nuk u ftohen. Pluhuri nuk çohet, kurse ajri i dhomës është këndshëm i freskët e i pastër.

Anët e mira, pozitive të ngrohjes me plafon qëndrojnë edhe në faktin se trupat ngrohës nuk zënë vend. Është e përshtatshme për ngrohjen e hapësirave të punës në halla të mëdha, në hangarë, tregje dhe vendosen edhe para vitrinave dhe vendeve të tjera ku tubohen njerëzit. Instalimet për ngrohje me plafon mund të shfrytëzohen edhe për ftohjen e lokaleve. Në këtë rast vetëm në vend të ujit të nxehtë futet brenda uji i ftohtë. Ajri i ftohur nga plafoni zbret njëtrajtësisht teposhtë dhe ftoh ambientet me konveksion.

Ngrohja e dyshemesë. Sistemi është për çdo gjë i njëjtë si te ngrohja e plafonit dhe dallohet vetëm për nga vendi i vendosjes së gypave. Ata betonohen në pjesën e epërme të pllakës së konstruksionit të ndërkatit ose shtrihen lirisht në mbishtesën e dyshemesë.

Te ngrohja e dyshemesë trupat gjenden në nivelin më të ulët në ambient, kurse nxehtësinë emetojnë me konveksion. Për shkaqe fiziologjike lartësia e ngrohjes së dyshemesë është deri më $25^{\circ} \mathrm{C}$. Ajri i ngrohur ngrihet ngadalë lart dhe nuk çon pluhur. Doemos duhet pasur kujdes për zgjedhjen e llojit të dyshemesë që të mos vihet ndonjëri që është izolues i nxehtësisë dhe nuk duhet shtruar tepihë.

Ngrohja e mureve, i ka të vendosur trupat ngrohës në muret e jashtme e të brendshme që nxehen dhe zakonisht nuk janë më të ftohtë kështu që njerëzve nuk ua marrin nxehtësinë. Ngrohja ekskluzivisht me mure zbatohet më rrallë, sepse është vështirë të gjendet sipërfaqe mjaft e madhe e lirë e mureve. Shërben të shumtën si plotësim i ngrohjes me dysheme ose plafon në viset me klimë të ashpër ngase ato nuk japin mjaft nxehtësi.

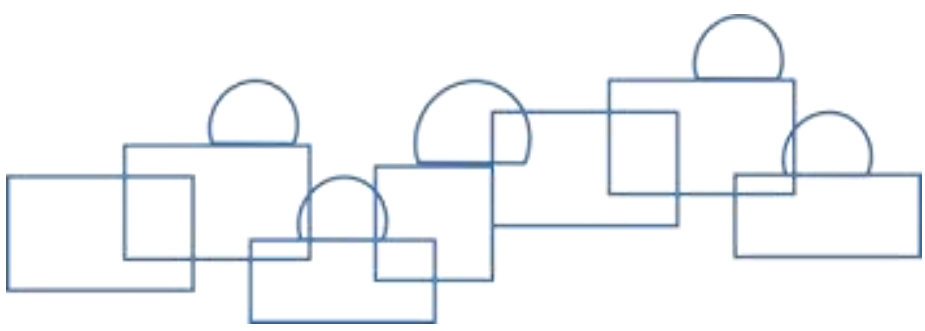




\subsubsection{Ngrohja së largu}

Te ky sistem nxehtësia prodhohet në mënyrë të centralizuar në ngrohtoret kurse përmbajtësi i nxehtësisë (nxehtës mbajtësi) përcillet me largpërçues termikë deri te ndërtesat. Në këtë mënyre nxehen komplekset me numër më të madh ndërtesash, për shembull, spitalet, industria, lagjet urbane e të ngjashme.

Përparësitë e ngrohjes nga larg janë të mëdha, sepse ndërtohet vetëm një kaldatore në vend të një numri të madh (në çdo ndërtesë), zvogëlohet ndotja e ambientit të njeriut .

Të metat paraqiten në shpenzimet më të mëdha investive dhe nëse ndodh prishje, një numër shumë i madh shfrytëzuesish mbeten pa ngrohje. Në ngrohtore prodhohet uji i nxehtë ose avulli i ujit.

Largpërçuesit e nxehtësisë punohen prej gypave të çeliktë dhe atyre pa tegel termikisht të izoluar mirë. Shtrihen nëpër kanale nëntokësore të pakalueshme që kanë puse në vendet e kthesave ose te valvulat. Shumë rrallë vendosen mbi tokë, e edhe më rrallë në kanale të kalueshme. Sipër pllakës së epërme kanalet mbushen me dhe, gypat shtrihen drejtpërdrejt në truallin e thatë ranor. Sipër mbulesës izoluese vendoset lëvozhga ose gypi prej çimento-azbestit për ta mbrojtur izolimin nga shtypja dhe shkatërrimi. Nëse lloji dhe temperatura e nxehtës mbajtësit është e njëjtë sikurse edhe për ngrohjen e ndërtesës, ai kyçet drejtpërdrejt në instalimet shtëpiake. Në të kundërtën, ndërtohet stacioni kyçës, zakonisht ne bodrumin e ndërtesës bashkë me tërë pajisjen e nevojshme dhe aparatin kundër rrymor. Sipërfaqja e lokalit të stacionit është $5.00-15.00 \mathrm{~m}^{2}$ dhe nevojitet edhe një mur krejt i lirë për vendosjen e aparaturave. Është i domosdoshëm ndriçimi natyror nëpër dritare dhe hyrje nga fasada që të mund të hyjë personeli lirisht edhe në çdo kohë për kontrollim e nevoja të tjera.

\subsubsection{Trupat ngrohës}

Trupat ngrohës janë impiante për shpërndarjen e nxehtësisë. Prodhohen nga hekuri i derdhur, llamarina e çeliktë, legurat e aluminit. Trupat ngrohës janë elemente të pajisjes së brendshme dhe projektuesit zgjedhin tipat të cilët përbëjnë një tërësi harmonike me elementet tjera në lokal. Përveç pamjes estetike, është e domosdoshme të jenë të sigurt dhe të kenë jetë të gjatë shërbimi të emetojnë nxehtësi sa më tepër përmes rrezatimit dhe me sa më pak humbje, të montohen lehtë të mirëmbahen në mënyrë higjienike dhe të jenë të lirë. Ka shumë rëndësi të emetojnë sa më tepër nxehtësi për njësi të sipërfaqes dhe të jenë të vendosur në vende ku nuk pengojnë në lokal dhe të bëhet shpërndarja më e volitshme e nxehtësisë. Për këtë arsye vendosen nën dritare dhe pranë mureve. Temperaturat e ajrit gjatë qarkullimit nëpër lokal në të cilat shihet se pozita e trupit ngrohës pranë murit të brendshëm është e pavolitshme.

Trupat ngrohës dallohen sipas: formave, konstruksionit, mënyrës së emetimit të nxehtësisë dhe vendit të vendosjes.

Trupat ngrohës gypor janë të thjeshtë sipas konstruksionit. Punohen prej gypave të lëmuar me diametër prej $32 \mathrm{~mm}$ e më të mëdhenj. Emetojnë nxehtësinë me rrezatim të fortë, nuk mbulohen me maska dhe për këtë arsye vendosen në vende ku pamja e tyre nuk pengon, në objektet industriale, shkolla, zyre. 
Gypat serpentinorë punohen prej gypave të lakuar serpentinor prej çeliku. Prehen dhe bashkohen aty për aty ndërsa lakohen duke i ngrohur, të mbushur që më parë me rërë të terur. Nëpër gypa me pjerrësi të caktuar në drejtim të bartësve të nxehtësisë uji i nxehtë ose avulli i ujit kalojnë në një rrymim.

Regjistrat gypor punohen me saldimin e gypave të drejtë. Janë të radhitur horizontalisht ose vertikalisht dhe bartësi i nxehtësisë nëpër ta ndahet në shumë rryma paralele. Gypat me brinjë prodhohen me derdhje përnjëherë me brinjë ose më vonë brinjët rrethore ose katrore vihen në këllëf dhe saldohen nëpër gypi të lëmuar me diametër $01,5 "-3 "$ ". Ato rrisin sipërfaqen ngrohëse të gypave 7-8 herë, prandaj edhe emetimi i nxehtësisë është rreth 4 herë më i madh. Me vështirësi pastrohen dhe pluhuri në ta digjet. Përdoren në vendet ku nuk pengon kjo e metë ose vendosen në arka të mëdha prej llamarinë me roleta për depërtimin e ajrit.

Radiatorët (lat. radiare-rrezatim) prodhohen nga hekuri i derdhur, llamarina e çeliktë dhe legurat e aluminit, në asortiman të gjerë, ndërsa shiten në treg të mbrojtur me ngjyrosje. Radiatorët formohen prej trupave të njëjtë të zbrazët, gjymtyrëve me një apo më shumë zbrazëtira për së larti nëpër të cilin qarkullon bartësi i nxehtësisë. Për shkak të gjymtyrëve dhe sipas numrit të zbrazëtirave quhen: radiator me gjymtyrë njështyllor, dyshtyllor. Me lidhjen (bashkimin) e gjymtyrëve për së gjati fitohet radiatori me sipërfaqe ngrohëse të nevojshme. Për ngjitjen nga ana e sipërme dhe e poshtme te gjymtyrëve shërbejnë dadot speciale me filetaturë të majtë dhe të djathtë. Në vrima në faqet anësore vendosen pjesët e nevojshme fasonike, dhe valvolat për lidhje me rrjetin.

Radiatorët dallohen sipas numrit të gjymtyrëve të shtyllave, lartësisë, përkatëse, dhe sipërfaqes ngrohëse. Nga katalogët e prodhuesve zgjidhet modeli i dëshiruar për lartësi të caktuar të parapetit. Prodhohen radiatorë të vegjël me lartësi $300 \mathrm{~mm}$, mesatare 500 dhe $600 \mathrm{~mm}$, ndërsa për mure të brendshme $1000 \mathrm{~mm}$ e më të lartë. Liferohen në bateri prej 10 gjymtyrësh ose me ndonjë numër tjetër gjymtyrësh.

Në projekte pranë shenjës grafike shënohet, për shembull:

$\underline{26-V I} .60 \underline{4-194}$

Kjo e dhënë shënon (simbolizon) radiatorin prej 26 gjymtyrësh me gjashtë shtylla me lartësi $604 \mathrm{~mm}$, gjerësi $194 \mathrm{~mm}$, dhe sipërfaqe ngrohëse $6,24 \mathrm{~m}^{2}$.

Së bashku me radiator prodhuesi dërgon edhe pjesë të pajisjeve për montim në mur ose bartës të dyshemesë. Disa modele kanë gjymtyrët e fundit me këmbëza për vendosje në dysheme. Radiatorët në mbajtës konsol. Mund të vendosen paraprakisht, sepse nuk pengojnë as gjatë punimit e as më vonë gjatë mirëmbajtjes së dyshemesë. Radiatorët me këmbëza të derdhura krijojnë vështirësi gjatë punimit të dyshemeve sepse këto punë kryhen në fund. Zakonisht lartësitë e këmbëzave nuk iu përgjigjen, dhe për këtë rrallë përdoren. 
Radiatorët e derdhur qëndrojnë shumë (rreth 50 vite), por kushtojnë dhe janë të rëndë (rreth $30 \mathrm{~kg} / \mathrm{m}^{2}$ ), transportohen dhe vendosen me vështirësi. Për shkak të masës së madhe nxehen gjatë, por një kohë të gjatë emetojnë edhe nxehtësi.

Prodhohen në formë dyshtyllore dhe me numër të madh shtyllash me dimensione të ndryshme, me këmbëza, dhe për vendosje në anëcakë dhe në mbajtësit e dyshemesë.

Radiatorët e çeliktë (prej llamarinës së çeliktë), shumë janë më të lehtë, më të lirë dhe afatin e shërbimin e kanë më të shkurtër (rreth 15 vjet), e nuk mund të përdoren për ngrohje me avull për shkak të korodimit. Prodhohen për ngrohje me ujë të ngrohtë deri $110 \mathrm{C}$ dhe shtypje punuese prej 8 barë.

Modelet e reja të radiatorëve janë prej llamarinës së petëzuar me trashësi 1,25 mm, por janë prej gypave me prerje tërthore katërkëndëshe $50 \times 15 \times 1,5 \mathrm{~mm}$. Radiatorët prej llamarinës të petëzuar mund të bashkohen dhe kombinohen për së larti dhe për së gjati. Me ta dërgohet edhe pajisja e nevojshme për montim në mur dhe dysheme.

Radiatorët prej alumini. Prodhohen prej legurave të aluminit me derdhje ose me bashkimin e profileve të petëzuara të ftohta me prerje tërthore të ndryshme, gjerësie dhe lartësie. Afatin e shërbimit e kanë 20-30 vite, kurse liferohen në bateri prej 1-20 gjymtyrësh. Radiatorët me emetim intensiv konvektiv të nxehtësisë nëpër kanale të drejtuara, me pjesën e epërme në drejtim të lokalit, kapacitetin e kanë për 50\% më të madh se radiatorët e zakonshëm. Radiatorët panel në formë pllake ose të rrafshët, kanë jashtëzakonisht gjerësi më të vogël dhe vendosen aty ku nuk ka hapësirë të mjaftueshme. Për rritjen e kapacitetit pllakat bashkohen nga dy ose tri paralelisht.

Konvertorët, apo Ventilo konvertorët, përbëhen prej ngrohësve lamelor të vendosur në kuti prej llamarine ose pas pllakës. Ngrohësi është bateri gypash me lamela të holla të përbashkëta të cilat rrisin sipërfaqen ngrohëse.

Për ngrohje me konvektor shfrytëzohet uji i nxehtë ose avulli i ujit, sepse janë të punuar prej gypash të cilët durojnë shtypje të mëdha. Lehtë vendosen dhe zënë hapësirë më të vogël se radiatori. Shumë shpejt ngrohen (për 12/15 min.) dhe për këtë vendosen në lokale të cilat duhet shpejt të nxehen.

Kohë pas kohe duhet pastruar prej pluhurit nëpër pjesën e lëvizshme të kutisë edhe pse në ta nuk digjet pluhuri; nuk i ndotin muret si radiatorët. Konvektorët vendosen para parmakëve në zgavër (zbrazëtirë) nën dysheme me grilë nga ana e epërme, ose në formë të dërrasave të dyshemesë shtjellohen për së gjati në të gjitha muret e jashtme. Ky tip është mjaft i përshtatshëm, sepse mbi ta mund të vendosen perdet, e kryesisht u përgjigjet lokaleve në katin përdhese me dysheme të ftohta

Radiatorëve me ujë të nxehtë janë një nga trupat ngrohës më të zakonshëm të sistemeve të distribuimit të ngrohjes. Ata janë zakonisht një radiator ose një dizajn i drejtë që i ngjan radiatorëve me avull. Problemi më i zakonshëm në sistemet e ujit të nxehtë është ajri i padëshiruar në sistem. Në fillim të çdo sezoni të ngrohjes, ndërsa sistemi është i rrjedhshëm, shkojnë nga radiator në radiator dhe të hapur çdo valvola për ç'ajrosje, pastaj mbyllët kur uji fillon të shpëtojnë përmes valvolave. 
Një ngrohje profesional mund të instaloj valvolave automatike të radiatorëve me ujë të ngrohtë, të kontrolluara nga termostati në çdo zonë të shtëpisë. Duke përdorur termostat të programueshëm arrihet ngrohja automatike.

Zonat ngrohëse mund të kontrollohen, po ashtu mund të veçohen zona të posaçme me cilësi të ndryshme të ngrohjes, çdo zonë e izoluar nga të tjerat. Në raste kur shtëpia nuk është e projektuar për kontrollin e zonave, duke lënë një seksion me një temperaturë më të ulët se sa ajo e kërkuara mund të shkaktohet probleme me dhoma fqinje, sepse ata do të humbasin nxehtësi në raport me zonat e tjera të shtëpisë. Kontrolli i zonave do të punojnë më mirë kur seksionet e zonave të shtëpisë mund të izolohen nga të tjerat, së pari duke mbyllur dyert. Në disa raste, dyer më të avancuara mund të jenë të nevojshme për të izoluar një zonë nga një tjetër. Po ashtu është me rëndësi që uji në tubacione të mbahet vazhdimisht nën kontroll nga ngrirjet e mundshme, të cilat gjatë sezonit të dimrit në Kosovë temperaturat mund të arrijnë edhe deri në $-25^{\circ} \mathrm{C} .^{94}$

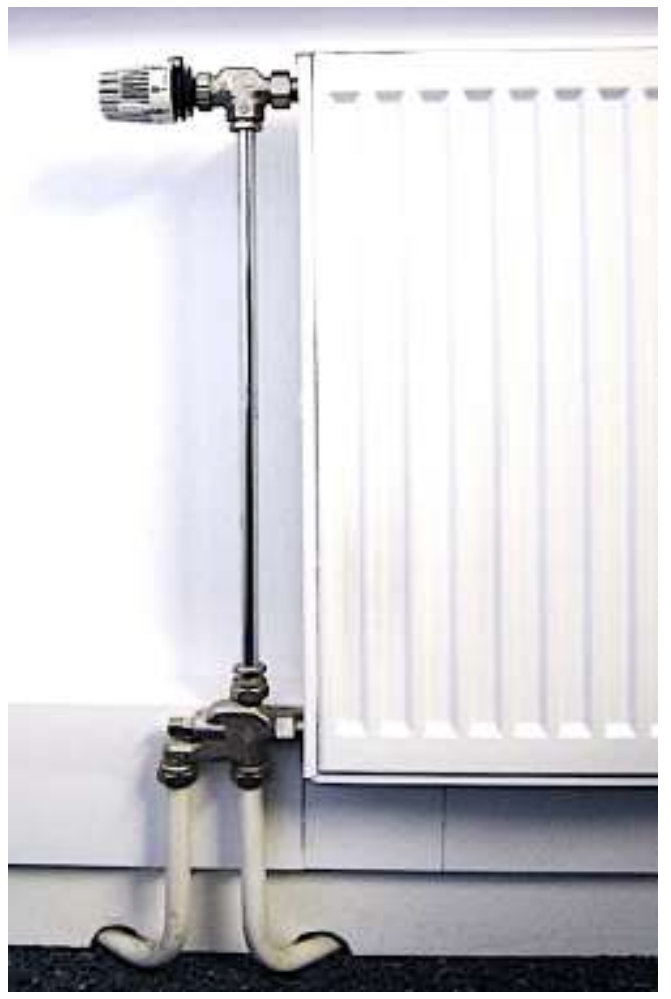

Figura 184. Radiatorët me ujë

(Burimi): Cschirp, 2014. (Flickr). Creative Commons Attribution Share Alike 3.0 Unported

\subsubsection{Llogaritja e radiatorëve}

Llogaritja e radiatorëve përfundon me përcaktimin e sipërfaqes ngrohëse të tyre. Në bazë të sasisë së nxehtësisë që duhet ta japë radiatori, përcaktohet sipërfaqja e tij, si te të gjithë këmbyesit rekuperativë të nxehtësisë (Krasniqi, Fejzullah. 2004) ${ }^{95}$ :

ku janë:

$$
\mathrm{Fr}=\frac{Q r}{\mathrm{Kr} \cdot \Delta_{t r}}\left[m^{2}\right]
$$

$\mathrm{Q}_{\mathrm{r}}[\mathrm{W}]-$ kapaciteti termik i një radiatori;

$\mathrm{k}_{\mathrm{r}}\left[\mathrm{W} /\left(\mathrm{m}^{2} \mathrm{~K}\right)\right]$-koeficienti i transmetimit të nxehtësisë së radiatorit, që zgjidhet varësisht nga tipi, madhësia dhe materiali i radiatorit;

$\Delta \mathrm{t}_{\mathrm{r}}\left[{ }^{\circ} \mathrm{C}\right]$ - ndryshimi ndërmjet temperaturës mesatare të fluidit ngrohës dhe temperaturës së ajrit në lokal, që merret:

\footnotetext{
94 http://www.energy.gov/energysaver/articles/heat-distribution-systems.

95 Krasniqi, F., Selimaj, R., Malsiu, I.(2004). Instalimet Makinerike. Universiteti i Prishtinës.
} 
Për ngrohjen me ujë:

$$
\Delta_{t r u}=\frac{\mathrm{t}_{d}+\mathrm{t}_{k}}{2}-\mathrm{t}_{b p}
$$

ku janë:

$\mathrm{t}_{\mathbf{d}}\left[{ }^{\circ} \mathrm{C}\right]$-temperatura e ujit në hyrje të radiatorit (më së shpeshti është $90^{\circ} \mathrm{C}$ ); $\mathrm{t}_{\mathbf{k}}\left[{ }^{\mathrm{u}} \mathrm{C}\right]$ - temperatura e ujit në dalje të radiatorit (më së shpeshti është $70^{\circ} \mathrm{C}$ ); $\mathrm{t}_{\mathbf{b p}}\left[{ }^{\circ} \mathrm{C}\right]$ - temperatura e brendshme e projektuar.

Kur përcaktohet sipërfaqja e nevojshme e radiatorit $F_{R}$, zgjidhet tipi i radiatorit dhe sipërfaqja ngrohëse e një anëtari të tij $\mathrm{f}$ [ $\left.\mathrm{m}^{2} / a n e ̈ t a r\right]$, atëherë numri i anëtarëve që e përbëjnë radiatorin është:

$$
\mathrm{n}=\frac{\mathrm{F}_{r}}{\mathrm{f}}[\text { anëtar }]
$$

Nëse dalin më shumë se 30 anëtarë të radiatorit, atëherë duhet të bëhet ndarja në dy radiatorë. Numri i anëtarëve të një radiatori mund të përcaktohet më lehtë kur dihet sasia e nxehtësisë që jep një anëtar, sipas shprehjes:

$$
\mathrm{n}=\frac{\mathrm{Q}_{r}}{\mathrm{q}_{a}}[\text { anëtar }]
$$

ku janë:

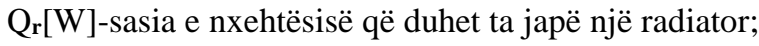

$\mathrm{q}_{\mathrm{a}}[\mathrm{W} / \mathrm{anëtar}]-$ sasia e nxehtësisë që jep një anëtar i radiatorit, që merret nga katalogët e prodhuesve të radiatorëve.

Tabela 26. Të dhënat për radiatorët e tipit " TERMIK" (për një anëtar të radiatorit) (Burimi): Krasniqi, F., Selimaj, R., Malsiu, I.(2004). Instalimet Makinerike. Universiteti i Prishtinës.

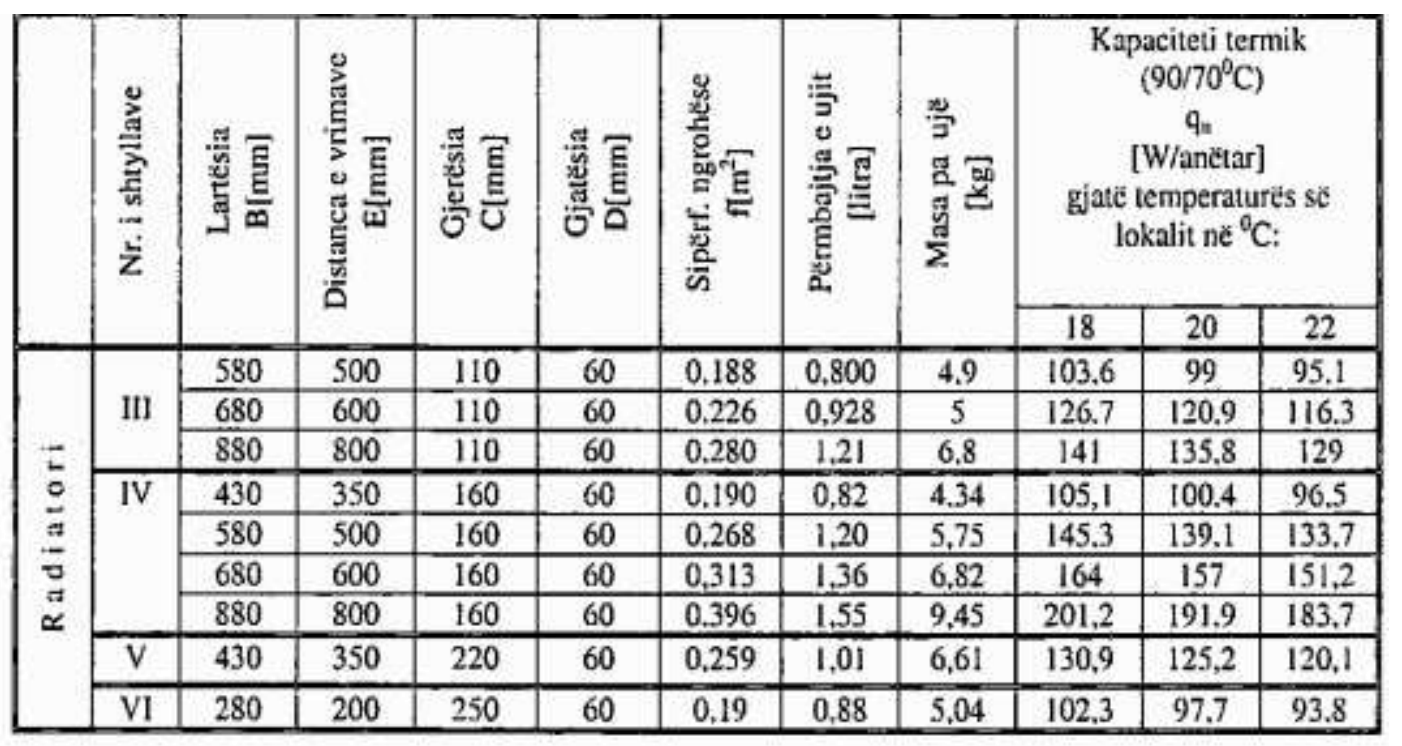


Të dhënat për radiatorin e derdhur të tipit "Termik", në varshmëri nga numri i shtyllave për një anëtar-element të radiatorit. Të dhënat për kapacitetin termik të radiatorit vlejnë për ujin e ngrohtë me temperaturë $90 / 70{ }^{\circ} \mathrm{C}$ dhe temperaturë të mjedisit $18 ; 20$; dhe 22 ${ }^{\circ} \mathrm{C}$.

$$
\Delta_{t r u}=\frac{\mathrm{t}_{d}+\mathrm{t}_{k}}{2}-\mathrm{t}_{b p}
$$

Ndërsa, koeficienti i transmetimit të nxehtësisë $\left(\mathrm{k}_{\mathrm{R}}\right)$ për radiatorët e derdhur dhe të çelikut vlerat janë dhënë si më poshtë për ngrohjen me ujë dhe për ngrohjen me avull me shtypje të ulët (vlejnë për aparatet ngrohëse klasike me elemente/anëtarë). Megjithatë duhet të theksohet se sot në treg gjenden aparate ngrohëse të formave dhe të konstruksioneve të ndryshme dhe se këto shënime merren nga katalogët e prodhuesve të këtyre pajisjeve.

Tabela 27. Koeficienti i transmetimit të nxehtësisë për radiatorët $\left(k_{R}\right)$.

(Burimi): Krasniqi, F., Selimaj, R., Malsiu, I.(2004). Instalimet Makinerike. Universiteti i Prishtinës.

\begin{tabular}{|c|c|c|c|c|c|c|c|c|}
\hline \multicolumn{9}{|c|}{ Lloji i radiatorit } \\
\hline \multirow{4}{*}{$\begin{array}{l}\text { Distanca } \\
\text { ndërmjet } \\
\text { vrimave të } \\
\text { radiatorit } \\
{[\mathrm{mm}]}\end{array}$} & \multicolumn{8}{|c|}{ Gjerësia e radiatorit [mm] } \\
\hline & 10 & & & 50 & & 200 & & \\
\hline & \multicolumn{8}{|c|}{ Ngrohja me: } \\
\hline & ujë| & avull & ujë & avull & ujë & avull & ujë & avull \\
\hline 300 & 9,3 & 10,6 & 9,0 & 10,0 & 8,6 & 9,7 & 8,3 & 9,3 \\
\hline 500 & 9,0 & 10,2 & 8,5 & 9,5 & 8,3 & 9,3 & 7,9 & 9,0 \\
\hline 600 & 8,8 & 10,1 & 8,4 & 9,4 & 8,1 & 9,2 & 7,8 & 8,8 \\
\hline 1000 & 8,5 & 9,8 & 8,1 & 9,2 & 7,8 & 8,8 & 7,4 & 8,5 \\
\hline
\end{tabular}

Dimensiononi radiatorin e derdhur i cili duhet të jep 2600 [W] nëse dihet se fluidi punues është uji i ngrohtë $90 / 70\left[{ }^{\circ} \mathrm{C}\right]$ dhe që temperatura në lokal është $20\left[{ }^{\circ} \mathrm{C}\right]$. Radiatori është treshtyllësh dhe vendoset nën parapetin e dritares i cili gjendet në lartësinë $0,9[\mathrm{~m}]$.

Shembull:

Dimensiononi radiatorin e derdhur i cili duhet të jep 2600 [W] nëse dihet se fluidi punues është uji i ngrohtë $90 / 70\left[{ }^{\circ} \mathrm{C}\right]$ dhe që temperatura në lokal është $20\left[{ }^{\circ} \mathrm{C}\right]$. Radiatori është treshtyllësh dhe vendoset nën parapetin e dritares i cili gjendet në lartësinë $0,9[\mathrm{~m}]$.

Zgjidhje: 
Për lartësinë e parapetit prej 0,9m merret lartësia e radiatorit 680[mm], (900-120$100=680 \mathrm{~mm})$. Nga tab. 1 shohim që sipërfaqja ngrohëse e një anëtari të radiatorit është: $\mathrm{f}=0,226[\mathrm{~m}]$. Duke pasur parasysh të dhënat në tabelën 1 dhe në tabelën 2 shohim që koeficienti i transmetimit të nxehtësisë së radiatorit (i nxjerrë me interpolim) është $\mathrm{k}_{\mathrm{R}}=8,72\left[\mathrm{~W} / \mathrm{m}^{2} \mathrm{~K}\right]$. Tani mund ta llogarisim sipërfaqen e nevojshme të radiatorit:

$$
\mathrm{F}_{R}=\frac{\mathrm{Q}_{R}}{\mathrm{k}_{r} \cdot \Delta \mathrm{t}_{r u}}=\frac{2600}{8.72\left(\frac{90+70}{2}-20\right)}=4,97\left[\mathrm{~m}^{2}\right]
$$

Numri i anëtarëve të nevojshëm të radiatorit është $n=F_{R} / f=4,97 / 0,226=21,99$ anëtarë. Merret numri i parë më i madh: $n=22$ anëtarë, ashtu që sipërfaqja e saktë e ngrohjes se radiatorit tani është .

$$
\mathrm{F}_{\mathrm{r}, \mathrm{s}}=\mathrm{n}-\mathrm{f}=22-0,226=4,972\left[\mathrm{~m}^{2}\right]
$$

Në rezultate të njëjta mund të arrijmë edhe në mënyrën tjetër! Nga tabela 1 për radiatorin treshtyllor me lartësi $680 \mathrm{~mm}$ gjejmë kapacitetin termik për një anëtar të radiatorit, përkatësisht $\mathrm{q}_{\mathrm{n}}=120,9 \mathrm{~W} /$ anëtar, për temperaturën e lokalit $\mathrm{t}_{\mathrm{b}} \mathrm{p}=20^{\circ} \mathrm{C}$.

Kështu tani mund ta përcaktojmë sasinë e nxehtësisë që e jep një anëtar i radiatorit:

$$
\begin{gathered}
\mathrm{q}_{\boldsymbol{a}}=\mathrm{q}_{\boldsymbol{n}}\left(\frac{\Delta \mathrm{t}_{r u}}{60}\right)=120,9=120,9[\mathrm{~W}] \\
\Delta \mathrm{t}_{R u}=\frac{\mathrm{t}_{\boldsymbol{d}}+\mathrm{t}_{\boldsymbol{k}}}{2}-\mathrm{t}_{\boldsymbol{b p}}=\frac{90+70}{2}-20=60\left[{ }^{\circ} \mathrm{C}\right]
\end{gathered}
$$

Numri i anëtarëve të radiatorit është:

$\mathrm{n}=\mathrm{QR} / \mathrm{q}_{\mathrm{a}}=2600 / 120,9=21,5$ anëtarë dhe marrim $\mathrm{n}=22$ anëtarë për një radiator.

\subsubsection{Trupat ngrohëse me gypa}

Trupat ngrohëse me gypa përdoren kryesisht në lokale të vogla (banja, tualete e të ngjashme) ku është e nevojshme të sillet sasi e vogël e nxehtësisë dhe ku zakonisht hapësira nuk lejon të vendoset radiatori, ose ku numri i anëtarëve elementeve të radiatorit është i kufizuar. Aparatet ngrohëse janë këmbyes të nxehtësisë të punuar nga gypat e thjeshtë të çelikut dhe mund të jenë horizontale dhe vertikale, kurse mënyra e realizimit mund të jetë e ndryshme. 


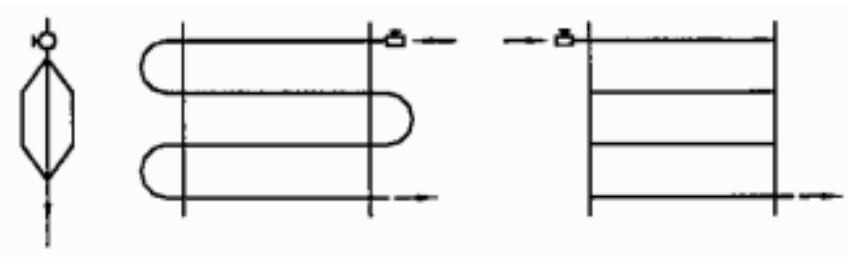

Figura 185. Aparatet ngrohëse me gypa

(Burimi): Krasniqi, F., Selimaj, R., Malsiu, I.(2004).

Për llogaritjen e regjistrit të gypave së pari përcaktohet sasia e nxehtësisë që jep $1 \mathrm{~m}$ gjatësi e gypit (për rënie të caktuar të temperaturës së fluidit ngrohës) dhe kështu duke ditur sasinë e tërësishme të nxehtësisë që duhet ta japë ngrohësi përcaktohet gjatësia e tërësishme e gypit dhe kjo gjatësi ndahet në disa pjesë. Kështu që gjejmë regjistrin me 1, 2, 3, 4 ose me më shumë gypa. Regjistrat e gypave ndërtohen nga gypat me diametër $\varnothing$ $15[\mathrm{~mm}]$ dhe më shumë.

Tabela 28. Nxehtësia që jep $1 \mathrm{~m}$ ' e gypit të lëmuar (Burimi): Krasniqi, F., Selimaj, R., Malsiu, I.(2004). Instalimet Makinerike. Universiteti i Prishtinës.

\begin{tabular}{|l|l|l|l|l|l|l|l|l|l|}
\hline$\varnothing[\mathrm{mm}]$ & 15 & 20 & 25 & 32 & 40 & 50 & 65 & 80 & 100 \\
\hline $\mathrm{q}[\mathrm{W}]$ & 58 & 72 & 87 & 107 & 114 & 126 & 160 & 188 & 223 \\
\hline
\end{tabular}

\subsubsection{Konvektorët}

Konvektorët janë aparate ngrohëse të kohës së re që në të vërtetë paraqesin tufën e gypave të brinjëzuar që vendosen në një kuti llamarine. Nëpër gypa qarkullon uji i ngrohtë dhe kështu ngrohen brinjët që janë të mbështjella nëpër ta në largësi shumë të vogël, prandaj mu për këtë arsye konvektorët kanë sipërfaqe ngrohëse të madhe. Në mënyrë që ajri të drejtohet dhe të intensifikohet rrymimi përdoret maska (kutia prej llamarine). Ajo ka vrima për hyrjen e ajrit të ftohtë në pjesën e poshtme dhe vrima për daljen e ajrit të ngrohtë në pjesën e epërme.

Konvektorët i kanë disa përparësi kundrejt radiatorëve: janë më të lehtë, kanë formë elegante, që mund të përshtaten mjaft mirë me arkitekturën e brendshme për lokalin, lehtë vendosen, përmbajnë sasi të vogël uji për shkak se janë të përbërë prej gypave të ngushtë dhe mu për këtë arsye ngrohen dhe ftohen shpejt dhe kërkojnë më pak material shpenzues sesa radiatorët 

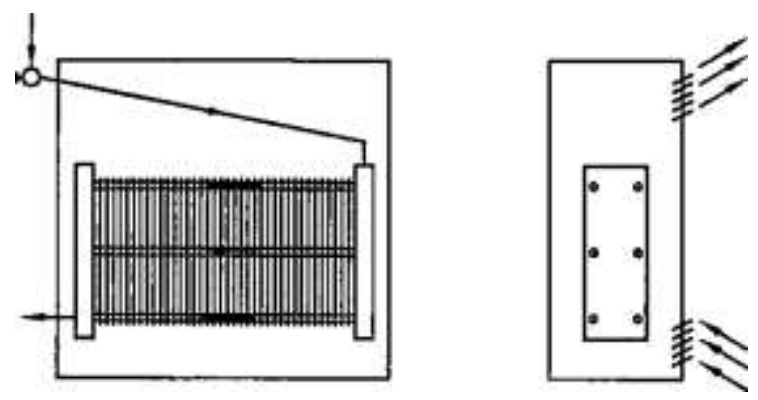

Figura 186. Aparatet ngrohëse me gypa

(Burimi): Krasniqi, F., Selimaj, R., Malsiu, I.(2004). UP. Prishtinë

Për shkak të shpejtësisë së madhe të ajrit, por edhe pasi konvektori është i vendosur në kuti llamarine, pluhuri te konvektorët nuk digjet dhe nuk i ndot muret, sikur te radiatorët. Është e qartë që me kohë në kuti mblidhet pluhur, prandaj është e nevojshme që kutia të hiqet ngadalë, ashtu që edhe pluhuri të largohet ngadalë. Llogaritja e konvektorit, rëndom, nuk bëhet, por ai zgjidhet sipas katalogut të prodhuesve, varësisht nga sasia e nxehtësisë që ai duhet ta japë dhe nga tipi që dëshirohet.

Për ngrohjen e lokaleve të mëdha, hallat e fabrikave, aparatet ngrohëse me qarkullim natyral të ajrit nuk mund të arrijnë efekt të duhur edhe po të ishin me përmasa shumë më të mëdha. Rreth këtyre aparateve ngrohëse ajri do të ishte i ngrohtë, ndërsa larg i ftohtë. Për këtë arsye për këto lloj ndërtesash përdoren aparate ngrohëse me qarkullim artificial të ajrit. Tek këto raste ajri qarkullon me anën e ventilatorëve centrifugalë ose aksialë përgjatë sipërfaqeve ngrohëse dhe në këtë mënyrë rritet sasia e nxehtësisë së këmbyer. Kaloriferët fig.187, janë aparate ngrohëse që përdoren shumë për ngrohjen e hallave dhe uzinave të prodhimit. Janë të përbërë nga: gypat e brinjëzuar, ventilatori për lëvizje të ajrit, kutia përzierëse, mbështjellësi dhe grilat për drejtimin e ajrit në dalje të kaloriferit. Kutia përzierëse ka për detyrë ta përziejë ajrin e jashtëm me një sasi ajri të lokalit dhe kështu të krijohet përzierja e nevojshme. Ajri i përgatitur në këtë mënyrë rrymon nëpër gypat e brinjëzuar, ku brenda tyre qarkullon uji i ngrohtë ose avulli i ujit, ashtu që ajri ngrohet e pastaj del nëpër grila në lokal. Temperatura e ajrit në dalje nuk duhet të kalojë vlerën $40^{\circ} \mathrm{C}$. Zgjedhja e kaloriferit zakonisht bëhet sipas katalogut të prodhuesit. Kaloriferët vihen në mur, ashtu që brinja e poshtme e tyre të mos jetë më pak se $2 \mathrm{~m}$ lart nga dyshemeja. Ky kufizim është i nevojshëm në mënyrë që ajri i ngrohtë të mos rrymojë drejtpërdrejt në kokat e punëtorëve që punojnë në afërsi.

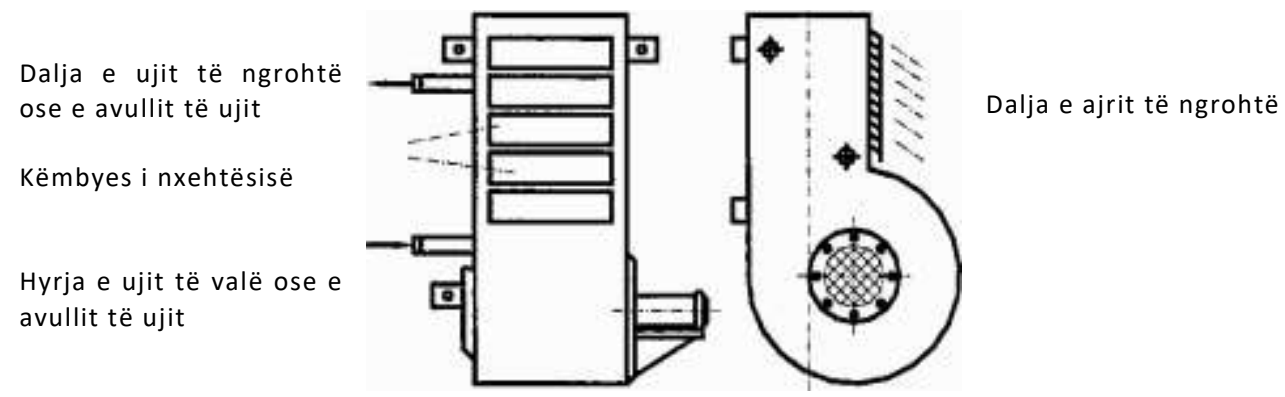

Figura 187. Kaloriferi

(Burimi): Krasniqi, F., Selimaj, R., Malsiu, I.(2004). UP. Prishtinë 


\subsubsection{Kaldajat}

Kaldajat janë gjeneratorë të nxehtësisë, pra janë pajisje në të cilat energjia termike që e përmban lënda djegëse me djegie shndërrohet në nxehtësi. Sipas llojit të lëndës djegëse që e përdorin, kaldajat janë:

1. Kaldaja me lëndë djegëse të ngurtë

2. Kaldaja me lëndë djegëse të lëngët

3. Kaldaja me lëndë djegëse të gaztë

Sipas bartësit të nxehtësisë kaldajat mund të jenë me ujë dhe me avull uji, kurse sipas përbërjes së materialit mund të jenë nga: giza e hirtë (hekuri i derdhur) dhe nga llamarina e çelikut. Kaldajat e derdhura-me elemente (kaldajat prej gize me elemente) që më herët janë përdorur shumë, përbëhen nga elementet e derdhura, që lidhen njëri me tjetrin dhe në këtë mënyrë e formojnë kaldajën. Me lidhjen e numrit përkatës të elementeve fitohet sipërfaqe përkatësisht kapacitet i dëshiruar i kaldajës. Kaldajat e çelikut në kohën e fundit po zëvendësohen nga kaldajat e derdhura. Kaldajat e çelikut janë kryesisht bllok kaldaja me një ose më shumë gypa flakëhedhës dhe me numër të madh të gypave të gazit. Tashmë këto kaldaja, që përdorin lëndë djegëse të lëngët dhe lëndë djegëse të gaztë, pajisen me instalime të rregullimit automatik. Si bazë e dimensionimit të kaldajës është sasia e nxehtësisë që e japin të gjitha elementet e ngrohjes. Kjo sasi e nxehtësisë rritet për aq sa janë humbjet termike të kaldajës dhe të rrjetit termik. Tek instalimet e ngrohjes së ndërtesave, rritja shtohet në përqindje kundrejt sasisë së nxehtësisë që japin elementet e ngrohjes, varësisht nga mënyra e vënies së rrjetit termik dhe e mbrojtjes termike të saj.

Kapaciteti termik i kaldajës përcaktohet sipas shprehjes:

$$
\mathrm{Qk}=\mathrm{Qnd}, \mathrm{R}(\mathrm{l}+\mathrm{a}+\mathrm{b})[\mathrm{W}]
$$

ku janë:

Qnd.R [W]-sasia e nxehtësisë së nevojshme për ngrohjen e të gjitha hapësirave të ndërtesës, e që arrihet nëpërmjet nxehtësisë që e japin radiatorët (aparatet ngrohëse);

$\mathbf{a}[\%]$-shtesa për humbjet termike të kaldajës dhe të rrjetit termik

$\mathbf{b}[\%]$-shtesa për ngrohjen e shpejtë të ujit dhe të masës së pajisjes.

Figura 188. Kaldaja, Hoval DuoLut LN (Burimi): Installation \& Service manual

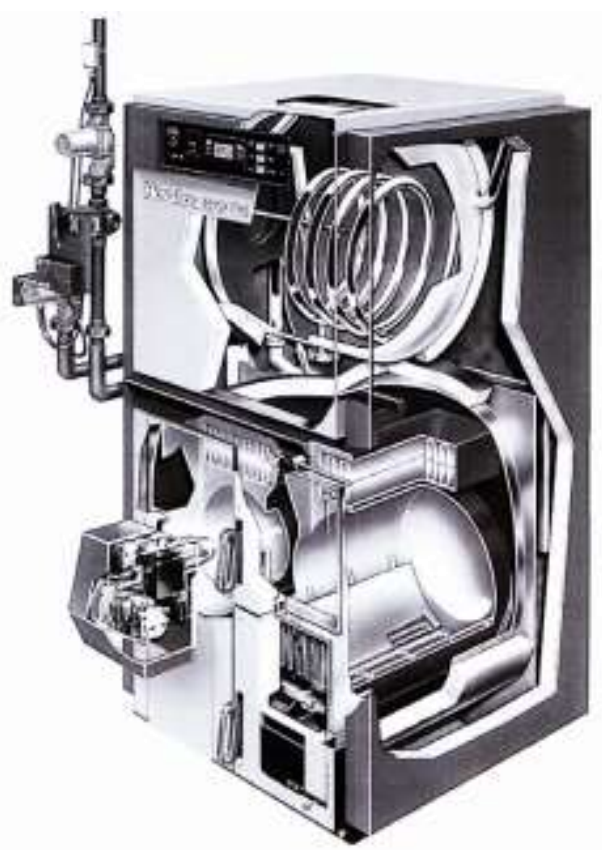




\subsubsection{Kaldatorja}

Kaldatorja është hapësira në të cilën janë vendosur kaldajat e ngrohjes qendrore me armaturën e nevojshme dhe me të gjitha pajisjet e tjera, që janë të lidhura me instalimet e ngrohjes. Në disa objekte, në mungesë të hapësirës, kaldajat për ngrohjen e kateve mund të vendosen në ndonjë hapësirë të dorës së dytë, por duke pasur parasysh mundësinë e kyçjes në oxhak. Në kushte normale duhet të sigurohet hapësirë e veçantë për kaldatore.

Kaldajat duhet të vendosen ashtu që ana e përparme e tyre te jetë e ndritshme, sipas mundësisë me ndriçim ditor ose me ndriçim të mjaftueshëm artificial. Përveç kaldajave këtu duhet të vendosen bojlerët, këmbyesit, pompat, kolektorët, shpërndarësit. Gjithashtu duhet të vendosen edhe aparatet e shuarjes së zjarrit dhe duhet të lihet hapësirë e mjaftueshme për shërbime në kaldajë për montim dhe demontim, për mënjanim të prishjeve. Për instalime të mëdha është e dëshirueshme që reparti makinerik të vendoset në hapësirë të veçantë. Fondamenti i kaldajës duhet të ngritët pak për shkak të lagështisë dhe të nxjerrjes sa më të lehtë të hirit.

Largimi i ujit nga kaldatorja duhet të bëhet nëpërmjet rrjetit të kanalizimit. Është e nevojshme të parashikohen vrima të mjaftueshme për hyrje të ajrit të freskët, dhe sipas nevojës parashihet edhe ventilimi i detyruar. Gjithashtu duhet të parashikohet edhe një hapësirë për lëndën djegëse, nëse përdoret lënda djegëse e ngurtë.

\subsubsection{Oxhaku}

Funksioni i oxhakut, në raport me kaldajën është që të mundësojë tërheqjen natyrale të produkteve të gazta dhe të materieve të ngurta të padjegura. Kurse sa i përket ambientit rrethues, oxhaku ka funksion që këto produkte që i cekëm më lart t'i dërgojë sa më lart në atmosferë në mënyrë që ato të shpërndahen në një sipërfaqe sa më të madhe. Sa i përket funksionit të tij të parë sot oxhaku gjithnjë e më tepër po e humb vlerën, sepse tërheqja natyrore e tij është e vogël kundrejt humbjeve në traktin e gazit të kaldajave moderne. Mirëpo funksioni tjetër i oxhakut, që ka të bëjë me mbrojtjen e ambientit rrethues, po bëhet gjithnjë e më interesant, pasi funksioni i oxhakut, sa i përket tërheqjes, po zëvendësohet me tërheqjen artificiale të gazrave dhe kështu oxhaku kryesisht po merr rol të mbrojtjes higjienike të ambientit.

Sipas mënyrës së tërheqjes së produkteve të djegies oxhaqet mund të jenë: me tërheqje natyrore, dhe me tërheqje artificiale.

Sipas vendit të ndërtimit, oxhaqet mund të jenë:

1. Oxhaqe të vendosura jashtë kaldatores

2. Oxhaqe të vendosura në objekt të kaldatores

3. Oxhaqe të vendosura drejtpërdrejt në kaldajë

Oxhaqet e vëna jashtë ndërtesës së kaldatores të shumtën janë të larta dhe kanë peshë të madhe. Ndërtohen me tulla, ose me beton të armuar. Oxhaqet e ndërtuara në objektin e kaldatores janë më të vogla se ato të ndërtuara jashtë objektit. Të shumtën ndërtohen nga llamarina dhe rëndom kanë tërheqje artificiale të produkteve të djegies. 
Kurse oxhaqet e vendosura në kaldajë kanë peshë dhe lartësi të kufizuar, ndërtohen nga llamarina, kanë tërheqje artificiale dhe mbështeten në skeletin e kaldajës. Sipas materialit nga i cili ndërtohen, oxhaqet mund të jenë: Oxhaqe prej llamarine; Oxhaqe të muruara; Oxhaqe nga betoni i paranderë dhe Oxhaqe të kombinuara.

Sipërfaqja e oxhakut saktësisht mund të përcaktohet duke i pasur parasysh sasinë dhe temperaturën e gazrave, përkatësisht llojin e lëndës djegëse, lartësinë, seksionin dhe formën e oxhakut. Kjo llogari është e komplikuar dhe për qëllimet tona e panevojshme. Ne me saktësi të mjaftueshme e përcaktojmë seksionin e oxhakut sipas shprehjes së thjeshtuar dhe të përafërt.

ku janë:

$$
\mathrm{Fo}=\frac{a_{0} \cdot Q_{k}}{\sqrt{\mathrm{h}}}\left[\mathrm{cm}^{2}\right]
$$

$\mathrm{Q}_{\mathrm{k}}[\mathrm{W}]-$ kapaciteti i kaldajave të lidhura me oxhakun;

$\mathrm{h}[\mathrm{m}]$ - lartësia e oxhakut;

$\mathrm{a}_{\mathrm{o}}$ [/]-koeficient, që merret:

$\mathrm{a}_{0}=0,017$ për lëndë djegëse të lëngët;

$\mathrm{a}_{\mathrm{o}}=0,026$ për koks;

$a_{0}=0,034$ për thëngjill të murrmë.

Gjatësia horizontale e kanalit të oxhakut nuk duhet të kalojë 1/3 e lartësisë së oxhakut (pra, $1<\mathrm{h} / 3$ ). Ky kanal zakonisht shkon duke u zgjeruar prej kaldajës kah oxhaku, dhe seksioni i tij është për 10-20\% më i madh se sa seksioni i oxhakut, d.m.th.:

$F_{h}=(1,1-1,2) \cdot F[m]$.

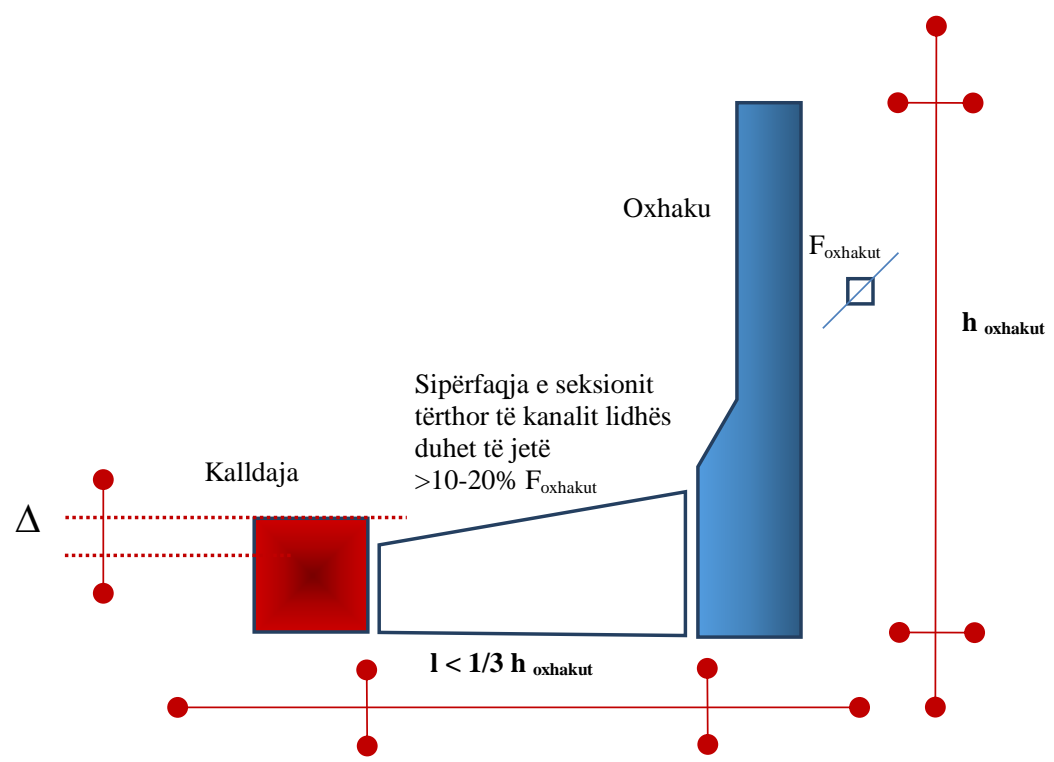

Figura 189. Kaldaja e lidhur me oxhakun nëpërmjet gypëzimit lidhës (Burimi): E përpunuar, Krasniqi, F., Selimaj, R., Malsiu, I.(2004). UP. Prishtinë 
Shembull:

1. Sipërfaqen e oxhakut, nëse kapaciteti i kaldajës është 70000[W], kurse lënda djegëse është thëngjill i murrmë.

$$
\begin{gathered}
\text { Zgjidhje } \\
\text { Fo }=\frac{a_{0} \cdot Q k}{\sqrt{\mathrm{h}}}\left[\mathrm{cm}^{2}\right]=\frac{0.034 \cdot 70000}{\sqrt{20}}=532\left[\mathrm{~cm}^{2}\right]
\end{gathered}
$$

2. Llogari aproksimative për nevoja Arkitektonike

Humbjet e përafërta termike :

Sasia e nevojshme e nxehtësisë specifike $\quad \mathbf{q}=\mathbf{5 0}\left[\mathbf{W} / \mathbf{m}^{\mathbf{3}}\right]$

Shembull : Të llogariten humbjet e përafërta termike për një lokal me dim. 4x5x3 m.

Vëllimi i lokalit, $V=\mathbf{4} \times 5 \times 3=60 \mathrm{~m}^{3}$

ashtu qe humbjet e përafërta termike do të jene :

$$
\mathrm{Q}=\mathrm{q} \cdot \mathrm{V}=50 \cdot 60=3000[\mathrm{~W}]
$$

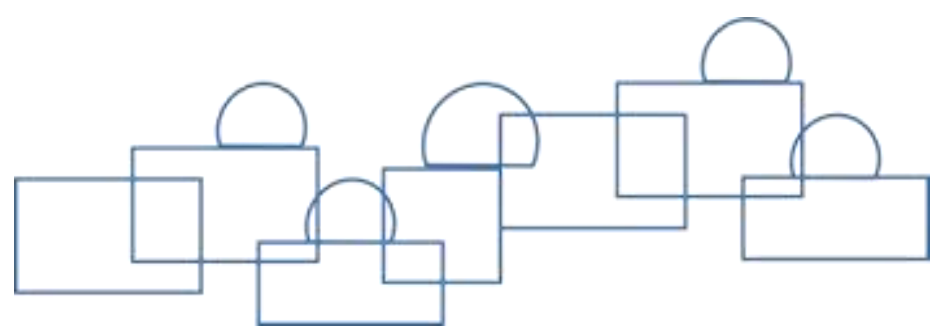




\subsubsection{Energjia solare}

Energjia e diellit është burim i renovueshëm dhe i pakufishëm, nga i cili rrjedhin pjesa më e madhe e burimeve të energjisë në tokë, kjo energji paraqet sasinë e energjisë e cila bartet me rrezet e diellit. Energjia e diellit më së shpeshti përdoret për shndërrim në energji të nxehtësisë në sistemet për ujë të ngrohtë dhe ngrohje, si dhe në centralet solare. Ndërsa për shndërrim në energji elektrike përdoren sistemet fotovoltaike. Intensiteti mesatar i rrezatimit të diellit në atmosferë është mesatarisht $1.37\left(\mathrm{~kW} / \mathrm{m}^{2}\right)$ e cila njihet si konstanta e diellit (solare). Gjatë kushteve normale në sipërfaqen e tokës mund të arrihet intensitet i rrezatimit prej $1.0\left(\mathrm{~kW} / \mathrm{m}^{2}\right)$, dhe vlera e vërtete varet nga lokacioni, stina e vitit, koha e ditës si dhe nga kushtet atmosferike.

Sistemet diellore energjetike mund të jenë:

1. Kolektorët diellor për ngrohje të ujit,

2. Përgatitja e ujit të ngrohët

3. Sistemet fotovoltaike.

4. Fermat diellore

Sistemet fotovoltaike realizohen me shndërruesit fotovoltaik të cilët energjinë rrezatuese të diellit e shndërrojnë në energji elektrike (shndërrim i drejtpërdrejtë). Sistemet fotovoltaike kanë konstruksion modular për aplikim të shumëfishtë dhe me koeficient të ultë të shfrytëzimit, i cili sillet prej 10-25\%. Sistemet fotovoltaike mund të përdoren si burime autonome të energjisë elektrike në kombinim me burimet tjera të energjisë elektrike ose të lidhur në rrjetin elektrik. Centralet diellore ndërtohen sipas dy teknologjive të prodhimit energjisë elektrike dhe atë:

1. Teknologjia me sistem parabolik

2. Teknologjia me sistem të kullave diellore

Teknologjia e sistemit parabolik në fillim është përdorur në SHBA, dhe centrali i parë në Evropë që punon me këtë teknologji është ndërtuar në Spanjë me fuqinë e instaluar 50MW. Në këtë central sistemi i deponimit absorbon një pjesë të nxehtësisë të prodhuar nga fushat me celula diellore parabolike gjatë ditës. Turbinat prodhojnë energjinë elektrike gjatë natës duke përdorur këtë nxehtësi. Ky proces mundëson dyfishimin e numrit të orëve të punës në vit të centralit. Teknologjia e sistemit me kulla është teknologji e veçantë diellore pasi ato kanë mundësi të krijojnë rezerva të energjisë. Ato mund të punojnë kurdo qoftë që konsumatori të kërkoj energji, pra gjatë nates apo gjatë motit të vranët. Kulla punon në principin e fokusimit nga fusha me mija copa pasqyra, me marrës i cili është i vendosur në maje të kullës. Marrësi grumbullon nxehtësinë e diellit ne lëngun e ngrohët i cili qarkullon dhe i cili përdoret për prodhimin e avujve për turbinën konvencionale me avull për prodhimin e energjisë elektrike, të vendosur në fund të kullës. (Wikipedia), 2015. 


\subsubsection{Potenciali i energjisë diellore}

Klima në Kosovë është e ndikuar nga klima kontinentale me mot shumë të nxehtë në muajt e verës, ku temperaturat mund të arrijnë $40^{\circ} \mathrm{C}$ dhe mot të ftohtë në sezonin e dimrit. Temperaturat gjatë dimrit mund të bien deri në $-25^{\circ} \mathrm{C}$. Rrezatimi global në vit arrin në $1400 \mathrm{kWh} / \mathrm{m} 2 \mathrm{a}$ në Prishtinë. Dallimi në rrezatim brenda vendit është në mes të 1200 dhe $1500 \mathrm{kWh} / \mathrm{m} 2 \mathrm{a}$. Pasi që rrezatimi global në mesatare është për 23\% më i lartë se në një qytet mesatar në Evropë, regjioni është i përshtatshëm për përdorimin e energjisë diellore. ${ }^{96}$

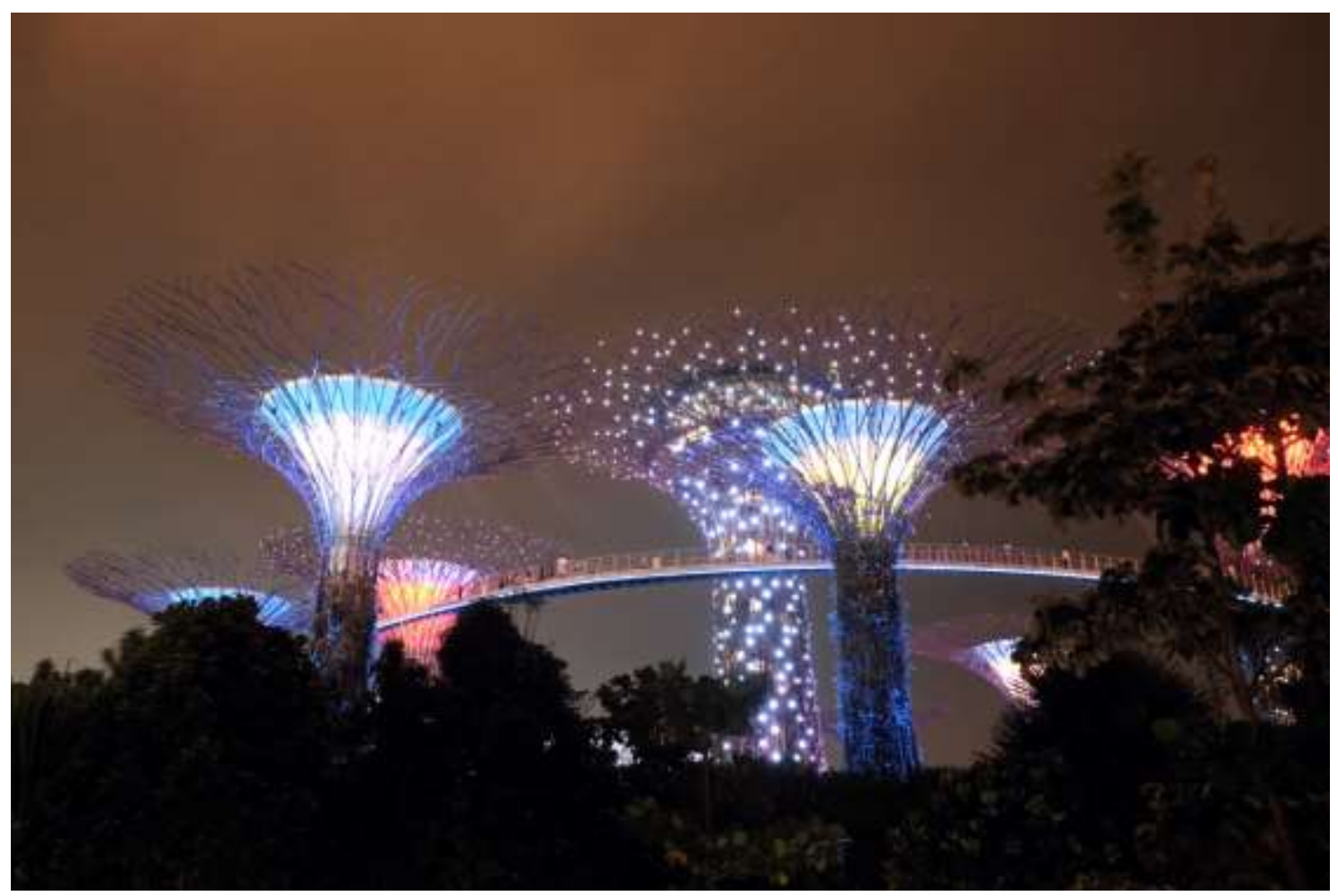

Figura 190. Gardens by the Bay, 'photovoltaic' trees

(Burimi): TinoM, 2016. (Flickr). E licensuar nga Creative Commons Attribution 2.0 Generic

Panelet tipikë solarë kanë një efikasitet mesatar prej $12 \%$, me panele më të mirë që janë në dispozicion për nevoja komerciale prej 20\%. Gjurmuesit dhe sensorët mund të optimizojnë performancën dhe shpesh instalohen për të rritur prodhimin, mirëpo ata e rrisin dukshëm koston kapitale të projektit. Rreshtimet e paneleve PV (fotovoltaik) që i qasen ose e tejkalojnë një megavat shpesh përdorin gjurmues solar. Një panel tipik solar, 150W, është rreth një metër katror madhësi. Një panel i tillë mund të pritet për të prodhuar mesatarisht $1 \mathrm{kWh}$ për çdo ditë, pasi të merret parasysh moti dhe gjerësia. Prodhimi elektrik i qelizës fotovoltaike është jashtëzakonisht i ndjeshëm ndaj hijes. Edhe kur një pjesë e vogël e një qelize, moduli

96 Bernd Sitzmann, IADK. Kosovë 
ose rreshti bie nën hije, përderisapjesa tjetër është në rreze drite, prodhimi bie në mënyrë dramatike për shkak të "lidhjes së shkurtë" nga brenda. Drita e diellit mund të absorbohet nga pluhuri, bora, ose papastërtitë e tjera në sipërfaqe të modulit. Kjo mund të zvogëlojnë përgjysmë sasinë e dritës që godet qelizat. Mbajtja e një sipërfaqeje të pastër të modulit do të rrisë performancën e prodhimit gjatë gjithë jetëgjatësisë së modulit.

Pajisjet që shndërrojnë energjinë diellore në energji termike quhen kolektorë të energjisë diellore (solare).

Ata përbëhen nga tri pjesë themelore:

1. Akumuluesi-përthithësi

2. Izolimi termik

3. Xhami

Kolektorët e rrafshët solar vendosen në anën jugore të ndërtesës (në kulme, tarracë, mure) dhe nëpërmjet tyre mund të arrihet temperatura deri $\sim 100^{\circ} \mathrm{C}$. Sipas fluidit punues kolektorët solar ndahen në kolektorë të ujit dhe në kolektorë të ajrit.

Energjia e krijuar nëpërmjet rrezatimit diellor, përdoret për ngrohjen e ujit higjieniksanitar, për ngrohjen e hapësirave, për ngrohjen e ujit të baseneve të hapura dhe të mbyllurave .

Tabela 29. Ndarja e komunave sipas zonave të intensitetit të rrezatimit diellor (Burimi): Studimi për përgatitjen e të dhënave projektuese për sistemet e shfrytëzimit të energjisë diellore në Kosovë i kryer nga B2B \& Energy, Ministria e Zhvillimit Ekonomik (MZHE) 2010

\begin{tabular}{|l|l|l|l|l|}
\hline Nr & \multicolumn{1}{|c|}{ Zona 1 } & \multicolumn{1}{|c|}{ Zona 2 } & \multicolumn{1}{|c|}{ Zona 3 } & \multicolumn{1}{|c|}{ Zona 4 } \\
\hline 1 & Pejë & Prizren & Podujevë & Gjilan \\
\hline 2 & Deçan & Dragash & Novobërdë & Viti \\
\hline 3 & Gjakove & Mitrovicë & Kamenicë & Kaçanik \\
\hline 4 & Klinë & Skenderaj & Istog & Shtërpcë \\
\hline 5 & Rahovec & Gllogovc & Zubin Potok & \\
\hline 6 & Suharekë & Obiliq & Leposaviq & \\
\hline 7 & Malishevë & Fushe Kosove & Zveçan & \\
\hline 8 & & Lipjan & Vushtrri & \\
\hline 9 & & Shtime & & \\
\hline 10 & & Prishtinë & & \\
\hline 11 & & Ferizaj & & \\
\hline
\end{tabular}




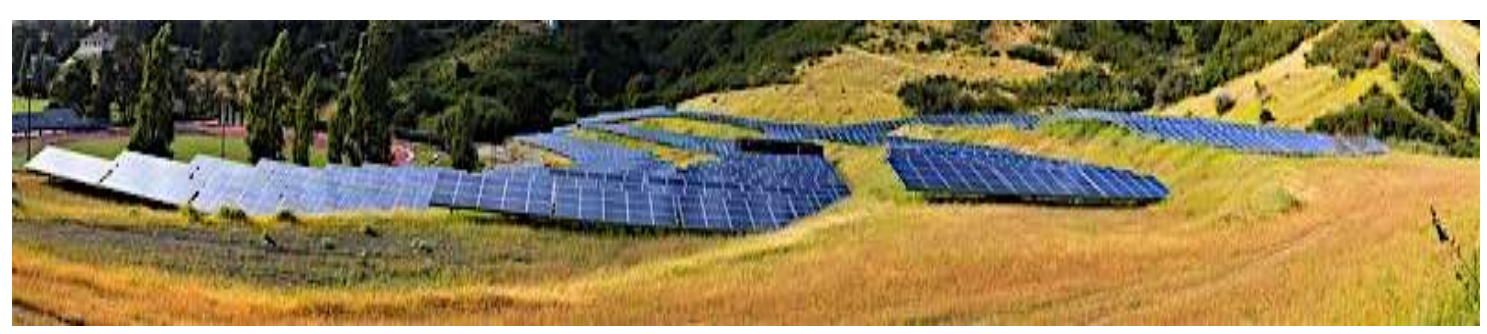

Figura 191. Ferma Solare

(Burimi): Michael Mess, 2011. (Flickr). E licensuar nga Creative Commons Attribution 2.0 Generic

Për projektimin e sistemeve të shfrytëzimit të energjisë diellore kërkohet të njihen një numër parametrash (variablash) klimatike, përfshirë:

Rrezatimi mesatar ditor në rrafshin e kolektorit diellor, që përdoret për të llogaritur rendimentin e kolektorit dhe energjinë diellore të kapur prej tij; temperaturën qiellore, që përdoret për të llogaritur energjinë e kapur nga kolektorët e pa mbuluar, dhe humbjet radiative në mjedisin përreth prej pishinave; temperatura e ujit të ftohtë, që përdoret për te përcaktuar ngarkesën termike që sistemi duhet te mbuloje/përballojë dhe ngarkesën ngrohëse (përveç rastit të pishinave). Sasia e rrezatimit diellor që arrin në secilën pikë të sipërfaqes së Tokës ndryshon në varësi të këtyre faktorëve:

1. Pozicionit gjeografik

2. Kohës gjatë ditës

3. Stinës

4. Gjeografisë të lokacionit dhe kushteve lokale klimatike

Performanca e PV Rrjetit Elektrik, në varg

Vlerësimet PVGIS e gjenerimit të energjisë elektrike diellore

Vendndodhja: 42 39'46 "Veri, 21 9'55" Lindje, Lartësia: $607 \mathrm{~m}$ lmd, bazës së të dhënave Rrezatimi diellor përdorur: PVGIS-CMSAF

Fuqia nominale e sistemit të PV: $1.0 \mathrm{~kW}$ (kristalor silic)

Humbjet e vlerësuara për shkak të temperaturës dhe rrezatim të ulët: $14.3 \%$ (duke përdorur temperatura lokale e ambientit)

humbjen e parashikuar për shkak të efekteve këndore reflektim: 3.4\%

Humbjet tjera (kabllot, inverter): $14.0 \%$ PV Kombinuar humbjet e sistemit: $28.8 \%$ 
Tabela 30. Të dhënat për Prishtinën për energjinë diellore sipas data bazës të Komisionit Evropian.

(Burimi): Bujar Bajçinovci, PVGIS (c) European Communities, 2001-2012.

\begin{tabular}{|l|r|r|r|r|}
\hline \multicolumn{7}{|l|}{$\begin{array}{l}\text { Sis tem fiks : këndi }=35 \\
\text { Orientim }=90 \text { deg. }\end{array}$} \\
\hline Muaji & \multicolumn{1}{|l|}{ Ed } & \multicolumn{1}{|l|}{ Em } & \multicolumn{1}{l|}{ Hd } & \multicolumn{1}{l|}{ Hm } \\
\hline Jan & 1.04 & 32.1 & 1.37 & 42.6 \\
\hline Shk & 1.59 & 44.7 & 2.07 & 58.1 \\
\hline Mar & 2.67 & 82.8 & 3.60 & 111 \\
\hline Pri & 3.23 & 96.9 & 4.47 & 134 \\
\hline Maj & 3.69 & 114 & 5.24 & 162 \\
\hline Qer & 4.16 & 125 & 6.08 & 182 \\
\hline Kor & 4.28 & 133 & 6.29 & 195 \\
\hline Gus & 3.86 & 120 & 5.72 & 177 \\
\hline Sht & 2.86 & 85.7 & 4.08 & 122 \\
\hline Tet & 2.12 & 65.9 & 2.92 & 90.6 \\
\hline Nën & 1.31 & 39.3 & 1.76 & 52.9 \\
\hline Dhj & 0.86 & 26.8 & 1.14 & 35.4 \\
\hline Vit & 2.65 & 80.5 & 3.74 & 114 \\
\hline TotalVit & & 966 & & $\mathbf{1 3 6 0}$ \\
\hline
\end{tabular}

Ed: Prodhimi mesatar i energjisë elektrike për ditë nga sistemi i dhënë (kWh) Em: Prodhimi mesatar i energjisë elektrike mujore nga sistemi i dhënë (kWh) HD: Shuma mesatare ditore prej rrezatim globale për metër katror të marrë nga modulet e sistemit të dhënë $\left(\mathrm{kWh} / \mathrm{m}^{2}\right)$

Hm: Shuma mesatare e rrezatim globale për metër katror të marrë nga modulet e sistemit të dhënë $\left(\mathrm{kWh} / \mathrm{m}^{2}\right)$

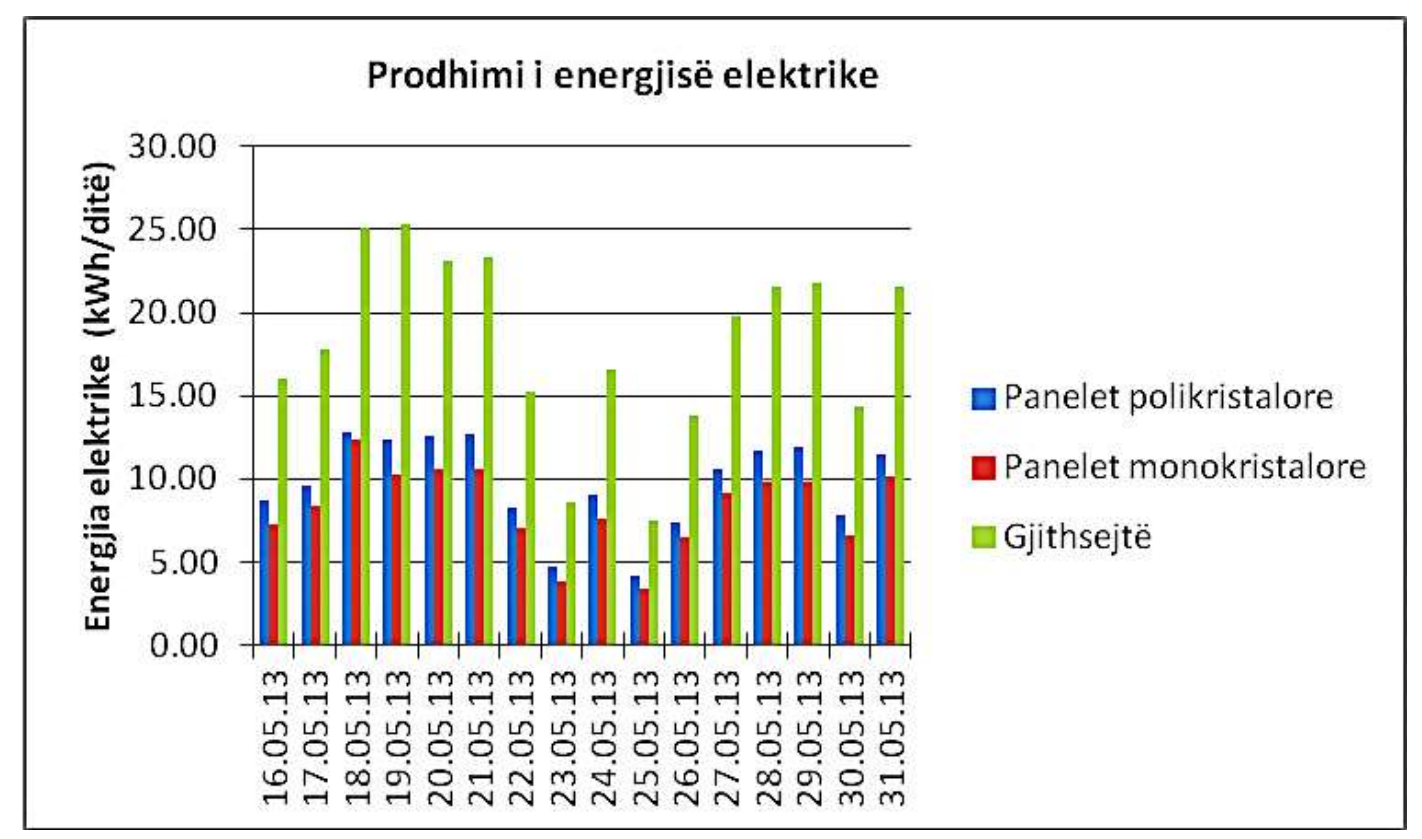

Figura 192. Prodhimi i energjisë mujore nga sistemi PV

(Burimi): Vjollca Komoni, Isuf Krasniqi, Arben Leka, Ilir Gashi. Analiza e performancës së sistemit fotovoltaik me fuqi $3.9 \mathrm{kwp}$ të palidhur në rrjetin elektrik. FIEK. UP. 


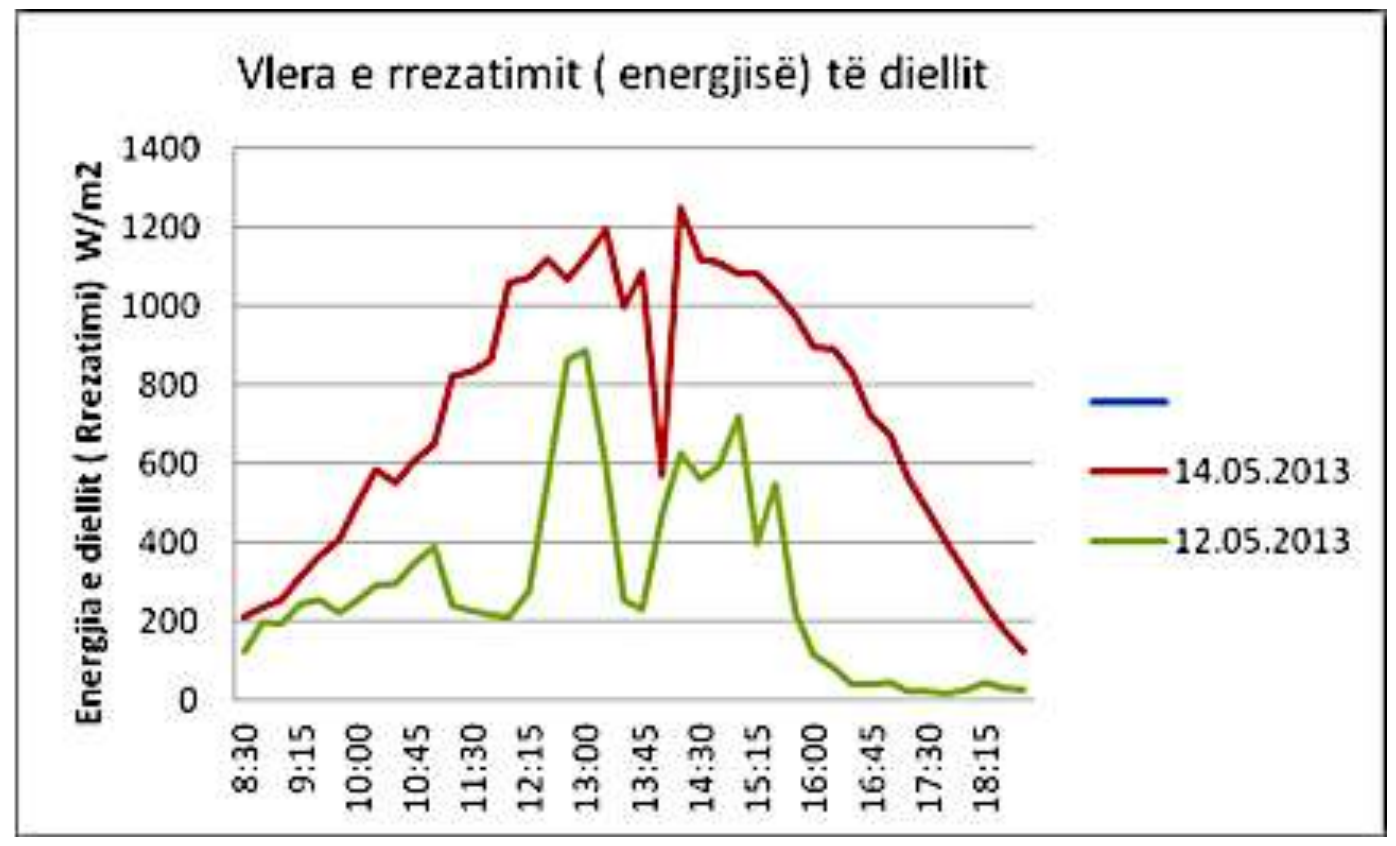

Figura 193. Energjia e diellit (rrezatimi) në dy ditë të ndryshme (Burimi): Vjollca Komoni, Isuf Krasniqi, Arben Leka, Ilir Gashi. Analiza e performancës së sistemit fotovoltaik me fuqi $3.9 \mathrm{kwp}$ të palidhur në rrjetin elektrik. FIEK. UP.

Pajisjet për përftimin e ujit higjienik nëpërmjet energjisë diellore quhen bojlerë diellorë. Fluidi punues i këtyre pajisjeve mund të ketë qarkullim natyror (gravitacional) ose të detyruar (nëpërmjet pompës). Varësisht nga konstruksioni bojlerët me qarkullim të detyruar mund të jenë sisteme solar direkt (me derdhje, të hapur) ose indirekte (qarkullues, të mbyllur). Uji në rezervuarët e tillë mund të ruhet i ngrohtë 2 deri 3 ditë. Forma e ngrohjes së ujit sanitar, përkatësisht sistemi i ngrohjes solare i përbërë prej komponentëve: kolektorit, rrjetit qarkullues, bojlerit dhe elementeve të tjera të sigurisë.

Tabela 31. Potenciali energjetik i rrezatimit diellor në rrafsh optimal (Burimi): Studimi për përgatitjen e të dhënave projektuese për sistemet e shfrytëzimit të energjisë diellore në Kosovë i kryer nga B2B \& Energy, Ministria e Zhvillimit Ekonomik (MZHE) 2010

\begin{tabular}{|c|c|c|c|c|}
\hline \multirow{3}{*}{ Rajoni } & \multirow{3}{*}{ Komuna } & \multirow{3}{*}{$\begin{array}{c}\text { Sipërfaqja } \\
{\left[\mathrm{km}^{2}\right]}\end{array}$} & \multicolumn{2}{|c|}{ Rrezatimi diellor } \\
\hline & & & kWh/ $\mathrm{m}^{2} / \mathrm{vit}$ & GWhivit \\
\hline & & & \multicolumn{2}{|c|}{ Mesatare } \\
\hline \multirow{5}{*}{ Prizreni } & Prizren & 636 & 1600 & $1,017,600.00$ \\
\hline & Dragash & 435 & 1625 & $706,875.00$ \\
\hline & Suharekë & 357 & 1625 & $580,125.00$ \\
\hline & Rahovec & 268 & 1650 & $442,200.00$ \\
\hline & Malishevë & 311 & 1600 & $497,600.00$ \\
\hline
\end{tabular}

Tabela 32. Potenciali energjetik i për panelet PV 
(Burimi): Studimi për përgatitjen e të dhënave projektuese për sistemet e shfrytëzimit të energjisë diellore në Kosovë i kryer nga B2B \& Energy, Ministria e Zhvillimit Ekonomik (MZHE) 2010

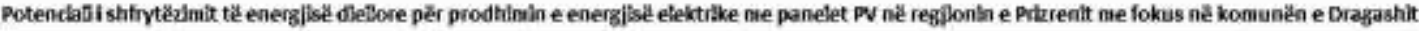

\begin{tabular}{|c|c|c|c|c|c|c|c|c|c|c|c|c|c|}
\hline \multicolumn{2}{|c|}{ Lokaciond } & \multicolumn{4}{|c|}{ Demografia } & \multicolumn{2}{|c|}{\begin{tabular}{|c|} 
Potendafi i meratinit \\
divilby
\end{tabular}} & \multicolumn{5}{|c|}{ 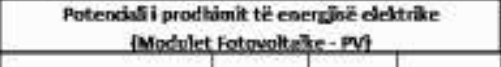 } & \multirow[t]{2}{*}{ 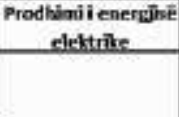 } \\
\hline & & & & & & & & \multicolumn{2}{|c|}{ 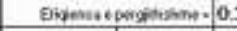 } & 0.15 & & & \\
\hline \multirow[b]{2}{*}{ Rajoni } & \multirow[b]{2}{*}{ romurse } & Zonapp ph & Populesia & $\begin{array}{c}\text { Dencesia } \\
e \\
\text { poopullstse }\end{array}$ & Anmisritc & $\begin{array}{c}\text { Intenzitedi } \\
\text { ireastimit } \\
\text { në matsh } \\
\text { optima! } \\
\end{array}$ & $\begin{array}{l}\text { Potencisi } \\
\text { i teoric }\end{array}$ & $\begin{array}{c}\text { Potenciali } \\
\text { neto }\end{array}$ & $\begin{array}{c}\text { Modhilsia } \\
\text { e modulit } \\
\text { PV }\end{array}$ & $\begin{array}{c}\text { Numrii } \\
\text { atmistive }\end{array}$ & $\begin{array}{c}\text { Sarsia o } \\
\text { paneleve } \\
\text { iv }\end{array}$ & $\begin{array}{c}\text { Potencisli } \\
\text { tocat plir } \\
\text { enecia } \\
\text { elektrike }\end{array}$ & \multirow{2}{*}{$\begin{array}{c}\text { Frodhimi i enersos? } \\
\text { elextrike }\end{array}$} \\
\hline & & $\mathrm{km}^{2}$ & Eanore & בanores/smé & Tonal & 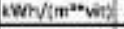 & GWh/vit & XWhilenting & $\pi^{2}$ & $x$ ecotalis & $m^{2}$ & KWhivet & \\
\hline Kanowa R: & Pither & 30920 & 1975000 & $1 B 1$ & 295695 & 1611 & 17576010 & 242 & $4 \mid$ & $10 \mathrm{~N}$ & 118278 & 28581879 & Po \\
\hline \multirow{5}{*}{$\begin{array}{c}\text { Aegioni } \\
1 \\
\text { Prizrenir }\end{array}$} & Prikien & 636 & 177250 & 276.7 & 29215 & 3642 & 3044312 & 245 & 4 & $10 \mathrm{~s}$ & 11566 & 2878262 & Po \\
\hline & Draeash & 435 & 33594 & $\pi 2$ & 6054 & 16255 & 707003 & 244 & 4 & $10 \mathrm{~s}$ & 2426 & 591422 & Po \\
\hline & Suharekd & 557] & 59702 & 167.2 & 9132 & 16578 & S01BSS & 249 & 4 & $10 \times$ & 3553 & 908342 & Po \\
\hline & Rahovec & 268 & 55063 & 205.4 & S028 & 1640.8 & 459734 & 246 & 4 & $10 \mathrm{x}$ & 3211 & 790341 & Po \\
\hline & Nalishere & 511 & Sabse & 175.8 & 6887 & 16617 & 516789 & 249 & 4] & 100 & 2755 & 605645 & Po \\
\hline
\end{tabular}

Te dhenat per kalkulame

\begin{tabular}{|c|c|c|}
\hline \multicolumn{2}{|c|}{ Numei i banesave ne Dragas } & \multirow{2}{*}{$\begin{array}{l}9773 \\
5952\end{array}$} \\
\hline Te barusia: & $00.90 \%$ & \\
\hline Te pobanuata: & $39.10 \%$ & 3321 \\
\hline \multicolumn{2}{|c|}{ Ekonomite familijare: } & 6094 \\
\hline \multicolumn{2}{|c|}{ Nuter i i popultsise: } & 99544 \\
\hline
\end{tabular}

Tabela 33. Potenciali energjetik solar për ngrohjen e ujit sanitar

(Burimi): Studimi për përgatitjen e të dhënave projektuese për sistemet e shfrytëzimit të energjisë diellore në Kosovë i kryer nga B2B \& Energy, Ministria e Zhvillimit Ekonomik (MZHE) 2010

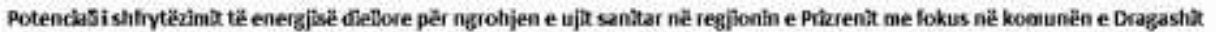

\begin{tabular}{|c|c|c|c|c|c|c|c|c|c|c|c|c|c|}
\hline \multicolumn{2}{|c|}{ Lokadond } & \multicolumn{4}{|c|}{ Denografis } & \multicolumn{2}{|c|}{$\begin{array}{l}\text { Potendidfi rrezatimit } \\
\text { diellor } \\
\end{array}$} & \multicolumn{5}{|c|}{ 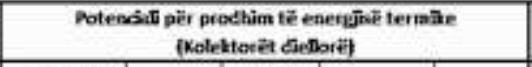 } & $\begin{array}{l}\text { Aphilina } \\
\text { potencial }\end{array}$ \\
\hline & & & & & & & & 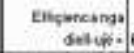 & 07 & $\begin{array}{l}\text { Enpenea: } \\
\text { of.upi. }\end{array}$ & 0.7 & & \multirow{4}{*}{$\begin{array}{l}\text { Neronja e ujit } \\
\text { thit saniear }\end{array}$} \\
\hline & & & & & & & & 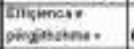 & 65 & & & & \\
\hline \multirow[b]{2}{*}{ Rejoni } & \multirow[b]{2}{*}{ Komuna } & Zona & Ropullsia & $\begin{array}{l}\text { Dendissia e } \\
\text { popullsise }\end{array}$ & Amverite & $\begin{array}{c}\text { Interuiteti i } \\
\text { rrezstimit ne } \\
\text { matsh } \\
\text { optinal }\end{array}$ & $\begin{array}{c}\text { Potendisi } \\
\text { it teorik }\end{array}$ & $\begin{array}{c}\text { Potenciall } \\
\text { neso }\end{array}$ & $\begin{array}{c}\text { Madhesia } \\
e^{\circ} \\
\text { kolektorit }\end{array}$ & $\begin{array}{c}\text { Numril } \\
\text { arnisive }\end{array}$ & $\begin{array}{c}\text { Sasia e } \\
\text { kolektorerve }\end{array}$ & $\begin{array}{l}\text { Pocenciali } \\
\text { total pêr } \\
\text { ngropje }\end{array}$ & \\
\hline & & $\mathrm{km}^{2}$ & Banore & Banora//esit & Tosal & 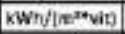 & \begin{tabular}{|c|} 
CWhy/vit \\
\end{tabular} & 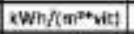 & $\pi^{2}$ & $\mathbf{s}$ e votalit & $\omega^{2}$ & kwhinit & \\
\hline \multicolumn{2}{|c|}{ Woroma efinsef } & 10910 & 1975000 & 181 & 295595 & 1611 & 17576010 & 3005 & 4 & $100 \mathrm{~s}$ & 118275 & 95272929 & Po \\
\hline \multirow{5}{*}{$\begin{array}{c}\text { Regionion } \\
1 \\
\text { Privrentit }\end{array}$} & prizen & 656 & 177200 & 2787 & 29215 & 1642 & 1004012 & 821 & 4 & 1005 & 11685 & 9594206 & Po \\
\hline & Dragash & 436 & 3054 & $\pi 2$ & 6064 & 16255 & 200095 & 81275 & 4 & $100 \mathrm{~s}$ & 2426 & 1972006 & Po \\
\hline & Sunareke & as? & 59702 . & 1602 & 9132 & 2657.8 & s91ans & 8289 & 4 & $10 \mathrm{~s}$ & asss & 3027806 & Po \\
\hline & Rahovec & 258 & ssoss] & 205.4 & 6028 & 1640.8 & 409734 & 820.4 & 4 & 1005 & 5211 & 20S496C & Po \\
\hline & Malisnevet & 312 & 54654 & 175.8 & 6es? & 96617 & $516 \mathrm{~mm}$ & R.2085 & 4 & $10 \mathrm{~s}$ & 2555 & 22 ka256 & $P_{0}$ \\
\hline
\end{tabular}

Tể chenat ôt kalkuline:

\begin{tabular}{|c|c|c|}
\hline Numti i banesor & Dragess: & 9773 \\
\hline Te banicara: & $60.00 \pi$ & 5052 \\
\hline Te patanuara: & $39.10 \mathrm{~K}$ & 3821 \\
\hline Exonomite fani & & 5094 \\
\hline Nemti i posulas & & 33584 \\
\hline
\end{tabular}

Në rastet kur me energji diellore nuk mund të sigurohet sasi e mjaftueshme uji për nevoja sanitare, parashihet mundësia e ngrohjes shtesë të ujit me anë të energjisë elektrike, ose nëpërmjet kaldajës me djegien e lëndëve djegëse, siç janë nafta, gazi, druri. Pra, bojlerët solarë konsiderohen të kompletuar nëse përveç kolektorëve të rrafshët solarë, këmbyesit të nxehtësisë, rezervuarit, pompës për qarkullim dhe automatikës elektronike për kontrollimin e fluidit punues, kanë edhe ngrohësin për ngrohje shtesë, që është i ndërtuar në rezervuarin e bojlerit ose në rezervuar të veçantë. 
Kombinimet për ngrohje shtesë dhe sistemet për ngrohje shtesë mund të jenë me role të ndryshme (kështu p.sh. ngrohja solare mund të jetë ngrohje shtesë (plotësuese) e ndonjë sistemi tjetër të ngrohjes). Për ruajtjen e nxehtësisë për disa ditë përdoren të ashtuquajturit akumulatorë të nxehtësisë. Në varësi nga përmasat e akumulatorit dhe nga mediumi akumulues i nxehtësisë (uji, guri, zhavorri, rëra, betoni, shamoti, tulla, dheu, .) varet edhe kohëzgjatja e ruajtjes së nxehtësisë. Zakonisht përdoren akumuluesit e nxehtësisë me ujë.

\section{Karakteristikat elektrike të Fotovoltaikëve ${ }^{97}$}

Ekstrakt nga punimi shkencorë, në tërësi sipas autorëve: Vjollca Komoni, Isuf Krasniqi, Arben Leka, Ilir Gashi.(2013). FIEK. UP. Prishtinë

“Paneli fotovoltaik përbëhet nga një aranzhim kompleks i celulave diellore. Siç kemi cekur më lartë, një celulë diellore ngjan me një fotodiod të silicit por sipërfaqja e lidhjes $p$ - $n$ është më e madhe për një konvertim të mirë. Celulat diellore përbëhen gjithashtu nga disa elemente të veçanta specifike, të cilat varen nga teknologjitë e prodhimit e jo me parimin e punës.

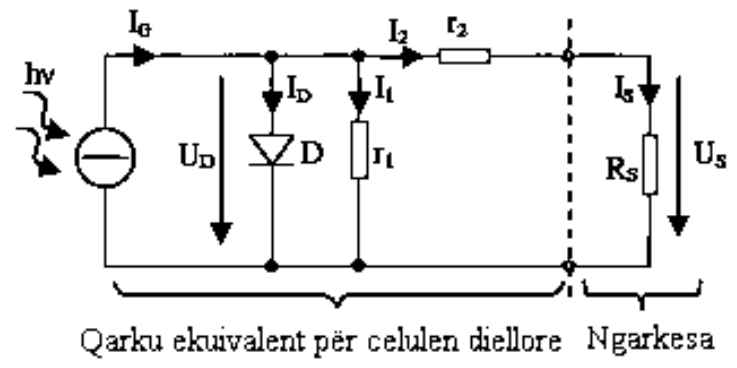

Figura 193-A. Qarku ekuivalent i celulës diellore

(Burimi): Vjollca Komoni, Isuf Krasniqi, Arben Leka, Ilir Gashi. Analiza e performancës së sistemit fotovoltaik me fuqi $3.9 \mathrm{kwp}$ të palidhur në rrjetin elektrik. FIEK. UP.

Në këtë figurë komponentet e veçanta janë: $I_{G}$ - rryma e gjeneruar nga rrezatimi i diellit $h v ; D$ - dioda ideale që lind si rezultat i lidhjes $p-n ; \quad U_{D}, I_{D}$ - tensioni/ rryma e diodës $\mathrm{D} ; \quad r_{1}$ - rezistenca e strukturës në vlera të ulëta të tensionit $U_{D}, ; r_{2}$ - rezistenca ekuivalente serike e shtresave metal- gjysmëpërçues; $R_{S}$ - rezistenca e ngarkesës dhe $U_{S}, I_{S}$ - tensioni/ rryma e ngarkesës. Nëse $R_{S}$ dhe niveli i rrezatimit të diellit $h v$ janë mjaftë të larta atëherë rezistencat $r_{2}$ dhe $r_{1}$ janë shumët të vogla dhe mund të mos merren parasysh. Kështu nëpër diodën ideale do të rrjedh rryma:

97 Vjollca Komoni, Isuf Krasniqi, Arben Leka, Ilir Gashi. (2013). Analiza e performancës së sistemit fotovoltaik me fuqi $3.9 \mathrm{kwp}$ të palidhur në rrjetin elektrik. FIEK. UP. 


$$
I_{D}=I_{0}\left(e^{\frac{U_{d}}{\eta U_{T}}}-1\right)
$$

$\mathrm{Ku} U_{T} \quad$ - paraqet tensionin termik në temperaturën $27^{\circ} \mathrm{C}$ dhe $\eta$ varet nga tipi i gjysmëpërçuesit dhe tensioni sipër lidhjes $p$ - $n$. Nga shprehja 1 dhe fig. 2 . rryma e ngarkesës e celulës diellore është:

$$
I_{S}=I_{G}-I_{0}\left(e^{\frac{U_{d}}{\eta U_{T}}}-1\right)
$$

Nga shprehjet 1 dhe 2, mund të llogaritet tensioni i qarkut të hapur $U_{S 0}$ për celulën diellore që është i barabartë me tensionin në diodë, pra:

$$
U_{S 0}=U_{D}=\eta U_{T} \ln \left(\frac{I_{G}}{I_{0}}+1\right)
$$

Gjatë lidhjes së shkurtër rryma në dalje të celulës diellore $I_{S S}$ është e barabartë $I_{G}$. Kështu, fuqia në dalje të celulës diellore e cila i ekspozohet rrezatimit të diellit është:

$$
P_{S}=U_{S} I_{S}=U_{S}\left[I_{G}-I_{0}\left(e^{\frac{u_{S}}{\eta U_{T}}}-1\right)\right]
$$

Vlera maksimale e fuqisë nga shprehja (4) fitohet nga kushti:

$$
\left.\frac{d P}{d U_{S}}\right|_{U_{S}=U_{M}}=0
$$

$\mathrm{Ku} U_{M}$ është tensioni në dalje të celulës diellore kur fitohet fuqia maksimale $P_{M}$ në dalje. Nga shprehja (5) kemi:

$$
\frac{I_{G}}{I_{0}}+1=e^{\frac{U_{M}}{\eta U_{T}}}\left(1+\frac{U_{M}}{\eta U_{T}}\right)
$$

Ekuacioni (6) mund të zgjidhet numerikisht dhe fitohet vlera e tensionit në dalje $U_{M}$ që shkakton transferimi e fuqisë maksimale në ngarkesë.” (Ekstrakt) ${ }^{97,97}$

\subsubsection{Orientimi i kolektorëve dhe këndi i azimitit}

Orientimi i kolektorëve duhet të jetë ashtu që kolektori të jetë në gjendje që sa më shumë kohë gjatë ditës të absorbojë rrezet e diellit. Në hemisferën veriore, në të cilën gjendet Kosova, kolektorët duhet të orientohen kah jugu në azimut. Këndi i azimutit, figura 4, është devijimi i rrafshit të kolektorit nga jugu; me kënd të rrafshit të kolektorit të orientuar kah jugu, këndi i azimutit është $0^{\circ}$. Pasi që rrezatimi diellor është më intensiv në mesditë, rrafshi i kolektorit duhet të orientohet sa më afër që është e mundur nga jugu. 
Megjithatë, devijimi nga jugu deri në $45^{\circ}$ në juglindje ose jugperëndim është i pranueshëm. Në këtë rast duhet të rritet sipërfaqja e kolektorëve në mënyrë që të kompensohen humbjet e krijuara nga devijimi nga këndi i azimutit.

Këndi i pjerrtësisë së kolektorëve:

Këndi i pjerrtësisë është këndi në mes të rrafshit horizontal dhe të kolektorit diellor, (shif figurën 194). Për kolektorët e integruar në kulm, këndi $\beta$ është vetë këndi i kulmit i cili në këtë rast është edhe këndi $\mathrm{i}$ kolektorit. Sasia më e madhe e energjisë që absorbuesi i kolektorit e merr nga Dielli është kur kolektori është në kënd të drejtë me rrezet e diellit.
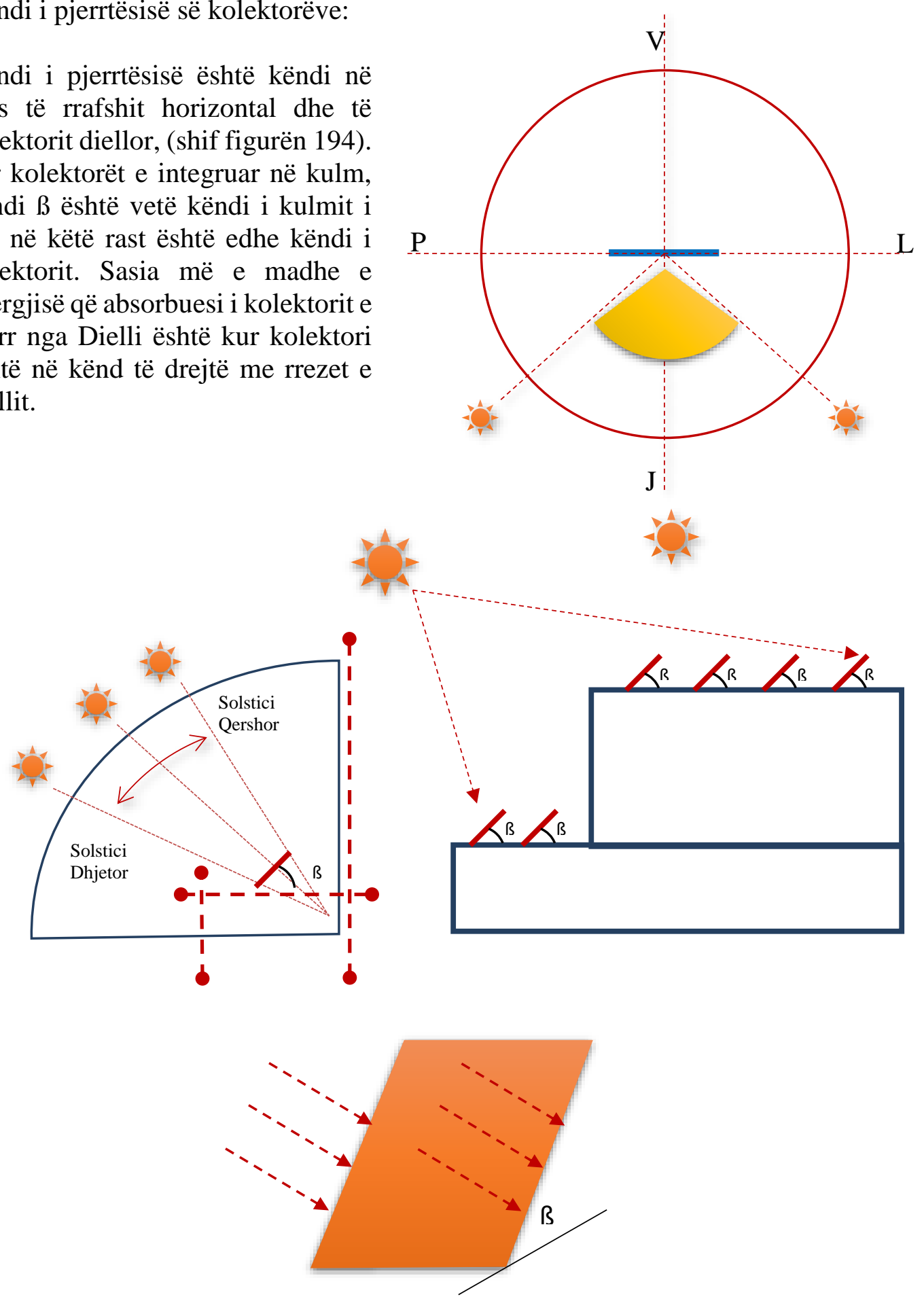

Figura 194. Analiza e pjerrtësisë, solstici, gjeometria e kolektorëve dhe paneleve solar (Burimi): Bujar Bajçinovci, 2015. 
Tabela 34. Potenciali energjetik solar për ngrohjen e ujit sanitar

(Burimi): Studimi për përgatitjen e të dhënave projektuese për sistemet e shfrytëzimit të energjisë diellore në Kosovë i kryer nga B2B \& Energy, Ministria e Zhvillimit Ekonomik (MZHE) 2010

\begin{tabular}{|c|c|c|c|c|c|}
\hline \multicolumn{2}{|c|}{ Lokacioni } & \multicolumn{3}{|c|}{ Përllogaritur për lokacionet me: } & \multirow{2}{*}{$\begin{array}{c}\text { Këndi } \\
\text { optimal } \\
\text { [Gradë] }\end{array}$} \\
\hline Rajoni & Komuna & $\begin{array}{c}\text { Gjerësia } \\
\text { gieografike }\end{array}$ & $\begin{array}{c}\text { Gjatësia } \\
\text { gieografike }\end{array}$ & $\begin{array}{c}\text { Lartësia } \\
\text { mbidetare }\end{array}$ & \\
\hline \multirow{5}{*}{ Prizreni } & Prizren & $\mathrm{N} 42^{\circ} 12^{\prime} 44^{\prime \prime}$ & $\mathrm{E} 20^{\circ} 43^{\prime} 12^{\prime \prime}$ & $395 \mathrm{~m}$ & 32 \\
\hline & Dragash & N 420 $3^{\prime} 41^{\prime \prime}$ & $\mathrm{E} 20^{\circ} 39^{\prime} 20^{\prime \prime}$ & $1054 \mathrm{~m}$ & 31 \\
\hline & Suharekë & $\mathrm{N} 42^{\circ} 21^{\prime} 41^{\prime \prime}$ & $E 20^{\circ} 48^{\prime} 58^{\prime \prime}$ & $387 \mathrm{~m}$ & 32 \\
\hline & Rahovec & $\mathrm{N} 42^{\circ} 24^{\prime} 7^{\prime \prime}$ & $\mathrm{E} 20^{\circ} 39^{\prime} 25^{\prime \prime}$ & $424 \mathrm{~m}$ & 32 \\
\hline & Malishevë & $\mathrm{N} 42^{\circ} 29^{\prime} 3^{\prime \prime}$ & $E 20^{\circ} 44^{\prime} 36^{\prime \prime}$ & $523 \mathrm{~m}$ & 33 \\
\hline
\end{tabular}

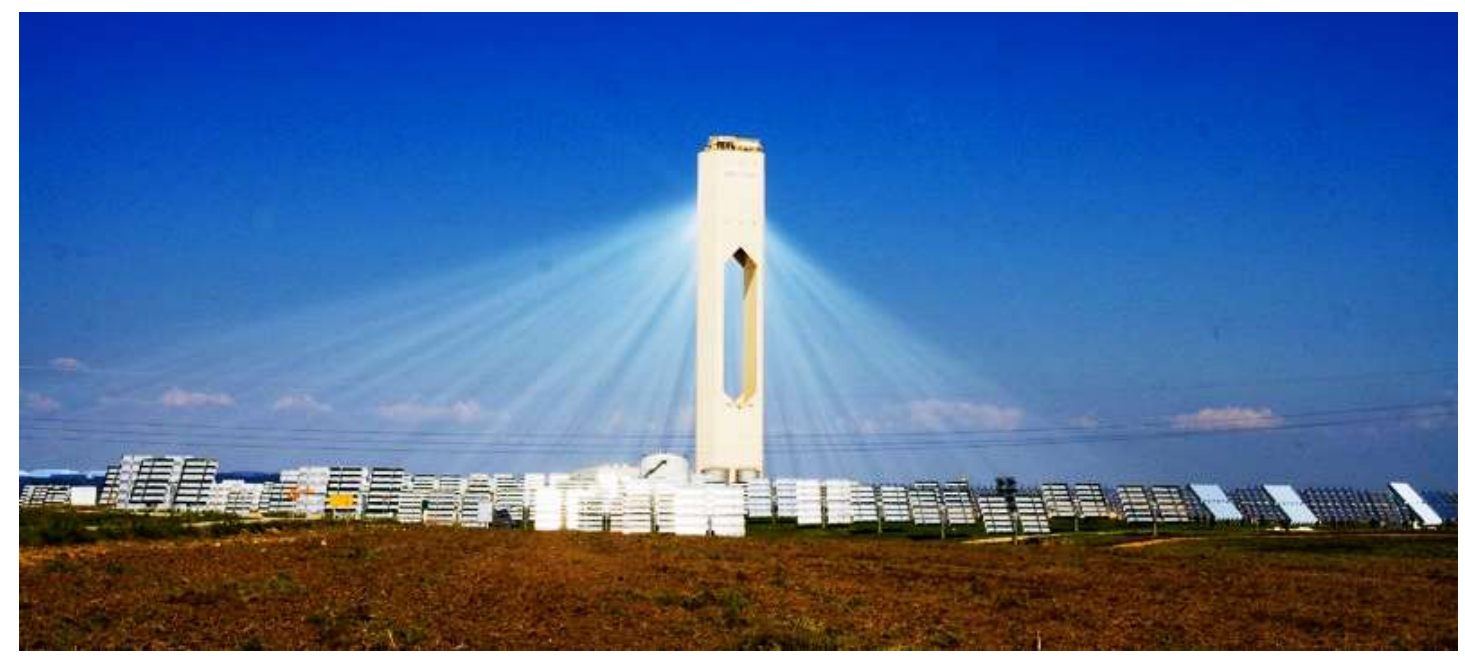

Figura 195. Solucar PS10, Spanjë

(Burimi): afloresm, 2007. (Flickr). E licensuar nga Creative Commons Attribution 2.0 Generic

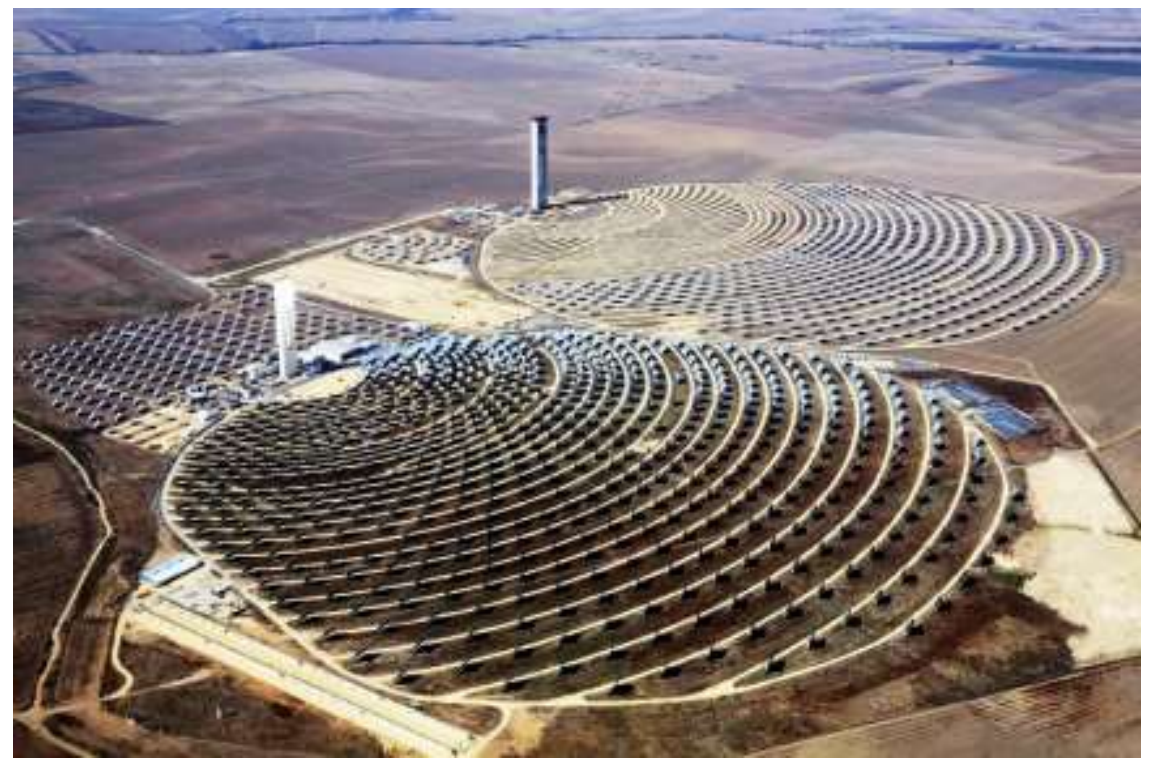

Figura 196. Solucar PS10, PS20, Spanjë

(Burimi): Koza 1983, 2007. (Flickr). E licensuar nga Creative Commons Attribution 2.0 Generic 
Solucar PS10 është centrali i parë i energjisë diellore i bazuar në kullë, që gjeneron energji elektrike në mënyrë komerciale.

Sipas:

(C) PVWatts Calculator

http://pvwatts.nrel.gov/pvwatts.php

Për Prishtinën:

Tabela 35. Potenciali energjetik solar për Prishtinën, PVW

(Burimi): Studimi për përgatitjen e të dhënave projektuese për sistemet e shfrytëzimit të energjisë diellore në Kosovë i kryer nga B2B \& Energy, Ministria e Zhvillimit Ekonomik (MZHE) 2010.

\begin{tabular}{|c|c|c|}
\hline Muaji & $\begin{array}{c}\text { Rrezatimi Solar } \\
(\text { kWh / m2 / ditë })\end{array}$ & AC ( kWh $)$ \\
\hline Janar & 2.58 & 245 \\
\hline Shkurt & 3.83 & 332 \\
\hline Mars & 4.60 & 429 \\
\hline Prill & 5.57 & 491 \\
\hline Maj & 6.75 & 593 \\
\hline Qershor & 7.35 & 615 \\
\hline Korrik & 7.72 & 661 \\
\hline Gusht & 7.33 & 624 \\
\hline Shtator & 6.05 & 501 \\
\hline Tetor & 4.23 & 382 \\
\hline Nëntor & 3.01 & 270 \\
\hline Dhjetor & 2.55 & 238 \\
\hline Vjetore & 5.13 & 5381 \\
\hline
\end{tabular}

Vlerësimet e prodhimit të energjisë dhe koston e energjisë të sistemeve fotovoltaike (PV) të energjisë. Kjo i lejon pronarët e shtëpive, pronarët e ndërtimit të vogla, instaluesit dhe prodhuesit të lehtë të zhvillojnë vlerësime të performancës së instalimeve të mundshëm PV.

$\mathrm{Ku}:$

DC System Size

Module Type

Array Type

Array Tilt

Array Azimuth

System Losses

Inverter Efficiency

DC to AC Size Ratio

Initial Cost
$4 \mathrm{~kW}$

Standard

Fixed (open rack)

$20^{\circ}$

$180^{\circ}$

$14 \%$

$90 \%$

1.1

$2.60 \$ / \mathrm{Wdc}$ 


\subsubsection{Hidro-energjia}

Kosova ka rezerva të pamjaftueshme ujore, që në të ardhmen do të jenë një faktorë kufizues për zhvillimin ekonomik dhe shoqëror të vendit. Vlerësohet se Kosova ka vetëm $1600 \mathrm{~m} 3$ /ujë/vit për kokë banori. Në aspektin hidrografik Kosova ndahet në 4 pellgje lumore: Drini i Bardhë, Ibri, Morava e Binçës, dhe Lepenci. Nga territori i Kosovës në vitin me lagështi mesatare rrjedhin përafërsisht 3.8 x 109 ujë përkatësisht $121.2 \mathrm{~m} 3 / \mathrm{sec}$. Karakteristikë kryesore hidrologjike në Kosovë është shpërndarja jo e barabartë dhe jo adekuate e resurseve ujore në krahasim me nevojat.

Potenciali për energji ujore në Kosovë është shumë i vogël dhe deri më tani shfrytëzimi i saj është mjaft modest. Rezervat e ujërave nëntokësore janë të kufizuara dhe gjenden kryesisht në pjesën perëndimore të Kosovës, ku edhe rezervat e ujërave sipërfaqësore janë më të mëdha, në krahasim me pjesën lindore me rezerva të pakta dhe pjesën juglindore ku nevojat për ujë janë shumë të mëdha. Kosova ka numër të vogël të liqeneve natyrore. Liqene artificiale janë: Batllava, Ujmani, Radoniqi, Përlepnica dhe Badovci, si dhe një numër të vogël të liqeneve për ujitje. Kosova ka burime të rëndësishme të ujërave termale të cilat shfrytëzohen për qëllime shërimi dhe rekreacioni. Mbrojtja, ruajtja dhe zhvillimi i resurseve ujore është shumë i rëndësishëm dhe një ndër sfidat më të mëdha mjedisore të Kosovës.

Elektroenergjia që prodhohet nga energjia hidrike është e ripërtëritshme dhe gjatë përfitimit të saj nuk çlirohen gaze, si gjatë përfitimit të energjisë nga djegia e lëndëve djegëse. Leverdishmëria e shfrytëzimit të burimeve hidroenergjetike kushtëzohet nga kushtet gjeologjike dhe topografike për ndërtimin e digave dhe sidomos nga kushtet topografike, për të pakësuar sa të jetë e mundur përmbytjen e tokave, nga investimet fillestare të mëdha dhe nga mundësia për të bërë rregullimin e rrjedhjes në shkallë të lartë me anë të rezervuarit akumulues.

HEC-et tashmë janë një teknologji shumë e avancuar dhe pothuajse janë zhvilluar në të gjitha vendet e botës. Megjithatë, shfrytëzimi i hidroenergjisë për prodhimin e energjisë elektrike sjell shumë probleme ekonomike, shoqërore dhe ambientaliste. Potenciali teorik hidroenergjetik zvogëlohet ndjeshëm po të marrim parasysh gjithë problemet që lindin me ndërtimin e tyre, ku në radhë të parë janë investimet e mëdha fillestare.

Nga ndërtimi i HEC-it me rezervuar, sipërfaqe të tëra toke përmbyten dhe për pasojë në shumicën e rasteve kjo shoqërohet me shpërnguljen e popullsisë që jeton në ato zona. Ndërtimi i digave të reja krijon probleme të mëdha ndërmjet zonave rurale në afërsi të lumit, kompanive energjetike, kompanive turistike dhe atyre të furnizimit me ujë, sepse secila nga këto kërkon të mbrojë interesat e saj që pothuajse janë diametralisht të kundërta me njëra tjetrën. Përfitimi më i madh nga shfrytëzimi i energjisë ujore realizohet nëpërmjet ndërtimit të hidrocentraleve të vegjël. Në fillim, ndërtimi i këtyre hidrocentraleve ka pasur si qëllim furnizimin me energji elektrike të zonave të thella malore, por më vonë, të gjitha hidrocentralet janë të lidhura në sistemin energjetik. Këto hidrocentrale janë kryesisht të tipit me derivacion dhe shfrytëzojnë burimet dhe rrjedhjet ujore pranë këtyre zonave. Jetëgjatësia e këtyre hidrocentraleve është së paku 25 vite. 
Direktiva 2009/28/ec e Parlamentit dhe e Këshillit Evropian e datës 23 prill 2009 për promovimin e përdorimit të energjisë nga burimet e ripërtërishme të energjisë, paraqet objektiva kombëtare të detyrueshme që duhet të jenë në përputhje me një pjesëmarrje prej $20 \%$ të furnizimit me energji elektrike nga burimet e ripërtërishme të energjisë dhe me një pjesëmarrje prej $10 \%$ të energjisë nga burimet e ripërtërishme të energjisë në transport në shpenzimin e energjisë nga komunitetit deri në vitin 20202. Si një shtet që nuk është anëtar i BE-së, Direktiva 2009/28 ende nuk është detyruese për Kosovën. Megjithatë, Kosova është një palë kontraktuese në Traktatin për Komunitetin e Energjisë. Në këtë kuptim, Traktati për Komunitetin e Energjisë parasheh që Direktiva e mëhershme 2001 e BE-së mbi energjinë e ripërtërishme - e cila kërkonte vendosjen e objektivave tregues kombëtar për prodhimin e energjisë së ripërtërishme3 - është detyrues për Kosovën. Përveç kësaj, Komuniteti i Energjisë tashmë e ka bërë të ditur se është duke shikuar të gjitha modalitetet për miratimin e Direktivës më të re 2009/28. Së fundi, Qeveria e Kosovës ka shprehur angazhimin e saj për plotësimin e të gjitha standardeve të BE-së, tani e tutje, përfshirë edhe ato në sektorin energjetik. Prandaj, politika e promovimit të gjenerimit nga burimet e ripërtërishme tashmë ka hyrë vendosmërisht në legjislacionin e Kosovës dhe kornizën rregullative për sektorin energjetik.

Kapacitetet gjeneruese ekzistuese të Kosovës nuk kanë mundësi që plotësisht të plotësojnë kërkesën për energji elektrike në Kosovë. Dekomisionimi që pritet për njësitë e vjetra do të rrisë boshllëkun në mes të gjenerimit në dispozicion dhe kërkesës. Sipas disa studimeve, të bëra nga organizatat të ndryshme, kjo mund të zbutet dukshëm me anë të implementimit të menaxhimit të kërkesës për energji, programeve për efiçiencë të energjisë dhe zvogëlimin e humbjeve, e po ashtu edhe me anë të zhvillimit të gjerë të potencialit të vendit për burime të ripërtërishme të energjisë. Pjesa më e madhe e këtyre studimeve kanë mungesë të analizave të detajuara dhe të plota të tjerat bazohen në të dhëna gjenerike dhe supozime joreale.

\subsubsection{Potenciali Hidro-energjetik}

\section{HC ekzistuese}

Gjenerimi hidro-energjetik ekzistues i Kosovës është mesatar. Ai përfshin HC Ujmani dhe disa HC të rinovuara më të vogla. Hidrocentrali i Ujmanit ndodhet në Veriperëndim të qytetit të Mitrovicës. Hidrocentrali është komisionuar në vitin 1981. Centrali elektrik nuk i përket KEK-ut (i përket Ibër Lepencit).

Qëllimi kryesor i objektit është ofrimi i ujit të pijshëm dhe industrial për Prishtinën dhe Mitrovicën. HC Ujmani ka rezervuarin e ujit me rregullim vjetor, i cili e arrin kapacitetin e tij maksimal në sezonin e pranverës dhe i cili përdoret gjatë pjesës së mbetur të vitit. Gjenerimi vjetor total varet shumë nga kushtet hidrologjike të vitit, të cilat ndryshojnë dukshëm. Vëllimi i përdorshëm i rezervuarit është 350 milion metra kub, ose ekuivalent me 75 GWh energji. Për shkak të kësaj, mënyra e operimit të hidrocentralit mund të jetë shumë fleksibile, mirëpo ajo drejtohet kah prioriteti për ujë të pijshëm dhe industrial.

Përderisa kapaciteti neto në dispozicion i HC Ujmani mbetet relativisht konstant gjatë një viti (cca 32MW) faktorët e kapacitetit mujor dhe energjia neto në dispozicion variojnë. Gjenerimi mesatar i energjisë mujore nga Ujmani është paraqitur në Fig. 197. 


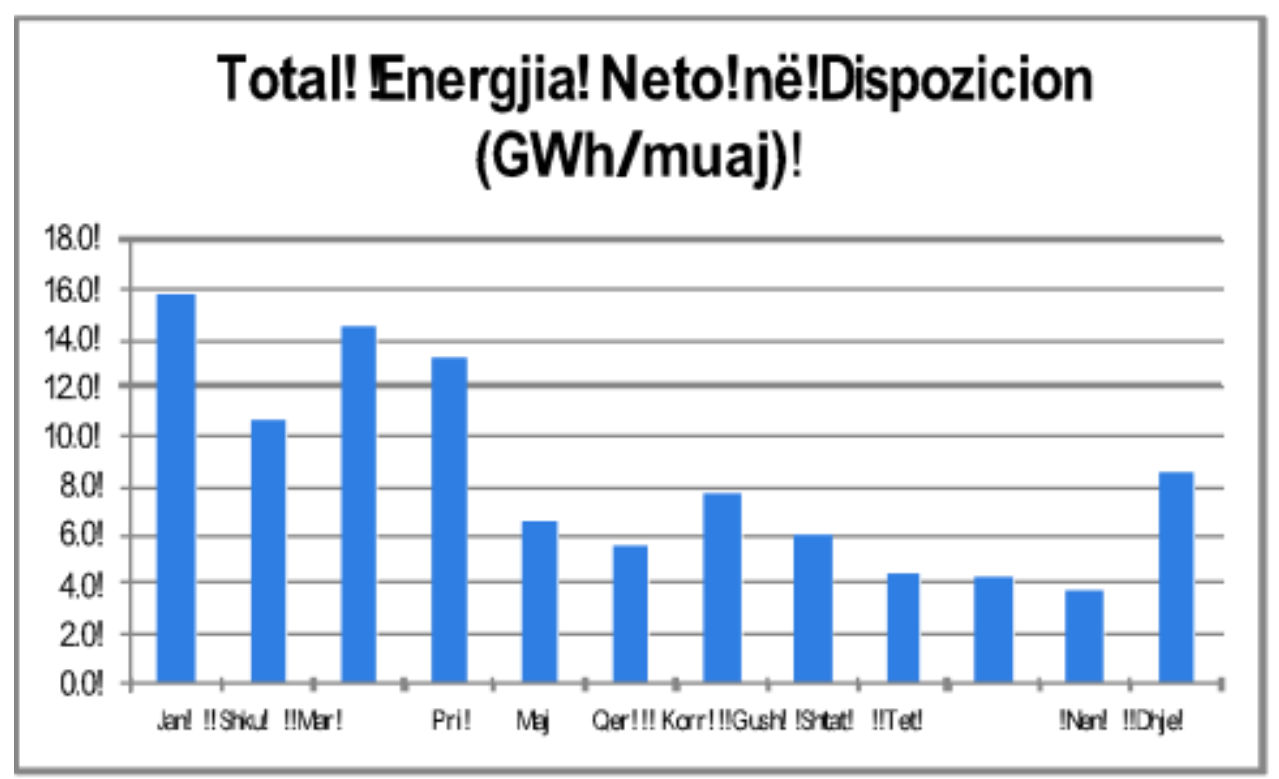

Figura 197. HC Ujmani - Energjia neto në Dispozicion

(Burimi): Jeannelle. Blanchard. KEK-energy. Një vlerësim praktik i potencialeve të BRE dhe MAK për energji në Kosovë.

Tabela 36-37. HC e vogla ekzistuese - Përmbledhje

(Burimi): Jeannelle. Blanchard. KEK-energy. Një vlerësim praktik i potencialeve të BRE dhe MAK për energji në Kosovë.

\begin{tabular}{|c|c|c|c|}
\hline $\begin{array}{l}\text { Emri i } \\
\text { Lokacionit }\end{array}$ & Përshkrimi & $\begin{array}{l}\text { Kapacite } \\
\text { ti } \\
\text { (MW) }\end{array}$ & $\begin{array}{c}\text { Prodhimi i } \\
\text { pritshëm Vjetor i } \\
\text { Energjisë (GWh) }\end{array}$ \\
\hline Lumbardhi & $\begin{array}{l}\text { Hidrocentral i tipit të } \\
\text { rrjedhës së lumit }-\mathrm{i} \\
\text { ndërtuar në vitin } 1957\end{array}$ & 8.3 & 32.6 \\
\hline Dikance & $\begin{array}{l}\text { Hidrocentral } \mathrm{i} \text { tipit të } \\
\text { rrjedhës së lumit }-\mathrm{i} \\
\text { ndërtuar në vitin } 1957 \text { me } \\
\text { një kapacitet fillestar prej } \\
\text { 1.9MW }\end{array}$ & 1.016 & 5.48 \\
\hline Radavc & $\begin{array}{l}\text { Hidrocentral i tipit të } \\
\text { rrjedhës së lumit }-\mathrm{i} \\
\text { ndërtuar në vitin } 1935 \text { me } \\
\text { një kapacitet fillestar prej } \\
\text { 0.35MW }\end{array}$ & 0.8 & 5.6 \\
\hline Burim & $\begin{array}{l}\text { Hidrocentral i tipit të } \\
\text { rrjedhës së lumit }-\mathrm{i} \\
\text { ndërtuar në vitin } 1948 \text { me } \\
\text { një kapacitet fillestar prej } \\
\text { 0.56MW }\end{array}$ & 0.8 & 3.5 \\
\hline
\end{tabular}

Vetëm katër HC të vogla janë aktualisht në operim. Të gjitha prej tyre janë projekte të vjetra të rinovuara bazuar në rrjedhjen e lumenjve. Përmbledhja e të dhënave për HC-të e vogla është paraqitur në Tabelën 37. Energjia mujore dhe kapaciteti në dispozicion 
varen shumë nga uji në dispozicion dhe hidrologjia e një viti të caktuar. Vlerat për një vit mesatar hidrologjik janë paraqitur në Tabelën 38 në vijim.

Tabela 38. HC e vogla. Kapaciteti Neto në Dispozicion dhe Energjia

(Burimi): Jeannelle. Blanchard. KEK-energy. Një vlerësim praktik i potencialeve të BRE dhe MAK për energji në Kosovë.

\begin{tabular}{|c|c|c|c|c|c|c|c|c|c|c|c|c|c|}
\hline \multicolumn{2}{|c|}{ HC-të e Vogla Ekzistuese } & Jan & Shku. & Mars & Prill & Maj & Qersh. & Korr. & Gush. & Shtat. & Tet. & Nen. & Dhjet. \\
\hline \multirow[t]{2}{*}{ Lumbardhi } & $\begin{array}{c}\text { Kapaciteti } \\
\text { në } \\
\text { dispozicio } \\
\text { n (MW) }\end{array}$ & 3.8 & 3.9 & 4.8 & 8.0 & 8.3 & 7.1 & 3.1 & 1.7 & 1.9 & 2.8 & 4.1 & 3.9 \\
\hline & $\begin{array}{c}\text { Energiia } \\
\text { neto } \\
\text { mujore në } \\
\text { dispozicion } \\
\text { (GWh) }\end{array}$ & 2.36 & 2.20 & 2.99 & 4.80 & $\begin{array}{l}5.1 \\
5\end{array}$ & 4.28 & 1.94 & 1.07 & 1.17 & 1.75 & 2.44 & 2.45 \\
\hline \multirow[t]{2}{*}{ Dikanci } & $\begin{array}{c}\text { Kapaciteti } \\
\text { në } \\
\text { dispozicio } \\
\text { n (MW) }\end{array}$ & 0.5 & 0.5 & 0.6 & 1.0 & 1.0 & 0.9 & 0.4 & 0.2 & 0.2 & 0.3 & 0.5 & 0.5 \\
\hline & $\begin{array}{c}\text { Energiia } \\
\text { neto } \\
\text { mujore në } \\
\text { dispozicion } \\
\text { (GWh) }\end{array}$ & 0.40 & 0.37 & 0.50 & 0.81 & $\begin{array}{l}0.8 \\
7\end{array}$ & 0.72 & 0.33 & 0.18 & 0.20 & 0.29 & 0.41 & 0.41 \\
\hline \multirow[t]{2}{*}{ Radavc } & $\begin{array}{c}\text { Kapaciteti } \\
\text { në } \\
\text { dispozicio } \\
\text { n (MW) }\end{array}$ & 0.4 & 0.4 & 0.5 & 0.9 & 0.9 & 0.8 & 0.3 & 0.2 & 0.2 & 0.3 & 0.4 & 0.4 \\
\hline & $\begin{array}{c}\text { Energiia } \\
\text { neto } \\
\text { mujore në } \\
\text { dispozicion } \\
\text { (GWh) }\end{array}$ & 0.40 & 0.38 & 0.51 & 0.82 & $\begin{array}{l}0.8 \\
8\end{array}$ & 0.74 & 0.33 & 0.18 & 0.20 & 0.30 & 0.42 & 0.42 \\
\hline \multirow{2}{*}{$\begin{array}{l}\text { Burimi } \\
/ \\
\text { istog }\end{array}$} & $\begin{array}{c}\text { Kapaciteti } \\
\text { në } \\
\text { dispozicio } \\
\text { n (MW) }\end{array}$ & 0.4 & 0.4 & 0.5 & 0.8 & 0.9 & 0.7 & 0.3 & 0.2 & 0.2 & 0.3 & 0.4 & 0.4 \\
\hline & $\begin{array}{c}\text { Energiia } \\
\text { neto } \\
\text { mujore në } \\
\text { dispozicion } \\
\text { (GWh) }\end{array}$ & 0.25 & 0.24 & 0.32 & 0.51 & $\begin{array}{l}0.5 \\
5\end{array}$ & 0.46 & 0.21 & 0.11 & 0.13 & 0.19 & 0.26 & 0.26 \\
\hline \multirow[t]{2}{*}{ Total } & $\begin{array}{l}\text { Kapaciteti } \\
\text { në } \\
\text { dispozicio } \\
\text { n (MW) }\end{array}$ & 5.1 & 5.2 & 6.4 & 10.6 & $\begin{array}{l}11 . \\
1\end{array}$ & 9.5 & 4.2 & 2.3 & 2.6 & 3.8 & 5.4 & 5.3 \\
\hline & $\begin{array}{c}\text { Energiia } \\
\text { neto } \\
\text { mujore në } \\
\text { dispozicion } \\
\text { (GWh) }\end{array}$ & 3.4 & 3.2 & 4.3 & 6.9 & 7.5 & 6.2 & 2.8 & 1.5 & 1.7 & 2.5 & 3.5 & 3.5 \\
\hline
\end{tabular}

Duhet të theksohet se duke pasur parasysh natyrën e këtyre hidro-projekteve dhe rrjedhat mujore të ujit në dispozicion, kapaciteti më i lartë në dispozicion dhe prodhimi i energjisë së këtyre centraleve paraqitet gjatë sezonit të pranverës dhe nuk përkon me kërkesën vjetore gjatë pikut të sistemit. 


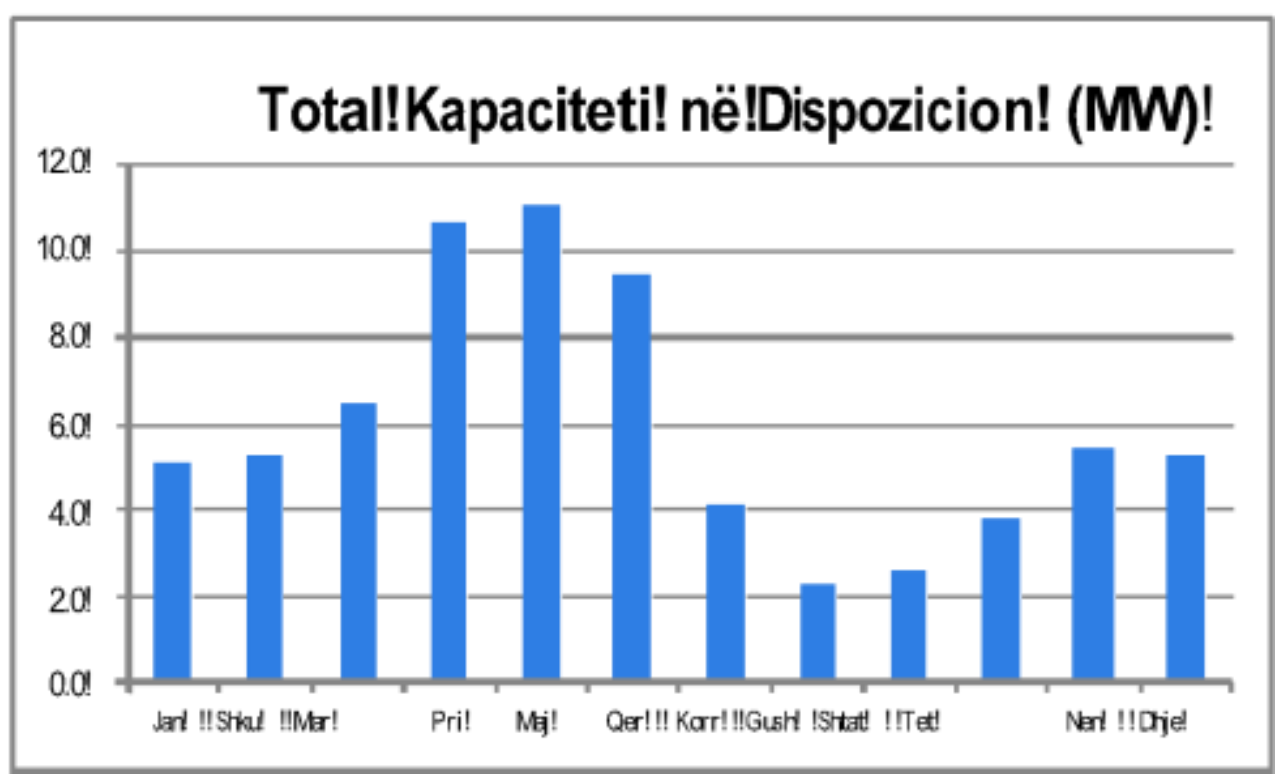

Figura 198. HC e Vogla Ekzistuese - Kapaciteti Total Mujor në Dispozicion (Burimi): Jeannelle.Blanchard. KEK-energy. Një vlerësim praktik i potencialeve të BRE dhe MAK për energji në Kosovë.

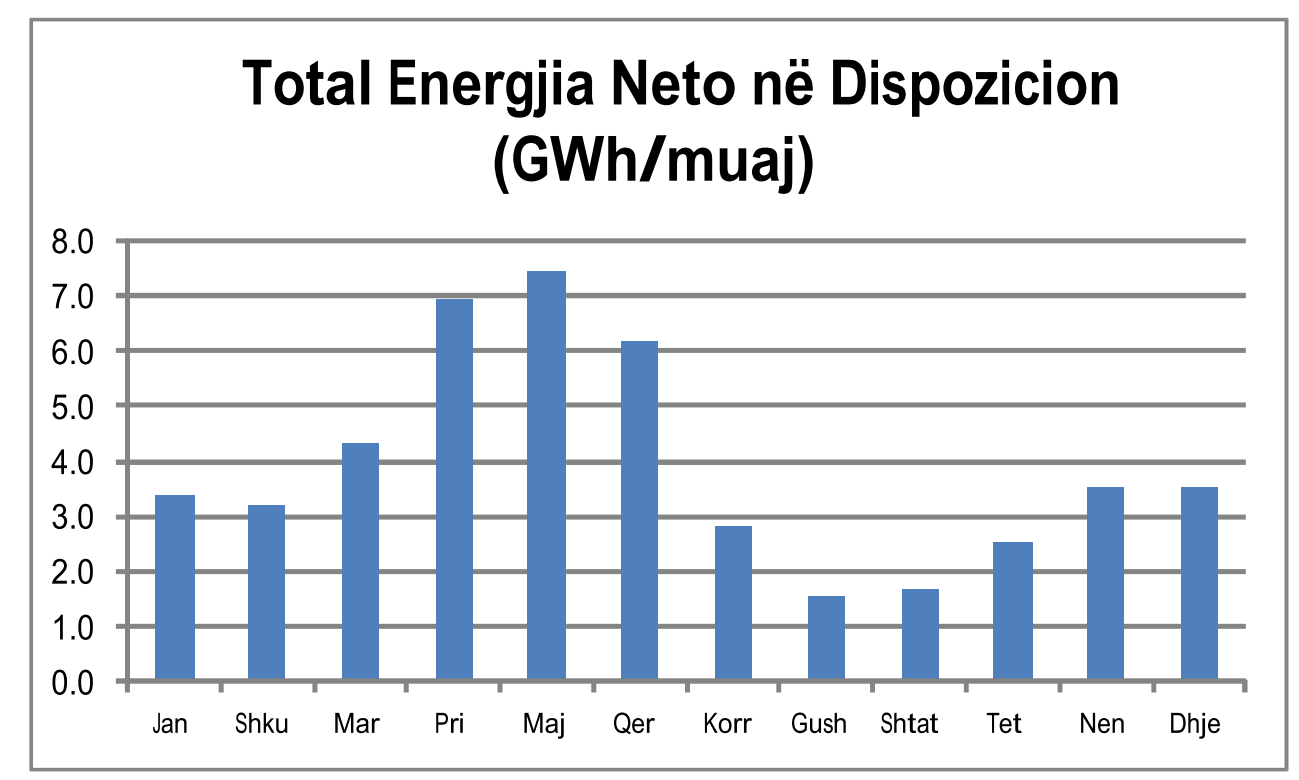

Figura 199. HC-të e Vogla Ekzistuese - Energjia Totale Mujore në Dispozicion (Burimi): Jeannelle.Blanchard. KEK-energy. Një vlerësim praktik i potencialeve të BRE dhe MAK për energji nё Kosovë.

Kapaciteti total mujor dhe energjia potenciale e të gjitha hidroprojekteve ekzistuese dhe të propozuara është përmbledhur bazuar në si më lart. Fig 200 paraqet kapacitetin neto, mujor, total në dispozicion për hidrocentralet e Kosovës. 
Figura 200. Hidro-kapaciteti Neto Mujor në Dispozicion

(Burimi): Jeannelle.Blanchard. KEK-energy. Një vlerësim praktik i potencialeve të BRE dhe MAK për energji пё Kosovë.
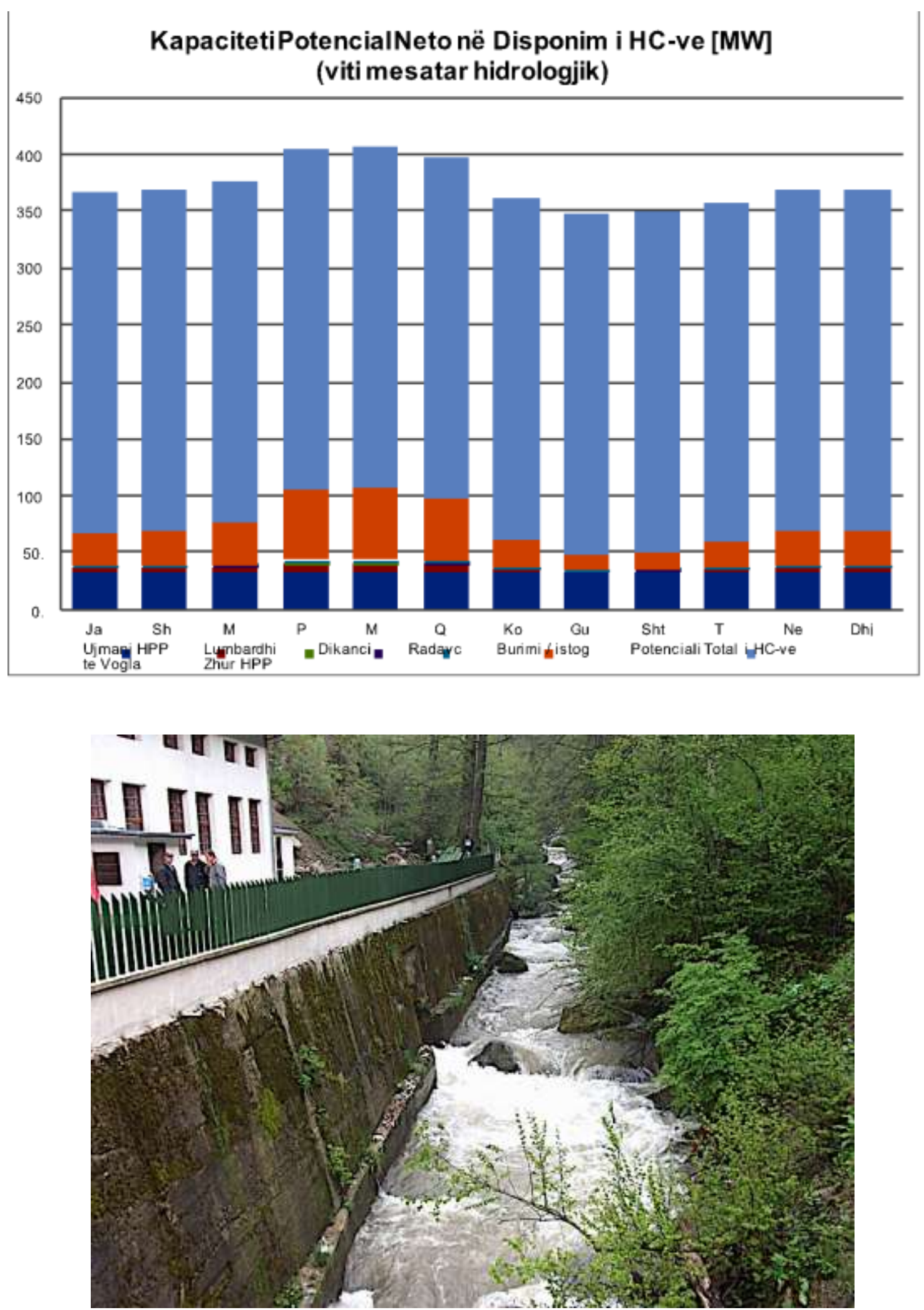

Figura 201. Hidrocentrali i Dikances - Dragash

(Burimi): Nj.tytyri. 2011.(Flickr). Creative Commons Attribution-Share Alike 3.0 Unported 


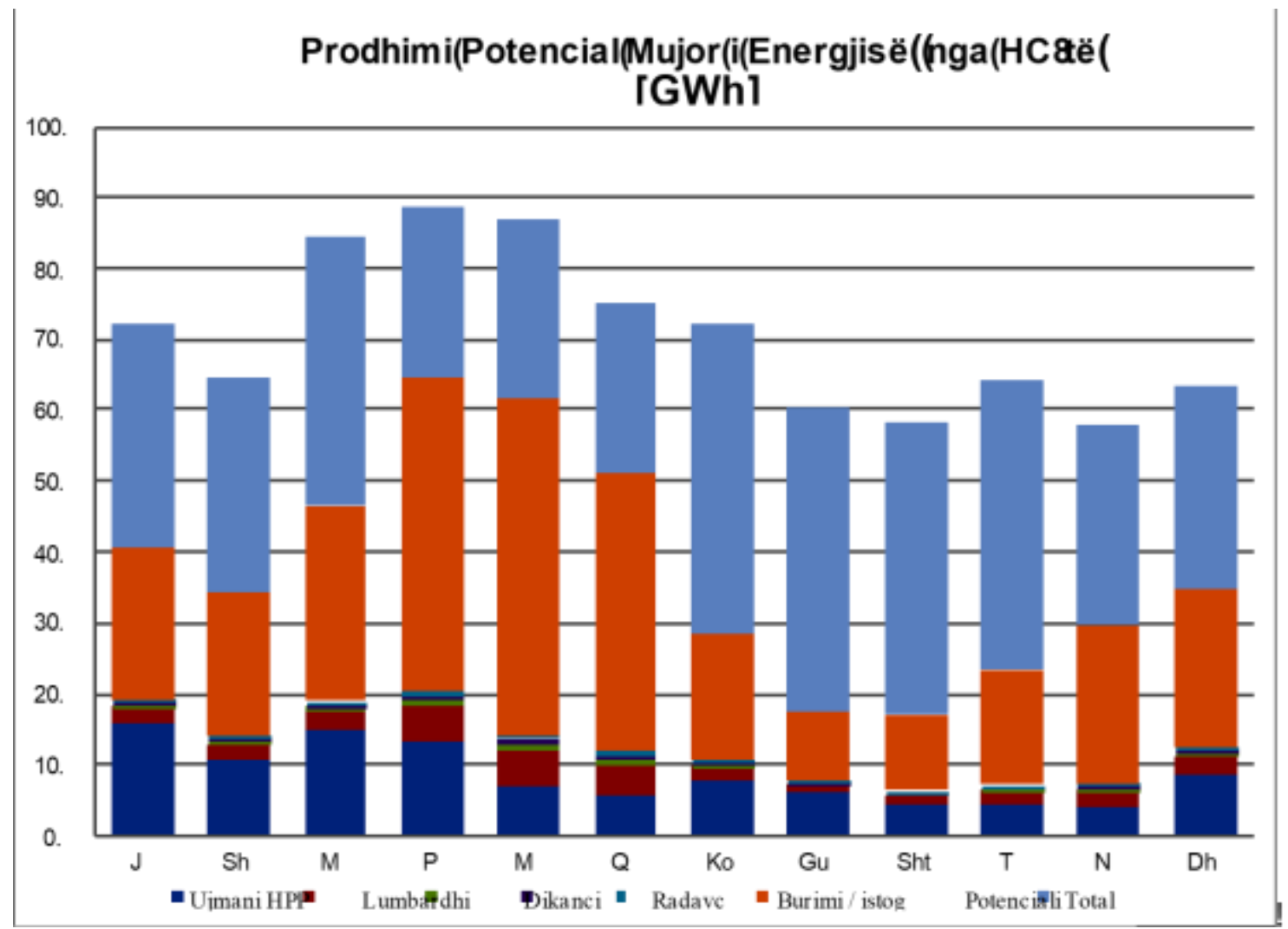

Figura 202. Hidro-energjia Neto Mujore në dispozicion

(Burimi): Jeannelle.Blanchard. KEK-energy. Një vlerësim praktik i potencialeve të BRE dhe MAK për energji nё Kosovë.

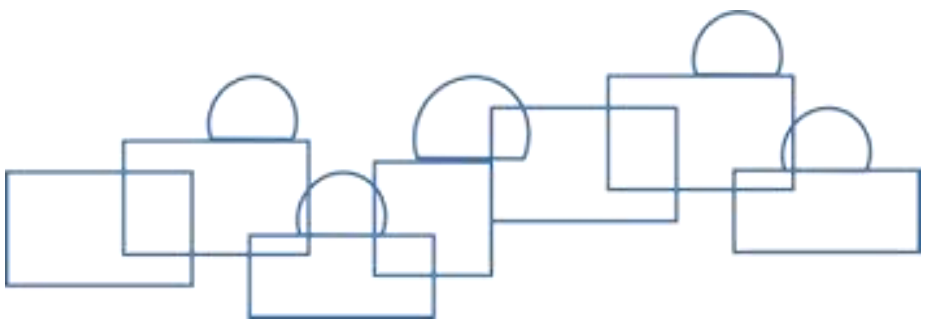




\subsubsection{Energjia e erës}

Energjia e erës premton një burim të pastër dhe pa lëndë djegëse të energjisë elektrike. Në disa vende ajo zvogëlon varësinë në lëndë djegëse fosile të importuara dhe lirimin e Gazrave Serë dhe ndotësve të tjerë. Prandaj, shumë qeveri, përveç energjisë aktuale, promovojnë ndërtimin e "mullinjve" (centraleve) të erës të përmasave të gjëra, inkurajojnë kompanitë private me subvencione zemërgjera dhe mbështetje rregullative, kërkojnë që kompanitë të blejnë energjinë prej tyre, dhe krijojnë tregje për tregtim të "fondit për energjinë e ripërtërishme" përveç energjisë aktuale. Kompanitë e energjisë dhe investitorët privatë po investojnë me padurim në energjinë e erës, duke parë që ky angazhim është mjaft fitimprurës. Megjithatë, duhet hulumtuar mundësitë e Kosovës, me hulumtim do të shihet se në të vërtetë energjia e erës duhet përkrahur, mirëpo duhet dëshmuar rentabilitetin e sajë në rastet konkrete.

\subsubsection{Njësitë Ekzistuese}

Në Kosovë ekziston vetëm një fermë e mullinjve të erës e shkallës së paisjevetë zhvilluara. Me kapacitet të instaluar/paraparë prej $1.35 \mathrm{MW}$ dhe prodhim energjetik të pritshëm vjetor prej 3.3GWh, kjo fermë e mullinjve është aktualisht jashtë operimit për shkak të mosmarrëveshjeve në mes të sipërmarrësit dhe ZRRE-së sa i përket aplikimit tarifor.

Korniza rregullative aktuale ofron një tarifë ushqyese për gjenerimin e energjisë nga era. Tarifa aktuale për energjinë elektrike që gjenerohet në centralet me erë, duke përdorur pajisje të reja, është vendosur në nivelin $84 € / M W h$, e cila është edhe më e lartë se çmimi mesatar aktual i tregut për energjinë elektrike të importuar. Kjo dhe përfitimet e mundshme nga tregtimi i lejimit të emetimit mund ta bënte zhvillimin e centraleve të erës më atraktiv për investitorët potencialë.

Sipas Raporteve Vjetore të ZRRE-së dhe KOSTT-it, në fillim të vitit 2009, disa investitorë të huaj kanë aplikuar për leje në ZRRE dhe për kyçje në KOSTT me një kapacitet të planifikuar total prej rreth 150 MW (sipas parashikimit të prodhuesit). Sidoqoftë, studimet e fizibilitetit, vlerësimi i potencialit për energji të erës ose të dhënat e tjera për këto projekte nuk janë në dispozicion publik dhe asnjë objekt për momentin nuk është në ndërtim e sipër.

\subsection{6..2 Potenciali i Energjisë nga Era}

"Dihet se energjia nga era është proporcionale me kubikun e shpejtësisë së erës. Përderisa energjia maksimale e erës e cila teorikisht mund të kapet nga një turbinë e erës është rreth $60 \%$, në fakt realizimet më të mira janë shumë më të ulëta. Shpejtësia e erës, kohëzgjatja dhe karakteristikat e tjera janë shumë specifike për lokacionine caktuar. Andaj, peformanca e një turbine të caktuar të erës, prodhimi i energjisë dhe kapaciteti në dispozicion nuk mund të vlerësohen bazuar në shifrat mesatare sikurse vlera $25-30 \%$ e faktorit të kapacitetit vjetor. Vlerësimi real dhe i saktë i burimeve të erës është një parametër kryesor në çdo projekt për energjie të erës qoftë i madh ose i vogël. ${ }^{98}$

98 Një vlerësim praktik i potencialeve të BRE dhe MAK për energji në Kosovë, APARES. KEK. 
"Sipas disa burimeve, si rregull e përgjithshme; gjeneratorët ekonomikë të erës kërkojnë shpejtësi ere prej $15 \mathrm{~km} / \mathrm{h}$ ose më të madhe. Një lokacion ideal do të kishte një rrjedhë të konstantës së përafërt të erës përgjatë vitit, me shanse minimale për devijim të papritur të fuqisë së erës.

Qasja për kërkesën lokale dhe kapacitetin e transmisionit është një faktor tjetër i rëndësishëm për pozicionimin e turbinës së erës. Vlerësimi real, analizat inxhinierike, mjedisore dhe ekonomike janë shumë më të ndërlikuara.

Shumica e hartave të erës në dispozicion dhe vlerësimet për potencialin e energjisë së erës në Kosovë bazohen në supozime dhe ekstrapolime. Statistikat në dispozicion nga institutet meteorologjike të ndryshme janë të papërfunduara dhe të pasigurta.

Studimi më i fundit dhe ndoshta i vetmi studim që është bazuar në matjet lokale është Vlerësimi i burimeve të erës në Kosovë i përgatitur nga NEK UMWELTTECHNIK AG në vitin 2010. Erëmatësit dhe sistemet e të dhënave ishin instaluar në lokacione të ndryshme duke përdorur strukturat në dispozicion (si shtyllat e operatorëve mobilë). Sidoqoftë, një numër i madh i të dhënave nuk ishin grumbulluar dhe kishin humbur si pasojë e ngrirjes së disa erëmatësve. Përveç kësaj, disa lokacione dhe rajone nuk ishin mbuluar nga matjet. Sipas NEK UMWELTTECHNIK AG: "Pjesa më veriore, rreth Mitrovicës, dhe pjesa më perëndimore, rreth Pejës, si dhe rajoni malor jugor në jug të Prizrenit nuk janë mbuluar me matjet tona. Shumica e këtyre rajoneve nuk janë të përshtatshme për zhvillime për shkak të kushteve topografike (tatëpjetave, qasjes së vështirë dhe mungesës së kyçjes në rrjet)."

Një konkluzion tjetër i rëndësishme i bërë nga ky studim është: "Në përgjithësi, mund të thuhet se shpejtësitë mesatare të erës brenda vendit janë mjaft të ulëta, për shkak të lokacionit topografik të vendit. Sidoqoftë, në lartësi më të mëdha, janë identifikuar disa vende me shpejtësi të mjaftueshme të erës për projektet e energjisë së erës.”

Megjithatë, për shkak të arsyeve të ndryshme është rekomanduar që të mbështeten zhvillimet e mëtutjeshme në vend, përderisa të vihet re se investimet mund të ballafaqohen me probleme. Si pjesë e projektit, është rekomanduar implementimi i një pilot projekti të mullinjve të erës prej $20 \mathrm{MW}$, lokacioni për zhvillimin e planifikuar i përket komunës së Rahovecit, në pjesën perëndimore të vendit, përgjatë vargmalit të fshatit Zatriq.Për shkak të interesimit dhe diskutimeve të vazhdueshme për potencialin e energjisë së erës në Kosovë, hulumtimi i lokacioneve të tjera dhe i potencialit total të erës në vend është i rëndësishëm. Një pyetje tjetër e rëndësishme është se cila pjesë e gjenerimit konvencional ekzistues të paraparë me djegie thëngjilli mund të zëvendësohet në mënyrë të qëndrueshme nga turbinat e erës.

Duke pasur parasysh këto që u thanë më sipër, duhet të rikonfirmohet se potenciali për energji të erës në Kosovë në rastin më të mirë është modest. Për më tepër, në shumicën e kohës turbinat do të funksionojnë në mënyrë joefiçiente, nën kapacitetin e tyre të paraparë/klasifikuar. Prandaj, për qëllime të krahasimit më të lirë të teknologjive të ndryshme dhe optimizmit të sistemit, kostoja kapitale e mullinjëve të erës (Euro/kW e kapacitetit të instaluar) duhet të nivelizohet në përputhje me këtë, d.m.th. me kapacitetin e vlerësuar në dispozicion." (Ekstrakt) ${ }^{98}$ 


\subsubsection{Kërkesat për një Mulli të Erës}

"Ekzistojnë shumë pako komerciale në dispozicion të cilat japin një pozicionim të saktë dhe efikas të turbinave individuale dhe caktimin e dimensioneve të një fermë të caktuar të mullinjëve të erës në kohën e studimit të fizibilitetit dhe dizajnimit. Megjithatë, në këtë fazë mund të bëhet një analizë e thjeshtësuar dhe caktime paraprake dimensionesh të përafërta, pa softuerë të sofistikuar.

NREL18 në bashkëpunim me Aleancën për Energji të Qëndrueshme sh.p.k. (Alliance for Sustainable Energy, LLC) ka një kalkulator që është në dispozicion online. Ky kalkulator vlerëson kërkesat e hapësirës së tokës për sistemet e energjisë nga era. Rezultatet tregojnë një “gjurmë" të hapësirës së tokës, e cila nuk është hequr nga prodhimi, për të ofruar hapësirë për mullinj nga era, rrugët dhe strukturat mbështetëse. Kjo llogaritje supozon që një turbinë tipike prej $1000 \mathrm{~kW}$ kërkon një hapësirë prej $\approx 1012 \mathrm{~m} 2$. Sipas NREL, "gjurma" e llogaritur nuk përfshin diametrat e 5 - 10 turbinave në hapësirën që kërkohet në mes të turbinave të erës. Është vënë re që për shkak të hapësirës, zona që përfshihet në perimetër të fermës së mullinjëve të erës duhet të jetë më e madhe.

Tom Gray nga Shoqata Amerikane për Energji të Erës (American Wind Energy Association) shkruan: "Rregulla ime e përafërt praktike është 60 ari për megavat për fermat e mullinjëve të erës, në hapësirë tokësore." Kjo prapë mund të mos jetë e mjaftueshme për efikasitet maksimal.

Sipas "Lejimi i distancës minimale në mes të turbinave të erës dhe habitatit dhe rreziku nga hedhja e lopatave" nga Scott Larwood, prezantuar në Forumin Bashkëpunues të Energjisë 2004, në Universitetin e Kalifornisë, Davis, distanca që turbinat duhet ta kenë mes njëra tjetrës në mënyrë që të ketë hyrje minimale të erës është diametrat e 3 rotorëve kur rreshtohen në pozicion pingul në erë dhe diametrat e 10 rotorëve kur janë në pozicion paralel me erën. Kjo është hapësira që është përshkruar nga Autoriteti për Zhvillimin dhe Hulumtimin e Energjisë së re të Nju Jorkut (New York State Energy Research and Development Authority).

Sipërfaqja minimale që kërkohet për rreth një turbine në një vijë të vetme ku era përgjithësisht është nga njëra anë, do të ishte $10 \mathrm{~d} \times 3 \mathrm{~d}$ (ku d-është diametri i rotorit). Zona minimale në një rreshtim do të ishte $10 \mathrm{~d} \times 10 \mathrm{~d}$ për një turbinë që qëndron e vetme, zona që kërkohet do të ishte $13 \mathrm{~d} \times 6 \mathrm{~d}$ ovale në lokacionin ku era përgjithësisht është nga një drejtim dhe deri në $20 \mathrm{~d}$, për rrotullim të gjerë për të përdorur erën nga secili drejtim." $(\text { Ekstrakt })^{98}$

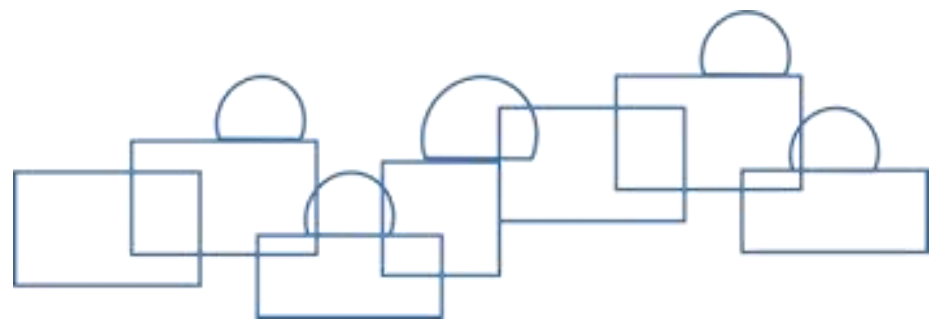


Varësisht nga tiparet e rrethinës, shtyllat shumë të larta mund të lejojnë zvogëlimin e asaj zone deri në një shkallë. Hulumtimi më i fundit i Universitetit të "Johns Hopkins" nga Charles Meneveau sugjeron që turbinat e mëdha në një rresht duhet të jenë larg njëra tjetrës sa diametri prej 15 rotorësh, duke i rritur largësitë nga shembujt e mësipërm në 185-250 ari (0.75-1 km katrorë) që kërkohen për megavatet e instaluar.

Bazuar në si më sipër, prodhimi i vlerësuar i energjisë dhe kapacitetit real dhe madhësitë tipike të turbinave të erës nuk janë vështirë për t'u llogaritur sa i përket hapësirës për një fermë me mulli ere me një prodhim neto prej vetëm 20MW (në kushtet më të mira të erës që kemi në dispozicion).

Tabela 39. Specifikat teknike të përbashkëta të turbinave të erës Burimi):Bujar Bajçinovci, Universiteti Prishtinës. OSANDER+PARTNER. Balkan.wind-index.com

\begin{tabular}{|c|c|c|c|}
\hline Modeli i Turbinës & $\begin{array}{l}\text { Fuqia RE } \\
48 / 600\end{array}$ & $\begin{array}{l}\text { Fuqia RE } \\
\text { MM } 82\end{array}$ & $\begin{array}{l}\text { GE 1.5-MW / } \\
\text { Vestas V90 }\end{array}$ \\
\hline Diametri i Rotorit $(\mathrm{m})$ & 48 & 82 & 92 \\
\hline Kapaciteti Maksimal ne Dispozicion (MW) & 0.5 & 0.7 & 0.6 \\
\hline Kapaciteti Total ne Dispozicion i Fermës së Erës (MW) & 20 & 20 & 20 \\
\hline Numri i Turbinave & 40 & 29 & 34 \\
\hline $\begin{array}{l}\text { Hapësira për një Turbine (km. katr) /ferma në vijë: } \\
\text { d.m.th. 3dx10d/ }\end{array}$ & 0.07 & 0.20 & 0.25 \\
\hline $\begin{array}{l}\text { Hapësira për një Turbine (km.katr) /ferma në rresht: } \\
\text { d.m.th. } 10 \mathrm{dx} 10 \mathrm{~d} /\end{array}$ & 0.23 & 0.67 & 0.85 \\
\hline $\begin{array}{l}\text { Hapësira e tokës totale e kërkuar për Fermë të Erës } \\
\text { (km. katr) /ferma ne vije/ }\end{array}$ & 2.76 & 5.85 & 8.63 \\
\hline $\begin{array}{l}\text { Hapësira e tokës totale e kërkuar për Fermë të Erës } \\
\text { (km. katr) /ferme ne rresht/ }\end{array}$ & 9.22 & 19.50 & 28.78 \\
\hline
\end{tabular}

Prandaj, së paku pyetjet vijuese duhet të adresohen nga investitorët potencialë dhe autoritetet rregullative:

- $\quad$ A ka "vend të erës", i cili është mjaft i madh sa për të zënë këtë fermë

- A janë të njëjta karakteristikat e erës gjatë gjithë vendit/lokacionit në dispozicion

- Cili do të ishte ndikimi potencial i asaj ferme të erës në mjedis

- A do të ishin investimet për kyçje në rrjetin transmisionit me kosto efektive

- $\quad$ A ia vlen ky investim për 20MW të kapacitetit të sigurt dhe të paqëndrueshëm

- Sa do të ishte ndikimi potencial i kostos te shfrytëzuesit e fundit të energjisë

- $\quad$ A është e mundshme që investimet të drejtohen në mënyrë më efikase

- $\quad$ Sa e madhe duhet të jetë hapësira që mbulohet nga një fermë me mulli e ere, në mënyrë që të zëvendësohen njësitë e dekomisionuara të Kosova A me kapacitetin e tyre aktual në dispozicion prej 300MW? 
Tabela 40. Të dhënat e matura për erën

(Burimi): Dragusha, B., Rexha, B., Limani, I. The use of wind generators in Kosovo. Universiteti Prishtinës.

\begin{tabular}{|c|c|c|c|c|c|c|c|c|c|c|c|c|c|}
\hline \multirow[b]{2}{*}{ Viti } & \multicolumn{12}{|c|}{ Muaji } & \multirow{2}{*}{ Mesatare } \\
\hline & I & II & III & IV & v & VI & VII & VIII & IX & $x$ & $\mathbf{X I}$ & XII & \\
\hline 2001 & 2.3 & 1.3 & 2.6 & 1.5 & 1.6 & 0.9 & 1.2 & 1.5 & 1.6 & 0.8 & 1.9 & 2.2 & 1.616 \\
\hline 2002 & 1.6 & 1.2 & 3 & 1.8 & 1.3 & 1.6 & 1.5 & 1.7 & 1.6 & 1.4 & 1.6 & 1.4 & 1.641 \\
\hline 2003 & 1.3 & 1 & 1 & 4.7 & 1.6 & 0.7 & 1 & 1.4 & 2.1 & 1.8 & 2.3 & 1.7 & 1.716 \\
\hline 2004 & 1.8 & 1.7 & 1.9 & 1.5 & 1.5 & 1.1 & 1 & 1.2 & 1.2 & 1 & 1.3 & 1.5 & 1.391 \\
\hline 2005 & 0.8 & 1.4 & 1.4 & 1.8 & 1.6 & 1.2 & 1 & 1.2 & 1 & 1.1 & 1.3 & 1.4 & 1.266 \\
\hline 2006 & 1.2 & 1.2 & 2 & 1.2 & 1.5 & 0.9 & 1.4 & 1 & 1 & 1.3 & 0.9 & 2.2 & 1.316 \\
\hline 2007 & 1.6 & 1.7 & 2.4 & 1.3 & 1.5 & 1.3 & 1.4 & 1.3 & 1.9 & 1.2 & 1.2 & 1.1 & 1.491 \\
\hline 2008 & 0.8 & 1.9 & 1.9 & 1.6 & 1 & 1.1 & 1.7 & 1.1 & 1 & 0.8 & 1.2 & 2.5 & 1.38 \\
\hline \multicolumn{14}{|c|}{ Mestare } \\
\hline $\begin{array}{l}2001- \\
2008\end{array}$ & 1.43 & 1.43 & 2.03 & 1.93 & 1.45 & 1.1 & 1.28 & 1.3 & 1.43 & 1.18 & 1.46 & 1.75 & 1.48 \\
\hline
\end{tabular}

Tabela 41. RETScreen në regjionin e Prishtinës

(Burimi): Dragusha, B., Rexha, B., Limani, I. The use of wind generators in Kosovo. Universiteti Prishtinës.

\begin{tabular}{|c|c|c|c|c|c|}
\hline Muaji & $\begin{array}{c}\text { Temperatura } \\
{\left[{ }^{\circ} \mathbf{C}\right]}\end{array}$ & $\begin{array}{l}\text { Lagështia } \\
\text { Relative [\%] }\end{array}$ & $\begin{array}{l}\text { Shtypja } \\
\text { Atmosferike[kPa] }\end{array}$ & $\begin{array}{l}\text { Shpejtësia } \\
\text { e erës } \\
{[\mathrm{m} / \mathrm{s}]}\end{array}$ & $\begin{array}{l}\text { Matja } \\
\text { në } \\
\text { lartësi } \\
\text { [m] }\end{array}$ \\
\hline I & -1.1 & $80.50 \%$ & 95.4 & 3.6 & 10 \\
\hline II & 1.7 & $73.50 \%$ & 95.1 & 3.1 & 10 \\
\hline III & 6.1 & $67.00 \%$ & 94.9 & 3.6 & 10 \\
\hline IV & 10 & $64.00 \%$ & 94.6 & 3.1 & 10 \\
\hline V & 15 & $65.00 \%$ & 94.9 & 2.6 & 10 \\
\hline VI & 18.3 & $64.00 \%$ & 94.8 & 2.6 & 10 \\
\hline VII & 20.6 & $59.50 \%$ & 95 & 2.6 & 10 \\
\hline VIII & 20 & $59.50 \%$ & 95 & 2.6 & 10 \\
\hline IX & 16.7 & $65.50 \%$ & 95.2 & 2.6 & 10 \\
\hline X & 11.7 & $71.00 \%$ & 95.2 & 2.6 & 10 \\
\hline XI & 4.4 & $80.50 \%$ & 95.2 & 3.1 & 10 \\
\hline XII & 0.6 & $82.50 \%$ & 95.1 & 2.9 & 10 \\
\hline Vjetore & 10.4 & $69.40 \%$ & 95 & & 10 \\
\hline
\end{tabular}


Bazuar në kapacitet të instaluar efikasiteti llogaritet si më poshtë (Sipas autorëve): ${ }^{99}$ Dragusha, B., Rexha, B., Limani, I.

$$
\eta=\frac{P}{P_{r} \cdot 8760}=\frac{3303000}{3 \cdot 450 \cdot 8760}=27.9 \%
$$

$\mathrm{Ku}:$

$\mathrm{P}$ - Energjia e përdorur

Pr - Fuqia reale

Siç mund të shihet shkalla e efikasitetit është $27.9 \%$.

Energjisë së erës, është llogaritur në [W]

$$
\begin{gathered}
P_{r}=\frac{1}{2}=\rho A v^{3} \\
P_{w}=0.6 v^{3}
\end{gathered}
$$

$\mathrm{Ku}:$

$\rho$-densiteti i ajrit në $15^{\circ} \mathrm{C} 1,225[\mathrm{~kg} / \mathrm{m} 2]$

A -sipërfaqja në metër katror, $\mathrm{m} 2$

$v$ - shpejtësia e erës $[\mathrm{m} / \mathrm{s} 2]$

\begin{tabular}{|c|c|c|c|c|c|c|c|c|c|c|c|c|c|}
\hline & \multicolumn{12}{|c|}{ Muaji } & \multirow{2}{*}{ Mesatare } \\
\hline Viti & I & II & III & IV & V & VI & VII & VIII & IX & $x$ & XI & XII & \\
\hline 2010 & 12.27 & 8.73 & 1.44 & 8.62 & 6.19 & 5.22 & 4.78 & 6.30 & 9.92 & 1.08 & 8.67 & 9.32 & 6.88 \\
\hline 2012 & 1.66 & 14.04 & 6.79 & 5.22 & 3.64 & 10.60 & 6.20 & 5.12 & 6.89 & 6.15 & 9.86 & 4.68 & 6.74 \\
\hline 2014 & 6.60 & 11.52 & 7.45 & 4.63 & 6.72 & 5.65 & 5.48 & 4.66 & 1.96 & 5.11 & 5.32 & 11.46 & 6.38 \\
\hline $\begin{array}{l}2010- \\
2014\end{array}$ & 6.84 & 11.43 & 5.23 & 6.16 & 5.52 & 7.16 & 5.49 & 5.36 & 6.26 & 4.11 & 7.95 & 8.49 & 6.67 \\
\hline
\end{tabular}

Tabela 42. Të dhënat e matura për erën. Prishtinë 2010-2014.

(Burimi):Bujar Bajçinovci, Universiteti Prishtinës. CSANDER+PARTNER. Balkan.wind-index.com

99 Dragusha, B., Rexha, B., Limani, I. The use of wind generators in Kosovo. Universiteti Prishtinës. 


\subsubsection{Ndriçimi solar, sistemet e brendëshme}

“Himawari”, sistem i ndriçimit diellor, mundësi për ti ndriçuar hapësirat e errëta!

Mbledhje shumë efikase dhe e qëndrueshme nga rrezet e diellit nëpërmjet një kombinimi të "Lens+Cable Optical Fiber". Respektivisht, kolektori i jashtëm merr sasinë maksimale të diellit gjatë gjithë ditës. Sistemi është imun nga kufizimet e tilla si, orientimi i një dhome, ekspozimit të një dritare ose lartësisë, praktikisht një zgjidhje e përkryer për diellosje aty ku kemi nevojë.

Sistemi automatik përcjell lëvizjen e diellit saktësisht. Thjerzat Himawari automatikisht përcjellin diellin gjatë gjithë ditës, pozitën dhe kështu japin vlera maksimale të ndriçimit.

Himawari është e pajisur me një mekanizëm të brendshëm të orës, një sensor diellor, po ashtu edhe me një mikroprocesor për të llogaritur pozicionin e diellit dhe për tu përshtatur këndit dhe azimitit. Në mot të mirë, vendndodhja e saktë e diellit konstatohet nga sensori diellor. Kur dielli është paksa i mbuluar nga retë, vendndodhja kalon me gjurmimin e mekanizmit të tij të brendshëm.

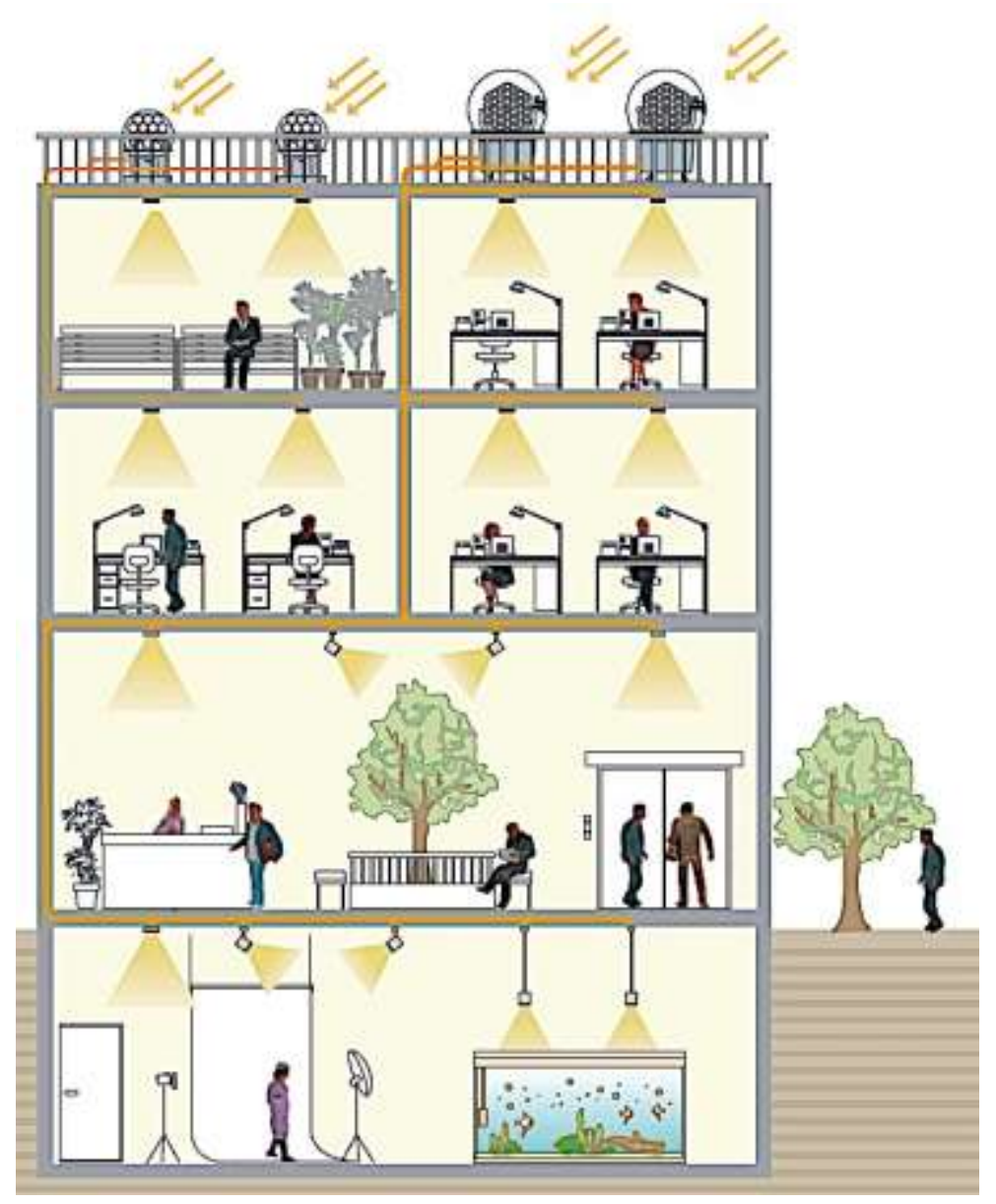

Figura 203. Ndriçimi solar në objekte publike, Administratë (Burimi): @ Himawari, La Forêt Engineering Co.,Ltd. Japan 


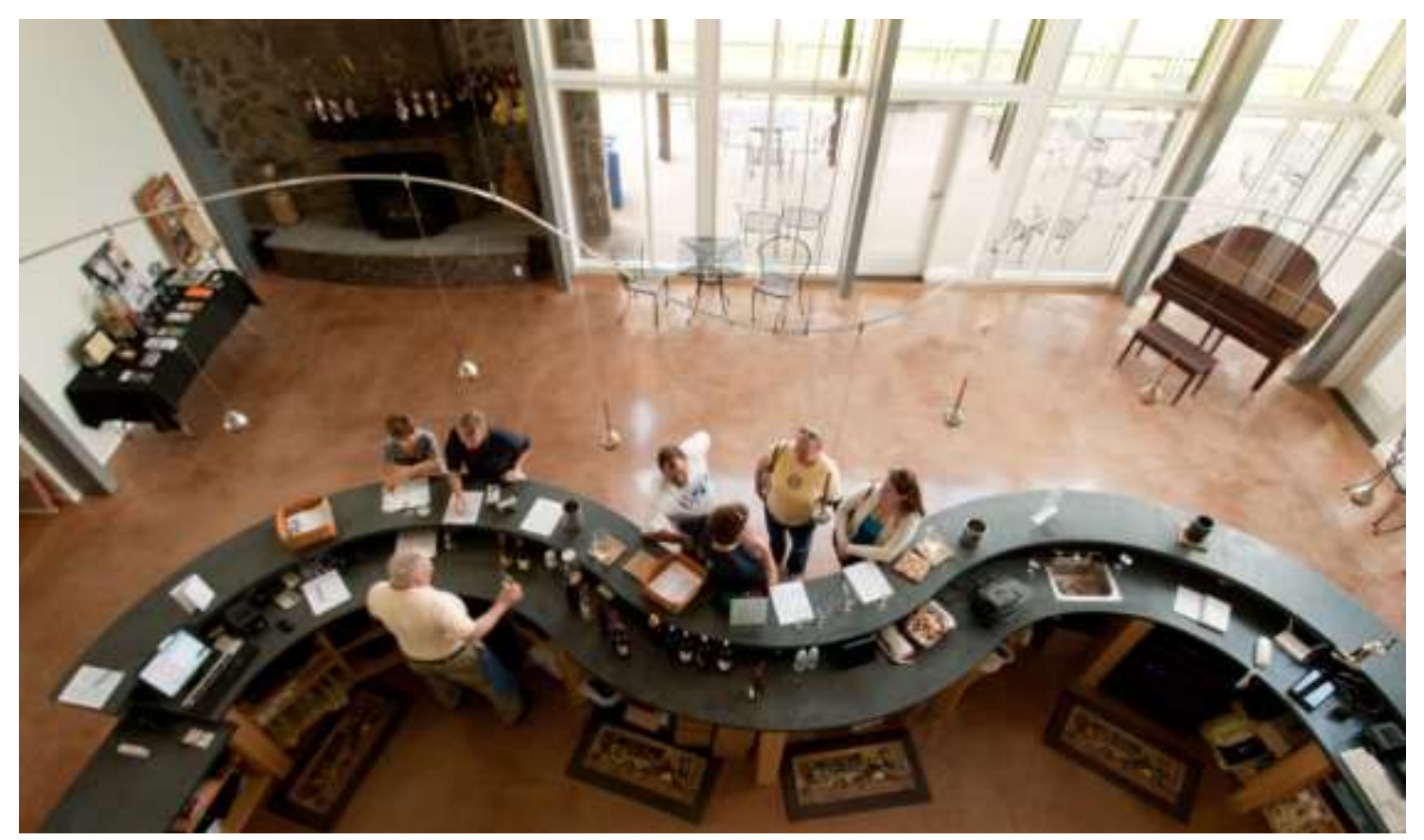

Figura 204. Cooper Veraria në Louisa, SHBA. LEED çmimi platinum

(Burimi): U.S. Department of Agriculture, 2011. (Flickr). E licensuar nga Creative Commons Attribution 2.0 Generic

Tabela 43. Specifikimet e Himawari, veçoritë

(Burimi): Përkthyer nga Bujar Bajçinovci, Himawari, La Forêt Engineering Co.,Ltd. Japan

\begin{tabular}{|c|c|c|c|c|c|c|c|c|c|c|}
\hline Lloji & $\begin{array}{c}\text { Numri i } \\
\text { thjerrëzave }\end{array}$ & $\begin{array}{c}\text { Thjerrëza } \\
(\mathrm{mm})\end{array}$ & $\begin{array}{c}\text { Ndriçimi } \\
\text { i siperf. } \\
(\mathrm{cm} 2)\end{array}$ & $\begin{array}{c}\text { diameter } \\
(\mathrm{mm})\end{array}$ & $\begin{array}{c}\text { Lart } \\
(\mathrm{mm})\end{array}$ & $\begin{array}{c}\text { Pesha } \\
(\mathrm{kg})\end{array}$ & $\begin{array}{c}\text { Numri } \\
\text { i kabll. }\end{array}$ & $\begin{array}{c}\text { Total } \\
\text { flux(Im) }\end{array}$ & Furnizimi & $\begin{array}{c}\text { Energjia } \\
\text { Harxhimi }\end{array}$ \\
\hline $\begin{array}{c}\text { XD-100S } \\
\text { /36AS }\end{array}$ & 36 & 95 & 2,552 & 1,000 & 1,475 & 88 & 6 & 11,520 & AC85V 264V & $5 W$ \\
\hline $\begin{array}{c}\text { XD-50S } \\
\text { /12AS }\end{array}$ & 12 & 95 & 851 & 520 & 810 & 14 & 2 & 3,840 & AC85V 264V & $2 W$ \\
\hline
\end{tabular}

Sistemi Himawari mund të adaptohet shpejt me kushtet e motit, duke mbledhur rrezet e diellit në mënyrë efikase. Pas perëndimit të diellit, mbledhësi mbyllet, (off) dhe pozicionohet në atë mënyrë, që të jetë i gatshëm për ditën e nesërme.

Transmetimi i diellit bëhet nga kabllot me fibra optike, konsiderohen që rrezet e diellit janë të kondensuara rreth 10,000 herë, kjo ndodhë nëpërmjet një lente shumë efikase. Kurse fundi i kabllos optike është i pozicionuar në pikën qendrore të lentës, për të funksionuar në mënyrë optimale.

Rrezet e diellit hyjnë në kabllo përmes mbledhësit, duke u përsëritur reflektimi i tyre i plotë, pastaj, gjatë rrugëtimit rrezet emetohen në dalje të fibër kabllos. Një kabllo shumë e pastër me fije optike, transmeton rrezet e dukshme me shumë pak humbje. Një kabllo 
e bërë nga fibrat optike është fleksibile dhe mund të instalohet në çdo ndërtesë të re ose ekzistuese, dhe mund të transmetojë rrezet e diellit kudo që është e nevojshme.

Gjatë eksploatimit, përdoruesi do të ketë kursim të energjisë dhe mirëmbajtje falas të Sistemit Himawari. Kostoja është shumë rentabile, më pak se $1 ¥$ Japonez në ditë për të operuar një mbledhës me 12 thjerrëza. Pasi të jetë instaluar, sistemi Himawari punon automatikisht pa asnjë operacion manual. Mbledhësi i rrezeve të diellit është i mbuluar me një kupolë akrilike, duke siguruar qëndrueshmëri shumë të madhe, ndërsa rezulton me performancë në mbrojtjen e sistemit kundër çdo ndërhyrje nga shiu dhe pluhuri.

Rekomandohet nga prodhuesi, mirëmbajtje e rregullt një herë në vit, për të ruajtur punën optimale të sistemit. Mbledhësi i rrezeve të diellit përbëhet nga dy pjesë: njëra është një grup i thjerrëzave tepër të efektshme dhe një sensor dielli, duke përcjellur trajektoren e diellit, e shtyrë nga një motor i mbuluar me kupolë akrilike, gjersa pjesa tjetër është një njësi e kontrollit e vendosur në një bazë mbështetëse. Disa veçori të sistemit:

1. Pamvarsisht orientimit në Veri apo në Jug, dhomat, banjot, dhomat pa dritare, hapësira të bodrumit apo oborret, falë sistemit mund të janë me diellosje

2. Pasi rrezet e diellit janë marrë direkt nga dielli, mund ti ndjeni ndryshimet natyrore të ngjyrave gjatë ditës. Po ashtu mund të përdorni edhe një prizëm për të bërë një ylber shtëpie.

3. "Sunbathing” mund të realizohet në shtëpi, kështu që është e përshtatshme për njerëzit me aftësi të kufizuar dhe të moshuar.

4. Shumica e rrezeve UV janë të eliminuara, kështu që nuk duhet të shqetësohemi për djegien nga dielli.

5. Ka vetëm një sasi të vogël të rrezatimit infra të kuqe, mund të freskojmë veten me një sunbathing.

6. Rrezet e diellit ndryshojnë si rrezet e diellit natyror, i përjetojmë ndryshimet gjatë ditës, kështu që shtëpia harmonizohet me ritmet natyrore të ditës.

7. Atmosfera në një vend pune i cili ndodhet në hije ose zyrat nëntokësore do të përmirësohen me rrezet e diellit.

8. Sistemi bën të mundur që bimët të rriten, duke u përcjellë rrezet e diellit brenda.

9. Kontrolli i temperaturës është i lehtë, pasi Himawari rrezet e diellit përmbajnë vetëm një sasi të vogël të rrezatimit infra të kuqe.

10. Përbërja e ndriçimit është pothuajse identike me spektrin e dukshëm të diellit natyror. Kjo është ideale për vizuelizimin e veprave të artit, bizhuterisë, fotografisë. 
11. Rrezet e diellit nga Himawari nuk janë të gjeneruara nga një burim elektrik $\mathrm{i}$ energjisë, kështu që është e sigurt për tu përdorur në zonat me lagështi, duke u përfshirë edhe pishinat.

12. Sistemi do të përmirësojë mjedisin e punës në një zyrë të nëndheshme.

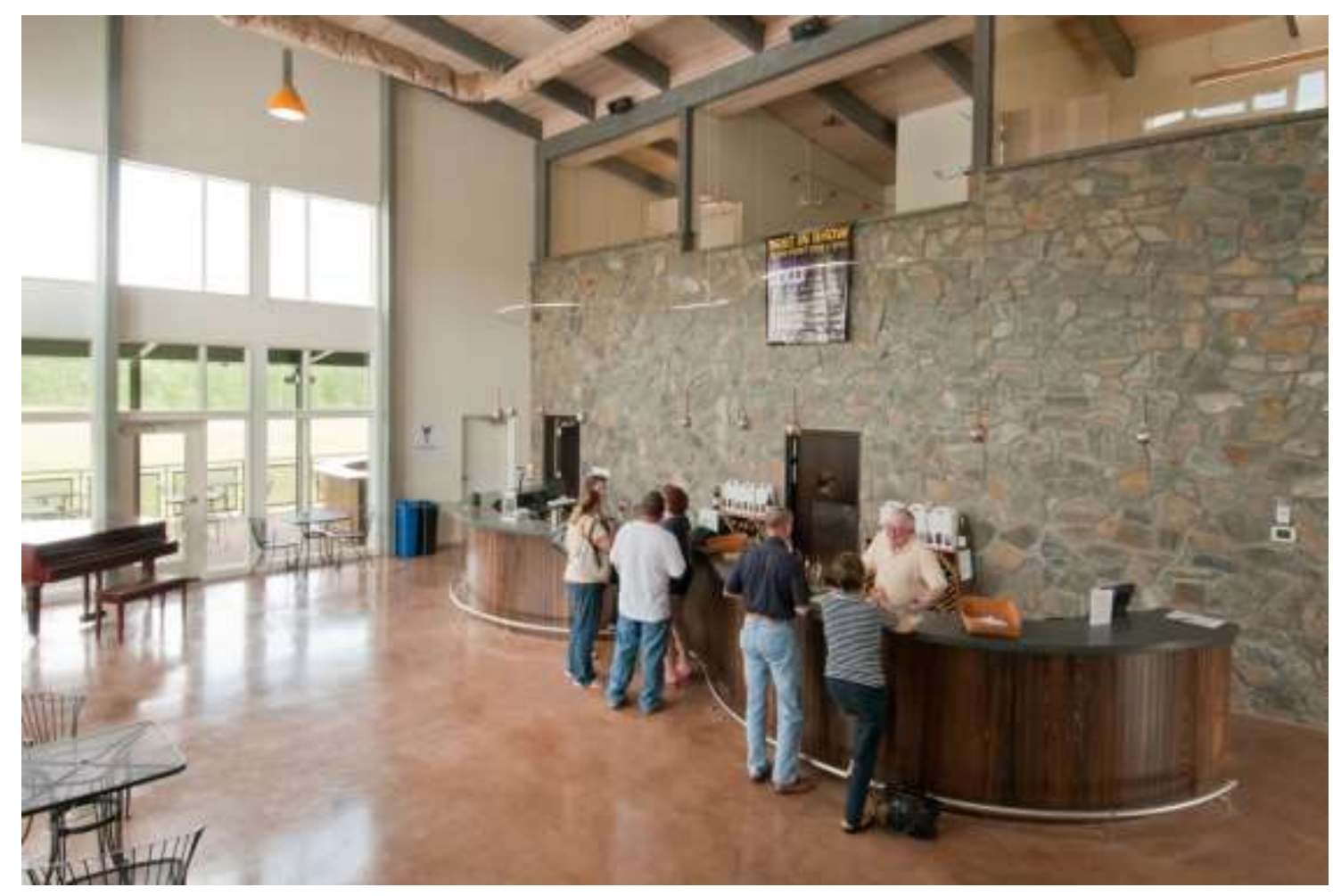

Figura 205. Cooper Veraria në Louisa, SHBA. LEED çmimi platinum

(Burimi): U.S. Department of Agriculture, 2011. (Flickr). E licensuar nga Creative Commons Attribution 2.0 Generic

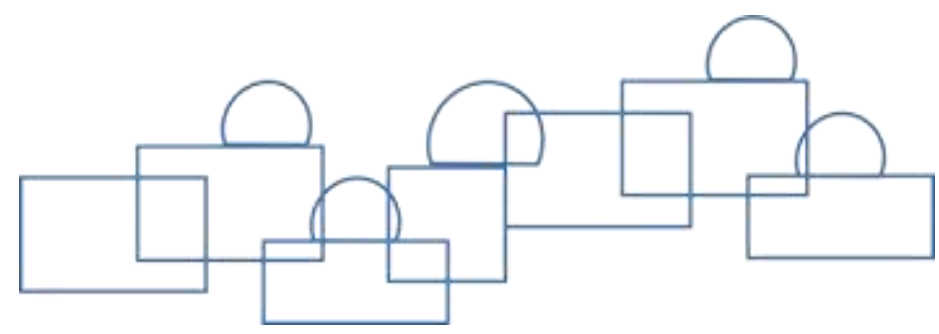




\subsubsection{AJRIMI}

Krijimi dhe mirëmbajtja e higjienës së domosdoshme, lagështisë dhe shpejtësia e ajrit bëhen me ajrim natyror dhe artificial. Ajrimi artificial është i domosdoshëm në lokalet: ku në të njëjtën kohë gjenden së bashku një numër i madh njerëzish, ku ekziston një numër i madh burimesh të ndotjes, ku është i pamjaftueshëm ajrimi natyror ose për shkaqe të ndryshme nuk mund të realizohet ventilimi natyror. Sasitë e $\mathrm{CO}_{2}$, avullit të ujit dhe të nxehtësisë që i liron njeriu brenda orës është dhënë në tabelën 44.

Lartësia e lokalit (hapësirës) dukshëm ndikon në frekuencën e ndërrimit të ajrit dhe në tabelë është paraqitur numri i ndërrimeve sipas Rregullores për masat teknike dhe kushtet për ajrim në ndërtesat e banimit. Sasitë e nevojshme të ajrit të pastër në industri janë shumë të mëdha dhe për çdo rast llogariten posaçërisht.

Tabela 44. Sasitë e $\mathrm{CO}_{2}$, avullit të ujit dhe të nxehtësisë që i liron njeriu brenda orës (Burimi): Krasniqi, F., Selimaj, R., Malsiu, I.(2004). Instalimet Makinerike. Universiteti i Prishtinës.

\begin{tabular}{|l|l|c|l|c|l|}
\hline \multicolumn{2}{|l|}{} & $\mathrm{C0} 2 \mathrm{l} / \mathrm{h}$ & $\begin{array}{l}\text { materiet } \\
\text { me erë }\end{array}$ & $\begin{array}{l}\text { Avulli i ujit } \\
\mathrm{gr} / \mathrm{h}\end{array}$ & $\begin{array}{l}\text { Nxehtësia } \\
\text { W }\end{array}$ \\
\hline \multirow{2}{*}{ Njeriu } & në qetësi & 20 & Të pamatura & 70 & 120 \\
\cline { 2 - 6 } & në punë & 70 & Të pamatura & 130 & 300 \\
\hline
\end{tabular}

\section{Dyoksidi i karbonit}

Dyoksidi i karbonit lirohet në procesin e frymëmarrjes (të njeriut) dhe me kohë përqendrimi i tij në lokal rritet. Por megjithatë përmbajtja e dyoksid karbonit mezi arrin në të mijtat pjesë, edhe kur është fjala për lokale të vogla, e të puthitura mirë. Sipas të dhënave të higjienistëve përmbajtja e dyoksid karbonit 1-2 \% pa efekte negative mund të durohet gjatë gjithë javës.

\subsubsection{Materiet me erë}

Materiet me erë janë përbërje organike të kombinuara, ku një pjesë lirohet nëpërmjet lëkurës, kurse pjesa tjetër me anë të frymëmarrjes. Sasia e tyre është aq e vogël sa shumë vështirë identifikohet nga aspekti kimik ose me matje, bile edhe kur era është tërësisht e ndjeshme. Kështu që prania e tyre ndërlidhet me praninë e dyoksidit të karbonit dhe konsiderohet që grumbullimi (akumulimi) i tyre shkon paralelisht. Kufiri i lejuar higjienik arrihet kur dyoksidi i karbonit rritet deri në 1\%, d.m.th. shumë me herët sesa përbërja e dyoksidit të karbonit të bëhet e rrezikshme vetvetiu. 


\subsubsection{Temperatura dhe lagështia}

Për këto madhësi duhet të flasim në të njëjtën kohë, pasi dhënia e nxehtësisë se një trupi nëpërmjet konveksionit dhe dhënia e nxehtësisë nëpërmjet avullimit të lëngut nga lëkura janë të njëkohshme. Kështu në hapësirat (sallat) ku qëndrojnë njerëzit njëkohësisht rriten si temperatura ashtu edhe lagështia. Nëse temperatura dhe lagështia në ndonjë lokal rriten aq shumë saqë trupi nuk mund të japë më as nxehtësi as lagështi, atëherë ndodh goditja termike. Sot me siguri mund të flasim se në sallat e mbushura, ajri i prishur nuk bëhet për shkak të mungesës së oksigjenit dhe nga teprica e dyoksidit të karbonit, por për shkak të temperaturës së lartë, të kombinuar me lagështi të madhe.

Nëse në sallë futet pak ajër dhe nëse në të ka shumë frekuentues, atëherë prishja e ajrit do të rritet shpejt dhe shpejt do të arrihet kufiri i lejueshëm higjienik . Posa të arrihet kjo gjendje duhet që të bëhet ndërrimi i fuqishëm i ajrit, me çka salla tërësisht ajroset (ventilohet), ashtu që sa më parë të arrihet gjendja fillestare e ajrit. Nganjëherë është e nevojshme që njerëzit të dalin jashtë (ndërprerja e aktivitetit për shkak të ventilimit).

Kur bëhet fjalë vetëm për përtëritjen e përmbajtjes së ajrit atëherë për këtë nevojitet vetëm pak kohë. Megjithatë duhet llogaritur në atë që materiet të cilat e prishin ajrin; frymëmarrja, tymi i duhanit, avullimi i gjellrave, ngrihen për mure dhe në gjësende tjera në lokal, nga të cilat më vonë paraqiten përsëri. Ventilimi i tërësishëm ka për detyrë që, përveç ndërrimit të ajrit, t'i pastrojë me ajër të freskët të gjitha gjësendet në lokal.

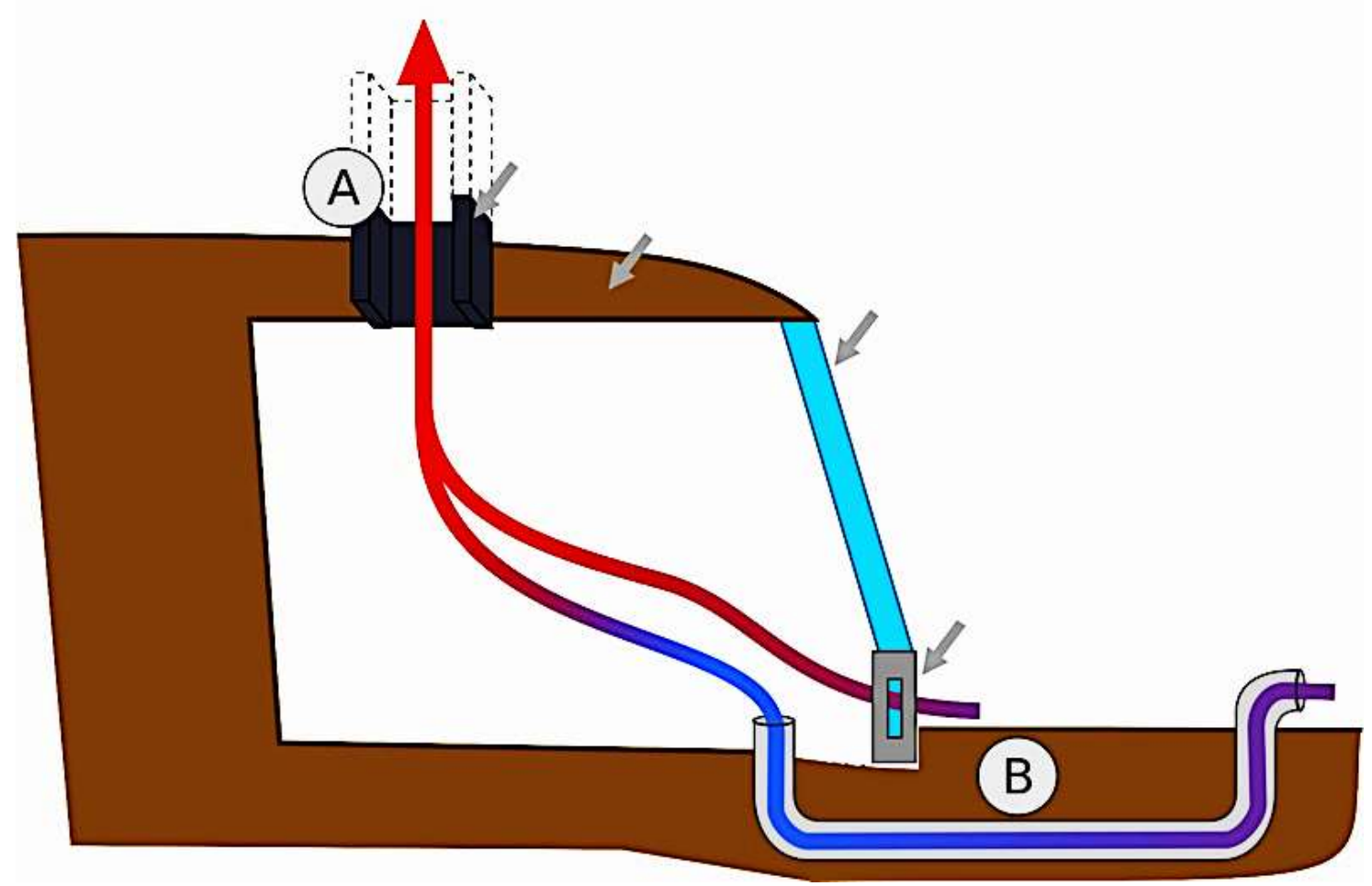

Figura 206. EarthShip, ventilimi natyror

(Burimi): Anasofiapaixao. (Flickr). Creative Commons Attribution ShareAlike 3.0 Unported 
Tabela 45. Ndërrimi i sasisë së ajrit në ore, varësisht prej funksionit (Burimi): Përkthyer, Bujar Bajcinovci. Sistemet - Instalimet

Ventilimi artificial bëhet si i veçantë me aparate mekanike dhe pajisje për ajrim qendror. Aparatet mekanike janë ventilatorët. Punojnë vazhdimisht, pa marrë parasysh ndryshimin e temperaturave dhe ndikimet tjera. Vendosen një nga një, dhe përbëjnë pjesën bashkuese të gjitha aparateve dhe pajisjeve për ajrosje dhe klimatizim.

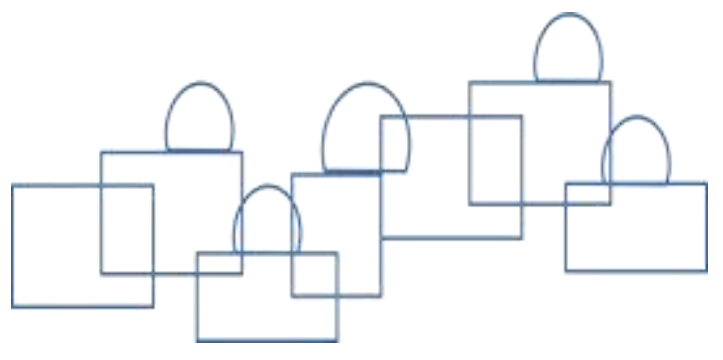

\begin{tabular}{|l|r|}
\hline \multicolumn{1}{|c|}{ Lloji i lokalit } & m3h \\
\hline Spitalet & $\mathbf{6 0}$ \\
\hline njeriu & $\mathbf{3 5}$ \\
\hline fëmija & $\mathbf{1 0 0}$ \\
\hline i sëmuri i infektuar & \\
\hline Shkollat & $\mathbf{1 5}$ \\
\hline nxënësi deri 10 vjeçar & \\
\hline nxënës me më tepër se & $\mathbf{2 5}$ \\
\hline 10 vjeçar & \\
\hline Kazermat & $\mathbf{4 0}$ \\
\hline njeriu ditën & $\mathbf{3 0}$ \\
\hline njeriu natën & \\
\hline Byroja & \\
\hline Njeriu & $\mathbf{3 0}$ \\
\hline Teatrot, kinemaja verës & $\mathbf{5 0}$ \\
\hline për individ dimrit, & $\mathbf{3 5}$ \\
\hline për individ \\
\hline Sallat për tubime & $\mathbf{2 0}$ \\
\hline verës, për individ. & $\mathbf{2 5}$ \\
\hline dimrit, për individ & \\
\hline Tualeti \\
\hline ne guaskë \\
\hline në pisoar \\
\hline Fermë & \\
\hline Ahur & \\
\hline Vathë & \\
\hline \multicolumn{1}{|c|}{1 dopële } & \\
\hline & \\
\hline
\end{tabular}

\subsubsection{Llojet e shtypjeve gjatë ajrimit artificial}

Te ajrimi artificial, ajri futet në lokale dhe krijohet mbi shtypje, nxirret-thithet dhe krijohet nën shtypje ose që të dyja shfrytëzohen në mënyrë të kombinuar (pulzive).

Shtyrja (futja) ose ajrimi me shtypje bëhet duke futur ajrin nga ana e sipërme e lokalit. Zona neutrale lëshohet dhe rrit shtypjen, kurse ajri i papastër del me anë të infiltrimit nëpër vend ngjitjet e përmendura nëpër muret e fasaduara. Në këtë mënyrë pengohet hyrja e ajrit nga jashtë e me këtë edhe e rrymave të ftohta.

Me ajrimin me thithje, ajri thithet dhe ngritët aksi neutral. Në lokal mbretëron shtypje e ulët, ndërsa ajri nga jashtë intensivisht hyn me anën e infiltrimit. Aplikohet në kuzhina, laboratorë, tualete dhe çdo kund ku ajri intensivisht ndotet dhe patjetër duhet të qitet jashtë, madje edhe përkundër rrymave të ftohta të padëshiruara. 
Ajrimi i kombinuar ka aplikim më të gjerë, sepse është më i miri, por edhe është më i shtrenjti. Sipas dedikimit të lokalit shtypja rritet ose zvogëlohet dhe kjo mënyrë përdoret në kinema, sallat e teatrove, restorantet dhe të ngjashme.

\subsubsection{Ventilimi qendror}

Ventilimi qendror vjen në konsiderim gjithkund ku nuk mund të aplikohet ajrimi natyror, kurse duhet të sigurohet ajër i pastër. Shfrytëzohet në viset me klimë të papërshtatshme, në rajonet me ajër të ndotur ose atje ku ka zhurmë të madhe, në ndërtesa shumë të larta (më tepër se $40 \mathrm{~m}$ ), për shkak të erës së fortë në lartësi dhe çdo kund ku janë erërat e forta dhe dritaret nuk guxojnë të hapen; pastaj në rastet kur lokalet ose ndërtesat janë të projektuara pa dritare dhe kur lokalet janë të vendosura nën sipërfaqen e tokës në thellësi më të madhe se $8 \mathrm{~m}$, kurse lartësia e tyre më e vogël se $3 \mathrm{~m}$.

Sistemi i ajrimit qendror, përbëhet prej marrësit për pranimin e ajrit nga jashtë, kanalit për prurjen e ajrit në kthinë ose në centralin ventilues, ku përpunohet (pastrohet) dhe kanalit për përcjelljen e ajrit të pastruar deri te vrima nëpër të cilën kalon nëpër lokale. Marrësit e ajrit të pastër shërbejnë për marrjen (pranimin) e ajrit të jashtëm nëpër vrima të ngritura për 1-1,5 m mbi truall dhe të mbrojtura me rrjetë kundër insekteve, dhe me roleta. Vendosen në muret e fasadës, në pjesë të veçantë të ndërtuar pranë ndërtesës, ose në të katër anët e shtëpizës për ajër.

Vrimat në ndërtesë hapen kah oborri, në anën e cila u ekspozohet erërave më të forta. Shtëpiza për ajër vendoset më së shpeshti në kopsht. Kanalet shërbejnë për kalimin e ajrit. Pozita e tyre është kryesisht horizontale, gropohen në dhe janë të izoluara mirë nga lagështia. Duhet të kenë aso dimensionesh në mënyrë që gjatë mirëmbajtjes së pastërtisë njeriu të mund të kalojë nëpër kanal dhe ajri të mos qarkullojë shumë shpejt dhe të merr me veti edhe pluhurin.

\subsubsection{Instalimet e ventilimit}

Nëse në hapësirën e lokalit, për shkaqe të ndryshme, nuk është i mundshëm ventilimi, apo nëse nuk ka ventilim të mjaftueshëm, atëherë nëpër dritare vendosen instalimet e ventilimit. Instalimet e veçanta që arrihen në veprim me anë të ventilatorit, janë të pavarura me punën e tyre nga gjendja e temperaturës dhe e erës në atmosferë. Për dallim nga ventilimi me rrymim natyror të ajrit, këto instalime disponojnë presion të mjaftueshëm që mundëson rrymimin më të mirë të ajrit dhe ajrosje (ventilim) më të mirë.

Nëse ventilimi bëhet për një numër të madh të lokaleve, ku ajri përgatitet në një vend (qendër), kemi të bëjmë me ventilimin qendror. Këto pajisje të ventilimit qendror përbëhen nga stabilimente për përpunimin e ajrit, kanalet e ventilimit e deri te vrimat në lokal ku bëhet shpërndarja/marrja e ajrit.

Sistemi i furnizimit me ajër përbëhet nga:

1. Kthina e ventilimit (kthina në të cilën përpunohet ajri)

2. Rrjeti i kanaleve, përmes të cilit ajri përcillet deri te vendi i përdorimit dhe

3. Vrimat në lokal, nëpër të cilat ajri hidhet, përkatësisht thithet 


\subsubsection{Furnizimi me ajër}

Ajri i freskët për ventilim duhet të merret në atë vend ku ai është më i pastër, pra nga vendi që është i mbrojtur nga era, pluhuri, tymi dhe bloza, madje nëpër kanale vertikale, jo me aso horizontale. Ajri hyn nëpër vrimën e mbrojtur nga shiu dhe bora, por para kësaj mbrojtjeje ekziston rrjeti që pengon hyrjen e shpendëve, të minjve, eventualisht edhe të gjetheve, .

Është e preferueshme që afër vendit të furnizimit me ajër të ketë gjelbërim, në mënyrë që aty të ndalet pluhuri i ajrit, por të mos jetë i përshtatshëm për qëndrim të fëmijëve. Ajri nuk bën të merret nga rruga, madje kurrsesi nga rruga me komunikacion të dendur. Nuk bën të merret as nga oborret e ngushta dhe të errëta. Vrimat e hyrjes së ajrit nuk bën të jenë afër tokës, as në kënde të oborreve, sepse aty ajri është shumë i pluhurosur. Është treguar, gjithashtu, e gabueshme që vendet e furnizimit me ajër të jenë kulmet e ndërtesave, meqë mu në kulm ajri është i ndotur për shkak të shumë oxhaqeve.

Brendësia e pranuesit të ajrit, sidomos e pjesës horizontale të kanalit, duhet të izolohet nga lagështia dhe të mbështillet me pllaka ose të lyhet me llaç çimentoje, për ta mirëmbajtur më lehtë pastërtinë dhe për kullimin e kondensatit të krijuar me ndryshimet e temperaturës.

Këto kanale duhet të jenë mjaft të mëdha, në mënyrë që shpejtësia e rrymimit nëpër to të mos jetë e madhe, sepse me ajrin bartet edhe pluhuri i tepërt. Duhet të mundësohet edhe pastrimi i këtyre kanaleve, prandaj duhet të parashihet kapaku i pastrimit. Duhet të parashihet edhe mbyllësi në hyrje të kanalit, në mënyrë që ai të mbyllet gjatë kohës kur instalimi nuk punon, që të mos ndotet.

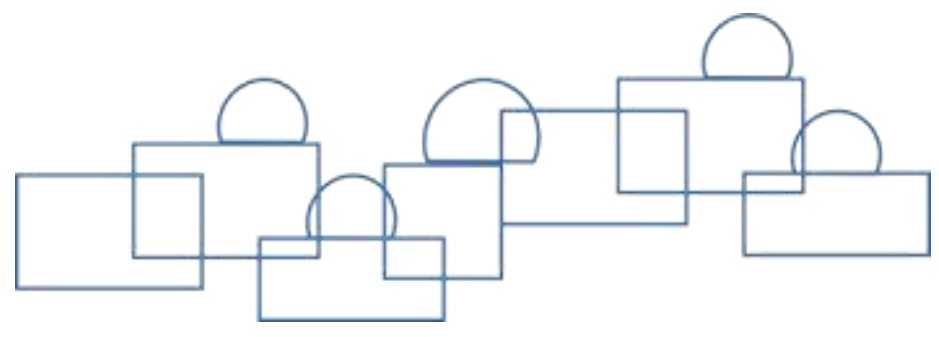




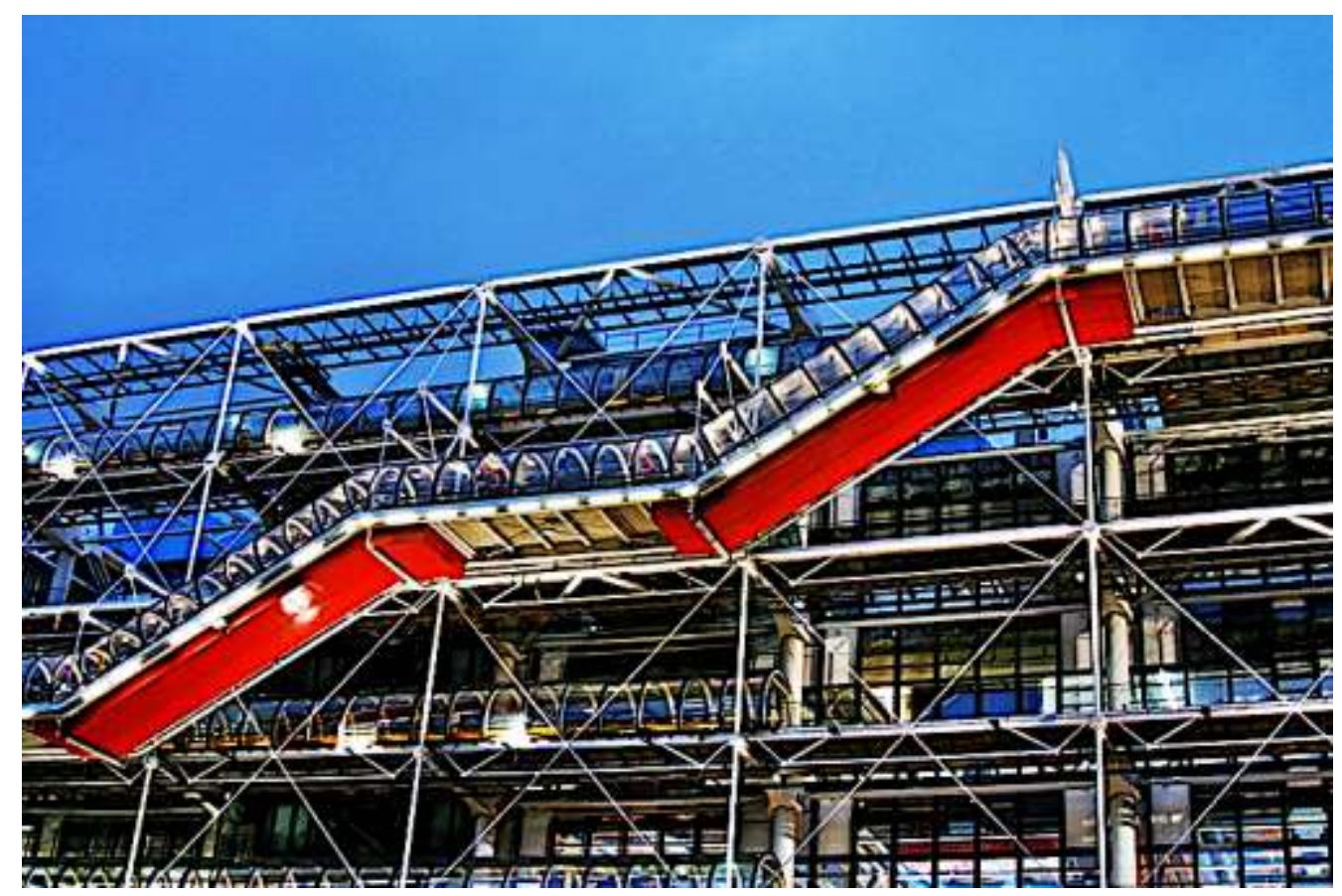

Figura 207. Pompidue, Paris

(Burimi): jandiano, 2008. (Flickr). Creative Commons Attribution ShareAlike 3.0 Unported

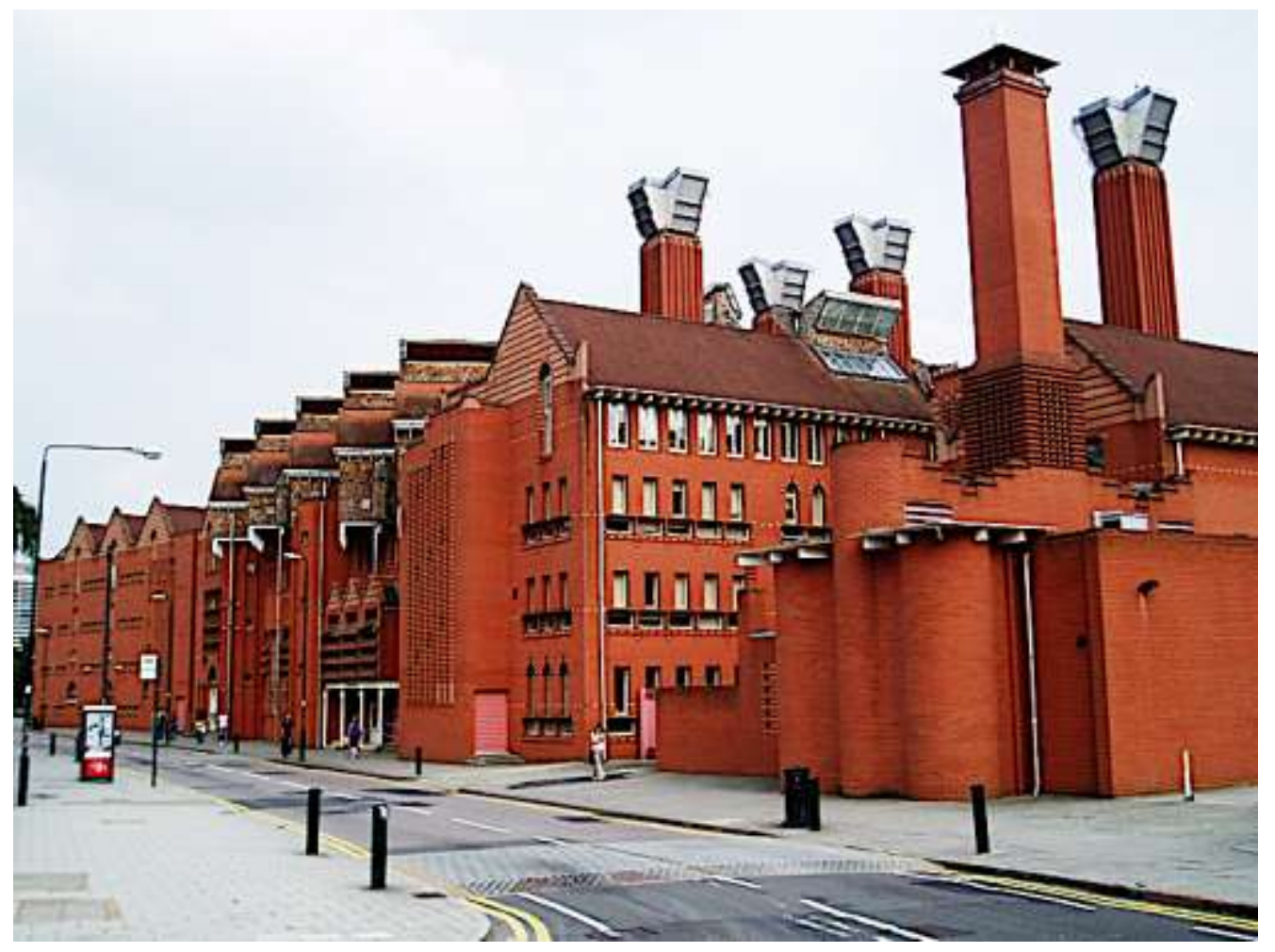

Figura 208. The Queen's Building, De Montfort University, Leicester

(Burimi): Steve Cadman, 2008. (Flickr). Creative Commons Attribution Share Alike 3.0 Unported 
Shembulli i "arkitekturës së gjelbër", është projektuar të jetë (në atë kohë) ndërtesa më e madhe e Evropës e ventiluar në mënyrë natyrore, "oxhaqet" janë dominante në vizurë. Ishte ndërtuar për shkollën e Universitetit të Inxhinierisë dhe prodhimit, praktikisht është në afërsi të një kishë dhe famullie, objekti i projektuar nga arkitekti George Gilbert Scott, i cili me sa duket e shpjegon dhe e potencon pamjet në oxhaqet e objektit, të cilat ngjasojnë në oxhaqet e një fabrikë si dhe zgjedhja e ngjyrës së kuqërremtë polikromatike të realizuara nga stili i tullave gotike.

\subsubsection{Dhoma e pajisjeve, centralizuar/decentralizuar}

Një temë e zakonshme dhe aktuale në të gjitha proceset e projektimit të mirëfilltë është se sa vend apo hapësirë i duhet dhomave të pajisjeve dhe integrimi i tyre në projektimin e përgjithshëm. Sfida më e vështirë duket se është në lidhje me hartimin e një vendimi nëse sistemet e ngrohjes dhe ajrit të kondicionuar duhet të integrohen në një funksion të centralizuar apo model i decentralizuar, në mënyrë që të ofrojë shërbim të veçantë për zonat me qiradhënie (p.sh) në katet individuale.

Në praktike këto hapësira për stabilimente janë rentabile vetëm deri në një lartësi prej rreth 25 kateve në ndërtesat shumë të gjata, sepse çdo lartësi më e madhe do të rezultojë me nivele të larta të presionit, veçanërisht në sistemet me ujë, të cilat do të kërkojnë instalime të rënda dhe pajisje industriale. Kërkesa për këto hapësira, apo dhomat e nevojshme të pajisjeve në varësi të zonave përkatëse është afërsisht si vijon:

Zonat e centralizuar të furnizimit, (deri në max. 25 katet e sipërme)

- $20-25 \mathrm{~m}^{2} / 1000 \mathrm{~m}^{2}$ hapësirë të përdorshme për furnizimin me energji të centralizuar

- $50 \mathrm{~m}^{2} / 1000 \mathrm{~m}^{2}$ hapësirë të shfrytëzueshme për ngrohje qendrore dhe sistemet e ajrit të kondicionuar

- $\quad 4 \mathrm{~m} 2 / 1000 \mathrm{~m}^{2}$ hapësirë të shfrytëzueshme për instalimet qendrore, kanalet

Zonat e decentralizuara të furnizimit, (deri në max. 25 katet e sipërme)

- $20-25 \mathrm{~m}^{2} / 1000 \mathrm{~m}^{2}$ hapësirë të përdorshme për furnizimin me energji të centralizuar

- $20 \mathrm{~m}^{2} / 1000 \mathrm{~m}^{2}$ hapësirë të përdorshme për përpunimit e ajrit të freskët

- Rreth $40 \mathrm{~m}^{2} / 1000 \mathrm{~m}^{2}$ hapësirë të shfrytëzueshme për instalimin e ngrohjes, me ajër të kondicionuar njësi të decentralizuara (njësitë përpunuese të instaluara veçmas në çdo kat)

- Rreth $1.5 \mathrm{~m}^{2}$ të zonës për kanale $/ 1000 \mathrm{~m}^{2}$ hapësirë të përdorshme

Janë të domosdoshme studime të veçanta për rastet të cilat duhet shqyrtuar, analizë krahasuese për të përcaktuar se cilat fusha duhet të ndërtohen, me çfarë kosto dhe me çfarë vlera specifike të zonave. 


\subsubsection{Filtrimi i ajrit}

Ajri që merret nga atmosfera nuk është i pastër sa duhet, ai përmban grimca pluhuri, blozë dhe papastërti të tjera, kështu që, para se të hyjë në përdorim pastrohet. Ky pastrim bëhet me anë të filtrave. Për punë efektive filtrat duhet të pastrohen sa më mirë, dhe rregullisht. Në të kundërtën ata jo vetëm që nuk e pastrojnë ajrin, por edhe më shumë e ndotin.

1. Filtrat me vaj

2. Filtrat e thate

3. Filtrat elektrostatikë

\subsubsection{Ngrohja e ajrit}

Për ngrohjen e ajrit më së shumti përdoren ngrohësit me lamela. Ata përbëhen nga gypat me një ose më shumë rende me brinjë (fleta) llamarine të trashësisë $0,5 \mathrm{~mm}$, që janë të ngjitura në gypa dhe që ndërmjet kanë distancë $3+5 \mathrm{~mm}$, të njëjtë si te konvektorët . Nëpër gypa rrymon uji i nxehtë ose avulli, kurse jashtë gypit dhe brinjëve (fletëve) rrymon ajri që ngrohet. Për shkak të sipërfaqes së madhe që arrihet nga brinjët (fletët), efekti termik i ngrohësit me lamela është i madh.

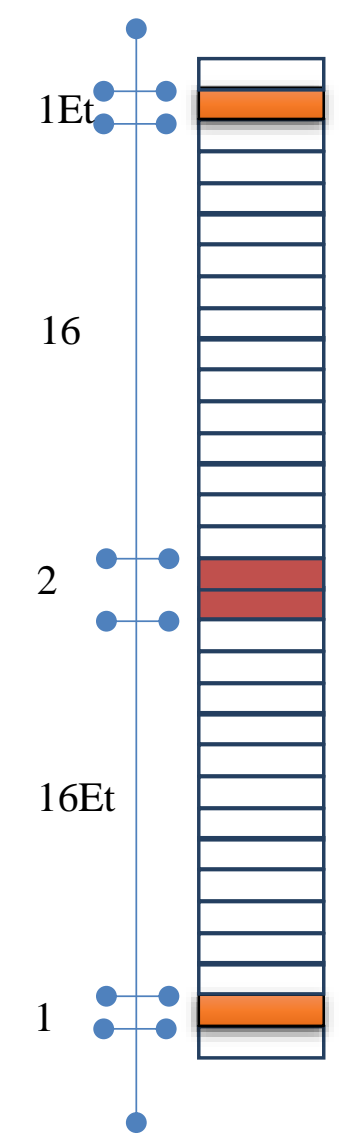

Figura 209. Etazhat teknike në objektet e larta (Burimi): Bujar Bajçinovci

\subsubsection{Kanalet e ventilimit}

Ajri që përgatitet në kthinën e ventilimit, duhet të hyjë në lokal nëpërmjet rrjetit të kanaleve vertikale dhe të atyre horizontale. Gjatë projektimit të rrjetit të kanaleve duhet patur kujdes për kërkesat, si vijon: pastrimi i lehtë i kanaleve dhe rezistencat e vogla të rrymimit. Pastrimi i lehtë i kanaleve. Edhe pse ajri filtrohet, kanalet ndoten nga pluhuri, andaj nevojitet që pastrimi i tyre të jetë i lehtë. Te kanalet e mëdha kjo arrihet duke hyrë në kanal, kurse në kanalet e vogla nevojitet të bëhen vrimat, nga të cilat çdo pjesë e kanalit mund të pastrohet me brusha ose me aparat thithës. Parashikohet që mjafton pastrimi i tërë rrjetit një herë në vit. Mbyllësit e vrimave për pastrim përforcohen me mbërthyese (bulona) sepse kanalet duhet të mbyllen hermetikisht, përndryshe mund të paraqiten humbje të paparashikueshme.

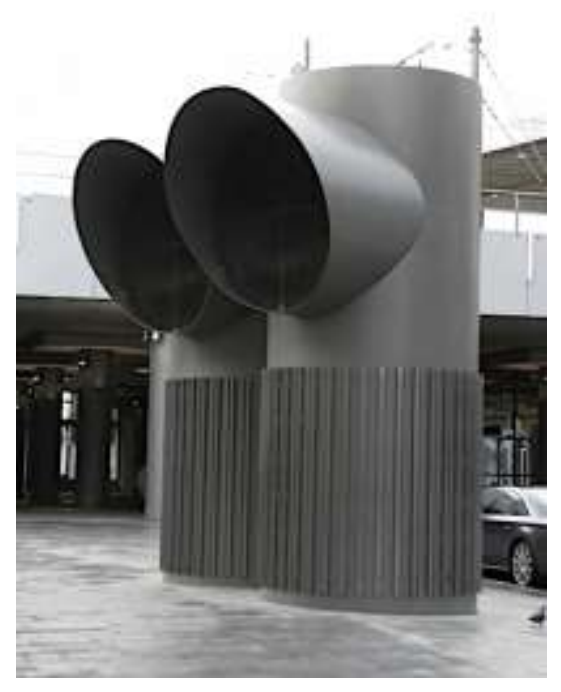

Figura 210. Antwerpen Stacioni, Ventilimi

(Burimi): Mark Ahsman, 2010. (Flickr). Creative Commons Attribution Share Alike 3.0 Unported 


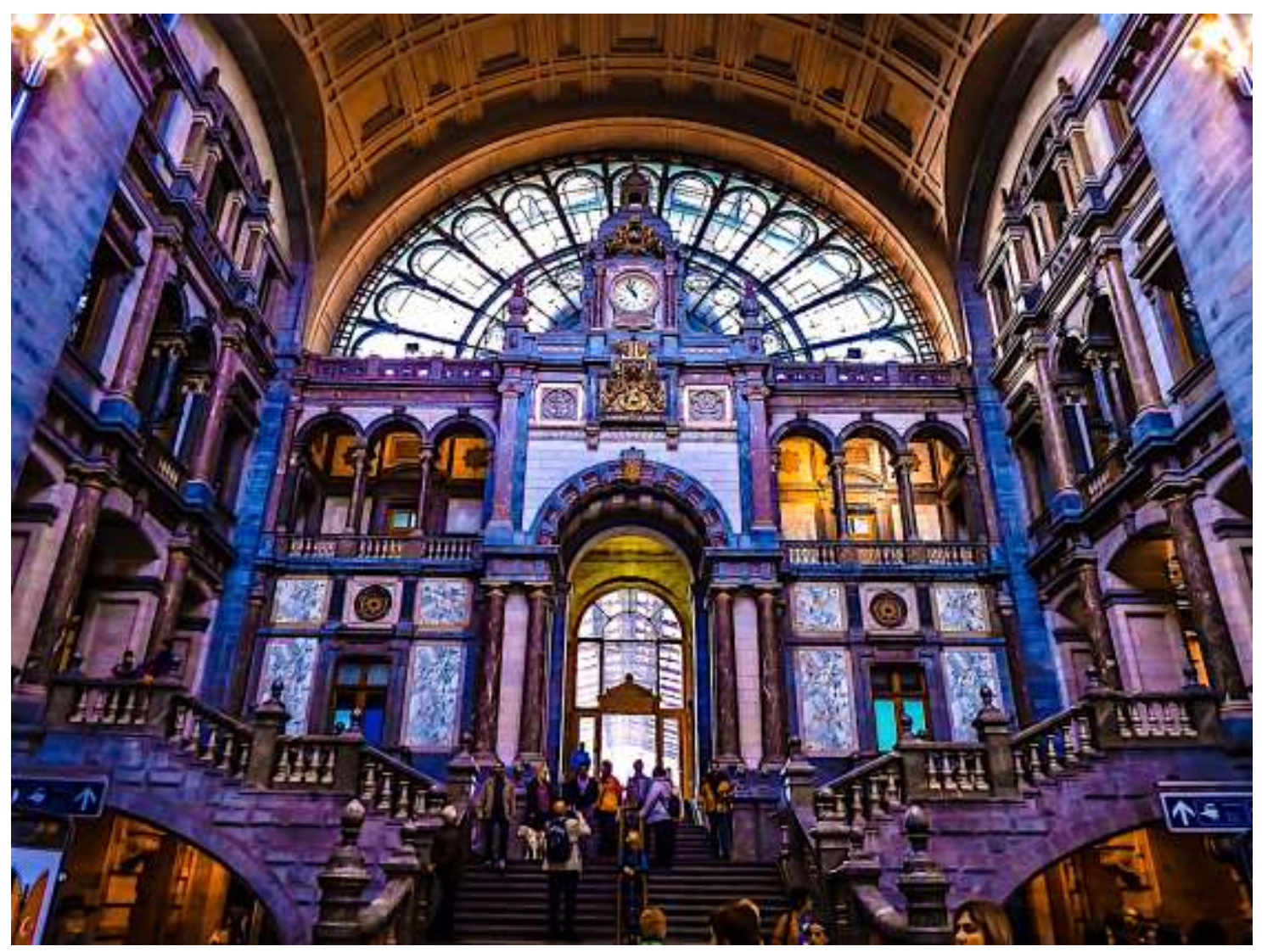

Figura 211. Antwerpen Stacioni, Ventilimi

(Burimi): ConstiAB, 2014. (Flickr). E licensuar nga Creative Commons-NoDerivs 2.0 Generic

Rezistencat e vogla të rrymimit. Dallojmë dy lloje rezistencash: rezistencat në pjesët drejtvizore të gypave (rezistencat gjatësore) dhe rezistencat vendore (lokale). Rezistencat e para paraqiten gjatë lëvizjes së ajrit dhe fërkimit të tij me muret e kanalit, kurse të dytat gjatë ndërrimit të seksionit të kanaleve, drejtimit të rrymimit, të degëzimeve, të grilave. Që humbjet të jenë të vogla rrjeti i kanaleve duhet të jetë sa më i shkurtër, që muret e kanaleve të jenë të lëmueshme, pastaj që ndërrimi i drejtimeve të jetë sa më i vogël (kthesat me rreze të mëdha), ndryshimi gradual (shkallë shkallë) i seksioneve të kanaleve.

Me qëllim që t'i plotësojmë këto kushte, më kujdes duhet të shqyrtojmë tërë rrjetin e kanaleve, sipas mundësisë që nga konstruktimi i ndërtesës në vizatim. Shpesh ka raste që kompetentët për ventilim konsultohen në kohën kur punët e ,ashpra" në ndërtesë kryhen. Në këto kushte rrjeti i kanaleve duhet t'i përshtatet situatës ekzistuese e me këtë arrihet rrjeti i kanaleve, që vështirë pastrohet dhe që ka rezistenca të mëdha gjatë rrymimit të ajrit.

Kanalet ndërtohen me lloje të ndryshme të materialeve të ndërtimit: nga tulla, betoni, pllakat e gjipsit dhe nga betoni e më së shpeshti nga llamarina e zinkuar. Kanalet nga llamarina kanë brendësi të lëmuar, janë të lehta, përforcohen (mbërthehen) lehtë, nuk korrodohen dhe janë të sigurta ndaj zjarrit. Për pengimin e humbjeve termike duhet të bëhet izolimi i kanaleve. 
Seksionet e kanaleve, zakonisht, janë katrore, katër këndorë, ose rrethore. Forma rrethore është më e mira, por vështirë u përshtatet mureve. Kanalet mund të vendosen në mure, tavane, dysheme, në formë të dukshme ose të fshehura, por gjithnjë në harmoni me arkitekturën e brendshme. Gjithmonë duhet të kihet parasysh se për pastrimin e kanaleve nevojitet vendosja e vrimave dhe që me vendosjen e konstruksionit të ruhet pamja e dëshiruar e lokalit.

\subsubsection{Hyrja e ajrit në lokal}

Mënyra më e mirë e ajrosjes është ajo që mundëson prurje të menjëhershme të sasisë së mjaftueshme të ajrit të freskët në vendin ku ajri prishet. Një nga çështjet më të rëndësishme është: ajri në lokal a duhet të futet vetëm nëpër vrimën e epërme, e të nxirret nëpër të poshtmen, apo anasjelltas. Që të mund t'i përgjigjemi kësaj pyetjeje, duhet të dimë a është fjala për futjen e ajrit të ngrohtë apo të ftohtë.

Shqyrtojmë së pari futjen e ajrit të ngrohtë. Nëse ai hyn poshtë dhe thithet (nxirret) lart, shpejt lëviz nga tavani për shkak se është më i lehtë dhe del nëpër vrimën e epërme. Në këtë rast ekziston rreziku të krijohen hapësira të ajrit të ,lodhur" dhe hapësira në të cilat nuk bëhet ndërrimi i ajrit.
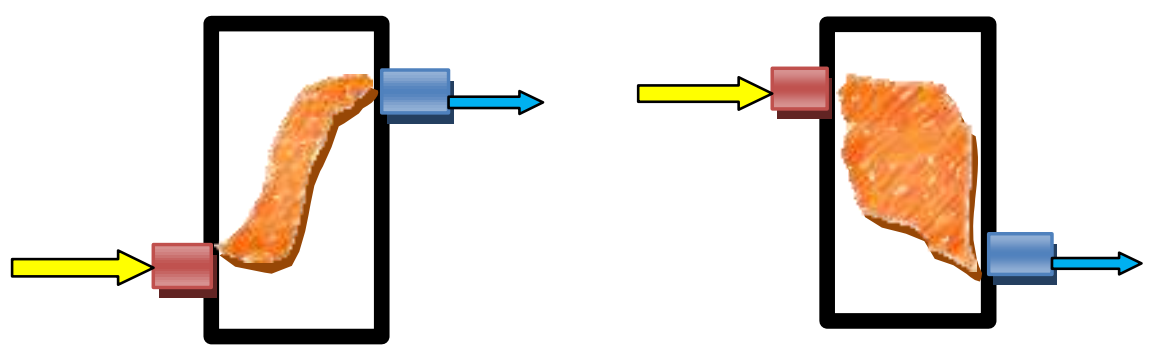

Figura 212. Futja e ajrit të ngrohtë: a- nga poshtë dhe b- nga lartë (Burimi): Bujar Bajçinovci, 2012.

Ndërrimi i njëtrajtshëm i ajrit arrihet nëse ajri i ngrohtë futet nga lart dhe nxirret poshtë. Ai i reziston lëvizjes nga poshtë dhe e përmbush tërë vëllimin e lokalit. Për ajrin e ftohtë rasti është i kundërt.

Megjithatë, ky nuk është kusht i vetëm që duhet të plotësohet, ekzistojnë edhe kushte të tjera, për këtë arsye nuk duhet të veprojmë njëanshëm (ngurtë). Mundësitë e vendosjes së vrimave për hyrje të ajrit, janë të ndryshme dhe varen nga shumë faktorë, para së gjithash nga përvoja dhe aftësitë e projektuesit. Më se thjeshti është që vrimat të vendosen në pjesën e epërme të lokalit në formë katërkëndëshi e që mbulohen me grila dhe nëse është e nevojshme, edhe mund të maskohen (mbulohen). Mundësi të njëjta për vendosje dhe për maskim, kanë edhe vrimat në tavan.

Dihet që është vështirë të bëhen vrima me madhësi të nevojshme në pjesën e poshtme të lokalit. Nga pikëpamja e ventilimit më së miri është që ajri në lokal të hyjë nëpër vrimat me shpërndarje të njëtrajtshme (uniforme) nëpër tërë dyshemenë. Mirëpo nuk është e lejueshme që gjatë kësaj në dysheme të vendosen grilat horizontale, pasi me këtë në kanalet e ajrit bie pluhuri nga këpucët (të mbathurat). 
Do të thotë grilat duhet të jenë vertikale. Në salla ku dyshemeja është e shkallëzuar (teatër, salla sportive) vrimat me grila mund të vendosen në pjesët vertikale të shkallëve. Meqë dyshemetë e rrafshëta të sallave nuk u përshtaten vrimave për futjen e ajrit, atëherë e përshtatshme do të ishte pjesa e poshtme e sipërfaqeve të mureve. Megjithatë vendosja e vrimave për të hyrë ajri në numër të nevojshëm dhe me madhësi të nevojshme, edhe në këtë rast paraqet vështirësi pasi që pjesa më e madhe e sipërfaqeve të mureve i takon dyerve dhe gjësendeve të tjera të brendshme arkitektonike.

Duhet të kemi parasysh se zgjidhja e kënaqshme në këto raste mund të jetë vetëm në saje të punës së përbashkët të arkitektit dhe të ekspertit-kompetentit të ventilimit.

Nëse bëhet fjalë për ventilimin e lokalit me bazë të zgjatur dhe përpjesëtimisht me lartësi të vogël, atëherë si vrimat hyrëse, ashtu edhe ato dalëse, mund të vendosen në gjysmën e epërme të lokalit dhe kështu arrihet ventilimi i tërthortë i tërë lokalit. Nëse vrimat hyrëse dhe dalëse vendosen njëra mbi tjetrën, drejtpërsëdrejti nën tavan, atëherë do të kemi ventilimin qarkor . Në këtë mënyrë ndërrohet tërësisht ajri i lokalit (nuk ka paraqitje të zonave të lodhura të ajrit). Shembujt e dhënë në figurat e mëposhtme tregojnë mundësitë e ndryshme të vendosjes së vrimave të ventilimit.
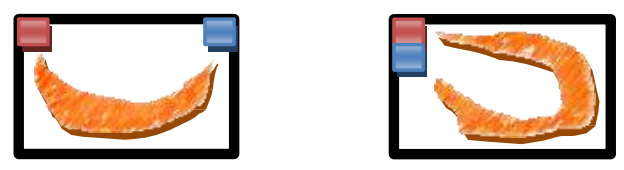

Figura 213. Ventilimi i tërthortë dhe ai qarkor i lokalit (Burimi): Bujar Bajçinovci, 2012.
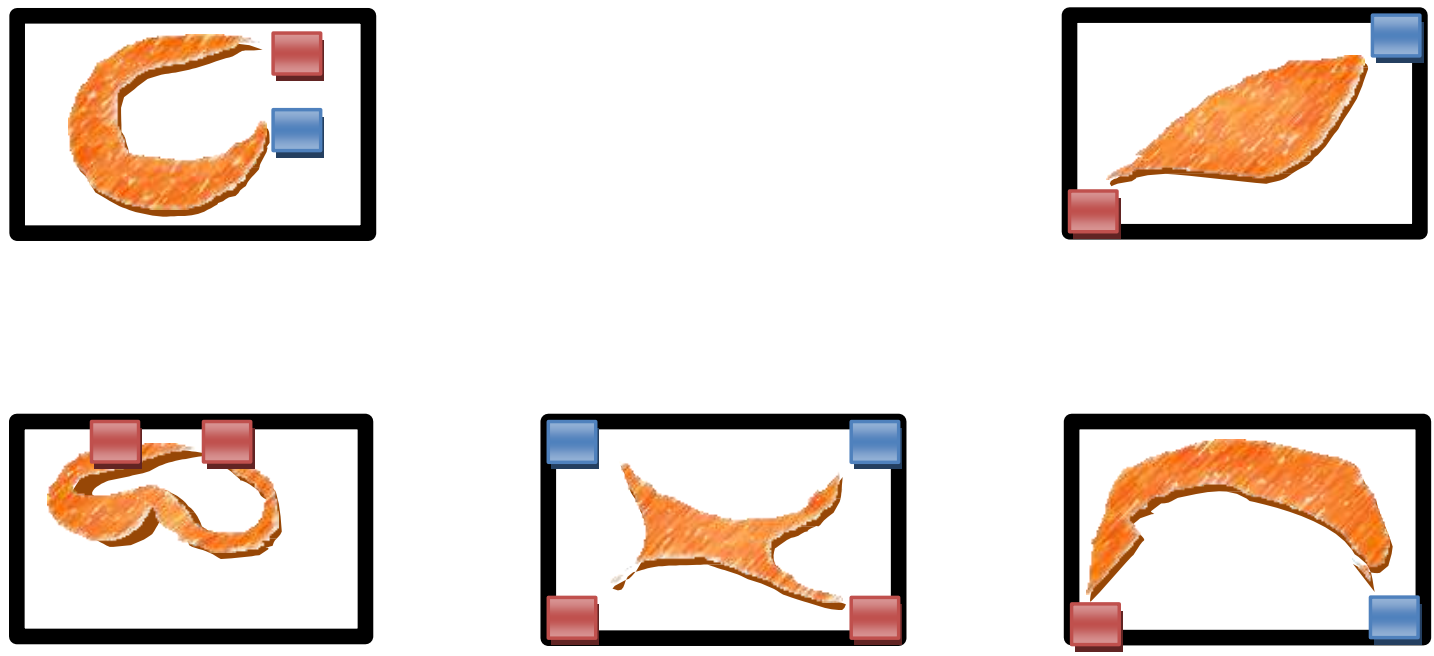

Figura 214. Mundësitë e ndryshme të vendosjes së vrimave të ventilimit. (Burimi): Bujar Bajçinovci, 2012. 


\subsubsection{KLIMATIZIMI}

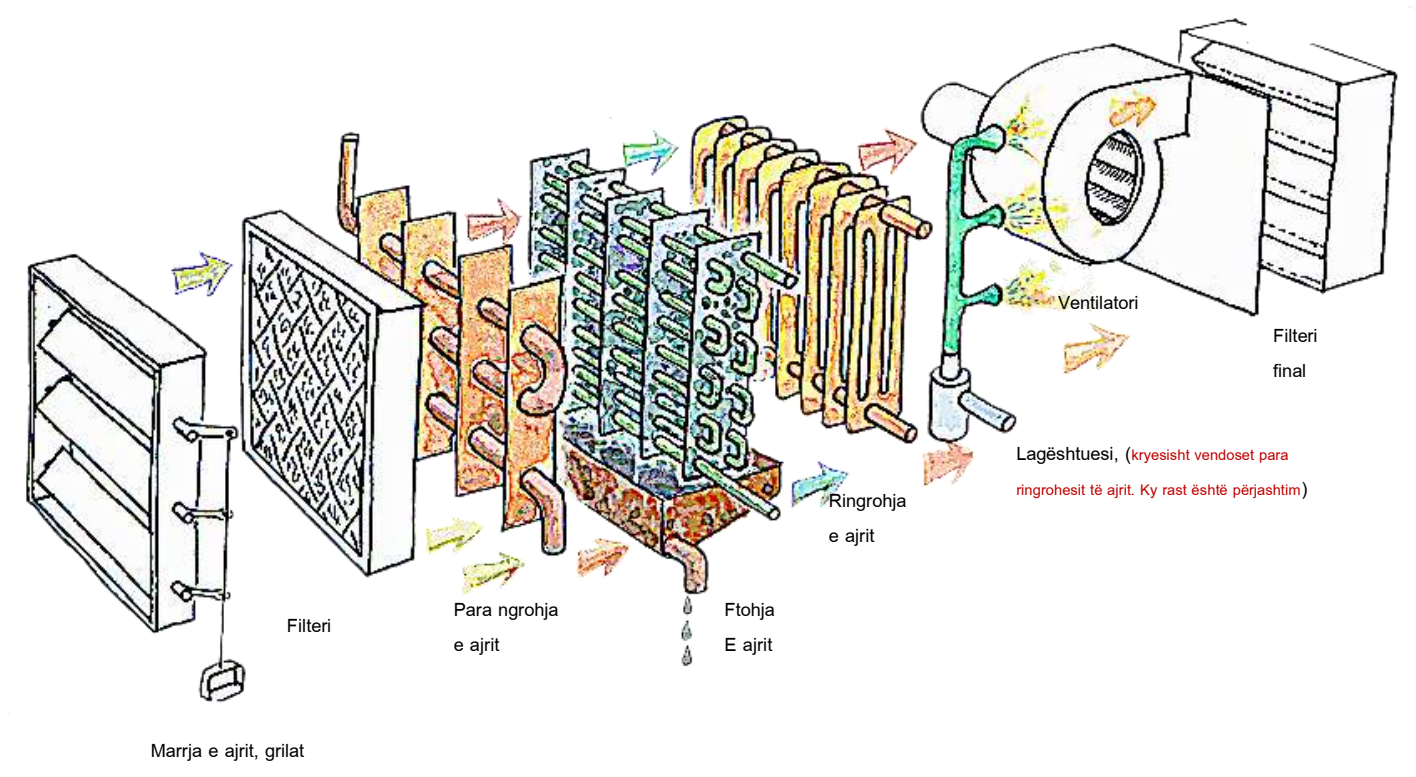

Figura 215. Struktura punuese e një kondicioneri (Burimi): Tim Padfield, 2000. How air conditioning works.

Në stabilimentet për klimatizim (klimë artificiale) në mënyrë krejt automatike bëhet përpunimi i ajrit (kondicionimi), kështu që në ambiente ajri është i pastër, me lagështi, temperaturë e shpejtësi të nevojshme, pa marrë parasysh ndikimet e jashtme ose sezonin vjetor.

Stabilimentet për klimatizim mund të jenë qendrore, lokale dhe të kombinuara.

Pajisjet qendrore për klimatizim funksionon automatikisht dhe sipas kësaj dallohen prej pajisjeve të ventilimit. Në klima centralin vendosen të gjitha pajisjet për përpunimin e ajrit, i cili deri te ambientet përcillet me një rrjet kanalesh. Klima centralet janë lokale me mure betoni ose të murosura në të cilat gjendet klimatizatori me të gjitha stabilimentet e nevojshme. Vendosen në bodrum ose në ndonjë pjesë tjetër të përshtatshme të ndërtesës.

Klimatizatorët janë kthina prej llamarinës së zinkuar. Në ta janë të vendosura elementet e parafabrikuara për përpunimin e ajrit madje në varg, ose njëri mbi tjetrin, në qëllim të zvogëlimit të gjatësisë së pajisjes. Përmasat e tyre varen prej tipit të klimatizorëve dhe sistemit të aklimatizimit 


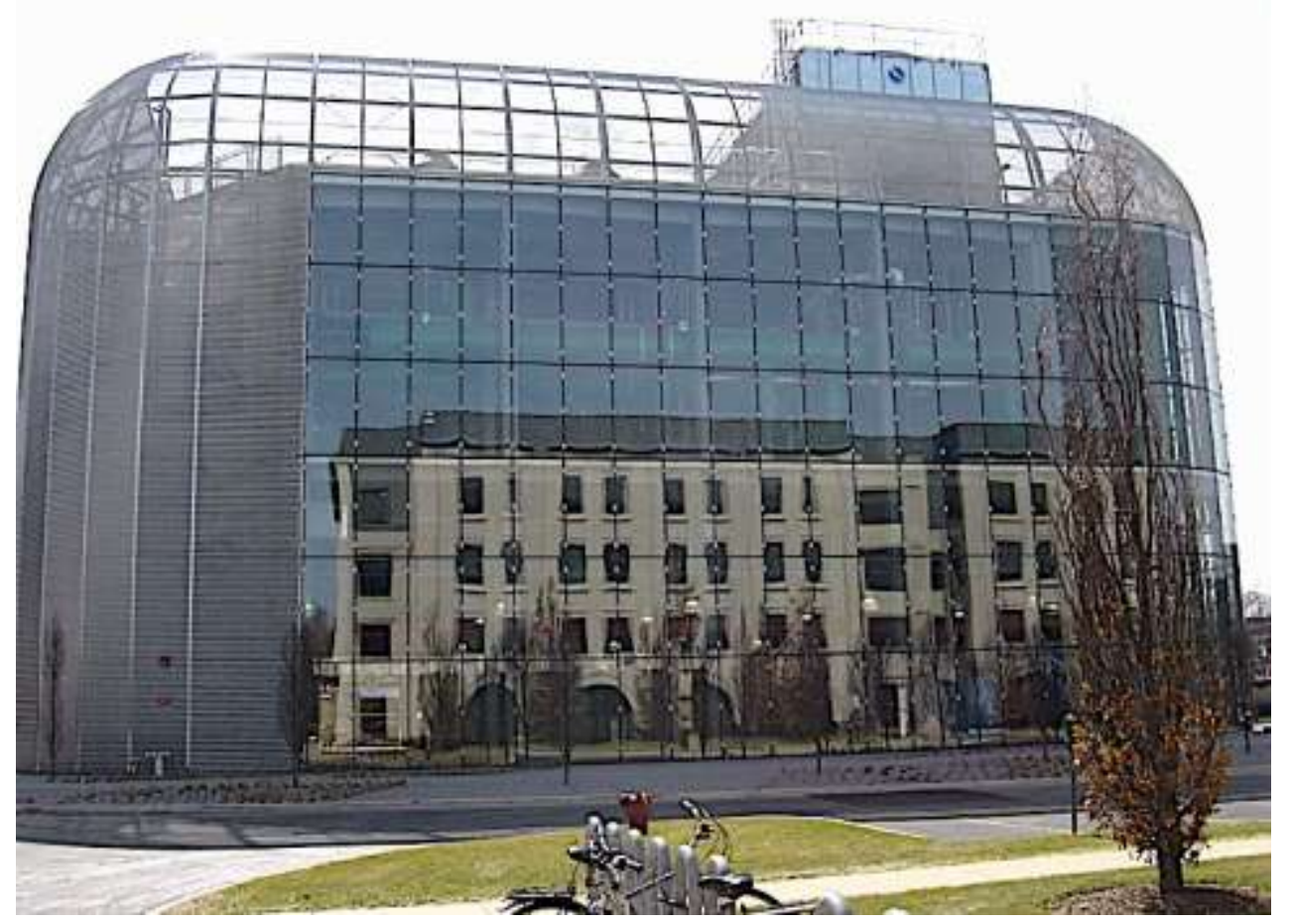

Figura 216. University of Chicago South Campus Chiller Plant (Burimi): angwe23, 2009. (Flickr). Creative Commons-NoDerivs 2.0 Generic

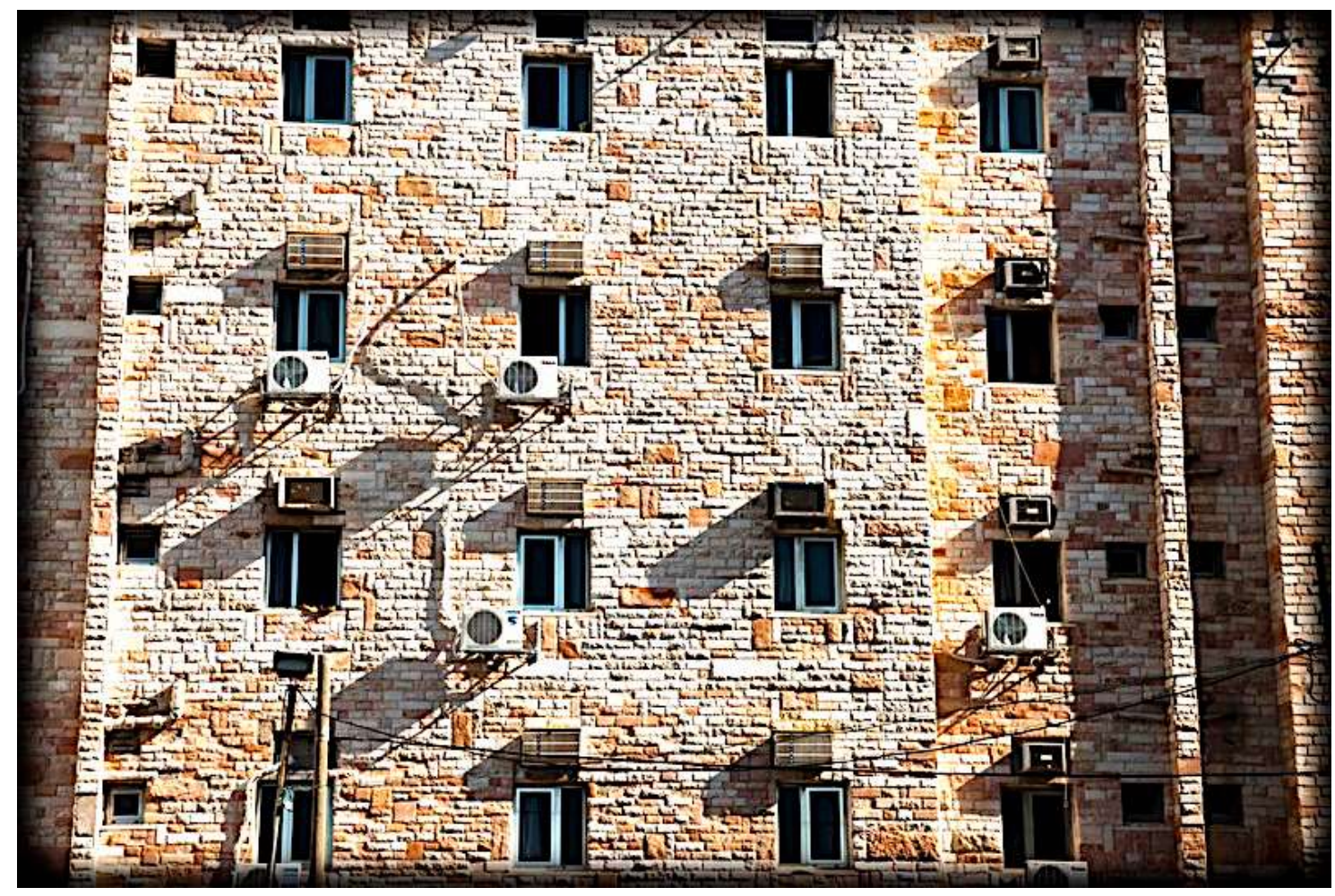

Figura 217. Klimatizimi në banim, Ha Yakon

(Burimi): Yoni Lerner. 2009. (Flickr). Creative Commons-NoDerivs 2.0 Generic 
Sipas sasisë së ajrit që e përpunojnë zgjidhet edhe tipi nga katalogët e prodhuesve. Klimatizimi qendror përcjell ajrin nëpër një apo dy kanale me shtypje të ulët apo të lartë. Në sistemin me një kanal ajri i përpunuar i cilësisë së njëjtë përcillet në të gjitha ambientet e ndërtesës. Për nevojat e ambienteve të ndryshme, për shembull, të atyre që u janë ekspozuar ftohjes më të madhe, bëhet ndarja në zona dhe në secilën sosh sipas nevojës vendosen ngrohës plotësues.

Në sistemin me dy kanale ajri sillet nëpër dy kanale në ambientin afër kutisë për përzierjen dhe lëshimin e ajrit. Ajri i jashtëm i përpunuar pjesërisht në njërin kanal nxehet me ngrohës, kurse në tjetrin ftohet me aparatin për ftohje. Temperatura e nevojshme rregullohet me termorregullues aty për aty në ambient. Sistemi i shtypjes së ulët ka kanale prerjes shumë të madha dhe janë të stërmëdha. Brenda tyre ajri ka shpejtësi të vogla, mirëpo janë të përshtatshme ngase funksionojnë pa shushuritje. Në sistemin e shtypjes së lartë kanalet janë prerjeje më të vogla, ajri ka shpejtësi më të madhe dhe krijon shushuritje e zhurmë në njëfarë mase dhe përkundër izolimit më të mirë. Ajri (klima) në lokal karakterizohet nga temperatura e ajrit, lagështia absolute dhe nga ajo relative e ajrit, nga shpejtësia e lëvizjes së ajrit, nga pastërtia e ajrit (pluhuri, erërat, avujt dhe gazrat), nga dridhjet dhe zhurma. Andaj, që ajri të jetë në kufij të kërkuar, duhet të përgatitet, përkatësisht të klimatizohet në instalimet e klimatizimit.

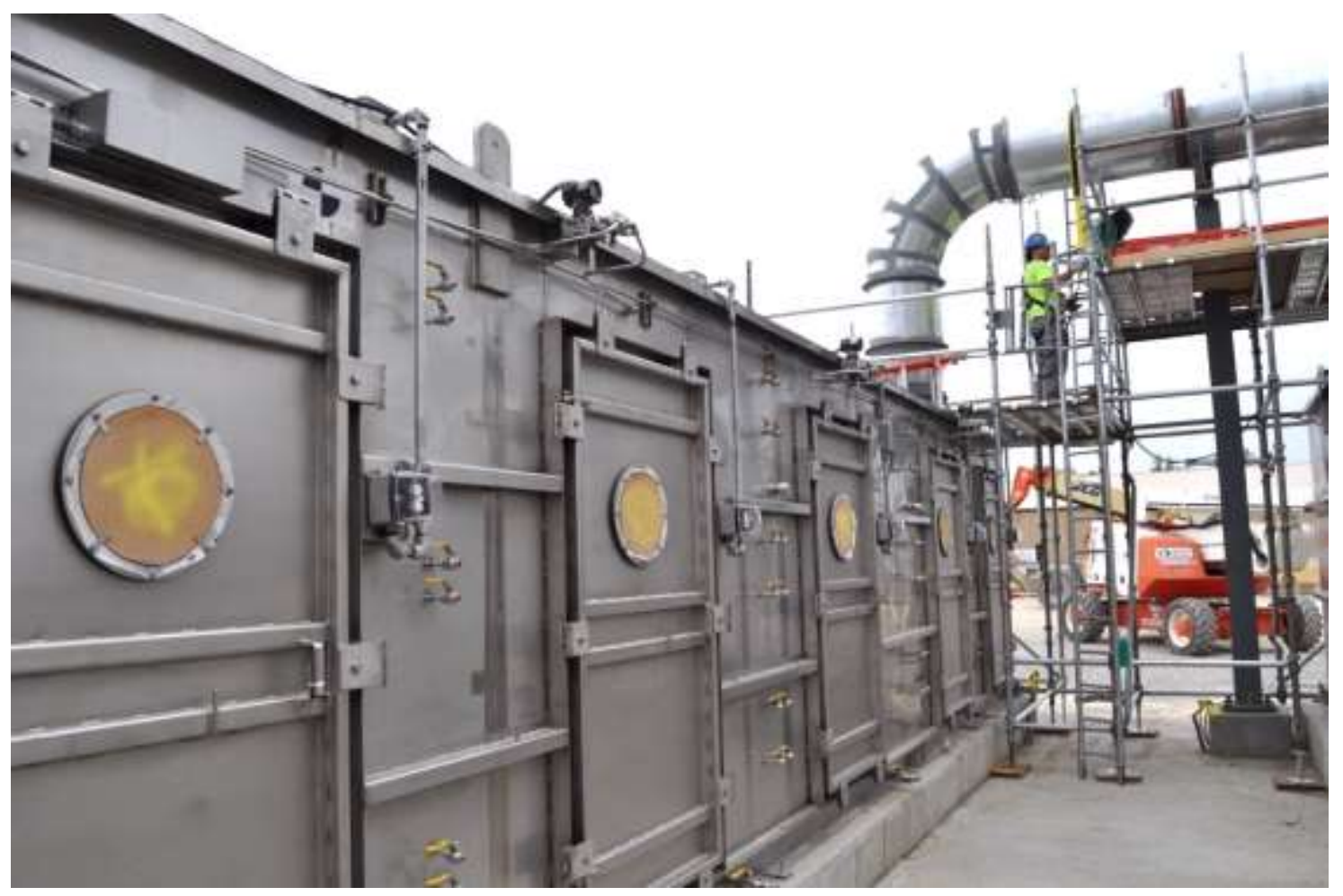

Figura 218. Klimatizimi, sistemi njësi.

(Burimi): PEO ACWA, 2012. (Flickr). E licensuar nga Creative Commons 2.0 Generic 


\subsubsection{Instalimet e klimatizimit}

Instalimet e klimatizimit kanë për detyrë, që pa marrë parasysh kushtet e jashtme, në një lokal të caktuar të mbahen temperatura dhe lagështia e ajrit në gjendje të dëshirueshme, në varësi nga destinimi i lokalit. Pajisjet e klimatizimit janë paraqitur në fillim të shekullit njëzet në Amerikë, së pari si pajisje për krijimin dhe për mbajtjen e ajrit në kushte të përshtatshme në degë të ndryshme të industrisë. Po ashtu janë përdorur edhe për prodhimin e mëndafshit artificial, të duhanit, prodhimeve të ndryshme kimike, filmave, të letrës, gjithnjë me domosdoshmërinë e ruajtjes së temperaturës së caktuar në lokal, posaçërisht të shkallës së lagështisë, nga të cilat varet cilësia e prodhimit të mallrave. Me zhvillimin e teknikës gjithnjë e më shumë po shihen përparësitë e këtyre pajisjeve edhe për lloje të tjera lokalesh, ku mblidhet numër i madh i njerëzve. Kështu këto pajisje sot përdoren edhe në sallat sportive, teatër, kinema, restorante, spitale.

Gjithnjë e më shumë po përdoren në objektet e banimit, me qëllim që gjatë tërë vitit të ruajnë temperaturën dhe lagështinë e ajrit në kufijtë në të cilët njerëzit ndihen këndshëm, e këto janë temperatura prej $20-25^{\circ} \mathrm{C}$ dhe lagështia relative $40-70 \%$.

Gjendja e ajrit, në lokalet që klimatizohen, përherë ndryshon për shkak të ndryshimeve të jashtme, gjithashtu edhe për shkak të ndryshimeve nga përfitimet e brendshme të nxehtësisë; nga prania e njerëzve, nga ndriçimi. Ruajtja e përhershme e gjendjes së ajrit për nga pikëpamja e temperaturës dhe e lagështisë mund të bëhet vetëm në mënyrë automatike.

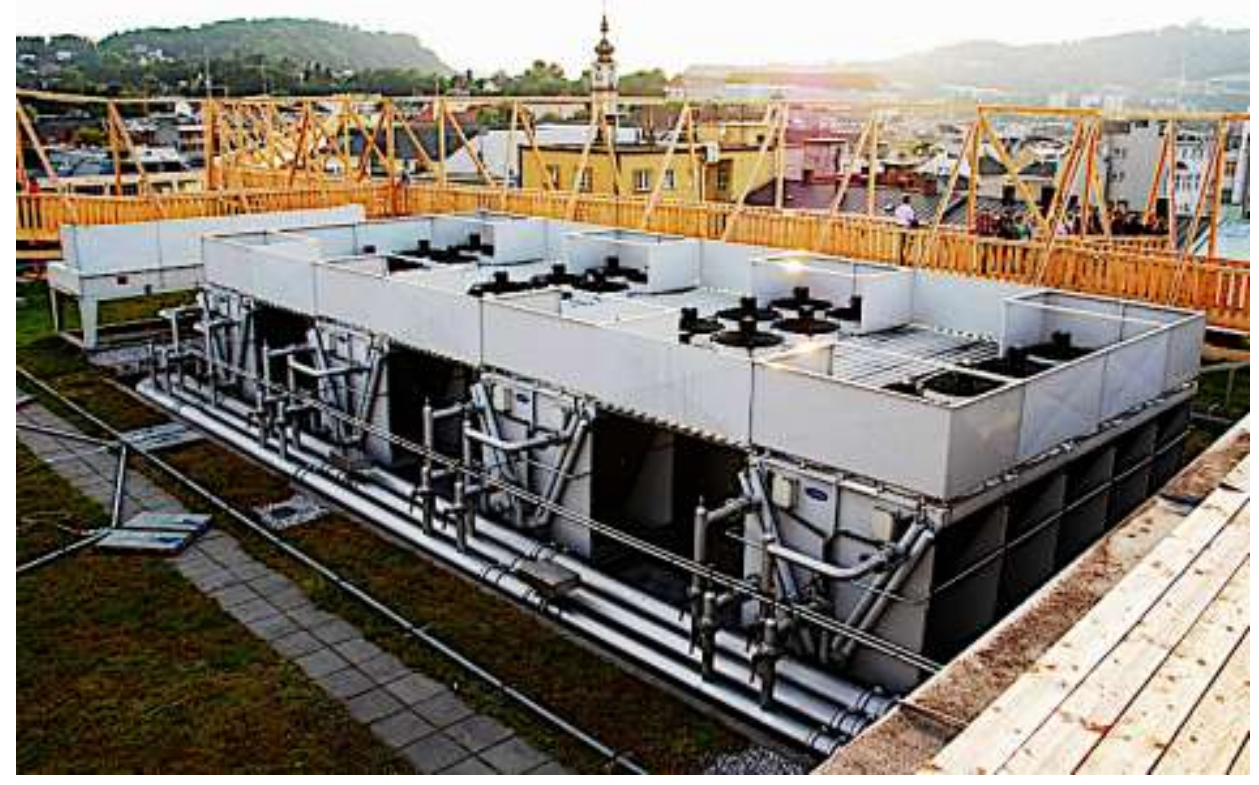

Figura 219. Njësia e ajrit të kondicionuar, Passage qendër tregtare në Linz, Austri (Burimi): Dein Freund der Baum, 2009. (Flickr). Creative Commons Attribution Share Alike 3.0 
Klimatizimi qendror ka kthinën e klimatizimit në të cilën gjenden pajisjet për përpunimin, qarkullimin dhe rregullimin e ajrit. Nga ajo, ajri nëpër rrjetin e kanaleve, sikurse edhe te pajisjet e ventilimit, kalon në lokal. Klimatizimi lokal nuk ka kanale të ajrit, por klimatizuesi në formë kutie, vendoset në lokal, dhe në të janë vendosur të gjitha pjesët për përpunim dhe qarkullim të ajrit, sikur te klimatizimi qendror. Vendosja e tyre më së shpeshti bëhet në mure ose në dritaret e lokalit.

Sipas rolit që luajnë, sistemet e klimatizimit ndahen në tri grupe:

1. Sistemet e klimatizimit të periudhës së dimrit, ku bëhen pastrimi, ngrohja, lëngështimi dhe ndërrimi i ajrit;

2. Sistemet e klimatizimit të periudhës së verës, ku bëhen pastrimi, ftohja, lëngështimi dhe ndërrimi i ajrit;

3. Sistemet për klimatizim të plotë, në të cilin kryhen të gjitha funksionet e të dy sistemeve të mëparshme

\subsubsection{Kthina e klimatizimit}

Për të krijuar kushte të kënaqshme, ajri trajtohet në kthinën e klimatizimit. Kthinat e vogla të klimatizimit zakonisht ndërtohen nga llamarina e fortë e zinkuar. Ato zënë pak vend në hapësirën e paraparë të lokalit. Kthinat e mëdha të klimatizimit ndërtohen nga betoni ose nga muri me tulla dhe për to parashihen hapësira të mëdha. Për këtë arsye arkitektët dhe ekspertët (kompetentët) për klimatizim duhet të vendosin bashkëpunim të ngushtë që nga hartimi i projektit të ndërtimit, ashtu që të sigurohet hapësirë e mjaftueshme për vendosjen e kthinës së klimatizimit.

Dhoma e përzierjes. Në dhomën e përzierjes ajri i freskët përzihet me atë ri qarkullues në sasi të caktuar me ndihmën e grilave (me hapjen dhe me mbylljen e tyre).

Filtri. Për filtrimin e ajrit përdoren kryesisht të njëjtit filtra që janë përshkruar në kreun për pajisjet e ventilimit (filtrat me vaj, të thatë, lëvizës dhe ata elektrostatikë).

Ngrohësi. Ngrohja e ajrit bëhet më së shpeshti me anë të ngrohësve me lamela, që ngrohen me ujë të ngrohtë ose me avull ose edhe me gaz ose me energji elektrike, siç janë përshkruar më parë.

Ri ngrohësi. Kanë konstruksion të njëjtë sikurse ngrohësit.

Ftohësi. Më së shpeshti përdoren ftohësit që kanë konstruksion të ngjashëm me ngrohësit me lamela, vetëm se këtu nëpër gyp qarkullon uji i ftohtë ose ndonjë fluid tjetër i ftohtë (amoniaku, freoni, dyoksodi i karbonit), kurse ajri rrymon rreth gypit të brinjëzuar dhe në këtë mënyrë ai ftohet duke ia dhënë nxehtësinë ujit ose fluidit ftohës. Të pajisjet me kapacitete të mëdha të ftohjes përdoren makinat ftohëse kompresorike me avullim. 
Dhoma e lëngështimit (spërkatjes). Në të lagështohet e ajri. Gypat e ujësjellësit vihen paralelisht në një ose më shumë rende dhe në distanca të caktuara. Nga spërkatësi, uji nën presion shpërndahet në shumë grimca të imta dhe në këtë mënyrë krijohen "perde" të ujit, nëpër të cilat kalon ajri dhe e merr lagështinë. Uji i përdorur bie në vaskë , prej nga me anë të pompës prapë përcillet nëpër gypa dhe në spërkatës dhe kështu vazhdon ri qarkullimin.

Eliminuesi i pikave të ujit._Vendoset para dhe pas dhomës së lëngështimit. Përdoret për pengimin e spërkatjes së grimcave të ujit në ftohës ose në ri ngrohës. Eliminuesi i pikave të ujit përbëhet prej pllakave nga llamarina, që janë të lakuara zigzag. Ajri që kalon nëpër dhomën e lagështimit dhe që është i pasur me pika të ujit, arrin në eliminues dhe kalon nëpër të. Për shkak të thyerjeve të dendura nga rryma e ajrit me pikat e ujit, uji i bartur nga ajri godet pllakën dhe derdhet në vaskë. Në këtë mënyrë pamundësohet që pikat e ujit të arrijnë deri të ventilatori dhe që me ajër të futen në lokal.

\subsubsection{Regjimi dimëror}

Në dhomën e përzierjes përzihen ajri i freskët dhe ajri ri qarkullues. Përzierja e tillë kalon nëpër filtrin, ku ajri filtrohet, kalon në para ngrohës dhe ngrohet deri në temperaturën e caktuar, vazhdon nëpër dhomën e lëngështimit ku lagështohet dhe pas kësaj ri ngrohet në ri ngrohës aq sa është e nevojshme. Në këtë mënyrë, ajri i përgatitur, nëpërmjet ventilatorit, përcillet nëpër rrjetin e kanaleve dhe futet në lokal nëpër vrimat përkatëse.

\subsubsection{Regjimi veror}

Edhe në këtë rast në dhomën e përzierjes përzihen ajri i freskët me ajrin ri qarkullues që kalon nëpër filtrin, për t'u filtruar, më pastaj kalon nëpër ftohës, ku zbritet temperatura. Në dhomën e lagështimit ajri lagështohet dhe nëse ka nevojë ngrohet në ri ngrohës. Kështu ajri i përgatitur, nëpërmjet ventilatorit përcillet nëpër rrjetin e kanaleve dhe futet në lokal . Sa i përket rrjetit të kanaleve nëpër të cilët rrymon ajri dhe të vrimave nëpër të cilat ajri futet në lokal është bërë fjalë te pajisjet e ventilimit dhe i njëjti përshkrim vlen edhe këtu.

\subsubsection{Sistemet e klimatizimit}

Sistemet e klimatizimit përbëhen nga disa pajisje dhe elemente me specifika të ndryshme. Zakonisht sistemet e klimatizimit klasifikohen sipas fluidit të punës (nëpërmjet të cilit rregullohet temperatura e lokalit) dhe sipas shpejtësisë së rrymimit të ajrit në kanale. Sistemet e klimatizimit sipas fluidit të punës ndahen në sistemet me ajër dhe sistemet e klimatizimit me ajër dhe ujë.

Sistemet e klimatizimit me ajër:

Sistemet me një kanal 
Ajri i përpunuar në një qendër të klimatizimit me cilësi të njëjta, dërgohet në të gjitha lokalet e ndërtesës. Ky sistem është i përshtatshëm për klimatizimin e ndërtesave me salla të mëdha siç janë sallat e kinemasë, sallat e mbledhjeve, teatrot, .

\section{Sistemet për shumë zona}

Duke pasur parasysh përftimet e nxehtësisë që paraqiten në lokalet që ndodhen në anën e jugut të ndërtesës, përkatësisht humbjet e nxehtësisë në lokalet që ndodhen në anën e veriut, atëherë ajri i përgatitur në një qendër të klimatizimit ndahet në zona, ku ngrohet sipas nevojës në ri ngrohës të veçantë zonal dhe u dërgohet lokaleve.

\section{Sistemet me dy kanale}

Ajri i përgatitur në kthinën qendrore të klimatizimit ndahet në dy kanale: në kanalin me ajër të ngrohtë dhe atë me ajër të ftohtë dhe shpërndahet me ngarkesa të atilla që u përshtaten të gjitha lokaleve. Temperatura e ajrit të përgatitur rregullohet në afërsi të lokaleve duke u përzier një sasi e ajrit nga kanali i ngrohtë dhe një sasi e ajrit nga kanali i ftohtë. Kjo përzierje e ajrit futet në lokal, për secilin lokal apo për disa lokale ku ndodhet një përziers i ajrit. Ky sistem është më i avancuar sesa sistemet zonale të klimatizimit me një kanal.

\section{Sistemet me dy rryma ajri}

Me sistemet e tilla çdo lokal furnizohet me dy rryma ajri: me ajrin parësor dhe me ajrin dytësor, të përgatitur në dy kthina të veçanta klimatizimi. Ajri parësor ka mundësi të jepet edhe me sasi të ndryshueshme me qëllim të balancimit të ngarkesës termike nga rrezatimi i diellit, nga procesi teknologjik, nga ndriçimi, .

Këto sisteme gjejnë përdorim te lokalet në të cilat ngarkesa termike gjatë ditës ndryshon shumë (p.sh. dhomat me shumë xhama ose lokalet ku zhvillohen procese teknologjike periodike me lirim të madh të nxehtësisë).

\subsubsection{Sistemet e klimatizimit me ajër-ujë}

Së pari duhet theksuar se aparatet apo ventilokonvektorët kanë përdorim të gjerë. Ventilokonvektorët janë pasisje për qëllime të klimatizimit të hapësirave, ku funksioni primar u tyre është ta bëjë ngrohjen, ftohjen dhe ventilimin. Ventilokonvektorët përbëhen nga një shtëpizë, në të cilën janë: një ventilator me disa shkallë kyçjeje; një këmbyes i nxehtësisë me ujë të ngrohtë dhe me ujë të ftohtë; filtëri; grilat për futjen dhe daljen e ajrit. Këto sisteme gjejnë aplikim në ndërtesa kryesisht publike, si: hotelet, galeritë, ndërtesa shkollore dhe akademike, muzeumet.

Ndërsa, funksioni i tyre realizohet me konvekcionin e shtytur nga ajri me ventilator nëpër këmbyest e nxehtësisë/ftohtësisë. Ventilokonvektorët e ashtuquajtur të tipit vertikal vendosen nën dritare, kurse ata të tipit horizontal vendosen nën tavan (rryma e ajrit duhet të orientohet në drejtim të gjatësisë së lokalit). Këmbyesi i nxehtësisë mund të ketë rrjetin dy gypor, tre gypor ose katër gypor. Ventilokonvektorët shpesh përdoren të veçantë, d.m.th. të ndarë nga lidhja me sistemin e klimatizimit. 
Kështu ajri përgatitet në pajisjen e ventilokonvektortt, $\mathrm{ku}$ behet filtrimi, ngrohja përkatësisht ftohja dhe tharja. Sasia e ajrit te jashtëm (rreth 25\%) përzihet me ajrin e ri qarkulluar .

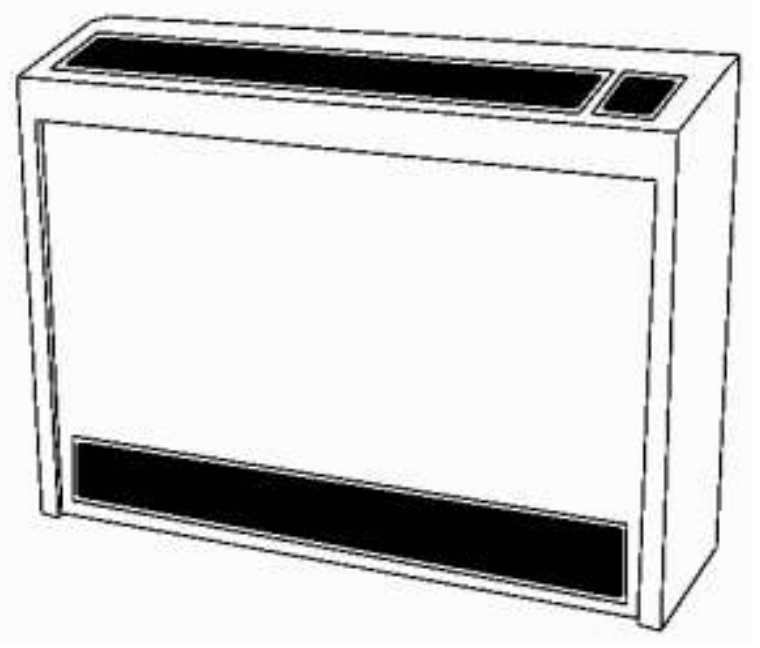

Figura 220. Ventilokonvektorët

(Burimi): Bujar Bajçinovci, 2015.

Kur parashihet lidhja me kaldajën dhe pajisjen e ftohjes, ventilokonvektorët vendosen në plafon ose pranë dritareve. Ventilatori në aparatet e ventilokonvektorëve e merr ajrin e lokalit dhe ajrin parësor të përgatitur, këtë ajër të përzier, ventilatori e shtytë në lokal. Sistemi është i ndarë në zona të caktuara, p.sh. për anën veriore dhe për atë jugore të ndërtesës apo sipa ndinjë kërkese specifike.Në periudhën e dimrit (për ngrohje të ajrit të lokalit) kyçet rrjeti gypor me ujë të ngrohtë nga kaldaja, kurse në periudhën e verës kyçet qillari me ujë të ftohtë $\left(10-12^{\circ} \mathrm{C}\right)$. Në periudhën kalimtare duhet të jenë në dispozicion uji i ngrohtë dhe uji i ftohtë. Kalimi nga një regjim në tjetrin, në secilën zonë, arrihet apo realizohet manualisht ose automatikisht.

Për ventilokonvektorët rekomandohet:

- Rryma e ajrit të orientohet në drejtim të sipërfaqes me xham;

- Të mos vendosen mbi portë dhe pranë dritareve që rrinë hapur.

Përparësitë e këtyre sistemeve janë:

- Mundësia e rregullimit individual, me dorë dhe automatikisht;

- Puna e pavarur edhe pa sistem të klimatizimit;

- Përmasat e vogla dhe vënia e lehtë në veprim;

- Kostoja e ulët e pajisjeve, e instalimit dhe e shfrytëzimit.

Mangësitë e këtyre sistemeve janë:

- Domosdoshmëria e pastrimit të filtrave;

- Prishja e ngjyrës së mbulesës së ventilator-konvektorit me kalimin e kohës;

- Zhurma e madhe. 


\subsubsection{Kthinat qendrore}

Këto pajisje janë kthina për klimatizim të ajrit dhe si njësi vendosen në kulmin e ndërtesës. Ajri i përgatitur shpërndahet (dërgohet) me anë të gypave ose të kanaleve të ajrit deri te lokalet e ndryshme që duhet të klimatizohen. Qendra përmban të gjitha pjesët e nevojshme në dhomëzën e cila është rezistence ndaj korrozionit, e izoluar termikisht dhe vetëmbahet në kulmin i cili nuk e lëshon ujin. Këto pjesë janë:

- Makina ftohëse me kondensatorin që më së shpeshti është me ftohje ajri

- Avulluesi për ftohje ajri

- Ngrohësi i ajrit që duhet të kyçet në rrjetin e ngrohjes të ndërtesës

- Ventilatori me motorin për futje dhe eventualisht edhe për nxjerrje të ajrit

- Dhoma e përzierjes së ajrit të jashtëm dhe të atij ri qarkullues që arrihet nëpërmjet grilave, lagështuesi i ajrit

- Rekuperatori eventual i nxehtësisë ndërmjet ajrit dërgues dhe atij kthyes

Përparësitë e këtyre pajisjeve janë:

- Shpenzimet e vogla për montim dhe kursimi i lokaleve në ndërtesa. Vendosja në kulm sipër lokaleve e sistemit gypor të ajrit është e thjeshtë.

- Mundësia e mirë e rikuperimit të nxehtësisë, pasi ajri i dërgimit dhe ai i kthimit, lehtë mund të përcillen/drejtohen.

- Makinat ftohëse me kapacitetin e tyre duhet t'u përshtaten nevojave për ftohje, për çka ekzistojnë mundësitë e ndryshme

- Përdorimi i shumë makinave ftohëse me një avullues

- Gypi i qarkullimit për gazin e vluar, ose për rregullimin e presionit thithës

Ajri që del nga pajisjet një zonalë ka gjendje të caktuar, kështu që vendosja e këtyre pajisjeve u përgjigjet vetëm zonave me destinim të caktuar, p.sh. lokaleve të mëdha, sallave të ekspozimit, shtëpive të mallrave dhe sallave të fabrikave. Për secilin lokal të madh, për ngrohje të ajrit, në vend të ngrohësit me ujë mund të përdoret pajisja që punon me vaj ose me gaz, kështu që nuk është e nevojshme ndonjë qendër tjetër e vogël. Për ndërtesat me shumë lokale mund të përdoret qendra në kulm dhe atë atëherë kur përdoren grilat rregulluese sikurse te pajisjet shume zonalë, ku për çdo zonë përzihet ajri i ngrohtë me atë të ftohtë varësisht nga temperatura. Qendrat e kulmit mund të përdoren edhe tek instalimet e klimatizimit me induksion për ajrin parësor (primar), sepse këtu përgatitja plotësuese e ajrit bëhet nëpërmjet aparateve me induksion për çdo lokal. Punën e ngrohësit të ajrit me ujë të nxehtë e përcjell rreziku i ngrirjes. Mbrojtja nga ngrirja eventuale mund të arrihet nëpërmjet ngrohjes me energji elektrike.

\subsubsection{Pajisjet shume zonalë të klimatizimit}

Këto pajisje përdoren kur shumë zona me ngrohje të ndryshme dhe me ngarkesë ftohëse të ndryshme duhet të kyçen në pajisjen e përbashkët. Ventilatori shtyn ajrin e thithur në lokal, ku gjenden ngrohësi dhe ftohësi i ajrit. Çdo zonë ka kanalin e ajrit me grila në të cilin përzihen ajri i ngrohtë me të ftohtin, d.m.th. çdo zonë mund të ketë temperaturë të ndryshme (nga zonat e tjera). Rregullimi bëhet nëpërmjet termostatit. 


\subsubsection{Freskuesit-qilarët (chiller-et)}

Pajisjet ftohëse të ajrit ndahen në: pajisje të ftohjes së drejtpërdrejtë (pajisjet e përmendura më sipër) dhe pajisje të ftohjes së tërthortë të ajrit, që quhen qilarë (freskues). Me ftohje të drejtpërdrejtë të ajrit nënkuptohet ftohja e ajrit derisa kalon nëpër avulluesin e pajisjes ftohëse. Me ftohje të tërthortë të ajrit nënkuptohet ftohja e ajrit me anë të ndërmjetësit-fluidit dytësor (ujit ose tretjes me kripë). Meqë këto pajisje kanë bartës për këmbimin e nxehtësisë nga ajri në fluidin ftohës në avullues, shihet që punojnë edhe me temperaturë më të ulët të avullimit dhe me koeficient më të ulët të ftohjes sesa sistemet me ftohje të drejtpërdrejtë.

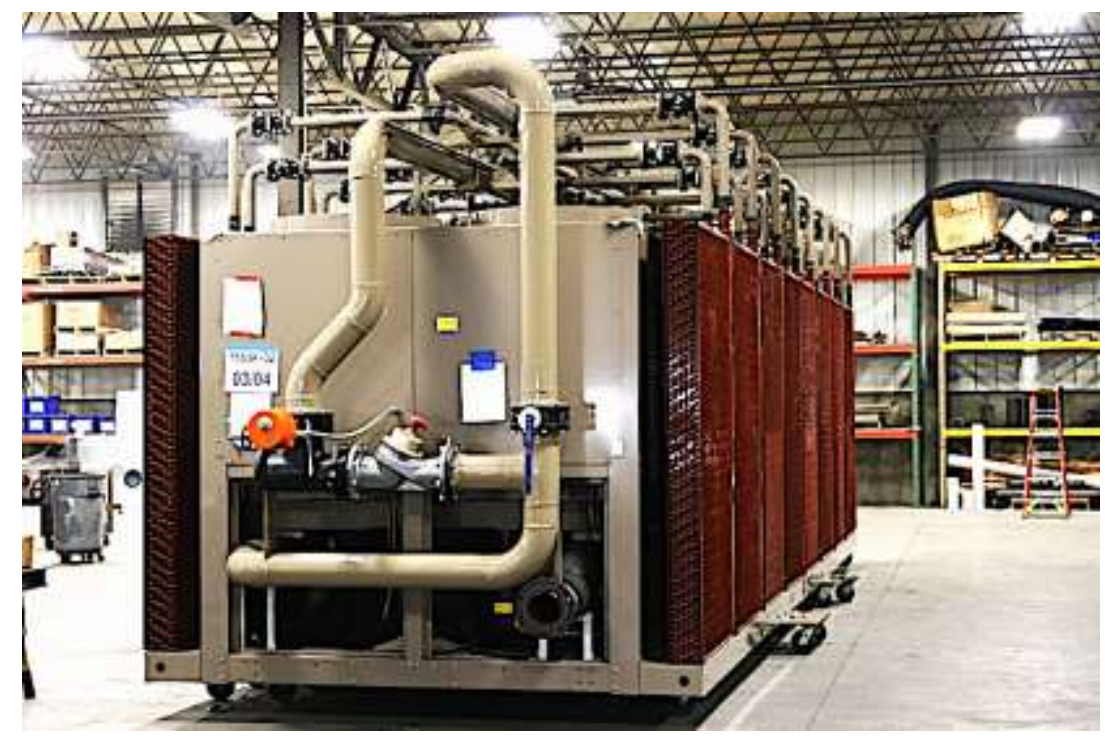

Figura 221. WS Econ Chillers

(Burimi): jblevine2004, 2011. (Flickr). E licensuar nga Creative Commons Attribution Share Alike 3.0

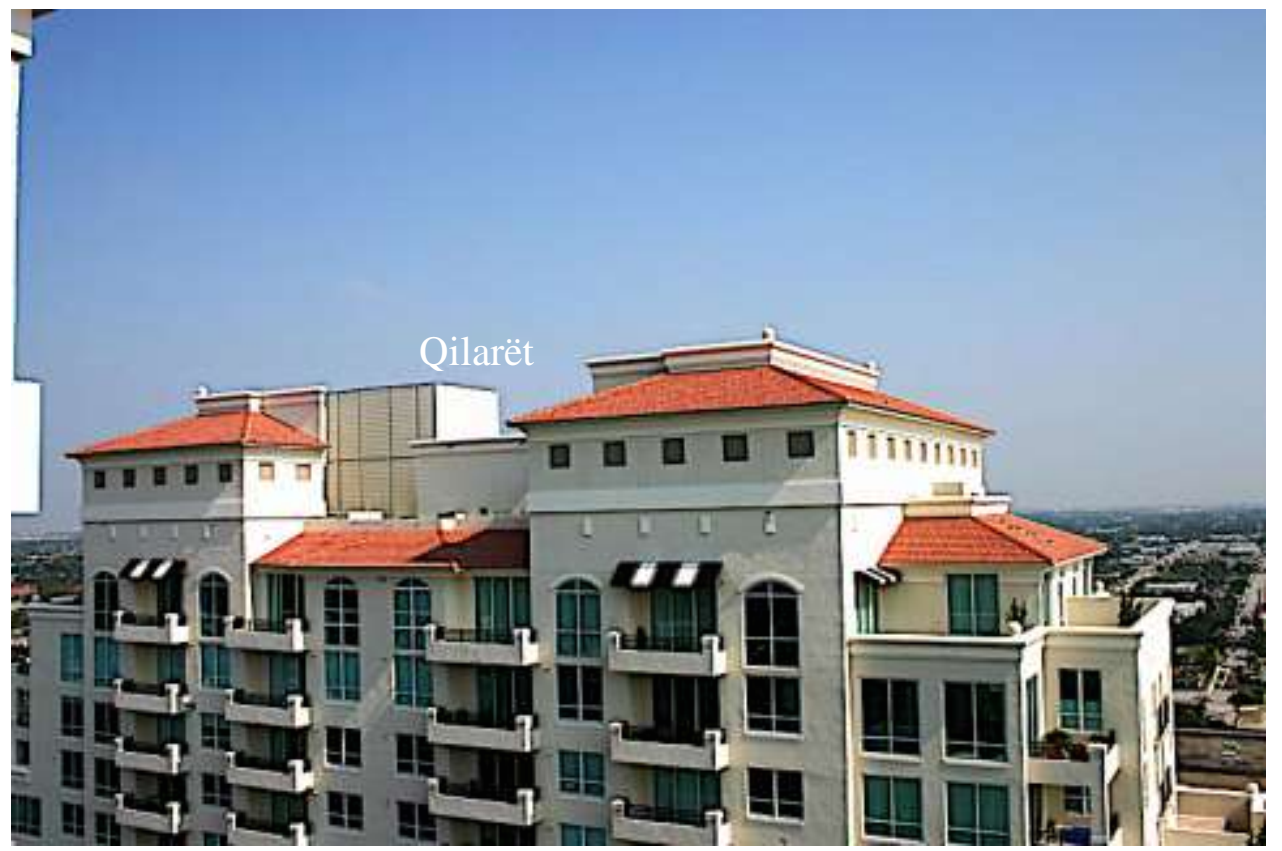

Figura 222. Projekt me banim luksoz. Qilarët dhe HVAC

(Burimi): Soundfighters Systems, 2007. (Flickr). E licensuar nga Creative Commons Attribution 2.0 Generic 
Qilarët mund të vendosen në lokalet që klimatizohen (në aparatet: ventilo-konvektor), ose janë kthina të ftohjes qendrore të ajrit e që nëpërmjet kanaleve e dërgojnë në lokalet që klimatizohen. Zakonisht kur nuk praktikohet sistemi i kondicionimit qendror me ajër atëherë mund të përdoret sistemi qilar i ftohjes. Qilari për ftohje përdorë kondensatorin me ujë (për kapacitete të mëdha), kondensatorin me ajër (për kapacitete të vogla) ose atë me glikolinë. Zakonisht për kondensatorët me ujë merret uji nga kulla ftohëse, kurse për kondensatorët me ajër merret ajri i atmosferës.

Në këto pajisje, siç shihet në fig. ftohet fluidi (ftohës) dytësor, që nëpërmjet pompës dërgohet te këmbyesi i nxehtësisë. Në përdorim janë edhe qilarët elektrik, që përdorin avullin e kompresuar nga cikli i ftohjes për transferim të nxehtësisë. Komponentët themelore të një qilari elektrik, përfshijnë: motorin elektrik, kompresorin ftohës, kondensatorin, avulluesin, pajisjen për zgjerim dhe për kontrollim. Përparësitë kryesore të ftohjes së tërthorte janë: Rregullimi i kapacitetit të pajisjes së klimatizimit është i ndarë nga rregullimi i kapacitetit të qilarit, nëpërmjet të cilit mbahet temperaturë pothuajse e pandryshueshme e fluidit dytësor; sistemi i dërgimit të fluidit ftohës dytësor mund të shfrytëzohet edhe për dërgimin e ujit të ngrohtë në stinën e dimrit; kapaciteti ftohës i shpenzuesve është relativisht i thjeshtë dhe rregullohet duke ndryshuar prurjen e fluidit dytësor nëpër shpenzues. Mangësi themelore e këtij sistemi të ftohjes: është rritja e shpenzimeve të energjisë për shkak të koeficientit të ulët të ftohjes dhe e shpenzimeve të energjisë për ngasjen e pompës, që realizon qarkullimin e fluidit ftohës dytësor.

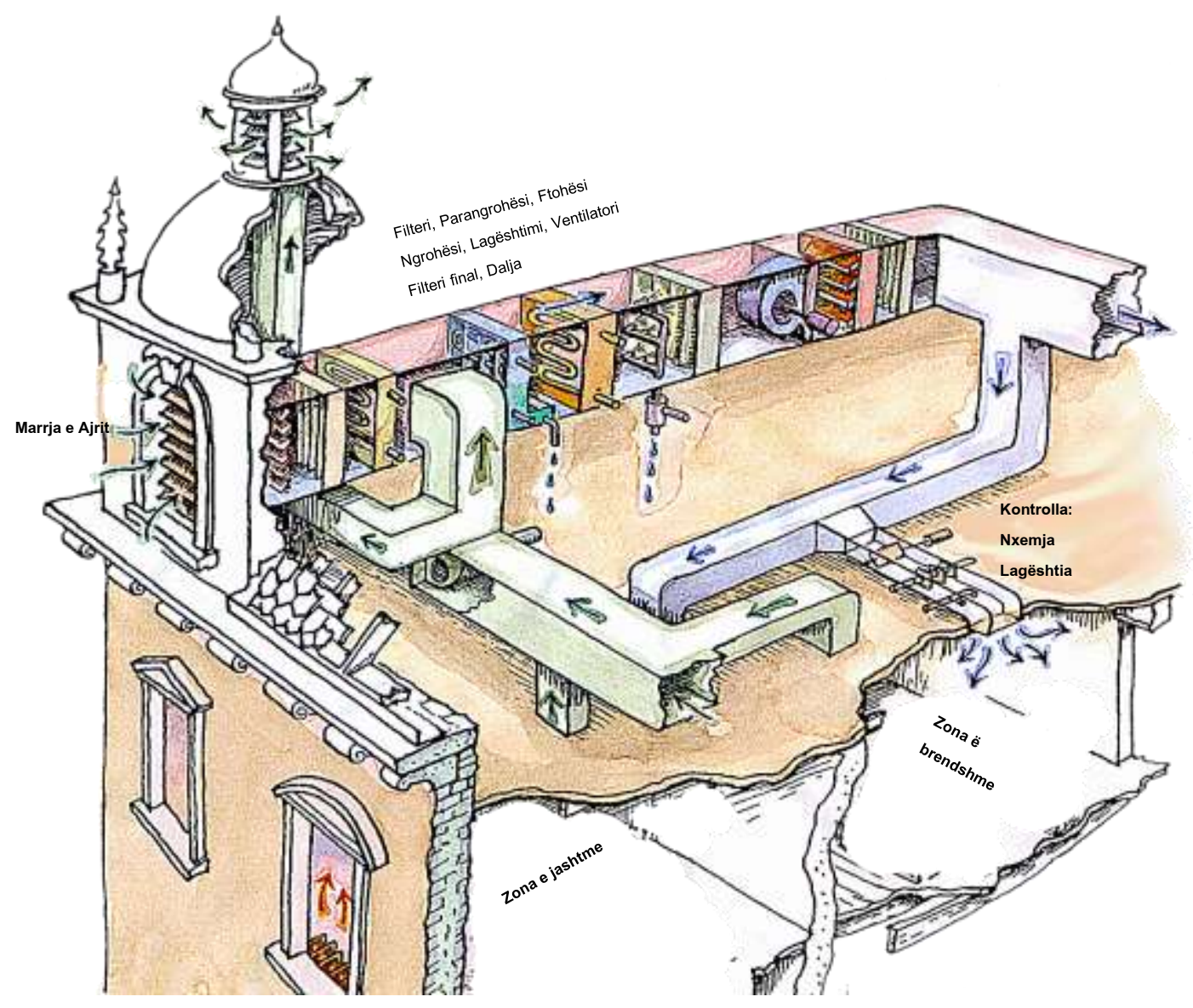

Figura 223. HVAC Sistemi, funksioni dhe komponentët (Burimi): Tim Padfield, 2000. How air conditioning works. 


\subsubsection{Gjeotermale - sistemi aktiv}

Programi i pompave termike të Rehau, shfrytëzon burimet e ngrohtësisë nga trualli, ajri ose uji dhe ka në dispozicion gamë të fuqisë maksimum derri në $56 \mathrm{~kW}$, temperaturë primare maksimale deri 55 gradë dhe është ideale për ndërtimet e reja si dhe për sanime energjetike. Pompat termike gjeotermale mund të ftohin në mënyrë pasive, kjo do të thotë se ,të ftohtit“ natyror nga trualli ose nga ujërat nëntokësore mund të përdoren për ftohjen e ndërtesës. Nëpërmjet ndryshimit të drejtimit të qarkullimit të pompave termike gjatë verës, pompa termike mund të përdoret për ftohje. Nxehtësia e marrë nga sistemi për ngrohje me ndihmë të kompresorit në mënyrë aktive përcillet te trupi ngrohës, bëhet fjalë për pompa termike reverzibile kurse bartja e drejtimit të rrjedhjes kryhet automatikisht. Kontrolli i rregullimit i vendosur në pompat termike është i përshtatshëm për regjimin e ngrohjes dhe ftohjes, siguron funksionim individual plotësisht të automatizuar.

Tabela 46. Pompat termike, funksioni dhe komponentët (Burimi): () REHAU

\begin{tabular}{|c|c|c|c|c|c|}
\hline $\begin{array}{l}\text { Të dhënat mbi } \\
\text { fuqinë }\end{array}$ & $\begin{array}{c}\text { Testuar sipas } \\
\text { DIN EN } \\
14511\end{array}$ & $\begin{array}{c}\text { Fuqia } \\
\text { sipas EN } \\
255\end{array}$ & $\begin{array}{c}\text { Fuqia e } \\
\text { ngrohjes }\end{array}$ & $\begin{array}{c}\text { Fuqia e } \\
\text { ftohjes gjatë } \\
\text { ftohjes aktive }\end{array}$ & $\begin{array}{c}\text { Niveli i } \\
\text { shtypjes së } \\
\text { zërit }\end{array}$ \\
\hline $\begin{array}{l}\text { Pompa termike } \\
\text { GJEO sole } \\
\text { /ujore }\end{array}$ & $\begin{array}{c}4,0 \text { deri në } \\
4,4\end{array}$ & $\begin{array}{c}4,4 \text { deri në } \\
4.7\end{array}$ & $\begin{array}{l}5 \mathrm{~kW} \text { deri } \\
\text { në } 45 \mathrm{~kW}\end{array}$ & $\begin{array}{c}6 \mathrm{~kW} \text { deri në } \\
56 \mathrm{~kW}\end{array}$ & \\
\hline $\begin{array}{l}\text { Pompa termike } \\
\text { AERO* } \\
\text { ajër/ujë }\end{array}$ & $\begin{array}{c}3,4 \text { deri në } \\
3,5\end{array}$ & $\begin{array}{c}3,7 \text { deri në } \\
3,8\end{array}$ & $\begin{array}{l}8 \mathrm{~kW} \text { deri } \\
\text { në } 33 \mathrm{~kW}\end{array}$ & $\begin{array}{c}10 \mathrm{~kW} \text { deri në } \\
35 \mathrm{~kW}\end{array}$ & $\begin{array}{c}40 \mathrm{db}(\mathrm{a}) \\
\text { deri në } 47 \\
\mathrm{db}(\mathrm{a})\end{array}$ \\
\hline $\begin{array}{l}\text { Pompa termike } \\
\text { AQUA ujë/ujë }\end{array}$ & $\begin{array}{c}5,1 \text { deri në } \\
5,5\end{array}$ & $\begin{array}{c}5,1 \text { deri në } \\
5,8\end{array}$ & $\begin{array}{l}7 \mathrm{~kW} \text { deri } \\
\text { në } 56 \mathrm{~kW}\end{array}$ & $\begin{array}{l}6 \mathrm{~kW} \text { deri në } \\
56 \mathrm{~kW}\end{array}$ & \\
\hline
\end{tabular}

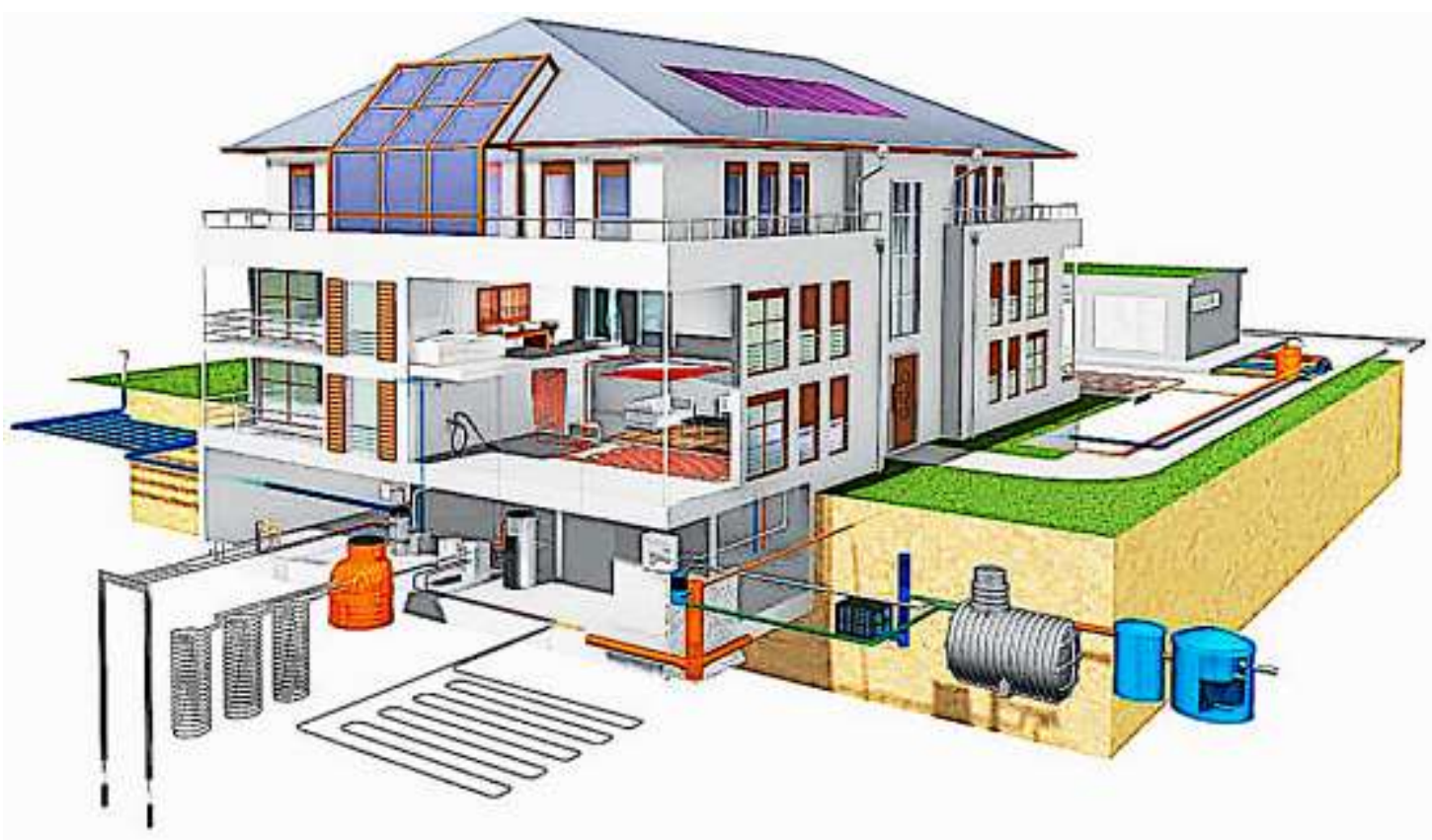

Figura 224. HVAC Sistemi, funksioni dhe komponentët (Burimi): (c) REHAU, 2014. 
PROJEKTIMI I QËNDRUESHËM

KJO FAQE ËSHTË LËNË QËLLIMISHT E ZBRAZËT! 


\section{SHEMBULL STUDENTESH NGA NIVELI MASTER}

Niveli Master 2013/14 ${ }^{100}$. Fakulteti i Ndërtimtarisë dhe Arkitekturës, Universiteti i Prishtinës. Lënda: Sistemet Bashkëkohore II. Kandidati: Alban Kabashi

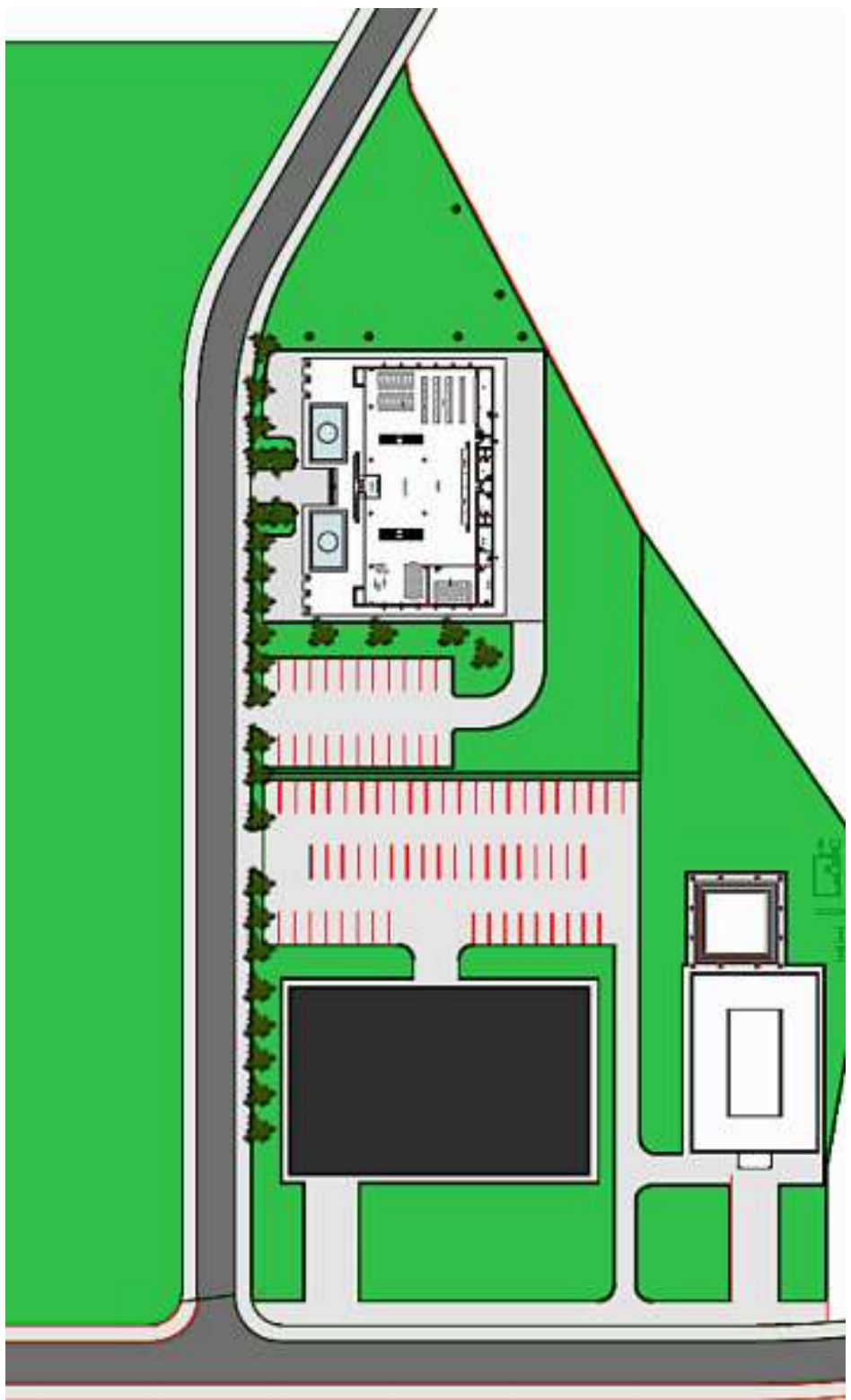

Figura 225. Bibliotekë, Situacioni, Therandë

(Burimi): Fakulteti i Ndërtimtarisë dhe Arkitekturës, Universiteti i Prishtinës, 2014.

100 Alban Kabashi, Lënda: Sistemet Bashkëkohore II. Master. Punimi i tërë sipas dorëzimit final. 

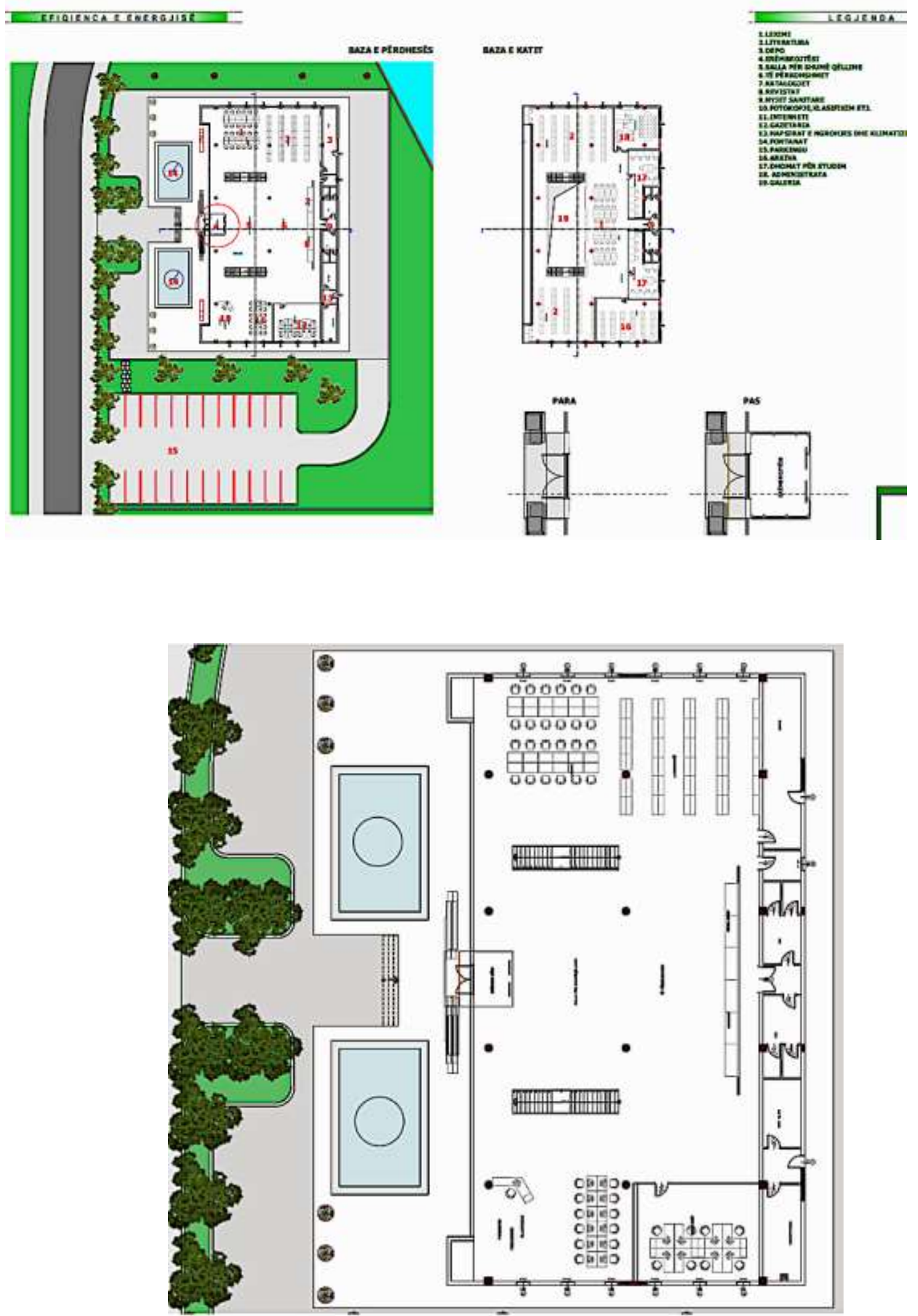

Figura 226. Bibliotekë, Situacioni, Therandë

(Burimi): Fakulteti i Ndërtimtarisë dhe Arkitekturës, Universiteti i Prishtinës, 2014. 
PRERJA GJATESORE E OBJEKTIT
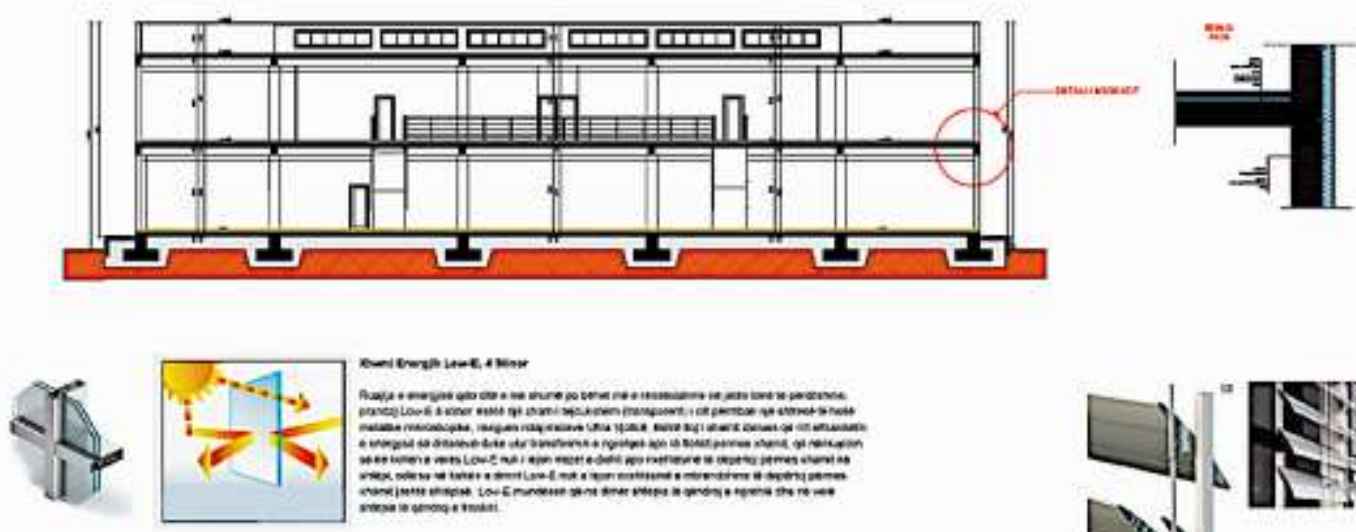

nom

PRERJA TERTHORE E OBJEKTIT
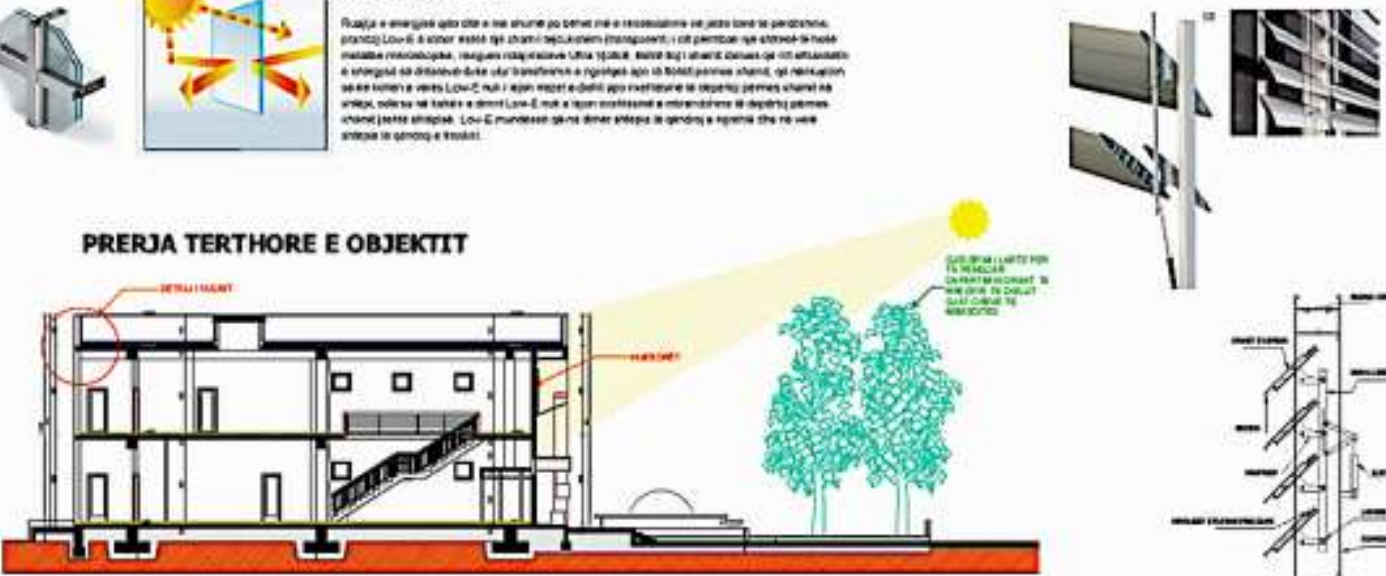

I

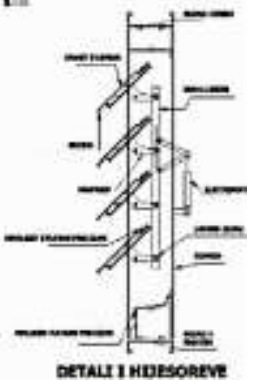

FASADA JUGORE

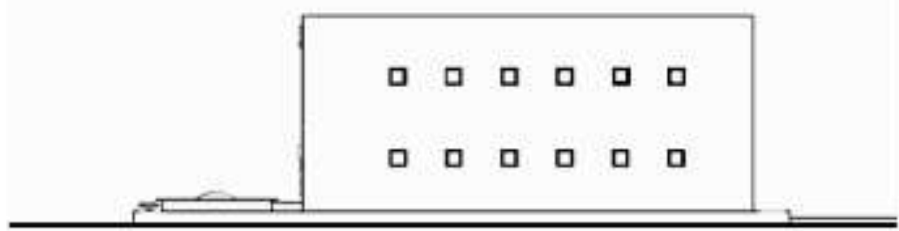

FASADA PERENDIMORE

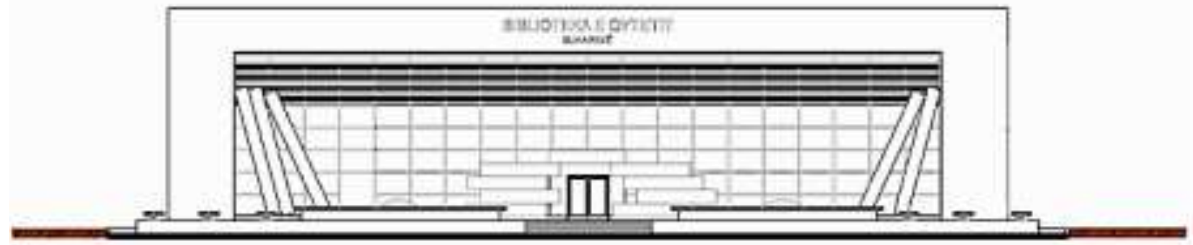

Figura 227. Bibliotekë, Situacioni, Therandë

(Burimi): Fakulteti i Ndërtimtarisë dhe Arkitekturës, Universiteti i Prishtinës, 2014. 

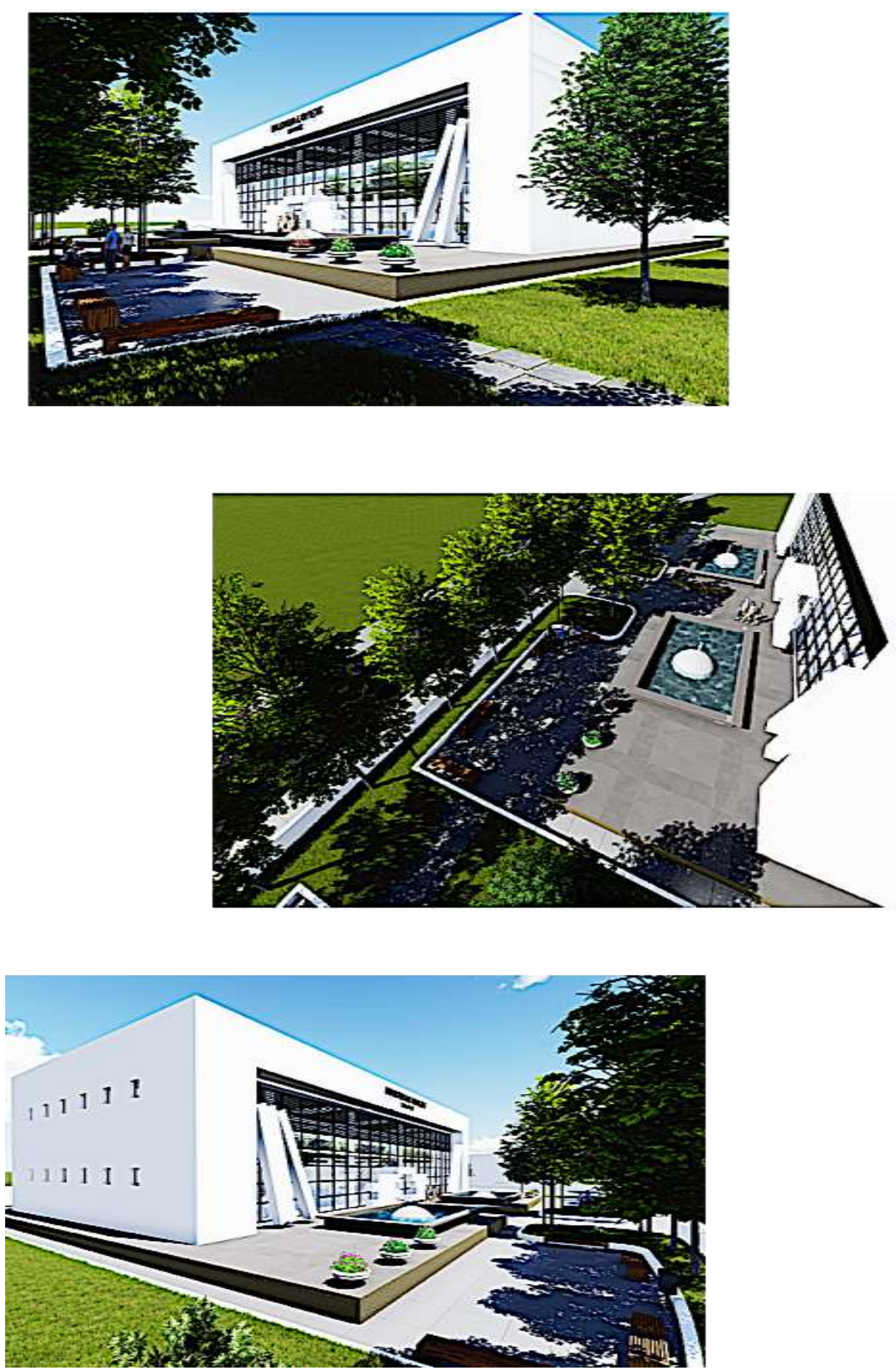

Figura 228. Bibliotekë, Situacioni, Therandë

(Burimi): Fakulteti i Ndërtimtarisë dhe Arkitekturës, Universiteti i Prishtinës, 2014. 
Niveli Master 2014/15 ${ }^{101}$

Kandidati: Berat Istogu

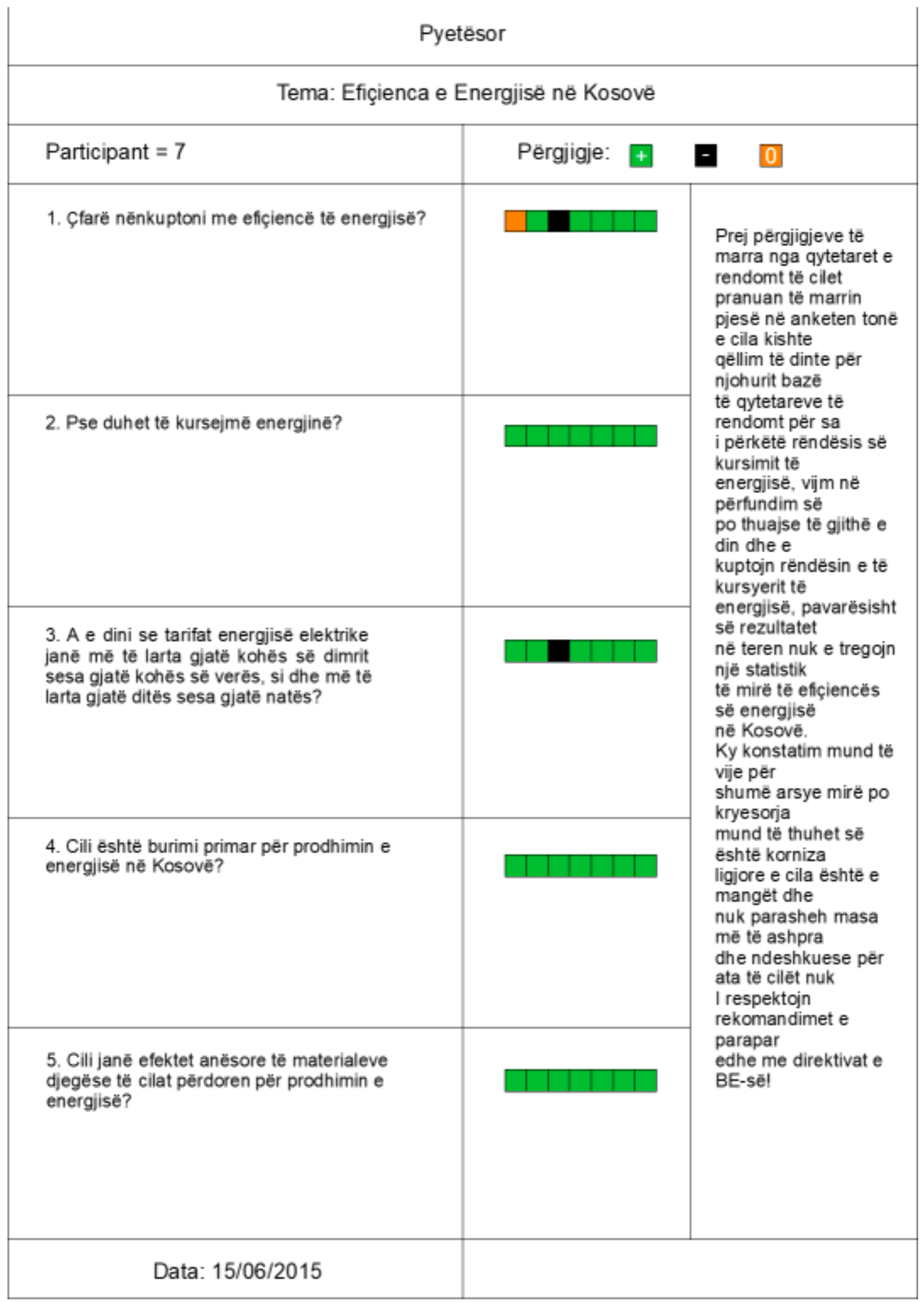

Figura 229. Pyetësori, Prishtinë

(Burimi): Fakulteti i Ndërtimtarisë dhe Arkitekturës, Universiteti i Prishtinës, 2015.

101 Berat Istogu. Lënda: Sistemet Bashkëkohore II. Master. Punimi i tërë sipas dorëzimit final. 


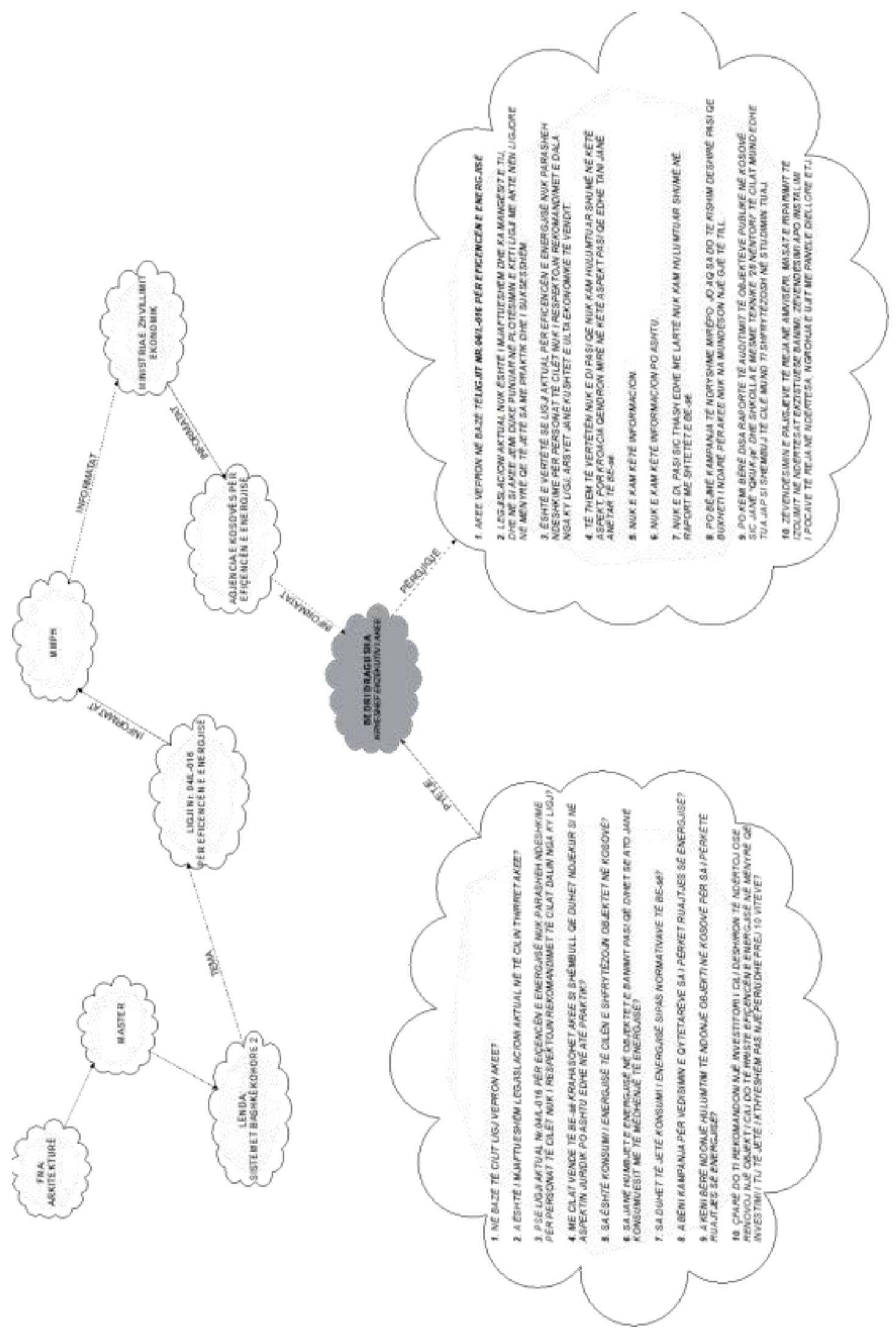

Figura 230. Mindmapping

(Burimi): Fakulteti i Ndërtimtarisë dhe Arkitekturës, Universiteti i Prishtinës, 2015. 

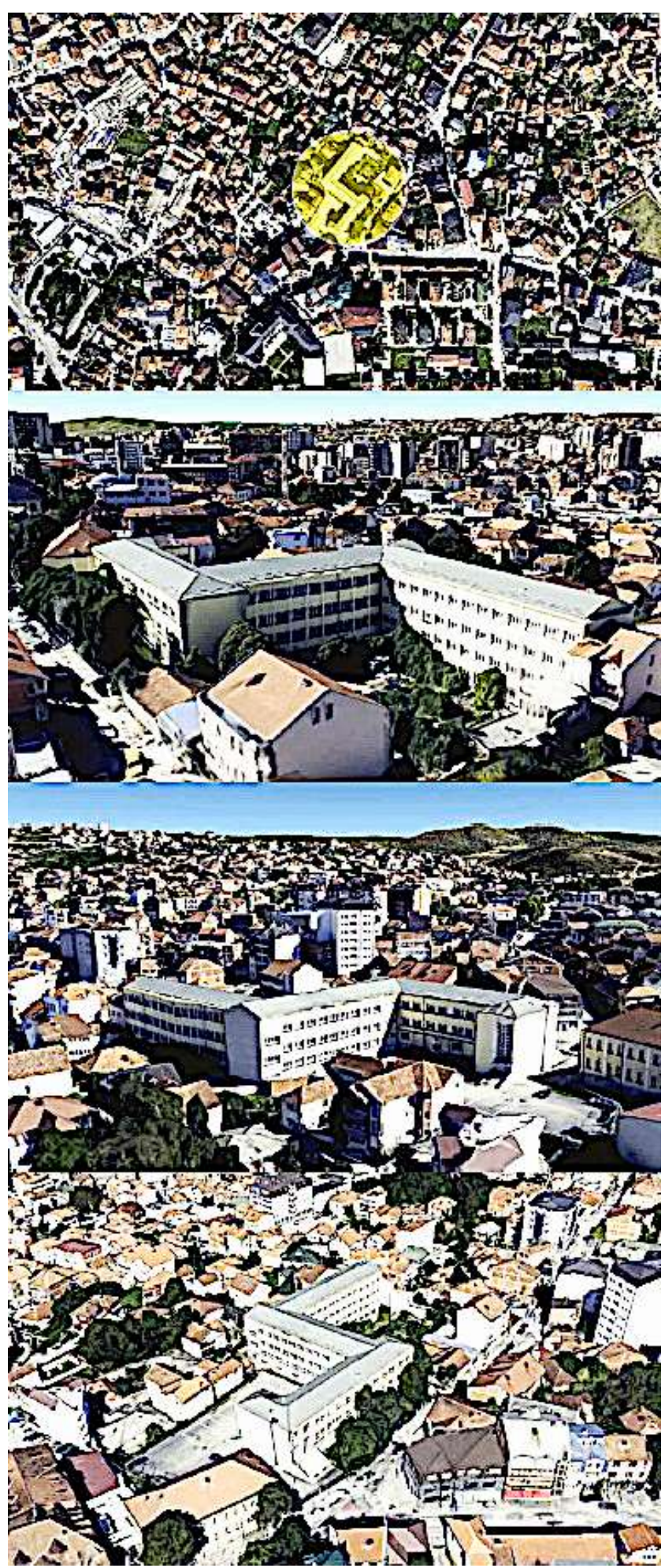

Shembull studimi: Rritja e energjisë eficiente. Shkolla e mesme teknike "28 Nëntori" Prishtinë

Shkolla e mesme teknike "28 Nëntori" gjendet në Prishtinë, përkatësisht në zonën e vjetër të qytetit.

Figura 231. Shkolla e mesme teknike "28 Nëntori"

(Burimi): Fakulteti i Ndërtimtarisë dhe Arkitekturës, Universiteti i Prishtinës, 2015. 

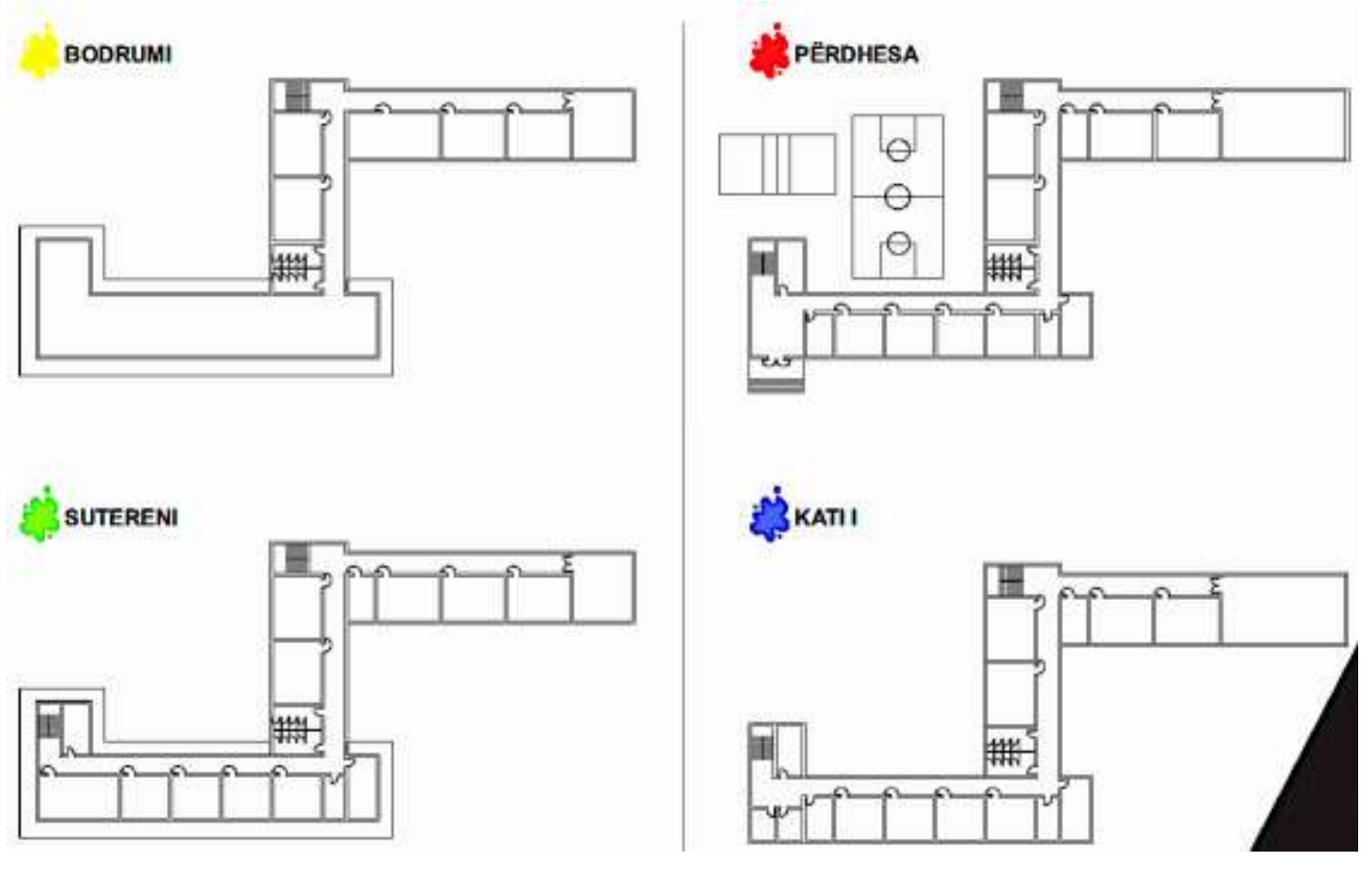

Figura 232. Bazat. Shkolla e mesme teknike "28 Nëntori"

(Burimi): Fakulteti i Ndërtimtarisë dhe Arkitekturës, Universiteti i Prishtinës, 2015.

Bodrumi - Bodrumi i ndërtesës është i vendosur vetëm në pjesën Verilindore të objektit. Ka hyrje të veçantë nga ana e oborrit të shkollës dhe shfrytëzohet për Sallë të Edukatës Fizike me zhveshtore si dhe hapësira teknike-depo, arkiva. .

Sutereni - Meqenëse Sutereni ka lartësi të madhe $(\mathrm{h}=5.5 \mathrm{~m}$ ') ka dritë të mjaftueshme për zhvillimin e procesit mësimor gjë e cila edhe zhvillohet për momentin. Hapësirat të cilat i përfshinë kjo etazhë janë 10 Klasa, 3 depo si dhe Kaldatoren.

Përdhesa - Përdhesa e objektit është e ngritur nga kuota e terrenit për lartësinë h=2 m'. Kjo etazhë shërben për të vendosur 8 Klasë, Një amfiteatër, 3 kabinete shkencore, tualetet dhe si dhe dy zyre.

Kati I-rë - Kati i Parë i ndërtesës është me lartësi $h=3.5[\mathrm{~m}]$ dhe shërben për vendosjen e 8 Klasave, 3 kabineteve shkencore, Një amfiteatër, tualetet, 3 zyre administratë dhe sallën e arsimtarëve. 


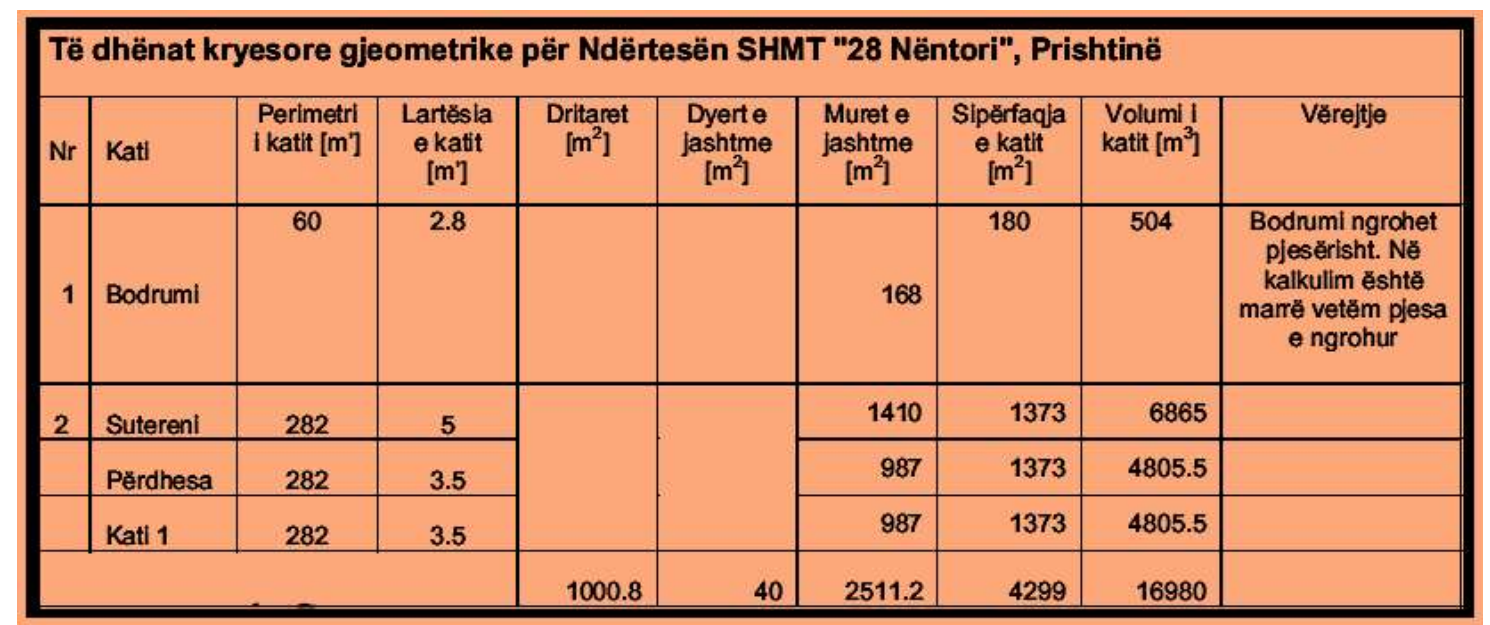

Tabela 47. Dimensionet. Shkolla e mesme teknike "28 Nëntori"

(Burimi): Fakulteti i Ndërtimtarisë dhe Arkitekturës, Universiteti i Prishtinës, 2015.

Raport Standard i Auditimit. Agjencia Kosovare për Efiçiencë të Energjisë (AKEE)

\section{Menaxhimi i energjisë dhe auditimi i energjisë në ndërtesa}

Auditimi i energjisë ka për qëllim që të identifikojë dhe balancojë mundësitë për kursim te energjisë me kosto-efektive për objekte banimi apo ndërtesa.

Në një auditim të energjisë qëllimi kryesor është që:

a. Të bëhet diagnostikimi i gjendjes ekzistuese te ndërtesës në raport me konsumin e energjisë.

b. Të identifikoj, evidentoj dhe prezantoj fushat e konsumit të energjisë,(ngrohje, ftohje, gatim, pajisje elektrike, ndriçim, përgatitjen e ujit sanitar)

c. Të evidentoj kapacitetet e instaluara, gjendjen si dhe efikasitetin e tyre.

d. Të analizoj gjendjen e mbështjellësit të jashtëm të ndërtesës dhe rekomandoj masa me qëllim të zvogëlimit të humbjeve termike në mbështjellës.

e. Identifikon nivelin e komforit, kushteve të punës, mësimit apo të zhvillimit të aktiviteteve ditore,

f. Të identifikojë mundësitë për kursim në fushat tjera,

g. Të propozoj masat për zvogëlimin e konsumit te energjisë duke ruajtur apo rritur nivelin komforit

h. Të rekomandoj masat si dhe koston e këtyre masave që janë të lidhura drejt për së drejti me kursimin e energjisë,

i. Përgatitë raportin final. 
Të dhënat që duhet analizuar janë:

a. Faturat e energjisë (energji elektrike, lëndëve djegëse) për periudhën e auditimit, për tri vitet e fundit (apo/dhe parashikimet për vitin e ardhshëm).

b. Planimetria arkitektonike e ndërtesës, mbështjellësi i jashtëm, instalimet elektrike dhe ato makinerike si dhe rendimenti i tyre.

c. Karakteristikat e ndërtimit/strukturës, destinimi, kohëzgjatjes së operimit të ndërtesës si dhe aparateve/pajisjeve të instaluara.

d. Të dhënat klimatike për periudhën në të cilën është duke u bërë auditimi.

Auditorët e energjisë janë persona të kualifikuar dhe të certifikuar për auditime të energjisë elektrike dhe termike, apo madje për auditimin energjetik të plotë të objektit dhe që kanë diploma në lëmitë përkatëse: Arkitekturë, Makineri dhe Elektroteknikë.

\section{Instalimet energjetike dhe termike te ndërtesës të cilat kontrollohen gjatë auditimit}

Procesi i auditimit energjetik të objekteve që në rastin konkret fokusi i këtij auditimi bazohet në këto fusha:

\section{Instalimet makinerike}

- Kaldatorja-Nënstacioni i ngrohjes me pajisjet përcjellëse

- Flakëdhensi, pompat dhe gypat në nënstacion

- Radiatorët dhe sistemi shpërndarës i tubacionit.

- Rendimenti si dhe koha e operimit të tyre

\section{Instalimet elektrike}

- Ndriçimi

- Pajisjet elektrike

- Pajisjet termo-elektrike

- Sistemet e alarmimit, sigurisë dhe emergjencës

- Pajisjet për IT

Ndërsa sa i përket fazës së Auditimit të Energjisë në ndërtesë, janë mbledhur të dhëna preliminare që kanë të bëjnë me sjelljen sa i përket konsumit të energjisë:

a. Informata të përgjithshme rreth ndërtesës (lloji i ndërtesës, viti i ndërtimit, lloji i shfrytëzimit dhe shërbimeve të ofruara, statusi i pronësisë, renovimet-zgjerimet e mundshme në fasadën e instalimeve të saj, sipërfaqja dhe vëllimi i ndërtesës, numri i shfrytëzuesve, produktet dhe pajisjet relevante të shërbimeve).

b. Të dhënat mbi konsumin e energjisë dhe faturat e energjisë për së paku tri vitet e fundit (evaluimi vjetor i konsumit të lëndëve djegëse dhe energjisë elektrike, variacionet mujore sa i përket konsumit brenda vitit që është nën hulumtim).

c. Statusi i Menaxhimit të Energjisë dhe ndonjë masë e kursimit të energjisë që është ndërmarrë. 


\section{Përfitimet nga auditimi energjetik}

Auditimi energjetik në ndërtesën e Shkollës Teknike "28 Nëntori” Prishtinë, ka sjellur këto përfitime financiare, operacionale dhe mjedisore

- Ka identifikuar gjendjen e tanishme në të cilën funksionon/operon ndërtesa

- Ka identifikuar nivelin e komforit dhe mundësitë për reduktim të konsumit të energjisë

- Ka identifikuar fushat e kursimit të energjisë, masat për kursim dhe koston investive

- Ka identifikuar fushat e përmirësimit të komforit dhe standardeve në të cilat operon ndërtesa

- Ka identifikuar kushtet për përmirësimin e rrethanave mjedisore

\section{Përfitimet financiare}

Ka dy metoda kryesore për vlerësimin e përfitimeve nga masat e kursimit të energjisë; metodat statike dhe dinamike e vlerësimit. Në raportin tonë ne kemi aplikuar metodat dinamike të vlerësimeve, për të llogaritur normën e brendshme të kthimit IRR, NPV dhe periudhën e thjeshtë të kthimit të mjeteve PBP. Analizat i kemi bazuar në çmimet financiare dhe ekonomike të parashikuara për 15 vitet e ardhshme.

Tabela 48. Potenciali i kursimit i prezantuar përmes indikatorëve financiar (Burimi): Fakulteti i Ndërtimtarisë dhe Arkitekturës, Universiteti i Prishtinës, 2015.

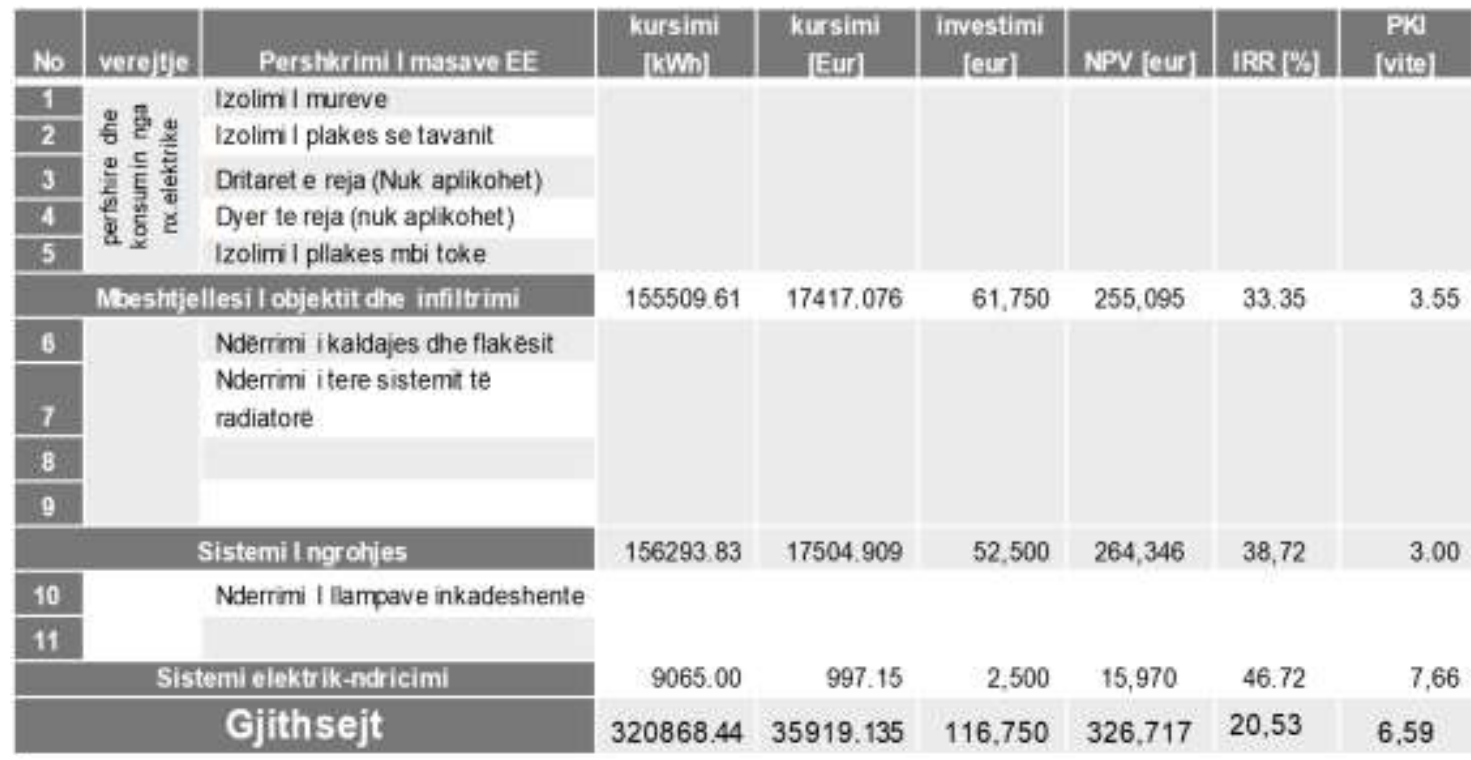

Analiza e bazuar në faktorët ekonomik merr parasysh jo vetëm aspektin financiar të investimit por edhe kursimet e vendit në aspektin e zvogëlimit të emetimeve të C02. 
Tabela 49. Potenciali i kursimit i prezantuar përmes indikatorëve financiar (Burimi): Fakulteti i Ndërtimtarisë dhe Arkitekturës, Universiteti i Prishtinës, 2015.

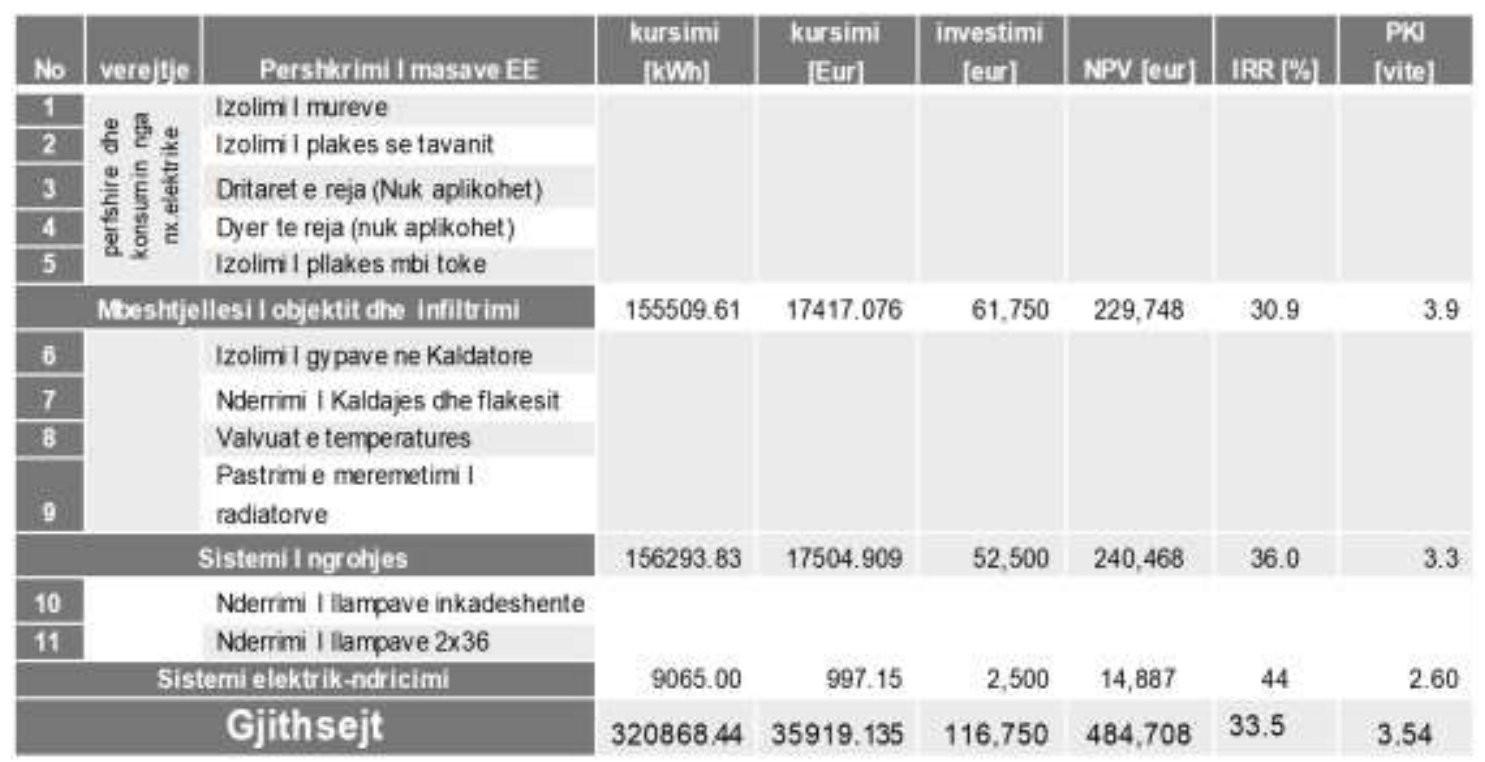

\section{Përfitimet operacionale}

Përfitimet operacionale janë si rrjedhojë e përmirësimit të kushteve në të cilat ka funksionuar/operuar objekti. Këto përfitime kanë të bëjnë kryesisht me përmirësimin e kualitetit të ajrit në objekt, ngritjen e temperaturës së brendshme në standardet e kërkuara, përmirësimin e ndriçimit në hapësirat punuese. Shprehur figurativisht diferenca mes kushteve operacionale ekzistuese (gjendja e raportuar apo e matur në vend) dhe gjendjes së llogaritur së komforit paraqet përfitimin operacional.

\section{Masat e ndërmarra}

Masat e ndërmarra mund të jenë me kosto të ndryshme financiare, duke filluar nga ato që nuk kanë implikime financiare (pa kosto), masat me kosto të mesme dhe masat me kosto të lartë financiare.

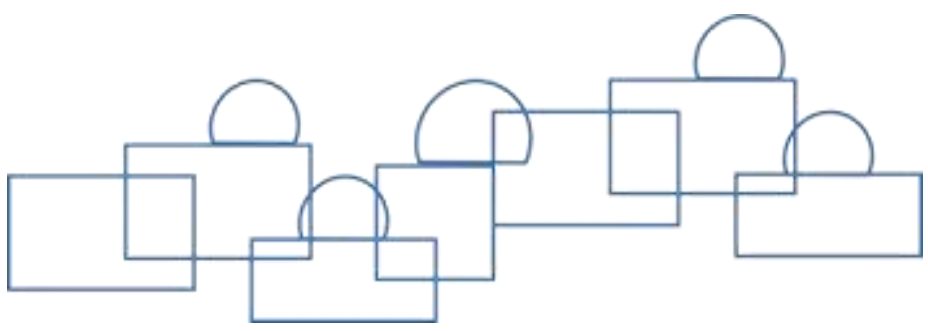


Tabela 50. Masat e propozuara

(Burimi): Fakulteti i Ndërtimtarisë dhe Arkitekturës, Universiteti i Prishtinës

\begin{tabular}{|c|c|}
\hline Kategorizimi i masave EE & पoji mases se propozuar \\
\hline $\begin{array}{l}\text { Masat EE pa kosto financiare apo me kosto te ulet } \\
\text { financiare. } \\
\text { (Keto jane masa qe kane te bejng kryesisht me } \\
\text { aspaktin e vetedijesimit dhe mirembajtjes) }\end{array}$ & $\begin{array}{l}\text { - } \quad \text { Ndalja e dritave kur nuk perdoren } \\
\text { - } \quad \text { Pastrimi i rregulit i kutise se dritave fluoreshente } \\
\text { pèrdorim } \\
\text { - } \quad \text { Mos-hapja e dritareve kur sistemet AC jane ne funksion } \\
\text { - } \quad \text { kjosja e rregulit e hapesirave por jo edhe hapja e drtareve } \\
\text { kur sistemi i nxerrjes eshte ne funksion } \\
\text { Mirembajtja e rregult e kaldase, flakesit, radiatoreve dhe } \\
\text { rezervuaréve }\end{array}$ \\
\hline Masat me kosto financiare té mesme & $\begin{array}{l}\text { Nderrimi i llambave inkadeshente me llamba HE Furoshente } \\
\text { dhe Llamba kompakte Fluroshente-CFL } \\
\text { Instalimi i siguresave automatike } \\
\text { Instalimi i dritave me senzore té lévizjes (ku èshté e mundur) } \\
\text { - Instalimi i termo-rregulluesve ne radiatore }\end{array}$ \\
\hline Masat me kosto te larte financiare & $\begin{array}{l}\text { Izolimi termik I mbeshtjellesit te objektit } \\
\text { Instalimi i sistemit ter ngrohjes gendrore } \\
\text { Nderrimi idritareve }\end{array}$ \\
\hline
\end{tabular}

\section{Përfitimet mjedisore}

a. Zvogëlimi i emetimit të gazrave të dëmshëm nga operimi i ndërtesës si dhe lartë gjerë të furnizuesi vendor me energji

b. Zvogëlimi i kërkesës për energji në nivel nacional

c. Ngritja e kualitetit jetësor nga redukimi i partikulave në ajër dhe redukimi i sasisë së gazrave të dëmshme.

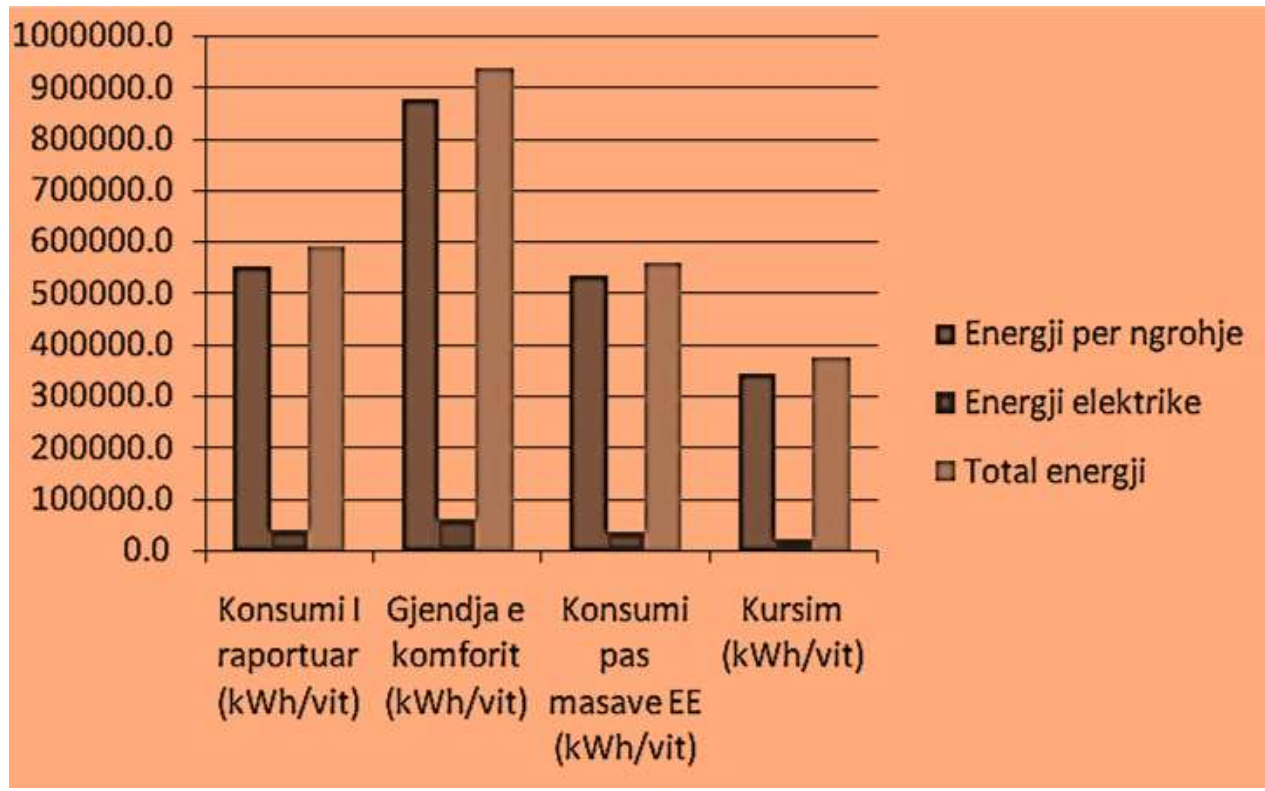

Figura 233. Vlerësimet energjetike. Shkolla e mesme teknike " 28 Nëntori" (Burimi): Fakulteti i Ndërtimtarisë dhe Arkitekturës, Universiteti i Prishtinës, 2015. 
Në bazë të analizës së bërë për skenarë të ndryshëm të konsumit të energjisë, arrijmë në përfundim se në përgjithësi ka hapësirë të mjaftueshme për kursim të energjisë në ndërtesë. Konsumi i raportuar për ngrohje ka qenë më i ulët se konsumi për gjendjen e standardizuar të komforit.

Tabela 51. Masat e propozuara

(Burimi): Fakulteti i Ndërtimtarisë dhe Arkitekturës, Universiteti i Prishtinës, 2015.

\begin{tabular}{|c|l|c|}
\hline No & $\begin{array}{l}\text { Masa EE të propozuar për } \\
\text { implementim }\end{array}$ & Total kosto investive $(\boldsymbol{\epsilon})$ \\
\hline 1 & Mbështjellësi i objektit & $61,750.40$ \\
\hline 2 & Energji Elektrike & $2,500.00$ \\
\hline 3 & Sistemi i ngrohjes & $52,500.00$ \\
\hline 6 & Total kostoja & $116,750.40$ \\
\hline
\end{tabular}

"Ndërtesa e shkolles teknike "28 Nentori” në Prishtinë, është një objekt i vjetër në gjendje të dobët sa i përket efiçiencës së energjisë. Në ndërtesë nuk ka komfor të brendshëm si në aspektin e ngrohjes ashtu edhe atë të ndriçimit. Në gjendjen ekzistuese ndërtesa paraqet një konsumator me $202[\mathrm{kWh} / \mathrm{m} 2 / \mathrm{vit}]$ e cila vie si rezultat i mureve masive nga tulla dhe dritareve të reja PVC. Pas marrjes së masave EE konsumi specifik zbret në [127 kWh/m2/vit]. Të gjeturat e auditimit në këtë ndërtesë tregojnë se me një investim prej 116,750.40 € periudha e kthimit të investimit është 5 vite, çka e bën këtë investim atraktiv dhe që ia vlen për t'u investuar.

Masat e rekomanduara për kursim me kosto të ulët financiare apo dhe pa kosto financiare

Këtu përfshihen ndërmarrja e masave me investim financiar të ulët apo edha pa ndonjë investim financiar të cilat zakonisht kanë të bëjnë me mirëmbajtje dhe vetëdijesim të përdoruesve të ndërtesës.

1. Mirëmbajtja periodike e kaldasë dhe gypacionit të shpërndarjes

2. Pastrimi i oxhakut

3. Fikja e dritave dhe ventilatorëve kur nuk qëndrohet në atë hapësirë,

4. Pastrimi periodik i kapakëve të dritave fluoreshente

5. Shumë pajisje elektronike shpenzojnë edhe kur nuk janë në funksion, çkyçja nga rryma e tyre.

6. Vetëdijesimi i personelit të që çkyç nga rrjeti kompjuterët dhe monitorët pasi të mbarojnë punën

7. Vetëdijesimi i përdoruesve të ndërtesës që të mos ndezin dritat kur ka ndriçim të mjaftueshëm natyral.

8. Mos hapja e dritareve për më shumë se nevojitet për ajrosje në mëngjes gjatë kohës kur sistemi i ngrohjes është në funksion.” 
Niveli Master 2014/15 ${ }^{102}$

Kandidati: Ermir Bajmaku

“Objektet shkollore në përgjithësi dhe Objekti i Ruzhdijes (Gjimnazit) në veçanti janë të rëndësishme sepse e paraqesin jetën kulturore të banorëve të Kosovës varësisht prej periudhës kohore. Diverziteti i shkollave (ne krahasim me shkollat osmane fetare) si në plane mësimore, koncept të mësuarit, dhe në aranzhimin e hapësirës së mësimit si dhe filozofia dhe trajtimi arkitektonik i objektit, e bëjnë të rëndësishme dhe prioritare ruajtjen e këtij objekti.

Ruzhdija në aspektin arkitektonik nuk është studiuar dhe trajtuar sa duhet për dallim prej objekteve tjera rezidenciale apo sakrale të qytetit të Prizrenit.

Ky trajtim neglizhues ndaj këtij objekti ka rezultuar në humbjen e pavërejtur dita ditës të tipareve të trashëgimisë sonë historike-kulturore. Krejt kjo humbje ka ndodh si rezultat i përqendrimit te vëmendjes tek objektet tjera monumentale sakrale apo rezidenciale të qytetit të Prizrenit. Deri tek humbja e objektit vie si pasojë e zhdukjes ose si pasojë e mos gjetjes së destinimit dhe funksionit të duhur në raport me kushtet e reja shoqërore apo mospërputhjes me dispozitat bashkëkohore urbanistike. Moskujdesi ndaj këtij objekti si nga qytetarët ashtu edhe nga administratat udhëheqëse të periudhave të ndryshme kanë bërë që ky objekt dita ditës të zhdukët. Kur i shtohen kësaj edhe ligjet e sotme te pakompletuara dhe ato të pakta funksionale që nuk zbatohen atëherë distribucioni i përgjegjësisë rriten dhe kap edhe instancat tjera vendimmarrëse prej inspektoratit dhe komunës e deri tek qeveria, Ministria e Kulturës, ligjvënësit dhe Ministria e Drejtësisë, Instituti Arkeologjik, Këshilli i Trashëgimisë.

Nën ndikimin e civilizimit evropian fillon të reformohet edhe sistemi i shkollimit, e me këtë rast edhe reformohen ndërtimet e shkollave. Faza e reformimit përfshinte edhe shkollimin e mesëm. Bazën e shkollimit të reformuar e përbënin Ruzhdijet (gjimnazet e ulëta). Ruzhdija e Prizrenit së pari evidentohet në vitin 1874 ku përmendet si shkollë më 3 mësues dhe 152 nxënës, dhe më 1893 me dy mësues dhe 119 nxënës. Arsimi në shkollën e Ruzhdije vazhdoi për katër vjet dhe pranë subjekteve fetare, lëndë të tjera që u ligjëruan ishin edhe : gjuhë lindore, historia, gjeografia, aritmetikë, gjeometri dhe kurse të tjera. Është ndërtuar nga guri (etazhet e poshtme) dhe tullat (Kati). Përbëhej nga përdhesa dhe kati. Ndërtesa ka qenë shumë impozante. Për një kohë ka shërbyer edhe si spital. Ky lloj i mësimit vazhdoi deri më 1912, kur ajo u ndalua për shkak të luftërave të Ballkanike dhe pastaj Lufta e Parë Botërore.

Ndërtesa e Ruzhdije është e vendosur në anën e kundërt të Tabakhane (punues lëkurësh) dhe në afërsi të rrethit Suzi, të cilat janë shumë të rëndësishme në aspektet historike dhe kulturore. Pas Luftës së Dytë Botërore, në ndërtesën e Ruzhdije shkolla kthehet në ndërtesën e spitalit. Pas kësaj disa ndërtesa ishin ndërtuar në pjesën anësore dhe u krijua një kompleks i spitalit. Më 1979 kur u bë përmbytja katastrofike, ndërtesa u braktis dhe më vonë u përdorur si depo dhe punishte. Më 13 janar të vitit 1992 ndërtesa është djegur deri në tokë dhe i është ekspozuar kushteve të këqija të motit kështu që gradualisht objekti është në shkatërrim dhe në kushte jashtëzakonisht të këqija. Gjendja ekzistuese e ndërtesës është shumë e keqe, ndërtesa dykatëshe është e dëmtuar dhe shumicën e pjesëve janë të shkatërruara."

102 Ermir Bajmaku. Lënda: Sistemet Bashkëkohore II. Master. Punimi i tërë sipas dorëzimit final. 
Ndërtesa ka dy etazhe me një plan drejtkëndësh 13,32 x 22,18 metra dhe e mbuluar me çati katër me 4 ramje. Fasada hyrëse është simetrike nga dera e hyrjes. Pas hyrjes, shkallët për lart janë të vendosura dhe ne të dyja anët janë dhoma. Në tërësi ka katër dhoma në katin përdhes dhe katër në katin e parë.

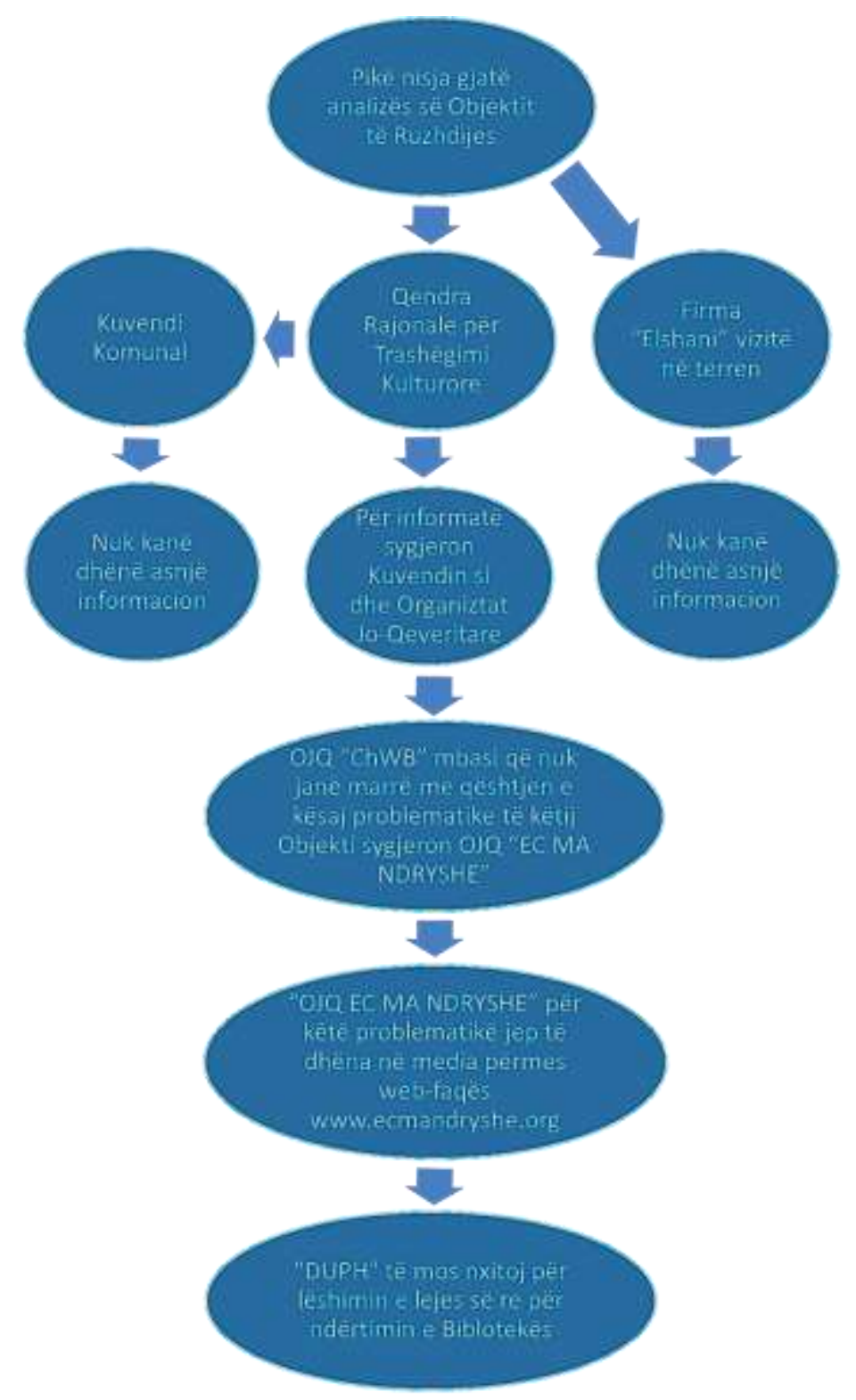

Figura 234. MindMapping

(Burimi): Fakulteti i Ndërtimtarisë dhe Arkitekturës, Universiteti i Prishtinës, 2015. 
Pyetësori është përpiluar prej 10 personave: ku në këtë pyetësor kanë marr pjesë 5 banor të lagjes, 3 nxënës të shkollës së mesme Teknike drejtimi Arkitekturë, si dhe 2 persona kalim rasti.

1.Si i shihni ndërtimet e reja ne Lokacionin e Shkollës se Lartë Ruzhdije në Prizren?
a)Mirë
b)Keq
c)Mesatare
d)Nuk ka mendim

2.Sa janë të integruara ndërtimet e reja me lokacionin rrethues?
a)Mirë
b)Keq
c)Mesatare
d)Nuk ka mendim

3.Sa janë në harmoni me objektet ekzistuese të trashëgimisë?
a)Mirë
b)Keq
c)Mesatare
d)Nuk ka mendim

4.A pajtoheni me përdorimin e materialeve të tanishme?
a)Po
b)Jo
c) Nuk ka mendim

5.Çfarë funksioni mendoni se duhet të kenë objektet e rindërtuara?
a) Kulturor
b) Turistik
c) Shërbyes
d) Të tjera

6.Çfarë struktura turistike kishit pasur dëshirë t`i keni në lokacion?
a)Muze
b) Hotel
c) Restorant
c)Të tjera 
Rezultatet dhe statistikat e pyetësorit:
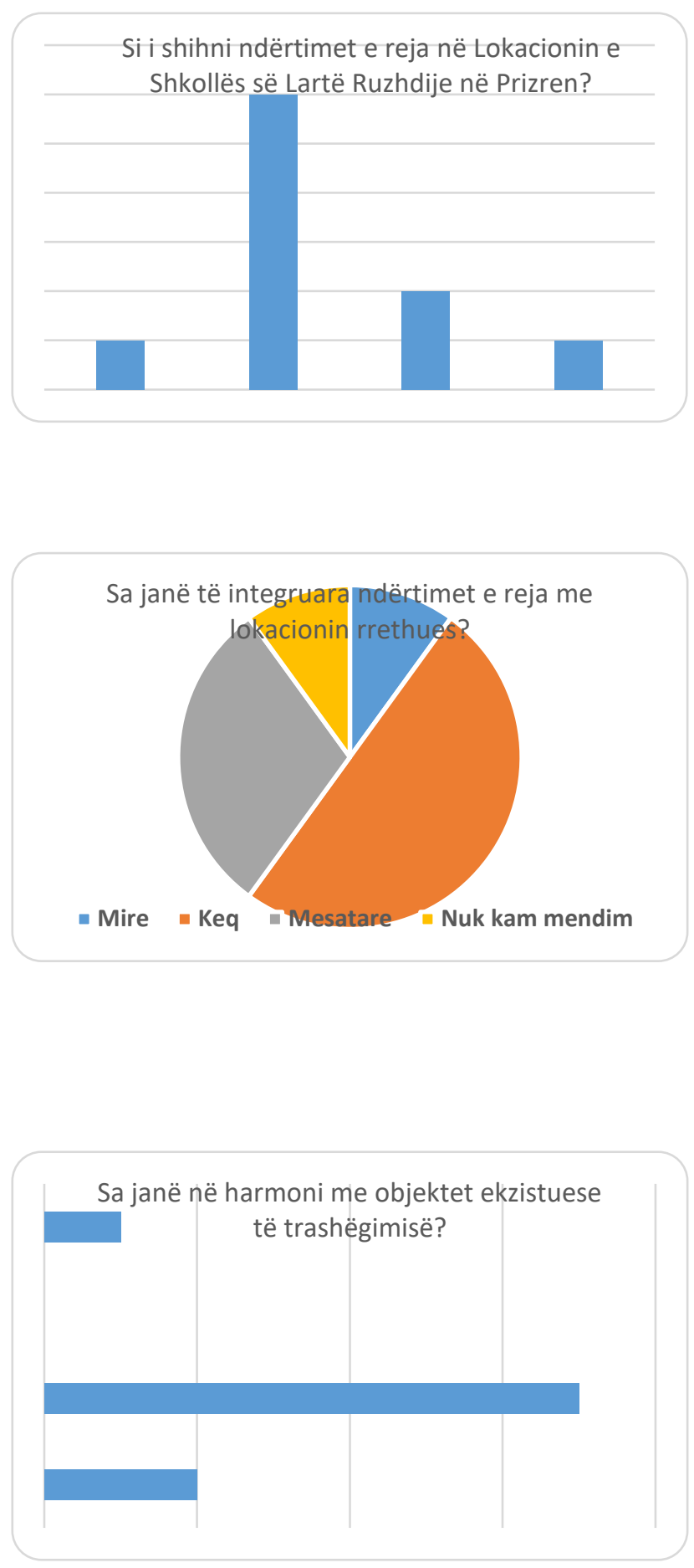

Figura 235. Rezultatet dhe statistikat e pyetësorit

(Burimi): Fakulteti i Ndërtimtarisë dhe Arkitekturës, Universiteti i Prishtinës, 2015. 

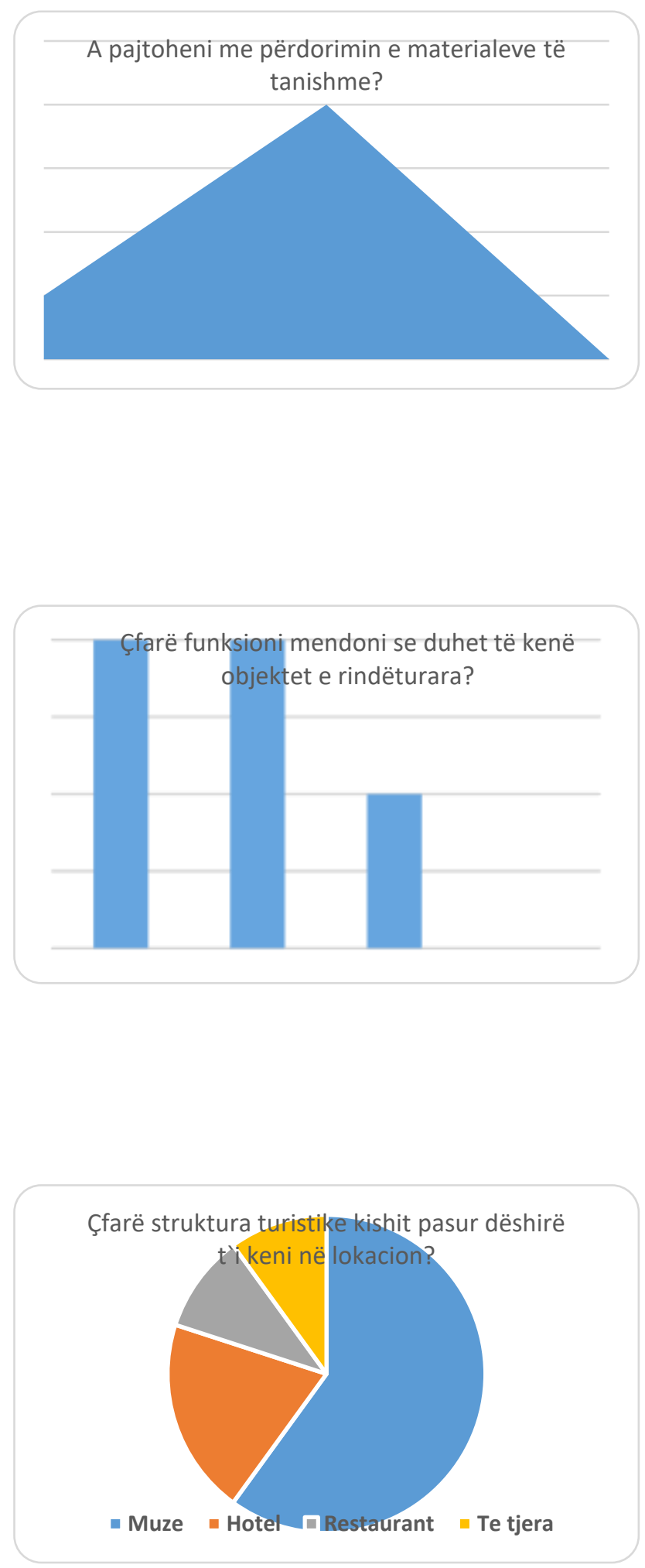

Figura 236. Rezultatet dhe statistikat e pyetësorit

(Burimi): Fakulteti i Ndërtimtarisë dhe Arkitekturës, Universiteti i Prishtinës, 2015. 
NIVELI MASTER

KJO FAQE ËSHTË LËNË QËLLIMISHT E ZBRAZËT! 


\section{ARKITEKTURA - UJI}

\subsection{UJI NATYROR}

Nën ndikimin e energjisë së diellit e të gravitetit të tokës uji në natyrë gjithmonë qarkullon, ndërron gjendjen agregate dhe në përbërjen e vet pranon materie të ndryshme nga ajri dhe mjedisi përreth. Sipas prejardhjes uji i natyrshëm ndahet në;

1. Atmosferik

2. Sipërfaqësor

3. Nëntokësor

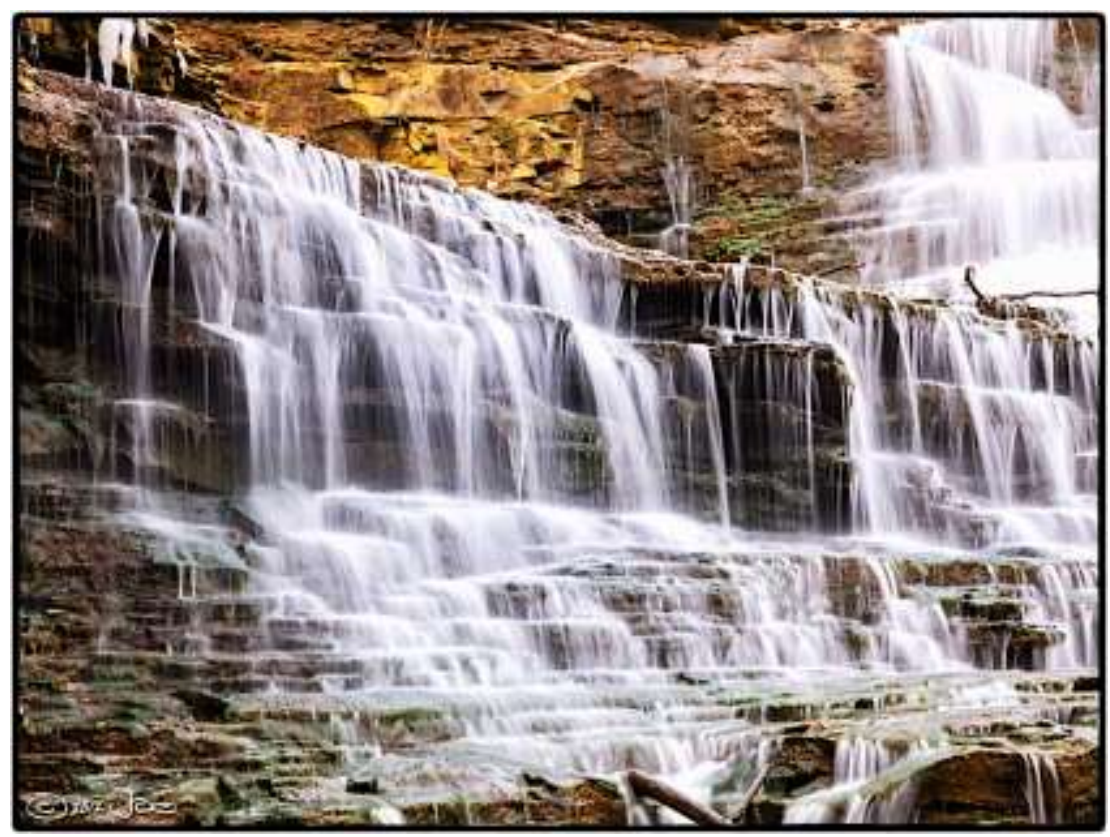

Figura 237. Albion Falls, Hamilton Ontario

(Burimi): Joe deSousa. 2012. E licensuar nga, Public Domain. CCO 1.0

\subsubsection{Uji atmosferik}

Për shkak të nxehtësisë së rrezeve të diellit uji avullohet dhe si më i lehtë ngritët lart. Me kondensimin e avullit në atmosferën e ftohtë krijohet mjegullina, diç më e dendur se mjegulla. Nëse ftohet nën pikën e vesimit, avulli kondensohet në pika të cilat nuk mund të qëndrojnë pezull në ajër kështu që ato bien poshtë në trajtë shiu. Me kondensimin nën temperaturën më te ulët se $0^{\circ} \mathrm{C}$ krijohet bora dhe po qe se ajri i lagësht ftohet prerazi, përnjëherë, atëherë krijohet breshri. Në sipërfaqen e tokës, mbi bimët, objektet ose tokën avulli kondensohet në vesë. Në temperaturën më të vogël se $0^{\circ} \mathrm{C}$ krijohet bryma. 
Vesa e ngirë quhet krahnezë e nëse ngrihet uji atëherë krijohen ehuj akulli. Emërtimi i përbashkët për të gjitha trajtat e përmendura të ujit janë: ujë i reshjeve, reshje ose ujë atmosferik, ndërsa karakteristika kryesore e tyre është se përmbajnë një përqendrim të madh të oksigjenit të tretur.

\subsubsection{Uji sipërfaqësor}

Në ujin sipërfaqësor hyjnë ujërat e përrenjve, të lumenjve, liqeneve, deteve, moçaleve dhe akullnajave dhe kanë prejardhje prej ujërave nëntokësore që burojnë në trajtë burimesh si dhe prej ujit atmosferik. Uji sipërfaqësor Është më i pastri në burim, por me rrjedhën e mëtejme si i përroit dhe si lumor vjen në kontakt me materie të ndryshme minerale e organike të cilat i tretë dhe bart me vete. Së këndejmi, ky lloj uji është i pasur me materiale të suspenduara dhe mund të jetë i turbullt, i ngjyrosur dhe fort i papastër ngase aktualisht ndotja e ujërave sipërfaqësore është shumë e madhe. Ato sot shërbejnë si mbledhësit ujërave të zeza dhe papastërtisë tjetër, sidomos ato nga qytetet prej industrisë. Dispozitat dhe ligjet urdhërojnë që ujërat e zeza para kyçjes së tyre në rrjedhat ujore duhet së pari pastruar e spastruar. Në shumë raste dispozitat nuk respektohen dhe kësisoj rrezikohet mjedisi natyror, kurse pasojat ndihen përherë e më tepër.

\subsubsection{Uji nëntokësor}

Uji nëntokësor gjendet nën sipërfaqen e terrenit, në gjendje kimikisht të lidhur e të lirë si ujë gravitues. Me humbullimin e ujit atmosferik nëpër shtresat poroze krijohen dy lloje ujërash: ujërat bredhëse nëntokësore në trajtë piklash që derdhen në currila ose vrushkuj që vazhdimisht e ndryshojnë kahun e lëvizjes; dhe ujërat e burimeve të akumuluara në vende të përhershme në shtresat ujë bartëse prej materiali kokërrzor ose në zbrazëtitë e shkëmbinjve.

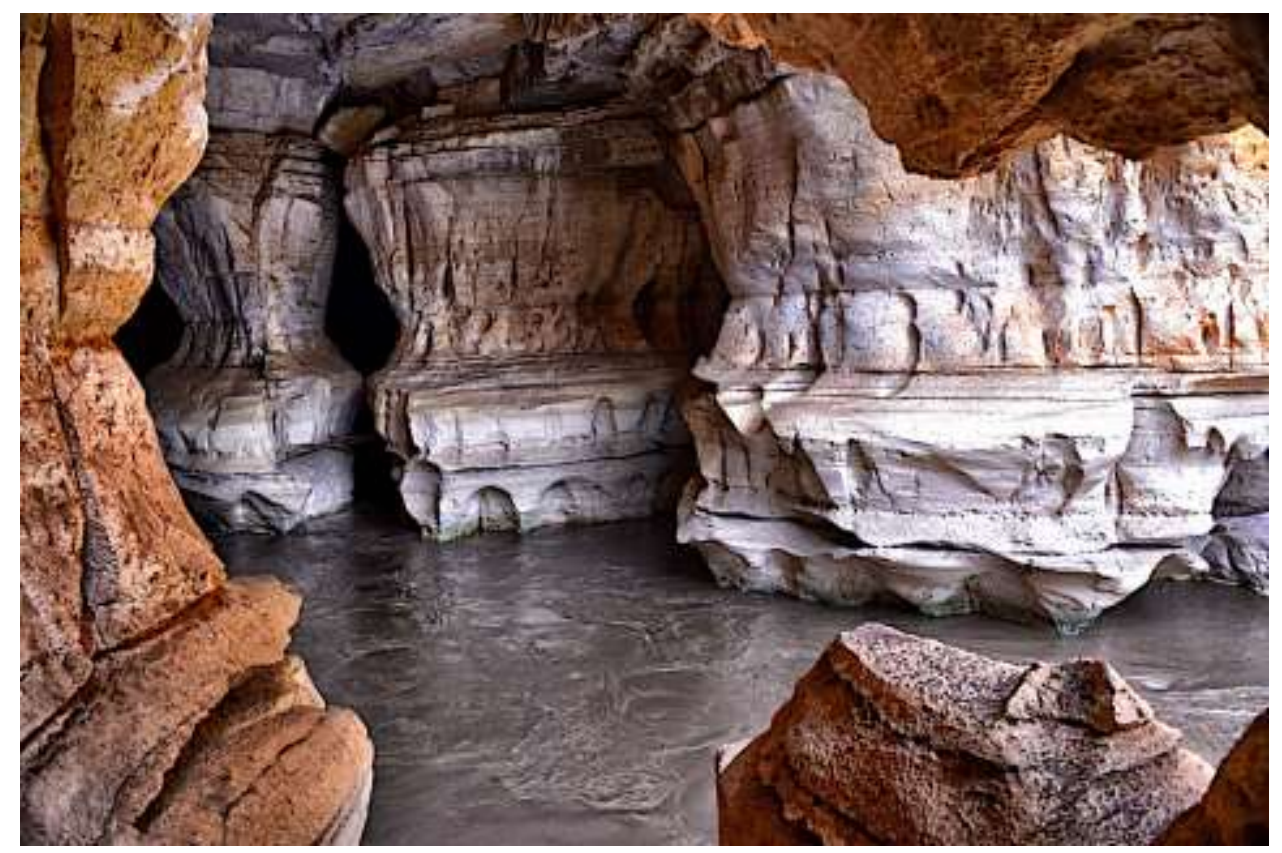

Figura 238. Lumi nëntoksor, Shpella Sof Omer, Etiopi

(Burimi): Rod Waddington. 2013.(Flickr). E licensuar nga Creative Commons Attribution ShareAlike 2.0 Generic 
Ujërat nëntokësore mund zënë hapësira shumë të mëdha. Mund të jenë të forta, të përmbajnë një përqendrim të madh të dyoksidit të karbonit dhe përqindje relativisht të lartë mineralesh të tretura. Me humbullimin nëpër shtresa materialesh të ndryshme dhe trashësish të ndryshme, uji atmosferik njëkohësisht pastrohet e filtrohet. Në viset krasike uji atmosferik ose lumor humbullon nëpër plasaritjet e shkëmbinjve gëlqerorë. Ky ujë quhet humbullor. Ka të gjitha karakteristikat e ujërave sipërfaqësore e nëntokësore. Në pikëpamje sanitare është e pasigurt. Nëse në sipërfaqe del nga të çarat ose shpellat, këto vende quhen gurra krasite. Ujërat nëntokësore jashtë zonave krasike që gjenden në pjesët e epërme të terrenit në thellësitë prej 1 gjer në $5 \mathrm{~m}$ nuk janë të mbrojtura me shtresë të padepërtueshme për ujin nga ndotja, prandaj përmbajnë një numër të madh materiesh organike e bakteresh dhe nuk janë të përshtatshme për pije.

Ujërat nëntokësore të gurrave nga shtresat e mesme e të thella prej 5-20m janë të mbuluara me material që nuk e lëshon ujin dhe kështu më pak i ekspozohen ndotjes. Varësisht nga konfiguracioni i terrenit e i renditjes, deri te uji nëntokësor arrihet përmes objekteve e pajisjeve të ndryshme ujësjellësve. Nëse tabani ose niveli epërme i ujit nëntokësor te gurrat e ulëta shtrihet nën kuotën më të ulët të terrenit, te uji arrihet me bunarë (puse). Te gurrat e larta dyshemeja del në sipërfaqen e terrenit, mbi kuotën më të ulët të relievit, kurse shtypja hidraulike ndikon që uji të ngritët në lartësi. Shtypja e këtillë quhet shtypje arteziane. Ajo shfaqet si komponentë vertikale e shtypjes e orientuar drejt sipërfaqes së tokës. Uji që sigurohet përmes vrimës natyrore ose pusit quhet ujë artezian. Nëse shtypja hidraulike është e pamjaftueshme, uji në puset e shpuara gjendet në një thellësi të caktuar dhe quhet ujë subartezian. Ujin nëntokësor në thellësi prej ndotësve të jashtëm e mbrojnë kryesisht shtresat e papërshkueshme. Për nga kualiteti i ujit, më i miri është uji nëntokësor nga puset e thella dhe burimet me kaptazhë të mirë.

\subsection{VEÇORITË E UJIT}

Uji natyror nga mjedisi përreth pranon materie të ndryshme me prejardhje minerale e organike. Llojet dhe sasitë e këtyre përbërësve përcaktojnë cilësinë e ujit, kurse sipas qëllimit për të cilin do të përdoret edhe kërkesat janë të llojllojshme në pikëpamje kualiteti. Para se do të ndërtohet objekti për furnizim me ujë, bëhen hulumtime, së pari aty për aty në vend duke kontrolluar terrenin për të parë se a ekziston ndonjë ndotës potencial dhe pastaj organizatat të specializuara me laboratorë dhe të autorizuara merren me ekzaminim e ujit. Me analiza laboratorike fitohen të dhëna të ndryshme, konstatohen veçoritë fizike, kimike, bakteriologjike, biologjike dhe radiologjike të ujit dhe nëse ka nevojë, edhe përshtatshmëria e saj teknike për destinime të caktuara. Nëse uji nuk u përgjigjet kërkesave, atëherë caktohet mënyra e përmirësimit (kondicionimit) të ujit.

Figura 239. $\mathrm{H}_{2} \mathrm{O}$

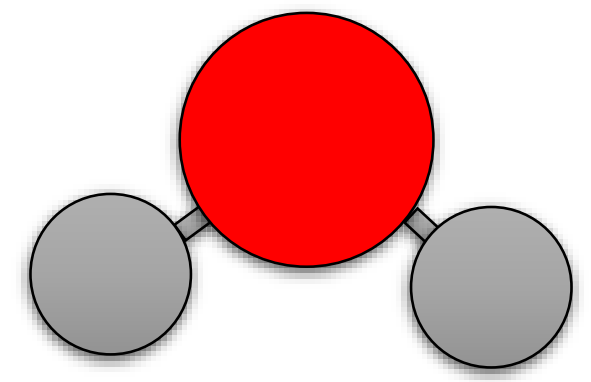

(Burimi): Bujar Bajçinovci, 2015. 


\subsubsection{Veçoritë fizike te ujit}

Temperatura 8-12 ${ }^{\circ}$ i jep ujit për pije shije të freskët, kurse ai më i ngrohtë është i samtë. Në praktikë temperatura e ujit ka pak rëndësi në veçori higjienike, veçse shfrytëzohet si tregues i rregullsisë higjienike të ujit. Çdo ndryshim i vrullshëm bën me dije se uji sipërfaqësor u është ekspozuar faktorëve të jashtëm dhe se ekziston mundësia e ndotjes. Ndërsa temperaturë konstante kanë ujërat e thella nëntokësore.

Densiteti i ujit varet prej temperaturës. Kur ngrohet uji bymehet e bëhet më i lehtë, ndërsa me ftohje tkurret e bëhet më i rëndë deri në temperaturën $-4^{\circ} \mathrm{C}$, kur edhe është më $\mathrm{i}$ rëndë, ndërsa me ftohjen e mëtutjeshme, sërish bëhet përherë më i lehtë (akulli noton mbi ujë).

Vëllimi i ujit zmadhohet me ngrohje, veçanërisht me kalimin në avull uji, i cili në makina shndërrohet në punë të dobishme. Me kalimin në akull vëllimi i ujit zmadhohet përreth $10 \%$. Bymimi, zgjerimi është shumë i fuqishëm dhe veprimi është më i madh ndërmjet $-2^{\circ} \mathrm{C}$ dhe $-6^{\circ} \mathrm{C}$, kështu që të gjitha pajisjet e pambrojtura që përmbajnë ujë gjatë acarit pëlcasin. Për ti mbrojtur, tubat futen në tokë nën zonën e ngrirjes (min. $80 \mathrm{~cm}$ nën tokë), ndërsa nëpër ndërtesë kalohen nëpër ambiente e vende ku nuk i ekspozohen veprimit të acarit.

Kohezioni i ujit zvogëlohet me ngrohje, prandaj uji i nxehtë rrjedhë më lehtë se i ftohti që është edhe më i dendur.

Adhezioni i ujit është më i madh se kohezioni. Uji puthitet në muret e tubave përmes të cilave kalon dhe duke u fërkuar për to lind rezistenca dhe shtypja zbret. Kjo veti është shumë e rëndësishme dhe merret parasysh me rastin e llogaritjeve të instalimeve të ujësjellësit dhe të ngrohjes së ujit.

Trysshmëria e lëngjeve e me këtë edhe e ujit, është veçori e tij që nën trysninë e forcave sipërfaqësore ta ndërrojë vëllimin e vet. Tryshmëria e ujit është fortë e vogël dhe në shumicën e rasteve konsiderohet si i patrysshëm.

Ngjyra e ujit. Ngjyra e kaltër është shprehur vetëm te sasitë e mëdha të ujit dhe vjen prej oksigjenit që gjendet në përbërjen e tij. Uji i pastër është pa ngjyrë dhe i kthjellët. Ngjyra e ujit tregon për praninë e materieve të tjera. Nijansat e verdhmëta tregojnë për praninë e materieve organike, ngjyra e verdhët në kuqërremtë tregon për praninë e hidroksidit të hekurit, e kuqërremtë e murrme për materiet humusore, e errëta për përzierjet e manganit, njollat e yndyrshme për naftën, kalbësirat në ujë për helme. Në bazë të ngjyrës së ujit përcaktohet përshtatshmëria për përdorimin e tij.

Turbullueshmëria e ujit mund të jetë tregues i vlerës sanitare të ujit. Nëse turbullohet në burim ose pus, kjo është shenjë se në të është duke u derdhur papastërtia nga sipërfaqja e trollit.

Era e ujit rrjedh prej pranisë së materieve organike ose joorganike. Është karakteristike se era ndihet fort pak ose nuk ndihet fare në ujin e ftohtë ndonëse edhe në të mund të ekzistojnë materie të dëmshme. Era zbulohet më së lehti në temperaturën $40^{\circ}-50^{\circ} \mathrm{C}$. 
Çdo materie ka erën e vet karakteristike. Ujërat nëntokësore nga terrenet moçalike kundërmojnë në torfë. Era e karbolit dhe e jodoformit tregojnë për prezencën e ujërave të zeza, kurse disa alga ujit e japin erë myku apo peshku .

Shija e ujit ndihet me shqisën e shijes dhe ekzaminohet, për shkaqe të arsyeshme, pas ekzaminimit kimik e bakteriologjik. Uji i pijshëm përmban mjaft oksigjen të tretur dhe ka një shije freskuese, ndërsa kur të ngrohet është i pashijshëm. Shija e ujit varet nga temperatura dhe nga përqendrimi i materialeve të tretura në të dhe sa më e lartë të jetë temperatura, aq më e shprehur është shija.

Prania e materieve organike ujit i jep shije të ëmbël, hidroksidi i hekurit të samtë, kurse sulfatet e magnezit e natriumit shije të hidhur. Acidi i lirë i karbonit krijon ujëra të tharta minerale. Sasitë e vogla të kripës se tretur, po ashtu japin shije të këndshme. Po qe se në ujë gjenden minerale te tretura mjekuese, të tillat quhen ujëra minerale, ndërsa ujërat e nxehta minerale quhen termale.

Shija e njelmët për shkak të sasive të mëdha të kripës në ujin e detit se në atë nëntokësor, si dhe për shkak të reagimit të organizmit të njeriut ndaj kripës nuk mund të shfrytëzohen për pije.

\subsubsection{Veçoritë kimike te ujit}

Veçoritë kimike të ujit natyror varen prej llojit dhe sasisë së materieve te tretura me prejardhje joorganike e organike dhe prej gazeve që ai merr nga mjedisi përreth. Ujëra kimikisht të pastra $\mathrm{H}_{2} \mathrm{O}$ nuk ka në natyrë. Veçoritë kimike të ujit përcaktohen në laboratorë me anë të ekzaminimit të gjedheve të ujit. Elementet kimike në ujë mund të jenë helmuese apo të dobishme. Elementet helmuese në ujin për pije janë lloje të ndryshme të metaleve: zhiva, amoniaku, kompozimet e fenolit e të tjera, veprimi i të cilave mund të manifestohet momentalisht ose duke përdoruar ujin e keq për pije gjatë një periudhe më të gjatë kohore. Përbërës të dobishëm të ujit janë mineralet të cilat janë të mirë për pije i japin shije të këndshme, kurse ujërave minerale edhe shije specifike.

Ligjet për masat higjienike-teknike për mbrojtjen e ujit të pijshëm përcaktojnë: sasitë maksimale të lejuara të elementeve në ujë, që nuk janë të dëmshme, fortësinë e ujit si dhe radioaktivitetin dhe veçoritë biologjike të ujit. Në bazë të tyre, pas mbarimit të analizave ekspertët nxjerrin përfundime për rregullsinë e ujit për pije bashkë me arsyetimet. Me rregullore janë rregulluar edhe sasitë e lejuara të mineraleve, ngase përqendrimi i madh i tyre mund shënojë edhe ndonjë ndotje tjetër organike ose bakteriologjike. Prania dhe përqendrimi i karbonit, hidrokarbonatit, kloridit sulfat të kalciumit e magnezit, ujit ia përcaktojnë fortësinë, e cita përbëhet prej dy komponentësh.

Nëse mund të ndahen e mënjanohen me valimin e ujit, fortësia e tillë quhet karbonate ose e kalueshme. Fortësia e përhershme (jokarbonate) nuk humb me valimin e ujit. Fortësia e ujit matet me shkallët e fortësisë $\left({ }^{\circ} \mathrm{d}\right)$, përkatësisht $10 \mathrm{mg}(\mathrm{CaO})$ në 11 ujë. Sipas shkallës së fortësisë, uji është shumë i butë $\left(0-4^{\circ}\right)$, i butë $\left(4-8^{\circ} \mathrm{d}\right)$, mesatarisht i fortë (8-12d), mjaft i fortë $\left(12-18^{\circ} \mathrm{d}\right)$, i fortë $\left(18-30^{\circ} \mathrm{d}\right)$ dhe shume i fortë mbi $30^{\circ} \mathrm{d}$. 
Uji mesatarisht i fortë është më i përshtatshmi për pije, kurse i buti ka shije të samtë. Me kalimin nga ujërat shumë të buta në atë të fortë dhe anasjelltas, te njerëzit krijohet gurthi në dhëmbë. Ujë i shiut dhe ujërat sipërfaqësore janë të buta e të pa shije për pije, por të përshtatshme për shumë degë industriale.

Industrisë së tekstilit i përgjigjet uji i butë, por pa ngjyrë, pa hekur e metale. Për kaldajat (gjeneratorët) e avullit, varësisht nga trysnia punonjëse, përdoret uji shumë i butë. Për ftohjen e stabilimenteve të qëndrueshme kërkohet që uji të mos jetë më i nxehët se $25^{\circ} \mathrm{C}$, e mund të jetë edhe shumë i fortë.

Ujin cilësor për pije por të butë e shfrytëzon industria e birrës, e sheqerit ., ndërsa industrisë së letrës i nevojitet uji edhe pa ngjyrë edhe pa hekur. Uji i fortë pengon shumimin e sapunit, kurse në industrinë e tekstilit ndikon edhe në cilësinë e prodhimeve. Në të gjitha paisjet me ujë të ngrohur, në kazanë, bojlerë, tenxhere për zierje dhe në tuba krijohet gurthi. Përpos që tubave ua zvogëlon diametrat ai edhe zmadhon rezistencat e kalimit dhe vepron edhe si izolues termik. Ai zvogëlon kalimin e nxehtësisë nëpër mure dhe së këndejmi nevojiten edhe sasi më të mëdha të energjisë për ngrohjen e ujit në sistem.

\subsubsection{Veçoritë biologjike te ujit}

Veçoritë biologjike dhe bakteriologjike të ujit përcaktohen me analiza bakteriologjike. Me ujë higjienikisht të rregullt ruhet shëndeti i njerëzve. Dihet se uji është i volitshëm për zhvillimin dhe transmetimin e baktereve patogjene të sëmundjeve të ndryshme ngjitëse. Numri i bacileve patogjenë në ujë mund të jetë aq i vogël, sa që në të gjedhen e ujit në pikëpamje bakteriologjike ekzaminohet as të mos zbulohen dhe kësisoj të jepet përfundim i gabuar për rregullsinë e ujit. Prandaj, gjithherë hulumtohet prania a baktereve polimorfe, kërkohen koli bakteritë (bacterium coli) që jetojnë në zorrët e njerëzve e të shtazëve dhe në ujë arrijnë me hedhurina organike. Prania e baktereve colimorfe shfrytëzohet si provë e ndotjes bakteriologjike e ujit. Ato shërbejnë si indikatorë të ndotjes së mundshme me bacile patogjene. Në ligjet për masat higjieniketeknike për mbrojtjen e ujit të pijshëm janë përcaktuar edhe kushtet bakteriologjike.

\subsection{PËRMIRËSIMI I CILËSISË SË UJIT}

Përmirësimi ose kondicionimi i cilësisë së ujit është i domosdoshëm nëse ndonjëra nga veçoritë e ujit natyror nuk i përgjigjen vendit ku do të shpenzohet, kështu prej destinimit të shpenzimit varet edhe mënyra e përmirësimit. Spastrimi i ujit bëhet kryesisht për mbrojtjen e shëndetit publik.

Veç kësaj, uji pastrohet:

1. Për shkaqe estetike (mënjanimi i erës, i ngjyrës dhe i turbullësisë)

2. Për shkaqe ekonomike (zbutja e ujit për të zvogëluar shpenzimin )

3. Për nevojat e industrisë dhe për shkaqe të tjera (përgatitja e ujit për pishina notimi, përpunimi i ujit me qëllim reduktimi të korozivitetit, të fluorozës ). 
Procesi i tërësishëm i kondicionimit të ujit bëhet nën kontrollin e ekspertëve, të cilët përcaktojnë numrin dhe llojin e procedurave të spastrimit dhe në ç'kohë do të zbatohen këto. Për përmirësimin e cilësisë së ujit të pijshëm procesi teknologjik përbëhet nga këto procedura:

Dekantimi i ujit. Në dekantues, ujit i ngadalësohet rrjedha me qëllim që grimcat (pjesëzat) mekanike të fundërrojnë në fund. Llumi nxirret kohë pas kohe, kurse uji përcillet në përpunimin e mëtutjeshëm.

Filtrimi i ujit. filtrohet duke e lëshuar nëpër shtresa rëre, thëngjilli aktiv, zhavorri e të ngjashme, në të cilat ndalen grimcat që qëndrojnë pezull dhe materiet koloide, por ndodh edhe ndryshimi i elementeve kimike ngase uji pastrohet në pikëpamje bakteriologjike me anë të oksidimit të materieve organike. Para filtrimit, ujit i shtohen mjete për ngjizje (koagulim) për të cilat ngjiten grimcat e papastërtisë.

Ajrimi. Pas filtrimit uji ajrohet (aerimi) në dy mënyra: duke përshkuar nëpër sita dhe duke spërkatur nëpër spërkatorë për të rënë në kontakt piklat e imëta, me ajrin. Materiet e shkrira, ne ujë bashkohen me oksigjenin nga ajri dhe me formën e re mënjanohen nga uji.

Pastrimi kimik i ujit, është i detyrueshëm, sepse cilësia ne pikëpamje biologjike në fazat pararendëse nuk mund të përmirësohet plotësisht.

Dezinfektimi më e rëndomtë e ujit bëhet me klor ose me komponimet e tij. Përdoret klor gazi, gëlqerja e klorit dhe gëlqerja klorike e lëngët, kalcium hipokloridi i ashq. kaporit si dhe natrium hipokloridi ose Uji i Zhavelit. Llojet dhe përqendrimet përcaktohen nga profesionistë të ujësjellësit. Po qe nevoja kryhen edhe procedura speciale, si fluorizimi, rrezatimi ultraviolet e sipas nevojës edhe dekontaminimi i ujit. Pastrimi i ujit në ujësjellës bëhet me procedurë e caktuar, në bazë të analizave të shpeshta, sepse edhe ndryshimet e cilësisë së ujit janë të shpeshta, sidomos kur furnizimi me ujë bëhet nga ujërat e rrjedhshme.

Sterilizimi i ujit në objektet individuale ujësjellëse. Filtrimi i ujit të rezervuarëve dhe puseve kryhet me impiante të vogla, hipoklorinatorë, me ujë të Zhavelit, i cili ngadalë rrjedh në sasi të duhura dhe ujin e sterilizon në mënyrë automatike. Provë se dezinfektimi është bërë, është prania e klorit rezidual në ujin për pije. Kjo është një sasi e caktuar e klorit të tretur në ujë në gjendje të lirë. Ajo nuk ndihet me shqisën e shijimit ose të nuhaturit dhe shërben si mbrojtje nga prania e baktereve në ujë. Për nevojat industriale, për shembull, për zbutjen e ujit për të furnizuar kaldajat (gjeneratorët), uji distilohet ose i shtohet tretje gëlqereje, gëlqere, e pastaj filtrohet.

\subsection{FURNIZIMI ME UJË}

Furnizimin me ujë e kushtëzojnë shumë faktorë, siç janë: llojet e konsumuesve, llojet e ujit, mënyra e furnizimit, shpenzimi i ujit, dhe sipas tyre ndërtohen edhe objektet, pajisjet dhe instalimet përkatëse. Llojet e konsumuesve u përkasin njerëzve, popullsisë të cilën duhet furnizuar me ujë higjienikisht në rregull, me ujë të pijshëm për pije dhe nevoja të tjera, mandej industria për procese teknologjike, bujqësia për ujitjen e fushës . 
Llojet e ujërave. Uji natyror është ndarë sipas cilësisë për pije, kështu që si më cilësori konsiderohet uji nëntokësor, pastaj ai sipërfaqësor dhe në fund uji atmosferik. Po qe se ekziston mundësia e zgjedhjes, atëherë më së miri është që popullsia dhe industria të furnizohen me ujë nëntokësor, sepse ai është i mbrojtur nga ndotja prej mjedisit të jashtëm.

Ky merret më së lehti e më së thjeshti me kaptazhimin e gurrave. Për konsumues të mëdhenj, për shembull për qytete dhe industri, shpesh nevojiten sasi më të mëdha uji, dhe së andejmi merret uji sipërfaqësor i lumenjve ose uji paraprakisht i akumuluar në liqenet e ndërtuara artificialisht.

Deri te konsumuesit uji sillet paraprakisht i pastruar dhe nën mbikëqyrje të përhershme të ekspertëve. Konsiderohet se më së miri është të shfrytëzohet uji burimor dhe me rrugë të gravitetit të sillet deri te konsumuesit, qoftë edhe nga largësitë më të mëdha sesa të shfrytëzohet uji sipërfaqësor. Me këtë problem merren një ekip i tërë profesionistësh, të cilit në bazë të rezultateve të marra me punë kërkimore dhe me matjen e sasive të ujit, me anë të hulumtimeve sanitare dhe analizave ekonomike vendosen për llojin e ujit e cila do të kaptohet me objekte.

Uji atmosferik shfrytëzohet kur nuk ka ujë tjetër ose ekziston në sasi të vogla kryesisht për konsumues individualë. Mënyra e furnizimit të konsumuesve me ujë mund të jetë individuale dhe lokale për një ose më shumë konsumator dhe e përbashkët ose publike me anë të ujësjellësit.

Për furnizimin individual ndërtohen objekte më të vogla, për shembull, puse, pompa, cisterna, meqë shpenzimi nuk është i madh. Këto mund të ndoten rastësisht ose qëllimisht, vështirë mund të kontrollohen secili veç e veç, çka do të thotë se nuk mund të merret kurdoherë uji higjienikisht i garantuar se është në rregull. Puset dhe krojet e përbashkëta të burimeve e të ngjashme mundësojnë furnizimin lokal të disa amvisnive me ujë.

Për furnizimin e përbashkët të konsumuesve ndërtohen impiante të ujësjellësve ku hyjnë të gjithë ujëmarrësit, paisjet për përpunimin e ujit, stabilimentet dhe pajisjet ujë nxjerrëse, rezervuarët, rrjeti ujësjellës me të gjitha kyçjet, dhe ujëmatësit (njehsorët e ujit) për matjen e shpenzimit të ujit. Pajisjet ujësjellëse konsumuesve u sigurojnë sasitë e nevojshme të ujit higjenikisht në rregull i cili përherë e vazhdimisht kontrollohet. Pajisjet e ujësjellësit, i ndërtojnë, eksploatojnë dhe i mirëmbajnë organizata e ujësjellësit komunal, publik ose urban (p.sh. KUR Prishtina).

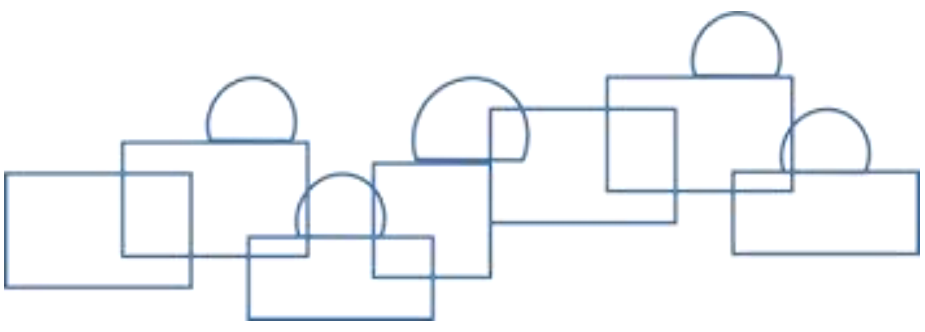


Tabela 52. Sasia optimale e konsumimit të ujit, për:

(Burimi): E përkthyer, Instalimet, uji, 2015.

\begin{tabular}{|c|c|c|c|}
\hline Konsumuesi & Q & \multicolumn{2}{|c|}{$=$ lit/ditë } \\
\hline Personi në ndërtesën individuale të banimit & 75 & - & 150 \\
\hline Personi në ndërtesa të mëdha të banimit & 50 & - & 120 \\
\hline Personi në hotel & 250 & - & 400 \\
\hline Shkollat / 1 nxënës & 12 & - & 15 \\
\hline Ndërtesat administrative / 1 punëtor & 12 & - & 15 \\
\hline Kampet e turizmit / 1 person & 50 & - & 60 \\
\hline Banjat dhe hamamet / 1 një person & 100 & - & 150 \\
\hline Spitalet / 1 i sëmurë & 250 & - & 400 \\
\hline Çerdhet ditore / 1 person & 55 & - & 90 \\
\hline Kinematë dhe teatrot / 1 vizitor & 2 & - & 4 \\
\hline Banjat grupore (të përbashkëta) / 1 vaskë në orë & 1000 & - & 1500 \\
\hline Banjat grupore me dushe / 1 dush në orë & 500 & - & 800 \\
\hline Mesatarisht një banor në vende të vogla & 60 & - & 100 \\
\hline Mesatarisht 1 banor në qytete & 100 & - & 150 \\
\hline Mesatarisht 1 banor në qytete të mëdha & 150 & - & 300 \\
\hline
\end{tabular}

Konsumimi i ujit është faktor shumë i rëndësishëm dhe për të duhet patur kujdes në projektimin e ujësjellësit, e të instalimeve të ujësjellësve. Vëllimi i konsumit të ujit është karakteristik për ndryshimet e përhershme. Ai ndryshon gjatë vitit varësisht nga stinët vjetore ngase shumë më tepër konsumohet në kohën e temperaturave të larta sesa kur bënë të ftohtë. Ndryshon edhe gjatë 24 orëve dhe më shumë shpenzohet ditën se natën.

Kjo varet nga niveli kulturor dhe standardi jetësor i popullsisë, nga fakti se çfarë destinimi ka ndërtesa, a është e banimit apo e industrisë nga lloji i objekteve sanitare, mënyra dhe dendësia, e përdorimit si dhe nga përdorimi i njëkohshëm. Me shprehjen konsumi i ujit, nënkuptohet sasia e ujit e shprehur me njësi të vëllimit në njësinë kohore. Te përdorimi shprehet:

1. Konsumi mesatar ditor ( $Q$ opt. ditë),

2. Konsumi maksimal ditor ( $Q$ max. ditë)

3. Konsumi maksimal në orë ( $Q$ max.orë)

Konsumi i ujit për njësinë lit/ditë për njeri në objektet me destinim të ndryshëm si dhe për shfrytëzuesit e tjerë, është dhënë në tabelën 52.

Objektet dhe stabilimentet për kaptazhin e ujit: 
Sistemi për kapjen ose marrjen e ujit prej vendburimit quhet kaptazh. Në kuptimin e ngushtë të fjalës kështu quhet edhe vetë mënyra e marrjes së ujit nga burimi.

Sipas vend gjetjes së ujit në natyrë, dallohen këto kaptazhe të ujërave:

1. Sipërfaqësor

2. Nëntokësor

3. Atmosferik

\subsection{KAPTAZHI I UJIT SIPËRFAQËSOR}

Mënyra e marrjes së ujit sipërfaqësor varet prej madhësisë së rrjedhës së ujit dhe konsumit të ujit. Prej lumenjve e liqeneve, nëse në fund të tyre nuk ka llum, uji kaptohet drejt prej rrjedhës ose në mënyrë indirekte me tipin bregor të marrjes. Për marrjen e drejtpërdrejtë nga rrjedha e ujit ose akumulimi shërben gypi thithës i fiksuar për rrjetën e cila mbron dhe ndal mbeturinat që gjenden në ujë.

Për kaptazhin e ujit me tipin e marrjes bregore, në brigje gërmohen puse me hapje në mbështjella, nëpër të cilat hyn uji. Sipër pusit gjendet shtëpiza. Uji mirët, nxirret me ndihmën pompave përmes gypit thithës me shportë e rrjetë të lëshuar në pus dhe përcillet më tutje në rrjet.

\subsection{KAPTAZHI I UJIT NËNTOKËSOR}

Për kaptazhin e ujit nëntokësor ndërtohen objekte ose puse vertikale dhe kaptazhe e galeri horizontale. Puset janë objekte vertikale nën nivelin e trollit. Ato shërbejnë për kaptazhin e ujit nëntokësor. Në ndërtimtari shfrytëzohen edhe për lëshimin, uljen e nivelit të ujërave nëntokësore, si puse hulumtuese për fondimin e objekteve. Për furnizimin individual me ujë shfrytëzohen të ashtuquajtura puse shtëpiake, por këta ndërtohen edhe për furnizim te përbashkët grupor. Te furnizimi i përbashkët me ujë, puset janë pjesë integrale e ujësjellësve.

Sipas kushteve hidrologjike puset janë të rëndomta, ku uji nuk është nën trysni, dhe subarteziane si dhe arteziane ku uji shpërthen nën trysni.

Për nga mënyra e punimit dallohen:

1. Puset e gërmuara

2. Puset gypore

3. Puset e kombinuara, të shpuara e të rrëmuara.

Puset e rrëmuara. Puset e rrëmuara shërbejnë për kaptimin e ujit nëntokësor prej shtresave të cekëta ujë bartëse dhe kanë thellësi më të madhe deri më $40 \mathrm{~m}$. Anët e mira të puseve janë konstruksioni i thjeshtë, mundësia e kontrollimit dhe që uji në to vjen në mënyrë të njëtrajtshme.

Puset rrëmohen me dorë dhe me makina me ndihmën e veglës pneumatike dhe motorike, kurse në shkëmbinj me mjete detonimi. Ndërmjet hapjes së puseve që mund të jetë 
rrethore, me diametër 1-1,5 m (të mëdhenjtë edhe më tepër se $5 \mathrm{~m}$ ) ose katrore, punohet një veshje e mbështjellë prej betoni dhe prej unazash të betonarmesë ose muroset me gurë ose tulla.

Mënyra e punimit të mbështjellës dhe e rrëmimit të pusit varet prej llojit të tokës, thellësisë së pusit, sasisë së ardhjes së ujit dhe bëhet në dy mënyra:

Te mënyra e parë, në tokën koherente dhe te puset më të cekëta, së pari rrëmohet pusi deri te thellësia e duhur dhe më pas, nga poshtë lart punohet mbështjella ose veshja. Ajo mund të jetë prej tullave me trashësie $25 \mathrm{~cm}$ ose prej guri deri më $50 \mathrm{~cm}$, ose e derdhur prej betoni me trashësi $7-12 \mathrm{~cm}$.

Mënyra e dytë konsiston në rrëmimin me mbështetje, çka është shumë më e sigurt për punë veçanërisht në terrenin që shkapërderdhet ose ku ardhja e ujit është e madhe. Pjesa më e ulët e pusit themelohet mbi një kurorë betonarmeje me majë të pjerrësuar. Kurora betonohet në hapësirën e rrëmihur cekët. Pastaj rrëmohet nga ana e brendshme, kurse materiali hidhet, nxirret jashtë pusit. Sipër kurorës veshja mund të muroset me tulla ose gurë ose bëhët mbështjellja prej betoni.

Mund edhe të palohen, vendosen njëra mbi tjetrën unazat e betonit. Për shkak të peshës së veshjes dhe nën rrëmihje të përhershme, mbështjella gjithnjë lëshohet teposhtë. Koha më e përshtatshme për rrëmimin e puseve është ajo gjatë nivelit më të ulët të ujërave. Nga fundi, nga anash dhe shumë rrallë vetëm nga anash uji vjen në puse. Kundrejt drejtimit të ardhjes së ujit, në pjesën më të ulët të pusit, mbështjella punohet me vrima ose pa to. Puset detyrimisht duhet mbrojtur nga ndotja, nga ndotësit e rrjedhave nëntokësore të ujit, sikurse nga tualetet, gropat septike, plehërishtat. Puset për furnizim individual e lokal së pari caktohen ndotësit në largësinë më të vogël prej $20 \mathrm{~m}$, kurse në vendet anësore 50-70 m. Puset e ujësjellësit vendosen në zona të mbrojtura prej çfarëdo ndotje të mundshme. Nën nivelin e terrenit veshja e pusit nga ana e jashtme mbështillet me një shtresë argjile të yndyrshme me trashësi $25-50 \mathrm{~cm}$ në thellësinë prej 3-6 m, për t'u penguar në këtë mënyrë depërtimi i ujit përgjatë veshjes teposhtë. Hapja e pusit ngritet mbi sipërfaqe deri në $1 \mathrm{~m}$ dhe mbulohet me kapak druri apo ndërtohet edhe shtëpiza. Po qe se uji nxirret me pompë, atëherë në fund vihet një kapak betoni. Për hyrje në pus ndërtohet edhe një hapje. Hapësira rreth pusit me diametër 8 deri 10m pllakëzohet me pllaka betoni ose në ndonjë mënyrë alternative higjienike.

Elevatorët përderisa të jenë në lëvizje tërheqin ujin vazhdimisht prej pusit. Elevatori përbëhet prej shiritit të pa fundmë që sillet rreth rrotës së poshtme të vendosur në ujin e pusit dhe rrotull rrotës së epërme, sipër pusit. Përgjatë gjithë shirit janë vedrat e fiksuara për marrjen edhe ngritjen e ujit, i cili me rrotullimin e vedërzave rreth qarkut të epërm derdhen në koritën pranë pusit. Shiriti i elevatorit mund të jetë i përbërë edhe prej një vargu fletësh mbi të cilat uji qëndron me anë të adezionit dhe derdhet te qarku i epërm me anë të gravitetit.

Pompat, për të nxjerrë ujin prej pusit lëshohet një gyp thithës i mbrojtur nga grimcat e ujit me një rrjetë. Në anën e epërme gypi gjendet mbi hapjen dhe është i lidhur me pompën e cila ngre ujin. Pompa motorike mund të vendoset në hapje ose në pus.

\subsection{PUSET GYPORE}


Për nga mënyra e punimit, dallojmë puset e hapura dhe puset e shpuara gypore. Puset e nguljes janë të njohur sipas emërtimit si puset Abisinase. Përbëhen prej një gypi të çeliktë të zinkuar me diametër $\emptyset 50-60 \mathrm{~mm}$ i cili ngulet në tokë deri në thellësinë prej 5-8 m. Për tu vendosur më lehtë, skaji i poshtëm i gypit është i mprehur, kurse vetë gypi është i përforuar për të kaluar uji. Mbi terrenin në lartësinë rreth 60-80 cm në gyp montohet një pompe dore prej hekuri të derdhur.

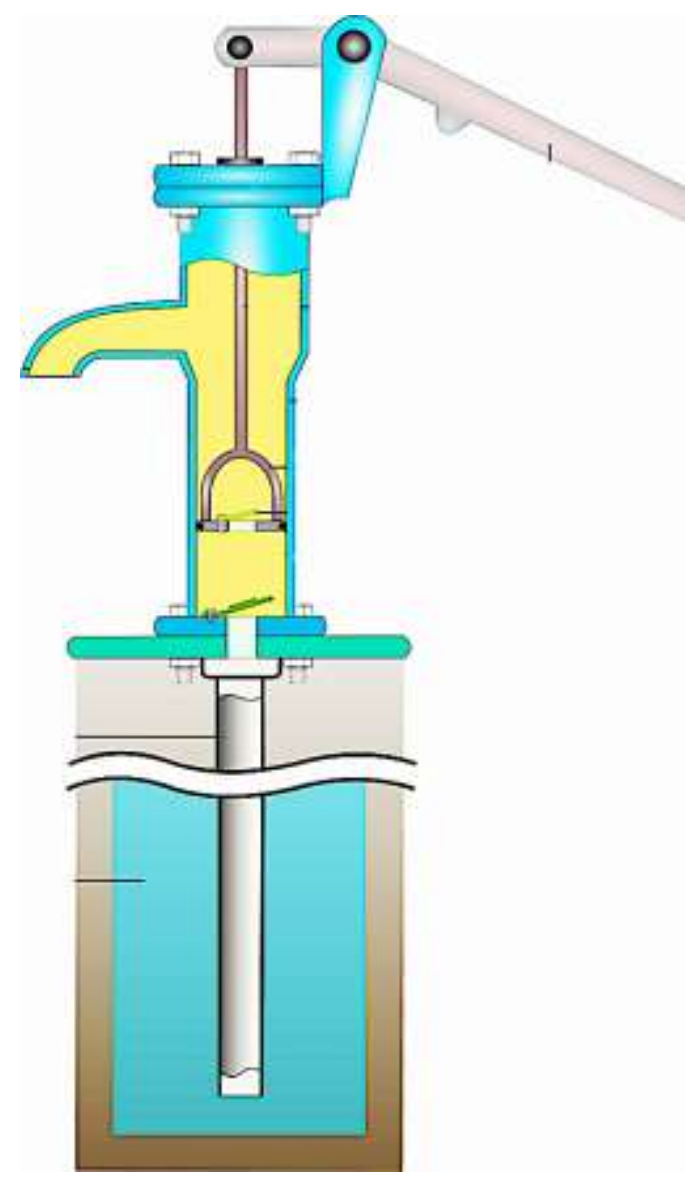

Figura 239-A. Pompa e dores

(Burimi): Manco Capac, 2008. (Flickr). E licensuar nga Creative Commons Attribution ShareAlike 3.0 Unported

Kjo ka trajtë të cilindrit vertikal me një degë shkarkuese dhe me levën me të cilën manipulohet. Me forcën e dorës, përmes levës pistoni lëvizet dhe krijohet një vakum i cili përthith ujin nga gypi dhe e nxjerr përmes grykës, varësisht nga pozicioni i cilindrit. Kapaciteti i pompave të dorës është 15-20 1/min. 


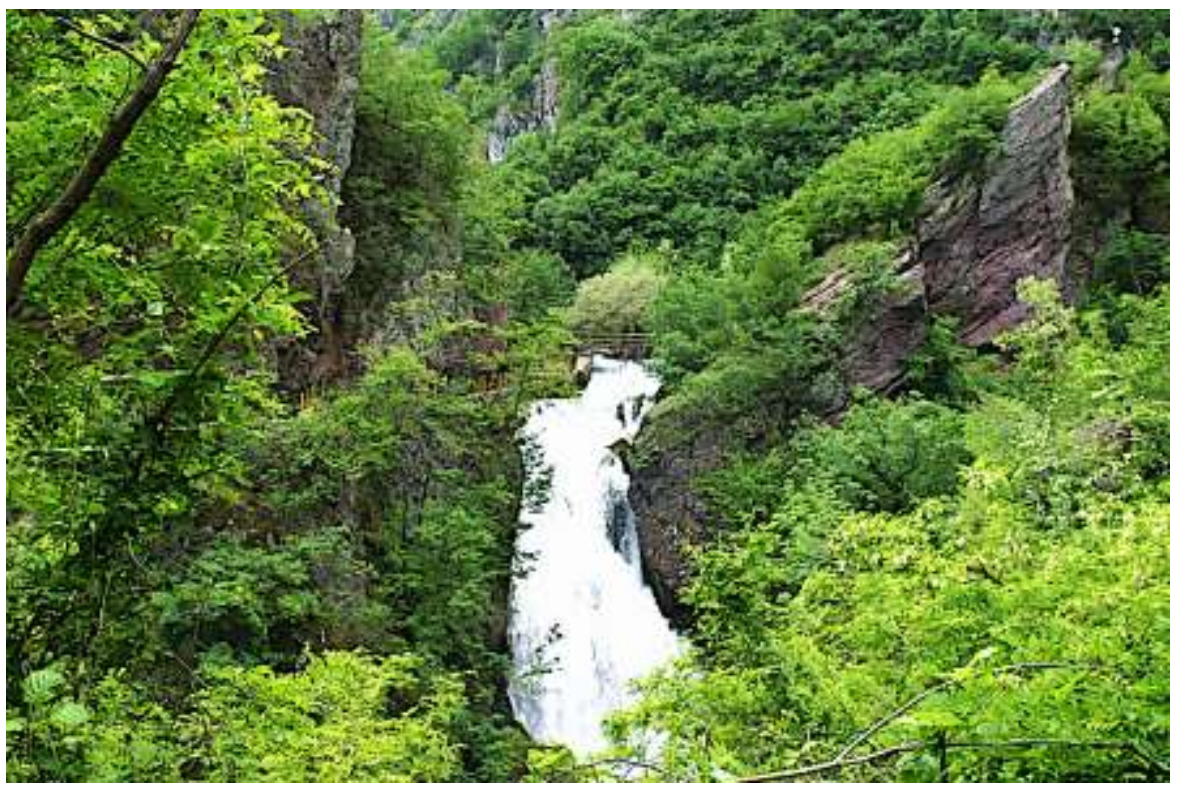

Figura 239-B. Burimi i Drinit, Radavci

(Burimi): Naserthaci, 2005. (Flickr). E licensuar nga Creative Commons Attribution ShareAlike 4.0 International

Për thithjen dhe ngritjen e ujit deri më $15 \mathrm{~m}$ lartësi vendoset pompa me piston. Pompimi i ujit është një punë e rëndë, kështu që kudo që është e mundshme në vend të pompave të dorës vendosen pompa me lëvizje motorike. Puset e shpuara janë puse gypore prej gypash të çelikut të zinkuar, hekurit të derdhur, bakrit, kurse për marrjen e ujërave minerale prej gypave a tubave të porcelanit me diametër Ø500-1000 mm. Shërbejnë për marrjen e ujit edhe nga thellësi shumë të mëdha, madje... deri në $500 \mathrm{~m}$. Tubi përfundimtar, me shportë e filtër sitor në skaji e poshtëm shfrytëzohet në shtresën ranore ujë bartëse. Për hapjen e pusit gypor, terrenin e shpojnë ekspertët e organizatave të specializuara, madje me turjela e makina të ndryshme shpimi varësisht nga lloji i materialit në shtresat nëpër të cilat kalojnë. Mbrohen me tuba mbështjellës që kanë diametra 50-100 mm më te mëdhenj se tubi amë apo i përhershëm i pusit. Tubi mbrojtës i shtyllës së eksploatimit mund edhe të nxirret aq sa është gjatësia e filtrit. Ne skajin e epërm, menjëherë nën terren ndërtohet një hapje në të cilën vendoset pjesa përfunduese e pusit, d.m.th. pajisja për thithjen e ujit (pompa). Nëse uji nxirret me ndihmën e stabilimentit thithës te ujërat e rëndomta nëntokësore ose subarteziane, në shtyllën e eksploatimit (në tubën e metalit) lëshohet gypi thithës i pompës për ujë.

Për sasi më të mëdha të ujit nga gurra ujë bartëse, uji thithet përmes një grupi pusesh të renditur ndërvetshëm në largësi 50-150 m. Kaptazhet horizontale, quhen edhe drenazhe dhe shërbejnë për kaptimin (përfshirjen, kapjen, marrjen) e ujit nga shtresat e cekëta ujë bartëse. Në këtë grup hyjnë galeritë gypore në formë të nën mihjes e të kaptazhit. Punohen prej materialesh të qëndrueshme ndaj ndikimeve të ujit siç janë qeramika, betoni, guri, tulla dhe hekuri i derdhur. Galeritë gypore janë tuba me vrima në gjysmën e epërme në për të cilat hyn uji, kurse rrjedh nëpër pjesën e poshtme të lëmuar të tubit. Galeritë në trajtë nën mihje janë tunele zakonisht prej betoni me vrima në muret anësore për të ardhur uji. Për kontrollimin e punës së drenazhit, në çdo 20-50 m ndërtohen puse për revidim. Sipër grumbulluesit patjetër ndërtohet një shtresë mbrojtëse prej argjilës së ngjeshur, e cila pengon depërtimin e ujit sipërfaqësor. 


\subsection{OBJEKTET PËR KAPTAZHIN E UJIT BURIMOR}

Për marrjen, akumulimin dhe shfrytëzimin e ujit burimor ndërtohen objekte kaptazhi. Këto përbëhen prej një ose më tepër dhomash që shërbejnë si rezervuar uji dhe si dekantues.

Në kaptazhet e burimeve dhoma e tretë shërben si pjesë zbritëse ku vendosen tubat dhe pajisja për përcjelljen e ujit në rrjetin ujësjellës ose deri te fyti lëshues në çezmë të vendosur në murin e përparmë të objektit prej së cilës merret uji. Në kohën e sasisë më të madhe të burimit, teprica e ujit të pijshëm mënjanohet përmes tubit kapërderdhës. Për ventilim shërben tubi që në majë është i mbrojtur prej insekteve, gjetheve, i realizuar me një rrjetë.

Trajta e objekteve, numri dhe renditja e dhomave varen prej kushteve hidrologjike dhe prej terrenit. Po qe se në shtresën shkëmbore uji shpërthen nga poshtë-lart, ndërtohen kaptazhe nënvorbullore, e nëse burimi del prej materialit ranor ose me zhavorr, marrja e ujit bëhet përmes filtrit me zhavorr. Objekti i kaptazhit dhe shtresa ujë bartëse, prej depërtimit të ujit sipërfaqësor mbrohen me një shtresë të argjilës së ngjeshur, kurse mbi të ngritët një pendë për të ruajtur temperaturën e ujit dhe mbrojtur nga ndotja.

Kaptazhi i ujit atmosferik, në viset pa ujë, në ishuj, në viset shkëmbore ku gjer te uji i pijshëm nuk mund të arrihet në ndonjë mënyrë tjetër, ndërtohen sterna tipesh dhe trajtash të ndryshme.

Pjesët përbërëse të sternës janë:

1. Sipërfaqet e grumbullimit

2. Pajisjet për filtrim

3. Rezervuarët

4. Pajisjet për qarkullimin e ujit

Sipërfaqja e grumbullimit mbrohet me rrethojë. Gjithmonë duhet të jetë e pastër, me sipërfaqe të pllakëzuara dhe me rënie. Mund të shfrytëzohen edhe pullazet e ndërtesave, por për shkak të shpesëve që zbresin mbi pullaze, uji amosferik mund të bëhet i papastër. Uji i shiut që sapo filloi të bjerë, zakonisht nuk shfrytëzohet, ngase shpërlan sipërfaqen dhe papastërtinë, prandaj ai ndahet me ndihmën e govatës apo të koritës së përmbytshme.

Uji atmosferik lirohet mekanikisht nga grimcat në para filtër, dhe më pas përcillet më tutje në dhoma me filtër prej rëre. Nëpërmjet hapjes filtri pastrohet, rëra nxirret dhe prej tij mënjanohet llumi, ose zëvendësohet me filtër të ri.

Rezervuarët, cisternat shërbejnë për ruajtjen e ujit. Bazën e kanë katrore, kënddrejte ose rrethore. Muret prej guri apo prej tullave muratohen drejtpërdrejt ose ndërtohen prej betoni. Suvatohen me llaç çimento dhe sipërfaqet u lëmohen. Për të mos e humbur rezervuari ujin dhe për t'u penguar depërtimi i ujit sipërfaqësor, bëhet hidroizolimi. Në anën e epërme rezervuarët janë të mbyllura me pllakë, sepse hapësira e brendshme duhet të jetë e errësuar. 
Mbi pllakë, për t'u ruajtur temperatura e ujit dhe niveli i terrenit, hidhet shtresë dheu. Në pllakën e sipërme duhet bërë një hapje për hyrje në rezervuar, sepse së paku një herë në vit atë duhet zbrazur, pastruar e dezinfektuar. Për t'u penguar hyrja e insekteve rezervuari ventilohet përmes vrimës së ventilimit.

\subsection{PAISJET PËR SHTYTJEN E UJIT}

Për përthithjen e ujit nga puset, rezervuarët dhe rrjedhat ujore, përdoren pompat motorike, të ndryshme për nga konstruksioni, kapaciteti dhe fuqia e shtypjes së ujit. Në praktikë më së shumti përdoren pompat centrifugale mbiujore ose nënujore. Për nga pozita ato janë vertikale ose horizontale.

Funksionimi i pompave centrifugale mbështetet në parimin e transmetimit të fuqisë centrifugale në masën e ujit, e cila shndërrohet në energji të lëvizjes së ujit nëpër tuba, e kur lëvizja është penguar, shndërrohet në shtypje (trysni). Pompat centrifugale përbëhen prej rrethit nga hekuri i derdhur, ku gjendet qarku me lopata (rotori) të lakuara, të cilat sillen me një shpejtësi shumë të madhe.

Lopatat janë të kthyera, lakuara asisoj që formojnë kanale radiale në të cilat uji hyn aksialisht dhe për shkak të forcës centrifugale rrymon me një shpejtësi të madhe nëpër kanal, drejt tubit shtytës. Në afërsinë e qarkut të kyçjes së tubit thithës për ujë, krijohet një vakum i cili përthith ujin nga tubi dhe e shtyn nëpër tubin shtytës. Prodhohen disa tipa dhe lloje pompash.

Pompat njëshkallëshe centrifugale kanë një qark me lopata. Nëse vendosen njëri pas tjetrit më tepër qarqe me rrema fitohen pompat shumëshkallëshe. Trysnitë e tyre mblidhen dhe shtyjnë ujin në një lartësi më të madhe. Pompat nënujore po ashtu janë disashkallëshe (shumëshkallëshe), por kanë trajtë cilindri dhe lëshohen tok me elektromotorin në tubin e pusit dhe zhyten në ujë i cili mund të gjendet shumë thellë, deri më $120 \mathrm{~m}$ thellë. Përdoren domosdo në puset me thellësi mbi $25 \mathrm{~m}$.

Pompat me kapacitet dhe lartësi të shtytjes, të çiftëzuar me motorin më fuqi korrespondues, quhen agregat. Dimensionimi i agregatit përcaktohet në bazë të prurjes së ujit dhe të lartësisë së shtyllës ujore. Në bazë të diagramit të karakteristikave që jep prodhuesi apo prospektit zgjidhet më i përshtatshmi.

\subsection{PAISJET E UJËSJELLËSIT}

Në praktikë emërtimi i përgjithshëm për objektet që shërbejnë për furnizimin e një numri të madh konsumuesish me ujë, është ujësjellësi. Përbëhet prej pajisjeve ujësjellëse ku hyjnë: vendet e marrjes, pajisjet dhe stabilimentet për përpunimin e ujit, stabilimentet dhe pajisjet thithëse, tubat për prurjen e ujit deri te vendbanimet (qytetet) dhe rrjeti përndarës i tubave me degët për kyçjen e ndërtesave. Në ndërtesa quhen instalime të ujësjellësve. 
Sipas vëllimit të stabilimenteve dhe qëllimeve për të cilitdo të shfrytëzohet uji dallohen: Ujësjellësi komunal (publik) përmes të cilit furnizohen me ujë për pije qyteti ose vendbanimi. Ujësjellësit për qëllime të posaçme ku hyjnë ujësjellësit lokalë, për grupe ndërtesash të bllokut banesor, për spitale, për komplekse industriale, ujësjellësi hekurudhor, speciale për aeroporte, stadiume, zjarrfikje, për ujitjen e parqeve, për ekonomitë bujqësore, për ujitjen e fushave.

Ujësjellësi individual shërben për furnizimin e instalimeve shtëpiake të ndërtesave që gjenden larg, jashtë vendbanimeve me ujë komunal, ose kur nuk është ndërtuar fare, për shembull, në qytete të vogla, në fshatra, pushimore për vendbanime vikend .

\subsubsection{Sjellja e ujit deri te konsumuesit}

Sipas mënyrës së sjelljes (prurjes) së ujit në rrjet dallohen:

Ujësjellësi i gravitetit me objektin ujëmarrës më të lartë se vendi i shpenzimit, ku uji vjen në rrjetin përndarës me anë të gravitetit dhe krijon shtypje të mjaftueshme.

Ujësjellësi me ngritjen artificiale të ujit, ku vendet e konsumimit janë në një kuotë më të lartë se objekti ujëmarrës. Shtypja e duhur për ngritjen e ujit arrihet, së pari, me ngritjen e ujit me pompa në rezervuare të ngritura lart e të futura në tokë në ndonjë kodër të afërme ose në rezervuare të lartësive pirgje.

\subsection{TIPET E RRJETIT TË UJËSJELLËSIT}

Rrjeti i jashtëm i vendbanimit (rrjeti urban ujësjellës) përcjell ujin deri te ndërtesat. Futet në dhe (tokë) për mbrojtje dhe për shkak të ndikimit të temperaturave të jashtme. Traseja e rrjetit shkon rrugëve në dy mënyra, si e degëzuar ose si unazore. Në rrjetin e degëzuar, për shkak të renditjes së rrugëve, trasetë u përngjajnë degëve të drurit, kurse skajet u mbarojnë në rrugët e ndryshme. Deri te ndërtesat uji përcillet vetëm nga njëra anë.

Rrjeti unazor ose qarkor është në trajtë unaze, ngase uji qarkullon nëpër sistemin e mbyllët të tubave të lidhura në mes veti të trasuara nëpër rrugë, ndërsa kyçjet e ndërtesave marrin ujin nga të dy anët. Në rrjetin e jashtëm vendosen qepenga për çkyçjen e ujit nga pjesë të ndryshme, pastaj hidrantët, ku kyçen zorrët për larjen e rrugëve, fikjen e zjarreve e të ngjashme. Rrjetet ujësjellësve me cilësi të ndryshme të ujit.

Përveç furnizimit me ujë të pijshëm të pastër shumë degëve industriale $u$ janë të domosdoshme edhe sasi shumë të mëdha uji për shpenzim industrie, për shembull, larja e xehes, ftohja e makinave e të ngjashme. Nëse nuk ekziston kaptazh vetjak i ujit të pijshëm, prej ujësjellësit urban furnizohen me ujë për pije, ndërsa prej një gurre të veçantë, për shembull, përmes stacionit thithës në lumë, marrin ujë industrial. Për shkak të rrezikut prej ndotjes së ujit për pije, vëmendje e posaçme duhet patjetër kushtuar ndërtimit të rrjetit, dhe sidomos mirëmbajtjes, për të mos u lidhur në mes vete rrjetit me cilësi të ndryshme të ujit. 
Ujësjellësi individual shërben për furnizimin individual të ndërtesave me ujë. Të gjitha objektet i ndërton investuesi me shpenzime të veta. Këtu hyjnë edhe objektet e marrjes, për shembull, sternat, puset, pajisja për sterilizim, nëse ka nevojë, edhe agregati i pompës për krijimin e shtypjes së duhur për prurjen e ujit deri te vendi i konsumit apo aparatet shtytëse: hidroforët, hidrocentralet, dhe rezervuarët .

\subsection{TUBAT E UJËSJELLËSVE}

Për përcjelljen e ujit prodhohen në mënyrë industriale, me diametra të ndryshëm, tuba të drejtë dhe pjesë fasonike prej hekuri, çeliku, bakri e plumbi të derdhur, prej azbest çimentos! dhe plastmasave. Diametrat nominalë janë diametra të brendshëm e të gjithë tubave pos atyre prej plastike tek të cilët diametri nominalë janë ata të jashtmit. Shprehen me milimetra, kurse për tuba të hollë me coll ("). Me rastin e hartimit të projekteve, të blerjes e të ngjashme, tubat ose gypat shënohen edhe me simbole edhe me shenja të shkronjave.

Tubave të gatshëm në industri u ekzaminohen cilësia dhe veçoritë e tjera. Për shkak se përcjellin ujin nën shtypje u ekzaminohet qëndrueshmëria ndaj shtypjes hidraulike (në praktikë quhet edhe shtypje punuese).

Rrjeti i jashtëm dhe ai oborrit deri te futja në ndërtesë, punohen me tuba prej hekuri, çeliku të derdhur e të zinkuar dhe plastmasave bashkë me pjesët përkatëse fasonike. Instalimet e shtëpisë mund të punohen sipas dispozitave: prej hekuri, çeliku, kurse kushtet për përdorimin e tubave të plastikës duhet të jenë te standardizuara. Ujësjellësi, institucioni komunal përcakton se cili material në cilin rast mund të përdoret.

Rrjeti shtëpiak përbëhet prej tri pjesësh:

1. Prej tubit kryesor ujësjellës ose kyçjes shtëpiake

2. Prej tubit kryesor përndarës

3. Prej tubit përndarës brenda ndërtesës

Kyçja shtëpiake shërben për t'u lidhur me vendin prej nga ndërtesa furnizohet me ujë. Prej kyçjes së shtëpisë nëpër ndërtesë shkon tubi kryesor shpërndarës. Prej tubit shpërndarës ndahen vertikalet, të cilat përmes degëve përcjellin ujin deri te vendet harxhuese.

\subsection{KYÇJA SHTËPIAKE}

Në vendbanimet me ujësjellës komunal tubi për kyçjen shtëpiake në njërin skaj lidhet për tubin rrugor ujësjellës. Gjatësia e kyçjes llogaritet deri te valvola e lëshimit prapa ujëmatësit. Në fig. është shënuar me gjatësinë. A prej tubit rrugor deri te pusi me ujëmatës para ndërtesës, prapa vijës së rregullacionit. 
ARKITEKTURA - UJI

KJO FAQE ËSHTË LËNË QËLLIMISHT E ZBRAZËT! 


\section{QASJA NË LËVIZJE}

\subsection{ASHENSORI}

Epoka e ashensorit të varur me litar, tani pas 150 viteve të përdorimit konsiderohet si kohë e perëndimit e kësaj teknologjie. Ndërtesat tani mund të zhvillohen dhe të arrijnë lartësi më të mëdha, forma dhe qëllime. Aplikimi i teknologjisë lineare magnetike të transportit vertikal maksimizon efikasitetin në arritje të lartësive më të mëdha në ndërtesa, dhe ofron komfor më të madh pasagjerët. Edhe pse dukuria me ashensor të varur është normë aktuale dhe trend në industrinë e ashensorëve, fakti se shumica e ashensorëve lëvizin vetëm në boshte vertikale, me një ashensor për bosht, është duke u bërë një kufizim për industrinë e ndërtimit, por edhe në kapacitetin e transportit të njerëzve. Për më tepër, ashensorët të varur për litar në një bosht kërkojnë dhe nxënë hapësirë më të madhe në etazhat e ndërtesave.

Një përpjekje e parë, nga këto synime për të avancuar në këtë drejtim ishte adresuar në vitin 2003 me sistemin ashensor TWIN, duke ofruar dy kabina për bosht dhe rritjen e kapacitetit të transportit me $30 \%$, si dhe një reduktim në hapësirë për ashensor në ndërtesa me $30 \%$.

ThyssenKrupp tani është duke hequr litarët, duke pezulluar teknologjinë për ashensor me motorët linear, duke i transformuar sistemet e ashensorëve në sisteme vertikale me kapacitete të transportit të cilat priten të rriten më se $50 \%$, po ashtu me kursim edhe në hapësirat për lëvizje apo pritet që këto hapësira të reduktohen deri në 50\%.

Figura 240. Ashensorët e së ardhmes (Burimi): Bujar Bajçinovci, 2015.

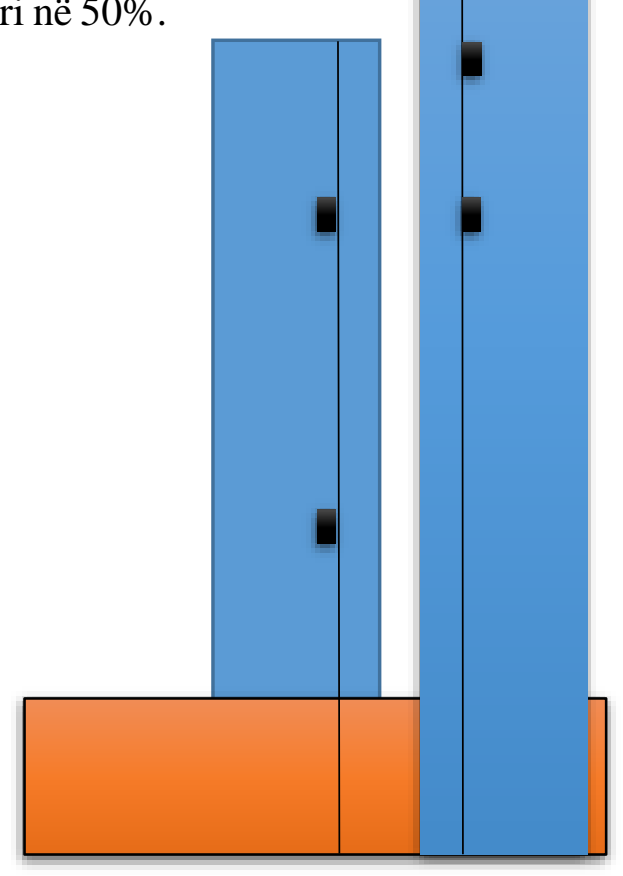

I konsideruar nga shumë profesioniste si shpikje e shenjtë në industrinë e ashensorëve, ThyssenKrupp MULTI aplikon teknologji të zhvilluar magnetike, analoge me teknologjinë Transrapid, ngjashëm me levitimin e trenit, duke bërë të mundur që të 
lëvizet në boshte në të njëjtën mënyrë sikur trenat që lëvizin në sistemet hekurudhore, me kabina të ndryshme për nga boshti, duke lejuar që lëvizjet të jenë vertikale dhe horizontale në të njëjtën kohë brenda ndërtesave. Siguria është siguruar nga shtytëset, si dhe nga frenimi i sistemit multi në kabina. Poshto sistemi i mirë provuar i kontrollit të sigurisë, i zhvilluar nga ThyssenKrupp.

Teknologjia e ashensorëve TWIN, parandalon afërsinë e kabinave me njëra tjetrën brenda boshteve. Shumë vendbanime urbane, njëherit për tu evidentuar që sipas të dhënave aktuale më shumë se gjysma e popullsisë së botës tashmë jeton në zonat urbane, si dhe pritet të jetë një rritje prej 2.5 miliardë e popullsisë urbane gjer në vitin 2050. Realisht me kufizimet e mëdha të mjedisit urban si dhe hapësirave në sipërfaqe të qyteteve, është menduar që me zhvillimin e teknologjisë të ketë rritje ekonomike dhe ekologjike për të akomoduar popullatën urbane në rritje të shpejtë. Andaj, koj teknologji përveç që zënë më pak sipërfaqe, duke ruajtur dhe siguruar sipërfaqe të gjelbra për qytetin, kjo teknologji lejon kontroll të centralizuar dhe inteligjente të energjisë. Përveç kësaj dukurie, numri i ndërtesave të larta është në rritje, lartësia mesatare e tyre ka tejkaluar parashikimet. Në vitin 2000, lartësia mesatare e 50 ndërtesave më të larta në botë ishte 315 metra, ndërsa në vitin 2013 arriti në 390 metra, një rritje prej 25\% në vetëm dekadën e fundit.

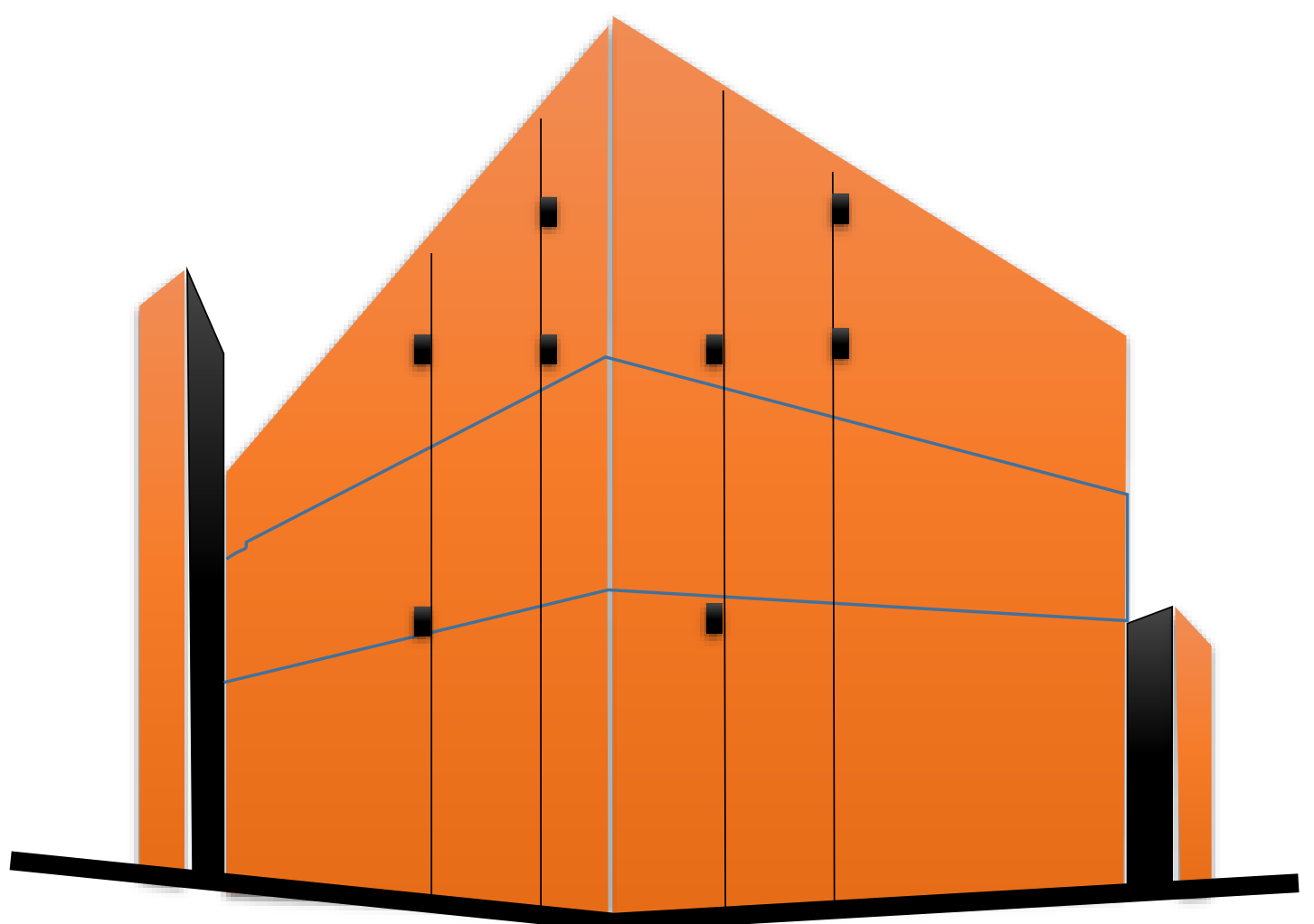

Figura 241. Ashensorët e së ardhmes. Lëvizje edhe në horizontale.

(Burimi): Bujar Bajçinovci, 2017.

Megjithatë, gjersa teknologjitë dhe mjetet ekzistojnë për të ndërtuar ndërtesa të larta, pa aftësinë për të lëvizur në mënyrë efikase banorët e ndërtesave në mes kateve, funksionaliteti në këto objekte është i kufizuar, po ashtu në humbje e të ardhurave nëse hapësira banesore dhe komerciale në katet më të larta nuk mund të shiten. Në këtë sfond, 
është e qartë se lëvizshmëria efikase në ndërtesa nuk është më një luks, por një domosdoshmëri absolute. Duke e bërë MULTI një nga risitë më të rëndësishme në industrinë e ashensorëve dhe në ofrimin e lëvizjes efikase në ndërtesa dhe në qytete. Fillim i një epoke të re për industrinë ndërtimore.

\subsection{INOVIMET E NEVOJSHME}

Një hulumtim i bërë nga studentët e Universitetit Columbia në lidhje me transportin vertikal me ashensor i bërë në vitin 2010, deklaron se: punëtorët e zyrave në New York City kanë shpenzuar një sasi kumulative prej 16.6 viteve, duke pritur për ashensorë si dhe i kanë kaluar 5.9 vite në ashensorë, duke rezultuar se sa kjo dukuri është jetike për të rritur disponueshmërinë dhe efikasitetin me ashensorë.

Andaj, sikurse zhvillimi i teknologjisë dhe mjeteve bashkëkohore për industrinë ndërtimore është duke u zhvilluar, është e domosdoshme që edhe industria e ashensorëve apo mjeteve për transport vertikal ti përshtat rinovimet dhe risitë teknologjike për të përmbushur kërkesat aktuale të efikasitetit në transportin vertikal, të pasagjerëve dhe mallrave, sidomos me më shumë se një kabinë në një bosht. Në këtë drejtim, ashensorët TWIN tashmë janë një avancim nga sistemi i mëvetshëm i kabinës, të cilët përmirësojnë kapacitetin dhe efikasitetin operacional.

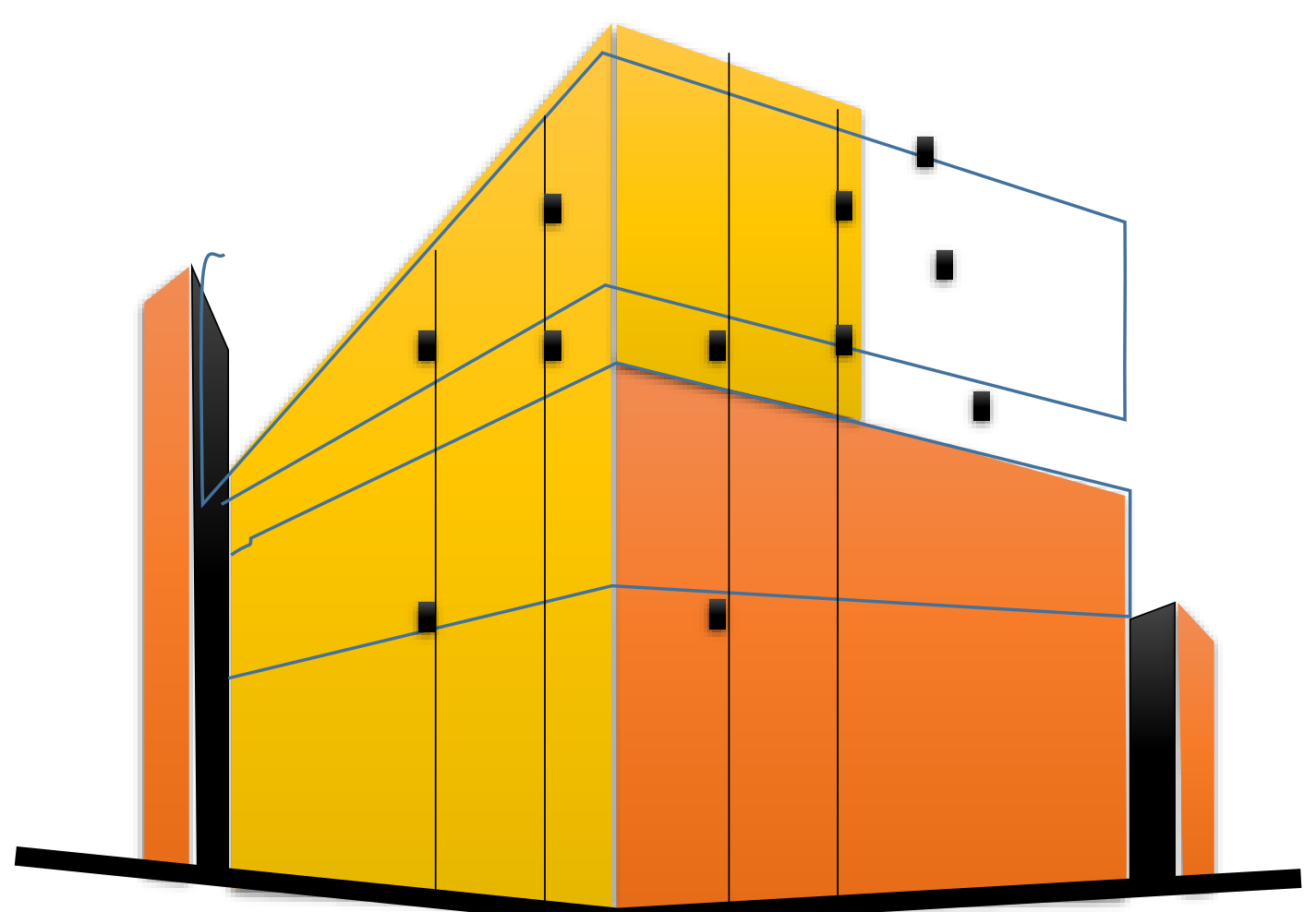

Figura 242. Ashensorët e së ardhmes. Struktura arkitektonike të pamvarura nga transporti klasik vertikal

(Burimi): Bujar Bajçinovci, 2017. 


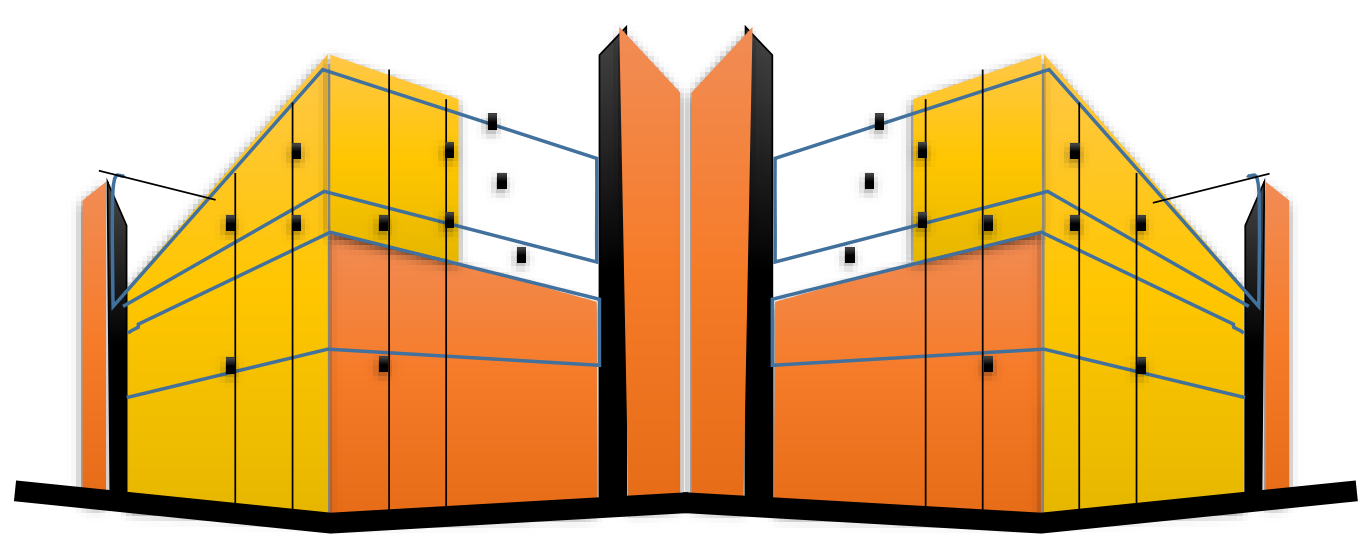

Figura 243. Mega Struktura urbane të pamvarura nga transporti klasik vertikal (Burimi): Bujar Bajçinovci, 2017.

\subsubsection{Multi}

MULTI është ofruar si teknologji e fundit e ThyssenKrupp në repertoarin e saj të gjerë të teknologjive me ashensor, përfaqëson një konvept historik në industrinë ashensorëve. Vazhdimisht duke kuptuar ëndrrën të gjatë të ndjekur që ashensorët apo makina të shumta të lëvizin në të njëjtin bosht.

Hulumtim dhe zhvillimi i fazave preliminare të MULTI ka arritur pikën e ndërtimit të modelit të parë apo prototipit, kulla e re e ThyssenKrupp në Rottweil siguron provat dhe certifikimin e ambientit të duhur për të marrë pjesë realisht në tregun aktual. Kulla për testime është paramenduar të përfundojë në fund të vitit 2016, nga kjo kohë, kompania synon të ketë një prototip të lëshuar në punë MULTI.

Si funksionon? Vepron në premisat themelore të një sistemi rrethor, MULTI përdorë teknologji magnetike për të vepruar me ashensorë, dhe një bosht $\mathrm{i}$ vetëm mund të përfshijë kabina të ndryshme. Me një shpejtësi të synuar prej $5 \mathrm{~m} / \mathrm{s}$, sistemi do të mundësojë qasje të vazhdueshme me një kabinë të ashensorit çdo 15 deri në 30 sekonda, me një transferim të shpejtë çdo 50 metra. Pasagjerët do të gëzojnë shumë pak pritje gjatë transportit, po ashtu opsioni i hyrjeve të dyfishta në etazha përmirëson lehtësinë e qasjes në ndërtesa të mëdha.

MULTI gjithashtu ofron kapacitete shumë më të larta dhe lëvizje më të shpejtë dhe më të rehatshme në krahasim me ashensorët me shpejtësi të lartë, të cilat janë të kufizuar nga efektet e presionit mbi trupin e njeriut, shumë njerëz përjetojnë jo rahati duke udhëtuar me ashensorë me shpejtësi më të lartë se $10 \mathrm{~m} / \mathrm{s}$. Edhe pse lartësia ideal e ndërtesave për instalimet Multi fillojnë në 300 metra, ky sistem nuk është i kufizuar nga lartësia e ndërtesës. Pa litarë, një sistem me frena "multilevel", dhe transfer induktiv të energjisë nga boshti në kabinë, MULTI kërkon boshte të vogla rreth $6 \mathrm{~m}^{2}$, ndërsa teknologjitë e tjera të tilla kërkojnë rreth $9 \mathrm{~m}^{2}$.

Kjo veçori mund të ketë kursime të konsiderueshme për projektuesit e ndërtesës. Rritja e përgjithshme në efikasitetin funksional gjithashtu përkthehet në një nevojë të reduktuar për shkallë dhe boshte të ashensorëve klasikë, duke zvogëluar sipërfaqet për ashensor në 
një ndërtese deri në 50\%. MULTI aplikon konceptin e sistemit të kontrollit të rreptë dhe të sigurisë, përfshin elemente të reja, të tilla si materiale të reja dhe të lehta të përbërë nga fijet e karbonit për kabina dhe dyer, të cilët peshojnë vetëm $50 \mathrm{~kg}$ në vend të $300 \mathrm{~kg}$ të ashensorëve standard, duke rezultuar në një peshë 50\% më pak në krahasim me teknologjitë standarde. Një makinë e re lineare gjithashtu mundëson që një motor të vetëm të jetë i mjaftueshëm për të kryer lëvizjet horizontale dhe vertikale, dhe një ndërrues që kabina të lëviz nga një bosht në tjetrin.

Duke kombinuar teknologjinë e re me një koncept të thjeshtë të operimit si dhe lehtësinë e përdorimit nga pasagjerët, MULTI ThyssenKrupp, ka transformuar idenë e kamotshme për një numër fleksibil të ashensorëve, duke lëvizur për bosht: poshtë, lartë, majtas dhe djathtas. ThyssenKrupp, dega e ashensorëve është një nga kompanitë kryesore në botë për ashensor, me më shumë se 50.000 të punësuar, kompania ofron produkte të reja dhe koncept të energjisë efiçiente, të dizajnuar për të përmbushur kërkesat e konsumatorëve. Portofolio prodhuese përfshin ashensorë për pasagjerë dhe mallra, shkallë lëvizëse. ${ }^{103}$

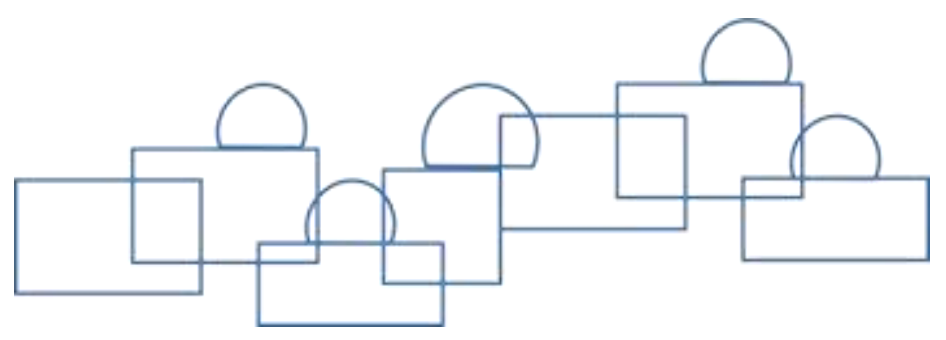

103 ThyssenKrupp Elevator AG, Elevator Technology Backgrounder. 11/2014. Press Release. 
QASJA NË LËVIZJE

KJO FAQE ËSHTË LËNË QËLLIMISHT E ZBRAZËT! 


\section{ARKITEKTURA - MJEDISI}

$\mathrm{H}$ ulumtimet në këtë lëmi, të kryera nga AgroVet për nevojat e Ministrisë së Zhvillimit Ekonomik, pjesëmarrës në këtë hulumtim është edhe autori i monografisë, hulumtimi dhe të gjeturat për mjedisin Kosovar do të prezantohen si ekstrakt apo pjesë e hulumtimit të kryer nga AgroVet në vitin 2013, të udhëhequr nga Prof. Xhevdet Elezi dhe Prof. Islam Fejza. Ky kapitull do të fokusohet në kontekst të shtjellimit të temës së ruajtjes dhe rivitalizimit të mjedisit, si pikë referente hulumtuese e dedikuar posaçërisht për studentet e Arkitekturës. Andaj ky kapitull është shkoçitur si ekstrakt nga studimi i sipërcituar.

\subsection{DEPONITË E BRAKTISURA}

"Deponitë e krijuara nga mbetjet e aktiviteteve minerale konsiderohen pika apo burime më të ndjeshme mjedisore, ato quhen edhe "pika të nxehta", ose në terminologjinë ndërkombëtare, Hot Spote mjedisore. Këto deponi janë krijuar gjatë eksploatimit dhe pasurimit të xehes, prandaj kanë përbërje shumë heterogjene dhe përmbajtje të lartë të elementeve kimike $(\mathrm{Pb}, \mathrm{Zn}, \mathrm{Cd}, \mathrm{As}, \mathrm{Hg})$, të cilët janë burim permanent i ndotjes së mjedisit.

Duke pasur parasysh këtë ndikim, si dhe rrezikun për shëndetin e komunitetit, këto mbetje janë adresuar në shumë dokumente, si: Strategjinë e Kosovës për Mjedis, 2004, Planin e Kosovës për Veprim në Mjedis 2006-2010, Planin e Veprimit për Partneritet Evropian 2009, si dhe Strategjinë Minerare të Kosovës. Nga të dhënat ekzistuese, llogaritet se si rezultat i proceseve të koncentrimit të xehes së $\mathrm{Pb}-\mathrm{Zn}$ me flotacion, si dhe të proceseve piro dhe hidrometalurgjike gjatë përfitimit të metaleve me ngjyrë dhe aliazheve të tyre, brenda hapësirave dhe përreth Kompleksit Mineraro-Metalurgjik të Trepçës, nga Veriu e deri në Jug-Lindje të Kosovës, janë krijuar 15 deponi me mbetje, që mbulojnë sipërfaqen prej rreth 200 hektarësh, me një sasi prej afro 60 milion tonelata.

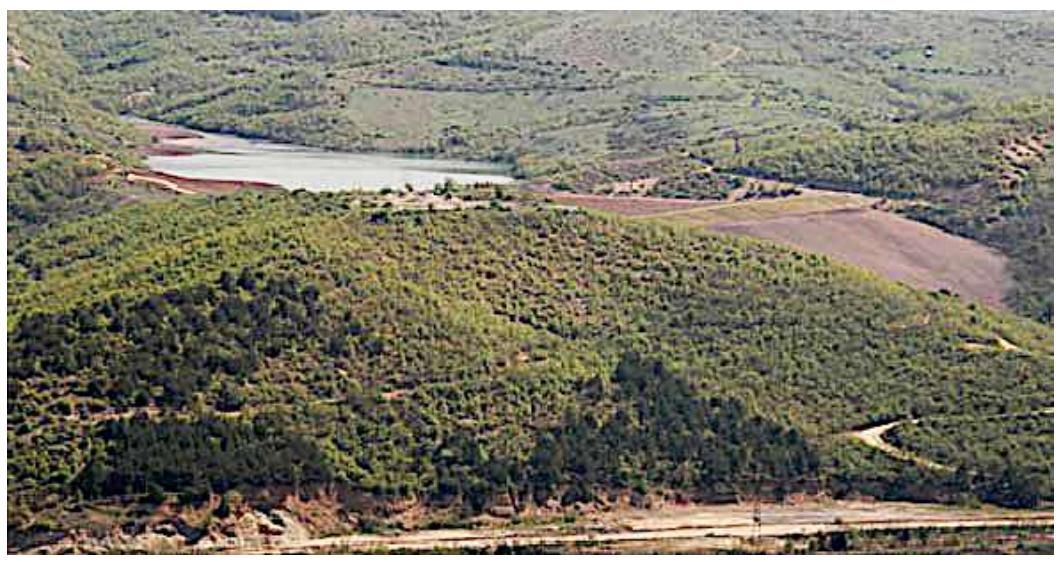

Figura 244. Pamje deponisë së Kelmendit (Burimi): AGROVET, 2013. MZHE 
Tabela 53. Evidentimi dhe verifikimi i lokacioneve me deponi në Kosovë (Burimi): AGROVET, 2013. MZHE

\begin{tabular}{|l|l|l|l||}
\hline Vendi & Emri i deponisë & Materiali & Aktive/braktisur \\
\hline Leposaviq & GornjiKmjin & Mbetje & Braktisur \\
\hline Leposaviq & Bostanishtë & Mbetje & Aktive \\
\hline Zveçan & Zhitkovc & Mbetje & Braktisur \\
\hline Zveçan /Mitrovicë & Gornje Polje & Mbetje & Braktisur \\
\hline Zveçan /Mitrovicë & Gornje Polje & Zgjyrë Pb. & Braktisur \\
\hline Mitrovicë & PIM & Mbetje & Pasive \\
\hline Mitrovicë & Kelmend & Mbetje & Aktualisht / period. pasive \\
\hline Artanë & Mareci 1 & Mbetje & Deri diku e trajtuar \\
\hline Artanë & Mareci 2 & Mbetje & Deri diku e trajtuar \\
\hline Graçanicë & Kodra e Kuqe & Mbetje & E mbyllur \\
\hline Kishnicë & K2 & Mbetje & Aktive \\
\hline Obiliq & Kosova A & Hiri & Aktive (pjesë. e trajtuar) \\
\hline Obiliq & Kosova B & Hiri & E mbyllur \\
\hline Drenas & Qikatova & Skorie & Aktive \\
\hline Gjakovë & Deva & Mbetje & Aktive \\
\hline
\end{tabular}

Tabela 54. Sasia e mbetjeve

(Burimi): Trepça, UNDP. 2011. Raporti i konferencës ndërkombëtare

\begin{tabular}{|l|c|c|c|c|}
\hline $\begin{array}{l}\text { Emri i } \\
\text { deponisë }\end{array}$ & Vendi & Statuti i deponisë & $\begin{array}{c}\text { Hapësira } \\
\text { e mbuluar (ha) }\end{array}$ & Sasia e mbetjeve (t) \\
\hline Gornji Kmjin & Leposaviq & E braktisur & 6.5 & 2600000 \\
\hline Bostaniste & Leposaviq & Aktive & $8-10$ & 3600000 \\
\hline Zhitkovac & Zveçan & E braktisur & 26 & 8500000 \\
\hline Gornje Polje & Zveçan & E braktisur & 50 & 12000000 \\
\hline Gornje Polje & Zveçan & $\begin{array}{c}\text { Llum plumbi - e } \\
\text { braktisur }\end{array}$ & $4-6$ & 2500000 \\
\hline Zveçan & Zveçan & Pluhur - e braktisur & $10-15$ & 10000000 \\
\hline Kelmend & Kelmend & Aktive & $8-10$ & 3600000 \\
\hline $\begin{array}{l}\text { Parku industrial } \\
\text { i Mitrovicës }\end{array}$ & Mitrovicë & E braktisur & 35 & 4200000 \\
\hline Staro Jalovishte & Graçanicë & E braktisur & 40 & 11000000 \\
\hline Badovc & Badovc & Aktive & 18 & 7700000 \\
\hline Artanë & Artanë & E braktisur & 4 & 1800000 \\
\hline \multicolumn{2}{r|}{} & Total & $\mathbf{2 0 9 . 5 - 2 2 0 . 5}$ & $\mathbf{6 7 5 0 0 ~ 0 0 0}$ \\
\hline
\end{tabular}

\subsubsection{Deponia në Kelmend}

Ndodhet afër fshatit Kelmend, deponia është periodikisht aktive, respektivisht në këtë deponi kohë pas kohe ndodhë procesi i mbushjes së hapësirave të shfrytëzuara me hidro mbushje në Minierën e Stan Tërgut. Deponia ndodhet në Perëndim të Flotacionit në Tunelin e Parë dhe zëne një sipërfaqe prej afro 18 ha, në të cilën janë depozituar rreth 3,6 milion tonelata. Mirëpo, duhet të theksohet se në këtë deponi, përpos materialit, deponohet dhe uji që vjen nga miniera dhe flotacioni. Të gjithë ujërat në deponi përmes Pajisjat derdhen në lumin Ibër duke u bërë vetëm trajtimi fizik i tij. 


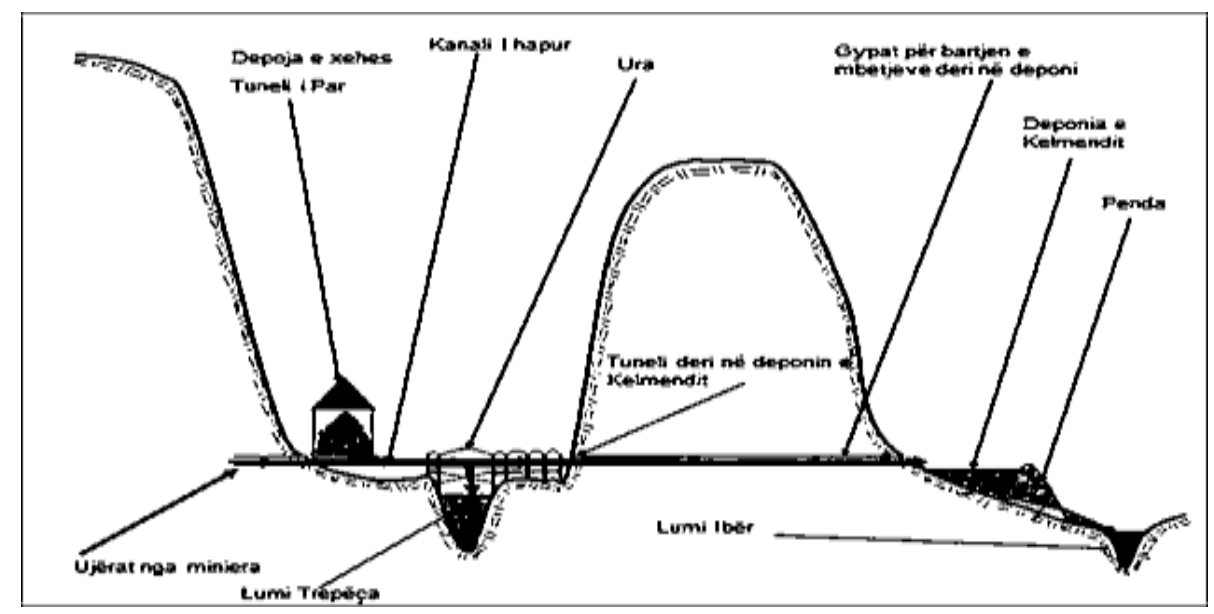

Figura 245. Skema e transportit të mbetjeve nga flotacioni në Tunel të Parë (Burimi): AGROVET, 2013. MZHE

\subsubsection{Parku Industrial Mitrovicë - „Trepça”}

Parku Industrial i Kombinatit "Trepça" në Mitrovicë shtrihet në Luginën e Rrafshit të Sitnicës-respektivisht në anën e saj të djathtë. Sipas shënimeve ekzistuese, investimet për këto kapacitete kanë filluar nga viti 1962, dhe ato tani zejnë një sipërfaqe 34,62 hektar, masa e tërësishme e këtyre mbetjeve industriale është rreth 1,520,000 tonelata.

Në kuadër të këtij Parku Industrial kanë zhvilluar aktivitet:

1. Industria Kimike nga viti 1963

2. Metalurgjia e Zinkut nga 1967

3. Fabrika e Akumulatorëve, gjithashtu nga viti 1967, të cilat pas procesit teknologjik kanë deponuar mbetje industriale

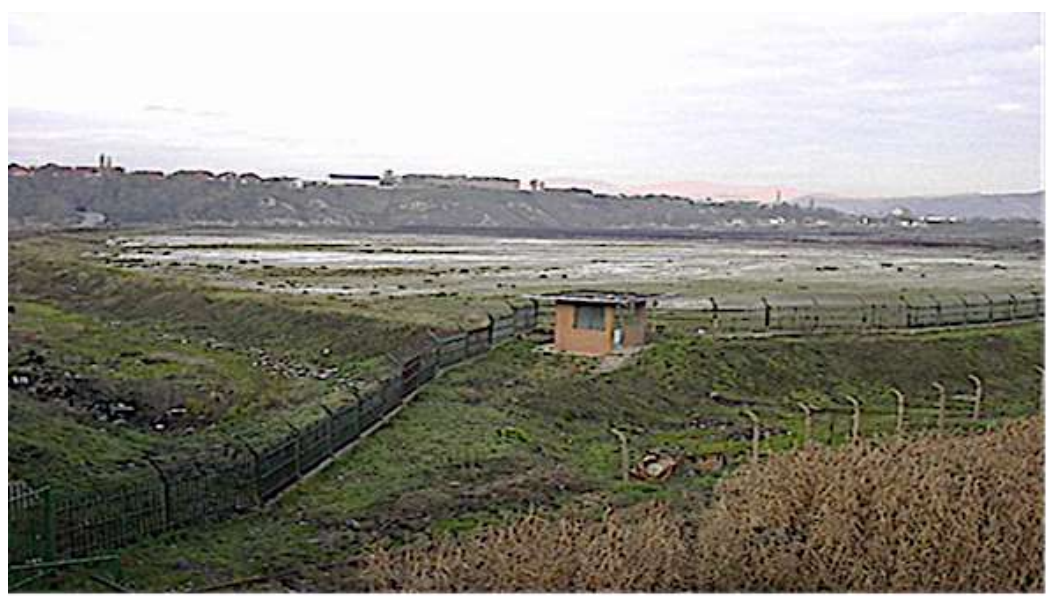

Figura 246. Deponia e mbeturinave industriale nga Industria Kimike (Burimi): AGROVET, 2013. MZHE 


\subsection{DEPONITË E HIRIT NGA TERMOELEKTRANAT}

"Deponitë e hirit të krijuara si rezultat i prodhimtarisë së TC, llogaritet se e kanë tejkaluar vëllimin e paraparë. Sipas vlerësimeve llogaritet se Deponía e TC-A, së bashku me djerrinë mbulon një sipërfaqe prej rreth 240 ha, ndërsa deponía e TC-B, rreth 55-60 ha. Nga aspekti gjeografik, konsiderohet se deponitë janë vendosur mbi tavanin e shtresës qymyrore (Pl12), ndërkaq, nga këndvështrimi gjeologjik, deponitë janë në plato me shtresa me përbërje argjilore, ndërsa në pozicione të veçanta ato zëvendësohen nga depozitimet aluviale dhe argjit të pjekur (brandi), i cili paraqet produkt të pjekjes së argjilit nga proceset e vetëndezjes së qymyrit. Sa i përketë situatës hidrogjeologjike, duhet të konstatojmë se ky basen përmban një rrjet hidrologjik të zhvilluar mirë me ujëmbledhësin kryesor që është Lumi Sitnica.

Lumenjtë tjerë në afërsi janë, Lumi Drenica në Perëndim dhe Lumi Llap në Lindje. Duhet të potencojmë se te dyja deponitë, në momente të caktuara në të kaluarën, janë shfrytëzuar për të grumbulluar qoftë mbeturinat e ngurta, ashtu edhe ato të lëngshme (për shembull, në Deponinë e Kosova A, janë identifikuar sasi të mëdha të vajit të përdorur dhe fenolit). Për fat të keq, nuk ekziston ndonjë gjendje e rexhistruar e tërë mbeturinave që janë hedhur në Deponi të TC A, por llogaritet se aty janë hedhur rreth 30,000 tonelata, dhe i kontaminuar, qymyr i lëshuar.

\subsubsection{Deponia e TC-A.}

Ndodhet afër TC-A, ajo zënë një sipërfaqe prej 110 ha, kurse vëllimi i saj sillet rreth 25 milion $\mathrm{m}^{3}$. Hiri i Deponisë së TC A, është i shumëllojshëm, qoftë nga aspekti i vjetërsisë, cilësisë së qymyrit, prandaj edhe përbërja kimike e tij ndryshon.

Tabela 55. Karakteristikat kimike të hirit të TC-A (Burimi): AGROVET, 2013. MZHE

\begin{tabular}{|l|l|l|l|l|}
\hline Parametri & \multirow{2}{*}{$\begin{array}{l}\text { Numri i } \\
\text { analizave }\end{array}$} & \multicolumn{4}{|l|}{ Koncentrimi [mg/kg] } \\
\cline { 3 - 5 } & 40 & Mesatare & Maksimum & Minimum \\
\hline Sulfur & 40 & 350.365 .6 & $14,940.9$ & $1,895.1$ \\
\hline Nikel & 40 & 438.0 & $1,228.4$ & 116.0 \\
\hline Krom & 40 & 234.9 & 375.3 & 16.7 \\
\hline Plumb & 40 & 6.6 & 127.1 & $<0.0001$ \\
\hline Kadmium & 40 & 19.7 & 68.5 & $<0.0001$ \\
\hline Merkur & 31 & 23.4 & 74.5 & $<0.0001$ \\
\hline Arsen & 31 & 1.3 & 4.0 & 0.4 \\
\hline $\begin{array}{l}\text { Fenole- } \\
\text { Indeksi }\end{array}$ & 40 & & & \\
\hline
\end{tabular}

Ekzistojnë mjaft informacione për vetitë fiziko-kimike (tabela 20) të hirit të raportuara nga shumë laboratore, por gjithashtu janë grumbulluar informacione edhe nga monitorimi sistematik i gjendjes së deponisë, si edhe nga vlerësimi i ndikimit në mjedis të kësaj Deponie. Hiri i Deponisë së TC A, është i shumëllojshëm, qoftë nga aspekti i vjetërsisë, cilësisë së qymyrit, prandaj edhe përbërja kimike e tij ndryshon. 
Ekzistojnë mjaft informacione për vetitë fiziko-kimike (tabela 20) të hirit të raportuara nga shumë laboratore, por gjithashtu janë grumbulluar informacione edhe nga monitorimi sistematik i gjendjes së deponisë, si edhe nga vlerësimi i ndikimit në mjedis të kësaj Deponie.

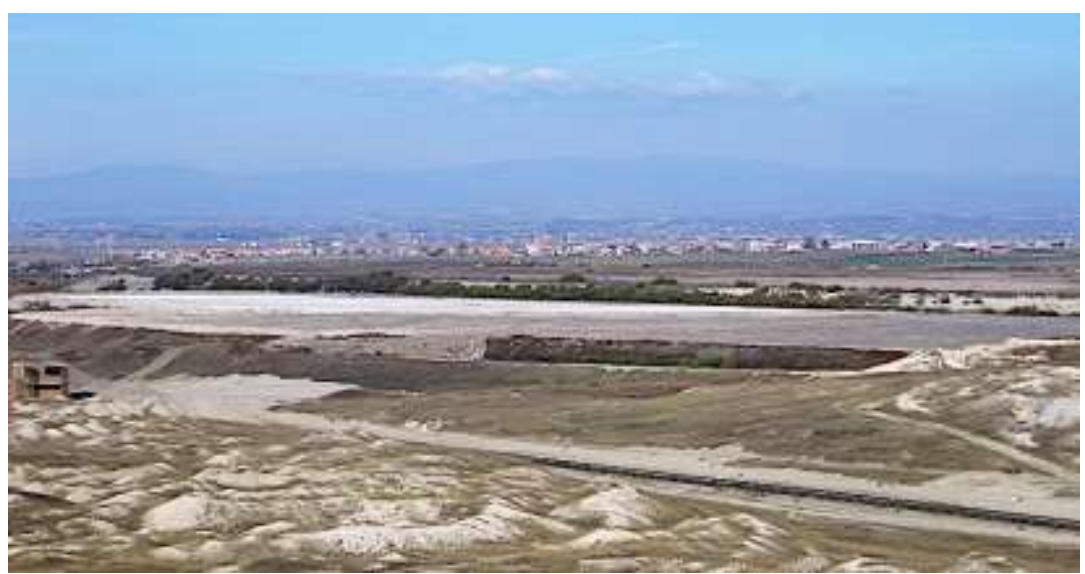

Figura 247. Deponia Kosova $A$

(Burimi): AGROVET, 2013. MZHE

\subsubsection{Deponia e TC- B.}

Deponia e hirit e krijuar si rezultat i aktivitetit të TC-B, zënë një sipërfaqe prej 92 ha. Mirëpo, duhet të potencojmë se deri në momentin e fillimit të transportimit hidraulik të hirit për deponim në hapësirat e krijuara, si rezultat i eksploatimit të qymyrit në mihjen sipërfaqësore Mirash, është zënë hapësirë me hi me një vëllim prej 14 milion m3, pesha/masa e të cilit arrijnë në rreth 20 milion tonelata." (Ekstakt, Agrovet 2013. MZHE)

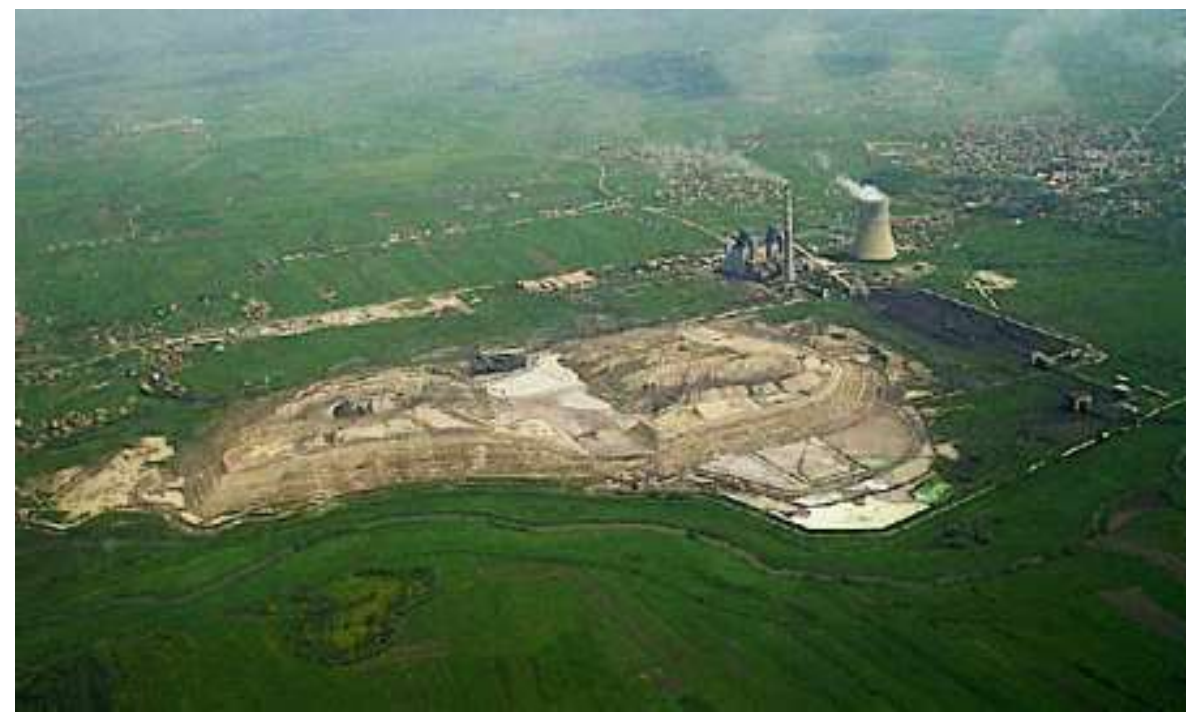

Figura 248. Deponia Kosova B (Burimi): AGROVET, 2013. MZHE 


\subsection{GURORËT E BRAKTISURA}

“Zhvillimi i hovshëm i industrisë ndërtimore dhe infrastrukturës rrugore ka paraqitur nevojën e madhe të hapjes së shumë korridoreve sipërfaqësore të shfrytëzimit të materialeve ndërtimore, si shkëmbinjtë të fortë, rërë, zhavorr, . Një numër i tyre për shkaqe të ndryshme kanë përfunduar shfrytëzimin e këtyre materialeve duke lënë mbrapa degradim të natyrës dhe ambientit në hapësirat e veprimit të tyre. Deri më tani në këto lokacione nuk kemi rast të rehabilitimit dhe rikultivimit të natyrës së shkatërruar. Ky fakt ka shtyrë institucionet vendore që të marrin hapa të nevojshëm që në një formë apo tjetër t’i obligojnë shkaktarët e kësaj gjendje t’i kthejnë natyrës një pamje të rehabilituar, duke larguar edhe mundësitë e rrezikimit të komunitetit që jetojnë në ato lokacione.

Krijimi i infrastrukturës ligjore është njëra nga këto forma, e cila obligon shfrytëzuesit e këtyre pasurive natyrore që pas përfundimit të aktivitetit eksploatues të ndërmarrin masat e rikultivimit. Andaj hulumtimet janë një hapë drejtë ndërmarrjes së masave rikultivuese të këtyre hapësirave dhe një herit është arritur që të evidentohen të gjithë operuesit dhe lokacionet ku ata kanë vepruar dhe që tani më kanë ndërprerë aktivitetin, ose edhe kanë humbur të drejtën e punimeve (Licencën). Duke pasur parasysh numrin e madh të tyre (rreth 254), të shpërndara në të gjitha regjionet e Republikës së Kosovës.

Si shembull më tipik për rikultivim është të trajtohet Gurorja e braktisur "Durimi" në fshatin Vasilevë, Drenas e cila gjendet në pjesën qendrore të Kosovës, në anën e djathtë të magjistrales Prishtinë- Pejë, gjegjësisht në kilometrin e 25 të saj, në një distancë rreth $1 \mathrm{~km}$ nga rruga. Gjendja aktuale e lokacionit në fjalë përveç që shëmton pamjen e natyrës së kësaj treve, ajo njëkohësisht paraqet edhe rrezik permanent për banorët e kësaj ane. Përcaktimi i opsioneve për rikultivim dhe përcaktimi i mundësive të shfrytëzimit të hapësirës së rikultivuar.

Realizimi i procesit të rikultivimin që nënkupton aktivitetin përfundimtar në veprimtaritë minerare është punë komplekse. Kompleksiteti dhe ndërlikueshmëria e këtij procesi bëhet edhe më e madhe, sidomos kur bëhet fjalë për mbetjet nga pasurimi (flotimi), por edhe i minierave të braktisura nga të cilat nuk janë eksploatuar të gjitha sasitë e xehes. Sipërfaqet e degraduara nga veprimtaria minerare në Kosovë, vlerësohen si më shqetësuese, gjegjësisht janë sipërfaqet me potencial më të lartë të ndotjes së mjedisit për shkak të përmbajtjes shumë të lartë të elementeve kimike që veprojnë si toksik te bimët dhe shtazët. Për këtë arsye, në këto sipërfaqe nuk janë shfaqur shenja të zhvillimit të vetërikultivimit. Vështirësia për rikultivimin e tyre shtohet edhe për shkak të mungesës së thërrmijave të argjilit dhe të lëndës organike (humusit) në këto materiale. Gjithashtu, duhet të potencojmë se hedhurinat minerale kanë vlerë të caktuar ekonomike dhe çdo ditë e më shumë është aktuale mundësia e riciklimit të tyre.

Çasje e njëjtë duhet të përqendrohet edhe sa i përket minierave të braktisura. Ato duhet të studiohen gjithanshëm dhe pastaj të përcaktohet për masat që duhet të ndermirën. Sidoqoftë, nga ky studim duhet të sugjerohen mënyra të rikultivimit të tipit të Deponisë në Kelmend dhe Minierës në Dubovc. Në deponitë dhe minierat e braktisura urgjentisht duhet të rehabilitohen pikat ose aspektet akute, ku mund të rrezikohet popullata. Të stabilizohen digat e tyre, të menaxhohen në mënyrë më të mirë ujërat që rrjedhin në këto objekte. Sugjerimi primarë janë që sa më parë të vendoset sinjalizimi në miniera dhe deponi të braktisura." (Ekstakt, Agrovet 2013. MZHE) 
Prandaj, aktualisht më së shumti mund të punohet në opsione të rikultivimit të sipërfaqeve në gurore të braktisura. Mundësitë e ridestinimit të sipërfaqeve të rikultivuara janë të shumta. Sipas konceptit të përgjithshëm, sipërfaqet duhet t'i përshtatën peizazhit ekzistues, por në zona ku ato mund të destinohen për shfrytëzim tjetër, atëherë, mund të shfrytëzohen për rekreacion, deponim specifik, vendbanime.

Përgatitja e planeve (projekteve) për rikultivim të një deponie, një miniere dhe një gurore të braktisur. Rekultivimi përbën/paraqet kompleks të aktiviteteve inxhinierike: gjeologjike, xehetarë, agronomike, biologjike, arkitektonike (pasazhit), të cilat duhet ndërmarrë në kohë dhe vend të caktuar me qëllim të transformimit/kthimit të tokës së degraduar në gjendje për prodhimtari bujqësore, pyjore, vende të përshtatshme për mbajtje të ujit, rekreacion, vendbanim, si dhe destinime tjera.

Rikultivimi ose rregullimi i tokës/sipërfaqes nënkupton aplikimin e tërësisë së masave teknike, hidroteknike, agroteknike dhe biologjike me qëllim të përmirësimit të kushteve për prodhimtari bujqësore, gjegjësisht rritë pjellorinë ose potencialin prodhues të saj. Potenciali prodhues nënkupton përgatitjen e horizontit sipërfaqësor me veti të përshtatshme fizike- kimike për prodhimtari. Me qëllim të realizimit të rikultivimit, sipas të gjitha normave dhe metodologjive që rregullojnë këtë problematikë është i nevojshëm Plani i aktiviteteve. Plani i aktiviteteve duhet të përmbajë të gjitha masat dhe afatet që duhet ndërmarrë për konstatimin e gjendjes (VNM, Vlerësimin e Ndikimit në Mjedis), që nga fillimi i shfrytëzimit të minierës e deri në fazën përfundimtare, respektivisht pas rikultivimit të saj.

Plani i aktivitetit, gjithashtu duhet të përfshijë analizën e tërësishme dhe të hollësishme të tërë teknologjisë së masave të ndërmarra për realizimin e këtij aktiviteti, gjegjësisht planin për ekzekutimin e rikultivimit teknik, bioteknik dhe biologjik, në tri etapa të nevojshme:

1. Faza e I, evidentimi dhe grumbullimi i informacionit të nevojshëm, nga statusi deri te kostoja e rikultivimit,

2. Faza e II, plani aksional i rikultivimit (studimi i ekzekutimit) dhe

3. Faza e III, përcjellja (monitorimi) dhe raportimi gjatë implementimit

Sipas planit të aktivitetit, Projekti i rikultivimit duhet të përmbajë përshkrimin e hollësishëm të veprimit të ndikimit në mjedis (VNM) të aktivitetit minerar në tërë resurset e zonës, gjegjësisht ndikimin në tokë, ujë, ajër, biocenozë (florë e faunë), pra edhe në efektet e ndikimit në popullatë.

\subsection{VLERËSIMI I NDIKIMIT NË MJEDIS (VNM) PËR MINIERËN E (Mg) DUBOVCIT}

Ne raportin e VNM-s për vendburimin e Mg në Dubovc, do të analizohen karakteristikat e gjendjes ekzistuese të mjedisit në lokalitetin Dubovc duke i përfshi të gjithë faktorët të cilët direkt ndikojnë në mjedisin dhe komunitetin për rreth. Miniera ka pushuar aktivitetin eksploatues në fundin e viteve 50 ta. Periudha e punimeve xehetare ka krijuar një gjendje shumë të keqësuar në këtë miniere, e cila ndikon negativisht në mjedis, por sidomos paraqet rrezikshmëri për sigurinë e komunitetit dhe gjallesave tjera. 
Lidhur me pozitën gjeografike dhe informacione tjera janë prezantuar në kaptinat tjera, në këtë kaptinë, do të flitet për faktorët që analizojnë vlerësimin e ndikimit në mjedis.

Ligjet me te rëndësishme të cilat duhet aplikuar në hartimin e raportit të VNM-së:

- Ligji për Mbrojtjen e Mjedisit Nr. 03/L-025

- Ligji për VNM Nr. 03/L-214

- Ligji për tokën bujqësore Nr. 02/L- 26

- Ligji për mbrojtjen e natyrës Nr. 03/L-233

- Ligji për mbrojtjen e ujërave Nr. 2004/24

- Ligji për mbrojtjen e ajrit Nr. 03/L- 160

- Ligji për mbeturina Nr. 02/L-30

- Ligji për mbrojtjen nga Zhurma Nr. 02/L-102

- Ligji për mbrojtjen nga zjarri Nr. 02/L-41

Duke marrë parasysh faktin se një pjesë e madhe e specifikave mjedisore nuk janë përfshirë në kuadër të rregullativës së sipërshënuar, për nevojat e hartimit të këtij Raporti është shfrytëzuar edhe rregullativa relevante ndërkombëtare, si dhe direktivat përkatëse për mjedis, si Direktiva e VNM-s (85/337/EEC).

Vlerësimi i ndikimeve sipas këtyre kualifikimeve:

1. Madhësia dhe lloji i ndotjes

2. Karakteristikat dhe dominimi i materialit ndotës

3. Gjendja e mjedisit në terrenin e analizuar

4. Vlerësimi i shkallës së rrezikshmërisë

5. Përcaktimi i masave mbrojtëse sipas rezultateve të arritura mbi vlerësimin e ndikimit në mjedis.

6. Pjesa më e rëndësishme e analizës së këtij raporti i kushtohet kuantifikimit dhe vlerësimit të gjendjes ekzistuese.

\subsubsection{Përshkrimi i Lokacionit dhe Mjedisi}

Të dhënat mbi Vendburimin e Mg datojnë që nga vitet e 50-ta dhe në të disa herë ka filluar dhe është ndërprerë eksploatimi i Mg, dhe përfundimisht është ndërpre më 1958. Paralelisht me shfrytëzimin, por edhe pas tij, në vendburim janë realizuar punime hulumtuese të vëllimeve të ndryshme, të cilat gjithashtu me ndërprerje kane vazhduar deri në vitin 1979. Në aspektin gjeologjik, vendburimi prezantohet me dy damarë të mëdhenj magneziti, me shtrirje VP dhe rrënjë në drejtim të Jugut. Përveç këtyre dy trupave të $\mathrm{Mg}$, nevoja për hulumtime të reja është e madhe.

\subsubsection{Popullata dhe Vendbanimet}

Njërën nga veçoritë kryesore të hapësirës së analizuar, në kuptim të përcaktimit të ndikimeve të mundshme në mjedis, paraqet popullata dhe demografia e saj. Këto fakte kuptimin e plotë të tyre e kanë në hulumtimin e hollësishëm të ndikimeve të mundshme negative në banorë që jetojnë në lokalitetin përkatës. (Ekstrakt, Agrovet 2013. MZHE) 
Rrethina e vendburimit, para luftës së fundit në Kosovë ka qenë mjaft e populluar, kurse tani ky numër i banorëve nuk dihet saktë, sepse shumë familje kanë migruar në zonat e qyteteve, Vushtrri, Mitrovicë dhe Skenderaj. Pjesa e mbetur e banorëve në këtë zonë, kryesisht merren me bujqësi.

\subsubsection{Erërat}

Erërat që fryejnë në këtë lokacion janë nga drejtimi i Veriut, Perëndimit, kurse me intensitet më të vogël janë nga Jugu.

\subsubsection{Pedologjia}

Në aspektin pedologjik, toka ku ndodhet miniera bënë pjesë në Klasën e tokave të pazhvilluara, me një shtresë të depozitimeve të materialit të shpatit (deluviume), të përfaqësuara nga materialet copëzore me përbërje: argjila me përzierje me copëza serpentine, karbonate me diametër 10 deri $30 \mathrm{~cm}$. Tokat e formuara kanë origjinë/gjenezë nga alterimi i shkëmbinjve për rreth lokacionit, por më tepër janë livadhe me vegjetacion të mesëm të shkurreve dhe gjysmë shkurreve. Toka e zonës është e mbuluar me vegjetacion të dobët me kullota natyrore. Toka është me ngjyrë hiri në të bardhë, ato lagën kryesisht nga reshjet (ujërat atmosferik). Vende-vende paraqiten tokat me ngjyrë kafeje, të cilat biologjikisht janë mjaft aktive dhe kryesisht shfrytëzohen si toka bujqësore dhe pyjore.

\subsubsection{Bimësia dhe vegjetacioni}

Lokacioni karakterizohet me reliev fushor-kodrinor-malor, me vegjetacion të ulët, here herë i zhveshur. Zona përmban vlera ekonomike në kuptimin e përdorimit si tokë bujqësore, por edhe si zone me vlera kullosore. Pjesët e ngastrave ku ndodhen punimet minerare janë të mbuluara me vegjetacion të kullosave, manaferra kaçubore, pyll me rritje mesatare, shkurre kaçubore të qarrit, bungut. Këto bimë u përshtaten kushteve të jetës së tyre në këta shkëmbinjtë dhe duhet të merren parasysh gjatë rehabilitimit të objekteve minerare.

\subsubsection{Fauna}

Bazuar në florën ekzistuese dhe kushtet klimatike të rajonit, e duke marrë për bazë edhe të dhënat nga vendasit, në këtë zonë përpos shtazëve dhe shpezëve shtëpiake jetojnë gjitarët, zvarranikët, brejtësit, insektet e ndryshme, lepuri i egër, dhelpra, ujku, derri i egër, .

\subsubsection{Peizazhi}

Është kriter me rëndësi në ruajtjen e mjedisit dhe nëse nuk zgjidhet drejt konsiderohet si degradim i tij.

\subsubsection{Ajri}

Me që tani për tani në këtë lokacion nuk ka aktivitete minerare, në këtë zonë nuk ka ndotje të ajrit. 


\subsubsection{Uji}

Në vendndodhjen e vendburimit ka burime natyrale të ujit të cilat shfrytëzohen nga banorët e zonës. Lumenjtë që kalojnë pranë minierës si dhe burimet natyrore në aspektin e cilësisë janë në nivel/kondita optimale, për faktin se nuk ka aktivitet minerar.

\subsubsection{Vlerësimet e ndikimeve në mjedis}

Ndikimet në tokë, Ndikim negativ në tokë paraqesin punimet minerare të braktisura (puset e ajrimit të cilat janë të shumta). Përveç pengesave gjatë punimit të tokave bujqësore, këto punime minerare të braktisura, paraqesin rrezik për banorët dhe bagëtinë. Ndikimi në Peizazh Aktiviteti minerar në të kaluarën ka degraduar peizazhin në masë të dukshme.

Ndikimet në vendbanime dhe popullatë, Puset e ajrimit të mbetura nga aktivitetet minerare (të lëna në mëshirën e kohës), paraqesin rrezik permanent për banorët e zonës. Në të kaluarën kanë ndodhur aksidente të cilat kanë përfunduar me fatalitet.

Masat për parandalimin dhe zvogëlimin e ndikimeve në mjedisin pritës Për këtë qellim, në vazhdim do të përshkruhen masat teknike, bioteknike dhe biologjike për sanimin/rikultivimin e gjendjes ekzistuese.

\subsubsection{Rikultivimi teknik}

Qëllim kryesor $\mathrm{i}$ fazës teknike të rikultivimit është arritja e përmirësimit të karakteristikave të qëndrueshmërisë ndaj forcave të deformimit të deponisë, të cilat drejtpërdrejt kanë ndikim ndaj veprimeve të erozionit. Kjo nënkupton krijimin e bazamentit stabil për objektin (minierën, deponinë, guroren) në të cilën do të aplikohen faza bioteknike dhe biologjike e rikultivimit. Në vijim janë përshkruar aktivitetet për realizimin e fazës teknike të rikultivimit në objektet e përzgjedhura për këtë studim.”

(Ekstrakt, Agrovet 2013. MZHE)

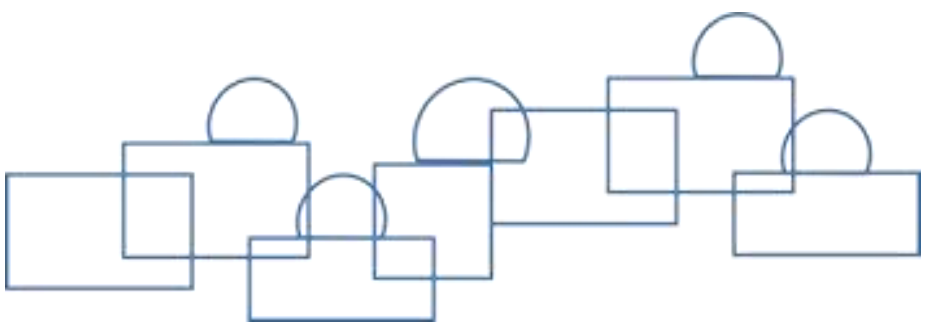




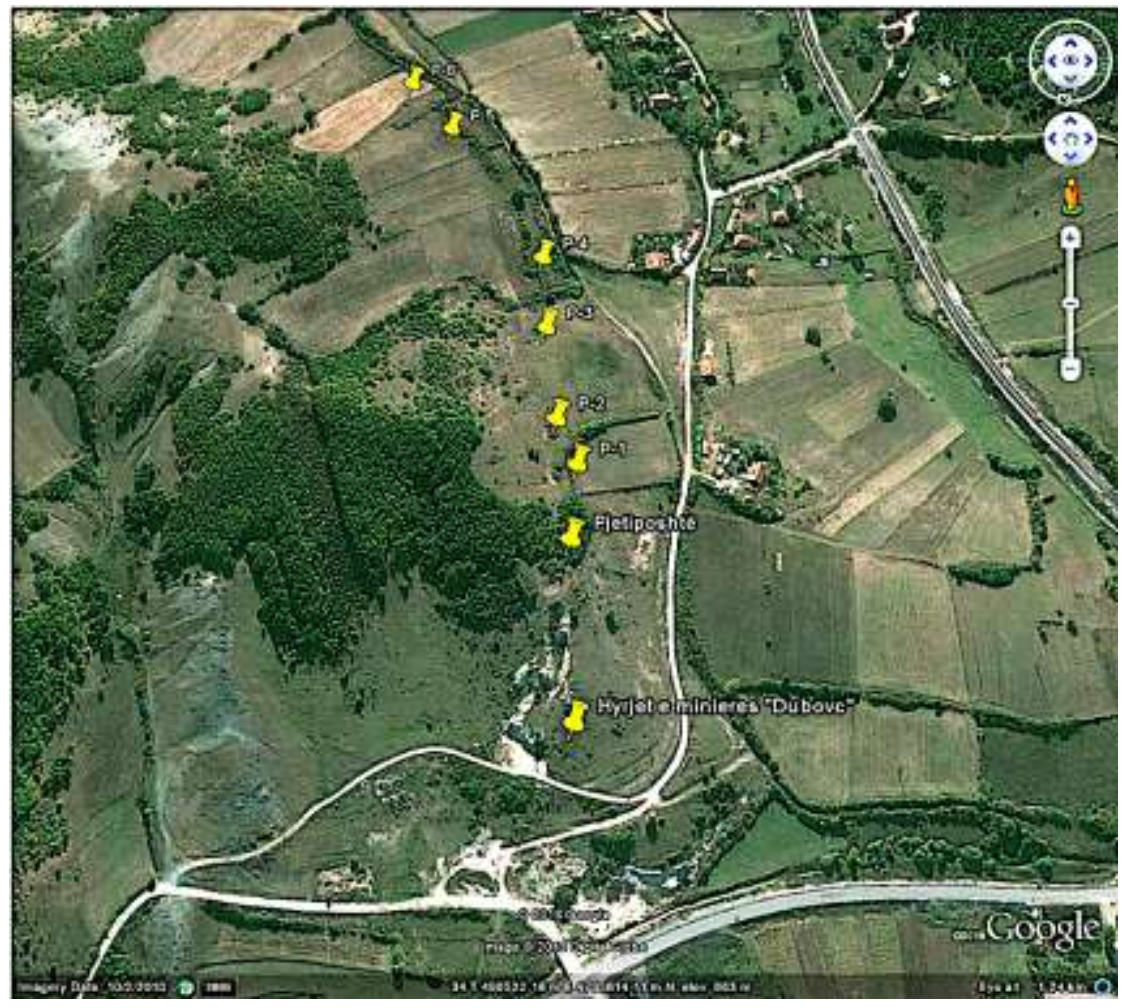

Figura 249. Miniera në Dubovc

(Burimi): Bujar Bajçinovci, AGROVET, 2013. MZHE

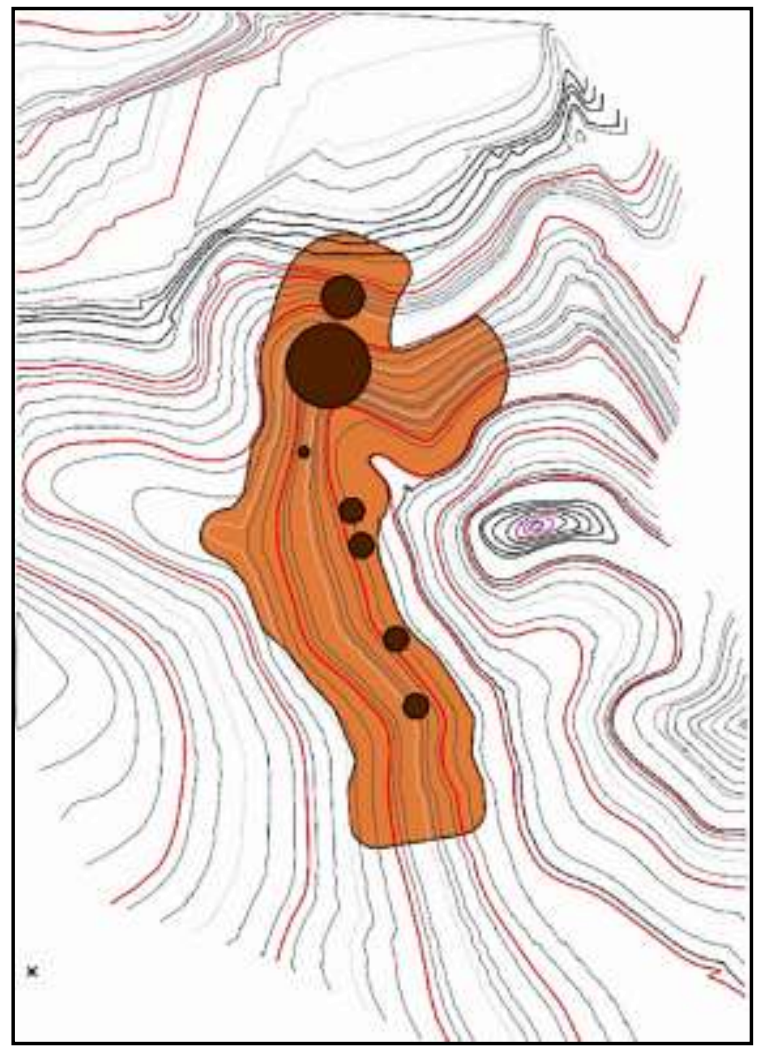

Figura 250. Tereni dhe morfologjia e minierës (Burimi): Bujar Bajçinovci, AGROVET, 2013. MZHE 

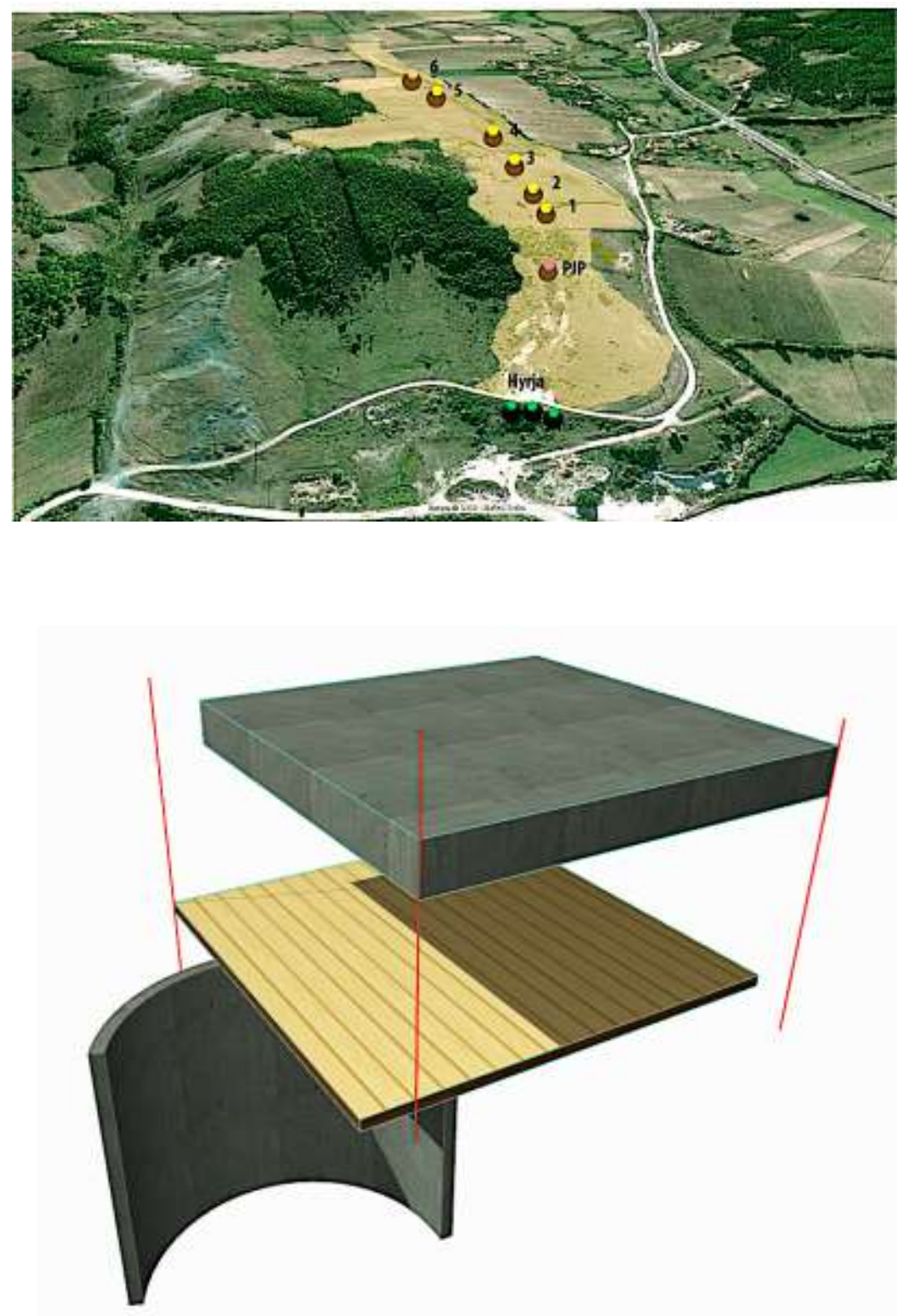

Figura 251. Realizimi i mbylljes së puseve dhe pjeti poshtë në miniere (Burimi): Bujar Bajçinovci, AGROVET, 2013. MZHE

\subsubsection{Punimet përgatitore për rehabilitimin e objekteve minerare}

Është konstatuar se pas mbylljes, objektet minerare kanë mbetur të pa trajtuara. Në këtë studim, propozojmë që për rehabilitimin e objekteve minerare të braktisura të përvetësohet varianti i mbylljes së hyrjeve të galerive kryesore me pllakë beton-arme dhe të definohen me koordinata. Kurse, pikat e puseve të paraqitura në sipërfaqe të terrenit, të sigurohen me pllaka me beton-arme dhe të mbulohen me formacione argjilore. Për mbushjen e hapësirës së puseve mund të shfrytëzohet materiali argjilor i pa selektuar, kurse shtresa përfundimtare me trashësi $0.5 \mathrm{~m}$ material i selektuar humusorë. 


\subsubsection{Rikultivimi Bioteknik}

Faza e rikultivimit bioteknik i pasojnë masat e ndërmarra gjatë fazës teknike të këtij procesi. Me masa bioteknike të rikultivimit nënkuptohet zgjedhja e drejtë e vegjetacionit e cila së bashku me masat teknike sigurojnë stabilitet të qëndrueshëm, qoftë në drejtim horizontal, ashtu edhe në atë vertikal. Gjegjësisht, masat bioteknike duhet të sigurojnë realizimin sa më të suksesshëm të fazës biologjike të rikultivimit. Me qenë se në këtë studim po shqyrtohen mënyrat dhe mundësitë e rikultivimit të plotë (vërtet), atëherë vëmendje e posaçme u kushtohet të dy fazave, sepse kjo nënkupton krijimin e vetive sa më të përshtatshme pedologjike të bazamentit për një ekosistem të suksesshëm. Në aspektin bioteknik, Projekti i rikultivimit, objektiv kryesor duhet ta ketë ruajtjen gjegjësisht krijimin e profilit të përshtatshëm pedologjik, prandaj plani për zbatimin e tij përmban:

1. Mënyrën e largimit dhe të kthimit të shtresës (horizontit) pjellore të tokës,

2. Përshkrimin e masave teknike, agroteknike dhe biologjike që do të ndermirën dhe përshkrimi i horizonteve të tokës që do të përfshihen,

3. Dinamikën kohore dhe teknologjinë e shfrytëzuar, si dhe

4. Metodologjinë e përcjelljes së pjellorisë dhe materieve të rrezikshme (toksike).

Me qëllim të realizimit me sukses të fazës bioteknike, por edhe të fazave tjera, është i domosdoshëm zbatimi i Rregullorës nr. 02/2012 për Administrimin e Mbeturinave Minerare të nxjerrur nga Ministria e Zhvillimit Ekonomik të republikës së Kosovës.

Objektivat e projektit të rikultivimit të minierës së braktisur të Mg në Dubovc janë:

1. Mbyllja dhe sigurimi i puseve, si dhe restaurimi i shtresës sipërfaqësore të tokës,

2. Mos optimalizimi i vetive fiziko mekanike dhe kimike të tokës varësisht nga destinimi (tokë pyjore ose bujqësore),

3. Përmirësimi i regjimit ujorë, ajror

4. Shtimi i aftësisë prodhuese-pjellorisë së tokës, gjegjësisht arritja e pjellorisë së ngjashme me sipërfaqet bujqësore që fermerët i kultivojnë.

Deposoli i krijuar duhet t'i nënshtrohet Programit të monitorimit, i cili ka objektiva të caktuar, varësisht nga fazat e zhvillimit të tij:

1. Faza e parë, menjëherë pas përfundimit të ri-kultivimit teknik;

2. Faza e dytë, para mbjelljes dhe

3. Faza e tretë, pas mbjelljes

\subsubsection{Rikultivimi Biologjik}

Në rastin e rivegjetimit të tetë pikave, përkatësisht dy hyrjet dhe gjashtë puset që përfshijnë një sipërfaqe prej rreth $300 \mathrm{~m}^{2}$ duhet shfrytëzuar lloje barishtore dhe shkurrore, si dhe të aplikohet masa e plehërimit të tyre me një sasi të plehut mineral, NPK. Plehu mineral NPK 3x15, duhet të shtohet në sasi prej prej $50 \mathrm{~kg}$ për $300 \mathrm{~m}^{2}$. Përzierja e farës, plehut mineral dhe dheut duhet të bëhet deri në thellësinë prej rreth $5 \mathrm{~cm}$. 


\subsubsection{Veçoritë e sigurisë}

Siguria duhet të jetë gjithmonë prioriteti i kryesor me rastin e eksploatimit të resurseve natyrore. Miniera në Dubovc e cila është jo funksionale, ka lënë pas veti shumë puse për ajrime, gropat e konsiderueshme të hyrjeve të pa trajtuara që përbëjnë rrezik permanent nga rrëshqitjet e kalimtareve të rastit, e sidomos në periudhën e natës ku nuk ekziston asnjë shenje apo një ndriçim sado pak modest. Pjerrtësitë e larta, rreziku nga rrëshqitja e njerëzve posaçërisht fëmijëve dhe të moshuarve është e mundshme në mënyrë permanente. Natyrisht, që qasja pas mbylljes së minierës ka mbetur në nivelin e atributeve të harruara, me rrezik permanent në shumë drejtime funksionale, e posaçërisht rreziqe fizike, kjo gjendje kërkon veprime të pa vonuara dhe konkrete, respektivisht ndërmarrjen e masave që janë propozuar nga ekipi projektues, pra mbushjen emergjente të puseve, pjetit poshtë dhe rikultivimit morfologjik të terrenit.

\subsection{GURORJA E BRAKTISUR NË VASILEVË}

\subsubsection{Vlerësimi i ndikimit në mjedis për guroren në Vasilevë}

"Raporti i Vlerësimit të Ndikimit ne Mjedis (VNM), pas shfrytëzimit të gurit gëlqerorë nga gurëthyesi në Vasilevës, përfshinë sipërfaqen rreth 2,5 ha. Meqenëse aktivitetet minerare në gurore janë përfunduar, atëherë kjo sipërfaqe e degraduar duhet të rikultivohet dhe të kthehet në sipërfaqe të shfrytëzueshme, duke mënjanuar problemet mjedisore së bashku me rreziqet për shkak të gjendjes aktuale të saj.

Në raport do të analizohen ndikimet në mjedis të tërë proceseve teknologjike gjatë eksploatimit dhe aktiviteteve tjera minerare, duke i parashtruar dhe ndërmarrë masa të domosdoshme për mbrojtjen e mjedisit në lokalitetin ku është ushtruar veprimtaria.

Duke u nisur nga qëllimi paraprak dhe në metodologjinë e hartimit të vlerësimit të ndikimit në mjedis, ky vlerësim bëhet me qëllim të përkufizimit të ndikimeve potenciale dhe caktimin e masave të cilat do të jenë të nevojshme për tu ndërmarr për mbrojtjen e mjedisit nga ndikimet negative. Ky vlerësim bazohet kryesisht në ndikimin në mjedis pas pushimit të aktivitetit minerar, duke $u$ orientuar edhe në rehabilitimin dhe rikultivimin e hapësirës në fjalë. (Ekstrakt, Agrovet 2013. MZHE)

Për hartimin e Raportit të VNM-së janë studiuar:

1. Ndikimet negative në mjedis

2. Popullata ekzistuese me karakteristikat demografike

3. Karakteristikat e tokës, topografia dhe peizazhi

4. Klima e lokacionit me të dhënat meteorologjike

5. Kualiteti i ajrit dhe ujit

6. Bota bimore dhe shtazore 


\subsubsection{Ujërat nëntokësorë}

Gjatë fazës hulumtuese mjedisore nuk janë takuar ujërat nëntokësorë. Mendohet se rrjedhja e këtyre ujërave në përgjithësi i përcjell morfologjia në drejtim me rrjedhjen e pellgut të lumit Drenica. Pra, nuk priten efekte negative nga ujërat nëntokësorë, po ashtu nuk mund të priten efekte negative nga rrjedhat e afërta, pasi që distanca në mes të vendburimit dhe lumenjve vlerësohet të jetë e mjaftueshme. Në këtë kontekst, nuk mund të themi se ekziston ndonjë zonë e theksuar.

\subsubsection{Stabiliteti i terrenit}

Nga pikëpamja e gjeostabilitetit të terrenit, lokaliteti i studiuar bënë pjesë në kategorinë e terreneve gjeostabile në kushtet natyrore. Nga kjo pikëpamje, vendi ku planifikohet të bëhet shfrytëzimi i formacioneve shkëmbore nuk është me interes për analizë më të thellë të ndikimit në mjedis për ndonjë objekt të veçantë natyrorë. Në këtë zonë përveç rrugës për në Vasilevë, nuk gjenden objekte tjera me rendësi të veçantë, qoftë natyrore apo artificiale, të cilat do të jenë të rrezikuara nga gjeostabiliteti i terrenit.

\subsubsection{Flora}

Në bazë te të dhënave nga literatura si dhe vizitës së terrenit gjatë periudhës së hartimit të Projektit është bërë edhe evidentimi i llojeve ekzistuese të florës, vegjetacionit në regjionin e shqyrtuar. Duke marrë parasysh karakteristikat e gjendjes ekzistuese, mund të konstatojmë se regjioni i analizuar nuk ka potenciale të cilat mund të kenë status të veçantë të mbrojtjes të cilat mund të rrezikohen. Në Vasilevë, në vendin ku është bërë shfrytëzimi, ekziston bimësi e lartë, ndërsa në Jug- Perëndim kemi hapësira të zhveshura. Nga bimësia e lartë, janë identifikuar: qarri, bungu, shkoza, lajthia të cilat janë veçori tipike e zonës.

\subsubsection{Fauna}

Gjendja ekzistuese e llojeve të shtazëve në raport/marrëdhënie me zonën e studiuar, janë konstatuar me vëzhgimin e drejtpërdrejtë në terren dhe është mund të përfundohet se hapësira e analizuar është e populluar me lloje të shtazëve të egra dhe shtëpiake. Burimet e ujit ne zonën e afërt nuk ekzistojnë, prandaj edhe speciet ujore nuk jetojnë. Nga shtazët, në këtë zonë jetojnë: lepuri, dhelpëra, derri i egër, ndërsa nga zvarranikët më të përhapur janë gjarpërinjtë, breshkat, hardhucat, prej shpezëve, skifteri, huti, pëllumbi, thëllëzat, bilbili, zogu i malit. Ndërkaq, nuk janë hasur potenciale të rëndësishme të faunës të cilat kanë karakter ligjor të veçantë të mbrojtjes.

\subsubsection{Peizazhi}

Peizazhin në këtë rajon e karakterizon hapësira vegjetative mjaft e bujshme. Në vendndodhjen e vendburimit, peizazhi gjithnjë e më tepër merr kahjen e një peizazhi industrial. Mirëpo, pas pushimit të shfrytëzimit të gëlqerorëve ka ardhur deri të degradimi i tij, i cili me implementimin e planit të rikultivimit dhe rehabilitimit, do t'i kthehet pamja në harmoni me kushtet reale në terren. (Ekstrakt, Agrovet 2013. MZHE)

12.5.7 Dukshmëria 
Dukshmëria në vendburimin e Vasilevës mund të themi se është i mirë. Vendburimi është në ambient të hapur dhe mundësia e dukshmërisë nuk pengohet nga as një anë. Paraqitja e mjegullës është në një periudhë të shkurtë kohore dhe atë kryesisht gjatë stinës së vjeshtës, mirëpo kjo nuk paraqet ndonjë pengesë apo efekt negativ nga aspekti i dukshmërisë gjatë shfrytëzimit dhe transportit.

\subsubsection{Masat për parandalimin dhe zvogëlimin e ndikimeve në mjedisin pritës}

Pas zbatimit te të gjitha fazave të rikultivimit të gurores së braktisur, vlerësohet se dukshëm do të ndryshojnë ndikimet në mjedis, të cilat do të prezantohen në vijim sipas faktorëve të përshkruar.

\subsubsection{Ndikimet në tokë}

Informacionet më pasqyruese për tokën e zonës janë dhënë në ,Hartën Pedologjike të Kosovës, në përpjesë 1:50000. Ndërkaq, në Hartën e rishikuar nga Fakulteti i Bujqësisë, Universiteti i Prishtinës janë përcaktuar klasifikimet ndërkombëtare të tokave, sipas standardeve të FAO/UNESKO. Nga kjo Hartë mund të përcaktohet vlera prodhuese e tokës, gjegjësisht klasa e bonitetit të tyre. Sipas bonitetit, tokat e zonës të përfshirë në studim, i takojnë klasës III, IV, VI dhe VII.

\subsubsection{Trashëgimia kulturore}

Sipas vëzhgimeve nga terreni është konstatuar se në zonën e vendburimit nuk ka monumente të trashëgimisë kulturore dhe historike.

\subsubsection{Kualiteti i ujit dhe drenazhimi}

Në thellësi të minierës ku shfrytëzohet guri gëlqerorë nuk ka ujëra burues. Bëhet fjalë vetëm për ujëra të grumbulluar nga të reshurat atmosferike të cilat nuk paraqesin potencial për ndotje.

\subsubsection{Kushtet ekologjike}

Marrëdhëniet e botës shtazore dhe bimore në lokalitetin në afërsi të Vasilevës janë të favorshme. Këtë e tregon prezenca e larmishme e florës dhe faunës. Faktorët ekologjik biotik dhe abiotik si drita, temperatura, lagështia, zhurma dhe pluhuri janë të përshtatshme. Këto kushte i favorizon edhe rrjedha e lumit Drenicë në këtë zonë.

\subsubsection{Kualiteti i ajrit}

Bazuar në të gjitha elementet e relievit, kjo njësi gjeografike veçohet me ajër të pastër. Deri te ndotja vie për shkak të punimeve dhe aktivitetit në minierë, sidomos në fazën e minimit, gërmimit, ngarkimit dhe transportit. Ndotësi kryesor është pluhuri i cili bartet me anë të erës, por falë konfiguracionit të terrenit me forma specifike të thepisura e të modeluara me shumë forma, bartja me anë të erës është mjaft e kufizuar dhe si e tillë nuk arrijnë as në vendbanimet më të afërta. 
Punimet në gurthyes zakonisht planifikohen të zhvillohen në një ndërrim, dhe për raste kur konsiderohet se kushtet atmosferike janë të tilla si (moti i thatë dhe me erë) që e përkeqësojnë kualitetin e ajrit nga ndotja me pluhur, atëherë aktiviteti i minierës ndërkrehet deri sa të qetësohen dhe të normalizohen kushtet atmosferike. Pastaj, spërkatja e rrugëve dhe respektimi i normave të transportit, do të ndikojnë në minimizimin e ndikimit në ndotjen e ajrit nga pluhuri.

\subsubsection{Zhurma}

Zhurma është rezultat $\mathrm{i}$ aktiviteteve të pajisjeve në minierë dhe proceseve të minimit, gërmimit, ngarkimit dhe transportit. Meqenëse aktivitetet zhvillohen në hapësire të hapur, zhurma është në kufij tolerues në radhë të parë për personelin tekniko-mbikëqyrës dhe se falë formës relievore për popullatën përreth është pothuajse e papërfillshme. Në afërsi të gurëthyesit nuk ka shtëpi banimi të cilat do të rrezikoheshin nga zhurma e krijuar në minierë.

\subsubsection{Rikultivimi teknik}

Projekti Kryesor i xehetarisë për minierën sipërfaqësore të gurit gëlqerorë në Vasilevë është hartuar në vitin 2002, nga NPPSh "Inzhinjering” Shtime.

Përkufizimi i fushës së shfrytëzimit është bërë në kuadër të zonës së hulumtuar të vendburimit.

Koordinatat e fushës së shfrytëzimit:

1. $Y=7496181,12 \quad X=4719778.31$

2. $Y=7496190.93 \quad X=4719904.82$

3. $Y=7496054.50 \quad X=4719946.80$

4. $Y=7496005.41 \quad X=4719779.93$

5. $Y=7496136.62 \quad X=4719731.21$

6. $Y=7496156.67 \quad X=4719716.42$

7. $Y=7496161.94 \quad X=4719715.52$

Sipërfaqja e fushës së përkufizuar të shfrytëzimit është: $S=28682.57 \mathrm{~m} 2$ ose 2.868 ha. Pika më e lartë e minierës arrinë kuotën +720 (lmd). Thellësia përfundimtare e projektuar e minierës është përcaktuar në bazë të punimeve kërkimore dhe arrijnë deri në kuotën +690. Disniveli i përgjithshëm i zhvillimit të punimeve minerare në këtë vendburim është $30 \mathrm{~m}$. Në bazë të gjendjes së projektuar, shkallët e projektuara janë të tipit të ngritur dhe janë emërtuar:

SH. +710 ( nga kuota +710 , deri +720$)$

SH. +700 ( nga kuota +700 , deri +710$)$

SH. +690 ( nga kuota +690 , deri +700 )

Shkallët e projektuara shtrihen përgjatë shtrirjes së fushës së përkufizuar të vendburimit në fazën e parë. Në këtë fazë miniera do të shfrytëzohet me lartësi të lejuar të shkallës prej $10 \mathrm{~m}$. 


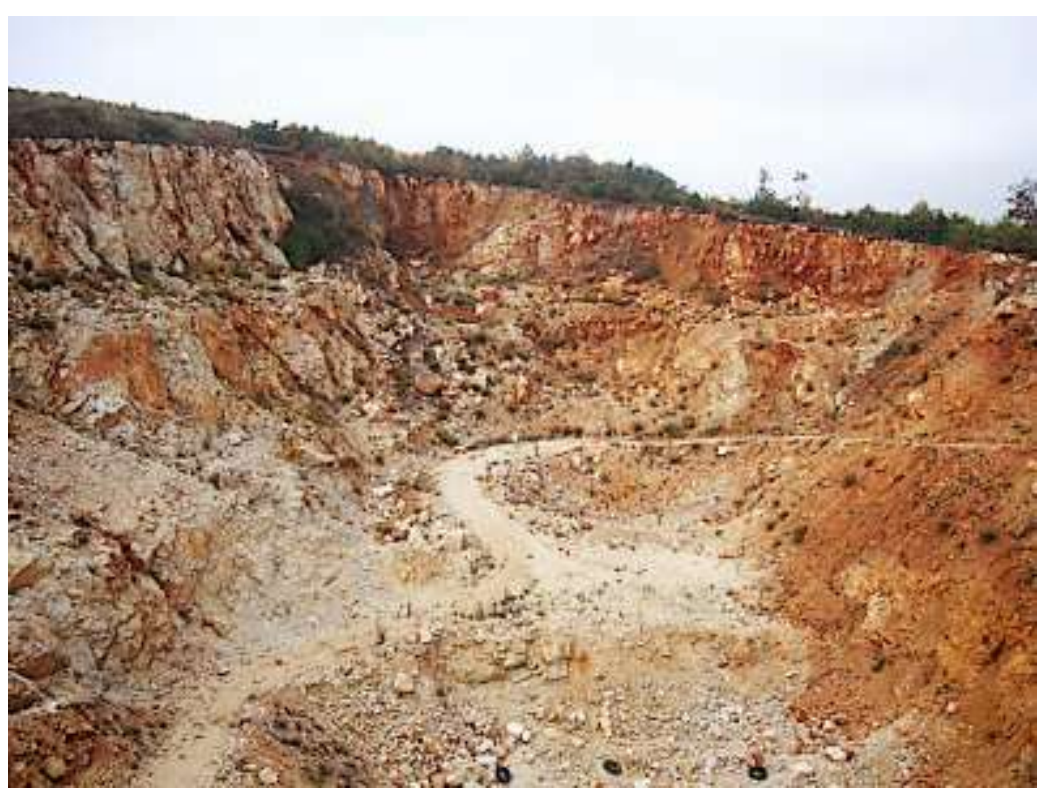

Figura 252. Miniera e gurit gëlqeror Vasilevë

(Burimi): Bujar Bajçinovci, AGROVET, 2013. MZHE

Gjatë realizimit të punimeve, nuk janë zhvilluar shkallët e projektuara, gjithashtu nuk janë lënë sheshet siguruese në shpatin përfundimtar të hartuara sipas Projektit Kryesor. Nga harta e situacionit për gjendjen ekzistuese rezulton se deri më tani janë shfrytëzuar rreth $211,867.75 \mathrm{~m} 3$ masë kompakte, e që me koeficient prej ksh=1.4 fitohen rreth 299,287.30 m3 masë e shkriftë. Llogaritja e masave është bërë me metodën e profileve paralele.

\subsubsection{Punimet përgatitore për rehabilitimin e gurorës}

Është konstatuar se në këtë minierë aktivitetet minerare kanë përfunduar. Pasi që është konstatuar se gjatë shfrytëzimit nuk janë zhvilluar nivele të shkallëve të projektuara, si dhe nuk janë formuar sheshet siguruese në shpate përfundimtare, propozojmë që për rehabilitimin e kësaj miniere të gurit gëlqerorë në Vasilevë të përvetësohet varianti $\mathrm{i}$ mbushjes së hapësirës së shfrytëzuar. Llogaritja e vëllimit të hapësirës për mbushje është bërë me metodën e profileve paralele dhe ajo është 211,867.75 m3 masë kompakte. Për mbushjen e hapësirës së shfrytëzuar mund të shfrytëzohet materiali argjilorë i pa selitura (material steril nga guroret), kurse shtresa përfundimtare me trashësi $0.5 \mathrm{~m}$ të mbushet me material të selektuar humusorë. Mbushja fillon nga niveli me i ulët i minierës nga kuota +680.Sipërfaqja e tërësishme e rehabilituar është 12,765.8 m3 që nënkupton se për trashësinë e humusit prej $0.5 \mathrm{~m}$ fitohet vëllim prej V=6,382.9 m3.

\subsubsection{Rikultivimi bio-teknik}

Projekti i ri kultivimit bioteknik përfshinë lokalitetin e Minierës së braktisur sipërfaqësore të gurit gëlqeror në Vasilevë, me sipërfaqe prej 12,765.8 m2, ose 1,276.5 ha dhe ka në konsideratë, mënyrën e shfrytëzimit të këtyre tokave në të ardhmen, principet e rehabilitimit, stabilitetin fiziko-mekanik, karakteristikat/vetitë kimike, si dhe çështjet që konsiderohen kritike për atë lokalitet. 
Objektivat e projektit të ri kultivimit të minierës sipërfaqësore të gurorit gëlqerorë në Vasilevë janë:

1. Restaurimi i shtresës sipërfaqësore të tokës

2. Optimalizimi i vetive fiziko-mekanike

3. Përmirësimi i regjimit ujorë-ajror

4. Shtimi i aftësisë prodhuese-pjellorisë së tokës

\subsubsection{Gjendja e ekzistuese dhe karakteristikat pedologjike të lokalitetit}

Lokaliteti i minierës në Vasilevë, sipas Hartës Pedologjike shtrihet mbi toka kafe të cekëta mbi substrat bazik (dijabaz, bazalt). Këto janë toka Distric cambisol, të cekta, profili i kësaj toke është njështresor $(A-C)$ dhe i cektë $(25-50 \mathrm{~cm})$. Sipas përbërjes mekanike është tokë ranore-lymore, ndërsa kullimin e ka të mirë. Thellësia mesatare e profilit në sipërfaqen e eksploatuar është $37 \mathrm{~cm}$, i cili plotësisht është shkatërruar dhe është larguar pa kurrfarë rregulli, gjegjësisht pa kujdesin minimal të paraparë.

Qëllimi i rikultivimit në këtë minierë nënkupton ri krijimin e një toke të re, me profil që i përgjigjet tipit të klasës Teknogjene, Deposoli. Ekspertët e xehetarisë kanë rekomanduar krijimin e profilit të tokës nga masat argjilore të paselektuara, si dhe me vendosjen e një shtrese sipërfaqësore (rreth $50 \mathrm{~cm}$ ) me material të selektuar me përmbajtje më të madhe të humusit.

Në praktikat e rikultivimit me këtë lloj të materialit, për shkak të vetive mjaft specifike të argjilit, gjegjësisht rikualitetit/përshtatshmërisë së materialit, Deposoli i krijuar duhet t’i nënshtrohet programit të monitorimit, i cili ka objektiva të caktuara, varësisht nga fazat e zhvillimit të tij:

1. Faza e parë, menjëherë pas përfundimit të ri-kultivimit teknik

2. Faza e dytë, para mbjelljes dhe

3. Faza e tretë, pas mbjelljes

Në Programin për monitorim, parashihet që toka e krijuar të analizohet në këta parametra:

1. Vetitë fiziko-mekanike (struktura, tekstura, dendësia specifike), si dhe fiziko ujore,

2. Vetitë kimike (reaksioni, pH, përçueshmëria elektrike, kapaciteti absorbues, elementet ushqyese, makro e mikroelementet, si dhe elementet toksike

3. Rekomandimi i masave agroteknike (kalcifikimi, humifikimi, për përmirësimin e tyre.

Ndërsa, për këtë studim, në vazhdim janë rekomanduar dozat melioruese për humifikim dhe pasurim të tokës me elemente ushqyese:

1. Humifikimi me 20 tonelata/ha, pleh mirë të djegur të stallës,

2. Plehrim themelorë me $600 \mathrm{~kg} / \mathrm{ha}$, pleh mineral NPK 10:30:20. 


\subsubsection{Rikultivimi biologjik}

Ndikimet negative të gurores së braktisur në Vasilevë përfshijnë pamje të degraduar, fragmentim të peizazhit, humbje të biodiversitetit dhe ndikime në rrjedhat ujore. Sipërfaqja e Minierës së Gurit (gurorës) në Vasilevë ka gjithsej 2,868 ha. Me që vegjetacioni për rreth gurores është gjetherënës, ku dominon bashkësia pyjore e Shpardhit dhe Qarrit (Querco fraineto-cerris cardicum), është e preferueshme që në rastet e tilla për rikultivim të shfrytëzohen llojet autoktone të asaj bashkësie pyjore.

Për mbushjen e hapësirës së minierës (gurores) ekspertët kanë vlerësuar se mund të shfrytëzohet materiali argjilor i pa selektuar (material steril nga guroret), kurse shtresa përfundimtare me trashësi $0.5 \mathrm{~m}$ nga materiali i selektuar humusorë. Nga këto të dhëna mund të konstatohet se për ri vegjetimin e hapësirës së gurores në Vasilevë duhet të shfrytëzohen llojet bimore siç janë: Shpardhi dhe Qarri me moshë 5-7 vite.

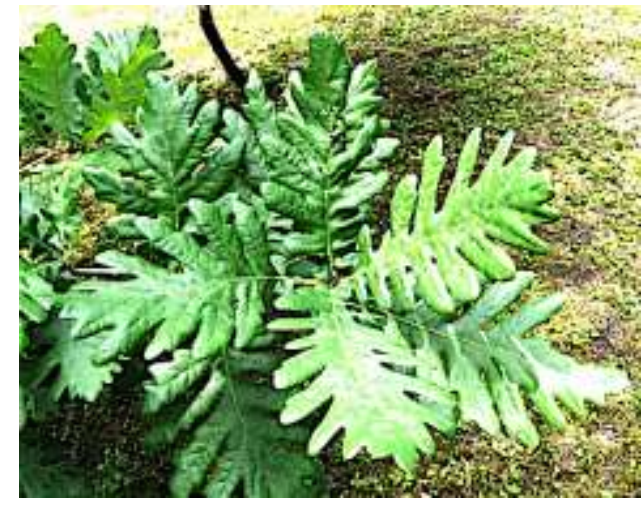

Figura 253a. Querco fraineto

(Burimi): AGROVET, 2013. MZHE

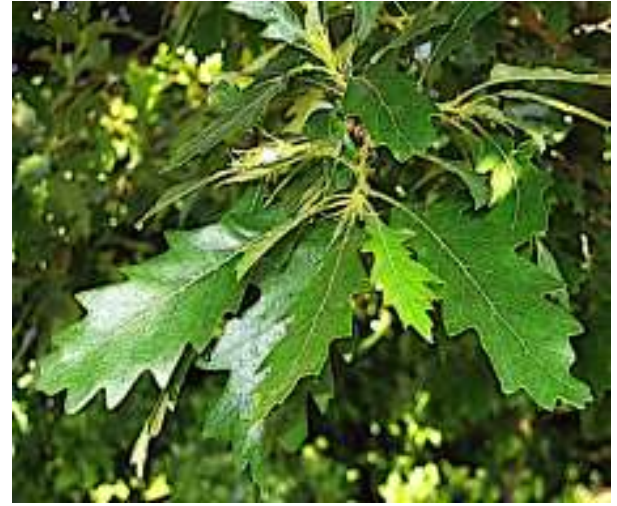

Figura 253b Quercus cerris (Burimi): AGROVET, 2013. MZHE

\subsubsection{Veçoritë e sigurisë}

Gurorja në Vasilevë, vizualisht prezanton një gropë të konsiderueshme të pa trajtuar e cila shkakton rreziqe permanente nga rrëshqitje e kalimtareve të rastit, e sidomos në periudhën e natës ku nuk ekziston asnjë shenjë apo një ndriçim sado pak modest. Pjerrtësitë e larta, rreziku ndaj rrëshqitja, pasi që rruga e cila i lidhë fshatrat e afërta kalon buzë cepit të gurores së përmendur, përbëjnë rrezik të vazhdueshëm në shumë drejtime funksionale, e posaçërisht rreziqe fizike dhe mjedisore.

Kjo gjendje kërkon veprime të pa vonuara dhe konkrete, të propozuara nga ekipi, i cili kur të interpolohet në peizazhin arkitektonik, merr pamjen dhe destinimin sikur është prezantuar në imazhet në vijim.” (Ekstrakt, Agrovet 2013. MZHE) 


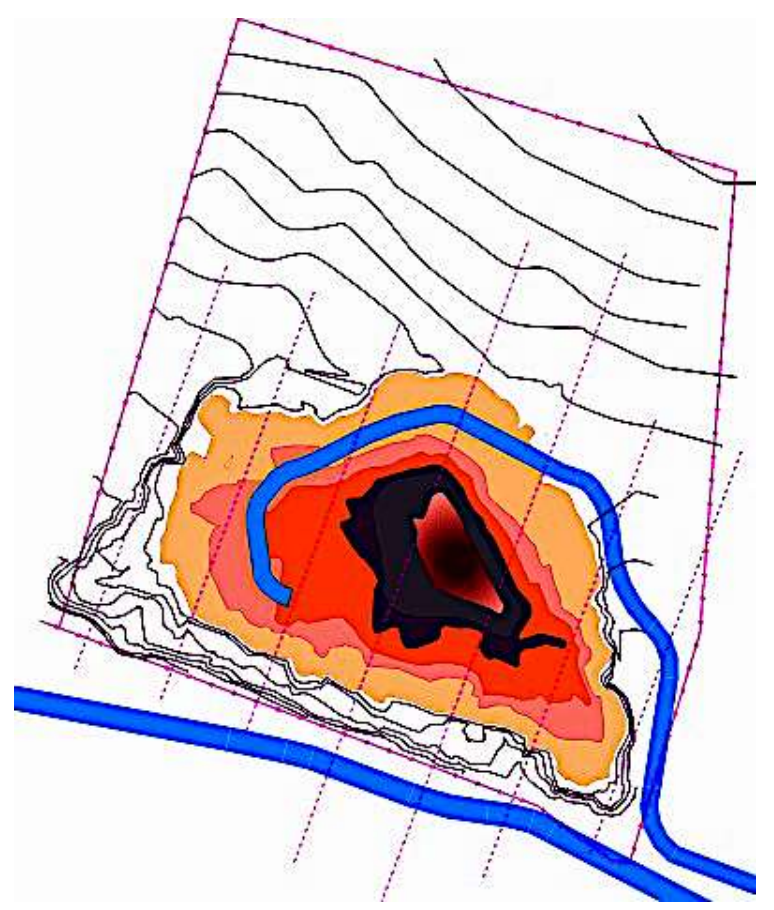

Figura 254. Tereni dhe gjendja aktuale e gurores në Vasilevë (Burimi): Bujar Bajçinovci, AGROVET, 2013. MZHE

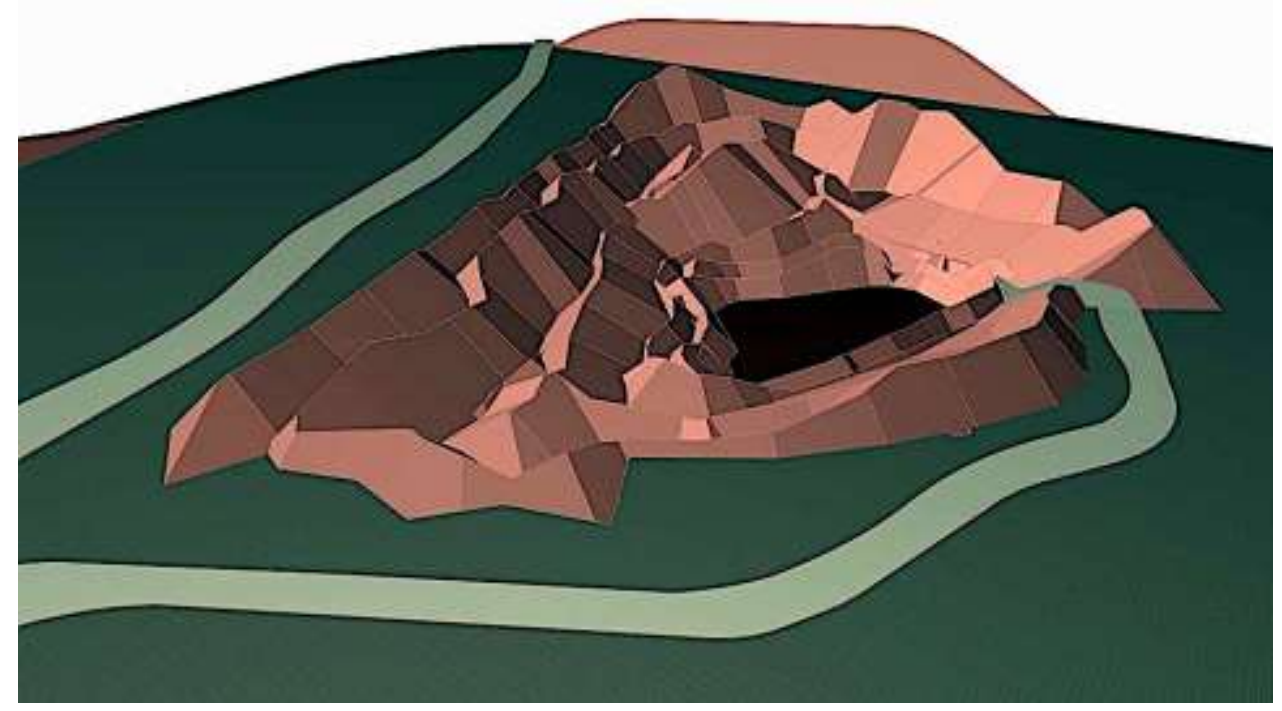

Figura 255. Tereni dhe gjendja aktuale e gurores në Vasilevë, në aksionometri (Burimi): Bujar Bajçinovci, AGROVET, 2013. MZHE 


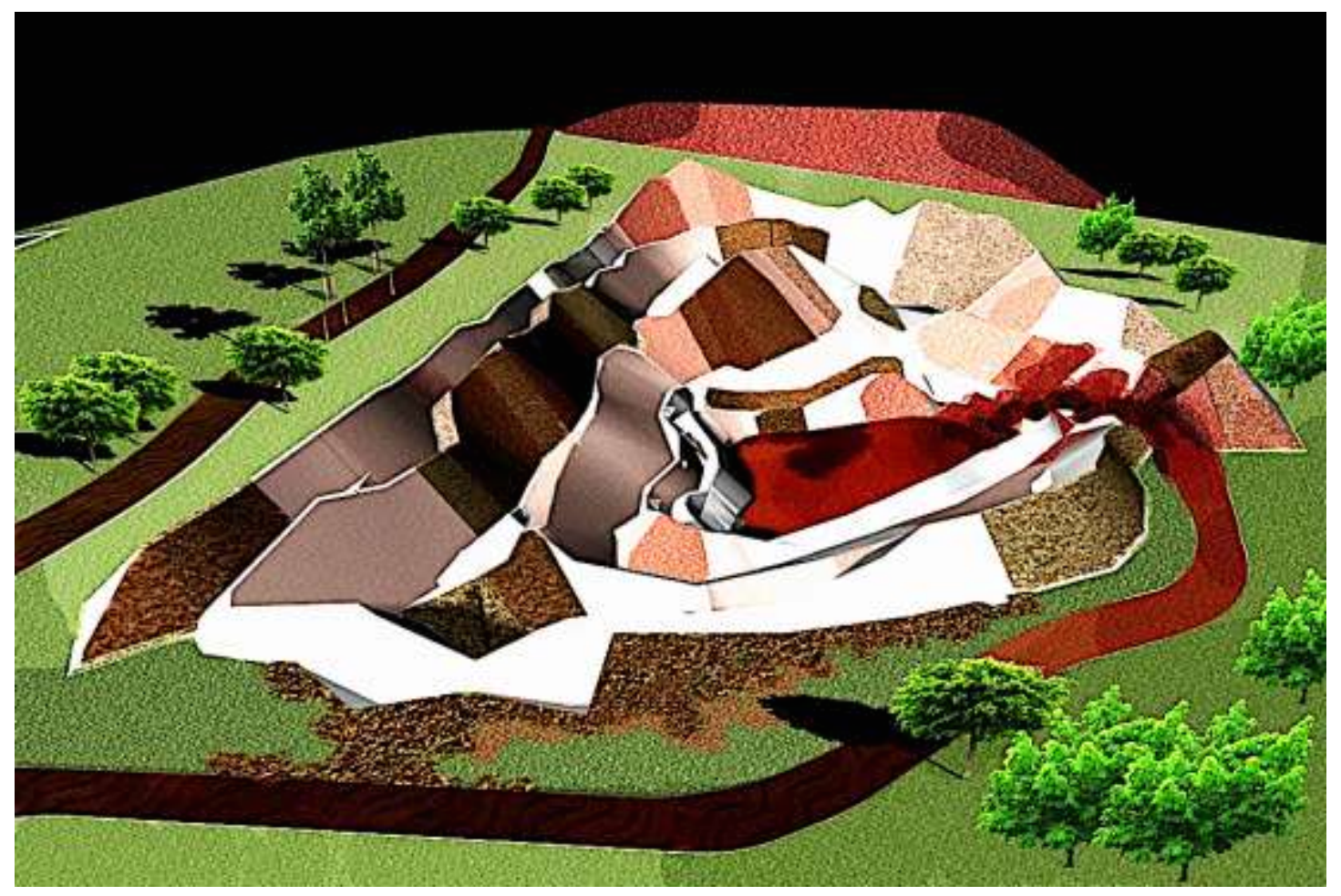

Figura 256. 3D Prezantimi, tereni dhe gjendja aktuale e gurores në Vasilevë (Burimi): Bujar Bajçinovci, AGROVET, 2013. MZHE

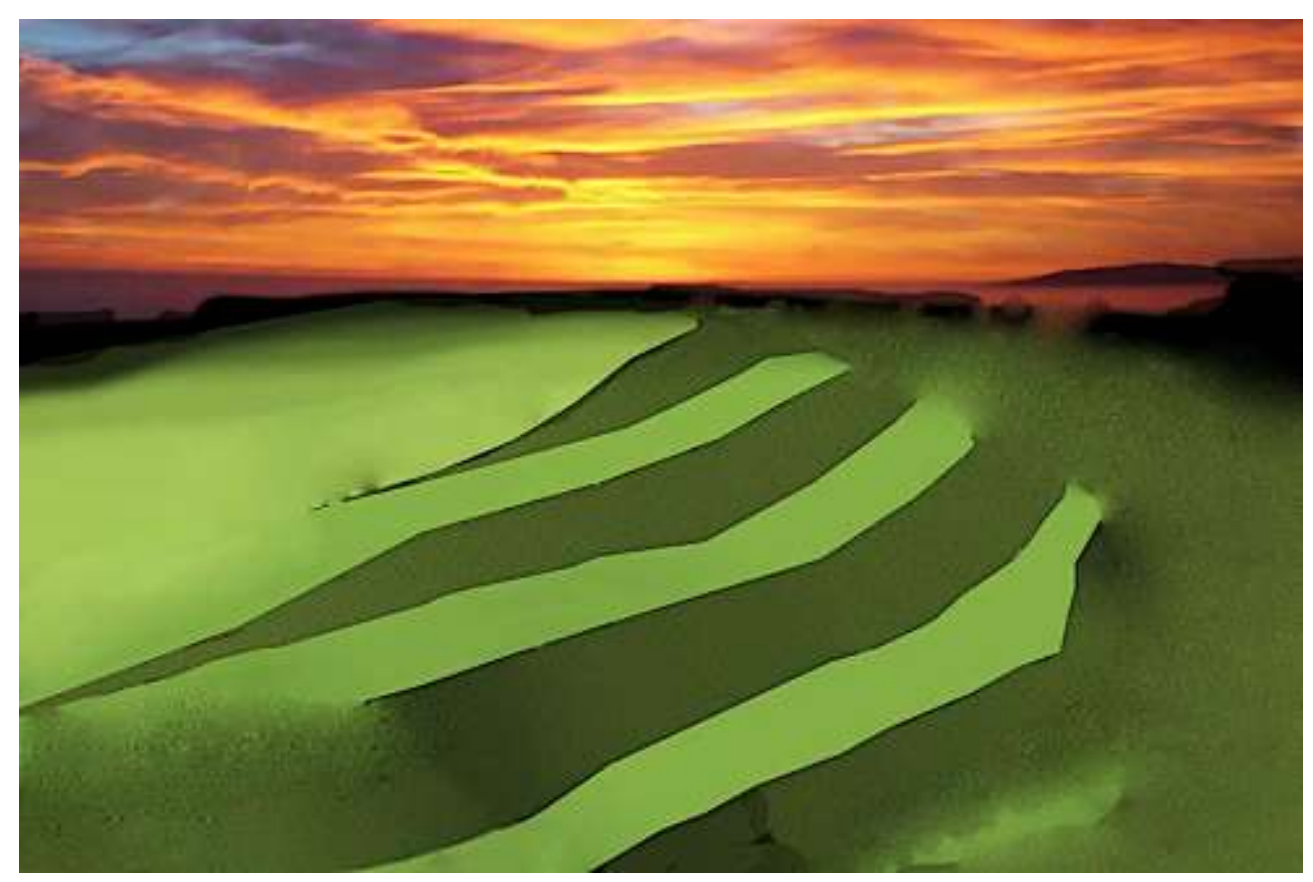

Figura 257. 3D Modeli, tereni dhe gjendja e ri projektuar e gurores në Vasilevë (Burimi): Bujar Bajçinovci, AGROVET, 2013. MZHE 


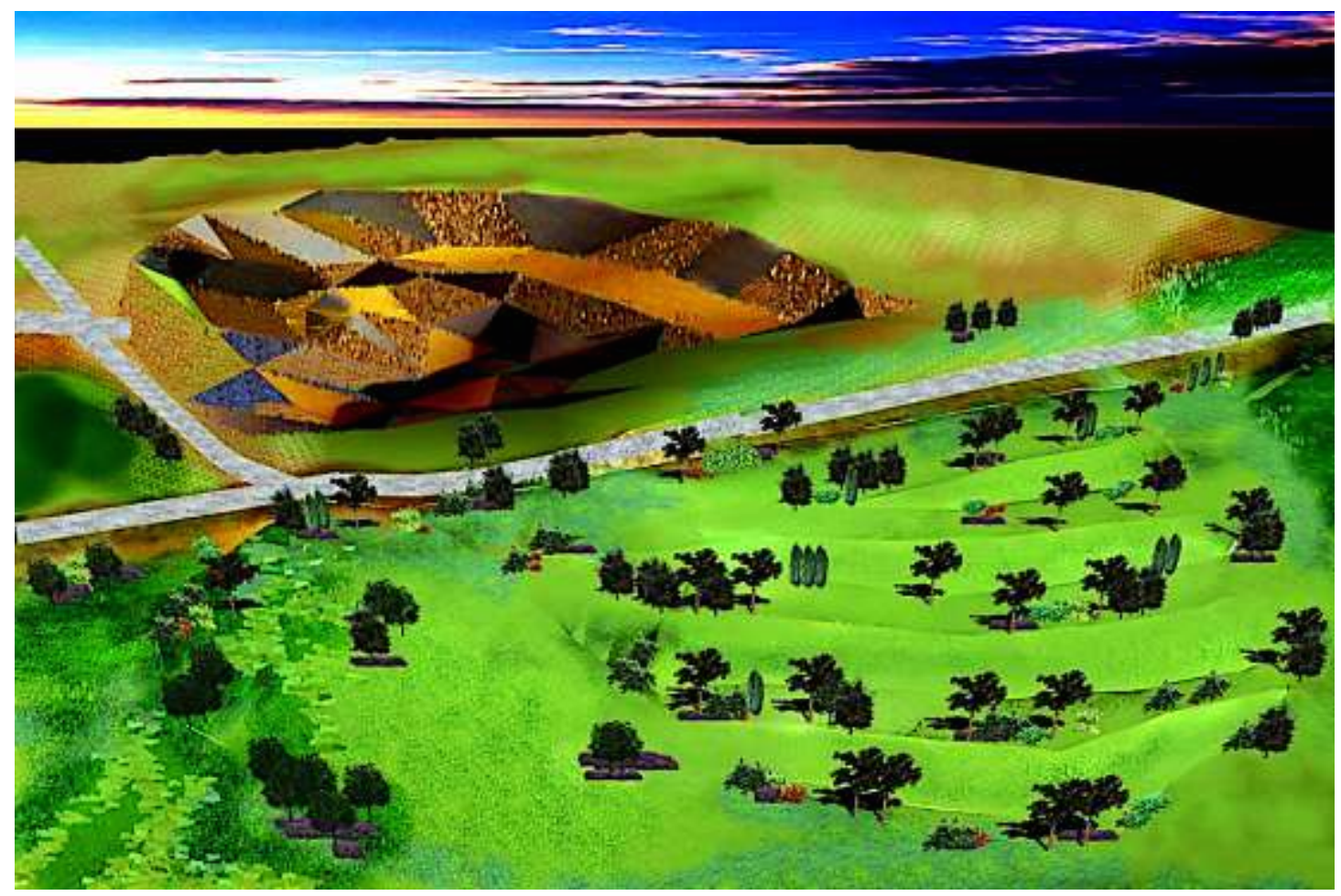

Figura 258. 3D Prezantimi, terreni dhe gjendja e ri kultivuar e gurores në Vasilevë (Burimi): Bujar Bajçinovci, AGROVET, 2013. MZHE

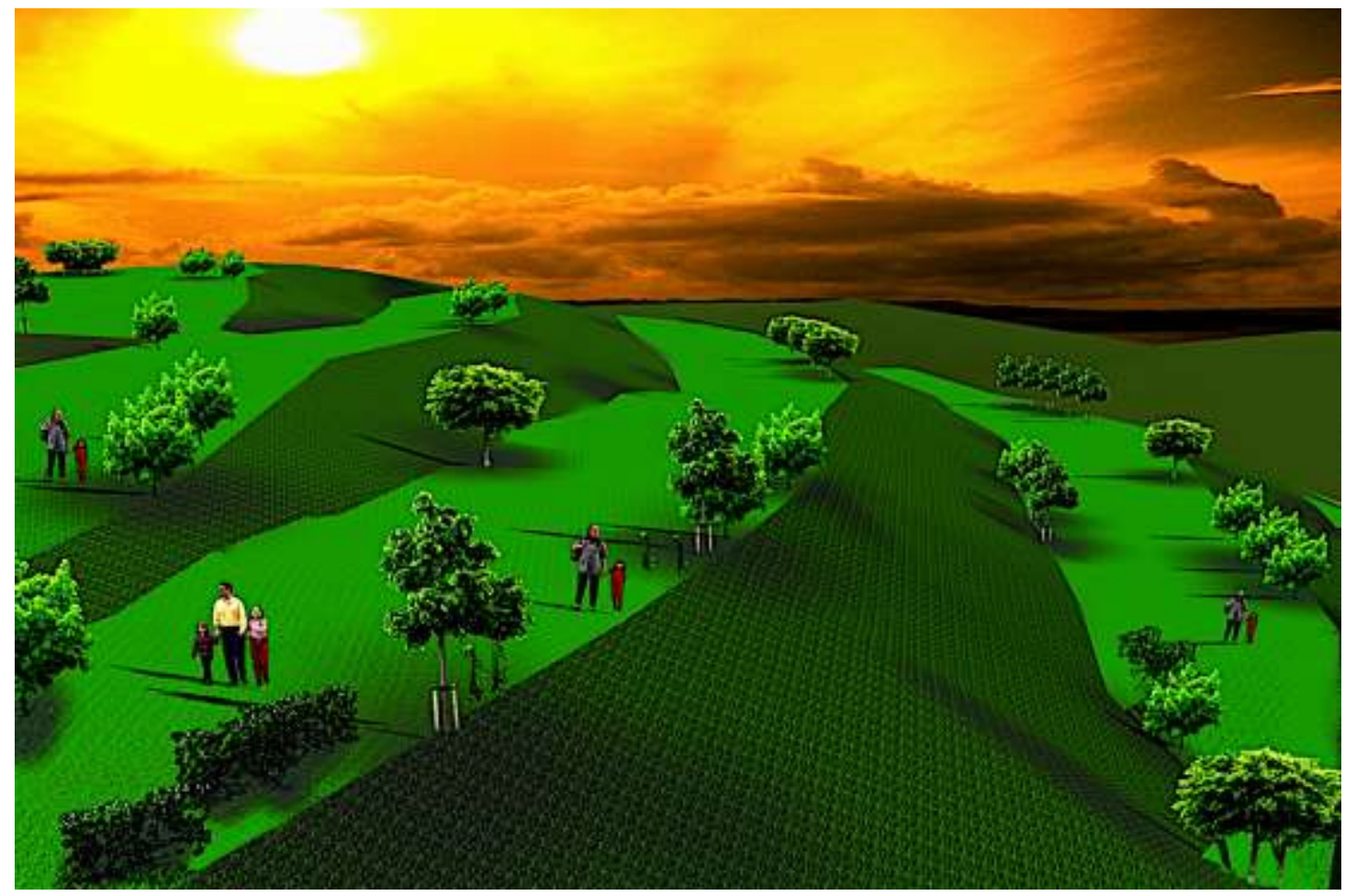

Figura 259. 3D Prezantimi, terreni dhe gjendja e ri kultivuar e gurores në Vasilevë (Burimi): Bujar Bajçinovci, AGROVET, 2013. MZHE 


\subsubsection{Rekomandimet}

Duke u bazuar në aktivitetet e zhvilluara për realizimin e kërkesave të parapara, për mundësitë dhe mënyrat e ri kultivimit të deponive dhe vendburimeve të shfrytëzuara minerale; rekomandohet se duhet patjetër të respektohet Ligji dhe të gjitha aktet dhe nën aktet Ligjore prej të cilave burojnë të gjitha masat parandaluese dhe mbrojtëse në ruajtjen e mjedisit të shëndoshë, i cili njëherit është edhe obligim ndaj direktivave të Bashkësisë Evropiane.

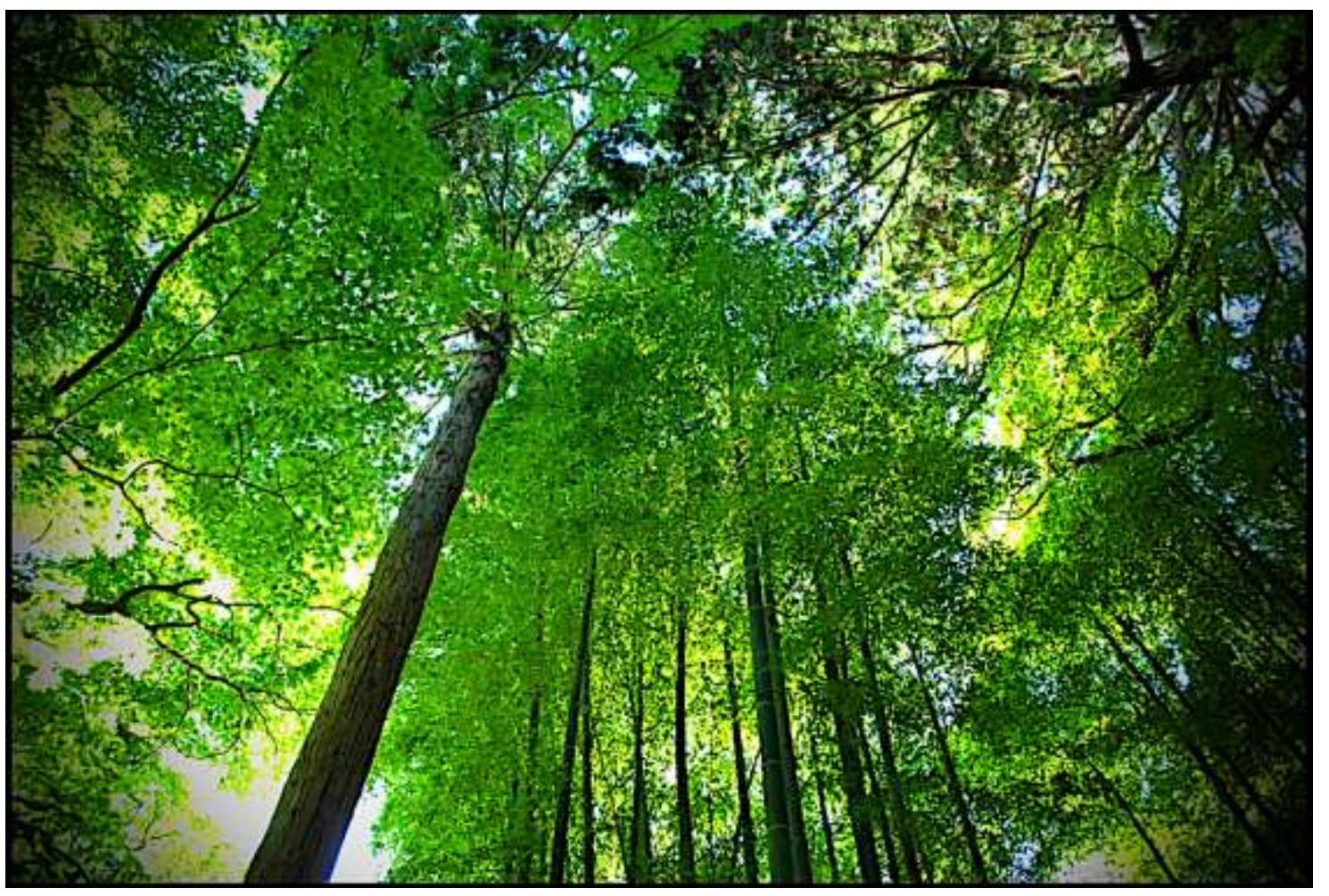

Figura 260. Kyoto, Say NO to the environmental pollution..

(Burimi): Pavel Ahmed, 2010. E licensuar nga Creative Commons Attribution ShareAlike 2.0 Generic

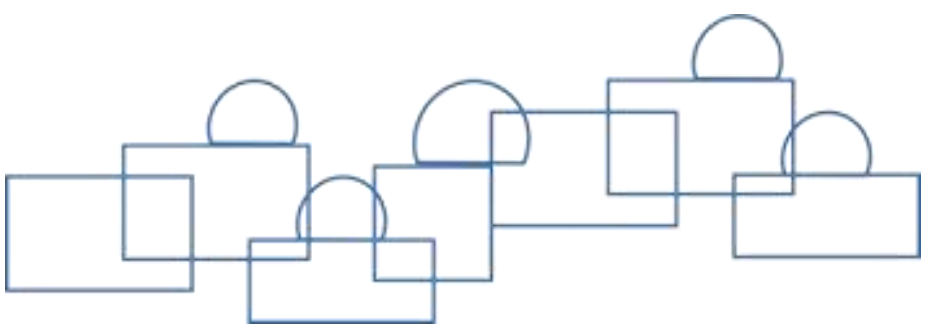




\section{MBETURINAT - MJEDISI}

\subsection{MBETURINAT}

$\mathrm{N}$ jë ndër çështjet më të rëndësishme për menaxhimin e qëndrueshëm të mjedisit në Kosovë, është edhe menaxhimi i mbeturinave. Deri me tani Ministria e Mjedisit dhe Planifikimit Hapësinor ka përgatitur bazën e duhur ligjore për menaxhimin e mbeturinave(Ligjin për mbeturina dhe një sërë udhëzimesh administrative që rregullojnë këtë fushë). Po ashtu, në kuadër të obligimeve ligjore dhe programore është duke u përgatitur edhe Plani Strategjik për Administrimin e Mbeturinave. Edhe përkundër faktit se roli i MMPH-së ka qenë i kufizuar vetëm në aspektin legjislativ, ajo ka bërë përpjekje të vazhdueshme për përmirësimin e sistemit për menaxhimin e mbeturinave. Në këtë aspekt, MMPH ka arritur që ta adresojë këtë çështje në mënyrën e duhur duke bashkëpunuar ngushtë me institucione e organizata të ndryshme. Ne jemi të vetëdijshëm se menaxhimi i mbeturinave nuk mund të kryhet vetëm nga një institucion $\mathrm{i}$ vetëm, por kërkohet një angazhim i përbashkët, që nga ne institucionet ligjvënëse, ekzekutive, zyra e rregullatorit, komunat, kompanitë menaxhuese të grumbullimit të mbeturinave dhe kompanitë që menaxhojnë deponitë. Është e qartë se rol kyç në këtë aspekt kanë edhe komunat, për faktin se ato janë bartëse të kësaj problematike, por është më se e qartë se rol esencial në këtë drejtim kanë edhe donatorët, shoqëria civile dhe komuniteti i biznesit. Ne duhet ta pranojmë se nuk jemi të kënaqur me sistemin për menaxhimin e mbeturinave. Vështirësitë dhe problemet janë evidente në të gjitha komponentët që nga grumbullimi, selektimi, deponimi, dhe se vështirësitë na shoqërojnë në të gjitha kategoritë e mbeturinave, si të atyre komunale, industriale, të rrezikshme, prandaj për organizimin e një sistemi të kënaqshëm të menaxhimit të mbeturinave kërkohet një bashkë koordinim funksional i të gjithë aktorëve të lartpërmendur. Ne duhet që të ndryshojmë qasjen tonë dhe perceptimin e përgjithshëm publik mbi mbeturinat. Mbeturinat duhet të definohen qartë, jo gjithçka që hedhim është mbeturinë, jo gjithçka duhet të groposet në deponi. Duhet të formojmë opinionin i cili tanimë është dëshmuar në shtetet e zhvilluara se mbeturinat nuk janë objekt për hedhje, por janë resurs për zhvillimin ekonomik të vendit, janë një mundësi për të krijuar vende pune, janë një mundësi për të kursyer resurset natyrore. Ne synojmë që në këtë proces, t'i kushtohet rëndësi opsioneve më të pranueshme në kuadër të menaxhimit të mbeturinave si: marrja e masave preventive, minimizimin e gjenerimit të mbeturinave, ripërdorimin, riciklimin, përdorimin e tyre si resurs energjie. Ajo që është kryesore, me një qasje të tillë ne i kontribuojmë ruajtjes së mjedisit, gjë që është edhe qëllimi ynë kryesorë.”

Ministër, Mahir Yagcilar,

(Burimi): MMPH. Agjencia e Kosovës për mbrojtjen e mjedisit, Gjendja e mbeturinave në Kosovë. 2008 


\subsection{KLASIFIKIMI DHE LLOJET E MBETURINAVE}

“Sipas Ligjit për Mbeturina, llojet e mbeturinave janë:

1. Mbeturinat komunale

2. Mbeturinat komerciale

3. Mbeturinat industriale

Një klasifikim tjetër i mbeturinave është edhe klasifikimi që merr për bazë ekspozimin dhe rrezikshmërinë. Sipas këtij klasifikimi mbeturinat ndahen në:

1. Mbeturinat inerte

2. Mbeturinat e parrezikshme,

3. Mbeturinat e rrezikshme, (Ligji për mbeturina- Ligji nr.02/L-30)

\section{Definimet dhe nocionet për mbeturinat ${ }^{104}$}

Mbeturinë: çdo substancë ose lëndë e specifikuar të cilën zotëruesi e hedhë, mendon ta hedhë ose është i detyruar ta hedhë.

Hedhurinë: pjesë e mbeturinës, lëndë ose substancë e cila mbetet pas përpunimit të mbeturinës, komponentë ose elemente të cilat nuk kanë më vlerë përdorimi.

Administrimi i mbeturinave: nënkupton grumbullimin, mbledhjen, ndërmjetësimin, marrjen me to, transportimin, përpunimin, trajtimin dhe deponimin e mbeturinave, duke përfshirë edhe mbikëqyrjen e operacioneve të tilla si dhe përkujdesjen pas mbylljes së deponive.

Riciklimi: proces për trajtimin dhe ripërdorimin e plotë ose të pjesshëm të mbeturinave.

Trajtimi i mbeturinave: përfshinë proceset fizike, kimike, biologjike, termale, ndarjen e mbeturinave në lloje, me qëllim të pakësimit të vëllimit dhe karakteristikave të dëmshme të mbeturinave si dhe lehtësimin për manipulim me mbeturina ose riciklimin e tyre.

Grumbullimi i mbeturinave: është aktivitet sistematik i mbledhjes së mbeturinave, me qëllim të trajtimit të më vonshëm ose deponimit.

Mbeturinat e rrezikshme: janë mbeturinat që kanë së paku njërën nga këto karakteristika si më poshtë: eksplozive, oksiduese, të ndezshme, toksike, kanceroze, korrozive, irituese, dëmtuese, infektuese, teratogjenike, mutagjenike, liron gazra toksike në kontakt me ujin, ajrin ose një acid. Ka mundësi për prodhimin e substancave tjera të rrezikshme dhe ekotoksike

Mbeturina të parrezikshme: janë mbeturinat që nuk posedojnë karakteristikat e mbeturinave të rrezikshme.

104 MMPH. Agjencia e Kosovës për mbrojtjen e mjedisit, Gjendja e mbeturinave në Kosovë. 2008 
Mbeturina inerte: janë mbeturina, të cilat nuk pësojnë ndonjë ndryshim të rëndësishëm fizik, kimik dhe biologjik në vendet ku janë deponuar. Mbeturinat inerte nuk treten, nuk ndizen ose nuk reagojnë fizikisht apo kimikisht, nuk biodegradojnë ose në kontakt me materiet tjera, nuk ndikojnë në mënyrë të ndjeshme në mjedisin dhe shëndetin e njeriut. Terë përmbajtja ndotëse e mbeturinës, mbetjet ekotoksike duhet të jenë të vlerës së papërfillshme dhe të mos rrezikojnë cilësinë e ujërave sipërfaqësore dhe nëntokësore.

Mbeturina komunale: janë mbeturinat nga amvisëritë, po ashtu edhe mbeturinat nga aktivitetet tjera, të cilat për shkak të përbërjes dhe natyrës së tyre, janë të ngjashme me ato të amvisërisë.

Mbeturina komerciale: mbeturina të cilat vijnë nga objektet që përdoren vetëm apo kryesisht për qëllimet e tregut ose biznesit, sportit, edukimit, rekreacionit, por nuk përfshijnë mbeturinat komunale dhe industriale.

Mbeturinat industriale: janë mbeturina të cilat prodhohen nga aktivitetet ose proceset industriale ose të prodhimtarisë artizanale dhe aktivitet tjera prodhuese.

Kompostimi: është proces i kontrolluar biologjik për zbërthimin e mbeturinave organike nën veprimin e mikroorganizmave në prezencën e oksigjenit që bëhet me qëllim të prodhimit të kompostit.

Asgjësimi i mbeturinave: përfshin proceset pas të cilave nuk parashikohet përpunim tjetër i mbeturinave dhe që mbyllen me groposje apo depozitim.

Mbeturina ushqimore: mbeturinat nga konsumimi i mishit të bagëtive, frutave, perimeve, mbeturinat nga përpunimi, përgatitja , gatimi dhe ngrënia e ushqimeve, janë cilësuar si mbeturina ushqimore.

Mbeturinat e papërpunuara: në këtë grup bëjnë pjesë mbeturinat e djegshme e të padjegshme që mbeten nga veprimtaria e institucioneve, aktiviteteve komerciale . Mbeturinat e djegshme përbëhen kryesisht nga: letrat, kutitë e kartuçit, plastikës, tekstilet, druri . Ndërsa mbeturinat e padjegshme konsistojnë kryesisht në materiale si: qelqi, alumini, hekuri si dhe materialet tjera jo prej hekuri.

Mbeturinat e ndërtimit dhe shkatërrimit: janë të gjitha mbeturinat prej ndërtimit, rimodelimit dhe riparimit të banesave individuale, objekteve tregtare dhe strukturave të tjera, janë klasifikuar si mbeturina të ndërtimit, ndërsa mbeturinat prej shkatërrimit të ndërtesave dhe të strukturave të tjera, janë klasifikuar si mbeturina të shkatërrimit. Materialet kryesore që bëjnë pjesë në këtë grup janë: gurët, betoni, tullat, hekuri, pjesët prej plumbi, pjesët elektrike.

Mbeturinat bujqësore: janë mbeturina që prodhohen si pasojë e aktiviteteve të ndryshme bujqësore: si nga trajtimet e ndryshme që i bëhen tokës, nga prodhimi i verës, nga prodhimi dhe përpunimi i produkteve të ndryshme bujqësore dhe blegtorale, janë quajtur në mënyrë kolektive si mbeturina bujqësore. 
Mbeturinat infektive: janë mbeturina me rrezikshmëri të llojit të veçantë, që gjatë manipulimit apo në kontakt me to, mund të rrezikohet shëndeti i njeriut dhe mjedisi. Janë mbeturina të cilat krijohen dhe gjenerohen nga spitalet dhe objektet tjera shëndetësore, por edhe nga ngordhja apo vrasja e qenve si dhe nga thertoret e kafshëve .

Mbeturinat speciale: janë mbeturinat radioaktive, kontejnerët e përdorur të gazrave të presuar, mbeturinat që përmbajnë përqendrime të mëdha të metaleve të rënda toksike ( arsenik, plumb ), sasi të rëndësishme të produkteve kimike të cilave u ka skaduar afati.

Mbeturinat prerëse dhe shpuese: janë shiringat e përdorur, veglat e ndryshme të operacionit dhe të gjitha mbeturinat e tjera shpuese dhe prerëse.

Mbeturinat kimike dhe farmaceutike:janë mbeturinat nga produktet farmaceutike dhe kimike brenda ambalazheve të tyre.

Djegie: trajtim termik i mbeturinave që konsiston në shkatërrimin e tyre nga zjarri. Djegia është proces i ndërlikuar, sepse furrat në të cilat bëhet djegia, duhet të jenë të dedikuara në mbrojtje të mjedisit. Është proces i shtrenjtë, joekonomik, por gjithsesi i nevojshëm.

Mbeturinat e qelqit: janë mbeturina nga ambalazhi (shishe, kavanoza .) që mund të riciklohen.

Mbeturinat e plastikës: janë mbeturina të pazbërthyeshme biologjikisht të cilat krijohen nga veprimtari të ndryshme (ambalazhe, enë, .)

Mbeturinat e gomës: janë mbeturinat e gomave të vjetra dhe ato që krijohen prej veprimtarive të ndryshme.

Mbeturina organike: janë mbeturinat që janë të afta me u zbërthye në procesin aerob apo anaerob. Si mbeturina organike klasifikohen mbeturinat e ushqimit, bujqësore, të letrës." (Ekstrakt) ${ }^{104,104}$

\subsection{MBETURINAT KOMUNALE}

Sistemi i menaxhimit të mbeturinave në Kosovë nuk ofron të dhëna të plota për gjenerimin, mbledhjen, trajtimin dhe mënjanimin e mbeturinave. Mesatarisht në Kosovë me shërbimin për grumbullimin e mbeturinave komunale shërbehen $42 \%$ (2007) përkatësisht $39 \%$ (2008) e popullatës. Regjioni i Prishtinës mbulon përqindjen më të lartë të popullatës me këtë shërbim me $64 \%$ (2007) përkatësisht $52 \%$ (2008), ndërsa regjioni i Mitrovicës më të ulëtin me vetëm $29 \%$ (2007-2008). Në zonat urbane (qytete) shërbimi i grumbullimit të mbeturinave ofrohet për rreth $90 \%$ të popullatës, ndërkohe që zonat rurale mbulohen me ketë shërbim me vetëm rreth $10 \%$ të popullatës. Të dhënat e detajuara për llojet e mbeturinave, sasitë dhe grumbullimin e mbeturinave sipas regjioneve janë prezantuar në tabelën 56 dhe figurën 261. (Ekstrakt) ${ }^{104}$ 
Tabela 56. Llojet e mbeturinave

(Burimi): MMPH. Agjencia e Kosovës për mbrojtjen e mjedisit, 2008.

\begin{tabular}{|l|c|c|c|}
\hline Llojet e mbeturinave & $\begin{array}{l}\text { Mesatarja } \\
\text { ditore në kg. / } \\
\text { banorë }\end{array}$ & $\begin{array}{l}\text { Sasia vjetore } \\
\text { Kganorë }\end{array}$ & $\begin{array}{l}\text { Sasia vjetore } \\
\text { në tonelata }\end{array}$ \\
\hline Mbeturinat e amvisërisë & 0.277 & 101 & 232541 \\
\hline Mbeturinat komerciale & 0.250 & 91.25 & 209875 \\
\hline Mbeturinat medicinale & 0.0024 & 0.876 & 2014.5 \\
\hline Mbeturinat e hirit dhe ngjyrës & 0.907 & 331 & 761426.5 \\
\hline Mbeturinat e ndërtimit/ shkatërrimit & 0.200 & 73 & 167900 \\
\hline $\begin{array}{l}\text { Mbeturinat tjera (ambalazh)plastikë, } \\
\text { gomë, pesticide, elektronikë, dru. }\end{array}$ & 0.360 & 131.4 & 302220 \\
\hline \multicolumn{1}{|c|}{ Total } & $\mathbf{2 . 0 5}$ & $\mathbf{7 2 9}$ & 1675977 \\
\hline
\end{tabular}

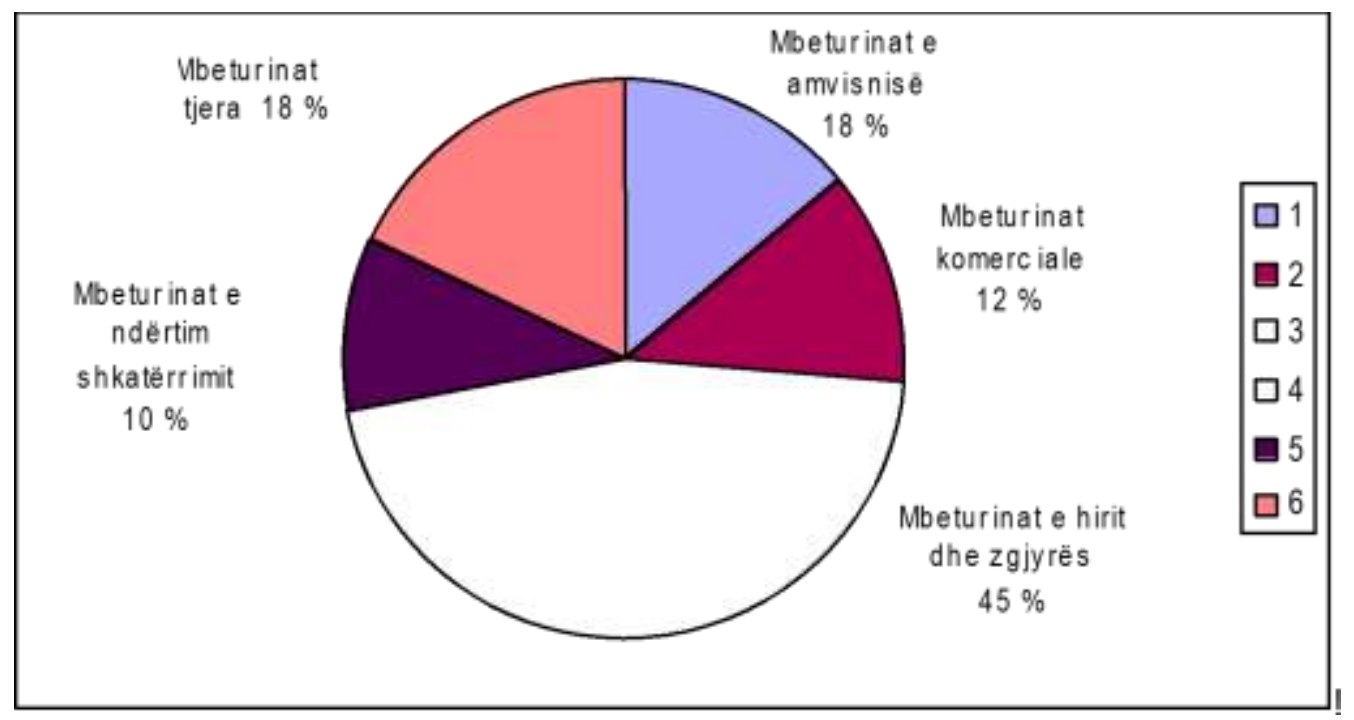

Figura 261. Pjesëmarrja e mbeturinave

(Burimi): MMPH. Agjencia e Kosovës për mbrojtjen e mjedisit, 2008.

Çdo mostrajtim i mbeturinave paraqet shndërrim të tyre në mbetje të rrezikshme. Në territorin e Kosovës kanë mbetur shumë materie të rrezikshme nëpër objekte industriale, të cilat ishin paraparë si lëndë e parë për prodhimtari, por fatkeqësisht në shumicën e rasteve janë shndërruar në mbeturina pa u përdorur një kohë të gjatë. Paketimet dhe magazinimi i tyre, është në një gjendje të mjerueshme. Me veprimet e tyre koroduese, kanë shkatërruar pajisjet apo paketimet, prandaj këto substanca, vazhdimisht kërcënojnë me katastrofë ekologjike. Zonat me koncentrim më të madh të mbeturinave dhe materialeve tjera të rrezikshme janë kryesisht ato që dikur kishin një zhvillim të madh të industrisë. Një përqendrim më të madh të ndotjes e kemi në Mitrovicë (Trepça) dhe Obiliq (KEK), pa i mohuar edhe vendet tjera, si Feronikelin, IBG në Gjilan. 
Problem në vete paraqesin mbeturinat që prodhohen çdo ditë dhe nuk trajtohen në mënyrë adekuate, duke paraqitur kërcenim të vazhdueshëm për tërë shoqërinë si: ${ }^{105}$

1. Vajrat e përdorura sidomos ato që përmbajnë $P C B, P C T$ dhe PBB

2. Bateritë, akumulatorët

3. Mbeturinat spitalore, infektive, shtazore, barnat e skeduara

4. Ambalazhi i substancave të rrezikshme

5. Mbeturinat e gomës dhe plastikës

6. Mbeturinat elektrike dhe elektronike

7. Pesticidet e skeduara

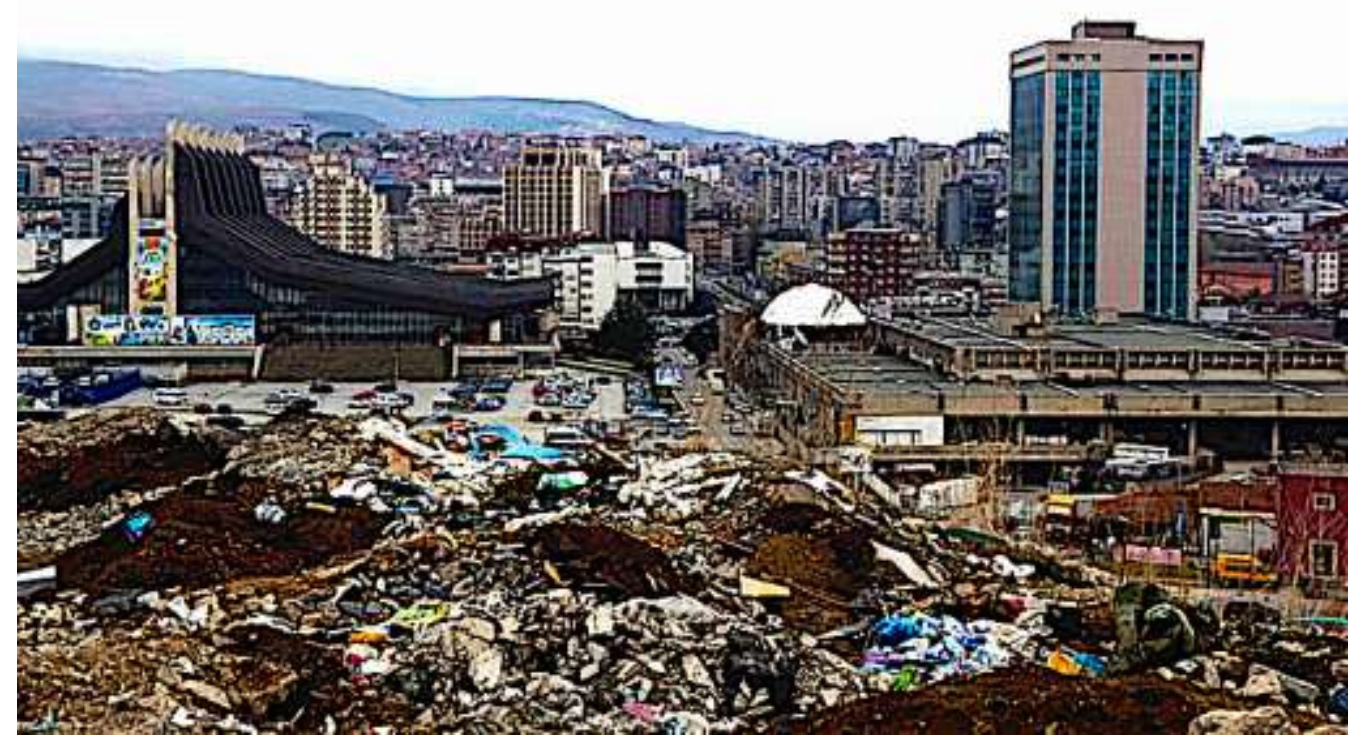

Figura 262. Deponitë e egra, Prishtinë.

(Burimi): Zyra e auditorit të përgjithshëm. Menaxhimi i sistemit të mbeturinave komunale në Kosovë. 2012

\subsection{MBETURINAT E NDËRTIMIT}

"Pas përfundimit të luftës, Kosova është përballur edhe me rritjen e sasisë së mbeturinave me prejardhje nga rrënimi i objekteve të banimit dhe objekteve tjera. Hedhja dhe grumbullimi i tyre në vende që nuk kanë qenë të destinuara për këtë qëllim ka keqësuar edhe më shumë gjendjen në sektorin e mbeturinave. Sidomos është shqetësuese dukuria e zënies së sipërfaqeve të tokave të punueshme dhe hedhja e mbeturinave pranë brigjeve të lumenjve. Përveç dëmtimit të peizazhit, mbeturinat e ndërtimit kanë ndikim të dëmshëm në mjedis e veçanërisht në ekosisteme, sidomos në rastet kur ato hedhen të përziera me mbeturinat të tjera urbane. Deri me tani nuk ka të dhëna të sakta për sasinë e këtyre mbeturinave dhe sipërfaqeve të zëna me to, por nga vizitat monitoruese në terren të ekipeve të AKMM-se, është vërejtur se këto mbeturina janë evidente në shumë lokacione të Kosovës. Për ilustrim po paraqesim disa foto me mbeturinat e ndërtimit."

105 z. Ilir Morina. Trajtimi i mbeturinave - zvogëlim i rrezikut për shëndetin dhe mjedisin. 2008. 


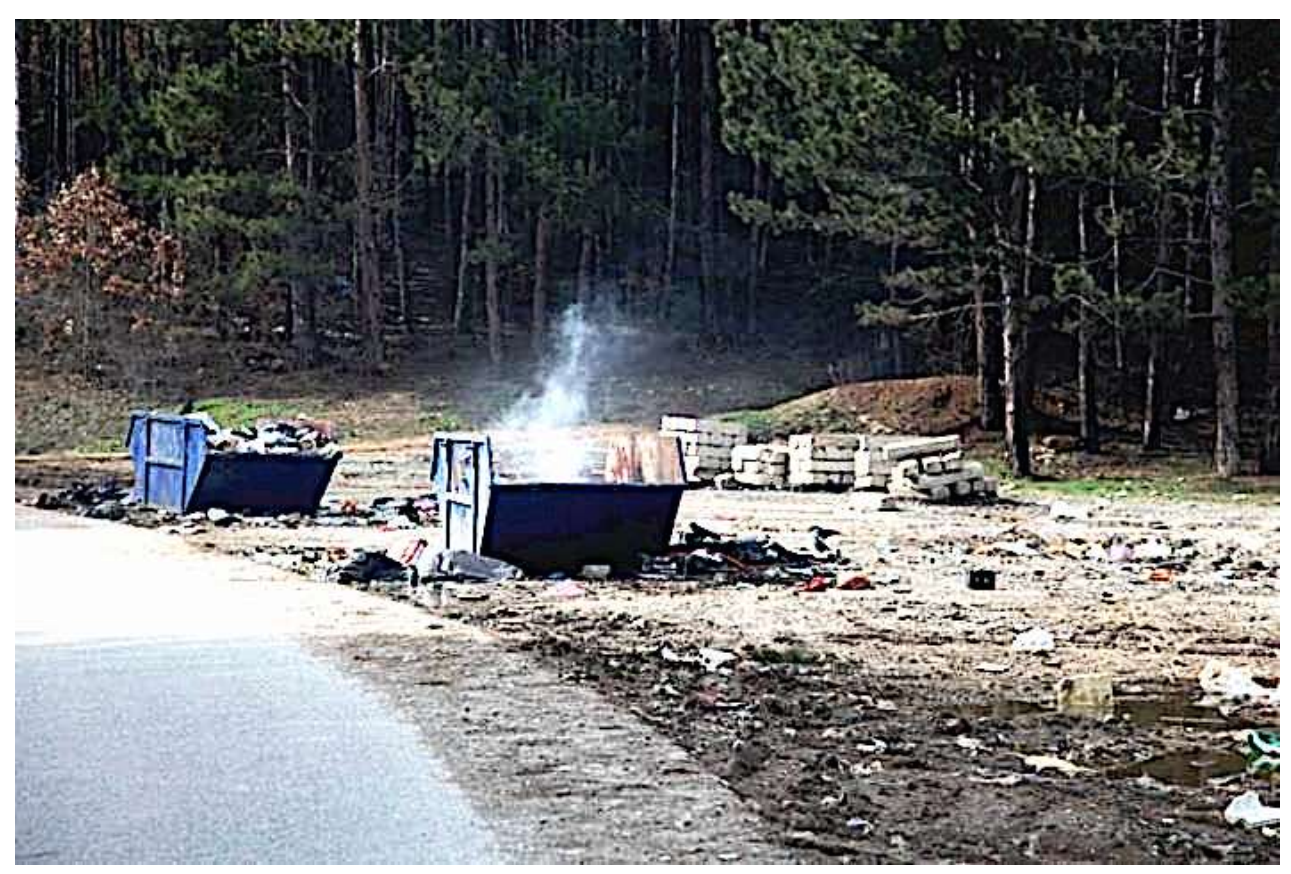

Figura 263. Kontejnerët dhe mbeturinat në liqenin e Batllavës.

(Burimi): Zyra e auditorit të përgjithshëm. Menaxhimi i sistemit të mbeturinave komunale në Kosovë. 2012

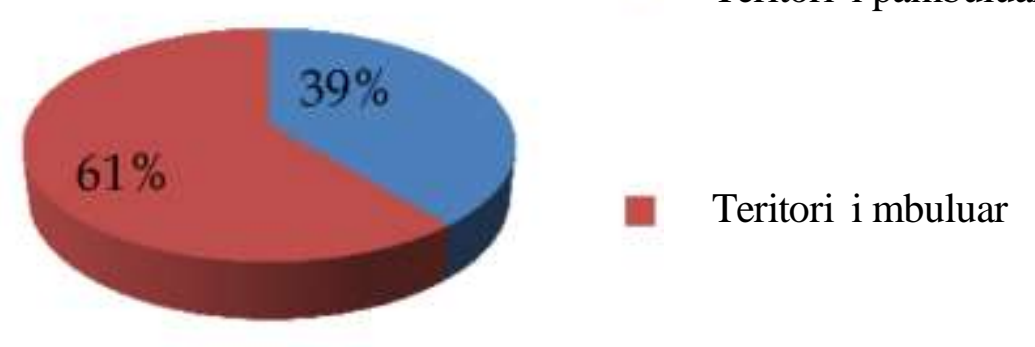

Figura 263-A. Niveli i mbulimit të territorit me shërbime pastrimi (Burimi): Raporti i Performancës së Komunave 2012. MAPL.

Popullsia e shërbyer
Popullsia e pashërbyer
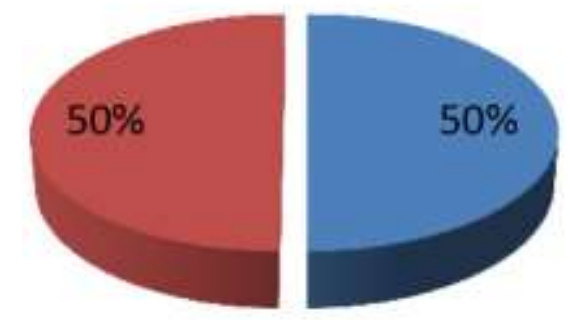


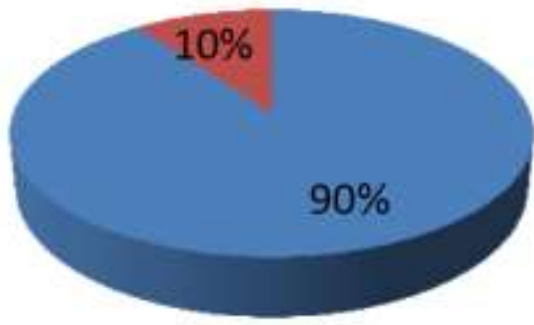

Popullsia e shërbyer

në zonat urbane

Popullsia e pashërbyer

në zonat urbane

Figura 264-A. Popullsia që ka qasje në shërbimet e pastrimit sipas zonave (Burimi): Agjencia e Kosovës për mbrojtjen e mjedisit. 2012. MMPH.

Tabela 57. Materialet dhe koha e shpërbërjes

(Burimi): AmEn. 2014. http://amen-ks.org/

\begin{tabular}{|l|l|}
\hline Materiali & Shpërbërja \\
\hline Letër tualeti & $2-4$ javë \\
\hline Lëvozhgë bananeje & $3-4$ javë \\
\hline Qese letre & 1 muaj \\
\hline Pambuku & $1-5$ muaj \\
\hline Gazeta & 1 muaj e gjysmë \\
\hline Bërthama e mollës & 2 muaj \\
\hline Kartoni & 2 muaj \\
\hline Lëvozhgë portokalli & 2 muaj \\
\hline Shpërpallka & $1-3$ vite \\
\hline Çorape e leshtë & $1-5$ vite \\
\hline Produktet e paketuara “ Tetrapack" & 5 vite \\
\hline Bishti i cigares & $10-12$ vite \\
\hline Këpucë prej lëkure & 25 vite \\
\hline Gotat e plastikës & 50 vite \\
\hline Kuti nga plastika & $50-80$ vite \\
\hline Kanaçet e aluminit & $200-500$ vite \\
\hline Shishet e plastikës & 450 vite \\
\hline Pelena & 600 vite \\
\hline Peri i peshkimit & 600 vite \\
\hline Qeset & $200-800$ vite \\
\hline
\end{tabular}


Të gjithë e dimë se mbeturinat janë dëmtues të mëdhenj të mjedisit tonë, mirëpo duhet analizuar ndonjëherë se sa dëm po i bëjmë mjedisit duke hedhur madje edhe një kanaçe të vetme, në vend se ta riciklojmë atë. Po ashtu duhet të jemi të vetëdijshëm se sa kohë nevojitet të shpërbehet bishti i cigares që sapo është pirë, apo qesja të cilën e kemi hedhur bashkë me mbeturinat e tjera. Gjeneratë pas gjenerate rëndësia e kësaj çështjeje neglizhohet sepse ende ekziston mendimi se nuk është problem i yni, koha po e bën të veten. Askush nga ne nuk ndihet mirë kur duhet të rregulloj diçka të cilën dikush para nesh e ka lënë ke, e pse pra presim që gjeneratat e ardhshme të jenë të gatshme të merren me mbeturinat e sotshme të cilat jemi ne duke i krijuar. Ato janë problem i se tashmes dhe ne duhet të gjejmë mënyra më të mira për të reduktuar mbeturinat në tokë.

Për të lehtësuar jetën tonë ne kemi shpikur gjëra të cilat mund të jenë kërcënuese për mjedisin, në kuptimin se, koha e nevojshme për shpërbërjen e tyre është tmerrësisht e gjatë. Në tabelën 57, të më sipërme, prezantohet se sa kohë u nevojitet mbeturinave të ndryshme të shpërbëhen në natyrë dhe ndoshta do të tregohemi më të kujdesshëm për atë se sa dhe çfarë do të hedhim në të ardhmen. ${ }^{106}$

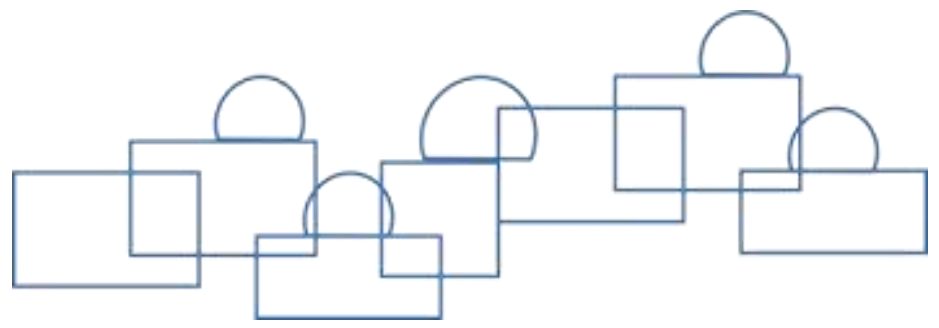

106 AmEn. 2014. http://amen-ks.org/ 
MBETURINAT - MJEDISI

KJO FAQE ËSHTË LËNË QËLLIMISHT E ZBRAZËT! 


\section{ARKITEKTURA NË KONTEKST}

$\mathrm{R}$

aporti i konkurrencës globale 2014-2015, raport ku vlerësohen raporte konkurruese të 144 shteteve dhe ekonomive, duke siguruar informata për produktivitetin dhe prosperitetin e secilit shtet. Raporti, mbetet vlerësimi më i plotë i konkurrencës kombëtare në të gjithë botën, duke ofruar një platformë për dialog midis qeverive, biznesit dhe shoqërisë civile në lidhje me veprimet e nevojshme për përmirësimin e prosperitetin ekonomik. Konkurrenca është përcaktuar si grup dhe sistem i institucioneve, politikave dhe faktorëve që përcaktojnë nivelin e produktivitetit të një vendi apo shteti. Niveli i produktivitetit, nga ana tjetër, përcakton nivelin e prosperitetit që mund të fitohet nga një ekonomi e zhvilluar. Aspektet e ndryshme të konkurrencës janë shqyrtuar në 12 shtylla, të cilat përbëjnë Indeksin e konkurrencës globale. Ky vlerësim, potencon në risi dhe aftësi, si veçori kryesore të rritjes ekonomike. Gjersa këto veçori ndikojnë gjithnjë e më shumë në konkurrencën dhe ekonominë globale e cila gradualisht po rimëkëmbet nga kriza ekonomike, rreziqet e mëdha mbesin dhe rezultojnë me një situatë të tensionuar gjeopolitike, rritje të pabarazisë në të ardhura dhe kushtëzim apo limitim të resurseve financiare. Prandaj është e rëndësishme që, për të adresuar këto sfida duhet siguruar rritje më të qëndrueshme dhe gjithëpërfshirëse ekonomike. Këto njohuri të prezantuara janë të rëndësisë së veçantë për Kosovën, realisht duhet të jenë informata udhërrefyese për drejtimin e duhur të zhvillimit ekonomik. Më shumë se kurrë, paraqitet nevoja e bashkëpunimit në mes bizneseve, qeverive dhe shoqërisë civile, kohezion veprimesh që është më së i nevojshëm për të rivendosur një rritje të qëndrueshme ekonomike, duke u reflektuar në rritjen e standardit të jetesës. ${ }^{107}$

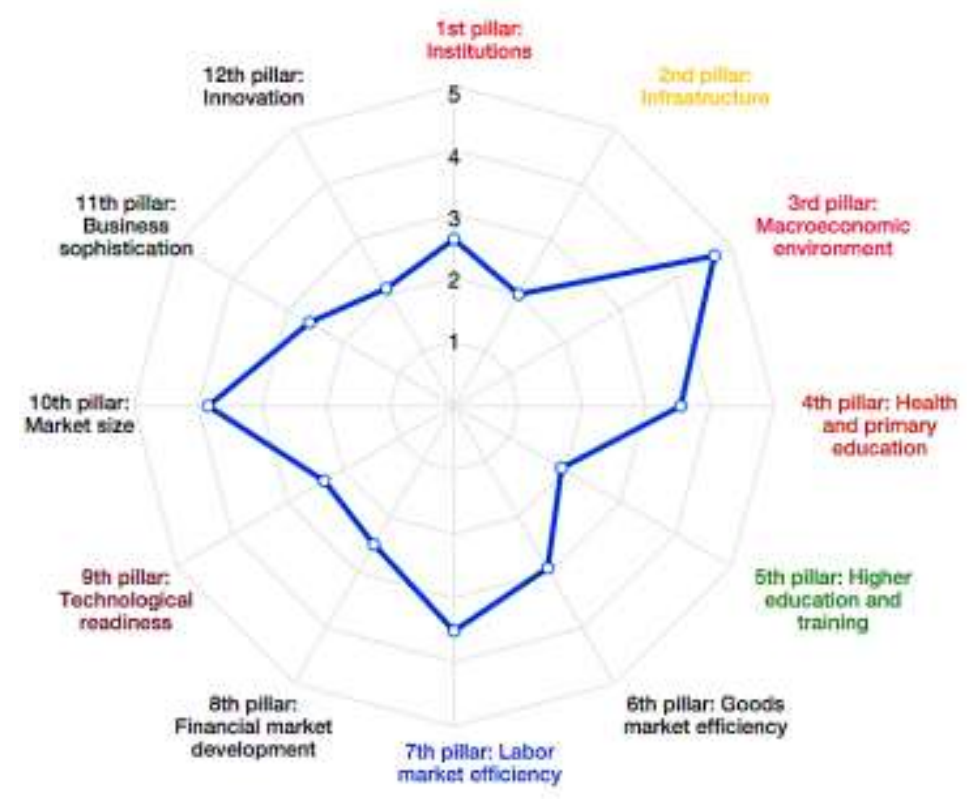

Figura 265. Përmbledhje e përformansave zhvillimore

(Burimi): The World Economic Forum,2015. http://reports.weforum.org/global-competitiveness-report2014-2015/economies/

107 The World Economic Forum. http://reports.weforum.org/global-competitiveness-report-2014-2015/ 


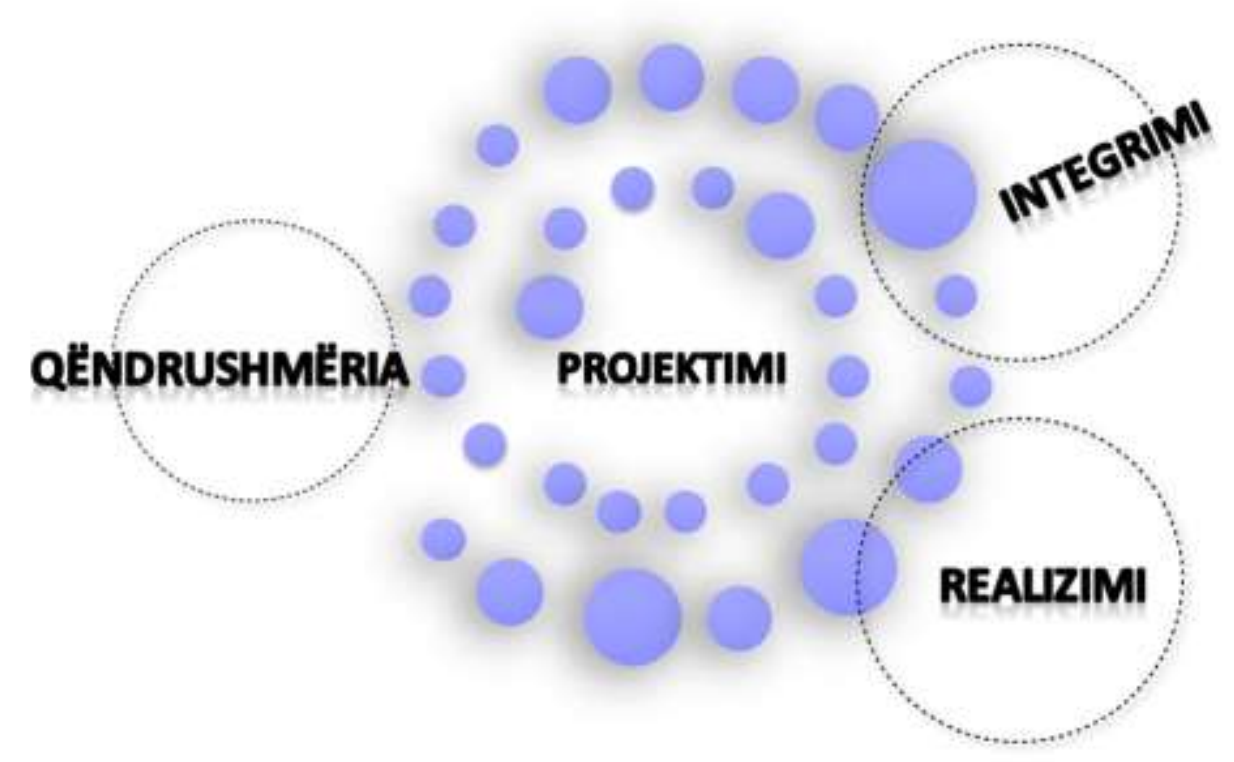

Figura 266. Ndërvarësia e projektimit të qëndrueshëm (Burimi): Bujar Bajçinovci, 2015.

\subsection{SFIDAT E QYTETIT ME ZHVILLIM TË SHPEJTË}

Qytetet janë ekosisteme komplekse, me fenomene specifike që drejtpërsëdrejti reflektohen në shëndetin tonë, në resurse natyrore, zhvillim ekonomik dhe social. Konceptualisht, mund të konsiderohet se qytetet në nivel lokal dhe rajonal janë në një mënyrë specifike dhe unike, dhe mu për këtë arsye sfidat dhe atributet e caktuara të zhvillimit të një qyteti janë të natyrës origjinale dhe specifike.

"Çfarë të ardhme për Prishtinën? Në menaxhimin dhe planifikimin e kryeqytetit të Kosovës." "Plani Strategjik 2020 është shumë i paqartë, nga realiteti i Prishtinës, përdorimi i kësaj strategjie është shumë i vështirë të implementohet, planifikimi dhe përdorimi vijnë nga supozime të egra. Përveç kësaj, kjo strategji pohon se nuk ka të dhëna të besueshme për popullsinë e Prishtinës". ${ }^{108}$

Figura 266. Hyjnesha në fron

(Burimi): Instituti Arkeologjik i Kosovës, 2012.

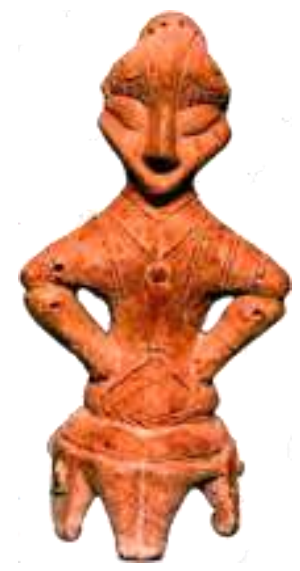

108 Knaus, V.,(ESI).(Jun/2006). European Stability Initiative. Prezantimi zhvillimor në komunën e PR. 
Për më tepër, Iniciativa Kosovare për Stabilitet (ESI) rekomandon që departamentet dhe drejtoritë në komunë duhet të punojnë ngushtë së bashku. Iniciativa Kosovare për Stabilitet e bën këtë rekomandim për institucionet lokale dhe qendrore. Por realiteti është se shumica e organizatave qeveritare ende varen nga AKM (Agjencia Kosovare e

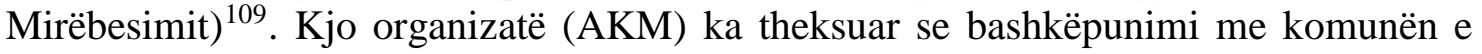
Prishtinës ende nuk është zbatuar në mënyrë efektive deri më sot (2006).

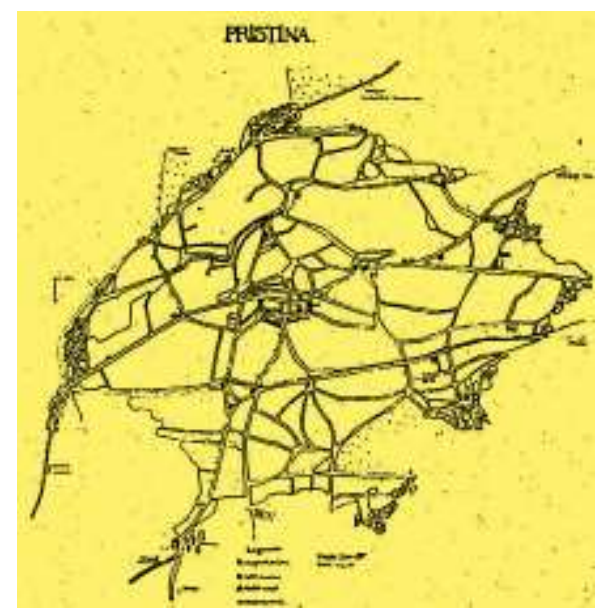

Prishtina cca 1916.

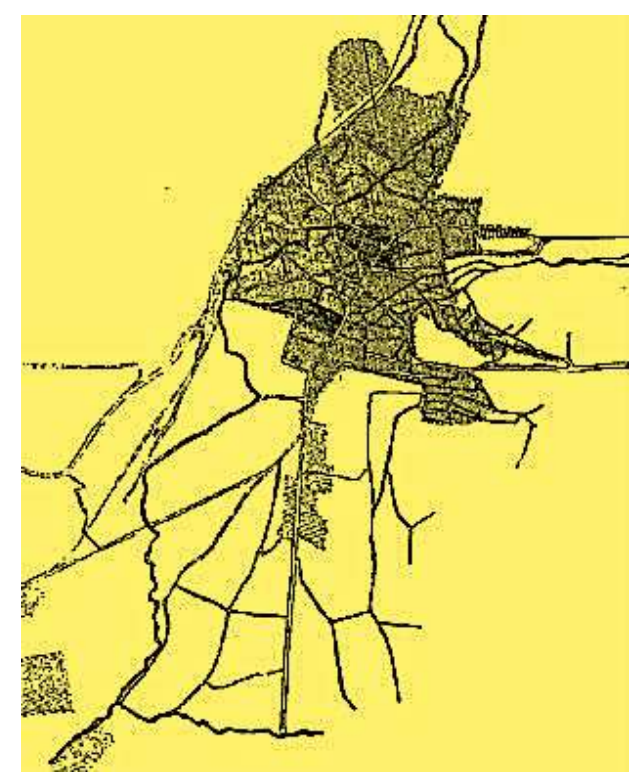

Prishtina 1950.

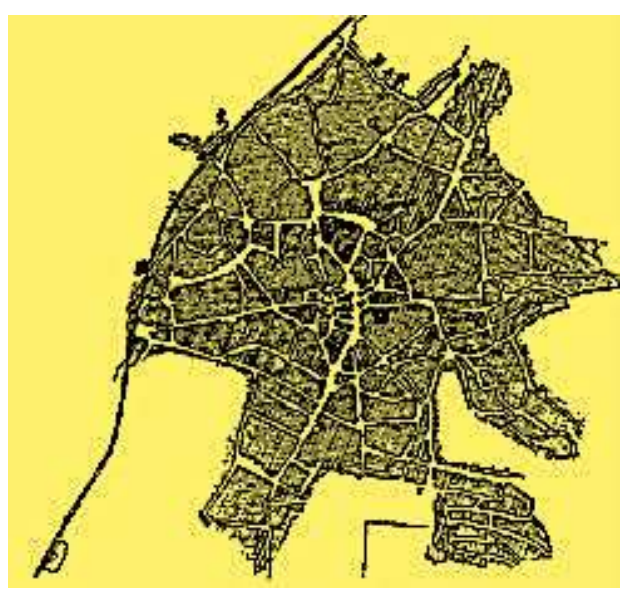

Prishtina 1937.

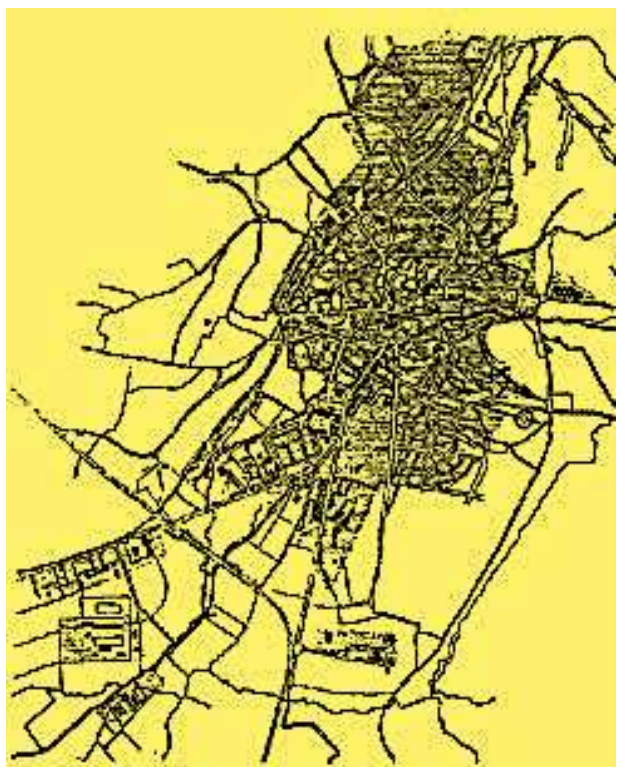

Prishtina 1960.

Figura 267. Prishtina në kohë dhe hapësirë (Burimi): PPU, 1987. Komuna e Prishtinës

109 Kosovo Trust Agency. http://kta-kosovo.org/html_shqip/index.php, 2011. 
Sfidat urbane me të cilat përballet qyteti i Prishtinës:

1. Planifikimi dhe vizioni, rritja e qytetit është e karakterizuar nga kërkesa për shërbime dhe servise efikase për të rritur kapacitetin e shërbimeve bazike urbane si menaxhimi ligjor, energjia, uji dhe kanalizimi, ngrohja, higjiena ku aktualisht mund të konstatojmë se kemi mangësi evidente në këto veçori.

2. "Rritje të shpejtë", qytetet kanë nevojat e tyre specifike emergjente dhe gjithashtu sfida krejtësisht të reja dhe origjinale. Qytetet me rritje të shpejtë janë të ngjashëm me rritjen e shpejtë e të rinjve në adoleshencë. Në mënyrë analoge, qytetet që në situata të caktuara dhe në kohë të veçanta rriten me shpejtësi, mbajnë me vete një numër të nevojave urgjente dhe kërkesave në mënyrë që të funksionojnë normalisht.

3. Zona të banuara të qytetit të përbëra nga strukturat polifunksionale të banimit dhe të ndërtesave me karakter publik, u pasuan me kritika të forta profesionale dhe vërejtje për shkak të vizionit, shkallës së natalitetit, sistemet e infrastrukturës, rrugët, cilësinë e ajrit dhe për jo qëndrueshmërinë e resurseve natyrore.

4. Fisioni demografik dhe socio-hapësinor i vitit 2000, proces i rritjes së pakontrolluar të qytetit si dhe improvizimet institucionale mbi planet strategjike të zhvillimit të qytetit, sidomos ato me korniza kohore afatmesme.

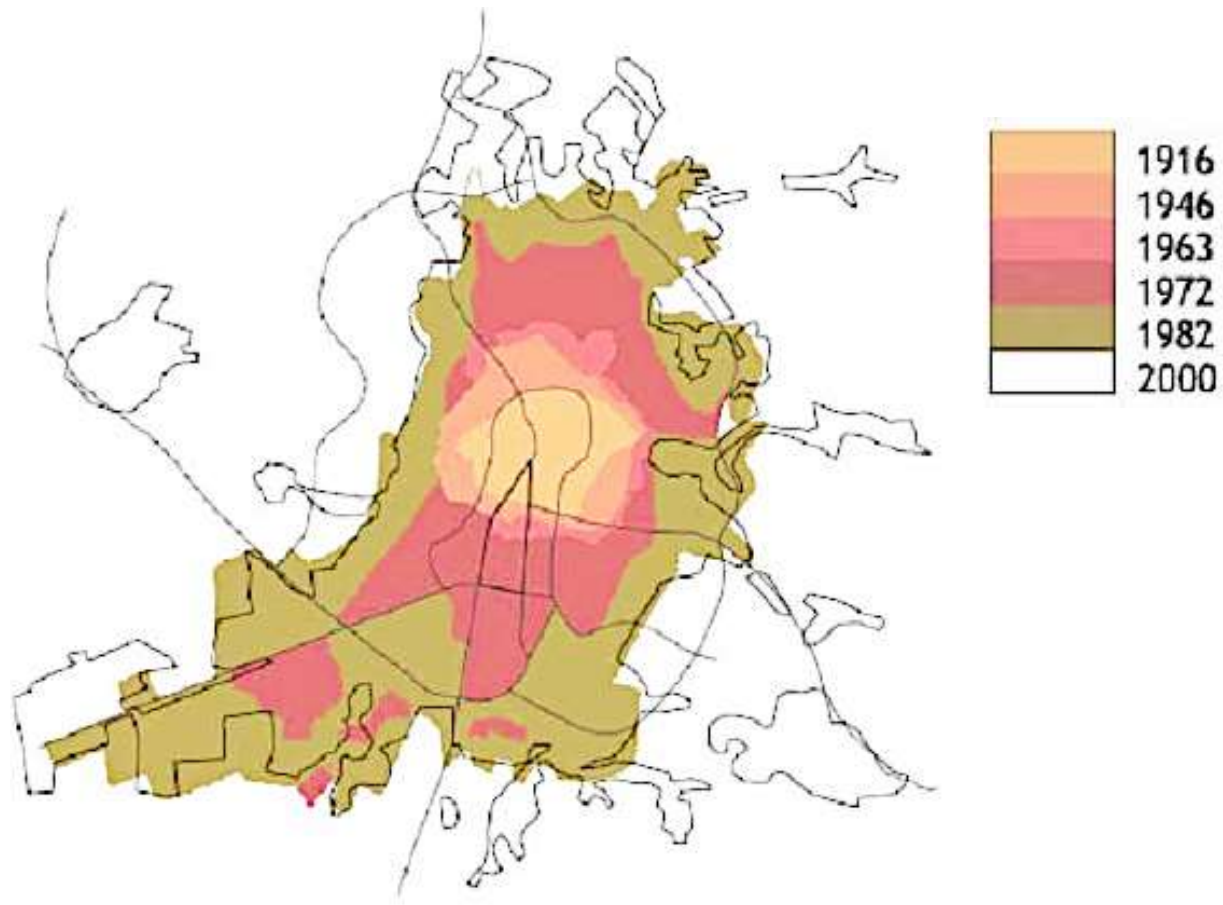

Figura 267. Prishtina në kohë dhe në hapësirë (Burimi): PPU, 1987. Komuna e Prishtinës 


\subsection{ZHVILLIMI I PRISHTINËS}

Duket se natyra e projektimit ende nuk është e lehtë për ta definuar plotësisht, dhe se çfarë ky term vërtetë do të thotë. Pjesëmarrësit në projektim jo që vetëm pasqyrojnë pikëpamjet e tyre profesionale, ata e shohin veten në një rol të ndryshëm, e shohin veten si pjesëmarrës në një proces evolutiv krijues. Proces me rëndësi të veçantë, e sidomos te njerëzit me fuqi ekzekutive dhe që kanë rolin e vendimmarrjës. Andaj, në çështjet e shumta që tangjentojnë ruajtjen e mjedisit dhe proceset e zhvillimit të qytetit, rol jetik kanë arkitektët të cilët janë të involvuar në projektimin e planeve përfundimtare zbatuese. Sipas PPU të Prishtinës të vitit 1987, ku potencohet zhvillimi historik i qytetit, paraqiten dëshmi të shumta të qytetit e posaçërisht të rajonit të Ulpianës që mund të dokumentohen me vendbanime parahistorike, të cilat dëshmohen në shumë pika arkeologjike. Janë të pranishme por nuk janë rilevuar në mënyrë të tërrësishme edhe gjurmët e vendbanimeve nga paleoliti, neoliti i hershëm, kulturat e vjetra dhe grupet e hershme neolitike të kulturave etnike, ku realisht instituti i arkeologjisë së R. Kosovës është duke bërë punë të mrekullueshme profesionale.

Në kohën e Perandorisë Romake, pozita e rajonit kishte një rëndësi strategjike, ishte në udhëkryqe të rrugës kryesore historike e cila lidhte Evropën qendrore me pjesët e jugut, juglindjes dhe jugperëndimit të Gadishullit Ballkanik. Mbretër të ndryshëm, princë dhe shkrimtarë, dëshmojnë zhvillimin e qytetit. Për tu përmendur, ishte perandori bizantin, Gjoni Cantacosin nga shekulli XIV, kimisti turk Neri Mullah Muhamed, po ashtu udhëtari i famshëm turk Evlija Qelebia, i cili me 1660 vizitoi Prishtinën, ku personalisht kishte regjistruar 2060 shtëpi familjare, dy hamame, 11 hane, 300 dyqane dhe shumë xhami. Shkrimtari shqiptar dhe prifti Pjetër Bogdani, e përshkroi Prishtinën me shumë ekonomi familjare, hamame, hane dhe dyqane.

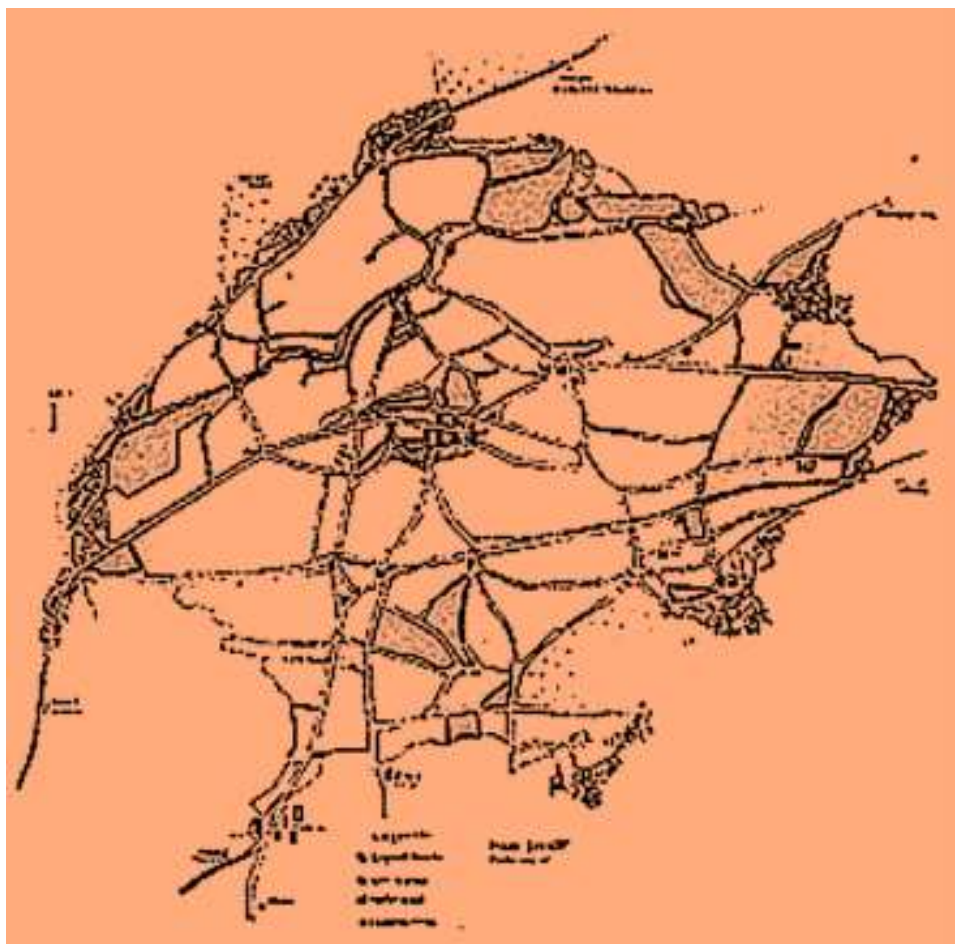

Udhëpërshkruesi Baron Gamera, në shekullin e XIX, deklaronte se në Gadishullin Ballkanik, në rrugën për në Selanik, ishtë një qytet relativisht i madhë, i ashtu quajtur Prishtinë.

Vlen të përmendet se konsuli francez Anton Vass dhe shkrimtari Ami Bue në vitin 1830 e përshkruan shënimin e panairit të verës për tregtarët që vinin nga Prizreni,Shkupi, Shkodra, Velesi, Nishi, Selaniku dhe Bosnja në Prishtinë.

Figura 268. Prishtina me 1916

(Burimi): PPU, 1987. Komuna e Prishtinës 


\subsection{MASTER PLANI - 1987}

Master Plani i qytetit të Prishtinës i vitit 1987, ishte plani i fundit i përgjithshëm i zhvillimit të qytetit në shekullin e fundit. Si i tillë, përbënte një bazë të mirë për kërkime të mëtejshme në kuadër të rajonit urban të qytetit. Gjithashtu ky plan iu referua vizionit për zhvillimin urban me projeksionet e vitit 2000. Andaj, karakteristikat themelore të planit ishin për tu përshëndetur. Natyrisht, plani i përgjithshëm urbanistik kishte edhe bazën ligjore, por njëherit edhe konotacione politike për tu përpunuar dhe për të përcaktuar:

1. Procedurat metodologjike, baza formale ligjore për fillimin planifikimit total dhe të vazhdueshëm për qytetin e Prishtinës.

2. Projeksionin e planit për vitin 2000, plani kishte edhe mundësinë për të zhvilluar kahjen dhe rregullimin e hapësirës urbane edhe pas vitit 2000.

3. Organizimi i punës profesionale, pjesëmarrja dhe diskutimi publik, subjektet e planifikimit, profesionistët, komisionet e ekspertëve.

4. Kohën dhe burimet e nevojshme për zhvillimin e planit, procesin e zhvillimit dhe planifikimin e përgjithshëm të Prishtinës urbane, e cila ishte pjesë e vendimit për të krijuar PPU, i cili përcaktonte fushat specifike të hulumtimit, fazat e punës, specifikat në planin e punës dhe përgatitjet për Master Planin. Në fund zbatohej procesi i miratimit me të gjitha përmbajtjet për zbatimin e planit.

Në përputhje me modelin e procesit të punës, planifikimi ishte zhvilluar në bazë të fazave si më poshtë:

1. Faza e përgatitjes - Grumbullimi dhe përpunimi i dokumenteve, vendimet për zhvillimin socio-ekonomik dhe rregulloret e zhvillimit urban.

2. Faza e dytë - Harmonizimi i qëllimeve dhe zhvillimi sektorial si zona për hulumtim, programet e zhvillimit si dhe prezantimi i varianteve për zhvillimin dhe organizimin e hapësirës me avokim.

3. Faza e tretë - Krijimi i kornizës për projektin apo propozim e PPU me të gjitha shtojcat dhe elementet e nevojshme për miratimin përfundimtar. ${ }^{110}$

Në mënyrë të pashmangshme, duhet theksuar se hulumtimet specifike ishin marrur drejtpërdrejt me organizimin e planit hapësinor të Prishtinës, duke hulumtuar zonën e brendshme dhe mjedisin më të gjerë të qytetit, si dhe ndotësit nga termocentrali "Kosova A" dhe "Kosova B". Hulumtimet në rezervat e mëdha të thëngjillit, linjitit, pasi me shfrytëzimin e tij për termocentralet paraqiste një ndotje e fortë e mjedisit, në radhë të parë me grimcat e suspenduara në ajër nga tymtarët si dhe nga deponitë të tjetra të mëdha, të cilat edhe sot e kësaj dite paraqesin sfidë dhe sidomos shfrytëzimi i kësaj teknologjie është shumë i papërshtatshëm për trajtimin e hirit.

110 PPU, Projekti, (1987). Projeksioni i Prishtinës 2000, Komuna e Prishtinës. 
Në theks të veçantë të hulumtimit ishte edhe sfondi hidrologjik, respektivisht lumenjtë konkret të cilët ishin dhe ende përdorën për ftohjen e blloqeve të termocentraleve, rëndësi tjetër paraqiste edhe ndotja për shkak të kimikateve të nevojshme të përdorura për procesin e prodhimit të cilat janë derdhur në lumë. Ndotja ishte bërë atëherë dhe ende është duke u bërë me primesa të ndotjes së përhershme të mjedisit me pasoja shekullore. Ndotja e mjedisit do të ndodhë deri në momentin kur të kemi rivitalizim adekuat të tokës, përmirësim të kualitetit të ajrit, florës dhe faunës.

Sipas PPU, nataliteti dhe banimi për qytetin, i bazuar në hulumtimet për të krijuar parashikimet hapësinore për popullsinë në vitin 2000, konceptualisht duhej të zhvillohej me dy premisa themelore: pjesa ekzistuese e qytetit (rindërtimi, restaurimi dhe rehabilitimi), si dhe zgjerimi dhe ndërtimi i zonave të reja zhvillimore.

Qëllimi kryesor i zonës së banimit ishte planifikuar për:

1. Banim kryesisht individual

2. Banim i përzier

3. Banimi kolektiv

4. Banim kolektiv me veprimtari

Karakteristika banim "kryesisht" individual, kishte domethënien se zonat e banimit në format themelore mund të siguronin edhe forma të tjera të banimit, me kusht, në respektimin dhe realizimin e parametrave të dhënë projektues, duke nënkuptuar indeksin e banimit, densitetit, $\mathrm{m}^{2} /$ banor, zonën e gjelbër etj. Plani theksonte banimin në lagjet ekzistuese. Mirpo pas një kontrolle të detajuar të zonave hapësinore të cilat pas hulumtimit ( dhe vendimeve relevante ) do të caktoheshin se çfarë zona do të mbeteshin, në kontekst cilat për tu rindërtuar, riparuar apo të rehabilitoheshin.

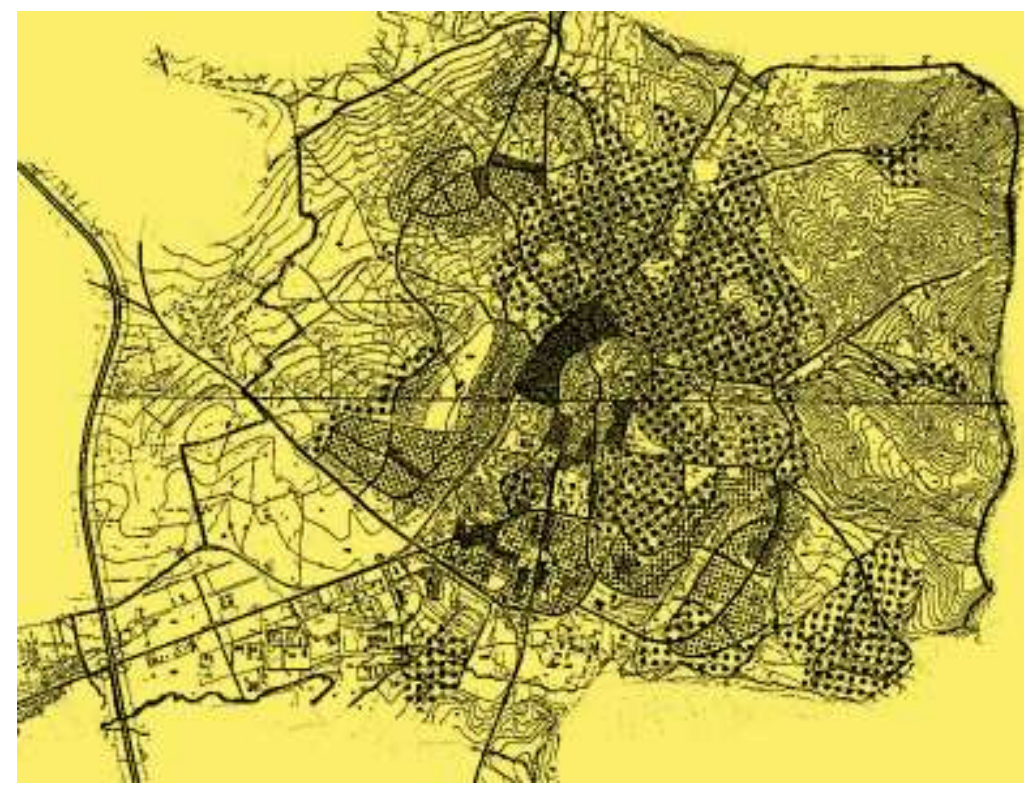

Figura 269. Hulumtimet urb-arkitektonike (Burimi): PPU, 1987. Komuna e Prishtinës 
Kategoria e banimit individual përfshinte dy nën kategori:

1. Banimi individual, ( banim në shtëpi të vogla ), në disa ngastra, shtëpi të vogla në varg.

Tabela 58. Banimi individual

(Burimi): Përpunuar, Bujar Bajçinovci. PPU, 1987. Komuna e Prishtinës

\begin{tabular}{|c|c|}
\hline Madhësia e parcelës & cca $420 \mathrm{~m}^{2}$ \\
\hline Dendësia banimore (bruto) & cca $135 \mathrm{ba} / \mathrm{ha}$ \\
\hline Dendësia banimore (për objektin) & cca $170 \mathrm{ba} / \mathrm{ha}$ \\
\hline Indeksi i ndërtimit (për objektin) & cca 0.40 \\
\hline Lartësia e objektit & $P$ dhe $P+1$ \\
\hline Numnri i nj. Banimore në parcelë & 1 \\
\hline Shtëpi mesatare, raporti ( banues) & $18 \mathrm{~m}^{2} /$ person \\
\hline
\end{tabular}

\section{Banim i përzier}

Banimi i përzier, do të thotë se ky sistem përmbante elemente të të dy trajtave: individuale dhe kolektiv ( trajta e banimit, e cila ishte afirmuar në Prishtinë, në shekullin e kaluar). Shumica e shtëpive individuale u realizuan me lartësi $\mathrm{B}+\mathrm{P}+1$ dhe $\mathrm{P}+2$, me strukturë në banimin e përzier me 3 deri në 5 njësi. Kjo strukturë konceptuale siguronte banim të mirëfilltë, me kusht që modifikimet e ardhshme të jenë në kufijtë e akceptimit planifikues, pa dëmtuar sistemin fillestar urban me etazhitet $\mathrm{P}+2$.

Tabela 59. Banimi individual i përzier

(Burimi): Përpunuar, Bujar Bajçinovci. PPU, 1987. Komuna e Prishtinës

\begin{tabular}{|l|c|}
\hline Madhësia e parcelës & cca $625 \mathrm{~m}^{2}$ \\
\hline Dendësia banimore (bruto) & cca $180 \mathrm{ba} / \mathrm{ha}$ \\
\hline Dendësia banimore (për objektin) & cca $240 \mathrm{ba} / \mathrm{ha}$ \\
\hline Indeksi i ndërtimit (për objektin) & cca 0.50 \\
\hline Lartësia e objektit & $\mathrm{P}, \mathrm{P}+1 \mathrm{i} \mathrm{P}+2$ \\
\hline Numri i nj. Banimore në parcelë & $1-6$ \\
\hline Shtëpi mesatare, raporti ( banues) & $16 \mathrm{~m}^{2} /$ person \\
\hline
\end{tabular}

Kategoria e banimit kolektiv nënkuptonte dendësi më të lartë të banimit dhe lartësi të ndërtimit max. P + 3 sipas PPU, megjithatë, duhet theksuar se kufizimi i lartësisë së ndërtimit të ndërtesave të reja i cili ishte kufizuar në max. $\mathrm{P}+3$, ishte jo real. Parametrat e projektuara për kategorinë e banimit kolektiv ishin sipas PPU: 
Tabela 60. Banimi kolektiv

(Burimi): Përpunuar, Bujar Bajçinovci. PPU, 1987. Komuna e Prishtinës

\begin{tabular}{|c|c|}
\hline Dendësia banimore (bruto) & cca $240 \mathrm{ba} / \mathrm{ha}$ \\
\hline Dendësia banimore (për objektin) & cca $360 \mathrm{ba} / \mathrm{ha}$ \\
\hline Indeksi i ndërtimit (për objektin) & cca 0.70 \\
\hline Lartësia e objektit & $\max . P+3$ \\
\hline Shtëpi mesatare, raporti ( banues) & $14 \mathrm{~m}^{2} /$ person \\
\hline
\end{tabular}

Të dhënat e grupuara për zonën e shqyrtuar të PPU, ose për të gjitha njësitë hapësinore të mbuluara me programim dhe planifikimin e projeksionit zhvilimor deri në vitin 2000 , për qytetin e Prishtinës, vijon sipas tabelave:

Tabela 61. Banimi si program urban zhvillimor i qytetit (Burimi): Përpunuar, Bujar Bajçinovci. PPU, 1987. Komuna e Prishtinës

\begin{tabular}{|l|c|}
\hline Zona neto, e përdorshme për banim & $3,079,537 . \mathrm{m}^{2}$ \\
\hline Zona bruto, e përdorshme për banim & $3,908,274 . \mathrm{m} 2$ \\
\hline Dendësia banimore (bruto) & $108.56 \mathrm{ba} / \mathrm{ha}$ \\
\hline Indeksi i ndërtimit (për objektin) & cca 0.342 \\
\hline Numri i banorëve & $209,438$. \\
\hline Shtëpi mesatare, raporti / ( banues) & $14,70 \mathrm{~m} /$ person \\
\hline
\end{tabular}

Zona neto e dobishme për banim në projeksionet e vitit 2000, ishte kalkuluar dhe përbëhej nga parametrat si më poshtë. Banimi në ndërtimin e ri ishte dhënë në zonat hapësinore IV, V, VIc, VII, si dhe në kontekstin e zgjidhjes merrnin pjesë lagjet si Kojlovica, Sofajlia dhe Mati.

Tabela 62. Banimi në tërësi, sipas PPU

(Burimi): Përpunuar, Bujar Bajçinovci. PPU, 1987. Komuna e Prishtinës

\begin{tabular}{|l|r|}
\hline Neto, Banesat me ndërtim të ri & $1,935,500 . \mathrm{m}^{2}$ \\
\hline Sipërfaqja ekzistuese e banimit, fondi solid & $954,231 . \mathrm{m}^{2}$ \\
\hline Sipërfaqja ekzistuese e banimit, fondi jo solid & $189806 . \mathrm{m}^{2}$ \\
\hline TOTAL & $3,079,537 . \mathrm{m}^{2}$ \\
\hline
\end{tabular}


Programimi dhe planifikimi, Plani i Përgjithshëm Urbanistik PPU i vitit 1987, në kuadër të destinimit të sipërfaqeve dhe nga korniza e studiuar, ishte ndarë në tri njësi hapësinore. Pjesa më e madhe dhe qendrore të Prishtinës ishte numëruar si e para, e cili ishte një hapësirë e madhe me kompleksitet të plotë dhe të veçantë në strukturën e saj të brendshme duke përfshirë bërthamën historike, ndërtesat kryesore publike brenda qytetit si dhe hapësirat më të vogla organizative. Organizimi hapësinor i pjesës qendrore të qytetit përgjatë boshtit kryesor rrugor, fillonte në qendër duke ruajtur dhe restauruar objektet historike e cila njëherit ishte edhe trajektorja kryesore e qarkullimit të këmbësorëve deri në qendër të qytetit. Ishtë zona kryesore për këmbësorë, objektet e dedikuara që të restaurohen, si dhe të gjitha objektet shoqërore dhe private në atë kohë. Natyrisht, me kalimin e kohës si dhe me evoluimin e qytetit, e definua nevoja për të krijuar objekte të reja, me theks tek ndërtesat me shumë qëllime si: galeri, salla të leximit, kinema, teatër, dyqane të vogla, restorante dhe objekte për shërbime të ndryshme. Po ashtu në këtë frymë, rivitalizimi duhej të përhapej edhe në restaurimin e fasadave të vjetra në qytet, një intensifikim i progresit të përgjithshëm me përmbajtje të re. Kjo nismë shihej si qasje e re në projektim dhe në mbrojtjen e mjedisit. Hapësira urbane e Prishtinës ishte qendër sociale, kulturore, komerciale dhe e biznesit për të gjithë banorët e Kosovës. ${ }^{110}$

Qendrat apo zonat e zhvillimit, të nivelit të dytë të hulumtimit, përfaqsojshin katër akset e qendrave të zhvillimit, sikurse: Kodra e trimave, Mati, Arbëria dhe Dardania. Sipas përmbajtjes dhe formës së qendrave të zhvillimit, ato ishin të organizuara si satelitë nga qendra e Prishtinës, me të cilën ishin të lidhura ngushtë nga karakteri, funksioni dhe vazhdimësia e qendrës, me premisë zhvillimore urbane se hapësira e përgjithshme e qendrës nuk do të prishej dhe do të funksiononte pa pengesa të mëdha. Qendrat e zhvillimit të njësive funksionale do të menaxhohej me të njëjtat përmbajtje sikurse qendra kryesore: ndërtesa publike, objekte me servise të specializuara, biznese të vogla, tregti në nivel lokal, shërbimet, kujdesi shëndetësor, kultura etj. Përveç kësaj, një përzgjedhje e veçantë e përmbajtjes (me rëndësi nga lloji i aktivitetit), ishte kërkesa kryesore me kombinimet e mundshme të veprimtarive terciare me zonat e banimit.

Hapësira e tretë zhvillimore e sistemit, sipas PPU, ishin planifikuar qendra të vogla jashtë pjesës qendrore të qytetit. Puna e tyre ishte që të sigurojë klientët me shërbimet e nevojshme të standardit të jetesës. Për shkak të formave jo standarde dhe madhësive të komuniteteve ekzistuese lokale, ishte me rëndësi që në mënyrë efektive të mbrohej e "vjetra" dhe trashëgimia e qytetit, si dhe zonat me interes të posaqëm nga komuna. Aftësia për të kombinuar përmbajtjen afariste me zona banimi ishte arsyeja që zona të caktuara të merrnin karakter polifunksional, kështu që zona të caktuara do të duhej enkas të zhvilloheshin si të tilla. Respektivisht, do ishin zona funksionale për fusha të veçanta, ku forma e organizimit hapësinor e këtyre mikro lokaliteteve do të përcaktohej me plane të detajuara konkrete.

Në tërësinë funksionale të hapësirës së projektuar ishte paraparë që të përfshihen veprimtari, sikurse: dyqane, njësi tregtare, njësi të vogla hoteliere, stacione shëndetësore, bare dhe klube sociale rinore. Megjithatë, përqendrimi i aktiviteteve të specializuara të shërbimeve terciare, sikurse: qendrat klinike, spitalet, kolegjet, universiteti, shkollat fillore dhe të mesme, sigurimet shoqërore, të cilat ishin të përcaktuara si sisteme komplekse me trajtim të veçantë, duhej trajtuar si veprimtari të posaqme me karakter të nivelit të lartë organizativ. 


\subsection{STRUKTURA EKZISTUESE URBANE}

"Në masë të madhe për shkak të shtimit të shpejtë të popullsisë së Prishtinës si qendër ekonomike dhe administrative pas vitit 1999, zhvillimi i qytetit ka qenë deri diku i pakontrolluar, që është shënuar dhe evidentuar me shkatërrimin e shumicës së bërthamës historike dhe zëvendësimit të saj me objekte të mëdha private për banim dhe afarizëm komercial. Ndonëse është identifikuar zona historike dhe monumentet janë vënë nën mbrojtjen zyrtare, akoma nuk është marrë asnjë masë për integrimin e saj në kuadër të planifikimit urban të komunës. Vlerësohet se rreth $44 \%$ të objekteve të inventarizuara historike tashmë janë shkatërruar, dhe veçanërisht shembujt të shtëpive tradicionale janë gjithnjë e më të rrezikuara nga lënia anash e vëmendjes dhe rrënimi. Sfida në Prishtinë qëndron në gjetjen e një kompromisi në mes të kërkesave politike dhe ekonomike të një metropoli modern, nevojave të qytetarëve të saj dhe trashëgimisë së saj. "111

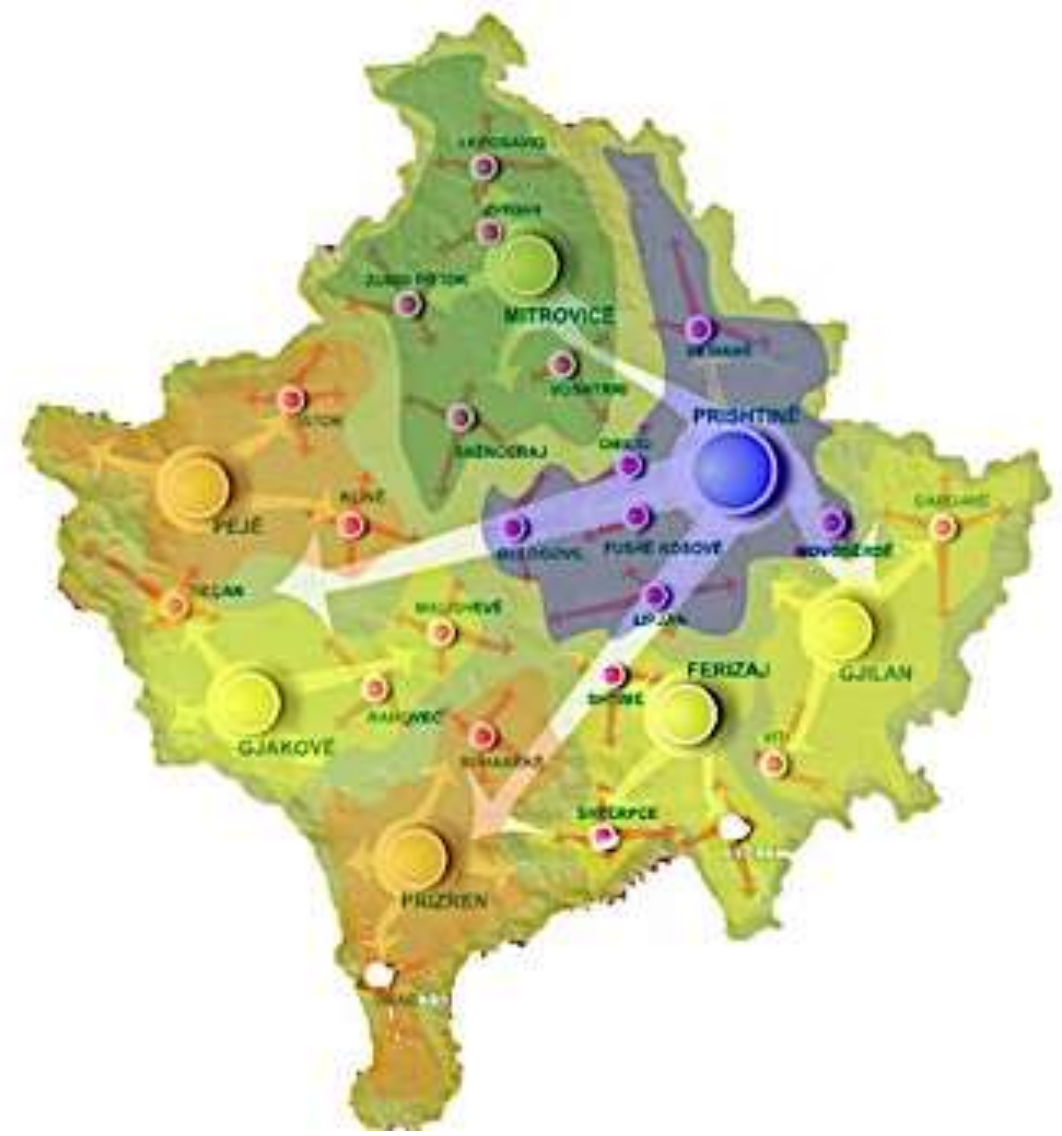

Figura 270. Prishtina në relacion me qendrat tjera

(Burimi): MMPH, 2011. Plani hapësinor i Kosovës

Ndryshimet politike, veçanërisht sociale dhe ekonomike, gjatë tri dekadave të fundit ndikuan që Prishtina të këtë ngecje në procesin e zhvillimit ekonomik dhe urban. Ku realisht, struktura urbane e Prishtinës ka pasur një numër të cikleve të ndryshme të ristrukturimit nën ndikimin e trazirave të ndryshme sociale, kulturore dhe politike. Sfida, të cilat kishin rezultuar me humbje gjithnjë e më shumë nga identiteti kulturor dhe urban i qytetit të planifikuar.

111 CHwB., (2011) Portrete të zonave historike në Kosovë dhe në rajonin e Ballkanit. Prizren. Kosovë 
Në periudhën nga viti 1993, Prishtina ishte e karakterizuar nga tendenca spontane e zhvillimit funksional, me iniciativa private për ndërtimin e objekteve të reja banimore, objekte të përkohshme biznesi. Realisht, këto ishin iniciativa për mbijetesë e cila rezultonte nga situata e përkeqësuar politike dhe sociale etnike. Ndërtimi i shtëpive të jashtë ligjshme si dhe ndërtesave kolektive të vogla, paraqisnin degradim të strukturës urbane, me sens të apatisë për qytetin e planifikuar urban. ${ }^{112}$

Prandaj, zonat urbane, pjesë të zonave urbane dhe rurale janë zhvilluar në hapësira pa infrastrukturë teknike lokale dhe si të tilla kanë krijuar pengesa që ndikuan në evoluimin e mirëfilltë dhe rritjen e një qyteti të shëndetshëm.

Aktualisht, Prishtina përbëhet kryesisht nga tri struktura të ndryshme urbane:

1. Qyteti i Vjetër, zona historike e Prishtinës, e cila mban ende strukturën e rrugëve të vjetra, të cilat për fat të keq, çdo ditë e më shumë zëvendësohen me struktura të reja ndërtimore, e cila rezulton me humbjen e mjedisit historik.

2. Pjesët e qytetit të urbanizuara me struktura komplekse sociale (banimore, kolektive dhe industriale), e cila zanafillën e ka pas Luftës së Dytë Botërore, të cilat janë të përqendruara kryesisht në pjesën qendrore dhe jugore të qytetit.

3. Pjesa e tretë e qytetit, të shpërndara përgjatë periferisë të qytetit, të përbëra nga një strukturë, kombinim i natyrës banimore, kolektive dhe komerciale, e cila përjetoi një bum të pakontrolluar urban në periudhën pas vitit 1999, e cila ishte e iniciuar nga ndërmarrjet private ndërtimore. ${ }^{112}$

Zona në mes të qendrës së qytetit dhe stacionit hekurudhor, e projektuar për funksionim të përzier urban, përbëhet nga struktura të vogla industriale dhe komerciale si strukturave të mëdha komplekse banimore nga ndërtimi i ri aktual. Pjesët jugore dhe lindore të qytetit jan të dominuar nga zona të mëdha të lagjeve të banimit, si Arbëria, Mati dhe lagjja Ulpiana, ndërsa pjesët tjera të qytetit jan të zhvilluara nga banimi i përzier nga shtëpitë individuale dhe objektet banimore kolektive.

Shumë zona që ishin menduar të jenë të lira, (parqet dhe zonat e gjelbra) janë zënë për të ndërtuar çdo lloj funksioni banimor. Kufiri urban është zhdukur praktikisht, sipas disa parashikimeve të zhvillimit të fshatrave fqinje, të cilët ishin të përfshirë në PPU, pothuajse kanë humbur karakterin e tyre rural. Respektivisht, qyteti i Prishtinës i ka digjestu këto hapësira në vete. Rast tjetër studimi është komunikacioni dhe trafiku i makinave në qendrën urbane të qytetit, i cili e kollabon dhe e bën qytetin të pamundur të funksionojë ashtu si duhet.

\footnotetext{
112 Prishtina. (2011). Plani Zhvillimor Strategjik 2004-2020 Prishtinë., http://kk.rksgov.net/prishtina/Municipality/Departments/Urbanizem,Ndertim-dhe-Mbr-Mjedisit/ Urbanizmi/Strategjik.aspx. Janar /2011.
} 


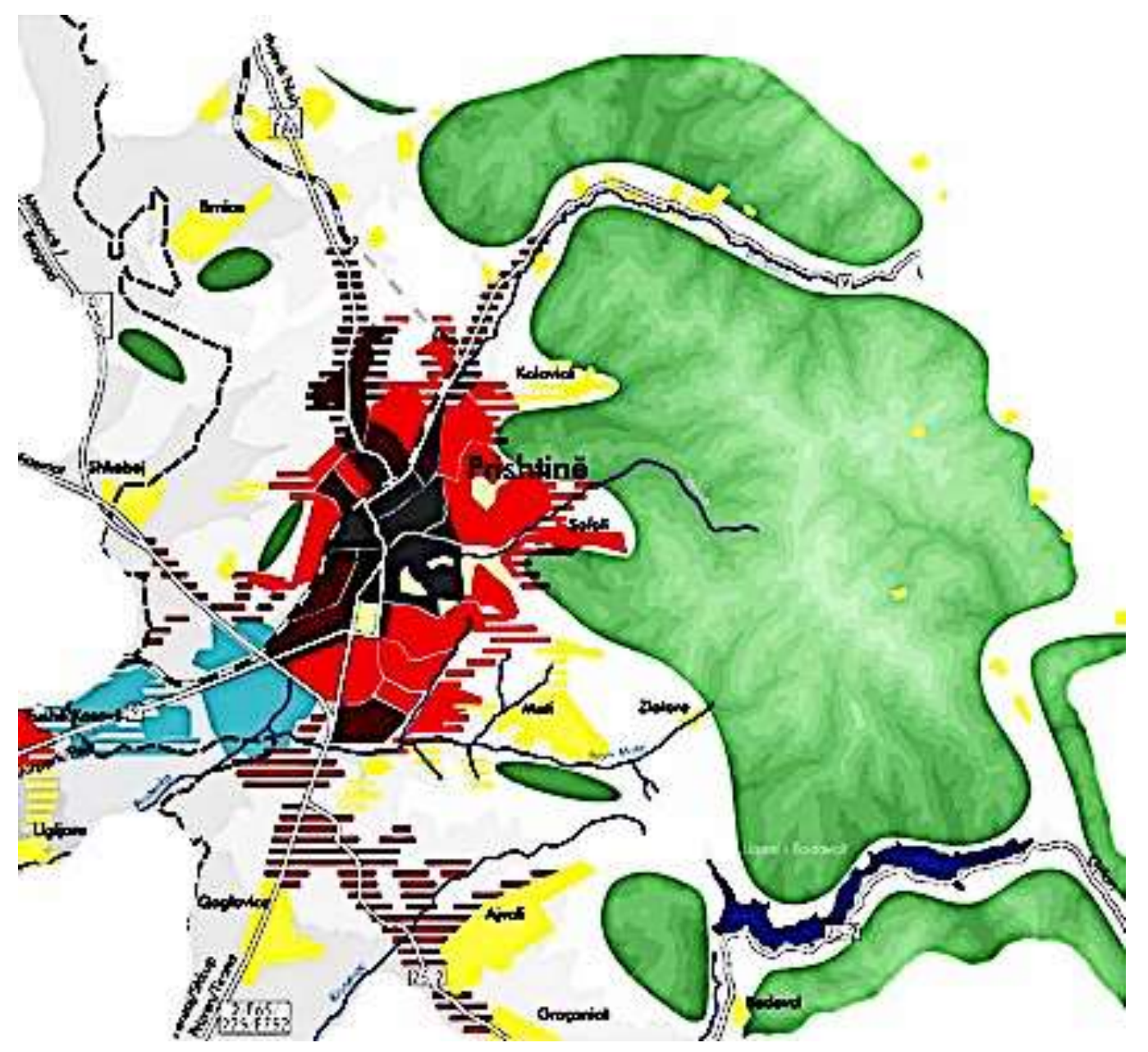

Figura 271. Prishtina, struktura urbane aktuale (Burimi): Komuna e Prishtinës. Zhvillimi strategjik 2004-2020

Nuk ka arsye më të rëndësishme se brengosja në lidhje me mirëqenien e mjedisit dhe shëndetit, e cila pa përkujdesje rezulton me dukuri negative të cilat reflektohen në shëndetin tonë, resurset natyrore, zhvillim ekonomik si dhe në estetikën urbane. Në përgjithësi, qëndrueshmëria urb arkitektonike është e vështirë për t'u zbatuar për shkak të maksimës së qëndrueshmërisë që shpesh e shoqërojnë, sikurse: konflikti i interesave, interesat e tregut, lobimet politike etj, ashtu që ideja për ruajtjen e mjedisit shpesh përfundon si aktivitet entuziastësh dhe natyralistësh. ${ }^{113}$

Sfidat e reja urbane, stimulojnë studime të reja të cilat duhet drejtuar në shfrytëzimin e burimeve intelektuale dhe mbi të gjitha atyre mendore, për të arritur jetësë më të mirë. Arkitektura në aspektin e aktiviteteve të saj kreative merr pjesë në zgjidhje me qasje transdisiplinare të problemeve, e cila faktohet edhe me raste nga historiografia. Respektivisht, se këso sfida ka mund ti zgjidhë edhe më parë në mënyre të përshtatshme dhe të mirë. Mileniumi i ri sjell me vete një mënyrë të re jetese, si rezultat i një sërë faktorësh përcaktues, kryesisht nga zhvillimi i teknologjisë. Kështu, lehtë pa u diktuar nga jeta e ditëpërditshme, arrijmë në një situatë kur duhet pyetur vetën në lidhje me domosdoshmërinë e ripërcaktimit të shumë zakoneve të deri tanishme.

113 Bujar, Bajçinovci. 2012. Integrirani proces projektiranja drustveno stambenih zgrada. UNSA, 2012. 
Retorika e promovuar vazhdimisht se ka arsye të drejtpërdrejta për ruajtjen e natyrës, shpesh janë të mbështetur nga intuita e shumë grupeve, organizatave, koalicionëve dhe individëve. Nga pikëpamja e moralit, janë veprime negative ato të cilat përfshijnë shkatërrimin e natyrës. Intuita dhe praktika e shumë njerëzve reflektojnë faktin se këto veprime dhe aktivitete janë veprime të amoralshme, kurse përgjigjet globale janë që këto aktivitete janë të dëmshme dhe shkatëruese për natyrën dhe njërëzimin.

Megjithatë, nga pikëpamja filozofike, nëse kjo deklaratë është e vërtetë, atëherë teoria e "gjykimit moral" etika normative, duhet të jetë në gjendje për ta përkufizuar më mirë këtë fakt. Andaj, kjo teori deklaron se vetëm qeniet njerëzore shqetësohen moralisht, megjithatë, si shpjegohet natyra e qenieve njerëzore për të shkatëruar. Si pra! Vetë njeriu disi shkakton dëme mjedisore dhe sociale, kurse mandej shqetësohet moralisht... ${ }^{114}$

"Projektimi nuk është duke u bërë për bukurinë. Bukuria vjen nga përzgjedhja, funksioni, afiniteti, integrimi, dashuria ..."

Louis Kahn

Aktualisht, mund të themi se ka një hendek të caktuar midis njohurive akademike dhe praktikës arkitektonike, parimet e strategjive të integruara të projektimit nuk janë duke u zbatuar në mënyrë adekuate në praktikë. Pra, nuk ka një cilësi e integrimit të mirëfilltë profesional, ka vetëm një reflektim të sistemit të përgjithshëm projektues, që i bën këto përpjekje të kufizuara dhe vështirë për tu zbatuar aktualisht në zgjidhjen e problemeve fondamentale. Megjithatë, nuk ka asnjë informacion të konsoliduar se çfarë janë pengesat reale, në zbatimin e procesit të integruar projektues. Ku çalon implementimi i strategjive të qëndrueshme në procesin e projektimit arkitektonik.

Për të ilustruar situatën, do të citoj Migjen Kelmendin: "Disa planifikues të çmendur të qytetit vendosën për ta varrosur një lum jo të vogël, lum të pafajshëm. Dhe kjo për mua do të thotë se ndonjëherë Prishtina nuk është vetëm një qytet, por një qytet që ka sekrete... Në vend se të ndërtohet shtrati i lumit i thjeshtë dhe bankinat me shtigje dhe karika, për fat të keq me pëlqimin e qytetarëve, ata vendosën për të ndërtuar një kolektor nëntokësor. Çfarë absurditeti! ... Kështu që u morr një ndërmarrje e madhe dhe e shtrenjtë që mbulon lumin, u bë një sarkofag nga betonit dhe çeliku, për të mbyllur rrjedhjen e lumit dhe kështu për të zgjidhur një problem tjetër, plehrat dhe mbeturinat që qytetarët $\mathrm{i}$ hedhëshin në lum, sidomos në verë kur qyteti ishte mbështjellë me erë të keqe dhe të tmerrshme. Duke e varrosur lumin, u mendua se një herë e për gjithmonë, do u varroste budallallëku i tyre." 115

Sipas Mittelstraß-it(1995), "konceptin e hulumtimit transdisiplinar e gjenerojnë problemet reale, qëllimi është tek identifikimi dhe zgjidhja e problemeve të dhëna pa $u$ mbështetur në disiplina kryesore të veçanta. "116 Kështu, koncepti transdisiplinar i vërë në lëvizje nga hulumtimi i integruar përmirëson të kuptuarit e sistemit, arrin zgjidhjet më të përshtatshme dhe potencialisht më inovative dhe idetë më të mira të projektimit.

\footnotetext{
114 Samuelsson, L. (2008). The moral status of nature.Umeå, Sweden,: Umeå University.

115 Kelmendi, M.(2000).http://www.leksikon-yu-mitologije.net/read.php?id=1008. Tetor/2011.

116 Hadorn, H. G. et al.(2008). The Handbook of Transdisciplinary Research.Zurich: Springer.,
} 


\subsection{DALLIMET KONCEPTUALE}

Bruder ${ }^{117}$, e përshkruan qasjen e procesit disiplinar: "Qasja ndërdisiplinore kërkon që anëtarët e ekipit të ndajnë rolin dhe duhet të kalojnë kufijtë e disiplinave bazike. Qëllimi kryesor i kësaj qasjeje është të tërheq dhe të integron ekspertizën e anëtarëve të ekipit dhe të jetë në gjendje për të siguruar vlerësim efikas gjithëpërfshirës dhe sistematik. Stili i komunikimit në këtë lloj të ndërveprimit, përfshin vazhdimisht qasjen duke dhënë dhe marrë informata në mesin e të gjithë anëtarëve, në mënyrë të rregullt dhe të planifikuar vazhdimisht. Profesionistë nga disiplina të ndryshme duke hulumtuar, mësojnë dhe punojnë së bashku për të arritur qëllimet e përbashkëta të zgjidhjes, ... Roli i diferencave në disiplina përcaktohet më shumë nga situata e rastit, sesa nga karakteristikat e zakonshme dhe roli i establishuar i disiplinave. Vlerësimi, koordinimi dhe finalizimi zbatohen bashkërisht nga të gjithë anëtarët e ekipit projektues."

Tranzicioni ose transformimi i proceseve ndërdisiplinore, i strategjive të projektimit multidisiplinar të përcaktuara nga premisat e përgjithshme projektuese, kërkojnë një fuzionim kualitativ të ekspertëve. Në këto raste të homogjenizimit profesional përfshihen në tërësi atributet e njohurive shkencore për të zgjidhur një problem të veçantë. Respektivisht, kërkohet një vetëdijësim në epistemologji nga ekipi projektues, kur kemi të bëjmë me zgjidhje të problemeve fondamentale projektuese.

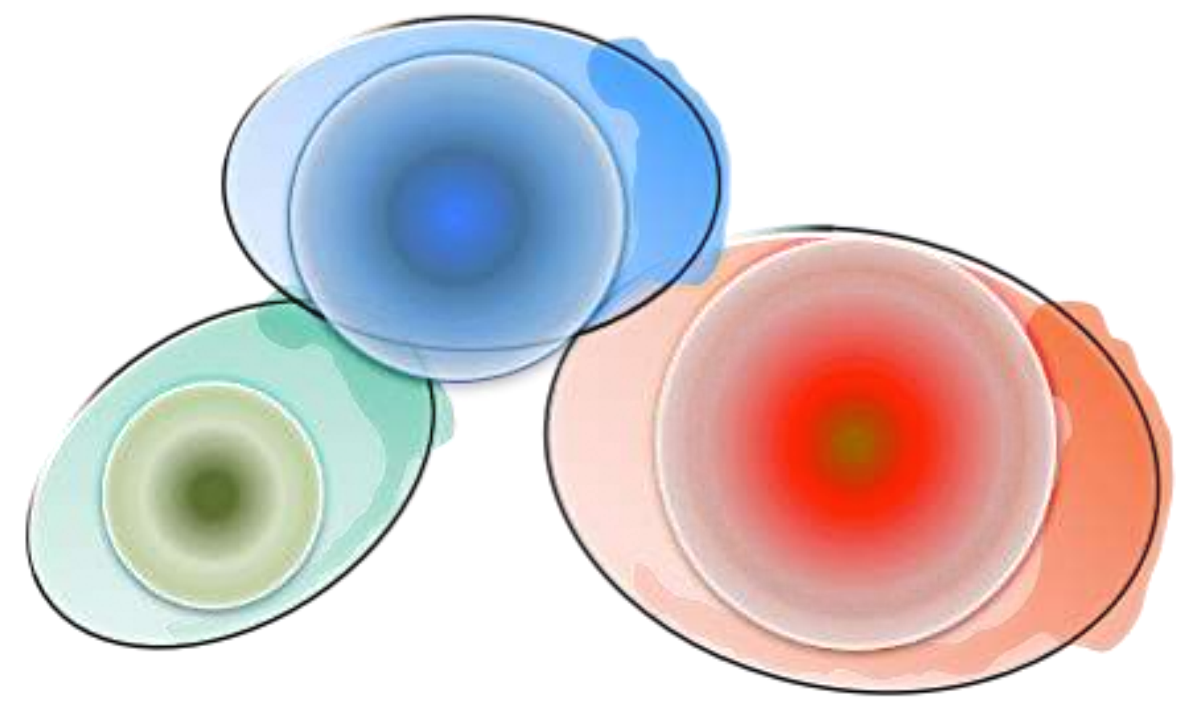

Figura 272. Transformimi i sistemeve, e veçanta deri të e përgjithshmja (Burimi): Bujar Bajçinovci, 2012.

Logjika e aplikimit të aftësive profesionale dhe e njohurive të nevojshme në procesin e projektimit janë iterimet e kërkuara dhe të preferuara deri në zgjidhjen përfundimtare e të knaqshme të problemit specifik.

117 Ibrahim, R., Fruchter,. R., Sharif, R. (2007). International Journal of Architectural Research. Framework for a cross-border transdisciplinary design studio education., fq. 90. 


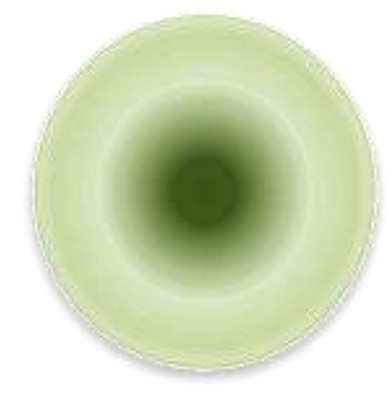

a.) Procesi Disiplinar

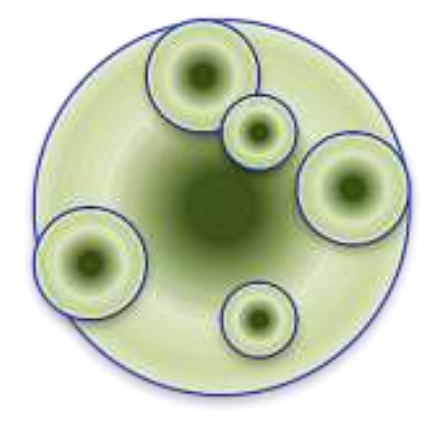

b.) Procesi Interdisiplinar

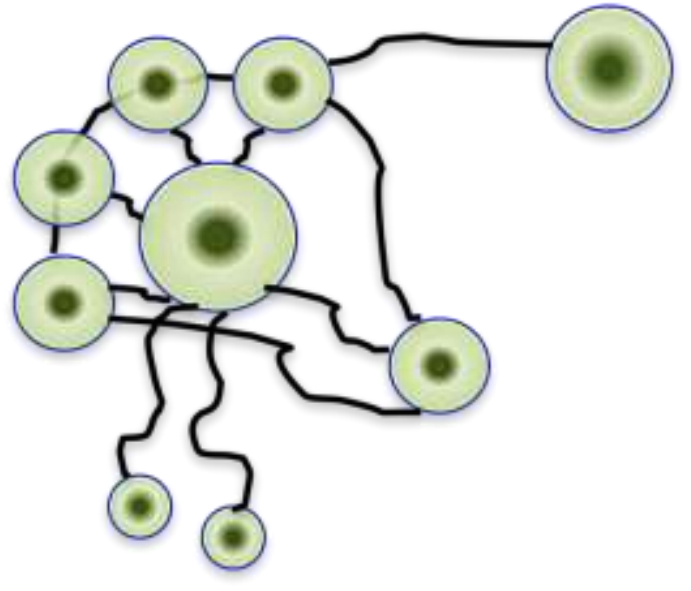

c.) Procesi Multidisiplinar

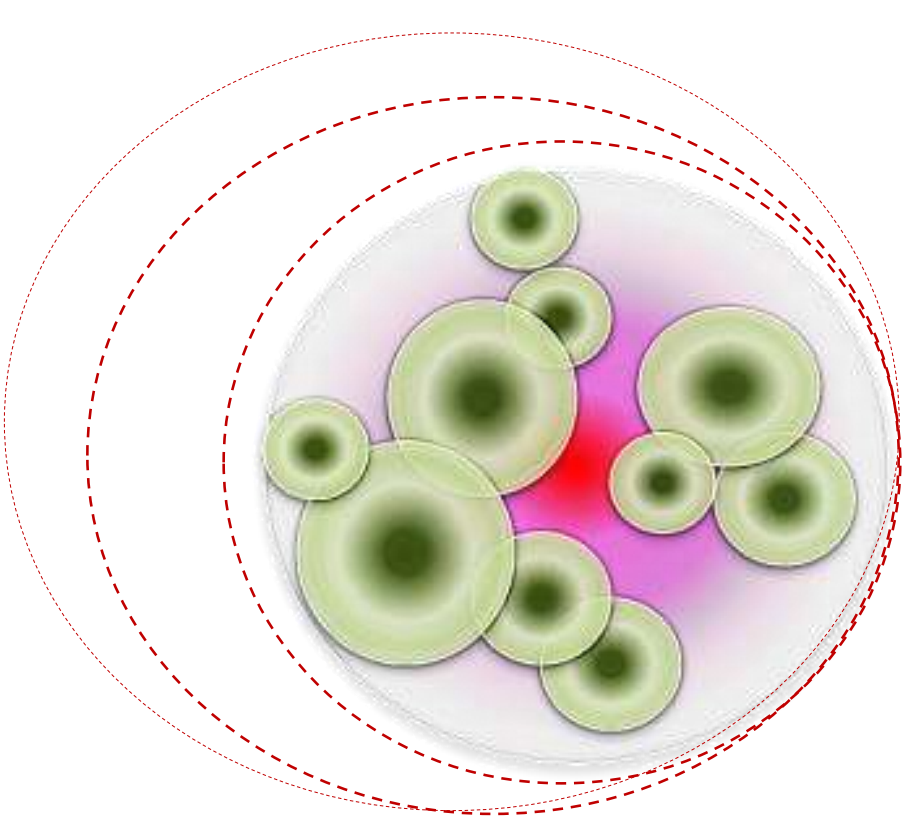

d.) Procesi Transdisiplinar

Përtej kufijve të zakonshëm dhe konvencional të disiplinave, me informata të reja që nuk përfshihen ekskluzivisht në asnjë nga disiplinat e përfshira në proces, pa barriera konvencionale lineare.

Figura 273. Sistemet disiplinare. Transformimi i sistemeve të hulumtimit.

(Burimi): Bujar Bajçinovci, 2012.

Megjithatë, mund të konkludohet konceptualisht se moszbatimi i parimeve të integruara në projektim jan pasojë e injorancës dhe e mungesës së njohurive të ngushta subspecialistike, arkitektët duhet patjetër të kanë njohuri shtesë suplementare të fushës së zgjedhur për hulumtim. 
Është e kuptueshme që të gjithë arkitektët nuk mund të kuptojnë problematikën e fushave të ndryshme specialistike, mirëpo, procesi profesional projektues fillon më idetë e para kreative në favor të zgjidhjes së problemit të caktuar, duke u pasuar me fazën e zhvillimit të skemës së dizajnit, pastaj bëhet evaluimi nëse këto ide janë pro dhe në favor të solucionit projektues. Praktika aktuale projektuese aktualisht definohet me aktivitete sikurse: projektuesit të ndryshëm në projekt do të takohen periodikisht për të siguruar që vendimet e tyre individuale nuk janë në konflikt, mirpo pjesën më të madhe të kohës personeli do të kujdeset që të mos kryqëzohen problemet me të tjerët.

Në procesin e integruar, nga ana tjetër, procesi kreativ vepron si një sistem kolektiv dhe zhvillohet në të gjitha aspektet e dizajnit. Procesi i dizajni atëherë është organik, evolutiv, me pjesëmarrje të plotë nga çdo ekspert. Respektivisht, do të paraqiten një mori idesh, të cilat vazhdimisht do të sillen rreth e rrotull si zgjidhje e mundshme. Kjo lloj përsëritje apo iterim zakonisht kërkon mishërim të secilës fushë të ekspertizës. Në varësi të madhësisë dhe kompleksitetit të projektit, mund të përfshihet edhe investitori, qiramarrësit e ardhshëm, menaxherët e ndërtimit, dhe një gamë e gjerë e këshilltarëve të veçantë. E gjithë kjo sublimohet me një projekt, më zgjidhjen më të mirë të mundshme, veçanërisht nëse idetë janë krijuar kur pjesëmarrësit kalojnë kufijtë e të menduarit konvencional dhe tradicional.

\subsection{BANIMI - ATRIBUTET EKZISTUESE}

Ulpiana, struktura urbane e nënsistemit të Prishtinës, me fat të njëjtë të zhvillimit urban sikurse edhe pjesa tjetër e qytetit, me apati funksionale arkitektonike. Rritja e shpejtë e vendbanimeve në çdo aspekt, migrimi njerëzor, kaos i ndërtimit, i transportit. Hezitimi i autoriteteve komunale për të vënë nën kontroll, duke veçuar natyrën e të gjitha këtyre ngjarjeve, Ulpiana reflektohet me probleme të shumta urbane, si më poshtë:

1. Trafiku

2. Mirëmbajtja e banesave kolektive

3. Reduktimet e energjisë elektrike dhe pasojat

4. Mungesa dhe reduktimet e ujit dhe pasojat

5. Mungesa e sipërfaqeve të gjelbra të kultivuara

Një nga problemet e vazhdueshme që përballet Prishtina e përditshme, është trafiku automobilistik. Ky është një rezultat i rritjes së numrit të automjeteve që hyjnë në kryeqytet çdo ditë. Sipas statistikave, rritja e numrit të makinave, kamionëve, autobusëve dhe furgonëve ka arritur numrin prej rreth 282000 mjete motorike dhe jo motorike të regjistruara në vitin 2013 në Kosovë, ose 16.76\% më shumë se në vitin 2012, "Agjencia e Statistikave të Kosovës (ASK)". Kjo është rreth 200\% rritje në normën e para vitit 1999. Një numër i madh i automjeteve shpeshherë shkakton kaos në hyrje të Prishtinës. Rrëmujë e madhe ndodh sidomos në mëngjes, ku shifen linjat e qarta të mëdha të makinave në pritje, si dhe në mbrëmje kur popullata kthehet në shtëpi. Bllokimi i madh prek veçanërisht "rrethet" në Veternik dhe në Ulpianë, gjersa bllokom të ngjashëm i madh ndodhë në rrugët e kryqit tek "semaforët e parë" vizavi katedralës dhe tek kryqëzimi afër xhamisë së Llapit. 
Transporti është i lidhur ngushtë dhe drejtëpërdrejtë me mungesën e hapësirës për parkim. Mungesa e parkingjeve publike i detyron qytetarët të vazhdojnë të parkojnë makinat e tyre kryesisht në trotuar, të cilat shkaktojnë jo vetëm kaos urban, por shpesh rezultojnë me përjetime frustruese nga këmbësorët për të lëvizur lirisht dhe natyrshëm.

Ndërtesat kolektive në Ulpianë nuk mirëmbahen nga askush në mënyrë të organizuar ligjërisht. Nuk ka arsyetime valide për mosfunksionim e organeve të komunës ose së paku në rregullimin e akteve nënligjore të cilët do e rregullonin këtë çështje. Kështu, nga aspekti historiografik mbijetimi i shoqërisë Kosovare para dhe pas luftës, krijojë një vakum institucional me pasoja ku disa institucione vitale pushuan të jenë funksionale në jetën normale të qytetarëve, sidomos në zonat strikt të banimit. Nga aspekti social, mund të ketë sens stagnimi i zhvillimit të qytetit, i cili rishtazi përjetojë konflikt të armatosur me pasoja të rënda shoqërore. Sidoqoftë, objektet që ishin ndërtuar para viteve të ' 90 , në këto apartamente kishte mungesë funksionaliteti në raport me numrin e anëtarëve të familjes, respektivisht, kishte mungesë esenciale në raport sipërfaqe/banor.

Qyteti i Prishtinës nuk ka hapësirë të mjaftueshme të gjelbër, dhe ka mangësi të vërtetë në bimësi, resurse të ujit dhe ajrit të pastër. Në vitet e fundit ka disa tendenca modeste për të zbutur disi këto dukuri, me disa ide nga komuna se disa hapësira të gjelbra duhet funksionalizuar në Dardani, në Ulpianë etj.

\subsection{GENESIS - ULPIANA}

Vendbanimet e "reja" në Prishtinë janë ndërtuar në periudhën nga vitet 1960, paraprakisht, këto zona janë të referuara si "Prishtina e re" asokohe. Karakteristikat kryesore të veprimit të ri urban ishin të strukturuara dhe të organizuara në ndërtimin e zonave për banim, si një prirje e atëhershme e qyteteve të mëdha të Jugosllavisë. Përveç në zonat e banuara, në të gjithë strukturën urbane ishin inkorporuar edhe struktura të rëndësishme sociale të vendosura në qytet. Për Prishtinën, ishte shumë e rëndësishme që të ketë një hapësirë për kampusin universitar, bibliotekën kombëtare universitare, mensën e studentëve etj. Pastaj, të dhënat demografike dhe urbane treguan se gati gjysma e popullsisë jetonte në Prishtinë (46.71\%). Numri mesatar i anëtarëve të familjes ishte 4.63, që do të thotë se ajo ishte më pak se numri i anëtarëve, në krahasim me mesataren e qytetit $5,27.110$

Këto veçori u shpjeguan atëherë si pasojë e sistemit social, gjendjes ekonomike të popullsisë dhe si rezultat i orientuar nga ndërtimi i banesave "sociale". Situata me infrastrukturën ishte si vijon: $100 \%$ të kyçur në energji elektrike, $86,80 \%$ duke përdorur ujë nga ujësjellësi i qytetit, $82,70 \%$ ishin të lidhur me sistemin e kanalizimit të qytetit, ndërsa $47.00 \%$ ishin të kyçur me ngrohjen qendrore të qytetit.

\subsubsection{Banimi - Rrokaqiejt}

Struktura urbane e Ulpianës atëherë rrezatonte jetë të shëndetshme, me të gjitha aktivitetet dhe program të plotë urban për një lagje të projektuar rreth të 70-tave si zgjidhje moderne. E vetmja Ulpiana asokohe kishte dhe ende e ka, zonën e projektuar e gjelbërimit, çerdhe të fëmijëve, shkollë fillore moderne dhe blloqet e banimit në strukturën urbane. 
Megjithatë, ajo që ndodhi ishte në kundërshtim me parimet e planit urbanistik, të importohen zgjidhje "me çantë në dorë", projekte nga një qytet i ish Jugosllavisë dhe në këtë mënyrë u zbatuan rrokaqiej të importuar. Andaj, u paraqitën konflikte urbano arkitektonike në implementimin e këtyre ndërtesave në mjedisin Kosovar:

1. Harmonizimi urban në mjedis. Projektet për ndërtimin e rrokaqiejve ishin projektuar për një kontekst tjetër, vendndodhje, klimë, mentalitet urban dhe strukturë sociale tjetër të familjes. Për shkak të vendndodhjes së gjerë dhe lartësisë mbi nivelin e tokës, ishin ndërtuar vetëm si monolite duke theksuar trajtën dhe lartësinë.

2. Infrastruktura e sistemit. Ndërtesat ishin menduar për sisteme të tjera funksionale të infrastrukturës, koha kishte shkuar, cila ishte arsyeja pse instalimet elektrike ishin realizuar nga dur aluminiumi dhe jo nga kabllo bakri, banorët asnjëherë nuk kanë qenë të kënaqur, gjithmonë ka pasur ngarkesa në tension. Uji ishte një fenomen tjetër, derisa në fshatra nuk ka pasur kufizime të ujit, apo kanë qenë të panjohura, banorët e rrokaqiejve kanë vuajtur për ujë, veçanërisht ato në katet e sipërme. Objekt i importuar, ndoshta për mjedisin e vet origjinal, ishte mbështetur nga pompat, por në një kontekst tjetër dhe në një mjedis kulturor urban tjetër kurrë nuk ka funksionuar si duhet. Ashensorët nuk ishin funksional si duhet dhe ka pasur disa aksidente, mosfunksionim dhe plagosje serioze.

3. Projektimi i ndërtesave, të destinuara për strukturën familjes Kosovare, ishin bërë në kurriz të sipërfaqeve improvizuese funksionale, duke mos marrë parasysh se një familje mesatare nga Kosova ka më shumë anëtarë në strukturën e saj, se sa mesatarja e ishJugosllavisë, si të akomodoheshin 6 anëtar të familjes në banesën e paraparë për 3 persona!

Zona neto e përdorshme për banor ishte përgjysmuar, e cila rezultoi në një reduktim drastik të cilësisë së banimit. Orientimi ishte tipik për rrokaqiejt të trajtës katrore, ku nuk mund ti keni të gjitha, diçka duhej të humbej nga orientimi. Fenomeni ishte se shkallët ishte me përmasa të ngushta, (rrokaqielli $\mathrm{P}+12-14$ ), ishin ndërtuar që të janë transparente me basamak jo të plotë, duke lënë gjithmonë ndjenjën e pasigurisë dhe të frikës nga ndërtimi jo i sigurtë, duke shkaktuar fobi tek banorët nga përmasat vitale. Zonat funksionale të banesës ishin të imëta në madhësi dhe të projektuara për një strukturë të tjetër të familjes, andaj, edhe duhej të improvizohej, kështu kuzhina për shembull, një hapësirë shumë modeste e cila në vetvete nuk përmbushte funksionin (duke ditur se Kosovarët gatuajnë tri vakte në ditë), nevoja e transformonte kuzhinën natën si një dhomë gjumi për një person të vetëm, dhe gjatë ditës si një zonë gatimi, me të gjitha llojet e erërave të gatimit. Funksioni i bërthamës strukturore përveç ashensorëve dhe shkallëve, kishte edhe një kanal vertikale, ishte diçka moderne?! Kanal për hedhje të mbeturinave, i cili nuk funksiononte, kryesisht për shkak të mirëmbajtjes dhe pjesërisht për shkak të kulturës së banimit.

4. Teknologjia dhe materialet. Objektet janë realizuar plotësisht me beton arme, si muret e brendshme të apartamenteve dhe muret e jashtme, u finalizuan me lesh qelqi dhe llamarinë të valëzuar në fasadë. Me kalimin e kohës, hapësira në mes të betonit dhe të llamarinës ishte bërë shtëpi për një shumëllojshmëri të kërpudhave, mykut dhe organizmave të tjerë të vogla, duke krijuar kështu kushtet johigjienike. E gjithë zhurma e mundshme ishte transmetuar nga ndërtimi me beton, objekti i tërë i realizuar nga betoni dukej i ftohtë. 
Materiali nga llamarina i cili u shkatërrua nga era edhe përfundimisht shumica ra, u bë një kërcënim i drejtpërdrejtë për jetën, me një erë pak më të fortë, fletat e llamarinës (raste të ndodhura) do të bien direkt në fushat e sportit apo piacetat për lojëra nga fëmijët, të cilat ndodhen afër, apo kërcenim me jetë ndaj kalimtarëve të rastit, në rast të fluturimit të pllakave të llamarinës të mprehta sikur brisku i rrojës.

5. Komfori. Nuk ka ndodhur kjo ndjenjë dhe nuk ndodhë as tani. Situata në të cilën një e treta e ditës, ose gjysma e natës nuk ka ujë, energji elektrike, ashensorët nuk punojnë ose punojnë kohë pas kohe, kur jeni të rrethuar tërësisht me beton, nuk jetë shumë për të folur në lidhje me komforin e brendshëm. Hulumtimet e fundit shkencore në lidhje me rrezatimet nga betoni adresojnë dhimbje reumatike si dhe cenojnë cilësinë e ajrit të brendshëm. "Përmbajtja e ujit në përzierjet standarde të betoneve mund të kërcënojnë cilësinë e ajrit të brendshëm, shfaqje myku dhe dëmtimit të mushkërive nga pluhuri i silikonit." Për më tepër, i gjithë objektit është mbuluar me fletë metalike, nga aspekti i rrezatimit elektromagnetik nuk është i përshtatshëm, veçanërisht nëse në çati keni të instaluar antena të telefonisë celulare apo më shumë sosh, siç është rasti.

6. Performanca e ndërtesave. Të gjitha objektet të realizuara nga betoni marrin kohë për tu ngrohur, si në mot të ftohët po ashtu duhet kohë për tu ftohur në mot të nxehtë. Struktura nga betoni funksion si një furrë termike, në verë gjithë ditën akumulon ngrohje, natën rrezaton, në këto rrethana nuk bëhet fjalë për efiçiencë të energjisë. Komfori është i kërcënuar në disa mënyra, siç u numëruan më sipër.

7. Barrierat dhe specifikat. Jo efikasiteti në zbatimin e qëndrueshmërisë dhe efikasitetit në nivele të ndryshme të atributeve të banimit, duke filluar nga programimi, planifikimi, ndërtimi dhe eksploatimi, janë identifikuar si barriera të veçanta ose pengesa aktuale të banesave si dhe mungesa në vizion të mundshëm për zhvillimin e procesit evolutiv të projektimit.

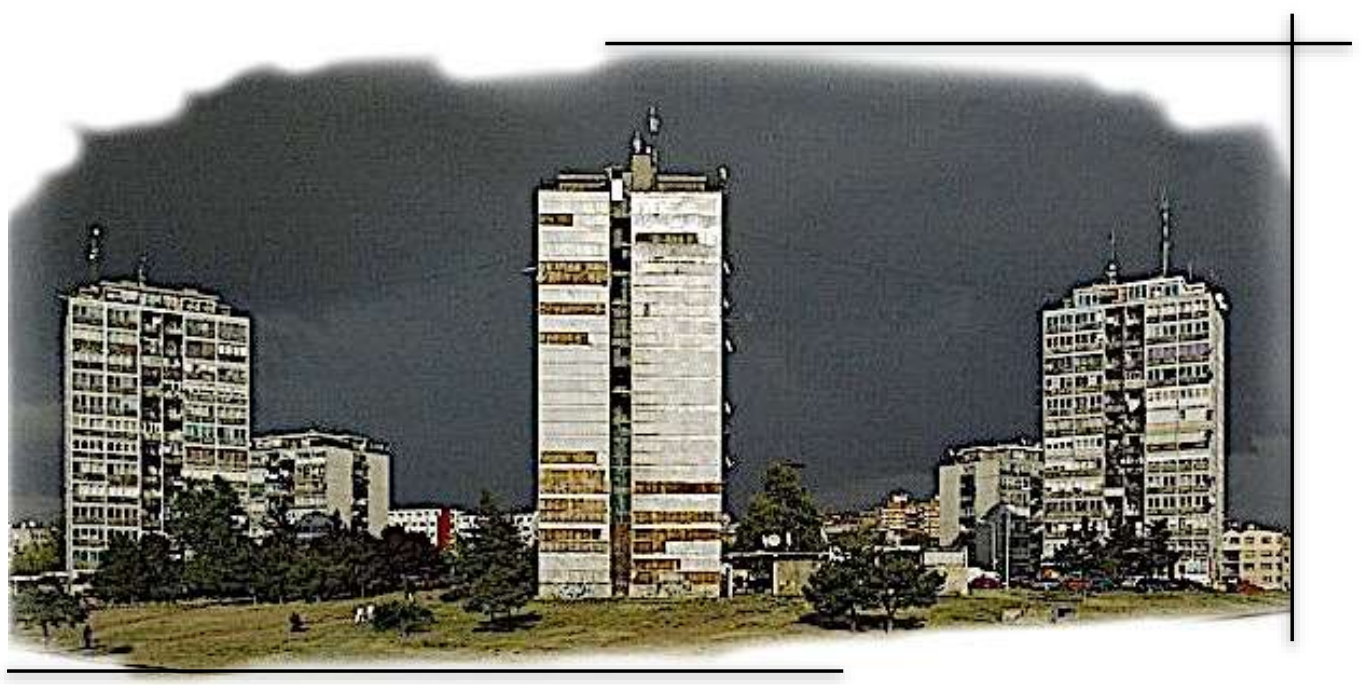

Figura 274. Rrokaqiejt në Ulpianë

(Burimi): Lowlso, facebook, 2011. 


\subsubsection{Rrokaqiejt ndryshe}

Ulpiana ishte imagjinuar krejtësisht ndryshe, për shkak se vendndodhja vetë ishte në lartësi, nga aspekti i trajtës morfologjike të qytetit të Prishtinës, lartësia ishte një sfidë për arkitektët dhe planifikuesit urban, ndoshta më shumë të intriguar nga aspekti vizual pejsazhor me rrethinën. Silueta e këtij lokaliteti ishte sfiduese, mbaj mend ligjëratat e prof. Bashkim Fehmiut në lëndën e urbanizmit I, gjatë kësaj ligjëratë profesori përmendi një arkitekturë bashkëkohore futuristike dhe me parime të arkitekturës së qëndrueshme. Kështu, sipas këtij prezantimi, rrokaqiejt ishin menduar të jenë të projektuar si monolite të kopshteve të varura më trajtë kaskadore apo të shkallëzuar drejt pikës referente të drejtuar nga sheshi i Ulpianës (fontana), me komunikim të dukshëm vertikal ose ashensorë vizual të dukshëm nga jashtë, gjithashtu me ndriçim natyror të mundësuar nga tarracat kaskadore, dhe ventilim të tërthortë natyror.

Struktura dhe organizimi i apartamenteve ishte koordinuar me strukturën shoqërore të familjes mesatare të Kosovës. Në kontekstin e kulturës urbane dhe shprehitë e banimit, disa elemente ishin thjeshtuar, reduktuar ose të mënjanuara. E gjithë kjo me qëllim të thjeshtëzimit dhe lehtësisë së shërbimeve të mirëmbajtjes dhe të infrastrukturës.

Kaskadat teracore me bimësi të inkorporuar vegjetative, sipas idesë fillestare projektuese në të njëjtën kohë përmirësonin pamjen e mikro lokacionit, fasadave dhe siluetës së përgjithshme duke krijuar mjedis natyror freskues me shumë oksigjen, hijezim dhe fllad për banorët e apartamenteve.

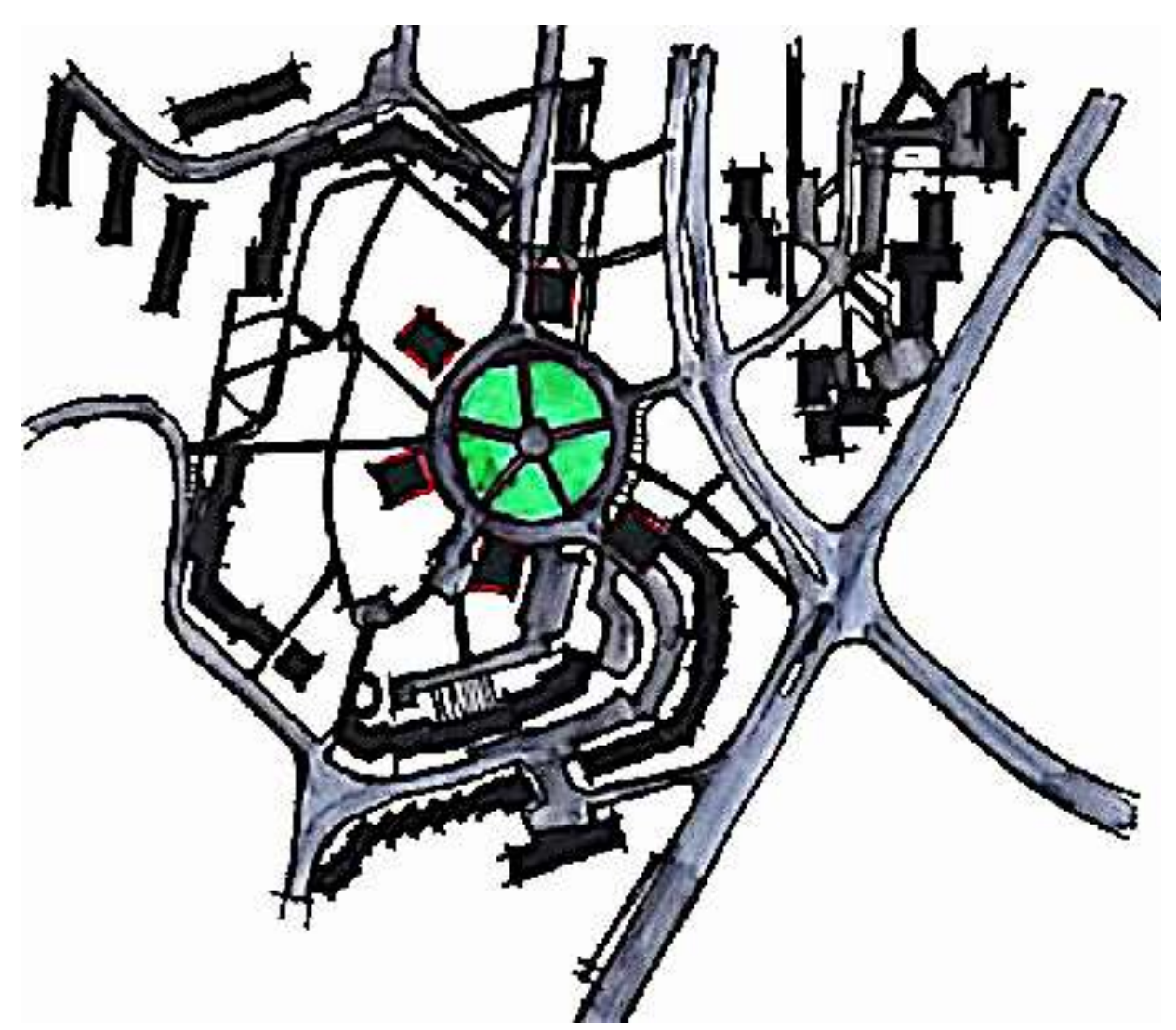

Figura 275. Struktura urbane, Ulpianë (Burimi): Vizatim, Bujar Bajçinovci, 2012. 


\subsubsection{Planet rregullative}

Prishtina me të gjitha atributet e saj kalimtare të një qytet pas konfliktit, duke shtuar se gjendja sociale, kultura, zakonet dhe nevojat reale të popullsisë për një jetë normale, kishin kërkesa themelore për një zhvillim mtë mirtëfilltë. Mirpo, pas luftës, fillimi i mijëvjeçarit të tretë nuk kishte përgjigje për shumë çështje të rëndësishme të adresuara nga qytetarët, një gjë ishtë e sigurtë se jeta vazhdonte me kërkesat dhe nevojat e shoqërisë për funksionimin normal.

Është normale dhe e natyrshme të pritet që pas një konflikti, të mbijetuarit me më shumë entuziazëm marshojnë për të ecur përpara me të gjitha nevojat e tyre, kjo është ajo dukuri që ndodhi me pothuajse të gjitha kombet, dhe kështu ndodhi edhe me ne. Çfarë u prezantua nga komuna si plane strategjike regullative?

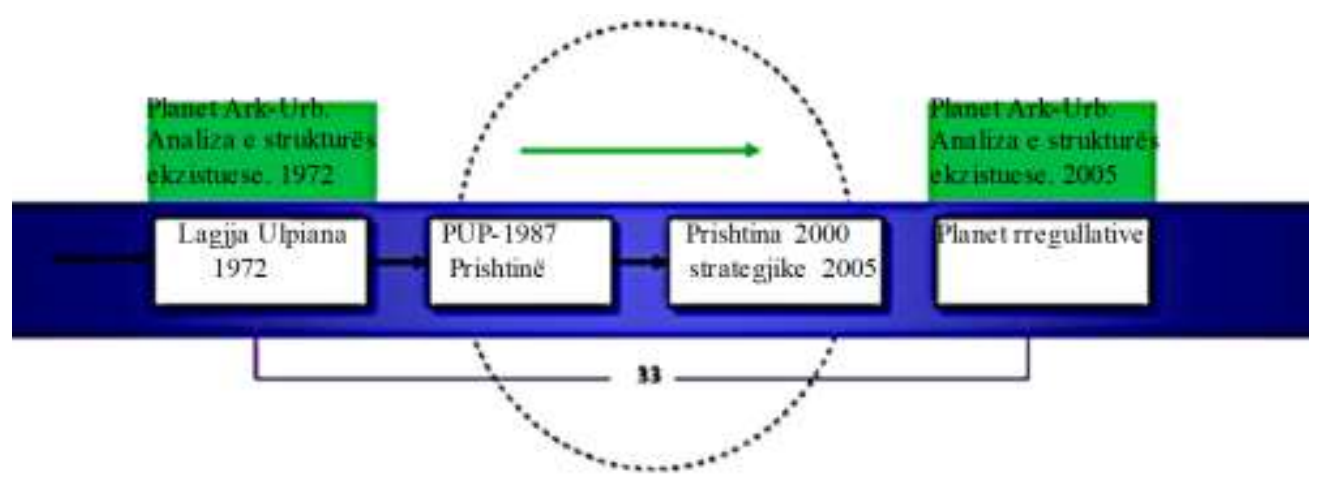

Figura 276. Timeline, zhvillimi urban dhe refleksionet zhvillimore në dekada (Burimi): Bujar Bajçinovci, 2012.

Edhe sot e kësaj dite nuk e kam të qartë se çfarë kishte këtu strategjike, me përjashtim të improvizimeve infantile, është për tu çuditur se si kjo vërtetë u aprovua si plan rregullativ strategjik, dhe u miratua nga komuna, në epokën e globalizimit, teknologjisë dhe vetëdijësimit global.

\subsection{ZHVILLIMI I PRISHTINËS SË RE}

Për hartimin e një plani strategjik urban, i cili përfshin periudhën kohore 2004-2020. Në zonën urbane të Prishtinës, pritjet janë në drejtim të cilësisë, zgjerimit të zonave të reja të banimit, zonave industriale rurale, gjithashtu pritën të realizohen dhe unazat apo qarkoret rreth qytetit që do kanë një perimetër prej më shumë se 40 km'. Po ashtu do të funksionalizohet rrjeti hekurudhor si një sistem i linjave hekurudhore të lidhura me aeroportin "Adem Jashari“" në Sllatinë, Fushë Kosovën e kështu me radhë në tërsi të Republikës së Kosovës.. 


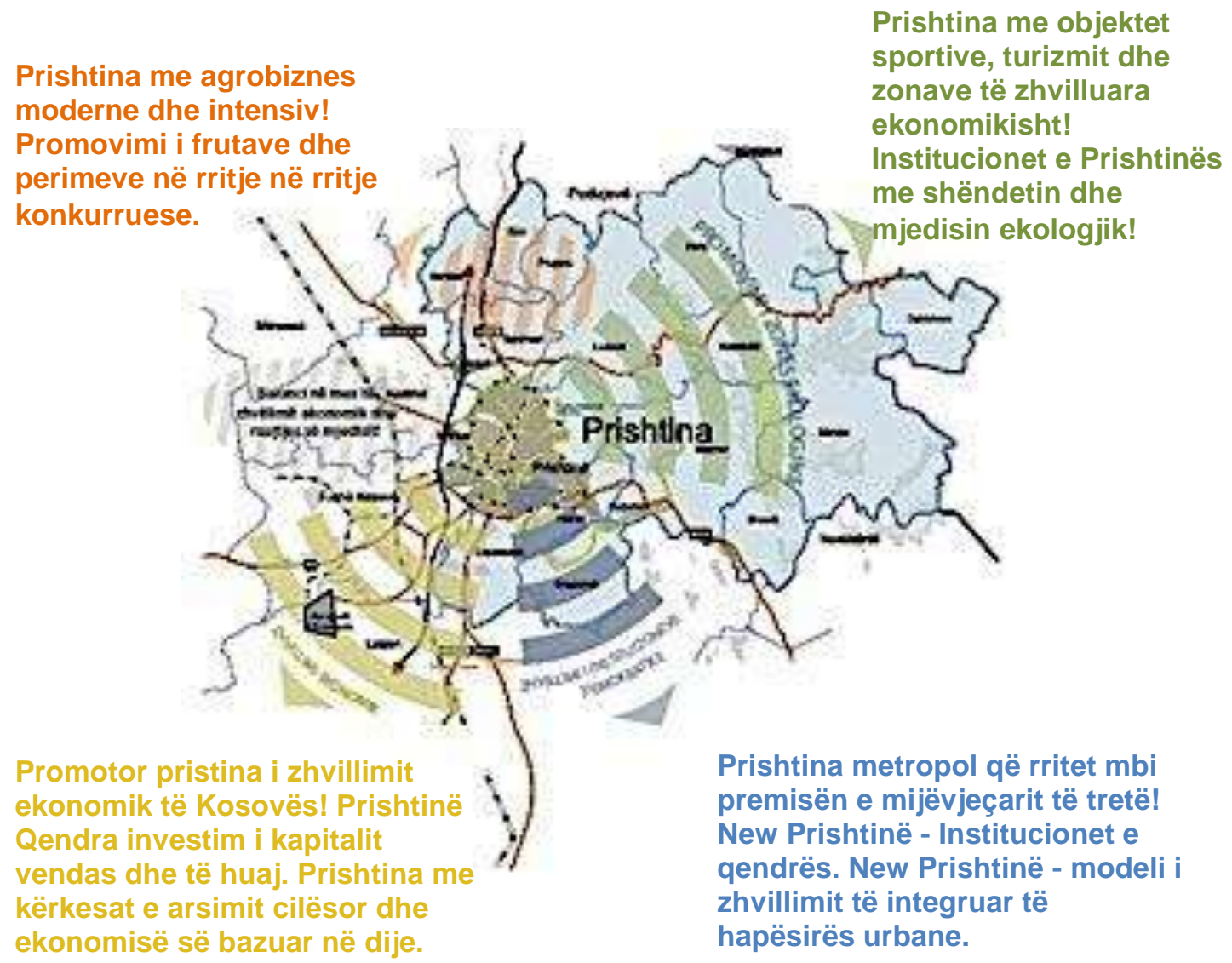

Figura 277. Prishtina, qytet metropolitan

(Burimi): Dr. Isa Mustafa. Programi dhe vizioni, 2010.

\subsection{KONCEPTI I STRUKTURËS SË RE URBANE}

Koncepti i strukturës së re urbane është parashikuar të jetë zhvillimi i Prishtinës drejtuar drejt pjesëve juglindore, konceptualisht nga liqeni i Badovcit. Është e kuptueshme se drejtimi i strukturave të reja urbane për të përmbushur të gjitha kërkesat e ardhshme të zhvillimit, duhet ndërlidhur në mënyrë efektive me pjesën "e vjetër" të qytetit. Kjo zonë do të përcaktojë ndërtimin urban me ndërtesa të përziera banimi, duke përfshirë edhe ndërtesat e reja të Qeverisë, Presidencës, Ministrisë së Drejtësisë, fshatrave ndërkombëtare (Mustafa, I. 2010). Prishtina e Re, arkitekti Uwe Volkov nga Instituti për Hulumtime Zhvillimore, plani i zhvilluar për Prishtinën me një popullsi prej 800 mijë banorë, aq sa janë projeksionet për Prishtinën deri në vitin 2020, me planin e ri për Prishtinën, duhet pritur zona gjelbërimi të qytetit si në ato pjesë rurale, veçanërisht në zonat malore, në Gërmi dhe në pjesën jugore të qytetit.

"Kemi parashikuar hapjen e shkollave të reja në të gjithë territorin e Prishtinës, spitalet e qytetit, spitalet kombëtare, dhe presim që furnizimi me ujë të jetë i pandërprerë dhe nuk do të këtë ndërprerje të energjisë." (Volkov, U. 2006). Andaj kështu, Prishtina urbane e 
re do ketë pjesën kryesore të institucioneve të Kosovës të ndërtuara rishtas, duke përfshirë: ndërtesën e qeverisë, presidencën, departamenti e drejtësisë dhe funksionet e tjera për realizimin e aktiviteteve terciare, në funksionim normal të qytetit." Të gjitha këto premtime sipas planeve strategjike të porositura nga drejtoria e urbanizmit dhe planifikimit hapësinor të komunës së Prishtinës, të prezantuara në vitin 2006.

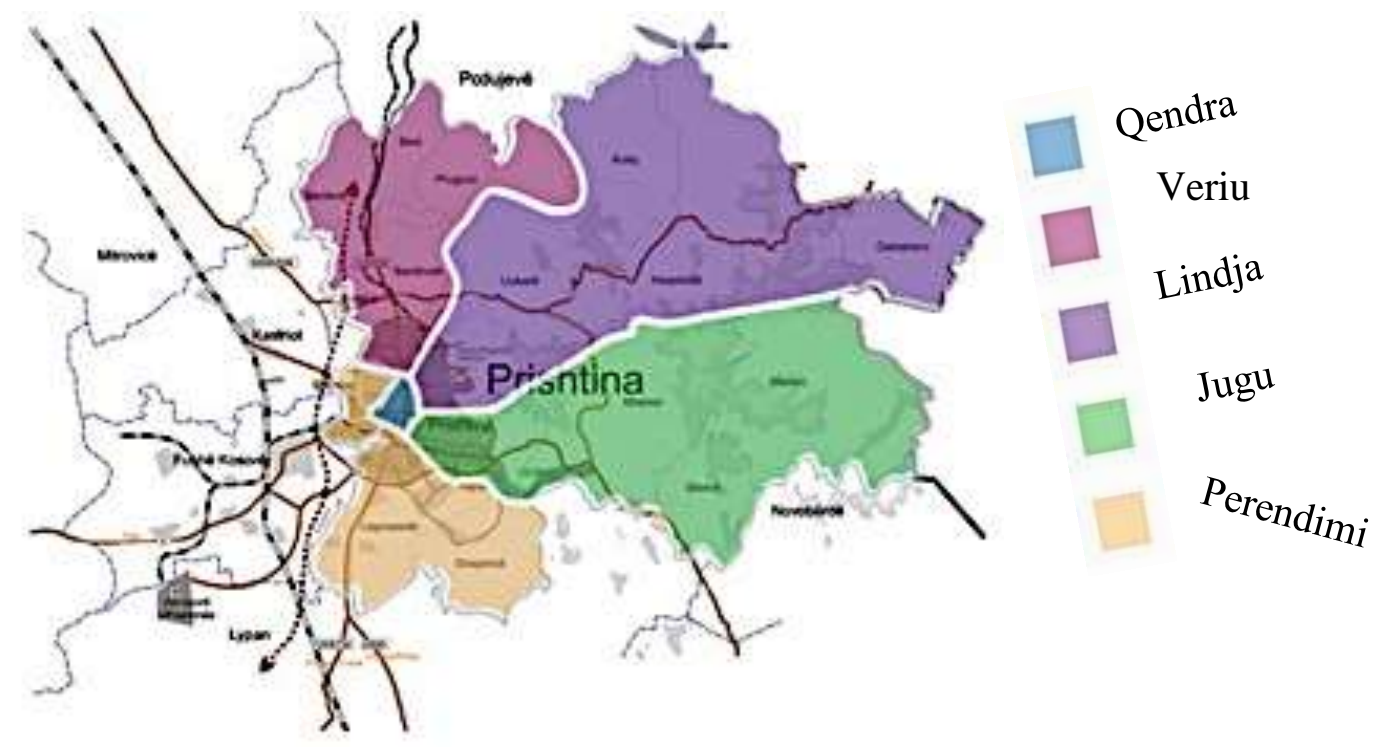

Figura 278. Tërësia urbane, me pesë zona rregullative

(Burimi): Dr. Isa Mustafa. Programi dhe vizioni, 2010.

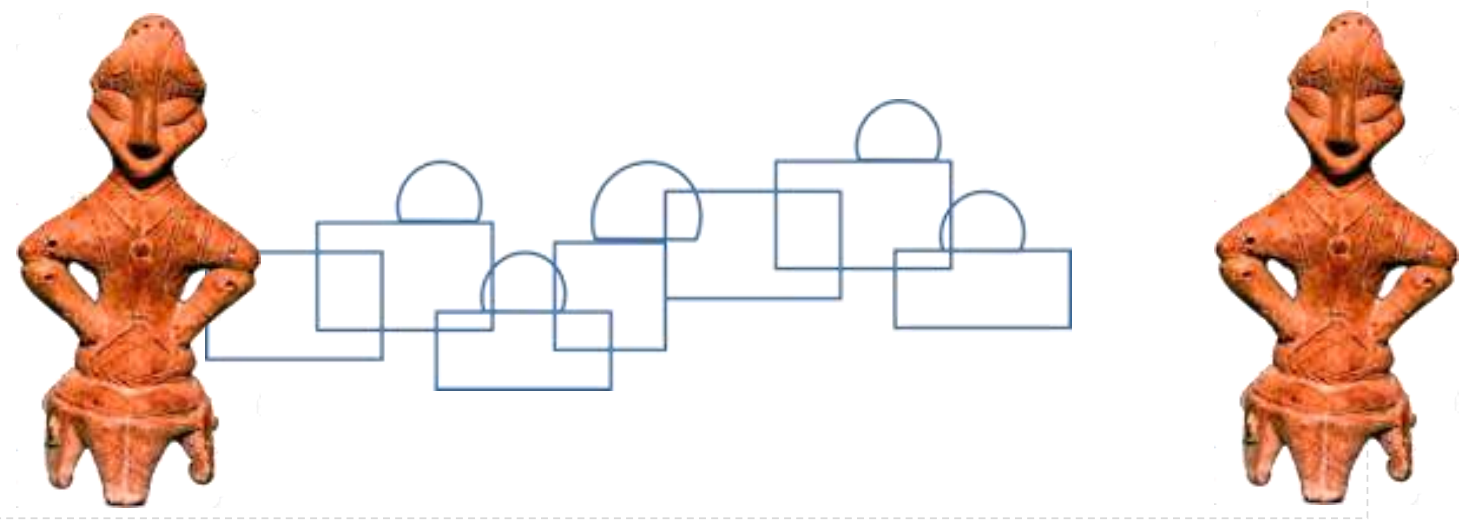




\section{KAPITULLI XV}

\section{PROCESI I INTEGRUAR I PROJEKTIMIT}

\subsection{PROCESI I INTEGRUAR I PROJEKTIMIT}

$\ddot{\mathrm{E}}$ shtë e njohur gjerësisht se ndërtesat përdorin të paktën gjysmën e energjisë totale të prodhuar në botë për ngrohje, ndriçim, ajër të kondicionuar, ftohje dhe për industrinë ndërtimore. Përqindja më e madhe e këtij shpenzimi është e lidhur direkt me projektimin arkitektonik dhe aplikimin e parimeve të qëndrueshëm të projektimit për të bashkëvepruar me natyrën. Dizajni arkitektonik është duke u përballur me sfida të mëdha si rezultat i globalizimit. Gjersa globalizimi përshkruhet si një proces me të cilin ekonomitë rajonale, shoqëritë dhe kulturat integrohen nëpërmjet një rrjeti global të ideve politike, komunikimit, transportit dhe trendëve të tregut, çfarë po ndodhë aktualisht?

Trendi i globalizimit është një proces i pandalshëm historik i cili po reflektohet në mënyrë përkatëse në teknologji, shkencë dhe me strategji dhe stile të reja urbane. Në dhjetëvjeçarin e fundit, globalizimi është bërë një manifestim i zhvillimit, me reflektim relevant në arkitekturë dhe në çdo sferë të jetesës.

Arkitektura si profesion, në aspektin e veprimtarisë së saj dhe pjesëmarrjes në zgjidhjet transdisiplinare të problemeve mund të jetë shumë e përshtatshme për ti adresuar këto trende të reja zhvillimore. Procesi i integruar i projektimit është praktika e projektimit të qëndrueshëm, në thelbin e sajë ka natyrën dhe njeriun, modeli i integruar i projektimit arkitektonik është evolutiv për nga natyra e funksionimit. Kështu, procesi që nga fillimi i formulimit dhe i identifikimit të problemeve përpiqet për ti përdorur ndryshoret si faktorë numerik gjatë procesit të projektimit, si një tërësi kohezive e shprehur me vlera vizuale, të cilat pastaj marrin funksione reale jetësore për të gjetur zgjidhjen e mundshme të problemeve specifike urb arkitektonike.

Lajm i mirë është se ne e dimë se çfarë duhet të bëjmë.

Lajm mirë është se ne kemi gjithçka çfarë na duhet për

t'iu përgjigjur sfidës së ngrohjes globale.

Ne e kemi të gjithë teknologjinë që na duhet, ...

Dhe, gjersa kjo teknologji bëhet më e vlefshme dhe

më e përballueshme për tu prodhuar në seri,

do ta kemi më lehtë për t'iu përgjigjur sfidës.

Por, ne nuk mund të presim, dhe nuk do të presim...

Al Gore 118

118 Al Gore. (2005). Nënpresident i SHBA. Adresim: National Sierra Club Convention. Shtator/2005. 
Në kuptimin e integrimit dhe procesit të integruar veçohet organizimi i përgjithshëm i një sistemi funksional, sistem që kërkon një zgjidhje të veçantë për të gjitha problemet përkatëse, duke adaptuar dhe ndryshuar strategjinë e dizajnit evolutiv. Procesi i dizajnit të integruar nënkupton punën në grup, me prioritetet e identifikuara në mënyrë të qartë, të cilat janë të formuluara nga iterimet e mjaftueshme deri te zgjidhja e problemit të kërkuar.

Në kontekstin e një procesi të integruar të projektimit, në rast të inkorporimit të strategjisë transdisiplinare në proces, rezultat i tërë procesit do të pasqyrohet me qasjen jokonvencionale të zgjidhjes së problemeve arkitektonike, ku realisht pritën rezulatete më të mira.

Pra, zgjidhje përtej pengesave dhe barrierave konvencionale, një zgjidhje komplimentare nga praktikat stereotipe. Në rrethana të zakonta mos adresimi i duhur, mund të kontribuojë në paraqitjen e situatave dëshpëruese, madje edhe me situata të cilat dijnë për të krijuar "rrethin vicioz". ${ }^{119}$

Epokë e re, kohë dhe rrethana të reja, të cilat sjellin me vete një sfond të fenomeneve të reja, të cilat ndikojnë drejtpërdrejt në cilësinë dhe stilin e jetës bashkëkohore. Mirëpo, dukuritë e reja dhe kërkesat e reja kërkojnë zgjidhje adekuate dhe efektive, duke filluar nga problemet ditore të përditshme e deri tek ato kardinale të rëndësishme. Vazhdimisht përjetojmë situata origjinale të njohura nga intuita, por ja që i kemi harruar, duke u kujtuar të njëjtën punë mund të bëjmë dhjetë herë më shpejt. Raste të ngjashme ndodhin edhe në rrafshin global të reflektuar në tregun botëror, kur në kontekstin e globalizimit dikush mund në një tryezë pune të marr vendim për një pjesë të tregut global, dhe në këtë mënyrë drejtpërdrejtë të ndikojë në çmimin botëror, i cili na afekton edhe ne?!

Situata të ngjashme mund të ndodhin, dhe do të ndodhin me siguri në mënyrë të pashmangshme do të reflektohen edhe në industrinë e ndërtimit, e cila realisht është një faktor relevant ne prodhimin e bruto të ardhurave financiare në arkën e shtetit, dhe jo vetëm të Kosovës.

Dizajni arkitektonik ka qenë gjithmonë një pionier i ndryshimeve sociale dhe shoqërore në bazë të asaj që çfarë quhet dhe është Moderne duke pasur rolin e avant gardës me primesa futuristike. Në aspektin e komforit dhe cilësisë së jetesës procesi i integruar, do të përpiqet për të gjetur zgjidhjet më të mira të mundshme për problemin specifik arkitektonik, rasti kur kërkohen funksione të reja në jetën reale. Asnjëherë më parë si sot nuk kemi përjetuar objekte multifunksionale, që janë në varësi të kërkesave të reja të kohës, të shoqëruara me teknologji të avancuar. Andaj, realisht len të kuptohët së ndikimet e tregut global ndikojnë dhe prekin ekonomitëe regjionit, e ketu edhe të Kosovës. Pra një sistem i tërë dhe homoogjen me nënsisteme të cilat ndërveprojnë së bashku, e posaqerisht kur kemi të bejmë me industrinë e ndërtimit. E sotmja, ka filluar të ndryshojë lehtë maksimat e vjetra dhe "rregullat" bazike të projektimit, duke futur në arkitekturë terminin e arkitekturës dinamike.

119 Situata, në të cilën një problem gjeneron një zinxhir të rrethanave të reja, krijon një problem të ri dhe rrit vështirësitë në zgjidhjen e problemit origjinal, duke krijuar situata të prapësimit në gjendjen e parë. 
Kjo është më së e rëndësishme, në rast të analizës në rrafshin projektues, me shembull: kur një dhomë është e dëshirueshme nga jugu, fare lehtë sot, pasi kjo mundësohet falë teknologjisë së sotme dhe konceptit të arkitekturës dinamike, rasti kur, një etazhë e tërë lëvizë rreth boshtit të caktuar dhe kryen një rrotullim sipas dëshirës së individit. E vështirë për tu imagjinuar para disa dekadave në aspektin për tu realizuar dhe ndërtuar.

Figura 279. Procesi dhe Koha

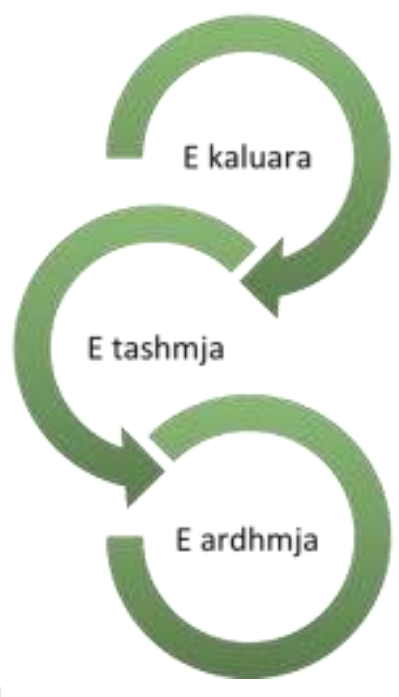

(Burimi): Bujar Bajçinovci, 2015.

Çështjet aktuale arkitektonike të përmirësimit të kualitetit të jetesës dhe futja e koncepteve krejtësisht të reja për zgjidhjen e tyre, ekspertët nga fushat specialistike do të integrohen në një grup për t'iu përgjigjur plotësisht sfidave të reja dhe stilit të ri të jetesës. Procesi i integruar synon të përfshijë të gjitha atributet e mundshme të problemit, në mënyrë që çdo vendim në procesin e projektimit të identifikojë sa më shumë fenomene të veprimit, procesi është i lidhur me të gjitha palët e përfshira në projekt dhe rrjedhimisht e ka rolin e transformimit të natyrës së punës, duke marrë një formësim të ri në zgjidhjen e problemeve arkitektonike në varësi të situatës aktuale dhe kërkesave të posaqme.

\subsection{ANATOMIA - MODELI I PROCESIT TË INTEGRUAR TË PROJEKTIMIT}

Shumë autorë, pohojnë se çelësi i të kuptuarit të kompleksitetit të procesit është përsëritja apo iterimi. Wolfram S. (2002), duke treguar se procesi përsëritës, zbatimi i rregullave të thjeshta zbulon aftësinë misterioze të natyrës në prodhimin e fenomeneve dhe proceseve komplekse. Struktura, funksioni dhe procesi në një kontekst të caktuar do të zgjidhin supozimet dhe dilemat e çdo elementi veçmas në sistem, dhe më pas në krahasim me anëtarët e tjerë të involvuar do të rezultojë me një zgjidhje. Iterimet e mjaftueshme duhet të përcaktojnë vlefshmërinë e supozimeve, më pas duke identifikuar pajtueshmërinë në mes ndryshorëve ose konfliktet e mundshme. Paraqitja e konflikteve mund të kërkojë një kontekst të ri të konceptualizimit të ndryshoreve ose variablave të përfshira në sistemin e shqyrtuar. Së fundmi, iterimet e njëpasnjëshme do të prodhojnë një zgjidhje të pranuar nga aspekti shkencor, në këtë rast të projektimit të integruar arkitektonik. $^{120}$

120 Gharajedaghi J.(2006).Systems Thinking . Managing Chaosand Complexity. London,

UK : Elsevier 


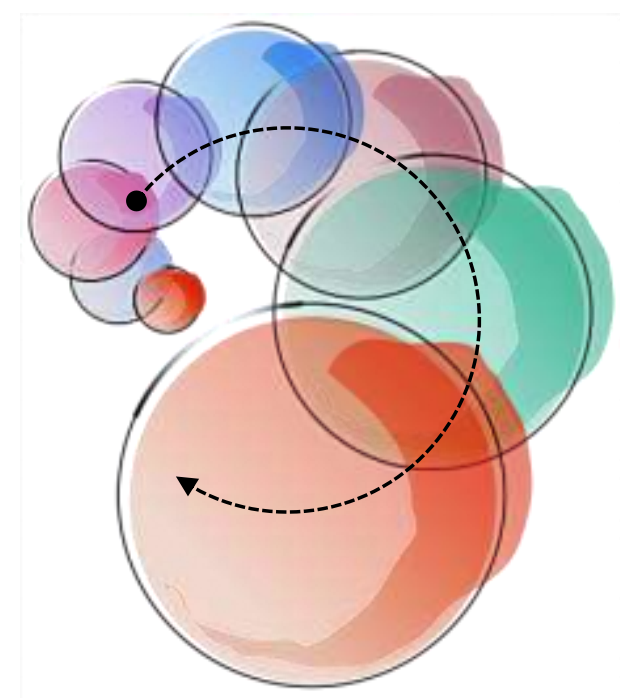

Figura 280. Natyra e procesit iterativ

(Burimi): Vizatim, Bujar Bajçinovci, 2012.

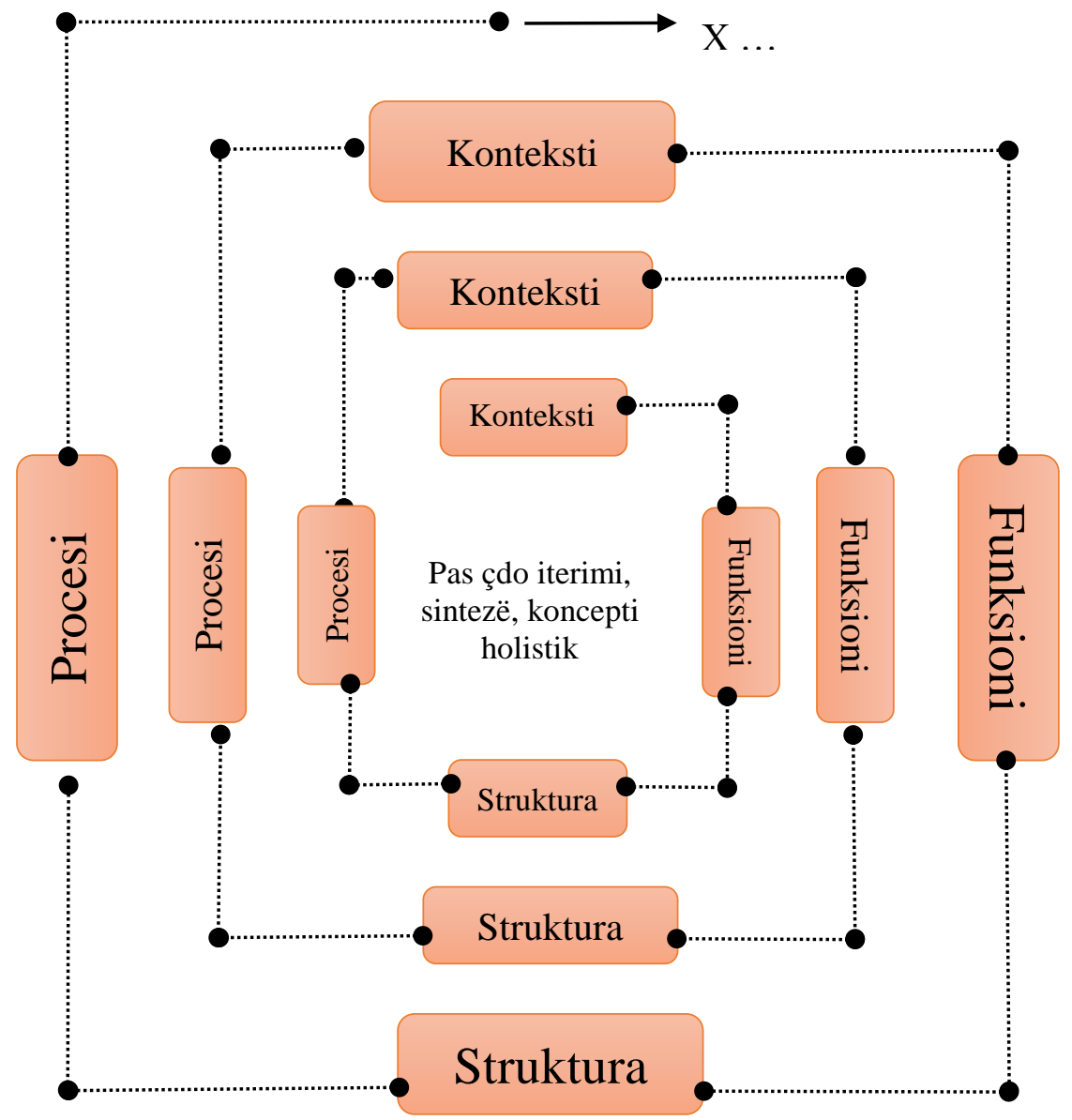

Figura 281. Natyra e procesit iterativ në kontekst të sistemit të integruar (Burimi): E përpunuar Bujar Baj̧̧inovci, 2012. Gharajedaghi J. (2006). 
Një qasje holistike e të kuptuarit të arkitekturës potencon në përputhje me këto parime të iterimeve mund të përdoret si një model pune në gjetjen e zgjidhjeve më të mira të mundshme të projektimit arkitektonik. Për shembull, nëse ne analizojmë një dizajn arkitektonik nga konteksti holistik, kemi nevojë për të kuptuar funksionin, strukturën dhe procesin e detyrës përkatëse.

Andaj, duhet kuptuar marrëdhëniet në mes të funksionit, strukturës dhe procesit së bashku, dhe i tërë ky ansambël duhet vënë në një kontekst të caktuar për të cilin kërkohet zgjidhja e mundshme. Kështu, duhet shikuar përtej kufijve të projektimit konvencional në gjetjen e zgjidhjes së kërkuar. Respektivisht duke zbatuar njohuri të reja nga fushat subspecialistike të involvuara në proces, konsiderojë se solucioni do të prezantohet me një arkitekturë më të mirë dhe më të përgjegjshme ndaj mjedisit.

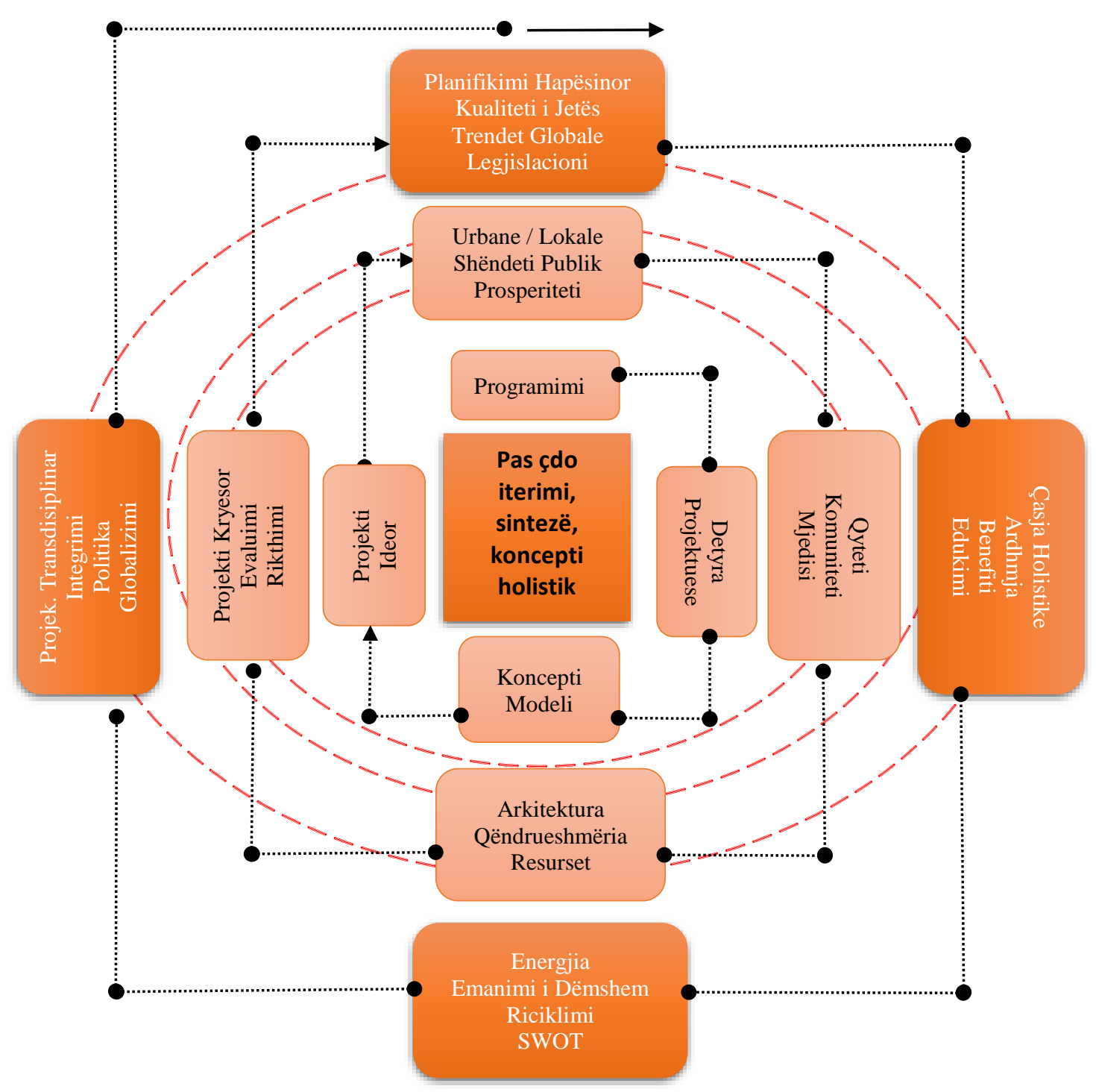

Figura 282. Procesi iterativ. Projektimi i qëndrueshëm arkitektonik (Burimi): Bujar Bajçinovci, 2015. 
"Njerëzimi po zhvillohet gjithnjë e më shumë më inteligjent, por në jetën e përditshme, ka shumë probleme dhe aq më pak fat. Si është e mundur kjo? Kjo është për shkak se inteligjenca nuk është njëjtë sikurse urtia. Kur shoqëria përdor inteligjencën e pjesshme dhe injoron urtësinë holistike, njerëzit harrojnë të përfitojnë nga jeta e zakonshme dhe e natyrshme. Duke u nxitur nga dëshirat dhe emocionet për vetën e tyre, ata bëhen skllevër të këtyre kërkesave, luksit, pushtetit, fesë së paekuilibruar. Duke u arsyetuar me të gjitha llojet e justifikimeve psikologjike, vetëm për të përfituar"121

\subsection{DALLIMI I SË TASHMËS}

Me evoluimin e shoqërisë dhe situatës aktuale, dominon mendimi se globalizimi është një tendencë për të dalluar të tashmen, ndërsa filozofët e shohin këtë fenomen si një shumëllojshmëri pozitive dhe udhëzuese e diversitetit, i cili shfaq homogjenizimin, mirëpo ka edhe nga ata që kanë një pikëpamje negative për fenomenin. Arkitektura adreson situatë tonë, filozofinë, politikën, identitetin kulturor dhe rajonal. Historia e arkitekturës është e dominuar nga lëvizjet dhe kulturat me diversitet estetik, sidomos kur në filozofinë e arkitekturës tregohet për konceptin e së konkurrences.

Qeveritë janë kryesisht sponsorët e vlerës aktuale, duke e përdorur arkitekturën për ta interpretuar trendin, modën, pushtetin, fitimin, edhe pse arkitektët e pavarur janë duke u përpjekur për të kritikuar cilësinë dhe nocionin e vlerës artificiale të impenjuar. Identifikimi i problemeve dhe strukturimi i problemit është një proces profesional, fazë në të cilën studiuesit dhe pjesëmarrësit punojnë së bashku për të identifikuar dhe për të kuptuar natyrën e një problemi specifik.

Në këto raste, pjesëmarrësit do të marrin pjesë në formulimin dhe strukturimin e çështjeve logjike rreth problemit, në terren të përbashkët në lidhje me: gjenezën dhe zhvillimin mundshëm të problemit, përcaktimin nevojës për ndryshe..., objektivat e dëshiruara dhe mënyrën më të mirë të veprimit të ndikuar nga teknologjia, parimet sociale, juridike, kulturore të cilat mund të transformojnë praktikat ekzistuese. Në fazën e kërkimit të identifikimit të problemeve dhe të strukturimit disiplinor kërkohet një situatë e re, sepse nuk mund të ndërtohet diçka vetëm në bazë të njohurive të cilat $\mathrm{i}$ posedojmë dhe i njofim, nuk mjafton! ${ }^{122}$

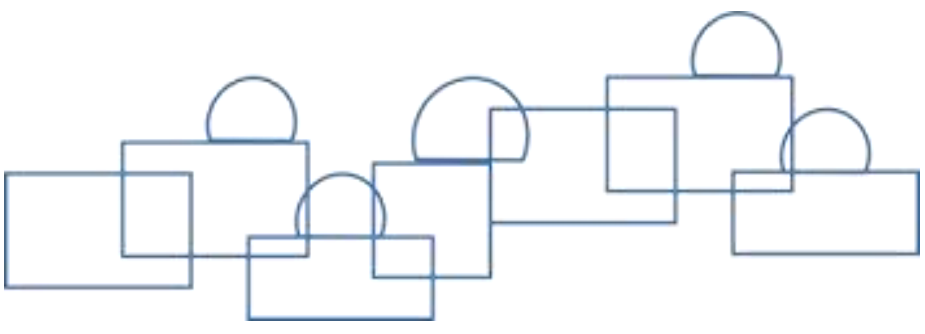

121 Walker, B.(1995). Hua Hu Ching: The Unknown Teachings of Lao Tzu. HarperOne

122 Hadorn, H. G. et al.(2008). The Handbook of Transdisciplinary Research. Zurich: Springer 


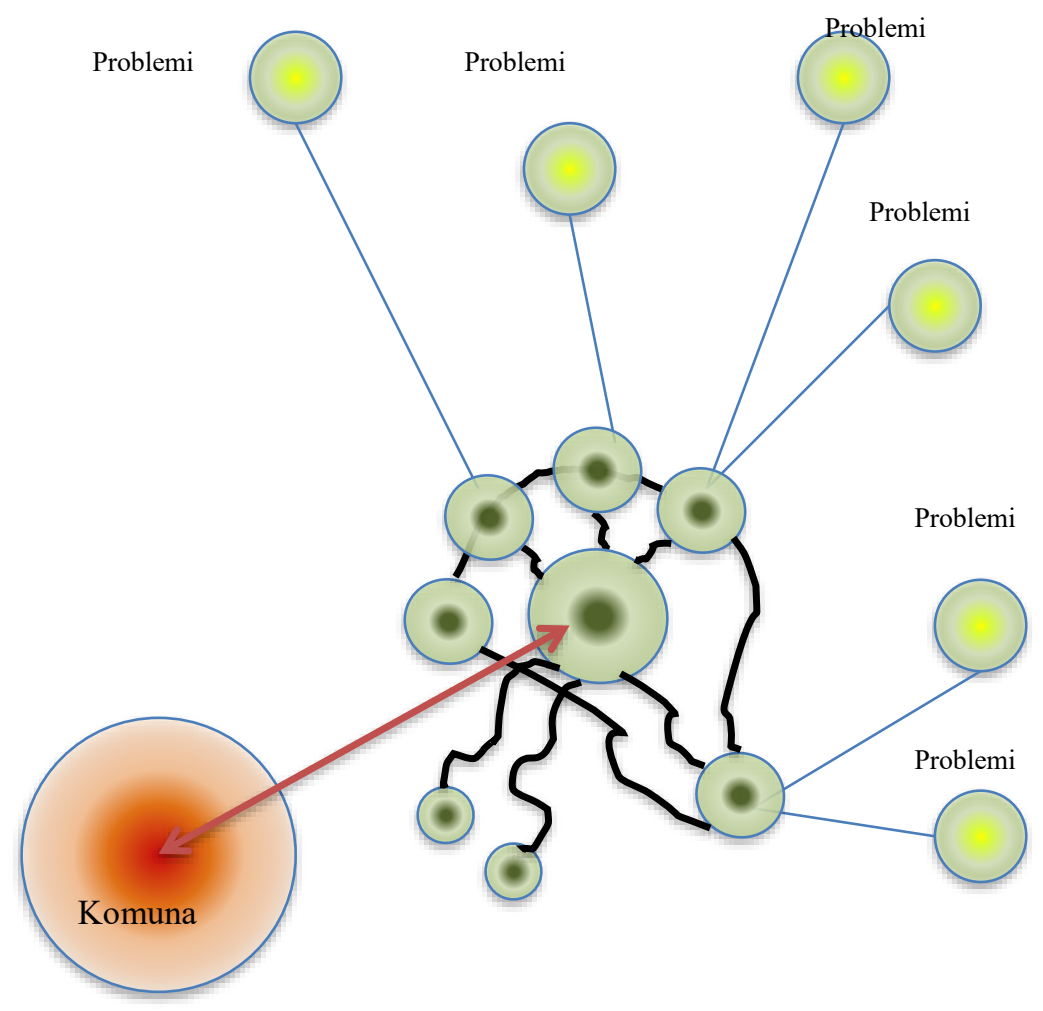

Figura 283. Procesi aktual i zgjidhjeve të problemeve arkitektonike (Burimi): Bujar Bajçinovci, 2012.

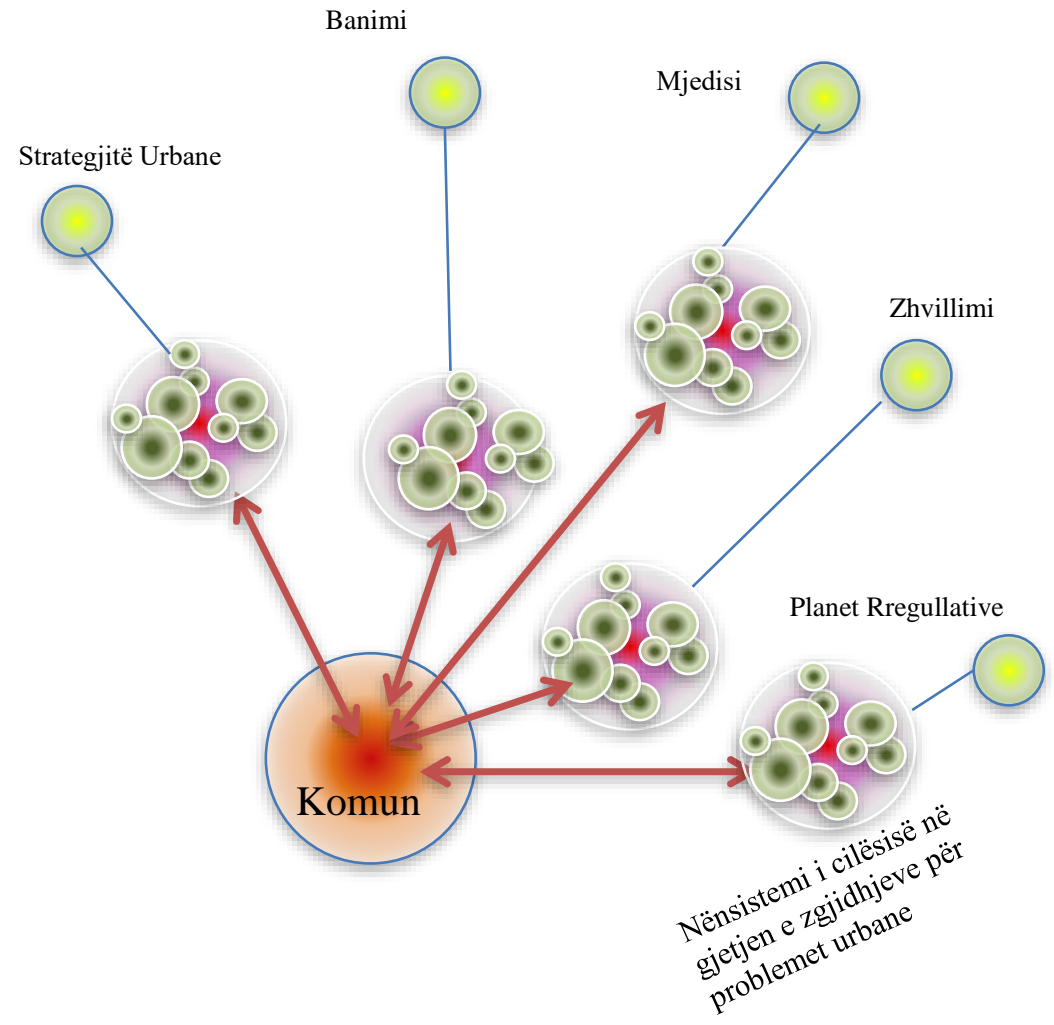

Figura 284. Procesi i preferuar në zgjidhjen e problemeve arkitektonike (Burimi): Bujar Bajçinovci, 2012. 


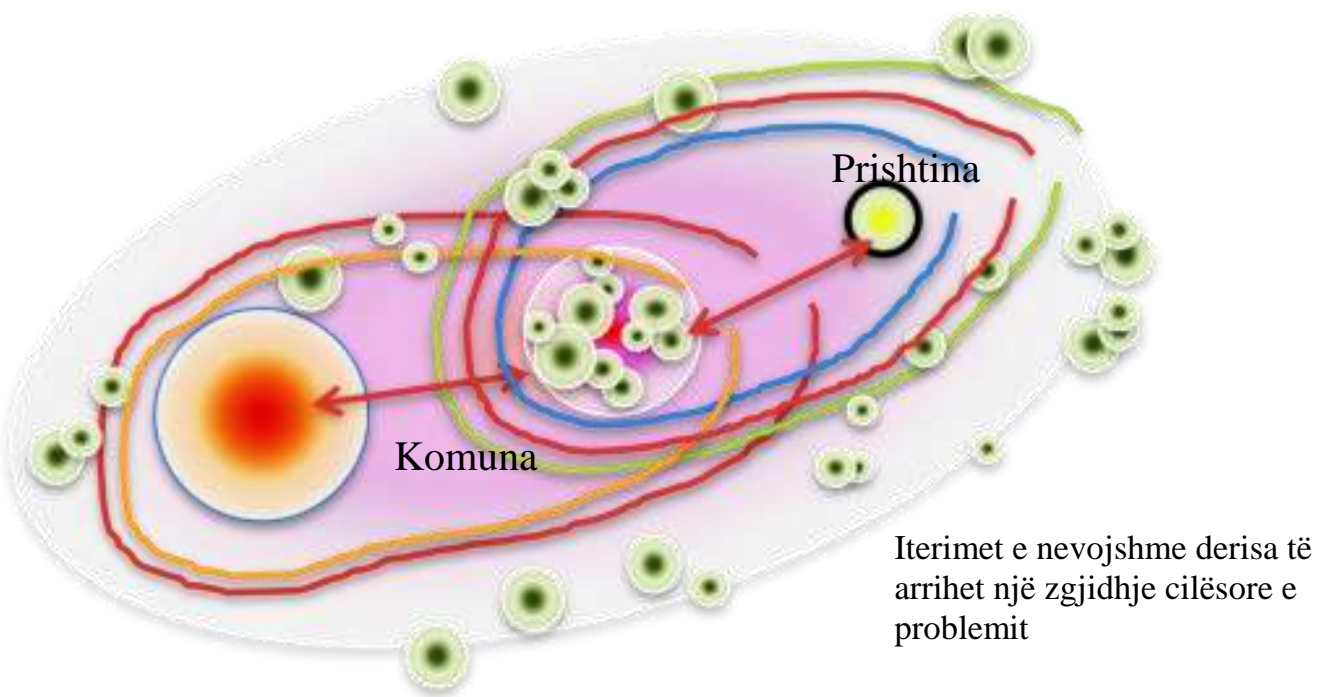

Figura 285. Zgjidhja e veçantë, problemi, sistemet dhe nënsistemet (Burimi): Bujar Bajçinovci, 2012.

I tërë sistemi dhe nënsistemi janë të përfshirë në zgjidhjen e problemeve të veçantë, ku të gjithë pjesëmarrësit kalojnë barrierat fiktive, duke formuar një tërësi të veçantë dhe grup unik e homogjen. Tejkalimi kufijve të zakonshëm dhe konvencional disiplinor me gjetjet e reja të cilat nuk janë të përfshira në ndonjë nga disiplinat e përfshira, gjen një zgjidhje unike në lëminë arkitektonike për problemet kardinale e jetike të qytetit.

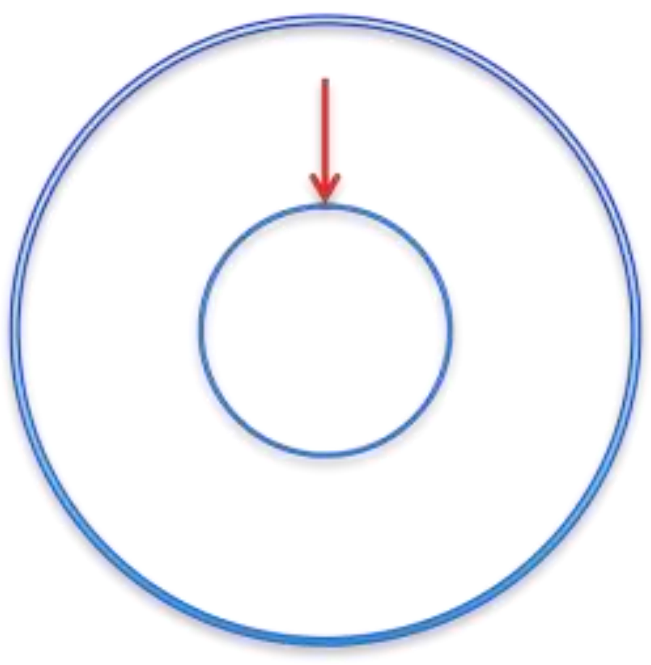

Figura 286. Vëzhgimi i sistemit nga hapësira "e jashtme"?

(Burimi): Bujar Bajçinovci, 2012. 
Pra, duke shikuar një sistem nga jashtë ne si vëzhgues ende jemi të vendosur brenda sistemit tjetër më të madh, (sa jemi të vetëdijshëm) është e pamundur për të adresuar zgjidhjen e problemeve të veçanta, duke mos i njohur dhe implikuar të gjitha atributet të cilat mund të ndodhë që "nuk i kemi në dispozicion".

\subsection{FAKTORET LOKAL}

Specifikat e mjedisit dhe e komunitetit janë të një rëndësie kardinale, sidomos kur reflektohet në projektimin arkitektonik dhe banimin. Atributet e veçanta dhe ide origjinale vijnë të parat në zgjidhjen e problemeve specifike. Kështu, dizajn i "mirë" përpiqet të inkorporojë të gjitha fenomenet e mundshme dhe faktorë të ndryshëm në procesin e zgjedhjes. Situata krejtësisht të reja dhe faktori kohë bartin me vete kërkesa krejtësisht të reja dhe specifike në të cilat procesi i "mirë" duhet të llogarisë.

Në raportin e tij vjetor në Parlament, auditori i përgjithshëm Sir. John Bourne NAO (2002), konkludon: Dizajni i mirë është thelbësor për arritjen e lidhjes mes vlerës dhe ndërtimit. Por kjo nuk është e vërtetë vetëm për objektet që janë përfunduar në kohë dhe brenda buxhetit, por duhet gjithashtu të brengosemi me sigurimin për shpenzimet operative të ndërtesave gjatë jetës së saj, duke optimizuar që ndërtesat përkatëse të marrin vlerën reale dhe nominimin e cilësisë për dizajn të mirë. Këto ndërtesa mund dhe duhet të bëjnë një kontribut të madh në përmirësimin e kushteve. Vazhdimisht potencojë në raportet e mia në parlament dhe paralajmëroj për rastet kur ka mungesë të adresimit të duhur e cila nuk është dhënë në procesin filestar të projektimit, me pasoja të dëmshme dhe me mungesë të shërbimeve adekuate. ${ }^{123}$

Andaj, dizajn i "mirë", nuk ekziston asnjë skenar i përsosur dhe nuk ka projekt të përsosur, megjithatë, ka udhëzime konceptuale që shkencërisht ju drejtojnë në drejtim të zgjidhjes optimale të procesit të mirëfilltë të projektimit. Udhëzimet konceptuale strategjike si udhëzues për të definuar problemet dhe prioritetet arkitektonike duhet të përfshijnë pyetjet, si më poshtë:

1. Cila është madhësia e projektit?

2. Është projekt kapital, apo jo?

3. A do kemi nevojë për teknologji të sofistikuar për të ndërtuar strukturën e ardhshme?

4. Prejardhja e buxhetit për ndërtimin: Shtetërore, qeveritare kombëtare, lokale, koncesion, partneritetit publiko-privat, privat?

5. Ka funksione speciale objekti?

6. A ka kushte vartëse projekti me planin e përgjithshëm urbanistik?

123 OGC, CABE,.(2002). Improving Standards of Design: in the Procurement of Public Buildings. London. UK 
7. Ekzistojnë rregulloret dhe standardet në nivel kombëtar dhe lokal për projektin e ardhshëm, dhe në çfarë niveli janë të koordinuar?

8. Projekti në kundërthënie me udhëzimet dhe rregulloret e BE-së?

9. Ndërtimi i objektit: Ka ndikime negative në mjedis, metropolitan, urban?

10. Çfarë mendimi ka popullata lokale, duhet të bëhet sondazh me intervistë?

11. Në aspektin e mikrolokacionit, cilat janë pritjet e mundshme negative, të ndërtimit apo pritën në të ardhmen?

12. Është e nevojshme për tu përfshirë në procesin e projektimit subspecialist, si dhe ekspert të jashtëm?

13. Çfarë lloj emanimeve negative mund të gjenerojë projekti në veçoritë mjedisore: Ajër, ujë, tokë, diellosje, zhurmë, komfortit, florën dhe faunën e mjedisit, era dhe rrezatimi i mundshëm i dëmshëm?

14. Cila është koha e planifikuar nga fillimi deri në fazën përfundimtare, sa reale janë periudhat e caktuara

15. Gjatë procesit, ekziston mundësia e lirë për kërkesa specifike dhe përdorim të teknologjisë së dëshiruar bashkëkohore?

16. Projekti mund të mbështetet në një fond shtesë?

17. Çfarë është kosto dhe çmimet bonus për ekipin e projektimit në gjetjen e zgjidhjeve projektuese me efekt origjinal inovues dhe kursyes?

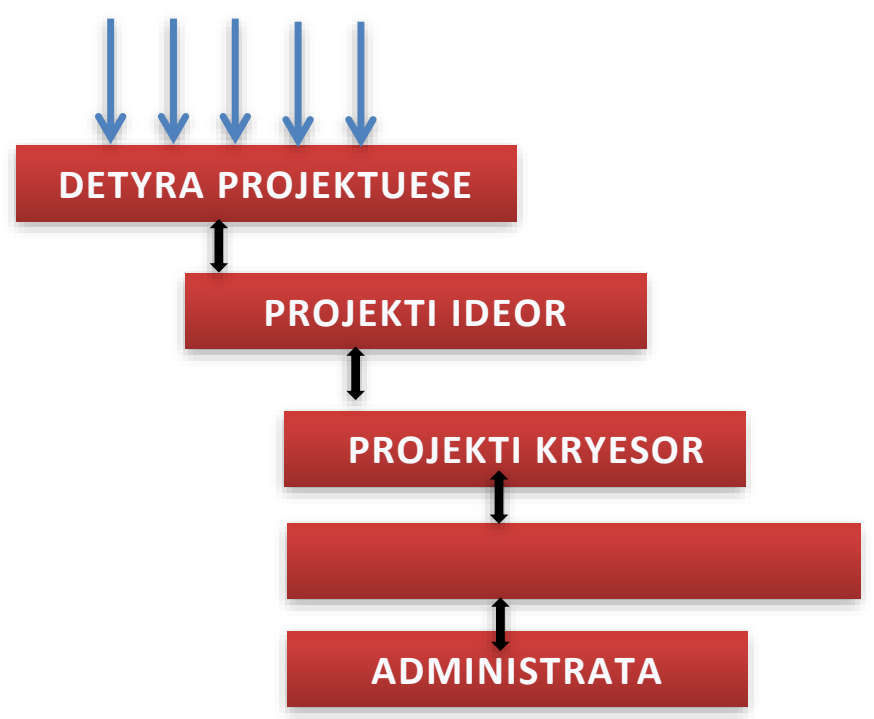

Figura 287. Procesi aktual i projektimit (Burimi): Bujar Bajçinovci, 2012. 
Duke zbatuar algoritmin në metodën standarde të projektimit arkitektonik, gjejmë një rrugë të re për të zgjidhur problemin, duke fituar lirinë e iterimit dhe ripërcaktimin pa një theks të veçuar mbi qëllimin përfundimtar. Roli i strategjisë transdisiplinare është liria e pakufizuar në adresimin e zgjidhjeve të mundshme të problemit, pa barriera konceptuale që lidhen me profesionin, gjithmonë duke synuar në zgjidhjen më origjinale kreative.

Në fillim mungesa e kufijve mendore që lidhen me profesionin, janë pjesëmarrës në procesin e krijimtarisë të liruar prej paragjykimeve të ndryshme, ego, tendencat dhe arsyetimet e ndryshme. Megjithatë, duhet të ketë një prezantim logjik fillestar për pjesëmarrësit dhe të gjithë ekipin, në trajtë të grafëve si përshkrime të thjeshta grafike, me informata të shkurta dhe koncize.

" Algoritmi është një procedurë për zgjidhjen e problemeve, duke i numëruar hapat në proces; duke përdorur operacionet logjike: nëse, atëherë, tjetër. "124

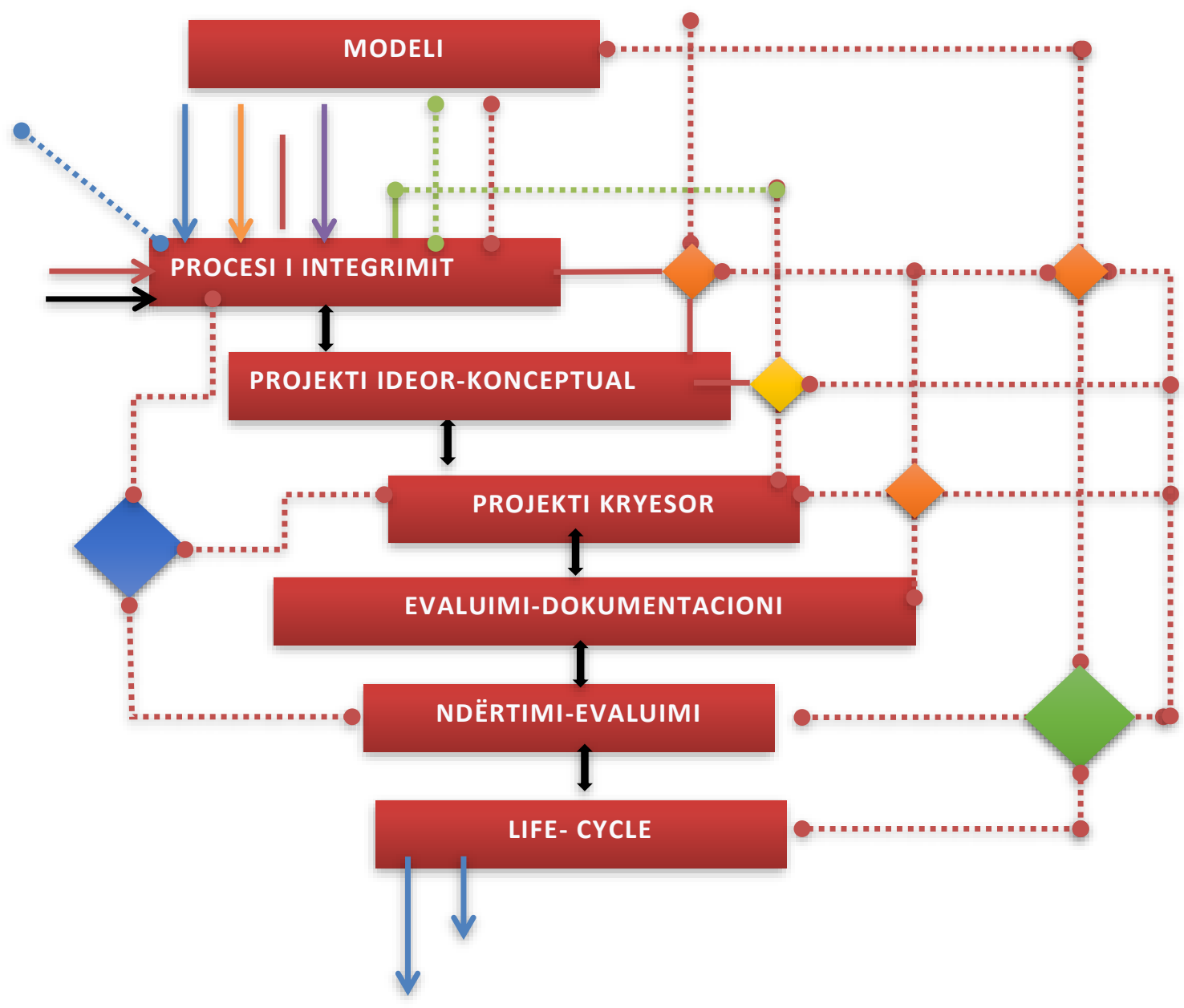

Figura 288. Metoda algoritmike iterative në procesin e projektimit. (Burimi): Bujar Bajçinovci, 2012.

124 Terzidis, K. (2006). Algorithmic Architecture. Oxford. Elsevier 
Proces më i lire, adaptiv dhe fleksibil në variante më zgjidhjen e të njëjtit problem potencial, arrihet duke i futur metodat e parimeve algoritmike në procesin e projektimit arkitektonik me iterime të nevojshme deri tek zgjidhja e mundshme, tashmë, duke preferuar në cilësinë e produktit përfundimtar.

Në fillim të procesit të identifikimit të problemit, strategjia transdisiplinare na lejon të kalojmë pengesat e ndryshme që janë si barrierë e të menduarit fillestar, kështu që kur ekipi e funksionalizon sistem pa kufijtë profesional, epilogu do të rezulton me zgjidhje të panumërta unike të problemit, natyrisht duke mos e kufizuar imagjinatën, me kusht që të jemi sa më objektiv.

Atëherë kjo zgjidhje merr fazën e ardhshme në të cilën sortohen më mirë variacionet për të sistemuar dhe përpunuar idetë evolutive, në drejtim të eliminimit të sa më shumë ndryshorëve që të jetë e mundur nga pengesat reale, duke përfshirë: buxhetin, një sërë çështjeve të natyrës politike të cilat mund të ndodhin që në fillim, dhe të cilat nuk kanë qenë të njohura filimisht, të shtuara më pas?

\subsection{OBJEKTIVAT E PROJEKTIMIT TË INTEGRUAR}

1. Qëllimet globale - konceptuale

2. Qasja - Strategjia projektuese

3. Qëllimet estetike

4. Kostoja - Efektive, qëllimet financiare

5. Objektivat funksionale arkitektonike

6. Rinovimi / Restaurimi / Mbrojtja

7. Produktiviteti dhe cilësia

8. Objektivat e sigurisë dhe ligjshmërisë

9. Qëndrueshmëria arkitektonike - mjedisore ${ }^{125}$

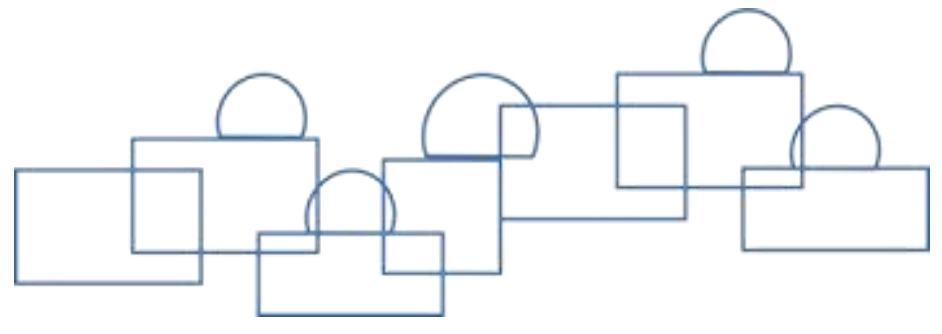

125 Deutsch, R.(2011). BIM and Integrated Design. Hoboken, New Jersey.USA : Wiley \& Sons. 


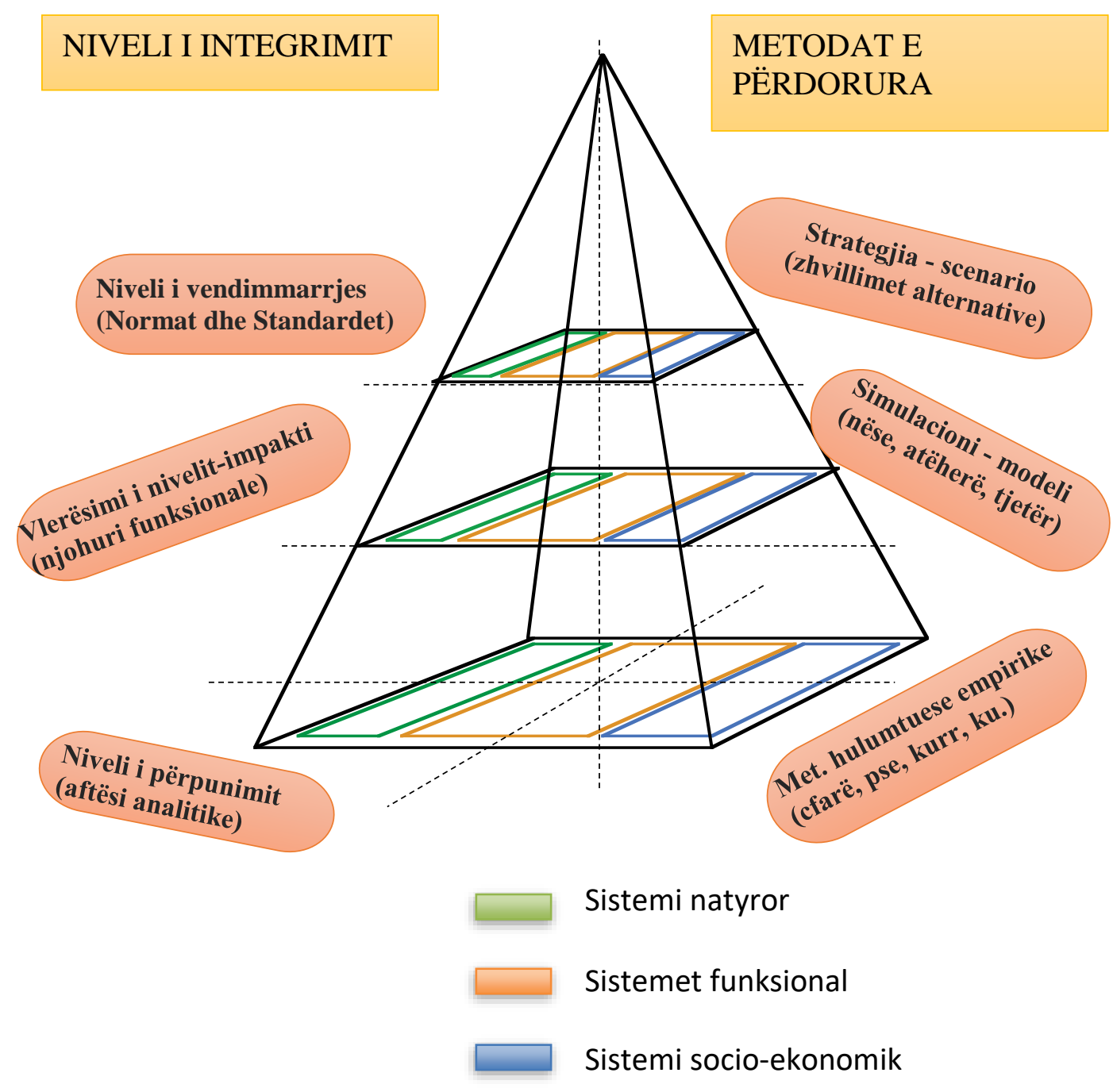

Figura 289. $M A B$, modeli. Skenari, Strategjia dhe Vendimmarrja (Burimi): Përpunuar, Bujar Bajçinovci. Hadorn, H. G. et al.(2008). ( P. Messerli, 1986.) ${ }^{126}$

\subsection{ZHVILLIMI I HAPËSIRËS KONCEPTUALE}

Prishtina me një atribut të qytetit në rritje të shpejtë përballet me një numër sfidash, përkatësisht, regjistrimi i fundit i popullsisë ishte me 2011. Rezultatet e paraqitura për qytetin e Prishtinës se ka 198,214 banorë ${ }^{127}$, së pari, kjo ishte përtej çdo pritje e të gjitha institucioneve relevante. Sidoqoftë, qyteti i Prishtinës ka potenciale hapësinore. Në qytetin e Prishtinës ekzistojnë hapësira të cilat kanë potencial për zhvillime të ndryshme. Pjesa e vjetër dhe qendra e qytetit ka potencial për zhvillim të funksioneve qendrore të kulturës, arsimit dhe administratës. Në perëndim dhe në jug të qytetit ekzistojnë potenciale për zhvillim të ekonomisë dhe industrisë.

126 Hadorn, H. G. et al.(2008). The Handbook of Transdisciplinary Research.Zurich: Springer.,

127 ESK.(2011). http://esk.rks-gov.net/rekos2011/ 


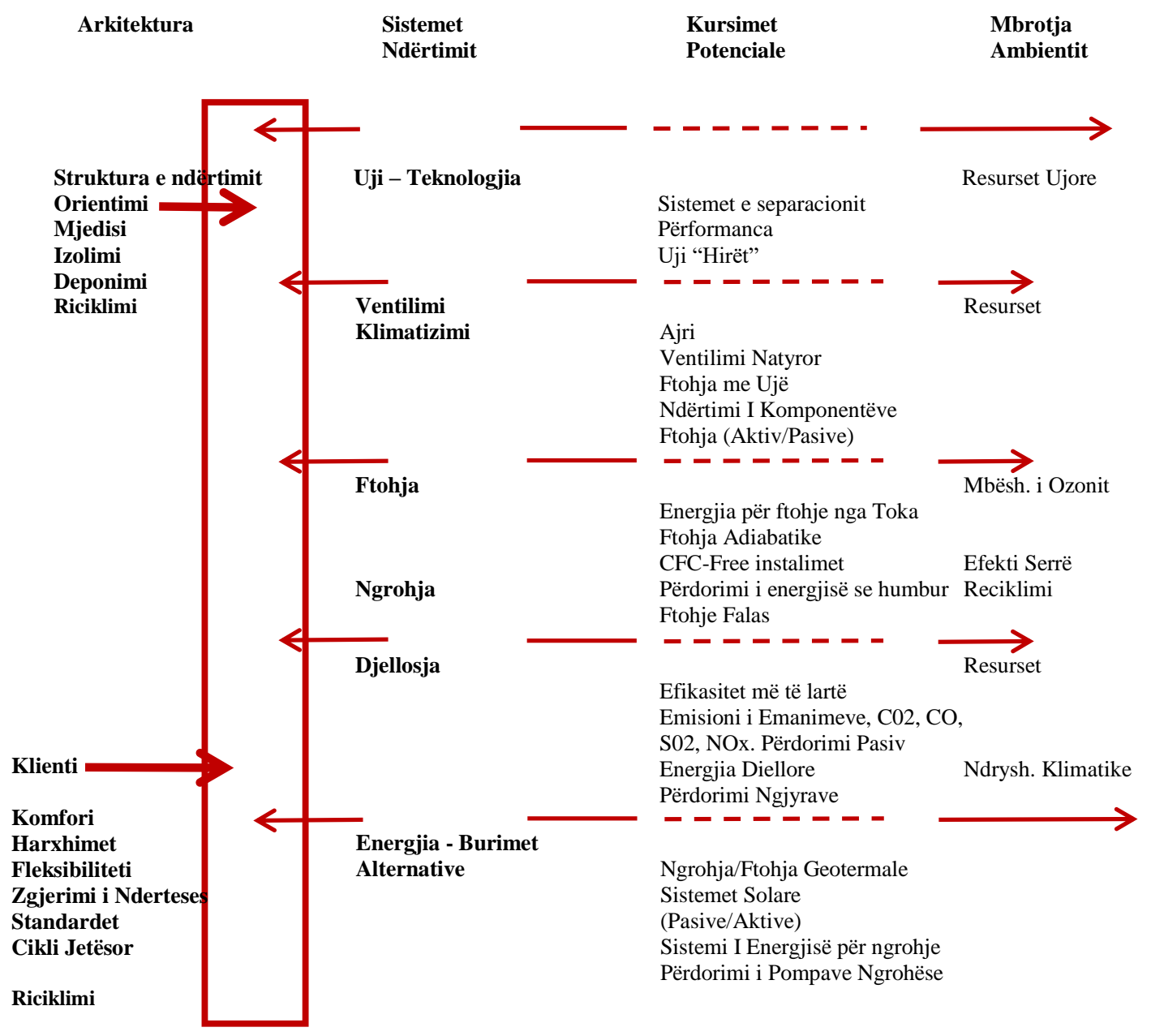

Figura 290. Tërësia e sistemit. Arkitektura, Teknologjia dhe Mjedisi. Përfitimet ekologjike (Burimi): Përpunuar Bujar Bajçinovci. Klaus Daniels,(2003) - Advanced Building Systems, 2012.

Në kodrat midis fshatit Mat dhe Hajvali, në juglindje të Prishtinës, ekzistojnë potenciale për rekreacion dhe banim atraktiv. Në pjesët fushore dhe në zonën e liqenit të Badovcit mund të zhvillohen zona të bukura natyrore. Me realizimin e rrugës qarkore të planifikuar, fshatrat përreth Gërmisë do të fitojnë potencial për rekreacion dhe banim rural atraktiv. ${ }^{112}$

\subsection{EU}

Komuniteti Evropian, një bashkim unik ekonomik dhe politik midis 27 vendeve evropiane. Bashkësia Evropiane ka një gjysmë shekulli të paqes, stabilitetit dhe prosperitetit, rezulton me rritjen e standardeve të jetesës, duke themeluar monedhën e përbashkët Evropiane. Në mënyrë progresive ka ndërtuar një treg të vetëm Evropian në shërbim të njerëzve, mallrave, serviseve dhe kapitalit, duke shkëmbyer lirisht në mes shteteve anëtare, si një shtet vetëm. 


\subsubsection{Strategjia $20 / 20 / 20$}

Pavarësisht nga metoda e prodhimit të energjisë, prodhimi ka një ndikim të rëndësishëm në mjedis. Së pari, totali i emisioneve nga prodhimin i energjisë, ka ndikim në mjedis duke përfshirë: ujin, ajrin, tokën, zhurmën dhe radioaktivitetin. Kosova prodhon energji elektrike nga termocentralet, por kjo nuk është e mjaftueshme për të mbuluar nevojat vetanake të Kosovës, po ashtu nuk kemi rezerva të gazit natyror apo naftës. Deri në vitin 2007, sektori i banimit është llogaritur si konsumatori më i madh i energjisë në Kosovë, dhe tani konsumon 50\% të energjisë totale të prodhuar. Tradicionalisht, sektori i banimit në veçanti mbështetet në energjinë elektrike. Energjia elektrike si burim kryesor i ngrohjes nuk është zgjidhje. Kosova është absolutisht e përkushtuar në premisat për ta reduktuar konsumin e energjisë duke inkurajuar efikasitet më të madh në përdorimin e energjisë nga burimet e ripërtërishme, si një anëtar i Komunitetit të Energjisë në Evropën Juglindore, e cila është e përkushtuar për këto sfida. Që nga plani kombëtar për efiçencën e energjisë, Kosova ka vendosur një objektiv që kursimet vjetore të jenë së paku $1 \%$.

Në rrafshin global të BE. Pesë objektivat e BE gjer në $2020^{128}$

1. Punësimi, $75 \%$ e $20-64$ vjetarëve, do të punësohen

2. R \& D, 3\% e GDP-së së BE, për të investuar në R \& D

3. Ndryshimet klimatike dhe energjia, qëndrueshmëria, emetimet e gazit $20 \%$ (ose edhe $30 \%$, nëse janë kushtet), më të ulëta se $1990.20 \%$ e energjisë nga energjitë e rinovueshme dhe Rritje prej $20 \%$ në efikasitetin e energjisë

4. Arsimi, duke ulur normat e braktisjes së hershme të shkollës nën $10 \%$, të paktën 40\%, e 30-34-vjeçare të përfundojnë arsimin e nivelit të tretë

5. Luftimi i varfërisë dhe mbështetja sociale.

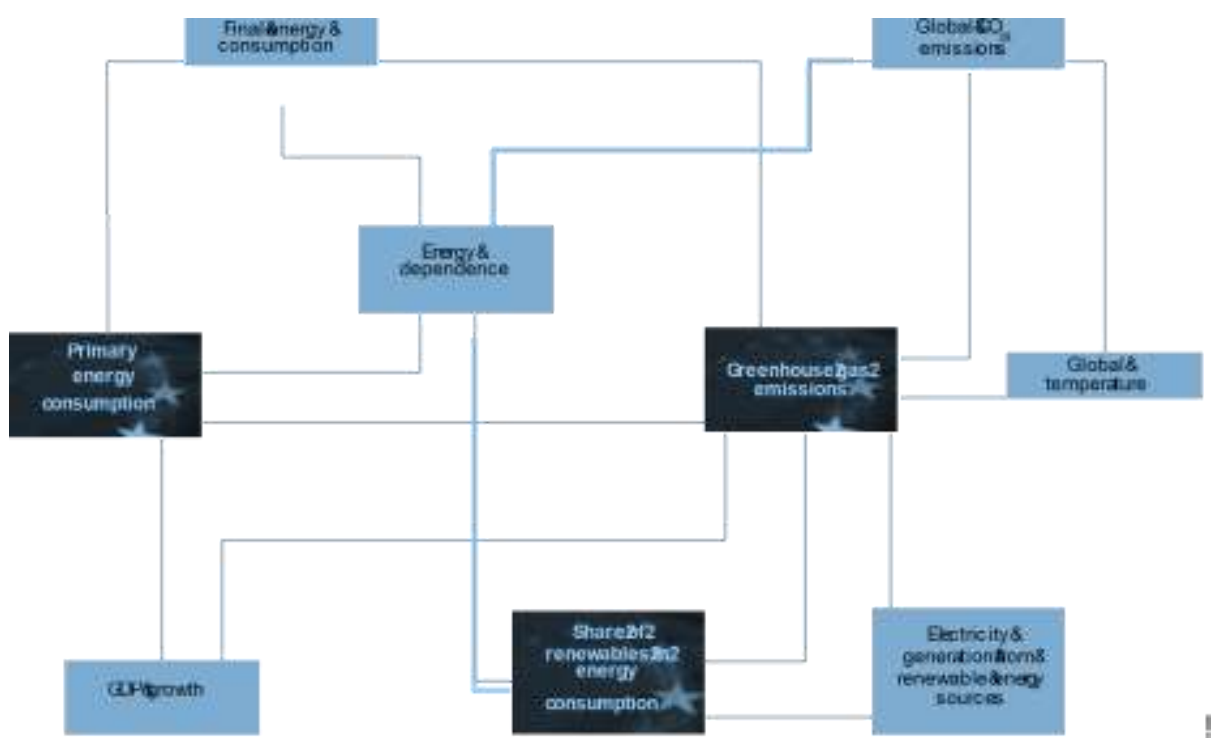

Figura 291. Indikatorët dhe konceptet, lidhjet e klimës dhe të energjisë. ${ }^{129}$ (Burimi): Eurostat. 2015.

128 http://ec.europa.eu/europe2020/europe-2020-in-a-nutshell/targets/index_en.htm

129 Eurostat. Indicators to support the Europe 2020 strategy. 2015. 


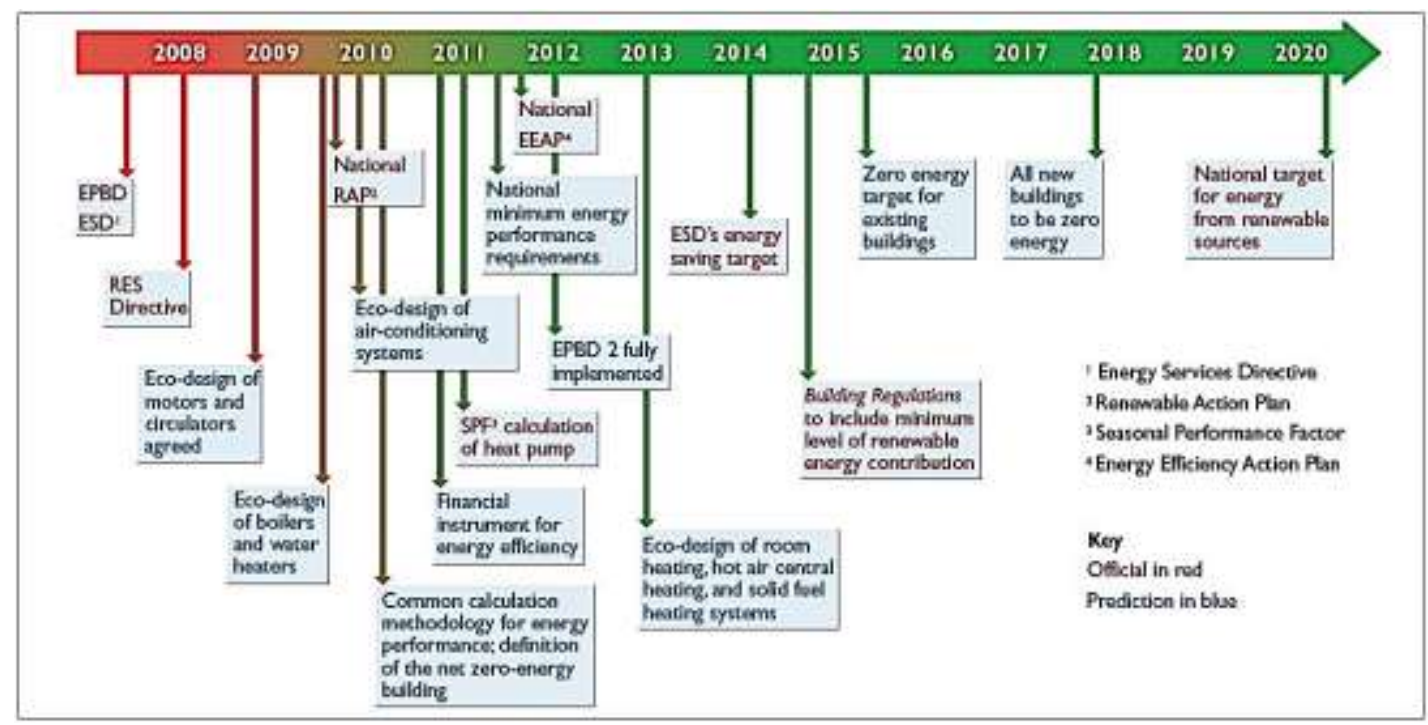

Figura 292. $B E$, strategjia $20 / 20 / 20$

(Burimi): http://www.bsria.co.uk/news/. 2011.

\subsection{ADOPTIMI I STANDARDEVE}

Sektori i banesave është konsumatori më i madh i energjisë në Kosovë dhe më gjerë, në vendin tonë nuk është rregulluar ende në detaje në nivelin e kursimeve të ligjit dhe efikasitetit të energjisë, por Akti i Energjisë, 2004/8, Neni 10, ofron një bazë ligjore për zhvillimin e efikasitetit të energjisë nga burime të rinovueshme në Kosovë, në veçanti, paragrafi (a) i nenit 10 kërkon hartimin dhe zbatimin e promovimin dhe përdorimin e energjisë nga burimet të rinovueshme të energjisë. Kërkesa është në përputhje me Traktatin e Komunitetit të Energjisë të nënshkruar nga Kosova. Programi i Kosovës për Efiçiencën e Energjisë dhe burimeve të energjisë në projektin e energjisë së rinovueshme përfaqëson dokumentin, i cili ka për qëllim për të aplikuar në vitet e ardhshme. Mbështetja e Komunitetit Evropian për përmirësimin e efikasitetit të energjisë do të jetë vendimtare për konkurrencën, sigurinë e furnizimit dhe për përmbushjen e detyrimeve për ndryshimet klimatike që janë bërë në bazë të Protokollit të Kiotos. Ekziston potencial i rëndësishëm për uljen e konsumit, sidomos në sektorët e energjisë intensive si ndërtimtaria, prodhimi dhe transporti. Duke promovuar standardin aktual apo rregulloret në fuqi: "Direktiva 2002/91/ EC e Parlamentit Evropian të datës 16/12/2002 mbi Performancën e ndërtesave në kontekst të energjisë ".

\subsection{IDENTITETI KULTUROR DHE REGJIONAL}

I tërë Ballkani mund të jetë krenar për historinë e tij, kulturën dhe identitetin rajonal, është zona me ngjarjet më të mëdha historike, fenomenet dhe gjenezën e luftërave botërore. Kosova, Prishtina ka diversitet specifik kulturor dhe rajonal për ti ofruar Komunitetit Evropian. Prishtina është një qendër e fortë universitare, e cila buron në Universitetin e Prishtinës, ku në vitin akademik 2004/2005 kishte 28.832 studentë, kurse sot në total afër 40 mijë studentë, masë kritike e njerëzve të rinj që studiojnë në procesin e Bolonjës, me synim në zhvillimin e Kosovës po ashtu më një të ardhme me punësim në vendet e Komunitetit Evropian. 
Megjithatë, në bazë të Ambasadës së Francës në Kosovë, Zhan Fransua Fitu: " E ardhmja Evropiane e Kosovës nuk është një çështje e zgjedhjes, por e gjeografisë," ju tha ambasadori studentëve në Universitetin Amerikan të Prishtinës. Ai ju bëri thirrje Kosovarëve të ndryshojë qasjen në paraqitjen para Evropës, “ Jo si viktima, por si burim dhe resurs i rëndësishëm. ${ }^{130}$

\subsection{PERSPEKTIVAT}

Ashtu si çdo aktivitet që është në proces të evoluimit, gjithashtu edhe arkitektura dhe projektimi arkitektonik ka nevojë për arsim shtesë apo të specializuar, përndryshe të gjitha veprimet e nevojshme të projektimit do të detyrohen në stagnim, improvizim dhe në fund depresion.

Sfidat e reja duhet të inkurajojnë kërkime të reja, duhet të drejtohen në shfrytëzimin e të gjitha potencialeve dhe resurse njerëzore, e mentale. Ku realisht Kosova ka sfond të mjaftueshëm të rinisë më vullnetin e pashoq për të prosperuar, karakteristikë e popujve të mëdhenj.

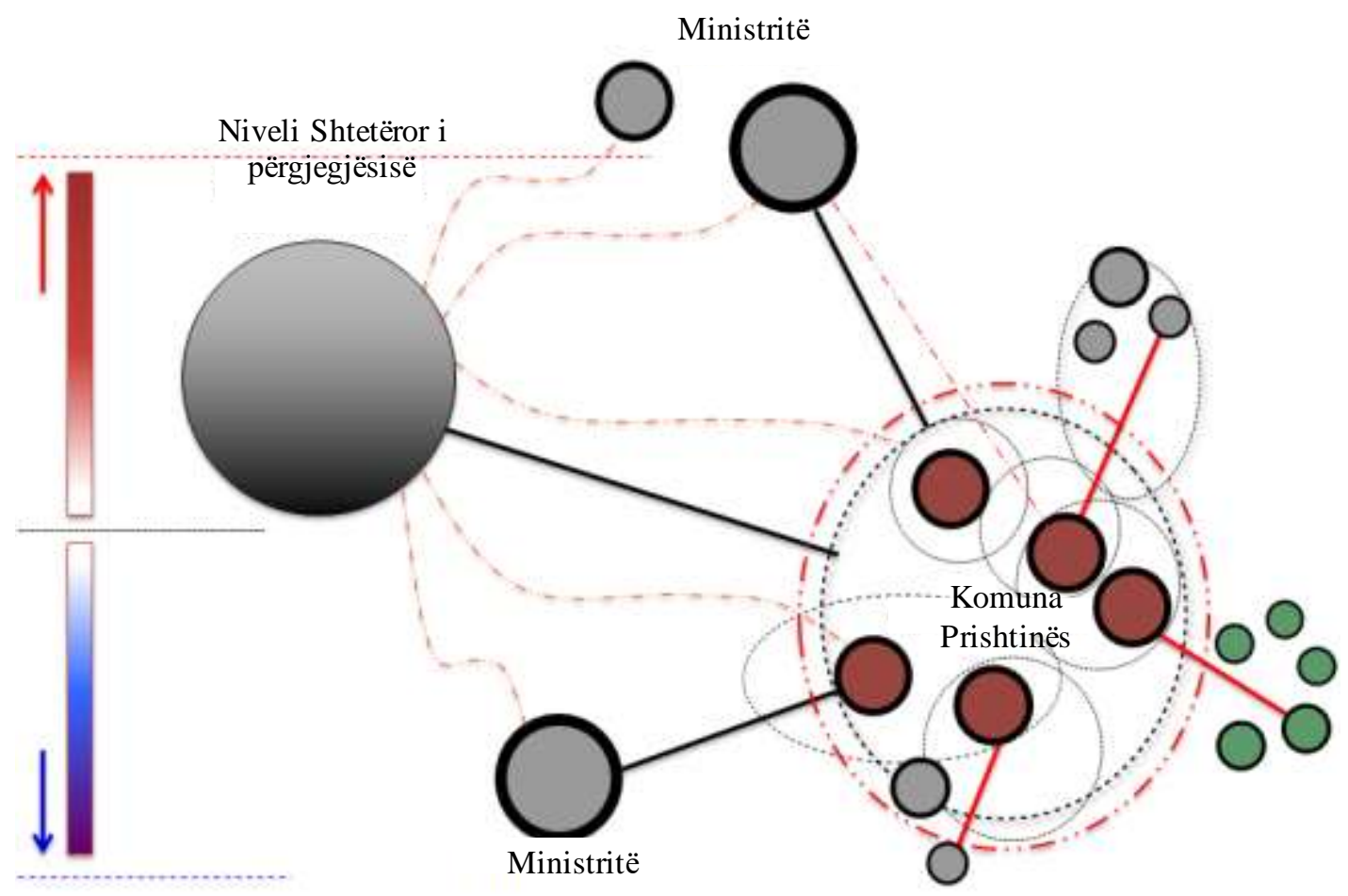

Figura 293. Nivelet e vendimmarrjes, qendror dhe lokal (Burimi): Bujar Bajçinovci, 2012.

130 Ekonomisti.Prihtinë. http://www.ekonomisti.info/artikulli/3/0/27856/fitu-kosovaretduhet-te-ndryshojne-qasjen-ndaj-evropes/. Tetor/2011. 


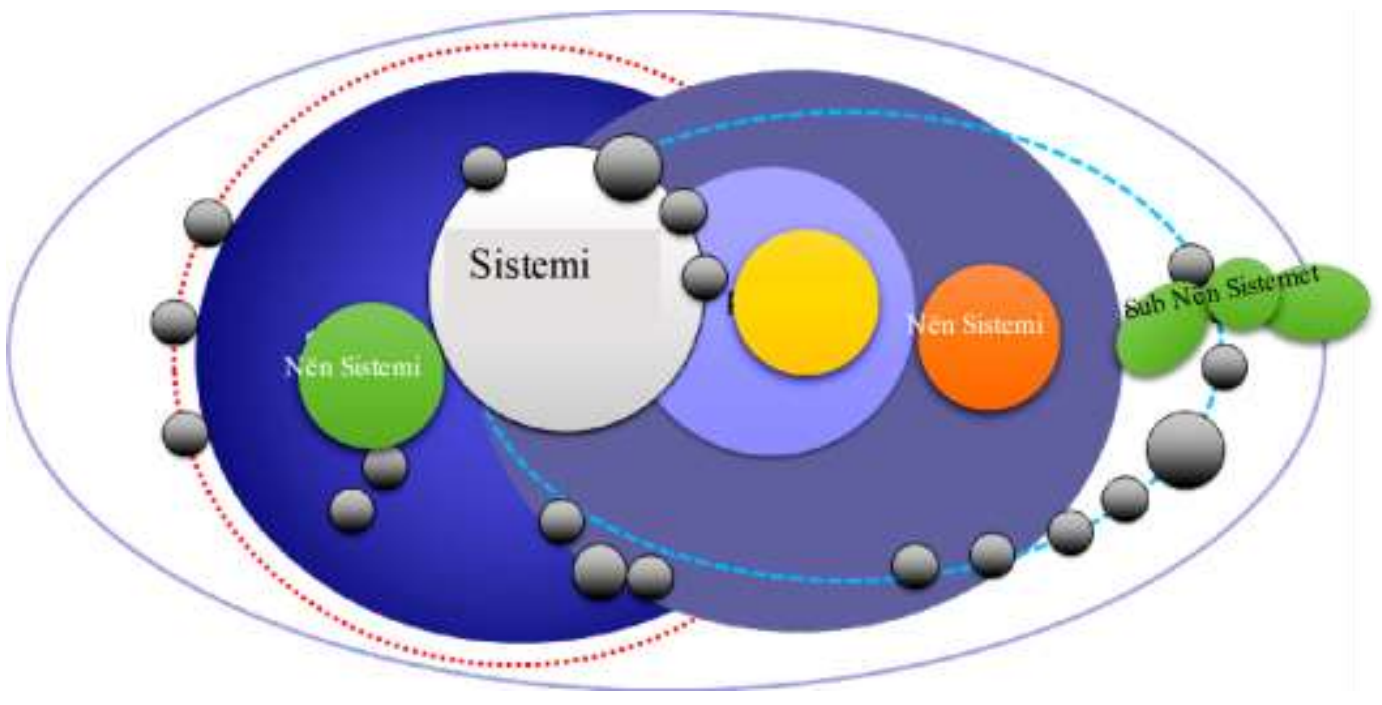

Figura 294. Ndërvarësitë dhe harmonia funksionale e sistemit dhe subsistemeve (Burimi): Bujar Bajçinovci, 2012.

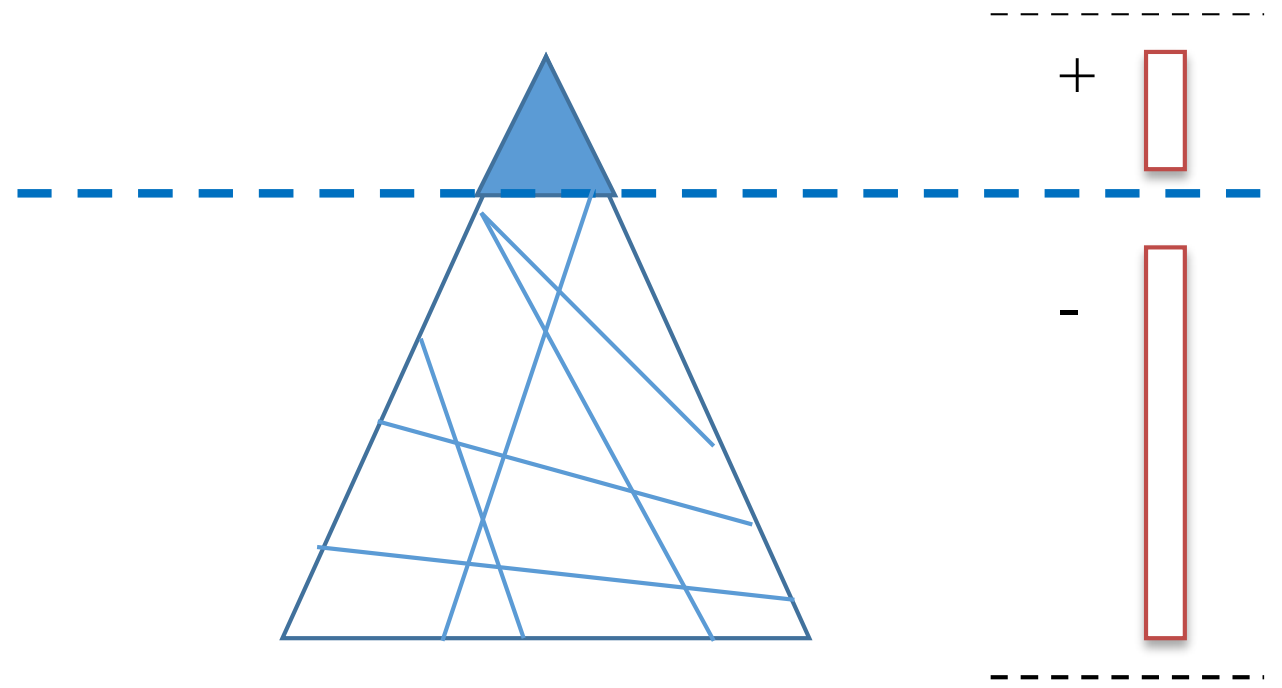

Figura 295. Realiteti i Ajsbergut, në procesin e projektimit.

(Burimi): Bujar Bajçinovc, 2015.

Realiteti i ajsbergut është shumë i ngjashëm me procesin e projektimit arkitektonik. Respektivisht, derisa dizajni dhe modeli përfundimtar janë të dukshëm, ekzistojnë një mori grupacionesh të informatave, hulumtimeve si dhe veprime kreative intelektuale $\mathrm{e}$ që janë vendimtare për finalizimin e duhur të projektit. Mirpo, shumë çka është e padukshme, reth $70 \%$ e procesit të projektimit i ngjan realitetit të Ajsbergut. 


\section{STANDARDET PROJEKTUESE}

\subsection{STANDARDET PROJEKTUESE}

$\mathrm{N}$ jerëzit me nevoja të veçanta, janë një komunitet në rritje e pjesës se popullatës sonë, me diversitet si nga grupmoshat ashtu edhe nga nevojat e veçanta. Në këtë monografi e kam parë të udhës që t'i përmbledh standardet projektuese si ndihmesë kryesisht për studentët e arkitekturës, që përpos ligjëratave ky kapitull t'iu shërbej si kujtesë për respektin dinjitoz që duhet ta kenë në çfarëdo rrethanë projektuese, e posaçërisht kur të kenë rastin të projektojnë me këto standarde si udhëzues modest fakultativ. I kam marrë me kujdes të veçantë standardet grafike projektuese nga qyteti Burlington, meqenëse janë standarde të publikuara shtetërore, dhe si të tilla paraqesin referencë zyrtare të besueshme. E gjithë kjo si ndihmesë për studentët në cilësinë e literaturës bazike njoftuese me dimensionet e kërkuara minimale, dimensionet janë të prezantuara në milimetra $(\mathrm{mm})$. Natyrisht, i sugjerojë studentët që nga këto standarde bazike ti fuqizojnë hulumtimet në këtë lëmi gjatë studimeve, të domosdoshme për një arkitekt të ardhshëm.

\subsubsection{Personat me nevoja të veçanta}
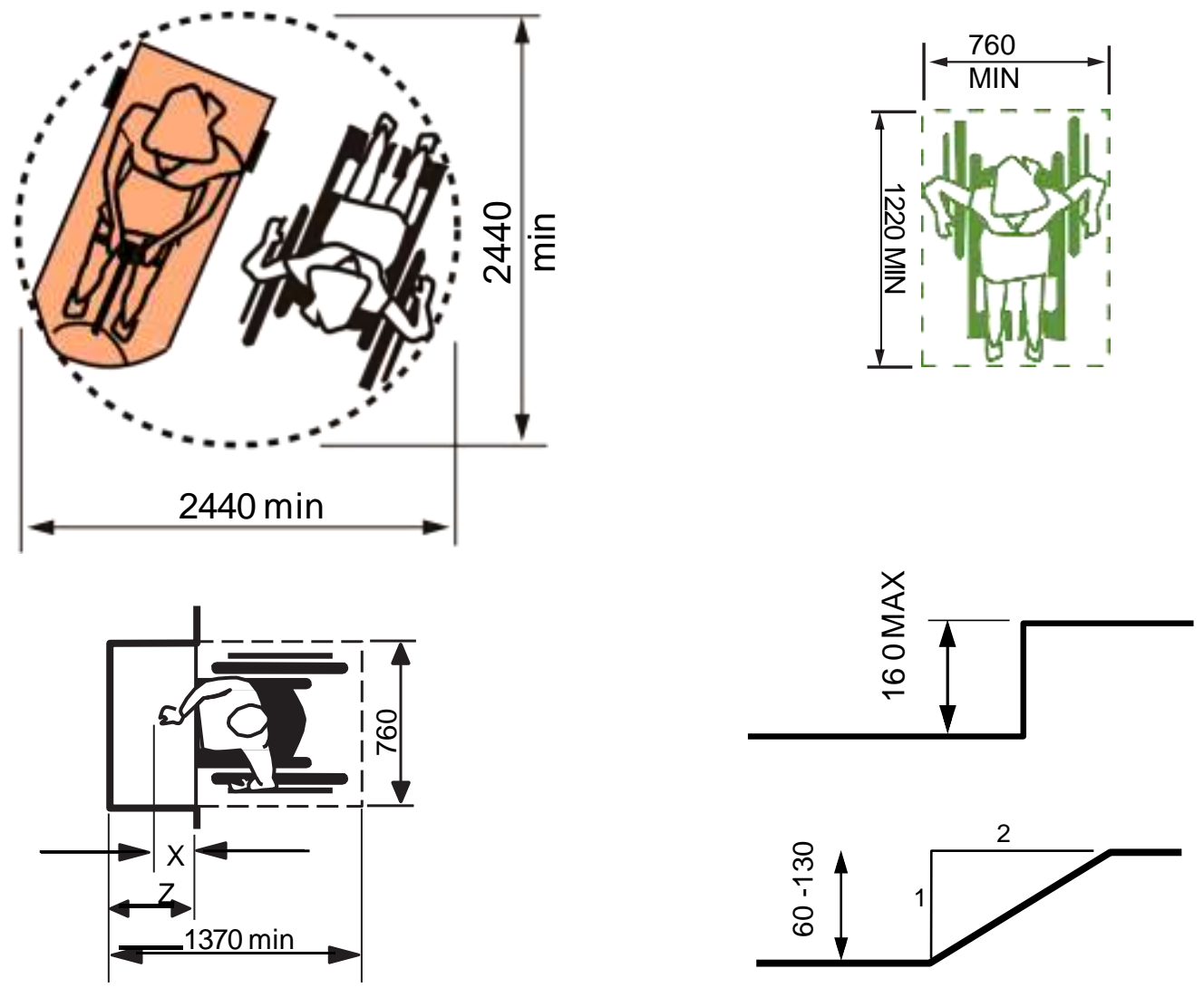

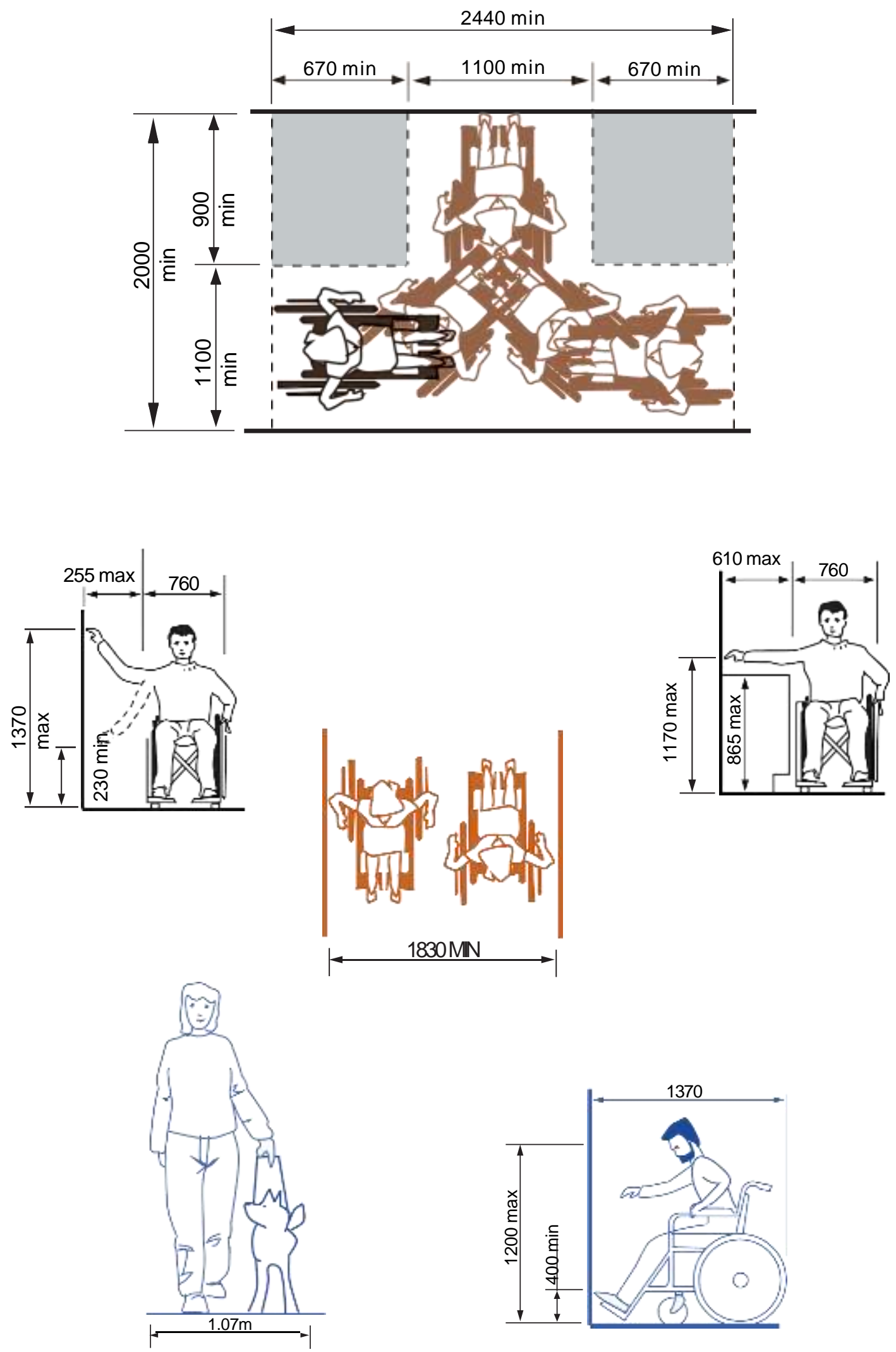
Numri i vendeve fikse në funksion

\begin{tabular}{l|c}
\hline Deri 100 & 2 \\
\hline $101-200$ & 3 \\
\hline $201-300$ & 4 \\
\hline $301-400$ & 5 \\
\hline $401-600$ & 6 \\
\hline Mbi 600 & Jo më pak se $1 \%$ i kapacitetit të ulseve
\end{tabular}
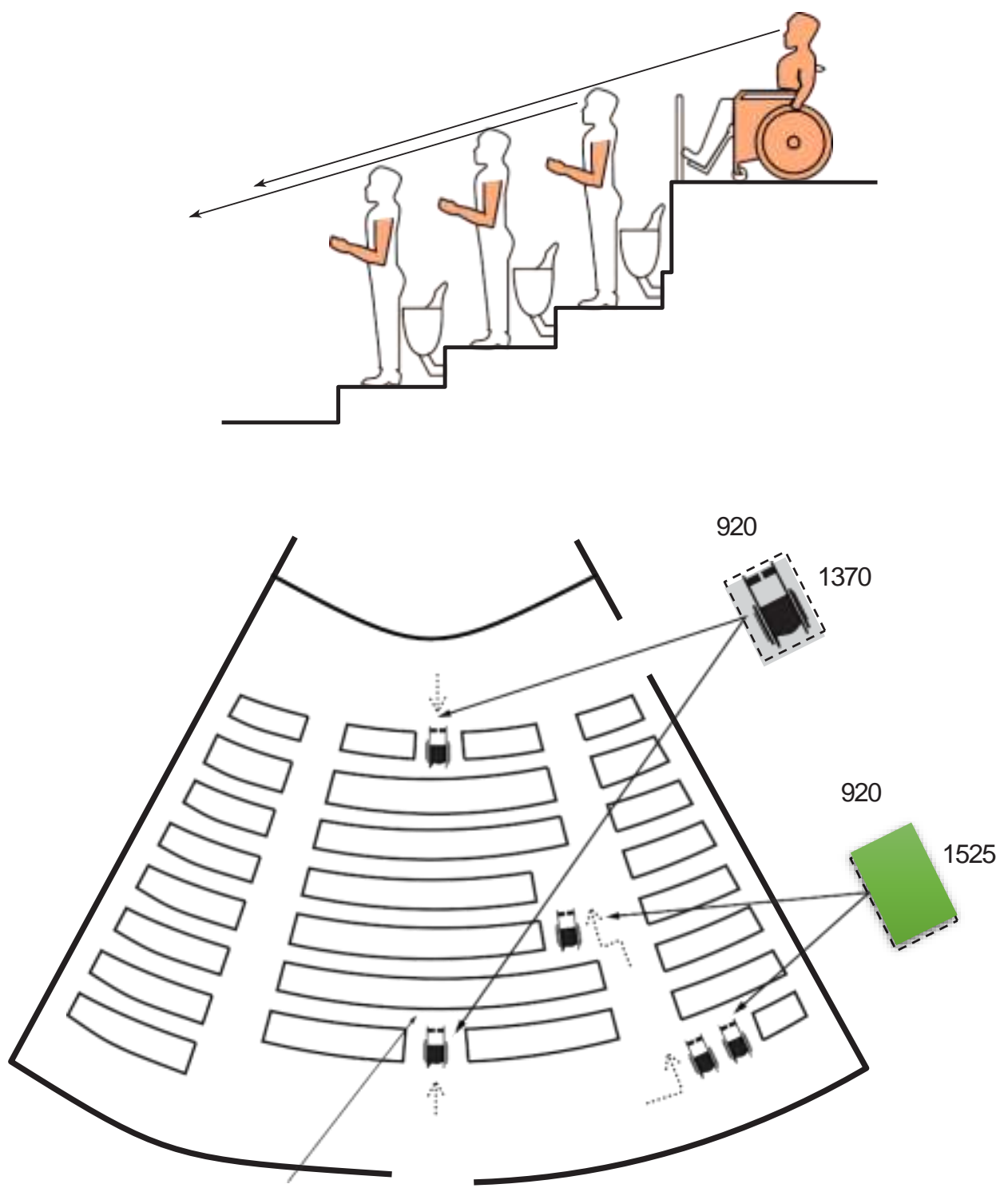

Burimi: City of Burlington Accessibility Contact Judi Lytle, Accessibility Coordinator 905-335-7600 ext. 7865 || Bell Relay 1-800855-0511 accessibleburlington@burlington.ca Clerks Department 426 Brant Street, P.O. Box 5013 Burlington, Ontario L7R $3 Z 6$ Fax: 905-335-7881 
1. Abel, C.(2004). Architecture,Technology and Process. Oxford, UK: Elsevier

2. AD. (2011). Architectural Design. Experimental green strategies. 2011.

3. Audi, R. (2011). Epistemology. London, UK. New York. USA : Routledge. Tailor \& Francis Group.

4. Banka evropiane për rindërtim dhe zhvillim. Strategji për Kosovën. 2013.

5. Batty, M., Torrens M.P. (2005). Modelling and prediction in a complex world. London, UK. Salt Lake City, USA : Elsevier.

6. Bavarian Climate Program 2020. München:Bayerisches Staatsministerium für Umwelt und Gesundheit (StMUG) : http://www.bcn.cat/climatechange/docs/ klimaprogramm2020_en_05_2009_ba.pdf. Maj/2011.

7. Bay Area Air Quality Management District. (2011). San Francisco. USA : http:// baaqmd.gov/Divisions/Planning-and-Research/Particulate-Matter.aspx. Dost. Maj/2011.

8. Bajçinovci, B., Thaçi, K. (2016). Heritage and Artistic Boon: Valuing Prizren Castle. Journal of Science, Humanities and Arts. JOSHA. ISSN: 2364-0626. Vol. (3), Is. 5. 2016. DOI: 10.17160/josha.3.5.228

9. Bajçinovci, B., Jerliu, F. (2016). Integrated Design as an Evolutive Transdisciplinary Strategy. European Journal of Technology and Design, Vol. (13), Is. 3: pp. 90-98. 2016. DOI: 10.13187/ejtd.2016.13.90

10. Bajçinovci, B. (2016). Challenges of Architectural Design in relation to Environment and Air Pollution. A Case study: Prishtina's first public parking Garage. Journal of Science, Humanities and Arts. JOSHA. ISSN: 2364-0626. Vol. (3), Is. 7. 2016. DOI: 10.17160/josha.3.7.254

11. Bajçinovci, B. (2016). Hybrid Structures as a Symbiotic Bond of Art and science. Journal of Science, Humanities and Arts. JOSHA. ISSN: 2364-0626. Vol. (3), Is. 5. 2016. DOI: 10.17160/josha.3.5.233

12. Bajçinovci, B., Jerliu, F. (2016). Urban Resettlements and Environmental Engineering as a Context for Human Development. A Case Study: Hade. Journal of Applied Engineering Sciences, Vol. 6(19), Is. 2/2016, Art. No. 203, pp. 7-14. 2016. DOI: 10.1515/jaes-2016-0011

13. Bajçinovci, B. (2016). Architectural Conceptual Design - the Sustainable Shopping Malls Structures. European Journal of Technology and Design, Vol. (14), Is. 4: pp. 136-143. 2016. DOI: 10.13187/ejtd.2016.14.136

14. Bajçinovci, B., Jerliu, F. (2016). Achieving Energy Efficiency in Accordance with Bioclimatic Architecture Principles. Environmental and Climate Technologies. Vol. (18), pp. 54-63. 2016. DOI: 10.1515/rtuect-2016-0013

15. Bajçinovci, B., Thaçi, K., B. Q. Bajçinovci (2016). Architectural Reflection on Italo Calvino's Invisible Cities. Journal of Science, Humanities and Arts. JOSHA. Vol. (4), Is. 1. 2017. DOI: 10.17160/josha.4.1.261

16. Bajçinovci, B., Jerliu, F. (2016). Complexity of Iterative Model - Architectural Integrated Design as an Evolutive Transdisciplinary Strategy. Case Study: A City Without a River. Journal of Science, Humanities and Arts. JOSHA. ISSN: 2364-0626. Vol. (4), Is. 1. 2017. DOI: 10.17160/josha.4.1.264 
17. Bajçinovci, B. (2017). Ecological Factors Regarding to the Site Selection and Architectural Design of Parking Garages. European Journal of Technology and Design, Vol. (5), Is. 1. 2017. DOI: 10.13187/ejtd.2017.1

18. Bajçinovci, B., Jerliu, F. (2016). The Concept of "Modelarium" and its Impact on Creativity and Artistic Education. Review of Artistic Education, Vol. (14), Is. 1. 2017. DOI: 10.1515/rae-2017-0030

19. Bajçinovci, B., Jerliu, F. (2017). Impact on pollution and Urban liveability Abandoned Quarries. Pollution Research, Vol. (36) , Is.1: 23-28.

20. Bajçinovci, B., Bajçinovci, U., B. Q. Bajçinovci. (2017). Aloft Metabolism: A Juncture of Architecture Future Design. European Journal of Technology and Design, Vol. (5), Is. 1: 14-19. DOI: 10.13187/ejtd.2017.1.14

21. Bijedić, Dženana. (2012). ARHITEKTURA: Holizam umjesto optimalizacije Integralni pristup u arhitektonskom stvaralaštvu. Acta arch. UNI. Sarajevo

22. Blomley, N. (2004). Unsettling the City:Urban Land and the Politics of Property. London, UK. New York. USA : Routledge. Tailor \& Francis Group.

23. Booth, W., Colomb, G., Williams, J. (2008). The Craft of the Research. Chicago \& London: The University of Chicago Press.

24. Brown, I., Brown, I. R. (2003). Quality of Life and Disability. An Aproach for Community Practitioners. London, UK. New York. USA : Jessica Kingsley Publishers.

25. CAA. (2006). An Architect's Guide to Designing for Sustainability. Edgware. UK:Commonwealth Association of Architects.

26. Cadima, P. (2007). An integrated building design approach. European Commission. EACI. Brussels, Belgium:Executive Agency for Competitiveness and Innovation. 6.

27. CHwB., European Union Special Representative Office (2011): Cultural Heritage without Borders Prizren. Kosova. 49.

28. Clayton, S., Opotow, S.(2003). Identity and the Natural Environment, The Psychological Significance of Nature. London, UK : MIT Press.

29. Creative Europe. European Union prize for contemporary architecture, 2015.

30. Darwin, Ch. (1871). The Descent of Man. New York: Prometheus Books. 1997.

31. Degen, M. M.(2008). Sensing Cities. Rgeneration public life in Barcelona and Manchester. London, UK. New York. USA : Routledge. Tailor \& Francis Group.

32. Dennis, A., Wixom, H. B., and Roth, M. R.(2009). System Analisys and Design.

Fourth Ed.Hoboken, New Jersey: Wiley \& Sons, Inc.

33. Deutsch, R.(2011).BIM and Integrated Design. Hoboken, New Jersey:Wiley \& Sons, Inc.

34. Dhankhar, S. S. (2010). Environmental Studies. CSS HAU. Hisar.Dept. Agrometeorology: Agricultural University. 28.

35. Doli, Flamur. (2009). Arkitektura vernakulare e Kosovës. Prishtinë

36. Downton, P. (2009). Architecture and Cities for a Changing Climate. Colligwood, Australia:Springer.CSIRO Publishing.

37. Eastman, C. (2009). Building Information Technology: Digital Building Lab@Georgia Tech. http://bim.arch.gatech.edu/?id=402. 2011.

38. Eastman, C., Teicholz, P., Sacks, R., Liston, R. (2008). BIM Handbook: A Guide to Building Information Modeling for Owners, Managers, Designers, Engineers and Contractors. Hoboken, New Jersey:Wiley \& Sons, Inc. 
39. Ed. Banister D.(Eds).(2005). Transport and Urban Development. London.UK: Taylor \& Francis. E \& FN Spon, an imprint of Chapman \& Hall.

40. Ed. Clayton, S., Opotow, S. (Eds).(2003). Identity and the Natural Environment, The Psychological Significance of Nature. London: MIT Press.

41. Ed. Quatman. W., Dhar, R.(Eds).(2003). The Architect's Guide to Design-Build Services. American Institute of Architects. New Jersey \& Canada: John Wiley \& Sons. Inc.

42. Ed. S. William et al..(Eds).(2005). Understanding the Global Dimensions of Health. New York, NY: Springer.

43. Ed. Wilson, A.(Eds).(2001). Greening Federal Facilities., Brattleboro, Vermont: U.S. Department of Energy.

44. EU. (2004). Architect's Council of Europe. Architecture and Quality of Life, Bruxelles, Belgium: EU.

45. EU. Legislation. Directive 2004/108/EC, of the European Parliament and of the Council.

46. Evans S. D.; Schmalensee, R.(2007). Catalyst Code: The Strategies Behind the World's Most Dynamic Companies, Harvard: Harvard Business School Press.

47. GAP (2009). Prishtinë, raport 2009.

48. Gallo, C., sala, M., Sayigh. M.(Eds).(1998). Architecture : Comfort and Energy. Oxford, UK : Elsevier.

49. Gharajedaghi J.(2006). Systems Thinking.Managing Chaos and Complexity.London. UK : Elsevier.

50. Hadorn, H. G. et al.(2008). The Handbook of Transdisciplinary Research. Zurich.Switzerland : Springer.

51. Hadrović, Ahmet. (2004). Definiranje arhitektonskog prostora. Acta architectonica et urbanistica: Sarajevo, BiH.

52. Hadrović, Ahmet. (2008). Bioclimatic Architecture: Searching for the Path to Haven. Booksurge Publishing: Amazon. com.

53. Highmore, B. T.(2010)Ordinary Lives: Studies in the Everyday.London, UK. New York. USA : Routledge. Tailor \& Francis Group.

54. Ibrahim, R., Fruchter,. R., Sharif, R. (2007, November). International Journal of Architectural Research. Framework for a cross-border transdisciplinary design studio education., 100(03).

55. I. Krasniqi, G. Latifi. (1982).Teknika e tensioneve te larta. FET, Universiteti i Prishtinës.

56. Kargon, R.,Molella, A.(2008).Invented Edens. Invented-Cities of the Twentieth Century. Cambridge, Massachusetts : Massachusetts Institute of Technology.

57. Krasniqi, Fejzullah. Selimaj, R., Malsiu, I.(2004). Instalimet Makinerike. Universiteti i Prishtinës.

58. Krasniqi, Fejzullah.(2000). Ngrohja dhe klimatizimi-II. Universiteti i Prishtinës.

59. Kull, Kalevi.(1998). On Semiosis, Umwelt, and Semiosphere: Semiotica, vol.120 (3/4), pp. 299-310.

60. Kuvendi i Kosovës, Qeveria, http://www.mmph-rks.org/sq/Ligjet-e-Mjedisit1. 2015.

61. Komuna e Prishtinës. Qeveria e lokale. http://kk.rks-gov.net/prishtina/. 2015.

62. Klaus Daniels,(2003) - Advanced Building Systems, 2012. Birkhäuser Architecture

63. Kwok G.A. et al.(2007). Environmental strategies for schematic design. Oxford. UK : Elsevier. 
64. Lawson B.(2005). How Designers Think. Oxford. UK :Elsevier.

65. Lebel J.(2003). Health, An Ecosystem Aproach. Canada : IDRC.

66. Lee, G., Sacks, R., and Eastman, C. M. (2006). Specifying parametric building object behavior (BOB)for a building information modeling system. Automation in Construction, 15(6), pp.758-776.

67. LEED. (2011). U.S. Green Building Council, standard certificates : USA.

68. Ligji nr.2004/15 për ndërtimin, Republika e Kosovës.

69. Lyons, P., Doucek, J. H. (2010). The Disssertation. Oxford, UK : Oxford University Press.

70. Mallgrave, F. H.(2010). The Architect's Brain : Neuroscience, Creativity, and Architecture. Chichester, West Sussex, UK : Wiley Blackwell, Wiley \& Sons,

71. Margolis, L., M., Robinson, A.(2007). Living Systems : InnovatIve MaterIals and technologIes for landscape archItecture. Berlin, Germany:Birkhäuser Verlag AG.

72. Mega, P. V.(2010). Sustainable Cities for the Third Millennium: The Odyssey of Urban Excellence. New York, Dordrecht, Heidelberg, London : Springer.

73. Meijer, F., Visscher, H., Sheridan L.(2002). Building regulations in Europe. I. Nederlands :Delft Uni. pp. 6-188.

74. Ministria e Energjisë dhe e Minierave, (2008). Raport

75. MMPH. Raport për gjendjen e ajrit. 2012.

76. OECD (2010), Cities and Climate Change. Paris, France :OECD Publishing.

77. OGC, CABE,.(2002). Improving Standards of Design: in the Procurement of Public Buildings. London,UK:OGC. 24.

78. OPR. (2007). ASHRAE.Energy Efficiency and Environmental Sustainability. ASHRAE Standard 90.1-2004. Atlanta, USA :ASHRAE.

79. Orr W. D. (2002). The Nature of Design. Oxford, UK :Oxford Uni. Press.

80. Pllana, R. (2015) Klima e Kosovës. ASHAK, Prishtinë.

81. Phillips C.(2009). Health Economics, What is a QALY. Sec. Ed. Swansea University. UK :Hayward Medical Communications.

82. Piotrowski, A.(2011). Archirecture of Thought. Minneapolis, USA : University of Minnesota Press.

83. Pratchett, T. (2008). Making Money. Discoworld Series,. UK :Transworld.

84. Projekti PUP, Prishtinë. (1987). Projeksioni Prishtinës 2000.

85. Program for Environmental Responsibility. http://137.145.170.165/cpdc/sustainability/envr-res.shtml

86. Rabbi Ashlag Y. (2009). Shamati. New York, NY : Laitman Publishing.

87. Republic of Turkey, Ministry of Culture and Tourism. 2012. Göreme National Park and the Rock Sites of Cappadocia.

88. 7Group,Reed, B., (2009). The Integrative Desig Guide to Green Building. New Jersey, USA\& Canada : John Wiley \& Sons. Inc.

89. Salthammer, T., Uhde E., (Eds).(2009). Organic Indoor Air Pollutants. Braunschweig, Germany: Wiley - VCH, Verlag GmbH \& Co. KgaA.

90. Sara Kunkel, Eleni Kontonasiou, Aleksandra Arcipowska, Francesco Mariottini, Bogdan Atanasiu. (2015). Indoor air quality, thermal comfort and daylight. Buildings Performance Institute Europe (BPIE).

91. Samuelsson, L. (2008). The moral status of nature. Umeå,Sweden : Umeå University.

92. Shedroff, N.(2009). Design Is the Problem, The Future of Design Must be Sustainable. Brooklyn, NY. USA: Rosenfeld Media. 
93. Smuts, J. (1927). Holism and Evolution. London, UK: McMillan and Co Limited.

94. Spruce, B. D., Tresher,T.(Eds).(2008). The Land has Memory:Indigenous Knowledge, Native Landscapes, and the National Museum of the American Indian : The University of North Carolina Press. Smithsonian.

95. Tahirsylaj S. i Latifi L.(2010).Quality of Air in Urban and suburban Area's of the Prishtina. Ohrid, Macedonia.BALWOIS : Water Observation and Information System for Balkan Countries.

96. Terzidis, K.(2006). Algorithmic Architecture. Oxford, UK : Elsevier.

97. Tomlinson, B.(2010). Greening throught IT. Information Technology for Environmenal Sustainability. Cambridge, Massachusetts: Massachusetts Institute of Technology.

98. UAE. Abu Dhabi.(2001). The Reality of Future Energy. Abu Dhabi : Masdar Publishing.

99. UK. RIBA. (1965).The Royal Institute of British Architects. Architectural Practice and Manual. London, UK : RIBA British Architectural Library.

100. UNMIK., MER. (2006).

101. UNESCO Venice Office.(2009). Macedonian cultural heritage. Ohrid world heritage site.

102. U.S. (1991). Department of Housing and Urban Development.

103. UNMIK. http://www.unmikonline.org/regulations/2004/re2004_48.pdf. 2015.

104. UNMIK., MEM. (2006). Programi i Kosovës për Efiçiencë të Energjisë dhe të energjisë së ripërtëritshme. 2007-2009. Prishtinë. Kosova

105. Walker, B.(1995) . Hua Hu Ching: The Unknown Teachings of Lao Tzu. HarperOne.

106. WHO, Europe., Marttuzi M. et al,(2006). Health impact of PM10 and ozone in 13 italian cities. Copenhagen, Denmark :WHO Regional Office for Europe.

107. WHO, Europe.(2005). Effects of air pollution on children's health and development. A Review Of the Evidence.Copenhagen, Denmark :WHO Regional Office for Europe.

108. Vjollca Komoni, Isuf Krasniqi, Arben Leka, Ilir Gashi. (2013). Analiza e performancës së sistemit fotovoltaik me fuqi $3.9 \mathrm{kwp}$ të palidhun në rrjetin elektrik. FIEK. Universiteti i Prishtinës.

\section{(-) Prof.Ass.Dr. Bujar Bajçinovci 2017}

